\title{
The Ayes Have It: The history of the Queensland Parliament, 1957-1989
}





\section{The Ayes Have It: The history of the Queensland Parliament, 1957-1989}

JOHN WANNA AND TRACEY ARKLAY

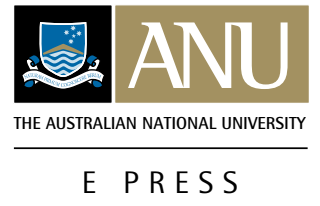




\section{ANU}

E PRESS

Published by ANU E Press

The Australian National University

Canberra ACT 0200, Australia

Email: anuepress@anu.edu.au

This title is also available online at: http://epress.anu.edu.au/qldparliament_citation.html

National Library of Australia

Cataloguing-in-Publication entry

Title:

The Ayes Have It: History of Queensland Parliament 1957-1989 / John

Wanna and Tracey Arklay

ISBN:

9781921666308 (pbk.) 9781921666315 (pdf)

Notes: Bibliography.

Subjects: $\quad$ Politics, Australian Politics

History of Australian politics,

Queensland Parliament History

from 1957 - 1989

Other Authors/Contributors:

John Wanna and Tracey Arklay

All rights reserved. No part of this publication may be reproduced, stored in a retrieval system or transmitted in any form or by any means, electronic, mechanical, photocopying or otherwise, without the prior permission of the publisher.

Cover design and layout by ANU E Press

All images supplied by the Queensland Parliamentary Library.

Printed by Griffin Press.

This edition (C) 2010 ANU E Press 


\section{Contents}

Acknowledgments. . . . . . . . . . . . . . . vii

1. Inside the Queensland Parliament . . . . . . . . . 1

\section{Part I}

2. Parliament's refusal of supply and defeat of Labor, $1957 \ldots 29$

3. The early Nicklin years, $1957-1963$. . . . . . . . . . . . 57

4. Safely in the saddle: the Nicklin government, 1963-1968 . . 87

5. The Nicklin government's legislative program . . . . . . . 125

6. The oppositional parties in the Parliament, 1957-1968 . . 167

7. The Pizzey-Chalk interlude, $1968 \ldots \ldots$. . . . . . . . 203

\section{Part II}

8. The early Bjelke-Petersen years, 1968-1969 . . . . . . . . . 249

9. The slide towards uncertainty, 1969-1972 . . . . . . 285

10. Commanding the Parliament, 1972-1975 . . . . . . . 335

11. All power corrupts, 1976-1980 . . . . . . . . . . . . 377

12. The government's legislative program, 1968-1989 . . . . 425

13. The doldrums in opposition, 1968-1989 . . . . . . . . . 469

14. The demise of the Coalition and the Nationals governing alone, $1981-1983 \ldots \ldots \ldots \ldots 03$

15. The implosion of Joh Bjelke-Petersen, 1983-1987 . . . . 545

16. The end of an era, 1987-1989 . . . . . . . . . . . . 589

17. Conclusion: do the 'ayes' have it? . . . . . . . . . . 643

Appendix 1. . . . . . . . . . . . . . . . 653

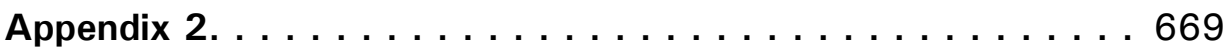

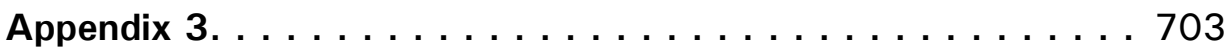

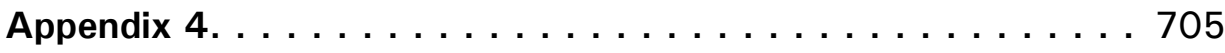

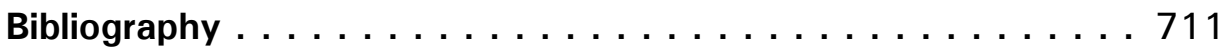

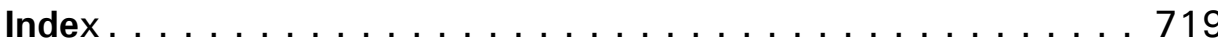





\section{Acknowledgments}

This project began almost by accident. In 1995, John Wanna approached the Queensland Parliament with the intention of spending his sabbatical research leave of six months with the parliamentary research staff. His original intention was to assist their research endeavours and contribute something back for the privilege of living in Queensland and in recognition of the wonderful opportunity of being attached to the Parliament. He was not a born-and-bred Queenslander but Queensland had very much become his adopted home state. The Deputy Clerk, Michelle Cornwell, was most keen to accept, as was the then Clerk, Robert Doyle. The Speaker of the day, Jim Fouras, was equally accommodating, always asking 'how are you going' and was there anything he could do. The thinking at the time was that, as a political scientist, Professor Wanna could work on a series of parliamentary research papers that raised interesting political issues as an independent researcher attached to Griffith University. He had in mind, say, writing research papers on the development of question time in the Queensland Parliament, perhaps the development of the committee system (a short history undoubtedly) or even the contribution of private member's bills to public policy (an even shorter project). On taking up the secondment as a sort of 'academic in residence' in the Donovan Library, Cornwell suggested that the Parliament had been intending to update its history and had begun to collect a few timelines and documents from the 1950s. The last semi-official history of the Queensland Parliament, overseen by the journalist Clem Lack (Three Decades of Queensland Political History, 1930-1960), ended with the change of government in 1957 and covered the first period of the Nicklin-Morris government. She asked him to help out with a chapter covering the demise of the long-running Labor regime and the transition to a Coalition government in 1957. He agreed to help, thinking it would take three weeks. The 'help' became Chapter 2 of this volume. Then the request was can you do any more...

The chapter took some months of research and poring through the Hansards and other parliamentary records of the period. Tracey Arklay, a research student from Griffith University, came aboard in October 1995 to assist with sifting through the vast volumes of parliamentary debates, newspaper clippings, other newspaper original searches and finding other evidential sources or dates from everything imaginable: books, archives, biographies, biography entries in the Dictionary of Biography, pamphlets and cabinet records. She expedited the process of data gathering and together they read each Hansard from 1957more than 100 volumes. 
Meanwhile, 'The History', as it was called by the authors, had grown into a full-blown history of the Queensland Parliament from the demise of the Labor governments around the bitter Labor split of the mid-1950s, to the change of government in 1989 when the Nationals, led by Russell Cooper, lost to the Labor Party under the leadership of Wayne Goss. To go any further at the time (closer to the present day) was seen as 'too risky' and 'too recent yet to do' and unlikely to be able to be divorced from the politics and personalities of the day. So, 1989 was agreed on as a convenient and appropriate end date. It also mirrored Lack's earlier publication covering three decades, in that he had written about the 1930 s to 1950s, and ours would essentially describe the 1960s to 1980s. The sabbatical, however, was at an end and it was back to full teaching for Wanna, while Arklay had to finish her honours degree and begin a PhD. It was agreed that the two researchers would continue the project one day a week for much of the year, progressing through the period of coverage. Despite Wanna being head of school in Politics and Public Policy at Griffith, and spending a year in the Department of Finance in Canberra researching budgetary policy, 'The History' progressed at a little more than a chapter a year so that by the end of 2003, the first 10 chapters were substantially drafted. Professor Wanna was then appointed as the national research director for the Australia and New Zealand School of Government (ANZSOG) based at The Australian National University in Canberra. With these new duties and responsibilities, Wanna put 'The History' on hold for a few years, until the present Clerk contacted the researchers in mid-2009, saying: 'Hey, we have our sesquicentennial coming up in May 2010, any chance of "The History" being finished so we can launch it as part of the commemorative events?' The researchers agreed and this is the final product. It is a far, far bigger project than either of the authors had contemplated at any time in its production. While Arklay provided purely research assistance for most of the period, she eventually took the lead in authoring two chapters and making important contributions to others as well as the appendices. Sally Irwin added the biographical/character studies of the former Speakers as part of a parliamentary internship project, and these are included in the appendices.

The authors would like to stress that this project has been an almost entirely honorary endeavour. It was not completed as a consultancy, no research grant has been used and no premier's history grant has been issued. Neither the Queensland government nor the Parliament has ever paid any of the author's time spent on this project, except for one contribution (in 1997), when the Parliamentary Library contributed $\$ 5000$ to reimburse salary costs for Arklay. Wanna's salary during this period has been paid entirely by Griffith University, and later by The Australian National University via a personal chair appointment under ANZSOG. Arklay's casual salary has been paid over the years by Professor Wanna from research funds he generated independently to cross-subsidise the project. Together they were happy to make these sacrifices and have never 
asked for, or expected, any reimbursement or compensation; this volume is compensation enough. Neither researcher is a member of any political party nor has any particular axe to grind.

In undertaking this enormous project over some 14 years, the authors have incurred many debts but built many friendships. They would like to thank: Neil Laurie, the present Clerk of the Parliament, and his predecessor, Robert Doyle; Mary Seefried, the current Parliamentary Librarian, and Nick Bannenberg, her immediate predecessor, who oversaw most of the research and was a font of historical knowledge. As mentioned, the former Deputy Clerk, Michelle Cornwell, was the original inspiration for the history and gave her undiminished support. Also helpful to the researchers in the Parliamentary Library (which they came to regard as their home away from home) were Brian Stevenson, Ros Bailey, Carol Stinson, David Embury, Eve Francis, Michael Zeremes, Suzanne Campbell, Lynda Pretty, Melissa Cook, Robyn Moore, Glenda Emmerson, Tim Moroney and Zac Dadic. In the educational unit of the Parliament, Graeme Kinnear and Ted Newton were generous with their time and thoughts.

The authors have worked under a number of Speakers over the years. All have been encouraging and supportive. They wish to thank Jim Fouras, Neil Turner, Ray Hollis, Tony McGrady, Mike Reynolds and the current Speaker, John Mickel. Neil Turner, a taciturn bloke, had our manuscript vetted by his chauffeur, Justin Choveaux (who had featured as the 'worst' witness in the Criminal Justice Commission's 'Joh Jury' investigation), but then jokingly showed us his unique skill with a stockwhip just in case we got out of line.

A number of other people have helped in the preparation of the manuscript. A number of former members were also generous enough to read the penultimate drafts to provide comments and alert the authors to lacunae, including: Denver Beanland, David Hamill and Bill Hewitt, who read most chapters, while some years ago the late Jack Houston read Chapter 6. More than 50 copies of chapters were circulated to serving members in the late 1990s, and a formal presentation was delivered to about 40 attendees of the former members' association about the same time. Other former members who were helpful with occasional points were the late Jack Melloy, Harry Dean and Ray Smith, as well as Colin Lamont. The authors benefited from the detailed comments, among the parliamentary staff, of Brian Stevenson, Ian Thompson, Darrell Martin and Tim Moroney. Three former Labor staffers read the opposition chapter (Chapter 13) to help fill in blanks and check facts: Joe Begley, Malcolm McMillan and Terry Wood.

Both authors wish to thank Griffith University. Without its assistance, the project would not have been possible; and latterly The Australian National University provided the time and space to complete the final preparation of the manuscript. Others have assisted the project in various other ways. Professor Pat Weller and 
the staff in the Department of Politics and Public Policy at Griffith University have been very supportive of the project, and covered some of Arklay's travel costs. As mentioned, Sally Irwin contributed the biographical portraits of the Speakers of the period covered by this history. Shellaine Godbold, Joel Marks, Evert Lindquist and Jeannie Haxell based at The Australian National University were of great assistance during the final stages of the project. Jan Borrie assisted with the copyediting.

Finally, we would like to thank our understanding families who have equally lived through the ordeal: Jenni Craik, Erinn, Sean and Aidan Wanna, and Tony, James and Elise Arklay for their forbearance with the demands of the project and support over the years.

- John Wanna and Tracey Arklay 


\section{Inside the Queensland Parliament}

Before Queensland was established as a separate colony in 1859 'separationist settlers' in the Moreton Bay region had pushed for independence and self-rule. Ideas about self-government and the establishment of a local parliamentary democracy were important inspirations in the formation of colonial Queensland. Early settlers in the territory then known as 'Northern Australia', the 'Northern Districts' or 'Cooksland' showed a strong preference for separation from Sydney and New South Wales and campaigned vigorously for recognition as a new colony. Although nine representatives from the Moreton region sat in the NSW Assembly, separation from the 'tightly-drawn' strings of New South Wales became the subject of much local political activity and petitioning to the monarch after 1856 (Pugh 1859). The desire to create a local parliament was not, however, just a philosophical commitment to regional democracy and self-rule. Rather, it reflected an economic desire to manage their own interests, attract additional settlers and develop the northern lands themselves without waiting for the NSW governors to determine their fate. And, the emerging colonial political leaders were prepared to take on the risk of forming a new colony. They knew they would have to make a substantial material commitment over time and impose a major financial burden on the new colony to establish its embryonic political institutions. They also had to inherit a large public debt of some $£ 20000$ as part of separation - the so-called 'Moreton Bay Debt', which was transferred from New South Wales to Queensland.

Although the issue of forming a further colony in northern Australia had been as contentious in London as it was in New South Wales, Queen Victoria signed the Letters Patent establishing 'Queensland' as a new colony in June 1859. She had apparently chosen the name herself, preferring 'Her own Royal Title' to any other contenders such as 'Cooksland'. The first Governor, George Bowen, and his Colonial Secretary, Robert Herbert, then immediately set about exploring and developing the colony and planning the bicameral political system. A series of government public works was commissioned for the new colony with the priorities of construction reflecting the formal status of the day. First, the Governor was to be suitably housed in a splendid mansion alongside the Brisbane River, then the parliamentarians provided with two adjoining chambers. The Colonial Treasury and other government administrative offices were to complete the parliamentary compound in one interconnected building. This early desire for the institutions of self-government, however, almost drove the new colony bankrupt. 
For a colony to be granted its own parliament and attendant institutions meant it had achieved political or strategic significance and was considered able to manage its own affairs. The main arguments for Britain granting self-government related to prevailing colonial development policies, local settlement patterns, the need for regional administration and military considerations. Britain was also anxious to ensure that the plethora of new colonies it was establishing would not be a drain on the Crown. Colonies were meant to be administratively self-financing and yet conducive to private enterprise. From the outset, self-government in Queensland was not premised on high democratic ideals of building a new political system or a more humane, tolerant society. It was also not based on political, religious or cultural differences or the desire to establish a more liberal 'paradise of dissent' as found in other colonies (see Pike 1967). Indeed, early attempts to establish Moreton Bay as a Protestant enclave (as J. D. Lang had attempted in 1849) were decidedly illiberal. There is scant evidence early Queenslanders were inspired by the liberating potential of the 'rights of man' or by the tolerance associated with a society based on 'civic humanism'. Rather, self-government was anchored on territorial identity, consociational values and geographical distance. Responsible and representative government were not symbolic of a commitment to democratic citizenship but to the incorporation of another colony of British 'subjects' into the unfolding Empire. And early notions of representation were based on producer representation rather than popular democracy. A parliamentary system was needed to attract and hold intending settlers and sustain settlement in the longer term. Queensland's Parliament, thus, began as an extension of a business venture, designed to facilitate investment and spur development in the new colony - a role it has maintained even to this day (see Government of Queensland 1909:Pt 1).

The Queensland Parliament was also intended to be a symbol of sovereign power in Queensland. Parliament would provide regional authority and recognition of the special needs of a largely tropical colony. The buildings housing the Parliament were to reflect this vision of confidence and authority. Housing a colonial and later state parliament, Queensland's Parliament House was planned as an impressive and distinctive edifice that would provide the society with a sense of legacy. The gracious structure was meant to convey confidence in the colony/state and the integrity of public office and public service. Here was a sign of wealth, prosperity and pioneering ambition. It was, however, also a sign of imperial values, colonialism and derivative styles; it served as a foundation stone of a largely Anglo-Irish-Scottish society within which many sections of the wider society were invisible, such as Indigenous and Islander peoples or the Kanaka cane workers. (Interestingly, because of the property qualification used as the basis of the state's electoral roll, a small number of Aborigines enjoyed the right to vote in colonial times, particularly in the 1880s and 1890s.) 
Queensland's Parliament was and remains a blend of contradictions. It is part imperial, part colonial; part deferential yet often robust and defiant; sometimes exceedingly proper and rigid and at other times lax and rough and ready; pretentious and at times elitist but also with a streak of Antipodean egalitarianism. Anthony Trollope judged Queensland to be among the better colonial parliaments in the 1870s. Writing of his Australian and New Zealand experiences, the British novelist said: 'the Queensland Assembly has not been distinguished for rowdiness among colonial parliaments, and has held up its head, and done its work, and attained respect without which a parliament must be worthless' (Trollope 1873). Others though could be less kind-describing it as 'the wailing wall' that 'transacted its business at a very leisurely pace [and] for about half the year it lay empty' (Moles 1979:154-5). Throughout its history, the Queensland Parliament has served as an adversarial forum and a congenial club for members - certainly displaying the attributes until very recently of a 'gentleman's club', comprising white, elderly males who developed an institutional camaraderie or mateship - still often demonstrated by retired members in the Former Members' Association. It was also a parliament in which rural and urban and Protestant and Catholic denominations were regularly represented at the most senior levels.

Queensland has traditionally shown pride in its parliamentary heritage, if mainly out of habit or parochialism. From colonial times, parliaments were never intended to be governments, merely to enable governments to be formed. Indeed, the Constitution required it to meet but once a year, implying it was important that the assembly of representatives met but that it was not itself the standing government. Parliament was in effect an electoral college, choosing the government of the day, and a debating, grievance and scrutineering body. Restricted manhood suffrage was sufficient to ensure commitment to the polity - but not a model of democratic expression. From 1860, only domicile males over twenty-one years of age (and principally British) meeting property and residential requirements were entitled to vote, and this excluded itinerant workers, many labourers and 'wandering beggars'. Women were allowed to vote after 1905. In the first 50 years of self-rule, Queensland operated as a 'squatter democracy'. Various electoral devices were used to sustain elite patterns of representation (such as plural voting, giving landowners with multiple properties two or more votes, multi-member constituencies in which only the wealthy could nominate for election and first-past-the-post voting), until compulsory registration and compulsory voting were introduced in 1914 (for the 1915 election; see Campbell 1995). After that, the mechanics of the voting system, the adjustment of boundaries and the declaration of malapportioned 'zones' all became part of the accepted political spoils of office. Accordingly, electoral arrangements generally confirmed the survival of political regimes and incumbents rather than scrutinised governments or refreshed parliaments with 
new blood (the two exceptions were the election of the radical Ryan government in 1915 and the significant renewal of the Parliament in 1989 with the incoming Goss government).

After Federation in 1901, state parliament was often relegated to performing perfunctory roles for powerful premiers and their state governments. Elsewhere in Australia, the standing of the Queensland Parliament as an institution was sometimes questioned, often treated with a degree of scepticism and occasionally the object of ridicule or the butt of jokes (see Chapter 15). A former Deputy Clerk of the Parliament admitted that the 'Queensland Parliament was not held in high esteem' throughout Australia and another political commentator, Peter Coaldrake (1989:66), stated that the 'appallingly lame condition of the Queensland parliament in terms of its ability to secure accountability is not entirely surprising'. Commonwealth colleagues tend to pay scant regard to state parliaments, some holding the view that the state chambers 'are not real parliaments' - implying that parliamentary sovereignty has passed solely to the Australian Parliament. For those who identify more with the states and support states' rights, these comments could be considered patronising or misguided. Outside views nevertheless inject another perspective: the Queensland Parliament has not generally been regarded throughout the twentieth century as a particularly diligent institution that has stood steadfastly for parliamentary sovereignty and maintained its own integrity. Beyond the Queensland borders, there is usually an appreciative recognition of the significance of the state government as a strong developer and regional administrator, but far less of the Queensland Parliament as a vibrant legislature making a contribution to Australian democracy.

\section{The parliamentary buildings: colonial ambitions for a 'noble palace'}

The first Queensland Parliament met on 22 May 1860 in temporary accommodation in the Old Convict Barracks situated at the upper end of Queen Street in the centre of Brisbane. Along with the Governor, the first colonial Parliament consisted of 26 elected members of the Legislative Assembly and 15 appointed members of the Legislative Council. The councillors were to be the equivalent of a board of directors consisting of investors and notables - and were originally intended to number 14, but Governor Bowen appointed four from Sydney and a further 11 from Brisbane (making 15 in total). At that time, the colony contained only 23520 people (a ratio of population per representative of about 1500) and 4790 electors (giving a ratio of one representative to only 320 voters). The new Parliament immediately decided to build suitable accommodation for 
the Governor just beyond the city centre along the river, adjacent to the present city Botanic Gardens. ${ }^{1}$ The impressive two-storey Government House, complete with a large bay porch, was built between 1860 and 1862 and served as the residence of the Governor until a new Government House, 'Fernberg' at Bardon, was acquired by the Kidston government (initially through a lease arrangement in 1910 and then purchased the next year).

From the outset, the Parliament was intended and designed as a bicameral legislature. Construction of a new parliament building, on a conspicuous site in 'Queen's Park' (now the Botanic Gardens) south-west of George Street, began in earnest in 1864. Initial planning had been undertaken in 1863 by a parliamentary commission comprising equal numbers from both houses, and their preferred site on the river at the southernmost end of Brisbane was chosen to minimise the likelihood of fire and to be away from the hustle and bustle of the city. The commissioners called for a competition to design the structure of the new Parliament but received only four entries. Dissatisfied with progress and after delays and disagreements, the commission was abolished by the government (or in the vernacular of the day 'done away with'; $Q P D$ 1868:vol. 6, p. 612). So, from the start, the new Parliament was provided and supervised by executive government. Well before the first wing was completed, the new 'Parliament Houses' were the subject of controversy between members and the executive over the plans, unsatisfactory architecture, the unreliability of construction firms, slow completion, cost overruns, overdrawn accounts, extravagance and accommodation problems (and some of these concerns have percolated throughout its history). The front wing with the two chambers was sufficiently completed by 4 August 1868, when the delayed second session of the third Parliament was opened by the administrator or 'Acting Governor', Colonel Maurice O'Connell. Despite piles of debris, O'Connell, in opening the Parliament, described the 'noble' building as a 'future palace of the Legislature' (QPD 1868:vol. 7, p. 1).

The early intention of the planners was to design the parliamentary and government buildings around a quadrangle featuring an enclosed courtyard and internal verandas. With Government House located a short distance across the gardens, this hub would form part of a government precinct at the southern end of the city. The legislative wing containing two chambers of equal size would face north-east towards the Botanic Gardens, while parliamentary and 'public offices' were to occupy the south-eastern and north-western connecting arms (see the original plan of the New Houses of Parliament and Public Offices). A 'porte-cochere' was to have graced the main entrance but was dispensed with due

1 The Governor had previously resided at the Government Resident's House at Newstead, which had been used to accommodate the 'government's resident' before self-rule and occasionally the NSW Governor when he was visiting the Moreton Bay settlement. 
to costs (and then eventually added in the restoration of 1979-82; see Chapter 11). The main entrance provided access to both chambers and the parliamentary library via a 'grand staircase' decorated with stained-glass portraits of Queen Victoria, Prince Edward (later King Edward VII) and Princess Alexandra. Across the southern river-side of the building, the 'Colonial Treasurer's Department' was to be located - ostensibly because it was felt that those with most need to be near the parliamentarians ought to be physically adjacent. Yet in conceiving such an integrated design, the colonial administrators already showed great difficulty separating the functions of parliament from those of the executive and colonial administration.

The plans for the Queensland Parliament envisaged a completed quadrangle structure operating as a composite whole. Conscious of the expense, however, the government was obliged to build it in stages. The architect of the original building and winner of the competition, Charles Tiffin, set out to combine a French renaissance style with inspiration from 'revival classicism' and some arcading concessions to the subtropical climate. The ribbed-zinc (and later copper) roof resembled the Louvre in Paris, open colonnades (added in 1880) graced the front wing underneath the chambers and external verandas surrounded the inner first floor alongside the chambers, offices and dining areas. Indeed, one of the early problems with the building was the glare and lack of shade, and since that time external windows have been bedecked with heavy internal blinds and shades. ${ }^{2}$ The masonry of the old wing was crafted from Goodna sandstone possessing a slightly pinkish hue. In elevation, the threestorey walls reflected a colonial utilitarianism or military barrack style with an eye to regency simplicity (some of which could have emerged in the process of construction as some of the masons were recruited immediately after building jail walls). Ornate wrought-iron apex embellishments crowned the roof ridges of the main chambers, adding to the grandeur of the four domed roofs against the skyline.

The grand intentions of the planners were, however, compromised before even the first wing was complete. The cost escalations and economic recessions curtailed ambitions and the more elaborate features of the building were jettisoned. The architect was recalled and told to modify the project and a second firm of builders (John Petrie) was contracted to finish the first wing. With the north-eastern wing unfinished, the three other wings were cancelled.

2 Members frequently complained of the heat inside the Chamber-especially when combined with the traditional standards of dress inherited largely from the British Parliament. In the decades before airconditioning, the fishbowl-like Chamber produced conditions that were at times stifling in Brisbane's subtropical heat. It was not unusual for members to complain about the dress code. For instance, John Herbert (Lib., Sherwood) argued Queensland parliamentarians 'cling to the dress worn by our forefathers who came from countries where there was snow on the ground'; he also suggested, 'if members of Parliament made a move on dress reform in Queensland, I am sure that thousands of perspiring citizens would be happy to follow suit' (QPD 1957:vol. 218, p. 592). 
A north-western wing of ministerial and member offices and dining facilities was added in 1891 as finances permitted, and thereafter the remaining features of the 'Tiffin concept' were abandoned entirely. Federation diverted some of the need for the further expansion of state parliaments, and by that time other public works had moved the main government precinct further down George Street as far as Adelaide Street.

Additions to the parliamentary buildings occurred occasionally over the years, at one time adding a provedore's (caretaker's) cottage and separate refreshment rooms - both located on the rear lawns. These were later removed while catering facilities for staff and visitors were incorporated into other plans. Perhaps the most intriguing addition to the old house was the construction of an external stone stairwell behind the legislative council chamber at the back of the northern wing. The spiral stairway connects a ground floor office past the council chamber to the president's gallery on the second floor, apparently serving no official functional purpose. An apocryphal story has it that the stairwell was built so that one of the councillors (perhaps even a president of the council) could receive his mistress from the public gallery without her being seen or stopped. This appears unlikely to have been the real reason.

As the number of parliamentarians rose roughly commensurate with the size of the state's population, office accommodation for members in Parliament House became an issue. The number of members increased from 62 in 1947 to 75 throughout the 1950s, to 78 in the 1960s and 82 after 1972. Overcrowding in Parliament House became a major concern in the 1950s with sometimes up to 15 members sharing the same office (in the early 1950s), which had only a few chairs, a couple of desks and one phone. Before the parliamentary annexe building was completed in 1979, members frequently shared offices, with six to eight backbenchers occupying one room with access to a single secretary. Many former backbench members retain vivid recollections of the overcrowding that existed but also the camaraderie it encouraged. They frequently criticised the accommodation in the old house as akin to an overcrowded 'rabbit warren'. The old library consisted of just two rooms sandwiched between the two chambersand, to store papers, a storage cavity was opened up in the Louvre-style roof.

The buildings of the parliamentary complex eventually became fashioned into a quadrangle consisting of old and new sections. The quadrangle was completed in 1979 by the juxtaposition of a modern 24-storey parliamentary annexe to fully accommodate members. ${ }^{3}$ The new complex was designed by the State Works Department and the Parliamentary Building Committee and constructed by Watkins Limited during 1975-79. Built of reinforced concrete clad with

3 Before the annexe was built, non-Brisbane members stayed at the famous Bellevue Hotel across from the Parliament on Alice Street, until it was controversially demolished in 1979. 
pebble-dashed concrete panels, the annexe tower contains the members' private offices, includes 78 flats for non-city members (the only Australian parliament, and one of the few in the world, with substantial accommodation on site), plus ministerial suites above the eighteenth floor. Additional lounges and dining rooms together with a swimming pool, squash court and gym were built for the convenience of members. A new and far more spacious parliamentary library was included in the annexe along with facilities for the Speaker, political parties and eventually accommodation for the secretariats of the parliamentary committees. A conference hall designed in modern style but retaining the traditional horseshoe debating form was included in the design and was used as a temporary assembly chamber while restoration of the old house was undertaken. Although great thought and attention had gone into the design of the annexe to suit members' needs, a major design fault was soon discovered. The planners had overlooked the need for members to proceed quickly to the Chamber when division bells were ringing and allowed for only one lift well (two lifts) to service the 24 floors; consequently many members, especially the infirm, could not make it with ease from their offices/flats to the Chamber to vote. In recognition of this oversight, the lifts have been reserved for members only when division bells are ringing and the time allowed to reach the Chamber for divisions was increased from two to four minutes in 1983 under the Standing Rules and Orders. Even so, when numbers in the House were tight (as they were in the late 1980s and mid-1990s), government members were sometimes 'banned' from going above the seventh floor of the annexe to ensure their attendance at divisions.

Parliament House still appears from the outside as a palatial building, basking in the subtropical sun behind jacarandas and palm trees. The original building, colloquially known as the 'old House', was fully restored (1979-82) following an outbreak of West Indian drywood termites and years of deterioration. The parliamentary complex, however, once a principal landmark overlooking the river, is now squeezed from all sides by modern city structures. On the south-western side, Parliament House abuts a traffic-choked, six-lane freeway suspended over the river. To the north-west, Alice Street is a major thoroughfare dividing Parliament House from the sprawling government works offices. And to the south-east, the encroaching hotchpotch of buildings of the Queensland University of Technology dominates the scene and magnifies the congestion. Only the north-eastern side retains the sanctity of the original conception, where the main foyer overlooks a courtyard containing the state's emblem leading towards the city Botanic Gardens. 


\section{Within Parliament House}

The original 'old House' contains the two legislative chambers-both rectangular and equal in size. The dark-green Legislative Assembly chamber was spacious when the number of members was fewer (initially accommodating 26 in 1862 and increased to 32 in 1868, but then climbing to 82 members after 1971). Since 1985, the Legislative Assembly has consisted of 89 members and they still deliberate under an old Moreton Bay colony clock located over the bar of the House. ${ }^{4}$ The state's coat of arms, hand-crafted in local timber, resides over the Speaker's chair in the Assembly. Tiffin had originally proposed that a sculptured sheep's head should grace the Speaker's chair in recognition of the colony's main primary industry, but this proposal was not adopted lest the Speaker was ridiculed as a 'mutton-head'.

The layout of the Chamber has changed considerably over the years. Whereas debate once took place over central tables dividing two rows of elevated open benches on each side, the Chamber more recently is structured around a U-shape away from the Speaker's chair with members allocated in benches of threes each with individual desks and microphones. Members address the House from their own seat, not from a central rostrum, and can request a lectern stand for their notes. Although the effect from across the floor is like a goldfish bowl, the spectacle from the second-floor public gallery is often disappointing, with few seats offering a complete view of proceedings. Internal television cameras monitor debates and proceedings but must continually scan the benches to provide coverage. When filled, the Chamber provides an intense battleground: a combative debating forum in the best tradition of adversarial Westminster politics. Although critics often claim that Australian lower-house chambers resemble 'bearpits', the atmosphere of the Queensland Legislative Assembly has a special quality often lost in more spacious or less combative legislatures.

This live atmosphere is not necessarily evident from reading past parliamentary debates in Hansard, the daily record of parliamentary debates. Under Standing Orders (the rules of the Parliament), members were once not permitted to read written speeches out aloud (although sometimes this was not enforced and members still read their speeches verbatim). Members, speaking from notes or from memory in the House, are, however, in danger of rambling or meandering, losing coherence, becoming repetitious or generally stumbling along. Their speeches might be delivered while a rowdy argument is raging in the Chamber, where the person speaking often becomes sidetracked by interjections and

4 The clock in the Assembly (and a duplicate one in the former council chamber) was made by Baynes of London. It carries the inscription 'London and Moreton Bay' - the latter the name of the Brisbane district in the convict period. The clocks were originally located either side of the flogging posts outside the Queen Street prison barracks. 
catcalls. Some speeches might be intensely passionate if not always grammatical. In a state once not known for its educational prowess, many members often displayed major problems with syntax or expressed their ideas unclearly. Yet, the assiduous parliamentary reporting staff usually took great pains to ensure that the contributions of members were clear and meaningful for the historical record (although their professional ethics prevented them from changing the meaning of anything expressed in the Chamber). Nonetheless, as a historical record, Hansard does give a somewhat sanitised impression of the character of real debates.

Across from the Assembly lies the old Legislative Council chamber resplendent in its gold and crimson oak-leaf decor. The council chamber has enjoyed better days, although it is still perhaps the most impressively decorated room in the Parliament (since its refurbishment). The chamber now boasts a commanding pair of Waterford Irish crystal chandeliers suspended from an ornate gold-leafed ceiling (replacing an old gas light). The president's chair, situated under the royal coat of arms, was a personal gift to the colony from Queen Victoria, who had named and commissioned the colony with Letters Patent in 1859. Since the Legislative Council was abolished in March 1922, the council chamber is rarely employed for formal occasions. The Governor opens each session of parliament from the council chamber, and recently some parliamentary committees have held hearings there (including occasional Commonwealth parliamentary committees when hearings take place in Brisbane). Joint-party meetings of the Country and Liberal Parties were also once held there. Since 1994, parliamentary estimates committees have begun to quiz ministers and departmental staff in the Chamber. The council chamber is, however, more regularly used for parliamentary social and ceremonial functions and for informal gatherings, including various events organised by voluntary associations and community groups, speech nights, fashion shows, school visits and guided tours, and an occasional television debate. Some members have also been known to use it for a quiet repose or as a place to relax if 'tired and emotional' during latenight sessions of the Assembly - some attracting the odium of party whips and leaders if they miss crucial divisions. Paradoxically, the council chamber could be used more frequently even than the working assembly.

As a unicameral institution, Parliament House is really used by government only when the Parliament is sitting - on average about 60 days a year (see Votes and Proceedings; Coaldrake 1989:65-6, 173 for a historical table of sitting days recorded). Ministers and whips have personal offices adjacent to the chambers (on the north-western side) but use these facilities only when the Parliament is sitting (and they are overcrowded by advisers and support staff when occupied). The rest of the time these facilities are rarely used. Queensland ministers all have plush ministerial offices in their own departments and do not need to 
attend the Parliament outside sitting times. The Speaker has an office in the 'old House' and personal quarters in the annexe - and with the assistance of support staff, maintains a continual schedule of official engagements and duties. When the Parliament is in session, the political parties tend to hold caucus or party meetings in the building (often at the beginning of each sitting week), and opposition parties usually tend to enjoy accommodation in the parliamentary annexe throughout the year. The standard of accommodation and the number of staff provided by the government to opposition parties have been a contentious grievance in the Queensland Parliament for some decades (see The Commission 1991:R6).

New members used to receive a brief induction from officers of the Parliament (the Clerk, committee secretaries, the education and protocol office, administration and the library staff) but after that were left to their own devices. One former member once quipped that the whips 'showed them where the dunnies were and left them alone'. Since 1998, a comprehensive new members' induction program, now running over three days, has been provided. The Parliamentary Library offers a personalised service to members and provides research assistance on a confidential basis including reference help, assistance with speeches and collection of statistics and background information. The library also conducts its own research and produces reports and occasional publications. Some members make arduous demands on the library; others do not and rarely venture in. Since the late 1990s, the library has tended to produce and distribute much of its work electronically, but members generate an enormous amount of preparatory and referencing work, as indicated in the Parliamentary Services annual reports. On the floor below, the old Strangers' Bar was once well patronised when the Parliament was sitting and was popular with journalists, backbenchers, ministerial staffers and the occasional academic. More recently, however, the Strangers' Bar has been closed and refurbished into a coffee/bar lounge. For a while it was called the 'Bellevue' in memory of the famous nineteenth-century hotel that sat opposite the Parliament and which was demolished by the BjelkePetersen government in 1979, but it has reverted back to its old title.

\section{Parliament and its operations}

To constitute a new parliament, the Governor formally initiates the electoral process enabling the people to elect representatives. The Governor, acting for the Sovereign, issues a writ (or letter of summons) for all electoral districts. After the issuing of the writ, a minimum of 26 days (and maximum of 54 days) to polling day is provided - although the real 'election campaign' may be either longer or shorter than this period. After the election, the results are tallied, confirmed and the representatives declared, and the writ is then returned. 
Parliament is summoned to meet by the Governor issuing a commission and, in consultation with the party holding the majority of seats or commanding the majority support, the Governor announces a date for the new Parliament to assemble. The Governor's proclamation conventionally sets the date for the new Parliament to be convened about one month hence, with all parliamentarians conventionally assembling on a Tuesday at llam to take their oath of allegiance (or affirmation) and elect a speaker. The Clerk of Parliament informs members of the summons to attend the new Parliament.

The Governor's commission empowered three commissioners, all of whom were usually (or about to become) senior ministers, each sworn in by the Governor, to conduct the procedures necessary to inaugurate the new Parliament. Technically, only the Crown can assemble the Parliament, although the British Parliament has in exceptional circumstances assembled itself on its own authority. After the Clerk announces the proclamation summoning parliament and lists the members returned at the election, the three commissioners swear in the other members of the Assembly individually. The Constitution of Queensland Act 2001 provides for either an oath of allegiance or an affirmation to be made to the Sovereign, and an oath of office before each member signs the Roll of Members. Members must swear or affirm the following oath of allegiance or affirmation:

I...[full name] do sincerely promise and swear (or, for an affirmationdo sincerely promise and affirm) that I will be faithful and bear true Allegiance to Her (or His) Majesty...[name of Sovereign] as lawful Sovereign of Australia, and to Her (or His) heirs and successors, according to law; and I will well and truly serve the people of Queensland and faithfully perform the duties and responsibilities of a member of the Legislative Assembly to the best of my ability and according to law. So help me God! (or omitted for an affirmation).

As the original preamble to the oath assumed all members were male ('No Member to sit or vote until he has taken the following oath of allegiance'), the Electoral and Administrative Review Commission (EARC) recommended in its 1993 review of the Queensland Constitution that this clause be revised into non-gender-specific language while simplifying provision for either oaths or affirmations. Since 1994, the Clerk of the Legislative Assembly has been granted the power to swear in the Members of Parliament. This change was made in order to place a little symbolic distance between the Parliament and the executive. New members taking an oath through ministers of the Crown certainly reinforced the notion that the Parliament and the executive were closely melded in Queensland.

The first official duty of the duly sworn-in representatives is to elect a speaker to act as the 'spokesperson' and preside over the business of the House. The 
selection of the Speaker can be a political and tortuous process, particularly if there is some dissension among the parliamentary majority about who should fill the office. The vote for the Speaker is taken on party lines - often with the vote 'whipped' (that is, a disciplined party vote). Generally, the government side will meet beforehand and preselect a candidate hoping that only a single nomination is made and accepted. If this happens, the successful member 'nominated will be called to the Chair' of the House (Standing Rules, no. 39). It is not uncommon for the opposition or minor parties to nominate a non-government member, but typically these candidates lose to the government's numbers. On rare occasions, rival candidates both from the government side have vied for office, each hoping to be elected by combining their own support base with opposition support. For example, in 1972, two Country Party members stood for the speakership, one preferred by the Premier and most of the party room, and the other with support from some backbench dissidents. They split the governing party's vote and the government's preferred nomination was not successful. The vote for the Speaker is not by a show of hands in the Chamber but each member has a personal vote that they make to the Clerk. One of the problems with this process was that the election conducted by the Clerk took place at the front 'table', which meant that it was not entirely a secret ballot because votes could readily be seen by other members or by visitors and the local press in the galleries above the table. Within the present-day culture of party discipline, members could feel constrained to vote for an endorsed candidate when votes are required, rather than according to their own assessments of the best interests of the Parliament as an institution. Put differently, the government may use its numbers to elect an accommodating party worthy in place of an independent and vigorous candidate.

The Clerk of the Parliament attempted to chair the Assembly during the period when a speaker was being appointed. As chair, the Clerk was not in control of the House but could only point to the next member to speak (who could speak for as long as he or she wished). Until the Standing Orders were altered in October 1989, few procedures constrained the debate pending the election of the Speaker; this led to meandering polemics, frequent character assassinations of people inside and outside the House, occasional verbal abuse and much bellyaching. The independent MP Tom Aikens frequently used these intervals to attack the judiciary, police, doctors, academics and anyone else who came to mind. In later years, the rules governing the debating time for members before a speaker is elected have been tightened, requiring that debate 'shall be relevant'. Once chosen, and after being 'dragged' to the chair by other members, the Speaker-elect is presented to the Governor at Government House, traditionally by the three commissioners (and later by senior ministers) and any other members wishing to accompany the delegation. 
The ceremonial opening of each session of parliament begins with the Governor's speech, given in person in the Legislative Council chamber (see Chapter 5 for further details of the content of these opening speeches). Because the Sovereign (or their local representative) traditionally does not enter the lower house, a written copy of the speech is provided to the Speaker of the Assembly, ostensibly 'for greater accuracy'. The speech, written largely by the government, traditionally lasts for 45 minutes to one hour and includes a record of state progress, a survey of recent projects and undertakings, budgetary losses or surpluses, statistical information concerning growth and government activity and an incomplete list of the government's proposed legislative program for the new session. The proposed list of legislation may indicate what the government intends to introduce or indicate its chosen 'highlights'. Often important pieces of legislation were not mentioned, perhaps because the government preferred not to disclose its intentions early, or possibly it had not finalised the legislative provisions or in some cases, it had not yet even conceived of the need for new legislation. On policy content, the speech can record the minutia of operational decisions (such as cactus-clearing projects in Collinsville, irrigation channels at Mareeba, a bitumen road to Mossman or a new maternity hospital for Kingaroy). Mostly, the Governor's speech provided the government with a propaganda opportunity, and considerable state-wide or local 'boosterism' was usually injected for popular consumption. Each year certain phrases tended to make regular appearances, such as 'has never been surpassed' , 'rarely ever equalled', 'the first ever', 'pleased to report' and 'debt of gratitude'. The opening of the third session of the thirty-eighth Parliament in August 1968 reached new heights of self-congratulation when the Governor ventured that

those who know our history well cannot but be overwhelmed with admiration for the magnificent people in all walks of life who have gone before us to establish this State, to nurture and advance its people, to secure its democratic traditions and practices, and protect it at all times...So, as Honourable Members take their seats in this chamber for another century of responsible parliamentary endeavour in the interests of Queenslanders, they have sure, firm foundations upon which to build and can set a ceiling height of their own selection. (QPD 1968:vol. 249, p. 2)

After the Governor's speech, the sitting is adjourned to the next day and the members enjoy a ceremonial garden party with the Governor. The next day, the House proceeds with any necessary housekeeping such as the appointment of temporary chairmen, ministerial statements or changes to the ministry, information to the House concerning other parliamentary positions on both sides, such as the whips and deputy whips, party secretaries and the Leader of the Opposition and any papers to be tabled or ordered to be printed. Any 
motions of condolence for deceased members are carried and reported in the proceedings. The debate on the Address in Reply (from the Assembly as a whole back to the Governor) then begins, with two incoming government members initiating debate usually reciting more propaganda and approbation for the government. The opposition then has the opportunity to respond through the Leader of the Opposition and other senior opposition members. They tend to focus on the performance of the government as a whole, on individual ministers and on contentious or badly managed issues. The Address-in-Reply debate lasts for between seven and 10 full sitting days unless the Parliament decides otherwise, and it provides opportunities for new members to make their maiden speeches.

A typical day in the Parliament begins with prayers, notification of any assent to bills, followed by any petitions and the tabling of any government papers or annual reports (including announcing any deemed to be tabled during a recess of the Parliament). These are essentially housekeeping matters. Ministers then have the opportunity to make statements on any topic relating to their portfolio likely to be of interest to the Parliament, and these often relate to continuing business or specific questions or matters of public concern. Ministers have tended to use ministerial statements to announce policy decisions but avoid debate, as there is often no immediate reply granted to the opposition (there can be if the minister moves 'that the House takes note of this statement').

The main interest of the day for the media and those attending the public gallery usually centres on question time, when any member (alternating between opposition and government) can ask ministers questions. Historically, two types of questions have been permitted: first, questions upon notice (for which, decades ago, members had to provide written questions to the Speaker before the sitting day and the Speaker would grant those considered appropriate). These questions upon notice generally provided some advanced warning to the government to allow ministers sufficient time to prepare their responses (most being answered on the next sitting day). Indeed, opposition members sometimes complained that questions they had listed to ask appeared in the press answered by the government before they were asked in the Chamber (see QPD 1970:vol. 254, p. 78). Some ministers also insisted through to the early 1970s that questions conventionally had to be 'on notice' and written and presented to them before they would deign to answer them from the floor of the Chamber. Questions without notice (to the Speaker) occurred very rarely in the late 1950s and there still appeared to be a practice of providing the minister concerned with the written question beforehand. Questions without notice were permitted from August 1970 under the sessional orders of each parliament and authorised more regularly from 1983 under the parliamentary Standing Orders. During the period of this history, however, questions without notice were still quite rare as the 
government and speaker continued to insist that intended questions be written down and presented to the Speaker beforehand. In more recent times, questions without notice may be asked from the floor of the Assembly by catching the eye of the Speaker, although certain protocols and an approximate order are still observed. These questions are asked without prior warning of the topic to the relevant minister - a tradition observed in practice only by the opposition members. Government members also may ask questions but these tend to be rehearsed 'Dorothy Dixers' usually prepared by a team of political advisers and shown to the ministry beforehand. Such lame questions typically seek 'good news' responses from selected ministers and, some would argue, tend to be a discreditable waste of the Parliament's precious time. Members were, however, permitted only two questions on any sitting day. These could be supplemented with written questions on notice - to be answered by ministers and their staff within 30 days. Members may also ask questions of any other member (who is not a minister) provided the question relates to a bill, a motion or a member's specific responsibility for a 'public matter connected with the business of the House'.

Question time lasts no more than one hour and on specific days must finish by noon (for example, when matters of public interest are being discussed or the Address in Reply is debated). This is followed by the formal 'Orders of the Day', which consist of government business (proposed bills or other matters of interest to the government). Members may also propose a matter of public importance by writing to the Speaker (but not less than one hour before the House meets on sitting days), who, if sufficient cause is given, can allow the House's order of business to be delayed while the matter is discussed. There is a time limit on such matters of public importance and ministers (usually the Leader of the House as the leader of government business) may gag such matters at any time by moving '[t]hat the House do pass to the next business' (Standing Rules and Orders, 1995, no. 137).

Opportunities for questioning government ministers, airing grievances and debating issues of public importance are significant components of the Parliament's role in the political system. It can appear to an observer that a grievance debate or question time is bluff and banter, but the right to challenge the government, criticise, propose alternatives and raise concerns is a fundamental right in parliamentary systems. To guarantee debate and the exchange of views, the quorum or minimum number of members required to be in the Chamber at any time is only 16-a figure unchanged since the nineteenth century, although the EARC recommended in 1993 that this be increased to 23 (a recommendation not as yet implemented).

The legislative process is one of parliament's operational functions. Legislation is introduced (almost exclusively by government ministers) after being drafted 
by the Parliamentary Counsel in consultation with the relevant department. Parliament considers the bill according to conventional practice, which subdivides consideration into a number of discrete stages or 'readings'. Although called 'readings', the bills are no longer read out in full to the Parliament but written copies are provided for the perusal of members. Usually the bills were presented to members before the debate began, but occasionally not (for example, the 1965 Thiess Peabody Mitsui Coal Pty Ltd Agreements Act was presented to the Parliament before it was even printed, let alone circulated to members, and the Aurukun Associates Agreement Bill 1975 was initiated six days before the opposition was allowed to see the text; see Courier-Mail, 14 April 1976). Sometimes allegations were made by opposition critics that the press had access to bills well before they as parliamentarians did.

The minister responsible for the legislation usually introduces the bill. During most of the period of this history (before 1980), the Parliament would engage in a 'first reading debate' at which the government would justify the need for the bill and defend its clauses, but the opposition would have no time to digest the bill or prepare its case (the Leader of the Opposition would often initiate a reply). The old first reading debate was often regarded as a pointless exercise. In 1973, the governmental parties proposed to eliminate the first reading debate but this did not get through the Standing Orders Committee. Since 1980, the first reading has consisted of the title of the bill being introduced by a motion from the relevant minister, who would then proceed directly to the 'second reading', which outlined the rationale for the legislation. At this stage, the debate would be adjourned and no immediate debate would follow. The debate on the bill would be resumed some days later after the opposition (and government members) had had time to read and think about the bill's content. Hence, the main debate on the bill now takes place in the second reading stage when not only does the minister present the government's reasons for introducing the measure, he or she outlines the principles and purposes of the key provisions. At this stage, the Parliament then debates the merits of the proposed legislation and the opposition has the opportunity to criticise the principles of the bill. Throughout the period covered in this history, members discussed the legislation as a 'Committee of the Whole' (that is, without the Speaker in the chair and with all members present rather than a specialised committee process). In 'committee', members could propose changes to the details of a bill and debate the bill clause by clause. The opposition (and any other member, government or independent) then had an opportunity to comment on the bill (but often at short notice since usually they were given the bill only a matter of days before it was discussed). At the second reading stage, members then could endorse, criticise or propose amendments to the provisions. The relevant minister would then provide responses and answer 
questions (accepting or rejecting any amendments). The final 'third reading' was usually only perfunctory but provided the last opportunity for the Parliament to reject the bill (which was unlikely if it had passed the second reading).

If passed (with whatever amendments were agreed to, including any the government might move), the legislation then proceeded to the stage of royal assent (authorisation by the Crown - usually the Governor, except in rare cases when bills were reserved for the signature of the Sovereign). Since 1986 and the Australia Act, bills are rarely reserved for assent by the Monarch but are instead assented to by the Governor. After receiving assent, an act will generally be proclaimed on a date fixed by the legislation and announced in the Government Gazette. With sufficient urgency and the use of guillotine tactics (cutting short debate by closure motions), legislation can be passed through all three stages in one day.

Another of the Parliament's main functions is to appropriate expenditure and authorise proposed budgetary expenditure required by the government for the year ahead. Appropriation bills are necessary to secure funds (taxes and charges) to enable the government to function. These now are aligned with the financial year (that is, they are presented and passed before the start of the budget year). Previously, supply bills were required to allow the government to function before its budget was passed. The Treasurer presents the annual budget documents and financial statements in the budget session of parliament (previously they were presented at the beginning of August but since 1994 this has usually been brought forward to May/June so as to be passed before the financial year starts). Budgets outline the government's priorities shown in terms of planned expenditure and revenue projections for the year ahead. From the 1950s to 1993, budget estimates were scrutinised only by the Parliament acting as a Committee of the Whole (that is, not scrutinised by separate specialised estimates committees) and usually debating only the estimates from a few selected departments. Budget debates were thus historically very general and largely ineffectual. Since 1994, a system of estimates committees has been adopted, whereby the proposed expenditures of each portfolio are examined by one of seven committees in public hearings.

\section{Offices and positions of the Parliament}

\section{Governor}

The Sovereign as head of state, and represented by the Governor, constitutes a formal part of the Parliament. The Governor, however, usually takes part only in ceremonial parliamentary functions and in performing ceremonial duties in 
giving the assent to legislation. The Governor nevertheless is a formal figure of authority. The role and duties of the Governor were inherited from Westminster conventions and in some cases codified in specific legislation. In the early days of Queensland's history, the Governor was a powerful figure with significant decision-making powers and the capacity to make personal appointments (including even to the Legislative Council). Today, these substantive powers have passed almost entirely to the executive with the Governor maintaining a nominal but formal role. The Crown (rather than the people) still summons the Parliament to meet and dissolves the Parliament when necessary. The Governor commissions ministers (usually twice, first as portfolio ministers with areas of responsibility and second as members of the Executive Council) and may dismiss them or replace them subject to advice, election results or the confidence of the House. Governors may, under extreme circumstances, exercise reserve or original powers and dismiss ministers without advice (for instance, if a premier or minister is corrupt or acting illegally).

The Governor is a member of the Executive Council—-formally a council of senior ministers advising the Crown in relation to executive decisions but subject and accountable to the Parliament (that is, the doctrine of parliamentary sovereignty is supreme rather than crown sovereignty based on the divine right of kings). Governors are, however, typically not part of the deliberative or decisionmaking process of the executive. They serve as both a final stage of approval and a formal authorisation of decisions. Conventionally, the Governor takes the advice of the Chief Minister (Premier) and the Executive Council, but may take advice from others (for example, the Chief Justice or opposition members). The powers of the Governor were clarified and entrenched in the Constitution Act Amendment Act 1977, in which it was provided that the Governor was not subject to the direction of any one source (for example, a premier) and was not limited in terms of sources of advice but may consult whomsoever he or she wished.

Government ministers are ministers of the Crown and act under the authority or in the name of the Governor, but generally the Governor is neither involved nor informed unless final consent is formally required-even with legislative powers delegated to the Governor-in-Council. Such conventions do not prevent the Governor being more actively involved-asking questions, seeking advice or requesting to be informed by ministers or other officers. The danger in the Governor being more activist is that the office of Governor may tend to become more political, whereas conventions of constitutional monarchy hold that the representative of the Crown should remain above political matters and any close involvement in specific decisions (hence the Crown cannot be blamed for decisions or actions but ministers and governments can). In recent years, some 
governors have requested regular briefings from ministers about government policy and intentions and these have been provided even though such behaviour could establish new conventions.

Over the period of this history, the office of the Governor has been enmeshed in five evolving points of controversy: whether appointees should be British or local; whether male or female; what powers they should exercise; whether they should speak out; and whether the position should remain imperial, become republican or be abolished altogether. In the 1950s and early 1960s, the issue of whether governors should be British or Australian attracted debate, with the opposition Labor Party advocating strongly that only Australians should be appointed. Opposition Leader Jack Duggan's Address-in-Reply speech (QPD 1962:vol. 233, p. 73) congratulated the British-born Governor, Sir Henry Abel Smith, on his reappointment to a further four-year term but noted that if British appointees were to be asked to be state governors then a 'reciprocal arrangement' should be devised so that Australians could be appointed to other parts of the realm. Since Abel Smith's term ended in 1966, all subsequent Queensland governors/administrators (Sir Alan Mansfield, Air Marshal Sir Colin Hannah, Commodore Sir James Ramsay and Sir Walter Campbell) have been born in Australia - until Leneen Forde, who was Canadian by birth, but related by marriage to Frank Forde, a former Australian Prime Minister. Her successor, Major-General Peter Arnison AC, was also Australian born. Second, the gender of the Governor increasingly became an issue - especially in the 1980sculminating in the appointment of the first woman Governor, Leneen Forde AC, in 1992. Forde was not only the first woman to hold the job, she was the first non-imperial titled Governor since 1877. The Beattie government appointed a second woman, Queensland-born Quentin Bryce AC, to the position in 2003, after initially suggesting the government would hold a democratic election for the Governor's position. The third successive female Governor, Penelope Wensley AO, also a Queenslander by birth, was appointed in 2008.

Third, the question of whether governors should speak out or make partisan statements became an issue after Sir Colin Hannah (a Bjelke-Petersen appointment) made statements critical of the federal Whitlam government in the mid-1970s (see Chapter 10). His comments were perceived as breaching conventions requiring the Governor to refrain from political comment. Although the government moved to reappoint the Governor to a further term, the move was considered controversial.

Fourth, periodically the scope of the Governor's reserve powers has come into question, usually in circumstances in which the Governor was faced with instability in the Parliament (for example, the Coalition crisis in 1983, the removal of Premier Bjelke-Petersen in 1987 and the close election or tied outcome of the Parliament in 1995-96). And fifth, increasing questions were 
raised about whether the office of governor was in fact needed at the state level, or whether as part of the wider republican movement, state governors could be either replaced by some form of president (state or national, elected or appointed) or indeed abolished as a head of state and with the relevant duties given to the Speaker and possibly the Chief Justice.

\section{Speaker}

The Speaker is ranked the most senior Member of the House and performs three main functions (other more historical and normative accounts of the roles of parliamentary officers are included in Lack 1962). The Speaker acts as the spokesperson for the Parliament and represents parliament to the Governor or Queen (and other bodies). He or she serves as the presiding chair over the debates in the Legislative Assembly (enjoying a casting rather than deliberative vote on some matters). The Speaker is also effectively the 'Minister of Parliament' responsible for the Department of Parliament as a functioning public service agency and is assisted by a Deputy Speaker (also called 'Chairman of Committees'), who takes the chair at the discretion of the Speaker (also temporary chairs from both sides of the Chamber are available as reserves). Each new parliament elects or re-elects a speaker who, once elected, is appointed to officiate at the summoning of the Parliament. Since 1978, the Parliamentary Mace has become the symbol of the Speaker's authority from the Crown. The Queensland Parliament adopted the mace only recently, in 1978, and before that (as in most colonial parliaments), the Speaker's warrant was the basis of authority and the Parliament's privilege. Made in Birmingham, in the United Kingdom, the Queensland mace was presented to the Parliament by the 'Government of Queensland' whose name appears on the head of the mace across the base of the crown. According to the Premier at the time, Joh Bjelke-Petersen, this mace would now represent the authority of the Parliament and remind the Parliament of 'the importance to democracy of a supreme Legislature to which the executive branch of government is fully responsible' (QPD 1978:vol. 276, p. 3049). Today, the mace is carried before the Speaker by the Sergeant-at-Arms to open the Parliament and at the beginning of each sitting day. The mace sits in brackets on the centre table, representing the authority of the Speaker. If the Speaker deliberately removes or withdraws the mace for any reason (other than that the House has resolved itself into a 'Committee of the Whole House') then the Parliament is technically adjourned and no longer sitting.

Traditionally, the Speaker was charged with the full authority of the Parliament and with being impartial in relation to the debates and proceedings. As in other Australian jurisdictions (and unlike Britain), however, in Queensland, the Speaker does not resign from his/her political party and does not refrain from partisan politics outside the chair of the Chamber. Indeed, speakers may 
vote on issues (including gag motions and adjournments) when votes are tied, and the Speaker as an ordinary member may vote on issues when the House is in its Committee of the Whole mode. Moreover, governing parties select their preferred candidate for the job and thus far since the advent of modern political parties no speaker has come from the opposition side. Candidates for speaker are often senior party identities who narrowly missed out on the ministry, rather than adherents committed to an independent Parliament. Parties and members often regard the Speakership as one of the spoils of office, with ministerial salary and perks and a much less onerous set of responsibilities than a ministerial appointment. This has meant that the job of speaker tended to be viewed as simply another 'prize' to be enjoyed by one of the government worthies, and often in the past by someone not likely to give offence to the Premier or ministry (see Coaldrake 1989:69). The dilemma in this situation is that the Speaker may have little real independence from the party or government and may find in the House that their authority can be undermined or questioned by strong premiers or others of the executive. Any member can challenge a speaker's ruling by appealing to the House, although in practice it is mostly the opposition that resorts to this. Governments usually support the Speaker's ruling as a matter of course, but if a number of Speaker's rulings were overturned by votes of the House this could indicate a loss of confidence in the presiding incumbent. Some speakers - most notably Jim Houghton (1974-79) — attempted to reinvigorate the role of the State Parliament, but others have presided over its enervation or were blissfully ignorant of their responsibilities in office. Selwyn Muller, Speaker from 1979 to 1983, once ventured that in his opinion, the Speaker's role was 'to apply the wishes of the government he represents' (Charlton 1983:90; Coaldrake 1989:70).

The equivalent position to the Speaker in the upper house, the President of the Legislative Council, was abolished in 1922, as was the Clerk of the Legislative Council and Usher of the Black Rod. The Usher of the Black Rod was drawn from Westminster traditions where the position was a personal appointment of the Crown whose job was to act as a messenger and escort the Monarch when visiting the Parliament-including knocking on the door of the lower chamber to summon representatives. Queensland's black rod, unused since 1922, is preserved in a glass case in the foyer between the two chambers, but has no formal use.

\section{Leader of the House}

On the government side, the Leader of the House is responsible for the order, organisation and arrangement of government business through the House. Any changes to the program of business on sitting days or the daily order of business are in the hands of the government's leader, who is by convention a senior 
minister and often an astute tactician (although non-ministers have occupied this position). The position of Leader of the House was established in the mid1970s during the Bjelke-Petersen era, because the Premier preferred to entrust the business of the House to a senior minister rather than to the whips as had occurred previously (Reynolds 1997). More recently, the House leader is also the chair of the Parliamentary Business and Legislative Committee of cabinet, which decides the order and priority of government legislation (and may discuss tactics for presentation). The smooth passage of the government's business through the Parliament is the responsibility of the Leader of the House (and not the Speaker). The Government Whip and Deputy Whip assist the Leader of the House with tactics, agendas and the listing of speakers for topics. Whips also have the responsibility of ensuring members are in the House for divisions and votes, ensuring that sufficient members from their side are in the Chamber for debates and, in the case of the government, maintaining a quorum. Whips also serve as the 'number-crunchers' within the party room or caucus and act as 'sensors' of backbench feeling towards the party leadership (and frontbench).

\section{Parliamentary opposition}

The Loyal Opposition has both formal and potential parliamentary roles. It is there to scrutinise government performance and hold the government accountable for its actions or inactions. It is expected to ensure that government members, and especially ministers, are held to account and act with honesty and integrity. The extent to which the opposition has the potential to fulfil its expected scrutiny role is, however, often limited because it might not be able to make much headway against the government numbers in the House. The other role for the Loyal Opposition is in preparing itself for government - as an alternative ministry. It should use the time in opposition 'schooling itself for the responsibility of office when its turn comes to carry on the Queen's government' (Queensland Treasury 1982:21). Shadow ministers are expected to familiarise themselves with portfolio areas, shadowing government ministers and providing alternative options or policies.

\section{Parliamentary committees}

Parliamentary committees have not been significant during most of the Queensland Parliament's history-certainly not throughout the period surveyed in this book. Indeed, the government was frequently criticised for not adopting more elaborate committee processes for scrutinising areas of expenditure (statutory committees such as public accounts or public works) or specific topics (select committees). The main parliamentary committees during the 1950 s to 1980 s were 'house committees', looking after member facilities 
and the Parliament as an institution, such as: the Standing Orders Committee, Library Committee, Refreshment Rooms Committee, Parliamentary Buildings Committee and Printing Committee. These committees did not examine wider spheres of government administration nor did they undertake an onerous internal workload; the Standing Orders Committee, although appointed for each parliament, did not in fact meet between 1962 and 1982 (Coaldrake 1989:59). A standing committee to consider subordinate legislation was established in the mid-1970s. Only at the end of the period did statutory parliamentary committees make an appearance (in particular, after Bjelke-Petersen was ousted as premier), and only after an earlier bitter struggle within the Coalition about the lack of parliamentary accountability.

A few select committees (established for a particular purpose but usually lapsing at the end of the parliamentary session) were important during the period of this history. For instance, in 1974, a Select Committee on Punishment of Crimes of Violence in Queensland was established and in 1978 a Select Committee on Education in Queensland was active for a couple of years in reviewing provision and researching curriculum issues.

\section{The Clerk of the Parliament}

The Clerk of Parliament is the most senior permanent appointee of the Parliament and head of the parliamentary staff. The Clerk is, in effect, the chief executive officer of the organisation. The Clerk serves as the manager of the Parliament subject to the Speaker and to the relevant acts governing parliament (and for a short time was also subject to the Parliamentary Services Commission-a tripartite committee charged with overseeing the Parliament in existence between 1988 and 1995; see Moroney 1998). The Clerk's principal duties are to provide advice and guidance on parliamentary matters to the Speaker, the Chair of Committees, the Leader of the House, ministers, the opposition frontbench and other members. The Clerk is the custodian of all documents produced by or tabled in the Parliament and is responsible for certifying the accuracy and authenticity of bills. As the chief executive of the Parliament, the Clerk is in charge of all parliamentary and administrative staff and is the accountable officer for all expenditure. While parliament is sitting, the specific responsibilities of the Clerk are to facilitate the procedural operations of parliament as a deliberative institution: performing functions in relation to standard operating procedures, the observance of Standing Orders, ensuring that the proceedings of parliament are recorded, issuing agendas of daily business as decided by the Leader of the House and authorising the minutes of proceedings. Although two officials sat at the table (the Clerk and another official), in 1992, a Deputy Clerk position was formally created to assist the Clerk with these functions. The deputy sat with the Clerk at the table in the Assembly and was also able to provide advice 
to members. In 1996, the Deputy Clerk's position was abolished as part of a 'restructuring' but was re-established in 1999 (this post was sometimes called the Clerk Assistant or the Deputy Clerk Assistant). The Sergeant-at-Arms is responsible for carrying the mace to and from the table each day the Parliament is in session, although in practice this position was sometimes merged with that of the Clerk Assistant (between 1922 and 1978), and Deputy Clerk Assistant (from 1981 to 1992).

\section{Other parliamentary officers}

Hansard reporters record all proceedings of the Parliament and produce the Queensland Parliamentary Debates (QPD or Hansard), a transcript of the debates, speeches and questions. Hansard is a record of what is said in the Assembly and a specialist stenographic staff transcribes and prepares each volume of debates. The Votes and Proceedings of Parliament once constituted the official record of the Parliament and a record of what was done in the Parliament. The Votes and Proceedings were produced and authorised by the Clerk and the Speaker. Since 2007, the Hansard and Votes and Proceedings have been merged into one record called the Record of Proceedings, which is now a complete record of the business of the Parliament.

The Parliamentary Librarian manages the Parliamentary Library and services the information needs of members. The librarian has to ensure that requests can be handled expeditiously and that the library collection is adequate. A diverse group of other officers form the complement of the Parliament as a working institution, including: the table officers, protocol staff, education officers, property services and catering staff, information services providers, security officers, gardeners and parliamentary attendants, and corporate service personnel from finance to human resource management. The Parliament also relies on a series of other specialised officers based in the executive, such as the Parliamentary Counsel responsible for drafting and advising on the precise form of legislation coming before the Chamber.

In conclusion, the Queensland Parliament might seem an unorthodox institution, with pedantic and at times archaic rules, proceedings and practices. At one level, it is. It should be remembered, however, that the Parliament is a political institution of the people's representatives, who come together to fulfil a number of roles and functions: the adherence to its constitutional responsibilities, the expression of democracy and the representation of the electorate, the formulation of a government (and usually an alternative government), the extent of 'confidence' in that government, the scrutiny and authorisation of legislation, the legal appropriation of expenditures and relevant taxation, the questioning of ministers (and occasionally other members), the debating of grievances and 
matters of public importance, the investigation of all manner of issues of public policy and on very rare occasions some judicial functions. The Parliament is part ceremonial and symbolic, part law-making and law amending. 
Part I 



\section{Parliament's refusal of supply and defeat of Labor, 1957}

By the 1950s, Queensland had already earned the dubious distinction of being ruled predominantly by one party. Queensland was a Labor-controlled stateand seemed destined to remain so for the foreseeable future. Continuity in office rather than changes of government had become the norm. Labor had enjoyed office for almost 40 years since 1915 and had been out of office for only a single term during the Great Depression years of 1929-32. The Australian Labor Party (ALP) began its long reign as a popular party of the people, but over time had seen its electoral support decline. Pork-barrelling and corruption associated with long-term incumbency were readily evident and some celebrated cases of ministerial corruption came to light in the 1950s (Parker 1980). From 1949 onwards, the Labor Party benefited from electoral malapportionment, which advantaged the number of parliamentary seats the party obtained (Campbell 1995). Labor's zonal electoral system enabled it to win the 1950 election, despite being out-polled by the conservatives, although by 1953 and 1956 Labor's support returned, enabling it to win more than 50 per cent of the vote in both elections (Hughes 1980:89-90).

A succession of powerful Labor premiers had stamped their mark on the state and on the character of Queensland politics. Strong and often charismatic premiers were the order of the day, with some - such as T. J. Ryan, 'Red Ted' Theodore, William Forgan Smith (nicknamed 'Foregone Conclusion' because he always got his own way) and Ned Hanlon - achieving mythical status. Premiers ran the state and the political process was characterised by the dominance of executive government. Most premiers had a close connection with the very powerful Australian Workers' Union (AWU), which many argued had long controlled the Labor governments. The Parliament was subordinate to the executive-and, for many Labor cabinets, the Parliament was an irksome appendage to the daily responsibilities of office.

At the 1956 state election, Labor had received 51.22 per cent of the statewide vote and secured 49 seats in the 75-seat Assembly-a very comfortable majority of 23. For the re-elected incumbents, the immediate prospects were ostensibly rosy and their tenure secure despite some internal rumblings within the organisational wing of the Labor Party. In contrast, the Coalition held a mere 24 seats with a combined vote of 44.34 per cent (the larger Country Party retaining 16 seats on just 19.27 per cent of the vote and the Liberals with only eight seats from 25.07 per cent). The impact of the 'first-past-the-post' voting 
system tended to inflate majorities and, together with the malapportioned electoral system based on unequal zones, the outcomes inevitably benefited the government of the day. There appeared to be little relationship between the proportion of state-wide electoral support a party received at the polls and the number of seats in fact gained in the State Parliament. Indeed, any close fit was more by accident than design.

The semblance of continuity was, however, dramatically ruptured in early 1957. After 25 years continuously in office, the Labor government self-destructed after a period of intense internal conflict and policy disagreement. The beginning of the end occurred in late February of that year, with an ultimatum given by the party organisation to the Labor government to deliver on a policy promise or face expulsion under party rules; in quick succession this led to the expulsion of the Premier, Vince Gair, from the Labor Party and the resignation of the Deputy Premier, Jack Duggan, from the Labor ministry. Although the ministry struggled on for a few months without the Parliament sitting, the final phase of the events took place in the Legislative Assembly in June when the Parliament was recalled.

\section{The origins and background of the Labor split of 1957}

In the mid-1950s, the Labor Party in Queensland was actively pursuing policies of state development and industrial regulation. Provided economic conditions remained favourable, the Labor government was looking with optimism towards the conclusion of its third decade in government. The Premier, Vince Gair, and his third ministry were sworn in on 28 May 1956. The 11-member cabinet consisted of

- Premier and Chief Secretary: Vince Gair

- Deputy Premier and Minister for Transport: Jack Duggan

- Treasurer: E. J. 'Ted' Walsh

- Secretary for Agriculture and Stock: Harry Collins

- Secretary for Labour and Industry: Arthur Jones

- Secretary for Health and Home Affairs: W. 'Bill' Moore

- Attorney-General: W. 'Bill' Power

- Secretary for Public Lands and Irrigation: Paul Hilton

- Secretary for Mines: Tom Foley 
- Secretary for Public Instruction: George Devries ${ }^{1}$

- Secretary for Public Works, Housing and Immigration: Colin McCathie

Its opponents, the Country and Liberal Parties, were fractured and a little despondent about the prospects of ever forming government in the foreseeable future. The Country Party's leader, Frank Nicklin, had led the opposition for a record 16 years, since June 1941, and by 1957, there were rumblings among his colleagues about his ability to lead the conservative side of politics to victory. Nicklin had presided over the opposition under four consecutive Labor premiers (Forgan Smith, Frank Cooper, Ned Hanlon and Vince Gair). The eight Liberals in the Parliament were an unknown quantity and had recently elected a new leader, Ken Morris (first elected to the State Parliament for the Brisbane seat of Enoggera under the banner of the Queensland People's Party and elected Liberal Party leader in August 1954). Hence, with only one-third of the seats in the Parliament and some disgruntled members anxious to topple Nicklin, the opposition parties did not appear to be a serious threat.

Behind the scenes, though, Labor was wrestling with some fundamental questions of ideology and the issue of internal party authority. With the benefit of hindsight, it is apparent that Labor allowed itself to be dragged into internecine feuding, with many of the leading protagonists taking for granted that they would always enjoy a steadfast grip on government. It is clear from the historical record that no-one within the government or the ALP camp was able or willing to call a halt to the infighting or offer an acceptable resolution to the dispute.

The conflict within the government boiled down to the issues of who controlled the policy decision-making process and what policy decisions were appropriate for a long-term Labor government in the context of the postwar Queensland economy. Issues of leadership style and personality conflicts were also contributing factors. Like many once socialist or democratic socialist parties, the Queensland Labor Party had moderated its policy positions and in government had become a pragmatic and institutionalised administration. Increasingly, Labor premiers and their ministries had steered the government well to the right of the party's earlier socialist-inspired doctrines. And like other parties of the left, the Queensland ALP was composed of two distinct organisational entities, each with different immediate objectives and with different pressures weighing on it: the smaller parliamentary party interested in electoral politics and the extra-parliamentary organisation of the party based on Trades Hall. Those

1 After Foley was expelled from the ALP, Devries became Secretary for Mines and Les Diplock was promoted to Public Instruction. Devries died one year later, on 13 July 1957, while still a minister — one month before the Labor government fell. 
associated with the parliamentary party consisted mainly of the Labor members elected to the Parliament and some supporters and personal assistants - with most of the political influence among this group residing in the Premier and ministry. The extra-parliamentary wing consisted of the party organisation, the powerful 65-member Queensland Central Executive (QCE) of the party and the affiliated trade unions. While there were many issues that the two wings agreed on, by 1957, there was much more that separated them.

The main conflict of the mid-1950s was over the degree to which the Labor government should deliver beneficial industrial policies to its own organisational supporters. In other words, the background context of the dispute could be reduced to different ideological or philosophical appreciations of the role of a working-class government. Would Labor be motivated more by the broader responsibilities of governing the state or remain attached to its original ideals of sectoral promotion? Should a Labor government (the political executive) be made to implement the official policy of the party? In political terms, the conflict became a fight between perceptions of the 'state interest' (sometimes referred to as 'parliamentarianism') and notions of 'class interest' (alternatively known as 'labourism').

The parliamentary or political wing represented mainly the right of the labour movement and they generally believed that a Labor government should govern in the wider interests of the state as they saw them. This group was strongest in the Labor cabinet of Vince Gair. On the left, the industrial wing consisted of the union movement (with the support of some parliamentarians), which tended to display a more militant approach to class politics. Their prime loyalty was to the interests of the labour movement as organised through the Trades and Labour Council (TLC) and they tended to be well represented in the internal organs of the party (executive committee, branches and factions). This extraparliamentary wing believed that Labor governments were elected as workingclass delegates to govern in the interests of their own supporters by transforming labour platforms into state policy. It was not a surprise that many issues on which Labor governments were called to act caused some tension between these two competing orientations to class politics. Usually such tensions were defused or contained, but in 1957 an industrial dispute over the issue of increasing annual leave for the state's workers culminated in the most acrimonious split between these two wings of the party.

The situation in Queensland was not the only contributing factor in the leadup to the rupture. For some years, the Catholic Church throughout Australia had been concerned about growing communist influence in the trade unions; it regarded such influence as a challenge to its own authority in society. Most members of the Catholic 'flock' in Australia were working-class families of Irish or Italian stock. Senior Catholics regarded communist leaders in the unions as 
atheistic revolutionaries intent on social change and industrial militancy. To challenge the communists, the Catholics formed the Catholic political 'Movement' and began to contest control of key unions. In the union movement, these Catholic organisers were known as 'Industrial Groupers' - Catholic agitators who grouped together and formed anti-communist factions. The Movement also hoped to be able to wrest control of the ALP from left-wing and communistoriented leaders. Already in Victoria, the ALP had split principally on the issue of communist control of the union movement and influence in Labor politics. A breakaway faction largely aligned with the Catholic Church had formed the Democratic Labor Party (DLP) in Victoria in 1955.

Fallout from this Catholic-communist struggle in the union movement began to impact on other states, including Queensland, from the early 1950s. In the Queensland branch of the ALP, however, the Catholics were already well represented in the party and in state government. The Premier was avowedly Catholic, as was a majority of his ministry, and many backbenchers in the Gair government were similarly of that faith. Ostensibly, these committed Catholics (and to some extent the Catholic Church as a whole) then wielded enormous influence in Queensland and had nothing to gain from splitting the ALP and forming a breakaway party. Catholics, however, exercised far less influence in the union movement although they were represented in some key unions such as the AWU. The leader of the AWU, R. J. 'Joe' Bukowski, had been a long-time opponent of communist influence in the union movement and had been active in supporting early Movement activities in Queensland aimed at 'cleaning out' communist sympathisers from union positions - especially in provincial Queensland and the sugar industry. There was also a longstanding feud between the AWU and the left-wing TLC unions dating back to the 1920s.

The immediate politics of the situation also played a crucial part. Personalities and personal feuding were other explosive ingredients in the 1957 split. The Gair ministry had governed Queensland from January 1952 and had been comfortably re-elected twice - in March 1953 and May 1956. Premier Gair was gruff and egotistical, and in his political style was often dictatorial and uncompromising, very much following in the mould of his predecessors; but, unlike his predecessors, Gair was the first Labor Premier to refuse to accept the conventional AWU membership and instead chose membership of the Clerks' Union-perhaps as a way of asserting his independence (Moroney 1983:3). Many contemporaries considered him a 'little tin god' who preferred to do things his own way (Galloghy Interview, 1998). His deputy and longterm Transport Minister, Jack Duggan, a non-Catholic, was bright, able and particularly forceful in debate but increasingly troubled by the directions the Labor cabinet was taking - particularly the stand-off between the contending party and parliamentary leaderships. Labor's Treasurer, Ted Walsh, a Catholic 
and firm Gair supporter, was capable and loyal and concerned about holding the cabinet together. Apart from Duggan, all the other ministers would side with the Premier in the eventual schism and oppose the directions of the wider party organisation.

If it takes two to tango, personalities were also important on the extraparliamentary side of the labour movement. The industrial wing of the labour movement (composed of the main Trades Hall unions and the AWU) was the decisive power within the Labor Party. The party's governing body, the QCE, was dominated by strong and forceful personalities from the main unions who had themselves risen through the rough and tumble of union disputes and were used to getting their own way. The two most powerful AWU leaders were Jack Schmella (Secretary of the QCE since 1952 and an ex-AWU officer) and Joe Bukowski (AWU Secretary and President of the ALP since 1956). The Trades Hall group consisted of a more numerous body of union leaders, of whom the most prominent were: Fred Newton (Building Workers' Union), Jack Egerton (Boilermakers' Society) and Jack Devereux (Amalgamated Engineering Union) (see MacGregor 1991:57-60). Even though many of these union leaders had their own differences, they gradually combined into an anti-Gair coalition, coming to the conclusion that 'Gair must go' - a deliberate campaign that, according to one conservative commentator of the day, was 'pursued with a ruthlessness and relentlessness which had obscured in the minds of those responsible the inevitable consequences of their own actions' (Lack 1962:475).

Significantly, all the main protagonists of the unfolding dispute were from the Labor side of politics. Their political opponents were mere bystanders. Both the Country and Liberal Party leaders were entirely marginal in the demise of the government and became significant players only when they were suddenly catapulted into office in the aftermath of the split.

\section{Immediate catalysts of the Labor split}

In the immediate chain of events leading to the split, relations between the two wings of the party had broken down even before the 1956 election. In February 1955, the ALP's federal executive voted to expel the pro-Grouper 'old' Victorian state executive just before the March interstate conference in Hobart. Premier Gair caused some disquiet among the wider Queensland party when he (along with four others of the six-member Queensland delegation) initially attended the ALP's federal convention but then withdrew in protest against the federal executive. As a Catholic with some 'Grouper' sympathies, Gair had opposed the purging of Grouper organisers in the party in February, and then in March tried to have the executive's expulsion of the Victorians reopened at the conference. 
When this failed, Gair led a boycott of the interstate conference and returned with most of the delegation to Queensland. Gair protested against the principle of the 'unconstitutional' expulsion and proposals to begin wider purges of those ALP members with suspected Grouper or breakaway DLP affiliations. For his renegade actions, Gair was subsequently censured by 19 affiliated Queensland unions, although a formal motion of no confidence in his leadership put to the QCE was narrowly defeated. Against such tactics, Gair managed to orchestrate a vote of confidence from his parliamentary colleagues in a Caucus ballot - a tactic he would exploit again in defiance of the executive's position.

In September 1955, the QCE requested cabinet introduce amendments to the Industrial Conciliation and Arbitration Act to allow for three weeks' annual leave (increasing paid holidays by a further week - a policy first adopted at the 1953 convention in Rockhampton). Cabinet considered this request but refused to accede - and indeed voted unanimously to reject the proposal. Gair, in particular, felt that the state could not afford to implement a decision in support of an additional week's annual leave for all workers. This put Gair along with his entire cabinet in headlong collision with the central executive of the ALP (as the Deputy Premier, Jack Duggan, had also initially been opposed to granting the three weeks' annual leave). In November, the QCE again raised the matter and asked the government to reconsider its opposition to granting the additional week's holiday. In January 1956, however, the parliamentary Caucus voted by 30 to 19 to again reject the proposal. Frustrated by the delays and lack of response to its requests, the QCE decided to put the matter to the 1956 State Convention to be held in Mackay in late February and early March (a body that was dominated by the industrial wing of the party). In Mackay, the convention not only passed a resolution to instruct the parliamentary party to implement three weeks' annual leave, it instructed it to do so by a specified time (directing legislative amendments to proceed in 1956 with the provision to apply from 1 January 1957).

As often is the case with state premiers, Gair began to think of himself as infallible and not to be crossed. Once he had decided on a course of action, he began to resent any challenge to his authority. He genuinely felt affronted by the notion that his government was supposed to abide by and implement official decisions taken by the wider Labor Party and labour movement. Instead, he sought to exercise greater autonomy so that the political executive could administer the state as it saw fit and not be subordinate to extra-parliamentary forces. Gair was adamant that, although he was not in principle opposed to three weeks' annual leave, as premier, he could not and would not grant such a request at that particular time. In his defence, he invoked the principle that parliament is supreme and that members should not be 'subjected to outside coercion, intimidation, or direction' (Lack 1962:445). At the Mackay convention, Gair told 
delegates that an emergency meeting of the Labor cabinet had again rejected the 'direction' from the convention. Cabinet regarded such demands as contrary to the philosophy of responsible government in which ministers were subject to the state constitution and answerable to the electorate. In secret conciliation talks after the convention, however, some compromise was apparently reached with Gair and Duggan, which implied that the government would move in the next session of parliament (that is, after the state elections) to introduce three weeks' annual leave (Lack 1962:448).

With the May 1956 election over and Labor returned (helped by some campaign issues such as legalisation of off-course betting and the unpopularity of the federal Coalition government under Robert Menzies), the annual leave conflict quickly resurfaced within the party. Meanwhile, Labor began the new session of parliament dogged by a series of contentious issues, which in turn produced a number of political and 'tactical errors' eventually weakening the Premier's position (Hughes 1956:481-2). A reduction by the Industrial Court to the shearing rate of pay to take effect from 1 January 1956 proved a bloody and bitter battle when the shearers imposed 'black bans' on wool shorn at the new rate. After nine months of the strike, the Premier antagonised unionists by collaborating with the federal Coalition government in stationing troops on Brisbane's waterfront to move wool bales declared 'black' by shearers. This was accompanied by a major rift between the cabinet and the AWU over the Royal Commission into Land Administration involving the corrupt conduct of a Minister of the Crown (the former Lands Minister, Tom Foley), who was demoted in the ministry and eventually expelled from the ALP for his corrupt activities. The AWU paper, The Worker, sparked the scandal by publishing allegations about corruption in the administration of leasehold land. The subsequent royal commission found the minister guilty of corrupt conduct, but meanwhile, a senior public servant, Vivian R. Creighton, was dismissed from his post as Chairman of the Lands Administration Commission for providing information about the case to the union. With some AWU and union support, Creighton appeared before the bar of the Parliament to explain his actions, but cabinet steadfastly refused to reinstate him.

These controversies were followed by further examples of the injudicious use of state power in specific legislation, which, according to Hughes (1956:482), caused the government to lose the 'good will of many middle class supporters of the ALP'. Such legislation included amendments to the University of Queensland Act, which increased government influence over the university and over staff appeal mechanisms, and the contentious Motor Spirits Distribution Bill (see below). Gair also further annoyed the AWU by sacking Dr Felix Dittmer, the ALP Member for Mount Gravatt, from the University of Queensland Senate. 
Dittmer, a one-time staunch supporter of Gair, was sacked because he had supported the industrial wing's attempt to force the government to implement legislation providing three weeks' annual leave.

Such conflicts between the AWU and the government eventually forced the AWU back into the arms of the TLC. Although it had disaffiliated in 1939, it now renewed its affiliation in July 1956 (but then disaffiliated again between 1958 and 1961). It appeared that Gair had foolishly lost the support of the party's industrial wing (and some of the parliamentary wing) and created a united combination of former enemies. In short, there was no single issue that precipitated the split, but a succession of issues and intense personality clashes, which contributed to the final breakdown. As the rift deepened, the rival camps were divided between pro-Gair supporters and anti-Gair opponents. Gair became both the essential and symbolic issue of the split. Religion and ideology were not fundamental catalysts of the dispute. Conflicts between the Catholics and non-Catholics or between communists and non-communists were associated more with the after-effects of the split - consequences rather than causes.

After Labor's Caucus voted on two separate occasions to rebuff the executive's direction to introduce three weeks' annual leave, the Caucus offered to meet the QCE to resolve the issue through a conference consisting of a parliamentary delegation and a subcommittee of the QCE. This token was accepted by the QCE only on the assurance that the other contentious pieces of legislation (the University of Queensland Amendment Act and the Motor Spirits Distribution Bill) be delayed for further consultation. Not surprisingly, by this stage, the appointed conference failed to resolve the issue, but not before relations between Gair and Duggan had irretrievably broken down. During the negotiations, Duggan, who now headed the industrial wing in the Caucus, had broken the convention of cabinet solidarity by revealing to the press that he had opposed the Motor Spirits Bill, claiming that despite being Transport Minister it was introduced over his objections, that it was a 'Gair baby' and was the 'rottenest piece of legislation ever brought down in State Parliament' (Hughes 1956:483; Lack 1962:464). In response, Gair told reporters that cabinet had effectively censored Duggan for his indiscretions and breach of solidarity. In this heated atmosphere, the full QCE moved a motion of no confidence in Gair on 18 April 1957-a motion that succeeded this time by a vote of 35 to 27 . The motion required the Premier to 'show cause why he should not be expelled from the Party' because of his 'defiance' of Labor's ruling body and persistence in refusing to accept ALP directives and rules. He was also accused of breaking 'the pledge which he and all other members of the party are required to sign, and which pledges them to uphold the policy and platform of the party' (see Lack 1962:472). At the QCE meeting, Deputy Premier Duggan voted against the motion - out of solidarity with a cabinet colleague and in an attempt to extend a lifeline to the Premier. 
Gair was not one to take such actions lying down. He countered the QCE's gambit by seeking a motion of confidence from cabinet, which he received on 23 April. The motion of confidence from the whole cabinet was divided into three parts and stated

1. that it has complete confidence in the Premier, and recognises the distinction with which he has led the Party, and his outstanding work as head of the Executive Government

2. that at no time, or on any matter, has the Premier done other than execute the decisions arrived at by Cabinet in accordance with the principle of Cabinet responsibility

3. that, therefore, Cabinet regards as a matter of the utmost gravity the attempt being made to impose on the Premier responsibility for decisions to which we individually and jointly subscribed, and to which we adhere. And, we, the undersigned members of Cabinet, wish it known that any punitive action by way of expulsion, suspension, or otherwise, taken against the Premier will therefore be regarded as having been taken against each Minister individually. (See citation in QPD 1957:vol. 217, p. 44; Lack 1962:473)

All members of cabinet personally signed the motion to confirm their support. Gair's deputy, Jack Duggan, however, in signing his agreement, wrote in the margin 'with the exception of the final paragraph, I agree' - meaning that he was prepared to support the intent of the first two sections of the motion but not the third. This was because Duggan was not prepared to either resign or be expelled personally in the event Gair was subject to 'any punitive action' from the QCE. Some other members of the ministry (such as Ted Walsh) 'pleaded' with Duggan to support the motion fully, reminding him that he was the next most likely leader of the party and that he should stand fully behind Gair. While Duggan was prepared to express his confidence in Gair as premier, he was not prepared to be expelled from the ALP in the event that Gair was expelled. This 'virtually unanimous' endorsement from cabinet was followed later that day by a more qualified endorsement of Gair from the entire Labor Caucus, which expressed 'unqualified support' for the Premier by a vote of 26 to 21 - a very qualified or lukewarm form of support for a serving premier. These votes ostensibly shored up Gair's premiership in his duel with the party executive, and to some extent the level of support the Premier managed to attract came as a surprise to the industrial wing in the QCE. Nevertheless, the signs were already apparent that Gair's days as premier were numbered.

The 'Gair must go' campaign within the Labor Party gathered momentum. Gair was summoned to appear before the QCE to explain his actions and answer a 
list of charges against him. These charges represented a backlog of grievances against the Premier - some of which, taken in isolation, would not have led to his removal as party leader. The final straw for the 'Gair must go' group appears to have been Gair's success in rallying support for his stand in cabinet and to a lesser extent in the parliamentary Caucus. The last charge made against the Premier refers to his 'organising and arranging the issue of a statement by cabinet which is a direct challenge to the Queensland Central Executive and undoubtedly political blackmail of the most vicious type' (QCE 1957 cited in Lack 1962).

Gair attended the QCE hearing on 24 April 1957 and, after a marathon fivehour debate, was expelled from the ALP for 'his continued refusal to accept ALP rules and platform'. Shortly before 8pm, the QCE voted by 35 to 30 to expel Gair. The author of the preceding volume of the history of the Queensland Parliament, Clem Lack, was so incensed at Gair's treatment that he wrote with some hyperbole:

For the first time in the history of democratic government the Premier of a State was placed on trial by a political organisation not responsible to the electorate, and his accusers also constituted the judges and the jury. There was no precedent in constitutional history for such a situation. (Lack 1962:473)

It is a moot point whether the 'Premier was placed on trial', whether Gair as party leader was called to account as a member of the Labor Party or whether there was no precedent to such an action. According to Lack, Gair in his own defence was more appreciative of the tension between two rival commitments. On the one hand, ALP members had pledged themselves to abide by the party's policy and platforms, but on the other hand, Ministers of the Crown had taken an oath of office to administer the state 'in the interests of the peace and welfare of all citizens'. Gair's personal predicament involved the difficulties in attempting to reconcile these competing affiliations when they apparently collided. In Lack's (1962:475) account of his oral defence, Gair responded that

[i]n such a moment of grave choice, [one] had no alternative in conscience. For a moment [party] tradition must be laid aside, as it had so often been laid aside in the times of national crisis, when the welfare of all must precede the welfare of some... How easy, how terribly easy to make the convenient decision, even though it was the wrong decision, and how hard, how terribly hard, to make the difficult decision, even if it were the right decision!

The QCE was unconvinced and with a small majority succeeded in voting for Gair's removal from the party. Gair responded on 26 April by assembling his 
ministerial and parliamentary supporters (totalling 25) and announcing their intention of forming a new Queensland Labor Party (QLP). Duggan was the only minister not to join the QLP. A small group began to draft a constitution and rules for the new party and Gair made it clear that the QLP would not affiliate with the largely Catholic DLP formed in Victoria in 1955.

Deputy Premier Duggan, who had been among the most conciliatory among the cabinet, eventually broke ranks with the rest of his cabinet colleagues and supported the ALP executive's decision. He resigned his portfolio as minister on 29 April rather than side with the 'deviationists' and be expelled from the ALP. The day before, on 28 April, he made a passionate radio address to the public on the ALP-owned radio station $4 \mathrm{KQ}$, in which he made the notorious comment:

There is only one decision to reach on the matter. Whether you like it or not, whether it is wise or unwise, the course to take is to endorse the official Labor decision. That is where Duggan stands - and where every true genuine Labor man stands and will continue to stand. (Hughes 1980:60)

Duggan was later reported to have said that he stood by the party's decision whether it was 'right, wrong, wise or unwise' (Sunday Mail, 1 May 1966). Gair embellished the statement even further, claiming Duggan had said 'sound or unsound, right or wrong, wise or unwise, I shall give effect to the decisions of the QCE' (QPD 1957:vol. 217, p. 31). His political opponents frequently used these deliberate misinterpretations of his words to damage his credibility and undermine his integrity. Hughes (1980:60) has claimed Coalition politicians 'conveniently misquoted' Duggan as saying 'wise or unwise, right or wrong' and, although inaccurate, the phrase subsequently stuck in the public's mind and entered the folklore of the political history of the state. Duggan was also later blamed in some quarters for 'precipitating the 1957 Labor split' because 'he refused to follow his Premier, Mr V. Gair, and his remaining nine cabinet colleagues in bucking a directive from the Queensland Central Executive' (Higgins 1961:15). The accusation that Duggan 'precipitated' the conflict tends, however, to exaggerate his role in the dispute, overlooks his conciliatory attempts and conveniently ignores the roles played by other key protagonists such as Gair and the QCE leaders.

In the immediate aftermath of the expulsion, Gair, as head of a minority government, continued as premier and as the head of cabinet. He replaced Duggan with Tom Moores as Minister of Transport and the Treasurer, Ted Walsh, became Gair's deputy (this was a quirk of fate as Walsh had earlier been deputy leader but had lost the position to Gair after he lost his seat for a term in 1947). The minority QLP government remained in a precarious position, which in effect could be maintained only for a period while the Parliament was not in 
session. When the Parliament resumed, Gair would either lose the confidence of the House and be forced to resign or negotiate some expedient coalition across the Chamber, perhaps with the conservative parties. Gair met with the Leader of the Opposition, Frank Nicklin, on 30 April, but no formal negotiations about a Labor-Country coalition were ever publicly admitted. Nicklin later denied that he had entertained any discussions with Gair about the possibility of exchanging support and sustaining the QLP ministry in office. Stevenson (1985), however, in a political biography of Nicklin, presents some evidence suggesting the 'first impulse' of the Opposition Leader was to assist Gair and that Nicklin's claim that no approach was made to him was false. Stevenson (1985:3-14) found

one item in the Nicklin papers consists of a press cutting...showing which of these [Labor parliamentarians] had joined the Gair and Duggan groupings. One of the annotations is revealing, as it shows one of the options that had crossed Nicklin's mind: 'carry on for a while / endeavour secure something in return for support-union controlled ballots - redistribution'. Sir Gordon Chalk has confirmed that there was a liaison between Nicklin and Gair during which the 'carrots' of courtcontrolled ballots for industrial unions and electoral distribution were discussed. He adds that a coalition between the two was never seriously contemplated.

The federal Country Party leader, Arthur Fadden, a former prime minister and serving Treasurer, also wrote that he had had to counsel Nicklin from joining Gair in a cobbled Labor-Country coalition. Fadden believed that the Country Party's interests would be better served by allowing the QLP government to collapse and for a new election to held in which the two Labor Parties would be at each other's throats.

With questions arising about the capacity of the QLP to govern and maintain the confidence of the Legislative Assembly, the State Administrator, Justice Alan Mansfield (deputising for the Governor), insisted on recalling the Parliament for the purpose of testing whether the government could pass supply. Without supply, the state government would run out of money and would be forced to resign, leading to the formation of a new ministry or more likely to fresh elections. The Administrator issued his proclamation on 14 May in order for the Parliament to be recalled on 11 June 1957; the session lasted but one and a half days before the House adjourned and, on 13 June, the thirty-fourth Parliament was dissolved. 


\section{The supply debate and the downfall of the Gair government}

The second session of the thirty-fourth Parliament was opened on Tuesday 11 June 1957 without much fanfare and without the customary speech from the Governor opening the session. The Administrator merely issued a decree informing the members that 'Parliament has been summoned to meet this day to consider the granting of Supply to Her Majesty and such other matters as may be brought before you'. His Excellency also expressed his desire for the Assembly to 'proceed forthwith to the consideration of the aforementioned business' (QPD 1957:vol. 217, p. 1). Few of the participants expected the parliamentary session to endure for long. Within two days, the QLP government had been brought down by the Parliament's refusal to pass the Supply Bill.

When the Assembly met at noon, there was acrimony and confusion between the divided Labor Parties and an immediate jockeying for position among rival party leaders. After Gair informed the House that Duggan had resigned as Minister for Transport and that Tom Moores had been appointed as replacement, Duggan rose to his feet to inform the House that he had been elected parliamentary leader of the ALP. Duggan was technically the leader of the largest non-government party in the Chamber (having 24 members to the Country Party's 16). At this point, the Country Party leader, Frank Nicklin (as the standing Opposition Leader), raised a point of order, questioning whether Duggan was implying that he should become Leader of the Opposition. The Speaker, John Mann (ALP, Brisbane and a Duggan supporter), initially ruled that according to Westminster conventions, the non-government party with the 'greatest numerical strength in the House' should be the opposition and that where any dispute arose the Speaker would make a 'final and conclusive' determination (QPD 1957:vol. 217, p. 2). Mann then ruled that

in view of the composition of the three parties, namely, the Liberal Party with eight members, the Country Party with 16 members and the Australian Labour Party with 24 members, I have decided that the Australian Labour Party is the party with the greatest numerical strength in opposition to Her Majesty's Government. (QPD 1957:vol. 217, p. 2)

The situation was further complicated by the fact that neither of the party groupings could claim the greatest numerical strength in that both had 24 members each if the conservative parties were counted together. Moreover, if the ALP retained the speakership, the numbers on the floor of the Assembly were 24 to the Coalition and 23 to the ALP. 
The Country Party leader dissented from the Speaker's ruling and, after a set of terse interchanges among the more voluble members, moved an extraordinary motion (all the more so in light of subsequent tensions that developed in the relations between the two conservative parties). It was an overtly political motion designed to split the old Labor ranks and get the Gair ministry to support the Nicklin-led coalition. It also sought to preserve the additional privileges and entitlements of those serving in the senior ranks of the opposition. The motion read:

That this House resolves that the Country Party and the Liberal Party shall be recognised by this House as being, and as having been since the commencement of this Thirty-fourth Parliament, one united party for all Parliamentary purposes, and that the officers notified to this House on 1 August, 1956, as being the Leader of the Opposition, the Deputy Leader of the Opposition, the Opposition Whip, and the Opposition Secretary respectively, shall be recognised by this House as being... the officers duly and properly entitled to the aforesaid offices and any salary, emolument, privilege, or entitlement attendant thereon, and that this Resolution be and be deemed to be an Order of this House within the meaning of Standing Order 333. (QPD 1957:vol. 217, p. 3)

Frank Nicklin and the Liberal leader, Ken Morris, both spoke from well-prepared notes in support of the motion. Duggan opposed the opposition's motion, stating that the ALP was the largest single party and that he supported secretarial aid to each of the main parties to assist them in their work. The ALP's new deputy, Dr Felix Dittmer (Mount Gravatt), argued it was 'unfortunate that, with so many visitors assembled in the galleries, we should have such an unseemly scramble to retain for an hon. member an office to which he is not entitled'. Dittmer felt the QLP government members would not support the motion 'because they will be aware of the damage it must do to parliamentary procedure and prestige' (QPD 1957:vol. 217, p. 7). Tom Aikens (NQLP, Mundingburra) argued that the Assembly had always regarded the Country and Liberal Parties as being one party inside the Chamber - whatever the differences outside the House. He considered that 'we must in all fairness and decency continue to regard it as such' (QPD 1957:vol. 217, p. 11). The Treasurer, Ted Walsh, was 'amazed that so much time should be wasted on determining who should or should not be the Leader of the Opposition' (QPD 1957:vol. 217, p. 13). Towards the end of the debate, Alan Munro (Lib., Toowong), the Deputy Leader of the Liberal Party, claimed that the Coalition was a united entity despite the separate status of the two parties and he confirmed that the parties had fought the previous election campaign under a joint Liberal-Country Party coordinating committee, which 
had 'considerable powers' over 'many material areas at the time of the election' (QPD 1957:vol. 217, p. 15). He also stated that a joint-party coordinating committee controlled the campaign in north Queensland.

The vote on the Opposition Leader's motion was passed after a three-and-ahalf hour procedural debate (at about $3.40 \mathrm{pm}$ ) by 50 votes to 23 . The Country and Liberal Parties in opposition were joined in support of the motion by the government (the Premier and his ministry and other QLP backbenches). Only the 23 members of the ALP sitting in the Chamber voted against Nicklin's motion. The effect of the motion not only reaffirmed the status quo in the Parliament regarding the opposition, it rejected the Speaker's ruling that the ALP was the largest single non-government party. It was effectively a no-confidence vote in the Speaker, but this was not the main game.

After the preliminary skirmish over the opposition, the Premier moved that the Standing Orders of the Parliament be suspended to allow the passing of supply to occur in one day. This was an extraordinary request made in extraordinary circumstances. The usual procedures laid out in the Standing Orders provided for a formal debate over the introduction of the budget followed by up to 17 sitting days of debate over the government's estimates for which the Assembly sat as a Committee of the Whole. In other words, a budget would generally require a minimum of about five to six weeks if the Parliament sat for consecutive weeks; should any non-sitting weeks be included this would prolong the process.

Not surprisingly, the ALP leader, Jack Duggan, opposed the suspension of Standing Orders, calling instead for an immediate dissolution of the Parliament and a new state election. Stung by suggestions from his political opponents that he was merely 'the leader of the deviationist party', Duggan objected to the suspension of Standing Orders to enable the supply debate to be concluded in one day because he felt the QLP ministry lacked the support of the Queensland electorate. He was also fearful that in the event the opposition voted with the minority government to grant supply, Gair would continue in office for some time and have little reason to recall the Parliament once the appropriation had been passed. Duggan defended his objections with some passion:

We meet on what might be correctly termed a momentous occasion. It is an occasion which the people of this State have been following with increasing interest. Over recent weeks tension has mounted regarding this political crisis. Nobody in the Australian Labour Party is gleeful about the position; nobody in the Australian Labour Party is happy that this event has occurred within the party. No-one relishes the prospect of having to deal with colleagues with whom one has sat for many years and for many of whom they have a high regard. Because of that position it is not easy for those of us here to say that we will not approve the 
resolution to be moved by the Premier. It is not because of any desire to prevent the Public Service from being paid. It is well known that if action had been taken, or even if action is taken now, that there will be ample time for the elections to be resolved and for Parliament to be convened and for Supply to be passed. We are sincere in the desire to have this matter determined by the electors and to make possible every facility for the people's voice to be heard. (QPD 1957:vol. 217, p. 18)

After a long speech interrupted continually by interjections, and with additional time extended to his case, Duggan finished with claims that the ALP was pledged to 'uphold the Christian way of life' and 'family life', that the next election would become highly charged with personal abuse and that when given the opportunity to have a say, the people of Queensland would 'send us back in numbers to this Parliament to uphold those things that some people are charging us with destroying' (QPD 1957:vol. 217, p. 24). In reply, the Treasurer spoke of the imperative of passing supply but spent most of his speech attacking the ALP leader. Frank Nicklin, however, putting the opposition's view, agreed with Duggan that an early dissolution of parliament was preferable but disagreed with the intention of opposing the suspension of Standing Orders to allow supply to be debated quickly. The opposition was anxious to hear from the Treasurer his 'case on Queensland's financial position. We propose to give him the opportunity by allowing Standing Orders to be suspended so that he can move a motion for Supply in Committee' (QPD 1957:vol. 217, p. 29). Nicklin stopped short of indicating at this stage whether the opposition would indeed give the QLP ministry support in such a motion for supply. The QLP ministry could secure supply if either the ALP or the Coalition parties was prepared to support the request - possibly in exchange for some other political commitments.

The Premier concluded the debate on his own motion-claiming he had not foreseen any opposition to his request - thinking that the real debate would be focused on the question of supply not on whether to bring on a truncated supply debate. Gair spent most of his speech attacking Duggan personally, describing his former minister's speech as a 'hysterical outburst' that showed the 'wouldbe Premier' had descended to a 'low standard today' (QPD 1957:vol. 217, p. 30). Gair was incensed by Duggan's criticism of Gair's wife speaking at public meetings in support of the QLP. He also criticised Duggan for not standing up to principle, but rather for kowtowing to union leaders who threatened the preselection of Caucus members. Gair concluded his attack on Duggan by stating that

these men round me were prepared to stand for a principle. They were not going to be directed as to when legislation should be introduced if we believed that the time was not propitious. You, Mr Speaker, know as 
well as I that there were times when this matter was discussed by the Parliamentary Labour Party and that the party was unanimous that the time was not opportune, but when big Boss Joe [Bukowski] and others started to wield their whips, we saw the way they went. When they were threatened with refusal of endorsement or withdrawal of endorsement and they feared losing their jobs, they said, 'To hell with principle; we must look after this job, it is the best we ever had and we will not get another one like it?' By their actions they imperilled the Parliamentary system of Government. (QPD 1957:vol. 217, p. 31)

When the Assembly voted on Gair's motion to suspend Standing Orders, the House divided and passed the motion 49 to 23 on party lines, with the Coalition siding with the Gair ministry against the ALP. Only Arthur Coburn (QLP, Burdekin), who voted in the earlier matter on the identification of the opposition, did not vote for the second motion to truncate the procedures to deal with supply.

Once the procedural formalities were removed, the Speaker, John Mann, read a message from the Administrator seeking supply to the Crown (Vote of Credit) of $£ 27$ million, whereupon he vacated the chair and the House went into committee to debate the Supply Bill. Treasurer Walsh, in presenting the bill, indicated that as an election was 'pending' and that the eventual government would require 'time to formulate its legislative programme, Parliament may not meet as early as usual'. This meant that while some salaries for officials (the Governor, judges, ministers, Members of Parliament and top public servants) and interest charges with respect to the public debt could be paid, the more general issue of 'supply and appropriation must be granted by Parliament to cover all other expenditure on Government services' (QPD 1957:vol. 217, p. 33). Walsh noted that $£ 26.5$ million had already been granted by a Vote on Account to see the government over to the end of August, but because of the likely delay in recalling parliament, he asked for a further two months' supply (of £27 million), ending on 31 October 1957-making a total of $£ 53.5$ million advanced for the next financial year. He then proceeded to launch into an attack on the ALP for its communist links, its secret 'pledge' that Members of Parliament had to sign and for the allegedly improper behaviour of its new leader (engaging in secret deals with oil companies over their opposition to the Motor Spirits Bill). Nicklin, following convention, presented the response by arguing that the state was virtually ungovernable and that the political mess had to be cleared up. He described the Treasurer's speech as an extraordinary mixture of recrimination and inter-party squabbling that was irrelevant to the question being debated. He accused Walsh of spending only a 'few minutes' on the state's finances and trying to 'get his money on the blind' by not providing any justification for the proposed increase in expenditure. Nicklin argued: 
[I]rrespective of the strange happenings on the introduction of the Appropriation Bill history is certainly being made in the Chamber today. This session of Parliament will probably go down as one of the shortest on record, but it will not be recorded in the history of the State because of its brevity but rather on account of the impact which our actions today will have on future generations of Queenslanders and the future advancement of this great State... What is happening to the best State in Australia at the present time? We have not got a Government; the affairs of Government are being neglected, and the administration of the State is being neglected because the Ministers and other members and ex-members of the Labour Party are not concerned with getting on with their job but with the fight one against the other... On an occasion like this one would expect the Treasurer to give some indication of what the intentions of the Government are. Will the Government attempt to carry on, or what will they do? It is no use coming here and asking this House for a certain sum of money...He did not make any attempt to justify an additional supply, so there is evidently no need for it; and we are not going to be a party to giving the Government one penny piece above the supply they already have. (QPD 1957:vol. 217, p. 47)

Then, more threateningly, referring to Walsh's promise to provide more details on the budget at a later date, Nicklin bit back in asserting 'the hon. the Treasurer did say that he would be coming to prepare future Budgets for us. We can do that quite well. We have men on this side of the Chamber who can prepare a better Budget than ever the hon. gentleman produced' (QPD 1957:vol. 217, p. 47).

As the supply debate rolled on, the main protagonists each rose to their feet to vent their spleen and defend their own political positions. Duggan spoke against granting further supply, saying, 'I agree with the Leaders of the Opposition that we say to the people as quickly as possible..."throw out these men who are masquerading as great crusaders, these men who say that they are preserving democracy, these men who claim that they represent Christian principles"' (QPD 1957:vol. 217, pp. 52-3). The independent Tom Aikens also rejected the government's request for supply, which he considered was merely 'political thimble and pea demonstrations' to hide the fact that the government did not want to go to an election ( $Q P D$ 1957:vol. 217, pp. 52-3).

When the House resumed the next day, the Premier defended his decision not to call an immediate election because the electoral rolls were not yet all printedand to taunts from interjecting members, he refused to indicate a date for a state poll. After this statement, a succession of speakers poured scorn on the government and indicated that they would oppose the granting of additional supply. The list of non-government speakers opposing supply included Ken 
Morris and Tom Hiley from the Liberals. No further Country Party members made a major speech. From the ALP, Jim Donald, Felix Dittmer, Les Wood, Pat Hanlon, Frank Forde, Eric Lloyd, Joe Dufficy and Cecil Jesson all opposed supply, while a group led by the QLP ministers supported the motion from the government's side: Paul Hilton, Bill Moore, Harry Gardner, Bill Power, Michael Brosnan and Alex Skinner. As the debate wore on, it became clear that the Gair government did not have the numbers to pass supply. The end became inevitable.

The final vote on supply took place at $10.30 \mathrm{pm}$ on Wednesday 12 June. The government voted in favour of granting interim supply but could muster only 25 votes. The combined vote against was 45, representing an unholy alliance of the ALP, the Country and Liberal Parties with the independent Aikens. After hearing the result, the Premier informed the Speaker that

in view of the adverse vote just taken in Committee of Supply I now wish to state that I propose calling on His Excellency the Administrator of the Government as early as possible to inform him that Supply was asked for by my Government and it has been refused by this House. (QPD 1957:vol. 217, p. 121)

The Premier's statement was not, however, the final act of the outgoing Parliament. After Gair's announcement, one of the senior Liberal members, Tom Hiley, rose to move an extraordinary motion seeking to disallow the proclamations of the Motor Spirits Distribution Act, which were to come into effect on 1 August 1957. His motion was based on the argument that an outgoing government 'under sentence of death' should not seek to extend administrative proclamations beyond the 'period during which they knew they could retain the mandate of the people' (QPD 1957:vol. 217, p. 122). Hiley was supported by Nicklin and Duggan, giving the motion the support of the three parties that combined to block supply. Gair and four of his ministers spoke against the motion, pointing out that the Parliament had earlier passed the proclamations by a vote of 42 to 23 and as such they should stand. The QLP ministers became acrimonious in their remarks and accused the ALP of political hypocrisy, of being a splinter party of former colleagues now drunk with political power and of 'lining up with the traditional enemies of Labour to help in the destruction of a Labour Government that has been in power for 25 years' (QPD 1957:vol. 217, p. 125). The ALP was also accused of siding with the oil companies to preserve their economic interests against the will of a parliament anxious to regulate oil distribution. The debate was largely polemic and the final vote mirrored the earlier vote over supply, with 43 supporting the motion and only 24 government members opposed. The motor spirits proclamations ceased to have effect. 
The House adjourned at $11.40 \mathrm{pm}$ on Wednesday 12 June. The adjournment signalled the end of an era of consecutive Labor governments. The refusal of supply by the Queensland Parliament also meant that a further substantive issue had been added to the Labor split occurring throughout Australia: in Queensland, a Labor Party had brought down a Labor government.

\section{The 1957 state election: a four-way contest}

Only 14 months since the last election, Queenslanders were back at the polls. The date set for the election was 3 August 1957 and writs were issued for each of the 75 Assembly seats. Under the electoral laws of the day, the election was fought on a simple majority 'first-past-the-post' basis, which meant that with two parties representing the Coalition and Labor split into two rival camps, the election became a four-way contest. Although the state-wide election campaign took the form of a four-way contest, the official Country and Liberal Parties did not challenge each other in any seat (although independent conservatives and independent liberal candidates did stand against their fellow parties). In contrast, the two Labor Parties stood against each other in 57 seats - most of which had been Labor seats in the previous parliaments. By challenging each other under the 'first-past-the-post' system, the Labor Parties risked splitting the 'Labor' vote and ceding seats to the conservatives by default.

In the 1957 election, 216 candidates stood (60 more than in 1956). Four seats were uncontested in the polls (receiving only one nomination: three by the Country Party and one by the Liberals). In only nine seats were the voters given the choice of a single conservative candidate challenged by a single Labor opponent. In contrast, there were 20 seats in which the Country Party was challenged by both the ALP and the QLP. In another four seats, a joint Country-Liberal candidate was challenged by both Labor Parties, and in 28 seats, the Liberal Party was challenged by both Labor Parties. In one seat, Clayfield, a Liberal candidate was challenged by a conservative rival - with no Labor candidates standing - and in another seat (Cunningham), a Country Party candidate was challenged by a conservative opponent. Only in Darlington (later renamed Logan) did an approximate four-way contest develop with candidates from the ALP, Country Party, an 'independent' Liberal and a non-aligned independent.

The principal theme of the campaign was who was capable of governing Queensland. The 'Labor Parties' focused on the rights and wrongs of the recent split and attempted to keep their supporters loyal with various emotive pleas. The ALP attempted to promote the three weeks' annual leave issue that was behind the collapse of the Labor government. The QLP remained supportive of arbitration and court-controlled ballots in unions to attempt to stop rorting and 
forms of political influence by organised political groups. The Coalition promised 'sane, efficient and just government' as well as constitutional protection of democratic and political rights, including property rights (governments would not be permitted to seek the 'compulsory acquisition of property otherwise than on just terms', as laid out in the Australian Constitution). All parties stressed decentralisation, regional development and rural investment schemes and various forms of state savings banking.

The QLP stressed that a vote for it would 'keep Queensland safe for democracy', but its attack on the ALP was strident. In one election poster, the QLP urged voters to

choose whether you will be ruled by your own elected representatives in Parliament, answerable only to you OR whether you want government by remote control from Dunstan House [the ALP's headquarters] and the Trades Hall. A Government led by Duggan and Dittmer would be a puppet government, masquerading under the label of Labor. It would take its orders from 'Big Boss' Bukowski, dictator of the QCE and his henchmen. Duggan has admitted that no matter what orders are given him by the QCE he will carry them out, RIGHT or WRONG, WISE or UNWISE. His sheep-like followers, Dittmer, Woods, Mann and the rest of them, are bound likewise by his decision. They must obey. Are these the men you would trust with the Government of Queensland? Weak, spineless men, who, to save their political skins are willing to be the tools of left wing autocrats and their extremist urgers and camp followers. (QLP election poster, 1957, Brisbane).

In other electoral material, the QLP ran a blatant scare campaign warning of a 'Communist plan to govern Australia' and 'secret Red moves' to bring about the amalgamation of the ALP and communist parties. They railed against 'Marxist totalitarians'. The party particularly attacked the AWU leader, Joe Bukowski (who was not a communist), demanding that he be removed and promising to remove him by court-administered ballots if they were returned to government. The extra-parliamentary wing of the ALP was subjected to pointed attacks from the QLP leadership — with the intention of building the perception that the ALP leadership was guilty by association.

The ALP and Duggan attempted to defend themselves against the QLP accusations. They directly rebutted QLP accusations and attempted to correct 'unashamed falsehoods in advertising'. This tactic risked extenuating attention to these issues and underscoring their significance in the public's mind. Nevertheless, Duggan persisted with not only replying to accusations but forecasting negative campaign techniques his QLP opponents would make. He tried to argue that 'the truth is, of course, that an unbridgeable gulf divides the political concepts 
which are the basis of Labor's philosophy and the alien creed of Communism' and that 'intelligent people will not be deceived by such transparent humbug' (Courier-Mail, 8 July 1957). Duggan placed enormous faith in the intellect of voters.

The ALP invited the federal leader of the party, Dr Herbert V. Evatt, to address a mass rally in Brisbane on 28 July, which 1000 unionists and party workers attended. Along with Duggan, Evatt made a rousing speech in which he derided Gair's chances of forming government, arguing that voters could 'treat next Saturday as a referendum. A vote for the ALP is a "yes" vote in favour of three weeks leave' (Courier-Mail, 29 July 1957). The invitation to Evatt backfired, however, as conservative politicians used the visit to direct attention to the ALP's links with communism. Nicklin accused Duggan of trying to 'dissociate himself and his party from any taint of Communism or extreme left wing socialism, but behind the scenes he has been working hand-in-glove with these elements' (Courier-Mail, 30 July 1957). The fact that Evatt had appeared for communists in legal proceedings and had made public speeches supporting their right to exist legally gave some credence to the Coalition's claims.

Despite protestations, the issue of the ALP's close links with communists appeared to have grown in salience during the campaign. Not only were the other three major political parties all pushing this message, so too were religious leaders from the pulpit, among church gatherings and in church newspapers. During the election, the role of the Catholic Church did not attract significant attention (except in the case of a few candidates and the occasional broadcasts on the ALP's radio station), but afterwards ALP supporters directly accused Catholic Church leaders of campaigning for the QLP and using their influence to defeat the ALP (Courier- Mail, 7 August 1957). In Toowoomba, Duggan complained of a local 'campaign of character assassination' involving house-tohouse canvassing by sectarian supporters of the QLP (Courier-Mail, 2 August 1957).

With the Labor Parties at each other's throats, the Coalition ran a low-key campaign focusing on the basics of state administration and parochial largesse. Its slogan drew inspiration from Churchill's wartime cry 'give us the opportunity and we will do the job'. The Country Party promised '4-D government': democratic government, decent government, development and decentralisation. Nicklin declared they would be a 'constructive government' and made promises to deliver many benefits to local communities such as commitments to build irrigation schemes. ${ }^{2}$ Nicklin offered to continue and enhance free public hospitals and support preschool education. He also committed his government to end

2 'Nicklin envisaged a network of small weirs throughout the state to boost primary industry' and new provincial abattoirs (see Courier-Mail, 1 August 1957). 
victimisation and review any 'dictatorial laws' to remove any anti-democratic provisions in legislation (such as over petrol supplies, abattoirs, liquor and the University Act). He also promised to end the electoral malapportionment whereby electoral boundaries had been 'gerrymandered by Labor with diabolical cunning...to keep Labor in power for so long' (Courier-Mail, 1 August 1957).

The Liberal leader, Ken Morris, promised that the Coalition would not conduct a 'witch-hunt' in the public service, but promised reforms to the Public Service Commission and to public servants' superannuation. He argued that only the Coalition could attract 'huge capital investment' into Queensland to develop the state. He and his deputy, Tom Hiley, promised better schools, free transport for children to school and increased public housing (Courier-Mail, 24 July 1957 and 3 August 1957). The Liberals made a point of rejecting any sectarian politicking or religious backing in the campaign, with Morris declaring 'God forbid I should ever do so' (Courier-Mail, 5 July 1957).

\section{A fluke win: "governments may go and governments may come'}

In the watershed election of 1957, the Coalition received 43.66 per cent of the state-wide vote compared with the ALP's 28.89 per cent and the QLP's 23.39 per cent. The Country Party vote increased slightly from 126183 in 1956 to 139220 (or from 19.27 per cent to 19.99 per cent). The Liberal vote in fact fell from 164 116 to 162372 (or down from 25.07 per cent to 23.23 per cent). With the two parties together, the vote for the Coalition increased by only 11793 votes from 1956. In contrast, the ALP vote fell from 335311 to 201971 (or from 51.22 per cent to 28.95 per cent), while the QLP achieved a first-time vote of 163534 votes (or 23.39 per cent). The combined ALP/QLP vote was 365 505, which was more than 60000 greater than the combined Coalition vote.

In terms of seats, however, the result was very different. The Coalition increased its representation from 24 seats in the previous Parliament to 42 members in the 75-member Assembly - equivalent to a nine-seat majority (with the Country Party gaining 24 seats, up from 16 previously, and the Liberals securing 18, up from eight). On the other hand, the ALP's representation fell from 49 seats to 20 , with the loss of six sitting members from those who had remained with the party, including the party's new leader, Jack Duggan, and deputy leader, Felix Dittmer, who both failed to hold their seats. The QLP had held 25 seats after the split but was reduced to 11 in the new Parliament. Two independents survived the contest, retaining their seats despite the general polarisation of the parties: the populist Tom Aikens, representing the self-proclaimed North Queensland Labor Party (NQLP), retained Townsville South (previously Mundingburra) and 
continued to represent the same electorate until 1977, despite the renaming and redistribution of the seat. Arthur Coburn held on to Burdekin. These two were the last of the great surviving 'true independents'.

Due to the death of George Devries, the former Secretary for Mines, within the election period on 13 July, the election in the seat of Gregory was held over to 5 October (Devries had nominated for the seat before he died). At the by-election, the Country Party's Wallace Rae won the seat, beating Labor's Jack Duggan by 2075 votes to 1328, with the QLP candidate, K. Smith, finishing third with 955 votes. Although the Labor Party had a candidate for the seat who would have contested at the general election - the AWU's A. Watson-he withdrew to enable Duggan to have a chance to resume his parliamentary career. On this occasion, however, he was unsuccessful.

Political assessments of the change of government at the time suggested that the Coalition 'Nicklin-Morris government got into power in 1957 through a political miracle - the Labor Party split' (Truth, 11 March 1962). Others described its win as nothing more than a 'fluke' (Courier-Mail, 9 November 1967), in which electoral victory was thrown to the Coalition by a government in self-destruction mode. Indeed, many even among the Coalition had begun to doubt whether the non-Labor parties would ever win government. Joh Bjelke-Petersen (who felt slighted by Nicklin) later recalled in his memoirs that by the mid-1950s some among the Country Party had been disgruntled with Nicklin's leadership in opposition (by then Nicklin had served as Opposition Leader for more than 16 years - a remarkable feat in itself!). Bjelke-Petersen (1990:64) believed

the Labor split may have come just in time for him [Nicklin], for there had been rumblings against him among some of the Country Party backbenchers. They had been in Opposition so long that several of them were saying, 'We're never going to get out of the woods with Frank. Maybe it's time to try another man'. There was a feeling among them that Frank was simply too nice a man to lead them to victory over the Labor Party. If it had not been for the Labor split, he probably never would have.

In typical fashion, Bjelke-Petersen (1990:63) referred to the fortuitous turn of events in 1957 as a 'political godsend'.

Others were less moved by the change of government. The independent Member for Mundingburra, Tom Aikens, heralded the arrival of a new Coalition government in 1957 with the observation that 'governments may go and governments may come and empires may crumble into dust, but Tom Aikens goes on forever' (QPD 1957:vol. 218, p. 4). Certainly, such statements reflect the bravado of an outspoken maverick member, but from the vantage point of the 
crossbenches Aikens highlighted a remarkable feature of Queensland politics. Despite the major disruption to the party system, Queensland governments tended to be marked more by continuity than substantial differences.

More generally, there was a growing consensus especially reflected in the press that the Coalition's win was long overdue and that they had soldiered on in opposition for long enough. Journalists wrote of the Coalition's main chance having come, acknowledging that after 25 years of Labor, the opposition had earned the right to a turn in government. There was also some cynicism and resignation shown among contemporary assessments: if the Labor Parties had demonstrated that they were clearly unable to govern competently then the Coalition had to be given the benefit of the doubt and installed as the alternative government. It is not an exaggeration to say that at the time there were few with high expectations of the likely performance of the Coalition in government and few who believed that the Country Party-led administration would survive for long once Labor sorted out its internal problems.

\section{Nicklin's measured and subdued style of government}

If the Premier, Frank Nicklin, inherited government in 1957 by accident, he did not let that get in the way of his determination to govern. He had served as leader of the Country Party since June 1941, serving 16 years as Opposition Leader - a dubious record in the history of the State Parliament. Nicklin had contested and lost a staggering five elections in succession (1944, 1947, 1950, 1953 and 1956), which was quite a phenomenon and a record of failure that seems inconceivable today. By the late 1950s, Nicklin had become an old hand at elections and seemed to be tiring of campaigning. After 1956, he had to be persuaded to remain at the party's helm. And in the midst of the Labor government's momentous split (coming so soon after an election), Nicklin had briefly flirted with the idea of joining forces with the outgoing Premier, Vince Gair, to form a new government based on the Coalition parties together with most of the previous Labor ministry. If, however, he was ever serious about this course of action his Country Party colleagues dissuaded him from pursuing this course of events.

Like many Queensland premiers before and since, George Francis Reuben (Frank) Nicklin was not Queensland born. He was born in 1895 across the border in New South Wales in the sleepy hinterland town of Murwillumbah. He was educated at the local primary school and Highfield College Turramurra (New South Wales) before enlisting in the Australian Imperial Forces to fight in World War I. While serving in France, he won a Military Medal for distinguished service, 
received a commission and was ultimately promoted to lieutenant colonel. As a returned serviceman, Nicklin became a smallholding farmer, buying an 8-hectare pineapple farm at Palmwoods on the lower Sunshine Coast. In October 1922, he married Georgina Fleming. He entered politics by winning preselection for the safe Country Party seat of Murrumba - an electorate that stretched at the time from the outskirts of Brisbane (the Pine River at Redcliffe) through the Sunshine Coast hinterland to the Maroochy River at Maroochydore. Nicklin convincingly won the seat in the election of June 1932. In his personal life, Nicklin remained a keen sportsman and was renowned for his abstemiousnessbeing known to prefer pineapple juice for light refreshment. Unfortunately, his wife was seriously ill before he became Premier and, according to later press reports, 'was never really well enough to share fully in his public life. He was deeply grieved by her death, but he rarely mentioned it and threw himself into his duties. His sister Mrs Colin Lind, became his official hostess and has been a tower of strength' (Courier-Mail, 8 January 1968).

Reflecting Nicklin's personal style, the Coalition parties were tentative in office after winning government in 1957. Nicklin imbued his new government with a measured and subdued style of leadership in which consensus between the Coalition partners was an important principle. Collectively, they were acutely aware that the last conservative government had lasted one term (1929-32) and had been voted out at the first opportunity. Twenty-five years of continuous opposition had also bred caution. The Coalition government was intent on remaining in office for the long haul.

Showing a presence of mind and a determination to establish some basic ground rules for the new government, Nicklin established procedures to ensure the smooth functioning of the administration; he began as he meant to continue. Such procedures were important because they helped his inexperienced government make a smooth start. They also began to define the culture and character of the Coalition ministry by enabling internal conventions to guide not only decision making on policy questions but more importantly relations between the two Coalition parties.

Nicklin took to heart Walter Bagehot's observation that 'cabinet is the buckle' in Westminster systems that binds majority government together. Whereas Bagehot's metaphor implied a bond between the executive and the legislature, Nicklin was more concerned with cabinet acting as an expedient means of combining the two parties engaged in an uneasy coalition. Nicklin's cabinet was the buckle that joined the two parties and smoothed relations between the two parliamentary caucuses. If the organisational wings of the two parties differed or on occasions feuded, the cabinet was a sanctuary of calm and order and a place where partisan political interests were generally placed second to government interests. This did not mean that party ideologies or interests were absent from 
cabinet but that whenever disagreements arose the cabinet members remained a team and demonstrated cabinet solidarity. In particular, the Premier and Deputy Premier, as the two leaders of the Coalition parties, worked assiduously to maintain a common and supportive alliance. They insisted that written notes would be taken of cabinet meetings and that these would be used as a record of decisions. Nicklin's cabinet was the first in Queensland to institute these procedures. Importantly, they also worked from the principle that cabinet had to agree to decisions and reach a consensus - and that the Coalition government would be in trouble if policies were to be routinely pushed through on the numbers of the senior Coalition partner. These were important principles of fairness and due process that could have been partly evident in previous ministries but that were now codified and observed.

\section{Conclusion}

The bitter recriminations of the Labor split took years, even decades, to heal. Many of the protagonists on both sides of the 'Labor' divide were absolutely convinced of the correctness of their actions and positions. Few entertained any doubts about their own political stand or about the need to compromise. Retaining power within the organisation (even if it were a rump of its former size) appeared far more important than resolving differences and rebuilding a viable party. The loyal ALP leadership, including the AWU and Trades Hall union leaders, became more interested in exerting their control over the remnants of the Labor Party than in capturing government. Jack Duggan's wry observation that they would be out of office for 30 years appeared more and more a selffulfilling prophesy.

The tumultuous year of 1957 provided a lifeline to Frank Nicklin, who, as the new Premier, steered Queensland politics into an era of conservative domination. The foundations on which Nicklin built the conservative regime would adapt and change but would eventually survive until December 1989. Over four consecutive parliaments (1957-68), Premier Frank Nicklin and his Country-Liberal Coalition underwent a longer-term transition, which saw it emerge as a formidable political force and the natural party of government. Chapters 3 and 4 recount this transition by focusing on the political history of the government parties in the Parliament. Chapter 5 then examines separately the legislative program of the Coalition government with an emphasis on how government business was steered through the Parliament. Meanwhile, the Labor opposition, as Chapter 6 records, went from being a disillusioned and fractured rump to a dispirited party seemingly content to remain indefinitely on the shadow benches. It was a spectacular fall from grace for a party that had held a hegemonic domination over Queensland politics for more than four decades. 


\section{The early Nicklin years, 1957-1963}

Queensland's Parliament during the early Nicklin years experienced considerable turmoil. In the late 1950s and early 1960s, successive parliaments did not resemble a traditional 'two-party adversarial' institution. The composition of the Assembly reflected the schisms of the 1957 Labor split and consisted of multiple parties together with independents or disaffected mavericks. The Parliament was a collection of disparate factions that had survived the tumultuous events of 1957. Many on the non-government benches were ex-ministers with long parliamentary experience and political acumen. Idiosyncratic individuals and a four-way party split were the most noticeable features of the era. Individual parties might have been disciplined, but for a couple of terms the standard adversarial structure was overlaid by the consequences of the momentous split.

In the early Nicklin years, the Parliament was not as tightly orchestrated as it would later become and parliamentary debates were more open but also vitriolic. Debates often meandered around with outspoken individuals attacking opponents at random or settling previous personal scores of little relevance to the topic under discussion. With time, however, the Country and Liberal Parties began to hold sway, sustained by comfortable majorities in the House over succeeding parliaments. As the most disciplined and unified political force, they began a new phase of Queensland's political and parliamentary history.

Historians have tended to view positively the early period of Coalition government after 1957, arguing that the Nicklin-led Coalition represented a high-water mark in cohesion, trust and amicability between the two conservative parties (Stevenson 1985; Hazlehurst 1987). With the benefit of hindsight, the Nicklin years were times of accommodation for the Coalition premised on a degree of mutual respect and a collective feeling of euphoria at finally being elected to government. Nicklin wanted to put in place the building blocks for stable Coalition government that would rival the longevity of the Labor regime. At the same time, however, relations between the Coalition parties were characterised by conflict and emerging distrust. Public conflicts were not the exclusive prerogative of the Labor side of politics. Despite signs of apparent goodwill, many of the conflicts later to tear apart the Coalition in 1983 with much rancour and bitterness were already evident behind the scenes even in its early years in government. 


\section{The new Coalition ministry of 1957}

The first Nicklin ministry was commissioned by the Governor, Sir Henry Abel Smith, and gazetted in 1957 (see Lack 1962:491). Like previous Labor ministries elected by Caucus, the Coalition ministry was initially elected by votes of the respective party-room meetings, although Premier, Frank Nicklin, and the Deputy Premier, Ken Morris, distributed portfolios (Hughes 1980:158). Because of inter-party sensitivities, the allocation of ministerial portfolios was a product of joint consultation between the two leaders (plus other senior party officials). Those successful in the ballot were likely to have been selected on the basis of parliamentary seniority, intra-party configurations of support and personality considerations, rather than any nominal factional persuasion or background factors. The full first ministry was gazetted on 12 August 1957 and appeared as follows.

- Premier and Chief Secretary: Frank Nicklin, CP

- Minister for Labour and Industry: Ken Morris, Lib.

- Minister for Education: Jack Pizzey, CP

- Attorney-General: Alan Munro, Lib.

- Treasurer and Minister for Housing: Tom Hiley, Lib.

- Minister for Development, Mines and Main Roads: Ernest Evans, CP

- Minister for Public Lands and Irrigation: Alf Muller, CP

- Minister for Health and Home Affairs: Dr H. Winston Noble, Lib.

- Minister for Agriculture and Stock: Otto Madsen, CP

- Minister for Public Works and Local Government: James Heading, CP

- Minister for Transport: Gordon Chalk, Lib.

Interestingly, the Labour and Industry portfolio was initially accorded much importance by the Nicklin government, in recognition largely of the centrality of state development and the need to expand secondary industry as part of the postwar boom. The Coalition also inherited from ALP governments a belief that these responsibilities were the key to state prosperity - on which in turn rested its political survival. Indeed, in the first two terms, Labour and Industry enjoyed ministerial rank second only to the Premier's portfolio. This arrangement persisted while Ken Morris, a former 'Rat of Tobruk', remained Liberal leader and occupied the ministerial benches. After his resignation in 1962, however, the portfolio was restructured and responsibility for state development and industry development was prioritised (and given to the Premier and Deputy Premier respectively), with the rest of the portfolio demoted in importance and given to relatively junior ministers. Hence, in contrast with the later Coalition 
ministries of the 1970s and 1980s, for a Country Party-led government, state development and industrial development were prime concerns, even though the particular minister responsible was generally from the Liberal partner in the Coalition.

Education became the third-ranking ministry under the competent Jack Pizzey. The new Country-Liberal government recognised the importance of education spending and policy decisions on local communities. Education was a bigspending department and politicians were conscious of the political kudos accruing from such expenditure. At the change of government, most electorates had primary schools but very few had secondary or high schools. In 1957, there were 1440 state primary schools in operation in Queensland, but only 40 public high schools (with 803 teachers and 17000 students) for a population of 1.4 million people. Labor had relied heavily on Catholic schools to provide basic education and in policy terms had been focused on developing primary industries (mining and agriculture) that had in turn impeded the progress of public education (McQueen 1979). The new government was well aware that ministers could enhance their personal profiles by being seen to make strenuous efforts to develop education and provide additional educational services in the electorate.

Given the prominence of education, therefore, it is all the more noteworthy that in the allocation of ministries under the Coalition, the Country Party secured this prized portfolio of Education and awarded it to its second-most senior minister, Jack Pizzey, who would subsequently become the next premier. Furthermore, the Country Party retained control over this important portfolio throughout the entire Coalition period of 1957-83; indeed, only in 1996 did a Liberal minister, Bob Quinn, finally secure this portfolio, in the Borbidge Coalition government.

Education was also one of the topics raised most frequently by members in question time - especially questions asked about the numbers of teachers and when particular schools would receive facilities or repairs/extensions to buildings. So, for instance, the Member for Condamine, Les Diplock (QLP), asked the Minister for Public Works 'when is it anticipated that work in connection with the installation of the septic system at the Dalby State School and at the Head Teacher's residence at Dalby will be commenced?' (QPD 1958:vol. 221, p. 203). He received the answer that it would begin before the end of the month. The former Premier's son, Pat Hanlon (ALP, Ithaca), also asked a typical question of Education Minister Pizzey:

(1) Can he indicate if any progress has been made with plans for provision of a State High School on land held at Bardon for that purpose? 
(2) Is work likely to commence in the current financial year with a view to opening the School for the 1960 School year? (QPD 1958:vol. 221, p. 556)

Pizzey, who was always matter-of-fact, answered that all new high school sites for 1959 had already been determined and that Bardon was not one of them.

The portfolio responsibilities of the Attorney General, Alan Munro, were extended in November 1957 to include responsibility for justice. Munro was appointed separately as Minister for Justice with the new portfolio renamed Justice and Attorney-General.

\section{Nicklin's immediate concerns}

The thirty-fifth Parliament began on 27 August 1957 with 18 new members taking their seats in the 75-member Chamber-close to one-quarter of the total. Sixteen of the new members were from the conservative side - most noticeably including: Eddie Beardmore (CP, Balonne), Tom Gilmore (CP, Tablelands), Max Hodges (CP, Nash), Keith Hooper (Lib., Buranda), Bill Knox (Lib., Nundah), Bill Lonergan (CP, Flinders), Wally Rae (CP, Gregory), Sam Ramsden (Lib., Merthyr), Harold Richter (CP, Somerset), Percy Smith (Lib., Windsor), Doug Tooth (Lib., Kelvin Grove) and Bob Windsor (Lib., Fortitude Valley). ${ }^{1}$ Two new Labor members entered the Assembly: Jack Houston (Bulimba) and Merv Thackeray (Keppel). Many of these members would become leading lights in the Parliament in years to come.

In keeping with convention, proceedings immediately turned to the election of the new Speaker. In the absence of other nominations, Alan Fletcher (CP, Cunningham), a relative newcomer, was elected unopposed. In nominating Fletcher, Pizzey acknowledged their nominee was an 'untried man' but he added:

[E]ver since he has been an hon. Member of this House he has shown himself to be a man of sound judgment, ready wit, impeccable character, and a man held in high esteem by both sides of the House-perhaps I should say by the three sides of the House as it is now constituted...He is by nature endowed with all the necessary qualifications for Speakership. $\mathrm{He}$ is a man of very even temper, not likely to be rattled in a crisis, a

1 For a full list, see Lack (1962:495) 
man of sound judgment, keen intellect, firm yet courteous. He is a man possessing great tact, infinite patience, and a deep understanding of human nature. (QPD 1957:vol. 218, p. 3)

While he might have had these qualities of a saint, Fletcher quickly showed he was also a stickler for the rules and protocols of the House. Within a few weeks of taking the chair, he reminded the House that Standing Orders insisted that members 'make obeisance to the Chair on entering and leaving the House', and nine days after that, he regretted 'it [was] necessary again to draw attention to this matter as some...have persistently ignored what is our usual concession to good manners, good taste and good order in the House' (QPD 1957:vol. 218, pp. $134,248)$.

The Administrator's opening speech was presented to the Parliament on 28 August 1957. The Governor, His Excellency Lieutenant General Sir John Lavarack, who was soon to retire, was too ill to make an appearance that day. It therefore fell to the State Administrator to present the government's forthcoming agenda, saying it would 'rigorously pursue further development of the State to fully exploit and develop [its] unparalleled natural resources' (QPD 1957:vol. 218, p. 9). The Parliament was told the government had already declared state development a key priority. Ernie Evans (CP, Mirani) was appointed to the ministry in the newly created Development portfolio. Local government was another priority and was given its own ministerial portfolio. The House was informed that the term 'minister' had replaced the older title of 'secretary' (AJPH 1958:vol. 3, no. 2, p. 238). Nicklin also insisted that his cabinet ministers resign from all directorships and positions in cooperative societies and other public bodies, to avoid conflicts of interest. This rule, intended to maintain propriety, would be gradually enforced less and less strictly, eventually to lapse entirely.

A still shell-shocked Les Wood (ALP, East Toowoomba) informed the House that he was now the Labor leader and Leader of the Opposition. He announced that Eric Lloyd (Kedron) was his deputy leader, Cec Jesson (Hinchinbrook) had been appointed as the Labor whip, while Jim Donald (Bremer) was elected to the secretary's post (QPD 1957:vol. 218, p. 14). Wood's ascension to the leadership was short-lived. His unexpected death in March 1958 saw a new leadership team take over, with Jim Donald appointed as the new Leader of the Opposition; Lloyd remained as deputy leader while Horace Davies (Maryborough) became the party secretary and Cec Jesson continued as party whip (see QPD 1958:vol. 220, p. 2140). The former Premier, Vince Gair, then announced that he had been elected as leader of the QLP, with Ted Walsh (Bundaberg) as his deputy, Les Diplock (Condamine) the secretary and Harry Gardner (Rockhampton) appointed whip. 
Guaranteeing supply was an urgent necessity and on the second sitting day of the new Parliament, the Treasurer, Tom Hiley, moved an urgent motion recalling how the 'failure of Parliament to grant such Supply brought about the defeat of the Gair Government' and 'the Vote on Account granted in November last will be exhausted very early next week... [and] I am bound to tell hon. Members that the nearness to exhaustion of our existing funds makes it imperative that we should deal with this Bill today' (QPD 1957:vol. 218, p. 32).

Despite the turmoil of the past year, the parliamentary session proceeded in an orderly fashion. The four main parties were seemingly determined to deal expeditiously with the matters at hand. There was little evidence of rancour between the main protagonists in the early parliamentary debates of the session (including between the QLP and the ALP). There were few major stoushes, relatively few divisions and relatively few expulsions ('withdrawals' in which a member was barred for the rest of the day) and no suspensions (in which members were expelled for up to 14 days).

That did not stop Labor's Les Wood from using the Address-in-Reply debate to attempt to present the new government as unrepresentative of Queensland and not genuine in its commitment to decentralise the state. Still smarting from the days when the Labor government was dubbed a 'Queen Street government', he argued that the new Country-Liberal government seemed to have even fewer representatives from regional Queensland in its cabinet:

Mr Wood: Except for the member for Mirani, the Minister for Development, Mines and Main Roads, not one Cabinet Minister, figuratively speaking, is more than a stone's throw from the metropolis of Brisbane.

Mr Dewar: What has that got to do with it?

Mr Wood: It has a great deal to do with the State. After all, the hon. member for Chermside [Dewar] has joined with others opposite in vaunting their claim to being an all-Queensland and decentralised Government. Their first act upon taking office was to elect a Cabinet that cannot in any sense of the word be termed a Queensland Cabinet. Four Ministers represent Brisbane electorates, five live within two hours of Brisbane by car and one lives not much more than three hours away...During the war the Tory Government in Canberra were rightly charged with throwing North Queensland to the wolves in setting up the Brisbane line of defence. This same system has been adopted by this new Queensland Cabinet - they have set up a Brisbane-line Cabinet.

Mr Dewar: What rot! (QPD 1957:vol. 218, p. 42) 
Rot it might have been, but before the government had managed to initiate anything for which it could be held to account, old-fashioned mud-slinging was about all the opposition could muster in the short term.

Questions in the House followed strict guidelines, with questions on notice given to the Speaker the day before they could be asked (questions without notice were not permitted until the 1970s, and even then were relatively rare). House rules did not prevent Fred Graham (ALP, Mackay) attempting to ask the Premier about a particular franchise agreement involving the Caltex Oil Company in Mackay. Graham asked Nicklin if he would table the agreement recently signed between the government and the company. His question was given short shrift by the Premier, who replied with a monosyllabic 'no' (QPD 1957:vol. 218, p. 134). Undeterred, the next day, Graham again tried to ask the same question without notice, but this time was put in his place by the 'Gentleman Premier', who told the Labor backbencher that

[w] hen questions are asked in this House without notice it is the usual courtesy to give the Minister concerned a copy of the questions beforehand. When the hon. member has sufficient courtesy to give me copies of questions he is going to ask me without notice, possibly I will give some consideration to them. (QPD 1957:vol. 218, p. 159).

The Premier did not seem to perceive the irony in demanding to see ahead of time questions that pertained to be without notice.

The Address-in-Reply debate in 1958 was unexpectedly quiet, with little animosity on display between the ALP and the QLP. Heated debate did arise, however, over the issue of resourcing the opposition. Johnno Mann, the previous Speaker, asked a question aimed at embarrassing the QLP's Vince Gair:

Mr Mann (Brisbane) asked the Premier-

In view of the fact that the Gair Cabinet refused secretarial assistance in June last to the then Leader of the Australian Labor Party in Parliament, and that in conveying this decision to Mr Duggan, the ex-Premier Mr Gair said-

to grant such assistance to the leader of a third party would be to establish a new and important practice; and

that this matter should be reserved for determination by the incoming Government-

1. Does he consider that in providing a secretary and a typist for $\mathrm{Mr}$ Gair, a new and important practice has been established? 
2. What were the grounds for departing from precedent?

3. Since the Liberal Party of eight members in the last Parliament received no such assistance, does the new practice imply that eleven members constitute a party and that eight do not?

He was told by the Premier:

My Government has no intention of perpetuating practices which it considers to be wrong. We have always held the view that the Leader of any major political party should be provided with the necessary secretarial and typing assistance to enable him to effectively carry out his Parliament duties. (QPD 1957:vol. 218, p. 172)

The government faced one want-of-confidence motion, in March 1958. Initially, the Leader of the Opposition, Les Wood, wrote to the Speaker informing him of his intention to move a motion for adjournment over 'the present grave unemployment situation' and the 'failure of the Government to provide any substantial correctives' (QPD 1958:vol. 220, p. 1640). A rich line-up of members spoke in the adjournment debate (used in those days as a censure motion), including Les Wood, Eric Lloyd, Vince Gair, Bill Power, Jim Donald, Pat Hanlon and Tom Aikens speaking against the government, while Frank Nicklin, Tom Hiley, Ernest Evans, Ken Morris and Gordon Chalk defended the government. Nicklin's reply was measured in comparison with Labor's attacks. He replied:

I have listened with a great deal of interest to the Leader of the Opposition and his Deputy in the hope that I might get some constructive suggestions to deal with the problem on which the motion is based, but I am grievously disappointed...Instead we have heard a tirade against the Government and many wild statements that cannot be substantiated... the Leader of the Opposition and his Deputy have done the State a grave disservice. (QPD 1958:vol. 220, p. 1652)

The same day, Vince Gair gave notice of a want-of-confidence motion that was formally moved two days later, on 6 March 1958. Gair's motion led to a marathon debate lasting more than 13 hours and finishing at 12.54 am the next day. In moving the want-of-confidence motion in the government, Gair cited unemployment as one of the issues of concern along with the cost of basic commodities, rent control problems and a growing disquiet over recent appointments in the Queensland Police Force (QPD 1958:vol. 220, p. 1701). Nicklin put on a brave face, saying 'it is very evident that there has been a battle of tactics between the two component Opposition parties in an endeavour to gain some political advantage' (QPD 1958:vol. 220, p. 1748). When the final vote 
was taken, the ALP members vacated the Chamber and the vote was lost with seven 'ayes' to 36 'noes'. The want-of-confidence motion in effect highlighted the deep divisions between the QLP and the ALP (see Lack 1962:499).

The government's announcement that it had appointed Frank Bischof as the new Queensland Police Commissioner also left the opposition smarting. Bischof was a known Freemason and his appointment was viewed by the QLP as being suspect and smacking of political patronage. Some believed that Bischof's promotion was proof of 'a Masonic cabal over the "Green Mafia" [police of Irish-Catholic descent] who had dominated the force under Labor' (Johnston 1992:186).

The Treasurer, Tom Hiley (QPD 1957:vol. 218, p. 345), had flagged in his first budget speech that he was unhappy with the format of the budget, expressing doubts about whether 'the form of presentation' was 'sufficiently clear'. Because of 'the brevity of the Government's period in office', however, his first budget was presented in the standard way of former Treasurers. By the next year, however, a new format was announced in which the consolidated revenue fund now included the full anticipated revenue of the year as well as the full anticipated expenditure. Hiley anticipated such changes would make the true budget position of the state clearer.

The government was also keen to restore the recognition and awarding of imperial honours. Successive Labor governments for decades had not recommended such honours. Nicklin reinstated the practice of recommending knighthoods to deserving Queenslanders. By July 1958, three knighthoods had been confirmed, including the Chief Justice, His Honour Mr Justice Mansfield (Lack 1962:514). Gradually, over time, many of the senior members of the Nicklin cabinet would be awarded knighthoods.

By the third session of the Parliament, the parties had settled into a routine of sorts. There were occasional indications that relations between the QLP and the ALP were calming, especially in relation to the performance of the government. In his Address-in-Reply debate, Jack Duggan, who had returned to the Assembly after winning the seat of North Toowoomba in May 1958 (see Chapter 6), made the point that since the government's election two years earlier, 'the rich have got richer [while] the poor are getting less' (QPD 1959:vol. 224, p. 30). Vince Gair seemed to concur, attacking the government over similar issues and arguing that over the life of this government, 'we have witnessed an appalling decline in the living standards of wage-earners' (QPD 1959:vol. 224, p. 215). Ted Walsh further fanned the flames of reconciliation when he stated:

There are conditions on which any member of the ALP will consider going back to the ALP or the Labour Movement. The government no doubt will continue to gloat over the disunity in the Labour Movement 
since individual interests have been allowed to supersede the interests of the masses. I do not care whether it is myself or anyone else, but in the role of a proper reconciliation of the Labour Movement individuals, no matter who they may be or where they may come from, should not be allowed to stand in the way of any such reconciliation. (QPD 1959:vol. 224, p. 188)

They were soon quashed, however, when an exchange between Duggan and Gair highlighted the tensions that still existed. To Gair's assertion that there was a communist influence within the ALP that could not be trusted, Duggan replied that any pleas for unity by QLP members should be regarded as deeply suspect (see $A J P H$ 1960:vol. 6, no. 1, p. 95). The two groups were in no way united and the government went into the election year virtually unchallenged. ${ }^{2}$

\section{Nicklin's re-election in 1960: patching compromise over emerging tensions}

By 1960 the fledgling Coalition government was now conscious that, in its second term, it would increasingly have to take a stand on controversial policy issues and be less able to rely on a honeymoon period of goodwill or point to the failures of previous Labor administrations. At its first re-election, the NicklinMorris government was intent on consolidation and making its tenure in office more secure. Press reports spoke of Nicklin's preference for 'urging restraint and caution' to the party faithful and his preparedness to operate as a 'mediator in inter-party differences and a brake on more headstrong members' (CourierMail, 28 March 1960, p. 2). Finally in office, some zealous branch members in the Country Party were anxious to bind the government to party policy, but the Coalition ministry (like the Gair ministry before it) was determined not to be bound by 'outside interests' even if these were its own cadre.

Premier Nicklin indicated definitively to his own party and rural supporters that his government would not be a puppet to 'outside interests' even from within the Country Party itself. This set the early pattern of government. Journalists were already acknowledging that, after only a few years in office, Nicklin very much ran his own show. One reporter, John Higgins, commenting on the government's first four years, reported that

resolutions passed at annual party conventions have been blandly ignored by Cabinet; policy pledges and election promises have been repudiated; and the Central Council of the Country party has actually

2 For further details of political events between 1957 and 1960, see Lack (1962), who also covers these years. 
had the humiliation of being told bluntly by a Country party Cabinet Minister that he regards them as a 'pressure group' and will not accept dictation [of policy promises] from them! (Higgins 1961:15)

The 1960 state election was held on 28 May. A total of 228 candidates nominated for the new House of 78 seats - with 74 standing for the ALP, a combined 73 for the Coalition (34 Country Party and 39 Liberal) and 57 for the QLP, six communists and 18 independents (two seats were retained by the Country Party as uncontested seats - namely, Cunningham, held by Alan Fletcher, and Isis, held by Jack Pizzey). In the 1950s and early 1960s, it was not uncommon for some very safe seats to be left uncontested by other parties or by local independents; the sitting member then took the seat uncontested. The main political issues of the campaign were debates over the government's record and achievements, contrasted with the perceived 'knocking' of the opposition and other critics. The internal wrangles within the Labor camp remained a persistent issue, especially the alleged communist influence over the ALP set against the credibility or standing of the QLP with its strident rhetoric and sectarian appeal. Gair appealed to voters to reject communists in government, saying 'if they are there - throw them out; if they are trying to get there-keep them out' (Courier-Mail, 10 May 1960). Economic issues provided the main policy themes, with debates centring on the recession and unemployment, plans for prosperity and job creation, the need for new industries, problems with inflation and the removal of price and rent controls, a proposal for a state bank, whether to legislate for industrial conditions (for example, annual leave provisions) and the regulation of trade union elections. Unemployment remained the principal concern of the day, with jobless registrations running at about 15500 a month in 1960. There was much criticism of the federal government's economic policies and fear of a looming recession. The magnitude of the problem was exacerbated by the nature of Queensland's industries, which were narrowly based and displayed a strong reliance on seasonal employment. The cost of living was increasing as the controls on prices and rents were removed. Social issues were generally restricted to the support for housing and free public hospitals.

Day-to-day campaigning was conducted around public meetings with set speeches, dour rhetoric and a great many precise statistics conveying growth, state development and employment levels. State politicians still invested considerable credibility in the incontrovertibility of facts and figures, reciting them at length to a largely poorly educated electorate. In the print media, each party received lengthy press coverage, which detailed their policies, campaign movements and audience responses. Journalists delighted in recounting selected quotations from witty hecklers - for instance, when the Liberal leader, Ken Morris, told a gathering '[n]ow I come to a matter which we consider of vital importance to Queensland's development', one witty interjector 
exclaimed: 'He's going to resign!' (Courier-Mail, 12 May 1960). To promote their message, political leaders were obliged to tour the state, usually without a large accompanying entourage. Compared with later years, the travelling political circus of the 1960s was still in its infancy. Even the Premier, who journeyed by rail coach, motorcar and occasionally by air, travelled with only his secretary, one other staff member and two accompanying journalists. He was reported as 'easygoing' on tour, making toast for staff and washing up 'out the back' of his railway coach (Courier-Mail, 26 May 1960). The ALP Opposition Leader, Jack Duggan, also crisscrossed the state, making conventional whistle-stop speeches criticising the Coalition government for 'repudiating' 14 of its 1957 pledges and defending Labor against the QLP. Significantly, the 1960 election was the first state campaign to use television and political leaders from all parties availed themselves of the new opportunity to reach voters. Both major parties received an allocated 45 minutes on the ABC, with the QLP given 25 minutes. Perhaps somewhat presciently, the press described the introduction of television as turning the campaign into a 'gala' event more like a 'Hollywood circus' with variety concerts, band recitals and 'personality' appearances (Sunday Mail, 17 April 1960). The razzamatazz certainly attracted the media's attention but it is not clear whether it attracted the voters.

Launching its 1960 campaign, the Nicklin-Morris government asked voters to renew its mandate and give it the chance to carry out its program. The Coalition parties produced a joint policy platform but took separate responsibility for launching key sections of the package. Each party leader attended the other's policy launch - a public gesture designed to emphasise harmonious collaboration. The Premier, anxious to deliver his policy launch in his electorate of Landsborough, addressed 400 people at Maroochydore compared with the 1000 who attended Ken Morris's speech for the Liberals in Brisbane. Without making rash promises, the government stressed its prudent record in providing expanded services in education and health and in attracting increased investment in factories and construction. Nicklin promised to maintain and improve the state's free hospital system, increase road construction and economic infrastructure (including a new power station at Callide), reduce rail freight charges and provide a modern plane for the flying surgeon. The Premier was also keen to establish an independent tribunal to set parliamentary salaries as these had become contentious during the previous Parliament.

The Liberals, defending the government's economic record, promised more homes, better job opportunities, better education and health standards and improved roads. Unlike the Country Party, the Liberals maintained an attack on the ALP, which at times became personal, with Morris labelling the Labor leader a 'puppet of the Trades Hall masters' (Courier-Mail, 12 May 1960). 
The Liberals also clarified their position in relation to the 'new state' movement active in the north by offering to hold a referendum on the formation of a new state in north Queensland. Although under the Australian Constitution the power to grant statehood was not vested in individual states, a number of petitions (13 in total) had been circulating in the north and had reputedly attracted more than 30000 signatures. The Liberals took this stance in part because the Coalition was facing 'new state' candidates in some northern electorates and, with little support to lose in the region, they felt that they could capitalise on the northern mood. In any event, were a new state to be formed, it would affect the Liberal's support base the least; a northern state would predominantly remove Country and Labor Party territory, thereby proportionally strengthening the Liberal heartland in the south-east. After the election, Premier Nicklin was cautious not to excite enthusiasm for the 'new state' movement. He announced in the House that while it was still the 'policy of the Government to foster the establishment of new States' there were 'many constitutional and financial problems to be overcome' (QPD 1961:vol. 229, p. 2373).

The ALP and the QLP attacked the government over what they perceived as broken promises, focusing on the poor state of the economy. Both criticised the government's policy of removing price controls and presiding over huge price and rent increases. Much of the opposition's momentum though was compromised by the hostility and mutual suspicion between the two Labor Parties. Hence, neither conservative party was particularly worried by either of the rival oppositional parties of Labor. After one term in Coalition government, the Liberals were describing Labor as the 'weakest Opposition in Queensland's Parliamentary history' and having a 'constant obsession with trivialities and personal bickerings' (What We Have Done... and What We Will Do, Liberal Party pamphlet, 1960). Indeed, the Country Party virtually ignored the Labor Party's campaign, refusing to lend credibility to the ALP or descend to engage in debate on Labor's chosen terrain. The fact that the ALP and QLP were also campaigning against each other allowed the conservative government to capitalise on the advantages of incumbency, to appear statesmanlike and unsullied by infighting.

Despite passionate speeches from the various party leaders, the 1960 state election was 'very quiet', according to seasoned observers of the day (Grimshaw $1960 \mathrm{~b}$ ), and 'one of the quietest in the history of Queensland politics' (Lack 1962:572). More importantly, perhaps, although the contest was ostensibly between the Coalition and the various Labor Parties contesting for the right to form government, the main battle lines were drawn within the two competing camps: the Country Party ensuring it prevailed over the Liberals, and the official ALP over the rump QLP. If by contemporary standards the election campaign appeared lacklustre and mundane, deeper conflicts were flowing below the surface. Certainly the contemporary policy issues were pedestrian 
and predictable, but the main political interest in the election was over the twin battles for supremacy on separate sides of the House. There did not appear to be much prospect of the ALP defeating the Coalition outright.

Within the Coalition, the Country Party was determined to remain the dominant political force and control key positions in the new Parliament. During the first Coalition government, the Liberals had made overtures about closer cooperation and had proposed arrangements for a full merger with the Country Party. The Liberals' 1959 state conference advocated a special conference of members of both parties to explore the vexed question of 'complete union'. The issue of relative representation in parliament, however, remained a divisive factor and the Country Party made it clear that a complete union with the Liberals was not high on its agenda. Moreover, the Country Party, at its state conference in Bundaberg, had rejected a proposal to replace the state's 'simple majority' voting system (first past the post) with a compulsory preferential system. The main reason for the rejection of preferential voting (which was soon to be introduced in 1962; see Chapter 5) was that the Country Party still felt in the late 1950s that it could maximise its advantage relative to the Liberals and the various fragmented Labor Parties. The Country Party believed that a 'winner-takes-all' system was far more advantageous to it, whereas a preferential system would benefit the Liberals, which could threaten the Country Party's dominance as the senior partner in the Coalition. As the Opposition Leader, Jack Duggan, was able to point out, Frank Nicklin had admitted that the Country Party was reluctant to reintroduce preferential voting because of pressure from rank-andfile members of the party (Courier-Mail, 5 May 1960).

\section{Party representation in the Parliament, 1960-63}

The eventual result of the 1960 election was never much in doubt; newspaper reports had largely predicted the Coalition's win well before the day of the poll. Given that the government comfortably held between 35 and 40 seats out of the old 75-seat Chamber, the local press had confidently predicted a conservative victory. The Sunday Mail announced as early as 28 February 1960 that the Country-Liberal government was 'virtually assured of a new three year term in office'. Political writer David Berry provided five reasons supporting his claim: the government had consolidated its position since the 1957 election; it had dodged controversial issues such as SP betting, liquor licensing and the bill of rights; there was no strong electoral challenge from the opposition (Labor was internally divided and the AWU had left the ALP - although the AWU still donated $£ 1500$ to the campaign); the ALP had slender financial resources with which to fight a television campaign (reportedly $£ 8000$ compared with the 
$£ 15-20000$ needed); and, most importantly perhaps to the final outcome, the electoral redistribution of 1959 in effect 'entrenched the government' (Sunday Mail, 28 February 1960).

Other press reports, nevertheless, still referred to bitter clashes over particular seats - especially Brisbane seats - as local identities fought for political survival. Some of these battles were fought between party representatives from the same political side, as in South Brisbane, where the former Premier, Vince Gair (who had held the seat since 1932), was challenged and beaten by ALP alderman and barrister Col Bennett; or in Lockyer, where the sitting Liberal, Gordon Chalk (who had occupied the seat since 1950 - and before that East Toowoomba from 1947-50 - and was a future Liberal leader), was challenged in a personal duel by an independent Country Party candidate and farmer, J. P. Martin, who had backing from local road hauliers. Implying an attack on Chalk, Martin tried to run a campaign with no strings attached, asserting that 'all the money I take will have to be absolutely clean. I won't take money from breweries and I won't take money from communists' (Sunday Mail, 3 April 1960). At the election, Martin was soundly beaten by Chalk by a margin of 2758 votes (5077 to Chalk and 2319 votes to Martin). These intense conflicts highlighted one of the more enduring characteristics of party politics in Queensland-that some of the main electoral battles and most bitter fights have occurred between party rivals ostensibly on the same side of politics. For the most part, the party leaders (Nicklin, Morris, Chalk and Duggan) tried to remain above the fray and observe a formalised 'gentlemanly' courtesy towards each other; indeed, there was some mutual affection between Nicklin and Duggan, and later between Duggan and Chalk. The same was not true for Gair, who fought tooth and nail. Party leaders were also active in attempting to minimise intra-party challenges - although their mixed success in this respect illustrated the relatively weak position of the leadership compared with the party branches and membership.

The final distribution of seats in the 78-seat Legislative Assembly was shaped by the 1959 electoral redistribution, which subdivided the state into three electoral zones (metropolitan with 28 electorates, provincial with 12 and the country with 38 electorates) (AJPH 1959:vol. 5, no. 1, p. 101). This provided a substantial electoral advantage to the Coalition government, especially the Country Party, and the eventual composition of the 1960 Parliament reflected this apportionment. The ratio of the largest electoral enrolment to the lowest was two-to-one, but in terms of numerical equality across the electorates the 1960 distribution was statistically the most 'equal' since 1944, with a relatively low Gini index of equality (Stevenson 1985:4/19-20). The weighting accorded to the various zones, however, combined with a careful drawing of electoral boundaries, provided significant advantage to the Country Party, enabling it to remain in government as the larger of the conservative parties. 
At the 1960 poll, both the government and the ALP opposition increased the number of seats they held, by four and five respectively. The Coalition parties each gained two seats, increasing their combined representation from 42 to $46-$ and increasing the government's majority from nine to 14 seats. The combined vote for the Coalition was 43.53 per cent from 72 candidates. The Country Party, however, with only 19.5 per cent of the vote, remained the dominant Coalition party in the Parliament with 26 seats, compared with the Liberals with 20 seats secured from 24.03 per cent of the vote. The ALP, with 39.89 per cent of the state-wide vote (an increase of 11 per cent from 1957), secured 25 seats in the new Parliament - up from 20 (although one had been reclaimed at a by-election earlier). The assurances given by the government at the time of the electoral redistribution that the election result would deliver a 'close correspondence' between the seats won and the vote cast was shown to be entirely false (Grimshaw 1960a).

The major loser at the election was the QLP. Its vote collapsed to half the figure it achieved at the previous election, falling from 23.39 per cent in 1957 to 12.27 per cent in 1960. It lost seven seats as its parliamentary representation declined from 11 to four. The main casualty was the party leader, Vince Gair. Despite his pugnacious oratory and aggressive campaign, the former Premier was defeated in South Brisbane by the ALP candidate, Col Bennett. With only four seats and no parliamentary leader, the QLP was in a parlous situation. Paul Hilton, a former Minister of Works, Housing and Local Government under the Gair government, was elected as party leader, but during the parliamentary term he suffered problems with his health and lost his seat at the next election. In addition, two of the four remaining rump QLP members - Ted Walsh (Bundaberg) and Herbert 'Bunny' Adair (Cook) - deserted the party over the issue of formally affiliating with the southern Democratic Labor Party, declaring themselves as independents before the 1963 election.

Three successful independents complemented the new Parliament: Arthur Coburn (Burdekin), James Houghton (Redcliffe) and Tom Aikens (Townsville South). Arthur Coburn survived as the independent Member for Burdekin until retiring in 1969. 'Big Jim' Houghton eventually joined the Country Party and went on to become an effective and respected Speaker of the House (serving from October 1974 to July 1979), but became notorious for other reasons immediately after his election in 1960 (see below). Tom Aikens had long been a remarkable figure in the Parliament, first as a representative of his own North Queensland Labor Party (NQLP), then from 1960 as the North Queensland Party (having dropped Labor from his party title). Aikens served continuously as an MLA from 1944 to 1977 . He gave vim to both sides on any subject that came to mind. He hated professionals (especially judges) and would frequently make personal attacks on other individuals. In the Parliament, he had almost legendary gall, 
was quick on his feet and had a good memory and a thick hide. Less certain with figures, Aikens was an accomplished orator who could make meandering speeches that were both powerfully cutting and humorous in their delivery. At times, though, he could also become foul-mouthed, predictably repetitious, go on and on unremittingly and be more of a nuisance than an addition to the deliberative process. Aikens, along with the QLP's Ted Walsh, was a persistent and incorrigible interjector.

The final results in terms of parliamentary representation attracted contention. The Opposition Leader, Jack Duggan, used the next Address-in-Reply debate to criticise the electoral malapportionment under which he pointed out that Labor's state-wide vote of about 40 per cent translated into only 25 seats, whereas the Country Party gained 26 seats with a mere 19.49 per cent and the Liberals 20 seats with 24.03 per cent (QPD 1960:vol. 227, pp. 100-1). He failed to mention that if the 'Labor' votes of the two feuding parties (the ALP and QLP) were combined, they secured 52.17 per cent of the popular vote statewide for just 29 seats in the 78-seat Assembly. Essentially, in addition to the zonal malapportionment, the first-past-the-post voting system used in 1960 had penalised divided parties and magnified representational margins.

\section{Balancing interests in the second Coalition ministry - and the 'mangy dog' kerfuffle}

The government in its second term retained most members of the first Nicklin ministry. The re-elected Coalition retained its 11 portfolios, which were again split six to the Country Party and five to the Liberals. In 1960, this six-five allocation roughly approximated the relative strengths of the Coalition parties in the Parliament, but significantly under-represented the Liberals in terms of the proportion of the primary vote they recorded. Only two ministerial changes occurred to the frontbench immediately after the election (gazetted on 9 June 1960). The Member for Whitsunday, Lloyd Roberts (CP), was elected to the ministry to fill the vacancy caused by the resignation of Jim Heading (CP, Marodian) in the portfolio of Public Works and Local Government. Heading, whose seat of Marodian was abolished in the 1959 redistribution, retired from political office at the 1960 election and was knighted shortly after-prompting some in the opposition to suggest that when the government wanted to dispose of ministers or other senior parliamentarians they softened the blow by awarding knighthoods (see the speech by ALP Member for Rockhampton North, Merv Thackeray, in QPD 1961:vol. 230, pp. 866-7). A week later, Alan Fletcher (CP, Darling Downs) was elected to the position of Minister for Public Lands and Irrigation, after Alf (Adolf Gustav) Muller (a former deputy leader 
of the Country Party and Member for Fassifern) felt compelled to resign his portfolio (see below). The Minister for Agriculture and Forestry, Otto Madsen, served as the Minister for Public Lands and Irrigation for one week (9-16 June) pending the election of a replacement for Muller from the Country Party.

The six Country Party ministers and five Liberal ministers in the new cabinet eventually then consisted of

- Premier and Chief Secretary: Frank Nicklin, CP

- Minister for Labour and Industry: Ken Morris, Lib.

- Minister for Education and Migration: Jack Pizzey, CP

- Minister for Justice and Attorney-General: Alan Munro, Lib.

- Treasurer and Minister for Housing: Tom Hiley, Lib.

- Minister for Development, Mines, Main Roads and Electricity: Ernest Evans, CP

- Minister for Agriculture and Forestry: Otto Madsen, CP

- Minister for Health and Home Affairs: Dr Winston Noble, Lib.

- Minister for Transport: Gordon Chalk, Lib.

- Minister for Public Works and Local Government: Lloyd Roberts, CP

- Minister for Public Lands and Irrigation: Alan Fletcher, CP

A number of the Coalition ministers were known for their distinctive personal characteristics or homespun philosophies. 'Postage stamp' portraits were sometimes recorded in the press: the Premier, Frank Nicklin, was 'popular', a 'gentleman premier' and showed the 'qualities of good average Australianism'; his hard-working deputy, Ken Morris, had a 'missionary zeal' and was 'impatient, restless [and had] a driving force that has thrown him into conflict with some other government members'. The Attorney-General, Alan Munro, was 'reserved'. The Education Minister, Jack Pizzey, shied away from controversy, while the Transport Minister, Gordon Chalk, who was 'hard-working but recently harassed', clearly did not shy away from controversy. The Health Minister, Dr Winston Noble, was considered 'suave', while the '24 stone' Otto Madsen was a knowledgeable Agriculture Minister and appeared 'jovial' and 'benevolent'. The Treasurer, Tom Hiley, affected a 'worldly' image in contrast with the Development Minister, Ernie Evans, who was tough, blunt and was known to 'call a spade a spade' (Courier-Mail, 28 March 1960). Hiley would later be remembered for his exacting dress sense; one Labor frontbencher said of Hiley: 'he earned the reputation as the vainest member in the House. Some hon. members will recall that he was always dressed in a three-piece suit, wore a carnation in his buttonhole and walked with a cane. He looked a picture of sartorial splendour' (QPD 1982:vol. 288, p. 1047). 
Other assessments were less homely and complacent. Some critics referred to the Country-Liberal government as a 'government by cabinet' (Higgins 1961:15). The Nicklin ministry was accused of centralising power around a few dominant personalities in cabinet (Hiley, Pizzey and Evans) who were less inclined to implement party demands or remain consistent with official party policy. Other writers have described the close friendship between Nicklin and Morris and cited this as a major reason why the Nicklin premiership represented a 'golden age' of Coalition harmony (Stevenson 1985:5/1 ff.). Some have argued in retrospect that Nicklin was neither a dominant nor a charismatic leader, but someone who earned the respect of his colleagues and party supporters because of his honesty, diligence and capacity to allow others to take credit for their own achievements (Hazlehurst 1987).

On the face of it, the Nicklin ministry was relatively cohesive and harmonious. Senior members of the cabinet often made reference to the durability of the Coalition in government. For instance, shortly after the 1960 election, the deputy leader, Ken Morris, reminded the Parliament that as the leader of the Liberal Party he was 'a partner - a happy partner - in the coalition Government' (QPD 1960:vol. 227, p. 22). Whether the Liberals were indeed 'happy' with their junior status was another matter, although public expressions of discord with the Coalition arrangements were not common among the leadership echelon of either party.

Behind the scenes, however, the Coalition ministry was far from united. In July 1962, the government announced that Premier Nicklin, who was then sixtysix years of age, would soon retire-possibly after the 1963 election (AJPH 1963:vol. 9, no. 1, p. 100). Nicklin, after all, had led the Country Party for 22 years since June 1941, leading it for 16 years in opposition and by then another six years in government. His deputy, Ken Morris, was energetic but due to ill health (and the illness of his wife) began a gradual withdrawal from office throughout 1962. The circumstances of Morris's departure from state politics were the subject of much dispute at the time.

Morris had come under intense leadership pressure in September 1961, principally from Dr Winston Noble, who campaigned ostensibly for a younger leader (Morris was then fifty-seven years of age), even though Noble's main complaint was that Morris was risking the Coalition by causing a public 'showdown' with the Country Party. The catalyst for the showdown occurred over the 'independent' member Jim Houghton. Now in the Parliament, Houghton had been a popular local mayor who had thrown his hat in the preselection ring for Redcliffe on Brisbane's outskirts, running as a Country Party candidate. When he was unsuccessful in securing the party's endorsement, he ran in the general election as a conservative independent and won the seat regardless. As 
a sitting member, he first began as an independent, then joined the Liberals in May 1961, causing inter-party friction within the Coalition. The Country Party refused to recognise him as a member of the Coalition with rights to attend joint-party meetings - in effect, they were 'dictating' to the Liberals who could and could not be counted as a Coalition member. The reason why the Country Party opposed Houghton joining the Liberals was simple: they regarded his electorate of Redcliffe as Country Party not Liberal territory. Moreover, if Houghton was allowed to join the Liberals this would have reduced the Country Party's majority over the Liberals in the Parliament to only four, or in absolute numbers 25 to 21 - too close for comfort.

Hence, the Houghton incident escalated into a major dispute between the Coalition partners, posing dilemmas especially for the Liberal parliamentary party and its state executive. Ken Morris was intent on supporting Houghton and making a stand against the Country Party's edict, so persuaded the Liberal state executive to refuse to bend to the Country Party's demands. The Liberal executive declared that its Coalition partner was an 'outside body' and that the Liberals would not 'accept that any outside body has the right to dictate who shall or shall not be removed from any unit of the party' (Courier-Mail, 16 September 1961). Other senior Liberals, however, took an alternative view, preferring to side with the Country Party rather than endanger the Coalition in government. Dr Winston Noble, Tom Hiley and Gordon Chalk were all reported to have told Morris that they would not support a move to have Houghton attend joint-party meetings as a Liberal against the wishes of the Country Party. So, the Liberals broke ranks over the issue and Morris withdrew rather than put his leadership immediately on the line. As far as Houghton was concerned, the Liberals had refused to stand by him and he responded by resigning from the Liberal Party in September 1961. At the time, the Liberal State President was reported to have claimed that Houghton's resignation from the Liberal Party was 'engineered under duress' (QPD 1961:vol. 230, p. 380). Subsequently, in July 1962, Houghton rejoined the Country Party and was re-elected in 1963, claiming on the way that he was not personally concerned which party he aligned himself with but was 'tired of being treated like a mangy dog' (CourierMail, 13 July 1962). The Houghton saga, although unique, indicates a degree of fluidity and opportunism extant among the political parties of Queensland at the time. It also indicates the fragility of the Coalition relationship and the tendency of 'collaborators' among the senior parliamentary Liberals to side with the Country Party for the sake of the survival of the government (and perhaps their own political careers). Yet even if the parliamentary leadership could resolve some issues, this did not prevent a 'continual bickering' between the two parties 'injuring the government's reputation' (Truth, 20 September 1964). 
As a result of a culmination of factors, Morris resigned as the leader of the Liberal Party in August 1962 and then resigned as Deputy Premier in September-a position that was largely nominal in the Coalition. In the late 1950s and early 1960s, the Deputy Premier was largely a titular position. The person enjoyed influence and prestige but the position did not carry any portfolio responsibilities, not being linked to a specific portfolio (as it generally was after 1974-usually the Treasurer's job). As Nicklin's deputy, Morris had performed an important political role and enjoyed a status as the leader of the minor party in the Coalition, although he would not normally be expected to assume the premiership should it fall vacant. Morris (who had separate responsibilities as the Labour and Industry Minister) articulated and personified the Liberal aspiration of becoming the dominant Coalition partner. Initially, the Liberal influence within the Coalition was strong under Morris's leadership but this began to wane in the early 1960s. Morris resigned his portfolio responsibilities in October 1962 but continued in cabinet until December 1962, thereby virtually completing two full parliamentary terms in government. In his last term, his leadership was dogged by political infighting, as well as by a personal scandal over land development. He became involved in the 'land scandal' when it was claimed he improperly used the police wireless to help secure freehold land for himself at Mossman. Morris argued in his defence that he had done nothing illegal and that the opposition merely implied it was improper for a cabinet minister to buy land and bring 'development to an isolated area'. He also confirmed that he frequently used 'the Police Wireless channel for exchanging messages, because it is both cheaper and quicker' than regular Post Master General services (QPD 1960:vol. 228, pp. 1241-2).

Alex Dewar (Lib., Wavell) was appointed as Minister for Labour and Industry in January 1963 after Morris's resignation from cabinet. Although illness prevented Morris from contesting the 1963 state election, he had in the meantime become an executive of a private firm relating to his previous portfolio (Industrial Estates Queensland Proprietary Limited). Colleagues claimed that Morris had left the Parliament in a 'state of physical and nervous exhaustion' but then 'made a splendid recovery...from a severe peptic ulcer' (Courier-Mail, 1 November 1963). The 'miraculous' Morris then stood for election as a Liberal senator for Queensland (presumably involving him in less-onerous duties) and completed five years in Canberra (1963-68) (Hughes 1980:115). He was eventually disendorsed by the Liberal state executive and replaced by Bill Heatley. Such infighting provided a feast for the Labor opposition who were always sceptical about the formal reasons given for Morris's early departure from the Parliament. Jack Duggan was wont to hark back to the Deputy Premier's retirement at any available opportunity. In debating the estimates for the Department of Labour and Industry in October 1963 (when Dewar was minister shortly after Morris's departure), Duggan indicated Labor's assessment of the events. He stated that 
not long ago we shared in the regret at the previous Minister's being unable to continue in office. We were told that he was suffering from ill-health, and it was necessary for him to relinquish his political responsibilities. He retired from Parliament. All I want to say now is that I would very much like the names of the doctors who have so miraculously restored him to health in about two or three months that he now feels fit enough to gird his loins and enter the political fray as a Senate candidate. This seems to suggest three things, namely (a) his health was not as bad as it was said to be; (b) he has made a remarkable recovery; or (c) because he was unacceptable to the majority of his party members he was pushed out, and he has used his campaigning skills to get the executive of the Liberal Party behind him in securing his endorsement. (QPD 1963:vol. 236, p. 1046)

Liberal parliamentarians still persisted in the view that Morris had retired because of ill health; Doug Tooth (Lib., Ashgrove) reiterated in response to Duggan that Morris had carried a heavy responsibility and was never home after 7.30am or home before 7.30pm. Tooth assured the Parliament that Morris suffered 'physical and nervous exhaustion' and also developed 'severe peptic ulceration' (QPD 1963:vol. 236, p. 1115).

The Liberal parliamentarians elected the Attorney-General, Alan Munro, to replace Morris as party leader in August 1962. As the new Liberal leader, Munro was then appointed to the position of Deputy Premier from September 1962. The Liberal Party then elected Treasurer, Tom Hiley, as deputy party leader. Hiley had already served as a leader of the party from 1948 to 1954, and was eventually to succeed Munro in 1965 but only for a short period.

Death and illness were also to strike other ministers in Nicklin's first two ministries. Following the death of Lloyd Roberts in April 1961, Harold Richter (CP) became Minister for Public Works and Local Government (4 May 1961). John Row (CP) became Minister for Agriculture and Forestry in June 1963, after the fifty-eight-year-old Otto Madsen underwent an operation and then resigned from the ministry and the Parliament shortly before his death. The appointment of Row, a northern canefarmer, to the ministry was significant because he was selected directly by the Premier rather than by party ballot (as provided by the amended party rules after the 1961 state conference). More ominously in light of subsequent events, Jack Pizzey, the man most likely to replace Nicklin as premier, was also in poor health and suffered a heart attack in 1962.

Nicklin's cabinet was notable because it operated according to prescribed understandings and procedures. Nicklin instituted a cabinet secretariat in 1957 that was intended to improve decision making and provide other ministers with 
single-page summaries of items to be discussed by cabinet. Nicklin also insisted on conventions to preserve the collective solidarity of cabinet as a political forum. Matters did not proceed if cabinet was divided along party lines (that is, six CP ministers to five Liberals), nor did cabinet vote on issues when the Premier and Deputy Premier were clearly at odds over a proposal. Nicklin was also a firm believer in holding country cabinets: convening cabinet meetings outside Brisbane so that the government could establish closer relations with local authorities and communities throughout the state. By early 1963, the Nicklin cabinet had met on 15 separate occasions outside Brisbane.

The second Nicklin ministry was the last ministry fully elected by the Coalition party membership in the Parliament. Thereafter Coalition ministries became a mixture of ministers appointed by the leaders and elected by the party room. The Country Party, in particular, was concerned that the mechanism of selection to the ministry could become too democratic, possibly compromising the internal cohesion of the ministry or restricting the scope of the leader. To provide greater flexibility for the leader, the Country Party amended its internal rules during the government's second term. At the 1961 state conference, the party decided that henceforth the party leader could either personally choose ministers or agree to selection by party-room ballot. Subsequent Country/ National Party leaders then exploited this provision to enhance their control of the ministry and backbench.

\section{Conflicts in the governing Coalition}

Coalition conflict began to surface during the government's second term and one of the first indications of discord arose over the selection of the Coalition's second Speaker. In its first term, the Coalition government nominated Alan Fletcher (CP, Darling Downs) as Speaker of the Legislative Assembly (effective from 27 September 1957). The appointment was not contentious. Fletcher served one term as Speaker before resigning the position on 15 June 1960 to fill a vacancy in the second ministry. This left an administrative hiatus between parliaments, which was seen by some members as a problem. At the opening of the first session of the thirty-fifth Parliament, Jack Pizzey, the Minister for Education and Migration, nominated the Country Party's preferred candidate, David Nicholson (CP, Murrumba), to be the new Speaker. There was considerable interest in the speakership among the governing parties and both the Country and Liberal Parties had proposed candidates requiring a Coalition joint-party ballot. A head-to-head contest occurred between Nicholson and a respected Liberal member, the serving Chairman of Committees, Harold Taylor (Lib., Clayfield). Subsequently, in the House, members from both sides of the Chamber 
drew attention to the intense contest for the position and the 'manoeuvrings that have gone on behind the scenes' (QPD 1960:vol. 227, p. 20). Such overt (or mismanaged) challenges between candidates for the position of speakership on the floor of the Parliament were not unknown, but the only previous occasion on which a challenge had taken place in public was in 1912, when a secret ballot was conducted by the parliamentary clerk.

In the early 1960s, the procedures for the election of a speaker were lax and basically non-existent. A tradition had developed whereby outspoken members would use the occasion to cover all manner of interests and personal obsessions. Before a formal chair had been appointed the House was under no-one's control, and the points raised by members could range widely and not necessarily concern the functions of the speakership or parliamentary procedures. In August 1960, the 'debate' over Nicholson's appointment rambled on for three hours. Tom Aikens (NQLP, Townsville South) exploited the opportunity to criticise both the 'flippant attitude' of the judiciary to the road toll and drunken drivers and the difficulty of raising matters of concern about the judiciary under standing orders once the Speaker was appointed (QPD 1960:vol. 227, p. 6). Enjoying the freedom of speaking on his pet concerns while no-one was in a position to prevent him, he also volunteered himself as Speaker at one stage of the debate, but was without support from other members. Ted Walsh (then QLP, Bundaberg), in a 'marathon speech of almost two hours' (Lack 1962:580), complained of unfair election tactics used against him, criticised the Queensland Club as a 'den of iniquity', attacked Russian communism, argued with Aikens about the Labor government's role in the 1948 railway strike and called for an 'appropriate authority to administer the affairs of the House during that interval between the dissolution and the reassembly of Parliament' (QPD 1960:vol. 227, p. 14). Walsh then mischievously nominated Harold Taylor as Speaker against Nicholson. The Liberal's candidate had already been unsuccessful in the party room and, although some residual resentment remained, Taylor declined the nomination (anxious to avoid 'ratting' on party colleagues; see Lack 1962:580-1). Walsh then chose to nominate Eric Gaven (CP, South Coast) although this move lapsed for want of a seconder. Nicholson was then elected unopposed even though he was seen as relatively inexperienced (with only 10 years in parliament and limited chairing experience). Harold Taylor was subsequently re-elected as Chairman of Committees - a consideration contingent on his declining the speakership nomination.

In congratulating Nicholson, the renegade Tom Aikens warned:

You have been in the House for 10 years, Mr Speaker, and you have seen how I have had to fight to retain for myself even the meagre rights and privileges that were grudgingly granted to me by a succession of 
Speakers, and by others, and I will continue to fight...I want to remind you that, if you care to try to do what some of the previous Speakers have done - if you think that you can persecute and intimidate meyou are welcome to have a go. (QPD 1960:vol. 227, pp. 24-5)

Although his election to office was rocky, Nicholson began a term as Speaker that was to last 11 years and nine months, making him the longest-serving occupant of the position in the history of the Parliament. He soon grew in the job and gained some respect from both sides of the House generally for his even-handedness - although many of his procedural rulings were partisan and some were directly challenged by the opposition and outspoken independents. Nicholson was reappointed by three further parliaments (effectively by the government), retiring after the thirty-ninth Parliament on 25 May 1972.

Other Coalition conflicts were quick to emerge within the ministry. In August 1960, the Opposition Leader, Jack Duggan, accused the government of orchestrating the 'expulsion' of the Public Lands Minister, Alf Muller, from the second Nicklin ministry ostensibly over a 'taxation matter'. The official reason given for Muller's demise was that he had committed a personal indiscretion, whereas Duggan suggested that this was simply a catalyst and that the real reason was an internal Coalition dispute over land politics. Although previously a deputy leader of the Country Party from 1949 to 1957 while the party was in opposition, Muller had become a 'bunny' because he 'was game enough to stand up to people who were endeavouring to gain some advantage for themselves', particularly large land owners and party supporters. Providing a colourful account of Muller's performance, Duggan maintained that

he does not have the sartorial elegance of the Liberals; he does not come in here dressed in suits made by the best tailors of the State; he does not have the vocal eloquence of the Treasurer and some of his other Liberal colleagues who occupy the Ministerial bench, but he was always a fearless and hard-hitting debater. Whatever else he may not have possessed, he certainly had the attributes of being a hard worker, having a sincerity of purpose and a high degree of common sense. We on this side differed with him very much on the Government's handling of their land policy... but I know that the Liberal people who had access to the entrepreneurs and real estate agencies, and the big graziers who threw their money at the Government, thought it would be better to deal with someone who had a less strong view on the cutting up of big estates. (QPD 1960:vol. 227, p. 104)

Duggan challenged the government to 'deny that they forced out their hardest and best-working Minister by using this tax matter as a device' (QPD 1960:vol. 
227, p. 104). The opposition generally regarded Muller's resignation with some scepticism, labelling the episode the 'Muller muddle' in the House (QPD 1960:vol. 228, pp. 1812-13). In his own defence, Muller claimed that he had been given the 'sack' after he put up a 'long fight to protect the Crown estate' (QPD 1960:vol. 227, p. 651). As an illustration of Muller's depth of feeling against his colleagues, he told the Parliament:

To my constituents and to the people of Queensland in general, let me say that I can be of greater service as an Independent than by sticking to a party led by Mr Nicklin and Mr Morris. I do not want to say the whole thing, of course, has weakened my confidence in Mr Nicklin, as far as Mr Morris is concerned, I never had any. (QPD 1960:vol. 227, p. 652)

This admission did not dampen suspicions that pressure had been placed on the government by vested interests to remove Muller from his portfolio, ostensibly over the taxation incident. It also subsequently transpired that the Premier, attempting to seek a way to ease the sacking (but against the wishes of the cabinet), had suggested to Muller that his exit could be accommodated by the Premier seeming to offer him another unacceptable portfolio, which he would then publicly reject. This was the second dumping of Muller by his parliamentary party colleagues, as Jack Pizzey had earlier deposed him from the deputy leader's position when the Coalition secured government. Not surprisingly, Muller became somewhat embittered over the incidents.

Conflicts also deepened within sections of the Coalition's support base. Relations deteriorated in the early 1960s between the Transport Minister, Gordon Chalk, and the road transport hauliers. As minister, Chalk faced the wrath of the industry for regulating the road transport industry and restricting access to road hauliers, especially in regional Queensland. From the Country Party's perspective, the government was principally concerned with keeping farm costs down and freight charges low to farmers (while extracting some 'contribution' from road hauliers for the roads they used). The Premier, Frank Nicklin, also stated in 1960 that the government 'would not allow road transport free use of the roads'. Regulation was needed to avoid the indiscriminate use of the roads by transport firms because, in the Premier's words, 'if transport companies could operate as they liked there would be chaos on the roads'. He also added that the public had ' 55 million invested in railroads and this had to be protected' (Courier-Mail, 9 April 1960). Additionally, the government was worried that Queensland freight intended for the railways was being 'stolen' by 'border-hoppers' in the road transport industry operating from across the NSW border. The local road transport industry, thus, felt squeezed from two sides: by government-subsidised rail and by NSW poachers. The Courier-Mail (9 April 1962) warned before the 1963 election that 'on the domestic front, the 
Government will have to do battle with an active road transport lobby. It has no easy solution here, with policy directed at removing the complaints of groups of primary producers, rather than of the road transport industry.'

The ill feeling was such that the road hauliers deliberately stood candidates against sitting government members particularly targeting those they felt were hostile to their cause. Although some impetus was generated in the Parliament (see Chapter 5) over state transport, the hauliers did not manage to dislodge any official Coalition candidates and their campaign gradually came to a halt.

\section{Changing the rules}

To augment its support base for the 1963 election, the Coalition reintroduced legislation in December 1962 to provide for compulsory preferential voting. The decision was not, however, uniformly welcomed. In essence, the voting change allowed the Coalition parties to contest selected seats against each other without unduly 'wasting' votes as occurred under the first-past-the-post system. The decision to reintroduce preferential voting, taken in November by the combined Coalition parliamentary representatives, was only narrowly passed with some reports claiming the proposal succeeded by only one vote, but in fact the vote was 24-21 in favour (Truth, 4 November 1962). Earlier, in September, a team of four MLAs (Alan Munro and Bill Knox from the Liberals, and Harold Richter and Ron Camm from the Country Party) had considered the issue and presented a report to both parties recommending preferential voting (but with the two Country Party members still perceiving party advantage in simple majority voting). The Liberals were again the strongest supporters, with many Country Party members either ambivalent or hostile to the idea. The latter's opposition was based less on principle (although some favoured a compulsory preferential system whereas the Liberals tended to favour optional preferential) than on the likely effects of the voting mathematics on its own electoral prospects. Coalition divisions over the proposal were reportedly 'bitter', pitting 'friend against friend'; but two agreements helped ease tensions. In July 1962, the organisational leaders of the respective Coalition parties (Liberal President, A. S. Hulme, and Country Party President, A. G. Lawrie) announced an 'agreement on seat entitlement' in which both agreed to respect each other's territory and limit its own candidates by standing 36 candidates each at the following elections (Courier-Mail, 13 July 1962). Although the agreement was made by the respective party organisations, it was difficult to enforce over the local branches. In particular, the Liberals began to exceed their seat quota, feeling the agreed limit held them back and curtailed their political ambitions. The next March, the continuing depth of ill 
feeling led to a second agreement - a mutual 'no poaching pact' — designed to minimise Coalition challenges and restrict the Liberal Party to contesting no more than 39 seats (Sunday Mail, 3 March 1963).

Although the decision to implement preferential voting was designed to suit conservative interests, a further consequence was to revitalise the spirits of the QLP, since the party was rapidly collapsing under the simple majority voting system (and with Gair wondering whether it would be worth standing at all without preferential voting). With the prospect of gaining preferences, the QLP stood more candidates in the 1963 election and expected to capture some ALP seats with conservative preferences. Hence, the Coalition's decision was of double benefit to its cause: it maximised its own vote and enabled the QLP to survive, which thereby sustained the thorn in the side of the ALP.

Parliament did not sit for eight months in 1963-from its adjournment on 6 December 1962 until 20 August 1963, well after the June state election.

\section{Conclusion}

The Coalition had a shaky start in government. They were not necessarily consummate politicians or particularly ambitious. They were motivated by the desire to remain in government, which meant walking a fine line between undertaking popular and unpopular measures and not unduly antagonising the electorate. Nicklin's concern was to provide a united government and collaborative ministry that was based on mutual respect and was largely insulated from the structural, organisational and philosophical conflicts dividing the Coalition parties. Such insulation between the executive and its constituent parties, however, eventually nurtured the seeds of the Coalition's own destruction.

In the late 1950s and early 1960s, the senior Coalition members often had years of political and parliamentary experience on which to draw. They treated the Parliament with a certain degree of decorum and respect, but (just like their Labor predecessors) were not predisposed to provide the opposition with sufficient resources or adequate opportunities to scrutinise government performance. Having learned many parliamentary tactics from years of watching Labor control the House, the Coalition knew how to use parliamentary procedures to good effect as a way of limiting scrutiny of the executive.

In these early years, as Chapter 5 shows, the government never really developed a keen legislative appetite. On occasions, the Parliament was not recalled for want of government business. The Parliament did not sit at all during the first 
3. The early Nicklin years, $1957-1963$

eight months of 1963 awaiting the state election - a practice that was accepted as normal in the context of an election year. Yet the legislation it did champion reflected mainly the Country Party's principal interests and concerns after so long in opposition. 



\section{Safely in the saddle: the Nicklin government, 1963-1968}

Premier Frank Nicklin served almost four terms as leader of the Coalition. Despite his age and gradually deteriorating physical condition, he was prevailed on to remain in the job after the 1963 election and to postpone plans to retire. There were no eager leadership challengers or anxious pretenders waiting in the wings. When the time came for a change of leader, seniority would determine the next in line - a promotion principle used generally by both Coalition parties in settling leadership questions. In the mid-1960s, the Coalition team was relieved to be in government and Nicklin was their most attractive asset with the electorate. Eventually, he continued in office until he was seventy-two years of age, retiring simultaneously from the premiership and leadership of the Country Party on 17 January 1968. By that stage, a smooth leadership transition was envisaged, with the deputy Country Party leader, Jack Pizzey, anointed as his successor. Even the best-laid plans, however, sometimes go astray.

\section{The 1963 election: the first using compulsory preferential voting}

The thirty-sixth Parliament was dissolved in December 1962 and the Parliament did not meet in 1963 until after the election, which was held on 1 June. The 1963 state election was the first postwar election conducted on a compulsory preferential voting system and a record total of 240 candidates stood for the 78 Legislative Assembly seats. Labor contested every seat and won one uncontested. The Coalition stood 73 candidates (the Liberals standing 38 and the Country Party 35). Despite the setback of 1960, the QLP managed to field 60 candidates - three more than the previous time. The other candidates consisted of three communist candidates, nine Social Credit League candidates and 18 independents. The Coalition could afford to drop only eight seats before losing majority government, whereas the ALP had to win 14 seats to win government in its own right. Should either of the major-party blocks not achieve a majority, it would have been interesting to discover which side the QLP would have supported as a minority government. Anecdotal evidence suggests that they would have leaned to the conservative (non-ALP) parties, but such a circumstance did not come about. 
Given that Queensland had traditionally been a Labor state, early media assessments downplayed the chance of a third conservative victory for the Coalition. Opinion polls in 1962 seesawed, with Labor initially in front, then the Coalition took the lead and then they were shown neck-and-neck. QLP support had declined and was often less than 10 per cent (see AJPH 1963:vol. 9, no. 1, p. 100; Hughes 1969:192). The Courier-Mail predicted in 1962 that the government's performance implied the poll would be close and that the Coalition might have to rely on sympathetic independents to govern. The Truth reported in March 1962 that voters looked like ditching the incumbent government, predicting that Labor could gain about 18 seats - enough to govern with a comfortable majority. A Truth (11 March 1962) columnist commented that only a 'political miracle' would save the government and, after conducting its own opinion survey, found that 'there is no doubt Labor confidence is well based'. The Courier-Mail (11 March 1963) by then was even more blunt: 'can the Nicklin-Morris Government win a third term... at the moment the answer would be no.' Nevertheless, as a pro-government paper in those days, the Courier-Mail urged its state-wide readership to vote for the Coalition because of its record on state development and to preserve stability. Labor could not be entrusted with office, according to the editorial writers, because it was influenced too much by left-wing unions and would harm business confidence. As it transpired, the media's early prognoses of a likely rebuff to the Coalition subsequently proved to be flawed.

Unemployment, employment relations, road transport and land policy were the prominent policy issues of the campaign, although Hughes (1969:183) fails to classify anything 'approaching a "Big Issue" in Queensland in 1963 or 1966'. Unemployment was a particularly emotive issue in a state so dependent on seasonal employment and vulnerable industries. Unemployment levels had risen to more than 30000 in February 1962 and had dropped only slightly to 26600 a year later. By the eve of the election in late May, however, the registered unemployed had fallen to 14 600-thus defusing the potency of the issue as a political factor. For those in employment, the promises of three weeks' annual leave and shorter working hours were much more important; and as well as the state council of the Liberal Party calling for three weeks' annual leave, a petition to this effect organised by trade unions and signed by 7000 electors was presented to the Parliament in late 1962 (AJPH 1963:vol. 9, no. 1, p. 100; Courier-Mail, 3 November 1962). A protracted industrial dispute at the Moura coalfield from February to April shaped up as an election issue mainly because the dispute tested the strength of industrial labour against a state minister (Ernest Evans). The dispute also counter-posed union demands for improved wages against the poor living conditions of workers engaged on the coalfields - described by a tribunal arbitrator as 'nauseating, revolting and degrading' (Hughes 1969:202). 
Road haulage continued to dog the government as an issue (see Hazlehurst 1987). Primary producers had long complained about the provision and costs of road and rail transport. Farmers were interested in cheap, effective farmgate road haulage, whereas the haulage industry was subject to cartelisation and zoned into non-competitive areas. Government backbenchers, such as Joh Bjelke-Petersen, had already complained that it was not 'always practicable to use the railways because they are not flexible enough to give the service that can be given by other more modern forms of transport' and that 'when people in some parts of the State's [sic] are offered concessional freight rates such as those offered in the south-western corner of the State, someone elsewhere has to pay' (QPD 1962:vol. 231, pp. 1365, 1364). At a public meeting in Roma, Bjelke-Petersen publicly fought with Gordon Chalk and Frank Nicklin over the issue of cheaper freight charges for farmers. The government found it difficult to resolve the issues because they feared the powerful road transport lobby, which began threatening to stand candidates in safe Country Party seats in the state's south-east. Land policy was also contentious in four respects. The Coalition government had come under increasing pressure over the 'rapid development' of land by property promoters on the south coast. There were suggestions of government collusion over property speculation, even that developers were sometimes aided by government subsidies, which were then 'repaid' by lavish parties for invited political guests (see QPD 1962:vol. 231, pp. 1263-4). Large increases in land tax for city landowners had occurred in 1962. In addition, suburban residents faced large increases in land valuations for their own blocks (on which their rates bills were set). Brisbane land valuations (in 13 ratings districts) had risen by 200 per cent on average during early 1962 - and criticism of the Valuer-General washed over to the government (Courier-Mail, 10 May 1962). Finally, the government's attitude towards rural land had come under criticism - from rural pastoralists eager to move from leasehold to freehold land and the opposition, which criticised the government for plundering the Crown's assets.

The campaign speeches were becoming a highly structured technique of electioneering. By later standards, the speeches were overly long and filled with excessive detail. Although none of the policy speeches was regarded as particularly 'striking' by contemporary commentators, some parties were praised for making 'constructive', 'well-considered' and 'interesting suggestions' even though there was 'little that was new' overall (see AJPH 1963:vol. 9, no. 2, pp. 187-9). The QLP's leader, Paul Hilton, was the first to launch his party's campaign, on 29 April (fully 32 days before the poll). Labor came next, with its leader, Jack Duggan, splitting his address over two days (2 and 3 May), with the first speech to an audience of 200 stalwarts attacking the government's record and presenting Labor's general commitments, and the second speech focusing explicitly on rural and land policy. Labor's strategy was to challenge the 
Country Party head-to-head for rural and provincial votes. Duggan criticised the government for a 'giant propaganda campaign' that pretended 'everything in the garden was rosy' when 'there is not much to the claims they make'. In his speech, he argued that the 'Premier's Department is now staffed by five trained journalists, and the Government has spent a great deal of public money on propaganda and booklets to point out - in a manner I think unjust and unfairthe Government's achievements' (Courier-Mail, 27 May 1963). According to Labor, the government had failed to redress structural problems within the state's economy and had presided over high levels of unemployment running at between 3 and 4 per cent in 1963 (and even higher among so-called 'juvenile unemployment'). In contrast, Labor promised to 'restore full employment'. Labor also offered a series of improved industrial conditions (three weeks' annual leave, better long-service leave, equal pay for women, apprenticeship reforms), plus price controls for subsistence items, low-interest housing loans, more rental housing, police reform, improved $\mathrm{TAB}$ regulation and a review of liquor laws. The ALP's rural policy commitments included a rural finance board, reform to land usage, water conservation, irrigation and improved rural communications, assistance with marketing and research, together with various subsidies and assistance schemes for primary industries (dairy, tobacco, wheat). To convey his message to provincial voters, Duggan chartered a light plane for a six-day speaking tour of regional centres. When in Charters Towers, Duggan told supporters that the ALP would fight for full citizenship for Aboriginal people.

Once again, the Coalition divided the government's policy speech between the Premier and Liberal Deputy Premier, delivered on 7 and 9 May respectively. In Maroochydore, Nicklin reminded voters of the confidence of investors in his government, of the 'unexampled progress' in state development and gave a 'guarantee that in our lifetime Queensland will become the greatest state in the Commonwealth' (Courier-Mail, 8 May 1963). Queensland was entering the 'golden Sixties' - the confidence of investors was now restored and 'wise state legislation had led to the finding of oil' (Courier-Mail, 28 May 1963). The economy was healthy, he maintained, because of the government's record, which included: extensive road-building (including 'beef-cattle roads'), 'a new deal to the landholder', record spending on public works, oil discovery and the planned construction of two oil refineries, the Mount Isa-Townsville railway, Comalco's £25 million alumina plant at Gladstone and more generally increases in exports, investments and savings. Nicklin made much of his government's relaxation of oil exploration leases and looked to Queensland becoming a commercial oil-producing state. The health of the state's economy was also recognised, according to Nicklin later in the campaign, by the independent Arbitration Court, which on the basis of economic growth had granted three weeks' annual leave for award workers (a move that effectively negated the need 
for statutory provisions for three weeks' leave as advocated by the opposition). The court's decision was interpreted as a vindication of the government's 'nondecision' stance in refusing to consider legislating for increased leave, while waiting for the Arbitration Court to award the increase. Nicklin later stated that the government had maintained an 'unswerving policy of support' for the Arbitration Court (Courier-Mail, 22 May 1963).

In a lengthy speech, Nicklin promised further reductions in probate, succession and gift duties, lifting the untaxed amount a man could leave to 'a wife or children under $21^{\prime}$ from $£ 4000$ to $£ 5000$ and extending the 'widow's benefit' to either spouse. Demonstrating a degree of political nous, he promised that 'should the Government find itself in receipt of considerable revenues, such as oil royalties, we will be prepared to examine all forms of state taxation with a view to passing on still further benefits by way of either increased exemptions or by reduction in rates of tax' (Courier-Mail, 8 May 1963).

Nicklin promised to review rail freight rates and improve services through the so-called 'dieselisation program' - replacing steam trains with diesel locomotives. Country towns were promised electricity, water supplies, school swimming pools and other basic amenities. And for landholders, the government announced its continued commitment to transfer leasehold land to freehold title for farmers and pastoralists. Nicklin suggested that the 'paramount features of our land policy have been freeholding, security of tenure, establishment, and stabilisation of stud holdings, and a uniform approach to closer settlement based on living areas' (Courier-Mail, 8 May 1963). Nicklin ended his speech with a warning that Labor was 'unfitted and unworthy of the tasks and responsibilities of government'.

Despite his encroaching age, Nicklin was anxious to embark on the campaign trail, which would last the better part of a month. The Premier followed tradition by undertaking an extensive meet-the-people tour of the entire state. His physical presence throughout the state was intended as a reassuring gesture, an appearance of stability and continuity. For the rest of the campaign, Nicklin's tour progressed from country town to country town, but as election day approached, his performances changed. His speeches became less policy focused and his rhetoric far more of a strident attack on Labor's communist links. By the end of the campaign, in late May, he was actively campaigning on the stump and desperately kicking the communist can.

The Deputy Premier, Alan Munro, presented the Liberals' campaign slogan 'Keep Queensland Free in '63' - again hoping to make the opposition the pivotal issue of the election. He stressed the government's policy of diversification and regional development through the encouragement of manufacturing and large-scale industries (especially bauxite and oil). Mentioning achievements 
in ministerial portfolios held by Liberals, Munro stressed commitments to education, claiming that 41 new high schools had been established in the past six years in office. Law reform and legal aid were promised. Other Liberals talked of 'the tidal wave of expansion and prosperity that is already sweeping through Queensland' (Courier-Mail, 31 May 1963). The Liberal Minister for Labour and Industry, Alex Dewar, claimed that since the Coalition had been in government, investment in secondary industry had been facilitated because much of the 'red tape' in the department had been eliminated. Mostly, however, Liberal promotional material was general and options canvassing rather than specificwith claims that Queensland would go back to becoming a 'pick and shovel' state if Labor won. The General Secretary of the Liberal Party, Charles Porter (later the Member for Toowong), argued on election eve that the main election issue was simple: 'whether to go forward with a Liberal-Country Government that has already worked wonders with a great program of industrial expansion, or whether to go back to those dreary days when Labor-hostile to business and suspicious of all industrial development - deliberately discouraged investment and expansion' (Courier-Mail, 31 May 1963).

Both Coalition partners attacked the extra-parliamentary 'control' seemingly imposed on the Labor leadership from the party organisation and trade unions. Liberal campaign advertisements showed a stark photograph of the Queensland Parliament with a shadow of the hammer and sickle superimposed over the legislature (a tactic Labor objected to strongly in the House immediately after the election; see Chapter 6; QPD 1963:vol. 235, p. 267). Its slogan ran: 'Keep the Trades Hall Shadow off our Parliament' (Courier-Mail, 23 May 1963). Nicklin said that 'possibly the main issue to be decided at the election was whether Queenslanders wanted to be governed from Parliament House or the Trades Hall' (Courier-Mail, 16 May 1963). He delved back into history and accused prominent Labor trade union leaders of running joint 'unity tickets' with known communists in union elections in the mid-1950s.

On the policy front, the Premier claimed Labor would nationalise key industries if returned to government. One suggestion was that Labor would nationalise the operations and cancel government contracts at the recently discovered Moonie oil field (a suggestion rejected by Duggan in Labor's opening speech). Left-wing influence was a sensitive issue in the context of Cold War geopolitics and conservative accusations that Labor was 'socialistic' or union dominated had the potential to damage Labor's vote (although the real impact on the ALP's state-wide vote is disputable). Parallels were drawn between the state ALP and the 'faceless men' dictating federal ALP policy after the federal leaders Arthur Calwell and Gough Whitlam were caught sitting outside Canberra's Kingston Hotel awaiting the party's decision on its attitude to US communications installations in Australia. Although Jack Duggan explicitly denied in his policy 
speech that Labor would be dominated by extra-parliamentary interests, the impression stuck and appeared to dampen the resurgence of ALP support across the state.

Inter-party animosity between the two Labor Parties was again a feature of the campaign. The QLP, after formally affiliating with the southern DLP in November 1962, was vehement in its attack on the ALP, claiming that the party was a front for communism and that 'the ALP under [its] present leadership must be smashed and broken for [the] security of Australia' (QLP, The Standard, 1963). Such attacks seemed to encourage retaliation. ALP demonstrators disrupted some QLP political meetings and speeches. Occasionally tempers flared and hecklers became abusive or resorted to fighting to settle scores. At one Brisbane meeting of the QLP, the fisticuffs turned into an 'all-in' street brawl between QLP and ALP supporters, who fought on the footpath outside the Norman Hotel for a good 20 minutes. The melee involved the former leader, Vince Gair, who reportedly tried to intervene to end the fighting, but who later said 'our blokes looked after themselves all right' (Truth, 19 May 1963).

To give some bite to its bark, the QLP decided to punish the ALP at the ballot box. The QLP's previous leader, Gair, had declared in July 1962 that if preferential voting were introduced, the breakaway party would allocate its preferences to the Liberal and Country Parties. This was an act of revenge politics in an atmosphere of intense animosity. In the event, as Hughes (1969:12-15) has recorded, the impact of preferential voting across the state was less significant than expected. Hughes (1969:14) found that only in three seats 'did the preferences change the result from a first-past-the-post count'. Although a handful of Coalition candidates relied on preferences to achieve a majority, the QLP's preferences were instrumental only in assisting two Liberal candidates over the line (Peter Delamothe and Merv Anderson). Both had come from behind to win with QLP preferences. The only other seat affected (Fassifern) involved a contest between Alf Muller (the ex-Country Party Lands Minister, who was contesting the election as an independent) and his official Country Party challenger, Albert Hall (whose parents must have had a sense of humour!). Despite coming second in the primary vote (with Hall on 3211 votes to Muller's 3028), Muller narrowly held the seat after the distribution of ALP and QLP preferences; but then, before the next election, he rejoined the Country Party in September 1965. ${ }^{1}$ The relatively slight impact of preferential

1 His rejoining came after lengthy meetings between himself, the County Party's President, John Ahern (the father of Mike Ahern, later Premier), and the local Fassifern electorate committee, involving an agreement to run Muller as the official Country Party candidate for Fassifern in the 1966 elections - a contest he won before standing down at the 1969 elections. 
voting probably ensured its survival, especially given that some in the Country Party were already having second thoughts immediately after they had decided to reintroduce the system for the 1963 election (Courier-Mail, 3 November 1962).

Despite predictions of a close result, the final outcome largely maintained the status quo. The Coalition was returned with exactly the same number of seats it had held in the previous Parliament. Many commentators found the result surprising precisely because little change occurred. Certainly, the decision to adopt compulsory preferential voting advantaged the Coalition but proved of negligible significance to the QLP. The Coalition again stood 73 candidates and its vote remained remarkably stable at 44.06 per cent - up slightly from the 1960 result when it captured 43.52 per cent. While the Country Party's vote fell back by 0.5 per cent, the Liberals' total rose by 1 per cent. Once again, the Liberals outpolled the Country Party by 23.75 per cent to 20.31 per cent, but the Liberals stood 38 candidates to the Country Party's 35. This level of support translated into 46 seats ( 20 for the Liberals and 26 for the Country Party). In contrast, the ALP stood 77 candidates and received 43.83 per cent of the primary vote (up by 4 per cent from 1960), but received only 26 seats in the Parliament (one of which was uncontested by other candidates). In other words, standing roughly the same number of candidates, and achieving virtually the same proportion of the primary vote, the Coalition secured 46 seats to the ALP's 26.

On state-wide figures, the Coalition managed to gain just 1877 votes more than Labor from a total electorate of 770 998. Had proportional representation been in place for the election, the Coalition would have won 34 of the available 78 seats to Labor's 34, with six QLP seats and four independents.

Duggan blamed the 'gerrymander' for restricting Labor's gains despite a 4 per cent rise in the primary vote. He claimed that the Coalition had benefited from a 'slander' campaign against the ALP and that 'smears made about the Labor Party have stuck to some extent, without justification. Time will erase the false image created by dishonest propaganda' (Sunday Mail, 2 June 1963). The ALP secretary produced figures after the election to illustrate that the Country Party had received 156594 votes in the state for 26 seats, whereas Labor had polled 337861 votes and achieved only the same number of seats (Truth, 15 September 1963). The Country Party had, however, stood only half the number of candidates compared with Labor.

New members in the Parliament were: the Liberal reformers John Murray, Geoffrey Chinchen and William Lickiss, together with Henry McKechnie (CP) and Edwin Wallis-Smith and Peter Wood from the ALP. Shortly after the election, the former Agriculture Minister, Otto Madsen (CP, Warwick) died suddenly. At the ensuing by-election, the Country Party's David Cory narrowly held the seat, suffering a 10 per cent swing against him (Hughes and Graham 1974:280). 


\section{Nicklin's expanded third ministry}

The first session of the thirty-seventh Parliament was opened on 20 August 1963. Parliament had not sat since 7 December 1962. The previous ministry was retained for a little more than one month while the Premier introduced legislation to increase the number of ministers by two. Consequently, the third Nicklin ministry was not announced to the Parliament until 26 September 1963.

The ministry was expanded under the provisions of the Officials in Parliament Act from 11 ministers to 13. This meant the Country Party retained seven portfolios to the Liberals' six. The two new members appointed to cabinet were the long-serving Johannes Bjelke-Petersen (first elected to parliament in 1947 and subsequently to become a future leader of the Country Party and State Premier) and Peter Delamothe, who had served for just one term in parliament but who would serve for eight years as a competent and innovative AttorneyGeneral. Some scholars of Queensland politics have described Delamothe as one of the best Coalition ministers of the era with perhaps the exception of Jack Pizzey. While Delamothe was elected by his Liberal peers to the position, BjelkePetersen was appointed at the discretion of the Premier. Bjelke-Petersen would become an astute Minister for Works, using his portfolio and position to enhance his influence within the wider Country Party and business networks. From the mid-1960s, he began to perfect a system of patronage based on the deployment of capital works and infrastructure in return for political payoffs and support. He had obviously more going for him than that, however, otherwise every Works Minister would end up premier! Nicklin also abolished the ministerial title of Chief Secretary from his own portfolio.

The ministry was

- Premier and Minister for State Development: Frank Nicklin, CP

- Minister for Industrial Development: Alan Munro, Lib.

- Minister for Education: Jack Pizzey, CP

- Treasurer: Tom Hiley, Lib.

- Minister for Mines and Main Roads: Ernest Evans, CP

- Minister for Health: Dr Winston Noble, Lib.

- Minister for Transport: Gordon Chalk, Lib.

- Minister for Lands: Alan Fletcher, CP

- Minister for Local Government and Conservation: Harold Richter, CP

- Minister for Labour and Industry: Alex Dewar, Lib.

- Minister for Primary Industries: John Row, CP

- Minister for Works and Housing: Johannes Bjelke-Petersen, CP 
- Minister for Justice and Attorney-General: Dr Peter Delamothe, Lib.

The expansion of the ministry allowed for a more extensive reorganisation of the portfolio responsibilities. Under the new ministry, the Premier assumed an active responsibility for state development. This acknowledged that the Premier's office was the main decision-making authority on development matters and the avenue through which business proposals, investments and new projects were often negotiated. It also brought formal responsibilities into line with prevailing practice, recognising that the Premier's office was responsible for coordination and frequently engaged in direct horse-trading with business over terms, conditions and economic incentives. Industrial development was also elevated to the Deputy Premier and identified as a separate senior portfolio responsibility. Such a move highlighted industrial development over other types of economic development. It also emphasised the importance of industry over the other components of the previous 'grab bag' portfolio containing mines, main roads and electricity.

A series of other substantial portfolio changes was made - from the relatively conventional and somewhat anachronistic composition of earlier ministries. Home Affairs was jettisoned. Migration was removed from education and dispensed with altogether. The portfolio of Local Government and Public Works was separated. Responsibility for irrigation was removed from Public Lands and reconstituted as conservation and combined with local government. This was the first time that environmental and conservation responsibilities had been recognised symbolically within a specific ministerial title. The Department of Agriculture and Forestry became the Department of Primary Industries, with the government expecting it to broaden its sphere of activities. Housing was uncoupled from the Treasury portfolio and incorporated into a new ministry with works. Specific responsibility for electricity was dropped as a ministerial title. Finally, in the portfolio restructuring, the duties of one continuing minister, Ernest Evans, were lessened, leaving him with the peculiar combination of mines and main roads.

The hierarchy of the ministers in the new ministry was largely as it had been in the previous Parliament, with seniority in the ministry a key determinant of position. Three Liberals received promotions in the rankings - namely, Tom Hiley, Winston Noble and Gordon Chalk - while Alan Fletcher in the Country Party was elevated from last on the ministerial list to eighth.

Changes in the third ministry were brought about by turnovers in the Liberal Party leadership during the Parliament. Alan Munro resigned as Deputy Premier, Liberal Party leader and Minister for Industrial Development in January 1965, but remained in the Parliament as a backbencher until the election of 1966. The Queensland Parliamentary Handbook records that Munro resigned the Deputy Premiership on 23 December 1965 but this is incorrect; he resigned all his 
positions in January - and officially his membership of the Executive Council (Queensland Government Gazette Extraordinary, 28 January 1965, no. 22). Munro was replaced as party leader for almost one year by Tom Hiley, who had previously been leader of the Queensland People's Party and then the Liberal Party from 1948 to 1954. The appointment of Hiley - then aged sixty - to the leadership was a transitional and largely 'honorific' arrangement, which paid 'tribute for past services' and gave him due recognition in government (Hughes 1969:79, 1980:32). Following Liberal conventions, Hiley was simply next in line for the post. Significantly, he was the first Liberal to hold simultaneously the positions of Deputy Premier, party leader and Treasurer (positions that later became fused in conventional Coalition arrangements). At the helm of the party, Hiley's tenure was short-lived and in June 1965 he announced of his own volition that he would not stand at the next state election and would resign his leadership at the end of the year (he had apparently promised his wife he would resign). He duly resigned his three leadership positions in December 1965, causing a more substantial ministerial reshuffle. Hiley then moved to the backbench briefly and, along with Munro, stepped down from parliament at the next state election in May 1966. The Liberal candidate chosen to replace Hiley for the seat of Chatsworth was W. D. (Bill) Hewitt, a thirty-four-year-old business manager who had been active in the Young Liberals and would become one of the avid 'reformers' inside the government known as the 'ginger group'. He had a background in 'time and motion' studies and long attempted to persuade his parliamentary colleagues to improve their own efficiency in assembly debates and over scrutinising legislation.

The parliamentary Liberals' decision to recycle Hiley as party leader was symptomatic of deeper divisions in the party. After Munro resigned and Hiley accepted the leadership in January 1965, the deputy's position was contested by two senior ministers representing different wings of the Liberal Party. Gordon Chalk (the Transport Minister and an ardent Coalition loyalist) was challenged in the election for the position of deputy leader by Alex Dewar (then the Minister for Labour and Industry but about to be appointed the Minister for Industrial Development in January 1965), representing the 'ultra-Liberals', who were anxious to push Liberal interests even at the expense of Coalition interests. In the event, Chalk managed to win but only by the narrow margin of just two votes. At the end of 1965, Hiley then vacated the parliamentary leadership and was replaced by Chalk, who was elected only after a fierce party-room struggle. Chalk was again challenged by Alex Dewar, but managed to win by a slightly greater margin of 12 votes to eight. Dewar then stood again for the deputy leadership position, this time against the Justice Minister, Dr Peter Delamothe. The party-room vote was tied at 10 votes all. In the fifth and final ballot, Dewar finally managed to gain a majority of 11 votes to nine (Telegraph, 8 December 1965). Trying to avoid such internal rifts, the Liberals then amended their party 
procedures and conventions to allow the parliamentary leader to select the other ministers (and the deputy) rather than rely on a party-room election (CourierMail, 26 March 1966). A short time after, Chalk's main rival, Dewar, ran foul of the Liberal hierarchy and was eventually forced out of politics after being embarrassed by a personal scandal involving sexual harassment of departmental staff (see below).

Chalk became the fourth deputy Coalition leader to work with Nicklin since 1957. Before the Hiley/Chalk appointment, the Liberals' claim to the Deputy Premier's position had not been combined with the portfolio of Treasurer (although the Treasury portfolio had earlier been allocated to the Liberal partners in the Coalition). Not until Chalk became Liberal leader and Deputy Premier and Treasurer in December 1965 did the three positions become an excepted norm in Coalition arrangements. At this stage, however, the position of 'Deputy Premier' was merely a title and status demarcation rather than a specific ministerial portfolio; subsequently the position of Deputy Premier was constituted as a portfolio area in its own right, in December 1974.

There were other changes among the Liberal members of the third ministrysome forced by circumstance. In March 1964, the Minister for Health, Dr Winston Noble, died suddenly while still in office. He was replaced in the Health portfolio by a new Liberal Minister, Seymour 'Doug' Tooth (Ashgrove), while Norman Lee (Liberal) won Noble's seat of Yeronga in a by-election in June 1964. After Munro quit the leadership, Alex Dewar, the Minister for Labour and Industry, was promoted to the position of Minister for Industrial Development in January 1965 under Hiley's brief leadership tenure - a ministerial portfolio that would be his last. Dewar's former Labour and Industry job was given to another new Liberal minister, John Herbert (Sherwood), who was the next most senior Liberal in the Assembly, defeating William Knox (Lib., Nundah) by 13 votes to seven in the party-room ballot. Herbert served as the Labour and Industry Minister for more than six years and remained in the Coalition ministry for more than 13 years. After Chalk moved to Treasury in December 1965, his Transport portfolio was assumed by the next in line, William Knox. In short, three new Liberal ministers entered the ministry in the period 1964-65: Doug Tooth, John Herbert and Bill Knox-each waiting his turn to enter the ministry according to his parliamentary seniority.

In contrast, the line-up of Country Party ministers was relatively stable. Only one change occurred and again this was through dint of circumstance. The longserving member for Mirani, Ernest Evans, who entered the Parliament in 1947 and had served as the Minister for Mines and Main Roads since 1957, died on 28 February 1965; he was sixty-two years of age. His party colleague Ronald Camm replaced Evans on 11 March 1965. Camm would later challenge unsuccessfully for the leadership of the Country Party, in 1968, before becoming the 'younger' 
deputy leader under Bjelke-Petersen. A few years after these events, BjelkePetersen claimed he had initially been offered the Mines and Main Roads portfolio when Evans died, but had turned it down (Sunday Mail, 9 March 1969).

With Munro's retirement and the sudden death of Evans in 1965, only four of the original 1957 Nicklin ministry remained in office by mid-1965 (namelyNicklin, Pizzey, Hiley and Chalk). Three years later, Chalk would become the sole surviving member of the original cabinet.

\section{Allegations of police corruption: the 'flawed' National Hotel inquiry}

The Parliament was one sanctuary in which members could raise contentious or potentially libellous issues without fear of civil action. Sometimes this privilege was used to smear individuals (a tactic that becomes abuse if the smear is for personal or selfish purposes). At other times, however, it was a useful accountability instrument that allowed serious allegations to be aired and investigated. In September 1962, allegations of mismanagement were raised in the Parliament about the Queensland Police Force, particularly concerning public complaints and the lack of responsible action from the Police Commissioner, Frank Bischof. The independent Member for Bundaberg, Ted Walsh, claimed that

there has been much unfavourable criticism of the administration of the Police Force in this State. It is useless blaming the subordinate ranks, and it is no good picking out individual policemen who may have been charged with bashing, or some other offence. These incidents can be encouraged only by weak supervision - the lead must come from the top. It does not matter whether it comes from the Commissioner's office or the chief of the CI [Criminal Investigation] Branch. (QPD 1962:vol. 233, p. 317)

He added that the 'administration of the Police Force cannot be expected to improve whilst it has a Commissioner who goes round glamorising, and opening agricultural shows and public functions' - to which Colin Bennett (ALP, South Brisbane) added that Commissioner Bischof 'reckons he is going to be the next Governor' (QPD 1962:vol. 233, p. 318). Walsh also attacked the notion that policemen had to make ' 25 arrests to prove his efficiency' as a 'silly idea'.

Later, during the supply debate on 29 October 1963 when the House was in committee scrutinising the estimates of the Department of Labour and Industry (under which the Police Department fell), further and more serious allegations 
were made concerning the incidence of corruption, improper conduct and political collusion among senior police officers. Bennett, who was the opposition's main spokesman on police matters (and a lawyer), detailed specific instances of corruption and misconduct. He alleged that the Police Commissioner along with other officers had actively campaigned against the Labor opposition at the previous elections in 1963, claiming senior officers were currying political favour (see Chapter 6 for further details). More sensationally, however, he charged that

[t]he Police Force itself is seething with discontent. There are what might be termed camps in the Police Department, and police officers are in one camp or the other depending on the treatment that they are receiving from the Commissioner and some of his top colleagues...the Commissioner and his colleagues who frequent the National Hotel, encouraging and condoning the call-girl service that operates there, would be better occupied in preventing such activities rather than tolerating them. (QPD 1964:vol. 236, pp. 1061-2)

Such allegations were dynamite. The statement that the Police Commissioner was 'encouraging and condoning' prostitution operating from a city hoteleven though in the speech it was more of an aside - was a specific charge that could not easily be ignored. Initially, government members did not 'controvert' the allegations, preferring instead to continue with their prepared supply speeches. Gradually, however, the enormity of the allegation struck home and various government members took Bennett to task. That evening, the debate livened up considerably. One commentator later describing the parliamentary debate (James 1974:4) claimed that Bennett's allegations 'sparked off one of the most heated political discussions in years, brought government members back into the House, and caused the establishment of the Royal Commission'. Shortly before Bennett had spoken, the Deputy Leader of the Opposition, Eric Lloyd, had drawn the Chairman of Committee's attention to the fact that the House was not 'quorate' (that is, it did not have at least 16 members present excluding the chair) and only five government members were present.

John Herbert (Lib., Sherwood), who regarded himself as a 'decent' member of the House, claimed later that evening to have heard

the outpourings of a diseased mind. The accusations he made against Police Commissioner Bischof were so serious that he now has a clear duty to produce evidence to support the charges. If he does not do so, he must be branded as a character assassin of the lowest order and a man who would use the privileges of this Chamber to attack a public servant who has not the right of reply...If the hon. member can produce any 
proof to support his charges, he can rest assured that this Government will take action. I challenge him to produce this proof. (QPD 1963:vol. 236, p. 1077)

The responsible minister, Alex Dewar, Minister for Labour and Industry, weighed in to read out the relevant sections of the Police Act that provided for the punishment or dismissal of corrupt officers 'by the Commissioner' ( $Q P D$ 1963:vol. 236, p. 1087). Given that the allegations concerned the Commissioner himself, this defence missed the mark. Other attempts to rebut or comment on the allegations (by Doug Tooth, Ted Walsh and 'Bunny' Adair on 31 October) merely served to keep the issue alive. The Police Union also wrote to the minister asking for a full inquiry open to public scrutiny. Then on 5 November, the Premier announced in a ministerial statement that the government had 'given serious consideration' to Bennett's claims especially in relation to the Commissioner and his colleagues. The Premier informed the Parliament that the government would take 'appropriate action' if Bennett 'could make specific charges...that call for investigation', to 'give the names of credible witnesses prepared to give first-hand evidence' and show that the persons charged are identifiable' (QPD 1963:vol. 236, p. 1205). Nothing more was reported in the Parliament before the government announced the appointment of a royal commission on 12 November 1963 (QPD 1963:vol. 236, p. 1366). Outside the Parliament, however, a raging debate ensued - coming to a head when the Courier-Mail ran an editorial calling for a full inquiry. The editorial stated:

[O]nly a Royal Commission with [the] widest powers can clear the air now. Queensland's police force has been under suspicion since an Opposition MP (Mr Bennett) made grave allegations against high police officers in Parliament last month. Despite public concern the Government has refused an open inquiry into the allegations on the plea that it wanted more concrete evidence. But the matter has refused to die down after this let's-do-nothing decision. The Opposition Leader (Mr Duggan) has given the Government further material in a letter (contents still withheld from the public), and a Brisbane man has revealed that he is the one who gave information to Mr Duggan. The Government may feel that it is pursuing a wise policy of masterly inactivity. If so, the Government never made a bigger error. (Courier-Mail, 9 November 1963)

After receiving a report from the Crown Law Department on the allegations, Nicklin established a royal commission under Mr Justice Harry Gibbs (later to become Chief Justice of the High Court) to examine whether police misconduct had occurred and whether a prostitution service operated from the National Hotel. The terms of reference announced in the Parliament limited the investigation to one hotel, the National Hotel, and to selected police - both of which curtailed the scope of the commission. The inquiry quickly established that the National 
Hotel was a popular venue for police functions and, along with the Grand Central Hotel with its 'Passion Pit' and 'Red Lounge', had become hang-outs for 'goodtime girls'. A string of hotel waiters gave evidence that many women frequented the pubs but they could not tell whether they were prostitutes. Few witnesses came forward with specific allegations. ${ }^{2}$ In the new year, the Commissioner, Frank Bischof, gave evidence at the hearings denying all charges and claiming that to his knowledge no prostitution racket operated from the hotels. The hotel proprietor, William 'Roley' Roberts, also gave evidence refuting allegations that prostitutes operated from his pub, blaming business rivals and other publicans for having 'pushed along' the call-girl rumours to damage his business because they were envious of his trade (Courier-Mail, 25 January 1964).

The report on the National Hotel inquiry was tabled in the Parliament in April 1964 (see QPD 1964:vol. 238, p. 11). Mr Justice Gibbs was concerned to establish that any evidence of misconduct should be proved 'beyond all reasonable doubt', rather than on the balance of probabilities. Not surprisingly, given the conspiracy of silence, he found little such hard evidence. Most of the report evaluated the character and testimony of the principal (non-police) witnesses, which were often unreliable or contradictory. Most had not managed to furnish absolute proof, any collaboration or detailed records to support their claims. Far less attention was paid to the police witnesses, some of whom were equally if not more unreliable, and to similar weaknesses in police testimony. Gibbs found that Commissioner Bischof had been unfairly maligned and that the state should pay his legal costs and that no 'culpable neglect' could be proven against any police in relation to the policing of the National Hotel. The exoneration of senior police subsequently encouraged police to become more brazen in condoning and seeking kickbacks from illegal activities, perhaps leading them to believe they were beyond the law and untouchable. Despite the narrow terms of reference, later events and a much more powerful second royal commission headed by $\mathrm{Mr}$ Justice Tony Fitzgerald in the late 1980s were to challenge and cast doubt on the flawed investigation conducted by Mr Justice Gibbs.

The National Hotel inquiry was not the subject of much immediate debate when the Parliament resumed in August 1964, and some members regarded Bennett as having made an error of judgment in not having all his facts established and verifiable (see QPD 1964:vol. 238, pp. 74, 165). Aikens questioned the cost involved in conducting the inquiry ( $£ 13427$ ) and later asked whether Bennett would be required to pay these costs. Police matters (especially discipline and transfers), however, continued to be regular topics of questions to the minister.

2 David Young and Shirley Briffman were the most prominent. Ominously, Briffman died in suspicious circumstances in March 1972 shortly after confessing to working as a prostitute between 1965 and 1969 and making allegations of misconduct and perjury against police officers Tony Murphy and Glen Hallahan - the latter of whom had faced earlier departmental charges but was let off after a secret inquiry. 
In March 1965, Bennett was suspended from the House for five days after again raising police issues (the 'closure' of a police liquor canteen at the Roma Street station). After altercations with the Speaker, David Nicholson, over whether or not one of Bennett's written questions was tampered with, the debate degenerated until Bennett was suspended after a division (resulting in a vote for suspension of 40-23). The Speaker intervened in question time to take Bennett to task because he 'seizes every opportunity to criticise'. The Hansard transcript (QPD 1965:vol. 240, pp. 2523-4) continues as follows:

Mr Speaker: He runs to the Press with his complaints at every opportunity. Unfortunately, the Press believe him. I want the Press to understand that questions are altered or disallowed only when they do not conform to the Standing Orders.

Mr Bennett: I rise to a point of order. I strongly resent your personal attack on me. It is untrue...

Mr Speaker: Order!

Mr Aikens: 'The Courier-Mail' pays him dirt money.

Mr Speaker: Order! If the hon. member [Bennett] continues to interject during question time I will have no alternative but to deal with him under Standing Order No. 123A.

Mr Bennett: No-one is going to make untrue allegations about me...

Mr Speaker: Order...The hon. member for South Brisbane has continually interjected during question time, and under Standing Order 123A I ask him to leave the Chamber.

Mr Bennett: I would like to say...

Mr Speaker: Order!

Mr Bennett: Your remarks about my continually running to the Press are untrue.

Mr Speaker: Order! The hon. member is now named. He will resume his seat... [He was then formally 'named' to the House and the Premier, who felt that the Speaker had been 'very tolerant' and gave Bennett the chance to apologise to the chair and the House]

Mr Bennett: Mr Speaker, I believe that you used your position this morning to conduct a personal attack on me. Your remark about my continually running to the Press is untrue. 
Mr Speaker: Order! The hon. member has denied that he runs to the Press. I accept his denial, but I will not tolerate his constant disorderly conduct in this Chamber. This morning was the breaking point so far as I am concerned.

Hon. G. F. R. Nicklin: If the hon. member for South Brisbane is not prepared to do the proper thing, I have no alternative but to move'That the hon. member for South Brisbane be suspended from the service of the House until Tuesday next'.

Question put - and the House divided - 40 to 23 in favour.

At one level, such incidents were minor skirmishes fought over sensitive issues, when the Parliament did not want to raise the larger issues. They appear as trivial if not petty reflections of relations between both sides of the House. In this particular case, the Speaker (rather than affected ministers) was prepared to take up the attack on Bennett after the inquiry had run out of steam. Then once challenged, the government resorted to its 'sufficient numbers' to have matters always determined in its favour. There were others even among the Labor side who believed that Bennett sprayed mud around too freely, and that as a barrister he would occasionally attempt to get thrown out when he had to go up town to his legal practice or attend an important court case in which he was appearing (like many other parliamentarians, Bennett continued his professional business while a Member of Parliament). Such stories are, however, often apocryphal, as Bennett was not often really thrown out. Whatever the motivation, though, such behaviour was not uncommon in the Assembly. Bennett also distinguished himself with his fists on occasions, such as when in December 1963 he punched Greg Kehoe (a former Labor member and defector to the QLP) in the mouth, breaking a tooth and splitting his lip! Kehoe broke a finger trying to retaliate.

\section{The Mount Isa Mines industrial dispute and the Parliament}

In 1964-65, a bitter and protracted industrial dispute began at Mount Isa Mines between the company and the local members of the Australian Workers' Union (AWU, called the 'Committee for Management Control') plus other unions of the Trades and Labour Council (TLC). In many ways, the dispute was a consequence of the tightening of the Industrial Conciliation and Arbitration Act 1961 by Deputy Premier, Ken Morris, which prevented the commission from awarding increased prosperity loadings through the tribunal. Unions felt this provision was 'unjust', especially as the company refused to negotiate over bonus payments. There were also suggestions that the government and the company 
were in cahoots over the strategy to take on the union. Once the dispute flared, inter-union rivalry became an additional feature of the dispute. The AWU was recognised as the main union at the site but its state leadership did not reflect local sentiment and its virtual monopoly position was challenged by (left-wing) craft unions associated with the TLC. The strike/lockout was led on the ground by Pat Mackie, a breakaway leader of the local AWU who was dismissed by the company during the dispute and later became an outcast from his union.

The magnitude of the Mount Isa dispute illustrated that the institution of parliament was not a good forum in which to deal with wider societal or economic crises. It was difficult to use an adversarial parliament in either a deliberative or a consensual capacity - and as the government of the day found passing tougher legislation was technically possible but it did not necessarily resolve the conflict. The Mount Isa dispute, though, became a celebrated case, and for years after became a favourite topic of parliamentary debate, providing ample ammunition to both sides of the Chamber for the apportionment of blame. The fact that the government sided with the company (and subsequently the official AWU; see below) throughout the dispute was divisive and tensions were exacerbated after Nicklin authorised the use of police to quell any disturbance in Mount Isa. In retrospect, however, perhaps more serious was the government's persistent inactivity and preparedness to allow the dispute to run on and fester.

Premier Nicklin was reportedly ill and in hospital during part of the dispute (Courier-Mail, 9 February 1965), leaving the Treasurer, Tom Hiley, as Acting Premier. When the Parliament resumed in March 1965, the government faced a want-of-confidence motion from the opposition, introduced because it was critical of the government's handling of the Mount Isa dispute. Jack Duggan outlined seven grounds for the motion: that the economy was adversely affected; hardship and suffering were occurring; the government's actions were inept; the Parliament had not been reconvened early to debate the matter; emergency powers issued under Orders in Council were aggravating the dispute; the statutory limitations imposed on bonus payments by the 1961 act were counterproductive; and 'disquiet' existed over the use of police to intervene in the town (QPD 1965:vol. 240, pp. 2309-10). This was one of the longest debates in one sitting day, beginning at 11.37 am on Thursday 4 March and lasting until 3.50 am the next day (although the final result was never in doubt and was lost 38-22 on party lines). Nicklin amended the want-of-confidence motion to negate directly its intent (contrary to conventional debating rules and UK parliamentary procedure set out in Erskine May, but not prohibited under Standing Orders). Nicklin's amendment expressed the House's confidence in the government over its actions throughout the dispute. Interestingly, although Duggan challenged this tactic on the floor, he was overruled by the Speaker, who felt 'it places before the House two alternative propositions' (QPD 1965:vol. 
240 , p. 2336) - a novel interpretation of debating practice. While eventually the want-of-confidence motion was defeated and Nicklin's amendment was successful, the debate placed the government under scrutiny and indicated increased vigour from the opposition.

The government's response to the Mount Isa dispute was announced a little more than one week later, on St Patrick's Day. The Premier, however, in proposing amendments to industrial law to outlaw picketing (see Chapter 5), made a surprising speech to the Parliament. Introducing the legislative amendments in the first reading stage on 17 March 1965 (QPD 1965:vol. 240, pp. 2640-1), the Premier argued to the effect that

[i]t is true that the genesis of the Mount Isa dispute may have been industrial in that it was detonated by a refusal on the part of the Industrial Commission in August last to increase the rates of pay provided under the Mount Isa Mines Award...Let us for just one moment take the situation for what [it] is today, namely, a bitter, vicious, and unscrupulous attempt by the Queensland Trades and Labour Council to eliminate the Australian Workers' Union from the Mount Isa mining field. This is obviously the first step in a considered and planned campaign to decimate this great union.

The government chose to adopt the tactics of 'divide and rule' by supporting the moderate AWU leadership against rank-and-file activists they regarded as communists. The Premier went on to speculate:

By whom has this campaign been considered and planned...Its most vociferous proponents are either self-professed Communists or those who, without professing, associate with Communists. Its most active leader [referring to Pat Mackie] has a long and varied record of criminal convictions in various countries, which establish him as a nomadic thief, swindler, dope-pedlar, gangster, and gunman. (QPD 1965:vol. 240, pp. 2640-1)

The opposition had difficulty responding to the government's actions and, being split into different industrial factions, even had trouble expressing a coherent case out of fraternal solidarity with the unions concerned. Labor had introduced similar emergency (anti-picketing) powers legislation when Premier Ned Hanlon had broken the railways strike of 1948. Jack Duggan was left to criticise the government for its inaction and for its unwillingness to convene conciliation conferences or have discussions with the protagonists. A succession of other Labor speakers (including Eric Lloyd, Fred Newton, Pat Hanlon, Doug Sherrington and Alex James Inch - the local member who was ineffective during the dispute) criticised the government for being 'smugly complacent' and not 
being prepared to resolve the dispute. The QLP's Les Diplock supported the government's anti-picketing legislation, yet similarly bemoaned the previous inactivity of the ministry - even going so far as to state that the government's own tolerance had left it open to criticism of being initially hardline but then walking away from the dispute.

Treasurer Hiley responded by stating that the opposition's points appeared spurious and hypocritical. Hiley reminded them:

[I]f one stays in this Chamber long enough one frequently encounters instances of where other times produce other views, but I must confess that never in all my long period in this Parliament have I heard such a tirade of abuse by the Opposition against the decisions and the legislation of a Labour Government of less than 20 years ago, legislation which today they describe as inept, hill-billy and useless but for which, less than 20 years ago, several of the present members of the Opposition voted. Today, by this clear inversion of mental process, we hear a presentation reeking with class hatred, studded with personal abuse and producing what I am sure the historians of this Parliament will put down on record as one of Parliament's less-than-good days. (QPD 1965:vol. 240, p. 2658)

Overall the government did not emerge from the Mount Isa dispute unscathed. Criticisms of their performance went far wider than the parliamentary opposition. Press reaction, while slow to see the significance of the dispute, tended to hold the government responsible both for the cause of the dispute (the restrictive legislation) and the lack of leadership shown to resolve the issue. The Truth (14 February 1965), for example, reported a Sydney Morning Herald assessment that claimed the cabinet had shown 'administrative ineptitude' and had mismanaged the dispute by 'wretched inaction'. Later, the Truth (28 February 1965) argued that 'even influential men very close to the government feel that there are too many in Cabinet with too little experience' to deal with complex industrial disputes. It reported that fellow conservatives in the Liberal and Country Parties were saying 'a farmer-dominated government such as we have in Queensland is not equipped for big industrial strife' (Truth, 28 February 1965).

\section{Ferocious politicking over three-cornered contests}

Increasingly frustrated and gradually emboldened, the Liberal Party initiated challenges to the dominance of the Country Party in the Coalition. Certainly few, if any, Liberals considered that they could ever govern alone, but an increasing 
proportion of the rank-and-file membership began in the mid-1960s to feel that some redress in parliamentary representation was overdue. The Liberals had been traditionally well represented in the ministry (five Liberals to six Country Party, then six to seven more recently) and few had complaints over the portfolio areas they were allocated. They were, however, disgruntled over two issues: the number of seats they achieved relative to their state vote and the prospect of being corralled entirely into the geographic region of the south-east.

Other political incidents hardened their resolve from time to time. When the long-serving MLA Alf Muller (Fassifern) rejoined the Country Party in September 1965, the Liberals opposed his return to their Coalition partner. Muller had spent almost three years as a conservative-leaning independent after his demotion from Nicklin's second cabinet and subsequent falling out with the party. Liberals attacked the Country Party's decision to allow Muller to rejoin, while the Country Party responded by attacking the Liberals for daring to propose that challengers from the junior partner could depose sitting members of the senior party. In the Parliament, some ardent breakaway Liberal backbenchers proposed on two separate occasions (in 1963 and again in 1966) that the members of the two Coalition parties should sit apart in the Legislative Assembly. The backbenchers were concerned that the Liberals should develop a separate parliamentary profile so as to be able to pursue issues of particular concern to them. On both occasions, a secret ballot was held by the joint Coalition party room, which duly rejected these moves (Courier-Mail, 30 June 1966).

Until 1964, a status quo arrangement between the Country and Liberal Parties had existed. This arrangement (or rather understanding) committed both parties to agree between themselves before every election which seats each would contest. Underlying this arrangement was an understanding that each party had established seat 'rights' and that the other Coalition partner should not normally challenge sitting members. This arrangement, however, worked to the advantage of the Country Party because historically it was the larger party with a stronger state-wide organisation. Gradually, however, this electoral arrangement came under criticism from the organisational arm of the Liberal Party, which began to dismiss notions that a formal arrangement had ever been agreed (Sunday Mail, 17 October 1965). In order to break out of this electoral straitjacket the Liberals found themselves in, they were prepared to initiate 'three-cornered contests' in which the Coalition parties stood against each other as well as against Labor. As Hughes (1969:16) points out, 'three-cornered' contests were something of a misnomer as almost invariably the DLP contested the seats in question in addition to the other three. By initiating these contests, 
however, the Liberals ignited the ire not only of the Country Party organisation but of senior Liberals in government. The split was not simply party against party; it also divided the Liberals on tactics.

Generally the unrest within the Coalition was presented in the press as a 'punchup' caused by inter-party 'feuding'. The rift was regarded as somewhat senseless and likely to lead to further disunity that would undermine the government's support (for example, Truth, 20 September 1964). There was little regular media support for the justification of the separatist or ultra-Liberals' claims, or that some renegotiation of the Coalition was appropriate. Rather, those Liberals seeking a better deal were presented as either naive or malicious troublemakers who were unsettling good government. In retrospect, it is remarkable how little criticism the Country Party attracted even though it adopted a most intractable stance throughout the dispute. One report, in 1964, quoted a former parliamentarian as saying that the Coalition government was 'beginning to come apart at the seams. After the last election it looked as if it could stay in power for 50 years. But now I'm not so sure. [Labor leader] Jack Duggan could find himself Premier one day' (Truth, 20 September 1964).

Leaders of the Country Party rarely justified their ruthless stance, but rather emphasised the damage to Coalition unity and the threat to the government's survival. John Ahern, as President of the Country Party, argued that Liberalinspired three-cornered contests 'must lead to unnecessary bitterness' (CourierMail, 3 April 1965). Later, Ahern argued that the breakaway Liberal Party executive was 'prepared to ignore the welfare of Queensland in its grasp for power' (Courier-Mail, 21 June 1965). Then, as the Liberals began selecting candidates to challenge sitting members, Ahern slammed the Liberal Party's organisation, saying that they were becoming 'lost in their wishful dreams of power' (Courier-Mail, 29 September 1965). Other coalitionists tried to restrict challenges to seats where there was less at stake - where there was a natural vacancy in Coalition seats or where neither side had a current sitting member (namely, seats with Labor, DLP or independent members). There were also widespread rumours about this time that the Country Party with the support of the ALP would reintroduce first-past-the-post voting to quash the Liberals' momentum.

Young Liberals in particular were anxious to exert their influence. They attacked those complacent Liberal members who tended to accept the party's subordinate status, calling them 'benchwarmers' and part-time members who were more interested in their private businesses and in other 'trivial duties' such as 'afternoon tea parties and garden parties' (Courier-Mail, 24 February 1965). At their 1965 annual conference (attended by about 200 participants), the Young Liberals unanimously adopted a resolution favouring three-cornered contests at forthcoming elections (Sunday Mail, 2 May 1965). The Young 
Liberals also criticised Nicklin for placing the Country Party's political fortunes ahead of the government's fate. Others within the Liberal organisation and on the backbench (such as John Murray, Clayfield) were supportive of a greater presence for the party. The state president, Senator Robert 'Bob' Sherrington, was described as the 'arch advocate for extending Liberal influence into CP held areas. He preached the creed that the Liberals should not be content to remain as the minority party' (Truth, 23 March 1966). Along with the state executive (and especially the state secretary, Charles Porter), Sherrington argued that the Liberals had to become a state-wide party. The Lands Minister, Alan Fletcher, described his words as 'those of not an ally but an opponent' (AJPH 1966:vol. 12 , no. 3, p. 3).

In 1964, in anticipation of the next senate election, many Liberals sought to end the practice of running a joint Coalition team (favouring the Country Party, who were first on the ticket) and instead fielding a separate ticket of purely Liberal candidates. With five senate positions available, the issue revolved around whether the Liberals could force the Country Party into a lower place on the joint ticket or do better by running separately hoping to get two senators elected in their own right. The Liberals sought to have the Country Party relegated to the number-three position on the ticket (the most vulnerable) and pay a higher proportion of the campaign costs than the customary one-third (Courier-Mail, 17 August 1964). After some intense negotiations, the Coalition agreed to retain the joint ticket with the Country Party agreeing to accept the second position and pay half the costs.

If Young Liberals, backbenchers and the organisational 'heavies' were the 'young turks', the older, senior parliamentary Liberals tended to be more circumspect. Sam Ramsden (Lib., Merthyr), who had been in parliament since 1957, was a strong supporter of the Coalition and publicly defended the government's unity and record. Others warned that 'some of the seats we hold in rural areas such as Bowen, Rockhampton and Toowoomba East are gone if the Country Party retaliates' (Truth, 27 June 1965). Coalition loyalists pointed out that when the decision to reintroduce preferential voting was taken, the Liberals had promised the Country Party that they would not initiate three-cornered contests - and that doing so in 1965-66 was 'one of the greatest political double-crosses in Queensland history' (Truth, 27 June 1965).

Senior Liberal ministers enjoying positions of influence in the cabinet (such as Munro, Hiley, Chalk and Delamothe) came to be regarded as part of the 'establishment' by the ultra-Liberals (Courier-Mail, 21 March 1964). The Transport Minister, Gordon Chalk, was reluctant to support the breakaway Liberals overtly and discouraged the formation of Liberal branches in rural areas. His stance was due partly to his close relations with Country Party ministers in cabinet and partly because he usually relied on Country Party organisational 
support in his semi-rural seat of Lockyer (a seat he held for 26 years, but which the National Party eventually captured in 1980 after Chalk's intended successor, Liberal Tony Bourke, was beaten by Tony FitzGerald). ${ }^{3}$ Chalk was, however, fighting on two fronts. He was interested in putting the case strongly for loyalty and 'Liberal unity' to keep the party together and in coalition, while in the meantime he was confronted with backbenchers who were beginning to question his own loyalty to the Liberal cause. In 1963, he had already been warned that if he continued to refuse to assist with the establishment of Liberal branches outside the metropolitan area, he faced expulsion from the party (Courier-Mail, 7 August 1963). Breaking with tradition, Chalk then found himself challenged for the deputy leadership in January 1965 and then for the leader's position in December 1965 when Hiley stood down. On both occasions, his challenger was Alex Dewar, representing the 'ultras' in the party (and both times Chalk managed to win only by narrow margins). Later, similar attacks were made against the Liberal Attorney-General, Peter Delamothe, after he campaigned in 1965 for the Country Party's David Nicholson in the lead-up to the 1966 state election; previously, too, the Country Party had attempted to revamp its branches in Delamothe's Liberal seat of Bowen. Delamothe's sin was to have shared a platform with Nicholson - and to speak with courage and passion against the prospect of three-cornered contests. Criticism of Delamothe became intense and personal, such that he was obliged to threaten to sue other members of his party for defamation. There is also some evidence that the attacks on Delamothe in 1965 were part of a wider struggle for the position of deputy Liberal leader after Chalk became leader, and that the attempt to denigrate Delamothe was designed to dissuade him from nominating for the position.

Politicians outside the state also issued warnings about Coalition disunity in Queensland. The Deputy Prime Minister, Jack McEwen (Country Party), told the Queensland Coalition in 1965 that three-cornered contests 'could have disastrous results' and that 'moves for the contests were related to promoting party or person above the state or the issues'. McEwen added that 'there could be no amicable relationship between the parties in a situation where the Premier was defending a sitting member and the Deputy Premier was trying to unseat him' (Courier-Mail, 5 July 1965). This argument assumed that members facing challenge would be from the over-represented Country Party and that only Liberals were to blame for the prevailing political infighting. Against McEwen, Harold Holt, the federal Liberal Treasurer, told Queensland Liberals that they should not 'surrender to any political party' because they had an 'obligation to carry the Liberal story to every part of Australia' (Courier-Mail, 26 June 1965).

3 Lockyer was an unusual seat, in that it had a Liberal member in a rural seat, in which strong Country Party branches existed. The dynamics of campaigning in Lockyer were thus different to other Liberal metropolitan or provincial seats. 
Holt also maintained that the Liberal Party had a broader base than the other parties and was the only party 'which could fairly claim to be representative of all sections of the Australian public' (Courier-Mail, 26 June 1965).

The criteria decided on by the Liberals in selecting which additional seats to contest were simple. First, they would challenge if both organisations could claim an interest in the seat (for instance, because of previous levels of support, anticipated gains or changing electoral compositions). Second, a Liberal candidate would be fielded if the presence of an alternative non-Labor candidate could tip the balance in seats where previously a single Country Party candidate had been unable to defeat an ALP member (and in such cases the intention was that the Liberal would finish ahead of the Country Party candidate). Although spoiling for a fight, the Liberals still pledged to allocate preferences to the Country Party in all cases where three-cornered contests were waged (Courier-Mail, 3 April 1965). Such criteria led the Liberals to consider up to 10-12 additional seats for possible contest against the Country Party's sitting members or candidates. At the 1966 elections, Coalition candidates were engaged in three-way challenges in eight seats (five in the south-east corner: Albert, South Coast, Logan, Redcliffe and Murrumba; and three in provincial towns: Cairns, Toowoomba East and Port Curtis [Gladstone]), although none of the sitting members was unseated (see further details below).

Some of the momentum was taken out of the ultra-Liberals' challenge with the sudden death of Senator Bob Sherrington in March 1966. Indeed, the Truth (20 March 1966) noted that his passing 'could not have come at a worse time for the Liberals. The big State political game was just about to begin in earnest when the Liberals lost their captain.' Chalk also put his leadership on the line in March 1966 over the issue of Coalition unity. He suggested to the Liberal organisation that he would surrender his position if the party refused to allow him to fight the forthcoming state election alongside Premier Nicklin, delivering a 'jointparty' platform. As indicated below, this strategy was designed to take the heat out of the discord caused by three-cornered contests.

The three-cornered issue also became a catalyst for the emergence of an inner Liberal Party group known as the 'ginger group' (beginning about 1965-66 and surviving until the early 1980s). The name came from an address given by the state secretary, Charles Porter, to a Young Liberal convention in Rockhampton in which he was critical of the party's obsequiousness within the Coalition. Porter went on to say: 'every party needs a ginger group and you are that group' (Courier-Mail, 31 January 1966; but see his own accounts in Porter 1981:38-9, 46-7). The Liberal 'gingers' tended to be 'ultras' more interested in maintaining a separate identity for the party, extending the party's influence and fighting for small-' 1 ' liberal issues. In 1966, they also opposed the right of the party leader to select the Liberal ministry, fearing such power could be used to discipline or 
compromise their faction (or other dissidents). The members of the faction were largely state parliamentarians and wider support among the party for the 'ginger group' tended to wax and wane over time. Interestingly, given the attention this group has since received, they did not meet as a regular faction and indeed, according to one member, Bill Hewitt, never held formal meetings as such - a point also confirmed by Porter. Rather, common interests and the physical overcrowding of the old Parliament House threw the group together (six Liberal members, for example, shared a single office). The members of the parliamentary 'ginger group' included William Lickiss, John Murray, Geoffrey Chinchen, Clive Hughes, Charles Porter, Bill Hewitt and Arthur Crawford after 1969; others in the organisational wing included the president, Dr Arthur Hartwig, and Young Liberal leader, Keith Livingstone. Hartwig had little time for the Country Party and claimed that 'to believe that all parties which are against the Labor Party are pro-Liberal is to delude ourselves' (Courier-Mail, 26 March 1966). He was later suspended from his position of state president (and subsequently defeated in a ballot) after he indicated he would support the local 'liberal' candidate in the seat of Landsborough when Frank Nicklin retired (despite the Liberal executive deciding not to run a candidate). Although the 'ginger' faction was not solely concerned with three-cornered contests, this issue became symbolic for them as an assertion of the party's identity and standing (AJPH 1967:vol. 13, no. 2, p. 266, and 1968:vol. 14, no. 3. p. 429).

\section{The 1966 election: expected to be a 'lively' show}

One of the more interesting aspects of the 1966 election campaign was that the Courier-Mail predicted the date of the election (28 May) as early as 22 November 1965. This could indicate either that the Courier-Mail was very good at guessing from among possible dates or that political journalists were taken into the Premier's confidence some five months before the set date. It also indicates that state politics were far more predictable and routine so that elections could be set with such precision so far into the future. Hughes records that the 1966 election was fought on the same electoral arrangements as those operating in 1963. There had been no redistribution and no further amendments to electoral laws or weighting mechanisms. Indeed, Hughes observed that the sole change in electoral matters between 1963 and 1966 was that pubs were now permitted to remain open during polling hours (Hughes 1969:15).

For the first time since the conservatives had regained government in 1957, the Coalition made a 'joint policy' speech to launch their campaign. The 'joint' policy was, however, delivered in two parts and presented separately by the 
two leaders: Nicklin on 9 May at the Star Theatre in Maroochydore, and Chalk at the Albert Hall in Brisbane on 12 May. Both leaders had agreed to present policy details in their combined speech as a way of patching up differences. The idea of a joint launch was initiated largely by Gordon Chalk, who in his first presentation as leader sought to make a symbolic pretence at unity. Much was made in the Liberal Party and in the media about the fact that this was Chalk's 'maiden' policy launch. Confirmation of the commitment by the Liberals to stage a 'joint' launch was made late in the piece at their annual convention in Brisbane in March 1966. They agreed 'unanimously' to the proposition (or more accurately ultimatum) put forward by the leader, Chalk (despite delegates earlier attempting to amend the motion in favour of a separate speech). At the convention, Chalk delivered a 'fighting speech' in support of the joint policy launch, informing delegates that Nicklin had already agreed to the proposal if Chalk could sell the idea to his party. Many Liberal Party members had serious reservations and did not believe this strategy to be in the best interests of the party in the longer term. They felt that a joint launch would be a public symbol of their subservience and that it would be more difficult to maintain their own identity and policy orientations. Those with this view were soon provided with ample justification for distrusting their senior Coalition partner. When the campaign proper began, press reports carried the allegation that Nicklin had taken part in a 'secret' television program to be broadcast on all channels to kick-off the election, with the intention of pre-empting both the Labor and Liberal policy initiatives.

To add further insult to injury, the Country Party refused to offer an official partyto-party exchange of preferences with the Liberals. Well into the campaign proper (on 7 May), the Country Party informed the Liberals that it would not agree to an entire exchange of preferences. The Liberals had earlier declared their intention of allocating second preferences to their coalition partner, but the Country Party headquarters (conscious of local branch antagonism) was more cautious. They decided that responsibility for deciding preference allocations would rest with local Country Party branches where three-cornered contests were being held. This allowed local branches some discretion over preferences where a range of candidates was standing (especially if other conservative independents had nominated or the respective Liberal candidate was considered objectionable). In one case, press reports claimed that a Country Party candidate would encourage his voters to place the ALP second in exchange for ALP preferences (CourierMail, 22 April 1966). The Liberals were offended by this snub and regarded it as a further sign of Country Party ruthlessness. One spokesperson for the Liberals said 'from the viewpoint of ensuring a return of the Country-Liberal coalition the Country Party is being very foolish if it does not exchange preferences with Liberal candidates' (Truth, 8 May 1966). 
In consideration of his age and failing health, Nicklin proposed to shorten the real campaign to three weeks - from the date of the Country Party's launch to the day of the election. Commentators had been expecting a lively campaign but such a short, 'hard-hitting' campaign was considered likely to maximise political advantage to the government. Yet within that time Nicklin attended three Brisbane speeches or rallies and visited 12 provincial towns in 17 days. Unlike earlier campaigns, he chose mainly to fly across the state rather than consume time in rail travel. Following tradition, he launched the government's campaign in his own electorate of Landsborough at Maroochydore but went on to deliver addresses in Redcliffe and in Cleveland, located then in Logan (two outer Brisbane seats in which the Country Party was engaged in three-cornered contests). Nicklin considered his main achievement was to have delivered 'stable and progressive government for all sections of the community' (Courier-Mail, 10 May 1966). He also announced that under his leadership the Coalition had brought government closer to the people, and he was especially proud of the fact that in the past three years, 22 cabinet meetings had been held in provincial towns. Five days before the poll was conducted, Nicklin announced to the state that he would definitely retire from the premiership before the next Parliament was dissolved, naming his deputy, Jack Pizzey, as his automatic successor. To modern political observers, such behaviour within the context of an election campaign could seem incomprehensible. Yet Nicklin was able to make the announcement appear as an indication of continuing strength under Country Party rule.

Together, the Coalition stood 81 candidates for the 78-seat Assembly - an increase in candidates of eight from 1963. The Country Party stood 36 candidates (one of whom secured an uncontested seat) and the Liberals stood 45-the largest number of seats they had challenged in their history. As such, the prospect of three-cornered contests increased to eight, with sitting Country Party members challenged in five south-eastern seats: Albert, Logan, Redcliffe, South Coast and Murrumba (the seat of the Speaker, David Nicholson). Three-way contests also took place in three safe Labor seats in provincial towns-namely: Cairns, Toowoomba East and Port Curtis.

Nicklin was privately and publicly worried that opposition to the Vietnam War would have 'an unforeseen' effect on the state election-perhaps tainting incumbents or linking the Queensland Coalition government with the HoltMcEwen Coalition government in Canberra. A long list of specific parish-pump promises was forthcoming from Nicklin to counter any prospect of political disenchantment. He promised quicker processes to transfer leasehold land to freehold, simplified timber valuations, increased availability of land for pastoralists and an improved drought relief scheme (assisting water storage and fodder carriage). The sugar and dairy industries were singled out for special 
state assistance (especially given that some 'sugar seats' such as Mirani and Whitsunday were held by Country Party members on slim margins). Other old favourites such as more police officers, more police promotions and improved public service superannuation were offered to the electorate. Education scholarships would be expanded, together with a $\$ 200$ per annum grant for remote country school students and a 'living-away-from-home' allowance of $\$ 4$ a week for schoolchildren who had to board. Many of his promises were detailed and specific, sometimes down to the actual number of land lots to be released for public auction from particular land development schemes.

Gordon Chalk, in presenting the Liberals' part of the joint speech, offered more aid to independent schools, along with increased grants, subsidies and concessions for all school students. He promised to build new institutes of technology at Toowoomba and Rockhampton and new teachers' colleges in Brisbane and Townsville. The Liberals sought to give inducements to apprentices undergoing training and provide increased industrial land around provincial cities to spur industrial development. Housing and roads were key issues for Treasurer Chalk, with incentives offered to home-buyers and funding set aside for the first stage of Brisbane's Riverside Expressway north of Victoria Bridge. He was also prepared to reinvestigate the feasibility of the Burdekin Dam project and provide greater funds for the Agricultural Bank to on-loan. The Liberals were also keen to undertake another migrant recruitment drive in the United Kingdom.

The QLP, by now a waning electoral force, still delivered an impressive array of policy proposals to the electorate. They promised to establish a judicial tribunal to reconstruct the basic wage, arguing that because of price increases workers should have greater entitlement to a share of profits. The QLP committed itself to increase Housing Commission loans, provide marriage loans to young couples, continue to support state aid to non-government schools and assist small farmers through a range of initiatives. The QLP leader, Leslie Diplock (Aubigny), the sole QLP member in parliament, still spent a good portion of his electoral speech criticising the opposition Labor Party while dismissing the government as 'confused and frustrated by an internal power struggle' (CourierMail, 12 May 1966). The QLP still managed, however, to stand 58 candidates for the Legislative Assembly - only two down from the previous election-but almost all were political novices.

The Opposition Leader, Jack Duggan, declared that Labor would fight the 1966 election on three principal issues: the expansion of the sugar industry; irrigation; and outright opposition to large-scale transfer of freehold title to rural land. These were no doubt worthy issues, and important to certain specific interests, but hardly the type of issues to capture a popular mood or marshal any resentment against the longstanding government. Duggan delivered his policy 
speech on 4 May (to 1000 supporters at Brisbane's City Hall) and followed this with a rural policy launch at the Vogue Theatre, Nambour, on 5 May. Labor's campaign was based on the slogan that it was time for a change, with their most prominent promise to provide free school textbooks to students in state and non-state schools. Labor again clung to the salvation of price controls backed by stricter standard controls for commodities. Improved employment conditions were envisaged (including increased long-service leave, equal pay for equal work and the basic wage indexed to the consumer price index). Duggan promised to amend the Public Service Act to allow women to remain in employment after marriage. Specific policies for culture, youth affairs and sport were announced - as were plans to electrify Brisbane's rail system. For rural Queensland, Labor offered aid for the sugar industry (subject to highly regulated market arrangements) and wider access to land through the preservation of leasehold provisions. Against the government's developmentalist propaganda, Duggan argued that Queensland had experienced the second-lowest population growth in Australia, the highest increase in the cost of living and high increases in state taxation.

Labor stood candidates in 76 of the 78 electorates and, according to their party president, B. R. Milliner, 'the ALP regarded all other parties as being the Opposition and opposed to the principles of the ALP' (Courier-Mail, 22 April 1966). Duggan made much in the campaign about how the 'gerrymander' disadvantaged Labor and about the malapportionment between the parties in terms of the votes received and the seats gained. He also promised to abolish preferential voting (to remove a perceived advantage to the Coalition) and lower the voting age to eighteen to give young people the right to participate in selecting their representatives.

Labor was, however, also hard on its own candidates who did not toe the party line. Bill Baxter (Hawthorne and formerly a deputy opposition whip, but no great performer in the Parliament) was dis-endorsed before the 1966 election, ostensibly because he did not stand by party decisions and had been rude or 'rather brusque' to women party members (Sunday Mail, 1 May 1966). The victim of factional infighting, Baxter fell foul of the 'powers that be', but did not take his dis-endorsement lying down. Moments before official nominations for the seat closed with the Electoral Commission, he nominated himself as an independent. Under party rules, he was automatically expelled from the ALP by standing against an officially endorsed candidate: T. Burton, from the Printing Industry Employees' Union. Baxter, as the sitting member, was defeated miserably in 1966, gaining only 1546 votes from the 11361 Hawthorne electors. The Liberals' Bill Kaus won the seat. Trailing Burton on the primary vote, Kaus was able to claim victory by securing the DLP preferences and more than half of Baxter's renegade vote. Baxter did not contest a seat again. 
The results of the 1966 election were virtually identical to the 1963 outcome. Against the national backdrop of the Vietnam War, continued arrests at protests, the visit by US President L. B. Johnson and the looming federal election, the result was remarkable. Each of the parties secured exactly the same number of seats as before. Labor won 26 seats from 350254 votes across the state (43.84 per cent), the Country Party won 27 from 154081 votes (19.28 per cent) and the Liberals, with 203648 votes (25.49 per cent), managed 20 seats. Together, the Coalition recorded a vote of 44.68 per cent - only 0.84 per cent ahead of Labor. From the total electorate of 798973 , the combined Coalition vote was only 7475 more than the ALP vote, yet the Coalition held 47 seats compared with Labor's 26.

In the three-way contests, all five Country Party members held their seats. Three were reliant on Liberal preferences to get over the line: in Redcliffe, the popular Jim Houghton held off against a poor Liberal showing; Nicholson retained Murrumba by 999 votes on Liberal preferences; and in Logan, Ernest Wood, a one-timer, won by 700 votes on Liberal preferences. In two Country Party electorates, the Liberals mounted a serious challenge, coming second on the ballot. In Albert, the Country Party sitting member, Cecil Carey, hung on by only 49 votes against his Liberal challenger, E. Harley (5566 votes to 5517), while in South Coast, the new Country Party candidate (and former Chairman of Albert Shire), Russ Hinze, defeated the Liberal candidate, H. Winders, by 6175 to 5598 votes. Hinze did not win the seat on the primary vote (indeed, he was almost 1000 votes behind on first preferences) but claimed the prize only after taking 80 per cent of Labor preferences from the third candidate (gaining 2178 preferences out of a total of 2702). Hinze later went on to become one of the stalwarts of the Bjelke-Petersen ministry after 1974. The fact that Hinze had initially won his seat on Labor preferences did not prevent him from being a strident adversary of Labor in the House - even if some opposition members were later to describe him as a likeable 'old bastard' and a 'real larrikin with a down-to-earth wit and an unconventional approach to Government matters' (QPD 1991:vol. 319, pp. 6-7). He reserved most of his hatred for the reforming Liberals who continued running challenges against him, at one time describing them as 'mongrels'. Hinze had also made 'dark threats' suggesting that Country Party candidates could well have reason to allocate their preferences to the QLP ahead of the Liberals, if the Liberals continued to seek to stand in Country Party-held seats (AJPH 1966:vol. 12, no. 3, p. 444).

The DLP (ex-QLP) won one seat, recording the lowest level of support since its formation in 1957, with only 49948 votes state-wide (6.25 per cent). The party's leader, Les Diplock, comfortably held the seat of Aubigny (based around Dalby) against both ALP and Country Party adversaries (taking the seat on the primary vote, securing 56.29 per cent). Four independents made up the complement of 
the Assembly. Ted Walsh held Bundaberg against the ALP; Tom Aikens retained Townsville South with a generous margin; Arthur Coburn defeated Liberal and Labor challengers in Burdekin; and Herbert 'Bunny' Adair (an ex-QLPer) retained his seat of Cook against a spirited challenge from the ALP's J. Bethel.

In 1966, however, the Country Party secured its second-lowest state-wide vote since it formed government - again sitting on just more than 19 per cent. In the four elections since the Coalition came to government in 1957, the party's vote had slipped back rather than increased (19.99 per cent in 1957 to 19.5 per cent in 1960, then 19.03 per cent in 1963 and 19.28 per cent in 1966). This result represented an electoral nadir to which they would never again descend, even in the major electoral collapse of 1989 when the party managed a respectable 24 per cent. So, in 1966, less than one in five electors was casting a positive vote for the senior party of the government - and this was looming as a dangerous problem not because Labor was threatening from across the party divide, but because the Liberals were consistently outpolling the Country Party, and often by considerable margins (in 1957 by 3 per cent, in 1960 by 4.5 per cent, in 1963 by 5 per cent and in 1966 by their largest margin, 7 per cent). The slow attrition in the proportion of the state vote captured by the Country Party was a constant concern to both the parliamentary and organisational leaders of the party. This rebuff also served to convince Nicklin that he should consider handing over to another leader well before the next election to ensure stability and improve the primary vote for the Country Party. Although Nicklin's period in government is regarded as a successful political period for the Country Party, their vote was declining precariously under the 'gentleman premier'. It was not until a new leader was firmly in place that the Country Party vote picked up. Thereafter the Country/National Party vote gradually increased (or plateaued at new levels) through to 1989.

\section{Nicklin's final ministry}

Nicklin's fourth and last ministry was sworn in on 10 June 1966 and ran for 18 months until his resignation as Premier on 17 January 1968. The size of the ministry was retained at 13 - split again in favour of the Country Party by seven to six. All incumbent ministers who fought the election were reappointed and maintained in their existing portfolio areas. There was remarkable stability about the ministry with three surviving from the 1957 change of government (Nicklin, Pizzey and Chalk, the first two of whom had also remained in the same portfolio since coming to government) and a further four having continuous service from the period of the second ministry (1960-63). The other six ministers were all retained from the previous ministry (1963-66) with many remaining in their 
existing portfolios. Altogether the fourth Nicklin ministry could collectively boast 55 years of experience or an average of 4.25 years per minister. Continuity and seniority were prized qualities on the frontbench of the Coalition.

Furthermore, the allocation of portfolio areas between the two Coalition partners remained unchanged. Each side continued to 'own' areas of responsibility closest to their interest base of political concerns. The Country Party retained Education, Lands, Primary Industries, Local Government, Works and Housing and Mines and Main Roads - in short, the visible portfolios in which ministerial pork-barrelling was prominent and influential clientele could be looked after. There was no attempt to swap portfolio areas or give the Liberals a chance to make a name for themselves in these instrumental/material departments. The six Liberals were consigned to the invisible or 'bad news' areas such as Treasury, Justice, the Attorney-General's area, Industrial Development and Labour Relations. Only the Health and Transport areas allowed much scope for largesse and the latter was clouded by constant disputes over freight charges. The composition of the fourth ministry was

- Premier and Minister for State Development: Frank Nicklin, CP

- Treasurer: Gordon Chalk, Lib.

- Minister for Education: Jack Pizzey, CP

- Minister for Industrial Development: Alex Dewar, Lib.

- Minister for Lands: Alan Fletcher, CP

- Minister for Local Government and Conservation: Harold Richter, CP

- Minister for Primary Industries: John Row, CP

- Minister for Works and Housing: Johannes Bjelke-Petersen, CP

- Minister for Justice and Attorney-General: Dr Peter Delamothe, Lib.

- Minister for Health: Doug Tooth, Lib.

- Minister for Labour and Tourism: John Herbert, Lib.

- Minister for Mines and Main Roads: Ronald Camm, CP

- Minister for Transport: William Knox, Lib.

After one year, Frederick Campbell (Lib., Aspley) was added to the ministry (on 20 June 1967) to replace Alex Dewar as Minister for Industrial Development (see below). The demotion in the ranking of the Industrial Development portfolio effectively meant that the policy area was accorded lowest priority in the cabinet. This decline in emphasis was all the more noticeable given the earlier prominence the portfolio had enjoyed when occupied by Deputy Premier, Alan Munro.

Dewar resigned from the ministry in June 1967 over allegations that he had sexually harassed two girls in the Department of Labour and Tourism while 
acting minister, and that he could have had conflicts of interest after investing in a tourist company (Oasis Proprietary Limited) when Minister for Industry. In the Address-in-Reply debate in August 1967, Dewar told the Assembly that the Premier and Deputy Premier had summoned him in May to request his resignation from cabinet. In his speech, Dewar evaded the issue of harassment, implying that the allegations had been made by some discontents in the department who had too little work to do. He went on to give his account of the ostensible reasons for his resignation: that the Liberal Tourism Minister, John Herbert, and the Country Party Primary Industries Minister, John Row, had refused his firm permission to establish a koala enclosure at Oasis Gardens in Sunnybank. Dewar recounted that after he indicated he would resign, the Premier agreed to issue the permit for Oasis to stock koalas - prompting Dewar to claim 'four little koalas cost a Cabinet Minister his portfolio' (QPD 1967:vol. 246, p. 308).

The Deputy Premier, Gordon Chalk, however, made an extemporaneous speech supplementing the former minister's account and insisting that John Herbert had requested action be taken against Dewar for his behaviour while serving as acting Minister for Labour and Tourism. Chalk reported on the 'unfortunate circumstances':

The House has been told that the Minister for Labour and Tourism [John Herbert] was away for a period. On his return to his office certain charges were made to him by two female employees. The Minister was somewhat in doubt as to how the matter should be handled, and he came to me, as the Leader of the Liberal Party and Deputy Premier, and asked for my advice. I told him I would not be prepared to listen to charges of the nature that were made unless the persons concerned were prepared to repeat in my presence...the occurrences that were alleged...The two young ladies concerned repeated certain charges to me. They accused Mr Dewar of kissing them, and of certain other actions. I recorded these happenings, but I was not prepared to accept their evidence alone. I decided that the only way to ascertain whether these young ladies were telling the truth was to send for certain members of the staff of the department involved and question them...I interviewed three officers associated with the department. All told me stories which indicated to me that there was truth in the accusations...In the meantime, I was interviewed by a parent of one of the girls...the father was extremely concerned - in fact, he indicated thoughts about taking a certain line of action-I requested him to give the Premier and me time to discuss the charges with the hon. member for Wavell...I shall tell this House that when he was confronted with the charge of kissing these young ladies, the hon. member for Wavell admitted that he had done so. He indicated 
to the Premier and me that such happenings were acts of stupidity - and I repeat the word he used, 'stupidity' - because of his personal make-up. We all have our own peculiarities in normal life. He said that it had been an act of endearment...Further opportunity was taken by me to discuss the happening with the father of one of the girls. It was a question of whether some action would be taken by the parent or whether it could be settled without the good name not only of the girls concerned, but also the hon. member, being hurt...I discussed with the hon. member for Wavell all the problems that would confront him, his family and the Government. I indicated to him, as he has said, that I believed that in some cases there could have been some exaggeration. I do not deny that, because anyone who has been in public life knows only too well that a rolling stone gathers a heck of a lot of moss. (QPD 1967:vol. 246, pp. 314-15)

Titillating press reports further sensationalised the episode, highlighting the complaints made by the girls about Dewar 'kissing' them and committing 'certain other actions'. No charges were ever laid, however, and his resignation as minister on 9 June seemed to end the matter as a public concern. Both Herbert and Dewar later made statements to the Parliament attempting to set the record straight about the koala permit, although Herbert described the koala issue as a 'red herring' and took the opportunity in his ministerial statement to insist that 'the girls made allegations that Mr Dewar, whilst Acting Minister, forced his intentions upon them by kissing and other actions' (QPD 1967:vol. 246, p. 333).

One year after his resignation from the ministry, however, Dewar went a step further and quit the government. He resigned from the Liberal Party in July 1968 to sit in the Parliament as an independent (see Chapter 7). Standing at the May 1969 state election as an independent in his north Brisbane seat of Wavell, Dewar was defeated by the official Liberal Party candidate, Dr Arthur Crawford. Dewar's demise occurred shortly after he had emerged as a rival to Chalk and a serious contender for the Liberal leadership. There has always been some speculation that the scandal was fanned by those in government with the most to gain from his removal. Much later, after Dewar died in 1995, one of his nephews wrote that it should be remembered that this occurred in a period of a power struggle between the Liberals and National Party' and that 'there was a widely held view that the "beat up" was designed to remove him because of his strengths and leadership potential' (Sunday Mail, 12 February 1995). As with many such allegations against political identities in Queensland, the claims made against Dewar were never proven (or disproved), though the damage ended his political career. 


\section{Doubts over the continued stability of the Coalition}

Far from resolving Coalition discord, the 1966 election kept it simmering. Indeed, shortly after the 1966 election, the Liberals announced their intention of contesting all seats in Queensland at both state and federal levels, thereby exacerbating the 'problem' of three-cornered contests (Courier-Mail, 1 April 1967). During 1967, members of the 'ginger group' were also active in the Parliament. They moved amendments against government legislation and delivered speeches that began to raise the ire of the cabinet and especially Nicklin and senior Country Party ministers. Their speeches expressed backbench disquiet over government policies during the Coalition's fourth term. Chalk attempted to clamp down on the dissidents and on alleged disloyalty within the Liberal party room, adopting a tougher line on Coalition dissent and periodically threatening to resign if not fully supported. In exasperation, Chalk insisted that as leader of the party he be informed of any intention or tactic to be used in the Parliament by the restless backbenchers (The Australian, 3 December 1966).

The Nicklin period was, however, inevitably coming to an end, and with the pending retirement of the ageing Premier, a new political phase with new challenges would present itself. In 1968, when Nicklin retired from all his official positions, he had served a continuous term of 35 and half years in state parliament (making him then the fifth-longest serving member of the Parliament-and the sixth-longest serving after subsequently being overtaken by Bjelke-Petersen). At the time of Nicklin's retirement, he had become the state's longest-serving premier (10 years and five months) - a statistic surely inconceivable when he assumed office in 1957. Senior Country Party ministers were paving the way for Jack Pizzey to assume the leadership unchallenged, despite earlier health scares. Gordon Chalk, however, as the Liberal leader, increasingly began to voice more separatist sentiments under pressure from his colleagues. By late 1967, he was actively advocating that the Liberals had to 'attain supremacy' in the Queensland administration and that 'this state is destined to be governed principally by those who follow the Liberal party platform' (Courier-Mail, 2 September 1967). His prediction did not turn out as he hoped, but it placed him far more secure in the leadership of the parliamentary party. Nicklin had earlier warned at a Country Party conference in May 1967 that the 'government parties could not indulge in a struggle for party supremacy and hope to escape severe censure by the electors' (AJHP 1967:vol. 13, no. 3, p. 423). Nicklin's prediction proved to be far more prescient. 



\section{The Nicklin government's legislative program}

Frank Nicklin led a conservative government that believed steadfastly in the power of the state and the responsibility of governments to govern. His governments undertook a relatively activist legislative program, which was maintained over four succeeding parliaments throughout the decade of his premiership, 1957-68. The government's legislative appetite generally increased with its tenure in office, reflecting perhaps increasing confidence in incumbency or the tendency for modern governments to resort to legislative solutions. Increased legislation was also part of modern society-in particular, the policy areas under the justice portfolio had large increases in legislation as more areas came under regulation and scrutiny. During its first term (1957-60), the government averaged 44 pieces of legislation per annum, then managed 54 per annum in the second term (1960-63), rising to 62 acts per annum during the thirty-seventh Parliament (1963-66). Even in his final year as Premier, Nicklin was responsible for steering 53 legislative measures through the Assembly.

In total, the Nicklin government passed 591 pieces of legislation. Of this total, the number of new acts was 192 (or about 17 per parliamentary session), with 394 pieces of amending legislation (approximately 100 per parliament or 36 per session). Over the Nicklin decade, five repeal bills were passed (see Table 5.1). As Table 5.2 indicates, the government's main legislative activity, judged according to the number of measures, was predominantly directed towards two areas: justice issues or measures under the Attorney-General's portfolio (107 acts) and Treasury and financial measures (103 acts). These were followed by legislation covering industrial relations (61), land and irrigation (52), works and local government (47), primary industries (47), the Premier's portfolio and general government (46) and state development (41). Collectively, more than half of all legislation was confined to four policy areas: the Attorney-General's area, Treasury matters, economic development and industrial relations (these were mostly administrative regulations). Enjoying relatively less attention were health and home affairs (40), education (20) and transport (16). Community and social policy areas were relatively insignificant while environmental or conservation measures were attached to works and local government towards the end of the period. 
The Ayes Have It: The history of the Queensland Parliament, 1957-1989

Table 5.1 Total number of acts passed in each parliament

\begin{tabular}{|l|l|l|l|l|}
\hline \multicolumn{1}{|c|}{ Parliaments } & $\begin{array}{l}\text { Number of } \\
\text { legislative acts }\end{array}$ & New acts & Amendment acts & Repeal acts \\
\hline 35th 1957-59 & 134 & 45 & 89 & 0 \\
\hline 36th 1960-63 & 161 & 50 & 108 & 3 \\
\hline 37th 1963-66 & 186 & 57 & 127 & 2 \\
\hline 38th 1966-69 & $\begin{array}{l}145 \\
\text { (breakdown } \\
\text { below) }\end{array}$ & 40 & 104 & 1 \\
\hline 1st session & 53 & 18 & 35 & 0 \\
\hline 2nd session & 57 & 13 & 43 & 1 \\
\hline 3rd session & 35 & 9 & 26 & 0 \\
\hline
\end{tabular}

Notes: Premier Nicklin retired, Jack Pizzey died and Joh Bejlke-Petersen was finally selected to lead the government in the thirty-eighth Parliament. Hence, to assist with analysis, the tables in this chapter show the breakdown of legislation passed in the separate sessions of the thirty-eighth Parliament.

The above record represents a statement of the government's priorities. They reflect the aspirations of the Coalition government to the extent that they were required, or felt it was necessary, to take proposals to the Parliament for statutory attention. In the main, the record indicates that the government was preoccupied with regulation and regulatory amendments, financial arrangements and developmental initiatives - especially enabling legislation for industrial projects, mines or developmental ventures. The Parliament was essentially conceived as a glorified boardroom where government ministers, performing like company directors, made strategic interventions to expand economic growth.

Other policy areas of concern to the community and consuming considerable budgetary resources nevertheless attracted slight legislative attention compared with these developmentalist areas. Even with strong ministers driving their portfolios such as Jack Pizzey and Gordon Chalk, the areas of education and transport were relatively devoid of statutory interest over the Nicklin years, attracting only 20 and 16 bills respectively in 10 years. Moreover, even such figures appear somewhat inflated and therefore misleading given that the legislation classified under this heading adopted a fairly liberal interpretation of education (Record of Legislative Acts, 1957-58 to 1967-68). 
5. The Nicklin government's legislative program

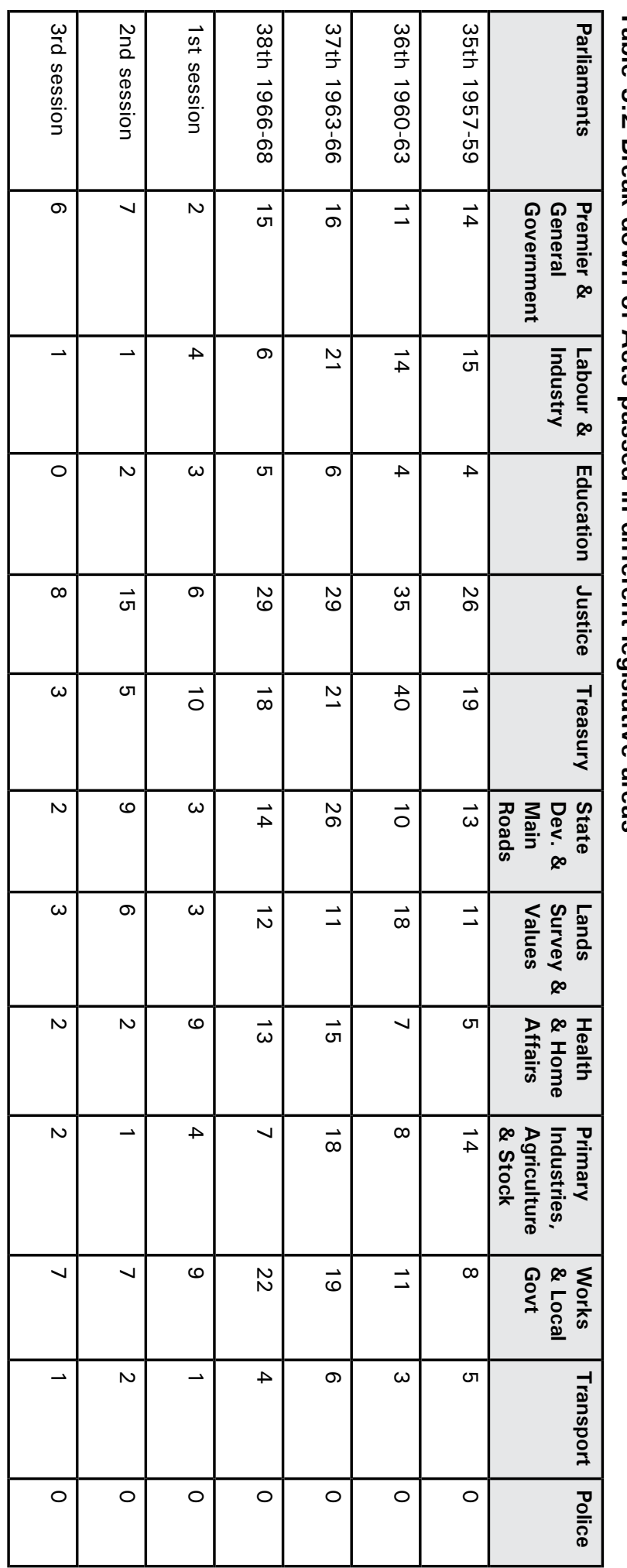

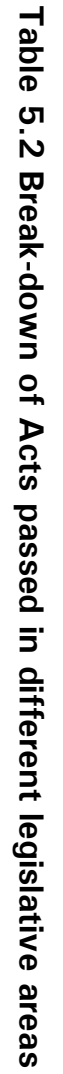




\section{Outlining the government's objectives and defending the record: the Governor's opening speech}

The Governor's speech opened most but not all opening sessions of the Parliament. In the 1960s, the Governor (or Administrator as deputy governor) delivered the speech in person in the Legislative Council to an audience of Members of the Legislative Assembly (before 1962 the Assembly was used). As the Governor entered Parliament House, the Speaker would meet the Governor at the bar of the Assembly and escort the vice-regal representative to the dais in the council chamber. At the conclusion of the speech, the Governor would typically convey to members the hope that 'Divine Providence attend your labours' and that 'the blessing of Almighty God may rest on your counsels'. Thereafter, the Governor would leave the Chamber (and prepare to receive members and guests at the ceremonial garden party held on the parliamentary lawns). The Speaker accompanied by the other members would then return across the foyer to the Assembly and resume the ceremonial sitting only to move and carry a motion adjourning the day's proceedings to the next day. Members then joined the Governor for afternoon tea on the lawns. Conventionally, on the next sitting day, the Speaker would formally table a copy of the Governor's speech in the Assembly in order to incorporate the government's program in the official record of the Parliament - the Votes and Proceedings - as well as in the daily Hansard.

Most opening speeches in the late 1950s and 1960s were typically dry affairs. Their format remained little changed and stock paragraphs and phrases interspersed the text. The first paragraph in the early 1960s usually read:

You have been summoned to attend this, the...Session of the...Parliament of Queensland, to consider important business of concern to the people of this State which arose during the last Session of the...Parliament and to consider legislative proposals which my Ministers have prepared for submission to the present Parliament.

At other points in the speech, the Governor would inform the Parliament that 'my ministers inform me that for the first time in the...financial year, both receipts and expenditure actually exceeded' a particular figure, such as 'the $£ 100$ million mark'. Budgetary surpluses or deficits were a constant point of reference and precise expenditure allocations were often recorded as a sign of the government's commitment to a particular area of concern. Later, the Governor would list proposed legislation, which the forthcoming session would be asked to consider. For example, the proposed legislation for the first session of the 
thirty-sixth Parliament in 1960 was to introduce measures to protect territorial waters from oil spills, to protect the general public from improper inducements over investments, amend the Public Service Superannuation and Miners Pension Acts, amend the Oaths Act, Traffic Act and Harbours Act and 'modernise' the procedures for the election of senators to the Federal Parliament. The list was often not spectacular, extensive or inclusive. Generally, the proposed legislation was introduced in the specified session and with only a single chamber to negotiate was usually passed within the session-although as will become evident below the fact that intended measures were presented in the Governor's speech was not a guarantee that legislation would necessarily follow.

The purpose and importance of the Governor's speech were to outline the government's achievements and defend its past record - a record that would then be debated in the Address-in-Reply debate from the whole Parliament. The precise content of the Governor's opening presentation was selected by the ministry (often the Premier) and the speech was written by government administrators, who without much flair for prose often presented the state of play rather like a dull statistics lecture to undergraduates. The main recurring themes of the speeches were typically the opportunities and difficulties of sustained development, the need for economic infrastructure, announcements of key projects to which the government was committed, migration and settler statistics and the recognition of some social areas of serious concern. The Coalition government gave many commitments to meet the costs of the reception, welfare and settlement of 'British migrants', who often numbered in excess of 42000 per annum in Queensland alone (QPD 1960:vol. 227, p. 32). Always building on its record, doing more and going further, the government would announce commitments to major infrastructural developments (bridges, dams and water projects, harbours, rail improvements, public housing, electricity and prisons), which in the midst of perennial droughts or episodic economic recessions would help stimulate regional employment. The Coalition government often highlighted its intentions to provide special assistance to favoured industries such as mining, tourism, the timber industry and rural production, and regularly expressed its hopes for the further expansion of secondary industry. In short, state activism was relatively robust and the Governor's speech articulated the expanding responsibilities of government.

In 1957, the new government announced that its main priority was to 'attract to Queensland the huge capital investment necessary to fully exploit and develop the unparalleled natural resources of our State' (QPD 1957:vol. 218, p. 9). Deputising for the Governor, Sir John Lavarack (who was ill and due to retire), the State Administrator, Alan Mansfield, told the members of the new Parliament that his ministers 'propose a full-scale drive throughout the Commonwealth and abroad to publicise Queensland to potential investors'. They also intended to 
encourage 'the decentralisation of existing and prospective industries so that all parts of the State can share in the resultant expansion and prosperity'. To assist this drive, Mansfield informed members that the government had created a senior portfolio for development (ranked sixth in cabinet and initially held by Ernie Evans, CP). Mansfield further told the assembled members that

in accordance with their election promises, my Advisers propose to take as soon as practicable legislative action to entrench in the Constitution of this State certain provisions designed to protect and preserve the political institutions of the State, the basic political rights of the people, the freedom of the individual and the protection of his property, and to maintain an independent judiciary. (QPD 1957:vol. 218, p. 9)

Nothing came of this intention in the first session of the thirty-fifth Parliament. In the second session, the Governor announced that the Parliament would deliberate a 'Bill to Amend the Constitution of Queensland so as to Secure the Blessings of Liberty to our People and our Posterity' (QPD 1958:vol. 221, p. 5), but nothing appeared in that session either. Then, in August 1959, the new Governor, Sir Henry Abel Smith, announced the Nicklin government would enact a Bill of Rights for Queensland in the third session of the Parliament and before the approaching state election. This time a Constitution (Declaration of Rights) Bill (drafted with the assistance of a consultant, Dr Frank Louat, QC) was introduced to the first reading stage, at which point the Premier announced that the government intended 'leaving the Bill before the people for their consideration' (QPD 1959:vol. 225, p. 2007). The bill attracted various criticisms from members and even from the preliminary debate it was clear that the enunciation of constitutional principles would have far-reaching implications and perhaps unintended consequences. Three issues in particular attracted attention: the advisability of codifying electoral rights; the issue of binding future parliaments to particular provisions in the bill; and the issue of property rights (and the compulsory acquisition of property from such groups as primary producers under marketing arrangements). Provisions for the appointment of judges were condemned because they did not go beyond existing practice. The bill was not further debated in the last days of the third session in 1960. Finally, following its re-election at the state election of 1960, the government indicated a change of heart over the declaration of rights initiative and sought to allow the issue to lapse quietly. This tactic, however, did not save the government from criticism over its handling of this matter or from occasional embarrassing references to the rights bill by opposition speakers in subsequent parliamentary debates. 


\section{Box 5.1 \\ The Constitution (Declaration of Rights) Bill 1959}

The provisions of the 1959 bill included

- affirming the sovereignty of the Parliament as the representative authority of the people of the state

- limiting the Parliament's ability to bind its successor by restricting its powers to entrench legislation (not 'fetter its successors') but removing any impediment to its powers to repealing laws

- the Assembly would be composed only of members 'directly chosen by the electors' with the state divided into electoral districts from which 'one member and no more of the legislative Assembly shall be chosen', and the number of electorates not less than 75

- electorates would be derived by a quota 'subject to a margin of allowance', implying electorates would be roughly of equal proportions (one vote, one value); no electorate could exceed one-third of the quota or fall less than one-third; the quota would come from dividing the number of voters in the whole state by the total number of electorates

- any person (subject to some minimum criteria) could nominate for election to the Assembly (nominated by 10 electors) even if the nominee was not enrolled as an elector for that or any other electoral district; and the Parliament was prevented from adding further disqualifications in the future

- enrolment to vote was to remain compulsory, by secret ballot, with one vote only and 'it shall be the duty of every elector to record his vote'

- British subjects older than twenty-one years could vote if they had been in Queensland for six months or more

- electors were supreme and the Parliament could not diminish or take away the right of a person to claim enrolment and vote

- referendums were provided for, also with compulsory voting

- the judiciary was afforded a degree of independence - they would still be politically appointed by the Governor-in-Council but could be removed only by the same body after a vote from the Assembly

- people had basic civil rights associated with arrest, legal representation and release by the courts if detention was unlawful (habeas corpus)

- people had property rights and the Parliament's power to seize property 'shall not extend to authorise, by any law whether made before or after such commencement [of this act], the compulsory acquisition of property otherwise than on just terms'

- bill seeking to repeal, amend or be contrary to the provisions of the constitution was not to be presented for assent until the proposed bill had 'been approved by a majority of electors voting at a referendum'.

The proposed bill was deferred when the Parliament resumed in 1960 and was never reintroduced. 
At the opening of the thirty-sixth Parliament on 24 August 1960, Governor Abel Smith used the occasion to remind members that Queensland had entered its second century. Taking the opportunity of the anniversary to reflect on the state's heritage, he became more adventuresome in his address, waxing lyrical on the past and speculating on the future:

The pioneers brought with them to this vast continent Western civilisation which rests on Christianity. They believed in individuality as an integral part of their faith, yet they realised that they were also members of a community who had received great privileges in the gift of this rich land, and therefore, it was their responsibility to develop its latent wealth for the benefit of mankind. These early settlers, together with the generations who succeeded them, have passed on to us a magnificent heritage. Our State is entering her second century; wide horizons lie ahead. (QPD 1960:vol. 227, p. 27)

The words, of course, were those of the government. Such confidence and 'stateboosterism' always seemed high and the government's appetite for pioneering challenges was keen. It had used the opportunity of the state's centenary (the so-called 'Triumph in the Tropics') to associate its own developmentalism with that of the pioneering past. Like most state governments at the time, the Nicklin ministry believed that governments fundamentally existed to do things and expand opportunities for those like themselves able to take advantage of the opportunities.

Citing its successes and administrative achievements, the government would resort to providing regular bulletins recording outputs or welcomed increases. The number of infrastructure projects (water supply, sewerage, railways, bridges) built each year was faithfully recorded as progress; additional migrant settlers, new schools, colleges, houses and health facilities were all signs of Queensland's steady growth. The construction and improvement of roads were perennial indicators of success, signalling not only the opening up of the state, but the provision of convenient public infrastructure to rural industries across the state. Each year the Parliament was informed of the magnitude of the road-building effort throughout the state (an effort due not only to the state government, however, but to the three levels of government acting in conjunction). Under the Main Roads Act, the government declared a construction target of an additional 20000 miles (32 000 kilometres) of new roads to be completed in the period 1960-66. Each year the total funds expended on road construction was mentioned with some pomposity; in some years road fund expenditure was equal to about one-seventh of the total budget.

Despite the obvious pride with which road construction figures were presented, the government regularly admitted to being 'distressed' by the 'ever-increasing' 
road toll throughout the state. It made frequent rhetorical undertakings to help reduce accidents and road fatalities. Often the remedy was to advocate more sealed roads (including the major undertaking of covering the Bruce Highway from Brisbane to Cairns with bitumen during the 1960s). Motor vehicle inspections, zebra crossings, railway crossings, traffic lights and oneway streets all regularly received mention, as did new police stations and praise for the 'excellent work' of the Queensland Police Force. Other remedies against drunk-drivers were, however, often resisted and measures such as random breath testing for motorists would have to wait until 1988 - near the end of the conservatives' tenure in office. ${ }^{1}$

Health announcements were also a prominent feature of the government's administrative and legislative agenda. Unlike other parts of Australia, Queensland had established a strong tradition of free health treatment at public hospitals and successive governments continued the commitment and basked in the credit. In 1961, the Governor told the Parliament that '[m]y Ministers inform me that the policy for providing free treatment for both inpatients and outpatients at public hospitals has been maintained' (QPD 1961:vol. 230, p. 6).

Commissioning new public hospitals was invariably a popular preoccupation and the government would frequently add new specialist facilities to existing public hospitals. For example, the state government implemented the Commonwealth's policy of compulsory chest X-rays in 1959 and within two years more than 250000 people had been examined. In 1960, plans were made to integrate psychiatric services with general health services provided by public hospitals. The next year, the government planned to train and appoint 'teachers to tutor the sub-normal population of mental hospitals' (QPD 1961:vol. 230, p. 6). In other areas of health policy, the government regularly announced its intentions to reduce occupational accidents by establishing safety boards or creating specialised occupational health and safety units in departments such as labour and industry.

Occasionally, when outlining the government's intentions to a new session of parliament, some announcements seemed curious or quirky. Beginning its second term, the government announced that Aboriginal income and employment were to be developed by a 'native curio industry' (QPD 1960:vol. 227, p. 31). Another year, the government boasted that it had successfully developed the technology to remove 'weed taint from butter oils' (QPD 1961:vol. 230, p. 4). In 1963, it was felt important to record that 'a film of the State sponsored by a prominent Southern organisation covering industrial and tourist matters' was being produced and that 'Queensland was well represented by a pavilion at

1 In the 1970s, breath testing for alcohol was permitted but not random testing. Police had to suspect a driver of driving under the influence or observe erratic driving behaviour. The limit then was 0.08 . 
the Sydney Trade Fair' (QPD 1963:vol. 235, p. 16). In the same speech, the Governor reported that 'a total of 233 new classrooms was provided at existing State High Schools' (QPD 1963:vol. 235, p. 18).

\section{Address-in-Reply debates: meandering, roaming non-debates}

Under parliamentary conventions, the Governor's speech was the catalyst to initiate the Address-in-Reply debate, which allowed the Parliament (and principally the opposition) to debate the government's record and the issues of the day at considerable length. The Address in Reply is conventionally the Parliament's reply to, and acknowledgment of, the Governor's speech, handed down from the British practice in which parliamentarians would humbly thank the monarch for his/her 'gracious speech' to the two Houses. In the early 1960s, the Queensland Standing Orders permitted the Address-in-Reply debate to run for seven sitting days (having earlier been increased from only four days in November 1950 by the then Premier, Ned Hanlon). Convention also allowed, however, two additional days for reply - the first of which was when two new backbench members from the government would open the defence highlighting their appreciation of government projects, and a second allowed the Leader of the Opposition to begin the opposition's response to the government's program; then seven further dates were 'allotted' with speakers from alternating sides of the House. Thus, between seven and nine sitting days per annum were designated to the Address in Reply and this constituted approximately oneseventh or 15 per cent of the available sitting days in a typical parliamentary session in the 1960s (sessions averaged 67 days throughout the 1960s). While not always the most important debate, the Address in Reply generally consumed the most amount of debating time.

In opening the Address-in-Reply debate, two new government backbenchers would move and second a standard motion expressing loyalty to the Crown and thanking the Governor for giving the speech opening the session. They would add:

The various measures to which Your Excellency has referred, and all other matters that may be brought before us, will receive our most careful consideration, and it shall be our earnest endeavour so to deal with them that our labours may tend to the advancement and prosperity of the State. (QPD 1963:vol. 235, p. 29)

The two novice backbenchers would then speak about their electoral concerns, providing a rundown of state development issues usually from the local 
perspective. Incentives to local industries were important, such as sugar, cattle, fruit, timber or tobacco. The virtues of major local projects were extolled as governments helped develop 'the north' or 'the west'. Hence, when Henry McKechnie (CP, Carnarvon) rose to speak in his first Address in Reply in 1963, he concentrated on listing the government's achievements within Carnarvon (from Goondiwindi to Stanthorpe), but added for good measure what he felt were the urgent remaining needs of his electorate - principally, water provision, electricity and sealed roads. A certain flavour of the debates is conveyed in the following extract from McKechnie's speech:

Due to lack of water, the productivity and general confidence in the Inglewood irrigation area had gone into a decline, and in my election campaign I stressed as an emergency item that a major dam must be built on the Macintyre Brook. It was very gratifying that there was such a quick response from this new Parliament in that Cabinet approved the $£ 2.4$ million Coolmunda Dam to impound 61,000 acre-feet of water so that in the driest years 9,000 acres can be irrigated past Inglewood to Yelarbon. In his speech yesterday His Excellency said that this approval was subject to the acceptance of the landholders downstream, and that has now been obtained... Realising that water is the key to progress, the implementation of the Border Rivers scheme is ever in my mind. This scheme envisages a large dam on Pike's Creek, south-west of Stanthorpe and above Texas, to store 90,000 acre-feet in its first stage and increasing to 200,000 acre-feet in its second stage to yield an assured supply of 74,000 acre-feet per annum to irrigate 31,000 acres along the Dumaresq River at a cost of $£ 6.5$ million, and then, at a later stage a still larger dam to be built on the Mole River opposite this site in New South Wales to impound 430,000 acre-feet at a cost of $£ 12.5$ million to irrigate a further 63,000 acres of land...The Border Rivers project is being prepared in detail for the two State governments to present to the Prime Minister, and prospects look excellent for this project of national importance. (QPD 1963:vol. 235, pp. 30-1)

Hardly sensational stuff, but then again such extracts reflect the concerns of backbench government members on local development and progress. Later, other government members would contribute to the debate, often making their maiden speeches in the reply debates. They did not want to criticise their own administration, so much of the content of their addresses was reportage and routine; the speeches were essentially formulaic.

With somewhat greater latitude for political scope, the opposition's 'reply' could roam across policy, performance and politics. Its aims in the debate were usually to embarrass the government and force it to improve its performance, while presenting itself as a viable alternative government. In practice, however, the 
opposition's reply debates meandered, with many opposition members straying from topic to topic seemingly at will. This practice meant that reply debates were often long, tortuous and scattered in their content. They occupied an important formal role in the proceedings of parliament but the real debates often lacked coherence and purpose, and not many topics were in fact 'debated'. The Address in Reply for the second session of the thirty-sixth Parliament in 1961, for instance, ran for nine sitting days between 22 August and 19 September, with the Hansard record of the debate extending to 245 pages (QPD 1961:vol. 230). Customarily, once the debate was completed, the Speaker dutifully presented the entire Address in Reply to the Governor for his edification; provision also existed for the Governor to answer the reply debate but usually this was merely a formal acknowledgment of receipt, reported back to the House by the Speaker.

\section{General government business}

\section{Budgets, supply and financial affairs}

The annual passing of the budget - authorising monies for proposed outlays forms one of the main rituals of the parliamentary process. Under Westminster conventions, the Crown requests the Parliament (by message from the Governor) to authorise funds to provide for the executive government's requirements. Parliament is asked to impose taxes or expend public monies. Specific money bills provide ' $[\mathrm{t}]$ hat there be granted to Her Majesty, for the service of the year [a particular financial year] a sum not exceeding' a certain stipulated amount for expenditure. Hence, all revenue measures and expenditure commitments require regular appropriation by the Parliament, which authorises grants to the Treasurer to pass on to departments and other public bodies. These grants - or 'votes', as they are known in parliament - are approved on an annual basis with provision to ensure the continuity of administration. To approve such financial measures, Standing Orders in the 1960s required the Parliament to meet as a committee of the whole house (in the Committee of Supply and Committee of Ways and Means). Once the Address in Reply was completed in the Legislative Assembly, the budget and supply debates ostensibly examined the government's proposed budget before eventually passing the appropriation bills. These annual debates in the 'budget session' conventionally lasted up to 17 sitting daysapproximately one-quarter of a parliamentary sitting year.

The budget session of parliament generally began in the new financial year, usually in August. The Parliament was presented with estimates of expenditure for the year ahead, but because the government needed resources to operate while the Parliament was deliberating the supply, two separate appropriation bills were required to be passed each year (constituting 'votes on account'). The 
Annual Appropriation Act No. 1 was passed at the start of the budget sitting in August and provided authority to draw funds for government services for the period September to November. The second appropriation bill (no. 2) was passed at the conclusion of the budget debates and authorised funds 'on account' for the next July and August to enable the business of government to continue while the Parliament was examining the budget. Both acts empowered the Treasurer to spend public monies from consolidated revenue (the public account), from trusts and special funds and to borrow any additional funds needed for approved purposes.

Treasurers introduced the government's budget (or annual financial statement) through the yearly budget speech, which highlighted the main points or provisions of the intended budget according to the government. Traditionally, the Leader of the Opposition would reply to this speech a few days later. Members then had six days to debate the general components of budgetary and economic policy. The remainder of the 17 supply days was then set aside for supply and departmental estimates with the House forming itself into the Committees of Supply and Ways and Means (with the Supply Committee considering departmental estimates and Ways and Means formally authorising appropriation). Revenue proposals were passed for consolidated revenue, trust and special funds, and for the loans fund. In the 1960s, departmental estimates were considered by the whole House (and not by a special committee) but only selected portfolios were subjected to detailed scrutiny. Each year cabinet would nominate the particular portfolios to be considered in detail and, after discussing these, the Parliament would pass the remaining estimates en bloc at the conclusion of the supply debates. Those selected for review were supposed to be chosen on a rotational basis, but the practice allowed the government to carefully nominate those portfolios they were most confident would survive scrutiny, while shielding others from detailed examination.

Compared with other Australian parliaments, in Queensland, the budget and supply debates tended to lack a certain interest because of its unicameral structure and tight two-party adversarial system. Because there was no upper chamber, perhaps with a different perspective or political composition, there was no other opportunity to scrutinise and authorise the money bills. The budget debates themselves did not have to be persuasive or comprehensive because at the end of the allotted time the government could always muster its numbers and authorise the required appropriations. The government could vote down any amendments proposed in the Assembly, whereas other state governments in Australia often had to expect compromises with a second chamber. This meant that in Queensland the character of the debates generally lacked a focus on detailed departmental expenditure estimates or on how effectively public money was spent. Frequently, the Commonwealth Government (also a Coalition- 
led administration at this time) was used as a convenient distraction or scapegoat for any resource shortfalls or problems experienced with commitments. For instance, the Treasurer, Tom Hiley, had a significant argument with Robert Menzies in 1959-60 over the financing of the Townsville to Mount Isa rail line. As in the Address-in-Reply debates, members often used budget debates for matters entirely tangential to the question of supply or the budget proposals under discussion. Political opportunism and verbal attacks on the other side tended to dominate proceedings and from session to session patterns emerged closely related to particular members. Some ministers, government members and opposition members were conscientious in deliberating supply issues within a portfolio under discussion, keeping their comments focused and relevant. Others, however, strayed into esoteric or irrelevant topics, used the debates to launch political attacks or seized the opportunity to 'have another go' at a favoured topic of concern.

The chair tended to exercise little control over the range of issues raised while ostensibly discussing appropriations and financial matters. For instance, in 1961, during the debate on the general estimates, the topic of discussion eventually swung around to censorship and pornography. According to Clive Hughes (Lib., Kurilpa), the Queensland Literary Board of Review allowed 'raunchy novels to be sold', which poured 'filth into this country to the detriment of the minds and education of our young people'. Although Hughes was nominally discussing the estimates of the Education Department (totalling £19 191 118), which he generally felt was well spent, he believed young people were being put at risk by the availability of such 'dirty novels'. To the amusement of many present, he began to read into Hansard some assorted extracts and titillating passages from the 'obscene literature' approved by the Review Board (with lurid titles such as Call Girl, Gutter Girl and even the Black Leather Barbarians). He went on to admit that he had read 'dispassionately' the book Call Girl and, among other things, the 'unexpurgated version of Lady Chatterley's Lover'. Not all opposition members present entirely shared Hughes' concerns and some began to ridicule his statements. At one stage after Hughes had listed some of the 'dirty novels' he had read, one member interjected to ask him if he had ever 'read any decent books', and later whether he kept 'these books at Liberal Party headquarters'. When Hughes described the cover of Gutter Girl, Labor's Jack Houston asked hopefully whether such books were available 'in the Parliamentary Library', later adding 'no wonder we could not find any there; you had them all out' (QPD 1961:vol. 230, pp. 670-8). The temporary Chairman, Alex Dewar, was reluctant to intervene on the relevance of the speech, but did call the House to order saying that '[t]here is far too much levity in the Chamber'. Hughes was immediately followed in the debate by Harold Dean (ALP, Sandgate), who managed to return to the estimates, but questioned the wisdom of printing 
Hughes' speech in Hansard because it would be 'distributed freely' and was likely to bring discredit on the Parliament. The next speaker, Joh Bjelke-Petersen (CP, Barambah), opened his speech by volunteering that he agreed

100 per cent with the attitude and action taken by the hon. member for Kurilpa. In my opinion it is very necessary to draw attention to the fact that these books are in circulation, so that those in authority may do something about them. I congratulate the hon. member on his speech. (QPD 1961:vol. 230, p. 682)

This interchange might illustrate the kind of topics parliamentarians of the day thought were important or it might also indicate that despite their formal significance the routine supply debates could be tedious and boring and a little light relief was welcomed. Over the years, the prospect of introducing more interesting topics often proved alluring.

Yet, parliamentarians themselves were sometimes critical of the effectiveness of budget debates and the way members performed. Sam Ramsden (Lib., Merthyr) claimed as early as October 1961 that budget debates tended to be misused by parliamentarians. He was not alone in his party in considering the budget debates somewhat wasted, often notoriously rambling and frequently degenerating into longwinded political diatribes. He called for a specialist public accounts committee in 1961, suggesting that such a committee was necessary to fulfil the Parliament's designated role of scrutinising the executive on financial matters (QPD 1961:vol. 230, p. 691). His call for a public accounts committee would remain dear to the hearts of the Liberal Party members, surfacing from time to time and ultimately becoming a catalyst for the eventual Coalition breakdown in 1983.

During the period of the Nicklin government, the state budget underwent steady growth, with expenditure from consolidated revenue dropping in only one year (in 1962/63), and even in that year an additional injection of spending from trust funds meant that total expenditure still rose. Interestingly for a conservative and avowedly 'low-taxing' government, expenditure commitments gradually increased ahead of the rate of population growth. On a per capita basis, expenditure increased from $\$ 206.20$ in 1957 to $\$ 396.10$ in 1968. The Nicklin government was not averse to using public expenditure deliberately to sponsor the various components of state development.

All recurrent outlays (expenditure on administration, salaries and operating costs) were funded largely from the consolidated account, with capital works expenditure (construction and major projects) drawn from loans funds. Before the change of government in 1957, the Coalition in opposition had been critical of the Labor government's failure to spend on services and Queensland's tendency 
to fall behind the average Australian state standard (see Lack 1962:517). In government, Nicklin and Hiley were anxious to keep pace with the national average of spending and in some areas greatly expand expenditure, such as in education, where the number of schools and teachers rose substantially (admittedly from a low base). Expenditure on education tripled in the first 10 years of the Coalition government, from $\$ 23$ million in 1957 to $\$ 71.7$ million in 1968. In the same period, the state population increased by the lower figure of less than one-fifth (18.9 per cent).

Revenue and taxation issues were subjects of much controversy over the years in budget debates. Revenue receipts (from taxation, grants, borrowing and trust funds) increased at a regular rate although the government was often at pains to stress the low-tax status of Queensland. It was inevitably walking a fine line between being fiscally conservative and containing revenue take, and having sufficient expenditure to enable it to do what was required or needed. Making the state tax system more effective became a key issue at the outset of the Nicklin period. As a conscientious Treasurer, Tom Hiley was initially 'horrified that some State taxes were costing more to collect than they yielded' (CourierMail, 12 November 1957). Hiley conducted a review of all state taxes within his first 12 months as Treasurer (Courier-Mail, 17 June 1958).

To meet other shortfalls (and augment a 'poor tax effort'), the government looked to additional support from the Commonwealth. The Premier was determined to secure increased funds from the Commonwealth (rather than raise state taxes), arguing in his maiden speech to the Loans Council that from a Queensland perspective 'we need more' (Courier-Mail, 14 February 1958). A series of comparative statistics was read into Hansard illustrating that the Queensland government spent far less on services than other states - and also that Queensland received far less in per capita terms from the Commonwealth Government. In the supply debate after the introduction of Hiley's first budget, the Deputy Leader of the Opposition, Eric Lloyd (ALP, Kedron), congratulated the Treasurer on his budget and made the point that 'it is obvious that although Queensland has the greatest potential of any State in the Commonwealth and the largest area, it is given the smallest grant from the Commonwealth government on a per-capita basis' (QPD 1958:vol. 218, p. 380; see also Lack 1962:518). Both sides of the House shared a bipartisan view that Queensland was hard done by in its share of Commonwealth funding - and this was to remain a perennial feature of Queensland state politics. The Coalition government was later instrumental in convincing the Commonwealth Government to accept Queensland as a 'claimant state' qualifying for additional revenue assistance.

Debates about the state level of taxation did not all go one way. At times the government deliberately chose to run deficits and defend them publicly. The Coalition consisted of an amalgam of agrarian socialists and urban 
interventionists. As a second-term backbencher, Bill Knox (Lib., Nundah) informed the Parliament in October 1961 that the Coalition government would not shy away from increasing taxes - something of a heresy in terms of later public representations from Queensland governments. Knox gave a lengthy defence of the government's spending commitments, stating 'we are spending to the limit of our capacity this financial year'. When challenged by an opposition interjection that this would result in a deficit, Knox continued:

If this is the defence of a deficit, I am not ashamed to defend it. We are trying to get on with the job of development. We will spend every penny that we can lay our hands on. We are spending to bursting point. We will do this rather than conserve funds and provide a balanced budget. (QPD 1961:vol. 230, p. 627)

Generally, however, Treasury and the Parliament placed considerable importance on delivering a 'balanced budget' with either a small surplus or a small deficit recorded. To achieve a 'balanced budget' in the consolidated revenue account, the government could draw funds from various 'hollow logs' and trust accounts, from Commonwealth sources or directly from increased borrowing. Hiley, in particular, was anxious not to have money sitting idly in 'hollow logs', preferring it instead to be used for practical purposes. In 1960, both revenue and expenditure exceeded $£ 100$ million for the first time while the government reported a comparatively small deficit of $£ 164675$ for the previous financial year. In 1960, loan or trust fund expenditure on capital works represented almost one-third of outlays (£29 361845 of the $£ 100$ million). By 1968, trust fund expenditure used largely for capital works was greater than recurrent outlays.

The proportions of expenditure allocated to particular functions or policy areas changed slightly in the decade of the Nicklin government. The allocation of outlays remained predominantly consumed by infrastructure and resource development, with far less provided for education, health services and 'social amelioration'. In 1957, the combined expenditure on railways, other state enterprises and development purposes was equal to 56.5 per cent of total expenditure (24.5 per cent alone was spent on the railways - the single largest item of expenditure). By 1968, this combined figure had fallen back to 47.8 per cent, largely because expenditure on railways had dropped to 14.8 per cent. Indeed, because of the associated costs, the state's railways constituted a significant imposition on the budget. Each year the Railways Department would report its activities to the Parliament, generally returning losses on its operations. Typically the Governor's speech would note the losses in passing. For instance, in 1958, the railways lost £1.46 million (QPD 1959:vol. 224, p. 2); in 1960 , they lost a further $£ 2.6$ million from a turnover of $£ 34.8$ million; and in 1962, they lost only $£ 500$ 000, which was much better than the previous 
year, when $£ 1.5$ million had been lost (QPD 1963:vol. 235, p. 14). In 1964, the government announced with some pleasure that for the first time in nine years the railways had broken even.

In contrast with the amounts spent on railways and other developmental projects, the proportion of expenditure on social items (education, health and welfare) was low. Education consisted of only 9.1 per cent in 1957, rising to 13 per cent by 1968. Expenditure on health made up just 10.5 per cent in 1957 and had fallen to 9.6 per cent by 1968. Social amelioration consisting of relief assistance, child welfare, homes for the aged and Aboriginal welfare consisted of just 1.6 per cent in 1957 and 1.8 per cent in 1968. The breakdown for the various proportions of expenditure according to functions is shown in Table 5.3.

Table 5.3 Expenditure outlays by function, 1957-68

\begin{tabular}{|l|l|l|}
\hline Policy function & $\mathbf{1 9 5 7}(\%)$ & $\mathbf{1 9 6 8}$ (\%) \\
\hline General administration & 4.1 & 3.8 \\
\hline Law, order, public safety and regulation of trade & 4.0 & 5.9 \\
\hline Education & 9.1 & 13.0 \\
\hline Health & 10.5 & 9.6 \\
\hline Social amelioration and welfare & 1.6 & 1.8 \\
\hline Business enterprises and railways & 32.0 & 21.5 \\
\hline $\begin{array}{l}\text { Development of resources, land, irrigation, } \\
\text { infrastructure and housing }\end{array}$ & 24.5 & 26.3 \\
\hline Local government & 3.3 & 6.4 \\
\hline Debt charges & 10.8 & 11.6 \\
\hline
\end{tabular}

Source: Queensland Year Book 1959, no. 20; Queensland Year Book 1969, no. 30.

Finally, in the mid-1960s, a convention began of coining a particular label for each year's budget. The aim was to identify a name or theme that could be used in selling the budget. Gordon Chalk as Treasurer in 1966 labelled his first budget 'a push ahead' budget. This was followed by the 'march of progress' budget in 1968. The media, however, was less kind, referring to Chalk's 1966 budget as the 'little horror state budget' in reference to the 1951 federal 'horror budget' of Artie Fadden. The opposition also picked up on this theme retrospectively, labelling Hiley's last budget, of 1965, the 'dishonest budget' because of the pending 1966 election and then regarding Chalk's 1968 budget as the 'guilty conscience' or 'election jitters' budget (Houston in QPD 1968:vol. 249, p. 613). 


\section{Selected legislative policy areas}

\section{Political, legal and administrative}

Having been kept out of government for such a long period, the Coalition had a lengthy backlog of political issues to address and legislative amendments to introduce covering administrative and legal areas. Amending the provisions of the electoral laws was one of the most pressing issues for the new government in its first term. In particular, the government was determined to make its own amendments before facing the people again in 1960. Neither side of politics had shown a commitment to one vote, one value and both continued the practice of dividing the state into zones to weight votes unequally (or represent some sections of the community better than others). Just as the outgoing Labor administrations had manipulated the electoral system to gain maximum benefit (to use Premier Nicklin's words), so the conservatives adopted a similar philosophy when proposing amendments to the Electoral Districts Act in 1958. Indeed, Nicklin told the Parliament that the new government was basing its amendments on the framework of the earlier 1949 Electoral Act introduced by Labor. The four zones created by Labor became three under the new legislation: metropolitan Brisbane with 28 electorates; provincial cities with 12 electorates; and the country zone occupying the rest of the state with 38 electorates. The legislation made provision for redistributions within zones (but not between them) and maintained first-past-the-post voting. The Premier regarded this legislation as providing a 'better distribution of electoral districts' and a more 'realistic approach to the rectification of anomalies which exist in the present distribution' (QPD 1958:vol. 222, p. 1616). He defended the bill on the grounds that it was more aligned with population growth and was fairer than the previous zonal arrangements that 'sprung from the manipulation of electoral boundaries by our predecessors'. He thought the new bill was fairer to Labor than the previous malapportionment, pushed through by Labor, had been to him. The opposition, however, was incensed by the changes and opposed virtually every clause. Labor opposed the addition of three extra seats to the Parliament (from 75 to 78 ) and the allocation of four additional seats in the Brisbane zone to only one extra for the country (see Chapter 6). Duggan even accused the Coalition parties of conspiring to fix the system, 'huddling' over maps and using Harold Richter (CP, Somerset) and Seymour Doug Tooth (Lib., Kelvin Grove) as a subcommittee to inquire into 'the best ways in which they could carve up the State to ensure the return of the present government' (QPD 1958:vol. 222, p. 1619). The government used its numbers to reject every opposition amendment and ensure that each clause of the bill was passed intact.

Electoral tinkering was not over, however, with the changes to the zonal system for partisan advantage. The Coalition again modified the electoral laws to secure 
its position once it had comfortably achieved re-election and seen the demise of the QLP. After much soul-searching and dispute among the Coalition partners, the Elections Acts Amendment Act 1962 reintroduced preferential voting as a way of shoring up support for the Coalition where two or more conservative candidates stood for election (but this time preferential voting was compulsory not optional). Compulsory voting on a preferential basis meant that voters had to allocate a numerical preference (1, 2, 3, 4, and so on) to all candidates standing for the seat for votes to be counted as valid. Failure to allocate preferences in order to all candidates (or all bar the last) would render the vote invalid. The government argued that this change brought Queensland into line with Commonwealth practice on preferential voting and reduced the 'wastage of votes' (that is, those cast for all defeated candidates). The Country Party was, however, also increasingly aware that if it persevered with first-past-the-post voting then it risked losing seats where two or more conservative candidates stood or where renegade conservative independents split the vote. Compulsory preferential voting, together with a system in which each of the Coalition partners would 'stake a claim' on particular safe seats, seemed a far safer bet. As a result of the 1962 preferential voting amendments, however, the issue of which Coalition party 'owned' particular seats then became a controversial issue dogging relations between the party machines and within some local branches.

Political advantage in local government elections became an issue for the government in its second term. Changes to the electoral system for Brisbane were made in the City of Brisbane Acts Amendment Bill 1960. The bill intended to increase the number of Brisbane electoral wards by four (to 28) bringing council wards into line with the recently redistributed 28 state electoral districts in Brisbane. The four new wards were likely to be Liberal-held wards giving them a projected hold of 18 wards in total. Lloyd Roberts, the Minister for Works and Local Government, at the time introducing his first and one of his last bills, argued that this measure was necessary to allow council elections to use the state electoral rolls, which 'meant a tremendous saving in cost' - despite the additional cost of providing for four additional aldermen (QPD 1960:vol. 227 , p. 420). Labor criticised this measure because it felt that four additional wards would 'bring about an over-abundance of electorates within the city of Brisbane' (Eric Lloyd, Deputy Opposition Leader, in QPD 1960:vol. 227, p. 439). The Opposition Leader, Jack Duggan, accused the government of again seeking to tamper with the electoral system, asking whether the 'reported horse-trading at last night's meeting of the joint Liberal and Country Parties, by which the Liberals forfeited their one vote one value policy in return for the creation of an additional four metropolitan electorates, indicate[d] the Government's conception of fair and clean procedures?' (QPD 1960:vol. 227, pp. 442-3). The minister brushed aside any criticisms by responding that 'there was a hue and cry this afternoon about gerrymandering. I am not going to deal with that 
because nobody would know more about gerrymandering than hon. members opposite. They have had a lot of experience of it and have been absolute past masters at it' (QPD 1960:vol. 227, p. 455).

Ministerial salaries and additional payments to parliamentary officials were invariably controversial with representatives anxious to demonstrate their worth and the public concerned about the rising costs of political representation. Parliamentary salaries had emerged as a sensitive election issue in 1957. This did not prevent the government the next year from awarding large increases to the annuities paid to members under the parliamentary superannuation scheme (more than doubling the weekly rate payable), while raising the level of member contributions from $£ 2$ to $£ 4$. The Public Service Superannuation Act was also amended in 1958 to increase provisions for the compulsory contributors. Then in March 1961 the government introduced legislation that allowed the practice of paying additional salaries to ministers in Queensland, thereby bringing the Queensland government in line with other states. The Constitution Acts Amendment Act 1961 was drafted after the report of an external committee of inquiry into parliamentary remuneration. To the disappointment of many members, the bill declared that the existing salary for ordinary members was sufficient and should not be altered (at $£ 2501$ 10s.), but that Ministers of the Crown and officials of the Parliament would be provided with additional remuneration. The bill listed the additional amounts of salary to be paid to officers according to the then pecking order: Premier, £2700; Deputy Premier, $£ 1600$; ministers, £1350; Opposition Leader, £1000; Speaker, £750; the Deputy Opposition Leader and Chairman of Committees each received £250; and the whips of the government and opposition received £100. Interestingly, the Premier received double the increment of ordinary ministers and the Speaker received a little more than half the additional salary of a minister (QPD 1961:vol. 229 , p. 2861). The Premier's salary was then $£ 5201$ 10s. in total.

Parliamentary salaries were again increased by legislation in March 1964, when the Premier justified an increase for all members' annual salaries from £2501 10s. to $£ 2650$ on relativity grounds with other official positions (departmental secretaries). The Premier described the increase as 'moderate' despite the fact that the rise of $£ 148$ and 10s. was equal to 10 weeks' pay for workers on the basic wage. The new parliamentary salary was four times the basic wage. The additional payments to some ministers and other senior officials were also increased, lifting the Premier's salary now by $£ 2750$, the Deputy Premier's by $£ 1800$, the Speaker's by $£ 900$, the Deputy Opposition Leader's and Chairman of Committees' by $£ 300$ each and the whips' by $£ 200$. The additional salary increment of other ministers, however, and the Opposition Leader was left 
unchanged. In a separate act, the Governor's salary was increased to $£ 6500$, bringing his annual salary in line with senior ministers and the Chief Justice (and almost 10 times the basic wage).

These increases were soon seen as insufficient and in 1965 the Constitutional Acts Amendment Act awarded further increases to members and other officials in the Parliament. Again the recommendations of a committee of inquiry were used as the basis for the rises. Ordinary members were given an increase in their salaries of $£ 700$, bringing them to $£ 3350$ per annum; ministers' salaries were increased by $£ 1500$ to $£ 5500$; the Premier and Deputy Premier were awarded a total of $£ 7000$ and $£ 6000$ respectively; the Leader of the Opposition received $£ 4750$ and the Speaker $£ 4600$. The act noted that the large increases in salary would be partially offset by some reductions in the allowances paid to members. Moreover, sensing public disquiet, the act allowed individual members to refuse in whole or in part any of the increases awarded. This provision could be interpreted cynically as a device to temper public outrage or discourage any hypocrisy from the opposition who might choose to attack the rise but still accept the increase.

The size of the ministry was expanded from 11 to 13 in September 1963 to spread the workload of the cabinet 'in the interests of good government'. A special act was required to create two new ministerial positions (the Officials in Parliament Acts Amendment Act 1963). By increasing the ministry, the Coalition government faced a dilemma. If they added only one position arguments would arise over which party should secure the job. ${ }^{2}$ To smooth the way and avoid an inter-party brawl, the government chose to add two new ministerial positions, one for each party, which would preserve the relativities within cabinet (seven Country Party ministers to six Liberals, up from six-five respectively) and still provide promotion to a backbencher from each side. This was typical of Nicklin's style of handling the politics. Justifying the increase in the Parliament, Nicklin was unapologetic, saying that the 'field of government had widened tremendously'. He pointed out that in 1898 the ministry was set at eight; it was increased to nine in 1920 by Theodore; a tenth position was added by the Gillies government in 1925; and the eleventh spot was added by Hanlon in 1949. Thus, according to Nicklin:

[I]n a period of 43 years only two additional ministers have been appointed, although in that period the population of the State has more than doubled and State government expenditure from all funds has

2 The Country Party would argue it deserved an extra position relative to the number of parliamentary members and that the Liberals should not be equal in cabinet. In contrast, the Liberals would argue for the position on the strength of their voting support and that they should be equal to the Country Party in cabinet. 
increased more than tenfold, reflecting the development of the State and a consequent enormous increase in the scope and volume of ministerial responsibility. (QPD 1963:vol. 235, p. 204)

The opposition opposed the increase suggesting that no recent changes in circumstance warranted the increase and that Nicklin had himself opposed the last increase of only one position under Hanlon. Duggan was critical of Nicklin's arguments for the increase claiming that they were unconvincing and lacked logic. Indeed, there was no justification offered by the Premier to the Parliament as to why two positions suddenly had to be created. On the three previous occasions when an increase in the size of the ministry had occurred, it had been executed by majority Labor governments unconstrained by Coalition politics. Nicklin's solution of doubling increases to preserve party standing was not, however, followed when the ministry was next increased by the Bjelke-Petersen government in 1969; then only one position was created for an additional Country Party nominee.

A special bill was introduced in 1964 to exempt a particular member of the Assembly from disqualification due to holding offices of profit under the Crown simultaneously. The Percy Raymund Smith Declaratory Act 1964 exempted Ray Smith (Lib., Windsor) from this clause in the constitution because of extenuating circumstances. Smith was a distinguished air force pilot in World War II and was asked to serve as a replacement Judge Advocate-General of the Air Force while sitting in the Parliament. The special act allowed him to accept this additional position under the Crown. The Parliament was assured that the Air Force appointment was not a form of permanent employment and that Smith would not be paid a formal annual salary for his services, but would be reimbursed only on a daily basis. The act gave Smith an exemption from the requirements of the Officials in Parliament Act and to some extent the constitution (QPD 1964:vol. 238, p. 208).

Beyond its own electoral and pecuniary interests, the government gradually addressed other concerns close to its own heart or those of its supporters. One such concern was over legislation affecting the legal community. On its return in the second term, the Nicklin government was eager to repeal the Barristers $A c t$, a piece of Labor legislation passed in 1956 that had liberalised competition and thus angered local lawyers, many of whom were close to the Liberal Party. On largely parochial grounds, the government wished to disallow barristers and solicitors from other states from practising in Queensland. The Minister for Justice, Alan Munro (Lib., Toowong), introduced the repeal bill, arguing against the mutual recognition of qualifications because, he argued, it had resulted in 'only a one-way traffic of members of southern Bars to Queensland'. Munro told the Parliament that most of the major law firms in Australia were based in Melbourne and Sydney and with local access (and recognition of their rights to 
practice) these firms could begin appearing before Queensland courts thereby bypassing local barristers or relegating them to junior roles. He also added that it was important to protect the local bar because it served as a training ground for future members of the judiciary. Munro expounded the view that it was 'in the public interest, to have a strong, independent and capable Bar in Queensland', but that subsequent to Labor's legislation there were 'indications that, if the practice under the 1956 Act was continued, it would have the effect of weakening the Queensland Bar' (QPD 1960:vol. 227, p. 224).

In a long parliamentary debate, the opposition accused the government of working for the interests of the Queensland bar and displaying hypocrisy in that it preached the virtues of competition and free markets except when its own vested interests were threatened. Jack Duggan, Ted Walsh, Col Bennett and Tom Aikens each took an active part in the debate, at one stage interjecting that the Queensland bar had 'asked' for the bill to protect its monopoly and that the government had acted despite evidence that only 'about a dozen' lawyers from interstate had in fact appeared before the bar in the four years since the act was passed. Other criticisms were that the repeal bill represented a regressive step, that the ban was discriminatory, would lessen the pool of available talent and that it was illogical that a Queensland barrister could travel a thousand miles north to take work in the state's provincial towns yet Brisbane clients would not be able to secure the services of a barrister a few hundred miles away across the NSW border. Aikens was his usual vituperative self, accusing the government of introducing a 'monstrous measure' that struck at the heart of liberty and protected a corrupt and incompetent legal monopoly. It was clear, Aikens felt, that the repeal measure was basically designed to erect a fence around the Brisbane legal 'fraternity'. He challenged the government to put a similar fence around the lawyers operating in his area of north Queensland, but his challenge was to no avail. This demonstrated to Aikens that the Coalition believed in 'free and unrestricted enterprise for everybody except margarine manufacturers and barristers'. Then, turning the debate towards one of his favourite sportsbashing the judiciary-Aikens attacked local Queen's Counsels as intellectual snobs with 'magic letters' after their names who took fees of 1000 guineas a day. He remembered that

when the original [1956] Act was introduced, some suggestion was made that Royal Commissions had been held in Queensland and everybody who wanted to employ a QC could not do so because there were not enough QCs available. Why they should want to brief QCs, goodness only knows; it is probably a question of intellectual snobbery. Someone suggested that one QC who was rather under the weather had been briefed to appear before the commission and another QC had given an assurance that he would keep him on his feet for the term of the 
commission. These things were said in the House, and I believe there was some substance in them. [But] with the Government swinging the big stick and cracking the whip to bring members of the Government Parties into line, this Bill will become law. (QPD 1960:vol. 227, p. 230)

In the same year, the government introduced the Police Acts Amendment Act, which extended rights of appeal to serving commissioned police officers (except the most senior) against the decision of the Police Commissioner in cases of dismissal. In the debate on this bill, the Minister for Labour and Industry, Ken Morris, was forced to defend the reputation of the police after the opposition had used its time to criticise police administration. Labor's persistent complaints of police corruption (see Chapter 4) led eventually to the establishment of a royal commission (the National Hotel inquiry) in late 1963.

\section{Economic and state development}

The regulation of primary industries was a continual preoccupation of the Country Party government, as it had been of previous ALP governments. Many amending pieces of legislation were introduced to modify the terms of production, supply, marketing and forms of state levying of primary products. Acts were introduced to regulate trade, set prices and limit production quotas or areas of supply. Some acts intended to promote the consumption of farm products (such as dairy foods) and to 'fix and declare prices for milk and cream' so that the arrangements could ensure profitable returns to the farmer. Typically producer boards were maintained to fix prices and set the terms of production and trade, although these usually required the approval of the responsible minister before being published in the Government Gazette and becoming law. Farmers and stockkeepers were also given legislative protection to rid their properties of pests. The Stock Routes and Rural Lands Protection Acts Amendment Act 1961 enabled pastoralists to control noxious weeds and destroy stray dogs. Later in 1964, this act was further amended to allow for the elimination of dingoes from the sheep-rearing areas of the state.

Other legislation governing agricultural industries allowed the government to levy charges on producers (by volume, weight, herd size, crop size or sales returns) in order to fund research and disease-control programs, usually administered by the Department of Agriculture. The Swine Compensation Fund Act 1962, for instance, provided for the establishment of a special fund to compensate pig farmers should their stock be destroyed in the event of the outbreak of swine fever. The fund was financed by the imposition of levies on all pig farmers - in this case, a stamp duty imposed on the point of sale initially set at a rate of 0.5 pennies per $£ 1$ of sale price achieved. Similarly, the Tobacco Industry Stabilisation Act 1965 included Queensland in a national scheme to structure the market for locally grown tobacco. Under the scheme, three States 
(Queensland, Victoria and New South Wales) shared an agreed national quota of 26 million pounds permitted to be produced; each state quota was then subdivided across the individual growers according to a two-year 'best-crop' formula. Entry into the tobacco industry was tightly restricted and growers faced substantial fines if they attempted to sell non-quota leaves (that is, surplus produce above their quota limit). For the Country Party members in the ministry, government was about social insurance, compensation and regulatory provisions - in short, agrarian socialism.

Not all protective legislation was, however, plain sailing. In December 1959, the Minister for Agriculture and Stock, Otto Madsen, introduced an Abattoirs Acts Amendment Bill 1959 designed to prevent suppliers from outside the Brisbane area sending meat to the Brisbane market. This response followed a piece of amending legislation passed in 1958 that had allowed abattoirs to supply markets beyond their local area. The 1959 bill, therefore, was essentially a U-turn and a restriction to trade aimed at protecting local suppliers in the urban market. The second amendment was tabled before the 1960 election ostensibly with the government's full support; but then somewhat surprisingly the bill was allowed to lapse and was not brought on for debate after the election when the next Parliament returned. According to the opposition, the bill was withdrawn because the government came under pressure from powerful vested interests outside the metropolitan area anxious to preserve their access to the lucrative Brisbane markets (Courier-Mail, 5 May 1960). Such incidents indicated the inherent complexities of politically regulating markets.

Queensland joined the national scheme for uniform business regulation in 1962 through the passing of the Companies Act 1961. This act originated from a series of intergovernmental agreements that required the various state parliaments to pass identical legislation bringing their codes of company law (and associated regulation of corporate affairs) into harmony. Drafting the new bill was problematic and very complex, as the minister, Alan Munro, admitted in a ministerial statement to the Parliament in 1961 (QPD 1961:vol. 229, p. 2256). The eventual act represented a massive legislative rewrite incorporating 361 sections and running to 420 pages. When debated in the House, the Companies Act received opposition support as a reformist measure. This episode indicated that on occasions the Queensland government was able to put aside parochial interests and cooperate with other governments in joining the national scheme. That said, however, once this act was passed many states, including Queensland, began passing their own amendments, which began to undermine the uniformity of the common code.

In response to the recessionary downturn of the early 1960s, the government in 1963 declared industrial development as the state's top priority (while assuring its own clientele that it would not neglect primary industries). State 
development generally became the responsibility of the Premier while a separate portfolio for industrial development was created under a high-ranking minister: the Deputy Premier, Alan Munro. Because of a perceived need to promote secondary industry more specifically, the government introduced the Industrial Development Act 1963, which encapsulated the government's philosophy about securing industrial investment in Queensland. The new Minister for Industrial Development introduced the act with much fanfare, naming the key personnel he had recruited and outlining that the intent of the legislation was to provide financial assistance to any new industries prepared to establish in the state (QPD 1963:vol. 236, pp. 1502-8). According to the Premier, the special legislation was an 'outstanding act' that showed the government's foresight. A new Department of Industrial Development was established (from the old Electricity Supply Department, the Companies and Commercial Acts Office and the secondary industries section from the Department of Labour and Industry) with a mission 'to get new industries on their feet' (Courier-Mail, 25 January 1965). Munro was particularly interested in attracting overseas investors to Queensland (an issue that was becoming increasingly controversial) and undertook an overseas tour in 1964 to promote the state.

The government's plans were, however, soon frustrated. Within one year, the government had cause to amend the 'outstanding act' due to problems of administration. One particular reason behind this amendment was staff problems at senior levels in the department. The government had lured, at considerable expense, a highly regarded public servant (Sir David Muir, then Queensland's Agent-General in London) to head the department as DirectorGeneral of Industry. Muir initially accepted the appointment but resigned within a few months ostensibly because of ill health (although allegations were made in the Parliament about his relations with the government). In response, the government then downgraded the position of the department head (to Director of Industrial Development) and split the roles across the minister and two other senior officers (under a new head, Colin Curtis). Opposition Leader Duggan claimed there was more to the resignation of Muir than had been publicly acknowledged and that the new department was still 'overloaded with highly paid officers' (Courier-Mail, 23 October 1964). In the Parliament, Jack Melloy (ALP, Nudgee) claimed that

when the government appointed Sir David Muir in July, 1963 it described the work that he was to do as a priority job. It was given top priority because it was considered to be one of the most important appointments yet made for the industrial development of the State. Now that Sir David Muir is not able to take up the appointment, apparently the job is not as important as it was; it has been down-graded. What are we to think 
of a Government that takes action such as that? Is it concerned with the development of Queensland, or is it just trying to pull the wool over the eyes of the people? (QPD 1964:vol. 237, p. 2351)

Labor's deputy leader, Eric Lloyd, ventured that the government was curtailing the discretionary power of the department head because Muir was not prepared to accept the job. In responding to Munro, Lloyd told the Parliament:

I am sorry that the Minister has not retained the title of Director-General of Industrial Development [sic] and has not transferred that title from Sir David Muir to Mr Colin Curtis. It sounds like an act of snobbery on the part of the Government that because a man is a 'Mister' he is not regarded as entitled to the title of Director-General. Why the difference? Why take away the discretionary power? (QPD 1964:vol. 237, p. 2340)

The minister did not accept the opposition's claims and in concluding the debate reiterated that the amendment was but a solution to a 'minor administrative problem' (QPD 1964:vol. 237, p. 2355). He criticised the opposition for introducing much irrelevant material and for diverting the debate away from the legislation at hand.

Many state development bills tailored to particular projects were introduced in each parliament. Occasionally these acts provided for state activity in opening up areas of Queensland. If necessary, the acts could authorise the terms and conditions of specific borrowing for development purposes. Land development acts such as the Brigalow and Other Lands Development Act 1962 enabled the state to borrow money from the Commonwealth for the specific purpose of land improvement in the Fitzroy River 'brigalow lands'. Lands acts and various amendments increasingly extended private ownership of land by transferring leasehold crown lands to freehold. Legislation provided for state-subsidised loans (20-years interest free) or credit for leaseholders interested in private ownership. Successive acts liberalised the terms and conditions under which graziers could apply for freehold ownership (for example, lifting acreage limits and extending the types of land available for freeholding). The 1964 Lands Act Amendment Act, however, also addressed the emerging problem of freeholders becoming large landowners as a result of purchasing additional properties. While broadening the scope of freehold, the act nevertheless introduced measures to control the aggregation of such lands once they had been converted to freehold.

Other development legislation authorised state support for individual firms engaged in major developmental projects and tended to include some degree of state protection or guarantees for the private interests involved. For instance, some development acts authorised terms and conditions for private development ventures with state subsidies or other outlay commitments to assist in major 
investment projects (railways, pipelines, loading jetties, and so on). Such development legislation also generally contained some means of recouping state outlays or imposing royalties or rentals. In general, the acts gave the force of law to what were essentially private agreements between government and private interests and authorised the Premier (or other state officials) to enter into agreements on behalf of the state.

One celebrated case involved the foreign-owned oil company Amoco (Standard Oil of the United States). The Queensland government through the Labour and Industry Minister, Ken Morris, gave statutory ratification to an agreement with the company to establish an oil refinery at the mouth of the Brisbane River. Amoco was the first company to have a special act of parliament that set out the terms of agreement and guaranteed state commitments (the Amoco Australia Pty Ltd Agreement Act 1961). The agreement, which lasted for 30 years with a further 20-year optional renewal, gave Amoco a monopoly to supply oil and petrol to the government. Morris informed the Parliament that the government's main objective had been to secure an oil refinery for the state. Expressions of interest were called for, preliminary negotiations held and some exploratory investigation of possible port sites undertaken (Brisbane, Gladstone, Port Alma and Mackay). Morris undertook most of the negotiations himself and later argued that he had received only one detailed offer-that from the US firm Amoco. In the Parliament, the minister was questioned about why the government had favoured an American company over the Australian company Ampol-a decision both Morris and Nicklin defended strenuously.

Hence, not all of Morris's efforts were well received. The Amoco act was criticised because it consolidated development in the south-east rather than the north and because it gave a privileged position to a foreign company instead of an Australian one. Some writers have claimed subsequently that 'Nicklin had been forced to defend his deputy against charges of rushing a deal with Amoco to the exclusion' of the other (Fitzgerald 1984:224). The record of the debate in Hansard, however, merely has Nicklin concluding the debate (as was his custom) with a supportive statement. The opposition's attempt to defer the legislation for six months - on the grounds that this period would allow Ampol to match the proposals offered by Amoco - met with little joy. Indeed, Nicklin told the Parliament that he had 'heard not one single argument that would justify the deferring of the passage of this Bill...if we deferred the second reading of this Bill for six months, we should not be worthy to remain the Government of the State' (QPD 1961:vol. 229, p. 2543). When asked why, as head of the government, Nicklin had not signed the agreement personally, the Premier replied: 'the Minister for Labour and Industry did the major portion of the 
negotiating regarding this agreement and I thought he should have the honour of signing it. I was very pleased to witness the signature on the agreement' (QPD 1961:vol. 229, p. 2545).

Also of note in the same period was a series of legislative measures passed to assist the Thiess Peabody Mitsui company, a multinational coalmining consortium operating in the mid-north of the state (Thiess Bros was Queensland based, the Peabody Coal Company was based in the United States and the Japanese Mitsui Company was the major end user of the coal). In 1962, the government introduced special legislation for this company designed, in the Premier's words, to facilitate the 'development of Queensland's almost illimitable coal and mineral resources' (Record of Legislative Acts 1962:iii). The act provided that the state would tax the company on a reducing rate for royalties on coal produced and (initially) that the company would build and operate a railway to link the company's inland coalmines with the coast (with buy-back provisions for the state). The government changed its mind, however, on the issue of a companybuilt railway (largely due to Chalk, Hiley and Treasury's insistence) and instead agreed to build the railway itself and charge freight rates, as well as higher lease rentals and royalties. This modification became a standard policy response used by the Coalition government to obtain revenue from the development of mines.

In 1965, the government introduced a further Thiess Peabody Mitsui Coal Pty Ltd Agreements Act, which presented a new agreement for the state to build and operate a railway from the company's mines at Moura to Barney's Point, Gladstone. The bill was rushed into the Parliament and at its first reading stage was not even printed, let alone circulated to members for consideration. The act 'authorised' two agreements already between the state and the company and provided that 'freight rates can be escalated by agreement between the parties' (QPD 1965:vol. 240, p. 3015). The Transport Minister, Gordon Chalk, described the bill as a 'tangible example of the unprecedented development program and prosperity which the present State government has brought to the State'. He acknowledged the role of the Treasurer, Tom Hiley, in negotiating the financial details of the agreement, commenting: 'I am prepared to say without fear of contradiction that this is the biggest single financial venture negotiated at ministerial level in the history of this State' (QPD 1965:vol. 240, pp. 3012-16). The bill was passed by the Assembly through both second and third readings on 8 April 1965 without amendment and with broad opposition support.

\section{Industrial relations and work-related matters}

Industrial relations was an issue of great significance to the government in its early years, with the Coalition anxious to correct what it perceived to be years of accommodation of the trade union movement by Labor governments. In the second session of its first term, the Nicklin government introduced 
the Industrial Conciliation and Arbitration Acts Amendment Bill of 1958 in September 1958 (receiving Royal Assent on 24 February 1959). The debate took place throughout November 1958 and the contentious clauses were voted on separately. The proposals laid out in the bill included allowing the Industrial Court to refuse to proceed with a hearing if unions were engaged in industrial action; the enforcement of secret ballots for official positions in industrial unions (and employer associations); provision to allow individual members to declare any 'irregularities' in union elections and have the Industrial court investigate; and provision for unions or branches to request court-run ballots to prevent 'irregularities' occurring (Industrial Conciliation and Arbitration Acts Amendment Act 1958; Votes and Proceedings 1958). The decision to provide for secret ballots had been promised by the Coalition in the election campaign of 1957 (extending an existing clause of the act inserted by the Hanlon Labor government requiring a secret ballot for industrial action). The act specified that the Industrial Registrar 'shall not register' a union unless the registrar is 'satisfied that the rules of the union or association relating to an election for an office...provide that the election shall be by secret ballot' (Clause 4). Moreover, either the management committee of a union or 10 per cent of the membership could request a court-administered ballot - and the costs would be met by the state. Predictably, the four contentious clauses (4, 8, 9 and 14) met with fierce opposition from Labor Party members - principally because they were ideologically opposed to the bill's provisions, because it challenged previous industrial laws passed by Labor governments and because the legislation targeted the ALP's main clientele interests: the unions. Many of the new amendments were to be enforced by the insertion of tough penalties (£100 fines or 12 months' imprisonment) and such penal clauses met with stiff opposition in the Parliament and outside.

Subsequent administrative tidying up to this act occurred in October 1959 when Ken Morris, the Minister for Labour and Industry, introduced amendments to clarify the validity of awards after their stipulated time had expired. In September, the Supreme Court ruled that the Industrial Court could not vary industrial awards once they were more than one year old. Morris told the Parliament that 'we regard our responsibilities so highly that we are not going to permit any incorrectness to remain for even one hour longer than is unavoidable' (QPD 1959:vol. 224, p. 544). The minister then tabled provisions clarifying that the Industrial Court 'has and always did have the power to vary, alter, amend or modify any award whether made after the expiration of the period specified or not' $^{\prime}(Q P D$ 1959:vol. 224, p. 545). It is noted that the state government did not introduce a more extensive redraft of industrial relations legislation in its first term and took more than four years to bring state legislation into line with the decision of the High Court in the Boilermakers Case 1956. This could indicate that the government was unsure of its political survival and was not prepared to 
risk a major controversy with the unions. It could also indicate at the same time that the Queensland government was reluctant to feel compelled to legislate by Commonwealth decisions (a philosophy shared by the Labor opposition, who questioned in the Parliament whether Queensland had to follow the federal example).

The government waited until after the May 1960 election to introduce a far more extensive re-enactment of the Industrial Conciliation and Arbitration Act 1961. Ken Morris initiated the first reading of the bill on 2 March 1961, explaining that the re-enactment repealed a series of obsolete acts (trade union and wages acts), streamlined union registration, tightened union regulation and separated the arbitral functions of an Industrial Commission from the judicial functions of an Industrial Court. Responding to the Boilermakers Case 1956, the new law established a dual structure of the court and commission (and industrial magistrates) in order that appellate jurisdiction be kept institutionally separate from the original decisions of the commission. Morris described the bill as a 'very big Bill' of 'absolute and outstanding importance'. Other senior Liberal members of the Coalition such as Doug Tooth (Ashgrove) also argued in supporting speeches that the bill is probably the most important legislation that this Parliament has enacted [sic], and probably the most important legislation during the life of this Parliament, because it touches on the welfare, happiness and well-being of all sections of the community' (QPD 1961:vol. 229, p. 2950). Labor's Doug Sherrington (Salisbury) declared at the time of the bill's introduction that it seemed to enjoy the enthusiastic support of all government members. Sherrington personally recorded that he had 'never seen as many Government members rise to support a Minister introducing a Bill into this House as have risen on the second reading of this Bill' (QPD 1961:vol. 229, p. 2953). He was implying that the minister needed this expression of political support.

The government's principal reasons for undertaking the major rewrite of the act were to: 1) modernise and consolidate previous acts; 2) enhance state development by 'improving the processes of determining differences arising between employers and employees'; 3) 'reduce lost time as a result of industrial disputes'; and 4) 'strengthen the authority of the rank and file unionists by giving them-(a) greater control of their own union machinery [and the] opportunity of...rectifying injustices and abuses within their union'. Morris believed that the underlying rationale for the act was to 'reduce the power of extremist union leaders over, and against the will of, rank and file members of their unions [and] to reduce and ultimately abolish the encroachment of Communists and their ideology into our industrial life' (QPD 1961:vol. 229, p. 2893). The bill restated the 1958 amendments requiring unions to conduct elections via secret ballots, but also gave statutory protection for individual members of unions 
who wished to resign their membership (by providing three months' notice of resignation, in s. 48-a clause that in essence attacked union or closed shops). The act directed that the commission would set the same wage to persons of either sex performing the same work or producing the same return of profit to their employer' (s. 12). Such wages were to be set in accordance with 'conditions of living prevailing among employees' so that they were 'sufficient to maintain a well-conducted employee of average health, strength, and competence and his wife and a family of three children in a fair and average standard of comfort' (s. 13). Over-award bonuses (defined as 'payments in excess of a just wage') were, however, no longer to be determined by the commission but subject to 'negotiation between employee and employer' or unions on their behalf. A commissioner may be provided to help mediate over bonuses if requested by the parties but that person may not actually determine them (s. 12). The minister defended this provision by stating: 'let it be remembered that bonus payments superimpose an additional payment on what has been regarded as the correct wage for the employee' (QPD 1961:vol. 229, p. 3013).

Opposition to the Industrial Conciliation and Arbitration Bill at both the first and second reading stages was intense and, according to the QLP leader, Paul Hilton, generated 'a great deal of heat' (QPD 1961:vol. 229, p. 2419). According to the historian Margaret Cribb (1983), however, Hilton's contribution in the Parliament did not indicate he knew what was happening. Although the debate at the end of the first session of the thirty-sixth Parliament was restricted to only four days (2 March and then 21, 22 and 23 March), the debate consumed virtually the entire proceedings on those days - covering 286 pages of Hansard or about 44 hours, with the final day's proceedings lasting until 4.40 am on the Friday. Yet the length of the debate did not necessarily indicate quality of legislative scrutiny. On the government's side, the Minister for Labour and Industry, Ken Morris, noted part-way through the debate that

more than 50 percent of the time taken up by Opposition speakers has been used to attack me, my capacity and my ability, not only in the field of this Bill, but also in general departmental administration...If ever there has been a complete example of woolly thinking in this House, I think we have it in this debate. I must confess I am amazed at some of the speeches that were made. (QPD 1961:vol. 229, pp. 3004-5)

From the opposition, Alex Inch (ALP, Burke) told the House:

This debate has been impaired to some extent by the asinine remarks of several members on the Government side. They leave no doubt in my mind that they are endeavouring to ape that well known character in a Shakespearian play, called Bottom. As hon. members will remember 
he always adopted the part of placing the head of an ass upon himself, acting as an ass and passing asinine remarks. (QPD 1961:vol. 229, p. 2962)

Much of the detailed content of the debate was about the ALP's alleged links with communists and communist infiltration of the union movement. The opposition charged that the government had rushed this important bill to the House without due consultation (mentioning that the Trades and Labour Council had not been consulted in marked contrast with the 'model' processes followed in the Companies Bill). This was a suggestion rejected by the minister, who listed the various stages of community input into the redrafting process and cited the many delegations he had received. Jack Duggan stated that the bill attacked unions and workers and showed that the government did not appreciate that unions were 'vital for workers' to give them some semblance of bargaining strength against employers. Paul Hilton argued that although the bill was 'deemed' to be concerned with reform to the arbitration system, it was principally directed against the trade union movement. Yet many of the sections of the act entrenched the role of unions provided they operated in a 'responsible' manner - provisions that both the ALP and QLP regarded as 'undue encroachments' on trade union activities. In particular, both Labor Parties in the Parliament were critical of the section prohibiting the Industrial Commission deciding bonus payments in industry. Although bonus payments could still be negotiated by collective agreement (with existing ones remaining in force until varied or absorbed in base rates), the commission could not award further bonuses. According to the ALP's deputy leader, Eric Lloyd, the government had introduced this clause to keep Queensland the low-wage state and make bonus payments difficult to obtain. The definition of 'bonus payments' in the act, he felt, was too broad and was likely to lead to unnecessary industrial conflict. This assessment proved somewhat prescient because the issue of bonus payments subsequently became of considerable importance in the protracted Mount Isa dispute of 1964-65 (see Chapter 4). Indeed, Lloyd warned of such consequences in the supply debates of 1961, threatening to call a vote of no confidence in the government over the 'precipitate hostile action taken by the Minister for Labour and Industry' (QPD 1961:vol. 230, p. 745).

The government's industrial relations legislative agenda did not wane once the 1961 re-enactment was through. As industrial disputation increased (and particularly the notorious strike at Mount Isa), so the government's legislative activity rose in the mid-1960s. Industrial action was met with statutory responses. In 1965, the government introduced the Industrial Law Amendment Bill designed to prevent industrial picketing. The catalyst for this amendment was the Mount Isa dispute where industrial pickets were active at the mine site. The cabinet decided to send the Police Commissioner along with a 'plane-load 
of police' to put down the disturbance and then extend police powers under industrial law. Premier Nicklin defended the aims of the bill, which gave police the powers to remove picketers, made it an offence to induce, compel or counsel workers from working and prohibited banners and posters. The police were also given additional powers to enter and search and to require industrial 'offenders' to provide and verify their true names. For offences under the act, a fine of up to $£ 100$ or six months in prison was provided. Naturally the opposition was again critical of this legislation, but its attack was blunted because previous Labor governments had passed identical restrictions on workers (for example, the Hanlon government during the railways strike of 1948). And Nicklin told them so in the debates. Jack Duggan nevertheless criticised the government for its negativism and for its unwillingness to convene conferences or discussions with the relevant parties. Doug Sherrington castigated the government for its entire track record on industrial legislation. He claimed that industrial unrest would occur while the 1961 act was in place. Taking the fight to the government, he asked:

Forgetting all the other issues involved in the 1961 Act and getting down to the basic cause for the removal from the Industrial Court of the power to increase the bonus, what in the name of tarnation ever induced the government to do such a foolish thing? There is no evidence that prior to 1961 a bonus determination of the Industrial Court had had an adverse effect on the economy of the State; certainly it had no adverse effect on the powerful Mount Isa mine company's profits. Why did the Government sow the seeds of discontent in our industrial laws by introducing such a stupid and arrogant piece of legislation? (QPD 1965:vol. 240, pp. 2656-7)

In other work-related areas, however, the government displayed a benign paternalism and protectionist stance. The Factories and Shops Act 1960 extended legislative protection to employees in relation to workplace safety issues. Building on earlier acts going back to 1896 and 1900, which regulated only occupational health and welfare, the 1960 act revised the provisions for factory or shop registration and inspection. A revised set of registration fees was enacted. The 1960 act also added provisions for 'anti-sweating' (that is, not allowing employees to work outside factory hours) and for occupational safety, which thenceforth became a matter of legislative regulation rather than simply a feature of certain industrial awards. Industrial safety became an acrossthe-board concern and the act established a health, welfare and safety board consisting of employer and employee representatives. Shop trading hours were maintained at 40 hours a week as a base state level, but such hours could be varied by the Industrial Commission. 
The Workers' Compensation Acts Amendment Act 1962 was described as the most important and far-reaching revision of the legislation since the original act was passed in 1916. Treasurer Hiley told the Parliament that the government had agreed effectively to index worker compensation payments (increasing injury and disability benefits by 10 per cent). Other payments were reviewed and liberalised with some payments increasing up to 120 per cent.

\section{Transport and infrastructure}

The Country Party announced a new transport policy at its 1958 party conference in Toowoomba. From this policy a new State Transport Bill was presented to the Parliament and passed in November 1960. This act was a most contentious piece of legislation, which directly hit sections of the support base of the Coalition (exciting some industry figures to stand against Coalition politicians at election times). The act overturned the provisions of the 1946 act, which established a regulatory system of licensed services for the road haulage industry. The new legislation introduced greater opportunities for competition between road hauliers in gaining business and providing competitively priced services. Speaking to the bill, the Transport Minister, Gordon Chalk, was critical of the monopolistic tendencies inherent in the previously highly regulated system. Unpopular with sectional interests over this reform bill, Chalk spoke of the need to revise the licensing system, to introduce licences for goods transportation that extended throughout the state and to introduce more competition into the road haulage industry. Chalk was particularly critical of drivers who sought protection from the government that allowed them to work the profitable routes while leaving the other areas of the state un-serviced. The 1960 act replaced the old licence-franchise system that led to local monopolies with a permit system to carry goods provided hauliers did not exceed a statutory-imposed fee for their services ( $3 \mathrm{~d}$. per tonne per road mile). The act increased the penalties for carrying goods without a permit or in contravention of the act. In an attempt to prevent 'border-hoppers' evading the law (drivers from New South Wales mainly, who left the state once stopped for an offence), the act allowed the transport authorities to seize the vehicle if necessary to pay for any fines imposed on the driver, irrespective of ownership of the vehicle (that is, even if the driver was not the owner, the vehicle could still be seized to pay the fines). Offences relating to false papers or counterfeit documents were also increased as a means to curtail border-hoppers.

The opposition to the StateTransport Act was intense. In the Parliament, Jack Duggan referred to the day the bill was introduced as 'black Thursday' for the industry, claiming that the freeing up of road haulage would impact severely on the rail system. Duggan then called for a royal commission into transport matters. The QLP's Paul Hilton endorsed the call for a royal commission largely 
because he considered corruption was prevalent in the industry. Hilton subsequently tabled documents ostensibly implying collusion and inside deals. The documents came from a William Bolton of Cobb and Co. who was later discredited by Chalk as a 'profiteering self-interested person' who was out to remove his competitors from the industry ( $Q P D$ 1959:vol. 228, p. 1537, passim; AJPH 1960:vol. 6, no. 2, p. 244). Chalk regarded the allegations of corruption as nothing more than an attempt to blackmail the government to back down on the transport legislation. Nonetheless, many operators in the industry remained resentful of these changes and some considered challenging the legal validity of the legislation. Subsequently, a challenge to the State Transport Act in the High Court found the state act valid, but such a finding did not prevent a firm in Toowoomba suing the government for compensation of $£ 250000$ ( $A J P H$ 1963:vol. 9, no. 2 [November]).

Country Party members believed passionately in constructing rural infrastructure. The scale of road planning and building became the source of much pride among the Coalition government. In 1961, before becoming Minister for Works and Housing, Bjelke-Petersen praised the government's record of expenditure on roads, telling the House that 'my wife often says to me, "Our roads are getting so good that you hardly need your aeroplane any longer. You can use the car because the bitumen roads to Kingaroy and elsewhere are excellent"' (QPD 1961:vol. 230, p. 683). (Good roads and faster transport did not, however, prevent the Country Party from using arguments of distance and isolation in support of its electoral zone malapportionment.)

Traffic congestion in Brisbane was a major topic in the Parliament attracting many questions from members in question time. The government responded to criticism with the Traffic Acts and Other Acts Amendment Act 1965, which was designed to transfer authority for traffic engineering to the relevant local authority. Up to that time a state body, the Traffic Commission (consisting of the Coordinator-General, the Commissioners of Police and Main Roads and the Town Clerk of Brisbane), had exercised responsibility for traffic planning and congestion management in Brisbane. The amending legislation of 1965 intended to delegate this responsibility because, as the Minister for Mines and Main Roads argued in introducing the bill, 'traffic engineering is a local problem' so 'powers to deal with local traffic matters, in accordance with the policy laid down in the Acts, will be handed over to the local authorities, except in respect of gazetted roads. The Traffic Commission, as such, will cease to exist' (QPD 1965:vol. 240, pp. 2929-31). The minister also told the Parliament that because the Traffic Commission had accepted responsibility for Brisbane traffic, the 'Brisbane City Council enjoys considerable relief from the responsibilities of what is a local problem' (QPD 1965:vol. 240, p. 2930). The minister informed the Parliament that accompanying this legislative amendment, a major study 
of Brisbane road needs was being undertaken by an American firm, Wilbur Smith and Associates, which would eventually bequeath the Southeast Freeway to Brisbane. Debating the bill, the opposition did not propose any alternative measures, but claimed the government was again handing over issues that were 'too hard' for others to fix. Duggan became agitated during the debate partly because he was an ex-Minister for Transport and partly because the bill would impinge on the Labor-run city council. Not one to shy from hyperbole, Duggan called the measure 'one of the most revealing political reverses in the history of responsible Government in this State' (QPD 1965:vol. 240, p. 2935).

\section{Educational, social and recreational policies}

The educational area was relatively devoid of statutory interest during the Nicklin years, with the government introducing only 20 bills in 10 years. Even with a strong and dedicated minister such as Jack Pizzey, the government did not actively attempt to drive policy by statutory provisions, although out in the community it was keen to establish new schools to keep pace with the growing postwar population. Of the acts passed many were tangential to education given that the classification of legislation under this heading adopted a fairly liberal interpretation of education (Record of Legislative Acts 1957-58 to 196768). Hence, even such low numbers of legislative measures are misleading. For instance, occasional legislation governing Indigenous peoples was included in this category (as with the Aborigines and Torres Strait Islanders Affairs Act 1965 and the Aboriginal Relics Preservation Act 1967). Also listed under 'education' were some recreational or cultural activities, as in the Queensland Art Gallery Act 1959; but other measures were even more tangential to education such as the Vagrants, Gaming and Other Offences Amendment Act 1967, the Firearms Acts Amendment Act 1967 and the Electrical Workers and Contractors Act 1962. Only eight acts during the decade were closely related to educational mattersthe Education Act 1964 being the main legislative framework-with most of the others providing statutory provision for nominated educational institutions (tertiary institutions and some school bodies).

The Education Act 1964 was the government's main reform measure for public education covering children between the ages of six and fifteen years. It maintained a free public and compulsory system of state education while allowing withdrawal provisions from the public system (provided approved private or non-government education institutions were available). The act established the formation of advisory committees called Parents and Citizens' Associations to forge closer links with the general community while representing parents on school committees. The act included provision for post-school technical and 
agricultural instruction and adult education. Scholarships were provided for 'children of talent' along with other special allowances to secondary school students.

The Education Act also recognised that the emphasis of public education was gradually shifting to secondary-level education. While total state school enrolments increased from 214000 in 1957 to 287000 in 1968, a big explosion in numbers occurred in secondary education. In 1957, only 14000 students were enrolled in state secondary schools; by 1968, the figure had increased almost sixfold, to 80300 . Although the total number of state schools across Queensland had in fact decreased (from 1560 in 1957 to 1260 in 1968), the numbers of state teachers had risen from 7600 to 11400 .

Social legislation was equally eschewed, but a few legislative measures were important statutes. The government introduced the Aliens Act 1965 to remove discriminatory legislation preventing aliens (especially of Chinese descent) from acquiring property. The Aborigines' and Torres Strait Islanders' Affairs Act 1965 combined all previous legislation concerning Indigenous peoples (other than voting rights, which were to be granted but left to the Electoral Act). The legislation introduced by Education Minister Pizzey was designed to assimilate Indigenous peoples while, in the minister's words, attempting to overcome paternalism. The act gave Aborigines and Islanders the rights to drink alcohol in hotels (but not on settlements), to marry European ('white') Australians without permission and to enter pleas in courts of law.

The Liquor Acts Amendment Act 1961, introduced by the then Attorney-General and later Deputy Premier, Alan Munro, made provision for licensing a limited number of restaurants to supply alcohol with food and for the limited opening of pubs and hotels on Sundays (for bone fide travellers who had travelled 40 miles, but this did not apply to Brisbane hotels). Initially seen as controversial and a threat to family values, the Liquor Act forced the government to make hard political and social choices. Some senior Coalition members (such as BjelkePetersen) spoke out against the bill, maintaining that Sundays should remain sacrosanct. Despite attracting frequent amendments in the second reading stage of the bill, this legislation was later regarded as a successful innovation. Similarly, the Racing and Betting Acts Amendment Act 1961 allowed off-course betting on horseraces with the state-owned totalisator facilities (TAB) in metropolitan and provincial areas and licensed bookmakers in country areas. This act attempted, as one government member, Sam Ramsden (Lib., Merthyr), said, to outlaw the 'graft and corruption which is attendant upon any system of illegal SP [starting price] betting which has now been almost completely eliminated'. Ramsden also maintained that under the Coalition government, 'overnight, Brisbane found that the brothels which had been tolerated houses under the previous Labor government had been obliterated by this government's action' (Courier-Mail, 
3 March 1965). The government had closed down three particular brothels that had formerly been tolerated (one in Brisbane's Albert Street, another in Margaret Street and one in South Brisbane). Although the government took this tough action at the time, subsequent history would show it would also come to tolerate the underworld.

One contentious item of legislation occurred over the introduction of the Chiropractors' Bill (introduced in March 1967) after a reputedly heated cabinet exchange. The bill was introduced by the Premier and debated on two occasions in March. The Health Minister, Doug Tooth, apparently opposed the bill and did not wish to introduce it. In making his introductory remarks, Frank Nicklin said 'public interest in unorthodox medicine [is] increasing' and chiropractic was 'the science of treating human ailments by adjustments of the spine and leaving the rest to nature'. He went on: 'healing by the laying on of hands dates back more than 3,000 years, when the replacing of displaced vertebrae for the relief of human ills was practiced by the ancient Egyptians' (QPD 1967:vol. 245, p. 2640). Nicklin denied any 'discord' with the Health Minister and claimed that Tooth did not 'refuse to introduce the Bill' despite the measure facing strong opposition and gaining only a slim majority vote in the joint-party room. After the opposition announced it would support the introduction of the bill (but not necessarily support all measures at the second reading stage), Tooth admitted the proposal was not 'a matter of Government policy', that he had asked to be relieved of the responsibility to introduce the bill and would personally oppose the bill (QPD 1967:vol. 245, p. 2651). The government allowed a conscience vote on the bill and, after a spirited six-hour debate, lost the motion by 32 'ayes' to 38 'noes'. Three ministers (Doug Tooth, Gordon Chalk and John Herbert) voted against the government along with seven other Liberals (John Murray, Bill Lickiss, Geoff Chinchen, Bill Hewitt, Charles Porter, Bill Kaus and Col Miller) and one Country Party member (Russ Hinze). Part of the reason for the bill's introduction was that the Country Party's annual conference in 1967 had voted to recognise chiropractors and had directed the government to push for their registration. There was press speculation that 'Mr Nicklin has had the courage to "bell the cat"3 rather than leave it as a "festering sore" for his successor as premier later this year' (Courier-Mail, 14 March 1967).

\section{Conclusion}

The government came to office in 1957 with a great deal of inexperience and naivety - and even Gordon Chalk admitted that 'when we came in we knew bugger all about administration' (Stevenson 1985). They had idealistically

3 'Bell the cat' was a colloquial phrase used to imply doing something risky or performing a daring act. 
spoken of bills of rights for citizens, new states for northern regions of the state and efficient and just government. Within a few years of incumbency, however, they had become preoccupied with developmentalism and industry assistance. They departed from this early constitutional idealism as the burdens of office weighed on them. The government also indicated that it was not averse to opportunism and legislating to enhance or defend its political interests.

Government business invariably dominated the Queensland Parliaments in the late 1950s and throughout the 1960s. During the period from 1957 to 1968, no private members' bills or opposition-sponsored bills were ever introduced to the Parliament let alone debated or passed! Legislation reflected precisely what the government intended, was introduced when and if the government chose and proceeded largely in the manner decided by the government. The only occasions when this pattern faltered was when the government lost its nerve for some reason or was forced to take account of extra-parliamentary pressure or vested interests. Insofar as the Coalition itself could agree on a proposed policy approach, the government's legislative will invariably prevailed in the House. In short, the legislative program was set entirely by the cabinet, with almost no input from the Parliament. At this stage, of course, parliamentary committees did not exist.

Only rarely did the government accept amendments to proposed legislation from the opposition, and these often involved minor technical issues that were accepted as beneficial by the minister concerned. Thus, in 1965, Treasurer Hiley accepted minor amendments from Pat Hanlon (ALP, Baroona) to the Decimal Currency Bill involving the timing and scheduling of the intended act. These occasions were, however, rare.

Generally the government could always brush off opposition or criticisms and use its numbers to defeat any attempts to modify or compromise important aspects of bills. On countless occasions when the opposition tried to defeat or amend clauses, the government would simply debate the issue out and then defeat the motion on the floor. Rarely were closure motions or other guillotine tactics used to silence the opposition; the numbers at the end of the debate were sufficient. After 25 years in opposition, Nicklin's government was characterised by a political style of patience and stoic resolve.

In a unicameral legislature, the executive was also well placed to contain other parliamentary procedures or processes designed to scrutinise government behaviour. Only questions with notice were allowed, subject to the Speaker agreeing to allow members to ask them. Questions from the opposition were often not well informed but usually answered in some form, while those from the government's own backbench tended to be less than probing. Ministerial statements were laboriously read out in the Chamber, ostensibly to inform 
members but simultaneously consuming much valuable sitting time. Members also complained that they were not always fully conversant with the legislative measures brought before the Chamber by the government. Some legislation was introduced simply by the minister tabling a copy of the bill before it had been printed and before other members (and the opposition) had been given the chance to see it. Jack Houston, the Opposition Leader at the conclusion of the Nicklin years, 'quite forcibly' criticised the government's habit of rushing its legislative program into the House. He told the Parliament:

[W] e want ample notice of impending legislation, we want ample time to study the legislation after its introduction, and, on any matters of a controversial nature, we want sufficient time between the introductory stage and the second reading to allow the public to consider the purpose and operation of the legislation. (QPD 1968:vol. 249, p. 54)

Within the government's evolving program, the areas of legislative interest were bounded by the current concerns of the day and the relatively narrow developmentalist attitude to governance. Specific legislation did signal a change of emphasis from that adopted by their predecessors (for instance, in land administration and freehold property rights). Much of the legislative output was, however, generally neither pathbreaking nor adventurous in nature. Other states did not regularly look to Queensland legislation as a model for other jurisdictions or for innovative statutory provisions. Many of the individual acts passed during these years were tinkering with existing statutes. The Parliament was called on to consider incremental modifications to existing provisions or formulaic acts tailored to specific development projects. Ministers came to rely on the mechanism of amending existing acts because it was a convenient and expedient way of prosecuting government business. Such patterns might be common to unicameral legislatures because there is no impediment of a second chamber to negotiate (as was also the case in New Zealand during these years). Such patterns also indicate, however, that the Parliament was used as a final body of authorisation for decisions made elsewhere; the Parliament appears subordinate to the decisions taken by the executive and the bureaucracy.

Yet, the Parliament in the 1950s and 1960s was not irrelevant. There was a basic respect for the institution, even from the most assertive members. The Parliament functioned as an important institution of record and over time issues could be shaped by deliberation and debate. And on some matters, such as allegations of police corruption and misconduct, the Parliament could be an important instrument for extracting responses from executive government. 


\section{The oppositional parties in the Parliament, 1957-1968}

Parliamentary opposition to the Nicklin government came from a host of diverse players in the decade between August 1957 and January 1968. Especially after the Labor split of 1957, opponents of the Coalition government were a dispirited and dishevelled band, most of whom appeared as individualistic dissidents. Each had their own particular fights to fight and wars to wage. Each had different enemies in sight. Labor's Jack Duggan and the QLP's Ted Walsh never spoke to each other again privately after the split, despite afterwards sitting together in the Assembly for more than a decade, and frequently interjecting against each other. Adversarialism was not only a matter of formal battlelines drawn across the Chamber. Indeed, some of the most intense acrimony was found within the oppositional groups among remaining members who survived the 1957 split.

If occasional internal conflicts simmered through the government side of politics, they at least demonstrated the capacity to remain in office while enjoying the comforts and trappings of power. The circumstance of being in government was sufficient to instil a collective solidarity between the Coalition parties, which was evident most strongly in the ministry. In contrast, the oppositional members were far more fragmented and querulous. They demonstrated little prospect of ever forming a single cohesive opposition. Indeed, after only one term in government, the Liberals were describing Labor as the weakest opposition in Queensland's political history. Only towards the mid-1960s did the Labor opposition gradually develop any coherence and commitment of purpose. By its third and fourth terms as opposition, Labor began to appear credible as an alternative government and its frontbench was gradually able to mount and sustain a concerted attack on the government. By then, however, Labor had been out of government for about 10 years and some backbench members were beginning to doubt that they would ever sit on the Treasury benches again.

After 1957, the remnants of the official ('loyalist') ALP were the largest nongovernment grouping in the House and remained so throughout the period, although their representation increased only marginally throughout the 1960s. Only 20 ALP members were returned in 1957. Of these, 18 were survivors of the split, with two new members entering the Parliament for the first time (Merv Thackeray, Keppel, and Jack Houston, Bulimba), both of whom defeated Labor defectors. These 20 ALP members represented about one-quarter of the Assembly (then consisting of 75 seats). In the next three state elections, the 
ALP's numbers increased by only six, taking them to 26 of the 78-member Assembly until the 1969 poll. In other words, for 12 years, the ALP accounted at best for only one-third of the members of the Assembly.

Because all but one member of the previous Gair ministry had defected to the Queensland Labor Party (QLP), the ALP rump possessed little ministerial or senior parliamentary experience. Its main rivals on the non-government benches, the QLP, consisted initially of 11 members with considerable parliamentary experience, but within two elections they had declined to a single member. The party's leader, Les Diplock (Aubigny), who was personally popular in the Condamine, was the sole survivor of the QLP at the 1963 elections. The QLP members were mainly Catholic, anti-communist zealots with working-class origins and sympathies. The third but more disparate grouping consisted of various independents who managed to hold on to their seats usually because of strong personal and local support. The independents as a group in the Parliament rarely acted as a block but in numerical strength were better represented in the mid-1960s than at any time since. Some of these independents had broken away from the traditional parties (often over preselection or policy disputes) and not all were ideological opponents to the conservative Nicklin government; indeed, independents frequently voted with the government and some, such as Jim Houghton (Redcliffe), had initially entered the Parliament unaligned but soon felt it necessary to join one of the Coalition parties for protection. Arthur Coburn (Burdekin) probably best typified the truly independent member, even though he had conservative leanings.

The composition of the non-government benches from 1957 to the early months of 1969 is shown in Table 6.1. The ALP constituted the official opposition in the House and provided the Leader of the Opposition.

Table 6.1 The size and composition of the non-government members in the Parliament, August 1957 - August 1969

\begin{tabular}{|l|l|l|l|l|l|}
\hline Seats held by: & 1957 & 1960 & 1963 & 1966 & 1969 \\
\hline Australian Labor Party & 20 & 25 & 26 & 26 & 31 \\
\hline Queensland Labor Party & 11 & 4 & 1 & 1 & 1 \\
\hline Independents & 2 & 3 & 5 & 4 & 1 \\
\hline Country-Liberal government & 42 & 46 & 46 & 46 & 45 \\
\hline $\begin{array}{l}\text { Total number of seats in the } \\
\text { Legislative Assembly }\end{array}$ & 75 & 78 & 78 & 78 & 78 \\
\hline
\end{tabular}




\section{Duggan's leadership of the opposition in the Parliament, 1958-66}

The ALP lost its experienced but short-term parliamentary leader, Jack Duggan, in the rout of the August 1957 state election. Duggan had been a longstanding member of the Legislative Assembly, representing the regional seat of Toowoomba since 1935, but lost it to the Liberals' J. R. Anderson in 1957. He had served as Minister for Transport from 1947 to 1957 under the Hanlon and Gair governments and as Deputy Premier from 1952 to 1957. He had led the 'loyalist' ALP into the 1957 election, serving a little more than three months as party leader. As the most senior ALP leader to remain loyal in the split, Duggan had justified his acceptance of the directions of the ALP's Queensland Central Executive (QCE) to support three weeks' annual leave through a statement that was later apocryphally reduced to: 'I am not too proud to accept direction — right or wrong, wise or unwise. ${ }^{\prime}$ This statement made Duggan seem prepared to serve as the puppet of the trade union-dominated ALP executive. The quote became infamous and in later years was frequently rehashed by political opponents to discredit Duggan personally (see the QLP's The Standard, 1 May 1963).

The surviving ALP Caucus sorely missed Duggan's absence and the party eagerly awaited his return via a by-election. In his place, Les Wood (North Toowoomba) was elected as Opposition Leader by the Labor Caucus when the Parliament returned. ${ }^{2}$ Meanwhile, shortly after the general election in October 1957, Duggan contested a by-election in the far western seat of Gregory-up to that point, a traditional Labor seat once held by a former Labor Speaker, George Pollock, who shot himself in his rooms in Parliament House in 1939. Gregory became vacant after the death of George Devries, a former Minister for Education and then Mines in the Gair Labor government and a QLP defector in the 1957 split. Devries had been a cabinet colleague of Duggan's, holding the positions of Secretary of the Department of Public Instruction-known by its staff as the 'Impartment of Public Destruction' - from 1950 to 1956 and Secretary for Mines, 1956-57. With the AWU unpopular in the region over the shearing strike of 1955-56, however, and the QLP running a candidate against him and splitting the Labor vote, Duggan lost in Gregory to the Country Party's Wallace Rae (who was later to become a Minister for Local Government and then Lands in the Bjelke-Petersen Coalition government, before being posted to London as Queensland's Agent-General). This was Duggan's second defeat in 1957 and Labor never again won Gregory.

\footnotetext{
1 Jack Duggan in fact said: 'whether you like it or not, whether it is wise or unwise, the course to take is to endorse the official Labor decision' (see Courier-Mail, 29 April 1957).

2 Les Wood announced his nine-man frontbench on 27 August 1957. It included: Deputy Leader, Eric Lloyd; Secretary, Jim Donald; Whip, Cecil Jesson; as well as Jim Clark, John Dufficy, Fred Graham, Pat Hanlon and John Mann, all without portfolios.
} 
In the Parliament, the Labor Opposition suffered a further blow when its new leader, Les Wood, died suddenly on 29 March 1958. He had been in the Assembly since 1946 but served only six months as parliamentary leader. Wood was not known to have been suffering ill health. As an interim measure, the parliamentary party elected its party secretary, Jim Donald (Bremer), as leader, knowing that Wood's death would mean another by-election was now required (leaving Wood's deputy, Eric Lloyd [Kedron] as the deputy leader). Donald served as Opposition Leader for only four months, from 14 April to 17 August 1958, but led the opposition in the House for only three days, as the Assembly did not sit after 17 April. Donald informed the House on 15 April of his own elevation, along with Horace Davies (Maryborough) as secretary, while Cecil 'Nugget' Jesson (Hinchinbrook) remained party whip. At the same time, Wood's seat was declared vacant (QPD 1958:vol. 220, p. 2140). Although there had been some speculation that Duggan might quit politics after his second straight defeat, he contested the North Toowoomba by-election (his home town) in May 1958; it is somewhat paradoxical that Duggan returned to the Assembly through a by-election caused by the unexpected death of his successor. On this occasion, however, the former Labor Deputy Premier won comfortably with 63 per cent of the primary vote, well ahead of his Liberal and QLP challengers.

On resuming his parliamentary career, Duggan regained the party leadership and was acknowledged as the Opposition Leader when the next session of the Parliament began on 19 August 1958. In Duggan's maiden speech as Opposition Leader, Jim Donald received fulsome praise because he had made a 'very great sacrifice' and 'voluntarily relinquished the office' of party leader to return to the position of party secretary (QPD 1958:vol. 221, p. 19). The fact that the Labor Party stood by Duggan, kept preselecting him for seats and held the position of leader open for him indicates the respect and high standing he enjoyed in the parliamentary party and the wider ALP machine. It also indicates that there was no other obvious contender in the Parliament at the time. Duggan had the opposition leadership to himself and remained in the position without challenge until he personally felt obliged to resign the leadership in October 1966 over serious tax irregularities (see below). He retired from the Legislative Assembly in May 1969 after serving 33 years in the Parliament (interrupted only by a 10-month absence around the change of government).

In the late 1950s and early 1960s, there was no formal shadow ministry with a frontbench scrutinising the respective ministerial portfolios. The parliamentary Labor Party, with about one-third of the Assembly seats (between 20 and 26 to select from between August 1957 and August 1969), retained largely a five-member 'parliamentary executive', designating the leadership group and allowing certain essential functions to be allocated. When Duggan resumed his position as Opposition Leader in August 1958, Eric Lloyd (Kedron) continued 
as his deputy in the parliamentary party - a position he would hold until June 1965 when he was challenged and beaten by Jack Houston (Bulimba). John Dufficy (Warrego) was elected as the parliamentary Caucus's representative on the ALP's QCE and Jim Donald (Bremer and then Ipswich East, and the former interim parliamentary leader) was reappointed secretary. The final member of the Caucus executive was Cecil 'Nugget' Jesson (Hinchinbrook), who was reappointed as party whip (a position he had held since 1950). Besides the fivemember parliamentary executive, the other members of the frontbench with no designated functions were John Mann (Brisbane), who had served as Labor's last Speaker (1950-57), Jim Clark, Fred Graham and Pat Hanlon. After the 1960 election, this same group (except Jesson) was again reappointed; Jesson was defeated in the 1960 election after he chose to contest the seat of Albert rather than remain in Hinchinbrook. The new whip was Horace Davies (Maryborough), who had earlier served as interim secretary when Donald had briefly led the party. Beyond this executive group, the other members of the opposition Caucus had equal standing and no designated responsibilities, although in the House some were more vociferous and argumentative on particular topics than others.

As Opposition Leader, Duggan was an accomplished performer, gaining respect as a hard-working and feisty parliamentarian. He was something of a self-styled orator and an accomplished, forceful debater. He was rarely intimidated or lost for words and, according to observers of the day, was a 'polished' debater with a 'resonant voice, good enunciation and a vocabulary that reflects wide reading'. Duggan was also, however, a 'fast speaker' who was inclined to race through speeches at a rate of knots, often averaging '200 words a minute' - a feature considered to reduce the effectiveness of his delivery (Lack 1962:623-4). Sitting opposite him, Bjelke-Petersen (1990:64) said of Duggan: 'you could wind him up and off he would go, hammer and tongs, never seeming to draw breath.' Duggan's main speeches in the Address-in-Reply debates were generally compelling, powerful tirades, demonstrating a raw political astuteness and taking the fight up to the government whenever possible. Yet, such speeches were also littered with examples of purple prose and were often not the most eloquent or wellcrafted presentations. In content, as distinct from polemic, they were usually a mixture of the substantial and the trivial; Duggan was wont to think on his feet, making points in debate as they occurred to him and meandering through lists of criticisms. When read today as a historical record of the debates, Duggan's speeches display a cobbled-together quality.

He was similarly not one to stand on ceremony, show due deference to the government or observe the niceties of protocol. A favourite tactic was to dismiss out of hand or ridicule the speeches of his opponents, implying they were worthless and vapid. In particular, he would criticise Nicklin's speeches as prone to exaggeration, evasive and specious. Other formal pronouncements 
from the government were equally fair game. The Governor's opening speech to the Parliament was a favourite target of complaint; but in castigating each speech, Duggan sometimes overdid the hyperbole and lessened the impact he sought. For instance, in 1958, Duggan described the Governor's speech as the 'most anaemic speech it has been my misfortune either to listen to or read' ( $Q P D$ 1958:vol. 221, p. 20). Indeed, he must have been taken with this line, because it was used once more in 1962 when he dismissed that year's opening speech as yet again 'one of the most anaemic documents it has been our misfortune to listen to' (QPD 1962:vol. 233, p. 74). On other occasions, he tried variations on the same theme, complaining one year when the Governor seemed to have trouble with his voice that

the memory of those in the Chamber will be very greatly taxed indeed to remember a period in the history of the Queensland Parliament when a Governor's Opening Speech contained so much written about so little. Yesterday was a classic example of time being taken up by His Excellency the Governor in reciting a lot of trivial matters in the House. On Monday evening many of us had the pleasure of being the guests of the Governor at the pre-sessional dinner he customarily extends each year to members of the Cabinet and other leading officials of the House. On that occasion he appeared to me to be in good health and had complete command of his voice. But we were all upset yesterday to see the obvious distress under which His Excellency was labouring in reading that very meagre document. I have no doubt that he would have had an opportunity on Monday of perusing the document, which perhaps explains his discomforture [sic] yesterday and obvious disinclination to recite these trivial matters with his customary enthusiasm. (QPD 1961:vol. 230, p. 32)

Another example of Duggan's preferred style when launching parliamentary attacks can be gained from his response to the Electoral Districts Bill 1958, a piece of legislation about which he was certainly not uninterested. He opened with his typical bluster and tortuous expression:

Rarely have I listened to such a number of pious, political platitudes as I have heard this evening, nor have I ever heard, on the introduction of an important piece of legislation, the political audacity and humbug that characterised the introduction of this measure. It reeks with hypocrisy because the intentions of the government are well known... The Premier is trying to hoodwink hon. members and the outside public into believing that he is perfectly innocent as to the intentions of the Government regarding the proposed boundaries, when he knows 
only too well that Government members have been discussing amongst themselves in detail the boundaries in their areas. (QPD 1958:vol. 222, p. 1619)

His general debating tactics were refreshingly simple and direct. He felt strongly that it was his responsibility as parliamentary leader to take the lead in the opposition's attack on virtually every bill and significant political matter coming before the Parliament. This gave him an enormous workload when the Parliament was sitting - and one to which he could not always do justice. It also meant that Duggan was generally the only visible member of the opposition in political debates or in media coverage going back out to the electorate. He gave the impression, perhaps unintentionally, of running a one-man band and was criticised for not delegating responsibilities to his frontbench. Generally, he would attempt to focus on the politics behind issues and wear down his opponent with dogged determination. He liked to provoke the Premier or a particular minister, or stir the government as a whole, with taunts and allegations. Exhaustion was a frequent tactic employed by the Opposition Leader, but its real effect was diminished by the government's self-restraint and unwillingness to react. Ministers were well aware of Duggan's war-of-attrition tactics and usually responded by not responding - something that, over the years, often proved very effective. They simply chose to hear opposition spokespeople out until they had nothing further to say or their time had expired. The Industry Minister, Alan Munro, once described the government's counter-tactics as being particularly 'generous in our attitude in that we listen patiently' ( $Q P D$ 1964:vol. 237, p. 2356). The Premier, in particular, rarely rose to Duggan's bait or provocations. Having himself acquired a certain shrewdness after being in opposition for more than 25 years - 16 of them as leader-Nicklin would quietly hear Duggan out however long it took, often with a wry smile on his face. Time was on the Premier's side, and moreover, in a unicameral parliament there was not much else the opposition could do besides fulminate.

Nevertheless, throughout the 1960s, the Labor opposition shared many of the values and policy orientations of the Coalition government (see below for policy similarities). Duggan and many ALP members were avid supporters of the system of constitutional government headed by the Queen of Great Britain. Indeed, in one of his earliest speeches in opposition, Duggan was glowing in appreciation of the new Queen. In his customary Opposition Leader's reply to the opening speech, he ventured:

On my own behalf and on behalf of those who are with me on this side of the House let me say that we join as sincerely, as quickly and as generously as hon. members on the government side in expressing and re-affirming our unswerving loyalty to Her Majesty the Queen. We are indeed fortunate that we live in a country with a monarchial [sic] system 
of government presided over by such a gracious person as Her Majesty, Queen Elizabeth...we are indeed fortunate to have the protection of a system of government that is invulnerable to corruption, a system which ensures the protection of the liberty of all people of goodwill and a system which protects the occupant of that high office from threat of assassination or removal. (QPD 1958:vol. 221, p. 19)

In many ways, therefore, the opposition conducted itself in a courteous and respectful manner. If not necessarily successful in politics, they nevertheless tried to be honourable in the Parliament. This was true under Les Wood's and Jim Donald's short terms of leadership as well as throughout the eight years under Duggan's leadership. In those days, too, there was also a degree of friendship and amicability shown across the Chamber and a certain amount of mutual respect especially for those considered worthy adversaries. A sense of this amicability is perhaps best illustrated by the close friendship between the successive Transport Ministers, Labor's Jack Duggan and the Liberals' Gordon Chalk. Both men lived in close proximity in the Toowoomba region and shared the ministerial car when returning home after sitting days. When Duggan was Transport Minister under Gair, he regularly gave Chalk - then a young opposition backbencher-a lift home. Chalk returned the gesture during the 1960s when he became Transport Minister and then Treasurer. Many former members who served during this period subsequently commented that the House was a much 'more friendlier place' in those days, and many considered such qualities to have long since disappeared to the detriment of the Parliament.

\section{Scarred by electoral contests in the early 1960s}

Elections are great levellers. They provide oppositions with the opportunity to shine and perhaps redress the balance somewhat after a period out of government. Elections present all sorts of new possibilities to political parties: an opposition might hope for a turnover of members allowing new blood to enter the Parliament; they might be able to win additional seats and strengthen the opposition's numbers in the Parliament; or best of all, the chance nature of any election offers the prospect of delivering a majority to an opposition enabling them to form government. If governments tend to lose office after a time, oppositions have only to look better at the right time. Few of these opportunities or possibilities, however, were realised throughout the 1960s by the Labor opposition in Queensland. Labor appeared more battle-scarred and dispirited by the experience of contesting elections. Indeed, after reversing the fortunes of the QLP by 1960, it became extremely difficult for the ALP as a 
whole to make further electoral headway. Some opposition members regarded elections with increasing unease, especially if they were in danger of losing their seats through lack of performance or political vicissitudes. Labor backbenchers were always susceptible to defeat by either one of the Coalition parties, and perhaps even the QLP in the early years (although it never really captured a Labor seat), and sometimes to others in their own party through preselection contests. Concerned about their seats and pensions, many Labor members found it was more secure to opt for safety in opposition.

The first election faced by the Labor opposition in 1960 was a dour struggle between four seemingly well-matched parties. The election could be seen as a 'four-cornered' contest fought on the basis of a winner-take-all, first-past-thepost voting system. Indeed, Hughes (1969:16) described the 1966 election as the first to involve real 'four-cornered' contests in that both conservative parties contested some seats together with both Labor Parties; but even so, relatively few seats in fact attracted all four parties at any election in the 1960s. On the government side, the Country Party was determined to remain numerically superior to the Liberals, while among the opposition, the ALP and QLP were locked in mutual combat to capture and monopolise the non-government vote. It was a bitter fight for the right to exclusive representation of the workingclass constituency. In the campaign, the QLP concentrated on attacking the ALP as if it were in government or likely to become so, while the ALP, in contrast, positioned itself as the main opposition and attacked the Coalition government over its mixed record and broken promises. Both Labor Parties, however, were critical of the government's market-oriented policy of removing postwar price controls. This had seemingly contributed to rapid increases in prices and rents. Both also complained about the impact of harsh economic conditions on the lives of the low paid, with the QLP - mindful of the Catholic proportion of its constituency - stressing more the impact on large families. Such lines of attack against the government were, however, blunted by the propensity of the contending Labor Parties to attack each other in public.

The ALP's 1960 campaign began by accusing the Nicklin government of breaking specific promises - among them Duggan listed the government's failure to introduce a bill of rights (promised in 1957), to maintain full employment, to proceed with the new state(s) movement in northern Queensland, to establish an independent public service commission headed by three commissioners, to establish a police appeals board and a teaching commission, failing to restructure the Lands Department and not maximising funding opportunities for roads. Labor also criticised price and rent increases, government-controlled union ballots and higher levels of unemployment (which they claimed to be three times higher than when the ALP was last in office, jumping from 4343 a month in 1956 to 15400 in 1960). Labor pamphlets claimed that the weekly shopping bill 
had risen by 18 per cent and that the government had not delivered on health and housing policies. And yet, in attacking the government, the ALP was not averse to stooping to occasional parochialism; they criticised the government for allowing property speculation on the Queensland coast by outsiders and especially 'Asian millionaires and financial interests in Hong Kong, Sydney and Melbourne' (Courier-Mail, 5 May 1960). Labor's own policy commitments in 1960 offered to expand education, increase the school leaving age first to fifteen and then to sixteen years, extend state housing relief and reintroduce the rental rebate system, legislate for three weeks' annual leave and establish a state savings bank and legal aid bureau (Courier-Mail, 5 May 1960).

In the campaign, Duggan also tried to focus attention on sensitive issues that divided the Coalition. He attacked the Country Party for not introducing preferential voting (something from which the ALP felt it could benefit once it was challenged by the QLP), suggesting that the senior Coalition partners were looking after their own electoral interests at the expense of the Liberals. Localbranch Country Party members remained anxious to exploit the first-past-thepost system because they believed that it was more to their advantage than to the Liberals. With two contending Labor Parties and the Liberals a lesser force than the Country Party, the last calculated that simple majority voting was most likely to bolster their parliamentary representation. Duggan claimed that despite the platforms of both Coalition parties advocating the reintroduction of preferential voting, the Premier had not done so for reasons of short-term expediency. In Duggan's electoral speech on 4 May 1960, he told his audience that the Premier had admitted in a television interview 'that preferential voting was not restored because the Country Party Conference at Bundaberg directed the government not to introduce it' (Courier-Mail, 5 May 1960). Such criticism from Duggan explicitly made the point that both the Premier and the Coalition government would accede to extra-parliamentary pressure when it suited them - a criticism more frequently made of the ALP parliamentarians and the union movement.

Yet, in state politics when parties are out of office, mounting election campaigns can often be an expensive exercise, especially when little financial support is forthcoming from business or other sources of funding. In 1960, the ALP had a bank balance of reportedly about $£ 8000$ at the start of the campaign, but the costs of television campaigning alone were estimated to have been about $£ 15$ 000-20 000 (Sunday Mail, 28 February 1960). Not surprisingly, Labor was interested in whatever free publicity it could get from the press, but with the labour movement divided, such coverage was often not favourable. Labor was also noticeably more restrained in advertising than the Coalition parties.

In contrast, the QLP directed its zealousness against Labor, and throughout much of the campaign the QLP's leader, Vince Gair, was negative and vitriolic. 
The party could not afford a big-spending campaign, but made up for this by attracting attention in other ways, including disrupting meetings and occasionally engaging in rowdy street brawls. The QLP's platform in 1960 was an assortment of commitments reflecting the issues in which the new party was most interested. The QLP declared itself in favour of independently controlled ballots in unions, a reimposition of price controls, increased recreation leave for workers (an ironic gesture given this was one of the main issues behind the Labor split) and an allowance for dependant marriage partners. They sought to attract younger voters with a 'marriage loans' policy (offering cheap loans of up to $£ 500$ towards the purchase of a house), increased funding for non-government (that is, Catholic) schools and an industrial education bursary scheme. Gair also offered to establish a 'rural and savings bank' and provide aid to small farmers but stopped short of providing details.

So, the real fight in the 1960 election was between the rival Labor Parties over who could claim the mantle of leadership of the non-conservative side of politics and of the labour movement. Among the rival candidates, it was a battle over who would emerge as the natural party of opposition. The ALP was intent on breaking the parliamentary power of the QLP and exposing its organisational weaknesses. The ALP also had to concentrate on defeating other splinter bodies or maverick individuals (such as the North Queensland Labor Party, the NQLP). For the QLP, the 1960 election was a test of survival and a chance to develop an alternative approach to capture the working-class vote. The political dogfight took place in the public arena and the mutual animosity was manifest. As Duggan presented the ALP's policy speech to an audience of 1600 in Brisbane on 4 May, fights broke out, punches were thrown and rowdy interjections from QLP supporters punctuated his address. Duggan described QLP attacks as improper tactics designed to promote the party's propaganda, which should be treated with 'contempt' (Courier-Mail, 5 May 1960). He also accused the QLP of receiving funds and support from the Liberal Party (to assist them to split the Labor vote) - a claim that was immediately denied by the other parties. Yet, he offered during the campaign to 'extend the hand of friendship to every QLP man who, realising he had genuinely made a mistake during the split, sought readmission to the ALP' (Courier-Mail, 7 May 1960).

Vince Gair, however, as a former premier, was not to be brushed aside so easily. He boasted the QLP would remain a 'virile, fighting, positive political force' (Courier-Mail, 10 May 1960). The QLP's election material suggested it alone could govern the state for prosperity 'in the interests of all sections of the community - free from dictation' - an undisguised criticism of the ALP and its left-wing union connections (QLP Election Pamphlet, Ashgrove, 1960). They made inflammatory claims that Queensland was confronted by two deadly sins: 'becoming squeezed by monopoly capitalism on one hand, and Marxist- 
inspired socialism on the other' (Courier-Mail, 10 May 1960). To an audience of 1700 in Brisbane, Gair argued that the 'communist-influenced' ALP constituted the principal threat to Queensland rather than the 'inexperienced, inept and amateur' Nicklin government. With his party sharing the name 'Labor' and a similar heritage, the former Labor Premier was anxious to distinguish his new party from any previous affiliations, declaring that the QLP 'positively rejects the full-scale socialism which was foisted on the ALP by the Communists and Fabian fellow-travellers' (Courier-Mail, 10 May 1960). Gair continued to paint the ALP as his bitterest enemy because he still felt the 'minority' ALP parliamentarians had betrayed him by crossing the floor to vote with the Country Party and Liberals to bring down his Labor government. The enmity and hyperbole remained unsurpassed, as Gair ventured that 'the Communist Party has so riddled the ALP that, riven by internal discords, sabotaged from within, an object of tragic contempt in the community, it is a prostrate giant, through whose gaunt and fleshless body the Red-ants roam at will' (CourierMail, 10 May 1960).

Notwithstanding the metaphorical prose of its leader, the QLP was finding it difficult to capture public sentiment, and even by the early 1960s was becoming a declining influence in Queensland politics. It never again showed any serious prospect of becoming a parliamentary force in its own right either as the largest opposition party or more realistically by being able to hold the balance of power between the major parties. Yet the main political significance of the QLP (and later as the DLP, the Democratic Labor Party) was not to be measured in terms of its own success, but by the damage it caused to the ALP's electoral prospects. From the vantage point of the Parliament, the QLP managed to return only 11 former Labor members to the Assembly in 1957, who for a short time added colour and passion if not substance to the quality of parliamentary debates.

The state election of 1963 was the second faced by the ALP in opposition. Before the election the government had again changed the electoral system, reverting back to a preferential voting system, which initially the ALP thought would be of advantage to itself (but the Country Party had agreed to this only after Gair had promised to give QLP preferences to the Coalition parties). This time, the campaign saw the ALP itself become an election issue, principally over accusations of demonstrating communist sympathies. Leading up to the 1963 election, the parliamentary Labor Party was continually hounded by criticisms of its dependence on left-wing unions and for its close relations with 'fellow travellers' (these criticisms were made principally by the Liberal Party and QLP and to a lesser extent by the Country Party). The QLP's newspaper, The Standard, attempted to draw comparisons between the ALP's policies and those of the Communist Party, listing 'parallel policies' of the parties on its front page (for example, recognition of communist China, withdrawal of troops 
from Malaya, abolition of penal clauses in the Arbitration Act and opposition to the Catholic industrial groups in the unions). Stating that these policies were designed to bring 'this country under the heel of international Communism', the paper advocated that the ALP under its present leadership must be smashed and broken for the security of Australia' (The Standard, 1 May 1963).

The ALP became increasingly sensitive to this type of criticism and continually objected to the communist tag, but most of its attempts to bury this issue were defensive or apologetic - and some could have helped to kick the issue along. In a well-reported speech, Duggan, as Opposition Leader, explicitly stated that 'communists were an embarrassment and a nuisance' to the ALP (Courier-Mail, 10 May 1963). He told the audience in Charters Towers in May 1963 that Labor did not want the help or support of communists in its battle for respectability.

The Coalition government was also quick to exploit any other divisions within the opposition leadership on matters of policy. Such divisions kept the ALP in the spotlight and helped undermine any claim to be a viable alternative government. For example, before the 1963 state election, Frank Nicklin tried to make political capital out of 'disagreements' between the leader, Jack Duggan, and his deputy leader, Eric Lloyd. Nicklin claimed that the disagreement occurred over the government's reduction of probate and succession duties. The Premier told electors that Lloyd had supported the government's initiative against the formal and forceful opposition to the tax relief expressed by Duggan (Courier-Mail, 17 May 1963). Press reports had also carried stories that some senior Labor members (even among the 'parliamentary executive') had been 'carpeted' (that is, disciplined) for making individual statements 'off the party line', not displaying unity or failing to demonstrate loyal support to Duggan (Truth, 4 November 1962). Eric Lloyd and John Mann among the executive were rumoured to have faced such disciplinary action.

Labor was confident of winning government at the 1963 election. ALP sources told the press that it would not only gain the 14 seats necessary to form government in its own right but win 18 seats. Press reports tended to support Labor's confidence. As mentioned in Chapter 4, the Truth and the Courier-Mail reported in early 1962 that Labor was well placed to win the next election. The Courier-Mail was definitively claiming that the Nicklin-Morris government could not win a third term (Courier-Mail, 11 March 1962). Labor pushed the issues of restoring full employment and improving industrial conditions for workers. The party was committed to introducing three weeks' annual leavethe issue that had been the catalyst for the 1957 split. Other workplace benefits promised included long-service leave, equal pay for women and reforms to the apprenticeship system. Labor stressed its support for education and more teachers and schools and better levels of equipment. Consumer price increases were a volatile issue and Labor undertook to reintroduce price controls for 
subsistence items and provide low-interest housing loans. The ALP supported full citizenship for Aboriginal people and presented an extensive set of rural policies to challenge the Country Party in its heartland. Labor was committed to rural subsidies through a rural finance board and various assistance schemes for specific primary industries (such as dairy, tobacco and wheat). In policy terms, Labor began to look like a professional party again and a viable alternative government.

Yet, the ALP gained only one additional seat in 1963, taking its total to 26 in the 78-seat Assembly. Labor's Edwin (Eddie) Wallis-Smith defeated the Country Party's Tom Gilmore in the northern seat of Tablelands by 3281 votes (or 51.5 per cent) to 2761 votes (or 43.3 per cent), with the QLP gaining only 116 votes (or 1.8 per cent) and an independent securing 204 votes (or 3.2 per cent). Tablelands was a traditional Labor seat, which had been taken by the Country Party in 1957 largely due to the split. The result was a major disappointment to the ALP, especially to the senior members of Caucus. Nevertheless, despite the loss, the poor result did not produce demands for Duggan's resignation or cause the party to search for a new leader. Rather Duggan's leadership was unquestioned and his position at the head of the opposition even more secure.

The big loser in the 1963 election was the QLP, which was reduced to only one representative. The deputy leader, Les Diplock (Aubigny), held his seat comfortably, winning 52.4 per cent of the primary vote. The party's leader before the election, Paul Hilton (Carnarvon), lost narrowly to the Country Party's H. A. McKechnie, who gained 3157 votes (or 36.3 per cent) to Hilton's 3073 votes (or 35.4 per cent), with the ALP's candidate, D. Gow, receiving 2449 votes (or 28.2 per cent). Two ex-QLP members, Bert Adair (Cook) and Ted Walsh (Bundaberg), retained their seats as independents, but all the other QLP candidates were defeated. A total of 61 QLP candidates had contested the election for only one seat secured.

When the Parliament resumed after the 1963 election, Pat Hanlon (ALP, Baroona), son of the former Labor Premier Ned Hanlon, used the Address-in-Reply debate to reject accusations that communist sympathisers dominated the Labor Party. In particular, he objected to one of the Liberal Party's campaign advertisements run in the Courier-Mail (on 24 May), before the June 1963 election. The advertisement played on the fears of voters by depicting Parliament House under the shadow of a hammer and sickle should Labor win government. Hanlon, who was widely regarded as a moderate within the ALP, told the Speaker:

I assure you, Mr Speaker, that I do not find amusing a photograph of this parliamentary building with the hammer-and-sickle insignia imposed on it. I say to you directly... as Speaker of the House, to indicate... whether you regard the dignity of the Parliament as grossly attacked 
and the Parliament itself held in contempt, which I say it is, by the use, or misuse, of such a photograph of Parliament House in this way. ( $Q P D$ 1963:vol. 235, p. 267)

The Speaker, David Nicholson (CP, Murrumba), replied in a formal 'Speaker's Statement' to the House. He claimed that there was little he could do because he was not in fact the Speaker at the time the advertisement appeared, as the House was dissolved. Nicholson went on to say that the only remedy he could see available to Hanlon was to go to the courts in a civil action. Not surprisingly, the opposition was not impressed with this reasoning. While the Opposition Leader, Jack Duggan, said he accepted the ruling, he added that Labor saw 'farreaching implications' in Nicholson's statement. He implied that the Speaker had allowed the House to be brought into disrepute without now being prepared to take action. He warned that the opposition would have to 'examine and deal with' these implications later in accordance with the Standing Orders. The two principal concerns of the opposition were that the Speaker apparently had no authority between parliaments and that once a particular parliament was dissolved the House could be used in a blatantly political manner or anyone could say anything about the Parliament without fear of reprimand ( $Q P D$ 1963:vol. 235, pp. 336-7).

\section{Controversies besetting the opposition in 1964-65}

Two major issues confronted the opposition in the mid-1960s. First, the Labor opposition was placed in a difficult position when Jack Egerton, President of the Trades and Labour Council (TLC), made serious allegations concerning members of the government. The ALP resisted the opportunity to embarrass the government in the parliamentary controversy that unfolded over an independent's motion to summon Egerton to the bar of the House to explain his allegations. Second, the 1965 Mount Isa Mine dispute and the continuing problems of the Arbitration Act eventually provided a shot in the arm for the dispirited opposition despite its initial reluctance to take up the issue.

The motion to summon Egerton took place on 20 November 1964. The independent from Bundaberg, Ted Walsh, moved the motion and was supported by Tom Aikens. The motion, which tended to be regarded initially by both sides as a case of mischief making, referred to allegations made by Egerton in his presidential address to the TLC on 16 October 1964. Walsh intended his motion to list 12 matters of concern ('recitals') and compel Egerton to attend the House and provide evidence under privilege to support his allegations. The motion proposed that 'John Alfred Roy Egerton be ordered to attend before this House 
at a time and day to be named by Mr Speaker but not being later than twentyeight days from the date hereof, to be here examined as to what he shall know concerning the aforesaid matters' (QPD 1964:vol. 239, p. 1711).

Walsh based his motion entirely on a report of the speech carried in the CourierMail (17 October 1964) in which it was revealed that Egerton had accused some ministers and other government members of being corrupt and of receiving payments outside and beyond their entitlements. The Courier-Mail reported that Egerton said: 'I believe that a thorough inquiry into the affairs of some Cabinet Ministers and government members would disclose such graft and corruption that the government would be forced out of office.' Ministers held shares in oil companies and overseas transport companies and Egerton claimed there was reason to believe 'some of these shares were not properly acquired'. He added: 'some of the trips of members overseas [were also] financed by overseas business interests... and a prominent public servant [had] informed [Egerton] that a certain Minister has received very expensive presents from Japanese interests... a car has been numbered among these.'

In seconding the motion, Aikens launched into a rambling speech that combined attacks on Egerton with many rumours and allegations about members of the government. He particularly singled out Gordon Chalk (Transport Minister), whom he described as 'tactless' for buying a Japanese car in Sydney instead of Queensland shortly after he had returned from a visit to Japan (QPD 1964:vol. 239, p. 1717). Aikens did not accuse Chalk of corruption but said Egerton should be given the opportunity to substantiate his claims. Chalk in his own defence interjected that he had purchased the car in Queensland and only took delivery of it in New South Wales. The Speaker continually had to call Aikens to order for drifting off the topic and introducing irrelevant observations about government ministers, who according to Aikens could potentially 'become corrupt' in time (QPD 1964:vol. 239, p. 1718).

Nicklin responded to the motion and defended the reputations of his ministers. He stated that he could have used parliamentary tactics to avoid the debate on summoning Egerton and simply allowed the motion to remain on the business paper until the House rose (thus terminating the matter). To clear the air, however, Nicklin was prepared to have the motion debated because "the impression might have been conveyed that the government was "covering up" in this matter' (QPD 1964:vol. 239, p. 1720). Nevertheless, he went on to use his interpretation of parliamentary procedure to reject the motion, saying that 'before a witness can be summoned to the Bar of the House, the House must have resolved on some subject of inquiry in which the person called would be a witness'. Nicklin reminded the House that no motion to inquire into the charges made by Egerton had been passed by the House, so no witness could be called. Using sophistry, Nicklin argued: 'a resolution has not been passed 
moving that the House should inquire into the charges made by Egerton. If such resolution had been passed it would be in order then to move that Mr Egerton be summoned as a witness. This action has not been taken' (QPD 1964:vol. 239, p. 1721). Nicklin deliberately allowed debate on the motion to summons Egerton, but then stopped it on procedural grounds. He told the House:

In looking at the notice of motion before the House, I think you will agree, Mr Speaker, that this motion was not framed by the hon. member for Bundaberg. It was framed by somebody with legal training. Apparently the framer of the motion must have been aware of... [accepted parliamentary procedure] because in the motion an attempt has been made to overcome the defect mentioned by setting out some 12 recitals and then providing that the proposed witness shall be ordered to attend before the House, at a time specified, to be examined as to what he shall know concerning the recitals. This, however, does not overcome the objection previously mentioned because the House has not previously resolved to examine the matter set out in the recitals. (QPD 1964:vol. 239, p. 1721)

Nicklin then questioned the motives of Walsh ('a shrewd political campaigner') in moving the motion. According to the Premier, Walsh had a large axe to grind and was not sincere:

He is not so much concerned with the honour and integrity of Ministers of the Crown, which he claims have been assailed, as he is with putting the Government in an embarrassing position and at the same time endeavouring to discredit Mr Egerton, who is one of the leaders of the Australian Labor Party...I suggest, Mr Speaker, that we have before us today a classic example of political hypocrisy. (QPD 1964:vol. 239, p. 1722)

The Opposition Leader, Jack Duggan, began an attack on Walsh and Aikensremembering back to when the movers of the motion had 'an exchange of fisticuffs of some intensity outside this Chamber'. He accused Aikens of making an 'exaggerated and vicious attack on people who cannot defend themselves here', meaning principally Egerton. Duggan also tried to refute allegations Aikens had made that the union leader was on the take from employers to preserve industrial peace. The Opposition Leader was also, however, not impressed with the attack on Chalk, who was a personal friend and someone from the neighbouring electorate with whom he often shared transport when returning home from Brisbane. Duggan then expressed the opposition's belief that 
this government has scrupulously observed the ethical standards required of its Ministers in regard to taking appropriate action to divorce themselves from private operations outside that might be advantaged in some way because they were members of the Ministry...I say without any equivocation that, to the best of my knowledge and from my experience, the Premier has the reputation of being an honourable man, an honest man, and a man of undoubted political integrity. I know that he would take action - if he would not, I should reluctantly be compelled to take back what I have already said about the matter - if some specific information or evidence was supplied to him of a breach of the standards that he has laid down as those that he expects his Ministers to accept. On the evidence that is available to the Opposition in this matter, I do not think that I have any occasion to question in any way the Premier's statement that he is not culpable in this regard. (QPD 1964:vol. 239, p. 1727)

After making his speech, Duggan led all members of the ALP out of the Chamber. The walkout was in protest over the attacks on Egerton, over the intent of the motion and in order to avoid being 'pawns in a political chess game'. Duggan explained:

The Government has the numbers to do what it likes. It has a substantial majority in the House, including all the parties, to solve this problem to its own satisfaction. We will allow you to conduct this argument amongst yourselves - in peace if you like, in rancour if you like, and with recrimination if you like. But we in the Australian Labor Party do not intend to take part in it, and I now propose to leave the House with my colleagues. [Whereupon all members of the Australian Labor Party present withdrew from the Chamber]. (QPD 1964:vol. 239, pp. 1728-9)

Aikens chided them with running to Egerton's bidding, crying, 'Why don't you put your tails between your legs?' He then sought and received permission from the Speaker to occupy the Leader of the Opposition's seat 'seeing that they ran away'. He continued to interject when the next member (Alan Munro, Minister for Industrial Development) rose to speak, only to be told by the Speaker: 'The hon. member may be permitted to sit where he likes, but he cannot interject from any seat other than his own' (QPD 1964:vol. 239, p. 1729). Finally, Chalk rose to make some personal clarifications about what had been said or implied by other speakers. He also launched a personal attack on Jack Egerton, claiming he had made 'dirty, damnable insinuations' (QPD 1964:vol. 239, p. 1734), which had hurt him personally.

After five hours of 'debate', Walsh summed up. There had been no amendments moved, so the original motion was put and defeated under Standing Order 148, 
which states that ' $[\mathrm{w}]$ hen, on a Division taking place, fewer than five members appear on one side, the Speaker shall forthwith declare the resolution of the House'. With the opposition boycotting the vote and the government opposing the motion, Walsh secured fewer than five members to support his motion. The House resolved 'in the negative' and then adjourned.

The Mount Isa dispute was principally an extra-parliamentary industrial issue that simmered for months in the state's north-west and the arbitration courts. The Parliament itself was not much involved in the evolution of the dispute, except for the fact that the government's arbitral legislation was at issue between the company, Mount Isa Mines, and the Australian Workers' Union (AWU). At first, the opposition was not particularly incensed or active over the issue until the mine was reopened and police were sent in to prevent picketing (and some have ventured that they did not really understand the implications of the act). Then, Duggan announced, after a special ALP executive meeting, that as Opposition Leader, he would move a motion of no confidence in the government on the next sitting day because of its 'ineptitude in handling the Mount Isa dispute and industrial conditions generally, and over certain aspects of police administration'. The opposition's action was seen as somewhat belated; one of the main protagonists in the dispute later commented 'at last' when referring to Duggan's no-confidence move (Mackie with Vassilieff 1989:189). This was only the second time since 1957 that the opposition had resorted to the tactic of moving no confidence in the government. The fact that the opposition also added allegations of police corruption to the no-confidence motion indicated perhaps that they were either less sure of their credibility in attacking the government over strike breaking or simply preferred a multi-pronged attack on the government.

When the second session of the Parliament resumed on Tuesday 4 March 1965, the opposition managed to move a want-of-confidence motion immediately after question time. Duggan moved:

That the government does not possess the confidence of this House, for the following reasons, namely:-(1) The economy of Queensland and Australia is being adversely affected by the prolonged industrial dispute at Mount Isa; (2) Great hardship and financial suffering has been, and is being, experienced by a great number of people...(3) A major contributing factor to the foregoing has been the tragic and inept handling of the problem by the Government and its continuing lack of interest and effective action in bringing the dispute to a satisfactory conclusion; (4) Failure of the Government to convene Parliament earlier than March 2, 1965; (5) The provocative nature and circumstances under which the emergency Orders of Council were issued, thereby aggravating and prolonging the dispute; (6) Its failure to acknowledge that the 
basic provocation of the dispute was the sections of the 1961 Industrial Conciliation and Arbitration Act which deprived the employees of Mount Isa Mines and other industries of access to the Industrial Commission on the question of increased bonus payments, and its failure to indicate at any stage of the dispute its intention to amend the Act to allow the Commission to arbitrate on the bonus question. (QPD 1965:vol. 240, pp. 2309-10)

Duggan added for good measure a seventh reason largely unrelated to the other six: allegations of police corruption and cover-up and internal transfers of police relating to 'sectarian' internecine feuds. He moved simply:

(7) The public disquiet and concern by members of the Queensland Police Force regarding certain administrative decisions which-(a) have resulted in widespread discontent within the Force; (b) has caused grave doubts by the general public as to whether the Force is being permitted to operate at its optimum efficiency. (QPD 1965:vol. 240, pp. 2309-10)

The no-confidence motion ran for 14 hours, with the House rising at 3.50 am on the Wednesday (recording more than 107 pages of Hansard). One ALP member, Merv Thackeray (Rockhampton North), was ordered out of the Chamber for disorderly behaviour and constantly interjecting (under Standing Order 123A of the Legislative Assembly). Labor nominated its better performers to argue its case, with Duggan, followed by his deputy, Eric Lloyd, then Alex Inch (Burke), John Mann (Brisbane), Jack Houston (Bulimba), John Dufficy (Warrego) and Percy Tucker (Townsville North). The Premier responded for the government, followed by the Treasurer, Tom Hiley, then Bill Knox (Lib., Nundah), John Herbert (Lib., Sherwood), Gordon Chalk (Lib., Lockyer), Bill Ewan (CP, Roma) and finally Ray Smith (Lib., Windsor). Four ministers spoke against Duggan's motion and in defence of the government's record. Only two Country Party members spoke in the defence, while five Liberal members were represented-indicating perhaps their greater articulateness in off-the-cuff speeches. Interestingly, the fourth speaker in support of the no-confidence motion was independent Tom Aikens (Townsville South), who spoke with passion against the government but did not wait around for the vote after midnight. The last speaker (also in favour of the motion) was Ted Walsh (Ind., Bundaberg).

It was, however, hard for Labor to score much political advantage from the Mount Isa dispute or the other industrial issues - especially given that they had responded to industrial disruption in a similar way to the Nicklin government when the ALP was last in government. Moreover, the AWU in Brisbane was locked in a battle against the local AWU branch in Mount Isa for control over the strike. Shortly before $3.50 \mathrm{am}$, the Premier moved that his amendment expressing 'full confidence' in the government be put and this was carried (after 
a voided vote) by 38 to 22 votes. This then became the motion and was also carried by 38 to 22 votes (18 members were not in the Chamber, although four were paired for approved absences). The marathon no-confidence motion was defeated on party lines although none of the independents or the QLP leader, Les Diplock, took part in the final vote.

\section{The election of 1966}

By 1966, Labor in opposition was not a happy bunch. Factional rivalries and personalities occasionally flared among parliamentary Caucus and there was always the danger of extra-parliamentary influence generating public controversies. Duggan had warned the party in February 1966 that they were too preoccupied with internal party troubles (AJPH 1966:vol. 12, no. 3 [December], p. 443). Two union groups, the right-wing AWU and left-leaning TLC unions, were vying for dominance in the wider party and in the parliamentary Caucus. Labor parliamentarians would at times feel constrained to abide by the ALP's Queensland Central Executive (QCE), and episodically some took the serious step of challenging QCE decisions in the Parliament, in the media or their local electorate.

For example, in the lead-up to the May 1966 state election, one sitting Labor member, Bill Baxter (an MLA since 1953 representing Norman and then Hawthorne, and a factional member of the ALP right and a previous deputy opposition whip), was dis-endorsed by the full QCE (by a vote of 51 to seven, or in some reports 52 to eight). He was ostensibly dis-endorsed on a series of assembled charges (including punching a fellow party member, being rude to a woman travelling in his car and being involved in an 'incident' with a female parliamentary staff member outside Parliament House, which Baxter admitted had occurred but was not serious enough to warrant a reprimand from the Speaker). Baxter was also rumoured to be having an affair with a Labor alderman in Brisbane. How serious these incidents were considered at the time is open to question, but certainly these were hardly 'crimes' of which Baxter alone was guilty, and there were many others in the party who were known to favour physical resolutions to disputes rather than the power of reason, and he was more than likely not alone in any alleged infidelity. Baxter claimed in his defence that he was taking medicinal drugs and had no recollection of the events. Other evidence pointed to an intense factional brawl over Baxter's seat since his original seat of Norman was merged with part of Bulimba in the 1959 redistribution (Truth, 1 May 1966). After he was deposed, Baxter attacked the 'steamroller tactics' of the party machine, claiming he was 'unpopular with leftwing officials of the Trades Hall' and that the TLC wanted only parliamentarians "who would do their bidding "right or wrong, wise or unwise"' (this was a 
pointed reference to the inopportune statement Duggan had made in defence of the party executive's direction on three weeks' annual leave in 1957) (see Sunday Mail, 1 May 1966).

After his dis-endorsement in 1966, the former Labor member became a renegade. In the lead-up to the election, Baxter became even more belligerent, asserting 'I did not rat on the Labor Party. They ratted on me!' (Truth, 1 May 1966). Thinking he could capitalise on his local standing as a sitting member, Baxter was determined not to go easily and stood against the newly endorsed Labor candidate for Hawthorne (T. Burton) in the 1966 elections. He ran a negative campaign but was personally unsuccessful and in fact came third behind the Liberal (Bill Kaus, who would in 1983 swap to the Nationals) and the official Labor candidate. He did, however, ensure that Labor lost the seat. Dumping Baxter meant that Labor forfeited the seat. Later, when the Parliament resumed and Bill Kaus was giving his maiden speech, Labor members taunted him with interjections suggesting that he should thank the ALP's central executive for securing him his seat. John Mann (Brisbane) told Kaus he should donate '10 percent of your salary to the QCE for getting you here' (Courier-Mail, 5 August 1966).

The ALP was still the subject of attack in the 1966 campaign. The buoyant economy tended to divert attention to issues of political stability and credibility. Internal divisions within the ALP and the labour movement were damaging to the opposition. The ALP's stance on industrial issues during the mid-1960s became a constant source of criticism. Les Diplock, the sole QLP member in the House and a constant critic of Labor, suggested in the 1966 campaign that Labor 'was tied to a deliberate program of political sabotage' (Courier-Mail, 12 May 1966). He accused Labor of adopting a double-faced approach to industrial unrest. Referring to the bitter 1964 Mount Isa strike, Diplock said, 'during the strike the ALP characteristically showed its two faces. The frightened rightwing adopted an attitude of silence while the more outspoken left-wing openly collaborated with the Communist element, which took control of the dispute four months after it began' (Courier-Mail, 12 May 1966).

The 1966 state election was the fourth lost by the ALP in succession. There were few bright spots for Labor in the outcome. The number of seats Labor held in the Assembly remained the same (at 26 in the 78-seat Chamber). With only two seats changing hands, Labor lost one Brisbane seat (Hawthorne) to the Liberals (Bill Kaus) and, with its candidate Peter Wood, captured a Liberal seat (Toowoomba East). Labor's campaign had been lacklustre and there was not much cause for celebration among the opposition.

Two other features, however, remain of particular importance with the 1966 election. Violet Jordan was elected to the Queensland Parliament for the seat of 
Ipswich West, becoming Labor's first female parliamentary member (McCulloch 1994). Jordan was only the second woman ever elected to the Parliament (the first being Irene Longman, 1929-32, representing the Country Progressive National Party). To reach the Parliament, Jordan had to endure a tough ALP preselection process and plebiscite vote, but was elected comfortably at the general election. She found the Parliament an inhospitable place and recalled that when she first arrived there were no toilets for women members in the building. She was a conscientious member but not an outstanding performer in debates. She once mooted in August 1966 that she would introduce a private member's bill to provide for equal pay for women and to remove the discrimination against women in the public service, but nothing came of it. She was unkindly referred to as the 'biggest flop ever to be elected to this Chamber' by Tom Aikens-a comment that might say more about Aikens than about Jordan (QPD 1968:vol. 249, p. 430). She held the seat for three terms until she was defeated at the 1974 election. When she attempted to recontest her former seat in 1977, she was beaten in the preselection battle by her campaign manager, David Underwood, who won Ipswich West and held it for 12 years. The second item of interest was the enfranchisement of Aborigines and Torres Strait Islanders for the 1966 poll. Amendments to the Electoral Act allowed for the voluntary registration of Indigenous adults, but once registered, voting was compulsory (as it was for non-Indigenous electors). The nominal Minister for Native Affairs, Jack Pizzey, had announced the changes in March 1965 as part of a series of measures for Indigenous peoples.

Leadership issues became more pressing with the poor showing of the opposition in the 1966 election. Just before the election, Bill Baxter had accused the party of complacency in opposition and claimed that the party leader, Jack Duggan, 'does not know the meaning of mateship and under his leadership the party is degenerating' (Sunday Mail, 1 May 1966). Interestingly, after the election, the main target of attack was not Duggan, but his deputy, Eric Lloyd. Lloyd had fallen foul of the extra-parliamentary wing of the party in Trades Hall because of his stance on industrial issues. The parliamentary Caucus also perceived that the relationship between Duggan and Lloyd had gradually broken down and they were not working as well together in a way that would benefit the party. A view developed in Caucus after the election that either Duggan or Lloyd had to go; and given that no-one was prepared to run against Duggan, who was still regarded as the party's best parliamentary performer, Lloyd was the most expendable.

With Duggan's support, Jack Houston (Bulimba) challenged and defeated Lloyd by a vote of 15-10 (in a Caucus of 26). The contest over the deputy leadership was partly a factional struggle, with Lloyd representing the right-wing of the party (mainly with AWU links) and Houston enjoying the support of the 
leftish TLC unions. Another leadership aspirant, Pat Hanlon, refused to contest the deputy's position, as he was reluctant to stand against Lloyd. Once Lloyd was defeated, Hanlon stood against Houston for the position of parliamentary delegate to the QCE and the vote was tied 13 all. Many commentators of the day considered the TLC had 'deposed the parliamentary deputy' to put in its own candidate (see, for example, AJPH 1966:vol. 12, no. 3 [December], p. 446). The contest was also about positioning within the Caucus and who could be considered a likely successor to Duggan when his leadership finally came to an end. Houston had emerged as a capable and tough parliamentary performer and seemed a better prospect to lift the parliamentary party's stakes in the future. He also had the support of the dominant TLC faction.

\section{The spectacular fall of Jack Duggan in October 1966}

Jack Duggan was certainly an effective, hard-working opposition spokesman and party leader. The fact that he lost three elections in a row did not appear to diminish his standing with his colleagues. Indeed, they regarded him as a natural leader who was capable of debating issues with the government. For a long time, however, Duggan was also regarded as the party's only leader, and he did little to dispel this view so never cultivated a successor. He was also not good at delegating or devolving responsibilities to his colleagues. Some former members who served under Duggan remembered his tendency to pick their brains about legislation and use the material when beginning debates. One member, Jack Melloy, recalled how Duggan would occasionally be unprepared on a particular bill and would call members who were listed to speak in the debate up to his room before the Parliament resumed to ask them what was wrong with the legislation. The member, having undertaken some preparation and research, would present an assessment of the measure, then Duggan would go down to the Chamber and, initiating the opposition's case against the legislation, would deliver the assessment as if it were his own - often leaving the providers of the material floundering with nothing to say when their time came to speak. Melloy added that he soon woke up to this practice and thereafter refused to divulge the details of his own preparations to Duggan - sometimes deflecting Duggan's requests by claiming that the legislation under consideration was 'just administrative'. Duggan's methods ensured that the main focus of attention was on the leader without allowing others to gain much recognition. Consequently, when Duggan suddenly resigned from the leadership in October 1966, he left a big gap. 
To the surprise of the Parliament and most of Queensland, Jack Duggan announced his resignation from the leadership in the House on the morning of 11 October - just as Labor was about to reply to the state budget. In a personal statement to the House, Duggan admitted to a 'taxation difficulty of some magnitude' and gave this as the reason for his resignation. His statement was unexpected by both the Coalition and his own party (most of whom, including Jack Houston, his deputy, had been told less than one hour before the Parliament met) and was described by commentators as 'sensational', a 'bombshell' and a 'shock' to all parties in the Parliament. Duggan explained that he had operated an investment fund between 1955 and 1962 and now had been retrospectively classified as a 'trader' rather than an investor by the Taxation Department over his share dealings. He admitted 'responsibility and blame for not revealing my full share transactions' (QPD 1966:vol. 243, p. 797). As a consequence, he had become a tax defaulter and had understated his income by $\$ 66342$. He owed about $\$ 47000$ in back and additional taxes. Duggan made the announcement because he knew he was about to be publicly named by the Tax Commissioner for tax breaches (he was subsequently named in the House of Representatives on 12 October).

On hearing Duggan's personal statement, the Treasurer and Acting Premier, Gordon Chalk, immediately rose to his feet and, acknowledging he had known Duggan as a friend for 20 years, said 'whatever might be the outcome of the problems that confront him, from my personal point of view the hand of friendship and the hand of assistance will still be extended to him'. He hoped further that the former leader would 'be able to clear all his responsibilities and that he and his [wife and family] will have happiness, peace and contentment in this world' (QPD 1966:vol. 243, pp. 801-2). Chalk's remarks were a genuine expression of compassion from across the Chamber. One unforeseen consequence of Duggan's resignation was, however, that Jack Houston had to speak against the budget for about an hour with next to no notice or preparation; as one former member said, 'there was a good deal of sympathy for "being stuck with it"' (Hewitt, Personal communication).

With Duggan's resignation, there was no automatic successor. He had been Deputy Premier under Gair for five years (1952-57) and Opposition Leader for eight years. In June 1966, only four months before Duggan's departure, Lloyd had been dumped from the deputy's position and was now an embittered man on the backbench. His successor, Houston, had only just settled into the deputy's job and was still an unknown quantity. Widely seen as the TLC's candidate, Houston had to contend with the perception that he was promoted to ensure Trades Hall kept control of the parliamentary wing of the ALP. Other possible contenders were mentioned at this time, including: Pat Hanlon (Baroona), Percy Tucker (Townsville North) and Doug Sherrington (Salisbury), but these were 
long shots in 1966. So, when Duggan announced his intention to resign, he was pressured by his colleagues to remain - indeed the Caucus pleaded with him to reconsider. Either because no successor was apparent or out of recognition of his abilities, the party wanted him to remain as leader and passed a motion of confidence virtually unanimously urging him to resume the leadership. The motion was virtually unanimous because although the vote was 25-nil in favour, Lloyd, angered at Duggan's previous lack of support for the deputy's job, had stormed out of the meeting rather than support the confidence motion. Lloyd left his proxy vote with John Dufficy, who maintained the unanimity by voting in support of the motion. Duggan, however, declined to reconsider and retired to the backbench before bowing out of State Parliament at the 1969 election. He had served 33 and one-half years in the Parliament; at that time, he had been in the Parliament for more than half his lifetime.

\section{Jack Houston's opposition team: 1966 and beyond}

Two candidates stood for leadership of the opposition in 1966: Jack Houston and Pat Hanlon. The ensuing jockeying for support among the 26-member Caucus became a test of strength between rival factions: the Trades Hall union group represented by Houston and the AWU group backing Hanlon. The factional clash over the leadership reinforced the perception that Labor remained divided and fractious in opposition.

Houston was a Scottish-born electrical fitter who had been a trade schoolteacher for 15 years before entering the Parliament in 1957. Pat Hanlon was the son of the former Labor Premier Ned Hanlon and had entered the Parliament in 1956, winning the seat of Ithaca in a by-election. In a closely fought ballot, Houston, then aged forty-seven, defeated his younger and perhaps betterknown opponent by 14 votes to 12, and assumed leadership of the opposition. Even though the margin on the day was close, Houston thereafter comfortably retained the leadership and remained Opposition Leader from October 1966 until July 1974. His deputy elected at the same meeting was Percy Tucker, also a left-wing (TLC) member of Caucus, who defeated Col Bennett by 16 votes to 10 on the eighth ballot.

At the time Houston won the leadership he was regarded as something of an enigma, especially outside the confines of the Labor Caucus. When he had toppled Lloyd for the deputy's position, he had been euphemistically described in the media as someone yet to make his mark. One report (Truth, 19 June 1966) asked 'who is this Mr Jack Houston', and went on to say: 
Jack Houston, a well-built 46 years old one-time electrical fitter, has been in Parliament since 1957. Yet there can be very little in his scrap book to show for all those years. You have to scratch your head hard to remember when he last made a headline. But from now on we have the feeling that Jack Houston's scrap book is going to take on a new look.

On winning the leadership, Houston rapidly broadened his expertise across a range of policy areas and attempted to develop a collective expertise within the Caucus. In particular, he was concerned to see greater specialisation among the leading members of Caucus so that they were able to develop expertise in relation to specific portfolios. From 1966 on, Houston distinguished himself from his predecessor by establishing an informal arrangement of nominating 'shadow spokespeople' from among the elected executive of the parliamentary party. Houston's initial nine-man shadow team consisted of

- Opposition Leader: Jack Houston

- Deputy Opposition Leader and Treasury Spokesman: Percy Tucker

- Secretary and Spokesman for Conservation: Doug Sherrington

- Parliamentary Whip: Horace Davies

- Spokesman for Treasury: Pat Hanlon

- Spokesman for Works and Housing: Fred Newton

- Spokesman for Health: Jack Melloy

- Spokesman for Lands and Local Government: Eugene (Hughie) O'Donnell

- Spokesman for Labour and Tourism: Fred Bromley

In practice, each Labor spokesperson had between one and two ministries to 'look after' and on which to lead debate from the opposition side. Others also took the lead in speaking on particular matters - such as Col Bennett on police and legal issues. Four years later, this shadow arrangement was formalised into a declared 'shadow ministry' (passed at the ALP executive meeting on 14 October 1970), when the shadow ministry was extended to 14 members. The ALP's parliamentary executive had consisted of nine when Houston took over, but was increased by one in September 1969, before a further four were added in 1970. It must, however, be appreciated that initially these titles and responsibilities were recognised only within Labor's own ranks and in the media. The government, and especially the subsequent Premier, Bjelke-Petersen, did not recognise these positions and baulked at the title of 'shadow minister' as a non sequitur.

Labor's first formal 'shadow ministry' of 1970 thus consisted of 14 members of Caucus

- Opposition Leader: Jack Houston

- Deputy Opposition Leader and Treasury Spokesman: Percy Tucker 
- Secretary and Spokesman for Conservation: Doug Sherrington

- Whip and Spokesman for Education and Cultural Affairs: Horace Davies

- Spokesman for Treasury: Pat Hanlon

- Spokesman for Works, Housing and Police: Fred Newton

- Spokesman for Health: Jack Melloy

- Spokesman for Primary Industries: Edwin Wallis-Smith

- Spokesman for Lands: Eugene (Hughie) O'Donnell

- Spokesman for Labour and Tourism: Fred Bromley

- Spokesman for Justice: Colin Bennett

- Spokesman for Mines and Main Roads: Martin Hanson

- Spokesman for Transport: Ray Jones

- Spokesman for Local Government and Electricity: Harold Dean

\section{The effectiveness of the opposition in the Parliament}

If the parliamentary opposition was not particularly effective during its first decade out of government, it simultaneously laboured under some very significant handicaps for much of the time. Some of these handicaps were of its own making and some were imposed on it by the strictures of parliamentary politics. With the official opposition consisting of the ALP as the largest single non-government party, it was handicapped by its relatively small numbers. Labor was never able to command more than one-third of the members in the House. They were not particularly overwhelmed with talent or effective parliamentary debaters. And, indeed, some of the members who had survived from the days when Labor was in government were used to ministers and their advisers taking the lead and were unprepared to put in the hard work of opposition. The QLP, NQLP and a few maverick independents sitting on the crossbenches were often more noticeable and noisy - and prepared to take the fight up to the government.

The non-government sides of the Chamber were also characterised by acrimony. Rather than focusing on a common enemy and operating as an effective team, the non-government members were disorganised and undisciplined. They were 'led' by outspoken individuals (sometimes former ministers), who often carried enormous historical baggage with them into the political debates. Each tended to operate on the floor of the House as a 'one-man band' with their own predilections. Many parliamentary debates were 'three-cornered dogfights' in which self-proclaimed 'real' opponents to the government would begin to attack the Coalition, then turn to attack with much greater ferocity colleagues sitting 
alongside them - ostensibly part of the oppositional forces. The more vocal and active among the parliamentary opposition and the independents resembled a potpourri of individual talents, which were more often directed against fellow travellers than against the performance of the government.

From the outset of the Nicklin period, the performance of the Labor opposition became the subject of some comment. Political opponents, especially the Liberal Party, were dismissive of the opposition from the start, accusing Labor of not adjusting well to the rigours of political life out of government. Other criticisms, however, came from non-partisan sources from the very beginning. For instance, a stinging editorial in the Sunday Truth newspaper (4 June 1961) declared: 'Labor wake up!' The newspaper pointed out that over recent months the government had faced a 'series of body blows to its prestige' and criticism from 'former friends and supporters':

But where was Parliamentary Labor? Was it pitching in to make the most capital out of the government's ineptitude and embarrassment? Was it backing up the protests of country people seriously hurt by Mr Chalk's Transport Act? Was it attacking Cabinet's decision to allow the Westbrook secret inquiry - the first secret inquiry of this kind Queensland has known. And on hospitals - Queensland's cherished free hospitals. Did Parliamentary Labor organise a public outcry to see the free hospitals Labor itself created were properly maintained in the public interest... The answer to each question is No...No...No! Parliament is in recess. So apparently is the Opposition - with its Leader, Mr Duggan, overseas without published reason. In Queensland's name what has happened to Labor? The last weeks have seen Labor's biggest chance in four years to take the government on and win back the public's imagination. But it DID nothing, SAID next to nothing. The views of the people of this state who disagreed with government policy got no support from the Opposition. The role of Opposition was complacently handed over to the Press. (Sunday Truth, 4 June 1961)

In policy terms, there was not much to separate the opposition from the Coalition government. A change of emphasis rather than substantial differences was often the only real basis of distinction. Policy controversies were mostly over the speed, timing or effectiveness of particular measures. The opposition, for instance, was regularly critical of the government's regulations applying to road transport and its lack of transport planning. From the early 1960s, the ALP supported an integrated transport policy and advocated the establishment of a transport advisory committee to assist in gaining greater funds from the Commonwealth regarding road planning and development. Eventually such a committee was established, but both sides shared the main policy objectives of protecting rail while developing road transport. 
Labor was also continually critical of the level of unemployment and held the government accountable for the apparent slowness by which the figures were being reduced. Yet, the government was pursuing types of state development at breakneck speed and generally received the ALP's endorsement for stimulating economic growth. Even though the ALP was criticised for being too closely associated with or influenced by those with communist sympathies, Labor broadly agreed on the importance of state development, on the need for sustainable employment, increased migration and on the expansion of services in education and health care. Thus, both sides supported free public hospitals, the expansion of schools throughout the state and the need for a reliable public service to administer government policies.

Some philosophical differences were maintained between the two major camps. Labor was oriented more positively towards the public sector and opposed in principle the privatisation of public sector commercial assets. The opposition, for example, criticised the Coalition government for selling the Collinsville State Coal Mine, stating in the Parliament that 'they are a private-enterprise Government, disposing of very valuable public property at bargain rates' ( $Q P D$ 1961:vol. 230, p. 441). Labor was also not as predisposed towards the concerns of the bush or as receptive to the self-interested pleas of the rural sector and mining industry. Labor was continually critical of the Country Party's record on releasing crown land to freehold or pastoral leases, which it felt 'sold out' state interests or provided government legitimacy to land grabbing.

\section{The opposition and the effectiveness of parliamentary scrutiny}

To work effectively, the Parliament requires an effective opposition and adequate means to hold the government accountable. Being somewhat dispirited and fractious throughout the 1960s, the opposition rarely placed the government under close scrutiny. In its attacks on the government, it was typically more likely to be interested in personal misdemeanours, ministerial problems, issues of probity and inter-party conflicts. It was less interested in legislation unless interests close to its immediate support base were directly affected.

Slowly, the difficulties of scrutinising the government began to become apparent. After taking Labor to its second electoral defeat, Duggan recognised that the ALP would have to 'work hard to justify the confidence the Queensland electorate had placed in them' as the largest non-government party (CourierMail, 10 June 1960). Duggan was anxious that the party begin to take seriously the job of Her Majesty's Loyal Opposition and scrutinise the performance of the government. At the start of Nicklin's second term, he struck a new note, 
warning the government that they would now 'have to stand entirely on their own legs' and be less able to blame the legacy of previous Labor governments (QPD 1960:vol. 227, pp. 100-1). While the message was heard, it was, however, slow to sink in among ALP members. Some Labor members worked hard, but many did not. The opposition in the 1960s was generally noted for its tenacity and belligerence rather than for its skills or techniques in constructively scrutinising government performance. The opposition became known for displaying a dogged determination in pursuing selective political subjects (usually ones close to its heart and support base), while maintaining silence on other topics.

Few in the opposition were greatly interested in undertaking research into issues underlying proposed legislation or related policy areas. Many Labor members entered the Parliament from a trades background and tended to approach topics from a practical perspective. Their lifelong experiences and limited formal educational backgrounds did not necessarily predispose them towards an appreciation of the value of research. Others were not prepared for the solitary slog of opposition. Even among the leadership, the importance of thorough preparation was not always evident. Some leaders were reputedly infrequent visitors to the Parliamentary Library-and given the absence of personal staff in those days this illustrates much about their personal styles. Members of the opposition in the 1960s have lamented the fact that virtually no research was ever undertaken - because of a lack of resources and time and because members did not undertake it themselves. Shortly before he died, Harold Dean (Sandgate, 1960-74) reflected: 'in those days many members simply got to their feet and spoke off the top of their heads - it was often all rubbish.' Either by circumstance or style, the opposition tended to be reactive and focused on short-term horizons.

It should also be appreciated, however, that the opposition was not afforded much opportunity to exercise scrutiny. Its effectiveness was severely limited (as it had been when the non-Labor parties were in opposition) by the orders, proceedings and conventions of the Parliament. The opposition was not granted adequate means or resources sufficient to hold the government accountable. The government, with its command of the numbers, was in a position to amend these arrangements and generally was reluctant even to consider changes to improve scrutiny. The older Country Party members, and especially Joh Bjelke-Petersen, had a 'get even' mentality, insisting that 'they gave us nothing when we were in opposition' (Hewitt, Personal communication; see also Bjelke-Petersen 1990:48). For instance, the Standing Orders Committee, although formally established with senior members in each parliament, did not in fact meet to review or revise the Standing Orders throughout the period 1962-82. Hence, to be fair, the opposition's performance was hampered by the limitations of parliament 
and the government's control of business. There were few opportunities to 'put the government on the spot' and even question time was heavily policed (see below). The government was also able to explain its intentions or behaviour through ministerial statements to which the opposition had no right of reply.

Moreover, the Parliament did not meet all that often and, when it did, large parts of the day-to-day business were ritualistic and formalised. In the 1960s and early 1970s, the Parliament was usually not recalled early in the year in which an election was due. Thus, the last session would rise before Christmas (either in November or December, subject to government business) and would not resume before the election (conventionally held between March and June). In a worst-case scenario, the Parliament might not have sat for some six to eight months depending on how soon after the election the opening took place. Hughes (1980:122) has described this convention as a 'politically convenient practice' used by the government to avoid 'calling parliament together for some months before polling day, and thus preventing the opposition making use of parliamentary business to embarrass the government'.

\section{Question time}

The capacity to ask the government searching questions on the floor of parliament is a cherished tradition of most Westminster-derived parliaments. In Queensland, all questions had to be 'with notice', meaning that the opposition (and any government backbenchers) had to inform the Speaker some time beforehand, usually within 24 hours, of the nature of the question they intended to ask. This severely limited the interrogative possibilities of question time and the chances of pushing the government on its previous answers. Questions could be ruled out by the Speaker, so could not be asked. If members strayed from their intended question, they could be considered to be asking a question without notice (and so procedurally ruled invalid). Ministers could also select not to answer particular questions directly but take them 'on notice', enabling them to come back to the Parliament at a later date with a considered answer (and one probably prepared by officials in the minister's department). Most importantly, the opposition often charged that the government knew what questions they were going to ask so tended to be better prepared.

The opposition occasionally criticised this restriction on its capacity to question the ministry. There were calls from time to time for the Parliament to allow open questions without notice, but the government was unmoved by its representations. For example, Jack Houston ended the first Address-inReply debate under the Bjelke-Petersen government with a passionate plea for improved accountability: 
[M]ay I also say that it is about time the Standing Orders Committee met and brought in a system of questions without notice so that, when answers are given to questions, we get a ministerial opinion and not that of a public servant. The present system of having only questions on notice leads to arrogance, laziness, and finally incompetence, which is certainly not in the best interests of this State. (QPD 1968:vol. 249, p. 54)

The ALP would be 13 years in opposition before they were permitted to ask questions without notice, and then only rarely were they entirely without notice, as they had to show them to the Speaker. The Bjelke-Petersen government finally allowed questions without notice in August 1970.

\section{Parliamentary privilege and allegations of police politicisation}

Under parliamentary privilege, members could raise serious allegations about other public officials or the conduct of public administration, which, if made outside the House, could constitute defamation and attract civil action. For an opposition, this was a potentially powerful device, which could implicate the government or particular ministers. The intention of the opposition was generally to make some specific allegations often with a hint of other perhaps more sinister revelations to come and see how the government responded. If they accepted the allegations then the opposition had landed a political punch; but if they denied such claims, they could find themselves in more trouble as an issue unfolded - provided there was some substance behind the allegations. The record of the Parliament in this period shows that while some members used this privilege sparingly, many were carefree about smearing opponents, parties, public officials or groups to whom they took a certain dislike. The targets ranged far and wide. Government members often focused on communist infiltration of the ALP or unions; non-government members targeted 'corrupt' business links to the Coalition; sometimes 'freethinkers at the university' were attacked. At other times, members simply sounded off against all manner of things.

Others, however, were more careful about using such privilege and endeavoured to provide substance to allegations they made. Some allegations have remained no more than allegations or suspicions and subsequent history has failed to confirm them one way or another. Other cases have clearly been sustained by later evidence, even if at the time those making the fuss were unable to make much political headway in a unicameral system. For instance, Colin Bennett, in instigating the National Hotel inquiry, was treated with outright hostility from the government side, yet his allegations against the police were later proved to 
have substance and became significant in light of subsequent inquiries. True, this was an era that demanded respect for authority and the police were the public face of legal authority. The government's determination not to take the opposition seriously was, however, extreme.

So, persistent allegations ran through the 1960s claiming that police misconduct was rife and that they protected themselves by political partisanship. Nongovernment members made many allegations that senior police-all the way up to the Commissioner, Frank Bischof-were actively campaigning for the government and against the opposition. In 1963, Colin Bennett ventured:

I should say that the last thing a Commissioner of Police should do is participate actively in politics. Much to our amazement, we in the Australian Labor Party was [sic] inundated with complaints from places in the coastal area of Queensland, and in North Queensland, about the Commissioner's barnstorming campaign in support of the Country-Liberal Government prior to the last election. In addition to Inspector Osborn in the northern area, he had Inspector Bauer of the CI [Criminal Investigation] Branch working in close collaboration with him to secure the re-election to office of the present Government, and that is why the Government is not prepared to enforce certain regulations and rules as they apply to the top administration of the Police Force. The Commissioner has the Government by the throat simply because they were prepared to contribute campaign funds, to organise further donations and contributions to the Country Party and Liberal Party's campaign funds, and were prepared to canvass for them during the election. (QPD 1963:vol. 236, p. 1062)

According to Bennett, Commissioner Bischof was 'meddling in politics and endeavouring to keep the present Government in office because he knows that under its regime he can do as he pleases' (QPD 1963:vol. 236, p. 1063). Opposition Leader Duggan, however, told the Parliament that he had personally telephoned the Commissioner with such allegations and the Commissioner had denied them. In this case, the opposition's tactics seemed poorly conceived and uncoordinated. Strangely, despite the significance of the claims, the opposition did not follow up Bennett's allegations in the next question time. It was some time before senior members of the government such as Tom Hiley would concede that senior police were, indeed, corrupt (even though Hiley recalled that the Premier, Alex Dewar and himself privately confronted Bischof with allegations of his corruption, most likely in 1967; see Stevenson 2003:301).

Independents such as Tom Aikens also rarely missed a chance to stir regarding police and judiciary issues, although some of his allegations went from the serious to the ridiculous. Aikens generally attempted to be humorous but often 
there was a hint of bitter sarcasm in his questions. For instance, in 1961, he asked the Premier why a large contingent of police was undertaking a five-day course in creative thinking (QPD 1961:vol. 230, p. 141), implying such activities were oxymoronic.

\section{Conclusion}

The first decade in opposition gave the Labor Party a more sober appreciation of the importance of the Parliament. They were also acutely conscious of the limitations of oppositions in a single-chamber, adversarial parliament. After enjoying decades in government with rarely a thought given to the effectiveness of the Parliament, Labor was now subordinate within the institution and on the receiving end of the government's tactics. They suffered their opposition status and became jaundiced about parliamentary democracy.

'Ted' Baldwin (ALP, Logan) expressed Labor's ambivalence to the functioning of parliamentary democracy in his maiden speech in September 1969. Responding to the Governor's opening address, in which the Administrator had 'paid tribute to the institution of Parliament when he had described it as the bulwark of democracy', Baldwin continued:

I believe devoutly that this must be so. I shall strive during my term of office to help it to be so...I shall fight to defend this institution and to extend its influence as the chief instrument of democracy. But Parliament is not a bulwark of democracy simply because we say it is. It is the people of the State who decide ultimately what the role of Parliament will be...I will say at the outset that the last few months as a campaigning candidate, then as a member, have left me disappointed and disillusioned, if not depressed, about some aspects of the parliamentary system. (QPD 1969:vol. 251, pp. 321-4)

After criticising the condition of Parliament House as an inadequate building whose 'shortcomings as an instrument of operation for democracy become obvious', Baldwin went on to claim that

electors are not convinced that they are getting value for their 95 cents per head of population for parliamentary service - the third-cheapest in the Commonwealth. And who can blame them when the very composition and limitations of this Assembly force members - back-benchers - to act as 'fix-it' men, glorified but over-paid ombudsmen, public relations men, and clerks...A Parliament, to be ideally democratic, should have at least all major lateral sections of industry - primary, secondary, tertiary and services - represented, as well as all sections of society-owners, 
The Ayes Have It: The history of the Queensland Parliament, 1957-1989

professional, technological, technical, primary producing, semi-skilled and labouring classes represented in the House... it has been said scores of times to me that the task of legislating runs the risk of falling into the hands of public servants, persons who are not answerable to the people of this State...the primary raison d'etre of a member is as a legislator, and so I say it is clear to me that our Parliament will become less of a bulwark of democracy as its members are forced to become more and more 'fix-it' men, and as public servants become more and more the legislators. (QPD 1969:vol. 251, pp. 321-4) 


\section{The Pizzey-Chalk interlude, 1968}

With the retirement of Frank Nicklin as Premier in January 1968, the Queensland Parliament entered a period of turbulence and uncertainty. Nicklin had been the leader of the Country Party continuously since June 1941, accumulating a total of 26.5 years at the helm. He had been Premier for 10.5 years and had governed the state competently and conscientiously. He had stamped his own personal integrity and probity on the character of the government and had quietly maintained a guiding hand over the cabinet and party room. In the Parliament, he was uniformly held in high regard not only by his own Country Party colleagues but by his Coalition partners and members of the opposition. He had maintained a sense of decency in the Assembly that was recognised by friend and foe alike. At the time of his retirement, Nicklin had attained many parliamentary achievements, not the least of which was the general acceptance of the Coalition parties as the natural parties of government. He had also, perhaps more conscientiously, sustained the Country Party as the dominant party in the Coalition despite consistently polling fewer votes than the largely urban-based Liberal Party.

Nicklin's retirement at seventy-two years of age was not exactly a surprise; it had been expected for some time. His health and energy were waning and he had spent some weeks in hospital during the final months of his recordbreaking premiership. It was widely believed that Nicklin had hung on to the job for so long simply to beat the previous record of Labor's Forgan Smith as the longest-serving premier (Forgan Smith had served 10 years and three months). Nicklin resigned after he had beaten Smith by two months. His Country Party colleagues were preparing for a smooth leadership transition, without the rancour or negative publicity associated with a divisive leadership tussle. There was still some anxiety in the party about its chances of winning the next election (due by May/June 1969) - at maximum, only 16 months away. Hence, party opinion leaders intended that the required change in leadership ought to proceed as smoothly as possible and be virtually undetected. The new leader, they felt, should step quietly into Nicklin's shoes, carry on in his avuncular style and consolidate the government's record in office.

Well before Nicklin officially retired, it was widely expected that the Education Minister, Jack Pizzey — who had been the loyal deputy in the party for more than 10 years and was sixteen years Nicklin's junior — would inherit the mantle of premier. As deputy leader, Pizzey was generally considered the one and only successor who enjoyed unrivalled status and seniority. By 1967, Pizzey was the only other Country Party minister besides Nicklin to have served in 
each ministry since the change of government in 1957. Not only was he next in line among the Country Party ministers, he had the important advantage of receiving Nicklin's blessing as his successor. By 1968, it was seen as 'inevitable' that Pizzey would become the successor as Premier (Lunn 1984:27). His term in office seemed secured for the long term.

Yet, politics is laced with strange occurrences. Despite the best-laid plans to guarantee a smooth transition, events were to dash these hopes. Fate intervened, leaving the state in some uncertainty and the Country Party in a state of shock. Although Pizzey was just turning fifty-six at the time of his elevation to the Premiership, he had suffered previous health problems, including a heart attack in 1962 while a minister in the second Nicklin government. Within seven months of becoming Premier, Pizzey collapsed and died suddenly on 31 July 1968only the third Queensland Premier to die while in office (the other two were T. J. Byrnes in 1898 and Ned Hanlon in 1952). There had been little warning to those who worked closely with him or knew him well. His death was a blow to Queensland, which was already recovering from the shock of the tragic death of Prime Minister, Harold Holt, in 1967. Pizzey was replaced in the short-term by Gordon Chalk, the Liberal Treasurer, who became the new Premier, not merely Acting Premier.

Pizzey's unexpected departure from the political scene occurred before a logical successor could be groomed within the Country Party. With the issue of succession thrown open by this unfortunate turn of events, new opportunities opened up and other possibilities within the Coalition became conceivable. In early August, it was no secret that the senior ranks of the Country Party were divided over the next generation of leadership and in particular over who possessed the necessary skills and style to lead the party through a difficult period ahead. It was not inconceivable that the Country Party would be unable to agree on a successor and perhaps risk losing the top job to the Liberals. Among the Country Party ministers no obvious candidate stood out from the pack and no-one enjoyed across-the-board support. While seniority and standing were usually taken as important criteria in selecting successors, three or four of the remaining six Country Party ministers each felt they were the legitimate heirs and seemed intent on standing for the leadership. Aspirations were fanned and for the first time in decades contenders were campaigning on grounds other than the principle that they were simply 'next in line' or anointed.

Outside the party confines, there was also some discussion of the wider merits of the Coalition ministry. It was suggested in the press only a couple of days after Pizzey's death (Courier-Mail, 2 August 1968) that the next most senior minister in the Coalition, the Liberal leader, Gordon Chalk, should stake a claim on the Premiership. Indeed, many Liberals felt it was their turn to lead the Coalition and that they had been the junior partner for long enough. In their opinion, 
Chalk was the most qualified and able minister to lead the Coalition (a view not disputed at the time by many Country Party members). Conceivably, a strong push from the Liberals could have seen it attempt to wrest the Premiership and resist further nominations coming from the Country Party. On the other hand, if the Country Party was to insist it retain the Premiership as the larger Coalition partner, it first had to agree on a nominated candidate and be unanimous in its support. In the first week of August 1968, it was not clear whether a single candidate could gain sufficient support from within the parliamentary party to claim the top job.

Thus, 1968 became perhaps one of the more turbulent years in Queensland politics; certainly it heralded one of the more unpredictable periods during the long reign of the conservative parties from 1957 to 1989. The year began with the long-awaited and graceful exit of Frank Nicklin, followed by the untimely death of Jack Pizzey. In the hiatus created by Pizzey's departure, Chalk seized the helm and remained Liberal Premier for eight days, ${ }^{1}$ before the Country Party, anxious to regain the top job, replaced him with its nominee, Joh BjelkePetersen. For a state that traditionally changed premiers very infrequently, 1968 saw four in the job in short succession.

\section{Premier Jack Pizzey: ending years of waiting}

Jack Charles Allan Pizzey was born in Childers in 1911. An active cricketer and sportsman, he graduated with a Bachelor of Arts from the University of Queensland in 1942 and secured a Diploma of Education while in his first term as a parliamentarian. He began his career as a student teacher at the age of fifteen at Bundaberg State School, and subsequently taught in many schools across the state. During World War II, he enlisted in the forces, serving as an artillery officer and attaining the rank of captain before his discharge in 1945. After the war, he worked as an organiser for the Board of Adult Education but resigned in 1949 to become the manager of the Cane Growers' Cooperative in Childers. He subsequently became active in sugarfarming politics and rural producer bodies.

Pizzey entered the Parliament in 1950 as the Member for Isis, a country seat based on Wide Bay. He had spent much of his earlier life in towns and cities and was one of the very few with tertiary qualifications among the Country Party parliamentarians. After winning his seat, he resided with his family in Taringa, one of Brisbane's more prestigious inner western suburbs. In the Parliament, Pizzey - who was 'often referred to by his initials, J. C. A.'-impressed some observers as a 'fluent and forceful speaker' but on other occasions could become

1 He was 'King for a week' (Hazlehurst 1987:213). 
rattled in debates (Courier-Mail, 8 January 1967). Nicklin recognised Pizzey's experience and talents and, on winning government in August 1957, appointed him Education Minister - a position he held continuously until he was elevated to Premier in January 1968. With a professional background in education, Pizzey was a particularly interested and active minister who presided over an era of enormous expansion in the state school system. He was also a hard-working and competent minister who very quickly became one of the more politically astute ministers in the cabinet.

As Nicklin's protégé, Pizzey served the Premier by maintaining a personal loyalty that was rock-solid. Nicklin had given Pizzey his initial break and shown faith in him as a minister; Pizzey felt that in return this deserved his unfailing support and confidence. Gradually, Pizzey became Nicklin's trusted confidant in cabinet. He had good political instincts and provided a good ear and cool head when the Premier sought political and administrative advice. According to a contemporary ministerial colleague, who was perhaps a little envious: 'Pizzey had always been Frank's right-hand man. They worked so closely together that they almost seemed like twins...the two of them always seemed to have their heads together' (Bjelke-Petersen 1990:82). Both men came to symbolise the Coalition government in the 1960s: capable, dour, industrious and reliable. At times, the government resembled a two or three-man band led by Nicklin and Pizzey with Chalk becoming increasingly important from the Liberal side.

Press reports at the time of Pizzey's elevation to the Premiership spoke of his patience and dedication. They described him as the man 'waiting in the wings' who had developed a close personal friendship with the Premier, including a shared passion for cricket and a keen interest in the Returned Services League (RSL). Logan Sligo, a political reporter with the Courier-Mail (8 January 1968), acknowledged Pizzey's many qualities, while highlighting his preparedness to wait his turn as the 'loyal lieutenant':

Waiting is not a new experience for the 56 year old ex-school teacher from the rich sugar lands of Childers. His strength is that he has always put his periods of waiting to good advantage. While he waited for the war to end to resume his career as a teacher-he served as a captain in the Fifth Field Artillery Regiment-he continued his studies...Always a keen and above average cricketer, Mr Pizzey a left-hand bogey bowler practiced and waited and won selection for Queensland for the last [Sheffield Shield] match of the season against Victoria in 1932. In his ten years as deputy leader of the Country Party, and understudy to $\mathrm{Mr}$ Nicklin, he has been breaking records as the State's longest-serving Education Minister. 
The press made much of Pizzey being an educated Premier, with constant references to his status as an ex-schoolteacher (implicitly contrasting him with his various predecessors: Frank Nicklin, a smallholding farmer who followed three railwaymen - Vince Gair, Ned Hanlon and Frank Cooper-and before that a house painter, Forgan Smith). His considerable experience in the ministry combined with a stint of more recent overseas travel were regarded by his colleagues as having 'broadened' his outlook, 'restored' his health and 'completed his grooming for the Premiership' (Courier-Mail, 8 January 1967). Press comment also suggested, however, that the new Premier's 'most difficult task will be to steer the Coalition ship through troubled waters' - a reference to deteriorating relations between the Coalition partners as their years in government wore on (Courier-Mail, 8 January 1968). It was also recorded that Pizzey had developed a good personal working relationship with the Liberal leader and Treasurer, Gordon Chalk (the only other remaining member of the first Country-Liberal ministry formed in 1957). In many ways, therefore, Pizzey received a dream run from his party and in the press on his ascendancy to the Premiership.

\section{A tough contest for the deputy's position serving under Pizzey}

Although Pizzey was unchallenged for the leadership, the Country Party was far from being of one mind about who should be promoted into the deputy leader's position. The fight over this position was intense because the incumbent deputy would ostensibly become the future leader of the party once Pizzey retired. So, much was at stake. Yet, if the appearance of a smooth and harmonious transition was intended, the power struggle over the vacant deputy position gave short shrift to the intent.

The main contenders to replace Pizzey as the new deputy leader were all from the previous ministry. The most senior contender in cabinet rank and experience was the Lands Minister, Alan Fletcher (first elected to the Assembly in 1953). The second-most senior was the Works Minister, Joh Bjelke-Petersen, who entered the Parliament in 1947 but for his first 16 years had remained on the backbench. The third candidate, Ron Camm, was a comparatively junior minister. He had entered the Parliament through a by-election in 1961 and was the most recent addition to the ministry from the Country Party. Camm had become the Minister for Mines and Main Roads only in March 1965.

In the last Nicklin ministry (1966-68), Fletcher was the third Country Party minister in cabinet rank behind Nicklin and Pizzey. At sixty years of age, he was considered the elder statesman and a likely successor for the deputy's position 
despite limited breadth of ministerial experience (having singularly been the Minister for Land Administration since June 1960 after a term as Speaker). By 1968, however, he was not unanimously supported by his colleagues and was regarded as 'unpopular' in some quarters (Hughes 1980:27). Some felt a younger candidate was preferable. There was even some speculation before the ballot about whether Fletcher would agree to stand as a candidate.

Johannes Bjelke-Petersen was only the sixth-ranked Country Party minister in the final Nicklin government with not yet five years' ministerial experience and all in Works and Housing. Bjelke-Petersen was ranked behind not only Fletcher but also two other ministers: Harold Richter (Local Government) and John Row (Primary Industries). Bjelke-Petersen, who was about to turn fifty-seven years of age, felt slighted by Nicklin and overlooked when new ministers had been appointed at the Premier's discretion. ${ }^{2}$ A hard party worker, Bjelke-Petersen felt he deserved to be higher in the pecking order as a result of his longer seniority in the Parliament and the assistance he had given to other party colleagues over the years. In truth, however, Bjelke-Petersen was second-last among the Country Party ministry, with only Camm (aged fifty-three) lower on the ministerial list. Despite Camm being ranked seventh and having the least amount of experience as a minister, he was nevertheless taken seriously as a contender.

The relative experience of the three contenders is shown in Table 7.1.

Table 7.1 Seniority of the candidates for the Country Party deputy leadership position in January 1968

\begin{tabular}{|c|c|c|c|}
\hline $\begin{array}{l}\text { Candidates for the } \\
\text { deputy's position in the } \\
\text { Country Party: January } \\
1968\end{array}$ & $\begin{array}{l}\text { Years/months the } \\
\text { candidate had been in } \\
\text { State Parliament }\end{array}$ & $\begin{array}{l}\text { Years/months } \\
\text { the candidate } \\
\text { had been in the } \\
\text { ministry }\end{array}$ & $\begin{array}{l}\text { Highest cabinet } \\
\text { rank in the } \\
\text { Coalition ministry } \\
\text { (and among CP } \\
\text { ministers) }\end{array}$ \\
\hline $\begin{array}{l}\text { Alan Fletcher (Lands } \\
\text { Minister; aged sixty } \\
\text { years) }\end{array}$ & 14 years, 10 months & $\begin{array}{l}7 \text { years, } 7 \text { months } \\
\text { (plus three years } \\
\text { as Speaker, } \\
1957-60 \text { ) }\end{array}$ & 4th $(3 r d)$ \\
\hline $\begin{array}{l}\text { Joh Bjelke-Petersen } \\
\text { (Works and Housing } \\
\text { Minister; aged fifty-seven } \\
\text { years) }\end{array}$ & 20 years, 8 months & 4 years, 4 months & 7 th (6th) \\
\hline $\begin{array}{l}\text { Ron Camm (Mines and } \\
\text { Main Roads Minister; } \\
\text { aged fifty-three years) }\end{array}$ & 6 years, 6 months & $\begin{array}{l}2 \text { years, } 10 \\
\text { months }\end{array}$ & 11 th (7th) \\
\hline
\end{tabular}

2 He was especially irked by John Row's appointment after only three years in the Parliament (BjelkePetersen 1990). 
The contest for the position of deputy leader also captured attention because there were some doubts over the capacity of Pizzey to lead the state for any considerable length of time. In a prophetic comment made only days before Pizzey assumed the Premiership in January, the Courier-Mail's chief political reporter reminded readers that 'Mr Pizzey's health while not of great concern must be considered. He has had one heart attack and the possibility of his deputy taking over cannot be overlooked' (Courier-Mail, 5 January 1968).

As the jockeying for position began in the new year, the Courier-Mail (5 January 1968) described Camm as the 'hot favourite' to win party support for the deputy's job, probably ahead of Bjelke-Petersen. The paper speculated that Camm was considered by many in the party as having been groomed for the job. They reported a government member as saying 'Mr Camm is the one to watch. He is likely to become Deputy Country party Leader and could be earmarked for eventual Premiership'. Closer to the ballot, the paper acknowledged that BjelkePetersen was 'favoured to lead in the first ballot' with about 11 or 12 mainly backbench votes from the 27 party members (Courier-Mail, 9 January 1968). Although the candidature of Camm and Fletcher would split the vote against Bjelke-Petersen, a tight 'exchange of votes between supporters of Mr Camm and Mr Fletcher could see either of the two elected as the new deputy leader. But any leakage of votes to Mr Bjelke-Petersen from whoever is eliminated first... could see Mr Bjelke-Petersen elected' (Courier-Mail, 9 January 1968).

In the event, Bjelke-Petersen achieved an absolute majority in the first ballot for the deputy leadership. Camm and Fletcher polled poorly. By defeating Fletcher, Bjelke-Petersen had effectively overtaken the more senior minister and beaten off a 'young turk' challenge from Camm. He was then well placed to assume the leadership of the party whenever it should become vacant. Press reports - with the benefit of hindsight-belatedly acknowledged that Bjelke-Petersen was 'highly regarded by Country backbenchers' (Courier-Mail, 11 January 1968). Reports described the new deputy as 'quietly spoken', a family man with four children and a 'non-drinker' who bulldozed the brigalow scrub, held a flying licence and pioneered aerial seeding. The main reasons for Bjelke-Petersen's victory in 1968, however, are generally considered to be his closeness to the backbench and their feelings of obligation. Hughes (1980:27) has argued that Bjelke-Petersen's ascendancy was attributed to 'Fletcher's unpopularity and to his own favours to members as Minister for Works in the form of electoral district projects and services to the party generally as a keen campaigner'. His election was repayment for political debts.

The contest over the deputy's position was a significant clash of personalities and egos. These factors not only played a big part in the leadership struggle of early 1968, they went on to shape the party's leadership dynamics for the next two years. The feeling that the leadership had not been fully resolved in 1968 
led to subsequent fallout that affected the party and, in October 1970, almost brought Bjelke-Petersen down. Camm in particular remained a major challenger in the initial years of Bjelke-Petersen's premiership.

\section{Pizzey's new ministry: steady as she goes}

In announcing the new ministry, Premier Pizzey made few changes. Stability was the hallmark of the transition. Pizzey explained that he had decided against making any sweeping changes within the ministry to either personnel or portfolios, but those required would make for smoother administration and even greater efficiency. He also indicated that under his new government he intended to employ the talents more of those outside the ministry and added that 'I intend to examine ways of making the maximum use of the many and varied talents of government back-bench members - one way to do this was the greater use of committees to examine government business' (Courier-Mail, 17 January 1968).

On winning support from his own party colleagues on 10 January, Pizzey received endorsement from his Coalition partners as the Premier-elect, with Chalk issuing a statement congratulating the new leader. The immediate problem was to fill a vacancy in the ministry caused by Nicklin's resignation and then reallocate portfolios. The Country Party constitution permitted a leader to either directly appoint a member to complement the ministry or conduct an election in the party room. The latter option attracted considerable interest in the party and the media-despite Nicklin having selected the previous three ministers. Pizzey was also known as a strong supporter of the party policy allowing leaders the right to select ministers. Some backbenchers, however, were anxious to test the waters with a ballot (Hughes 1980:158) - for reasons not least of which were to establish their own credentials for promotion. The former minister Alf Muller (Fassifern) and the relatively new member for South Coast, Russ Hinze (an ex-chairman of Albert Shire), challenged Pizzey to conduct a ballot for the vacancy. At the party meeting, both made representation in support of a ballot, but Nicklin, who was chairing the meeting as the outgoing leader, ruled the matter one entirely for the incoming leader.

In the weeks leading up to the party meeting, the local papers began speculating about whether Pizzey would revert to a democratic election process or maintain recent practice and simply choose a new minister. There was also speculation about who should be considered for the ministry, with many outsiders discussed as possible contenders. The list of hopefuls included Wally Rae (Gregory), Henry McKechnie (Carnarvon), Max Hodges (Gympie), Vic Sullivan (Condamine) and the government whip, Vince Jones (Callide). Some of these members even 
attracted the label 'obvious candidates' or most 'likely' new appointee. Foremost among the contenders, however, was Neville Hewitt (Mackenzie), whose seat was in central Queensland. Coming from Rockhampton, Hewitt had 'strong claims' because of the perceived need to give his region representation in the ministry as well as considerable local support for promotion to cabinet (CourierMail, 5 January 1967). Hewitt also claimed that the new Premier had given him an undertaking that he was to be the next in line for promotion. There was still the expectation in those days that ambitious members simply got themselves onto the waiting list, served their turn in the queue and hoped to outlive their colleagues.

True to form, Pizzey ruled out an election for the vacancy to his cabinet and chose to nominate the additional minister personally. Against most expectations, however, he did not select Hewitt and instead promoted Vic Sullivan, who had represented the Western Downs area since 1960. Sullivan's appointment was somewhat surprising as he had been in the Parliament for five years less than Hewitt, who had served almost 12 years as a backbencher. Pizzey's decision was immediately controversial and within days it was reported that Hewitt intended to resign from all government committees from the day Pizzey officially became Premier (Courier-Mail, 13 January 68). In a letter to Pizzey written immediately after the party meeting, Hewitt was believed to have stated that his major grievance was that Pizzey had not kept his word. Hewitt believed that Pizzey had promised him the next vacancy on the last day of the previous session of parliament (7 December) when debating a bill on cooperative societies. After one government member (Alf Muller) had spoken against the bill and with Hewitt about to join him, Pizzey had spoken privately to the latter in order to obtain his support for the bill. When the bill was put to the vote, Muller crossed the floor to oppose it and Hewitt claimed he would have done the same but decided against such action after being led to believe he would receive Pizzey's endorsement for the ministry when the time came.

With the addition of Sullivan, the ministry was complete. Ten of the ministry remained in the same portfolios they held under Nicklin. Two Country Party ministers were required to assume new responsibilities: Pizzey as Premier and Minister for State Development, and Alan Fletcher, who was moved to Education and Cultural Activities. There had been some debate over whether the new deputy would be given the education portfolio (as it was considered the secondmost senior portfolio among the Country Party's responsibilities), but Pizzey preferred to retain Bjelke-Petersen in Works and Housing while promoting the unsuccessful Fletcher to his old ministry. Sullivan was given the lands portfolio vacated by Fletcher. The short-lived Pizzey ministry, which served from 17 January to 1 August 1968, was

- Premier and Minister for State Development: Jack Pizzey, CP 
- Treasurer: Gordon Chalk, Lib.

- Minister for Works and Housing and for Police: Johannes Bjelke-Petersen, CP

- Minister for Justice and Attorney-General: Dr Peter Delamothe, Lib.

- Minister for Education and Cultural Activities: Alan Fletcher, CP

- Minister for Local Government and Conservation: Harold Richter, CP

- Minister for Primary Industries: John Row, CP

- Minister for Health: Doug Tooth, Lib.

- Minister for Labour and Tourism: John Herbert, Lib.

- Minister for Mines, Main Roads and Electricity: Ronald Camm, CP

- Minister for Transport: William Knox, Lib.

- Minister for Industrial Development: Frederick Campbell, Lib.

- Minister for Lands: Victor Sullivan, CP

For the first time, separate ministerial responsibility for police was acknowledged and allocated to Bjelke-Petersen, who initially combined it with Works and Housing. A few months later, on becoming Premier, he insisted on keeping the police within his portfolio until after the May 1969 election. During this time, Bjelke-Petersen first became associated with police matters and with senior officers. Towards the end of his Premiership, however, Bjelke-Petersen's close association with senior officers and support of the police generally were seen to have begun with his initial period as minister.

\section{Public discontent in the Coalition: the contest over the Landsborough by-election}

After Nicklin's resignation from the Parliament, a by-election was called for his seat of Landsborough on the Sunshine Coast, to be held on Saturday 16 March. Formed by the electoral redistribution of 1949, the seat of Landsborough had been held continuously by the Premier and was regarded as a 'tied' Country Party seat. It was so safe that in 1957 it had remained uncontested by all other parties and independents (in other words, when the writ was issued only Nicklin's nomination was received). When he was contested, Nicklin had regularly polled more than 70 per cent of the primary vote. During the by-election, it was claimed that one in 10 registered voters was a member of the Country Party, hence, without doubt this was a most difficult seat to prise away from the Country Party. Winning was not, however, necessarily the prime motivation. With the Liberals' decision to contest the by-election, some were intent simply to show they had the courage to stand against their Coalition partners, especially in the increasingly suburban electorates on the outskirts of Brisbane. 
The announcement of the by-election in January 1968 initiated a major brawl among the Coalition partners and especially within the Liberals over whether to stand an official candidate against the Country Party candidate. The Liberal Party had increasingly become concerned in the 1960s about its restricted electoral territory, which was limited more by agreement with the Country Party than simply lack of votes. Dissidents within the Liberal executive had begun openly canvassing the notion of standing Liberals in Country Party seats. At this stage, the Country Party had not preselected its candidate and eventually a field of seven would stand for the position (with the preselection ballot called for 20 February). Labor contested the seat by renominating F. Freemantle, who was unsuccessful against Nicklin in 1966.

On 16 January 1968, the Liberal state executive met to discuss the issue of standing an endorsed candidate in Landsborough. The issue, however, split the party internally. The parliamentary leader, Gordon Chalk, was vehemently against standing an endorsed Liberal against the Coalition partner, but he was opposed by the party's president, Dr A. W. Hartwig, who then headed the 'ultraliberals'. Given that the Liberals had just committed themselves to the principle of challenging 'vacant' Country Party seats (that is, where no sitting member was re-standing), the party executive's decision not to contest the Landsborough by-election seemed timid and inconsistent. The Courier-Mail's political reporter described the resolution as a 'surprise decision'. The party president, however, pointed out that it was a majority decision but not a unanimous one. Hartwig was clearly disappointed and admitted the decision was 'against his expressed desire'. Coalitionists within the party regarded the decision was 'a victory for the Parliamentary Leader' (Chalk) and for his deputy, the Justice Minister, Peter Delamothe (Courier-Mail, 17 January 1968). Chalk was not only an ardent coalitionist, he had personal reasons for discouraging three-cornered contests as his own seat of Lockyer was regarded by the Country Party as one of theirs. Hartwig would say shortly after that he would prefer Charles Porter to lead the Liberal Party instead of Chalk (AJPH 1968:vol. 14, no. 3, p. 429).

Initially, the media greeted the Liberal Party executive's decision as a victory for commonsense. The day after the decision not to contest the former Premier's seat of Landsborough, the Courier-Mail (18 March 1968) stated:

[R]elations within the Cabinet, and within the Coalition, have begun on a sound note, for the Liberal party's decision not to contest Landsborough, when it is vacated by Mr Nicklin, should help it to gain the goodwill of its partner party. In all the circumstances the Liberal decision was a sound one. The Liberal party did not have the organisation to campaign and win this seat, and to have a three-corner contest just for the sake of maintaining the principle of the right to contest vacated government electorates would have been unwise. 
The editorial continued, however:

At some stage in the life of the Pizzey Ministry there will be Liberal pressures for an electoral deal which will give the Liberals, as the popular non-Labor party in this State, a greater say in the State's management. These pressures may prove irresistible. But in politics, as in anything, too much haste may make for less speed.

Such comments were remarkably prescient - except that the pressures erupted sooner than anyone predicted. Discontent over the executive's motion spurred some local branch members of the party in the Landsborough area to attempt to reverse the decision not to field a candidate. In the first instance, this caused the party's executive to meet again to reconsider its earlier view. The Courier-Mail, which was by now running the story as evidence of a major rift in the Coalition, reported that the heated second executive meeting lasted more than four hours and did not break up until $12.05 \mathrm{am}$. The paper recounted:

[A]fter a long and bitter debate, the Liberal party State executive early today announced that it had reaffirmed its decision not to contest the by-election... The statement disguised a debate which one delegate described as the most bitter he could remember...Some Liberals have felt that this decision was leaning over too far to the Country party and the Parliamentary 'ginger group' has openly urged a re-appraisal by the State executive. (Courier-Mail, 3 February 1968)

Another delegate at the meeting was quoted as saying 'the gap between the radical and conservative wings of the party had only temporarily closed, and that sooner or later there would have to be a showdown' (Courier-Mail, 3 February 1968). The ultra-Liberals expressed disappointment at the role their leader, Gordon Chalk, played in the decision.

Within days, however, Landsborough Liberals decided to defy the state executive and stand a local Liberal candidate (Peter Nelson-Gracie, a resident of Caloundra). Their action was in direct defiance of the executive, yet it gained the qualified support of the President, Dr Hartwig. Once a local candidate was selected, Hartwig volunteered that he would support Nelson-Gracie 'in a private capacity' but not as party president. Chalk distanced himself from the renegade candidate, claiming he 'would not take part in any campaign for a Liberal candidate in Landsborough'. Chalk publicly accused Hartwig of 'creating dissension' in both the Liberal Party and the Coalition 'by persisting in his support of the Liberal candidate'. Chalk stated he would assist the government win the seat by giving his personal support to the Country Party's candidate, Michael Ahern (the twenty-five-year-old son of the party's former 
state president, John Ahern). With obvious irritation, Chalk warned the dissident Liberals that he was 'determined they will not be allowed to wreck the government' (Courier-Mail, 19 February 1968).

Chalk, however, found it increasingly difficult to impose his authority on the party and other senior Liberals began to break ranks and support the 'rebellion' against the party executive's decision. The former Liberal leader and Deputy Premier, Sir Ken Morris, spoke out in favour of the Landsborough Liberals and, together with other sitting Liberal members associated with the 'ginger group' Charles Porter (Toowong), John Murray (Clayfield) and Bill Lickiss (Mount Coot-tha) - announced their support for the non-endorsed Liberal candidate. As the conflict intensified, both sides began raising the stakes as in a game of poker. The Liberal state executive suspended the party president for fanning dissension. The endorsed Country Party candidate, Mike Ahern, claimed on many occasions that he was the 'official government candidate' and that his Liberal challenger was an 'independent'. He upped the ante when he articulated the view of his party by stating that the 'Country party will not sit with this man [Peter Nelson-Gracie] in Coalition government if he is fluky enough to win' the by-election (Courier-Mail, 7 March 1968). Ahern told audiences he was 'honoured' by the presence of Chalk at his first campaign meeting. Many of the election meetings were, however, rowdy affairs with open antagonism between Country and Liberal Party members. Some Liberals responded to the news of Chalk attending Ahern's launch with chagrin-sometimes interjecting at meetings with cries of 'we don't want him' and that their leader was a 'captive'.

The result of the Landsborough by-election held on 16 March was a comprehensive victory to the Country Party. Ahern secured more than 51 per cent of the primary vote against his ALP rival on 29 per cent. The 'independentliberal', Nelson-Gracie, managed a respectable 18.97 per cent in the ballot. After Ahern won the seat, a Courier-Mail (18 March 1968) editorial claimed that the result was welcome news for the government and that Liberal 'wrangling' had not 'sent people scurrying to embrace the Labor party'. It warned:

Landsborough should not, however, encourage continued division within the Liberal party. The unofficial Liberal candidate's vote, while not a poor one, showed that an official Liberal would not have had any chance of winning, as the State Liberal Executive believed all along... the Liberal party should not avoid three-cornered contests, but should be discriminating in the seats it contested. There could be a lesson for the Country party, too, in the Landsborough result. It is that if the two parties are to work in harmony there must be fair 'give-and-take' by both. Another Landsborough-type by-election might not have as happy a result as Saturday's voting, or leave either the Liberal party or the Coalition healthy. (Courier-Mail, 18 March 1968). 
Landsborough marked the beginning of a period of Liberal assertion within the Coalition, which would continually widen the rift between the two parties.

\section{A brief parliamentary interlude}

The second session of the thirty-eighth Parliament sat for only 14 days while Pizzey was Premier. The sitting days began on 19 March and were adjourned on 17 April. The first sitting day was marked by an adjournment motion moved by the Leader of the Opposition on a matter of urgent public importance. Jack Houston wrote to the Speaker about the 'necessity for a Bill to be introduced to make provision for the equitable distribution of electoral districts' especially given the proximity of the next election and the length of time required to undertake such a redistribution. Houston refrained from making an emotional speech about malapportionment or gerrymandering, rather choosing to stress how the current 'electoral districts of Queensland are so much out of line with the desires of the 1958 redistribution that it would be against the intention of the Act at that time to have an election on the present boundaries' ( $Q P D$ 1968:vol. 248, p. 2394). This was an astute ploy as it forced the government to attempt a defence of the electoral situation when the population growth rates were considerably out of kilter with the ratios of representation laid out in the government's own legislation of a decade before. Labor speakers claimed that in 196819 electorates were over quota (with enrolments over the 20 per cent permissible margin under the act), whereas the government had earlier used the argument that 11 electorates were over quota as the stimulus for the 1958 redistribution. Houston told the Parliament that on the basis of the March 1967 electoral rolls, some electorates such as Salisbury, with (18 857 electors), were 66 per cent over the metropolitan quota of votes of 11 383; Aspley was 64 per cent over, Mount Gravatt was 53 per cent over and Mount Coot-tha was 42 per cent over quota. He pointed out that other metropolitan electorates such as Brisbane were down to 9559 electors and well under quota. Labor's deputy leader, Percy Tucker, supported his leader in the debate but added nothing new except to challenge the Liberal members present to support the opposition's call for an urgent redistribution on the grounds that they would also stand to benefit.

The Premier in his 'maiden speech as Premier' began by castigating the adjournment debate as a great example of 'political humbug'. The government recognised that it had been 10 years since the last redistribution and that many electorates were now over quota. These facts were not in dispute. Its defence, however, was that compared with 1957 when Labor was last in government the situation was not as grave. Pizzey claimed that the proportion of electorates outside the quota margins was less in 1967 than a decade earlier. He argued that a total of 10529 electors state-wide were above or below quota compared 
with a massive 33330 in 1957 (claiming this represented only 3 per cent of the state-wide roll in 1968 compared with 11 per cent in 1957). Criticising Labor's intentional malapportionment in the 1950s, the Premier reminded the opposition members

of some of the figures that satisfied them as being fair and reasonable, figures that did not indicate to them that there was any degree of urgency for a redistribution. In Mt Gravatt, in 1957 there were 25,944 electors compared with a country seat of 4,311. Again, the Kedron electorate... had 19,367 electors, yet Flinders had a mere 4,406. Today the disparity in the number of voters is nowhere comparable with what it was in the last year in which Labour was in office. (QPD 1968:vol. 248, p. 2398)

Pizzey went on to boast 'we can hold our heads high in relation to what we have done in the way of electoral redistribution compared with what Labour did' (QPD 1968:vol. 248, p. 2399). The Deputy Premier, Gordon Chalk, was more circumspect, accusing the Leader of the Opposition of desperation because 'not being able to get into power under existing electoral boundaries, he gambles that he could not be any worse off under any new set-up'. Chalk also recognised that he knew 'as well as anyone that what the Opposition is endeavouring to do is to manoeuvre itself into a position from which it may be possible for it to drive a wedge between the parties forming the coalition Government' ( $Q P D$ 1968:vol. 248, p. 2401).

Chalk went on to say that he hoped for the Liberals' sake that the redistribution would be undertaken after the next election (insisting 'I state quite candidly that I believe it will be during 1970'). Squirming to keep his dual loyalties in place, Chalk argued that now was not the right time for the redistribution, but volunteered his personal view:

I believe the time will arrive when the Government will be only too happy to arrange for a redistribution which, I believe, must take place when there is the growth occurring that has taken place in this State. We all know that there are boom areas in certain localities, but one cannot upset the whole of the State simply because of growth in a particular locality. (QPD 1968:vol. 248, p. 2401)

Despite supporting the need for redistribution in the future, he was not, of course, prepared to support the motion in the adjournment debate. After a three-hour debate, the vote for the adjournment was lost on party lines 25-42.

The remaining sitting days were consumed with routine matters. Question time was much the same, with questions on the dumping of pineapples and bananas, egg prices, flights provided by a private firm for a minister, the resignation of female teachers and flood mitigation works. Most legislative measures were 
amendment bills (for example, Succession Act Amendment Bill, Audit Acts Amendment Bill, Lands Act Amendment Bill) and warranted little controversy or debate. On the third sitting day of the year, Ted Walsh (Ind., Bundaberg) rose to raise a matter of privilege regarding support services to Members of Parliament-in particular, secretarial assistance for the typing of letters. Walsh referred to a letter from the Speaker to all members informing them that secretarial services would be restricted to 30 minutes per member per sitting day (on non-sitting days, members did their own typing). Walsh felt that the Speaker's ruling was harsh, that the secretarial services had not kept pace with the increase in workload and that some members used secretarial services improperly to have speeches typed that they were to read in the House. Walsh argued:

As at December 1949, there were 62 electorates and 694,035 electors in Queensland, and there were five members on the typing staff of this House. In 1966 there were 78 electorates, an increase of 16, and 882,683 electors, and there is now a typing staff of eight...When I entered this House in 1950 representing the electorate of Bundaberg, there were 9,900 on the roll. Today there are 15,071 , an increase of 5,171 . It is only natural that, as a member representing an electorate which has shown an increase of 5,000 voters since 1950, I have a great deal more correspondence to attend to than I had 18 years ago. (QPD 1968:vol. 248, p. 2478)

The Speaker, David Nicholson, replied that he was attempting to 'streamline and ultimately speed up the return of transcribed dictation' and denied his ruling was a 'negative action'. Nicholson confessed:

Last year I made an honest endeavour to assist members with their correspondence by introducing for a trial period tape recorders on which they could dictate their messages, which would be transcribed in the typing office. Unfortunately, only two or three members took advantage of that service, and although it was discontinued it is still in mind. If any hon. member can come up with suggestions on how a new service may be introduced, I will have no hesitation in recommending accordingly. I want to give a service to hon. members.

Mr Aikens: [interjected] You should have been here when the Labour party was in power. You would have been treated like a blackfellow.

Mr Speaker: Order! Frankly, I think hon. members have known me long enough to realise that I am possibly one of the most approachable persons in the House. It has always been my honest endeavour to help members not to hinder them. (QPD 1968:vol. 248, pp. 2479-80) 
Two of the more contentious bills presented to the Parliament concerned alcohol. The first bill sought to amend the Inebriates Institutions Act by allowing informal admissions to such institutions. The bill gained some debate principally because many members felt that the amendments did not go far enough in dealing with the causes of alcoholism. Labor's Harold Dean (Sandgate), an abstemious member who actively supported the Queensland Temperance League, countered that 'the cause of alcoholism is the liberalisation of drinking laws'; he was critical of the Education Department and advocated increased promotion of total abstinence in schools (QPD 1968:vol. 248, p. 2583). Doug Tooth, the Minister for Health, accepted the seriousness of the problem but did not accept Dean's suggestions and accused him of advocating prohibition. In summing up the debate, the minister argued that the Member for Sandgate had become a 'little bit confused' and had spoken largely about the education portfolio when the measure at hand was within the Health Minister's responsibilities.

The second drink-related bill was a personal project of the new Premier and created much heated dispute in the Chamber. Drink-driving had increasingly emerged as a major social problem, becoming a divisive political issue of the day. The Premier was personally committed to the introduction of tougher drink-driving laws and in particular to the use of the breathalyser (or breathanalyser as it was sometimes called) by police in testing suspected motorists. When the Parliament resumed, the Speaker announced that he had given permission for a 'demonstration of breath-testing devices for alcohol levels' to be available to all members in the former Legislative Council chamber of the Parliament (QPD 1968:vol. 248, p. 2467). In March, press reports described the Premier as the 'central figure in government moves to introduce breathalyser legislation before Easter'. The Courier-Mail (30 March 1968) noted that the Premier had circulated his intentions to the Coalition backbench, suggesting that 'Mr Pizzey has been commended for his system of giving party members a written outline of proposed bills' so that they can be better informed and refer to proposed legislative clauses during party-room discussions. At this stage, it was expected that a breath-alcohol limit of 0.08 per cent (or 80 milligrams of alcohol to 100 millilitres of blood) would be contained within the bill. The political correspondent for the paper reported:

If breathalyser legislation is approved it is likely to provide for a motorist with a .08 reading to be told not to drive his car for 24 hours. If he has been involved in an accident before being breathalyser checked by police he would be charged with the driving offence, with the breathalyser reading as evidence. (Courier-Mail, 30 March 1968)

The paper noted that the government parties were evenly divided on the wisdom of introducing such legislation. In the event, the Premier could only just muster sufficient support for his proposal and at the joint-party meeting on 3 April a 
five-hour debate ensued in which many Country Party members strenuously opposed the amendments to the Traffic Acts. The Transport Minister, Bill Knox, introduced the legislative amendments on 5 April, claiming that 'most importantly, the amendments are to introduce into Queensland for the first time compulsory breath and blood tests of persons suspected of driving, or being in charge of motor vehicles, whilst having a blood-alcohol content of 0.08 per cent or more in their bodies' (QPD 1968:vol. 248, p. 2858). Motorists found with 0.08 per cent blood-alcohol content by a breathalyser were to be given compulsory blood tests. It was an offence, however, only if the motorist had a real content of 0.1 per cent (that is, 100 milligrams per 100 millilitres), which incurred a fine of $\$ 200$ and a suspension of licence. Knox, however, clearly ruled out random testing in which police could intercept drivers at will and instead argued that the bill allowed police to test a motorist only after they had first 'observed that there is either a breach of the Traffic Act or an accident, or erratic driving behaviour' (QPD 1968:vol. 248, p. 2860). Other government members spoke of the provisions being long overdue, even courageous, and a vital safeguard to the community.

The opposition opposed the legislation. Its aversion was not because it was opposed to methods of reducing drink-driving, but because Labor felt the measures 'cut right across the principle that a free citizen shall not commit himself' (that is, not be forced by compulsion to self-incriminate oneself), and that the 'mild' measures proposed in this legislation would quickly 'become very drastic' (QPD 1968:vol. 248, p. 2861). They accused the government of 'bulldozing' the legislation through at the end of a short session of parliament without due deliberation. The opposition's case, however, was not entirely convincing and government members noted that after more than seven hours of debate, the Parliament had been presented with only 'a good deal of heat which has shed very little light on the Opposition's attitude to this matter' (QPD 1968:vol. 248, p. 3049). Col Bennett (ALP, South Brisbane) made a bizarre contribution towards the end of the long parliamentary debate, illustrating the opposition's awkward position on the bill. He spoke from personal experience of defending drunk-drivers in court and claimed that it would be the 'decent, law-abiding citizen' who would suffer under the legislation, which he believed was only a 'revenue producer for the government'. He concocted some specious reasoning for opposing the bill, which at one point included

a person could well drive home absolutely sober, not having had one drink, but, having parked his car in the garage, having got into his pyjamas and sat around in his family circle, proceeds to have a few Scotches, some beer, or some other alcohol that is to his liking. If the police saw him driving through, say, West End at half-past nine, they would be entitled to go to his home at any time up to half-past 
eleven and force him to take a breathalyser test. If it showed an adverse reaction, they could then cart him off to the police station against his will, using such force as was necessary...Those are real Gestapo tactics. It is a shocking incursion into the rights of a private individual, and I do not see any need for it...The average hon. member opposite... who often gets his alcohol limit up to .08 and drives home successfully, will be the one in jeopardy, and the way this Bill is being introduced, I think this State will be very sorry indeed that it introduced legislation of this nature, rushed in at the end of the short sitting in the early part of the year before Parliament had time to examine it properly. I know that the Country Party has not had time to examine it because its members have not even made any submissions on it. Certainly the legislation was conceived in haste and doubtless we will repent of it at leisure. (QPD 1968:vol. 248, pp. 3055-6)

The breathalyser amendments provided considerable controversy at the end of the second session of the thirty-eighth Parliament. Two separate votes at the final stages of the bill secured its passage, with the government mustering on the first occasion 38 to 22 votes on the floor, and after the dinner break 34 to 22 (with the discrepancies due to some government members not finding it necessary to remain in the Chamber). The Minister, Bill Knox, subsequently announced that 23 breathalysers would be purchased and operational by August. This was not, however, the end of the matter. The legislative provisions concerning drinkdriving were destined to be revisited on many occasions after this initial debate with the next major amendments - reducing the levels of permissible alcohol in the blood to 0.08-occurring in April 1974.

On adjourning the parliamentary session, Pizzey paid tribute to the Parliamentary Draftsman, John (Jack) Seymour, who was retiring after 34 years of service to the Queensland Parliament. The Premier noted that Seymour had served 12 parliaments and six premiers. The indebtedness relayed by the Premier was reiterated by the Opposition Leader, Jack Houston, the Speaker, David Nicholson, and one of the longest-serving members in the House, Ted Walsh, the independent Member for Bundaberg and former Labor Treasurer. Pizzey acknowledged that the job of the draftsman was difficult and the subject of some parody at times. He recited a verse composed apocryphally by one of Seymour's predecessors, which read:

I'm the Parliamentary Draftsman, and they tell me it's a fact

That I often make a muddle of a simple little Act,

I'm a target for the critics, and they take me in their stride- 
Oh, how nice to be a critic of a job you've never tried. (QPD 1968:vol.

248, p. 3099)

As was conventional, the Premier moved the motion of adjournment to end the session of parliament on the evening of Wednesday 17 April. It was the last parliamentary duty Pizzey would perform.

\section{Pizzey' legacy as Premier: a short but promising tenure}

The Pizzey government got off to a promising start. Given his wealth of experience, Jack Pizzey settled comfortably into the responsibilities and routine of his new position as Premier. Pizzey intended to continue the administrative style of the Nicklin years built on ministerial competence and close teamwork. Once the jockeying for ministerial positions was over, cabinet was relatively harmonious and consensual. The Pizzey government also continued to stress the importance of development and the provision of basic services to the regions of Queensland. Moreover, after some years of drought, economic and climatic conditions improved in the first half of 1968, lifting the spirits especially of farmers who received ample rains for the first time in more than a decade. Everything appeared to be favouring the revitalised Country Party as it entered the lead-up to the next state election, due by mid-1969.

As a new premier, Pizzey was anxious to promote initiatives with which he could be personally identified so as to distinguish himself from Nicklin. He was aware of the need to move out of the shadows of his former leader, especially as the Labor opposition had criticised him as a 'political lightweight' who could not put his own stamp on the Premiership. In this context, Pizzey was reputedly interested in introducing reforms to parliamentary procedure and involving party members from both parties more in the deliberations of government. Shortly after the Premier's death, a Liberal backbencher and 'ginger group' member, John Murray (Clayfield), told the Assembly that Pizzey had been interested in introducing a parliamentary committee of review into the third session of the thirty-eighth Parliament (late 1968 to 1969). Although the committee was never formally proposed or established, Murray claimed in the next Parliament that '[t]he late Mr Pizzey went very close to setting up a committee on subordinate legislation, but unfortunately he passed on. I feel that he would have given us that committee' (QPD 1971:vol. 257, p. 504).

The Deputy Premier, Gordon Chalk, meanwhile was being lured by offers of employment from an American company in the private sector. His initial interest in a possible career move was sparked by divisions within the Liberal 
Party and some dissatisfaction with his leadership. After some soul-searching, Chalk decided not to accept the business position, but to remain Deputy Premier. To tempt him from politics, the company had offered a much higher salary than his ministerial pay cheque and, in late April 1968, when Chalk announced his decision to refuse the offer, this was an issue that he made a point of emphasising as a way of demonstrating the sacrifices he was prepared to make for the party and his public duty. The Courier-Mail (22 April 1968) greeted the Treasurer's decision by editorialising that he 'retains the prospects of further political advancement' and 'it is possible that one day the State will have a Liberal Premier'. The paper went on to note that 'the fact that he was offered a substantially higher salary for a not-very-senior post in an American company suggests that there should be a review of State ministerial pay'.

The inadequacy of ministerial salaries did not deter the Country Party from debating the merits of increasing the size of the ministry from 13 to 14 ministers. At the party's conference in May, a motion to establish a Minister of Decentralisation and add a new portfolio to the ministry was narrowly defeated by 57 votes to 54 . The resolution came from rural delegates eager to follow New South Wales' model in assigning responsibility for decentralisation policies to a specific minister. The motion was opposed by the Premier and the former Premier, who argued that present arrangements were adequate and that decentralisation issues could not be handled by a single minister as such issues occurred across the range of existing portfolios. There was also an overt political aspect to the motion. Had the resolution been successful this would have in turn created problems within the Coalition over the respective proportion of ministers each claimed. Country Party members would have expected such a new ministry to go to a Country Party MLA (giving it eight to six in the cabinet), whereas the Liberals would attempt to insist on equal representation of seven ministers each. Not surprisingly, given the existing tensions in the Coalition, the Country Party leaders were reluctant to buy into this potential controversy unnecessarily. An alternative solution to increase the size of the ministry by two (allowing one additional minister each and preserving the majority of the Country Party) was not acceptable to Pizzey at this time (although later this would occur to accommodate the aspirations of the Coalition backbench).

By July 1968, after six months in the top job, Pizzey was described by local journalists as being 'firmly in the saddle'. The mid-term change of leadership appeared without hitch. And by now, Pizzey was 'preparing to launch new policies' because he foresaw increases in state revenues:

On the general political front, perhaps Mr Pizzey's major achievement is the smooth transition from the Nicklin leadership. Having consolidated... 
[he has] stepped out in his own right...His informality is appealing. His readiness to throw away his prepared speech and get down to the 'chit chat' level has won him many friends. (Courier-Mail, 15 July 1968)

One senior journalist, Logan Sligo, who was shortly to work for the AttorneyGeneral, Peter Delamothe, as press secretary, wrote at this time that Pizzey

delivering a serious speech can be a man of authority, who insists that he be listened to...[He] is a man wanting to put people at their ease by sensing and discussing the things they are interested in-be it politics, sport or bringing up children in the 1960s... He feels secure in his ability to lead and in his knack of being able to deal with people and situations.

(Courier-Mail, 15 July 1968)

In the parliamentary recess, Pizzey made three important trips as Premier. One overseas trip was particularly gruelling, involving a month-long journey to Britain, Switzerland (where he represented Queensland's interests at the international sugar negotiations held in Geneva) and to Japan for negotiations about the prospects for an iron and steel works for Queensland. This was followed directly by a visit to Canberra for the Premiers' Conference and Loans Council in late June, then followed immediately by a political tour of the state's northern regions - his only major tour of the state while Premier. He was also preparing to revisit Geneva in the near future to help secure a new sugar agreement if his presence would assist Australia's case at another world conference. In retrospect, the full itinerary and arduous travelling schedule Pizzey maintained during the winter recess could have added to the strain on his health.

Returning by plane from the sugar conference talks in Switzerland on 16 June, Pizzey prepared for the impending Premiers' Conference and Loans Council. Attending with Treasurer Chalk in late June, Pizzey argued against the Commonwealth's contractionary fiscal approach and gained a 10 per cent increase in financial assistance grants, but was reportedly 'disappointed' with the Commonwealth's offer of only an additional \$4 million for works and housing projects. Because Queensland received generous revenue assistance, Treasurer Chalk immediately announced that three new concessions would be introduced in the September budget (reduced rail freight charges for grain growers, reduced transport taxes and direct financial assistance to independent schools) (Courier-Mail, 29 June 1968). The Premier also attempted to extract Commonwealth support separately for other major state projects. Shortly before the Premier died, the cabinet decided to seek further Commonwealth financial assistance of up to $\$ 200$ million to build a power station in central Queensland. Pizzey and Chalk were active in championing this idea. 
The third tour, to the state's north, began in early July and was organised for political reasons with the intention of rebuilding harmony between the Coalition partners. Pizzey prioritised his three immediate political tasks as

1. At a parliamentary level...to give back-benchers, including the Liberal 'ginger group' a greater say on legislation before it was introduced.

2. At the party executive level...[to] counsel against statements that would provoke the Hartwig-led Liberal Executive.

3. At the Country Party grass-root level...[to] set about strengthening the party organisation in winnable seats. (Courier-Mail, 15 July 1968)

Some of these strategies had been attempted from the start, with the Premier going to great lengths to prevent Liberal members from attacking government legislation in the Assembly. On controversial issues, however, such as the breathalyser legislation, the Premier had often had more trouble from his own party, and reputedly 'had to be as persuasive in getting Country party members to accept the breathalyser legislation as he had been in overcoming their hostility to preferential voting some years previously' (Courier-Mail, 15 July 1968). While on the tour, he chaired a cabinet meeting at Mareeba, visited a number of regional centres and assisted in membership drives for the party. He also helped ensure the preselection of Valmond Bird-a credible candidate for the seat of Burdekin and a likely gain for the Country Party at the next election after the retirement of the longstanding conservative independent, Arthur Coburn. The Country Party had not stood candidates against Coburn because of his local popularity and propensity to support the government. After the tour, Pizzey returned home to Brisbane on 14 July.

In mid-July, the new Premier became embroiled-much to his distaste - in the acrimonious internal politics of the Liberal Party. Liberal infighting once again erupted, this time over the proceedings of the party's 1968 convention. And once again personality clashes were instrumental in fuelling the disputes. Criticisms of the party's internal difficulties were publicly expressed in midJuly when the high-profile Liberal Member for Wavell, Alex Dewar, announced his resignation from the party. Dewar had served as Minister for Labour and Industry (1963-65) and then Minister for Industrial Development (1965-67) and had served as the party's deputy leader from 1965 to 1967, and in some quarters was considered a prospective candidate for the party leadership. In announcing his resignation and intention of remaining in the Parliament as an independent (and vowing to stand as an independent for the seat of Wavell), Dewar remembered that he had been asked to join the party by Ken Morris (a subsequent party leader and Deputy Premier), who told him the Liberal Party would be 'a party of change, a vital party composed of people who were weary 
of the complacency of the old anti-socialist forces and who were anxious to bring a new look to Queensland politics' (Courier-Mail, 16 July 1968). Dewar castigated the contemporary Liberal Party for its disloyalty towards him and for stacking the most recent party convention:

During the 21 years to 1967 I gave of my utmost in the furtherance of the ideals of Liberalism and in particular in loyal and faithful service. Following the gross act of disloyalty meted out to me over 12 months ago I debated whether I should remain a member of the party...It was not my intention to depart from [the party] until the farce of the 1968 convention manifested itself. For the first time in my 22 years of association with the party I saw things happening that members over the years had deplored as being activities that occurred only in the Labor party. The commencement of [the] convention with obvious pre-organised numbers of committed votes. The appointment of proxy delegates in direct conflict with the constitution. The placing of the chairman in the invidious position of having to allow delegates, who were unconstitutionally present, to vote on whether or not they had the right to participate. The holding of a ballot at a time not laid down in the agenda for the all too obvious reason that the time was propitious as the known committed voting strength was present. The exodus of delegates after the voting for executive positions, making it obvious that their only purpose in being present was to cast votes in a pre-determined manner. The Gilbertian situation which unfolded itself throughout the first two days of [the] convention was, in my view, completely foreign to the idealism that surrounded the formation of the party in the early 'forties'. (Courier-Mail, 16 July 1968)

The party president, Eric Robinson (later Federal Member for McPherson and Finance Minister, 1977-80), rejected Dewar's explanation of the convention but regretted the member's action. He implied that the blame was with Dewar and stated he would 'make no comment on the reason for your resignation from cabinet 12 months ago as this does not come within my province' (Courier-Mail, 16 July 1968). The party leader, Gordon Chalk (a former rival of Dewar's), had fewer qualms when he declared in the Parliament that Dewar had been accused of behaviour unbecoming a Minister of the Crown and that his resignation had been arranged as a face-saving measure for all concerned. In resigning from the ministry and then from the party, Dewar maintained he was innocent of sexual harassment, denying that he 'had been guilty of any act that could be called "immoral or illegal"' (Courier-Mail, 16 July 1968). He was prepared to let the people judge his behaviour at the next election. When given the chance, however, the Wavell electors ousted the newly independent Dewar from his safe seat, returning the official Liberal candidate, Dr Arthur Crawford, in May 1969. 
Occurring during the winter parliamentary break, the Dewar episode represented a sordid affair in the short life of the Pizzey government. Personalities among the more senior members of the Liberal Party had played a large part in the prosecution of the scandal. The Premier issued a short statement genuinely regretting that Dewar was resigning from the Coalition.

\section{The sudden death of Jack Pizzey}

Shortly before midnight on 31 July 1968, Jack Pizzey, aged fifty-seven, passed away at Chermside Hospital. He had suffered a major heart attack - his second while in the ministry. The Courier-Mail (1 August 1968) announced the news the next morning with a front-page headline 'PREMIER IS DEAD-Mr Pizzey succumbs to a sudden heart attack'. The report noted the Acting Premier, Gordon Chalk, offered his condolences to the Pizzey family and described the loss as 'tragic'. The former Premier, Frank Nicklin, on returning home from a Miss Australia event in Nambour, told reporters that it was 'distressing to think that just as he was doing such a great job he has been taken' and that Queensland had 'suffered a great loss - the loss of a man whom I think would have proved himself a grand leader'. Jack Houston, the Opposition Leader, commented: 'I think it is a dreadful loss to the State to lose a Premier in office.' Houston recalled that despite political differences, Pizzey was 'always regarded as a first rate gentleman by the Opposition'. The Police Commissioner, Frank Bischof, was another to pay tribute, remembering that Pizzey 'had been a wonderful Minister in charge of police, and a Premier with a thorough understanding of the police force and all its problems'. Bischof solemnly announced the news of the Premier's death to a police social function late on Wednesday evening:

The news of Mr Pizzey's death reached Cloudland ballroom just before balloons were to be released at the annual police ball attended by $\mathrm{Mr}$ Bjelke-Petersen, Mr Houston and Mr Bischof. Mr Bischof called for a minute's silence in the memory of the former Police Minister and senior policemen stood with bowed heads. Couples who seconds before had been dancing stood to attention in silent tribute. (Courier-Mail, 1 August 1968)

In other comments, the former Premier was described as a 'kindly, friendly man' who knew his 'health was suspect' when he assumed office. Press eulogies painted him as a cautious leader, who nevertheless 'developed confidence and a style of his own that promised to make him one of Queensland's distinctive Premiers'. He was also judged to have 'won a firm grip over his party at all levels, and was beginning to assert himself as the State's administrative head' (Courier-Mail, 1 August 1968). 
Pizzey was honoured with a state funeral on 2 August 1968. The service was held at St John's Cathedral and the funeral procession wound through city streets before heading to the Albany Creek Crematorium. In the subsequent Addressin-Reply debate, Bill Hewitt (Lib., Chatsworth) recalled the state funeral in delivering what he considered 'the finest epitaph' for the former Premier: 'he lived with gusto; he died doing the things he wanted to do; his nation's flag draped his casket; and a grateful people honoured his memory' (QPD 1968:vol. 249 , p. 212).

When the Parliament resumed for its third session on 20 August, it had been intended that a celebration would occur to mark the centenary of the first sitting of the Parliament in the present building. Instead, the occasion was marked by its solemnity and gloom with the obituaries to Pizzey conveying a sense of shock and a bipartisan appreciation of his public and personal qualities. Those who spoke included: the Governor, Sir Alan Mansfield; the new Premier, Joh Bjelke-Petersen; the Deputy Premier, Gordon Chalk; the Opposition Leader, Jack Houston; the QLP leader, Les Diplock; Alex Dewar, Tom Aikens, Vince Jones (many of these members were colleagues who entered the Parliament at the same election in April 1950) and finally Jim Donald, the Deputy Opposition Leader. Many spoke of how proud they were to have known or worked with the late Premier. Others remembered his genuineness and commitment to the causes for which he strove. The Governor spoke of the state having 'suffered a grievous loss'; the new Premier also knew that all members were 'deeply shocked' and that 'Parliament and Queensland are the poorer for his passing'. The Premier continued:

In the short time in which he was Premier-just a little more than six months - he won the affection, respect and confidence of all with whom he came in contact. Jack Pizzey had the difficult task of assuming the high office of Premier upon the retirement of Sir Francis Nicklin at the end of a record term - a period in which Sir Francis, too, won the respect and affection of all Queenslanders. But Jack Pizzey demonstrated that he had the qualities of leadership so necessary in one charged with the responsibility of leading the Government of a State as big as Queensland...People admired him for what he was endeavouring to do for the State. It was his earnest desire to provide modern amenities for people, wherever they lived in Queensland. He was also admired by his parliamentary colleagues and we all appreciated the fact that he was a fighter to the last... Jack Pizzey was admired because he devoted a lifetime of service to the community and to our State. (QPD 1968:vol. 249, pp. 5-6)

Chalk spoke of Pizzey's calibre as a minister and his devotion and dedication. He commented particularly on the 'spirit of goodwill and affection' that marked 
his short premiership. Houston praised Pizzey's friendliness, tenacity and loyalty to his leader and party. Aikens remembered him visiting his Townsville home, sweating profusely while letterboxing adult education leaflets by bike; Aikens gave him the lend of his bike pump and a glass of water. Aikens admired his dedication to the job. Diplock and Dewar referred to his courage and commitment, with Dewar mentioning Pizzey's 'great capacity for forgiveness'. The last words on the condolence motion fell to Jim Donald, who was moved to

re-echo the sentiments expressed by other speakers that not only have Jack Pizzey's widow and family suffered a severe loss; the Country Party has suffered a severe loss; this Parliament has suffered a severe loss; and the State of Queensland has suffered a severe loss. (QPD 1968:vol. 249, p. 10)

The condolences were bipartisan, genuine and heartfelt; the Parliament was still in shock.

\section{Chalk's 'caretaker' ministry: a week is not a long time in politics}

Gordon Chalk was sworn in as Queensland's thirty-eighth Premier on 1 August. His tenure in the top job lasted only eight days inclusive - the second-shortest term as premier in the state's history. Accepting the Governor's commission, Chalk reduced the ministry from 13 to 12 and combined the portfolios of Premier, State Development and Treasurer under himself. He made no other changes to the ministry he inherited in the allocation of portfolio responsibilities. This could indicate that Chalk was well aware that he was but a caretaker premier and that the Country Party members would very shortly propose their own leader as premier. The complete Chalk ministry for the period 1-8 August was

- Premier, Minister for State Development and Treasurer: Gordon Chalk, Lib.

- Minister for Works and Housing: Joh Bjelke-Petersen, CP

- Minister for Justice and Attorney-General: Dr Peter Delamothe, Lib.

- Minister for Education and Cultural Activities: Alan Fletcher, CP

- Minister for Local Government and Conservation: Harold Richter, CP

- Minister for Primary Industries: John Row, CP

- Minister for Health: Doug Tooth, Lib.

- Minister for Labour and Tourism: John Herbert, Lib.

- Minister for Mines, Main Roads and Electricity: Ronald Camm, CP

- Minister for Transport: William Knox, Lib. 
- Minister for Industrial Development: Frederick Campbell, Lib.

- Minister for Lands: Victor Sullivan, CP

Chalk had earned a reputation as a serious and hard-working minister under the Nicklin and Pizzey governments. He was highly regarded as a capable and effective treasurer. He had frequently served as Acting Premier while Nicklin was either away from Brisbane or was ill in hospital in the last year of his term in office. Well before Pizzey became Premier in January 1968, there had been some discussion in media and business circles that Chalk had earned the right to be the next Coalition Premier. Early press reports mentioned that in some influential quarters in Brisbane there is a "Chalk for Premier" movement' (Courier-Mail, 2 December 1967). This was despite 'the stark political fact' that in the Assembly the Country Party retained 26 members to the Liberal Party's 19-and that the Country Party members were not prepared to cede their political advantage to a Liberal leader however competent or admired (Courier-Mail, 2 August 1968). Some reports mentioned that many Country Party members held Chalk in high regard and referred to growing pressure for Chalk to remain Premier until at least the next state election, due in 1969. Realistically, however, his only chance of remaining Premier was if the Country Party could not agree on a successor and unite behind a single candidate. If the Country Party remained divided over the leadership issue (between the Works Minister, Joh Bjelke-Petersen, and Mines and Main Roads Minister, Ron Camm), they risked elevating Chalk to the position as a compromise candidate. Another possibility-perhaps somewhat remote in hindsight - was for Chalk himself to switch parties and lead the Country Party (especially as he came from a country electorate, had many close links with Country Party members and, of course, other senior Liberals were subsequently to make precisely this switch in other circumstances). Either Chalk never contemplated this move or the Country Party's leadership was resistant, because the Country Party remained loyal to its own kith and kin.

Chalk had also been under pressure from within his own party to assert the influence of the Liberal Party and liberalism more generally. Since December 1965, when Chalk became the Liberal leader, he had been under increasing pressure from his colleagues to articulate a stronger identity for the party. Some Liberals even harboured separatist sentiments. Given the Liberals were the junior partners in the Coalition, the pressure from below left Chalk walking a precarious tightrope. By the end of 1967, however, Chalk was convinced the Liberals had to 'attain supremacy' in government over the Country Party and that 'this state is destined to be governed principally by those who follow the Liberal party platform' (Courier-Mail, 2 September 1967). This was an enormous step for someone who had once been described by the Labor opposition as a political chameleon with 'one foot in the Liberal party camp and the other in the Country party camp' (QPD 1958:vol. 222, p. 1623). 
The possibility of a Liberal-led administration emboldened the local Liberalleaning press. The Courier-Mail ran a courageous editorial on 2 August strongly supporting Chalk as Premier and describing the likely moves by the Country Party to remove him as not in the best interests of the state. The editorial stated that it was 'important for the State and for the Government that Mr Pizzey's successor be the best possible man for the post' (Courier-Mail, 2 August 1968). In the editor's opinion, that person was Chalk. The editorial continued:

It would be sensible if the government parties, when they meet to discuss the formation of a new government decided to appoint Mr Chalk to head the government. Mr Chalk has had great experience as Deputy Premier and Acting Premier and just as important, has been highly involvedand still is involved-in most important negotiations concerning the attraction of investment to the State. It would be a great advantage for Queensland to have Mr Chalk undertake these negotiations with the prestige and power of head of the government. To suggest Mr Chalk is not to criticise the abilities of the Country party's Deputy Leader, Mr Bjelke-Petersen, who as acting leader of the Coalition party with the most members, probably could obtain the necessary support, on strict party lines, for the post. The important thing is for the State to get the best advantage it can from Mr Chalk's negotiating abilities and experience. (Courier-Mail, 2 August 1968)

In the face of such pressure, the Country Party was anxious to appoint a successor. They called a party meeting for 2 August and announced that Joh Bjelke-Petersen was likely to be unopposed as the new leader of the Country Party. It was important to nip any talk of a Liberal premiership in the bud. The Courier-Mail (3 August 1968) reported the next morning that

[a]fter last night's brief meeting, Country party members said there could be no question of accepting the Parliamentary Liberal leader ( $\mathrm{Mr}$ Chalk)...who is now Premier of the caretaker Cabinet [sic]. A senior minister, not always favourably disposed to Mr Bjelke-Petersen, said: 'The numbers are the only things that matter in politics. This is the only Parliament in Australia in which the Country party has them. We'd be the laughing stock of the Commonwealth if we surrendered our right to the Premiership.'

Bjelke-Petersen reportedly commanded the votes of 20 members of the 26-member parliamentary party, but no formal vote was taken as he was appointed unopposed. In a ballot for the deputy's position, the Mines and Main Roads Minister, Ron Camm, easily defeated the Education Minister, Alan Fletcher, with 'support from three-quarters' of the party (Hughes 1980:28). Party members told reporters somewhat prophetically that the new leader 'had 
a mind of his own and would not be influenced by pressure groups' (CourierMail, 3 August 1968). At a joint-party meeting on 7 August, Bjelke-Petersen was elected leader of the government on party lines (despite an announcement that he had been selected unanimously). On 8 August, Chalk tendered his resignation and that of his ministry to the Governor and the first Bjelke-Petersen ministry was subsequently sworn in. Interestingly, Frank Nicklin had predicted in his scrapbooks that Bjelke-Petersen would one day lead the party, shortly after the transport controversy of the mid 1960s, which had damaged Chalk's reputation with rural Queenslanders.

\section{A turbulent year but an important watershed}

The year 1968 was a watershed year; it was a year of momentous leadership transition, with four premiers holding the reins of office in eight months. It also symbolised the end of one political era and the beginning of another. It ended the old-style Country Party leadership founded on the enduring partnership between Nicklin and Pizzey and heralded the new era under Bjelke-Petersen. At the time, such a transition was not readily apparent. Certainly some in the Country Party considered the new Premier - who, at fifty-seven and already with 21 years' experience in the Parliament - was most likely to serve for a term or two before handing over to a younger generation of leader. There were serious concerns within the Country Party that the new Premier could be an electoral liability and out of tune with the changing times. Despite such concerns about his popularity, Bjelke-Petersen was to lead the government for almost 20 years. When he was eventually removed from the Premiership by his own party, the two principal leaders of the party, Frank Nicklin and Joh Bjelke-Petersen, had together led the Country Party for 46 years, from 1941 to 1987 (with only a sixmonth interruption under Pizzey). The Country Party's emphasis on continuity stood in stark contrast with the brooding discontent and instability that emerged in the Liberal Party and in the Coalition relationship, which increased spectacularly from the initial years of Bjelke-Petersen's premiership. 


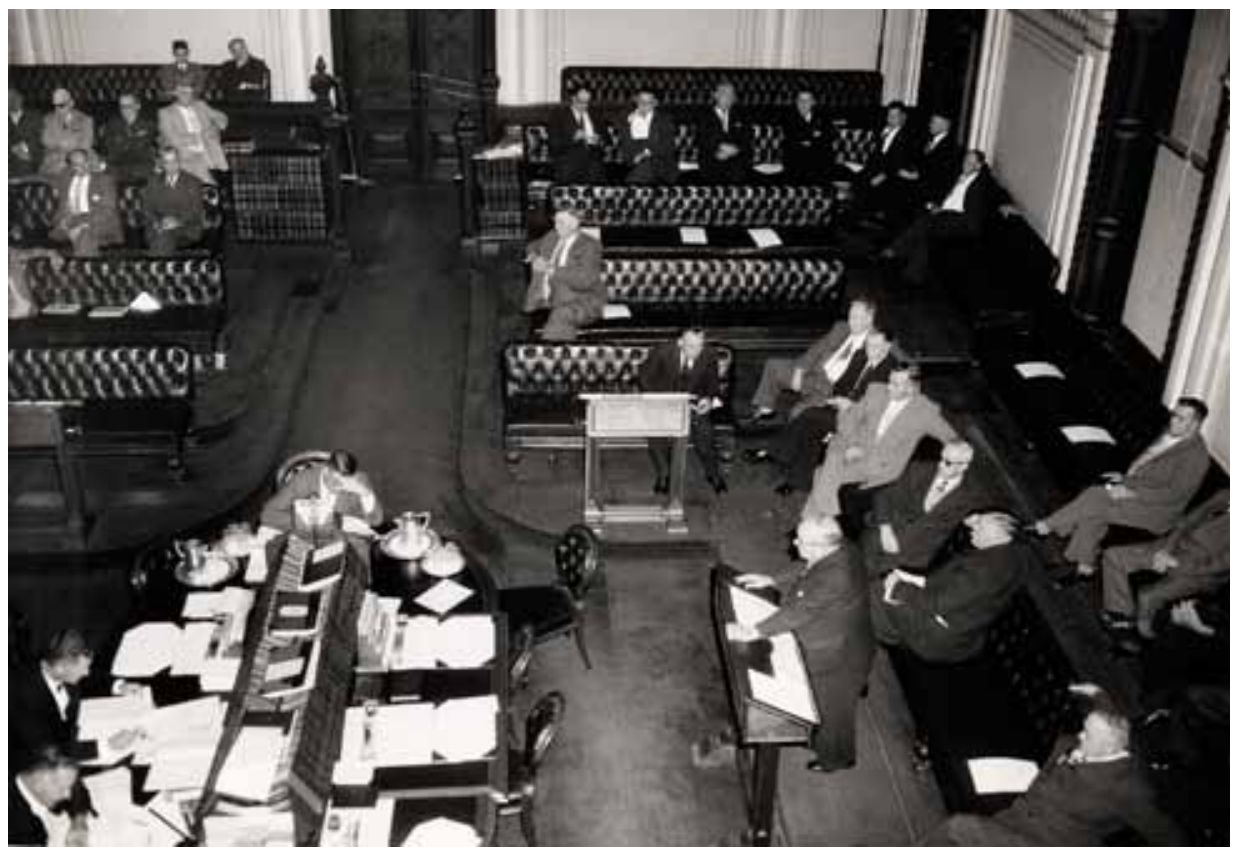

Image 1. The Premier, Vince Gair, standing in the foreground asking the House to vote supply in June 1957 before the fall of his government.

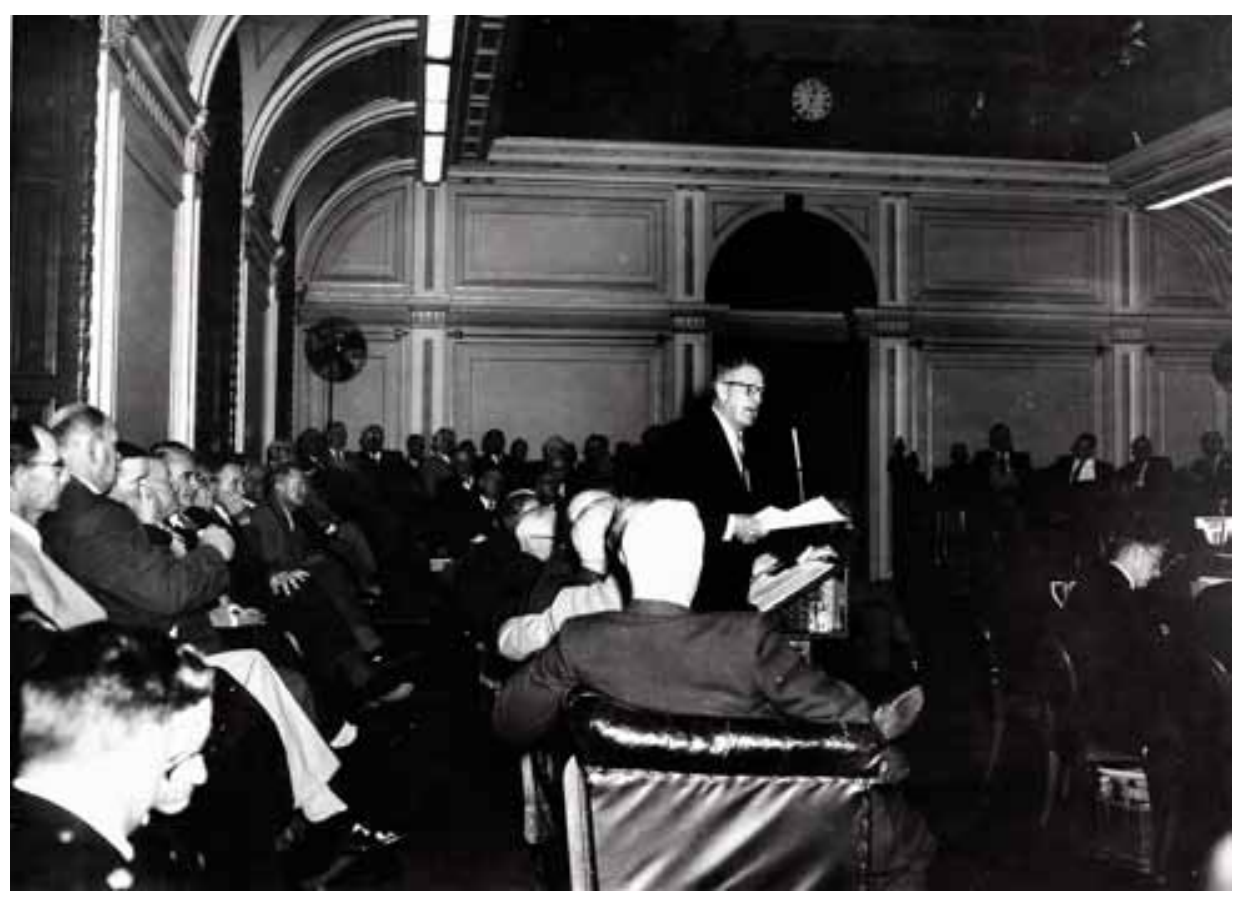

Image 2. The opposition leader, Frank Nicklin, addressing the House in June 1957, opposing Gair's supply bill. 


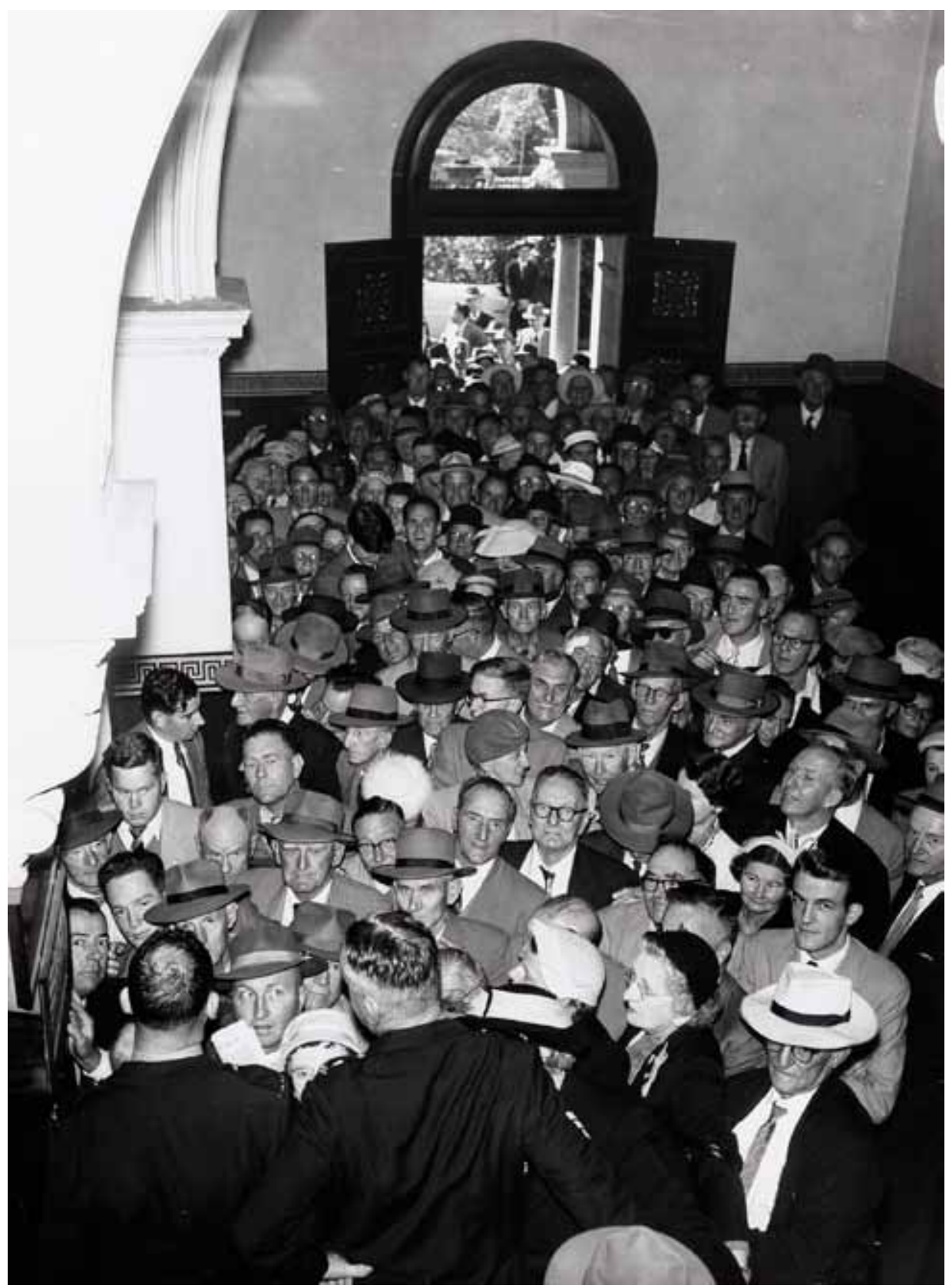

Image 3. Members of the public attempting to gain entrance to the public gallery to witness the fall of the Gair government in June 1957. 


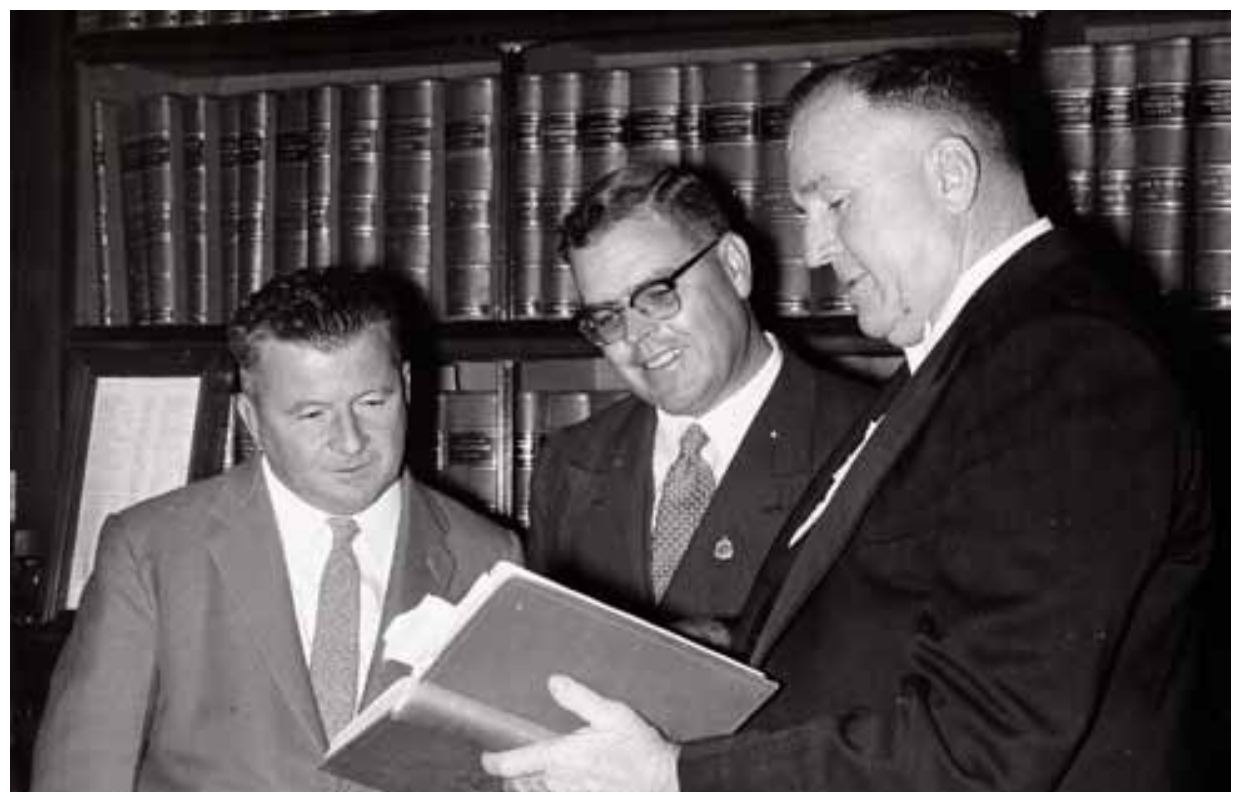

Image 4. On the eve of the June 1957 split, Labor's new deputy leader Dr Felix Dittmer (left) with the new leader Jack Duggan (centre) and the Speaker 'Johnno' Mann.

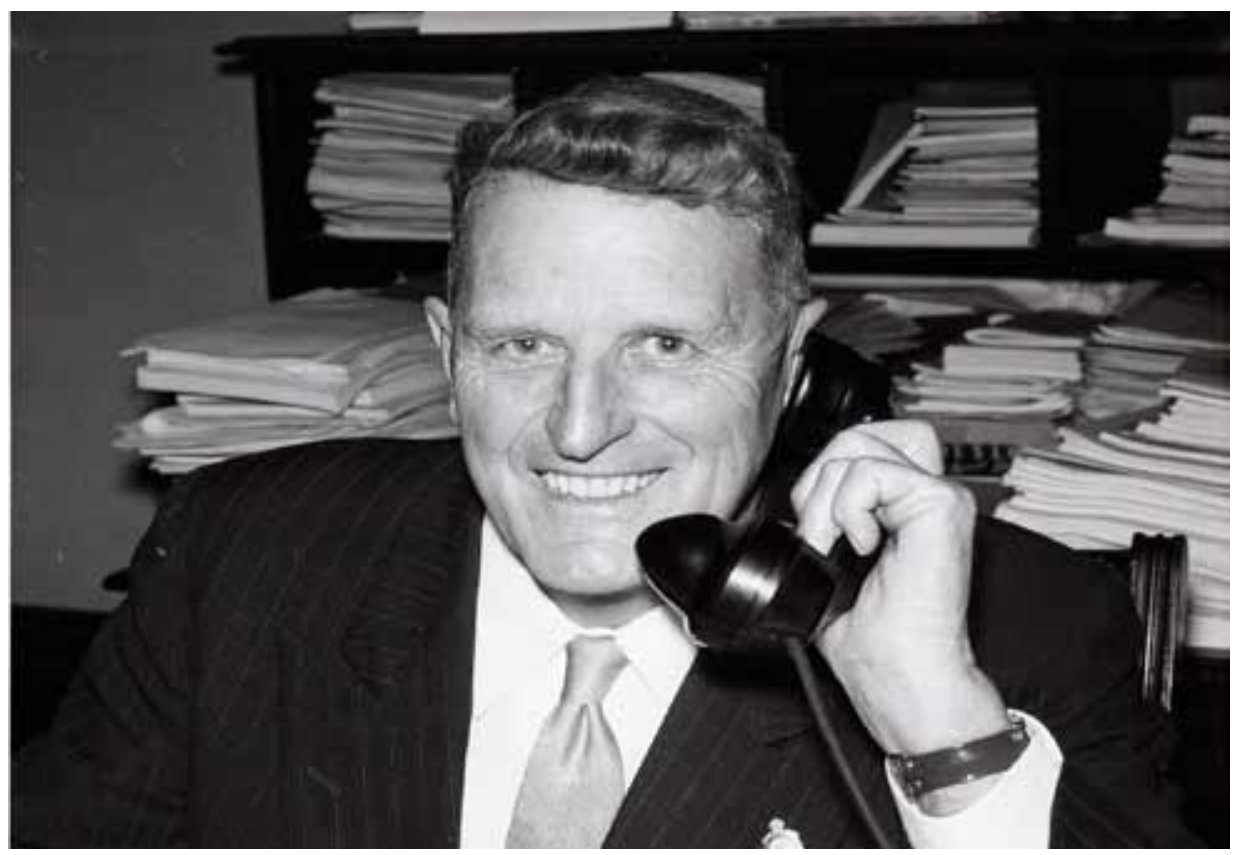

Image 5. Frank Nicklin, Leader of the Opposition in Parliament House June 1957. 
The Ayes Have It: The history of the Queensland Parliament, 1957-1989

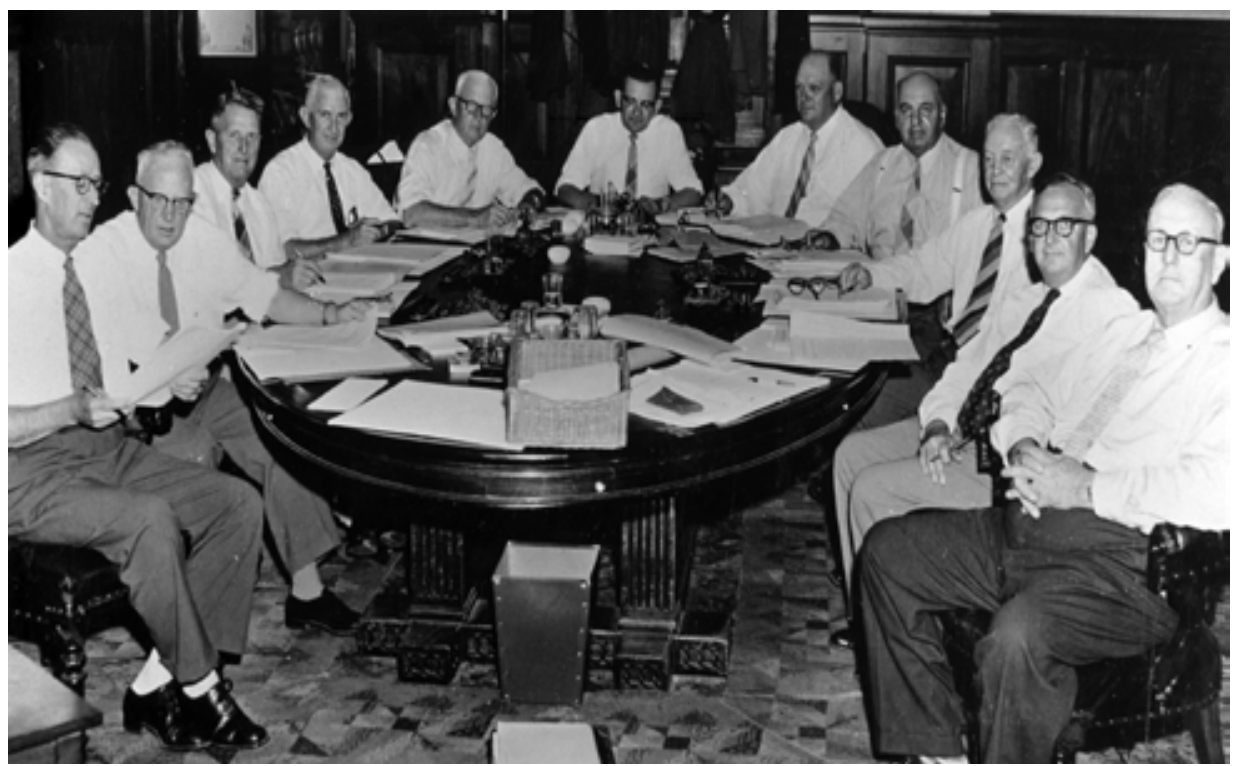

Image 6. Nicklin Ministry circa 1960s.

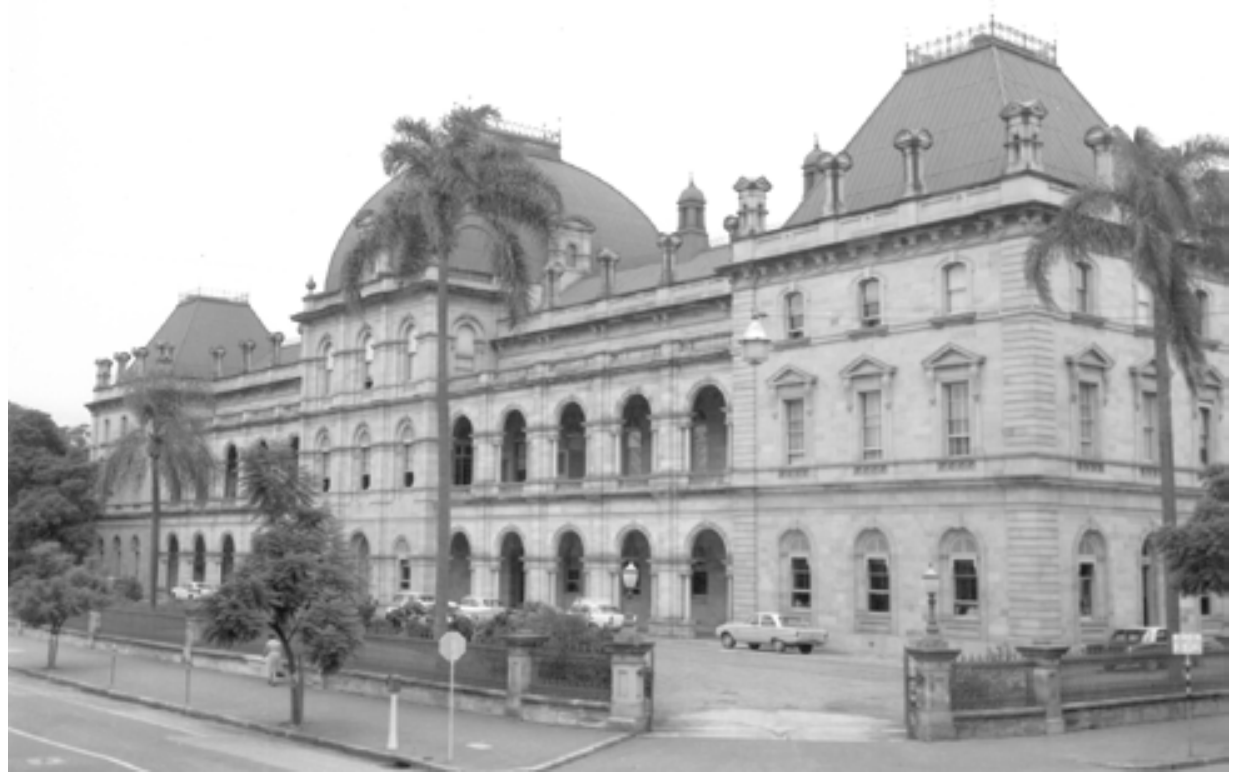

Image 7. Parliament House, circa 1960s. 


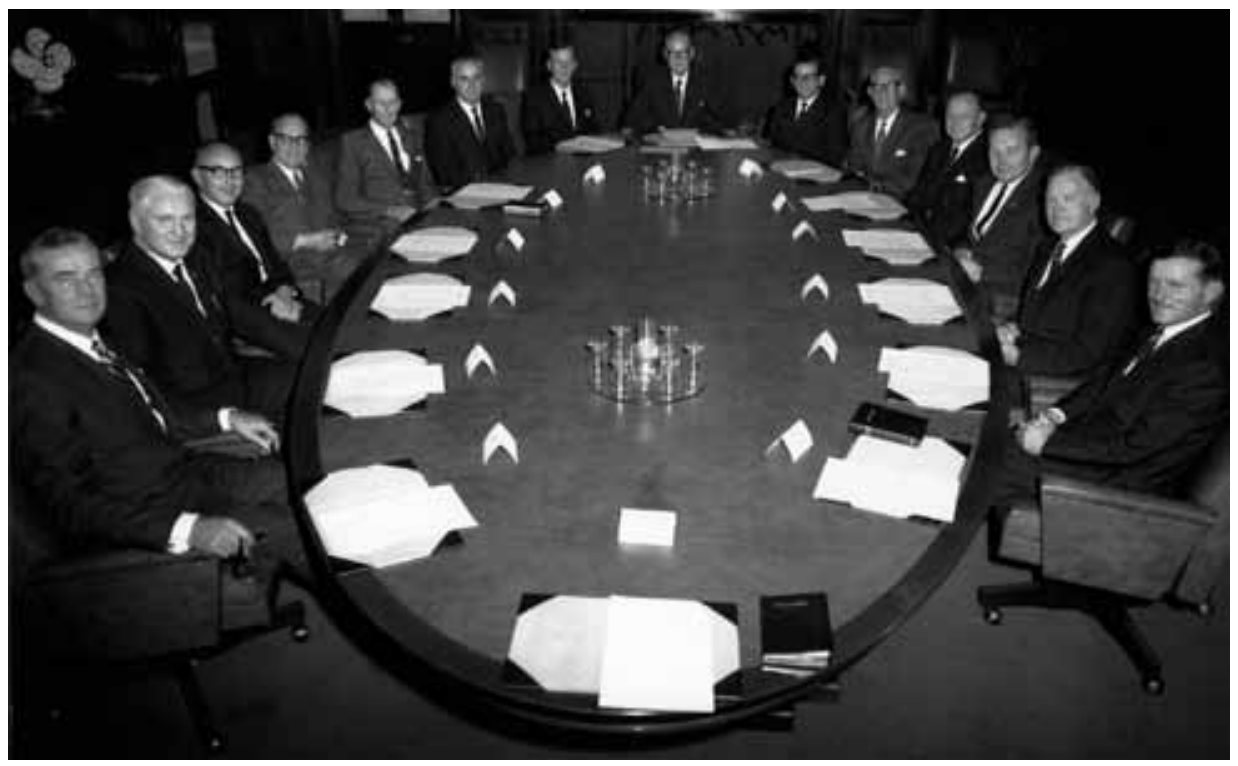

Image 8. The First Bjelke-Petersen Ministry in the early 1970s.

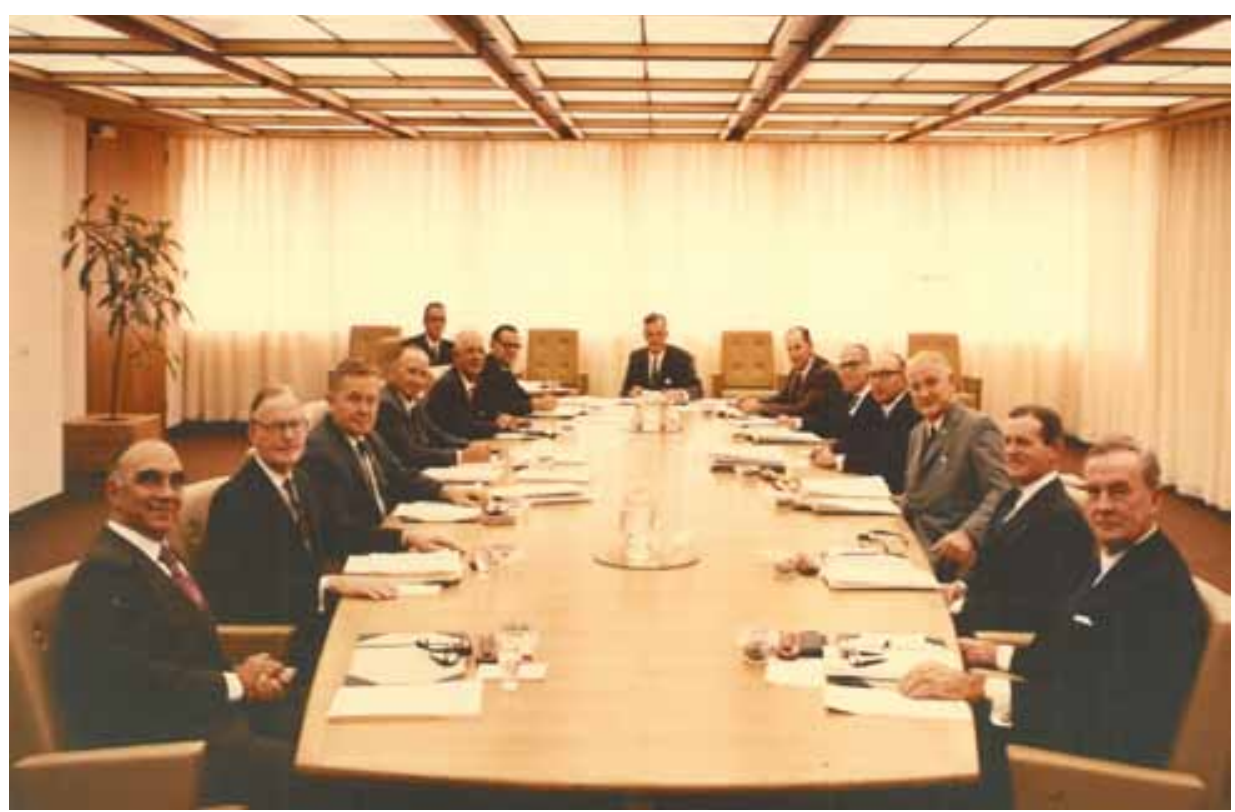

Image 9. The Second Bjelke-Petersen Ministry in the early 1970s. 


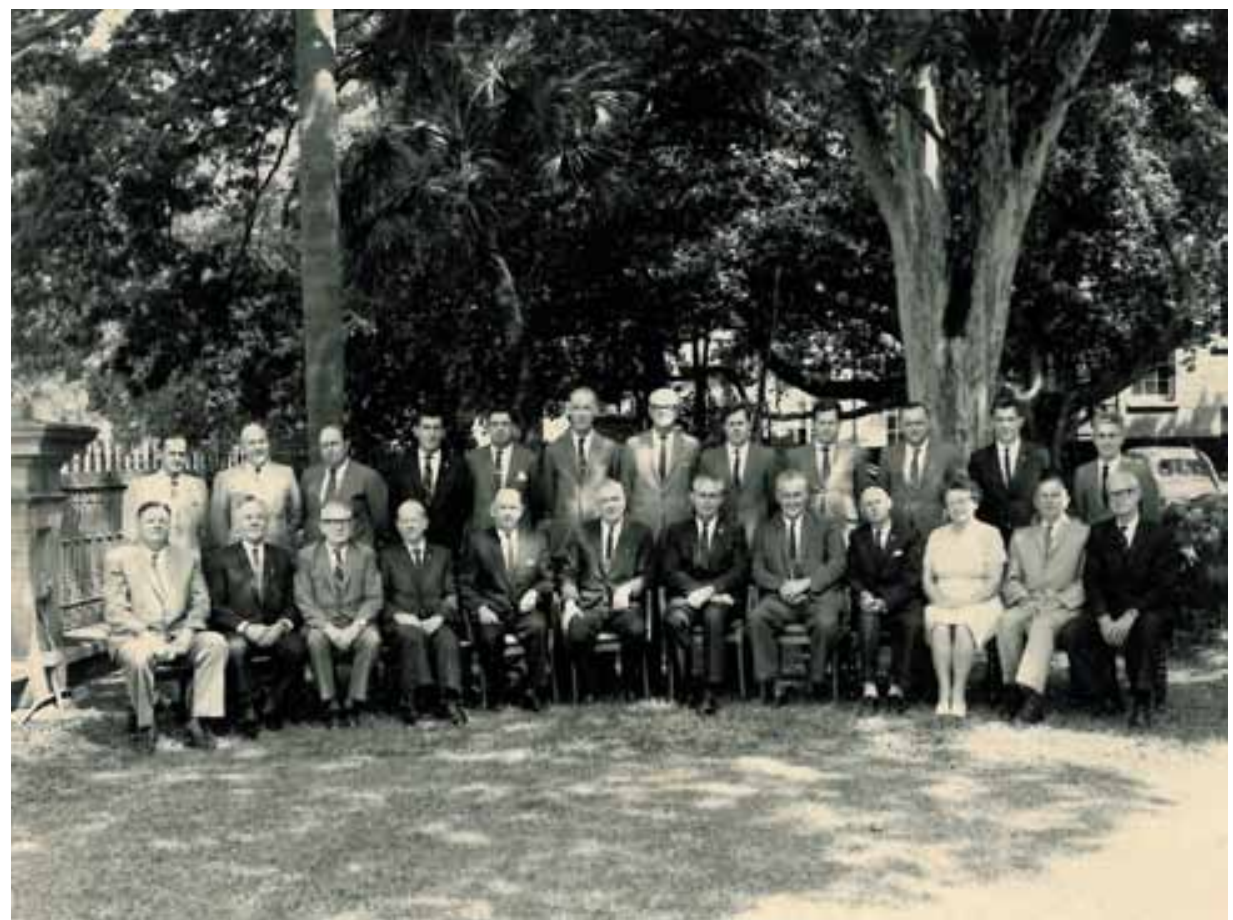

Image 10. The Opposition Leader, Jack Houston (seated centre), with some of the Opposition members circa 1971.

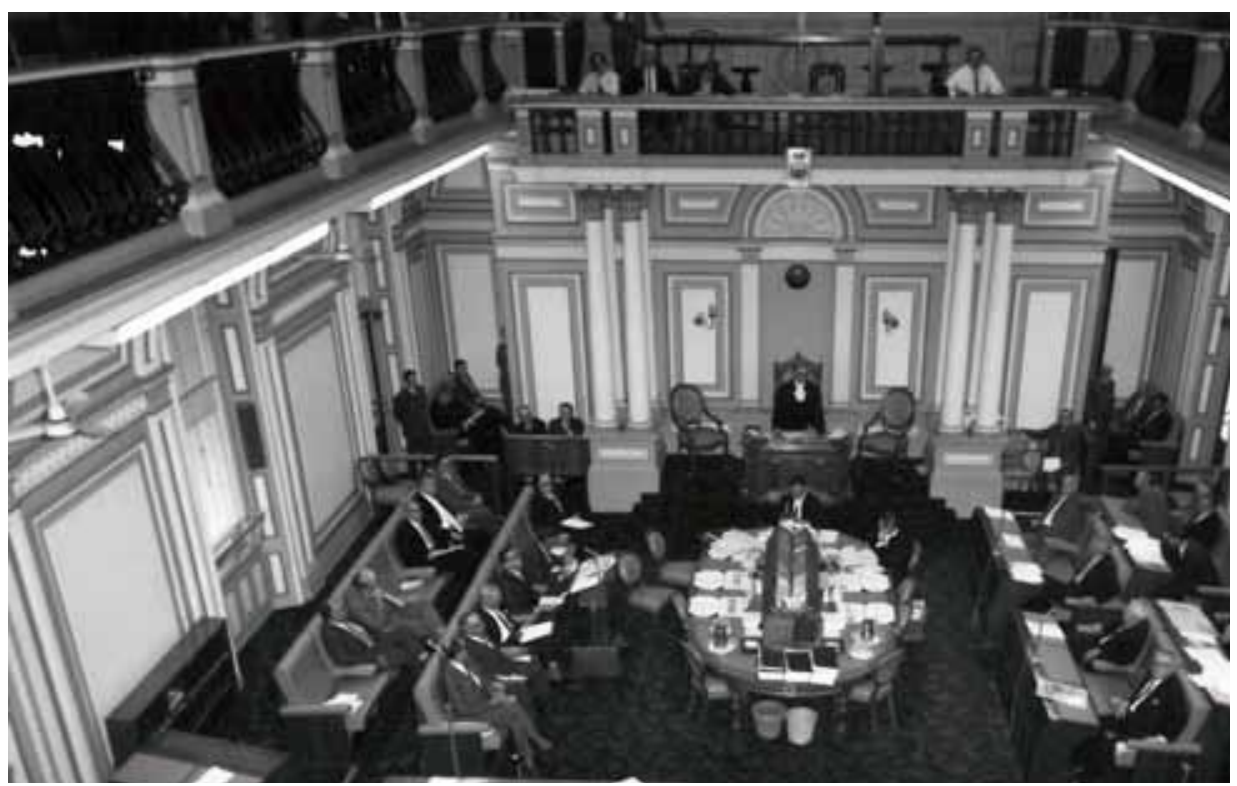

Image 11. The Queensland Legislative Assembly sitting in the early to mid 1970s, prior to the major restoration in the early 1980s. 


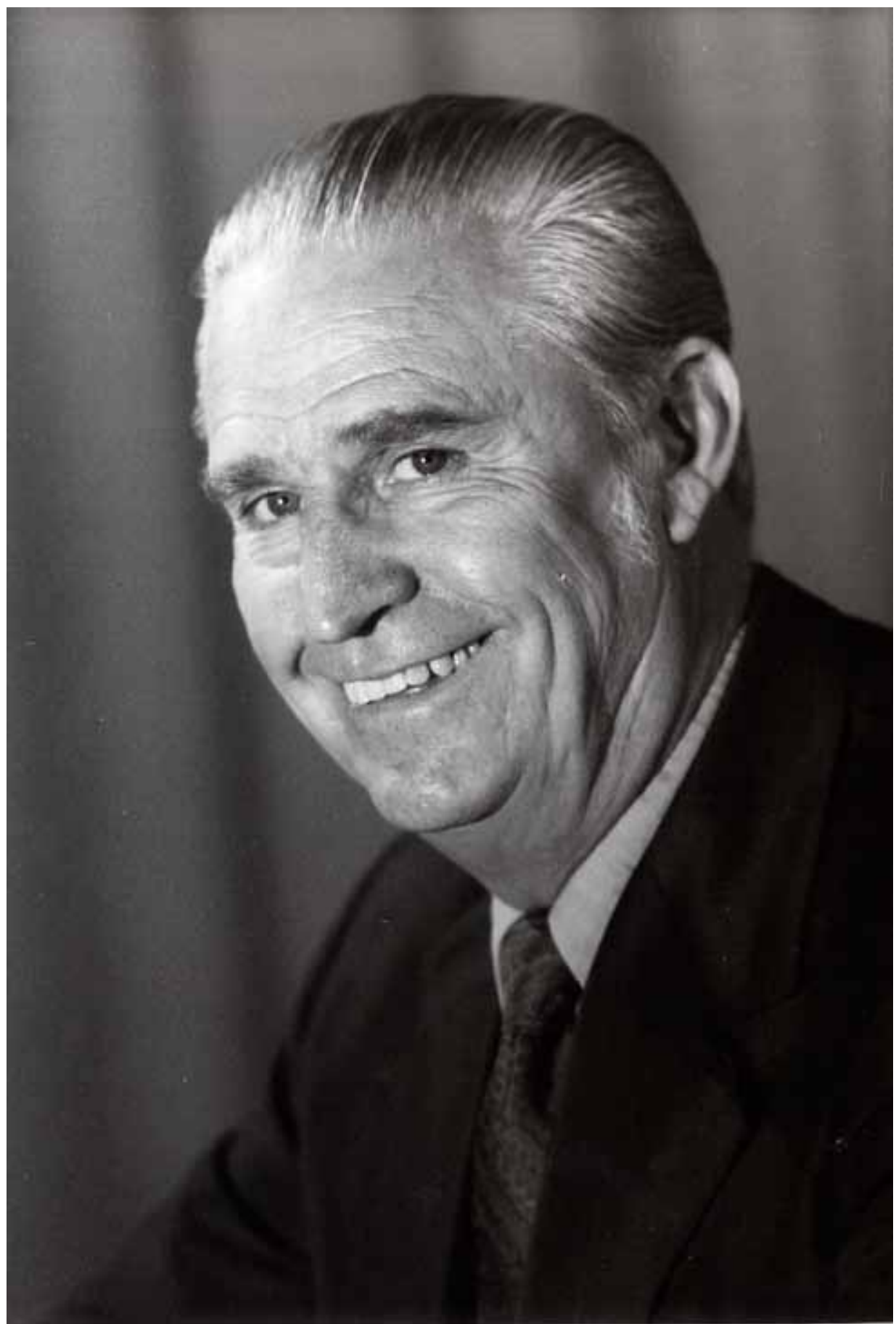

Image 12. Percy Tucker shortly before spectacularly losing the 1974 State election as Opposition Leader. 


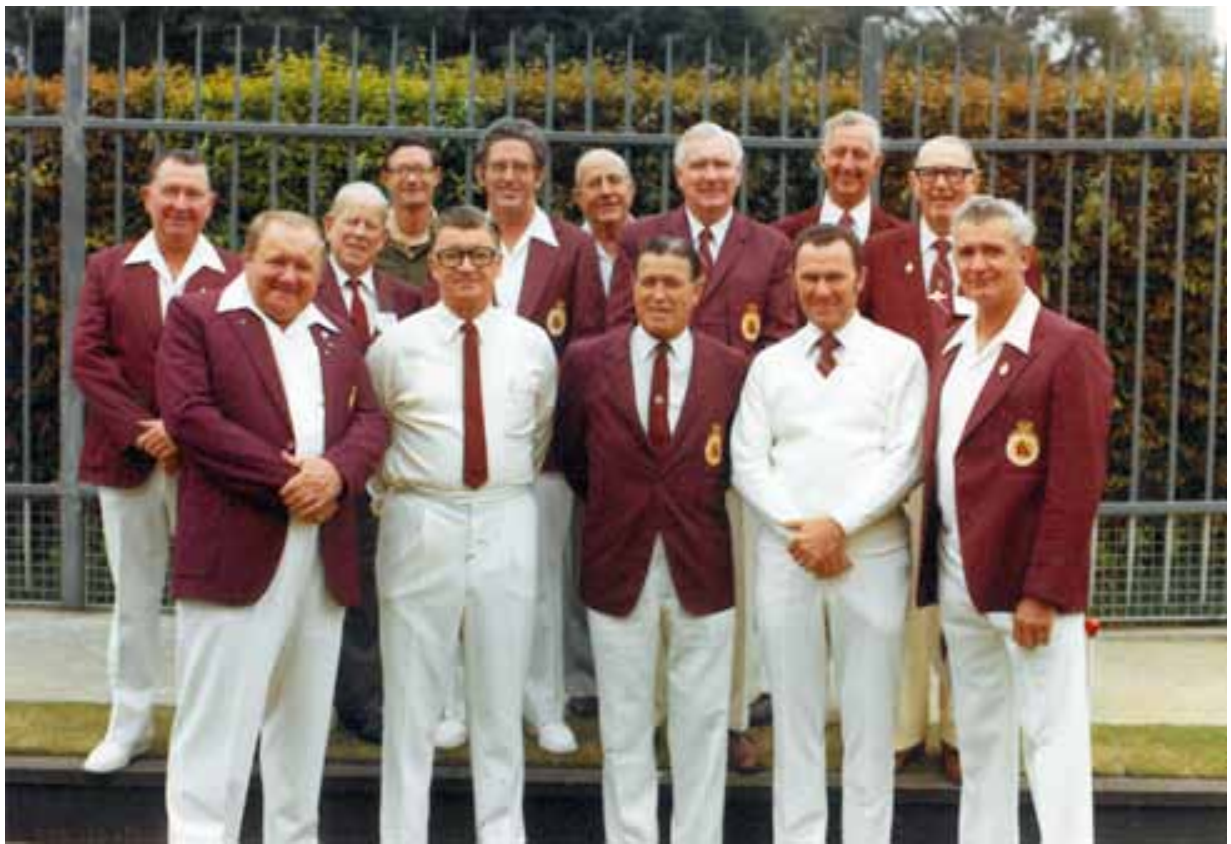

Image 13. The Parliamentary Bowls Team in full uniform in the late 1970s. Back row from left to right, Max Hooper, Harry Dean, Brian Davis, Sel Muller, Jack Houston, Col Miller and Roy Armstrong. Front Row: Lindsay Hartwig, Jim Blake, Bill Kaus, Ken Vaughan and Bill Glasson.

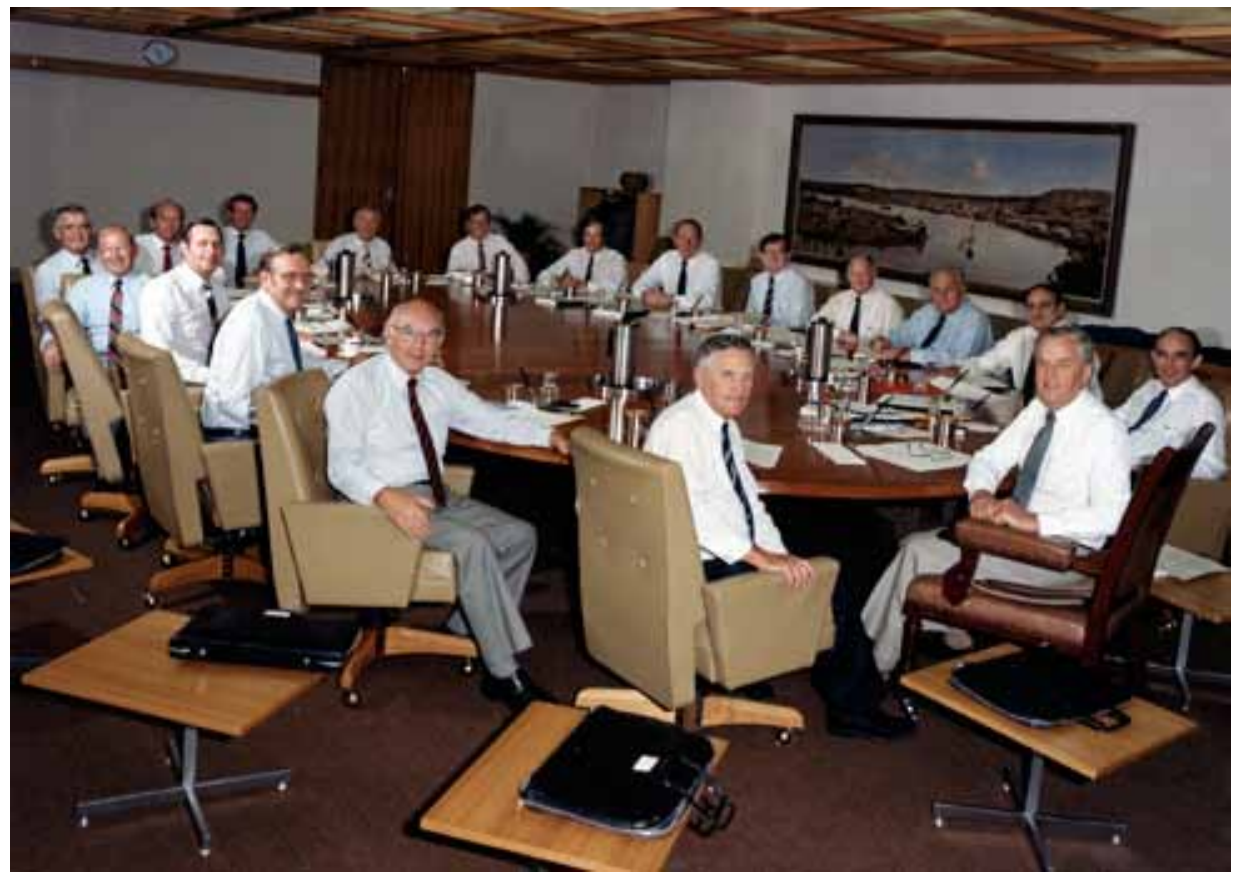

Image 14. The Sixth Bjelke-Petersen Ministry circa 1982. 


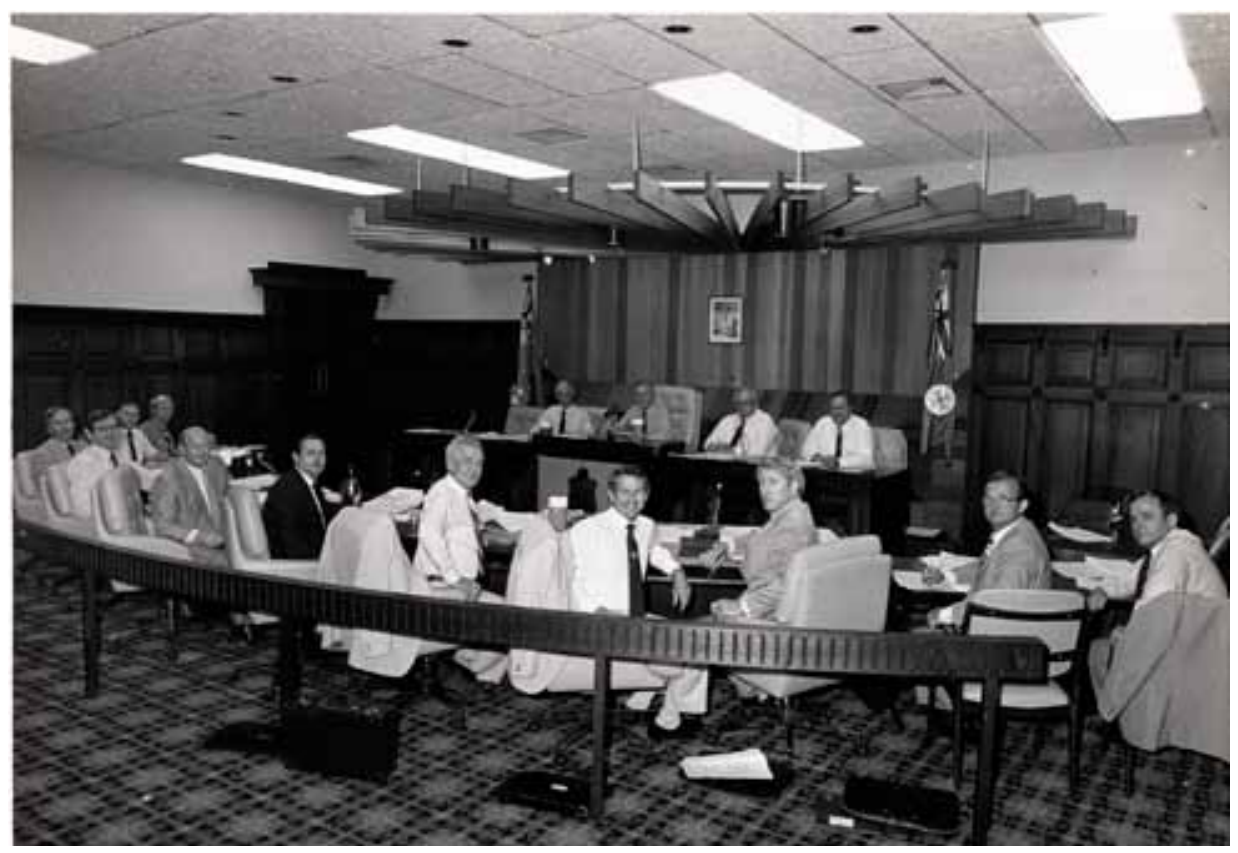

Image 15. The Seventh Bjelke-Petersen Ministry 1983, the so called 'Rump' Ministry composed solely of Nationals.

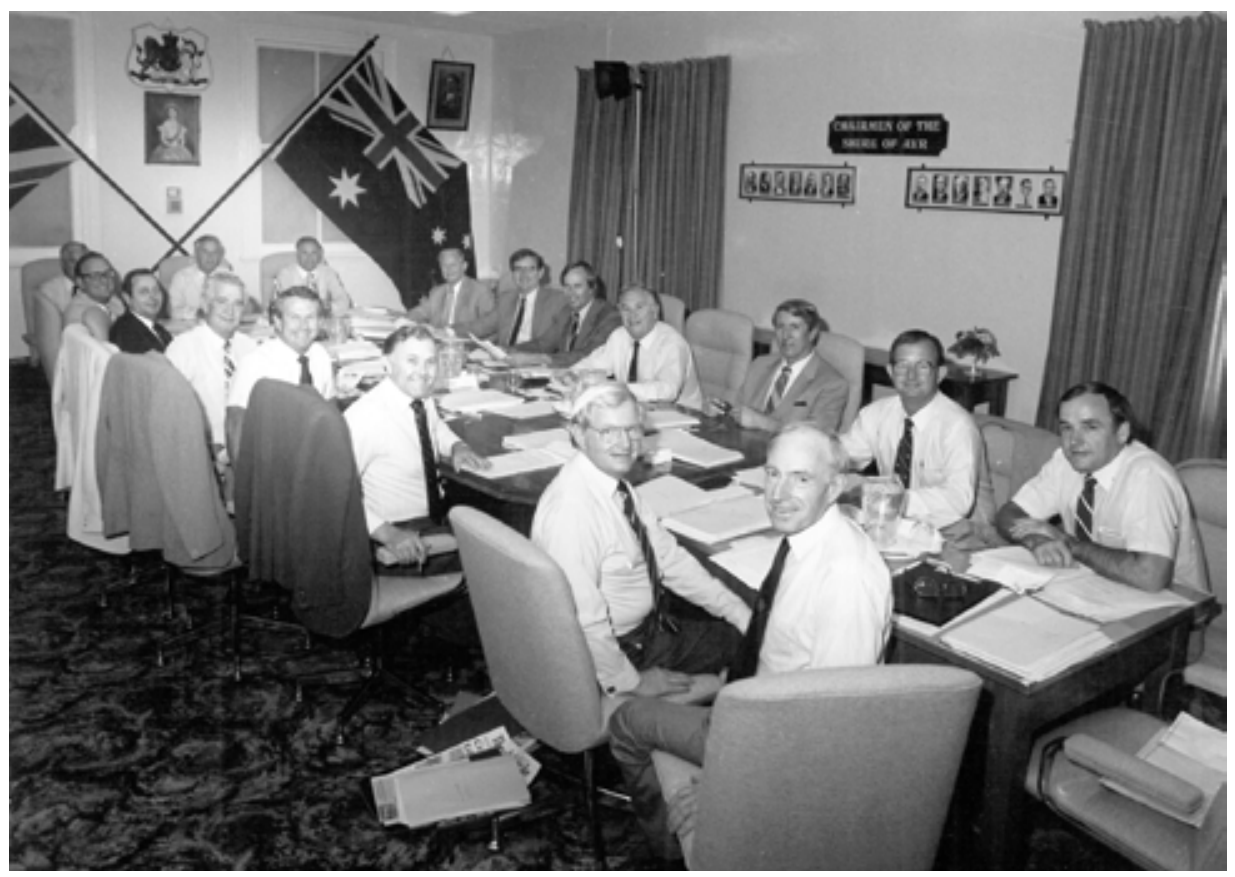

Image 16. The Seventh Bjelke-Petersen Ministry meeting at a country cabinet at Ayr, prior to the 1983 State election. 
The Ayes Have It: The history of the Queensland Parliament, 1957-1989

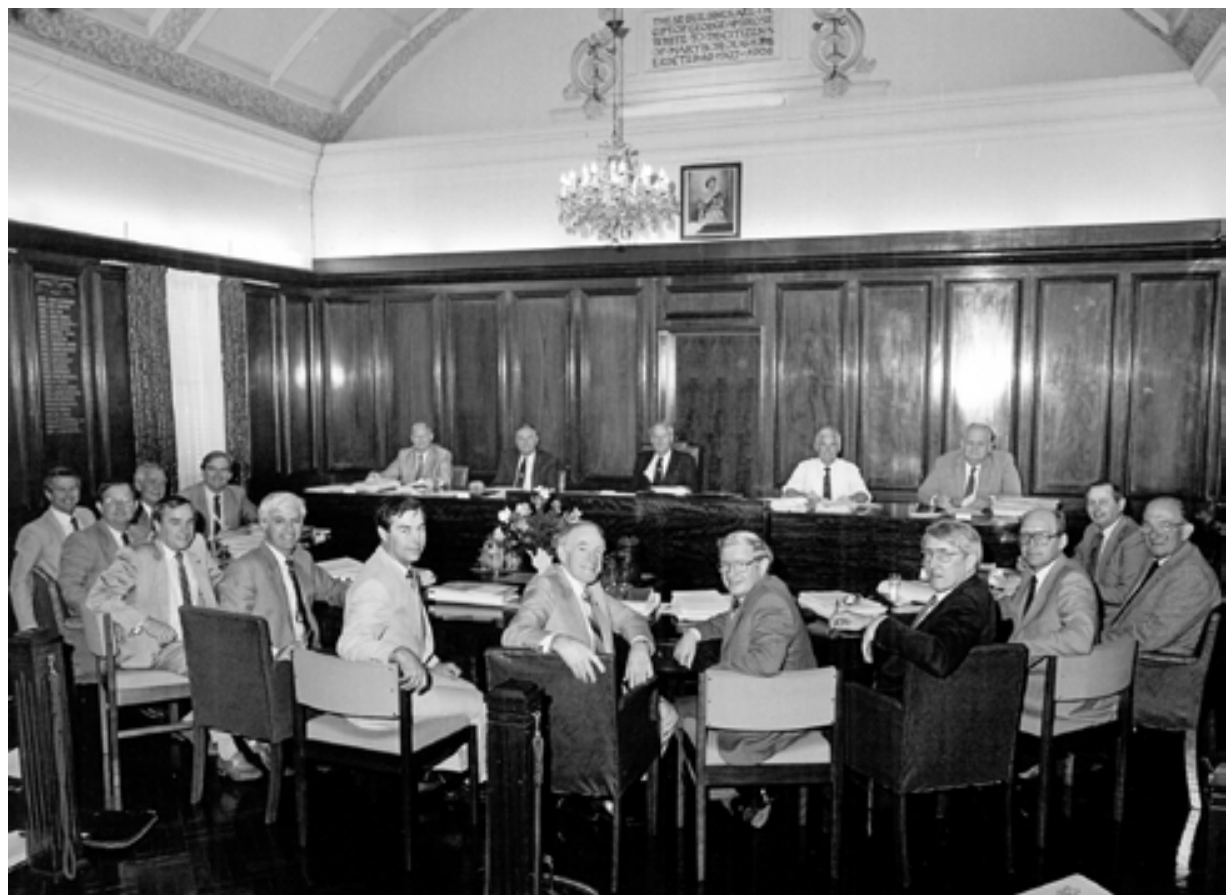

Image 17. A meeting of the Eighth Bjelke-Petersen Ministry at Maryborough circa 1984 or 1985.

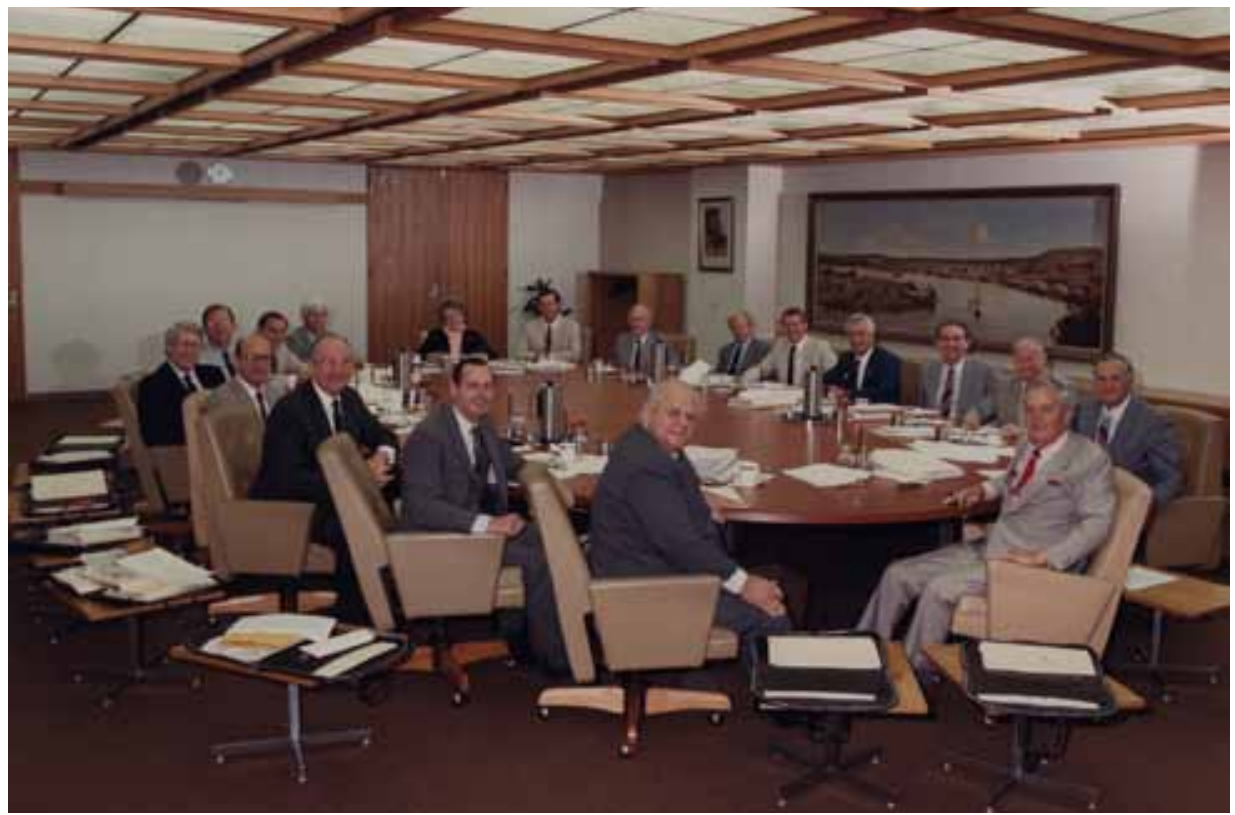

Image 18. The Eighth Bjelke-Petersen Ministry when the Nationals governed alone circa 1986. 


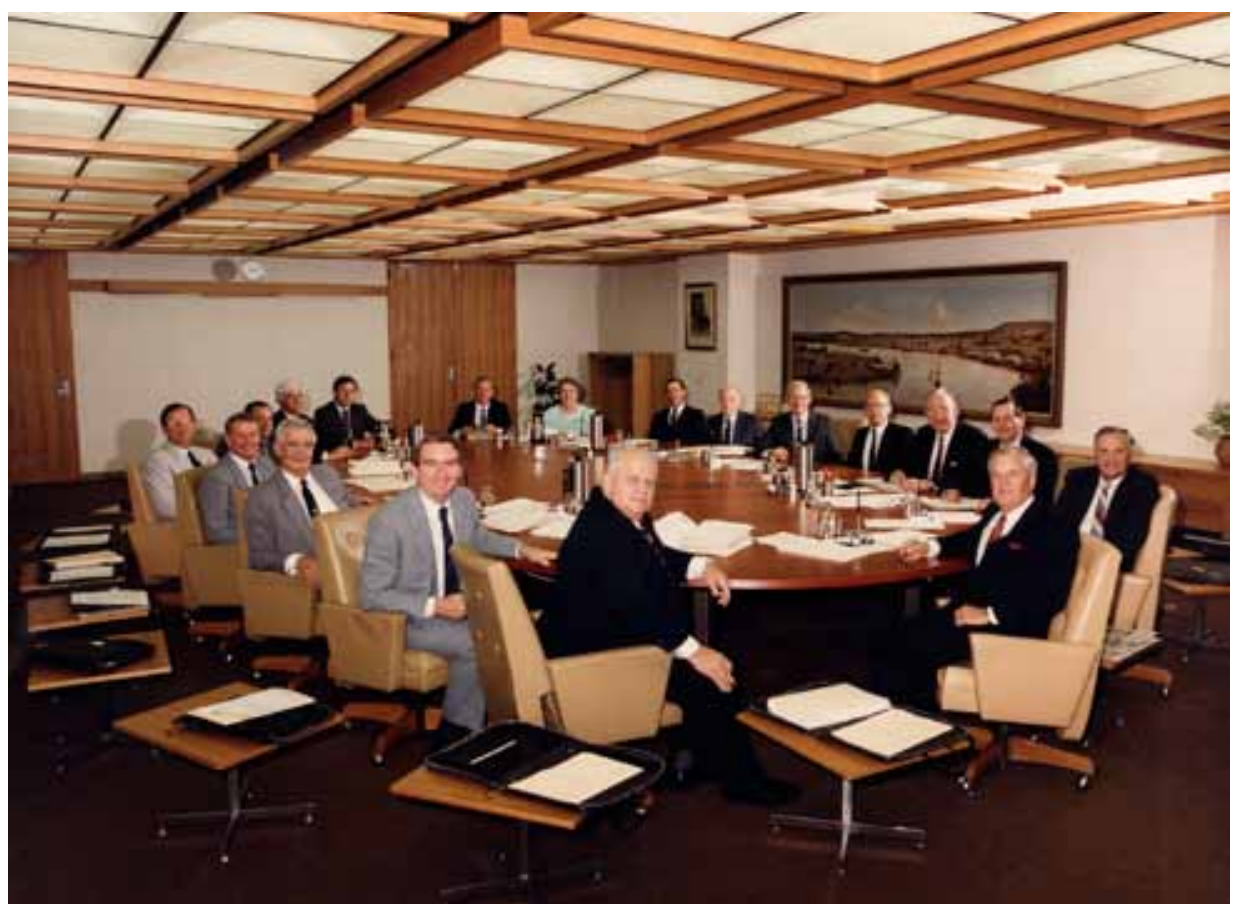

Image 19. The Ninth Bjelke-Petersen Ministry that lasted from December 1986 to December 1987.

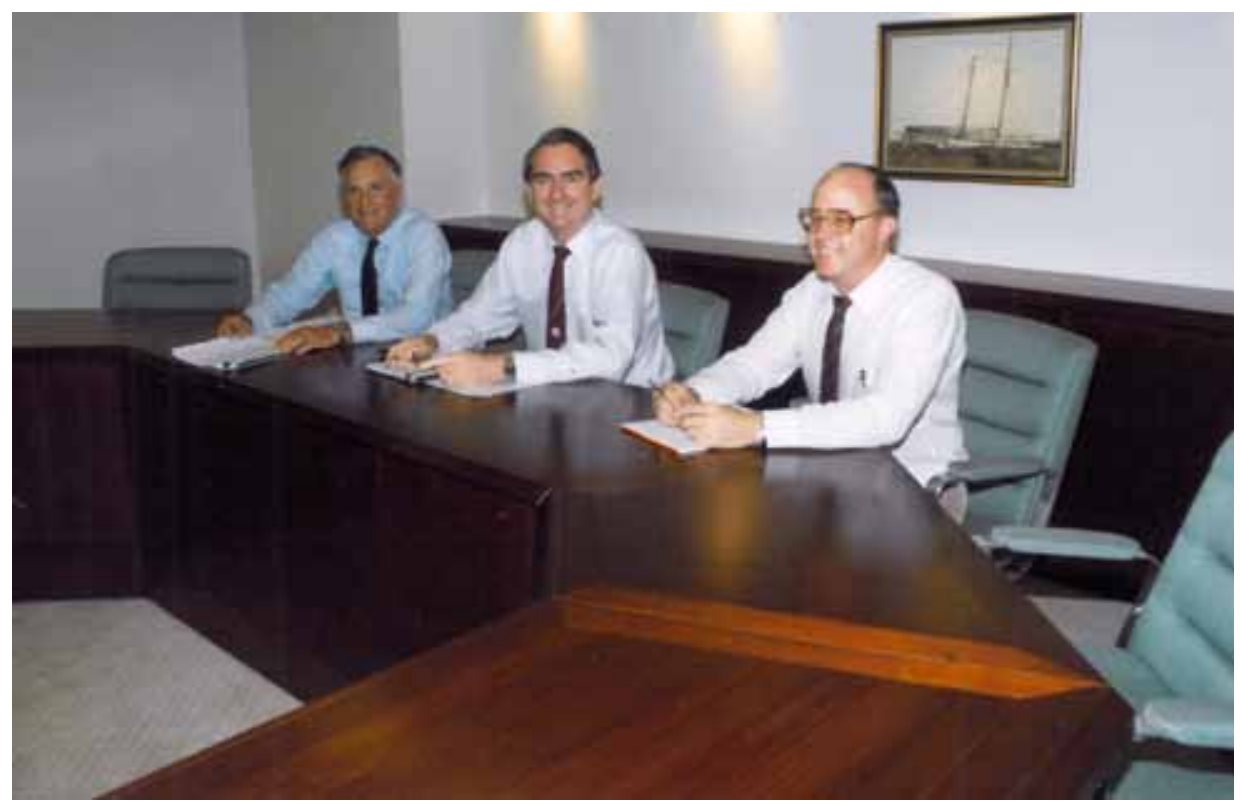

Image 20. The interim Ahern Ministry in 1987. 
The Ayes Have It: The history of the Queensland Parliament, 1957-1989

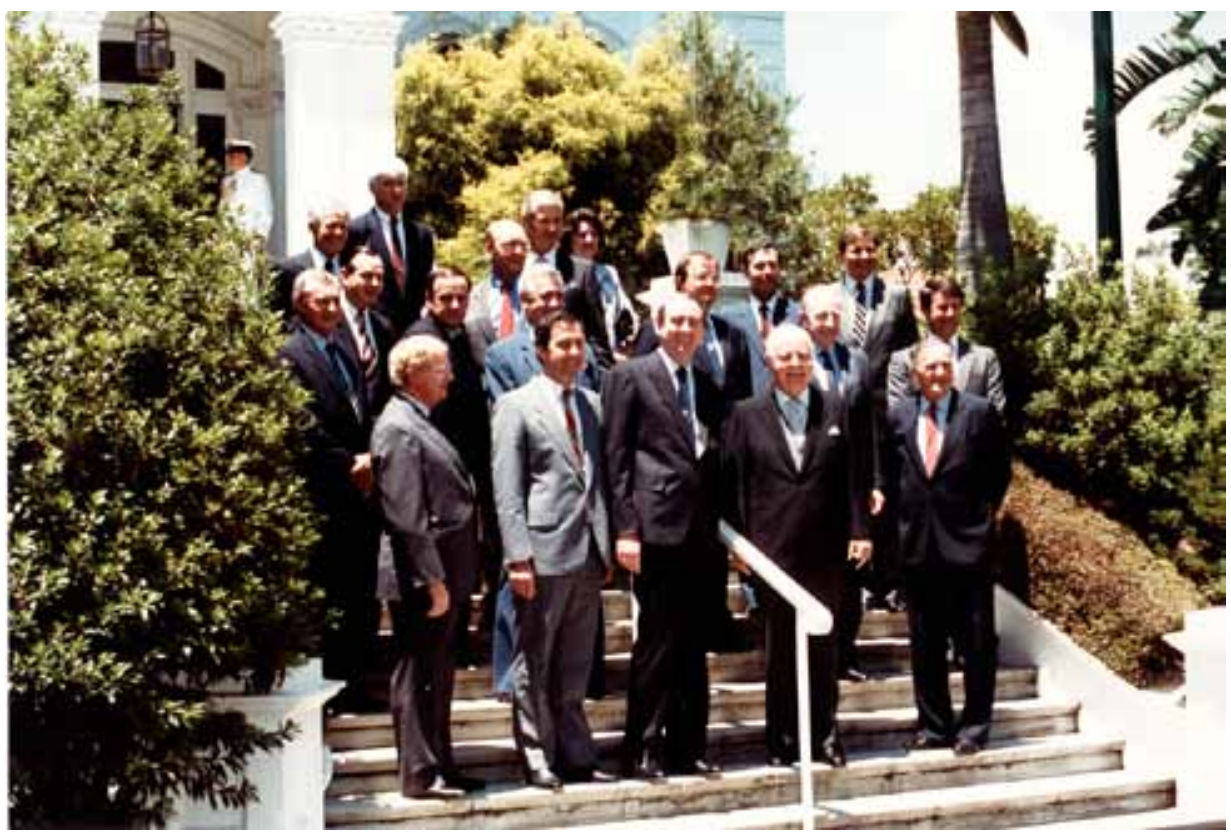

Image 21. The first Ahern Ministry after its swearing in with the Governor Sir Walter Campbell, December 1987.

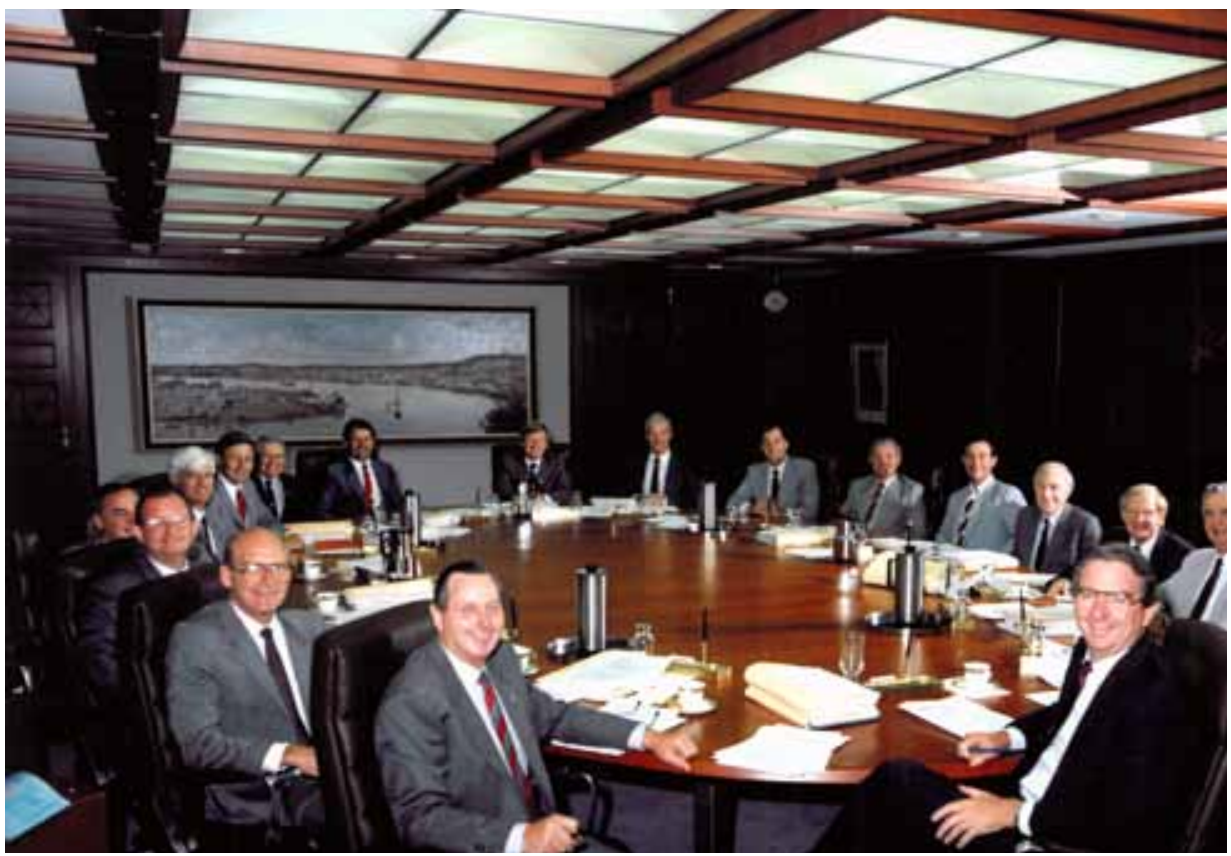

Image 22. The Second Ahern Ministry in 1989. 


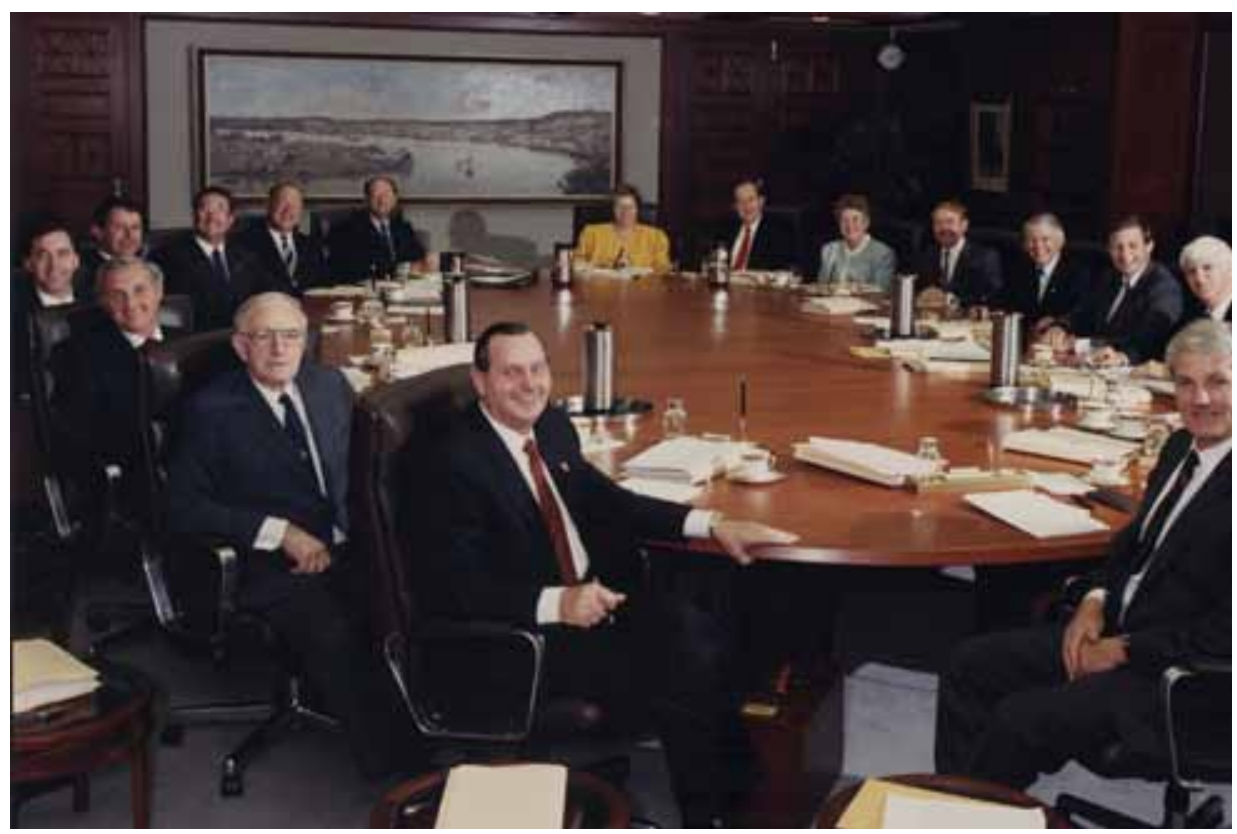

Image 23. The 18 member Cooper Ministry in September 1989, the first to contain two women cabinet members. 

Part II 



\section{The early Bjelke-Petersen years, 1968-1969}

The 'swinging Sixties' was a time of cultural change and challenge to the Establishment. Political protests and popular dissent took on a generational schism; social movements and mass demonstrations were inflamed by a distrust of government and a resistance to conscription and the Vietnam War. The 'New Left' was on the rise in university campuses. Student liberation seemed a potent force. 'Drop-outs' were in; hippies and flower power spread across the globe; and the drug culture and rock music became palliatives to the disenchanted. Assertive slogans came to symbolise a new generation: 'do it', 'free love', 'peace', 'make love, not war'. Meanwhile, in 1968, Czechoslovakia had been invaded by the Soviets, Paris was in turmoil with strikes and student protests, the Kennedy brothers and Martin Luther King, jr, had been assassinated and the Americans were preparing to land on the Moon. Pop songs plugged away at the themes of revolution, street-fighting men, the Age of Aquarius and emphasising the times they are-a-changing'. If Australia was somewhat shielded from the extremes of the 1960s, a postwar generation had now enjoyed full employment and come to expect a high standard of living as a right. The home, the Holden car and the Hills hoist were among life's little staples. The children born in the years after the war formed a huge wave of 'baby boomers' who by this time were entering adulthood and exercising their political expression and numerical strength.

In the social uncertainty and political turmoil of the late 1960s, Queensland appointed an abstemious, god-fearing Lutheran to lead the state into the 1970s. He was fifty-seven years of age and had been in the Parliament for 21 years by the time he became premier. Without a high profile, the new Premier was regarded as quiet and well groomed if a little of a 'country bumpkin' (Lunn 1984; Charlton 1983). The metropolitan press at the time presented him as a 'non-drinking, non-gambling Sunday School teacher' who was 'against just about everything' (Truth, 11 August 1968). Journalists produced long lists of activities he supposedly opposed (some came from his own mouth but others were allegations made by his political opponents). Included in this list were: trade unionism, the 40-hour week, long-service leave, gambling, the Golden Casket, wheels of fortune, drinking and divorce. In fact, many of Johannes Bjelke-Petersen's personal habits at the time were little different from his predecessors, but his self-righteousness and desire to inflict his own moral stance on others attracted comment. From the start, he created an impression that he was uncompromising on many political and social issues. To many observers, he soon became the object of ridicule and often his early statements 
invited derision. For instance, Lunn (1984:4), in his political biography, notes that Bjelke-Petersen regarded himself as 'the flying peanut' and when asked why he and not the African strongman Idi Amin was Premier of Queensland, he replied: 'Uganda had first choice.'

Yet, from the beginning of his premiership, Bjelke-Petersen showed signs of concern about his political image - a point often glossed over in some subsequent portrayals of his career. Lunn (1984:95-118), however, makes much of the claim that the Premier suddenly sought a 'new image' from 1971 after he fell under the spell of the media-savvy Allen Callaghan. There is some evidence, however, that Bjelke-Petersen had relied on significant journalistic advice before he hired Callaghan. Some time in 1969 he had engaged Hugh Bingham, previously from Rupert Murdoch's TheAustralian newspaper and a columnist in the Sunday Truth. Perhaps some of his initial concern was motivated by a desire to minimise his Danish ancestry or his New Zealand origins. He wished to be seen as a native Queenslander through and through, so initially he emphasised different versions of his name to suit his audiences. To newspaper readers of the Truth, for which he wrote a regular column (assisted by Bingham), he was plain 'Jo Petersen' — with a shortened 'Jo' and the 'Bjelke' dropped. He often used these columns to launch attacks on the opposition, as when 'Jo Petersen' claimed that his counterpart, Jack Houston, was merely a mouthpiece for vicious propaganda invented by the ALP's central executive (Sunday Truth, 9 March 1969). At other times, he was called 'Jo Bjelke-Petersen' by the same newspaper (Truth, 16 February 1969). In the Parliament, some members, as well as the daily Hansard, at first referred to him as 'Joe' Bjelke-Petersen with an anglicised version of Joh. ${ }^{1}$ Later, after he was more established and secure as Premier, he informed the Hansard staff that he preferred to be referred to as Joh whenever his first name was used.

Following his elevation to the Premiership, his parliamentary opponents were quick to seize on his perceived weaknesses or political shortcomings. Jack Melloy (ALP, Nudgee) greeted the appointment by stating:

[W]e have a new Premier, and to him I extend my congratulations and sympathies. I sympathise with him on three counts. In the first place, he is a member of the Country Party, which is doomed to destruction by the Liberal Party, so consequently his tenure of office as Premier cannot be a very lengthy one. I also sympathise with him because he has breathing down his neck all the time the de-facto Premier in the person of the Treasurer...I sympathise with him, too, because his principles are strangely out of place in this coalition Government. I do not think that

1 For example, Reg Pilbeam (Lib., Rockhampton South) in QPD (1968:vol. 249, pp. 15, 471). 
his colleagues can conform to the standard of principles of the Premier, and I think they are going to cause him many worries during his term of office. (QPD 1968:vol. 249, p. 171)

Such initial assessments of Bjelke-Petersen focused on the issue of whether he was the right leader for the times, whether he had the appropriate image and the political astuteness to survive as premier. His reception was certainly a mixture of some goodwill and considerable scepticism and criticism. Among his own side of politics, he made a better start principally because he enjoyed the broad support of his own party and quickly gained the acceptance of his Coalition partners. Chairing his first joint-party meeting as Premier, he apparently told all Coalition parliamentarians that 'I don't want you to work for me, but work with me' (Bill Hewitt, Personal interview), suggesting that initially he intended to pursue a cooperative approach on policy issues and Coalition politics. Whether this initial preference for cooperation was meant genuinely or was motivated by the uncertainty of his fledgling leadership remains the subject of some speculation. His pronouncements so shortly before the next election were, however, taken as evidence of his intention to reassure the public that his government operated on the principles of collective solidarity.

His deputy, Gordon Chalk, was, however, more measured in his initial assessment of the new Premier. In a long press interview in February 1969, he was asked a question about whether, after his close relations with Nicklin and Pizzey, the 'going would be tougher' under Bjelke-Petersen. He gave a lengthy but considered reply:

[Y]ou will recall that with Mr Nicklin I was his junior in every direction. He had much more experience as leader, yet he did consult with me on many occasions for advice. Working with the late Mr John Pizzey was quite easy. He left quite a lot of the administrative and financial side to me. Dealing with Mr Bjelke-Petersen has been slightly different. $\mathrm{Mr}$ Petersen, I know, has a major responsibility to the Country Party and there were people who said at the time he was elected [to the Premiership] that he had not had the experience of leader, and that would be true, because he had neither been a Deputy nor had he held the Premiership. Consequently there have been a few matters in which I have tried to guide Mr Petersen, but because of the fact that he has felt my views do not coincide with his, he has exerted his right as Premier to follow a particular line of thinking. Now this is not a question of us having a major disagreement but rather it is, I think, an instance of two leaders having different opinions and the Premier feeling that as he represents the major party his views must come first...It is true that both of us 
possibly are a little strong willed. On the other hand both of us have responsibilities to our parties and I suppose you can say there is a little politics in it. (Truth, 16 February 1969)

Although Chalk regarded Bjelke-Petersen as strong-willed, other assessments of his early days suggested he was weak and indecisive. Colin Hughes surveyed a history of state premiers, contrasting those who were weak with the strong. In Hughes' (1980:174) assessment, Bjelke-Petersen was initially a weak premier, but then became a strong one through circumstance and the force of his personality. Such initial assessments, however, did not anticipate the native cunning and utter ruthlessness Bjelke-Petersen would bring to the job.

\section{Bjelke-Petersen's first ministry: holding the fort}

In the first week of August, the Country Party was determined to wrest control of the ministry back from the Liberal leader, Gordon Chalk. Joh Bjelke-Petersen emerged from the party meeting as the nominated leader. He was at the time their most senior minister and had many favours owed him by his colleagues as a result of his time as Minister for Works and his tireless election campaigning for party colleagues in more marginal seats. Equally, however, the party saw Bjelke-Petersen as a stopgap appointment, someone his colleagues felt was deserving of the top job but who would not stay around long with younger pretenders such as Camm anxious to displace him. Bjelke-Petersen saw his main chance materialise because the Country Party had to have a nominee they could support unanimously and thereby deny Chalk the Premiership. Looking down the barrel of the gun, the Country Party members voted 20-six to nominate Bjelke-Petersen to the Premiership, and then once the vote was resolved, declared their candidate had unanimous support. Bjelke-Petersen quietly assumed the Premiership of Queensland on 8 August along with his first ministry of 13.

- Premier and Minister for State Development: Joh Bjelke-Petersen, CP

- Treasurer: Gordon Chalk, Lib.

- Minister for Mines, Main Roads and Electricity: Ronald Camm, CP

- Minister for Justice and Attorney-General: Dr Peter Delamothe, Lib.

- Minister for Education and Cultural Activities: Alan Fletcher, CP

- Minister for Local Government and Conservation: Harold Richter, CP

- Minister for Primary Industries: John Row, CP

- Minister for Health: Doug Tooth, Lib.

- Minister for Labour and Tourism: John Herbert, Lib.

- Minister for Transport: William Knox, Lib. 
- Minister for Industrial Development: Frederick Campbell, Lib.

- Minister for Lands: Victor Sullivan, CP

- Minister for Works and Housing: Max Hodges, CP

Camm kept his portfolio of Mines, Main Roads and Electricity but was promoted in the ministry to third place. Every other serving minister retained their existing portfolio, with the new minister, Max Hodges (CP, Gympie), taking responsibility for Works and Housing - a department that dropped in the changeover from third place to lowest in the ministry.

The third session of the thirty-eighth Parliament resumed 12 days after the new Premier was sworn in. The session opened on 20 August to debate the Address in Reply and ran to 11 December 1968 - a total of 51 sitting days. The main business of the session was twofold: to receive the Governor's opening speech and debate the Address in Reply and then allow the government to present its budget to begin the supply debate. In the opening speech, the Governor, Sir Alan Mansfield, offered condolences over the deaths of Jack Pizzey and Sir Alan Munro. He noted that the new session marked the start of the 'second century of Parliament's occupancy of this House' (QPD 1968:vol. 249, p. 1). After praising effusively the state's earlier pioneers and people for their contributions to the society, and listing the contributions of various industrial sectors, the Governor introduced the government's forthcoming agenda. Significantly - and paradoxically in the context of later perceptions - the new government stressed the importance of knowledge as the key to the state's future. The government took the view that 'education must continue to receive top priority in the years ahead' (QPD 1968:vol. 249, p. 3). Education was not, however, an end in itself; rather, it was intrinsically related to the development and occupation of the state by the residents. The Governor put the government's position cogently:

Our University, institutes of technology, technical colleges and teachers' colleges will continue to expand and develop to meet the growing needs of this State. The application of knowledge, special training, skills, and abilities is becoming increasingly important in all avenues of production, and managements as well as messenger boys must now lift their educational sights if they wish to succeed. As one of the sparsely populated parts of the earth Queensland is going to attract covetous eyes as the world's population explodes over the next 100 years, and succeeding generations may find it difficult to retain sole possession unless we and they exert every effort of a positive nature to settle and productively employ this domain. Morally our tenure of the country will become indefensible unless we can show before many more years are out that we have undertaken great works of development and settlement; that we are moving in expeditious and realistic fashion to eradicate the perennial spectre of devastating drought; that we are conserving and 
developing our very great natural assets in a fashion which will ensure that Queensland will actually become a home in the foreseeable future for a vastly more numerous population. (QPD 1968:vol. 249, p. 3)

The new government committed itself to achieve a 'well-balanced development' of the various state industries in the allocation of capital and recurrent expenditure. Not surprisingly, the speech highlighted several concerns of primary producers: a new wheat agreement and dairy reconstruction plan were pending, wool prices were depressed but expected to rise and the failure to renew the International Sugar Agreement was mentioned as a particular worry for the government. In line with the government's 'agrarian socialist' approach of subsidising primary producers, the Governor announced that 'the compensating of rural industries for losses incurred through the Commonwealth's decision not to devalue currency will continue to be closely watched by my Ministers' ( $Q P D$ 1968:vol. 249, p. 3).

In concluding the speech, the Governor listed the legislation the government intended to introduce in the session. Four items were mentioned: a bill to provide for a Law Reform Commission, a bill for a Mining Act, amendments to the Forestry Acts and a bill to amend the NSW and Queensland Border Rivers Act of 1946. In relation to the first, the Governor stated: 'my Government considers that the systematic development of the State's law, with a view to its codification, the elimination of archaisms and anomalies and its reform, should be entrusted to a permanent body' (QPD 1968:vol. 249, p. 4).

Treasurer Chalk introduced the budget on 26 September 1968 by saying that the state's recent drought was over and prosperity was set to return to Queensland. He titled his third financial plan as 'Queensland's march to progress' budget, describing it as 'a progressive budget of which the State will have reason to be proud' (QPD 1968:vol. 249, p. 593). Presented in a new 'attractive' format, the budget wiped out the previous year's deficit and promised a modest surplus. Chalk informed the House that his

desire has been to make the Tables more meaningful to the Committee [of Supply] and to assist Honourable Members and Queenslanders generally to a better understanding of the budget. I want to say to the Committee that I would be happy to consider a further review of the Tables next year, should it consider that a further alteration in presentation would be helpful. After all, this is the most important document presented to Parliament during any session and it is my sincere desire to present it in such a manner, that it can be fully understood by every citizen who desired to devote time to its serious consideration. (QPD 1968:vol. 249, p. 593) 
The Treasurer was able to deliver tax cuts (freight rate concessions for primary producers, succession duties and land tax exemptions), while increasing spending on education by almost 20 per cent, increasing capital works and providing extra police. The government also provided increased subsidies for non-government primary and secondary schools to $\$ 25$ a student. Salary ceilings on senior public servants were also lifted in an attempt to attract and retain administrators of high calibre or with professional qualifications. The Courier-Mail (27 September 1968, p. 2) labelled the document a 'budget of good cheer' that was 'attractively presented, both in the simple and clear financial statement and in the new form of the tables'. It hailed Chalk as the state's latest 'pin-up boy'.

As the Parliament resumed, it became clear that the talks would restart over the International Sugar Conference in Geneva (held under the United Nations Council on Trade and Development, UNCTAD). On 29 August, the Premier, in answer to a question in the House, announced he would be attending the forthcoming conference in October. His announcement indicated the Australian Deputy Prime Minister, Jack McEwen, would head the delegation with BjelkePetersen as deputy leader representing 'the Australian Sugar Industry' along with a host of other industry representatives and advisers from sugar producers. The Premier made no mention of representing the Queensland government, only the sugar industry. And, like many of his later sorties on behalf of major industries, his involvement attracted controversy.

On 25 September, Ray Jones (ALP, Cairns) attempted to ask a question on notice to the Premier about the sugar conference but was prevented by the Speaker, David Nicholson, after consultation with the Premier. The intended question had been given to the Speaker earlier that day as required under Standing Orders but was not included on the day's Business Paper on the grounds it was 'ruled out of order'. Jones tried to have the matter raised the next day, but was again ruled out of order by the Speaker, who advised that the question could be put in another form. Jones responded on 26 September by challenging the Speaker's ruling and attempting to debate whether the question should be put to the Premier. The incident led to a long and vitriolic interchange between the Speaker and Jones, with the former persistently insisting the latter was out of order and defying the chair and Jones equally adamant he should be heard and that the Speaker was at fault. Despite Jones not being able to ask his question formally, it is clear from Hansard that the question concerned some earlier press statements speculating on 'what effect certain things would have on Australia's representation at the International Sugar Conference' (QPD 1968:vol. 249, p. 583).

Jones, however, was quickly silenced and the exasperated Speaker felt obliged to name the member for disobedience of a ruling of the chair. Even after the 
member was named and about to be expelled, however, the Speaker offered a conciliatory gesture by giving Jones the opportunity to apologise. The Premier also urged the member to reconsider and 'express his regret' to the Speaker. The Speaker told Jones that 'I am prepared to withdraw the naming of the hon. member provided he apologises to the Chair and obeys the Chair's orders in future' (QPD 1968:vol. 249, p. 583). Jones refused, yet again trying to be heard, and put the question in its original form. The Premier moved for the suspension of the member for the rest of that morning's sitting (until 2.15 that afternoon) and, over an unruly opposition, the Speaker attempted to have the motion accepted but was forced to call a division and vote on the motion. The vote on the Premier's motion of suspension was carried on party lines with 34 for the motion and 25 against. By the time the vote was taken and with lunch approaching, Jones was effectively suspended for about two and one-half hours. At lunchtime, the Parliament was suspended for more than one hour and shortly after adjourned until 15 October; Jones did not miss much of the Parliament's business.

One month later, on 22 October, Jones managed to work his original question into his contribution to the supply debates (where it would go on the record but not be answered by the Premier). To the taunts that he 'got the old song "Bye, Bye, Blackbird"' (that is, he was expelled for the day), Jones read into Hansard the wording of his question - including the offending preamble. His question to the Premier concerned three points: the threatened withdrawal of the American delegation from the conference; the reports of a reduction in sugar mill production in 1969-70; and 'the announcement of Dr Prebisch-he was Secretary of the United Nations Conference on Trade and Developmentconcerning reductions by up to 28 percent in the production of free market sugar'. His preamble stated:

On the eve of his departure for Geneva next Saturday, is he [the Premier] able to allay the fears apparent, in one of Queensland's major primary industries, regarding these statements, and grant assurance for the preservation of the State's future sugar production at a level not below the aggregate of the present mill peaks? (QPD 1968:vol. 249, p. 879)

Bjelke-Petersen, conscious of some disquiet among sugar producers about the current state of the markets, did not wish to give such an assurance, so persuaded the Speaker to protect him. Jones later recalled that he had received information from the sugar industry and, as a 'bit of a rebel in those days', he wanted to ask the Premier why he was going to Geneva if they were not going to achieve anything. He also remembered Bjelke-Petersen had been reluctant to answer to the Parliament for his actions from the start and would use the Speaker to sidestep sensitive issues. Jones remembered that at the time he had been most insistent that his original question would get into the record, so deliberately 
used the supply debate to make his point, saying one of his favourite adages was 'there are many ways to kill a cat other than choking it with butter' (Ray Jones, Interview, 19 August 1998).

Bjelke-Petersen left shortly after this sitting day and spent five weeks overseas, mostly in October at the conference. It was his first chance to stride the world stage as statesman and represent Queensland's industrial interests abroad. On his return to the state, he presented a Ministerial Statement to the Parliament outlining his reading of the events. The Premier noted that 'the world free-market price [for sugar] has remained dangerously depressed for an uncomfortable period of years' (QPD 1968:vol. 250, pp. 1159-61). He admitted that Australia had been forced to accept both lower prices and a lower quota (of 1.1 million metric tonnes) although some concessions had been made with the acceptance of a flexible arrangement to lower quotas further should the price continue to fall. He acknowledged, however, McEwen's excellent and vigorous leadership of the delegation and complimented Trade Department officials, sugar industry personnel and advisers for their input, claiming that but for them the deal would have been far worse for Australian producers. He informed the Parliament:

I am greatly encouraged by the outcome of the five weeks of intensive negotiation in Geneva, during which many major difficulties confronted the 72-odd countries represented. These were overcome only as a consequence of what I judged to be a common acceptance of the urgent need for more orderly arrangements for the control of raw sugar being sold on the world free market. (QPD 1968:vol. 250, p. 1159)

Given that producer countries had agreed to withhold some 'minimum stocks', the Premier looked forward to rising future prices and to Queensland maintaining its peak mill-production tonnage.

If the sugar agreement had turned out better than expected, local politics soon took the wind from the Premier's sails. Shortly after Bjelke-Petersen returned from overseas, the government faced a gruelling by-election on 16 November for the former Premier's seat of Isis - a gap in representation of almost five months since Pizzey's death. The by-election, fought on the government's record, was the first litmus test for the new leadership. Unlike in later years, when a Melbourne Cup field of candidates would assemble for a by-election, only two candidates contested the seat: R. J. Lester for the Country Party and J. R. Blake for the ALP. Stretching from south of Bundaberg to Maryborough, the rural hinterland electorate was considered a safe Country Party seat. Pizzey had comfortably secured the seat in the general election of 1966 with 57.69 per cent of the vote to Labor's 35.34 per cent and the QLP's 6.96 per cent. The fickleness of by-elections, however, the loss of the former member's personal vote and the immediate difficulties of the government put a different complexion on the 
election. The result was close. Jim Blake won 4410 votes or 51.08 per cent to Lester's 4224 or 48.92 per cent. The swing against the Country Party was 8.77 per cent although the Labor candidate scored a larger swing, of 15.74 per cent, as the ballot was not contested by the QLP. It was the first time that Labor had taken the seat in its history and the result was a spectacular snub to the new administration. The Liberal leader, Gordon Chalk, admitted in his concluding comments to the 1968-69 budget that the '[g]overnment did receive a jolt in the Isis by-election', but he denied it would affect the result of the next general election (QPD 1968:vol. 250, p. 1834).

\section{'My bounden duty to uphold the dignity of Parliament'}

In the Parliament, the Premier took some time to adjust to his new position and to the additional scrutiny he was placed under as head of the government. In years to come, after Bjelke-Petersen had imposed his personality on Queensland politics and notched up some incredible political wins in the process, it was commonly acknowledged that his period in office became increasingly and intensely controversial. Much of the controversy associated with his premiership dates from the 1970s through to the mid-1980s, and various dimensions of these controversies appear in later chapters of this parliamentary history. It is clear from the day-to-day record of his premiership, however, that he was a controversial figure from the very outset. Controversy and the Premier went hand-in-hand, usually fuelled by the unorthodox or idiosyncratic things he did or said and, indeed, as time went on, he developed a peculiar mutually addictive or symbiotic relationship with the media. He seemed to feed on contentious issues and they on him; and even when his own behaviour was called into question, he often gave the impression that he relished the increased public attention rather than feeling either intimidated or apologetic.

One of the first controversies to involve the Premier occurred in November 1968 immediately after his return from overseas. The matter erupted in the Parliament over a relatively trivial matter, which led to the Premier misleading the House and incurring the wrath of the Speaker. In the final months leading up to the close of the parliamentary session, opposition members had asked a series of questions about the positioning and numbers of radar traps on roads in the Brisbane area. On 7 November, Jack Melloy (ALP, Nudgee) asked a seemingly innocuous question on notice about how many police radar traps were in operation at the bottom of Kelvin Grove Hill between August and October, how many had operated in the three months prior and how many accidents had occurred. The Premier answered the three-part question with a curt: 'Nil. One. 
Nil.' Melloy tried to ask a supplementary question the next day but was refused by the Speaker. He was successful on 12 November when he again asked the Premier:

Further to his Answer to my Question on November 7 about the radar trap at the bottom of Kelvin Grove Hill, will he check with the source of his information the matter contained in his Answer, as I possess a ticket which apparently contradicts the information he supplied... [and] In the light of his further inquiry, will he supply any further information in the matter? (QPD 1968:vol. 250, p. 1364)

Melloy was referring to a ticket issued to an ALP staffer, Jack Stanaway, who was booked for speeding but not breathalysed. The incident rattled the Premier, who admitted 'a further search was made of the records'. He then clarified that in fact

detection units were operated by police personnel in the vicinity of the bottom of Kelvin Grove Hill...on seventeen occasions...I regret that the information furnished to me by the Police Department on which my reply to the Honourable Member's Question on November 7 was based was incorrect and I wish to apologise to the Honourable Member and the House. (QPD 1968:vol. 250, p. 1364)

The matter did not, however, end here. The Speaker, who by then had served more than eight years in the position, was so incensed about the way the Premier, as the most senior minister, had perhaps inadvertently misled the House he wrote a letter to Bjelke-Petersen, which was also circulated to all cabinet ministers - and eventually leaked to the press. The Truth (1 December 1968) ran a headline describing the letter as the 'Speaker's bombshell' and an 'unprecedented reprimand' to a state premier. The paper regarded the Speaker's missive as a 'sensational "Dear Joe" letter' in which the Speaker wrote:

I am deeply concerned at a happening in the House wherein you were considerably embarrassed by one of your Departmental officers supplying you with false information for transmission to the House in the form of an answer to a question relating to police radar traps. As custodian of the rights and privileges of Members, it is my bounden duty to uphold the dignity of Parliament. Therefore, I must point out the seriousness of this matter in relation to privilege, and would respectfully request that you draw the attention of your senior officers to the fact that, had the matter been raised in the House at the time on a question of privilege, based on evidence presented by you, there can be no doubt a prima facie case had been established, and as a result of the deliberations of the House the officer responsible for furnishing the false information 
could have been charged with contempt. Should there be any repetition of this practice, I shall consider it my duty to take what action I deem necessary in the circumstances. I have forwarded copies of this letter to all Ministers to convey to them the seriousness of Departmental officers supplying false information for presentation by Ministers to Parliament. (Truth, 1 December 1968)

The paper suggested that the reprimand had 'rocked' cabinet ministers and was likely to 'widen still further rifts that have become serious in the coalition in recent months'. The incident also soured relations between the Premier and Nicholson as Speaker and, although Nicholson survived as Speaker for another term before resigning from the Parliament in 1972, it made the Premier more wary of his independence. This incident probably sharpened the Premier's instinct that independent-minded speakers were to be distrusted-and subsequent appointees to the office generally became more reliable and less troublesome to the Premier or the other members of the executive.

A more serious scandal soon dogged the new Premier's early years, involving his (or his family's) business interests and company share dealings, which he attended to while in office. The main concerns raised by his political opponents and media journalists were often over perceived conflicts of interest and over the lack of official procedures to handle conflict-of-interest situations. During the early months of 1969, various pieces of information and allegations surfaced concerning the new Premier's holdings of shares in oil companies that were also negotiating with the state government. Bjelke-Petersen had long held shares in mining ventures and saw nothing wrong with having private pecuniary interests when, at the same time, he was involved in making official government decisions that could advantage such interests. As he saw it, mining shares were inherently risky investments that could benefit the state and he was not one to relinquish his private holdings simply because he had become a minister of the Crown - nor did he have concerns about others in the ministry similarly holding shares or business interests in areas that were close to their portfolio responsibilities. When the Opposition Leader later attacked him over his share holdings, the Premier said:

[A]s far back as 1954 I first began looking for oil in Queensland. I always have been keen on development. I pioneered scrub pulling and aerial seeding and spraying in Queensland...Ask Mr Houston what he has done? He has done nothing except attack me for being a developer. (Courier-Mail, 3 March 1969)

This defence became one of the Premier's hallmarks: when confronted with accusations of conflicts of interest, he continued to spin the line that he was a pioneering premier who had been active in development. He argued that the 
state needed more such people to invest and take 'risks'. He also became adept at turning criticisms of himself back onto his critics. When attacked over his business interests, he would attempt to deflect criticism by suggesting that it was Houston who was not prepared to be personally involved in investing in Queensland development (a somewhat practical difficulty if not problematic for ideological reasons for a working-class trade union official). It is arguable that, even from these early days as Premier, Bjelke-Petersen began to develop the notion that he was, or should be, above criticism. It also represents an indefatigable belief that his activities were preordained and he was doing God's will.

One of the immediate problems facing the opposition and the media in 'exposing' the Premier (and his other ministers) over conflicts of interest was finding out accurate information. The Premier, for one, was generally very reluctant to disclose his personal affairs or those of his family members. He regarded them as private matters and not for public consumption. Speculation was fanned by the absence of confirmed evidence. Labor Senator George Georges raised allegations against Bjelke-Petersen in the Australian Parliament only to have them dismissed by the Premier, who claimed the use of federal parliamentary privilege was a 'grave injustice' (Courier-Mail, 5 March 1969). Jack Houston responded: 'I am disgusted at the arrogant attitude of the Premier towards the very serious charges levelled against him. No democracy can exist in a situation where a Premier is charged and he becomes his own judge and jury and declares himself innocent of the charges' (Courier-Mail, 5 March 1969).

Exact evidence was still difficult to discover. Eventually, Bjelke-Petersen was accused by Houston of demanding the right to hold 500,000 shares in an oil company actually dealing with his own government' (Telegraph, 15 May 1969). The ALP began calling for the Parliament to subpoena all records of transactions involving oil companies, not just from cabinet deliberations but across all government departments. In March 1969, the ALP's parliamentary executive called an emergency meeting on the matter and after a debate lasting more than eight and a half hours declared 'this executive has considered the evidence against the Premier in his petroleum share dealings and regards him as an unfit person to lead the Government of Queensland'. The ALP demanded the urgent recall of the Parliament and called on the Governor not to 'allow the present Government to extend the adjournment of Parliament beyond the existing date, March 11' (Courier-Mail, 4 March 1969). With the Parliament not in session in the lead-up to the state election, it proved impossible, however, for Labor to translate its demands into reality. Labor did succeed in elevating concerns about pecuniary conflicts of interest and government propriety as election issues, but the Premier, in particular, ignored such concerns with a 
grim determination and was able to survive the allegations. This would not be the only time such concerns would haunt the Premier; on the contrary, they would recur throughout his entire career and follow him into retirement.

\section{Au revoir, mes amis-we'll miss you}

With the term of the thirty-eighth Parliament drawing to a close, some members began to reminisce about their careers and acknowledge the culture of camaraderie within the legislature. On many separate occasions, members spoke of the bonds of friendship they enjoyed across the Chamber. On only the second day of the last session, Bjelke-Petersen touched on this when he read a motion of condolence for Sir Alan Munro, the former Minister for Industrial Development and Liberal leader in the early years of the Coalition government. In his speech, the Premier reminded members that

less than two years ago, on the rising of the Thirty-seventh Parliament, the late Sir Alan Munro, in responding to a tribute from all sides of the Chamber, said that although parliamentary life was something of a battle he was sure that, in spite of political differences, Parliamentarians could look upon the great majority of their fellows as friends. (QPD 1968:vol. 249, p. 12)

Later, another member, Cecil Carey (CP, Albert), used the supply debate to say farewell to a number of long-serving members who had indicated they would retire at the next election (due by mid-1969). He told the House that ordinary members had but

two opportunities during a session of Parliament to embark on a Cook's tour, as it were, and mention any matter at all. And I gladly use some of the time allotted to me in this debate to say thanks to those hon. members who are retiring for their wonderful friendship and fellowship, and for their goodwill to me during the $8 \frac{1}{2}$ years I have had the pleasure and responsibility of looking after the electorate of Albert... They certainly do not all belong to the Country Party or the Liberal Party. Some of them are Independents, and quite a few are Labor members, but I still regard them as my personal friends. We may argue in debate, and we may even get a little heated, but...I have not found one with whom I would not be happy to associate outside the Chamber. (QPD 1968:vol. 249, p. 951)

Carey continued his fervent speech by implying that the forthcoming election would be both a painful exercise and something of a nuisance. He genuinely felt remorse that 
some of us have to take the axe; but there is no-one here that I dislike to the extent of wishing to see him defeated. If I had my way, I would pass a Bill that we could all sit here for the next three years and have six consecutive years in this Chamber, instead of having the trouble of handing out 'How to Vote' cards and getting all hot and bothered, as we do, when an election is held. (QPD 1968: vol. 249, p. 953)

Overlooking the fact that the Chamber was not composed entirely of men (Vi Jordan, ALP, Ipswich West, had been a member since 1966), these were probably the last years in the Queensland Parliament when such amicable sentiments could be articulated by members.

Others, however, used the occasion to pour scorn on political opponents and the personal reputations of members opposite. In an Address-in-Reply debatesupposedly a debate on the government's policies and program - Fred Bromley (ALP, Norman) launched a venomous attack on the Liberals, accusing them of internal divisions and ruthlessness in dealing with dissidents. Returning to the Dewar affair, Bromley referred to the

move by the Liberal Party to get rid of the hon. member for Wavell, $\mathrm{Mr}$ Dewar. Everyone knows, of course, that when a member of the Liberal Party gets off-side with the strength, his head is chopped off. They say, 'Right! We will go about this properly. We will seek and destroy'...and they go about chopping his or her head off in a systematic way...In the case of the hon. member for Wavell, to add insult to injury, they chopped his head off and threw it in his face. Everyone in this Chamber knows the background to that case- how the Minister for Labour and Tourism [John Herbert], who is in the Chamber this afternoon, was jealous of the attraction that the hon. member for Wavell had for girls when he was a Minister of the Crown.

Mr Speaker: Order! I think the hon. member must realise that personal attacks against members of Parliament, whether they are members of the Government or members of the Opposition, are totally out of order. I ask him, please, to confine himself to decent remarks and to address the House as it should be addressed.

Mr Bromley: I have not attacked any Minister.

Mr Speaker: Order! I have not yet had to wear a hearing aid. I am perfectly well aware of what the hon. member said.

Mr Bromley: Thank you, Mr Speaker. We all know that one of the Commandments is 'Love Thy Neighbour'. It is one that I follow religiously. However, there are times when one must reveal to people in 
this State what really does go on and have it included in 'Hansard' so that it will go down in history. I do not intend, of course, to attack any Minister or former Minister; but all hon. members know that at one time the Minister for Labour and Tourism did hang the nickname of 'Alex the Adorable' on Mr Dewar. That seems to be well known, and I don't think that could be classed as an attack by me.

Mr Speaker: Order! I warn the hon. member for the last time that if he continues in that personal strain, reflecting on members of this House, I shall name him.

Mr Bromley: Very well, Mr Speaker. I shall deal with the events in Wavell. It was common knowledge in the Wavell electorate that the hon. member for Wavell was going to get the axe and that he would not be endorsed by the Liberal Party to contest the Wavell seat at the next election. So, of course, he was forced to resign from the party. He told us about this in the House the other day. He himself spoke about the incident. He had been on the outer with the party out there for some time, and in the House itself he was not even made welcome at Caucus meetings. Consequently, he did not attend any Caucus meetings... Then, in came the project 'D. D.', which is a code name used within the Liberal Party ranks. For the information of the House, it stands for 'Dice Dewar'. In addition to the various troubles that are appearing, and have appeared for some time, within the Liberal Party - the hon. member for Wavell has himself referred to disloyalty within the party - we all know about the move that was underway to dispose of the hon. member for Toowong, and other members such as the hon. member for Kurilpa. These manoeuvres operate under code names 'P. P.'- 'Pin-point Porter', and 'H. H.'- 'Hijack Hughes'. To date, the enemy in these cases has been repulsed. In Kurilpa, in the case of 'H. H.' - 'Hijack Hughes' - the ALP candidate will have to do the job. (QPD 1968:vol. 249, pp. 395-696)

So, not all was wine and roses among the good members in the Chamber. The point of such personal attacks on colleagues was not just salacious interest or disingenuous abuse of parliamentary privilege; rather the personal attacks became the catalyst for wider political criticisms of party procedures and machinations that would otherwise remain invisible in the general passage of parliamentary business.

In a similar vein, the ALP Member for Rockhampton North, Merv Thackeray, was also tempted to settle scores when given the opportunity. Thackeray was one of the few members who had ever said anything bad about Nicklin's character in public (see Stevenson 1985). As the Parliament was nearing its end, he began to reminisce on the 'old days', thanking Jack Duggan for being a 'father to 
me' and a very close friend. He praised his retiring Labor colleagues (especially Jim Donald, Johnno Mann and Jack Dufficy), but saved special mention for the Country Party's Alf Muller, who deserved 'some good words' because

if ever a man was crucified in this House it is Alf Muller. Two Premiers cut his head right off. They were Frank Nicklin and the late Jack Pizzey. The former Treasurer, Tom Hiley, should be included with them, too. If ever a man was ostracised and cut to pieces it was Alf Muller, and those three gentlemen did the job. (QPD 1968:vol. 249, p. 1046)

Address-in-Reply debates and supply debates gave ordinary parliamentarians the chance to strike back and get things off their chests - and some about to retire and without fear of reprisal decided to avail themselves of the opportunity.

To end the third parliamentary session, the Premier rose to move the adjournment of the Assembly on 11 December. In doing so, he acknowledged that 10 members had collectively served the state in the Parliament for a total of 223 years. He particularly singled out some of the more prominent retiring members for special mention. He also acknowledged the work of Alf Muller, who, despite running foul of former premiers, had served one term as Minister for Public Lands and Irrigation (1957-60). According to the Premier, Muller had remained 'a very close personal friend of mine and is greatly respected by all of us'. Next, Labor's 'Johnno' Mann, a former Speaker, and Jack Duggan, the former Deputy Premier and Opposition Leader, were both 'farewelled' with the observation that 'whilst we did not always like their opposition we have appreciated their friendship and will miss them'. Others acknowledged were the ALP's Fred Graham (Mackay), Jim Donald (Ipswich East), Peter Byrne (Mourilyan) and Joe Dufficy (Warrego). Two longstanding independents were also retiring: Arthur Coburn (Burdekin) and 'Bunny' Adair (Cook). Finally, the Premier thanked the retiring Eddie Beardmore ( $\mathrm{CP}$, Balonne) for his jokes and songs, remembering that on one occasion when out west campaigning for another member he had been asked to sing an 'Eddie Beardmore song'. Not one to break out into song, the dour Premier had instead chosen to tell an 'Eddie Beardmore story' to the assembled group, which he recounted to the amusement of the Chamber:

One day when Eddie came home from work to his property outside St George, his wife said to him, 'Eddie, there's a job for you. Young John is away up under the house (the house was a very low-set one) and he won't come out. You get under the house and get him out and give him a good hiding because he's been a naughty boy.' Eddie said, 'I got down and I wriggled and crawled, and when I got up near where John was he said, "Dad, is Mum after you too".' (QPD 1968:vol. 250, p. 2326) 
If Beardmore was fondly remembered for his wit, others were seemingly more equivocal. Thackeray had earlier bid farewell to Beardmore by saying he was 'a great old guy', but added: 'He came into Parliament a little late in life, and I do not think he had an opportunity to fully grasp the activities of Parliament. However, while he was here he devoted himself to his parliamentary duties' (QPD 1968:vol. 249, p. 1046).

Faint praise indeed!

In closing, the Premier generously thanked and acknowledged the retirement of the Clerk of the Parliament, Roy Dunlop, who, remarkably, had served the Parliament for 50 years from 1918. Dunlop had been appointed Clerk in 1954 and had worked under 13 different premiers and 10 speakers. This observation caused Bjelke-Petersen to comment somewhat caustically that it seems that Speakers last longer than Premiers'. Such was not to be the case, however, with this Premier-he would outlast six speakers in his term as Premier, and in the 40 years he served as a Member of Parliament (1947-87), would sit under nine different speakers.

\section{The 1969 election: the 'most strenuous campaign' the government had ever faced}

The Parliament did not sit between December 1968 and the state election, which was called for 17 May 1969 - almost three years to the day since the previous election. It was a long and hard-fought campaign, which Treasurer Chalk described as 'the most strenuous of his nine campaigns' (Sunday Mail, 11 May 1969). It was also an election in which the Labor Party, having lost four previous campaigns, was generally expected to improve its vote, not only because it had rallied somewhat since the change of premier, but because the government was beginning to look jaded and out of touch with the popular mood. Labor's stocks were also bolstered by its recent victory in the Isis by-election. There were also clear conflicts within the Coalition, especially over the issue of leadership, with doubts about whether Bjelke-Petersen had the charisma and political skills to lead the government. The fear of communism within Australia was receding as an election issue and the DLP was now much less a force, with only one-quarter of its former electoral support (down to 6.38 per cent at the 1966 election). As was common in those days, however, the weaknesses of the opposition and the achievements of the government tended to be magnified in people's minds. So, in the end, Labor would come close to matching the Coalition in the primary vote but, under the zonal system, would fall far short of winning sufficient seats to oust the government. 
A total of 246 candidates stood for the 78 seats in the 1969 election. Twelve seats were vacant at the election - a Queensland record-because of the large number of retirements of sitting members. Against 77 ALP candidates, the Country Party stood 39 candidates and the Liberals a further 44 candidates. The DLP contested 61 seats, while 23 independents contested the election. From the start, the main protagonists had to work hard to inject enthusiasm into the campaign. Opinion polls seemed to suggest that even midway through the campaign 'most electors are standing aloof'. The Courier-Mail went on to comment that endorsed candidates were resorting to gimmicks to attract voters. Under the headline 'Banners in fight to win the vote', the paper described the campaign as one in which

boaters, banners and boomerangs and even the old-fashioned morning tea party are being injected into the state election campaign to give it more sparkle...For the candidate, electioneering means as much of the door-knock hand-shake approach as one can possibly do in four weeks. Fifteen gross [or 2160] of straw boaters with a distinctive band have come from the ALP box of election tricks to identify candidates and leading supporters. The party's Greenslopes candidate, Aboriginal rights worker Mrs Kath Walker, has a boomerang motif on her election signs. (Courier-Mail, 29 April 1969)

Not only was the 1969 campaign a protracted affair, the sudden change of Premier in mid-1968 effectively meant that the main four parties had been actively campaigning long before the election date was announced. Questions about the political leadership of the state became pronounced in the campaign, overshadowing differences of policy. Chalk told the press at the end of the campaign that personalities appeared more prominent than policy issues in both the popular mood and the reporting of the election. He was of the view that 'people this time are looking at the images of the Premier, the Opposition Leader, and my own as Leader of the Liberal Party'. He felt that this meant 'people are considering quite seriously who they believe would be most able to be at the head of affairs of government in Queensland'. For Chalk, this represented an entirely new scenario because 'when Sir Frank Nicklin was Premier and $\mathrm{Mr}$ John Duggan was Opposition Leader, the images were known. They weren't a question in elections. This time they're important' (Sunday Mail, 11 May 1969).

The new Premier was still struggling to establish a distinctive image, so that became one of the main political issues of the campaign. He went to great pains to stress he was a determined and forceful figure: 'For my part as new Premier with quite definite ideas of my own, I hope to show quite clearly that I am not afraid to tackle fundamental issues. I believe Queenslanders will accept that I would still tackle them, election year or not' (Truth, 9 February 1969). 
He also emphasised his rural background and frequently directed media attention to his previous and continuing farming activities as a peanut farmer and land-clearer. He was also anxious to convey his own personal style as matterof-fact, earthy and unpolished-just like his electors. What is more, even from the beginning of his premiership, he was sensitive to criticism. In February, Bjelke-Petersen felt obliged to respond to opposition attacks criticising the antidrinking attitudes of his government. He promised a 'review' of liquor licensing laws but hit back at the Opposition Leader for attacking the government

for daring to protect people from their own weaknesses. A man had the right to drink himself to death if he so wished, the ALP leader said. 'Provided,' he added rather lamely, 'he does no harm to others.' To me, this is an incredibly irresponsible statement by a man who aspires to premiership. Would he also say that a man has the right to 'drug' himself to death? Or 'drink-drive' himself to death? This is typical of the irresponsible 'catch-cries' the ALP is applying in a wretched attempt to confuse the public mind. ('Jo Petersen reports', Telegraph, 23 February 1969)

The Premier announced in opening the annual Warwick Show in March 1969 that 'people are getting sick of these attacks on my sincerity and character...I get irate when our political opponents continually knock Queensland and try to shatter the confidence of others willing to help in the development of the State'. He told the gathering that Labor had 'made many attacks on the Government in recent times and this is only natural in an election year. These attacks have failed and the ALP has now switched to personal attacks on me as Premier' (The Australian, 8 March 1969).

More than anything else, however, Bjelke-Petersen wanted to be portrayed as a man of action, someone who could get things done. So, to assist with the cultivation of a new image, Bjelke-Petersen became the first Queensland Premier and one of the first Australian politicians to employ the services of a public relations consultant - or, in the language of the day, a 'PR man' (namely, L. J. McGovern, who became the head of the state Public Relations Bureau). The Premier, intending to soften his image, had hired the outside consultant in late 1968 and was persuaded to visit racetracks and pubs to broaden his appeal (Lunn 1984:70-4). He was persuaded to turn a blind eye to an occasion of public drinking in the main street of Finch Hatton in north Queensland when three kegs of free beer were provided illegally at a 'Meet-the-Premier barbecue'. The Premier was subsequently 'rewarded' with the headline: 'Teetotal Premier in beer keg party - street is closed; police join illegal drinkers.' The report also mentioned that the first keg was bought by Tom Newbery (CP, Mirani) and that the Mines Minister, Ron Camm (CP, Whitsunday), 'shouted' the full bar of the local pub when the Premier entered (Truth, 16 February 1969). One 'staged' 
press photo of the Premier admiring a racehorse was captioned 'showing the flag and socking it to them in the country' (Sunday Mail, 16 February 1969). Country Party election material picked up this message, urging voters to 'vote Country Party and Premier Jo!' (with an exclamation mark under a smiling avuncular face) and suggesting that 'Premier Jo Petersen's Country Party team' is the 'party that cares about people' (Sunday Mail, 11 May 1969).

The use of public relations expertise for political leaders opened a new chapter in Queensland political campaigning. Indeed, the 1969 campaign came to mark a watershed in state politics, as from that point on political leaders were increasingly packaged as products to be marketed to a public that was at times over-credulous. This was the first election in which the techniques of 'image making' were used and played a significant role. Although the Public Relations Bureau had existed as a unit under Nicklin, the bureau now took on a more politicised role. It 'prepared election telecasts and broadcasts for the Premier, placed newspaper blocks and copies of Bjelke-Petersen's biography with every Queensland newspaper and issued 80 sets of speakers' notes to each of the coalition parties, and for three months before the election the unit supplied film footage on state development projects to local television stations (Hazlehurst 1987:253-4). The new Premier's minder, McGovern, was reported to have stated in 1969 that his unit had 'been a very powerful support for the present Government since it assumed office' (Hazlehurst 1987:254). From that moment on, the increased focus on the political leader, together with the reliance on media advisers, began to change the nature of campaigning. Electioneering would become increasingly presidential and stage-managed in form, promoting a favourable leadership image.

The Coalition government again chose a joint policy launch with Bjelke-Petersen giving the first speech in Toowoomba on Tuesday 22 April and Chalk delivering part two in Brisbane on Wednesday 23 April. In Toowoomba, the Premier pledged a 'continuation of sound, progressive government for every section of the community'. He told voters the issue of the election was either to 'continue on the high road to development by the bold partnership between government and private enterprise, or whether to enter an era of hesitation, confusion and stagnation with development controlled by the militant left-wingers of the Labor Party and the doctrinaire socialists of the Brisbane Trades Hall' (CourierMail, 23 April 1969). About 350 local people turned out to hear the Premier and journalists reported that they were attentive and 'at times enthusiastic' in hearing the hour-long speech. The crowd made no interjections and asked no questions after he had finished (Courier-Mail, 23 April 1969).

Bjelke-Petersen's main policy commitments in the campaign promised government assistance for housing and schools. He made a point of rejecting demands to liberalise the hotel trading of liquor on Sundays, but did agree to 
grant more restaurant, motel and club licences. Pensioners would receive lower motor vehicle registration fees and dairy farmers more subsidies, while charges for road and rail transport would be reviewed after the election. The Premier also announced a reorganisation of the senior police command.

Elsewhere in the campaign, Bjelke-Petersen attempted to portray the Country Party, which was often perceived as anachronistic, as a 'modern and allembracing political force'. He also suggested that the party 'offered a sound platform in the modern sense to all sections of the community-it was free of factions and jealousies and rock solid in Parliament' (Courier-Mail, 28 March 1969). He rated the main achievements of the Coalition government as: the world's largest alumina refinery at Gladstone, the location of a 'modern town built at Weipa on remote Cape York Peninsula' to mine bauxite, the first state to operate a commercial oil field and the first to pipe natural gas to a capital city. He continued by boasting of the 'world's largest [coal] dragline at Moura' and that Queensland would become the 'largest coal-exporting State'. He also mentioned that 'in one area alone - education - voters may be surprised to know that there were only 36 state high schools built in Queensland up to 1957. Today there are 101' (Telegraph, 16 May 1969). These messages were directed not only to his Labor opponents but to the Liberal Party, which was attempting to enhance its own stocks by suggesting unfavourable comparisons between the two Coalition leaders. The Liberals chose an electoral pitch that featured Chalk as a more dynamic 'premier' more 'in tune' with prevailing attitudes, whereas Bjelke-Petersen was portrayed as old fashioned and lacking initiative.

The Deputy Premier completed the joint policy speech by emphasising the unity among the Coalition over the advancement of Queensland interests. $\mathrm{He}$ told a rowdy Brisbane audience that economic growth was above the national average and that Queensland was no longer a 'veritable no-man's land' but had now been 'lifted to the forefront'. Business was 'no longer worried about the socialistic ideology which it experienced while Labor was in office and is prepared to invest here because it trusts us' (Courier-Mail, 24 April 1969). Chalk announced tax concessions, a major new power station for central Queensland, enhancements to transportation and an extension of the state's free public hospital system. He made special mention of the government's intention to establish a series of community-based geriatric centres to provide care to the growing number of aged patients. He committed the government to begin to tackle environmental problems by setting up an advisory pollution-control council consisting of representatives of state and local government, business and 'housewives' organisations'. The Liberal Party had also indicated that it would seek to extend the life of both state and federal parliaments by one year from three to four years. This proposal derived from an earlier state council resolution of March in which the party suggested that under present three-year 
terms there was effectively only one year of real legislative life in a parliament before members began to consider their own re-election (Courier-Mail, 20 March 1969).

In contrast with the government, the opposition fragmented its policy speeches, with Jack Houston delivering three regional policy speeches before 'summing up' with a further four to complete the campaign. The fragmented policy speeches aimed at specific target audiences were a departure from the interminable speeches (usually provided without written copies being available) associated with policy launches of the past. The ALP announced it was 'looking to this innovation to give its policy the widest possible coverage and to allow electors to digest it piece by piece' (Courier-Mail, 17 April 1969). In February, Houston gave some indication of his likely cabinet if he were to be successful at the forthcoming poll. He told journalists that

we haven't a shadow Cabinet as such. What we have had over the past three years has been chairman of committees - with one chairman virtually pairing two ministerial portfolios. If we are returned as a government then these men will be the nucleus of the Cabinet and include-Horace Davies, Pat Hanlon, Fred Newton, Doug Sherrington, Fred Bromley, Eugene O'Donnell and Percy Tucker. (Courier-Mail, 27 February 1969)

The ALP's promises included 'sweeping' changes to the liquor laws, reduced rail freight rates, 'an overhaul of the breathalyser legislation' and a restriction on police using radar speed traps (the last two were a source of much complaint from residents of city electorates). Houston delivered a special policy speech for women (believed by ALP officials to be the first time this had occurred in Australia) in which he announced a series of 'women's reforms' including legislation on consumer protection, the welfare of children unable to attend school and the removal of discriminatory practices against widows who had to leave their Housing Commission homes if their husbands died. Houston also kept returning to the theme that 'Brisbane is the forgotten city' for the Country Party-led government (Telegraph, 15 May 1969). He claimed that only Labor would prioritise policies for the city and that even a vote for Liberal candidates was a vote for the continuation of Country Party control, for Bjelke-Petersen remaining as Premier and for the neglect of Brisbane and neighbouring areas.

Houston accused the new Premier, Bjelke-Petersen, of trying to introduce the 'ugly head of sectarianism' into the campaign, attacking him personally for raising the 'state aid' issue in front of schoolchildren in Emerald (Courier-Mail, 12 March 1969). The Opposition Leader also attacked the government over claims of politicisation of the public service. In late March, Houston produced a copy of a letter by Bjelke-Petersen, which, he said, proved the Premier was trying 
to use the public service in the government's election campaign. The produced letter had been written to Country Party ministers seeking information from their departments on selected electorates - a task that would involve public service assistance (the letter sought information and photographs of examples of buildings, schools, irrigation schemes and primary industry projects). The information was sought for 39 of the state's 78 electorates, which either were held by sitting Country Party members or had been targeted by the party as possible gains. Houston rebuked the Premier, claiming: 'I deplore this blatant misuse of the public service and public money for party political gain' (Sunday Mail, 30 March 1969). Houston kept returning to the theme that the public service had been used during the campaign to collect a 'blatant piece of propaganda for the election' (Courier-Mail, 14 May 1969).

The Democratic Labor Party (DLP) reported that it had more funds at its disposal in 1969 than ever before. Its policies were aimed at increased provisions for 'pensioners and elderly people', arguing that the 'government should provide funds for young people willing to care for aged relatives in their own homes' (Sunday Mail, 11 May 1969). The DLP favoured less government debt and lower taxes, but their message was becoming increasingly marginal to the main campaign.

Among the various policy issues raised, economic development dominated the campaign. In March, the government had indicated that 'development is [the] election issue' (Courier-Mail, 20 March 1969). The government committed itself to 'encourage the channelling of private capital into the establishment of resource-based industries' to assist regional industry and promote mining exports. Bjelke-Petersen managed to win strong business support with this appeal especially as his message was accompanied by a public scare campaign insisting that a Labor government would undermine development.

The terms under which mining exploration and mineral exportation took place, however, and the involvement of foreign investors became particularly contentious. In the face of sustained opposition pressure, the government sought to justify 'the use of overseas capital to develop coal export industries based on Moura, Blackwater and Goonyella' (Courier-Mail, 20 March 1969). It also highlighted further expansion of the major alumina project at Gladstone as evidence of the attraction of overseas capital. Against these claims the ALP argued that the Coalition government was 'selling the farm bit by bit' such that the state was dominated by Japanese and American mining interests. Houston maintained a constant attack on the Queensland government's 'open-door' foreign investment policy, saying that the state was

becoming known as the last haven in the world where foreign interests can easily secure 100 per cent control over rich mineral assets...for 
bargain rate returns...The Country Party/Liberal Party Government demanded the right to hand over billions of tons of Queensland coal until the year 2010 for 5c a ton royalty - the price of an ice cream cone. (Courier-Mail, 16 April 1969)

For the ALP, the other significant element associated with this attack was that many cabinet ministers had been accused of benefiting personally from mining. Although most ministers ducked for cover during the election campaign, BjelkePetersen appeared politically astute in countering the allegations he had engaged in any impropriety or conflicts of interest over his own pecuniary interests and particularly his vast mining shares.

Not all comment was, however, favourable to the government's policy approach to the economy. In a stinging rebuke to the Premier, journalist Ken Davidson, writing in The Australian (3 May 1969), argued that

the drought in Queensland may yet cost the Australian taxpayer more than if it had happened in some other State. In a State which has a Country Party Government and a valuable rural vote, the current drought adds a highly volatile element to the elections to be held this month. Already the Prime Minister, Mr Gorton, has offered the Premier, Mr Bjelke-Petersen, 50-50 assistance up to \$4 million for the direct costs of drought and 100 per cent assistance beyond that point. In effect, the Commonwealth Government has said that the direct budgetary costs of the drought to the Queensland Government will be limited to $\$ 2$ million... But Mr Bjelke-Petersen is not satisfied...He wants also subsidised wheat as feed for stock in drought areas...Subsidised wheat for stock feed is not an economical proposition because it would have to be kept up for 7 months. It is unlikely that any rain will now fall in the drought-affected areas until the normal seasonal summer rains come at the end of the year. In the national interest it would be better if stock levels were reduced to a nucleus of breeding animals during the rest of the drought period. Of course rational policies are difficult to accept in a state where acres are more important than people in an election year. It is perhaps for this reason that the State spends less money per capita on...social welfare (education, health, hospitals and charities and law, order and public safety) than any other in the Commonwealth.

These issues of federal-state disagreement and the inconsistencies of policy approaches were to remain constant themes throughout the Bjelke-Petersen era and beyond. 


\section{'Jekyll and Hyde' premiers, protesters, three- way contests and preference swaps}

Tensions within the Coalition emerged publicly during the election campaign due to two related incidents: an overt campaign by the Liberals to promote Gordon Chalk as the future Premier and a decision by the Country Party to swap preferences with the ALP in one Gold Coast seat. Again the vexed question of which Coalition party would or should remain the senior partner reared its head in April when press reports carried articles stressing the Country Party 'won't bow to [the] Liberals in Coalition' (Telegraph, 11 April 1969). The Premier told journalists that his rural party was not prepared to 'abdicate as the dominant partner' in the Coalition and that 'the Country Party is the dominant party and undoubtedly will stay as such'. The Liberals, however, deliberately chose to launch a provocative campaign in the last week of the election with advertisements in newspapers claiming 'Gordon Chalk is the one to lead' (Telegraph, 11 May 1969). The Telegraph claimed that key Liberals were behind the campaign, which was described as a 'new move for Chalk as Premier'. The advertisements were carried in provincial newspapers in areas where Liberal candidates were challenging Country Party candidates. Resorting to such public tactics was a telling sign that the Liberals were dissatisfied with their junior status in the Coalition, which gave them only the Deputy Premier's position and fewer ministers in cabinet. The Liberals' advertisements were thus directed not at general voters but at their Coalition partners, reminding them that Liberals had not relinquished their aspirations for Chalk to become Premier and were indeed prepared to step up their campaign to this end. This was an unusual political move in the last week of the campaign and risked drawing attention to the disunity in the Coalition.

The Country Party regarded this push as an overt and none-too-subtle tactic to promote Chalk into the Premiership. When interviewed, however, BjelkePetersen appeared relatively relaxed with the slogan and denied a rift with Chalk, commenting that although 'there had been differences of opinion on certain issues, these had been made quite clear' and he had no objections to Chalk's 'ultimate objective to becoming Premier - that is quite good' (Telegraph, 11 May 1969). Although Bjelke-Petersen sounded relaxed, it was clear the Liberals had made their point.

Chalk, however, had his own problems closer to home. In April, he had been roundly heckled at a public meeting in the Brisbane suburb of Camp Hill, in the Liberal electorate of Chatsworth. The meeting, called in support of Bill Hewitt's re-election, turned into a rowdy session when Chalk spoke. According to press reports of the incident, the Deputy Premier was booed and hissed at his first 'meet the people meeting', when a small group of young people within the 
crowd challenged him on education, police powers at student demonstrations and freedom of speech. The students were critical of the Liberals for not standing up to the Country Party 'that controls [the state] with only 19 per cent of the State's vote' (Courier-Mail, 2 April 1969). Chalk told his Liberal supporters that the youths were interested only in being ejected from the meeting and arrested. On a serious note, Chalk warned the meeting that the campaign had degenerated into 'character assassination' but promised that the Liberals would not participate in such tactics.

Three weeks later, he was again the subject of controversy in his own electorate of Lockyer. Long seen to be a city-based Liberal, Chalk began to have difficulty convincing the local constituency he as a Liberal was their best option as their local member. A major 'rift' developed in April in which Chalk was publicly told that Coalition members were 'dissatisfied' with his performance. After a meeting in Grantham, a 'cross-section of Government supporters' including some senior Country Party officials (operating under the label of the Committee of Political Realists) 'accused their long standing Member of Parliament, Liberal Party Leader (Mr Chalk) of having failed to represent them adequately, and warned him he might lose his seat' (Courier-Mail, 28 April 1969). Chalk was attacked particularly because he did not live in the electorate but instead chose to live in Brisbane. One of the organisers of this protest, Les Metcalf, also authorised a vicious leaflet in which Chalk was shown as the 'Jekyll and Hyde of Lockyer': in his Dr Jekyll guise, he was shown as a benign country representative but in his Mr Hyde form he became a self-interested demagogue who had sprouted horns and who fought only for the Liberal cause. In the leaflet, Chalk is portrayed as being only irregularly in the Lockyer Valley and saying 'as a Liberal in Lockyer I have the wholehearted support of the Country Party (through its State President) - I think!'; but most of the time when he was in Brisbane (where he lived), Chalk was shown with campaign buttons reading ' $I$ 'm the Greatest' and 'Me for Premier'. He was shown saying 'defeat the Country Party. Liberals are King. I'll be Premier. More power for the city-less for the country. I'm for road taxes. One vote, one value - almost! Pity about Jo...Liberal me for rural Lockyer? Wonderful' (the leaflet was subsequently published in the Telegraph, 15 May 1969).

Chalk replied to these criticisms when he addressed a gathering of 350 disgruntled people in Lockyer. Both groups of protagonists-hecklers and supporters - were present and, according to the press reports, the day after the

Liberal leader vigorously defended himself against a stream of local criticism in his own electorate of Lockyer... While most of them came to cheer, they heard Mr Chalk handle brilliantly scores of interjections and a series of questions from his chief public critics of recent days...In the lively meeting, Mr Chalk's 'Trump card' in defence of his representation 
of Lockyer was the revelation that Cabinet had decided only yesterday that the Government would buy the private hospital in Gatton, renovate it, and turn it into a public one, to fill a long-felt need in the district... Throughout, Mr Chalk faced sporadic interjections. When he revealed that he had had lucrative opportunities to get out of politics an irritated farmer shouted: 'Want to grow spuds?' 'You are always in Japan or somewhere', complained another. Stressing that he had spent 163 days out of [the last] 316 as Premier, he asked his constituents if they wanted him to tell vital visitors and potential investors in Queensland he was sorry but he had to go up to Gatton... Mr Chalk said he had turned down a $\$ 100,000$ contract spread over five years in favour of politics for which he got $\$ 12,000$ a year...he believed the Government would be returned. 'Are you going to toss its Deputy Leader out onto the street so you can have some fellow who will be a knocker everytime the Government brings something forward?' he asked. (Courier-Mail, 30 April 1969)

Chalk also justified his residency in Brisbane on the grounds that as Deputy Premier and Liberal leader he could not live in the electorate (Courier-Mail, 28 April 1969). He argued that the only reason the head of the Lockyer Area Electorate Council, Les Metcalf, had made such charges against him was that he coveted the seat. Chalk said Metcalf would like to have him 'railroaded' so he would then be in a position to try for political endorsement as a Country Party candidate for the safe rural seat - and thereby corralling the Liberals back to a metropolitan base.

Coalition difficulties were also emphasised in arguments over the state's voting system and the allocation of preferences. Initial skirmishes were fought with the Labor Party but the repercussions of the issue rebounded back on the Coalition. In March 1969, the Premier challenged Labor members from regional or country electorates to publicly repudiate the ALP's policy of 'one-vote, one-value' (Courier-Mail, 26 March 1969) because such a system would result in less rural representation. The challenge was meant to embarrass the ALP, but succeeded in raising the ire of the urban Liberals. The rift became public when the Liberals chose to publicly disagree with the Premier when he had defended the fairness of rural weighting in preference to a system based on all electors having votes of equal value. Prominent Liberals, such as Charles Porter (Toowong), stated that as a Liberal he was 'committed to the policy platform of one-vote, onevalue' (Courier-Mail, 31 March 1969). The Premier became defensive on the issue, arguing that 'one vote, one value' was not Coalition policy; the Country Party did not subscribe to the principle even if it was part of official Liberal policy. Bjelke-Petersen adopted the view that the Liberals' enthusiasm for 'one vote, one value' was simply an opportunistic strategy aimed at destroying the Country Party as a political force in Queensland. 
The argument over voting methods did not remain solely at the level of principle. In the campaign, a bitter preference-swap row erupted between the Coalition partners over the vexatious issue of allocating preferences on 'howto-vote' information provided to voters. The Country Party felt strongly that three-cornered contests were detrimental to the stability of the Coalition. Alan Fletcher was reported to have blasted the idea of three-cornered polls, 'calling them a "spanner in the works" that could cause the destruction of a smooth running Coalition machine'. In the same article, Russ Hinze (CP, South Coast) insisted that he did not regard the challenge to a sitting Country Party member by a Liberal candidate as 'fair dinkum', adding 'we will be out of Government if we allow ourselves to be subjected to three-cornered contests such as this' (Courier-Mail, 29 April 1969). In retaliation to the challenge, Hinze directed his preferences to the ALP candidate (F. Culell) in return for ALP preferences rather than give preferences to the Liberals. This decision to exchange preferences with the ALP created an 'unseemly uproar' within the Coalition, with Hinze accused of traitorous behaviour and of intensifying friction between the Coalition partners. Chalk attacked Hinze, calling his actions 'an act of madness'. In his defence, the Premier responded by claiming the Country Party had acted with 'honour and restraint' over the Gold Coast seat, indicating that such forms of retaliation would not recur because 'I doubt that we'll again be confronted by the three-cornered election problem that brought about the preference swap this year. The experience to be gained from this three-cornered contest is obvious. These contestants [sic] are completely futile' (Sunday Mail, 11 May 1969). Hinze was less restrained, commenting just before the poll that the Liberal President, Eric Robinson, 'has run out of names to call me' and that Chalk 'hasn't a hope in hell of becoming Premier' (Courier-Mail, 16 May 1969).

In another case of retaliation through preference allocations, Alex Dewar refused to allocate his preferences to the Liberals in the Wavell electorate and instead chose to issue no preference instructions - a tactic that would 'scatter his preferences' in the event he finished third or worse in the ballot. His election pamphlets described him not as an independent but as 'Alex Dewar - the local man' (Courier-Mail, 11 May 1969). There was also no sign of the bitterness between the DLP and the ALP subsiding: as the state election campaign began, the DLP federal leader and ex-premier, Senator Vince Gair, steadfastly refused to give any official DLP preferences to Labor (Courier-Mail, 21 April 1969). 


\section{'The moment of truth': the final stages and election outcome}

Due to the provisions of the national Broadcasting and Television Act, political advertising was banned in Queensland for two weeks of the campaign. A federal by-election in Perth (due to Sir Paul Hasluck retiring from the House of Representatives seat of Curtin to become Governor-General) imposed a blanket ban on media advertising in April. This was followed in early May by the Tasmanian state elections, which triggered a second ban. Both sides therefore had to contend with a disrupted on-again, off-again campaign. A total of 246 candidates stood for the 78 parliamentary seats and for the first time in decades every seat was contested.

In the final days before the poll (held on 17 May 1969), commentators disputed whether the campaign either was 'one of the most remarkable campaigns ever conducted' or had been a 'colourless' affair likely to favour the incumbents. Because policy issues generally took second place, the opposition's Jack Houston claimed the 'extraordinary factor in this election has been the Government Coalition's lack of policy initiative', adding: 'You'd swear we were the Government putting up ideas and they were the Opposition just tagging along behind' (Sunday Mail, 11 May 1969). He accused the government of missing the great men of yesterday, leaders such as Nicklin, Pizzey, Hiley and Munro. 'They were the four big men. They kept the Government together.' The personal attack on Bjelke-Petersen asserted that there was now a leadership vacuum in the government. The Premier had earlier made his views known on the stance of the opposition, claiming that 'Houston was merely a mouthpiece for vicious propaganda prepared by the Party's Queensland Central Executive' (Sunday Truth, 9 March 1969). Bjelke-Petersen also believed that the

ALP has committed a grave election blunder in making foreign investment and development policies its main election attack. It's evident that the shallow slogan 'Give Queensland back to the People' is one of them-having been conceived by unthinking doctrinaire socialists sitting behind closed doors in Brisbane, paying no attention to the true thoughts of the Queensland People. (Sunday Truth, 9 March 1969)

On the eve of the election, Bjelke-Petersen wrote a further newspaper article in which he stated:

The Labor Party in Queensland is so dominated by left-wing elements that even the Australian Workers' Union, the most powerful union in Australia, has withdrawn financial support of the ALP. Surely this is 
condemnation enough when unions, which traditionally support the ALP, withdraw their support on the eve of the election. (Telegraph, 16 May 1969)

The Premier also made a sideswipe at the Liberals, who had been claiming that they were largely responsible for the high rates of economic development, saying that the Country Party had been responsible mainly for attracting investors and championing industrial and mining projects. Bjelke-Petersen especially mentioned the efforts of two ministers - the former Mines Minister, Ernie Evans, and his successor, Ron Camm - for having 'vision' and drive and for giving 'the incentive for an unprecedented in-flow of money and men which led to the discovery of oil at Moonie and later natural gas at Roma'. He also cited his own contribution as Works and Housing Minister, for 'obtaining homes for workers engaged in new large industrial undertakings'. Evoking the memories of past greatness, he recalled:

[A]ll of this had happened under Country Party Premiers like Sir Francis Nicklin and the late Jack Pizzey. Down through the years many prominent Country Party members had left their mark in the State and federal spheres of Government. They were men of broad vision and understanding and had ably represented the Country Party which was a true middle of the road party. (Courier-Mail, 16 May 1969)

The Premier was in no doubt that the 1969 election represented an electoral struggle on two fronts: between the Coalition and Labor for overall supremacy and the right to form government and between the Country and Liberal Parties for the right to lead the government, hold the most influence and claim the top positions. As the day of the election approached, he was reasonably confident he would win on both fronts and publicly predicted only days before the poll that his government would be returned. This was a rare moment of self-confidence from a Premier under intense political pressure from all sides.

As the votes came in, the Premier's prediction proved accurate. Overall, the twoparty preferred vote was almost identical to the 1966 result, with 52.3 per cent to the Coalition and 47.7 per cent to Labor. The Coalition secured 45 seats in the 78-seat Chamber - down by two from the 1966 result but still a comfortable majority of 12 on the floor of the Assembly. The ALP had gained five seats, mostly at the expense of independents, and held Isis, taking its numbers in the House from 26 to 31. The Liberals lost two seats but regained one (Wavell), leaving them with 19 seats in the new Parliament - down from the 20 they had held previously. The Country Party retained the same number of seats it had held in the previous Parliament (26), losing Isis again but winning one (Burdekin) to make up its numbers. Les Diplock, the DLP's sole member in the Assembly, retained his seat of Aubigny, and the last-remaining independent, Tom Aikens 
(labelling himself as the North Queensland Labor Party, NQLP), again held on to Townsville South. The state of the parties in the new Parliament was thus: Country Party, 26; Liberals, 19; ALP, 31; DLP, 1; and NQLP-independent, 1.

The election was, however, closer than at first it appeared. The primary votes cast for the Coalition and Labor were almost identical. On a state-wide basis, the Coalition received a primary vote of 44.7 per cent (virtually identical to its level of support in each election since 1957). With 44.7 per cent of the vote, the Coalition gained 57.7 per cent of the seats. Labor attracted a primary vote of 44.99 per cent of the vote but received only 39.7 per cent of the seats. The DLP achieved 7.24 per cent of the votes on a state-wide basis, which was a slight improvement on the two previous elections, but this translated into only one seat or 1.28 per cent of the available seats.

With the large number of resignations from the former Parliament and some members defeated at the polls, a total of 16 new members entered the Parliament. Among the more notable newcomers was Selwyn Muller, the son of the former Country Party minister Alf Muller, and eventually to become Speaker of the Assembly. On the Labor side the more noteworthy members elected included Keith Wright (Rockhampton South) and Ed Casey (Mackay), both of whom would later become parliamentary leaders of their party. Neither man made it to Premier but Casey would become a minister in the Goss government and Wright, who quit state politics in 1984, would serve in the Commonwealth Parliament before serving time in jail for sex crimes. For the first time in the Queensland Assembly, identical twins were elected as members. Both were Labor Party members but represented electorates at opposite ends of the state: Peter Wood (ALP, Toowoomba East) was first elected in 1966, while his twin, Bill Wood (ALP, Cook), was elected in 1969. One newspaper report looking for an angle claimed the event was unique among parliaments in the British Commonwealth and predicted the twins would pose a 'worry for the Speaker' in telling them apart!

Alex Dewar, the former Liberal minister for Labour and Industry, who had resigned from the Liberal Party to become an independent for the last year of his parliamentary term, was unsuccessful in his attempt to retain his seat of Wavell. So bitter was he towards his former colleagues that during the campaign he had defied the Liberal Party to defeat him. The Liberals enjoyed the last laugh when Dewar finished third with 25.4 per cent of the vote-behind the Labor and the Liberal candidates. The Liberal candidate, Dr Arthur Crawford, defeated Labor's Herbert Bromley (the brother of Fred Bromley) with 54.7 per cent of the two-party preferred vote.

Reaction to the result of 1969 was mixed. For the government, the result virtually maintained the status quo. They were back in government and the victory 
provided a temporary affirmation of Bjelke-Petersen's leadership as Premier and leader of the Country Party; his better than expected performance kept his detractors inside the party at bay. The Liberals again outpolled the Country Party (this time by 23.7 per cent to 21 per cent) but they were disappointed they had not made greater inroads into the Country Party's seat majority. Labor was again consigned to opposition, pleased to hold five additional seats, but becoming restless and resentful as the years in opposition began to stretch out. The party's support for Houston as parliamentary leader was maintained due largely to his impressive performance in the campaign and Labor's improved position after the election, but also to the fact that no obvious successor was yet apparent. After the election, Tom Burns, the ALP's state secretary, offered a 'hand of friendship' to the Liberals, claiming Labor would vote with the Liberals to introduce a fair election system - a gesture that was rejected by Chalk, who said he had no truck with Labor and did not want any (AJPH 1969:vol. 15, no. 3, p. 102).

Shortly after the election, however, the government was forced to fight a byelection in the seat of Albert after the unexpected death of Cecil Carey. First elected in May 1960, Carey had held the largely rural seat of Albert for the Country Party until suffering a fatal stroke on 26 December 1969. He had won the seat in 1969 with an absolute majority of the primary vote. The by-election called for 14 February 1970 again saw a three-cornered contest between the major parties. A 'young goer', Don Beck (a thirty-three-year-old businessman), was endorsed as the Country Party's candidate. The Liberals ran the fortynine-year-old William (Bill) Heatley (a former Liberal senator for Queensland, 1966-68) and trawler fleet operator. Labor preselected a young school principal, Bill D'Arcy (then just thirty years old), who would later rise to become Labor's deputy leader before falling from grace and being charged with paedophilia 28 years later. An independent, Eric Nunn, also stood. On the primary vote alone, the Liberal candidate nosed just ahead of the Country Party to claim second position overall by a mere 79 primary votes. Heatley won 3899 votes to Beck's 3820. Nunn finished last with 416 votes (2.91 per cent) but allocated his preferences to the Liberals. Although Labor won the primary vote with 6143 votes (43.02 per cent), it lost after a distribution of preferences, as Table 8.1 indicates.

Table 8.1 The result of the by-election for Albert, 1969

\begin{tabular}{|l|l|l|l|l|l|}
\hline Name & Party & $\begin{array}{l}\text { Primary } \\
\text { vote }\end{array}$ & $\begin{array}{l}\text { Second } \\
\text { count (\%) }\end{array}$ & $\begin{array}{l}\text { Third count } \\
(\%)\end{array}$ & Total (\%) \\
\hline Eric Nunn & Ind. & 416 & & & \\
\hline Don Beck & CP & 3820 & $47(11.30)$ & & \\
\hline Bill D'Arcy & ALP & 6143 & $131(31.49)$ & $798(20.64)$ & $7072(49.53)$ \\
\hline Bill Heatley & Lib. & 3899 & $238(57.21)$ & $3069(79.36)$ & $7206(50.47)$ \\
\hline
\end{tabular}


Heatley narrowly won the seat by 134 votes ahead of D'Arcy. Newspaper speculation before the by-election had warned that the leadership of the government would rest on the poll result. Commentators believed the by-election was more about a confidence vote in the Premier than it was a local contest between the candidates (Courier-Mail, 5 February 1970). Their speculation was most prescient.

Surprisingly, Heatley would not hold Albert for long, remaining an MLA for just more than 20 months. Ironically, for a man who had twice attained political office through the death of a former member (first inheriting a senate vacancy from Bob Sherrington, then Carey's former seat in the Assembly), Heatley himself-a heavy drinker-died on 29 October 1971. The seat was then not filled until the next general election (leaving it vacant for seven months), when it was eventually claimed by Bill D'Arcy for Labor.

\section{Conclusion}

Later representations of Bjelke-Petersen's style of government highlight his strength of character and his rugged determination in office. During the 19 years of his premiership, he gained notoriety for his toughness, his commitment to win political fights and his unorthodox ways of doing business. He generally became portrayed as an astute strategist who was ruthless and sometimes vindictive to his opponents, both across the political divide and within his own side of politics. He was later to assume an almost mythical status in political folklore and among his supporters was considered to possess many 'larger-thanlife' qualities. Populist images of the idiosyncratic Premier gradually came to characterise not only his government but the nature of politics in Queensland. His penchant for controversial statements provided a regular diet of 'good copy' to the eagerly awaiting 'chooks' of the media. He was also a convenient target of ridicule for cartoonists, satirists and impersonators.

Certainly, within a decade of becoming Premier, he was an unrivalled champion of the right not just in Queensland but throughout Australia. He would later attract a following and a loyalty among colleagues and sections of the public that would stand the test of time. Those avid supporters who later became known as the 'Friends of Joh' placed an unshakeable faith in the Premier, irrespective of any charges or criticisms his accusers could level. To these supporters, he was a man surrounded by enemies who had become a beacon for the conservative cause. Others, however, saw him differently. To his detractors, he was a demagogue with a mean streak who was prepared to use state power to achieve whatever immediate ends were uppermost on his agenda. Bjelke-Petersen was certainly a paradox, not only because his 'country-bumpkin' ordinariness 
was combined with an intensity and Machiavellian complexity, but because he skilfully managed to translate those characteristics into enduring political success.

There are, however, two other sides of Bjelke-Petersen as a political leader that are generally less acknowledged in popular accounts of his premiership but which are evident from his early years in the position. First, his sense of accountability was not well developed and his understanding of responsible government was at best partial. To him, governments were there to get on with the job (or get out of the way of private interests) and he tended to see the Parliament as an imposition on or impediment to strong executive government. He was never committed to notions of parliamentary sovereignty or to the conventions of parliamentary democracy. His relations with the Parliament were at best grudging and, like the Labor governments before him, he worked from the principle that state politics was a 'winner-take-all' system. There is evidence, however, that he was more open and trusting in his early years in the Parliament but became more withdrawn and circumspect as his political attackers made capital from his predicaments.

Second, while he is subsequently remembered as a decisive and uncompromising leader, in his early years in the Premiership he was often unsure of direction, ambivalent and fickle in his decision making. Initially, it is clear that he lacked confidence and seemed awkward with the media until he had an image 'makeover' and had his performances coached. His premiership did not appear initially to offer much promise and many even among his own party saw him as a stopgap leader who would make way for someone younger and more adventurous (such as Ron Camm). History, however, indicates how wrong initial impressions can be. Bjelke-Petersen certainly did not regard himself as a stopgap figure and, as opposition to his premiership grew, he strenuously fought to retain the top job; and once that fight was over, he would remain virtually unchallenged as leader for another 15 years. 



\section{The slide towards uncertainty, 1969-1972}

The Parliament resumed after a break of seven and a half months - a relatively long intermission but by no means unusual in those days. When an election was due in the new year (from March to June), it was common practice for the Parliament to adjourn in late November or early December (before Christmas) and to not reconvene for another six to eight months. This was the pattern followed throughout the 1940s to the mid-1950s and again from 1962 to 1972. The thirty-ninth Parliament would run from 5 August 1969 to 10 December 1971 (202 sitting days in the three-year term or 67 days a year) and not meet again before the May 1972 election. It was the last Parliament to meet with 78 members and, for the first time since winning government, the Coalition governed with a reduced majority. Under Nicklin, the Coalition's majority had risen from nine in 1957 to 10 in 1960, to 14 in 1963 and 16 in 1966, but fell back to just 12 after the 1969 election-Bjelke-Petersen's first electoral test as leader. With the benefit of hindsight, it is clear the 1969-72 Parliament was to become Labor's high-water mark in its period in opposition, when for a few years it posed a credible challenge to the government. It was also a period when the Premier was at his most vulnerable politically - a condition deeply troubling to his own party colleagues, who would eventually be incited to rebel against his leadership.

\section{'To drive home the supremacy'}

Bjelke-Petersen's second ministry was sworn in on 29 May 1969. The initial ministry of 13 preserved the seven-six balance of power between the Country Party and the Liberals. The former Minister for Public Works, Local Government and Conservation, Harold Richter (CP, Somerset), indicated he no longer wished to be part of the ministry and was then knighted and replaced by Neville Hewitt (CP, Mackenzie), who had had quite a considerable wait to reach the frontbench. The full ministry consisted of

- Premier and Minister for State Development: Johannes Bjelke-Petersen, CP

- Treasurer: Gordon Chalk, Lib.

- Minister for Mines, Main Roads and Electricity: Ronald Camm, CP

- Minister for Justice and Attorney-General: Dr Peter Delamothe, Lib.

- Minister for Education and Cultural Activities: Alan Fletcher, CP 
- Minister for Primary Industries: John Row, CP

- Minister for Health: Doug Tooth, Lib.

- Minister for Labour and Tourism: John Herbert, Lib.

- Minister for Transport: William Knox, Lib.

- Minister for Industrial Development: Fred Campbell, Lib.

- Minister for Lands: Victor Sullivan, CP

- Minister for Works and Housing: Max Hodges, CP

- Minister for Local Government and Marine Activities: Neville Hewitt, CP

Within a matter of months, however, the second ministry was amended significantly. On 20 August, the Premier introduced an amendment to the Officials in Parliament Act 1896-1968, seeking to increase the number of ministers from 13 to 14 . The official reasons for the increase in the ministry were the growth rate of Queensland, the higher workload on ministers and the decentralised nature of the state, coupled with the fact that "ministers have made themselves more and more accessible to the people generally' (QPD 1969:vol. 251, p. 104). During an unusually protracted first reading debate, Bjelke-Petersen did not indicate directly in the Parliament that he would be appointing an additional Country Party minister (although he had suggested this outside the House) and opposition members speculated on who the new minister might be. Predictably, Labor opposed the move, claiming Bjelke-Petersen was 'empire-building', that Queensland had too many ministers compared with other states and arguing that the money could be better spent on improving facilities for the opposition. Both the Leader of the Opposition, Jack Houston, and his deputy, Percy Tucker, implied that the additional portfolio was being created to 'give dominance to the Country Party in Cabinet' (QPD 1969:vol. 251, p. 106). Tucker added:

If the Country Party keeps on as it is going, it will have more chiefs than Indians. The Country Party receives only 21 per cent of the votes of the people of Queensland yet it dominates the coalition Government. If this measure is passed the Country Party will have an additional Minister to help it dominate the coalition. Surely the Leader of the Liberal Party can see what is happening... The Liberal Party must know that it is designed to give the Country Party more freedom in Cabinet. (QPD 1969:vol. 251, pp. 112-13)

In total, six Labor members spoke against the bill in the first reading (Houston and Tucker plus Hughie O'Donnell, Jack Melloy, Doug Sherrington and Peter Wood), with Sherrington insisting that the move was 'designed for one purpose only, that is, to drive home the supremacy of the Country Party in this Government' (QPD 1969:vol. 251, p. 118). Believing that Bjelke-Petersen had deliberately begun to cultivate his image as a 'strong' premier, Sherrington 
was quick to criticise this engineered transformation. He suggested that Gordon Chalk had more stature and had earned the reputation as the government's strongman. Sherrington then reminded members that the Liberals had urged Chalk to remain Premier in the week after Pizzey's death. According to Sherrington, Bjelke-Petersen felt Chalk was looking over his shoulder, so needed to change popular perceptions. Sherrington told the Parliament: 'It was evident to everybody connected with politics that, right through the election campaign, the Premier, through his Press relations officers, and particularly through his column in Sunday Truth, had to prove that he was the strong man of Cabinet' (QPD 1969:vol. 251, pp. 118-19).

Then, with some prescience of mind, Sherrington added:

There was a time when I admired the Premier for being a man of integrity. However, I believe that since he has become Premier, and because he has been forced into having to prove himself as a strong person, he has descended on many occasions to launching any type of attack that he chooses. (QPD 1969:vol. 251, pp. 118-19)

In the debate, only the Premier and his Liberal deputy spoke in favour of the amendment to increase the size of the ministry. With his final remarks, the Premier indicated the bill had the full support of the cabinet, which effectively locked-in Liberal support for the amendment. In the second reading speeches, many of the same protagonists repeated identical points, but this time with Charles Porter (Lib., Toowong) and Treasurer Chalk replying to the opposition's criticisms. ${ }^{1}$ Chalk, in particular, denied that the increase was designed to give the Country Party control in cabinet. He argued that only one additional minister was needed (rather than two - that is, one each) and that the bill had been discussed in cabinet and within the Liberal Party (which he argued supported the idea). He volunteered:

At Cabinet meetings every Minister looks at matters not on a partypolitical basis between the two arms of the coalition but on the basis of what is best for Queensland. There is no such thing as a majority in Cabinet meetings...In my whole time in Cabinet I have not seen one vote taken. (QPD 1969:vol. 251, p. 252)

\footnotetext{
1 Jack Houston also accused the Bjelke-Petersen cabinet of being internally divided. In reply to the Premier's comments that the opposition did not know what went on in cabinet (especially about votes on contentious issues in cabinet), he said: 'I remember that some time ago in this House we heard an entirely different story. It related to the chiropractors' legislation, on which the Cabinet was so divided that, when the numbers were counted, it was decided that there should be a free vote on the matter in this Chamber. Surely the Government will not suggest that every Cabinet decision is unanimous' (QPD 1969:vol. 251, p. 243).
} 
The first reading of the bill was passed by a vote of 41 to 29 after nearly three hours of bickering. On 27 August, the bill was carried at its shorter second reading by 40 to 31 votes and declared read a third time without debate or vote.

As predicted, a further Country Party minister was appointed in September, resulting in a minor reshuffle of portfolios. In the reallocation, Ron Cammstill considered a rival to the Premier-was stripped of responsibility for the electricity industry and returned to his previous portfolio responsibilities for Mines and Main Roads. Neville Hewitt lost Local Government and was given instead responsibility for a new portfolio of Conservation, Marine and Aboriginal Affairs. And the ministerial newcomer, Wallace Rae (CP, Gregory), from the far west of the state, was appointed Minister for Local Government and Electricity. Rae had developed a reputation as a politician who had 'at times risked his political career to speak out for his people' (Courier-Mail, 4 September 1969). Importantly, the addition of Rae to the ministry represented a major departure from the conventions established by Nicklin in 1957. The relativity between the Coalition parties in cabinet was now changed to eight to six in the Country Party's favour.

The real reasons underlying the Premier's pre-emptive action are open to speculation. Certainly, the decision allowed the Premier to enhance his personal support within his own party while allowing him to trim the influence of Camm. It also allowed him to reinforce his leadership credentials vis-a-vis Chalk. Moreover, the fact that the Country Party had not lost a seat in the 1969 election, whereas the Liberals had lost one, could also have been a factor in the Premier's decision (but perhaps less plausibly given that the announcement was made in September and not in May). Behind the scenes, the Premier's quest 'to drive home the supremacy' of the majority party was resented by some sections of the Liberal Party, but at the time its resentment was to no avail. Gradually, however, such manifest signals of its junior status fed into its growing disenchantment with its senior coalition partners.

\section{On party lines: Nicholson's fourth term as Speaker}

With the inability of the Administrator, the Senior Puisne Judge Joseph Sheehy, to attend the opening ceremony of the Parliament, three commissioners were appointed to conduct the return of the writs, the swearing in of members and the election of the Speaker. Bjelke-Petersen nominated the former Speaker, David Nicholson, to reoccupy the position, commenting that he 'conducts himself with dignity, ability and fairness to all' (QPD 1969:vol. 251, p. 3). Treasurer Chalk seconded Nicholson's nomination. The Opposition Leader, 
Jack Houston, accused the government of politicising the office of Speaker and of being so indifferent to the office that they merely repeated the nomination speeches made by Jack Pizzey and Chalk three years earlier. In nominating Hughie O'Donnell (ALP, Barcoo) as the opposition's choice for Speaker, Houston spoke for more than half an hour. He complained about the mismanagement of the House under Nicholson, especially the favouring of government members, the cramped conditions for the opposition and the failure to allow the Standing Orders Committee to meet for more than three years. Percy Tucker, the Deputy Opposition Leader, seconded Labor's nomination. The outspoken member for Townsville South, Tom Aikens (NQP), attacked both sides for their hypocrisy. He argued that there was a lot of 'pulling shirt-tails, blowing down ears and working rackets with regard to the appointment of officers of this House' (QPD 1969:vol. 251, p. 9). Speaking for almost an hour, Aikens told the members that Nicholson had made many mistakes when he first became Speaker, but 'like good whisky, he improved with age' (QPD 1969:vol. 251, p. 10). He then launched into a diatribe against free speech, university students, the 'Brian Laver group', erotica, pornography, as well as communists, members of Trades Hall and 'all the other political riff-raff' around. At one stage, he warned the sole female Member of Parliament, Vi Jordan (ALP, Ipswich West), that she had 'no right to hide behind her sex in order to dodge her responsibilities' as a legislator and should she seek to do so 'she should either leave Parliament or change her sex'. This threat was issued not because of anything Jordan had said or done but because Aikens was tempted to read extracts from an erotic publication he thought she should not hear. The whole speech was a typical spray of vituperation, more suitable for the front bar of a local pub than the Parliament.

In the ballot for the Speakership, the vote went on party lines. Nicholson received 45 votes to O'Donnell's 31 votes, with one informal vote cast (Tom Aikens) and one member not voting. Bjelke-Petersen offered the government's congratulations, claiming - without the slightest trace of irony - that because Nicholson maintained 'a very high standard in the conduct of business in this House', 'we in Queensland have gained a reputation that is the envy of other Parliaments' (QPD 1969:vol. 251, p. 15). Houston also congratulated the Speaker on behalf of the opposition. Accepting the position, Nicholson (who had been Speaker since August 1963) stated:

If this were the House of Commons following the vote which has just been taken I could, of course, no longer occupy the chair, because there it is thought that the Speaker should resign if he has lost the confidence of all, or even some, members. Here, of course, the position is entirely different. In Australia, Speakers are in rather an unfortunate situation. I well remember that when I was elected in 1966 the then Leader of the Opposition, Mr Duggan, also expressed the view that it is unfortunate 
that a Speaker has to be nominated and still has to retain his party membership. I believe that on that occasion I replied that I would be very happy to resign my party affiliation as long as the Opposition also entered into an agreement not to play politics with the Chair and did not compete against me in the election. That is the right of Speakers not only in the House of Commons but in many other Parliaments. (QPD 1969:vol. 251, pp. 15-16)

Nicholson then indicated that his acceptance speech was 'possibly the only opportunity I will have to speak my mind, and speak it I will, no matter how long it takes'. He castigated the opposition for 'a spate of untruths' and trying to 'forget the past'. Faced with interjections and issuing threats to expel members opposite, Nicholson acknowledged the level of office space provided to members was 'not in accordance with my desires'. He indicated that he had not wished to allocate three to four members to a room or locate a similar number in 'The Lodge' $^{2}$ (but added that 'this is the only Parliament in the Commonwealth in which members are even provided with a bed') (QPD 1969:vol. 251, p. 16). He finished his speech by praising the government for refurbishing the House with 'over \$500,000 spent on Parliament House since a Country-Liberal Government first came to office'. There was now a 'desk for every Member of Parliament and a telephone on each desk'. And although 15 Labor members shared a single room, this was, according to Nicholson, not as bad as when he 'first entered Parliament [when] there were 15 Country party members in a room 25 feet by 15 feet. It contained one table and two telephones and not enough chairs for the 15 members to sit on.' He concluded in a frank manner by reflecting:

I realise this is a democratic world and while we have a system of politics where the election of Speaker is based on a political plane, as it was today, then it is a difficult job for any occupant of the chair, irrespective of his political affiliations, to convince the people that he is being impartial. And that will continue, irrespective of who occupies the chair. That doubt will always remain while the election of Speaker is conducted on a political basis. (QPD 1969:vol. 251, pp. 16-17)

Nicholson would go on during the thirty-ninth Parliament to become the longestserving Speaker of the Legislative Assembly (a record term of 11 years and nine months - still unsurpassed to this date). His achievement was recognised on the

2 The Parliamentary Lodge was a timber boarding house located next to the Provedore's Cottage at the end of the ministerial wing of the parliamentary buildings on Alice Street, running towards the river. It was demolished to be replaced with the Parliamentary Annexe in 1973. The Lodge was often the subject of criticism from members. Ray Jones (ALP, Cairns) complained that he was unable to perform his parliamentary duties adequately because 'when I return to The Lodge, unless I get to bed and to sleep before my two roommates, I spend hours lying awake listening to their snoring. Three of us share one room, and their beds are nearly as close to mine as are the tables in the office that I share with other members' (QPD 1969:vol. 251, p. 541). 
appropriate day (15 October 1970) in a Ministerial Statement by the Premier. In the statement, Bjelke-Petersen described Nicholson as having 'displayed all the attributes of a great Speaker' (QPD 1970:vol. 254, p. 1072).

The Administrator's opening speech to the first session delivered on 6 August 1969 in the former Legislative Council chamber noted that the Governor had represented Queensland at the investiture of the Prince of Wales in July. He mentioned that state finances would 'face a number of difficulties' because of drought and higher pay for government employees. New land was being cleared, new dams and irrigation schemes were under construction, regional sewerage works were approved, new roads and tunnels built, new harbours and jetties were planned, a new prison was forthcoming and other public works were announced. The government noted that the Attorney-General had received the first report of the Law Reform Commission of Queensland. Interestingly, among the new bills to be presented to the Parliament was one to impose death duties. The Death Duties Assessment Bill provided 'for the imposition, assessment and collection of duties upon the estates of deceased persons in place of the existing scheme which is based upon the succession of a beneficiary to property' ( $Q P D$ 1969:vol. 251, p. 20). The government also announced it intended to introduce a bill to 'regulate the marketing of processed packaged chickens to protect the consumer from an excess water content' (QPD 1969:vol. 251, p. 20). Nothing, apparently, was too banal or insignificant for the head of state to itemise.

The Speaker also announced the appointment of the new Clerk of the Parliament, William Johnson, who had served as Clerk-Assistant and Sergeant-at-Arms under the previous Clerk, Roy Dunlop, who had retired on 31 December 1968. Johnson had formally begun his duties as clerk on 1 January 1969 and was due to be sworn in officially once the Parliament met; as chance would have it, he was absent on the day through illness. His deputy, Cyril George, took the oath of allegiance on 7 August, while Johnson was eventually sworn in on 2 September 1969. Johnson's term as clerk was to be short-lived as he suffered a major heart attack the next year and died on 19 August 1970. Johnson's initial appointment as Clerk-Assistant (back in 1954) had been somewhat controversial as he was accused of being a political appointment. Johnson had a background in Labor and trade union politics and had been appointed by the Hanlon Labor government to the Land Court. The Labor Premier, Vince Gair, then appointed him to the deputy clerk's position (in conventional practice becoming the next designate for the top job) and elevated him above Cyril George in seniority. He was also believed to have been a close personal acquaintance of Gair.

The Parliament noted the death of Sir James Heading, a member for 13 years and former Minister for Public Works and Local Government in the first Nicklin government (1957-60) (QPD 1969:vol. 251, p. 23). Also noted was the passing 
away of William Dart, a former member (1938-44) and one of the original aldermen of Greater Brisbane. Heading's career was typical of the Country Party members of his generation. As the Premier reminded the House:

The late Sir James Heading came from Victoria as a young man to the South Burnett and settled in the Murgon district at a time when land was being thrown open for closer settlement. He became one of the district's most successful farmers and was a noted stud breeder of Australian Illawarra cattle and Large White pigs. For more than half a century he was an active supporter of agricultural shows...He was chairman of the Murgon Show Society for many years, became a councillor of the Royal National Agricultural Association in 1940, and was that association's president from 1951 to 1955. Before the outbreak of World War I Sir James had become chairman of the Murgon Shire Council. He served with distinction in that conflict, in the 47th and 45th Battalions, and was awarded the Distinguished Conduct Medal and the Military Medal...He devoted much energy to the promotion of primary producer organisations for many years... [and] was not averse to change when new methods meant increased efficiency, and his progressive and dynamic approach to all problems stamped him as a leader in advancing the interests of primary producers generally. He was a great man, who contributed so much to the benefit of many people in this State. (QPD 1969:vol. 251, p. 24)

After the condolence motion, the Speaker had to warn members engaged 'inappropriately in audible conversations' - some of whom were apt to 'move about the Chamber, retire from the Chamber, and re-enter it' during the condolence debate. The Speaker ruled that this was disrespectful and undesirable. When the long-serving independent member Arthur Coburn died later that month (21 August 1969), the Speaker did not have to warn members. Eulogies from the Premier, Opposition Leader and Tom Aikens all recalled his earnestness and dedication to the Parliament and community (QPD 1969:vol. 251, pp. 190-2).

As was customary, two new members from the government's side initiated the Address-in-Reply debate. In 1969, the debate was opened by Harold Hungerford (CP, Balonne) and Dr Arthur Crawford (Lib., Wavell). While Hungerford's address was rich in hyperbole (but included one of the few mentions of the Vietnam War in the Assembly when en passant he prayed that the war will 'soon come to fruition'), Crawford launched into a passionate plea for new health legislation, new structures of health care, better health management and reforms to hospitals and nursing. His speech ended with a call to repeal the present health legislation, arguing that 'reform is imperative' (QPD 1969:vol. 251, p. 36). Crawford's attack placed him offside with the government and, as one of the Liberal 'ginger 
group', he never made it into the ministry before he retired in 1977 over the lack of political leadership and policy follow-through in the Liberal Party. His 1969 Address-in-Reply outburst was sufficient, however, to force Russ Hinze (CP, South Coast) to opine that 'after he gets a few spots knocked off him' he would become a 'valuable member of the Government because he has indicated that he is prepared to say what he thinks' (QPD 1969:vol. 251, p. 142).

\section{Parliament a 'sham show'? Complaints about the lack of openness}

With the resumption of parliamentary business, Labor raised questions about potential offshore oil spillages on the Great Barrier Reef. This was after a major blow-out (or spill) had occurred in the Santa Barbara Channel off California causing environmental damage. Initially, the Mines Minister, Ron Camm, presented a series of partial answers prepared by departmental officers providing some, but by no means all, requested information. Later, he informed the Parliament that although the government had been granting permits to drill for oil offshore close to the Great Barrier Reef, it had decided to suspend any new exploration permits until further safety requirements were met by industry (without repudiating any existing agreements). Camm argued that 'drilling is an essential step in finding deposits of petroleum, so all rights to explore for petroleum include the right to drill' and that any repudiation of agreements (under the Petroleum [Submerged Lands] Act 1967) would be unacceptable. He told the House: 'This Government will not repudiate any agreement that it has entered into. Repudiation would cause a world-wide loss of confidence in the integrity of the Government of Queensland, resulting in a drying up of capital for investment in the State and a flight of capital from the State' (QPD 1969:vol. 251, p. 65).

Labor was clearly unhappy with Camm's statement but in those days it was unable to formally respond to ministerial statements. Opposition members were determined not to allow the issue to disappear and repeatedly came back with questions and allegations. A similar issue that escaped parliamentary notice in late 1971 was the negotiation between the Queensland and federal governments over proposals to establish a uranium-enrichment facility in the state. Both governments were supportive of establishing an enrichment plant but the Prime Minister, William McMahon, 'stated it is not intended to give any publicity to the proposed studies' (Queensland Cabinet Submission no. 14908). The government was more successful in keeping this issue under wraps.

Nicholson was sometimes partial in disallowing opposition questions on notice, giving various reasons for why he would not 'call' proposed questions so they 
could be asked on the floor of the House. The procedures under Standing Orders then required the opposition (or any member) to present proposed questions on notice to the Speaker, who determined which questions were permissible and which would be 'called'. In August 1969, he ruled out questions from Labor for a variety of reasons: because they contained 'implications and innuendoes', 'contain more information than they seek', should be 'addressed to the Postmaster-General' (that is, another level of government) or were 'out of order in their present form' (QPD 1969:vol. 251, pp. 37, 66). He would also disallow questions on notice he considered repetitious and not include them on the daily Business Paper of the Assembly, meaning that the Labor members concerned could not ask their nominated question. The Deputy Opposition Leader, Percy Tucker, twice challenged the Speaker's interpretation and was 'named' and then suspended for a day for disregarding the authority of the chair. He was given a chance to withdraw his accusation that the Speaker was 'covering for the Government' but refused and was then voted out by 41 to 30 . Later the same month, Nicholson warned Labor members that when they were giving notice of questions they tended to 'impart more information than they seek' and that 'the purpose of a question is to seek information, not to impart it' ( $Q P D$ 1969:vol. 251, p. 239). Two new members, both of whom would subsequently become opposition leaders, were named as among the main offenders: Ed Casey (Mackay) and Keith Wright (Rockhampton South) - both of whom were first elected that year. ${ }^{3}$ Casey and Wright gave their maiden speeches in the Addressin-Reply debate of 1969. They were joined in this debate by the new Liberal members, Arthur Crawford and Bob Moore (Windsor); the Country Party's Harry Hungerford, Val Bird (Burdekin) and Selwyn Muller (Fassifern; the son of Alf Muller, the former member); and Labor's Peter Moore (Mourilyan), Evan Marginson (Ipswich East), Eugene (Lou) Jensen (Bundaberg), William (Ray) Bousen (Toowoomba West), John (Jack) Aiken (Warrego), Edgar (Ted) Baldwin (Logan), Bill Wood (Cook) and Brian Davis (Brisbane). In addition, some 17 months after his election to the seat of Landsborough, Mike Ahern, the eventual

\footnotetext{
3 Interestingly, Keith Wright in his maiden speech gave a passionate plea for greater moral education and respect of authority. He said: 'I wish to put before this Chamber a number of my views on what has been described as the "Sodom and Gomorrah" society of the 20th century. Judging by the examples set by many of the so-called intellectuals at the university and the upper crust of society who are versed in the arts, the days of morality, chastity and self-respect are things of the past. Their cries are well-known: "Do away with censorship"; "Remove the laws that prohibit drugs"; "Give men and women the right to make love how, when and where they so desire". They say, "What does it matter if children see pornography. After all, this is life". As representatives of the people we have a responsibility to them, and we will meet this responsibility only if we accept the moral code of the majority of the people. With all the "freedoms" that are now part of living, our young people are looking for someone to set and maintain a standard' (QPD 1969:vol. 251, pp. 483-4). A former teacher, he also advocated a tougher system of discipline for students in schools. In the mid-1990s, Wright was jailed for nine years for raping and indecently dealing with an underaged girl.
} 
successor to Bjelke-Petersen as premier, delivered his first free-ranging speech typical of the maiden speeches of new members. ${ }^{4}$ Jim Blake (ALP, Isis) also gave his maiden speech despite being first elected in November 1968 at a by-election.

Further issues of concealing information arose often over minor matters. For instance, Horace Davies (ALP, Maryborough) asked the Premier for information on the refurbishments to the bedrooms and offices in the parliamentary lodge and was somewhat characteristically told: 'the information sought by the Honourable Member is not readily available and the time and expense that would be involved in securing it could not be justified' (QPD 1969:vol. 251, p. 51). A similar dispute arose over the payment by the Crown of fees to barristers and solicitors for work performed for the government. Labor moved an amendment to the tabling of a list of payments, requiring the figures to be fully disaggregated to show which payments were made through solicitors to barristers (to show who was receiving government money). There were also allegations made that some lawyers were receiving preferential treatment and public money because they were prepared to 'door knock for members of the Liberal Party and of the Country Party' (QPD 1969:vol. 251, p. 68). Labor's main spokesman on legal affairs, Col Bennett (South Brisbane), accused the government of concealing sensitive information to protect itself. He argued:

When Parliament meets, I do not think it should be any sort of a sham show. When we seek information or ask questions, or even when we may have some information ourselves, we are entitled to test the authenticity and truth of that information and that is why Ministers are here. That is what they are here to do...It is very difficult to get information from any Government members or anything other than abuse and sarcastic comments...However, I do know that certain barristers receive preferential treatment from this Government and from individual Ministers... [then after taunts from Gordon Chalk to 'name them'] Government members know very well who worked for Peter Connolly at West End, and if they do not, they do not know what is going on in their own parties. The [Liberal] 'ginger group' can tell them because they keep their ears to the ground. (QPD 1969:vol. 251, p. 68)

\footnotetext{
4 Mike Ahern's maiden speech was given in the second reading speech on the Beach Protection Bill in April 1968 (QPD 1968:vol. 248, pp. 2772-5). His maiden speech was thus constrained by the necessity of discussing clauses of the bill under debate. In August 1969, Ahern's first opportunity arose to speak on any matters of interest to him. He chose to congratulate the new minister Nev Hewitt (but gave his speech before the second new Country Party minister Wally Rae was appointed), criticised Labor for conducting a personal attack on the Premier in the recent campaign, then stressed the importance of drought relief and irrigation schemes to farmers, as well as agricultural research and farm management ( $Q P D$ 1969:vol. 251, pp. 288-93).
} 
Treasurer Chalk retorted that it was the 'prerogative of any Government to spend its money engaging the services of those men in the legal profession who the Government considers have the ability and experience to either present or defend a case' (QPD 1969:vol. 251, p. 70).

Another tactic used by ministers to mask accountability was to flick questions on notice that were not squarely within their formal responsibilities. Rising to ask a series of questions on notice, Jack Melloy asked the Justice Minister, Peter Delamothe, about the government's intentions with respect to controlling gambling. Melloy (later an avid poker machine player) was deadly serious when he asked whether the minister was 'aware of the dens of iniquity and gambling hells which flourish throughout Queensland, in which women and children are involved in the game of bingo'. Delamothe responded by stating that he was not aware such places were flourishing and anyway the relevant act was not under his portfolio but was administered by his colleague Max Hodges, the Minister for Works and Housing (QPD 1969:vol. 251, p. 83).

During the Address-in-Reply speech, it transpired that the government had established a partisan committee to 'conduct an inquiry on matters associated with Parliament and parliamentarians'. This inquiry, consisting only of government members, canvassed whether any of the existing Standing Orders should be revised. The Opposition Leader, Jack Houston, claimed that the inquiry was an attempt to bypass the Standing Orders Committee, keeping the opposition in the dark. He stated that he believed that 'Standing Orders and associated matters were based on the requirements of the times, with the basic idea of making this nation and Parliament as democratic as possible' and that 'Sir Francis Nicklin when Premier, made it clear that there would be no change in the Standing Orders unless there was unanimity'. Houston recalled that Nicklin 'said he did not want the operation of this House-and I supported him on this - to depend on the party in power running the proceedings and deciding what the Standing Orders should be' (QPD 1969:vol. 251, pp. 79-80). In response, the Speaker denied that any unilateral decisions would be taken on the basis of the Coalition's inquiry and in the end the government did not place any matters before the Standing Orders Committee. Houston then complained about the infrequency of parliamentary sittings, comparing Queensland with the Federal and Tasmanian Parliaments, which often sat regularly up to and immediately after election times. He reminded members that

[i]n this State, Parliament rose on 10 December last year. The election was held on 17 May. It was not until 5 August that we met for the first time. This is not in the interests of the State, but it certainly suits Cabinet and lazy members of Parliament. Let me make it quite clear that it does not suit the Opposition, and I believe it does not suit the people of Queensland. (QPD 1969:vol. 251, p. 80) 
To this, the Minister for Industrial Development, Fred Campbell, interjected 'it is no worse than it was in 1956' when Labor had last been in government. Trying to be helpful, Russ Hinze later suggested that 'with the responsible coalition Government that we have in this State I feel sure that the days of Parliamentary recesses of eight months are behind us' (QPD 1969:vol. 251, p. 142).

Hinze, a colourful and 'effervescent' character, personified the rough and tumble Queensland politician. A former Gold Coast dairy farmer, he had firm if extreme views often grounded on instinct or prejudice. He was also beginning to gain notoriety on the floor of the Parliament for his controversial stances. In the Address-in-Reply speech, Hinze let go with both barrels. He rubbished the Opposition Leader, claimed the opposition could not think of questions to ask, complained he could not take his wife into the parliamentary lodge and then advocated 'the establishment of a Government-sponsored Queensland mining trust' supporting the government's intention to drill for oil on the Great Barrier Reef. He also produced a stout defence of the electoral gerrymander, arguing that Labor was being 'cynical', even though he had himself done a 'shirt-tail' deal with the Labor Party for a swap of preferences in 1966. Hinze then went into a tirade about 'our sickening society' involving lurid tabloids, underage sex, the availability of drugs, predicted explosions of crime (predicted by criminologist Paul Wilson) and the spread of venereal disease among young boys (from a newspaper article written by Haydn Sargent!). ${ }^{5}$ The police force was subjected to daily attacks, while 'ratbag radical' students had a 'complete disregard of any semblance of law and order'. He urged greater vigilance in the censorship of books, films and stage plays (after one performer at the Twelfth Night Theatre was arrested for uttering obscene language - the words 'fucking boongs'). He believed 'sex worshippers' were depraved and if they went to artistic plays were likely to be 'sexually deprived or homosexuals, lesbians, wife-swappers or spivs'. He continued:

To those who suggest that we should emulate the United Kingdom, I refer to the latest importation from that country, the 'junkie' Mick Jagger. Of course, 'old Mick' had to receive a suspended sentence for drug-taking before he could leave the United Kingdom. In addition, he brought with him his mistress, Marianne Faithful, who had to have a stomach pump applied to her before she could recover from an overdose of drugs...Imagine these freaks being brought to Australia by the motion picture industry to play the part of poor Ned Kelly! No doubt the indomitable bushranger would turn in his grave at the thought of

5 Journalist and radio announcer Haydn Sargent (a former Churches of Christ minister) was charged in New South Wales with child sex crimes in 1998 (unlawful intercourse and indecent assault dating back to 1959 and 1960). The charges were dropped in 1999 after files were reportedly 'lost' and the main victim was too disturbed to testify. He had also unsuccessfully contested the state seat of Ashgrove for the ALP in 1969. 
it...No matter what magnificent achievements a country is capable of, if that country becomes morally bankrupt, as the United Kingdom is obviously becoming, it is only a matter of time until the lesson of the fall of Rome is repeated. (QPD 1969:vol. 251, p. 146)

He was proud to be 'square', a 'wowser' and adored the 'old curiosity State for all its weaknesses'. He concluded his speech with a plea for the erection of a boat harbour in his electorate at Currumbin. Some things always stay the same in Queensland politics. ${ }^{6}$

Criticisms of the Parliament also emerged occasionally from academia. Denis Murphy, a senior tutor in history at the University of Queensland (and a future Labor member for Stafford for eight months, 1983-84), gave a stark assessment of the inadequacies of the Parliament in 1970. He wrote:

The Queensland Parliament does not give the impression of being the vibrant forum of democracy. Standing Orders seem to be designed to prevent rather than encourage debate; questions without notice are not allowed; ministerial statements are not debated and there is no private members' debate at the daily adjournment... Many backbenchers feel completely frustrated at their powerlessness and their inability to become legislators. Some burst forth into the news, occasionally, with a criticism of the lack of effectiveness of a parliamentarian while most retire to 'farming' their electorates: becoming de facto social workers, visiting flower shows, being patrons of local organisations, writing letters and asking questions in parliament. Ah! Question Time in the house. Ask me another one, do! Where the Liberal and Country party members find solace in being on the winning side, the opposition members gain relief and mount an interrogative attack by asking questions. During the fiftyfive days of the session almost 1,600 questions were asked of which nearly 1,400 came from the opposition, with some questions having as many as twelve parts. What happens to all the answers is a useful question itself. Question Time in the state house lacks life; in many ways it seems to lack purpose and so it is to be hoped that the cabinet accepts its committee's recommendations of forty-five minutes a day for questions without notice. (AJPH 1970:vol. 16, no. 1, p. 92)

A long-overdue reform was about to be introduced. The opposition had long complained about its questions on notice being censored. They again accused

6 A few years later, when Hinze was Minister for Local Government and Main Roads, a Labor frontbencher asked when the minister would get out and about and visit parts of the state. Gene (Lou) Jensen (Bundaberg) said Hinze had 'not visited Bundaberg and district in his ministerial capacity even to open the new $\$ 400,000$ Main Roads building'. To which Hinze replied that he would visit 'as long as I was supplied with a bottle of Bundaberg rum' (QPD 1976:vol. 270, p. 2772). Interestingly, some decades later, Mick Jagger received a knighthood for his services, while Hinze went to his grave without one. 
the Speaker, David Nicholson, and the Clerk, William Johnson, of censoring their questions on notice by cutting out or restricting those that were critical of the government. The charge against Johnson seems somewhat implausible given he was meant to have been a personal friend of Gair's (QPD 1969:vol. 251, p. 556). Partly as a result of the opposition's criticisms of the lack of openness, however, and partly due to the government committee's review of Standing Orders, the restrictions on questions were suddenly relaxed. On 1 September 1970, after the cabinet had agreed to some of the committee's recommendations, the Speaker announced a 'new format for questions' would be introduced allowing questions without notice. Nicholson told the Chamber:

In introducing the new form of question time, I feel that Ministers and members generally may be guided by a few observations by me with respect to the posing and answering of questions. A question should not be in effect a short speech and should contain only sufficient information to make the reason for asking the question clear. All questions should be framed to seek and not to impart information. Members who desire to ask questions without notice should not do so on matters known to require lengthy research, such as statistical matters, etc. Questions without notice must of necessity be concise yet still clearly convey their meaning. Ministers may reserve the right to answer such questions either fully or in part, or to request that notice of any question be given. Members may ask three questions without or upon notice. One supplementary question is permissible, but it will be regarded as one of the three allowable questions. I must repeat, as I have said on so many occasions, that provocative or politically loaded questions invariably encourage similar answers. (QPD 1970:vol. 254, pp. 407-8)

Seventeen questions without notice were asked that morning on topics as diverse as artificial insemination, night-time greyhound racing, police resignations, child murderers, shire boundaries and why the Premier wrongly considered the replica of Captain Cook's ship, the Endeavour, to be the real thing (which he continued to affirm). The government quickly learned to throw 'Dorothy Dixers' at ministers to use up the time and allow the government to go on the attack. For instance, Henry McKechnie (CP, Carnarvon) asked the Premier whether he had read that the annual conference of the Young Labor Party had voted to legalise 'marihuana'. The Premier replied he had (of course) read the article and stated that, although the issue had not been brought before the joint-party meeting, he 'would oppose such an irresponsible move very strongly, because I believe it would only lead to the greater use of drugs in this State' (QPD 1970:vol. 254, pp. 415-16). While initially up to three questions a day were allowed from each member, the next Speaker, Bill Lonergan, reduced the number permitted to two a day in July 1974. 
Shortly after questions without notice were permitted, Bill Hewitt asked the Premier whether he would examine the new Senate Estimates Committees as a model for Queensland to adopt. He prefaced his question with:

I have here a copy of what I consider to be a historic document. It emanates from the Federal Senate and establishes that last week, for the first time, an Estimates committee composed of eight senators from all parties gave detailed consideration to the Estimates of the Department of Supply, and that attending that meeting were departmental officers. As this is a historic step in Federal politics, I ask the hon. gentleman whether he would be prepared to study closely the procedures that have been adopted, with the possibility in mind of incorporating some or all of those procedures into the ways of this House. (QPD 1970:vol. 252, p. 710)

The Premier was courteous but brief with his reply: 'the matter raised by the hon. member is one that I would be quite happy to study. I have not seen the document yet.'

\section{Normal service is resumed}

As a forum, the Parliament could serve as an information exchange. Seemingly innocuous questions could receive informative answers, giving a glimpse of important contemporary concerns. The Parliament was told that women were now applying for permanent employment in the public service after marriage and that of the 82 applications received 80 had been granted. Among the teaching profession, of 151 applications from women teachers, a total of 147 had been offered continuing employment after marriage (QPD 1969:vol. 251, p. 178). Justice Minister Delamothe informed the Parliament that first-time offenders were not segregated from older recidivists at Brisbane's Boggo Road Gaol on the grounds of economy. He also ventured that homosexuals were similarly not segregated, reporting matter-of-factly that:

It has never been the practice in Queensland to segregate known homosexuals. However, known homosexuals are placed in such areas of work or of exercise where they are under complete supervision, and the practice of homosexuality in prisons over the years has been restricted almost to the extent of non-existence, and when it does occur the offenders are prosecuted in open court. (QPD 1969:vol. 251, p. 183)

Queenslanders could rest safely in their beds. Other types of information were presented to rebuff any hint of assumed profligacy. For instance, when the Premier was asked how many journalists the government employed, he revealed 
that in 1969 a total of 43 journalists was employed in the public service, arguing that they all needed to have experience sufficient to convince a 'competent interviewing panel' of their bona fide credentials but were not required to be members of the Australian Journalists' Association (QPD 1969:vol. 251, p. 185).

In the supply debate, Treasurer Chalk reported that interest rates were increasingly placing additional burdens on the state in financing its debt. He ruled out a 'horror budget' but warned of the dangers of 'over-full employment' forcing wages up by an average of 6.75 per cent. Labor's Jack Houston argued that the problems were caused by the Federal Government under John Gorton, which was arrogant while treating the states as 'being of no great importance'. Tom Aikens interjected that the Commonwealth 'regard us as a glorified local authority', to which Houston responded: 'that is very true...I do not think they even regard us at all to any great extent, except when an election is imminent' (QPD 1969:vol. 251, p. 196). State sovereignty (or lack thereof) was an emerging concern. At one point, Bill Hewitt (Lib., Chatsworth) suggested that making federalism work was one of the main challenges facing governments. His comments on making government work better prodded Houston to say if you are fair dinkum on this, let us start on a non-party basis and have a look at the operation of our own Parliament'. Hewitt responded: 'I take it that the hon. gentleman is now offering some criticism of the working of this Parliament', bringing a resounding 'yes' back from Houston (QPD 1969:vol. 251, p. 200). Warming to this theme, Charles Porter (Lib., Toowong) stated that he would prefer an upper house to be in place, but could not foresee one being reestablished. He argued that the absence of a house of review meant that

[m]inisters have a vastly different role to play, as there are not the checks and balances provided where there are two Houses. Ministers therefore have the extra responsibility of ensuring that the work they do is properly done and that the decisions they make are good decisions, because they cannot be looked at again in another place. (QPD 1969:vol. 251, p. 250)

Few doubted his beliefs were genuine, but others were less sanguine.

In the Chamber, the cut and thrust of debate was often robust but speeches tended to meander off the topic. The usual suspects came up regularly for attention: irrigation and drought, mining ventures, dams, the image of the police force, hospitals, permissive literature and occasionally education and health topics. Drought relief remained political not because the government and opposition philosophically disagreed, but because they often tried to out-do each other in advocating the provision of additional relief. Hence, in September 1969, Hughie O'Donnell (ALP Barcoo) criticised the Coalition for not doing enough to alleviate the drought in western Queensland, repeating newspaper 
headlines that the Premier possessed 'feet of clay' for capitulating to Canberra. Medical matters also featured prominently in legislation in 1969 and 1970especially over the Medical Act Amendment Act 1969, the Chiropodists Act 1969, the Medical Act and Other Acts (Administration) Act Amendment Act 1969 (to restructure the medical boards) and the Queensland Institute of Medical Research Act Amendment Act 1969, the Radioactive Substances Act Amendment Act 1970 and amendments to the Children's Services Act to allow medical examinations for children in care and protection. Vi Jordan (ALP, Ipswich West) advocated increased spending on child care in order that women could play a greater role in the workforce. She also lamented the 'increasing number of deserted wives and the fast-increasing number of young unmarried mothers' (QPD 1969:vol. 251, p. 926). The main topic of debate on law and order was the pending appointment of a new police commissioner. ${ }^{7}$ The government was accused of procrastinating over police reform, at one stage admitting to inviting the South Australian Commissioner of Police to 'advise us on how to run our Force' (QPD 1969:vol. 251, p. 740). Col Bennett also accused the government of politicising the office of Commissioner of Police by arranging for the outgoing Commissioner, Norm Bauer, to address a rally organised by the Young Australian Country Party ( $Q P D$ 1969:vol. 251, pp. 766-7).

Adversarial attacks were common, as were personal attacks on other members and their respective party organisations. Martin Hanson (ALP, Port Curtis) accused the Mines Minister, Ron Camm, of getting his promotion to the executive 'by putting sugar in the Premier's tea'. He also attacked a Liberal sympathiser and publicist for Queensland Breweries, 'Mr [Hugh] Bingham', who had campaigned for the Liberals' Peter Nelson-Gracie in the Landsborough by-election, but had now gone to work for the Country Party as a consultant. Hanson maintained that 'politics breeds strange bedfellows' because the Premier, 'who told this Parliament that drink was a "twin evil" is now jaunting around the State with a brewery publicist' (QPD 1969:vol. 251, p. 507). Hanson's claims were not disputed, implying that Bjelke-Petersen had already realised he needed a publicist and press adviser before he more famously engaged Allen Callaghan in 1971.

In his penultimate speech before his sudden death, Cecil Carey (CP, Albert) even went so far as to threaten opposition members who used their maiden speeches to have a go at the government. He warned them that, while maiden speeches conventionally allowed members the opportunity to criticise their political opponents without fear of interjection, once completed the gloves were off. 'I say to those hon. members who have made their first speech, "You have had your day. From now on we will be at you"' (QPD 1969:vol. 251, p. 412). Other

7 Initially Norm Bauer, who was nearing retirement, was appointed during 1969-70 and then the reforming Ray Whitrod was made commissioner in 1970 - and survived in the post until 1976. 
members became perennial mutual antagonists. For example, Col Bennett (ALP, South Brisbane) and Tom Aikens (Ind., Townsville South) had regular stoushes, with Aikens accusing Bennett of prostituting his position as a politician and being the 'worst of the lot', while Bennett called Aikens a 'mushroom of the Tory Government' - kept in the dark, fed on 'bull', 'and he cops the lot and is very happy provided he is doing what they tell him to do' (QPD 1969:vol. 251, p. 573). Aikens retorted that Bennett lacked 'a fair amount of native intelligence' and deliberately provoked the Speaker only to catch the eye of the press gallery and 'get headlines in the Press tomorrow' (QPD 1969:vol. 251, p. 576). Never in the field of human conflict was so much love never lost by so few!

Occasionally, attacks extended to political actors outside the Parliament, and unionists were fair game. In September 1969, Bill Lonergan (CP, Flinders)nicknamed 'Bugger'em Bill' because of his habit of throwing correspondence and files on the floor and saying 'Ah! Bugger'em' — asked the Justice Minister why a drink-driving charge against the TLC President and ALP President, Jack Egerton, was delayed. The minister answered that Egerton had been arrested and charged but had pleaded not guilty in the Magistrate's Court. The date set for the hearing (11 September) coincided with an Australian Council of Trade Unions (ACTU) conference and an adjournment was agreed until December of that year. Jim Houghton (CP, Redcliffe), who described himself as an 'old rabid Tory', was also fond of accusing Labor parliamentarians of an overly close 'affinity with the boys from Trades Hall who are professed communists'. He sprinkled his attack with statements such as 'he who lies in the gutter with dogs gets fleas' (QPD 1969:vol. 251, p. 885).

Others could be more introspective of the changing nature of parliamentarians. Pat Hanlon (1956-74), who would survive to become the last member of the Gair Labor government of 1957, recounted to the new Parliament:

When one looks through the list of those who retired and those who passed on in the last three years, one sees a remarkable combination of colour, character, and-not the least-controversy by which those members, through their contributions for perhaps a generation, made this Parliament a vital institution in this State... The biggest difference today is in the environment of Parliament itself. Most members will recall that Mr Duggan, who is now retired, said towards the end of last session that he regretted that much of the colour and the atmosphere that had pervaded the Chamber during most of his time as a member did not seem today to exist to the same extent. The hon. member for Logan referred to the fact that Parliament should keep in mind whether it is in danger of becoming regarded by a great percentage of the population, particularly the younger generation, as something of an irrelevancy, an old curiosity place, a 'talk shop', which does not have the importance 
that it once had in our democratic system. That it should be regarded... as an old curiosity rather than as the living, breathing institution it should be, is a matter that must concern members of this House and the public alike. It is true that this Parliament, in the heyday of Mr Duggan, Mr Mann, Mr Walsh, Mr Alf Muller and others who are now retired, was a place of confrontation on issues that affected the life of the people of the day, confrontation that was duly reported to the people through the news media, which essentially were the newspapers of the day. Now, with the change of media, particularly television, that confrontation appears to have moved more and more from this Chamber into the media, so that instead of the news media reporting to the public the ultimate discussions of these issues where they might be altered, that is, in this Assembly, the discussion is actually transferring itself discernibly to the media - television and the columns of the press... we have to watch and be careful that the media, in all aspects, do not become more important than the decision-making in this Parliament. (QPD 1969:vol. 251, p. 528)

Technology and news management were becoming increasingly influential to how the Parliament operated.

\section{Ruckuses over the reef and the concrete jungle over the Brisbane River}

One of Labor's most important cause célèbres was the drilling for oil on the Great Barrier Reef. The issue recurred frequently, partly because of the significance of the decisions and partly because Labor sensed it had great community support. Showing some reluctance, the government was forced to provide detailed information on specific applications and drilling sites (although rarely did anyone from the government benches take part in the debate except for the Mines Minister). Labor members accused Treasurer Chalk of having secret negotiations with the Prime Minister, John Gorton, at the Liberal Party conference in Toowoomba in mid-1969. While Labor was supportive of industrial decentralisation and regional development, the party was adamantly against oil drilling on the Great Barrier Reef. Various tactics were used to extract information. Labor's parliamentary whip, Horace Davies, painted an apocryphal picture of the Prime Minister's visit:

We can well imagine their sitting around the coffee or tea table and $\mathrm{Mr}$ Gorton saying to our Treasurer, and the Premier, if he was there, 'Well, a Federal election is looming; evidently there is great indignation on the Queensland coastline about what is going to happen to the wonderful reef. I did not say anything during the State election campaign, but 
personally I am against these developments; I believe the reef should be preserved. A federal election is coming up and the electorates of Herbert, Capricornia and Dawson must be considered'...Mr Gorton made his statement against drilling on the Barrier Reef, but where was he during the last State election when this matter was of great concern in the North and South of Queensland? If the Prime Minister has such a vital interest in our reef waters why did he fail then to express his opinions on the policy of the Queensland Government, and to try to influence the Queensland Government in this matter? (QPD 1969:vol. 251, p. 211)

During the next months, Labor fielded a series of questions about oil exploration, offshore exploration permits, the process of issuing permits and the environmental protection measures taken. Some questions were simply fishing exercises because little hard information was to hand. These questions were designed to flush out the government's intentions and actions to date. Mines Minister Camm confirmed that 11 exploration permits had been issued (or 'transitioned') for six years from the date granted (either 1 September or 1 October 1968). Applications had been sought through notice in the Government Gazette on 5 October 1968. At other times, when Labor members questioned whether the government had entered into agreements with oil companies to explore in certain regions, the minister would respond blandly that no agreements existed or that permits had been granted that 'might' cover the areas mentioned.

In September, Camm took the unusual step of entering the Address-in-Reply debate to outline the government's policy in relation to offshore oil drilling. He did so because of the 'great deal of publicity' that the issue had attracted. Camm's address sketched the history of state authorisations to mine on the seabed for petroleum under the various acts dating back to 1923. He mentioned that since 1953 Queensland governments had granted 30 'authorities to prospect' for oil. Since 1926, five wells had been drilled to depths of up to 1700 metres in the vicinity of the reef (at Michaelmas Cay, Heron Island, Wreck Island and two at Capricornia), but no oil or gas had been found. Camm accused the opposition of having agreed to the Petroleum (Submerged Lands) Act of 1967 although Jack Houston disagreed saying that Labor had not known the act included drilling on the reef. Camm went on to state that the government was motivated by exploring any potential resource and earning higher royalties for the state, even though it recognised that 'more stringent safety precautions might be necessary in future off-shore drilling' (QPD 1969:vol. 251, p. 496). He turned the attack back on the opposition, saying that they had deliberately distorted statements he and the Premier had made for their own purposes. He then chided them over their apparent confusion about the issues: 
Claims were made that we had permitted an oil rig to drill on the Barrier Reef at Anchor Cay following the [Santa Barbara] blow-out, whereas as a matter of fact, an announcement about this drilling was made by me on 15 January, 1969 - some two weeks before the Santa Barbara blowout - and a Press statement, including all the details of the drilling was issued from my office. Yet the Leader of the Opposition on 10 May was still talking about the drill being down 12,000 feet [3700 metres] and just moving off. Here in my hand is the Press statement that I issued on 15 January outlining all the conditions that would be imposed.

Mr Bennett: That's eyewash.

Mr Camm: Ah, the hon. member for South Brisbane! It is nice to see him in the Chamber. Following criticism made by the Leader of the Opposition on 10 May, I thought I would reiterate what I had said right back in 1967, so, on 13 May, in another Press statement, I set out full details of the anticipated drilling in the Repulse Bay area. There appears always to have been some confusion in the minds not only of the Opposition but also of other critics regarding the terminology used in off-shore exploration. This is understandable, as I mentioned earlier, on account of the original authorities to prospect being transitioned into prospecting permits and some of the authorities to prospect being divided into two titles, one as a prospecting permit off-shore and one as an authority to prospect covering land mass. However, I want to emphasise here something that I have always said and which has confused some people - that is the fact that there are no petroleum leases granted off shore in Queensland waters. (QPD 1969:vol. 251, p. 497)

His lengthy rebuttal was extended by a motion from the Primary Industries Minister, John Row, and, after a division (won by the government 41 to 25), Camm was able to speak for another 30 minutes or so. Camm quickly became sidetracked, however, in his extension of time and spent the remaining allocation attacking Tom Burns (Labor's state secretary and not yet in the Parliament) and other union members of the Queensland Central Executive of the ALP.

The proposal to build a Chicago-style suspended freeway alongside the Brisbane River also became a controversial issue in the Chamber. During a supply debate, criticism of the Brisbane Transportation Study (conducted by the US firm Wilbur Smith and Associates) was made after the Transport Minister, Bill Knox, informed the House that the consultants were finalising a report 'on public transport', hoping to give the government 'some idea of what shape it might take in the next 30 years' (QPD 1969:vol. 252, p. 1344). The review had been announced in August 1969 and when the report was released in 1970 it recommended the dissection of Brisbane with freeways, some involving aerial 
suspension over the Brisbane River. Labor had periodically raised criticisms of the Riverside Freeway plan, arguing it spelt the end of Brisbane's trams ( $Q P D$ 1968:vol. 250, p. 1537). Government members also expressed dissatisfaction with the proposals, with Charles Porter (Toowong) and to a lesser extent Geoff Chinchen (Mount Gravatt) both critical of the tunnel-vision of the planners. Porter argued that more emphasis ought to be placed on public transport (rail, ferries, buses and trams) rather than planning 'only for motor cars' and described the Wilbur Smith freeway proposals as creating problems not solving them. Chinchen argued for more high-density living and pointed out that the terms of reference given to Wilbur Smith were too narrow. He commented on Porter's attack by stating:

I do not quite agree with his statement that the freeways proposed in the Wilbur Smith survey will give us a concrete jungle like those of San Francisco and Los Angeles, which may not be in the best interests of the city. I remind the hon. Member that Wilbur Smith himself, when speaking to a number of members of Parliament and aldermen of the Brisbane City Council, pointed out that a transit system was outside the terms of his investigation. He said he was asked to find a means of ensuring that what he termed 'free-wheeled vehicles' could move through and about the city. (QPD 1969:vol. 252, p. 1425)

Chinchen went on to say it was noteworthy that 'the same firm has been employed to look into the bigger question of the best form of public transport for the city', and that he supported their claims that a public transport system could be 'imposed' on the plan. He criticised the lack of planning for transport in Brisbane and ventured that instead of merely catering for cars the planners should use railways as the basis of a transport system and locate high-rise accommodation within 'three, four or five blocks of the station' (QPD 1969:vol. 252, p. 1426). Paradoxically, given many Labor members held Brisbane electorates, the opposition was uncharacteristically quiet over the freeway proposal.

\section{'We are men of integrity': all aboard the Comalco express, constructing a shareholding oligarchy}

Concerns over government transparency and apparent conflicts of interest were often raised throughout the 1970s. One of the most controversial incidents occurred on the first sitting day back in the second session of the thirty-ninth Parliament on 21 July 1970. Col Bennett (ALP, South Brisbane) fired the first salvo and attempted to ask a question that Speaker Nicholson refused to allow 
on the grounds that it 'imputes improper motive'. Not one to be easily silenced, Bennett continued to bait the government, stating: 'You certainly imputed improper motives. You are "Comalco kid, the Treasurer". You are sour because you got too many Comalco shares and have been exposed as a result' ( $Q P D$ 1970:vol. 254, p. 5). Bennett was immediately followed by Jack Houston, who moved for the suspension of Standing Orders so that the shareholdings by ministers in Comalco could be discussed ( $Q P D$ 1970:vol. 254, p. 5).

What then transpired was a sordid story of Comalco shares offered at a vastly reduced price to members of the government and the opposition. According to Houston, there were a total of 13 million fully paid 50c shares issued by Comalco. He informed the House that

the option was for the starting price of $\$ 2.75$ to be paid in full on application, or for a split payment of $\$ 1.40$ on application and the $\$ 1.35$ balance on $31 \mathrm{March}, 1971$. It was reported in the Press - the Ministers can deny it if I am wrong and I will accept their denial-that they accepted the second method, which was to pay the $\$ 1.40$ down, the rest to be paid on 31st March 1971 .

He claimed that the market price of the shares was at least $\$ 3.90$ a share and then went on to report the various holdings of the ministers - namely:

- Mr Chalk and his family-2,500 shares

- The Industrial Development Minister Mr Campbell-700 shares

- The Works, Housing and Police Minister Mr Hodges-1,200 shares

- The Conservation Minister Mr Hewitt-1,200 shares

- The Local Government and Electricity Minister Mr Rae-1,500 shares

- The Health Minister Mr Tooth-1200 shares. (QPD 1970:vol. 254, p. 10)

He alleged that this implied that all the ministers had made a healthy profit from their favourable allocation, with Chalk making \$6250, Campbell \$1750, another $\$ 3000$ each to Hodges, Hewitt and Tooth, and Rae making \$3750.

According to Houston, he was offered some shares also, but refused the offer. Recalling Nicklin's early ruling on becoming Premier in 1957 that ministers should refrain from investing in oil shares, Houston suggested that the share offer was clearly connected with the ministers' official duties and their ability to look favourably on the company in any future dealings. He moved that 'legislation be introduced to forbid Cabinet Ministers and members of their immediate family from holding shares in companies which could be expected to have dealings with the Government through a member of Cabinet' (QPD 1970:vol. 254, p. 13).

Houston was passionate when he stated: 
I do not care what any other member of the community does; that is his own affair. What I am concerned about is the feeling towards the integrity of our Cabinet and our parliamentary system. For very much of the time this State is governed by Orders in Council; it is not governed by this Parliament for more than half of each year. The State is governed by Cabinet and Cabinet decisions, and as a result its whole workings and operations and any agreements entered into are governed by its Cabinet. Cabinet members have these matters completely in their hands. (QPD 1970:vol. 254, p. 13)

Houston pleaded that the

only sane thing to do is to bring the whole matter into the open... The only credit I want is to be able to say to my children and grandchildren, 'Irrespective of its political beliefs, the Government in Queensland is one whose Cabinet Ministers are beyond reproach in their dealings with companies'. (QPD 1970:vol. 254, pp. 13-14)

During the debate, it transpired that the Premier had told a local newspaper that any suggestion there should be a public disclosure of any shares a minister might hold reminded him 'of what you expect in Soviet Russia'. The Premier added that he regarded 'this atmosphere of distrust as an insult' (Telegraph, 15 June 1970). The Premier refused point-blank to disclose his shareholdings - to either the Parliament or his cabinet colleagues.

The plot deepened when Tom Aikens informed the Parliament that some Labor members had indeed accepted the preferential share offer from Comalco. He advised that Tom Burns had received 400 shares (although Burns later claimed he gave the allocation to his father), while Jack Duggan had received 1652 shares and Jack Egerton had accepted 400 shares in total (QPD 1970:vol. 254, p. 17). So while Houston did not himself acquire any shares, some in his opposition team certainly did (although of course they were not ministers). Ironically, however, it was not the members who had accepted shares who came in for criticism from the Premier; instead Bjelke-Petersen made much of the fact that Houston had not participated in the share deal. Bjelke-Petersen reasoned that Houston could not be trusted to run the state because he was not willing to back new investments with his own money. He replied in the Assembly, somewhat unbelievably, that Houston had

confessed that he had no shares in any company or in anything else in this State. I ask what kind of man he is to seek to lead this State after making such a confession? He is not prepared to invest in any company or back any company in this State. (QPD 1970:vol. 254, p. 22) 
Bjelke-Petersen's idiosyncratic views on ministerial responsibility became increasingly controversial. He appeared unable or unwilling to grasp any sense of impropriety if ministers owned shares or had other pecuniary interests over which they were likely to be asked to make official decisions in the future.

Australian Broadcasting Corporation $(\mathrm{ABC})$ journalists, in particular, posed questions about perceived conflicts of interest to the Premier, but he regularly appeared at a loss to see what the fuss was about. He feigned a startling naivety or chose to bluff any intense media scrutiny. For example, when asked whether he found it acceptable for ministers to accept preferential treatment over their business interests, he rejected the implication of the question by responding that the issue was merely the 'emotional side of the issue' and that the media was pursuing this line of questioning merely 'to sell papers' (QPD 1970:vol. 254 , pp. 8, 21). His defence was that the people should accept that he was an honest man and that if ministers 'are prepared to back companies in this state with their own money you can't expect them to back down every time the press attacks, we would be a pretty spineless group' (Lunn 1984:78). Russ Hinze had a similar line with journalists who quizzed him on his business interests, saying to them, 'if you're so f...king smart, how come you've got no money'.

Such statements from the Premier represented a significant break with the conventions of ministerial accountability insisted on by his predecessor, Frank Nicklin. Bjelke-Petersen was indicating to his ministry and party colleagues that under his leadership it was almost expected that ministers should invest in development projects in the state irrespective of the fact that they might have to make decisions that could affect their own pecuniary interests. He generally evaded giving definitive answers to such questions, accusing the journalists of stirring and trying to leave the impression he was simply being entrepreneurial. In one interview on This Day Tonight, in 1970, he was asked:

Reporter: Well could you silence your criticisers? Have you got any shares Mr Premier?

Bjelke-Petersen: Well have I got any land? You could ask me also, have I got any Crown land that is held by the Crown...You are trying to misconstrue it so I'm not going to discuss with you when you try to create a situation such as this.

Reporter: I'm not trying to create any situation, Mr Premier...

Bjelke-Petersen: No, no, You are...

Reporter: I'm asking you whether you maintain your attitude that what you did was right and proper and whether you will continue to hold shares in public companies? 
Bjelke-Petersen: I haven't got any in this particular issue at all, as you jolly well know.

Reporter: But you have held shares in companies that have had dealings with the public?

Bjelke-Petersen: If you are going to try and misconstrue it just for your own political propaganda you've got another thing coming.

The Country Party conference in June 1970 passed a motion banning ministers from accepting shares issued to them on a preferential basis. Some colleagues of the Premier would later suggest that he did not understand that he was breaching any regulations because he did not comprehend the 'concept of a conflict of interest'. Liberal leader Llew Edwards, for example, said, 'I would be surprised if he understood it fully. I think that if it was good for Queensland then that was the predominant view' (Four Corners, ABC TV, 2008). The Premier expressed similar views in the same Four Corners program: 'Would you like to have a premier or a minister or a government that never owned anything, never did anything, never achieved anything? Is that the sort of person you'd like to have?'

The Premier insisted that the ownership of shares would not 'interfere with our decisions'. He asked Queenslanders to take him on trust. Gradually, however, he was developing the paternalistic armour he would later epitomise in the saying 'don't you worry about that' - the title of his autobiography.

Some years later, the visiting British interviewer David Frost interviewed the Premier, and again the issue of ministerial shareholdings and the perception of conflicts of interest were raised. Asked about his active shareholding history while a Minister of the Crown, Bjelke-Petersen responded:

Bjelke-Petersen: We are men of integrity. We have been put there by the people year after year. The people know us.

Frost: Why not have a declaration system where you can declare all your share interests, and those of cabinet, so there can be no suspicions? They are bringing that system in Britain. Why not do that because justice must be not only done, but it must be seen to be done.

Bjelke-Petersen: The people know me and trust me. We fought an election on it. (Lunn 1984:81)

His answers were effectively a restatement of his defence made in the Parliament in July 1970 when he said: 'I can say that all members of cabinet have a reputation for honesty and integrity, and no-one can take that reputation from them' (QPD 1970:vol. 254, p. 24). 
Significantly, therefore, Bjelke-Petersen was the subject of occasional media scrutiny over his financial dealings from the outset of his premiership. Rumours persisted throughout the next two decades that ministers used their influence and internal knowledge to advantage themselves. Shares, land deals, rezoning, the tendering of contracts were all fair game for private profit. By the time Bjelke-Petersen was deposed as Premier in late 1987, it would become clear that there was very little sense of accountability or probity displayed by many of his ministers.

\section{The leadership abyss: saved by guile, cunning and deceit}

Bjelke-Petersen's initial grip on power was most tenuous, especially as he had two contenders for his position: the Liberals' Leader, Gordon Chalk, and from within his own party the Deputy Leader, Ron Camm. ${ }^{8}$ Despite winning the May 1969 election, Bjelke-Petersen was still feeling his way and remained unpopular among colleagues. His unpopularity stemmed from his awkward, wooden image and dour demeanour, as well as the controversies he seemed continually to attract, the fears of some Country Party members of losing electoral territory in provincial seats and the need for the party to find a credible leader equal to the Liberals' Chalk. The new Premier was also often offside with his own cabinetearning him the moniker of a 'lone ranger'.

Initially, some speculation suggested that Camm was after the Premier's job. Marty Hanson (ALP, Port Curtis) told the Assembly that 'as the deputy leader of the Country Party, [Camm] wanted to start the session as Deputy Premier [instead of Chalk] and when the Premier was away on official business he wanted to be known in the Press and elsewhere as the Acting Premier'. Hanson concluded that 'the minister has plotted against his colleagues' (QPD 1969:vol. 251, pp. 507-8). Jack Houston later suggested that Bjelke-Petersen's leadership had been questioned as early as June 1969 in retaliation for the Premier organising against Camm (QPD 1970:vol. 255, p. 1333). Houston then argued that when the formal challenge arose in October 1970 this was in fact the second challenge to BjelkePetersen's leadership by his party colleagues.

Later, Chalk recalled that 'the older members of the Cabinet considered that Camm would be a better leader...there was fear within CP ranks that Petersen was losing ground particularly in provincial city areas such as Ayr, Mackay,

8 The story of the failed coup against Bjelke-Petersen in October 1970 has been adequately documented in other publications - notably, Hugh Lunn's Joh (1978) and Johannes Bjelke-Petersen: A political biography (1984) and Rae Wear's Johannes Bjelke-Petersen: The Lord's premier (2002:91-5). 
Gladstone, Redcliffe, Gold Coast' (Hazlehurst 1987:251). Chalk named the following Country Party members as being 'worried about their own future': Val Bird (Burdekin), Ron Camm (Whitsunday), David Nicholson (Murrumba), Jim Houghton (Redcliffe) and Russ Hinze (South Coast). At the time, only Camm was a minister.

Most speculation, however, focused on whether (and when) Chalk would take over the Premiership. Labor would regularly accuse Bjelke-Petersen of being 'subservient to the Deputy Premier' and being 'completely subservient' to the Liberal-led government in Canberra. Lou Jensen (ALP, Bundaberg) kept rubbing salt in the wound, insisting right up to the leadership challenge that the Treasurer, we know, wants to be our next Premier... [but] is not game to have a go against the Premier' (QPD 1970:vol. 254, p. 1137). Pat Hanlon (ALP, Baroona) added further jibes by claiming that 'at the Premiers' conference the Premier of New South Wales, Mr Askin, referred particularly to the "Liberal" Premier of Queensland' (QPD 1969:vol. 251, p. 976). He claimed that the other premiers regarded Chalk as the real premier. Hughie O'Donnell (ALP, Barcoo) argued that because Bjelke-Petersen was 'subservient to the Liberal party interests' the Parliament should question his 'leadership of this State when it comes to obtaining' financial support for Queensland. Such attacks tarnished BjelkePetersen's image not only among his Coalition colleagues but more importantly in the eyes of Country Party supporters in the bush. Rural newspapers were also beginning openly to question the performance of the new Premier. ${ }^{9}$

Some Liberals added fuel to the fire, escalating public dissent over the new Premier's style. After Arthur Crawford launched a thinly disguised critique of cabinet's decisions on health funding in late 1969, his colleague Charles Porter came to his defence, claiming:

We Liberals have seen a big and oppressive change come over the scene in the last three years...I think one of the main reasons is that we have tended to abandon a basic tenet of our philosophy, particularly the role of the individual in our society. There has been a growing tendency for those on top to want the power of decision left in the hands of the relative few. To me, the philosophy which my party stands for means nothing once we abandon the right of individual members to dissent, object and criticize. Otherwise we appear to be adopting Labour's very servile acceptance of decisions from the top - right or wrong, wise or unwise. If we are to successfully commence the long, hard road back

9 For example, the Longreach Leader ran attacks on Bjelke-Petersen's lack of gravitas as a leader. The paper accused him of caving in to the city-based Liberals over the lack of adequate drought relief. It ran a headline stating 'Does Joh Bjelke-Petersen possess “feet of clay"?' (28 August 1969). 
we have to return to a basic tenet of Liberal philosophy, namely, the recognition of the fact that there is at least as much virtue, and sometimes more, in dissent as in assent. (QPD 1969:vol. 252, p. 1244)

Porter linked the decline in the support for the Liberals at the 1969 election (a drop of 2.2 per cent) with their compliance and subservience towards the Bjelke-Petersen-led cabinet. Porter would later become something of a rallying point to the ultra-Liberals, who tried to back Porter in a challenge to Chalk's leadership.

The loss of a second Country Party seat in a by-election (Albert was lost to the Liberal's Bill Heatley in February 1970 and Isis was lost to Labor in November 1968) served only to further diminish the Premier's standing among his colleagues. Certainly, the ALP attempted to portray such results as evidence of voter dissatisfaction with the new Premier-and mud began to stick. Allegations of conflicts of interest over shareholdings fuelled the uncertainty over his leadership (although other government members had received shares from companies doing business in Queensland and at the time such investments were not considered improper or inappropriate by many of his colleagues). Bjelke-Petersen had also been out-manoeuvred by public opinion opposed to the mining of rutile sands on the Sunshine Coast - the so-called 'battle of Cooloola'. By late 1970, Bjelke-Petersen was looking accident prone, unpopular, politically on the defensive and at times economical with the truth, while selfinterestedly avaricious and somewhat devious over his business interests. He appeared incapable of matching the stature of Nicklin.

In a state renowned for its strong domineering premiers, a leadership spill soon became inevitable. The timing of the move against the Premier was, however, sudden and unexpected. ${ }^{10}$ According to one biographer, Bjelke-Petersen 'had no idea of what was going on' and was taken by surprise at the actions of his colleagues (Lunn 1978:83). Townsend (1983:279) suggests that due to his mother's recent death, 'Joh's sixth sense failed to alert him of the impending crisis'. Murphy (1971:121) recorded that the Speaker, David Nicholson, planned a 'coup' that was 'thwarted when news of the plotters' intention to overthrow the Premier and replace him as leader with the Minister for Mines, Mr R. E. Camm, was given to Mr Bjelke-Petersen by one of his supporters'. In the Parliament, Houston gave a different version, claiming that 'the actions of the rebels was [sic] a well-kept secret until, apparently, one person in the know had

10 A number of contemporary accounts refer to the unexpected timing of the coup catching everyone a little cold - for example, Lunn (1978:83) and Chalk (quoted in Hazlehurst 1987:251). Those Country Party members voting against the Premier included: Mike Ahern, Ron Camm, Alan Fletcher, Russ Hinze, Jim Houghton, Vince Jones, Bill Lonergan, David Nicholson, Harry Richter, John Row and Vic Sullivan. 
too much to drink and spilled the plot to one of the Premier's supporters' ( $Q P D$ 1970:vol. 255, p. 1330). The plotters intended to make the Lands Minister, Vic Sullivan, deputy leader.

Nicholson then led a delegation of four (himself, plus Jim Houghton, Russ Hinze and Bill Lonergan) on the evening of Tuesday 20 October 1970 to inform the Premier that a vote of no confidence in his leadership would be put to the party room the next morning (Wednesday 21 October). Claiming they had the numbers for a leadership spill (potentially by 16 to 10 of the 26 members of the party room), they 'asked him to resign' (Murphy 1971:121). The meeting was marked by 'angry exchanges between the Premier and Mr Lonergan' over who should lead the party to the next election (Courier-Mail, 22 October 1971). Bjelke-Petersen threatened to sack any minister who was not loyal to his leadership - and confronted with this ultimatum, Camm indicated that he would agree to be a candidate only if the position was vacant. Press reports lend weight to this interpretation with indications that the four plotters had originally intended to warn the Premier on Wednesday morning just before a leadership vote was called in the party room, but 'brought the meeting forward because they believed that Mr Bjelke-Petersen had heard of their plan from another source' (Courier-Mail, 22 October 1970).

A number of other writers (Lunn 1978:83; Hughes 1980:176; Hazlehurst 1987:250; Reynolds 2002:30; Walter and Dickie 1985:35; Walter 2003:310) do not mention that Bjelke-Petersen independently got wind of the coup and accuse the plotters of ineptitude or foolishness in committing the 'fatal courtesy of forewarning' the Premier the evening before. They stress that the mistake allowed time for the Premier to use his native guile and political cunning, staying up most of the night phoning colleagues to win over their support. From the Premier's own account (Townsend 1983:264), he attended a business dinner that went to $11 \mathrm{pm}$, then 'went to bed for a few hours and by 5 am I was already on the telephone endeavouring to make contact with colleagues'. In any event, by the morning, Bjelke-Petersen had convinced two to change their vote; he also used his tactical nous to initiate a vote of confidence in his leadership (moved by Henry McKechnie) rather than face a no-confidence motion from his opponents (because he reasoned he would have no ministerial challenger if the party room was unable to have the position declared vacant). At the weekly party meeting, the Premier orchestrated a vote of confidence in his leadership. Accounts of the vote differ. One account, seemingly accurate according to press reports the next day, suggests the vote was tied 11-11 after which the Premier used two proxy votes to hold on to the post by 13 to 11 (Hughes 1980:176). Twentytwo party members attended the meeting, implying four parliamentarians were absent and did not vote. Another version, in Lunn (1978), suggests BjelkePetersen appeared to be losing the confidence vote 11-13, but then claimed to 
have the proxy vote of one absent member (Neville Hewitt, who was overseas). According to Lunn, when the initial vote was 11-13 the Premier then voted for himself and used Hewitt's supposed proxy to tie the vote 13 all (a result also repeated by Walter 2003:310). Significantly, four of the six other Country Party ministers voted against their Premier (namely - Ron Camm, Alan Fletcher, John Row and Vic Sullivan). Only the newcomer, Max Hodges, voted for the Premier. While the tie was humiliating, it meant, as Lunn (1978:84) argues, 'his opponents thus could not command the votes to get rid of him'. There has been much speculation about whether Bjelke-Petersen ever spoke to Hewitt and in fact had his proxy. While the Premier insisted he had the proxy, one of the two tellers at the party-room vote, Mike Ahern, claimed the Premier never secured the proxy and lied purely to survive. The Courier-Mail (22 October 1970) the next day carried a report that 'some disappointed Country Party members last night claimed that one of the proxies held by the Premier was from a member who reversed his decision by telegram only early yesterday morning'. So, if the Premier did manage to contact Hewitt, he could have convinced him to change his mind. If he could not contact Hewitt, he almost certainly manipulated his vote and lied.

Some of the losers sought to have a second go by defeating the Premier either in the House or at a joint-party room meeting. The dissidents seemed prepared to risk a vote against his leadership on the floor of the Parliament but the party acted swiftly to shore up Joh's leadership. Robert Sparkes, the Country Party's President, flew to Brisbane to warn the disgruntled party members 'you have had your go and failed so the question is now settled' and he added 'if you go into the House and support any no-confidence motion you do your endorsement' (Lunn 1978:84). Sparkes was effectively threatening MPs and promising to arrange their dis-endorsement if they voted as they themselves wished (which was illegal intimidation of a member under state law). Chalk had also given Bjelke-Petersen his personal commitment of support on the morning of the challenge. He remembered:

There is no doubt that the intervention by Sparkes prevented a vote of no-confidence, but I have never believed that such a vote would have taken place in open Parliament. What was brewing was a special meeting of the Joint Party Parliamentary members, and if a vote of noconfidence was then moved by and seconded by two CP members, and a secret ballot taken, Joh would have lost. (Hazlehurst 1987:251)

The fate of the plotters was sealed: Camm was too powerful to demote from the ministry, but he remained in substantially the same portfolio until he retired in 1980. Lunn (1978:85) records that 'of the four men who came to see him, BjelkePetersen never forgave one [Nicholson] and shunted him into political oblivion, although he made another [Hinze] a minister'. Neither Lonergan nor Houghton 
ever made the ministry but both became Speaker-Lonergan in 1972 and Houghton in 1974. In contrast, Hewitt's ministerial career prospered perhaps as a result of his silence over the proxy issue; and McKechnie was elevated to the ministry in June 1972. Although the botched coup ended a little inconclusively, the event underlined Bjelke-Petersen's 'persistence and endurance' (Walter and Dickie 1985:34). From that point onwards, his parliamentary performances indicated his confidence was growing tangibly. For instance, when challenged for using the new government aircraft 45 times in the first four months after its purchase (most of which were return trips to his hometown of Kingaroy), he was asked 'how does he justify this?' The Premier responded on the offensive:

I am the Premier of this State and I have a very big responsibility not only in my electorate but throughout Queensland. As the honourable member knows, I have travelled very extensively throughout Queensland on Government business, and I inform him that I intend to continue to do so. (QPD 1971:vol. 257, p. 148)

The immediate result of the failed coup led to a want-of-confidence motion against the Premier moved by the Opposition Leader in the Parliament. On Friday 23 October, directly after question time, Houston moved that BjelkePetersen 'obviously no longer has the support of the majority of members of the coalition parties and so should, in such circumstances, resign his Commission as Premier' (QPD 1970:vol. 255, p. 1329). He cited British cabinet practice that required a prime minister to 'bind together his cabinet colleagues' or step aside. He believed two other reasons lay behind the revolt. He speculated that the coup was a parliamentary revolt 'against the outside influence of the executive of the Country Party, headed by the now well-known Mr Sparkes, as it was against the premier' (QPD 1970:vol. 255, p. 1330). He also linked the plotters' motives to 'sour grapes' over missing out on getting some of the Comalco shares in April 1970. According to Houston:

The Minister for Local Government (Mr Rae) received 1,500 shares, the Minister for Conservation (Mr Hewitt) received 1,200 shares, and the Minister for Works (Mr Hodges) received 1,200 shares...it is strange that, when the shares were being handed out, only those Ministers whom the premier could rely on were included in the offer. If they had been the senior members of the coalition perhaps that could have been a reason why they, and just they alone, received the shares. But three junior Cabinet Ministers were involved-important men to the company no doubt. There was no seniority or any other apparent reason why, out of eight Country party Cabinet members, three should be given special treatment. (QPD 1970:vol. 255, p. 1332) 
All three junior ministers voted to support the Premier (with the Premier claiming Hewitt's proxy).

Percy Tucker told the Assembly that the four plotters had secretly met in a room in 'this House which I am told the Premier now calls the 'treason room' (QPD 1970:vol. 255, p. 1334). He concluded with the statement:

The question before the House is not whether the Premier is a 'good bloke'. It is not whether he is a fine Christian gentleman. It is not whether he is a decent sort of fellow. Rather [it is] whether he has the capability, the resolution and the ability to manage men that would make him a good leader. And the members of the Country Party, by their own actions, have given a resounding 'no' to that vital question. ( $Q P D$ 1970:vol. 255, p. 1340)

In defending the Premier, Gordon Chalk pointed out the apparent contradiction in the opposition's case, with Houston implying that Bjelke-Petersen was a 'weakling' while his deputy denounced him as a 'dictator and an arrogant man' (QPD 1970:vol. 255, p. 1340). He reiterated that the Premier had successfully orchestrated a vote of confidence in his leadership, was the leader of the largest party in the Coalition and implied it was not the business of the Liberals who the Country Party chose to lead it. Ron Camm, who accused Tucker of having a 'thick skull', was more forthright, stating:

In any worth-while political party comprising men of independent spirit, there must at times be differences of opinion on how a situation can best be handled. There was no suggestion at all in the discussions on this matter that the policy of the Country Party, or of the Government, was in question. The only issue for discussion was how was that policy being presented, and how the Government's decisions were being accepted by the people... The internal workings of any political party are not the business of Parliament. We all have our differences internally, but we do not come into this House and air them. (QPD 1970:vol. 225, p. 1347)

Bjelke-Petersen completed his own defence by claiming Labor was merely engaged in personal attacks on his character and that Houston in particular 'has in a scurrilous and vicious manner endeavoured to impute things to me that he knows are completely untrue' (QPD 1970:vol. 255, p. 1348). He suggested the government now displayed 'solidarity' and that Labor was trying to 'confuse the public'. And on the question of his public image, he responded:

The image of the Government, or the Opposition for that matter, is not entirely tied up with the leader. He is the focal point, but his image is reflected through every member of his organization or party...the parliamentary members of the Country Party decided last Wednesday to 
pass a vote of confidence in my leadership; the ballot result was accepted by all members of the party. It has been accepted by our coalition partners. Any issues involved have been resolved. (QPD 1970:vol. 225, p. 1347)

The no-confidence motion was lost on party lines by a vote of 40 to 29 .

\section{The Springboks' rugby union tour of 1971: the grooming of 'Jackboots Bjelke'}

Bjelke-Petersen had been worrying about his image and public standing for the whole of his period as Premier. He had reluctantly tried to soften his image by attending fetes and horseraces and providing country meetings with free beer and, as previously mentioned, also sought the services of a publicity consultant, Hugh Bingham, to work on his image problems. In May 1971, however, Bjelke-Petersen elevated his concerns to new heights by engaging ABC journalist Allen Callaghan as his media adviser and press secretary (formerly Government News and Information Officer), after the Premier had famously had an on-air spat with him. Callaghan would professionalise his communications with the media, crystallise the message and give him an image of 'a man of steel' (Townsend 1983:318). From this moment on Bjelke-Petersen would earn himself the nickname of 'Jackboots Bjelke' (see Lunn 1984; Wells 1979:Ch. 3) and forever after be depicted in cartoons in a tropical Nazi uniform with jodhpurs and banana swastikas on his sleeve. Callaghan was an astute political adviser, playing to the Premier's parochialism and reminding him that 'there are no votes south of Coolangatta'.

The Parliament was in recess and not recalled when cabinet declared a state of emergency on 14 July 1971. The emergency measures were taken in anticipation of expected public demonstrations and possible strikes to be held against the tour of the white South African Springboks rugby team. The Police Minister admitted that cabinet had made the decision to impose emergency powers only on a verbal report from the minister (Lunn 1984:89). No written report was submitted. The Governor, Sir Alan Mansfield, then proclaimed the monthlong emergency powers under the State Transport Acts 1938-43, which was published in an extraordinary Government Gazette. The proclamation gave the government, the police and other departmental officials wide-ranging powers to guarantee the staging of the event and to maintain public order. It was the first such emergency declared since the Mount Isa strike of 1964-65 called by Nicklin and before that by Hanlon over the Ipswich railway strike in 1948 . Never before had one been declared over a sporting contest. 
Bjelke-Petersen acknowledged at the time that the Police Commissioner, Ray Whitrod, had not requested such special powers for his police (Courier-Mail, 15 July 1971, p. 1). The police had, however, claimed the rugby ground at Ballymore could not be secured for the games and recommended the venue be switched to the Exhibition Ground (RNA Showgrounds) instead. The President of the Royal National Agricultural Association, however, protested. According to Bjelke-Petersen, he

rang the President of the Show Society and I said to him...'I want the exhibition ground for playing the Springbok matches'... They said: 'No way, Mr Premier, we've got an exhibition coming up in three weeks... and the unions will black ban us'. So I said: 'Well you had better all come into my office'. So I had in the meantime, ready for the fact that they wouldn't do it, I had the papers to declare a State of Emergency drawn up and I just signed them in front of them when they said no...so I signed the State of Emergency and handed it to the President and said: 'Well the grounds are mine now and I'll take them'. (Wear 2002:137)

When the South African rugby team arrived in Brisbane, their hotel in Wickham Terrace was the site of demonstrations, with protesters holding placards saying 'Welcome home racists' (Harris 1972:129). Major demonstrations then followed at the Springboks' games (in Brisbane and Toowoomba) and at a large public rally in Brisbane on 26 July. A one-day strike also reputedly cost Queensland more than $\$ 6$ million in lost wages and production. Police were awarded an extra week's annual leave to reward their loyalty during the episodes.

The Opposition Leader, Jack Houston, was reportedly shocked at the lack of consultation and urged the immediate recall of the Parliament. He claimed the emergency declaration was politically motivated and designed to divert attention from the government's own shortcomings 10 days before two byelections were due to be held. He said it was absurd for a government to use such powers to 'cope with a sport event' (Courier-Mail, 14 July 1971, p. 3). In reply, Bjelke-Petersen claimed he had given no consideration to the effect his action would have on the upcoming elections although he admitted that 80 per cent of Queenslanders favoured the tour going ahead (Courier-Mail, 15 July 1971, p. 1). Only two dissident Liberals protested over the extreme action of the government. Backbencher Bill Hewitt sent a telegram to the Premier claiming cabinet had 'overreacted', stating '[i]t is questionable whether such measures should have been taken'. Federal member for Moreton, Jim Killen, stated that the government's action was a 'grossly improper use of political power' (CourierMail, 15 July 1971, p. 3). Generally, Bjelke-Petersen enjoyed the support of his Liberal Party colleagues and some have even claimed part of the planning was down to Chalk (Wear 2002:137). 
When the Parliament returned on 27 July 1971, Houston rose on a matter of privilege, noting that it was 'unique in the history of this Parliament in that we are opening this session under a state of emergency imposed by proclamation made on 14 July'. Although the Speaker was unwilling to allow a matter of privilege to go ahead on the opening day, Hanlon interjected that in such extenuating circumstances the matter should be raised immediately. Houston reiterated that the Premier 'had every opportunity of calling Parliament together earlier and he should have'. Russ Hinze chose to respond by replying: 'You brought it on yourselves.' The Speaker then remarked that the 'present situation portends a very bleak future for the coming session' and placed on record that he intended 'to see that this Parliament runs in accordance with the decorum to which it is accustomed' (QPD 1971:vol. 257, p. 5).

Bjelke-Petersen's stance over the Springboks' tour and his tough suppression of protesters became the making of his political career. He went from being 'Joh the uncertain' with a wooden image to Joh the 'man of steel' with a high profile not only in Queensland but throughout Australia. The Springboks incidents not only made Joh's career, they galvanised the conviction of a future Queensland Premier, Peter Beattie, who was beaten by police inside the old Trades Hall during a running demonstration. The major casualties in the immediate term were civil liberties and the ALP.

\section{In the heat of the moment: fighting two by- elections, in Merthyr and Maryborough}

In April 1971, Sam Ramsden (Lib., Merthyr) announced he was disillusioned with politics and was quitting his seat. He had served on the Liberal backbench since the Coalition formed government in 1957. A second vacant seat was caused by the death of Labor's former Whip, Horace Davies, in Maryborough on 4 June. On the day of Davies' funeral, the government announced that both by-elections would be held on the same day: 24 July 1971. The Liberal Party nominated Don Lane, a former police detective senior constable (Special Branch), to contest the Merthyr by-election, while the ALP, with Alderman Brian Mellifont, and the DLP, with Peter Flanagan, also ran candidates. In one of his first unsuccessful tilts at entering parliament, the later federal minister Con Sciacca, then twenty-three, also contested Labor's preselection. Lane attributed his comfortable win to his 'strong law and order' campaign against political and industrial dissidents, especially over the Vietnam War and more recently over the South African Springboks' tour, while the DLP, finishing third, claimed the 'result was obviously a protest by the people against the drift towards anarchy' (Sunday Mail, 25 July 1971). While Labor tried to paint the former Special 
Branch detective as 'Shady Lane the police spy', Lane later recalled that the 'violent climate of demonstrations and protest...undoubtedly helped me to win my way into Parliament' (Lane 1993:63, 72).

In the Maryborough by-election, the Liberals' Alderman Gilbert Alison and the Country Party's E. R. Jurss challenged Labor's Alderman G. A. Zamek. The DLP, with M. Minnegal, and an independent, B. Dau, also ran. Alison defeated Zamek, recording a narrow win to the Liberals - its third by-election win in a row. The Labor Party argued that its loss of the seat was due to 'racism' while the Liberals maintained that voters wanted 'stability and responsibility in government'.

The Liberal victories - achieved on the same day the Springboks played in Brisbane - were touted by the Premier as vindication of the government's tough stance on law and order (Harris 1972:139). As a result of these by-elections, the standing of the parties in the Parliament was Country Party 25, Liberals 21, Labor 30, with the DLP and NQLP having one seat each.

\section{A messy electoral redistribution: the ginger revolt}

Queensland governments had long tinkered with the electoral rules, usually amending legislation to favour their incumbency. The last redistribution had taken place in 1958 and a further one was overdue. An initial Electoral Districts Bill was introduced on 25 March 1971, which proposed to retain the existing 78 seats and the three zones (metropolitan with 30 seats, provincial cities with 20 and the country zone with 28). This bill was premised on the Liberals agreeing not to initiate any further three-cornered contests. Bjelke-Petersen insisted in the Parliament that all government members sign a 'pledge' promising they would not take part in such contests. He was rebuffed, however, by six members (five Liberals - Charles Porter, John Murray, Bill Hewitt, Geoff Chinchen and Arthur Crawford-and one Country Party member, Bill Lonergan).

The proposed bill was most contentious to the Liberals. The party's state executive voted to oppose the bill because of its perceived 'electoral injustice'. In the early hours of 31 March (in a sitting lasting beyond midnight), the government lost a vote on the bill by 38-39, with eight Liberal backbenchers (the 'ginger group': Chinchen, Crawford, Hewitt, Hughes, Lickiss, Miller, Murray and Porter) voting with Labor to defeat the bill. When these members crossed the floor, Russ Hinze reputedly said 'fucking traitors, fucking traitors' - a comment not recorded in Hansard, but alluded to in the Courier-Mail (Lunn 1978:122). The same combination voted to pass an amendment moved by Charles Porter that would have reduced the country weighting and increased the seats in the south- 
eastern zone (Porter proposed six western seats, six south-western seats and 66 eastern seats, of which 45 were in the south-east and 21 were along the eastern coastline to Cooktown). Gordon Chalk was somewhat furious over the defeat of the government because it skittled a deal he had secured with the Premier over the zonal mix in exchange for the promise of no further three-cornered contests. It then appeared the government would allow the bill to lapse, implying the forthcoming 1972 election would be fought on the 1958 boundaries.

The government, however, reintroduced the Electoral Districts Bill, this time with 82 seats divided into four zones with different quotas of electors but based on local authority boundaries. The four zones were: the south-eastern zone (47 seats); the provincial cities zone (13 seats); the country zone (15 seats); and the western and far northern zone (with seven seats). The bill provided for three electoral commissioners to conduct the redistribution and finalise the eventual boundaries of the seats within the zones. This time the 'ginger group' was placated with promises and the bill was passed over five sitting days on party lines. Bjelke-Petersen was in no mind to provide a platform on the floor of the Parliament for dissenters and at one stage in the debate gagged John Murray (QPD 1970:vol. 257, p. 140). The divisive passage of this bill is important not only because it illustrates the electoral tensions within the government and the first real revolt by the Liberal backbench to the Country Party-led government, but because the eventual new boundaries entrenched the zonal disadvantage against the Liberal and Labor Parties.

One casualty of the 1971 redistribution was the Attorney-General, Peter Delamothe, whose seat of Bowen was carved up and placed largely within the adjoining Country Party seat of Whitsunday. He was offered a safe Liberal seat in Brisbane but declined the offer (Delamothe and Stevenson 1989:104). The effect of Delamothe's departure was to wipe out Liberal Party representation in the north of the state.

\section{The claimant state: the budget is broke}

The Treasurer, Gordon Chalk, delivered his sixth budget in September 1971, claiming it was the most difficult he had prepared and announcing that Queensland faced tough financial pressures. He declared it his 'go ahead budget', but admitted that the state would run up a $\$ 7$ million deficit in 1971/72. To help make ends meet, he indicated that Queensland would apply to become a 'claimant state' dependent on special funding assistance from the Commonwealth Grants Commission, but also with strings attached. This was the first time the state had applied for such additional budgetary augmentation. 
The Courier-Mail (24 September 1971) commented that 'Queensland will not lose control of its own affairs when it becomes a claimant state. The gains will outweigh the disadvantages.' It commented in an editorial that the 1971/72 budget was 'perhaps the most significant introduced by a Queensland Treasurer in all the years since World War II'. It then added, however, that 'no Budget which increases taxes, fares and charges makes for pleasant reading. This Budget is no exception.' Queensland was able to make the case for special assistance due to a deterioration of revenues in comparison with other states. Over the next few months, Queensland would receive an additional \$9 million from the Grants Commission and a further \$2.35 million from the premiers' conference. Business groups criticised the government for failing to control its spending and not practising restraint.

\section{Daylight saving experiment}

In 1971, the Daylight Saving Act was passed providing for 'summer time' from 31 October 1971 to 27 February 1972 as a one-off trial. The government made it clear it would evaluate the 'purely experimental' trial at its conclusion and was not necessarily committed to adopting it into the future. The proposal to put clocks forward by one hour was largely to keep Queensland in line with the southern states, especially Victoria and New South Wales, which were pushing ahead with their own trials. At the end of the Queensland trial, the government decided not to continue with the experiment. It did not attempt another trial until Mike Ahern's government in its final days tried a further test in 1989 to appease city residents, business groups and tourism groups. After the 1971-72 trial, community attitudes generally hardened against daylight saving, but the issue would resurface during the Ahern administration, leading to a divisive second trial in 1989-90. A referendum on daylight saving was put to the electorate in February 1992 and was soundly defeated.

\section{Foul language: earning the Speaker's wrath and a proposal for all-party committees}

The Queensland Parliament was ever a robust chamber with many vehement interchanges and much personal abuse. In October 1971, the Speaker, David Nicholson, became concerned about the current standard of debates and warned members about the decline in the standards of their language on the floor of the Assembly. The Courier-Mail (16 October 1971) took up the issue, commenting that it was not surprising that Nicholson 
believes the language being used by Queensland's Parliamentarians has 'never been worse than at present'. Parliamentarians might be excused for occasional lapses into the colourful local idiom which always has set Australian Parliamentary debate apart from that in less lusty chambers. Some speakers no doubt feel they can express themselves better when they add a little home-grown slang. But there is a difference between idiom and coarseness. Language lapses are in danger of becoming commonplace in the Queensland Parliament. There is no need to resort to using expressions such as 'rat', 'cheat', and 'liar' as reverberated around the Chamber on one day this week. Threats of 'punch ups' and one description of a member as the 'most loud mouthed flapjack to enter the Chamber' hardly have a place in Parliament's official record.

In a surprise move, on 17 March 1971, the Liberal reformer and member of the 'ginger group' Bill Hewitt called for the establishment of a series of 'allparty parliamentary committees' (meaning select committees that would be established by a parliament and lapse when the project was completed or when the Parliament ended) to investigate areas of policy such as Aboriginal affairs, social problems, pollution, industrial safety and the road toll. He stopped short, however, of suggesting standing committees looking into public accounts or public works (QPD 1971:vol. 256, pp. 3017-19). His proposal had some support among some Liberals but very little across the government more broadly.

\section{All pushing their own barrows: the election campaign of May 1972}

A number of longstanding members announced their intention not to recontest their seats at the May 1972 elections. Two ministers called it quits after 12 years in government: John Row and Peter Delamothe, both of whom had served for nine years respectively as the Primary Industries Minister (Agriculture and Forestry) and the Minister for Justice and Attorney-General. Delamothe (Lib., Bowen) had been appointed in December 1971 to the post of Agent-General for Queensland in London largely because his seat of Bowen had been abolished in the redistribution. Others who chose not to re-stand included Sir Harold Richter and Les Diplock. Four Assembly seats were vacant at the time of the 1972 election: Callide after Vince Jones (CP) died in October 1971 a year after the failed coup; Albert after Bill Heatley (Lib.) died; Balone after Harold Hungerford (CP) died in January 1972; and Bowen after Delamothe resigned. With the 1972 election pending, no further by-elections were called to find replacements. 
On the opposition side, the Labor Party had dis-endorsed three sitting members in January 1972 - namely: Col Bennett (South Brisbane), Merv Thackeray (Rockhampton North) and Ed Casey (Mackay). The dis-endorsements occurred not because the members concerned were regarded as dead wood. ${ }^{11}$ Rather, their ousting as official candidates occurred because they had all challenged the Trades Hall machine. Bennett, in particular - one of the most outspoken members in the Parliament - claimed that he had been 'knifed' by Tom Burns in a 'Trades Hall purge' but insisted he would 'not run like a whipped dog' (Sunday Sun, 30 January 1972). He argued that the attack on his endorsement came as no surprise, because as soon as he had made statements critical of Burns, the ALP State Secretary, during the 1971 Springboks tour, this meant that 'the knife went into me then and I expected what happened'. Each of the three dis-endorsed candidates decided to re-stand as independents (under a title of the "True Labor Party!' - making this Queensland's fourth Labor Party grouping within a decade). Only Casey, who had resigned his ALP membership in February, managed to retain his seat, defeating the Country Party candidate with ALP preferences (and winning the seat with 63.38 per cent of the two party-preferred vote). Thackeray (on just 23.18 per cent) and Bennett (19.61 per cent) polled poorly in the primary vote and were heavily defeated by the endorsed Labor candidates, Les Yewdale and Fred Bromley respectively. Bromley was the sitting member for the neighbouring seat of Norman, which was abolished and merged into the existing South Brisbane. Bromley's key campaign tactic was to doorknock the entire electorate with cooking recipes: he delivered 'how to vote- how to cook' cards that included recipes for peanut drops, date shells, coconut biscuits, cornflake cookies and raspberry ruffs (Sunday Sun, 23 April 1972). Interestingly, Jack Houston claimed that his team was the 'most competent team than ever before' (Courier-Mail, 31 January 1972). Not surprisingly, Bjelke-Petersen chose to disagree, claiming that because of political expediency Labor was ditching its 'Old Team' based on the Jack Houston-Percy Tucker leadership and replacing it with the Houston and Clem Jones partnership (Courier-Mail, 3 March 1972). The Premier was referring to a large poster that was plastered around Brisbane (on rubbish bins!) with Clem Jones's smiling face over the slogan 'Vote the HoustonJones Team'. This was in reference to the announcement that Brisbane's popular Lord Mayor, Clem Jones, would stand as a Labor candidate for Yeronga. He would prove to be unsuccessful in ousting the Liberal sitting member, Norman Lee.

The membership of the new Parliament was increased by four-from 78 to 82 - and for the second time running every seat was contested. A total of 279 candidates stood for election (an increase of 33 from 1969), and for the first time since the war the ALP stood a candidate in every electorate (as the party would

11 Thackeray — whom Denis Murphy described as a 'log' — had served since 1957 and Bennett since 1960, but Casey had served only one term, and all were relatively active performers. 
then do in each election to 1992). The reason for standing in each electorate was that Labor wanted to have a state-wide vote to use in its arguments over malapportionment. The DLP made its last big stand (contesting 72 electorates) and believed its preferences would determine the result. It also stood the first Torres Strait Islander candidate, in the seat of Cook: Ben Nona, a former policeman and local pearl diver from Badu Island.

Three-cornered contests were again a significant element of the campaign. The initiative for these contests generally came from branch-level Liberals anxious to wrest territory from the 'ownership' of the Country Party. The Liberal state campaign committee attempted to prevent three-cornered contests or limit their number, with Chalk taking a strong line against them and insisting on unity between the parties. The Transport Minister, Bill Knox, admitted that while there could be some benefit to the Coalition's overall vote from a tight exchange of preferences, 'there are political dangers and hazards involved in running candidates against sitting candidates of our coalition partner' (Courier-Mail, 11 March 1972). The Premier also warned the Liberals of 'serious consequences' if local branches challenged sitting Country Party members (Courier-Mail, 16 January 1972). These edicts did not, however, prevent them occurring.

The Liberals again challenged Russ Hinze in the 'key seat' of South Coast. Hinze tried unsuccessfully to stave off a three-cornered contest by offering a deal to the Liberals that he would not try to extend the Country Party's influence on the Gold Coast if he was not personally challenged. When this was rejected, Hinze warned that 'if anybody attacks me I'll fight like hell. And I don't care what I do or how I do it.' He blustered: 'If they want to have a crack at me, they'll know they are in the ring' (Courier-Mail, 16 January 1971). The ALP, however, decided this time to allocate its second preferences to the Liberal candidate, Bruce Bishop, making Hinze's fight all the more difficult. In the final result, the Liberals finished a poor third in South Coast behind Hinze, who held his seat on Liberal preferences against the ALP's Ron Todd.

The Liberals also selected Redcliffe and Landsborough for challenges. In Redcliffe, the Country Party's Jim Houghton narrowly survived a three-way contest, coming second to the ALP but winning on Liberal preferences, while in Landsborough Mike Ahern held his seat easily with a majority of the primary vote. The Country Party, however, decided not to retaliate by entering its own candidates against sitting Liberal members in the election (although it did float the idea of running the popular Toowoomba Mayor, Nell Robinson, for Chalk's seat of Lockyer). The Reverend Alan Male from the Churches of Christ (later to stand as a National in Murrumba, and then appointed to head the Department of Families, Youth and Community Care in the Borbidge government, 1996-98) stood as a Country Party candidate for the new seat of Pine Rivers, but lost to the ALP's Ken Leese - a 'oncer' who would lose his seat in the rout of 1974. 
Denver Beanland, later to become Liberal leader and then Attorney-General, also stood in Everton only to be beaten by another oncer, Gerry Jones, from the ALP.

Some of the heat generated by the inter-coalition conflicts impacted on the Liberals themselves. Some sitting Liberals came under preselection pressure or threats of dis-endorsement. The Liberal Party state executive failed in a bid to withdraw endorsement from Charles Porter, who was popular with local branches but offside with some of the executive. Porter was reported to have told the selection council that his duty as a Liberal was 'to serve the party rather than agree with a small group in Cabinet'. And the executive had to go to strenuous lengths to defend the Health Minister, Doug Tooth, who had earned the ire of local Liberal branches. While most executive members strongly supported Tooth, most branches had voted against him. One Liberal member said he had not seen area selection council meetings so stacked with state executive members. A local Christian 'independent liberal', Ivan Alcorn, stood against Tooth but was unable to unseat the minister (although his intervention caused Tooth to come second in the primary vote). In the end, the Liberals ran an additional nine candidates, contesting 53 electorates.

The Premier also came under challenge from a conservative opponent again. The Australian (26 April 1972) reported:

A Kingaroy businessman is forming a new political party to challenge the Queensland Premier...Percy Edwards, a businessman and farmer, will oppose $\mathrm{Mr}$ Bjelke-Petersen for the seat of Barambah as the representative of the Greater Australia Moderate Party. Mr BjelkePetersen won Country Party endorsement for the seat 25 years ago when Edwards' father, the late J. B. Edwards, retired after 27 years as the area's representative in State Parliament [Nanango, 1920-47]. Mr Edwards ran against Mr Bjelke-Petersen in the 1963 State election as an independent Country Party candidate, but has become disillusioned with the party. 'The wrong people have got charge of the Country Party' he said. 'They are too interested now in big business and finance.'

Paradoxically, his ALP challenger praised the Premier's work, claiming 'BjelkePetersen had been a very good member for Barambah' (Courier-Mail, 9 March 1972).

The media was unsure how the electoral tide would turn. A poll result in February 1972 put the Premier's satisfaction rating at 55 per cent compared with 41 per cent who were dissatisfied. The Sunday Sun (16 February 1972) described this result as a 'shock vote in [the] State Poll', commenting that 'this must be the best reviver Premier Bjelke-Petersen has had for a long time- he 
is rating unexpectedly high among Queensland voters' except among highly educated sections of the community. The Telegraph (10 April 1972) commented that this poll 'looks like the toughest battle for votes in 15 years'. In contrast, the Courier-Mail ran an editorial on 29 March suggesting 'voters are unpredictable, but with eight weeks to go to the State election on May 27, it seems unlikely that Queenslanders will change their Government-or should'. It argued that while 'it would be foolish to claim that the Bjelke-Petersen and Chalk coalition has been a perfect one...that bumpy period seems to have passed. Despite some rivalry, which is not at all unhealthy, the two parties and their leaders have been working well together.' It continued by assessing that 'disunity is more apparent in the ranks of the Government's opponents', and suggested that

apart from the three former Labor members refused endorsement, there undeniably are sections of the Opposition unhappy with the present militant domination of the party. They have reason...At the Merthyr and Maryborough by-elections Queenslanders showed their overwhelming disapproval of Labor support of Trades and Labor Council black bans imposed for non-industrial reasons...If electors returned a Labor Party with subservience to the Trades Hall (which, following endorsements, it has got), there could be even Government support for black bans and stoppages.

The editorial writer thought that the government had been responsive to criticism and had kept the state's finances well, but criticised the government for not having been more 'adventurous' in social policy.

The 1972 campaign was fought largely on the grounds of stability versus instability: an experienced incumbent team against a largely unknown and untried opponent. According to the Premier, the choice was 'between the present stable, progressive Government which had done an excellent job and was responsible solely to the electors, and a disunited Labor Party ruthlessly purged of its moderate men and which openly took orders from an outside body over which the electors had no control' (Courier-Mail, 4 May 1972). Certainly, Labor's internal difficulties hurt its cause, surfacing periodically and somewhat embarrassingly in the lead-up to the poll. Moreover, such disunity was largely self-inflicted.

Political campaigning was gradually becoming more professional and slick. Some reports talked of jazz bands and streamers thrown from balconies and stages. Another account described the Country Party's campaign, led by party secretary, Mike Evans, as an 'American-style political rally with bands, marching girls and beautiful hostesses' designed to create a 'dynamic display'. It continued: 
A fanfare from a 16 piece 'big band' will open the rally at Brisbane's Crest Hotel as the Premier, Mr Bjelke-Petersen, enters through a guard of marching girls. Young Country Party girls dressed in black and white silk jerseys with a long front slit will escort each of the party's other 43 election candidates to the stage...'Closed circuit television will be used to give candidates pointers on TV presentation, advertising experts will outline effective use of the media, public speaking training will be given' Mr Evans said.

All leaders made extensive campaign tours of Queensland throughout the campaign, with Chalk focusing on the south-eastern corner and the Darling Downs. The Coalition's policy speech was given in two parts in early May with Bjelke-Petersen delivering the opening salvo in Rockhampton. He said 'the Government would introduce new legislation on public safety', then added ominously: 'we intend to safeguard Queenslanders' rights against organised attempts to undermine them.' Because forces were trying to 'destroy the community's confidence in democratic institutions', he stressed: 'We regard "law" as meaning the protection of the rights of all in the community-and "order" as the orderly working of society' (Courier Mail, 4 May 1972). Among other things, he suggested that the proposed appointment of an ombudsman was another measure to protect the rights of the community. For good measure, he also announced the commitment to build a $\$ 200$ million power station at Gladstone.

More than 500 people heard the hour-long speech. Apparently, it was

the liveliest meeting of the campaign so far and there were persistent interjections. The Premier ignored most, but when an active interjector said: 'You need a Labor Government', the Premier said: 'Yes, to stagnate and go backwards'... The Premier said: 'I'll sum it up by saying that if you've a good job with a secure future, a car in the garage and you're thinking about a new house-you must be living in Queensland.' (Courier Mail, 4 May 1972)

He spent much of the address talking up improvements to roads and rail services.

Chalk's policy speech was delivered in Brisbane and emphasised promises including a preschool scheme for all children in state schools and better city transport, saying the government would set up an authority to rationalise all Brisbane public and private transport services. He was then left to outline the government's intention of reducing probate and succession duties. He became more passionate, however, when he said 'we will strenuously oppose mob violence in the streets' and 'preserve the right of every Queenslander to go about his business unmolested by rioters and Communist inspired troublemakers' 
(Courier-Mail, 5 May 1972). He also promised that the Liberal Party would become the dominant partner in the Coalition. To an earlier meeting, he was reported as stating: 'the 1972 election should be the party's best chance of all time to reach the senior position in the coalition Government. Let me say that in this campaign I aim to push that barrow and to push it hard for the Liberal Party' (Sunday Mail, 23 April 1972).

Jack Houston described the Coalition's policy speech as an 'I'm alright Joe' document. He labelled the Premier's speech as an 'exercise in inadequacy and complacency - a travelogue in triviality'. He claimed 'most of the key promises in the speech on subjects such as education, health and water conservation are obvious and long overdue' (Courier-Mail, 4 April 1972). Houston nominated local government as the big issue in the upcoming election, insisting the Regional Planning Act was 'one of the worst Acts he had seen in State Parliament' because it could nullify the legitimate actions of a local authority.

Labor plugged away at the uninspiring slogan 'Labor plans to get things done Jack Houston's way'. It appeared an empty and non-arousing slogan. The government countered that if a Labor government were ever to be elected it would not be Houston's way at all. Instead, it charged that the QCE, with its strong Trades Hall connections, would dictate Labor policy from outside the Parliament. Labor tried to make an issue of the government's overseas-oriented state development program, claiming 'you are selling us out'. It also claimed that Queensland was squandering its coal reserves and letting the 'black gold' go at throw-away prices. It conceded, however, that the state was getting a good deal by way of money in rail freight charges and other fringe benefits.

After all the posturing, the final result pretty much maintained the status quo. The Coalition secured 42.23 per cent of the vote (down by 2.5 from 1969) to the ALP's 46.75 per cent (up 2 per cent). This was Labor's highest vote since Vince Gair was leader in 1956. In terms of seats, the Coalition held 47 with 26 to the Country Party and 21 to the Liberals. Labor managed just 33 seats - after some of their glamour candidates (such as Aldermen Clem Jones, Bryan Walsh and Ian Brusasco) failed to impress in the state poll. Two independents were returned: Ed Casey in Mackay and Tom Aikens in Townsville South. Some notable politicians who later became significant players entered the Parliament at the 1972 election, including: Tom Burns (ALP, Lytton, and ALP federal president), Bill Gunn (CP, Somerset), Bill D'Arcy (ALP, Albert), Dr Llew Edwards (Lib., Ipswich), Kev Hooper (ALP, Archerfield), Don Neal (CP, Balonne), Lindsay Hartwig (CP, Callide), Bruce Small (CP, Surfers Paradise, who came third in the primary vote but took the seat on a knife edge with Liberal preferences), Norman Scott-Young (Lib., Townsville) and Edward (Ted) Row (CP, Hinchinbrook, the son of the 
retiring minister, John Row). A couple of well-known but one-time members also made an appearance, such as the anti-apartheid campaigner Gerry Jones (ALP, Everton) and Roy Harvey (ALP, Stafford), later Lord Mayor of Brisbane.

While the government claimed its victory was the result of its sound record in the past 15 years, Labor blamed its loss yet again on the 'gerrymander'. The Premier revelled in his victory, saying: 'we are not concerned at the low percentage. We are only concerned with seats. The Country Party as always received a low percentage in Queensland. It is the tradition. We are satisfied we will be the government. Labor and socialism have been halted again' (Sunday Sun, 28 May 1972). Houston replied in the same paper that the 'gerrymander was far worse for Labor than I had anticipated' and added 'it is a queer kind of democracy where a party gets 48 percent of the vote and does not look like being the government'. Tom Burns called for a referendum in Queensland to test whether proportional representation should be adopted.

\section{The last of the high-water mark}

The election of 1972 was Labor's high-water mark in terms of votes received and seats won. It did not exceed this milestone until it finally won office in 1989 after 32 consecutive years in opposition. The next decade or so was marked by divisiveness, disastrous decisions and serial disappointments for state Labor. Their plight was brought on by their own misfortunes, but also by Queensland's subsequent antipathy to the Whitlam federal government. More than anything, however, their fate was sealed by the astute and relentless politicking of BjelkePetersen, who exploited their every weakness. Soon Labor would be reduced to a pitiful rump in the Parliament, almost unable to form a viable opposition.

On the conservative side of politics, the Coalition had seen off a difficult couple of years and its fortunes were about to improve greatly. After a difficult and unruly baptism as Premier, Bjelke-Petersen had now won two straight elections and had a clear mandate in this own right. He had seen off the doubters on his own front and backbenches and proved he could win the all-important electoral contests. He had experimented with novel campaigning techniques and jazzed up his party's appeal - a tactic that probably reduced his potential losses rather than won him many new votes. More significantly into the future, he had learned the importance of displaying unity and cohesion in contrast with one's political opponents - especially if they appeared divided or unstable. Having run a law and order campaign from 1971, the Premier had seen how to divide his political opponents and magnify their weaknesses. Gradually, he became merciless in the pursuit of political advantage. The 1972 election result 
9. The slide towards uncertainty, 1969-1972

and the lessons of that campaign became a watershed for the Bjelke-Petersen government, which went on to politically annihilate parliamentary and extraparliamentary opposition to its rule. 



\section{Commanding the Parliament, 1972-1975}

The fortieth Parliament began its first session on 1 August 1972. It would run until 1 November 1974, sitting for 193 days in the two and a half years it existed. Fifteen new members made their appearance in the House-almost onefifth of the Assembly. They included, from the ALP: Tom Burns, Bill D'Arcy, Roy Harvey, Kevin Hooper, Gerry Jones, Ken Leese and Les Yewdale; from the Country Party: Des Frawley, Bill Gunn, Lindsay Hartwig, Donald Neal, Ted Row and Bruce Small; and from the Liberal Party: Dr Llewellyn Edwards and Dr Norman Scott-Young.

The Country-Liberal Coalition had been in office for 15 years and was starting to become more than a little cocky in government. There were occasional telltale signs in the Parliament during question time or in debates in which ministers were summarily dismissive of opposition concerns. While the government's electoral position was not threatened, there was evidence of seething tensions brewing within the Coalition itself. These tensions would gradually increase during the 1970s, leading to an eventual breakdown of the Coalition in early 1983.

The third Bjelke-Petersen ministry was sworn in on 20 June. It consisted of 14 ministers, again split eight to the Country Party and six to the Liberals. The Transport Minister, Bill Knox, a businessman by profession, was promoted to the vacant Attorney-General's portfolio. Vic Sullivan took over the vacant Primary Industries portfolio and two new members were elevated into the ministry: Keith Hooper (Lib., Greenslopes) and Henry McKechnie (CP, Carnarvon). A few strange portfolio combinations were announced, suggesting that the government was conscious of the emerging importance of new policy sectors but not prepared to establish these as full departments under a dedicated minister. A new portfolio of Tourism, Sport and Welfare Services (!) was established, as was one for Conservation, Marine and Aboriginal Affairs (!) - both an eclectic mix of responsibilities.

The full ministry was

- Premier: Johannes Bjelke-Petersen, CP

- Treasurer: Gordon Chalk, Lib.

- Minister for Mines and Main Roads: Ronald Camm, CP

- Minister for Justice and Attorney-General: William Knox, Lib. 
The Ayes Have It: The history of the Queensland Parliament, 1957-1989

- Minister for Education and Cultural Activities: Alan Fletcher, CP

- Minister for Health: Doug Tooth, Lib.

- Minister for Tourism, Sport and Welfare Services: John Herbert, Lib.

- Minister for Development and Industrial Affairs: Fred Campbell, Lib.

- Minister for Primary Industries: Vic Sullivan, CP

- Minister for Works and Housing: Max Hodges, CP

- Minister for Conservation, Marine and Aboriginal Affairs: Neville Hewitt, CP

- Minister for Lands and Forestry: Wally Rae, CP

- Minister for Transport: Keith Hooper, Lib.

- Minister for Local Government and Electricity: Henry McKechnie, CP

\section{The unseemly tussle over the election of the new Speaker}

With the retirement of Sir David Nicholson, the Assembly had to elect a new Speaker, as was customary practice. The Country Party members were, however, divided as to whom they would support. On the first day back, Vic Sullivan moved that Jim Houghton take the chair. His motion was seconded by Mike Ahern, the new parliamentary secretary of the Country Party, who stated that the reason he had so moved was because 'I know him to be the best man for the job...For the office of Speaker he has received the nomination of the Parliamentary Country Party unopposed, and his nomination was endorsed at a meeting of the joint Government parties, again unopposed' (QPD 1972:vol. 259, p. 3).

Despite Houghton having already moved into the Speaker's office, putting a sign on the door calling himself the 'Speaker elect' and commandeering the Speaker's car and chauffeur, two Country Party members - Roy Armstrong (Mulgrave) and Val Bird (Burdekin) - then nominated 'Bugger-em' Bill Lonergan because he represented a northern electorate. Lonergan had been elected party whip, but announced he would stand for the Speakership on the floor of the Parliament. Some Country Party members were angry that there were no ministers representing north Queensland (with no-one north of Whitsunday, held by Ron Camm). Sensing the government was split over its preferred nominee, Labor chose - instead of nominating its own candidate - to complain about the lack of meetings of the standing committees before trying to seek assurances that new furniture that had been delivered to the Parliament would be made available to the opposition (Ah! Ever people of principle!). Jack Houston said that Labor did not support Houghton because we 'are not keen on having Jim Houghton, or anybody else, barking at us from the chair' (in a none too subtle reference 
to his 'mangy dog' statement when he was an independent and before he was a member of the Country Party) (QPD 1972:vol. 259, p. 5). Houston supported Lonergan because he believed he would 'convene meetings of the standing committees' and stand up for 'principles that he believes are right'. The debate proceeded but more than an hour later, Lonergan won the 'secret ballot' by 47 votes to 32 , with three informal votes. There was speculation that a few Country Party members, and quite a few Liberals, voted for Lonergan (with the Liberals voting against Houghton because of his previous treachery). This was the only time in the period of the Coalition government that there was a formal challenge to the government's nominee from within its own side. Liberal Party President, Robert Sparkes, 'voiced his disapproval' over the actions of the breakaway members, accusing them of breaking the 'basic principles of party solidarity' and threatening 'disciplinary action' (AJPH 1972:vol. 427).

As Speaker, Lonergan seemed reluctant to accept frequent interjections and kept calling for order and for members to reduce the level of noise, even from among the government's own members such as Russ Hinze. Within days, he was struggling with interjections, insisting: 'Order! I am in control of the House. I do not want any advice on how I should control it' (QPD 1972:vol. 259, p. 144). He would later attract much criticism for his partisanship and his 'biased' rulings and be accused of unnecessarily evicting Labor members in debate. At one stage when defending one of his rulings, Lonergan let slip his attitude to parliamentary politics by stating 'after all, politics is not a Sunday-school picnic, and honourable members must expect a little rough and tumble' (QPD 1973:vol. 261, p. 2934). His deputy and Chairman of Committees was Bill Lickiss. More importantly, Labor nominated Vi Jordan (Ipswich West) as one of the panel of deputy speakers, making her the first female deputy speaker in Queensland. Subsequently, according to one of the Liberal members who made a speech on the role of women in the Parliament, Jordan became

the first woman to preside over an Australian Parliament, notwithstanding that a few months later the Victorians, who are always trying to take our historical claims away from us, said that Mrs Edna Roper had presided over a Committee... [but] Mrs Jordan certainly has that small claim to history. (Bill Hewitt, in QPD 1975:vol. 267, pp. 464-5)

The date was most likely 12 October 1972, and the House was debating the supply bill.

The Governor's address contained the usual list of parish-pump spending proposals: new dams, new hospital wards, new trains, aged-person nursing homes, technical colleges, farm support packages, more police and a new police academy, new wharves and coastal groynes to be built. The government planned to introduce legislation to appoint an ombudsman, to amend succession duties 
and workers' compensation laws and to regulate tow trucks. It also planned to introduce politically inspired electoral changes to the Brisbane City Council Act to reduce the number of wards and have the Lord Mayor elected by the aldermen rather than elected-at-large (a supposedly 'get Clem' move in retaliation against Clem Jones standing at the state election of 1972).

Once the proposed measures were disclosed, the Labor Party produced a petition to the Assembly signed by 18085 electors 'praying that the Parliament of Queensland' will 'set up a referendum of electors to decide whether or not any alteration is desired in the election of the Brisbane City Council and the Lord Mayor' (QPD 1972:vol. 259, p. 236). Houston claimed in the subsequent debate that the bill was full of 'piffle' and that it would go down in history as 'McKechnie's folly', named after the new Minister for Local Government. When the bill came to a vote, the Country Party's Jim Houghton distinguished himself by stating he would vote against the government's proposal; he was impressed with Clem Jones and he believed 'insanity has taken over democracy' (QPD 1972:vol. 259, p. 270). Some on the government's benches felt that Houghton spoke against the bill out of sour grapes because he had not secured the Speakership. In the end, at $1.25 \mathrm{am}$, after a mammoth series of amendments requiring 23 divisions at the second reading stage, the bill was passed by $42-32$ votes. Houghton declined to vote and abstained along with five other members (Aikens, Casey, Hughes, Lickiss and Tooth. Percy Tucker was also absent because he had been suspended earlier in the proceedings).

The debate on the City of Brisbane Act Amendment Act occupied some 137 pages in Hansard, suggesting the heat of the issue and the importance politicians attached to their own electoral interests. During the early stages of the debate, the vituperative Aikens reminded the House of the parochial nature of Queensland politics when he confessed:

I do not care very much what happens to this great big rat-ridden, overgrown dump of a city called Brisbane. As far as I am concerned, it can slide into the Brisbane River any day it likes. It would not be missed by the useful people of the back country, because the people of Brisbane have fattened and battened on us for years. Without the people of the back country, Brisbane would still be a collection of bag and bark humpies along the Brisbane River. (QPD 1972:vol. 259, p. 257)

Aikens made his passionate speech because he believed Brisbane was corrupt. He felt it was about time various land scandals were exposed and he believed that the council was led by a one-man-band, Clem Jones, who had degraded services rather than improved them. He made the telling point that Queensland operated under two local government acts: a special one for the City of Brisbane and one for the rest of Queensland. He agreed that mayors ought to be elected 
by the aldermen - as was the case throughout the state except for Brisbane. He indicated he supported the City of Brisbane Amendment Bill because it brought the capital into line with the remainder of the state. When the voting was conducted, however, Aikens was a notable abstention or absentee.

A number of Labor speakers made reference to the fact that the new Minister for Local Government, Henry McKechnie, had publicly admitted that he was motivated to bring forward the bill partly because disgruntled taxidrivers had complained to him about conditions in Brisbane. In a quirky moment, Labor's Doug Sherrington revealed his 'latent poetic talent' when he dedicated the following poem to the minister after hearing that local taxidrivers had told him to 'fix Jones'. Sherrington recited:

Henry, dear Henry, come home with me now; The clock in the town hall strikes one.

Your taxi-man's waiting to give you advice, On just how old Clem should be done.

What matters the fact that the public object, What matters the Press tans my hide,

The taxi-men tell me that Clem's got to go, So you've just got to keep them on side.

Though Sparkes and his crew say I'm making a blue, And say it's a ruddy poor show,

The taxi-men tell me that Clem's got to go, And who am I to say no?

The amendment may stink, and I could be a fink, But I always can look back with pride,

And with hillbilly logic, the city I wrecked, And the taxi-men stood by my side.

So, Henry, dear Henry, your day's work is done, You're now firm favourite with Joh.

You'll go down in history as the bloke in the cab, Who just really couldn't say no. (QPD 1972:vol. 259, p. 282)

The day after the vote on the Brisbane City Bill was taken, Houston challenged the Speaker's ruling the previous night that declared material Houston had alluded to in the debate the day before was out of order and could not be raised. Houston's challenge was made on the grounds that Speaker Lonergan had not shown the appropriate leniency and tolerance in curtailing the debate and that 
he had not abided by the principles laid down in Erskine May's Parliamentary Practice. His dissent motion got nowhere, however, and the challenge to the Speaker's ruling was lost on party lines, with 30 Labor 'ayes' to 42 Coalition 'noes'.

Other early debates were largely interwoven with Labor's constant complaints against the electoral redistribution and the 'gerrymander'. Houston moved a motion against the Address in Reply, claiming the government did not have the confidence of the House because it had

failed to provide a fair and impartial redistribution to enable the election of a Government in accordance with the true wishes and desires of the community....and [because] the Country Party, gained the least number of valid votes cast for all the major parties, yet maintained its seniority with a mere 20 percent of the vote. (QPD 1972:vol. 259, pp. 53-4)

Again, he got nowhere.

Interestingly, during 1972, citizens also began to look at the diligence and performance of their politicians. A consumer protection group called Campaign Against Resting Politicians (CARP, sometimes recycled by its leader as Campaign Against Rising Prices), led by consumer activist Vilma Ward, set itself the task of reporting on the performance or lack of performance of politicians - with CARP members occasionally sitting in the public gallery and holding regular meetings to swap information and compile dossiers. This initiative, which many Coalitionists considered a union or Labor stunt, angered Hinze and really got his blood up. Using colourful language, he called their monitoring 'pimping on politicians'. So irate did he become that he departed from the business of the Address in Reply to have a go at Ward:

It is a pity that Vilma Ward would not come in here and say what she wants to say instead of pimping on politicians. A lot she would know about us, anyhow... When I was asked 'Will you go on This Day Tonight with Vilma Ward?', I said, 'I would love to have such an opportunity. Let us see how good she is'. But, of course, she could not be found anywhere in Brisbane once she heard that I was going to give her a little bit of a 'touch-up'. The person who made the approach from This Day Tonight said, 'Never mind, Russ, she'll keep' ... as far as I am concerned, anyone who sits in the gallery and takes notes and pimps on members can go to hell. The people of the South Coast electorate put me here originally...they are the only ones of whom I take any notice. (QPD 1972:vol. 259, pp. 123-4)

Usually an unapologetic bully, Hinze later showed his more humorous side when he defended his party's policy of defending marine mammals in coastal 
waters. On the one hand, he argued that wild dolphins deserved compassion and should be protected, but, on the other, he approved of keeping them in captivity at marine parks similar to Marineland on the Gold Coast. As someone not small of girth, he shared a personal moment with members:

Mr Hinze: No doubt honourable members have seen the excellent photograph in today's issue of 'The Australian', which shows that, as proof of my love for these wonderful creatures, I jumped into the pool with them. I know some people might have trouble in distinguishing the dolphin from me.

[Interjection from] Mr F. P. Moore: You should have worn your glasses.

Mr Hinze: I should have had my glasses on. (QPD 1972:vol. 259, p. 129)

Subsequently, the Minister for Justice, Bill Knox, was asked a question without notice by Hinze suggesting that Vilma Ward was not qualified to advise on the quality of any consumer product. Knox responded by saying that he did not know Ward personally, but thought that it was unusual for someone purporting to be an independent authority in the community to then endorse particular commercial products (such as potato chips). He considered it undermined her bona fides to spruik for particular brands. Those in the Parliament treated such incidents as light relief, but in reality it was an early inkling that Queenslanders were gradually expecting better of their politicians and were prepared to do something about it themselves.

\section{Handcuffing the puppets of the executive: the momentum for reform flickers}

Many of the new members made their maiden speeches in the Address in Reply. One noted speech was from Tom Burns, the former state secretary and federal president of the ALP (QPD 1972:vol. 259, pp. 486-95). Against the prevailing custom, the speech was interrupted by numerous interjections, including some from the heavyweights Joh Bjelke-Petersen and Ron Camm. Burns blasted the government for 'handcuffing' the Parliament and for keeping it endlessly in recess. He argued the government was not providing adequate resources to the Parliament and that the government was hiding behind an armour of secrecy. He ventured that cabinet was dominated by seniority and that government press secretaries put words in the mouths of ministers and were writing speeches for government backbenchers. It was a trenchant critique. He also accused BjelkePetersen of being an associate of a stockfeed merchant who had defrauded 
the state of $\$ 100000$ from drought relief funds, but whose 'trial' was held in secret in the Treasury Building. He finished his maiden speech by making six suggestions for parliamentary reform - namely

- joint parliamentary committees on issues of public importance

- provision for private members' bills

- relaxation of Standing Orders to permit urgency debates on questions of public interest

- changes to Standing Orders so that questions on notice were tabled in writing one day and answers tabled again in writing on the next day

- joint standing parliamentary committees on administrative aspects, such as public accounts and public works

- extension of research and secretarial assistance available to members.

While Bjelke-Petersen returned to the Chamber to make Burns withdraw his statement concerning the stockfeed merchant (which Burns did), the next speaker, Claude Wharton ( $\mathrm{CP}$, Burnett), asserted he had never heard such political piffle in his life. This was, however, one of the first major calls made by Labor in the postwar period for the explicit establishment of a public accounts committee and other institutional reforms to parliament. It began an era in which parliamentary reform itself became of increasing concern not only to the Labor opposition but to many Liberal backbenchers, media commentators and reform-minded interest groups. Only a month later, Geoff Chinchen (Lib., Mount Gravatt) argued that a public accounts committee helps members 'determine whether money is spent wisely' (QPD 1972:vol. 259, p. 972). He urged the Queensland Parliament to establish such a committee because backbenchers had considerable trouble finding out what was going on from the estimates debates (and even those dealt with only half the departments each year). Chinchen argued that the Parliament could not rely on the Auditor-General to ascertain whether spending was 'wise' as opposed to expended properly, so a public accounts committee was essential to place the Parliament back in control of spending. He stated:

As members, we must have much more control. This can only be done through a public accounts committee. This would establish the supremacy of Parliament over executive Government. Surely this is our job. Such a committee is not a policy-making body; it operates within the Government's policy. It would be a means of allowing members to feel that they were playing their part in the expenditure of money, which is a most important area of Government. It would allow members to be satisfied in their own minds that money was being spent wisely. (QPD 1972:vol. 259, p. 975) 
Earlier, in the previous Parliament, following Jack Pizzey's supposed support for a subordinate legislation committee, Bill Hewitt had called for the introduction of 'all-party parliamentary committees' to investigate social problems and policyrelated matters (see Chapters 7 and 9). He had also suggested the establishment of an estimates committee along the lines of the Senate's estimates committee. He was supported by other Liberals over the next few years, including John Murray, but opposed by others less interested in transparency, such as Don Lane. When Murray called for 'all-party committees' in 1973, he said that 'when members from both sides of the House serve on these committees, there is an extraordinary absence of political bias...in the main, committee members rise above fighting on party-political lines'. His fellow Liberal Don Lane, however, interjected: 'how naive can you get!' (QPD 1973:vol. 263, p. 2078).

In late 1972, the government agreed to allow the establishment of a privileges and regulations parliamentary committee following the recommendations of a 'parliamentary investigating committee' chaired by Mike Ahern and with Keith Wright's support. The privileges committee must not have been a priority, however, as it was not officially established until April 1976 - three and a half years later. In 1972, the government ruled out the establishment of a public accounts committee and a public works committee despite pressure from some members.

Hewitt continued his interest in improving parliamentary procedures, giving a speech on 6 December 1972 highly critical of the wasteful and inefficient procedures of the House, which allowed meaningless debates to 'drag on interminably'. The Standing Orders, he claimed, were 'soul-destroying' and did 'nothing to uplift the parliamentary institution'; rather they served to 'drag it down into a morass of senseless, useless verbiage that makes the parliamentary proceedings dull and stultifying' (QPD 1972:vol. 260, p. 2370). He suggested shortening the Address in Reply to make it punchier, shortening estimates debates undertaken by the House (committee of the whole) and economising over speeches introducing new legislation especially given before the members were presented with the actual bills. He was concerned to economise on time, while making proceedings flow more smoothly. To do this, he called for the Standing Orders Committee to meet and review all procedures, warning:

There is a ground swell of opinion among honourable members that our procedures are not good enough...It is our task to administer the affairs of this State efficiently and well. How can we be seen to do that when our own procedures are more in keeping with those of a bygone age? (QPD 1972:vol. 260, p. 2371)

The government did occasionally act on this sentiment, as it did in late 1972 when it cut the time allowed for speeches on the supply debate from 25 minutes 
to 20 minutes - a measure that had the opposition incensed. The government also extended the sitting hours late in 1972 to include Tuesday and Thursday nights, Wednesday afternoons and Fridays. It also reaffirmed the dress code of the Parliament after Don Dunstan famously wore pink hotpants into the South Australian Parliament (as a 'dare' he had made with his then partner). With tongue in cheek, Clive Hughes (Lib., Kurilpa) asked the Deputy Premier whether the Queensland Labor members ought to be permitted to adopt a similar style of attire in the local Parliament. Gordon Chalk played a straight bat saying that 'the style of dress worn by the Premier of South Australia lowers the dignity of the Parliament'. He favoured the traditional dress code that had been used by the Queensland Parliament since its inception - 'namely, shirt, trousers, coat and tie'; there was no mention of female attire (QPD 1972:vol. 260, p. 1966)! When Jack Melloy wore a safari suit, his attire was deemed unsuitable and he was asked to withdraw.

\section{Four Labor members 'suspended' by the chair (or by the Premier); then Lane is evicted}

Four members were excluded from the Chamber in October 1972 over socalled 'grossly disorderly behaviour'. They were all Labor members but their behaviour did not appear any more disorderly than that of their government counterparts. Three were ordered by the chair (the Deputy Speaker or Acting Chairman) to 'withdraw' themselves from the Chamber under Standing Order $123 \mathrm{~A}$ (they had to leave for the rest of the day but could return the next). They were Doug Sherrington, Tom Burns and Fred Bromley. Bromley and Sherrington were perennial offenders and were regularly thrown out for clashing with the Speaker; Sherrington was again evicted a few days later for calling Chalk a 'ratbag', as was Bromley a short while later. Another Labor member, Gerry Jones, was also named and then suspended for seven days on a motion from the Premier, which was passed by 33 votes to 26 . Finally, Don Lane (Lib., Merthyr) was expelled for a day on the penultimate sitting day of 1972.

The expulsion incidents blew up over a series of heated exchanges supposedly relating to the supply debate, held after the dinner recess in the evening of 26 October - no doubt after a few members had been drinking during dinner time. Most of the initial acrimony was between Brian Davis (ALP, Brisbane) and Lane over Lane supposedly spying on trade unions when he was with the police's Special Branch. With Bill Hewitt in the chair, the Chamber descended into personal abuse and invective, with, among other things, Lane accusing Davis of stealing hub caps and Davis calling Lane a 'pimp and a police stooge'. The 'debate' then drifted to conflicts of interest involving Bruce Small (CP, 
Surfers Paradise and Mayor of the Gold Coast) and suspicious land sales from his company to the council and the takeover of land on the coast by foreign interests who allegedly used Small as a facilitator. Hewitt was then replaced in the chair by Claude Wharton (CP, Burnett), who tried to refocus the debate back onto the budget. After a rash of interjections, Sherrington was ejected after being warned (a warning he received by stating 'the honourable member for Merthyr has been interjecting all night. He can do as he likes'). Burns was then expelled (by Hewitt this time) for interjecting that Bruce Small was 'still an old crook'. Hewitt then asked Gerry Jones (ALP, Everton) to withdraw from the Chamber for disobeying the chair's rulings, but Jones, who was a new member, refused to go immediately, saying he had only sat in the Chamber for three weeks and 'have not been allowed to open my mouth'. When Hewitt threatened to name him, he said: 'Name me.' With Lonergan as Speaker in the chair, Jones was then named and suspended. Finally, Fred Bromley was expelled when he responded to the Treasurer's plea to return to a 'more serious side of the debate (if one can describe it as a debate)' with the interjection: 'excuse me while I go out and vomit' (QPD 1972:vol. 260, p. 1384). Hewitt, back in the chair, then asked him to leave. Bromley apparently left the main chamber but lurked around outside in the corridor; he later re-entered the Chamber, claiming that the Acting Chairman had instructed him to 'withdraw' not in fact leave the Chamber. The incident finished with an almost-Lewis Carroll moment:

The Acting Chairman: Order! The honourable member for South Brisbane was ordered to withdraw from the Chamber earlier this evening. I now ask him to leave the Chamber.

Mr Bromley: I was outside the Chamber.

The Acting Chairman: Order! I ordered the honourable member to withdraw, and I stand by my ruling.

Mr Bromley: I disagree, Mr Hewitt. I was outside the Chamber.

The Acting Chairman: Order! I do not intend to debate my ruling. My interpretation is that I ordered the honourable member to withdraw, and I now ask him to leave the Chamber.

Mr Bromley: I was outside the Chamber.

Sir Gordon Chalk: I do not propose to speak on this matter.

Mr Bromley: You can't throw me out.

The Acting Chairman: Order! I ordered the honourable member to withdraw earlier in the evening. I again order him, for the last time, to withdraw from the Chamber. 
Mr Bromley: I will withdraw, but I don't think you did order me out of the Chamber.

The Acting Chairman: Order! I do not intend to debate my ruling. Will the honourable member leave the Chamber, or do I have to name him?

Mr Bromley: I don't care what you do.

The Acting Chairman: Order! The honourable member will leave the Chamber.

[Whereupon the honourable member for South Brisbane withdrew from the Chamber.] (QPD 1972:vol. 260, pp. 1394-5)

The pathetic incident caused subsequent comment in the media, with The Australian (30 October 1972) reporting that the incident showed the government was losing control of the House but was also guilty of abusing its power over the opposition. The newspaper commented that Labor MPs were right to be 'bitter about the suspension of four of their number', that they were 'treated unfairly' and that it was 'unfortunate too, that the Premier, Mr Bjelke-Petersen, bought into the argument'. It ventured: 'his statements that he will take severe action again could lead to the belief that the Premier, and not the Speaker, $\mathrm{Mr}$ Lonergan, is in charge of the House.' Partly in response to such negative press reports, Lonergan excluded Don Lane for a day on the evening before the last sitting day of the year. Lane was fast gaining a reputation as a 'political bruiser' who showed considerable animosity towards the opposition (feelings that were mutual). He was ordered out because he constantly crossed swords with the Speaker and had been constantly interjecting, although he complained he was being gagged in debate. Lane left the Chamber without incident, but did not recount the incident in his memoirs.

Although Charles Porter rose to complain about The Australian's coverage of this matter as an issue of privilege the following week, this was the first time that Bjelke-Petersen was accused of ruling the Parliament with an iron fist (QPD 1972:vol. 260, p. 1427). Then, without a hint of irony or hypocrisy, at the adjournment of the Parliament for the summer break, the Premier thanked the Speaker and the various chairmen of committees 'for their valuable role of ensuring proper conduct while the House is in Committee' (QPD 1972:vol. 260, p. 2635).

\section{Matters of less public importance}

Speaking on a 'matter of public interest', Tom Burns raised the issue of the conversion to metric measurements, complaining it 'will affect all our lives'. 
Burns went on to say it would impact on people from the cradle to the grave, reporting in all earnestness that a grave now dug to six feet would have to be dug to two metres, costing more in fees for bereaved families! He asked somewhat poignantly: 'what benefits will the average Australian housewife and worker derive from metrication?' (QPD 1972:vol. 259, p. 756). He called for the state consumer protection body to be given the power to control prices to stop business increasing the price of goods (or reducing the contents) in the changeover period.

The issue of creating new states within Queensland surfaced again after the Premier made statements to the press to the effect that the government was giving consideration to a new state in north Queensland. His statements came about because, along with Gordon Chalk and Jack Houston, the Premier had attended a conference on constitutional matters involving the Commonwealth and state governments. The Queensland government had proposed listing new states on the agenda for a forthcoming constitutional convention, but was having difficulty convincing other state governments to support this bid. In the Parliament, Bill Wood (ALP, Barron River) asked the Premier whether all the views of north Queensland would be listened to and not just the advocates of the North Queensland Self-Government League based in Townsville. The Premier replied:

The whole question of the division of Queensland into a number of States has been discussed by Cabinet on a number of occasions. Our legal advisers, as we have informed those in the North who are particularly interested in this matter, are of the opinion that complete agreement would be required between the Commonwealth and all the other States on the suggested establishment of a new State. The responsibility for organising or arranging something of this nature is in the hands of the Commonwealth...I will be calling for views and expressions of opinion from all people and organisations, wherever they may be. That is a natural consequence of holding such a convention. (QPD 1972:vol. 259, p. 826)

The issue lost salience for the government after 1972 and was swept aside by other political conflicts with the Commonwealth after Labor's Gough Whitlam won office.

\section{Finances and superannuation}

Gordon Chalk presented his seventh financial statement to the Parliament in September 1972. He was most proud that the state's finances had miraculously turned around. The state's income for the past year was \$595 million compared 
with spending of $\$ 592.3$ million-leaving a surplus of $\$ 2.7$ million instead of the projected deficit of $\$ 7$ million. The result was achieved after the injection of $\$ 9$ million from the Commonwealth Grants Commission together with higher revenue returns (some $\$ 31$ million higher than expected) and expenditures held fairly constant. Revenues were increasing sharply because of the booming nature of the state's economy. The budget for 1972/73 increased expenditure by $\$ 107$ million to $\$ 679$ million - an increase of 18 per cent in one year. Revenues were expected to increase to $\$ 674$ million or 14.1 per cent, meaning a slight deficit was projected. Chalk told the House:

When the accumulated surplus of $\$ 2,711,919$ brought forward from 1971-72 is taken into account, the accumulated position at 30th June next is expected to be a deficit of $\$ 1,897,788$. In anticipation of the receipt of Grants Commission completion grants for 1971-72 and 197273 in subsequent financial years, I am satisfied the State can prudentially budget accordingly. (QPD 1972:vol. 259, p. 799)

He forecast no increase in the rates of taxation or in rail freight charges, which were very profitable for the state, especially from the mining companies in central Queensland. Reactions to the budget were not so fulsome from the opposition. Jack Houston described the financial statement as a 'Budgerigar Budget': 'it talks well; it has colour, but, instead of taking the forward look of statesmanship, it is caged in the opportunism of politics' (QPD 1972:vol. 259, p. 827). Percy Tucker also bought into the debate, pointing out that the Commonwealth Treasury had questioned the validity of the state's figures it used in making its submission to the Grants Commission. Tucker alleged that Queensland had won \$9 million not because of Chalk's submission, but because an election had been pending. The debate continued, with Tucker suggesting:

If the Queensland Government presented such a slovenly and inept submission in our hour of greatest need - and it was an hour of greatest need - what of the previous submissions made over the years...In the past five years Queensland would have received, on a per capita basis, which is applied to South Australia, not $\$ 9,000,000$ but an extra $\$ 123,500,000$. When the Treasurer managed to get $\$ 9,000,000$ he came back and held it aloft, but he hid the fact that, because of his poor presentation, Queensland has lost many millions of dollars over the past five years.

Sir Gordon Chalk: You are sillier than I thought you were. You are completely off the beam.

Mr Tucker: Now the Treasurer is frightened.

Sir Gordon Chalk: I am not frightened of you. I will deal with you later. 
Mr Tucker: I am not worried about that. This clearly demonstrates how the Federal Government has exploited the incompetence of the Government. If the Treasurer is not worried about it, he is making a lot of noise.

Sir Gordon Chalk: I am worried because you are misleading the people of Queensland with such stupidity. (QPD 1972:vol. 259, p. 851)

And, so it went. Tucker also said it was clear that the people of north Queensland 'want to escape from the Government led by the Premier and the Treasurer', adding that if a new state were to be established in north Queensland it would be governed by Labor and he would 'certainly do my best to influence a Labor Government to renegotiate every rotten mineral contract let in the North' (QPD 1972:vol. 259, p. 851). Chalk, it seems, was doing precisely this and, to help balance the next year's budget, he announced a new deal over mining royalties had been agreed with the companies, which would generate an additional \$28 million.

A new public service superannuation scheme was introduced, replacing the older scheme, which had become too costly to older workers. The new 'defined benefit' scheme (applying to public employees including teachers) required contributions rising from 2 per cent to 6.5 per cent of salary after thirty-five years of age, and provided benefits of up to forty-five sixtieths of the average salary over the last three years of service. It was a pioneering scheme in that Queensland unlike the other states established a fully funded scheme so that it would not constitute a liability to future taxpayers; in 1972-73, this required an additional subsidy of $\$ 3$ million.

\section{Fighting the 'communist evils' of Canberra}

With the election of the federal Whitlam Labor government in December 1972, the Queensland Premier emerged as one of the staunchest critics of this administration. He opposed almost everything the federal Labor government proposed while resorting to various forms of subterfuge and isolationist tactics to unsettle the new leader. As Chalk would later recall, 'Joh had an obsession about Whitlam' and the 'longer Whitlam remained as Prime Minister, the more "Joh's hatred of him grew"' (Hazlehurst 1987:269). Bjelke-Petersen particularly honed in on the fears and anxieties of parochial Queenslanders, playing up fears of a socialist centralisation and the drift towards republicanism (Townsend 1983:346). He talked of secession, of Queensland going it alone, of making the 
monarch the 'Queen of Queensland' to forestall any move towards a republic. ${ }^{1}$ More generally, he began a relentless 'anti-Whitlam' campaign, denigrating everything that emanated from centralist Canberra - labelling them 'communists in Canberra' and immoral evildoers. Bjelke-Petersen called Whitlam a 'dictator' who should 'remember he is not a feudal lord' (QPD 1973:vol. 262, pp. 789). He constantly goaded the local ALP, accusing it of being anti-Queensland, asking its members whether 'they stand on the side of Canberra, or on the side of Queensland and loyal fellow-Queenslanders?' (QPD 1973:vol. 261, p. 2652).

Bjelke-Petersen began a conscious campaign to carve out a more strident and independent image for the state and for himself as a conservative leader of national and international standing. He undertook an ambitious (and expensive) international tour of London, Tokyo and Washington, meeting various bodies but also conducting extensive media interviews for home consumption (which became a talking point in itself). When asked in the Parliament by Percy Tucker who he had met while overseas, the Premier replied elliptically, 'many important people' - to which Fred Newton replied 'name one' (QPD 1973:vol. 262 , p. 8). He claimed he had spoken to the US Ambassador and 'many other important people in Washington', where he had done 'everything in [his] power to counter the attitude being adopted by many people as a result of the Federal Government's actions' (QPD 1973:vol. 262, p. 8). He also built up the capacities of his own department, which increased its budget vote from \$2 million in 1968 to $\$ 5.5$ million in $1973 / 74$. Much of this increase was devoted to additional staff, but some was spent on the Premier's government jet, which he used frequently and which became a sore point with the opposition. At times, the opposition criticised his extravagance and complained loudly if he was 'flying around the state' when he should be attending parliament. At other times, it argued that if the government cared about democracy it would 'give the Opposition the plane on an equal basis and for equal time to tour the State' (QPD 1973:vol. 263, p. 2108). When frequently asked about his use (or misuse) of the government's jet, Bjelke-Petersen, however, would turn the issue around and accuse the opposition of not always using their entitlements for the purposes for which they were intended. He responded to one attack by Houston by claiming the members of the opposition were not all 'cleanskins':

Nobody can convince me that the Leader of the Opposition, or any other Opposition member, has never used his secretary, office, telephone or motor-car other than on parliamentary business. That is a lot of nonsense. I think it is fair that they should be used. I am not criticising that at all. What I am criticising is the attack by Opposition members on the use of the Government aircraft, trains, or any other facilities. They

1 Described at the time by Percy Tucker as the first step towards setting up a 'Banana State as a colony of Britain' (QPD 1974:vol. 265, p. 31). 
have to remember that they, in their turn, are in a similar position. They are not the cleanskins they make themselves out to be. (QPD 1973:vol. 263, p. 2117)

He failed to acknowledge that the scope available to the opposition to misuse any entitlements paled into insignificance compared with the resources at his disposal.

Labor moved an 'Alleged Lack of Confidence in Government' motion in March 1973 over the government's isolationist policy towards Canberra and the Premier's failure 'to meet and discuss with the new Prime Minister, Mr Whitlam, the hopes and desires of the people of this State' (QPD 1973:vol. 261, p. 2692). Labor's main argument was that Bjelke-Petersen was engaged in Canberra bashing to cover the disunity and bitterness among the government parties. Tucker accused the government of a 'dangerous deception' over 'its senseless confrontation with the Federal Labor administration' (QPD 1973:vol. 261, p. 3135). The Premier's defence was that Whitlam was adopting an 'anti-free enterprise foreign policy' and was shifting Australia into the orbit of Red China. He also believed there were 'very dangerous trends of the Commonwealth Government towards centralist control of power and towards exerting its influence over areas to the north of this State [the Torres Strait region] and also throughout the length and breadth of Queensland'. After a largely predictable debate that meandered from topic to topic (for example, mining, foreign affairs, Aboriginal affairs, the revaluation of the dollar, the price of T-bone steaks, police discontent and the crime rate, sick patients falling off hospital trolleys and even the Premier's psychological state of mind), the no-confidence motion was defeated with 34 votes for and 42 votes against. A number of ALP members continued the attack on the Premier, however, with Tom Burns describing his stance towards the Commonwealth as one of 'stubborn, conceived confrontation with Canberra' (QPD 1973:vol. 262, p. 258).

In opening the Parliament on 31 July 1973, the Governor, Sir Colin Hannah, gave the usual hyperbolic run-down of achievements and upcoming intentions. His speech was unremarkable except for one paragraph in which, on behalf of the Bjelke-Petersen government, he criticised the Whitlam government's coal export policy. The Governor said: 'Under normal conditions the mineral industry can be expected to continue its great expansion of recent years, but problems could be encountered because of the suggested changes in overseas marketing brought about by the attitudes of the Commonwealth Government' (QPD 1973:vol. 262, p. 2).

He was referring to the federal Labor government's plans to bring all mining exports under Commonwealth control and, in doing so, restrict Queensland exports, which had recently overtaken those of New South Wales. As the 
Premier explained the next day: 'we outlined some of our legislative programme and at the same time we voiced our concern about Commonwealth attitudes on issues which vitally affect the States' (Courier-Mail, 2 August 1973).

Houston immediately declared the speech improper, saying the government had acted incorrectly by including party-political references in the opening speech. He regarded it as a partisan political attack on federal Labor. A few days later, in the Address-in-Reply debate, he refrained from criticising the Governor overtly (out of respect for the office), but instead attempted to defend the Commonwealth's position in the House. Later in the reply debate, Keith Wright went further, claiming that the Governor had breached tradition when he referred to the problems that could be encountered because of the Commonwealth government. This, according to Wright, had undermined the 'strength and the foundations of this high and honourable position' (QPD 1973:vol. 262, p. 212). The government, he believed, followed tradition only when it suited it to do so. Houston also warned-after seeing reports in the press that Bjelke-Petersen favoured secession from Australia- that this would be impossible because Queensland would not be able to go it alone, citing the small population of the state (1.8 million), but also listing the numbers of sheep, cattle, grain production and even mining output as a way of demonstrating the state was not viable as a separate nation. Although the Premier subsequently denied in the Parliament that he had favoured secession, it was clear that he had made statements to reporters that he was considering such moves if he felt it was warranted.

Celebrating his fifth full year as Premier, Bjelke-Petersen became embroiled in yet another personal conflict-of-interest matter over the proposed location of the Tarong power station and his personal business interests. When asked a question by Gerry Jones about his involvement in a mining lease at Nanango (whether he was part lessee), Bjelke-Petersen replied carefully that he had 'now no personal interest in that lease'. A week later, however, he made a ministerial statement to the Parliament clarifying his earlier statement, now claiming that the mining lease was held by Bjelke-Petersen Enterprises Proprietary Limited. He claimed he thought he had transferred his shares in mining leases to that company and that he was not a member of the company. The shareholders of Bjelke-Petersen Enterprises were his wife, his sister and his four children! He then admitted, however, that he might have misled the Parliament because his interest in the mining lease (a one-quarter stake) had, in fact, not been transferred to the new family trust company, as he had believed. He added, as though to invite scepticism:

It should be clear from the foregoing that I acted to the best of my knowledge and belief when, at the time of answering the question, I understood that I held no interest in any application for a mining lease...I 
mention this to dispel any suggestion that I stand to obtain material benefit should a Cabinet decision be made to site the new powerhouse at Tarong. (QPD 1973:vol. 262, p. 75)

Cabinet did subsequently make a controversial decision to build a new powerhouse at Tarong. And, of course, the Premier continued to benefit from the leases as happened the next year when the stake of a now deceased partner with a half share was transferred to the Premier and the other business stakeholder.

One early example of Bjelke-Petersen's obsession with defeating Whitlam at every juncture was his hasty introduction of a bill to preserve the rights of Queensland appellants to appeal from the State Supreme Court directly to the Privy Council in the event Whitlam tried to abolish such an avenue. To ram the Appeals and Special Reference Bill through, the government suspended Standing Orders, putting the bill through all three readings in one day. BjelkePetersen's rationale was that the bill preserved the rights of the ordinary citizen to appeal to the Crown against the judiciary's rulings; it protected the traditional system of law as he understood it from change; it was also evidence he was prepared to stand up for state rights against possible encroachments of a central government. The Attorney-General, Bill Knox, argued that the Commonwealth was taking powers away from Queensland and that the state government had to take 'a protective stand'. He suggested that the state government was not defending 'forever appeals to the Privy Council' but that for the Commonwealth to take them away required constitutional change through a referendum. The opposition's position was that the preservation of the appeal to the Privy Council was a token of imperial deference and lack of independence. Houston said the move was a desperate attempt to retain a colonial system. After a four-and-a-half hour debate that was gagged 15 times, and was characterised mostly by yelling and name-calling, the bill was passed by 38 to 31 votes. Immediately this vote was taken, the entire opposition walked out of the Parliament, with Houston shouting 'You can have your Bill', before the bill was passed at the third reading with only government members present (QPD 1973:vol. 262, p. 74). On top of this, Bjelke-Petersen also announced his intention to maintain and increase the issuing of imperial honours in Queensland even if the Commonwealth decided against this course of action (but he did not mention he would later 'sell' such honours to rich supporters of his party). 


\section{The ombudsman that never was...but then was...}

The Coalition had promised in the 1972 election campaign to appoint an ombudsman for the state with powers of investigation, even though the Premier had given a speech to the Parliament before the election in which he stated: 'The Government remains unconvinced that any ombudsman-type appointment in Queensland could effectively supplement or replace the very efficient liaison between the people and the Government presently provided by the 78 elected Members of this Parliament' (QPD 1971:vol. 257, pp. 1200-1, and recycled in QPD 1974:vol. 264, p. 3607).

During 1973, the opposition accused the government of ignoring this electoral commitment. Labor urged the government to press ahead and implement the scheme. It also believed that the appointment should not be at the whim of the Premier. The Premier informed the House that the government had not overlooked the issue but the matter remained 'under consideration' (QPD 1973:vol. 262, p. 241). In mid-1973, however, the government suddenly announced that the (now) 82 Members of Parliament would each receive a private secretary and an electoral office but these measures would come at the expense of the proposal to create an ombudsman. The Treasurer told members that the private secretary post was to assist electors in an electoral office, although some members wanted the secretary to assist with their parliamentary business. After some heated exchanges, it was agreed that the secretary would be located in the electorate unless other mitigating circumstances were taken into account. Later in the proceedings, Ed Casey (Ind., Mackay) even praised the Works Department for preparing his electoral office efficiently after the government's 'change of heart'.

Members were then informed that there would be no ombudsman established, as they would now be able to undertake such work with their enhanced resources. The government viewed the backbenchers collectively as a squadron of miniombudsmen. In question time and in interviews with the press, however, some Labor members highlighted the deficiencies in this argument. Members of Parliament, they appreciated, had few formal powers or rights of investigation open to them. They could not officially search files or interview officials.

Then, following this about-face, the government had another spectacular change of heart. It announced in March 1974 that it would now go ahead with the ombudsman initiative (but called it the 'Parliamentary Commissioner for Administrative Investigations' to emphasise the position was to be responsible to the Parliament). This time, Bjelke-Petersen supported the bill wholeheartedly and, in introducing the bill at its first reading, claimed the legislation was 'a model of its kind' (QPD 1974:vol. 264, p. 3158). Labor supported the legislation, 
but in the ensuing debate most of the contributions focused on the issue of who had proposed the idea first and who could take most credit for its appearance before the Parliament. It was a case of never stand between a popular idea and a politician seeking credit. Not long afterwards, in 1976, the government introduced an amendment bill to limit the retiring age of the commissioner. By then, the opposition had become somewhat critical of the office, considering that the act 'lacks teeth' (QPD 1976:vol. 270, p. 2743), while the ombudsman's office had few staff and no women investigators. The then opposition leader, Tom Burns, said 'the Premier cannot be forced to lay the [Ombudsman's] report before the parliament. I suggest that we made a mistake when we called him "Parliamentary Commissioner". Maybe we should have called him "Premier's Commissioner"' (QPD 1976:vol. 270, p. 2741).

In areas of administration, the system of public health was mounting as an explosive issue. The sector was dogged by shortages of doctors and nurses, shortages of funding and with hospitals being run-down. There were claims people were being left to die in hospitals, injured babies were being left unattended and wards were being closed in the Royal Brisbane Hospital. Labor alleged that ever since the Coalition had come to government it had allowed the public health system gradually to deteriorate. There were also repeated calls for a public inquiry to investigate the effectiveness of the public health system (QPD 1972:vol. 260, p. 1711). The Minister, Doug Tooth, who was by then seventy years old, came under constant criticism for his ineptness and inability to fix the problems in health. Later in the session, he indicated he was intending to resign from the Parliament at the next election.

\section{With friends like these...}

The Queensland Police Force continued to attract controversy on almost a daily basis. It was faced with increased crime rates, growing juvenile crime and various forms of public unrest from political protests to union street marches and student demonstrations. Other reforming policies directed at the police proved internally contentious and had bred antagonism - such as the attempt to recruit university graduates or the legislation to enable married women to become or remain police officers, which had not gone down well with the male-dominated hierarchy. On this last issue, the Police Minister, Max Hodges, did not proclaim the legislation providing women with enhanced employment opportunities for almost a year after it passed the Assembly. He was perhaps derelict in his duty, too lax or distracted or pressured by the police hierarchy.

A new Police Commissioner, Ray Whitrod, with an interest in reforming the police, had been appointed in 1970. He had come to Queensland from the 
South Australian force and the Australian Security Intelligence Organisation (ASIO) - an issue of some irritation to the parochial Queensland force - and had more recently served as Police Commissioner in Papua New Guinea. Indeed, the Police Minister had personally flown to Port Moresby to assist in the recruitment of Whitrod. Despite holding a master's degree from The Australian National University and being described by his minister as the 'most highly qualified Commissioner the Queensland Police Force has ever had', Whitrod had quickly lost the support of the Police Union. The Parliament was frequently told the 'academic' Whitrod was being undermined by senior police and by the powerful union. Whitrod also tended to speak out publicly about the problems he was encountering - such as when he called his officers 'a bunch of ningnongs'. He also volunteered that criminals in Queensland were probably better educated than his police officers - principally to highlight the latter's lack of educational training. In the early days of Whitrod's tenure, however, both the Premier and the Police Minister were publicly forthcoming in his defence, with Bjelke-Petersen telling the Parliament in March 1973 that he was 'four-square behind the Police Force' and that 'we are very fortunate to have in Queensland the standard of Police Commissioner' we have. Others were less fulsome in their praise, with Bob Moore (Lib., Windsor) ungraciously labelling Whitrod as 'the head-hunter from New Guinea' (QPD 1973:vol. 261, p. 3421).

There were, however, regular and persistent calls from the opposition for Police Minister Hodges to resign. From 1968 to 1974 (with the exception of nine months during 1968-69), responsibility for police was included in the Works and Housing portfolio. Hodges, who had been Police Minister since 1969, was criticised for leaking confidential correspondence, for covering up alleged police brutality (especially against trade unionists) and for losing the confidence of the police rank and file (and especially the powerful Police Union). Press reports claimed that up to 99 per cent of police officers agreed that Hodges should resign - probably because he was associated with the Whitrod appointment and was a firm supporter of the latter's reforming ideas. Hodges would remain minister until he was moved by Bjelke-Petersen in August 1976 (to the portfolio of Tourism and Marine Services). Ministerial responsibility for the police would remain a vexed issue, with a total of eight National Party ministers holding the job between 1976 and 1989. Whitrod would face a torrid time while Commissioner, dealing with his political masters and with the internal politics of the police. In 1976, he resigned his commission early insisting that the level of political interference in the police was too great to withstand.

If Whitrod lacked friends in high places, his successor, Terry Lewis, did not. In one revealing assembly speech on rising youth crime, the former police officer, Don Lane, praised Detective Senior Sergeant Terry Lewis's work at the Juvenile Aid Bureau. Lane reported to the Parliament that Lewis had been promoted to 
inspector and had recently 'travelled the world under a Churchill Fellowship' to study the problem of juvenile delinquency (QPD 1973:vol. 263, p. 1380). With such public recognition from government members, Lewis's star was certainly on the rise.

\section{Increasing claims of partiality against Speaker Lonergan}

Bill Lonergan was never going to have an easy time as Speaker of the Assembly. His brusque manner and penchant for playing politics were inevitably going to land him in trouble. He was also considered to be falling under the Premier's influence and doing his bidding, although the two had not got off to a good start (Bjelke-Petersen 1990:68). Throughout 1973 and 1974, the opposition constantly called his rulings into question, not merely through comments in the Chamber but also via the outside media. Most of these dissentions were because Lonergan would change his rulings to suit the government ${ }^{2}$ and for not protecting opposition members from 'imputations of improper motives and personal reflections' such as when the Premier accused the Opposition Leader of being a coward and selling out Queensland. Keith Wright went further than most when he told the Rockhampton Morning Bulletin that 'the rulings of the chair needed to be seriously investigated', and continued:

It would seem the traditional independence of the speakership is being eroded because of the belligerent attitude of the Premier, who continually pressurises the Speaker into compromising situations... Hansard recorded the vitriolic attacks and personal abuse Government members had launched on the Opposition, yet these attacks were given the 'blind eye' by the Chair. (QPD 1973:vol. 263, p. 2054)

When Lonergan asked Wright to withdraw the remarks and apologise, Wright responded by saying that he stood by his earlier comments but agreed he would withdraw his comments 'only in accordance with your request'. Lonergan considered this a conditional withdrawal and named him for his disrespect. While Gordon Chalk, as leader of the House, stood to move the exclusion, he offered Wright the chance again to unequivocally withdraw and apologise, before the motion was moved. This time, Wright replied: 'Mr Speaker, I withdraw, and I apologise' - to which the Speaker commented: 'Very well. The apology is accepted' (QPD 1973:vol. 263, p. 2054).

2 For example, closing down an Address-in-Reply debate in September 1973 (QPD 1973:vol. 262, p. 482). 
Such incidents, however, merely magnified perceptions of the Speaker's bias. Lonergan at times allowed government members to explain any absence from the House but not opposition members. Jack Houston frequently challenged the Speaker's rulings on what was permissible in debate. Shortly before he was deposed as Opposition Leader, Houston challenged the right of the Speaker to refuse to accept matters of public importance being raised. When Lonergan prevented debate on the state of public health in Queensland, Houston moved a motion of dissent against his ruling from the chair. The motion incited some rowdy exchanges and multiple expressions of dissent from opposition spokespeople for more than an hour. In the slanging match, Houston stated:

Democracy in this House has reached a stage where we are debating whether your opinion was correct, and you are occupying the chair and determining whether I can speak on particular matters. Nowhere else in the world could this type of democracy be found, but it is covered by the Standing Orders. (QPD 1974:vol. 264, p. 3506)

Houston also alleged that Lonergan had tipped off the Health Minister that a matter of public importance about his portfolio was being proposed by the opposition and, that although the matter was not allowed, the 'clairvoyant' minister

on the same morning as the letter was written to you, Mr Speaker, he was able to look into the future, and, knowing that a letter was already in your hands, he rose in the House and delivered a vicious and vile attack on the honourable member for Mourilyan [Peter Moore, the shadow health minister]. There was no opportunity in the House to debate that. (QPD 1974:vol. 264, p. 3507)

Labor also felt that the Premier was giving instructions to Lonergan on what to rule. Labor members, however, were not the only sources of complaint. In September 1974, Russ Hinze was involved in a heated altercation with Lonergan over the Speaker ignoring his attempts to ask questions in question time. Hinze, who was a large man, said he was not 'going to jump up every time' he wanted to ask a question and keep being ignored. He said question time was antiquated and a waste of time, as he found it impossible to get your call when I want to ask questions in this House'. He then alleged that the Premier indicated to Lonergan who should be invited to ask questions, saying to the Speaker 'apparently you've got your favourites'. Lonergan named the Member for South Coast, and on Bjelke-Petersen's motion to suspend him, he was evicted from the Chamber (QPD 1974:vol. 265, p. 486). At the time, there was not much love lost between the Premier and Hinze, who became only the second government member suspended from the Parliament. 
Lonergan resigned as Speaker and from his seat (Flinders) on 28 October 1974. Although he had not been the first choice of the government in 1972, he had shown himself to be a loyal political supporter of the government. The then independent Ed Casey, who later rejoined the ALP, said that many in the Labor Party had severe regrets about voting for Lonergan over Houghton.

\section{Avoiding political oblivion: re-branding the Country Party's image}

The Country Party State President, Bob Sparkes, and State Secretary, Mike Evans, had long advocated a name change for the Country Party-principally to broaden its appeal, especially in urban areas. Initially, the Country Party organisation flirted with the idea of merging with the DLP to appeal to conservative working-class voters and create a 'middle-of-the-road anti-socialist force'. This was a delicate move because many sections of the Country Party were fervently anti-Catholic. The Liberal Party, fearing that this was just another ruse to maintain the electoral dominance of the rural party over the urban party, strongly opposed the merger and indeed had earlier offered a merger between the Country and Liberal Parties, which was rejected by the Country Party. Liberal sitting members also often relied on DLP preferences to win their seats. Despite Evans holding a press conference announcing the merger, nothing much happened. Interestingly, the DLP claimed not to know much about what was going on. Over time, this merger proposal died, largely because the DLP regarded the Country Party's actions as a hostile takeover.

Then, in 1973, a confidential report produced by Sparkes argued that 'as surely as night follows day, if the Country party opts to remain an essentially ruralbased party, it is doomed to political oblivion' (Lunn 1978:138). Re-branding the image rather than shotgun weddings was now the preferred strategy. With previous incarnations of the party having 'national' or 'nationalist' in their titles, and the example of the conservative National Party in New Zealand, the choice for a new name was obvious. Sparkes and Evans persuaded Bjelke-Petersen of the need to go National, but had less success with Country Party divisions at the federal level or in other states. Accordingly, in April 1974, the Country Party in Queensland became the 'National Party of Australia - Queensland', although this was sometimes shortened and advertised as the Queensland Nationals. It was claimed that the name change was 'not just a change of name' but instead 'provides a fresh and new opportunity to prove and demonstrate through political philosophies, policies and actions that the National Party of Australia is truly a national party working in the interests of the entire nation and its people'. The new party was supposedly 'alive with new expanded policies, 
energetic fresh thinking, and a determination to protect the welfare and freedom of all Australians' (Sunday Mail, 7 April 1974). Press advertisements spoke of a new 20-page policy booklet and a recorded song marking the occasion, and a large party in a city hotel was hosted to mark the occasion (see the account of this in Lunn 1978:140-3). It was planned that speeches at the launch of the new party would be made under a portrait of the Queen, but when the state president was about to speak, it 'inauspiciously fell down as Sparkes rose to open the proceedings' (Lunn 1978:140).

\section{The sordid conspiracies to discard Senator Gair}

The Whitlam government's attempt to lure Senator Vince Gair out of the Senate to create an additional vacancy in the 1974 elections (that would presumably have advantaged Labor) involved at least three interrelated conspiracies. First, there was the scheming by Whitlam and Lionel Murphy to create an additional senate vacancy in 1974 by offering Gair the Ambassadorship to Ireland and the Holy See. Second, was the conspiracy to get Gair drunk in Canberra so that he did not formally tender his resignation to the President before the Queensland Government acted. Third, was the counter-conspiracy by Premier BjelkePetersen (knowing Gair was about to resign and create a vacancy) to force the Governor, Sir Colin Hannah, to issue the writs early for the five seats that were due so as not to include the Gair resignation - thereby avoiding the Queensland electors deciding who would fill the vacancy.

By 1974, Senator Gair was a forlorn figure in Canberra with his career going nowhere. He had been ousted from the leadership of the DLP the previous year and faced almost certain political defeat at the end of his senate term in 1977. Angry and full of resentment towards his DLP colleagues, Gair indicated to Whitlam that he would consider accepting a diplomatic posting. If Gair should resign before the 1974 half-senate election, this would mean that six senate spots would need to be filled, giving the Labor government an excellent opportunity to secure three of them (capturing back a DLP seat) and possibly gain control of the upper house. Labor stood the chance of winning 31 of the 60 seats in the upper house, giving the government the numbers in the Senate necessary to prevent the Coalition obstructing its legislative agenda. Whitlam seized on the opportunity, putting to one side his own antipathy to one of his most bitter political enemies, and began the process of appointing Gair as Australia's Ambassador to Ireland. Whitlam handled the arrangements personally and in the utmost secrecy. The press gallery got wind of the appointment, however, on 1 April after a leak to a reporter from the Melbourne Sun, and Whitlam's devious plan began to go awry. 
On learning of Whitlam's somewhat unorthodox scheme to secure a third senate seat in Queensland, Bjelke-Petersen immediately bristled and set about attempting to abort the plan by any means at his disposal. The Premier remained unrelenting in his personal hatred of Whitlam and, with his departmental and legal advisers, hatched a remarkable counter-conspiracy to thwart the government's intentions. Time was of the essence. Bjelke-Petersen calculated that if Gair had not officially tendered his resignation to the Parliament then the Queensland government could legally issue the writs for the election before he did so, meaning that Gair's resignation would create a casual senate vacancy to be filled by the Queensland government until the next House of Representatives election. Bjelke-Petersen's plan involved two key tasks: first, to prevent Gair from officially tendering his resignation until the writs were issued, and second, to expedite the issuing of the writs. Both tasks had to be carried out in complete secrecy to maintain the element of surprise and prevent Whitlam from learning of his tactical counter-manoeuvres. For the Premier's scheme to work, the writs had to be signed and issued the day before Senator Gair tendered his formal resignation.

Gair was by this time a very heavy drinker, so a strategy to keep him from resigning his senate seat before the writs were issued was not hard to conceive. Bjelke-Petersen contacted the Country Party's Senate Whip, Ron Maunsell (who was a long-time friend of Gair), and told him to keep Gair occupied. To do so, Maunsell invited Gair to a beer and prawn evening in his parliamentary office in Canberra. In what was to become known as 'the Night of the Long Prawns', Gair was plied with free beer and Queensland crustaceans until the early hours of the next morning. As Maunsell learnt during the course of the evening's festivities, Gair was still yet to officially tender his resignation and, as he had voted in a senate division during the evening, he could not be considered to have formally resigned from the Senate. Importantly, this enabled the Queensland government to show Gair was still an active senator after it had issued the writs for the halfsenate election. Bjelke-Petersen's rum plan to stall Gair's resignation had worked to a tee (see Stevenson 2007).

While the beer and prawns did their work in Canberra, Bjelke-Petersen had been working furiously in his Brisbane office to have the writs for the next election signed. Throughout the afternoon, Bjelke-Petersen signed the various documents needed to have the writs issued, which were later rushed to Government House for signing by Governor Hannah, who must have been complicit in the conspiracy. The Governor's approval was conveyed to the government printer where the writs were announced by extraordinary Government Gazette. Having completed both tasks, Bjelke-Petersen had out-manoeuvred the Prime Minister and stifled federal Labor's plan to pick up a third senate seat in Queensland at the forthcoming election. With hindsight, it is clear that one act of political 
opportunism was countered by other acts of political cunning - to deny a senate majority. In Queensland, Bjelke-Petersen's supporters felt that he had pulled off an astute political masterstroke.

\section{Dumping the pilot and all aboard with a new opposition leader}

Labor had endured a tumultuous time in opposition but its parliamentary leadership showed remarkable stability after 1958. Just two leaders had held the post in 16 years: Jack Duggan and Jack Houston. After years of dedicated if uninspiring service, Jack Houston was eventually ousted as opposition leader in July 1974, after seven years and nine months in the job. Houston had soldiered on, losing two elections in a row, and after Tom Burns had entered the Chamber, he was thought to be fast approaching his 'last supper'. Towards the end of his time as leader, he had perhaps lost his enthusiasm and interest in the role. For instance, he went to New Zealand to judge a dog show in October 1972 when parliament was sitting, then in 1973 it was reported that he would be appointed to the Qantas board and would relinquish the leadership (but this did not occur, as Jack Egerton was appointed instead). In 1973, the influential newsletter Inside Canberra appeared, claiming Houston was going to be appointed as High Commissioner to New Zealand to make way for Burns to lead the party. Very much acting in character, however, the dour and determined Houston seemed to be intending to fight one more election campaign in 1974 or 1975, touring the state in readiness. Such was not to be. He was defeated six months out from the state election in a coup orchestrated by his deputy, Percy Tucker, along with the help of Kev Hooper and Fred Newton, who combined the numbers to depose him.

Houston's demise followed an almost Machiavellian script of deceit to the letter. First, in March 1974, the parliamentary Labor Caucus unanimously carried a vote of confidence in his leadership (moved duplicitously by Tucker). Then, in June, it was reported from Labor sources that Houston was unlikely to face a challenge and would have a third attempt at becoming premier in 1975. One month later came the swift execution. At a hastily convened Caucus meeting, Tucker organised a vote of no confidence in Houston after the state executive of the ALP had asked him to resign voluntarily (which he refused to do) over the poor showing of Labor at the May federal election. As Houston later admitted, he was 'not a numbers man and didn't do any lobbying' (Courier-Mail, 2 July 1974). At the Caucus meeting, Houston lost by 17 votes to 15; then Tucker 
was elected by the same vote. Fred Newton beat Burns for the deputy leader's position by 23 to nine. It was a slap in the face for Burns (who at the time was labelled a 'new leftie'!).

When Houston was deposed as leader, he continued to sit in the Parliament for another six years until his retirement in $1980 .{ }^{3}$ Houston was widely regarded (even by government members) as a 'nice bloke' and a 'nice chap', but also as someone who was not aggressive enough or sufficiently cunning to win the premiership.

With Tucker at the helm, Labor now had a new leader to sell and not long to sell him. He had developed a reputation as an aggressive parliamentary performer and 'fiery debater' but was relatively unknown to the wider public. He was fifty-four years of age, had a craggy almost funereal face and wore his Brylcreemed hair in a slicked-back style - and unfortunately had a quick temper and questionable judgment.

\section{Labor's failed gambit: 'Go out on the hustings, Joh, and I'Il slaughter you'}

As early as August 1973 and throughout much of 1974, there was a crescendo of press speculation about the government going to the polls early. Journalists were fed titbits of information from the government concerning its intentions of capitalising on its standing in the polls and renewing its mandate. Journalist Hugh Lunn in The Australian (6 September 1974, p. 9) claimed an early election was likely to 'beat an expected large increase in inflation and unemployment early next year'. He reported that Gordon Chalk was supposedly behind the early poll push, designed 'to cash in on the present unpopularity of the Federal ALP in Queensland'. Cabinet was, however, far from unanimous in support of the proposal. In early October, the National Party's 33-man Management Committee voted overwhelming against an early poll, but resolved to leave the final decision to Bjelke-Petersen. Unlike Chalk (who also felt a large pro-government swing would advantage the Liberals in seat gains over the Nationals), Bjelke-Petersen was more circumspect. Press reports talked of a row occurring about the poll date, with the Premier ruling out an early poll. On a number of occasions, he stated definitively that there would be no early election. There were also rumours many ministers were tiring of the responsibilities of office and wanted to call it a day. ${ }^{4}$

3 Beginning a tradition of former Labor leaders remaining in the Chamber, followed by Burns, Casey, Wright (but only for three months), Warburton and eventually Goss.

4 Labor had been calling the ministry 'the reluctant government'. According to Hugh Lunn, 'so many of the State's ageing Cabinet have been angling for political sinecures that the Opposition is fast labelling it the 
The government could not believe its luck, however, when, in an otherwise unremarkable supply debate, the hapless Percy Tucker challenged BjelkePetersen to go to an early election ostensibly on the issue of rising unemployment. His goading of the Premier came about on 8 October 1974 when Tucker was speculating on the leadership rivalry between Chalk and the Premier. According to Tucker, the government was afraid to go to the people and Bjelke-Petersen was prevaricating because he wanted Chalk to announce his retirement from politics (which he had indicated he would do if the government went to the polls in May 1975). Tucker believed Bjelke-Petersen wanted the Treasury portfolio himself, so had put out the line that 'he had decided against an early election because in the present circumstances an early election would be irresponsible'. When Bob Moore (Lib., Windsor) interjected with the taunt 'You're frightened of an election', Tucker then committed an act of impetuous naivety from which there would be no return. He responded to the interjection with:

I am not concerned. If the Government wishes to hold it tomorrow, it is all right with the Opposition. Let us fight it on the issue on which I am now speaking. My challenge to the Government is both responsible and serious. There is no doubt that, electorally, my party will win more seats at an election next May than at an election next month-I realise that - but the ALP will win whether the Government brings it on now or next May...If an election is needed to create jobs in this State, then let us have an election - and let us have it right now! Whatever it takes, this State must go back to work. (QPD 1974:vol. 266, pp. 1115-16)

He had thrown down the gauntlet. Media commentary was astounded that the Opposition Leader would make such an explicit challenge. An editorial in the Courier-Mail (10 October 1974) described Tucker's challenge as poor judgment, saying: 'It is amazing that the State Opposition Leader...has challenged the Government to an election on unemployment.'

A few days later the press announced the 'Premier rejects Tucker poll tip' (Courier-Mail, 14 October 1974). The paper reported that Tucker was expecting an election announcement the next day or in the next few days, claiming BjelkePetersen had capitulated to Chalk's wishes for an early election (not all Liberals were keen on an early poll: Bill Knox was opposed, as was Colin Lamont from the Young Liberals, a preselected candidate for 1974). From his Kingaroy property, the Premier was quoted as saying he had no intention of naming a date for the election any time soon. On 22 October, however, the Coalition held a two-hour

\footnotetext{
"reluctant Government". So many of the 14-man cabinet wanted to get the cocktail circuit job of Queensland Agent-General in London, that Cabinet last month had to have a secret ballot to decide which minister would get the post' (The Australian, 6 September 1974). Four ministers had expressed interest but the Minister for Lands and Forestry, Wally Rae, won the ballot, and when he next appeared in the Chamber he was greeted with opposition catcalls of 'Arise, Sir Wal!' from Kev Hooper (QPD 1974:vol. 265, p. 697).
} 
emergency meeting called by the Premier to discuss the election. Clearly the temptation was too good to ignore. So, after almost daily speculation that the poll was about to be called, the Premier finally announced, on 23 October, that the election would be held on 7 December and that he was tipping a 'smashing win'. It was a calculated decision to bring forward the election by five months, made some 14 days after Tucker's blunder. Chalk told reporters, however, that he had not been informed by the Premier of the final decision and had 'heard this morning from a member of the news media that November 4 was going to be the date for launching' the government's campaign (Courier-Mail, 25 October 1974). Already in the Parliament, the Member for Callide, Lindsay Hartwig, had volunteered that if he were premier he would accept the Opposition Leader's challenge to hold an early election, predicting that, because so many in the community had changed their minds in recent months, 'in an early election half the Opposition members would disappear from this Chamber' and adding that many will be 'missing in the new Parliament' (QPD 1974:vol. 266, p. 1352).

The Parliament continued to sit for another seven days after the Premier had announced an election would be called. On 23 October, a famous incident arose when Bjelke-Petersen moved to suspend Standing Orders to prevent a matter of public interest being moved by the opposition. The Premier had just finished an emotive 'broadside' spray against 'Labor's socialist policies' and against 'the ever-increasing threat of restrictive socialist domination'. The election, he maintained, had to be called so 'we will consolidate the forces against socialism in this State and throughout the nation' (QPD 1974:vol. 266, pp. 1533-4). Tucker protested vehemently over the attempt to prevent him from speaking and launched an attack on the government. He kept insisting 'I want to be able to be heard', 'I have the right to be heard', adding to the Premier: 'You haven't got any guts. You made your own statement and you won't let me speak. You are a gutless Premier.' He then added 'democracy is dead in this Chamber'. He was so incensed he refused to leave the Chamber when he was asked to withdraw by the Speaker. When Bjelke-Petersen moved to suspend him, he let fly: 'you brought this on by your filthy tactics... You haven't the guts to take the medicine I was about to give you.' He also claimed 'I would have given him a bucket today'. When the Premier's motion to suspend Tucker was passed 39 to 28 votes, Tucker blurted out: 'Go out on the hustings, Joh, and I'll slaughter you!' Tucker's bravado has subsequently passed into political folklore as one of the most foolhardy statements in Australian politics. Within a week, the fortieth Parliament was dissolved and an election called. 


\section{A spectacular landslide for Joh and a wipe-out for Labor}

A total of 255 candidates contested the 1974 election (some 24 less than in 1972). Beginning Labor's election campaign in mid-November, Tucker came out fighting, saying he wanted to win 'like mad', adding 'I'll go like hell to win, I hate defeat' (Courier-Mail, 16 November 1974). He also stated that 'if the Premier plays it rough, I'll be prepared to box on with him' (Courier-Mail, 24 October 1974). Although starting late, his election campaign was described as the 'most extensive Queensland election campaign by a State Labor leader'. The ALP chartered a plane - similar to the one used by Bjelke-Petersen, except that the ALP plane had the campaign slogan 'LET'S GO' emblazoned on its side. Tucker, who held one of Labor's most marginal seats in Queensland (he had won Townsville West by a few hundred votes in 1972), had problems in his own backyard. His chances of retaining his seat were reduced when he was challenged by two Country Party candidates, Alderman Max Hooper (the Townsville Mayor) and B. Newell (a local businessman), one Liberal candidate, K. Rundle, and Dr K. Dorney from the DLP. The Country Party's 'how-to-vote' card gave its supporters a split ticket with one version endorsing Hooper and the other Newell, but both promoted a tight exchange of preferences. Elsewhere, Col Bennett, the former Labor frontbencher who had been dis-endorsed in 1972 (and lost his seat), announced his intention to run for the seat of Kurilpa as a National Party candidate!

In an unusual move, Russ Hinze, the outspoken member for South Coast, was appointed to the ministry the day after the election date was announced. He replaced Henry McKechnie, who had become too ill to remain Minister for Local Government and Electricity. Although not one of Joh's favourites (and feeling himself overlooked), Hinze was effectively made minister on the eve of the caretaker period (the writs had not yet been issued and, as mentioned, the Parliament sat for another week). His appointment signalled he was likely to be retained within the ministry after the election was over. He told journalists at the time that his appointment would 'curb his tongue' and improve his parliamentary behaviour. He had recently been suspended for provoking the Speaker, when he reputedly spent the rest of the day drinking in the bar before chasing a young woman (not a staff member) round Parliament House in his underwear!

The Liberals' campaign stressed its economic management credentials, especially with the threat of unemployment rising in the future. They favoured going early to capitalise on their own popularity and the anti-Labor sentiment in the electorate. Chalk gave much prominence to the leadership contest between himself and Bjelke-Petersen and declared his intention to be premier after the 
election. He stated: 'whether Mr Bjelke-Petersen or I am elected Premier, the principal thing is that we must take certain action now so that we are leading the government when the crisis arrives' (Courier-Mail, 23 September 1974). He also gave his opinion that if the Liberals dominated the Coalition after the election, '[m]y colleague Mr Bjelke-Petersen will accept the position' (Sunday Sun, 27 October 1974). The Courier-Mail (28 October 1974) kicked the story along the next day with the headline 'Premier Chalk? No chance-Joh', quoting the incumbent as saying 'I'm Premier now and I'm going to be Premier after the election'.

The Nationals' campaign again stressed the government's record of state development, warning that further economic prosperity was, in the Premier's own words, jeopardised by 'the alien and stagnating, centralist, socialist, communist-inspired policies of the federal Labor government' (The Australian, 24 October 1974; see also AJPH 1975:vol. 21, no. 1, p. 74). The Premier conducted this crusade against socialism and communism by casting 'himself in the role of leader and saviour of Queensland' (The Australian, 24 October 1974; AJPH 1975:vol. 21, no. 1, p. 74). The Premier also briefed journalists that his next government would likely contain an additional two ministers, possibly looking after energy, the environment or urban and regional planning.

The electoral result was a landslide to the Coalition. The National Party won 39 seats (a net gain of 13, up from 26); the Liberals won 30 seats (up nine from its previous total of 21); and two independents were returned (Aikens and Casey). The Coalition now held 84.2 per cent of the seats in the Assembly. In the new Parliament, seats rather than total votes counted for everything and on election night at the tally room, Chalk finally realised that he would never become premier in his own right. The primary vote for the Nationals was 27.88 per cent - a swing towards it of almost 8 per cent. The Liberals managed a higher vote, with 31.09 per cent - an increase of 9 per cent. Bjelke-Petersen polled a massive 83.4 per cent of the primary vote in his seat of Barambah against his ill-fated Labor challenger.

In the new Parliament, 17 new Nationals would take their seats for the first time, many of whom would become major actors in the next 15 years. They included: Ivan Gibbs (Albert), Martin Tenni (Barron River), Vince Lester (Belyando), Eric Deeral (Cook), Tony Elliott (Cunningham), Gordon Simpson (Cooroora), Bill Glasson (Gregory), Bob Katter (Kennedy), Lionel (Lin) Powell (Isis), Albert Hales (Ipswich West), Angelo Bertoni (Mount Isa), Victoria Kippin (Mourilyan), John Goleby (Redlands), John Warner (Toowoomba South), Max Hooper (Townsville West), Neil Turner (Warrego) and Bill Lamond (Wynnum). Significantly, Eric Deeral, who narrowly won Cook by 344 votes (3459 to 3115), was the first and, thus far, only Aboriginal member of the Queensland Parliament. He would hold his seat for just one term (1974-77). 
A further 10 new Liberals joined the Parliament-namely: John Greenwood (Ashgrove), Dennis Young (Baroona), David Byrne (Belmont), Harold Lowes (Brisbane), Brian Lindsay (Everton), Rob Akers (Pine Rivers), Rosemary Kyburz (Salisbury), Colin Lamont (South Brisbane), Terry Gygar (Stafford) and John Lockwood (Toowoomba North). Unsurprisingly, many of these new members would be 'oncers' - five Liberals (Byrne, Lamont, Lindsay, Lowes and Young) and three Nationals (Deeral, Hales and Lamond).

In contrast, Labor slumped to just 36.03 per cent-its lowest primary result since 1909, excluding the debacle of the 1957 split. It had suffered a 10 per cent swing against it. In the House, Labor managed to hold just 11 seats, and was reduced to the so-called 'cricket team'. It was not the outcome Tucker had in mind when he adopted the slogan 'LET'S GO'. To add to the ignominy, Tucker lost his seat to Max Hooper (NP) and his deputy, Fred Newton, also lost his seat, to David Byrne (Lib.). Some years later, Geoff Smith (ALP, Townsville West) recalled Tucker's defeat:

In the 1974 election, Mr Tucker was opposed by a representative from the Liberal Party, two National Party candidates, one of whom was $\mathrm{Mr}$ Max Hooper, and Dr Dorney from the DLP. It will probably surprise many newer members of the Parliament that in that election Mr Hooper polled only 1652 primary votes from the total of 12428 valid votes cast. That 1600 votes represented, as a primary vote, only 13 per cent and may well be a record for the minimum percentage of votes cast to have a member elected to a seat in this house. Nevertheless, Mr Hooper, after attracting the second preference votes of the DLP and subsequently the second preference votes of his co-candidate Mr Newell, was able to pull slightly in front of the Liberal Party candidate and attract his second preference votes to finish up with a total vote of a few hundred over Mr Tucker. That was how, for the first time and after 15 years, the seat was lost by the Australian Labor Party and became for a short period a Government seat. (QPD 1981:vol. 283, p. 220)

Eventually, Hooper beat Tucker by 886 votes (6657 to 5771). In total, Labor had lost 22 seats. Those ALP sitting members who had contested their seats in 1974 but who were swept out included: Jack Aiken, Ted Baldwin, Jim Blake, Ray Bousen, Fred Bromley, Bill D'Arcy, Brian Davis, Ted Harris, Roy Harvey, Gerry Jones, Violet Jordan, Ken Leese, Peter Moore, Fred Newton, Percy Tucker, Bill Wood and Peter Wood. Labor lost other seats it had held where sitting members had chosen not to re-stand (for example, Doug Sherrington, Pat Hanlon, Alex Inch, Hughie O'Donnell and Edwin Wallis-Smith).

Labor's surviving 'cricket team' consisted of Tom Burns, Harold Dean, Martin Hanson, Kev Hooper, Jack Houston, Gene (Lou) Jensen, Ray Jones, Jack Melloy, 
Evan Marginson, Keith Wright and Les Yewdale. After its tiny Caucus met in early 1975, they nominated Tom Burns as Opposition Leader, with Jack Melloy as his deputy, Evan Marginson as whip and Kev Hooper as secretary. They had few options open to them and no stomach for a tussle over the posts after such a mauling.

Vi Jordan had lost her seat after eight and a half years, but two new women entered the Parliament: Vicky Kippin and Rosemary Kyburz - the former was only the second Country-National woman to sit in the Chamber while Kyburz was the first Liberal woman ever to do so. Kyburz would marry another member (Rob Akers) and become the first woman to fall pregnant and have a child while sitting as a member. Kippin would serve for two terms, while Kyburz and her husband would both survive three terms in marginal seats. Into the realm of Trivial Pursuit, there were now three Hoopers in the Parliament: one for every party. Keith Hooper was a Liberal minister, Max Hooper had just won Townsville West for the Nationals, while Kev Hooper carried the flag for the Labor Party.

\section{Bjelke-Petersen's fourth ministry}

The original ministry operating from 23 December remained at 14, but after the passing of the Officials in Parliament Act 1975 in March the ministry was expanded by four to 18. Four ministers had left the Parliament at the previous election (Alan Fletcher, Henry McKechnie, Doug Tooth and Wally Rae, who had become Agent-General). ${ }^{5}$ They were immediately replaced by Russ Hinze (who had joined the ministry, replacing Rae just before the election), Tom Newbury, Ken Tomkins and Llew Edwards. Three months later, however, the additional four ministers were sworn in: Val Bird and Claude Wharton from the Nationals, and Norman Lee and Bill Lickiss from the Liberals. The final ministerial line-up was complete. It consisted of

- Premier: Johannes Bjelke-Petersen, NP

- Deputy Premier and Treasurer: Gordon Chalk, Lib.

- Minister for Mines and Energy: Ronald Camm, NP

- Minister for Justice and Attorney-General: William Knox, Lib.

- Minister for Community, Welfare Services and Sport: John Herbert, Lib.

- Minister for Industrial Development, Labour Relations and Consumer Affairs: Fred Campbell, Lib.

5 It was alleged later in the Parliament by Kevin Hooper that when Wally Rae was appointed Agent-General he 'took a lot of [parliament] furniture with him' (QPD 1980:vol. 282, p. 51). Rae was also involved in an international 'witch-hunt' to obtain information in Switzerland on the notorious 'Loans Affair', which had already brought down the Whitlam government. 
The Ayes Have It: The history of the Queensland Parliament, 1957-1989

- Minister for Primary Industries: Vic Sullivan, NP

- Minister for Police and Leader of the House: Max Hodges, NP

- Minister for Water Resources: Neville Hewitt, NP

- Minister for Transport: Keith Hooper, Lib.

- Minister for Local Government and Main Roads: Russ Hinze, NP

- Minister for Tourism and Marine Services: Tom Newbery, NP

- Minister for Lands, Forestry, National Parks and Wildlife: Ken Tomkins, NP

- Minister for Health: Dr Llew Edwards, Lib.

- Minister for Education and Cultural Activities: Val Bird, NP

- Minister for Works and Housing: Norman Lee, Lib.

- Minister for Aboriginal and Islanders Advancement and Fisheries: Claude Wharton, NP

- Minister for Survey, Valuation, Urban and Regional Affairs: Bill Lickiss, Lib.

The Nationals enjoyed 10 cabinet posts to the Liberals' eight. A new portfolio of Deputy Premier was formerly established for Chalk and coupled with the Treasury portfolio. Ron Camm and Bill Knox were deputy leaders in their respective parties. The forty-first Parliament first met on 25 February 1975; it was to be a momentous year.

\section{Bjelke-Petersen's pre-emptive strike and the demise of Whitlam}

In mid-1975, Bjelke-Petersen was infamously involved in a second major political controversy concerning the replacement of a senator from Queensland. In June 1975, one of Labor's Queensland senators, Bert Milliner, died suddenly, requiring a senate vacancy to be filled by the State Parliament. Under longstanding parliamentary practice, it was conventional that when a senator's seat became vacant before the expiration of their term of service, a replacement would be chosen from the same political party by the relevant state parliament. Reflecting the deep animosity of the times, this convention was twice deliberately broken in 1975. The first breach occurred when Senator Lionel Murphy from New South Wales resigned from the Senate to take up a position on the High Court, after which the Liberal NSW Premier, Tom Lewis, broke with convention and appointed an independent senator in Murphy's place (the Albury Mayor, Cleaver Bunton). In Queensland, after Milliner's death, the Labor Party announced that Dr Mal Colston, a teacher, would take up the vacancy in the Senate. Not one to abide by bipartisan convention when political advantage was a stake, BjelkePetersen was determined to frustrate and weaken the Whitlam government 
at every possible opportunity. He initially insisted that he would not accept Labor's sole nomination (it was not clear on what authority other than he believed he could control the numbers in the Assembly, and that Labor had earlier asked for a similar choice over Senator Bonner's appointment). Instead, he demanded that the Labor Party put up a list of three candidates from which the State Parliament would decide. The Premier communicated this demand to the Opposition Leader on 17 July. He probably chose to do this to create mischief among the Labor factions and personalities, indicating to them who 'called the tune' and insisting that he would decide which Labor person went to Canberra not the opposition (or he calculated all along that Labor would not produce three names, so he would have a less encumbered choice; see Lunn 1984:216). Labor refused to pander to Bjelke-Petersen's demand, so initially when the Parliament debated the issue (on 27 August) the government refused to allow it to appoint a senator to fill the vacancy brought about by Milliner's death; it defeated Labor's motion by 15 in favour to 63 against. Only three Liberals voted with Labor-Bill Kaus, Bill Hewitt and Colin Lamontas did the independent Ed Casey. Voting to break the convention were all the Nationals and the remaining Liberals, including: Mike Ahern, Rob Akers, Joh Bjelke-Petersen, David Byrne, Gordon Chalk, Geoff Chinchen, Llew Edwards, John Greenwood, Terry Gygar, John Herbert, Russ Hinze, Bill Knox, Rosemary Kyburz, Norman Lee, Bill Lickiss, Colin Miller, Bob Moore, Charles Porter, Norman Scott-Young and Bruce Small, as well as the Speaker, Jim Houghton, and the independent Tom Aikens (NQP). Interestingly, many of the small-l Liberals who put themselves forward as reformers were nevertheless prepared to use the Parliament for partisan advantage.

The second vote occurred in the Parliament on 3 September 1975. Behind the scenes, the Premier and his closest advisers (including Allen Callaghan) had been looking for any disgruntled Labor-oriented identities who opposed Whitlam but who might agree to have their names put forward. It was rumoured that they had found up to four - among them were Pat Field, a sixty-four-yearold French polisher who was the President of the Federated Furnishing Trades Union and a card-carrying member of the Labor Party, and Ted Harris, the former ALP Member for Wynnum (1966-74) who had allowed his membership to lapse. The Premier apparently had in his possession Field's ALP membership card (no. 830), which had been renewed on 26 March 1975, so took the opportunity to nominate Field against Colston. Bjelke-Petersen also knew that Field was a religious conservative who was hostile to the Whitlam government and prepared to help the Coalition's obstructionist strategy in the Senate. He knew that Field had long aspired to hold a seat in the Parliament and calculated that despite being a previous member of the party (he was immediately expelled for agreeing to stand), he would assist the federal Coalition bring down the Whitlam government and force an early election. 
In the second debate, the government split but managed to elect Field to the Senate. The Premier's insistence to install Field caused considerable dissention within the ranks of the Liberal Party, as many strongly believed that the conventions governing political conduct should be upheld over the interests of short-term political gain. The Deputy Premier, Sir Gordon Chalk, spoke out against BjelkePetersen's nomination of the Labor renegade, but said the decision for each member was a conscience vote. The Minister for Industrial Development, Fred Campbell, also spoke out against the move, as did two Liberal backbenchers (Colin Lamont and Rosemary Kyburz). In the process, three Liberals - John Greenwood, Colin Miller and Norman Scott-Young-spoke in support of the Premier's nomination. At the conclusion of the debate, the vote for Tom Burns' nomination of Mal Colston was lost 26 in favour to 53 against. The vote for Field was carried by 50 votes to 26 . In total, 14 Liberals sided with Labor to oppose Field, including five ministers - Chalk, Campbell, Edwards, Hooper and Leeand nine backbenchers: Akers, Gygar, Hewitt, Kaus, Kyburz, Lamont, Lindsay, Lockwood and Dennis Young. Interestingly, four Liberals (Byrne, Herbert, Knox and Lickiss) abstained. A number of National Party members also wanted to vote against Field's nomination, but were deterred with the threat of losing party endorsement.

On securing the Senate vacancy, Pat Field immediately left no doubt about his political crusade, stating publicly that 'Mr Whitlam will never get a vote from me' (Kelly 1976:253). Crucially, the loss of a Labor senator (Milliner) and the appointment of Field gave the federal opposition the numbers needed to block the government's budget legislation, which would lead to the dismissal of Whitlam. The dismissal of Labor federally led to an incident of terrorism against the Queensland Premier, when a clumsily made letter bomb was sent to the Premier on 19 November, injuring two staff members.

Field was sworn in as a senator on 9 September 1975, amid a mass walkout by the Labor senators. He cut a forlorn figure in Canberra and apparently walked into the swing doors of the Senate chamber. Simultaneously, the Labor government questioned his eligibility to sit, claiming that he was still a member of the Queensland Public Service at the time of his nomination and, therefore, ineligible to hold public office. After being issued with a High Court writ challenging his right to hold a senate seat, he was granted a month's leave of absence from the Commonwealth Parliament. Although he was still entitled to vote, his absence meant little to the balance of power in the Senate as the opposition still held a majority of one over Labor. Yet, the Coalition parties again broke with parliamentary convention and refused to 'pair' a senator (abstain from voting) to maintain the relative positions of the government and opposition. The Whitlam government had been critically weakened in the upper house. With the opposition determined to bring down the government through withholding 
supply, there was nothing Whitlam could do to prevent the opposition using its numbers in the Senate to paralyse the government. While Senator Field served for only 90 days as a senator, asked one question and had largely brought ridicule on himself through his evident lack of knowledge of political matters or basic parliamentary procedures, his time in the Senate had served its purpose.

After Whitlam had gone, Bjelke-Petersen continued to run his own vendetta against former Labor ministers. He commissioned a secret financial investigation into the origins of the funds behind the Loans Affair, at one point dispatching a US financial adviser, Wiley Fancher, to Switzerland to investigate the paper trail. There was much speculation back in Queensland about how much these further investigations were costing, with press reports suggesting the Premier had spent $\$ 250000$, while he tried to downplay the amount, claiming it was more like \$10 500. Queensland's Agent-General in London, Wally Rae, was also sent to assist the cause. Labor described this as a 'sordid spy drama' and a 'putrid exercise by a man who has become possessed by his own hatreds and bigotries' (QPD 1976:vol. 270, p. 3030).

After the demise of the Whitlam government, the local business community held a celebration 'Thank you Joh' dinner at the Lennon's Plaza Hotel in April 1976. The dinner was sold out, with 550 admirers attending at $\$ 18$ a head and a further 160 on the waiting list who had paid so needed to be reimbursed when they missed out. The Liberals largely boycotted the dinner as they felt the testimonial should have been a joint one involving Chalk as well.

\section{Conclusion}

By the end of 1975, Bjelke-Petersen had made the National Party's position in government unassailable. In the process he had decimated the parliamentary opposition to the point where they were almost non-viable as an alternative government. He had also become the doyen of the conservative forces throughout Australia, an acknowledged strategist and leader of the 'anti-Canberra right' among state premiers. He had gained widespread notoriety as a tough politician who could fight boots and all, for his determination to win political fights and for his unorthodox ways of doing business. As one Labor frontbencher candidly admitted: 'if ever I saw a person changed by the need to survive, it is the Premier' (Doug Sherrington, in QPD 1974:vol. 265, p. 304). The Premier was also not one to draw fine distinctions between his personal and political interests or between his private business interests and public responsibilities.

Bjelke-Petersen was also beginning to command the Parliament. He had shaken off his nervous start, when the opposition was calling him '19 per cent Joh', referring to his party's vote at the 1972 election. He was, unlike Nicklin, 
depriving the opposition of oxygen. He was closing down debates, using the gag to push legislation through or bring forward votes. He was suspending Standing Orders when the opposition was attempting to move matters of public importance. And when he got wind that the opposition was planning to censure him, he would prevent them and bring on his own motions without noticeas he did in 1973 to advocate a 'no vote' in the national 'prices and incomes' referenda, which was not at all a state matter but one the Premier felt passionate about defeating. He kept repeating the tactic of firing off an unannounced ministerial statement but then denying the opposition from launching its own debate on a matter of public concern - as he did against Percy Tucker at the outset of the 1974 election. More tellingly, he was calling the opposition disloyal and 'traitors to Queensland'.

During this period, Bjelke-Petersen never really did comprehend how an effective legislature ought to operate - with inclusion, with resources and with some legitimacy attached to the opposition as the scrutineers of government (if not quite the alternative government in waiting). When commenting on the $\$ 1.2$ million budget for the Legislative Assembly, the Premier spoke about the 'marked improvements in the conditions under which Parliament functions' but indicated exactly what he meant in his next sentence when he said: 'the airconditioning of the Chamber has resulted in greater physical comfort for all concerned' (QPD 1973:vol. 263, p. 2074). Although the government eventually granted MPs greater assistance, which was long overdue, it came initially at the cost of jettisoning the proposal to establish a state ombudsman, which was later rectified in 1974. Bjelke-Petersen began to issue proposed bills to the media before he presented them to the opposition and on some occasions even started debates before the opposition had seen the written bill. Labor was convinced the Premier just did not get it. And even when, after some sustained pressure from his own side to establish parliamentary committees, Bjelke-Petersen eventually agreed to allow a committee to investigate violent crimes, it was permitted to include only government members, not members of the opposition. As the dissident Liberal John Murray said in December 1973:

I say unequivocally and very sincerely that I believe that no Parliament in the Australasian area is as inadequately served in basic, fundamental services vital to efficient functioning and preservation as the Queensland Parliament. I also believe that no other Parliament sets out so deliberately to prevent Her Majesty's Opposition from carrying out its time-honoured constitutional role. Further, I believe that no other Parliament attempts to operate with such a wide gulf between Cabinet and private members, and that no Cabinet acts in such a tight, corporate preserve, with such a well-drilled technique of 'divide and conquer' in dealing with Government members. As well, I doubt whether there has 
ever before been a Government that has promised to do so much by way of parliamentary reform and has done so little. (QPD 1973:vol. 263, p. 2553)

Before he quit his job as Opposition Leader, Jack Houston was more succinct. He simply said: 'Honourable members opposite talk about the operation of democracy. They make a mockery of democracy' (QPD 1973:vol. 263, p. 2107). 



\section{All power corrupts, $1976-1980$}

With Whitlam now gone-replaced by the Fraser Coalition government in Canberra-the Bjelke-Petersen government could ostensibly look forward to better relations with the Federal Government. Yet although relations had improved, they remained frosty rather than poisonous. The Premier never warmed to the new Prime Minister and within a few years was accused of having 'traded Gough Whitlam for Malcolm Fraser' in the demonisation stakes in order to appear the strongman of local politics. Federal spending was also being trimmed and the ample largesse of yesteryear that states enjoyed was no more. The economic recession of the mid-1970s was steadily worsening, with increasing unemployment and cutbacks to federal funding making the situation on the ground worse. Parochialism remained an appealing reaction.

Queensland's own budgetary situation was deteriorating. As a belt-tightening measure, the Premier was so moved in April 1976 that he cancelled his monthly promotional television program (the 'Joh Show') to save taxpayers \$127000 per annum. The opposition had been calling this program a 'widespread abuse and extravagant spending of public moneys for party political purposes' or a political adventure that was merely delivering propaganda (QPD 1977:vol. 272, p. 2339). At the same time, the Premier began running government advertisements in newspapers extolling the virtues of his government under the headline 'The Premier reports', with much of the copy sounding suspiciously like Allen Callaghan's polished words. Over the next few years, however, he also continued spending on 'Joh films' paid for by allocations in the Premier's Department budget ('miscellaneous expenses'), which chronicled his public engagements and was intended to produce special films that would promote the 'life story and achievements of the Premier' (QPD 1980:vol. 282, p. 390). Such filming was always intended for public release and was often planted with regional television stations (including one in which Callaghan pretended to interview the Premier even though he was his media officer).

In April 1976, the Parliament established a privileges committee to both protect members from the public and discipline members who abused privilege. The six-man committee included three Nationals (the party Whip, Mike Ahern, Lin Powell and John Warner), two Liberals (Bill Hewitt and Charles Porter) and Jack Houston from the ALP. The new committee could have had immediate business as two National ministers, Russ Hinze and Neville Hewitt, proceeded to have an enormous row in mid-April over the provisions of the Noise Abatement Bill-first in the joint-party meeting and then continuing on in the Assembly. The 'shouting match' erupted over the restrictions on lawnmowing times on 
weekdays and weekends and over what 'excessive noise' in fact meant. The initial bill proposed that householders who mowed before 7am on weekdays and 9am on weekends would face a $\$ 200$ fine; it also stipulated that any 'excessive noise' from a vehicle, appliance, piece of equipment or a musical instrument audible to other residents would be in breach of the law! Instead of referring the ministerial dispute to the privileges committee, however, the joint-party meeting deferred the matter to the August session to allow for further consideration.

\section{Sculpting a legacy: the 'tax crusade' and the passing away of death duties}

Premier Joh Bjelke-Petersen had for some years sought to reduce or abolish taxes to cement his image as a right-wing 'small government' reformer. In early 1976, he chose to champion the abolition of a very visible tax — death dutiesmuch to his own Treasurer's chagrin. When a leak of the Premier's crusading intention appeared on the front page of the Courier-Mail, Gordon Chalk was mystified. He told the Parliament in answer to an opposition question asked by Tom Burns: 'I think I would be misleading the House if I did not say that I was astounded at what I read on the front page of "The Courier-Mail" this morning. I had no knowledge of it...This article has caused me considerable concern' (QPD 1976:vol. 270, p. 2689). The issue of tax relief split the Coalition, with the Nationals favouring the complete abolition of death duties and payroll tax, while the Liberals favoured only their reduction over time. At the April Premiers' Conference, the Queensland Premier raised the issue with his interstate colleagues, who did not publicly oppose his plan. When asked by the new Member for Cunningham, Tony Elliott, whether the abolition of death duties was a fait accompli, the Premier responded:

My first concern is for Queenslanders and all who live in our State; what other States do is their affair. I have been disturbed for a long time by the effects of probate and succession duty on a very wide section of the community. Death duties were originally a wealth tax but they are now hitting people in all walks of life and can no longer be called a wealth tax in anyone's language...Doubtless, the abolition of death duties would generate a lot of interest in our State. A lot of assets and very much business will ultimately be brought to Queensland when this suggestion is taken up by Cabinet and the party and implemented. (QPD 1976:vol. 270, p. 2771)

Bjelke-Petersen then successfully ambushed the Treasurer, Chalk, at a cabinet meeting in June 1976 at which he proposed to abolish death duties in the forthcoming budget before proceeding to call immediately for cabinet approval. 
Bjelke-Petersen's proposal was purely verbal; he brought no written submission to the table nor had he circulated any formal documentation before the meeting. There were no projected costings or estimates setting out the impact on state revenues. Chalk lost against a united wall of National Party ministers. At a joint-party room meeting the next day, only three members opposed the move to abolish death duties (Chalk along with David Byrne and Brian Lindsay; see Hazlehurst 1987:291).

While Chalk and the Treasury conducted a rearguard action to try to limit the proposal or to phase it in over a number of years (probably so it would not be entirely phased out), they estimated the abolition of the tax would cost Queensland about $\$ 30$ million in lost revenue. They had not, however, counted on the demonstration effects of the measure. Thousands of elderly Australians began moving (or moving addresses) to the Gold Coast to evade death duties. In the short term, this provided a much needed boost to the economy; but in the longer term it imposed considerable additional costs on the state government as it had to grapple with providing services to a burgeoning ageing population.

Bjelke-Petersen was gradually exerting his dominance over his cabinet. With some astuteness, he was also sculpting the legacy for which he wished to be remembered. His impetuous gambit to abolish death duties made him the darling of the Gold Coast both among property developers (the 'white-shoe brigade') and retirees, who gradually returned the compliment by continuing to vote solidly for the Coalition (and mostly the National Party) for decades to come. There was some evidence that DLP supporters had transferred their loyalty to the Nationals - a point admitted by the DLP's state president when he announced the party was being 'mothballed' in April 1976.

Basking in the glory of his recent political successes, Bjelke-Petersen was not afraid of using rant and hyperbole to attack the policies of his Labor opponents. In one debate on a matter of public interest called in early 1976, he complained vehemently:

It is not very often that I rise to participate in this debate...I want to draw to the attention of this House and of the general public something that is about to happen in this State and in this nation. Throughout history, man has had to cope with many disasters. Firstly, there was the Biblical flood and later the eruption of Vesuvius and the destruction of Pompeii, the sinking of the 'Titanic', and so on. As from Friday another monumental disaster can be added to the list, one that will affect every household in Queensland and in Australia-Medibank. (QPD 1976:vol. 271, p. 754) 
Apparently, the Premier was able to deliver such an allegorical bluster with a straight face; he was ever the 'Lord's Premier' (Wear 2002).

\section{Preserving Aboriginal relics}

In March 1976, the Minister for Aboriginal and Islanders Advancement, Claude Wharton, introduced a bill to amend the Aboriginal Relics Preservation Act of 1967, claiming the state had been the first to introduce such legislation. The new amendments were designed to clarify the meaning of relics and prevent any misinterpretation, as well as allow the minister to delegate some of his powers to inspectors (such as over tourists visiting historical sites). The bill provided an opportunity for Eric Deeral, the National Party Member for Cook and the only Indigenous member of the Assembly, to comment on the government's heritage policies. Deeral considered that the government was belatedly moving to ensure the protection of relics in danger of being destroyed or lost. He said:

It is important that we preserve them, and I am happy to say that the Queensland Government has done that. I am sure that the Government today, while looking at the situation in Aurukun or any other place involving Aboriginal people, will look at these things and not lose sight of the need to preserve an almost lost culture. (QPD 1976:vol. 270, p. 2619)

Labor members, who did not oppose the legislation, were particularly critical of the government's failure to protect heritage sites. They criticised the poor implementation of such heritage legislation by the government and the reluctance to impose fines for any desecration. Ray Jones (ALP, Cairns) argued that ' $[\mathrm{t}]$ his parliament should be concerned about strengthening the administration, the policing, the caretaking and the inspection of sites...in many cases the damage has been done and it is too late to reconstruct items of so delicate a nature' (QPD 1976:vol. 270, p. 2613).

At the time, however, Labor was more concerned about the dismissal of Works Department employees who had been sacked as part of a major downsizing exercise.

Deeral had given his maiden speech in March 1975, claiming his family ancestors had lived in Cook for 20000 years. He called for greater development of the 'top end' and the construction of all-weather roads for his electorate so that more industry could be established. He complained about the lack of job opportunities, saying that 'no man can continually accept hand-outs without losing his initiative and self-respect'. He continued: 
I am the first Aboriginal member of this House and, I think, the first Aboriginal member of any State Parliament. Because of this there are a number of things I want to make clear. The first is that my forebears were both Aborigines and Islanders, and that I am home in both English and Kokoyiminir, my native tongue, but I am first an Australian from Queensland...I am not here to press for the advantage of any particular group, but to represent honestly and fight for the advancement of my electorate and for the people who live there. I am also a member of this Government, and I am a member of it because I believe in its policies and in the future it promises for the State...Queensland has been described as a racist State; it has been referred to as the Deep North, and legislation for Aborigines and Islanders has publicly been criticised as repressive. Every opportunity has been taken to criticise the Government and the people of Queensland by many in the South who should know better. I state quite clearly that I will be prepared to discuss the attitudes of those people when the States in which they live have Aboriginal parliamentary representation. (QPD 1975:vol. 267, pp. 370-1)

He finished his speech criticising the 'old hand-out philosophy of past generations', saying it had destroyed much of the initiative of his own people.

\section{Sir Gordon Chalk walks - leading to a contentious reshuffle}

One of the perennial mainstays of the Coalition government, Sir Gordon Chalk, resigned in August 1976. He had been contemplating retiring for some timeeven before the 1974 election-but had stayed on because of the early election. By early 1975, he had decided he would retire well before the next election, due in 1977. Many believed Chalk was the colossus behind the Coalition government: a man of integrity, hard work and resolve, who had a strong sense of purpose and a level head and who administered the state's finances with an eye always to the main chance. He had represented the people of Lockyer in the Parliament continuously for just more than 26 years, and had been in the ministry constantly since August 1957, when the Coalition came to office. He had been a minister for 19 years and one day-first as Minister for Transport (1957-65), then as Treasurer (1965-76), with one week sandwiched as Premier in 1968. He became the fifth-longest serving cabinet minister in the state's history and had earned a reputation for his prodigious work ethic. He had also been leader of the Liberal parliamentary party for a little more than one decade 
and had taken the Liberals from 20 to 30 seats in the Parliament and its primary vote from 25.9 to 31.1 per cent (although in 1969 and 1972 the support for the party had gone slightly backwards).

Towards the end of his career, he had become embittered and disillusioned with Bjelke-Petersen. He had tried to disassociate himself from the Premier's strident, almost pathological hatred of Whitlam and had kept open lines of communication between the Queensland Treasury and Commonwealth ministers and their senior officials. He had not approved of the cynical tactics to break convention and appoint any Tom, Dick or Harry to senate vacancies that happened to be politically expedient at the time. As Deputy Premier, he tried to block BjelkePetersen mounting a state investigation into the Loans Affair conducted by sleuthing journalists in Europe who were raking for further damaging material to smear Whitlam and his former ministers. And, most recently, he had also counselled Bjelke-Petersen against abolishing death duties in 1976. On almost all these points of contention, Chalk had lost or come out on the losing side. He had had enough!

With Chalk's departure, so too went the only rival to the Premier in the cabinet. There were some potentially able ministers in cabinet-for example, Russ Hinze and Llew Edwards - but they were then relatively junior in standing. The other senior ministers were mostly of ordinary ability together with a few time-servers, with perhaps the exception of Bill Knox (who had by then been in the Parliament for 19 years). With the Liberal leadership thrown open, most parliamentary Liberals assumed that the position of party leader (and the Deputy Premier's job) would go to Knox, then forty-six, and would be an uncontested appointment. On the morning of the party-room meeting, however, a surprise challenge from Dr Arthur Crawford precipitated a party-room vote, which Knox won easily. Crawford then challenged for the deputy leader's position against Fred Campbell and John Herbert (the latter had earlier stood against Knox for the deputy's post in 1971). Crawford was eliminated in the first ballot, before Campbell narrowly defeated Herbert for the deputy leadership post. Interestingly, Knox said at his first press conference as leader that he wished to see the full amalgamation of the two Coalition parties and would prioritise this as a major target of his term as leader; in his own words, he said he wanted a 'working coalition not a confrontation coalition'. At the time of his ascension, he was spoken of in the media as 'a man of sweet reason' who would leave the government 'much more free of friction at the top' (Courier-Mail, 6 August 1976). While Knox claimed he had a special 'rapport' with the Premier, the opposition mischievously suggested his elevation had 'suddenly accelerated the hold the National party had on the Liberal party' (Courier-Mail, 7 August 1976).

The Treasury portfolio was regarded as a major prize - and it was well known that the Nationals had wanted to claim this key portfolio for themselves (indeed 
the Premier had discussed such a possibility with his colleagues and been ribbed over it by the opposition in the Parliament). Although Knox, as Deputy Premier, could select his own portfolio and had indicated he wished to become Treasurer on 6 August, the Premier had second thoughts and delayed the announcement (after discussing the arrangements with Robert Sparkes and Mike Evans). The new cabinet was supposed to be announced before Monday 9 August but was delayed a further day. The Treasury post and the selection of the portfolio for the new Liberal minister (John Greenwood, Ashgrove) were given as the reasons for the delay. The new Liberal leader prevailed, however, and Knox became the third Liberal Treasurer in a row-and the second to combine Treasury with the Deputy Premier's job (he was also given Racing and responsibility for the State Government Insurance Office). Knox immediately attacked the first federal budget of the incoming Fraser government, not over revenue transfers to Queensland (as they increased by more than $\$ 100$ million) but over the lack of action in relation to unemployment. In the resulting mini-reshuffle of BjelkePetersen's fourth ministry in August 1976, Keith Hooper became Transport Minister, Bill Lickiss was transferred to the Justice and Attorney-General portfolio and the new entrant to cabinet, John Greenwood, was appointed as Minister for Survey, Valuation and Urban and Regional Affairs. The average age of the new ministry was fifty-five years, and one-third of the cabinet was at least sixty years of age.

The big loser in the reshuffle was Max Hodges, who was stripped of his Police portfolio and given the job of Minister for Tourism and Marine Services; he also resigned as Leader of the House. Hodges (and the Police Commissioner, Ray Whitrod) had both given support to a proposed inquiry to investigate allegations of police brutality at student demonstrations held in July 1976 (inviting two Scotland Yard detectives to investigate allegations), but had been defeated by the Premier in a 'dogfight' in cabinet the week before. ${ }^{1}$ In cabinet, Hodges had backed the Police Commissioner's decision to investigate, while Bjelke-Petersen chose to impose his authority, arguing that it was the students who were in the wrong not the police. After Hodges issued a press statement regretting the decision not to go ahead with a full inquiry, and claiming that a cloud remained over the police force, his tenure came under considerable pressure. It was widely speculated that he would lose the portfolio. His replacement as the new Police Minister (and Leader of the House) was Tom Newbery, who said he had 'many friends in the force' and promised to 'get some harmony back into the police (Courier-Mail, 11 August 76). In making the swap, the Premier denied he had sacked the minister due to union pressure, but admitted that 'this is an

1 The opposition charged that cabinet's decision to overturn the Police Commissioner's inquiry was illegal and sought legal advice to sustain this point. The opposition believed 'the Premier's action constituted a dangerous deviation from well-established principles that put the special office of Police Commissioner above party political pressure' (Sunday Mail, 8 August 1976). 
opportunity to give a change of drivers' (Courier-Mail, 11 August 1976). The Premier then clarified that Police Commissioner Whitrod was not in danger of being sacked or being asked to resign. He told journalists that 'he did not regard the Commissioner's newsletter of August 8th as an implied criticism of the Premier's decision not to have an inquiry into police action during a student's march on July 29' (Courier-Mail, 12 August 1976). The simmering issue of police unrest, however, and the independence of the Commissioner would soon erupt in a most spectacular manner.

\section{Cedar Bay and the departure of Commissioner Whitrod}

Tensions within the police force had been brewing for some years - initially over the campaign to weed out police corruption. The issue suddenly exploded after the police launched a brutal drug raid on a 'hippie commune' based in Cedar Bay (north of Mossman). The police were being increasingly impaled on the horns of an awkward dilemma. On the one hand, Commissioner Whitrod (and the former Minister of Police, Hodges) had been attempting to reform the police force internally, making it more managerial, performance oriented and better educated. On the other hand, the government wanted to use the police as a political tool to satisfy the government's political agendas. A merit-rating system for inspectors and commissioned officers was openly criticised by senior police (and by its anti-reform union) for being secretive, open to manipulation or 'payback' and for damaging morale. The scheme was intended to feed into the promotion system so that officers would be promoted on ability - a contentious concept in a force long structured on seniority. The Commissioner had to quell disquiet at meetings of senior police officers, where he promised to provide reasons to any senior officer who was 'bypassed' for promotion (a notion conceivable only if the principle of seniority prevailed).

After the Queensland Premier ordered the police to get tough on soft drugs and rid the state of marijuana, the police abruptly raided in a 'paramilitary' fashion a small alternative community living in Cedar Bay on 29 August 1976 ostensibly to arrest drug offenders. After the military-like action, the police were criticised for storm-trooper tactics in rounding up a bunch of harmless hippies and destroying their commune by burning their shacks to the ground. They had attacked the peaceful commune with armed police, aircraft and helicopters and a navy patrol boat expecting to find a huge haul of drugs. The Premier and the new Police Minister, Tom Newbery, denied that they had authorised the raid. The police found only small quantities of cannabis grown for personal use. Two residents were arrested for personal drug use (and sent to Cooktown) and a 
further 10 were fined - two for possessing cannabis but the other eight simply for vagrancy (that is, having no fixed abode or money). It soon transpired that the Cooktown court did not have the legal authority to impose jail terms or issue fines. The offenders were momentarily released and then rearrested under a court order legally issued from Cairns. Because of the widely perceived overreaction by police, an inquiry into the incident was proposed and accepted in principle by the Commissioner. The Premier, however, largely at the behest of the police unions, immediately overruled Whitrod. This led to conjecture as to who was really in command of the police: the Commissioner or the powerful police union. As the Courier-Mail (2 September 1976) editorialised, 'the union now seems to sit back and loftily tell the State Government which of the Commissioner's decisions are acceptable and which are not'. Due to public pressure, however, an internal inquiry was conducted by a senior police officer and some police officers involved in the raid were charged over the wilful destruction of property, but none was convicted and the report of the inquiry was never publicly released. The Premier further incensed the Commission by appointing Inspector Terry Lewis his Assistant Commissioner in 1976, leading immediately to Whitrod's resignation.

Despite capturing enormous media attention, Cedar Bay did not arouse much debate in the Assembly other than the occasional question. The Speaker, Jim Houghton, told members that the Parliament could not debate the issues arising from the Cedar Bay raid because matters were before the courts and therefore sub judice. He mentioned on three separate occasions that he had received a letter from solicitors acting for a client seeking damages from the ABC's This Day Tonight program. Labor members similarly did not wish to be seen as unsupportive of the government's tough line or too closely associated with drug-users. Later, the opposition accused Bjelke-Petersen of using the Cedar Bay raid to assert his law and order credentials in a desperate attempt to win the forthcoming by-election in Chalk's former seat of Lockyer. If the Parliament felt constrained to debate the issue, this did not prevent the Premier from releasing regular press releases justifying the government's actions and continuing to criticise the commune residents as drug-peddlers.

\section{Three by-elections triggered in 1976}

Three by-elections were occasioned in 1976. They eventually produced a return to the status quo but added enormously to the dissention among the Coalition ranks. As the year began, Martin Hanson (ALP, Port Curtis, the son-in-law of the former Premier Ned Hanlon) resigned from the Assembly in February and died the next day; he was just fifty-two years of age and had served in the Parliament for 13 years. In March, sixty-one-year-old John Murray-one of the Liberal 
'ginger men' who had also served 13 years in the Parliament — called it a day and resigned his seat of Clayfield. He was not always popular among his colleagues (as he had initially been a joint-endorsed candidate for the federal seat of Herbert who then swapped to the Liberals, where he emerged as a leading figure in the 'ginger group'); and when he resigned no-one formally acknowledged his departure. His colleague Geoff Chinchen said later:

I was extremely disappointed - and I am sure that many other honourable members were also - when Mr John Murray, the former member for Clayfield, left this Chamber last Wednesday without one leader saying 'We hope that you will enjoy your retirement'... when John Murray left not a word was said. (QPD 1976:vol. 270, p. 2859)

As already mentioned, Gordon Chalk resigned later in the year at the age of sixty-three.

The two initial by-elections for the seats of Port Curtis (Gladstone) and Clayfield were held on 29 May 1976. Although Labor's Bill Prest won the Central Queensland seat, he experienced a major reversal of fortune. Labor took the seat on the primary vote with 51.75 per cent (against the Nationals on 23.9 and the Liberals on 12.8 per cent). Prest, however, suffered a significant swing away from him of 11.34 per cent, making a combined swing of more than 30 per cent against Labor in the past two elections! The result was hardly an endorsement of Labor's new leadership or of its much-hoped-for regeneration; and in November 1976, Jack Houston was returned to the deputy leader's position (beating Keith Wright), replacing Jack Melloy, who, at sixty-eight years of age, stood down and was not contesting the 1977 election.

In blue-ribbon Clayfield, the Liberals' candidate, Ivan Brown, was challenged by the Nationals' increasingly high-profile secretary, Mike Evans (as well by a Labor candidate). From the outset, it was evident that this was going to be a major stoush between the Coalition parties. The showy Evans ran a glitzy 'American-style' campaign 'aimed at the Liberal Party rather than the ALP' and focusing on the abolition of death taxes. His pitch was to urge electors to vote 'for the one candidate in Clayfield pledged to abolish Death Tax this year' (see Arklay 2000:69-70). The outcome of the election on primary votes was the Liberal Party with 34.4 per cent to the Nationals on 28.1 per cent, with Labor recording 37.5 per cent. With Evans dropping out and a tight preference flow, the Liberals won the seat with a two-party preferred vote of 60.6 per cent to 39.4 per cent. Brown, however, held the seat for less than one year; he died as a sitting member on 12 May 1977, never having faced a general election. There was no by-election for his seat after he died as his seat was abolished in the 1977 redistribution. 
The by-election for the seat of Lockyer took place on 16 October 1976-just two months after Chalk had resigned (see Cribb 1980:27-46). Seven candidates stood for election. Again, both Coalition parties ran candidates. The Liberals stood Tony Bourke (another local chemist who was presented in party literature as the 'son of Chalk' — not the stick of chalk), while the Nationals ran Neville Adermann (the son of Sir Charles Adermann, the former federal Minister for Primary Industry and deputy leader of the Federal Country Party, who had been a mentor to Bjelke-Petersen). Labor, without much hope of winning, also nominated a candidate (S. F. Thomson). The Nationals claimed the seat should be their own, as it was a 'rock solid National party seat', while the Liberals spent big to try to hold the seat, admitting it was both an expensive and difficult fight. Labor finished a poor third, with 23 per cent of the vote to the Liberals on 40.6 per cent, with the Nationals finishing second on 30 per cent. After preferences were distributed, the Liberals held the seat comfortably by 66.2 per cent to 33.8 per cent. The Nationals were, however, breathing down their necks. Bourke would hold the seat for only one-and-a-half parliamentary terms before being beaten by Tony FitzGerald from the National Party in 1980.

\section{Resolution 210: a unilateral declaration of war}

During the Lockyer by-election campaign, the Liberal Party held its annual convention at Toowoomba in early October 1976. The new party leader, Bill Knox, was a key speaker anxious to preach the gospel of conciliation and restore calm. The ultra-Liberals, however - consisting of far more strident local branch delegates - moved Resolution 210, which was ultimately passed by the party's decision-making body. The resolution greatly widened the ambit for three-cornered contests and formally transferred the initiative for mounting such challenges to local branches. The resolution said, in part, that the state executive of the party would call nominations for any seat in the Parliament not currently held by the Liberal Party, providing that

- the local area executive requested it

- the local organisation or branches had the ability to mount a campaign

- there was a reasonable likelihood the local bodies would be able to fund such a campaign

- there was a reasonable prospect of being able to receive nominations from a good local candidate (see Cribb 1980:33).

This was a formal declaration of war against the Nationals. The Liberal rank and file was threatening to mount campaigns against sitting National members wherever the local branch Liberals could conceivably mount a credible campaign. Knox, like Chalk before him, was an ardent coalitionist, who spoke 
against the resolution to much booing and jeering from the delegates (Cribb 1980). He had already angered the ultra-Liberals in the party with his statement out of the blue that he was keen to see the complete amalgamation of the two parties. In a very public slap in the face to the new leader, Resolution 210 was passed and Knox suffered a humiliating defeat in his first battle as leader.

He would soon lose his second battle, which would eventually cost him his leadership of the party after a little more than two years in the job (but he later served a second term as leader in the 1980s after the breakdown of the Coalition). Installed as the new Liberal leader, Knox unilaterally announced that under his leadership the Liberals would not contest any National-held seats at the 1977 election (then amounting to some 39 in total). He was not, however, able to impose his authority successfully over the party rebels and local Liberal branches ran candidates in 11 National-claimed seats in 1977. In Knox's brief time at the helm, he was unable to carry his party with him.

\section{Projects, projects and projects}

As the forty-first Parliament settled down to regular business, it dealt with many amendment acts relating to infrastructure and attempted to combine multiple pieces of legislation into consolidated acts. For instance, in relation to electricity supply, the Electricity Bill of 1976 consolidated five acts and provided for the establishment of the huge power station at Gladstone (due to come into operation in 1982). While both sides of the Parliament welcomed the investment in new infrastructure, the issue of subsidies to rural consumers and higher charges for city users was criticised, with Houston claiming rural subsidies should come out of consolidated revenue rather than be passed on in higher prices for city people. Electricity supplies would soon emerge as a major political battlefield for the government, after blackouts and the union's campaign for a 35-hour week. The Parliament also moved to establish the Port of Brisbane Authority in 1976 to provide for a well-developed and self-funding port facility. Not all was plain sailing, however, in funding infrastructure. The Minister for Main Roads, Russ Hinze, informed the House that the government would be forced to seek finance for the Gateway Bridge over the Brisbane River, adding that it was nearly impossible to get the people in Canberra to understand Queensland's road requirements'. Hinze had been complaining of insufficient federal funding for transport projects, whereas his federal counterpart felt he was 'playing politics'. It was reported that the federal Transport Minister, Peter Nixon, had declared in exasperation that 'I sometimes think that Mr Hinze's mouth is bigger than his body' (QPD 1976:vol. 271, p. 502). Hinze replied in good measure that the only difference between Nixon and the former Whitlam ministers was that 'Peter Nixon smiles when he calls me nasty names' (QPD 1976:vol. 271, p. 502). 


\section{Economic expansion and Treasurer Knox's three budgets}

Despite recessionary economic conditions sweeping much of south-eastern Australia, the Queensland economy remained buoyant, especially because of the mining and tourism booms. The growing pains of rapid development, however, increasingly began to impose themselves on the annual state budget, on government services and the necessary provision of basic infrastructure.

In bringing down his first budget in September 1976 (the second of the Parliament), Knox paid tribute to the economic stewardship of Sir Gordon Chalk, saying he regarded the 'ten years during which Sir Gordon occupied the portfolio of Treasurer as ten years of very thoughtful and competent management of State finances'. He added that the state's finances were 'in a very healthy position even if problems currently facing the nation as a whole give us some cause for concern' (QPD 1976:vol. 271, p. 778). His first budget confirmed the abolition of succession and gift duties; it did not raise the level of any other state taxes; it promised to maintain services (but not to increase them in any 'significant degree'); it increased funding slightly to non-governmental organisations; and it cut capital spending heavily particularly where funding for projects was predominantly provided by the federal government. The 1976/77 budget projected a small operating deficit of $\$ 565000$ out of a total budget expenditure of $\$ 1,597$ million.

Knox's second budget was handed down on 22 September 1977. He was conscious of the looming state election, but also of the threats of high inflation, high unemployment and rising wages. He promised no increases in taxes, charges, fares or freights and gave commitments to further reduce payroll tax. He noted that a zero overall growth policy on public service numbers would be maintained and that any new staff positions would have to be met from transfers of abolished positions elsewhere. He made a modest allocation of $\$ 50$ million to assist job creation (going to such items as new police stations, government housing for railway staff, septic tanks for schools, road repairs and irrigation works). According to the Treasurer, the $\$ 1.806$ million budget was a prudent document and 'a consolidatory budget' that would 'ensure that the high standards developed over [the] years are maintained and consolidated' (QPD 1977:vol. 273, p. 879). He projected a small surplus. Meanwhile, the opposition accused Knox of 'self-delusion' and of committing 'economic deception and inconsistency', claiming the budget pretended economic projections were favourable when in fact they were worsening by the day. Tom Burns thought that the government had a hidden draft plan to increase taxes after the next election (QPD 1977:vol. 273, pp. 902-3). 
Knox's third and final budget was brought down on 21 September 1978, a few weeks before he was ousted as leader. With the economy still fragile, Knox told the Parliament that, from a total budget of $\$ 1,920$ million, in excess of $\$ 127$ million had been diverted from consolidated revenue to supplement the state's capital program - going mainly on schools, hospitals, railways and urban transport (QPD 1978:vol. 275, p. 1880). The 1978/79 budget committed a special capital allocation of $\$ 30$ million, with anticipations that it would generate 5000 new jobs. Knox said the budget would provide some scope to improve services across a wide range of government responsibilities (public hospitals, police numbers, funding for children's homes, non-government schools, community kindergartens, school travel schemes, teacher bursaries, remote area scholarships, free milk for schools, meals on wheels and assistance to the good neighbour scheme). He again promised no increases in taxes or charges while declaring the budget 'confers benefits where they are warranted and restraints where they are practicable' (QPD 1978:vol. 275, p. 1890). Labor again attacked the budget (after complaining about the government's move to restrict budget reply speeches to 30 minutes), arguing that unemployment was unacceptably high and that the cost of living was outstripping wage rises. The opposition laid most blame for this on the federal Coalition government but accused the state government of winding back the special capital works program - and thus reducing the creation of jobs. In his response to the budget, however, fellow Liberal Don Lane applauded Knox for producing a 'creditable effort in the present economic performance' (QPD 1978:vol. 276, p. 2173).

In one of the 'crucial reforms' of the period, the Bjelke-Petersen government introduced the Financial Administration and Audit Bill 1977 (with the first reading originally occurring in 1976 while the second reading took place in March 1977). This bill, which was ahead of its time, replaced the antiquated financial legislation first adopted in 1874 (Hielscher 1979). The draft bill had been widely circulated and praised at a special seminar of more than 400 accountants and auditors. It provided greater accountability between budgetary estimates, financial management and auditing and strengthened the powers of the AuditorGeneral. The legislation applied to the consolidated public sector (departments, statutory authorities and other accounts held by various commissions and boards). It also adopted the 'financial officer' model whereby senior executives (directors-general or chief financial officers) were legally accountable for financial propriety for all funds under their control. While the Premier was able to state that the bill had been thoroughly researched before it was presented to the House (and perhaps was implying that other bills were not so well researched!), Hewitt described the bill as a 'trail-blazer in Australian politics' because 'no other State at present is prepared to introduce a consolidated Bill dealing with both financial administration and audit procedures' (QPD 1977:vol. 272, pp. 2337, 2343). Not everyone on the government side was, however, so effusive. Dr 
Norman Scott-Young objected strongly to certain amendments (relating to the expenses of parliamentarians) because he felt that such provisions transferred financial control of members' financial affairs from the Parliament to the Premier's Department.

As Treasurer, Knox was also prepared to consider revising the budget format. He mentioned that Queensland could look at moving away from a 'line item' budgeting format to a planning, programming budgeting framework with performance information included. He told the Parliament that 'my feeling is that a programme budget, with a breakdown of expenditure under item or subjective headings, has much to commend it' and proposed to 'ask my Treasury officers to examine the possibility of this new form with a view to more effective work in the financial administration of the State's finances' (QPD 1977:vol. 272 , p. 2351). It would be more than a decade, however, before the budget was organised and authorised in any program format, consisting of 10 functional policy areas (Ford 1990; Smerdon and Bradley 1992).

Far less progressive in intent was the introduction of legislation (under the Traffic Act) effectively banning street marches. The Traffic Act was amended in September 1977 with the intention of eliminating demonstrations or protest marches on streets and thoroughfares. Organisers of demonstrations not allowed a permit to march were able to appeal only to the Police Commissioner (and not to a local magistrate). The government argued the legislation was designed to protect the rights of people who wished to travel on the roads so that they could go about their business in an unfettered way. The government claimedwith some hint of duplicity - that the amendments to the Traffic Act were not introduced to prevent people from demonstrating. The government claimed:

Nothing in the amending Act is intended to take away the right of people, no matter how small their number, from congregating or gathering to express dissent on any issue whatsoever... [providing they had a permit to do so, of course, from the District Superintendent of Traffic], but the community looks to the Government to ensure that in expressing such dissent nothing should occur to affect the rights of other people to travel on the streets. (Record of Legislative Acts 1977, p. 11)

The traffic amendments were rushed through the Parliament in one day, after Standing Orders were suspended to allow for the three readings of the bill to be heard in sequence.

The street marches legislation arguably had the opposite effect to that intended. It became a cause celebre and an incentive to demonstrate against such restrictions on civil liberties. Students and unionists, in particular, were keen to take to the streets protesting about the police state and increasingly repressive 
nature of the government's policies. The marches ban became the subject of not only dissent, but ridicule. The cartoonist Patrick Cook penned a famous cartoon depicting three people in every Australian state. Cook suggested three New South Welshpeople were 'a queue', three Victorians 'a consortium', three South Australians were 'a modern marriage', three West Australians were 'a departing delegation', three Tasmanians were all 'related' and three Queenslanders were 'illegal' (Australian Financial Review, 27 April 1978).

\section{The 1977 election: rising dissention amid the scent of victory}

Because the government had gone to the polls early in 1974 to maximise its electoral chances, there was speculation that Bjelke-Petersen would again call an early poll, perhaps by May 1977 (some eight months ahead of schedule). The Courier-Mail (3 September 1976) ventured not so presciently 'the general election campaign might be the Premier's last. He is tipped to retire during the next term.' Predicting the Premier's pending retirement date was fast becoming a perennial media fascination. Bjelke-Petersen was at the time actively engaged in touring the state opening trade fairs, holding country cabinet meetings, visiting local towns and 'farmfest' events and even 'opening' weirs by naming them after his senor ministers. He spent far less time in the Parliament - which sat for just 38 days in 1977-leading Tom Burns to assert that Queensland had been governed by the 'tyranny of the Cabinet'. Burns was incensed because he felt that '[f]or the past six months the Gang of Eighteen sitting on the benches opposite have made all the decisions, and made them in secret...The Gang of Eighteen have made all the decisions on matters that demanded an expression and a vote in this Parliament' (QPD 1978:vol. 274, p. 3).

Despite (or perhaps because of) their huge electoral success in 1974, there had been an increased festering of tension between the Coalition partners during the preceding Parliament. Despite Knox's intentions when he first became leader, this escalated when the Liberal Party controversially announced it would go head-to-head with the National Party in selected electoral contests. Slowly, the goodwill that had been built up by Nicklin, Hiley and Chalk was eroded by a new generation of more strident Liberals - and Bjelke-Petersen was not deterred from fighting back.

The 1977 election was complicated for the Coalition because of a contentious electoral redistribution of metropolitan seats that significantly affected four Liberal-held seats (namely, Baroona, Belmont, Clayfield and Brisbane), effectively eliminating the first three of them. The redistribution resulted in the merging of a series of inner-city electorates and the creation of an equivalent number 
of new seats largely on the expanding urban fringes but now open to National Party challenges. The Nationals took the opportunity not only to mount challenges in these urban fringe areas, but to retaliate against the Liberals by declaring that 'sitting members' (who supposedly were not to be challenged by joint-party agreement) were recognised only if they were standing again for the same seat that also bore the same name as previously. In other words, some Liberal members sitting in the Assembly were not regarded as 'sitting members' because their seats had been redrawn and had undergone a change of name. Some Liberals also found it necessary to jump seats. For example, Bill Hewitt was forced to switch from his seat of Chatsworth to the neighbouring one of Greenslopes (following the majority of his electors, who had been incorporated into the eastern inner-city seat). The sitting Liberal member and Minister for Transport, Keith Hooper, chose to retire in August 1977 rather than recontest the seat, but the Nationals were then able to argue Hewitt was not a sitting member in his original seat so were able to contest the seat.

When the election was held on 12 November, there were 24 three-cornered contests; sitting Coalition members in the previous Parliament held 14 of these seats. Nine sitting Nationals were challenged by Liberals and two further National-claimed seats also faced a Liberal challenger. In retaliation, the Nationals instigated three-cornered contests in three Liberal-held seats (Greenslopes, Mount Gravatt and Wavell). Local decisions to run three-cornered contests meant that preferences now became more important in this election than they had been previously. While preferences were counted in 23 seats in total, they changed the end result in only two seats - Southport and Surfers Paradise - where in both cases National Party candidates finished ahead on the primary vote but were defeated by Liberal challengers on ALP preferences. In Surfers Paradise, the sitting National Party member, Bruce Small, was defeated by Bruce Bishop, while in the new seat of Southport Peter White beat the National candidate. In both cases, these Liberals survived only one term in the Parliament.

According to Vaughan (1980:247), the 1977 state election had a 'significant impact' on all three parties in Queensland. He argued that 'in a sense, all three major parties were losers in 1977'. The ALP's support increased slightly with only a small number of its voting 'defectors' returning back to the party. The party's vote of 42.83 per cent was up from 36.03 per cent in 1974 but was also its lowest result - apart from 1974-since 1960. It won 12 additional seats so that it now held 23 seats in the new Assembly, but only took back its traditional territory. The Nationals lost four seats (down to 35) and the Liberals lost six (down to 24). The most notable feature of the election was that for the first time since 1941 the National Party outpolled the Liberal Party by 27.15 per cent 
to 25.22 per cent. The Coalition tensions created by this result should have provided a much-needed boost to the ALP, but they were unable to capitalise on the discord.

While many of the seats regained by the ALP represented a natural realignment after the debacle of 1974, some victories were particularly noteworthy. The ALP regained Bundaberg from Eugene (Lou) Jensen, who had resigned from the ALP and had held the seat as an independent. Jim Blake, who had earlier held the seat of Isis but lost it in 1974, beat Jensen. Ed Casey (Mackay) rejoined the ALP and retained his seat for the party. The seat of Murrumba, which had been held by the Country/National Party since 1912 but was altered in the 1977 redistribution, was won by the ALP's Raymond (Joe) Kruger. The ALP also claimed a special victory in Townsville South, which had long been held by the idiosyncratic independent Tom Aikens (representing his so-called NQLP). Aikens, then aged seventy-seven, had spent 33 years in State Parliament, initially serving also as the Deputy Mayor of Townsville (1944-49). He was the last of the genuine independents to hold a seat until Liz Cunningham won Gladstone in 1995.

After the election, Bjelke-Petersen announced the composition of his fifth ministry-again retaining 18 ministers, split 10-eight between the Coalition parties.

- Premier: Johannes Bjelke-Petersen, NP

- Deputy Premier and Treasurer: William Knox, Lib.

- Minister for Mines, Energy and Police: Ronald Camm, NP

- Minister for Labour Relations: Fred Campbell, Lib.

- Minister for Health: Dr Llew Edwards, Lib.

- Minister for Primary Industries: Vic Sullivan, NP

- Minister for Maritime Services and Tourism: Max Hodges, NP

- Minister for Lands, Forestry and Water Resources: Neville Hewitt, NP

- Minister for Local Government and Main Roads: Russ Hinze, NP

- Minister for Culture, National Parks and Recreation and Leader of the House: Tom Newbery, NP

- Minister for Transport: Ken Tomkins, NP

- Minister for Education: Val Bird, NP

- Minister for Industry and Administrative Services: Norman Lee, Lib.

- Minister for Works and Housing: Claude Wharton, NP

- Minister for Justice and Attorney-General: Bill Lickiss, Lib.

- Minister for Survey and Valuation: John Greenwood, Lib. 
- Minister for Aboriginal and Island Affairs: Charles Porter, Lib.

- Minister for Welfare: John Herbert, Lib.

Subsequent changes in the ministry occurred in August 1979 when Max Hooper (NP, Townsville West) was promoted to replace Max Hodges as Minister for Maritime Services and Tourism (although Hooper's own tenure would be short-lived, as he lost his seat in the 1980 election). Hodges own departure was sweetened with a plum board appointment.

\section{Eccentrics one and all}

The forty-second Parliament first sat on 28 March 1978. In a rare show of bipartisanship, Labor supported the government's nominee, Jim Houghton, who was elected Speaker without contest. The Opposition Leader, Tom Burns, explained:

We all know that the coalition parties have agreed that the National Party should nominate the Speaker and that the Liberal Party should nominate the chairman of Committees...During the last Parliament Mr Houghton showed that he was fair and reasonable, so we have no objection to his appointment as Speaker. (QPD 1978:vol. 274, p. 3)

This spirit of goodwill, however, soon evaporated. Burns returned to the theme of the government riding roughshod over the Parliament and then raised other controversial issues such as the Tarong power station deal and the Iwasaki resort project (QPD 1978:vol. 274, pp. 3-4). In questions without notice, Burns asked the Deputy Premier and Treasurer, Bill Knox:

As the Premier obviously means to supply no information to this Parliament on this highly suspicious decision, and as this strikes at the very heart of the principle of Cabinet being responsible to Parliament and also conflicts with his reported Press statement that the matter will be debated in Parliament, I ask the Deputy Premier and Treasurer: Does he support this cloak of secrecy at a time when there are undenied reports that the choice of Tarong will cost Queenslanders an additional $\$ 259,000,000$ ?

Mr Knox: The Leader of the Opposition already has had opportunities to debate the Tarong question in this House but has not done so... Let me give honourable members an assurance that while we have differences of opinion and different views in Cabinet, we stand together with our traditional principles of collective responsibilities. (QPD 1978:vol. 274, p. 322) 
The siting of a new coal-fired power station at Tarong, in the Premier's electorate, caused such a furore that Bjelke-Petersen took the unprecedented step of breaking cabinet confidentiality to detail the discussions cabinet had had, including the support given to the project by Knox:

As Premier, it is my duty to support the collective decision of Cabinet. However, I must now break a long-standing rule and outline the facts involved in a Cabinet decision. At the end of the Cabinet meeting on February 13 this year, the following statement by the Treasurer was recorded in the minutes: 'That regarding the establishment of a power station at Tarong, it would be incorrect for anyone to say the decision in favour of the Tarong site would mean an increase in electricity tariffs greater than there would have been had Millmerran been chosen'... That is the Treasurer's statement as recorded in the minutes of Cabinet. (QPD 1978:vol. 274, pp. 362-5)

After Burns unsuccessfully attempted to have the Premier table the document, Bjelke-Petersen alleged that the State Electricity Commission (SEC) had done an about-face on the deal:

Mr Burns: Are you saying that the SEC is crook?

Mr Bjelke-Petersen: The Leader of the Opposition may draw his own conclusions. I am not saying that at all. In fact, the SEC loaded $\$ 22,000,000$ against Tarong, but only \$3,400,000 against Millmerran for capital charges for water costs.

[The Premier continued, noting]... all the facts I have been quoting come from official departmental reports and officers - not from unnamed 'senior officials' who keep turning up in the Opposition Leader's and newspaper stories.

Mr Burns: Table the reports. I challenge you to table the reports.

Mr Bjelke-Petersen: It hurts the honourable gentleman so much that he does not want to listen.

Mr Burns interjected.

Mr Bjelke-Petersen: I am afraid that the honourable gentleman will just have to grin and bear it. (QPD 1978:vol. 274, p. 364)

During this session, other Liberal ministers also sought to differentiate themselves from the Premier. In April 1978, the Health Minister, Llew Edwards, was moved to issue a Ministerial Statement to disassociate himself and the government from the Premier over Bjelke-Petersen's controversial support of a self-styled 
cancer therapist, Milan Brych. The Cook Islands doctor, who had been struck off in New Zealand, had advocated a unique form of cancer treatment based on apricots, which had caught the Premier's attention. When the Premier invited Brych to come to Queensland to establish a cancer clinic, the Health Minister stepped in to expose the hoax. Edwards told the Parliament:

The Premier, in his capacity as a private citizen...invited Milan Brych to Queensland. The Queensland Government, as far as I am aware, and certainly my own department, have not been involved in any arrangements...[a] meeting was set for $4.00 \mathrm{pm}$ in the Premier's Department...The meeting was a great disappointment. All therapeutic and diagnostic procedures, drugs and reagents mentioned by Milan Brych, sometimes extremely vaguely, are known and have been known by Queensland doctors for a long time... Brych refused to discuss even simple scientific and technical details and procedures, and he continued to make contradictory statements about the results of his work in New Zealand. (QPD 1978:vol. 274, pp. 55-7)

Edwards then listed a series of significant factors that exposed Brych's fabrication. According to Lunn (1984:280), Edwards out-manoeuvred the Premier, which did his own leadership ambitions no harm. The opposition, however, remained unconvinced and attacked the 'Premier's reliance on eccentric advisers' (citing Wiley Francher, Lang Hancock, Charlie Porter, Prince Leonard of Hutt, Rona Joyner, Yohachiro Iwasaki and Milan Brych). Casey suggested:

[Bjelke-Petersen] had made arrangements with Brych not as a private citizen, as alleged, but as Premier of the State. He made a commitment a month ago to fly Brych to Queensland in the Government aircraft to be interviewed here, if necessary. That was a commitment that could be made only by a Premier, and certainly not a private citizen...

The Premier is going ahead in the manner of a person who is either in complete control of all who surround him or who is of unsound mind. This latter suggestion about the Premier is on the lips of many Queenslanders today, including prominent members of the National Party in this House. (QPD 1978:vol. 274, p. 166)

Casey called such eccentric advisers 'witch-doctors' and 'the Premier's con men, ratbags and shylocks' (QPD 1978:vol. 274, p. 167).

The new session was also marred with further controversy between the federal and state governments. In April, it was announced the Federal Government planned to acquire Queensland Aboriginal reserve lands in an attempt to stop the state government taking over the Aurukun and Mornington Island Aboriginal communities. Although both governments were of similar political 
persuasion, Bjelke-Petersen responded to the announcement by saying '[t]hey'll need the army' if they went ahead with the plan (Courier-Mail, 6 April 1978). Even his own supporters, however, began to question the Premier's judgments. One senior National Party member was quoted as saying the Premier must have been 'very tired. We think he needs a rest', but added the party 'would stick by the Premier' (Courier-Mail, 6 April 1978). The next weekend, at the party's central council meeting, National Party President, Sir Robert Sparkes, repudiated such suggestions, claiming 'Joh is quite efficient, alert and on the job-in no more need of a holiday than even I am' (Sunday Mail, 9 April 1978).

Newspapers continued to highlight the internecine conflicts occurring within the government (Courier-Mail, 5 April 1978). Reporters also reproached the government for decisions taken in the parliamentary recess including the unilateral decision by the Premier to ban two educational programs: the Social Education Materials Project (SEMP) and Man-A Course of Study (MACOS). The Premier banned these programs from being taught in Queensland schools after complaints from conservative sections of the community that these programs advocated 'secular humanism' (Reynolds 2003:339). It was this controversy that contributed to the establishment of a Parliamentary Select Committee on Education in April 1978, chaired by Mike Ahern.

The Member for Landsborough was regarded as one of the National Party's stars, but was distrusted by the Premier and, despite having served a decade in the Parliament, he remained on the backbench. Ahern performed credibly as chair of the select committee - only the fourth such committee to be appointed in more than 10 years - investigating issues and reviewing educational standards more seriously. The committee met for 21 months, published six Interim Reports and made 25 final recommendations (Reynolds 2003:340).

The opposition, however, continued to labour the theme that the government was neglecting the Parliament. Casey noted that in 1977 the number of sitting days (38) had reached an all-time low (QPD 1978:vol. 275, p. 9). Later in the year, the Parliament recorded its longest sitting day, not breaking until $6.30 \mathrm{am}$ on 17 May. The legislation considered in the mammoth sitting day included the Legislative Assembly Act and another act, the Local Government (Aboriginal Lands Bill) and the Queensland International Tourist Centre Bill. All were controversial. The Courier-Mail's (18 May 1978) editorial detailed the folly:

State Parliament goes from one foolishness to another, seemingly determined to appear the craziest legislature in the land. The nineteenand-one-half hour sitting which ended at 6.35 am yesterday was quite unnecessary and dangerous. Parliament passed too much important legislation too quickly and, for the most part too late an hour for many Members or the public to understand what was done. The practical 
effect amounted to legislation in camera, which perhaps was exactly what the Government wanted. It was at last year's longest all-nighter in April that parliament passed, just before midnight, amendments to the Constitution and the Legislative Assembly Act without knowing what it was doing and put at least two members out of Parliament. Now at another marathon sitting it has legislated to put them back. The Iwasaki resort bill was debated between 12.25 am and 6.35 am...Altogether three major bills, all of them controversial, were passed in the course of the sitting which was a night of legislative disgrace.

The other big issue became the abuse of parliamentary perks. In a matter-ofpublic-interest debate, Kev Hooper accused the Premier of spreading stories that Members of Parliament were cashing in their air-travel vouchers. Hooper asserted that, while the Premier jetted around the state in his own government jet (which Hooper called 'Peanut One'), he had alleged that members were abusing their entitlements - possibly as a way of diverting attention away from his own shortcomings. The Premier had thrown a shadow of suspicion over the members, Hooper argued, and had given the impression that parliamentarians were interested only in the lurks and perks of office. Hooper found this populist attack offensive, claiming it would be impossible to find a more experienced hypocrite than our Premier'. He continued:

For the past two weeks the Premier has invited the public to imagine that a few reasonable and overdue parliamentary reforms will turn this chamber into a gigantic travel bureau, with members and their wives jet-setting backwards and forward to the flesh-pots of the world. No member here or in any other State has ever dug his fingers deeper into the public purse than the Premier. He is a past master in perks. ( $Q P D$ 1978:vol. 275, p. 1319)

Hooper's bluster was a case of outrage designed to hide the facts. The AuditorGeneral, Jim Peel, had been called in to investigate reports (contained largely in the press) that members had not been observing due probity in their travel claims. Peel's report caused an immediate public outcry. He found that up to 23 members had improperly used their air-travel vouchers, swapping domestic entitlements for overseas trips, taking family members on trips, claiming expenses that had not been authorised or incurred and cashing in unused air warrants. Those accused included the Opposition Leader, Ed Casey. The members found to have taken unauthorised travel were expected to repay the amount they owed to the Treasury, but it is not clear whether any did. In desperation, some parliamentarians attempted to discredit the report. In particular, Jim Houghton defended the Parliament's right to determine its own activities. $\mathrm{He}$ 
claimed that the Auditor-General's report failed to acknowledge the supremacy of the Parliament and as a result he had now referred the report to the SolicitorGeneral. Houghton stated:

In considering the propriety of the expenditure of funds from the appropriations for the legislative Assembly, the Auditor-General has looked for Cabinet approval of expenditure and has correctly stated that Cabinet decisions are binding on all persons in government, but he has then mistakenly considered the Parliament to be part of the Government. (QPD 1978:vol. 275, p. 1782)

So presumably it was all right to engage in such impropriety? As a result of the Peel report, however, the Premier transferred from the Speaker to his own department responsibility for administering travel and other administrative matters associated with the Parliament. It seemed an almost forlorn gesture that the Queensland Parliament received its first mace in 1978 - supposedly the symbol of parliamentary authority! The mace was presented to the Parliament by the 'Government of Queensland' (not by the people of Queensland or even by the British House of Commons).

In the two-month adjournment of parliament (June-August), a succession of electricity blackouts occurred in south-eastern Queensland - caused by industrial disputes in the power industry. This would lead to legislation preventing strikes in the state's essential industries, which, alongside legislation banning street marches, would become leitmotivs of the Bjelke-Petersen government and part of the state's folklore. The Labor opposition, not surprisingly, constantly took a strong stand against both these pieces of repressive legislation, arguing that they would repeal the Essential Services Act and the street march laws (under the traffic acts). When the increased state powers under the Essential Services Bill were debated, the debate ran for 14 hours (ending after $4 \mathrm{am}$ ) and required 70 divisions (QPD 1979:vol. 280, pp. 1301-81) — and this was after a 12-hour debate the previous day. 


\section{Sherwood by-election and the sudden end of Tom Burns' leadership}

A year after the state election, a by-election was required in Sherwood after the Minister for Welfare, John Herbert, resigned on health grounds in September 1978, and died shortly afterwards. The by-election held on 25 November 1978 was contested by eight candidates - including the Liberals' J. Angus Innes, Labor's M. Kinnane and the Nationals' D. Draydon (an ex-Liberal lawyer and film censor), as well as candidates from the new Australian Democrats, the Progress Party, the Communist Party, the National Front and one independent. The Nationals did not expect to win the seat, according to the newspapers of the day, but they did 'expect a barometer of the Premier's and thus the party's popularity one year after the State Election' (National Times, 11 November 1978). As Hamill (1980:256) stated, 'it was evident that the Nationals saw Sherwood as an opportunity to gauge Bjelke-Petersen's popularity in the metropolitan area'. To test the waters, the Premier made regular appearances in the electorate despite the Nationals not having nominated a high-profile candidate. There were, however, also rumours circulating that Joh had 'lost the support of his own backbench' due to his 'despotic rule'. He was accused of 'earning the enmity of most Liberal members for his rough treatment of them in the party room' and alienating 'a substantial segment of the public by his obstinacy over the [street] march ban' (National Times, 11 November 1978). Other Nationals believed that the Premier's strongman image would go down well with voters. The by-election was seen largely as a test of the popularity of Bjelke-Petersen's divisive leadership - an indication of whether his excesses needed to be curbed (by the triumvirate of Sparkes, Evans and Callaghan) or whether he would become more adamant and belligerent.

With such a field of candidates, it was not surprising the primary vote of the two main parties declined. The Liberals suffered a swing of more than 16 per cent in their primary vote (down to 42.2 per cent), while Labor's vote dropped by 3.2 per cent to 32 per cent. The Nationals managed to poll just 10.3 per cent - a poor showing after all their efforts and well down from Mike Evans' showing in Clayfield. After the distribution of preferences, the Liberals' Angus Innes won the seat with 60.5 per cent to Labor's 39.5 per cent - a slight swing to the ALP of just 2.4 per cent (Hamill 1980). Hugh Lunn, writing in The Australian (27 November 1978), described the by-election result as 'the day Bjelke's march was halted'.

Labor's poor showing at the by-election had immediate impact: it led to the sudden resignation of the Opposition Leader, Tom Burns. Burns had held the post for almost four years, inheriting the job after Percy Tucker's spectacular loss in the 1974 election (losing his own seat in the process). Burns had been 
attempting to reform the Labor Party internally, seeking to rationalise local branches and give ordinary members a greater voice in party affairs. According to Lunn, however, Burns had put in a 'poor performance' in the by-election and had 'failed to live up to expectations', especially considering the state seat covered much of the same territory as the federal seat of Oxley (held by the Federal Opposition Leader, Bill Hayden). The poll result showed 'just how much disarray the Queensland ALP is in' (The Australian, 27 November 1978). Although the local media speculated that a keen contest for the post would eventuate (between Keith Wright, Ed Casey and Kev Hooper), in the end only Casey was nominated and elected unopposed, with Jack Houston remaining his deputy. Casey was the second Labor leader in recent years to represent a northern Queensland seat and he had just two years to make a mark before the next election was due, in late 1980. Not everyone was a fan of Casey: he had not impressed Gough Whitlam, who called him a 'troglodyte', and he antagonised many women's groups with his strident anti-abortion stance (Charlton 1983:128). Houston's second stint as deputy would not last long (15 months), as he would shortly after indicate he wanted to retire from the Parliament. The old patriarch was replaced by former teacher Bill D'Arcy (Woodridge) in early 1980, shortly before the next state election. D'Arcy's unanimous election was received coolly outside the party, with one commentator saying his 'two periods as an MLA totalled only five years and his public image to date is unlikely to excite the electorate at large' (AJPH 1980:vol. 26, no. 3).

\section{Knighthoods for favours - and the Bjelke- Petersen Foundation}

The conservative government had long favoured the awarding of knighthoods to its own senior members of the government. Previous stalwarts of the government had received knighthoods, such as Frank Nicklin, Tom Hiley, Ken Morris, Alan Munro and Gordon Chalk. Two National Party Speakers were also knighted: Alan Fletcher and David Nicholson. Under Bjelke-Petersen, the tradition continued but was accelerated. Former ministers Harry Richter, John Row, Doug Tooth and Wally Rae were all rewarded with the 'gong', while Bruce Small was knighted for his services to local government. Two Liberal leaders were knighted: Bill Knox in 1979, followed by Llew Edwards in 1984, after he had left the government. Then, perhaps impatient of waiting or apprehensive his successors would never get around to it, the Premier also put his hand up for a knighthood in June 1984 - supposedly for 'services to parliamentary democracy'! Inauspiciously, he dropped the medal when showing it to the media after the Queen in London had presented him with it. 
By the 1970s, however, the government's practice of awarding knighthoods to its members took on a new dimension. A string of 'National Knights' was appointed from local successful businessmen close to the Premier, and often with close associations with the National Party itself (senior officials, fundraisers, trustees). These included Sir Robert Sparkes, Sir Edward Lyons (nicknamed 'top-level Ted'), Sir Charles Holm, Sir William Allen, Sir Roderick Procter, Sir Ernest Savage, Sir Frank Moore and Sir Doug Logan. These National Party 'mates' were reputed to wield considerable influence behind the scenes in the government and many held high-paid executive posts on the government's payroll - often without declaring or sensing any conflict of interest.

Another way sycophantic business leaders could purchase knighthoods was to make significant donations to the National Party through its fundraising arm. Bjelke-Petersen had announced in 1979 that he required some \$2.5 million to fight the upcoming election (due by the end of 1980 but with a possibility that it would be called earlier to take advantage of Labor's disunity). He established the Bjelke-Petersen Foundation, a high-profile party fund, to raise money for the party and to assist with election campaigning. He appealed directly to private enterprise to support it, saying: 'We hope that private enterprise will back up and give us the power, in turn, to help them to further their private enterprise endeavours in the State' (The Australian, 19 February 1979). He then began approaching business leaders for substantial donations - often with the prospect of a knighthood in the wings.

One celebrated case involved a NSW businessman, Justin Hickey, who purchased a knighthood for $\$ 100000$. When questioned on television as to how he came to be knighted by the Queensland government, he said he had made the large donation to support a hospice in Bjelke-Petersen's electorate. When the journalist Peter Ross asked him whether he had made the payment before or after the knighthood was announced, he replied candidly: 'Oh no I paid the $\$ 100,000$ before I ever received the knighthood' (see Coaldrake 1989:141-2). When asked in the Parliament how much Hickey or his associates had donated to the BjelkePetersen Foundation, the Premier refused to answer, claiming tangentially that the Opposition Leader had outstanding debts. Others who exploited the system were perhaps not so forthright (and opposition members even claimed that 'Sir' Frank Luton, of the notorious Russell Island land scandal and facing trial for fraud, had paid \$25000 for a bogus knighthood in the 1980s). With hindsight, such abuses of state-nominated honours merely helped discredit the imperial honours system; and interestingly, Bjelke-Petersen was the last member of the government to be awarded a knighthood.

Former National Party MP for Callide, Lindsay Hartwig, later alleged that National Party parliamentarians were expected to donate $\$ 10000$ to the BjelkePetersen Foundation if they wanted to be considered for promotion to the 
ministry. He claimed that he personally had been asked to cough up \$10 000 for the trust fund - an allegation the Labor opposition was keen to repeat ( $Q P D$ 1981:vol. 283, p. 577).

\section{The vandalisation of the Bellevue Hotel in 1979}

During the 1970s, the destruction of heritage buildings became a major political issue. In the Brisbane CBD, in particular, a swath of demotions took place to clear away older properties and use the land for the development of high-rise apartments, new commercial buildings and some government offices. Although the preservation of heritage buildings became a political issue and the subject of demonstrations and popular campaigns, the state government did anything but preserve the city's heritage, and it was only when most of the older buildings were gone that the community woke up to what had happened.

The historic Bellevue Hotel, located on Alice Street opposite Parliament House, had long been a drinking hole and meeting place for parliamentarians and journalists. The government had leased it in part to provide overnight accommodation for up to 25 country members. It had, however, been allowed to fall into disrepair and was rotting and structurally unsafe. Rather than restore the old pub, the state government decided to demolish it as part of a redevelopment of the parliamentary precinct, with the Premier referring to it as 'just a heap of rubble', which it soon was. The Bellevue was clandestinely demolished late on the evening of Friday 20 April 1979 by an infamous firm of new-migrant demolishers, the Deen Brothers (who labelled what they did 'reverse-construction'). When word spread that the building was being bulldozed and smashed that evening, crowds of people turned up to protest against the demolition, including some parliamentarians (including from the government side). The hotel was ringed by barbed wire and a police cordon, with Special Branch officers in the crowd. When the Deen Brothers arrived with bulldozers, they smashed their way through the crowd and barbed wire. The police dealt with the demonstration by resorting to rough-house tactics, hitting demonstrators, physically apprehending them and removing them. The circumstances of the demolition led to the Bellevue becoming a cause celebre in both the Parliament and the wider community, which heightened popular awareness of heritage conservation. ${ }^{2}$ Interestingly, two dissident Liberals, Terry Gygar and Rosemary Kyburz, moved a censure motion against the way the demolition was undertaken (the clandestine method and the incidents that took

2 Later, in one of those little ironies of life, the Strangers Bar in Parliament House was for a period renamed the Bellevue Bar to commemorate the old lady and serve as a reminder of the vandalism of the era. 
place, not the decision to demolish it). The unusual censure debate became a lengthy business, running to some 64 pages in Hansard. Eventually their motion was defeated-30 votes in favour, but 41 against. Eight Liberals felt strongly enough to support the censure motion: Akers, Gygar, Hewitt, Innes, Kyburz, Lane, Scott-Young and (Peter) White (QPD 1979:vol. 277, pp. 4168-232).

The destruction was, however, not over. The Bellevue was followed by the demolition of the Hoffnung Building in the early 1980s, an act some members declared was worse than the destruction of the Bellevue and certainly attracted its own commentary and allegations. The Hoffnung Building was a state government building knocked down so the site could be redeveloped, although some government ministers tried to lay the blame for the demolition on the Labor-controlled Brisbane City Council, which they claimed had approved the demolition. The Cloudland Dancehall in Bowen Hills, near Breakfast Creek, was also demolished in 1982 to make way for an apartment complex. Each of these cases led to outrage, yet the public was not given the opportunity to object or to suggest alternatives.

\section{Restoration of Parliament House - the infrastructure not the institution}

The parliamentary buildings had not changed greatly since the second wing was completed in 1891, although the internal usage of the physical space and grounds had changed considerably over the century. During the period 197882 , a major bout of new construction and refurbishment was undertaken. A 24-storey Parliamentary Annexe tower was completed and opened in March 1979. It contained an additional chamber, library facilities, committee rooms, member rooms and sleeping facilities, a pool, sauna and sporting facilities. It was unkindly dubbed the 'Taj Mahal' by the local media and by a few disbelieving politicians. Suddenly, the Queensland Parliament went from being the smallest and most cramped legislature in the Australian states to being one of the largest and most spacious.

The older historic buildings were preserved and connected to the Annexe, but the two older wings including the Assembly and old council chambers were closed for restoration in 1980 due to an infestation of West Indian termites. The entire building was covered with massive tarpaulins and fumigated, after which much of the interior woodwork was restored or replaced. In the meantime, the Assembly met in the new 'third chamber' located on the fifth floor of the annexe (meeting there until 1982 when the restorations were completed). Work on the Chamber and associated rooms was completed by January 1982 and the remainder of the upgrade was finished by June 1982. Two additional lifts 
were installed. The restoration greatly improved the physical attributes of the buildings that had long been the subject of much complaint. It did not do much to improve the institution of the Parliament itself, which was criticised (like the old building) as displaying 'institutional rot' (Coaldrake 1989).

\section{Gympie and Redcliffe by-elections, and a new Speaker}

Two further by-elections were required in 1979-both held on 1 September. The Speaker, Jim Houghton, resigned from his parliamentary position in early July due to ill health and formally resigned his seat of Redcliffe in August. He held a press conference to announce his intention to quit on 4 July at which he said the standards of behaviour in the Assembly had fallen to those of a 'cess-

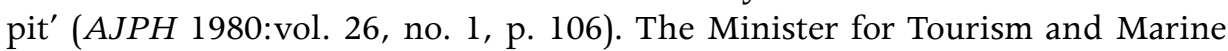
Services, Max Hodges, also resigned, from his seat of Gympie, on the same day (8 August). He had resigned from the ministry on the last day of July 1979 and was one of the last Country Party members to have served continuously since the Coalition came to office in 1957 (the other two being Bjelke-Petersen and Nev Hewitt). Hodges was appointed chairman of the Port of Brisbane Authority on his resignation from the Parliament.

The Nationals' state secretary, Mike Evans, talked down the prospect of the Nationals retaining Redcliffe even though the party stood Houghton's younger son, John, to maximise the personal vote (sponsored by the professional campaigner, Rona Joyner, a local Nationals branch member in Redcliffe) (see Cribb 1980). Running a strong local campaign (on the theme of restoring the Liberals' numbers in the Parliament) the Liberal Party took the seat at its fourth attempt to wrest it from the Nationals. A local chemist, Terry White, became the new member, winning the seat on his second attempt. White was a capable and ambitious politician (if sometimes naive), who would make it into the ministry within just more than 15 months of sitting in the Assembly, and would become party leader within four years (see Koch 2010).

In contrast with their result in Redcliffe, the Nationals retained Gympie, with Len Stephan beating his Liberal and Labor opponents but suffering an 11 per cent primary swing against the party (although only 2.52 per cent on a two-party preferred basis). Stephan would hold the seat for more than 21 years without rising to any great heights (becoming government whip for three months and chairing two committees), but he did see off the One Nation challenge in his seat in 1998. The mixed news from these by-elections caused the Premier to jettison any notion of calling an early election in late 1979. The Premier responded to the 
poor showing by the Nationals by saying 'you can't win everything' and that he would now not hold a general election until 'well into next year' (Courier-Mail, 3 September 1979).

With the resignation of Jim Houghton from the Assembly, a new Speaker was elected after much protracted argument and name-calling. As one contemporary commentator recalled: 'members seemed determined to prove Mr Houghton right. For four hours before a new Speaker was elected, government and opposition members indulged in an "orgy" of uncontrolled behaviouraccusations, insults, invective and constant interjections - while the Clerk of Parliament strove in vain to impose order' (AJPH 1980:vol. 26, no. 1, p. 106). Selwyn Muller (NP, Fassifern) was elected Speaker on 8 August 1979. Muller immediately disgraced himself by claiming that the Speaker's role in the Parliament was that of 'applying the wishes of the government he represents' (see AJPH 1980:vol. 26, no. 1; Coaldrake 1989:70) - a totally distorted view of the Speaker's significance (although he subsequently said he meant to say 'wishes of the Parliament he represents'). Muller went on to show considerable favouritism towards the government, at times disallowing questions and curtailing the scope of the opposition to probe government administration. Muller did, however, allow some relaxation in Sessional Orders that Houghton had agreed be retained (generally allowing more time for debates and speeches on legislation). He also invited all parties to propose amendments to Standing Orders - a body of procedural rules that had not been updated for some 30 years! $!^{3}$ Labor, however, and a number of Liberal backbenchers were unhappy about the intention in the Sessional Orders to prevent backbenchers from speaking at the first reading stage of a bill (probably suggested because most had never seen the legislation and tended to ad lib on anything that came to mind). Despite a debate lasting about two hours on the proposed changes, the government gagged the debate, defeated Labor's proposed amendment on party lines and passed the government's proposed changes, with only one Liberal, Rob Akers, abstaining. Although a division was required, Muller had declared the outcome: 'the "Ayes" have it' (QPD 1980:vol. 282, p. 129).

The Minister for Culture, National Parks and Recreation, Tom Newbury, resigned from the ministry on 21 August 1979 only a matter of days before the two byelections were held. He resigned to take up the plum post of Agent-General

3 Tom Burns stated in the Assembly that '[w]hen I first entered Parliament back in 1972, Jack Houston said that he would write to the Premier requesting a meeting of the Standing Orders Committee. Since then, every Opposition leader has written. But there has not been a meeting, because the Government does not want a meeting of the Standing Orders Committee.' He dismissed the Deputy Premier's suggestion that the estimates of every department should be debated, maintaining 'we will be lucky if we debate half a dozen department's Estimates'. He further criticised the Deputy Premier's idea of having adjournment debates (two five-minute speeches) on Tuesdays at the very end of a sitting day, 'when all the journalists have gone to bed' ( $Q P D$ 1980:vol. 282, pp. 122-3). He also said the government and Premier's Department were worried the opposition was using the Parliamentary Library to become 'a thorn in their side'. 
in London, but hung around in Queensland until after the upcoming state election. During the main campaign, Newbery ran a local rebellion against those he called the 'big-shots' in the National Party, perhaps placing his appointment at risk. It was reported:

The genial Mr Newbery is bucking the party machine and refusing to campaign for his party's endorsed candidate in his old seat of Mirani. The National Party has endorsed Mr Jim Randell as Mr Newbery's successor in the normally blue-ribbon National Party electorate. Newbery is backing independent candidate, John Comerford, his electorate secretary - who was still working for Newbery at the time. (Sunday Sun, 19 October 1980)

\section{The demise of Knox and the arrival of the more forceful Dr Edwards}

Knox was deposed as leader in a messy coup carried out in two attempts in 1978. He was removed because the Liberals seemed to be going backwards, feared they were too subservient to the Nationals and because Knox seemed to be getting too close to Bjelke-Petersen. Liberal parliamentarians had made criticisms that Knox was not leading the party and that he had shown no leadership over the Peel report into members' travel entitlements. Two no-confidence urgency motions in his leadership proposed to the Liberals' state convention in June were prevented by the ruling of the State President, Yvonne McComb. The issue did not go away, however, and disquiet remained in the party room.

The first coup attempt did not go exactly to plan. On 20 September, a party room spill of his leadership resulted in a tied 11-11 split among the members and Knox used his casting vote to hold onto the leadership position, surviving by one vote. It was a 'show of hands' ballot - that is, everyone saw who voted for whom, and the Liberal ministers were obliged to support Knox. After the party vote, Knox faced a five-hour grilling from his parliamentary colleagues, on 27 September, after which he said, 'I don't think my style is too bad' (CourierMail, 28 September 1978). Then, in early October, a second special meeting was convened to topple the leader. On the eve of the second coup, Knox was in Sydney attending his mother's funeral, but vowing to fight on. The party room vote the next day deposed Knox and installed Llew Edwards as the new leader (Bill Hewitt was reported as being prepared to stand against Knox if Edwards would not).

Edwards was unsettled over the 'callous' coup and performed badly at his first press conference, evading questions and refusing to say what debts he had 
incurred to his party supporters in the party room (Wells 1979:118). Although Edwards had apparently given undertakings to his key supporters that they would become ministers once he was leader, Edwards did not reshuffle his Liberal ministers until after the 1980 election (meaning Lee, Lickiss, Greenwood and Porter survived, while Hewitt, Lane and Austin had to wait). Edwards did, nevertheless, institute a policy of having Liberal 'shadow ministers' appointed to 'make statements and appear as Liberal spokesmen on the portfolios held by National ministers' (AJPH 1980:vol. 26, no. 3, p. 421). These spokespeople also produced separate Liberal policies for each of these portfolios. These provocative moves infuriated the Premier, who found such actions disloyal; he responded by insisting that the Liberals focus on promoting government policies.

Edwards kept being reminded of his callous coup in the Parliament. Casey said, a few months later, 'his standard is measured, I believe, by the way in which he displaced his former leader whilst that gentleman was away at the funeral of his mother' (QPD 1979:vol. 277, p. 3412). He was also criticised for being frequently absent from question time or for disappearing for periods during questions. The following interchange took place on 27 August 1980:

Mr Casey: The Treasurer has disappeared again. He seems to disappear quite regularly at question time. He did it yesterday.

Mr Sullivan: Stop trying to be smart.

Mr Casey: It is a pity he is not in the House at question time, when he is supposed to be. He disappears with monotonous regularity.

An Opposition Member: He's at the trots.

Mr Casey: Yes we all know he is in a bind over the trots. I will put the question on notice...

Dr Edwards: I rise to a point of order. I believe the Leader of the Opposition made some comments regarding my absence from the House. I am quite happy to receive a question without notice. The reason I was absent was that I was discussing a matter of great importance to the State regarding the trotting industry with the chairman of the Trotting Board. That was why I was called from the Chamber. (QPD 1980:vol. 282, p. 214)

The Speaker then asked whether Casey wanted to ask the question without notice or on notice. When Bill Hewitt objected, Casey said he would 'shuffle the pack' of intended questions and proceeded to ask a question to Edwards derived from the Courier-Mail a few days earlier on a budget leak! Budget leaks were the flavour of the month over the next few question times as various titbits of information had been leaked from the state budget (allegedly by the Education 
Minister, Val Bird), and these evoked parallels with the infamous leaking of the entire federal budget to journalist Laurie Oakes in 1980. Edwards clarified his position the next day with a Ministerial Statement claiming allegations of impropriety against the chief steward of the Trotting Board had been made and that he had been dismissed from employment.

Some senior government ministers, who had served throughout much of the Coalition's period in government, gradually let it be known that they were retiring at the next election. Ron Camm, the Nationals' deputy leader and current Mines Minister, announced his resignation as minister and from his seat of Whitsunday on 17 July 1980. His seat was declared vacant but no byelection was called. Other ministers who decided not to recontest included Fred Campbell, Nev Hewitt and Charles Porter - all of whom received valedictory motions at the conclusion of the session. None of the other retiring ministers caused a further by-election. Camm, who retired on a good superannuation payout ( $\$ 320$ 000), was immediately appointed to an executive government job as Chairman of the Queensland Sugar Board. A string of such appointments led to allegations from Ed Casey that the government was engaged in a 'jobs for the boys' scam, in which 'a generously superannuated political favourite [was] being hustled sideways into an extravagantly rewarded Government job at an age when most Queenslanders are either required to be retired or are on the edge of retirement' (QPD 1980:vol. 282, pp. 5-6). The Nationals' one-term Member for Wynnum, the 'unknown' Bill Lamond, was appointed to head the Small Business Development Corporation.

Outrage over ministers taking large superannuation payments and then receiving other government appointments drew attention not only to the jobs for the boys' issue but to the generous superannuation payments politicians could expect at taxpayers' expense. Many senior ministers of much younger vintage than the Premier were now retiring with very comfortable pensions, and yet Bjelke-Petersen had refused to join the parliamentary superannuation scheme when it was introduced and had remained outside it. This matter of the 'generous super' payments to long-serving members caused great envy with the Premier and would fester in his mind for years to come. It was alleged by some former members that Bjelke-Petersen tried to gain backdated entry into the superannuation scheme but this was not granted.

On Labor's side, Jack Houston announced his own resignation, dated from 25 July, confirming that he would not be recontesting his seat of Bulimba at the 1980 election. The older brigade was gradually making way for a new generation and perhaps an influx of talent. And the Labor Party was just starting to think of ways to augment its Caucus with a better quality of candidate. 
Finishing the last session of the forty-second Parliament, the government passed the Griffith University Amendment Act 1980, providing a major overhaul of the original act of 1971. In debate, the Liberal backbencher Bill Hewitt described the new university as 'a lusty youngster [whose] best and finest hours still lie ahead of it'. He claimed 'Griffith is one of the great tertiary institutions on the south side of the river' (there were not that many there in those days), and that he had a 'particular affinity with it'. To which Kevin Hooper interjected: 'they tell me that the only time you went through a university was on a pushbike' (QPD 1980:vol. 282, pp. 181-4). Hooper, nevertheless, graciously acknowledged Hewitt's performance as Chairman of Committees (effectively deputy speaker). Hooper volunteered that he had been

[r]eliably informed that, irrespective of the outcome of the election, the member for Greenslopes will not be seeking re-election as Chairman of Committees. It would be churlish of me if I did not pay tribute to the manner in which he has discharged his duties as Chairman of this Parliament...I believe that the member for Greenslopes has been one of the fairest and most impartial Chairmen to have held that position since I have been in this House. (QPD 1980:vol. 282, p. 793)

This was a rare moment of appreciation in a very torrid political atmosphere.

Elsewhere as the session drew to a close the Parliament talked of the virtues of hydrogen cars, the costs of aircraft for government ministers touring the state and making overseas trips, the new government jet (a Beech 200), the possibility of casinos and poker machines in Queensland, extravagant ministerial expenses, donations to the Bjelke-Petersen Foundation in exchange for 'favourable decisions' (including claims by federal Liberal minister Eric Robinson), female strippers at sporting club functions behaving like prostitutes, the cancer quack Milan Brych now that he had been struck off the medical register in New Zealand and arrested in California, what to do about explosives, firearms and weapons, and the prospects for the forthcoming Commonwealth Games to be held in Brisbane in 1982. It ended with Casey lamenting the parlous state of the Parliament during a series of valedictory speeches (something the Premier said he had never heard before). Bjelke-Petersen claimed it is the first time in my nearly 34 years in Parliament that a political speech has been made by the Leader of the Opposition during the valedictory...to me, this is completely wrong. This is not what a valedictory is for' ( $Q P D$ 1980:vol. 282, pp. 819-20). Casey responded with both barrels, saying:

$[\mathrm{T}]$ here is no doubt that we have reached the stage where people in the community regard the Parliament and all members with disdain. This has happened because of the way in which Parliament has been conducted. It has even spun off into the media. Pumpkin scones seem 
to excite more interest in the media than the first election challenge by a Queenslander [Bill Hayden] for the Prime Ministership in over 60 years. The Cabinet has become the censor of Parliament whereas it should be answerable to it. (QPD 1980:vol. 282, p. 819)

The Speaker, Selwyn Muller, said he was 'most disturbed at the comments of the Leader of the Opposition', not for their substance but because Casey was daring to break with the conventional protocol. Casey was pulled up by Peter McKechnie for his breach of convention and was 'severely reprimanded' by the Speaker (QPD 1980:vol. 282, p. 819).

\section{The lead-up to 1980 election: the 'Coalition' now but in name alone}

The 1980 election would be the last the Nationals and Liberals would contest in a coalition arrangement until 1995. Despite the semblance of unity, both conservative parties ran separate campaigns - for the first time since coming to government in 1957. The Premier maintained he had offered to run a joint campaign and said that Edwards had also wanted one but was overruled, claiming his deputy had said 'I'd like to stand beside you in the election. But you know that my organisation won't let me' (Truth, 19 November 1980). The animosities between the governing parties had become intense and for the first time actively involved the leadership on both sides. Moreover, with each of the Coalition parties launching overt public attacks on the other, the feuding boiled over in the campaign and was reflected in the campaign messages of each side. The Premier threatened the Liberals that they would 'now pay for disassociating themselves from him' in the past and added that the ALP and the Nationals will be 'doing all we can to oppose them and reduce their numbers' (Sydney Morning Herald, 23 September 1980), although he did say he was willing to go back into coalition should the government win the election. It was also reported in October that a 'new conservative force' was being mooted among sections of the National Party. A future conservative government could consist, not of a formal coalition combining both parties, but of a National-dominated government with the support of a few 'scab' Liberal members who would give it the numbers in the Parliament (perhaps about eight members swapping allegiance). Although Knox claimed he had no 'rats' who were considering deserting a sinking ship (Courier-Mail, 14 October 1980), the Nationals had hatched a portentous plan, which would come to fruition but not in this Parliament.

The Nationals were particularly incensed because their senate representation had fallen from eight senators in 1975 to just three Australia-wide after the 1980 half-senate election, at which the Liberals had chosen to contest as a separate 
entity (a split ticket). Bjelke-Petersen claimed that despite a high combined vote for the Coalition in Queensland (49.77 per cent), the National Party was at its 'weakest strength since proportional representation was introduced 31 years ago' (The Age, 8 November 1980). ${ }^{4}$ He blamed the debacle on 'dumped federal Finance Minister, Eric Robinson, State secretary, Stephen Litchfield, president Dr John Herron and failed Liberal Senate candidate Yvonne McComb - the force behind the running of a separate Senate ticket' (Truth, 26 June 1980). BjelkePetersen had a particular interest in the 1980 federal election as he had secured front spot for his wife, Florence, on the Nationals' senate ticket. He was quoted as stating: 'Any party needs the best-known and best candidate it can get for any election. To me that means Florence is high on the list' (Truth, 26 June 1980). In reality, some Nationals had planned to place Joh himself on the senate ticket as the number-one candidate, hoping his personal support would win two positions for the Nationals and at the same time remove him from state politics, allowing Ahern to step up to the Premiership. Joh would then have been able to serve six years as senator (superannuated) and the "party would never have to face the dreadful thought of dropping its most successful premier if things started to go horribly wrong' in the future (Lunn 1984:300-1). In other words, Flo was the fallback candidate, but still conveying the Premier's name. It must be acknowledged, however, that the 'split-ticket' plan did not really work for the conservatives as they managed to have only two senators elected (Flo BjelkePetersen and Neville Bonner). Despite the falling out over the senate split ticket, in the state election, the Nationals still intended to give their preferences to the Liberals in most seats.

The bad blood between the Coalition was further exacerbated by an apparent cooling of relations between the Premier and his Deputy Premier, Llew Edwards. A Morgan Gallup Poll published in August 1979 placed the Liberal leader on a higher approval rating as leader than the Premier. Edwards attracted 45 per cent approval to Bjelke-Petersen's 41 per cent and Ed Casey's 27 per cent. There was also some press speculation in the lead-up to the election that the Premier was engaged in an 'unholy' conspiracy with Labor, softening his attacks on the opposition so that it could take up the fight with the Liberals in the southeastern corner of the state (the so-called 'sweetheart deal'). In other words, the Nationals and Labor perhaps realised that they had a common political opponent: the city Liberals. It was alleged that Bjelke-Petersen had phoned Casey before the election was called to forewarn him of the announcement (before he told Edwards). Edwards claimed in October that his party was put at a disadvantage

4 The Nationals' representation in the Senate had fallen to just three from the 1980 half-senate election after the 1979 defection of Senator Bernie Kilgariff to the Liberals. The National senators were Doug Scott (NSW) and Stan Collard and Flo Bjelke-Petersen (Qld). 
not knowing the precise date of the election and 'even more so in a coalition government when one partner is kept in the dark' (Courier-Mail, 20 October 1980). He accused the Premier of keeping him guessing.

Labor's Casey was both optimistic and defiant in the lead-up to the election. His confidence was bolstered after the ALP in Queensland had secured a 5 per cent swing in the 1980 federal election held on 18 October-just 42 days before the state poll (although winning no additional seats). According to one journalist, Casey claimed one month out from the poll that he 'was convinced...that his party could win office' (Melbourne Argus, 22 October 1980). His optimism was also embellished owing to the fact that relations within the Coalition were clearly far from harmonious. The local media was similarly sanguine about the new Opposition Leader's chances, with the Courier-Mail (7 November 1980) arguing that because Casey held a central Queensland seat, he 'has a background similar to that of many past Qld Premiers', [which] meant he might capitalise on antigovernment feeling in Central and Nth Qld'.

A total of 271 candidates stood at the 1980 election. This was eight fewer than the record set in 1972 and more than 20 more than had stood in 1974 and 1977. The ALP provided the largest number of contestants (83), fielding candidates in all 82 seats and with two candidates standing in the seat of Caboolture. The Liberal Party ran 66 candidates, 15 more than in 1977, with the increase due to the party fielding more candidates against sitting Nationals. The party ran two Liberal candidates in two seats: Port Curtis and South Coast. The Nationals came third, running 58 candidates in 56 seats (with two standing in Cook and Lockyer). Trying to dislodge the Nationals' Russ Hinze, the seat of South Coast attracted the largest number of candidates, with eight vying for the spot. A further four seats had six candidates each.

Once again, three-cornered contests were a source of intense interest and rivalry. In 1980, three-cornered contests took place in almost one-quarter of all seats - 24 in total, the same as in 1977-although not many were pivotal to the eventual outcome. Again the highly contested areas were the Gold and Sunshine Coasts, a handful of Brisbane seats, some of the rural hinterland seats around Brisbane and a few far northern seats such as Cook, Townsville and Mulgrave. Fourteen Liberals contested seats held by sitting National members. With so many seats being bitterly contested by both conservative parties, a crucial political issue of the day was whether the party leaders would campaign for their candidates in seats held by their coalition partners. The new Liberal leader, Llew Edwards, refused to campaign for the Liberal opponent standing against Russ Hinze in South Coast, despite the Nationals standing a candidate (Roger Hayden) against Edwards in his seat of Ipswich. Other Liberal ministers were divided over whether to campaign for Liberal candidates in Gold Coast seats held by National ministers. When Liberal backbencher Bruce Bishop asked his own ministers 
to endorse Liberal candidates in the seats of South Coast and Albert, Edwards responded by saying he would not campaign against any cabinet colleague; in contrast, Bill Knox agreed to do so; Bill Lickiss proclaimed that he would have to consult his leader; and John Greenwood and Norman Lee both said no. Charles Porter expressed the dilemma many senior Liberals felt when he said '[a]lthough I support Liberalism this does not mean that I am prepared to work against a Cabinet colleague' (Truth, 25 September 1980).

With so many three-cornered contests, preferences were identified as one of the most important weapons in Labor's artillery - they could decide some seats on the conservative side. In a bid to destabilise the government further, the ALP opted to direct preferences to the National Party in selected seats - some held by the Nationals and some by the Liberals. Tom Burns publicly defended this tactic on $\mathrm{ABC}$ television, largely on the grounds that the Liberals were more of a threat to Labor in south-eastern Queensland (Sunday Sun, 26 October 1980). The effect of this strategy was to help consolidate National Party sitting members such as Hinze, who also managed to attract the support of former Labor state president Sir Jack Egerton. The old Labor warhorse was quoted in the paper as 'an unexpected political ally' supporting Hinze, saying 'I'm not campaigning for Hinze, but I think he'll win, and I believe he deserves to win' (The Australian, 17 November 1980).

\section{Campaign and policies}

With the state of the parties in the outgoing Parliament standing at 34 to the Nationals, 25 Liberals and 33 to the ALP, the Australian Financial Review (17 October 1980) claimed that the forthcoming campaign would see the 'most drama' since the Coalition came to power in the 1950s. It characterised the drama as not 'so much an election, but a battle between the National Party and the Liberal Party for Coalition supremacy. The ALP is not rated a chance.'

The Nationals' campaign was rather low key but cleverly populist. They stood on their record, continuing to stress economic prosperity and continued development. Bjelke-Petersen made one initial promise - that Queenslanders would get 'more of the same' with the return of his government: the creation of more jobs, payroll tax cuts and development (Courier-Mail, 6 November 1980). The Nationals were suddenly mesmerised with tax reduction. There were reports the party was considering a flat 20 per cent tax policy (that is, setting income tax at a flat 20 per cent rate with no other rates). The party had championed this idea in the recent senate campaign, with one meeting hosted by Flo BjelkePetersen, Robert Sparkes and the Coordinator of Enterprise 79, Ray Lord, attracting 200 supporters (Truth, 29 September 1980). The Premier, however, pulled off an audacious 'election eve turnaround' on the issue of casinos. After 
previously maintaining that Queensland would not allow casinos-'not while I'm Premier' - he did a sudden about-face and announced that after the election a casino licence would be granted to a Gold Coast location. Russ Hinze publicly welcomed the idea, realising it was likely to be a poll winner on the coast.

The Liberals in contrast stressed that Queensland needed a different style of government (The Australian, 4 November 1980). They promised that on becoming the senior Coalition partner they would deliver a democratic, less authoritarian government, with no 'jobs for the boys' and the establishment of a parliamentary watchdog on executive actions: a public accounts committee. Llew Edwards launched his run for his party's seniority with a 'sustained attack on the National Party and on Bjelke-Petersen', claiming that the integrity of the Premier must be doubted. He said the Liberals would have nothing to do with extremism, would not confront the churches and would not generate bitterness with minority groups. Edwards also attacked the Premier over his handling of industrial relations, saying Bjelke-Petersen took an irresponsible approach that led to a greater number of strikes. This attack led the Nationals' President, Robert Sparkes, to proclaim the inter-party fighting was 'downright irresponsible and crazy' (Courier-Mail, 8 October 1980), and accused Edwards of being disloyal to the Premier (The Australian, 17 November 1980). Edwards responded by telling a rally in Brisbane's King George Square that Joh's leadership was the 'butt of national jokes' (Courier-Mail, 20 November 1980). He said he did not want the sort of leadership that had brought Queensland into disrepute. And, while he had hoped he could refrain from personal attacks, 'the campaign has now taken an unhealthy turn... and the Liberal Party is being forced to take a different approach'. When asked by a heckler why the Liberals had not done anything about integrity in the past, Edwards replied 'because we haven't had the numbers' (Courier-Mail, 20 November 1980). Such public feuding continued during the campaign.

To make the point more forcefully, the Liberals ran advertisements with the heading 'New Leadership' over a huge photo of Edwards. Under the picture were the party's main messages

- new policies, more jobs is our top priority

- abolishing payroll tax

- a bonus of $\$ 15$ a week (paid to employers of apprentices during block training) and a full-time Apprenticeship Training Scheme

- open and progressive government of responsibility and integrity.

Liberal Party ads proclaimed it was time for a change and the party had the policies 'to ensure your Government works for you'. Other promises included the introduction of a code of ethics for ministers; a register of pecuniary interests; a 
full and equitable redistribution of electoral boundaries; making life easier for pensioners with greater subsidies and real help for families with the elimination of stamp duty for first home-buyers on homes costing up to $\$ 35000$.

The ALP ran full-page advertisements in the Courier-Mail (29 November 1980) with montages of a long list of controversial headlines that had occurred in the past: 'police wanted judicial probe', 'church men rap Jo on marches', 'resort plan may cost us millions', 'rally and wake as Bellevue crashes down' and 'the Russell Island caper' (where blocks of coastal land that were undrained swamp or covered at high tide were sold to unsuspecting buyers). Labor tried to hit the government's record, claiming that

This has been the Record of the Liberal-National Party in Office:

- the Bellevue - destruction of a building and a heritage

- Russell Island - another attempt to conceal scandals

- the Premier's own land

- Tarong power station

- street marches

- special treatment for Iwasaki

- the Port scandal

- education blunders

- ALP a Change for the Best

At the conclusion of the campaign, one local paper declared that the election had been not much fought on policy grounds but on contrasting styles of leadership that might appeal to the electors. It reflected that the campaign had done little except given voters a window into the different political styles offered by the three party leaders. It continued:

Despite its essential dullness, almost its matter-of-fact mediocrity, the election campaign has given the Queensland voters some interesting insights into the styles of the three leaders. And because a leadership style is easily superimposed on a government, we have seen a glimpse of the style of government each leader would run.

Mr Casey, a bluff, hearty chap with some problems in his party, has been largely ineffective. He is very good at the grass-roots level, at what the Americans rather tastelessly call 'flesh pressing'. But Ed Casey is not inspiring, and does not seem the kind of leader who can unite a divided ALP and bring it back to government after 23 years.

Dr Edwards, an intense man with some problems with his partners, is a nice guy. Too much of a nice guy, his critics say, in a business where 
nice guys finish last. With the exception of some intermittent flashes of anger, Dr Edwards has been rather too conciliatory. And it is easy to mistake conciliation for compromise, and thus for weakness.

Mr BP has been...well, Joh. At this stage of his political career, $\mathrm{Mr}$ Bjelke-Petersen is not going to change his style, nor his approach. Blunt, no-nonsense, determined, almost stubbornly so at times. Joh knows what is right for Queensland. No risk. Occasionally though, Johand his government-have been wrong. They were wrong over the Bellevue demolition and over the street march laws. If we knew all the details, they might have been wrong over Tarong and the Brisbane port extensions. Russell Island, ministerial expenses, the Peel Committee report, the attempts to change the Industrial Commission, the Police Act amendments, the Justices Act amendment... And in its lack of response to criticism, its absolute conviction that it knows what is right, the government has been reflecting the views of one powerful man-the Premier. (Truth, 28 November 1980)

\section{State of the parties in the new Parliament}

When final results from the election were returned, the Nationals held the same number of seats (35) as they had in the 1977-80 Parliament (but had one win and one loss). Labor recorded a net gain of two seats, taking them to 25 members, and the Liberals lost two, dropping their representation to 22 . In the state-wide votes, Labor fell back slightly, recording 41.49 per cent (down 1.34 per cent), the Nationals recorded a slight increase to 27.94 per cent (up 0.8 per cent), while the Liberals, despite losing seats, increased their primary vote to 26.92 per cent (up 1.7 per cent). It was almost a status quo finish. There was some speculation among Labor that a sacrificial gesture was required following Labor's poor showing. It was rumoured that Labor officials favoured dumping Casey as parliamentary leader to make way for the return of Tom Burns, but Casey survived - at least for a little while (The Age, 1 December 1980).

If Labor was disappointed it had not made more headway, the main party to feel aggrieved was the Liberals - as they had run a separate campaign, lashed the Nationals in public and gone backwards in terms of assembly seats. They had lost three seats to the Nationals (Lockyer, Southport and Surfers Paradise). To them, the election result was a major rebuff. The losses could, however, have been much higher given that many of the 'ginger group' Liberals (who had more vehemently attacked the government's record) sat on slender electoral margins - such as Terry Gygar (Stafford), Rosemary Kyburz (Salisbury), Brian Austin (Wavell) and Rob Akers (Pine Rivers). These critics had publicly 
challenged the Premier on contentious issues such as the demolition of the Bellevue and the defeat of the restrictive Pregnancy Termination Bill. Edwards was quick to accept some of the blame, admitting that 'Queenslanders obviously did not want the style of government I had offered them. I am man enough to accept that and I congratulate the Premier on his win' (The Age, 1 December 1980). He also said that the Liberals could not become the dominant party in the Coalition until after Bjelke-Petersen retired because of 'Joh's strong personal vote' (Courier-Mail, 3 November 1980).

In reality two of the Liberal losses were due largely to Labor's change of preference tactics. Labor's decision to shift its preferences away from the Liberals to the Nationals on the Gold Coast resulted in the loss of two Liberal seats to the Nationals: Southport to Doug Jennings and Surfers Paradise to Rob Borbidge. The Gold Coast was beginning to 'go National'-illustrated most clearly by Borbidge's huge primary vote in Surfers Paradise of 41.92 per cent, ahead of the Liberals' sitting member, Bruce Bishop, who managed just 32.83 per cent. Overall, however, the campaign for Labor was not a success. Given the all too obvious feuding within the party, the ALP managed to win just two seats in 1980 at the expense of the Nationals, although they claimed the important ministerial scalp of Max Hooper in Townsville West.

\section{The new ministry}

Immediately after the election, the Premier announced that he would reduce the power of the Liberals in the Coalition. He said the 'Liberals could not expect to retain the same number of portfolios after losing three seats in Saturday's election'. He also tried to lay claim to the prized Treasury portfolio, claiming that '[i]n every other coalition Government in Australia the principal coalition party holds the Treasury. I cannot see any reason why that should not be the case in Queensland' (The Age, 1 December 1980). The Premier was particularly angry that 'ginger group' members had publicly challenged (and crossed the floor against) his government in the previous Parliament, also that many renegade Liberal branches had tried to undermine his sitting members and that Edwards had publicly dissociated himself from the government during the election campaign and attacked him personally. Two ministers confirmed that the Premier had bolstered his right to hire and fire ministers by requiring them to sign undated resignation letters. The Australian ran the story in July 1980, and later Dr Scott-Young recounted:

It was admitted by Messrs I. Gibbs and M. Hooper that to obtain a ministerial position and a place in that exalted sanctum called Cabinet they signed an undated resignation at the direction of the Premier-a 
most honourable man. 'The Australian' of 29 July 1980 contained an article headed 'Joh held resignation letters' which reported that $\mathrm{Mr}$ Gibbs admitted to that and had said that Joh had the right to hire and fire. (QPD 1981:vol. 283, p. 693)

Scott-Young disputed the fact that the Premier had the right to hire and fire ministers; but in reality the Premier was exercising that power.

So, it was a full month after the election (on Christmas Eve) that Bjelke-Petersen announced his new cabinet (his sixth ministry). The announcement followed a protracted set of negotiations around a new coalition agreement. The negotiations confirmed that the Nationals' leader would remain Premier and that the Liberal leader would again be Deputy Premier and Treasurer, but that the ministers would be divided 11 to seven (meaning that of the 18 ministerial positions, the Nationals had secured an additional place at the expense of the Liberals). Although the Premier had indicated that he would cut the ministry by two from 18 to 16 (Courier-Mail, 13 November 1980), he retained the same complement. Three Liberal ministers were demoted to the backbench, each of whom had taken issue with the Premier's leadership. It was further agreed that the Speaker of the House would come from the Nationals (with Sel Muller retaining his position) and the Liberals would provide the Parliamentary Chairman of Committees (resulting in Colin Miller [Ithaca] being elected in March 1981). It was also agreed in the new coalition pact that all legislative and administrative decisions had to be compatible to both parties. Perhaps unsure whether the Liberals would abide by this clause, the Premier spoke of the absolute necessity of maintaining cabinet solidarity in the period ahead.

With a number of ministers retiring (including Ron Camm, Fred Campbell, Nev Hewitt and Charles Porter) and Max Hooper losing his seat, the new ministry had scope for a major injection of new faces. Further scope for change was created by the 'disciplining' of three Liberal ministers who were dropped from the frontbench: Norman Lee, Bill Lickiss and John Greenwood. ${ }^{5}$ So, 10 of the new ministers were novices or had less than 14 months' ministerial experience. Three new incoming ministers who had been appointed in the latter half of the previous Parliament retained their spots (Sam Doumany, Ivan Gibbs and Mike Ahern), and a further seven new ministers were added to cabinet: three Nationals and four Liberals (respectively, Bill Gunn, Bill Glasson and Tony Elliott; and Bill Hewitt, Don Lane, Brian Austin and Terry White). Many of these new entrants would play major roles in the decade ahead, such as Ahern, Gunn, Lane, Austin and White. In all, only four ministers remained in substantially the

5 The first two of whom had also reputedly disappointed Edwards, and the third of whom was 'unceremoniously booted out' for incompetence, according to Kev Hooper (in QPD 1981:vol. 283). 
same portfolio they had held in the previous government (and only eight who had served the full previous term continued as ministers). It was the biggest shake-up of any Coalition ministry since 1957. The full list was

- Premier: Johannes Bjelke-Petersen, NP

- Deputy Premier and Treasurer: Dr Llew Edwards, Lib.

- Minister for Commerce and Industry: Vic Sullivan, NP

- Minister for Justice and Attorney-General: Sam Doumany, Lib.

- Minister for Employment and Labour Relations: William Knox, Lib.

- Minister for Local Government and Main Roads: Russ Hinze, NP

- Minister for Water Resources and Aboriginal and Island Affairs: Ken Tomkins, NP

- Minister for Northern Development and Maritime Services: Val Bird, NP

- Minister for Works and Housing and Leader of the House: Claude Wharton, NP

- Minister for Mines and Energy: Ivan Gibbs, NP

- Minister for Primary Industries: Mike Ahern, NP

- Minister for the Environment, Valuation and Administrative Services: Bill Hewitt, Lib.

- Minister for Transport: Don Lane, Lib.

- Minister for Education: Bill Gunn, NP

- Minister for Lands and Forestry: Bill Glasson, NP

- Minister for Tourism, National Parks, Sport and the Arts: Tony Elliott, NP

- Minister for Health: Brian Austin, Lib.

- Minister for Welfare Services: Terry White, Lib.

This ministry largely of novices was relatively stable until a minor reshuffle in December 1982 (when Vic Sullivan and Ken Tomkins both resigned) and the spectacular meltdown in August 1983. The ministry, however, was far from harmonious. Hinze harboured ambitions to become Premier and had predicted in the campaign that he would be Premier within two years (Telegraph, 24 October 1980), later telling a journalist he would 'take over as premier after the commonwealth games next year' (AJPH 1981:vol. 27, no. 3, p. 392). The scandals and apparent conflicts of interest would, however, constantly impede his elevation, despite the 'rough-cut' minister gaining a reputation for his administrative abilities across a massive portfolio. 


\section{Epilogue to the era: 'Grandpa's Parliament'}

A satirical portrait entitled Behind the Banana Curtain, by journalist Hugh Lunn, tried to capture the flavour of the political culture in Queensland. It depicted the Nationals in the Queensland cabinet as a 'gerontocracy' that was 'as entrenched - and out of date - as ever' (1980:126). His pen portraits of the 10 National ministers had them all WASP men, virtually all farmers, none having gone past high school and all from small rural towns - and with an average age in excess of sixty. Lunn declared that Bjelke-Petersen was 'well past normal retiring age'; Russ Hinze was 'notorious for outspoken statements' that 'made him the best known National party minister after Joh'; Ron Camm was behind Queensland's moves 'to sell everything that can be sold'; Nev Hewitt was a 'man who likes to stay out of the limelight'; Ken Tomkins was amazingly 'the hottest tip in government circles for Joh's job'; Tom Newbery had been demoted from police to culture and recreation and was 'not well known for a man in his position'; Val Bird was the 'youngest' and most likely to prosper if 'his party kicks on in the 1980s'; Max Hodges had been 'shunted to the tourism portfolio and little heard from since'; Vic Sullivan was also 'little heard of in the capital'; and Claude Wharton had 'the widest range of [business] interests' and was 'minister for the big money portfolio of works and housing' (Lunn 1980:123-5). Elsewhere in the book, he mentioned somewhat tongue-in-cheek that Queensland had a 'reputation for barbaric corruption and repressive, malevolent government' (1980:195).

Not surprisingly, similar statements had been made on the floor of the Parliament. For instance, Opposition Leader, Ed Casey, in a supply debate on the eve of the 1980 election, declared the government was past it and that the Assembly had become a 'Grandpa's Parliament'. He continued:

The coalition is old fashioned, guided by bitterness and wowserish carry-overs from a disappearing past. It is a coalition that is out of date, out of touch and past its time. For possibly a few months longer it is a costly situation, for Queenslanders, anyhow, of yesterday's hasbeens fighting each other through the last days of what should be tomorrow's Government. As I said earlier, it has been three years of very bad Government for Queensland. In Queensland, with an election fortunately due, it is not so much a case of 'Dad's Army' as 'Grandpa's Parliament'. (QPD 1980:vol. 282, p. 296)

Most of the government considered Casey did not know what he was talking about. They responded to his barbs by poking fun at Labor's adopted slogan for the 1980 election - 'Labor ready to Govern' - when it was embroiled in a massive factional struggle for control over the party. As Bill Hewitt told the 
House: 'Labor ready to govern! That would have to be the sick joke of the decade' (QPD 1980:vol. 282, p. 31). It was perhaps not the 'joke' they had in mind, and not the 'joke' that would come to dominate the politics of the 1980s. 



\section{The government's legislative program, 1968-1989}

Between 1968 and 1989, the Queensland Parliament passed a total of 1715 legislative acts - an average of 81 pieces of legislation a year. While most of the bills presented were routine amendments to existing legislation, 500 entirely new statutes (principal acts) were also passed. The first full Parliament under Bjelke-Petersen's term as Premier (sitting from August 1969 to December 1971) saw 162 legislative acts introduced, but this rose steadily throughout the 1970s and 1980s, culminating in the forty-fifth Parliament (1987-89)-largely outside Bjelke-Petersen's time in office-when 316 pieces of legislation were introduced. This late flurry of activity, which included 111 new principal acts, was induced largely by the new Premier, Mike Ahern, who professed a personal commitment to substantive reform. Moreover, towards the very end of the Parliament, much new legislation was introduced primarily as a consequence of the Fitzgerald Inquiry. Although Bjelke-Petersen's Premiership is often remembered for its more extreme actions, ${ }^{1}$ the government passed many more acts of an uncontroversial nature, dealing with the routine concerns of government.

It will surprise some to discover that the government also introduced a raft of progressive legislation, but with a conservative twist, in areas such as children's services, public health, consumer protection, protection against the invasion of privacy, the provision of legal aid, the establishment of a small claims tribunal, a huge boost to cultural infrastructure (authorised by cabinet in 1969 when the decision was made to co-locate four creative institutions in the Queensland Cultural Centre) and the right of women not to be required to have to state their marital status in official transactions or in the context of employment (first introduced in 1975). Other areas, however, did not fare as well: Indigenous affairs were either neglected or patronised; community services and community facilities were not generally seen as government responsibilities (unless they were for sporting groups); there was disdain shown towards land-use planning or even ensuring new suburban areas had basic services; the environment was seen as something to exploit and in politics responsibility for the portfolio was pushed from pillar to post; leisure activities were off the radar; and liquor licensing and retail trade were heavily regulated to the detriment of consumers.

1 Such as banning street marches, conducting raids on abortion clinics, banning publications and other forms of extreme censorship, declaring states of emergency and his indifference to heritage protection, thus allowing the bulldozing of historical buildings. 
During the period covered in this chapter, the most marked increase in the number of legislative acts came from the Justice and Attorney-General's portfolio (some 347 acts in total), due in large part to the demands for regulations and legal safeguards that were increasingly accepted as the norm in modern society (but also the activism of Attorneys-General Delamothe and Knox). During this time, the Queensland Parliament introduced several acts that were a first for the state and, very occasionally, a first for Australia, including pioneering consumer protection legislation, financial management legislation, the abolition of succession and gift duties and the establishment of a state ombudsman in 1974. The other policy areas attracting considerable legislative attention were works and local government, development and main roads, primary industries, Treasury, health and home affairs, and labour and industry.

This chapter deals mainly with the record of the Bjelke-Petersen governments (1968-87). Towards the end of the chapter is a section dealing with the legislation introduced in the two years of the Ahern-Cooper government (1987-89). During this entire period, the government detailed its legislation in successive handbooks called the Record of the Legislative Acts, listing important legislation passed in different parliamentary sessions. These handbooks record legislation according to the minister charged with its introduction and administration. Generally this chapter follows a similar approach to categorise the range of legislation, but using headings similar to those used in Chapter 5. First, it discusses legislation of a political, legal or administrative nature, including changes to electoral laws, law and order issues, public administration and local government. Second, legislation pertaining to economic and state development is examined-not only towards the traditional major industries of mining and primary industries, but towards exploring newer employmentoriented industries such as tourism and in areas of regional development. Third, industrial relations and work-related legislation is discussed, before examining transport, infrastructure and the environment as the fourth area. Fifth, the areas of education, health, social policy and legislation relating to Indigenous peoples are explored. Finally, the Ahern-Cooper section records their most important contributions in this much shorter, but important period.

\section{The unicameral sausage machine and the difficulty of adequate scrutiny}

Many individual pieces of legislation passed by the state government during this period might now appear mundane - for example: the Margarine Act restricting market access of the product while seeking to have Queensland's products sold in southern states; various rezoning acts passed to override local 
councils; approval for flood mitigation; and specific legislation such as the Dividing Fences and Another Act Amendment Act in 1982 setting out neighbourly responsibilities for boundary fencing. They were in fact important statements of law clarifying or accepting responsibilities, while also proclaiming certain requirements, rules, processes and the rights of appeal applying to citizens, interest groups or the wider community. In the early years, some examples of uniform legislation were introduced (draft laws proposed and agreed by every state and the Commonwealth) as with the Marketable Securities legislation of 1970. Legislation was also needed to alter the number of ministers, to change the salaries of politicians, judges, the Governor and the Auditor-General, and even to set fire brigade insurance levies. This type of 'required' statute was sometimes referred to as 'machinery legislation', but this routine passing of required laws still occupied considerable time in the Assembly, which did not meet all that regularly and sometimes not for six or seven months at a time.

The debates accompanying the various readings of a bill varied enormously in efficacy - with the quality of the contributions usually dependent on three dimensions: how controversial or important were the proposed measures; how seriously did the opposition or government members prepare or research the provisions; and whether the opposition was briefed or consulted at the drafting stages of the bill or was merely presented with the final text in the Assembly as a fait accompli. An example of good practice was in relation to the preparation of the Consumer Affairs Bill, for which a tripartite committee of MPs from each of the main parties (assisted by two officials) undertook public consultations and produced a joint report before the drafting of the bill (see QPD 1970:vol. 254, p. 1175). Such consultative exercises were, however, the exceptions not the rule. Sometimes the debates could be as fierce as those interchanges occurring during question time (the traditional time allotted each day in the Parliament during which the Chamber more often than not resembled an adversarial jousting match). Industrial relations legislation often evoked the fiercest and most passionate debates, especially as it usually impacted intensely on Labor's primary constituency: the unions. Debates in the Chamber could, however, also meander far and wide, departing from the main provisions of the bill and introducing totally tangential issues. It might be euphemistic to regard these debates as 'scrutiny'. With no upper chamber to provide an alternative source of criticism, the opposition frequently chose to use its allotted time to speak to bills obliquely. Members raised issues other than those relating to the legislation specifically in front of them. As a result, the Speaker, or more generally the Chair of Committee, routinely had to call the House to order and ask members to return to the provisions of the bill. Legislative debates were pitted with interjections and complaints from the opposition and, post-1983, some Liberals about the government's tight control of the agenda or the Speaker's rulings defending the government's chosen course of action. 
Complaints were commonplace about restrictions in the Parliament that prevented adequate scrutiny. Specifically, members on the opposition benches constantly argued about the constraints of parliamentary procedures, including the government's tactical use of Standing Orders. Amendments from the floor were occasionally made but rarely accepted. At times, the government would rush through legislation in a few days - sometimes insisting on all three readings occurring on the same day. The government could (and did) close off debate at almost any time, by moving a 'gag' motion, moving that 'the question be now put' and using its numbers to ensure the termination of debate. The Parliament at times resembled a relentless sausage machine. Allegations were also made that bills were placed on the table without sufficient time being allowed to enable proper scrutiny. Such was evident, for example, in the lack of notice given to the opposition in the debate on the Wheat Industry Stabilization Act Amendment Bill in 1969. On this occasion, the Opposition Leader, Jack Houston, was not given early access to the bill and was forced to ask a question based on reports in the Courier-Mail. After being given assurances from the Minister, John Row, that the media reports were accurate, Houston then proceeded to comment on the bill using these media reports as a basis for his comments (see QPD 1969:vol. 251, p. 1031). There was no time to consult, consider, analyse, research or contemplate alternatives. The government regarded the opposition's contribution as little but 'hot air' that had to be endured to secure the passing of the legislation. Another example occurred during the Building Societies Act Amendment Bill (No. 2), when Labor's Kev Hooper complained: 'we have not been given time to peruse the Bill. It has been impossible to study it in the two or three minutes of the division' (QPD 1976:vol. 271, p. 528)! Such legislation was hardly politically sensitive or controversial, but the opposition was not given the opportunity to peruse the bill until it was presented to the House. During the period covered by this chapter, this became a more frequent complaint of the opposition, and tended to be most pronounced with bills that involved development, agreements with specific companies or tourism ventures.

Often legislation was introduced late in the sessions, leading to the Parliament sitting until the early hours of the next day to complete the necessary stages of debate (especially towards the end of the Bjelke-Petersen era). For instance, debate on the Queensland International Tourist Centre Agreement Act 1978 (the Iwasaki integrated resort legislation) lasted until well after dawn the next day. Terry Gygar (Lib., Stafford) would later reflect: 'I well recall not having to turn on the headlights of my car the next morning as I drove home after a very bitter, wide-ranging and somewhat acrimonious debate' (QPD 1989:vol. 312, p. 5174). Again, such practices resulted in repeated criticism that the Queensland Parliament was not a legislature in which complex changes to the law received due attention. In 1979, Keith Wright (ALP, Rockhampton) used the time in the Queensland Law Society Act and Another Act Amendment Bill to make the 
point that the Parliament seemed to be 'operating blindly', with sudden changes to the 'Orders of the Day' meaning that ministers were introducing legislation that the opposition was not expecting (QPD 1979:vol. 278, p. 4417).

The hasty or chaotic processing of legislation often resulted in additional amendment bills being introduced only months after the proclamation of the initial legislation. This was a common pattern. Errors, oversights, poorly drafted sections, the lack of adequate consultation or changed intentions were all causes of subsequent amendment legislation. Ed Casey complained specifically about this problem during the Fishing Industry Organization and Marketing Act Amendment Bill, stating:

An examination of the Business Paper shows that eight or nine Bills that are listed on it make amendments to legislation that was before the House only 12 months ago. That legislation, of course, was rushed through Parliament. Just as is happening at present, at that time Parliament was in its crazy season of sitting till half past 2 or 3 o'clock in the morning, followed by a sitting all next day and sitting again at night. (QPD 1983:vol. 290, p. 3712)

At other times bills were passed (and even assented to) but then allowed to sit without being proclaimed. While occasionally this was a deliberate ploy of the government to delay or ignore legislation it no longer wanted or needed, sometimes it was due to a ministerial slip. One example of the latter occurred in 1972 when the Minister for Works and Housing, Max Hodges, admitted that the proclamation of the Police Act Amendment Bill of 1972 that supposedly enabled married women to remain as police officers had been 'overlooked' (probably because male offices were hostile to its intention to provide equity to women officers). On the reintroduction of the legislation, Hodges asked the Parliament to forgive him for this oversight (QPD 1972:vol. 260, p. 1519).

If the Parliament lacked the time, the opportunity and sometimes the will to scrutinise legislation before it was made law, the public was no better off in being able to scrutinise government laws. A Liberal backbencher, Ian Prentice, raised the issue in 1982 of how many Queensland acts were currently out of print and not available for public scrutiny. He was told that there were then more than 940 separate principal acts of Queensland on the statute books (and many of these had been amended umpteen times), but that only about 650 were available and in 'common usage'. To keep up to date with an act at any point in time members of the public would have to attach various amendments to the main body of the act and note the new or overriding sections. Occasionally the government produced consolidation acts, which brought all the amendments together in one piece of legislation-largely for the convenience of public 
servants trying to administer the acts. When recently consolidated acts were not available, Members of Parliament would complain of the difficulties of keeping abreast of the detail. Labor's Fred Bromley pointed out in 1972:

I think it would be fair and reasonable, particularly when consolidated Acts are not available, if Ministers provided shadow Ministers with photocopies of all amendments since the Act under consideration was last printed. Surely that is not too much to ask...We are supposed to do our homework on Bills and criticise where necessary and give credit where it is due. Without a consolidated Act, honourable members can imagine the work that I and my [Labor backbench] committee had to do. (QPD 1972:vol. 260, p. 2571)

Legislative debates often provided opportunities for political differences to be aired in more humorous or light-hearted exchanges. Many members tried to put an occasional wisecrack or pun, a little parody or a pithy turnoff phrase into an otherwise non-memorable speech. For instance, during the debate on the Badge, Arms and Floral Emblem of Queensland Act Amendment Bill, Labor's Doug Sherrington suggested that in place of the chosen koala as the state's faunal emblem, a more fitting one for the government would have been '[a] kangaroo, hotly pursued by a shooter, dashing over a strip of beach that had been destroyed by sand-miners, and looking out towards a Barrier Reef liberally straddled with oil rigs' (QPD 1971:vol. 256, p. 2773).

His suggestion was ignored.

Particularly in the Coalition's early period in office, much of its legislation was geared towards the interests of its rural constituencies. With a strong developmental policy mind-set - which viewed almost any development as a good thing in itself - the government's legislative program centred on the expansion of the state's extractive-resource industries (and any potential ones that might seem viable), as well as the sustainability and development of the agricultural and pastoral industries. Facilitating the establishment, and then later the huge expansion, of the state's export coal industry was an especially high priority of the government and received considerable legislative attention (as well as backroom negotiations and infrastructural calculations; see Galligan 1986; Stuart 1985). Most major mining ventures were provided for with special enabling legislation. The government also sought to permit sandmining on Fraser Island (until it was prevented by the Federal Government) and constantly mooted the possibility of oil exploration on the Great Barrier Reef. Landownership and land-use issues (especially converting leasehold land into freehold land on favourable terms) were other areas of much statutory interest. 
Bjelke-Petersen's legislative program was, however, never confined solely to the interests of the rural sector and the development of the state's primary industries. During his Premiership, Bjelke-Petersen oversaw an expanded tertiary sector (higher education had been long neglected in Queensland and much of this legislative activity was motivated, now the Commonwealth was paying, by an endeavour to catch up with other states). His government introduced consumer protection legislation and oversaw an increase in the state's national park estate. The artistic, literary and curatorial institutions that had long struggled in their existence were provided with plush facilities alongside the Brisbane River. Medical research institutes were established. Notably, the government also introduced legislation to allow controversial tourist developments in national parks and on islands along the coast. It also adopted a strong law and order stance with regard to industrial disputes and strikes (not unlike its predecessors) but extended this approach, after the Vietnam War, to apply to students and radicals, who were prevented from demonstrating. The government was not easily deterred from any course of action it embarked on and was not against initiating legal action against citizens, students, environmentalists or unionists threatening to stand in its way.

Any legislation that concerned politicians' pay and conditions was inevitably controversial in the wider community, but, unsurprisingly, not so in the Parliament itself. ${ }^{2}$ The media used such pieces of legislation to highlight the perception that politicians were self-serving. Parliamentary salaries (and those of associated professions) were constantly upgraded, even in times when wage restraint was expected of the wider community. While the parliamentary superannuation scheme had been in operation for decades (since 1948 on a voluntary basis), Premier Bjelke-Petersen had notoriously decided not to join and contribute. When introducing an amendment to the Parliamentary Contributory Superannuation Act in 1971, making it compulsory for new members, he was happy to remind the House:

I am completely dispassionate about amending the Bill because I am the only member in the House to whom it does not apply. As a noncontributor to the parliamentary Superannuation Fund, I want it clearly understood that none of the implicit benefits that the bill bestows on members will be available to me or to my family at any time in the future. (QPD 1971:vol. 257, p. 1328)

In later years, Bjelke-Petersen attempted to gain access to the benefits of the lucrative superannuation scheme retrospectively (seeking to not only join but be backdated to when the scheme was first introduced). He sought approval

2 See, for example, the Constitution Acts Amendment Bill (QPD 1982:vol. 288, p. 1082) or the Parliamentary Salary Bill (QPD 1988:vol. 308, p. 5690). 
from the trustees, but they deemed this request inappropriate and turned him down. The Premier might have dropped the subject with his parliamentary colleagues, but this rebuff and his apparent lack of retirement income were often given as part of the reason for his using his public office to skim other monies from developers and others seeking favours, and for initiating defamation cases against critics or media outlets. He was, according to his wife, Flo, not very good with money (Bjelke-Petersen 1990:59). By the 1980s, colleagues with far fewer years of service then Bjelke-Petersen were retiring from the Parliament with generous lump-sum payments; it would be remarkable if he failed to feel some degree of envy as he made their valedictory speeches.

Table 12.1 indicates the legislative record of the Bjelke-Petersen, Ahern and Cooper governments from 1969 to 1989. Table 12.2 categorises this statutory record according to the main portfolio areas or policy sectors the legislation addressed.

Table 12.1 Total number of acts passed in each parliament, 1969-89

\begin{tabular}{|l|l|l|l|l|}
\hline Parliaments & $\begin{array}{l}\text { Number of } \\
\text { legislative acts }\end{array}$ & New acts & $\begin{array}{l}\text { Amendment } \\
\text { acts }\end{array}$ & Repeal acts \\
\hline 39th 1969-71 & 162 & 42 & 120 & 0 \\
\hline 40th 1972-74 & 205 & 64 & 140 & 1 \\
\hline 41st 1975-77 & 237 & 74 & 163 & 0 \\
\hline 42nd 1978-80 & 225 & 60 & 162 & 3 \\
\hline 43rd 1981-83 & 247 & 59 & 179 & 5 \\
\hline 44th 1984-86 & 288 & 90 & 199 & 1 \\
\hline 45th 1987-89 & 316 & 111 & 199 & 6 \\
\hline
\end{tabular}


12. The government's legislative program, 1968-1989

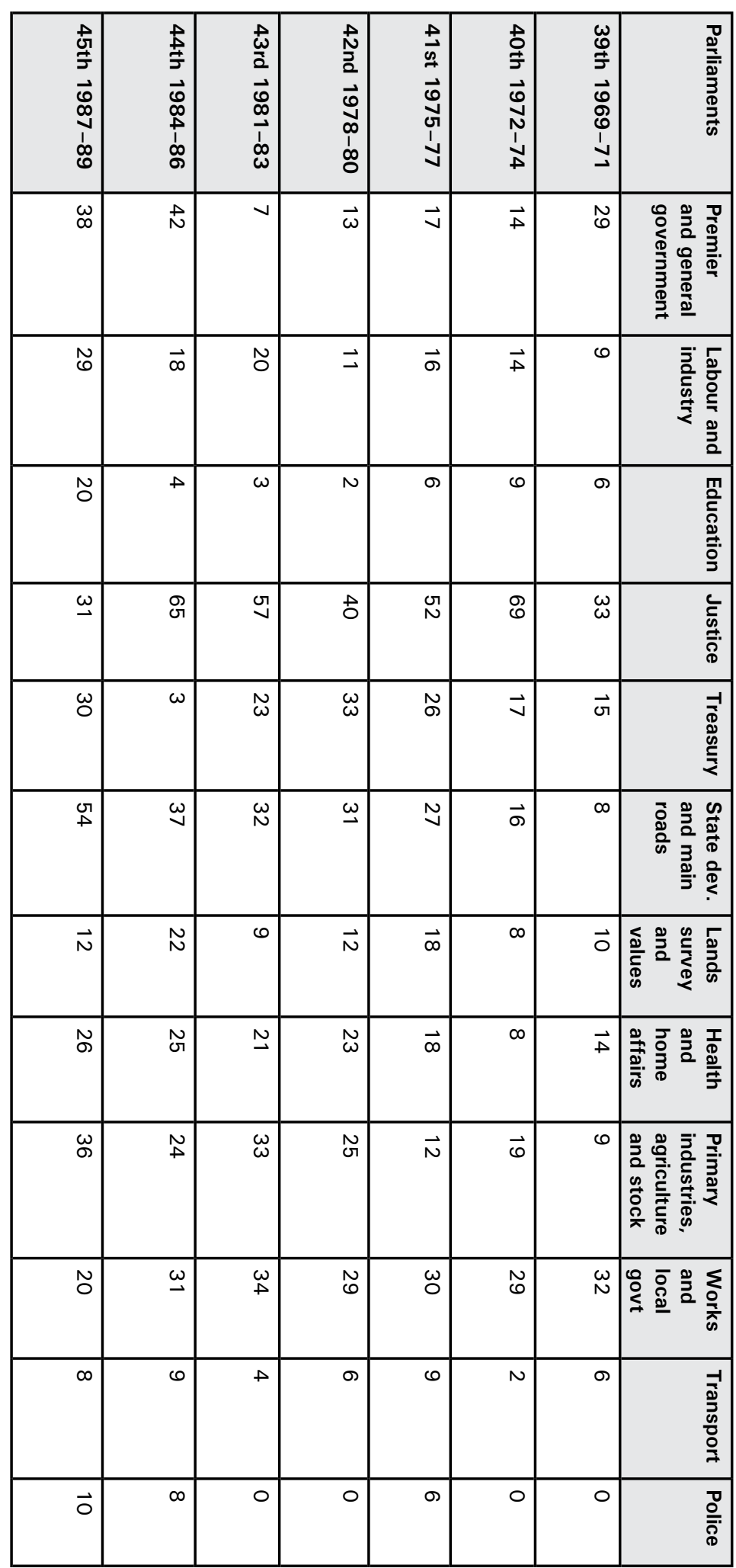

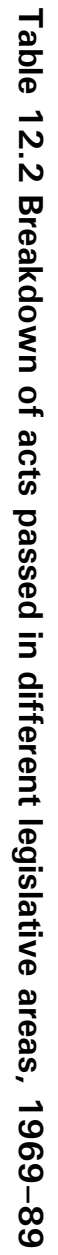




\section{Political, administrative, electoral and law and order legislation}

\section{General government, public administration and local government}

The Coalition government made three amendments to the Officials in Parliament Act, resulting in expansions of the ministry. First, Frank Nicklin increased his ministry by two in 1963 from 11 to 13, then Bjelke-Petersen increased it to 14 in 1969. After the landslide election of 1974, a major increase occurred with the Officials in Parliament Amendment Act 1975 that took the ministry from 14 to 18 members. It was argued that the measure was designed to help deal with the increased workload on the executive while providing ministerial representation to every region of the state. The Premier appointed two Nationals and two Liberals to add to his ministry, thus preserving the National Party's dominance over the Liberals in future cabinets (having eight ministers to six).

Bjelke-Petersen was outraged when the federal Whitlam government sought to remove the right of all Australians to appeal to the Privy Council in the United Kingdom. This move would have ended the rights of Queenslanders to appeal against the decisions of the state Supreme Courts. Whitlam's unilateral move - supported by the British government - sought to repeal parts of the state's constitution to allow this to occur, but the way it was attempted caused controversy. The Premier considered the move was ultra vires and argued that such a step could be done only by a Queensland act, by federal referendum or by joint agreement - but not by fiat. Other state governments reacted angrily to this move, but the Bjelke-Petersen government took matters a step further by introducing the Appeals and Special Reference Act 1973, which explicitly provided for appeals and references to the Privy Council from Queensland courts, bypassing the federal level. In introducing the bill to the Parliament, the Premier stated:

It is one of the most important measures ever to come before this Parliament because it involves the fundamental rights of this House, of Queensland and of Queenslanders. The issue - that of appeals to the Privy Council-is almost incidental. The real issue is the right of Queenslanders to decide this question for themselves and not have it decided in an unconstitutional manner by the Commonwealth Government. (QPD 1973:vol. 262, p. 49)

The effect of this state legislation was short-lived. While the Whitlam act had abolished appeals from the federal courts, and was supported by the Fraser 
government, appeals from state courts to the Privy Council were abolished by the Australia Act 1986, passed by the Commonwealth Parliament in the Bob Hawke era.

A further sign of distrust between the Queensland and Commonwealth governments was evidenced in the Treaties Commission Act 1974. The purpose of this act was to provide the Queensland Parliament with an advisory body to assess the impact on Queensland of existing and future treaties that had been ratified by the Commonwealth Government. With the Whitlam government in Canberra committed to an activist program of social justice, ratifying numerous international treaties, many of which sought to legally enshrine minimum standards of civil liberties, human rights and the status of women, the BjelkePetersen government sought expert advice on those matters that affected the implementation of these agreements domestically and impinged on its own constitutional authority. It was a sign the state government wished to be forewarned about the consequences of various international treaties. It was also a measure to curtail the Commonwealth's appetite for negotiating and ratifying treaties by highlighting the political or administrative difficulties ahead of time.

In recognition of the increased complexity and growing demands on the public service, the Public Service Amendment Act 1968 restructured the Public Service Board to enhance its leadership and management at the top. The act amended the previous legislation that had operated since 1920 requiring a single commissioner to head the board, and replaced it with a board consisting of three commissioners to oversee the service. This act also removed the 'marriage bar', which required women to resign from the service in the event of getting married, and made other changes to the appeals processes operating in the service (a perennial niggle among public servants). Further amendments were made in 1973, establishing three deputy commissioners, one serving under each commissioner, to share the leadership load, but the act then had to clarify the relations and lines of authority between these new posts and those of the other three commissioners. The Public Service Superannuation Act Amendment Act 1968 also provided for an increase in a number of benefits and payments available to the state's public servants under the scheme. This act was twice further amended in 1974 increasing the rates of pension benefits (in a time of increasing inflation) from the standard 3 per cent increase to a 6 per cent increase in 1974, and tying future changes to the consumer price index, as well as revising the benefit provisions for early retirement. A new superannuation scheme was introduced in 1974 for members of the state Police Force, moving from the old 'unit' contributory scheme to a formula based on the final salary and length of service.

The pioneering Parliamentary Commissioner Act 1974 was passed, creating the position of the first state ombudsman: the Parliamentary Commissioner of 
Administrative Investigations (to which post David Longland was appointed). He began service on 1 October 1974. The role of the Ombudsman was to undertake investigations into administrative decisions or recommendations across all government departments (except the police). The commissioner was given wide powers of access and authority but could not overturn a cabinet decision or one made by a minister. The Ombudsman could investigate any complaint and review the basis of the decision to ascertain whether it was illegal, unfair, unjust, oppressive or unreasonable, but had only recommendatory powers of correction or recompense. The Ombudsman could not change any faulty or unjust decision, and could only merely inform the original officer who had made the decision of his/her findings and recommend an alternative course of action. If a department did not comply or satisfy the Ombudsman with its subsequent actions or reasons, the commissioner had the right to send a report on the matter to the Premier and also to the Legislative Assembly (hence the title Parliamentary Commissioner of Administrative Investigations).

In 1977, the government passed further pioneering legislation underpinning the system of financial management in the public sector. It was a comprehensive and significant reform well ahead of its time. The Financial Administration and Audit Act 1977 had three important tenants

- the executive is accountable to the Parliament for the use of public moneys as it receives those moneys only in trust for purposes specified by the Parliament

- the administration, acting for the Crown, in accepting that trust, accepts the responsibility for reporting to the Parliament as to how it has managed those moneys

- an independent person-namely, the Auditor-General-must assure the Parliament that the accounts and financial reports of the administration are true and give a fair, objective and accurate picture of whether the given responsibility has been satisfactorily discharged (QPD 1978:vol. 276, pp. 3021-2).

The legislation adopted the 'accountable officer' model whereby the administrative head of a department or agency was personally responsible for all public monies entrusted to him/her. The Opposition Leader at the time, Ed Casey, did not show a great deal of understanding of the implications of the bill or its likely implementation across government. He opposed the bill on the spurious grounds that it would, he believed, 'make the parliamentary system of this State subordinate to a Cabinet that should be answerable to it'. This was because under the act the Premier was legally the accountable officer for the financial management and expenditure of the Legislative Assembly (and not the Clerk or the Speaker because those officials were not part of the executive). He thought that if the bill was enacted, it would strip the Parliament 'of its independence; to, in practice, reduce it in rank to a mere sub-department within the Premier's 
Department, with the eccentric Premier that we have in Queensland today as its financial master' (QPD 1979:vol. 276, p. 3024). In the full extent of the bill this was a relatively minor or technical point, which missed the bigger picture of the reform to the state's public finances. It is likely this bill, and the 'accountable officer' model it was premised on, was designed for the government by Treasury staff such as Leo Hielscher.

\section{Electoral district laws and redistribution legislation}

Three electoral redistribution laws were introduced during the period this chapter covers - namely, in 1971, 1977 and finally in 1985 (and the politics involved in all these exercises are discussed in detail in the relevant chronological chapters of this volume). Election legislation was guaranteed to inspire heated debate across the Chamber as it affected every member's own chance of re-election (and their future as a politician) and the relative advantage or disadvantage their party would experience at forthcoming elections. All three pieces of legislation split the state into four zones (south-eastern; provincial cities; country areas; and the western and far northern areas). The main differences between the acts were in the number of seats allocated to each zone (with major changes in 1971 and 1985) and the size of the electoral quota determined differently for each zone. Table 12.3 indicates the weighting relativities across the three redistributions imposed by the government before the commissioners were invited to draw particular seat boundaries.

Table 12.3 State electoral redistributions, 1971-85

\begin{tabular}{|l|l|l|l|}
\hline Year & Zones & Seat quota & Number of seats \\
\hline 1971 & South-eastern & 13212 & 47 \\
\hline & Provincial cities & 13170 & 13 \\
\hline & Country & 10054 & 15 \\
\hline & Western and far northern & 7784 & 7 \\
\hline 1977 & South-eastern & 16368 & 47 \\
\hline & Provincial cities & 15952 & 13 \\
\hline & Country & 11515 & 15 \\
\hline 1985 & Western and far northern & 8586 & 7 \\
\hline & South-eastern & 19357 & 51 \\
\hline & Provincial cities & 18149 & 13 \\
\hline & Country & 13131 & 17 \\
\hline & Western and far northern & 9186 & 8 \\
\hline
\end{tabular}

Note: The quota for the provincial cities is an average as the various city regions each had slightly different quotas. 
The 1971 redistribution was something of a shambles, mainly because some Liberal members were not prepared to endorse the government's initial proposals contained in the Electoral Districts Bill presented by the Premier in March 1971. The Premier said it was a most important bill and that 'a great deal of mature and considered thought had gone into its many months of preparation', indicating that the government did not propose to increase the number of seats, but simply retain the existing 78. After a number of Liberal backbenchers saw the draft bill, however, they indicated they would vote with Labor to amend it more to their liking (QPD 1971:vol. 256, pp. 3227, 3241, 3314, 3335). The renegade Liberal Charles Porter (Toowong) informed the House he could not support the whole bill and that he had drafted a series of amendments he hoped the Premier would accept. Much to the chagrin of the Premier, Porter sought to move an amendment splitting the state into three zones for the 78-seat Assembly (an eastern zone with 66 seats, and a western and south-western zone each with six seats). His own leader, Gordon Chalk, was equally furious, insisting to Porter that:

What is proposed by the hon. Member for Toowong negates the whole of the negotiations which took place among the Premier, the Deputy Leader of the Country Party, the Deputy Leader of the Liberal Party and me. It negates the whole arrangement we had relative to the presentation of this Bill. During the second-reading stage, I forecast that the ALP would vote with a section of the Liberal party to defeat this Bill. I want the people of Queensland to know that the ALP and a number of Liberal Party members, if this is carried, bear responsibility for the defeat of this particular law. (QPD 1971:vol. 256, p. 3391)

When Porter's proposed amendment succeeded narrowly by a vote of 39-38 (with eight Liberals crossing the floor to vote with the opposition), BjelkePetersen immediately adjourned the House.

Then in July 1971, a bill with an identical title was presented to the House. This bill now proposed to increase the number of seats from 78 to 82 as a compromise gesture to the Liberals (QPD 1971:vol. 257, p. 36). In responding to this new bill, Jack Houston reminded the House of past events.

Mr Houston: [The first draft bill] was brought before honourable members, and Parliament decided that it would support the introduction of the Bill. Parliament decided also that the second reading would be agreed to. Then honourable members went into the Bill in detail, and clauses 1, 2, 3 and 4 were passed without amendment. Clause 5 was amended by a vote of the majority of members in this Chamber. At that stage, of course, the Premier rose and said, 'I will have to have a look at this. We 
cannot have this. We cannot have democracy working in this way. I will not have Parliament determining these issues. They have to go along the way I want them to, irrespective of what Parliament determines'...

Mr R. E. Moore: Why didn't you carry on [after the successful amendment] if you had the numbers?

Mr Houston: We did not carry on because some members of the Liberal Party got cold feet and stayed on that side of the Chamber. I know what threats were made; I know what promises were made to one of the honourable member's colleagues. (QPD 1971:vol. 257, p. 37)

The second bill managed to win the support of the wayward Liberals and was passed on party lines in August 1971.

Each redistribution exercise lasted for roughly two to three further elections. In 1977, the number of seats remained the same but the electoral quotas for each zone were increased. This had the effect of preserving the advantage of the less populated zones over the more populous ones, although the margin narrowed slightly. Again, Labor was incensed. Tom Burns knew the Nationals already had their own electoral maps and plans drawn up even before the legislation was passed. He fumed: 'if this Bill [the Electoral Districts Bill] is passed the Premier will be free to redistribute according to his whim. There will be no reference to Parliament, no recourse to law, no restraint whatsoever' (QPD 1977:vol. 272, p. 2469). It was passed and a speedy redistribution was undertaken before the 1977 election.

The 1985 changes to the Electoral Districts Bill were perhaps even more controversial because the Nationals were in government alone and could devise an electoral system entirely of their own making (QPD 1985:vol. 298, p. 4510; see also Chapter 15 of this volume). The main legislative change was the addition of seven extra seats and the increase in electoral advantage enjoyed by the country and western and far northern zones. Four additional seats were assigned to the south-eastern corner, while two additional seats were given to the country zone and one to the most remote far northern zone. No additional seats were allocated to the provincial cities.

Outside the redistribution acts there was only occasional interest in other electoral reforms, mostly of a minor or technical nature. In 1971, an act was introduced to allow easier postal voting and to enable computerisation to be used in the processing of enrolments and production of the electoral roll. Legislation provided for the enfranchisement of eighteen-twenty-year-olds in 1973, in line with federal moves. In 1976, the Elections Act Amendment Act 1976 established a 'principal electoral officer' to help make electoral administration and reporting more consistent. Further administrative amendments were made 
in the Ahern-Cooper period, including minor changes to the act allowing candidates to receive electronic copies of the roll for the seat in which they were standing.

\section{Law and order policy}

No area of legislative activity attracted as much controversy in the BjelkePetersen years as its policies towards law and order. Throughout the almost two decades of Bjelke-Petersen's rule, a significant and increasing share of legislation concerned law and order issues, some of which was aimed at modernising existing laws (such as reform of the state's Criminal Code), but others were aimed more towards political or industrial repression or moral censorship. At various stages, the state's police force and other law enforcement bodies were granted additional powers to arrest or detain. Acts not ostensibly concerned with law and order could become so through amendment, such as with the Traffic Acts, which were amended to attempt to prevent street marches. Over time, the government's emphasis on law and order and its tough stance against protesters and unionists were seen by many as undemocratic and eroding individual civil liberties. Bjelke-Petersen's critics contend that with each passing parliament, Queensland came ever closer to an authoritarian, police state.

Interestingly, some of the government's toughest law and order actions were conducted not under enabling legislation but through executive fiat-via Orders in Council signed and authorised by the Governor. On 14 July 1971, the government declared (by proclamation) a state of emergency supposedly to allow the tour of the South African rugby Spring boks to proceed without interruption from expected anti-apartheid protestors. It chose not to pass special legislation. When the House reconvened on 27 July for the opening of the Parliament, the Opposition Leader, Jack Houston, immediately demanded an explanation from the Premier for this unprecedented action. The Speaker was disinclined to allow such an acrimonious debate to spoil the opening ceremony, yet Houston pressed on with his matter of privilege, saying he considered the Parliament to be in session and required an explanation from the Premier, adding: 'The Premier had every opportunity of calling Parliament together earlier and he should have done so. After all, if a state of emergency is proclaimed - something I have never seen done before in this State in similar circumstances...' (QPD 1971:vol. 257, p. 5).

Houston was cut short by the Speaker, who insisted: 'I place on record now that I intend to see that this Parliament runs in accordance with the decorum to which it is accustomed' (QPD 1971:vol. 257, p. 5). He had to wait to fight another day. The state of emergency power was used again in the electricity dispute of 1985 (see below). 
Legislation focusing specifically on the police as an organisation tended to tinker with structural arrangements or make amendments to certain ranks or classifications of police officers. Various policing acts sought to reorganise limited aspects of policing, change job titles or rank structures (and roles), create additional senior posts, adjust retirement ages and provide for internal appeal mechanisms for promotions, dismissals and demotions. In 1970, amendments contained in the Police Act and Another Act Amendment Act abolished the rank of deputy commissioner, allowed up to three assistant commissioners and urged a complete reorganisation of the force to strengthen supervision at the most senior levels. In 1977, however, further amendments were made to restore the rank of deputy commissioner in addition to those of assistant commissioners. Women officers who chose to get married were permitted to remain in the force after 1973. Adjustments to police superannuation were also regularly revised by statute. Photographs taken by police were also allowed under the Police (Photographs) Act Amendment Act1976 to be tendered as evidence in any legal proceedings undertaken by any court or tribunal. Most police enforcement powers were provided under a combination of other acts, such as the Criminal Code and Traffic Acts, Illegal Drugs or Drugs Misuse Acts, Domestic Violence Acts, Vagrancy Acts and, at the very end of the period, random breath testing legislation.

Yet it was the laws that impinged on the citizen's right to protest against the actions of the government that consolidated the government's reputation as tough, undemocratic and authoritarian. Amendments to the Traffic Act in 1977 were among the most controversial law and order amendments introduced in the Parliament. The act did not prohibit protests or prevent people congregating to demonstrate (for instance in a public park), rather it removed the right of protestors to appeal to a magistrate when a decision had been taken by police to refuse a permit to march on streets. All citizens, the government argued, had to have free and open access to streets and footpaths at all times (but presumably not protesters). The act specifically required intending protesters to apply for a permit to march (which would be refused by traffic police) and made it illegal for protesters to march without a permit or after one had been refused. An independent magistrate in court could no longer consider an appeal against a refusal, and instead this new amendment restricted appeals solely to the Police Commissioner, who was unlikely to overturn the decision of a fellow senior officer. In reality, the law gave police the right to ban street marches and effectively ended any right to appeal against their decision. The appointment of Terry Lewis as Queensland's Police Commissioner in 1976 meant that the government now had a force aligned with its interests, which would actively curtail what should have been legitimate forms of protest. Although this amendment would become notorious as the 'street march ban', it was 
introduced into the Parliament without notice and was hastily added to the business sheet for debate one day after lunch. When the surprise introduction of the amendment to the Traffic Act was announced, Tom Burns complained:

I am no longer surprised when we are brought back for a special afternoon or a few hours to rush some legislation through the Chamber. I am no longer surprised when I find that the Minister in charge of the House can come around in the morning and say, 'This afternoon we will be debating the evidence legislation and rape laws', and then find after lunch that we are debating a rather arrogant and dictatorial move to remove some rights of free speech and assembly. (QPD 1977:vol. 273, p. 610)

Law and order remained a high priority in particular because it was interpreted as electorally popular. Bjelke-Petersen often referred to protesters as communistinspired layabouts, anarchists, no-hopers, drug-users and hippies. The government constantly wished to appear to be tough on crime - or at least on visible crime and any intent of public disruption. Increasingly, the government would consider the judiciary soft on sentencing and imposed mandatory life sentences for certain offences. When debating the tougher penalties proposed in the Drugs Misuse Act Amendment Bill of 1989, the opposition highlighted the absurdity of 'having the most draconian legislation in Australia when there are not the police resources to adequately investigate the drug trade' ( $Q P D$ 1989:vol. 311, p. 3984).

Not all legislative measures concerning law and order were equally problematic. Many acts simply consolidated existing laws that were no longer relevant to a modern society. The government was prepared to enact the Law Reform Commission Act 1968 establishing the Law Reform Commission as a permanent body tasked with reviewing the state's laws and with consideration of any proposals for their repeal or reform. Although the government was enthusiastic in establishing this commission, it did not always choose to listen to its advice and many of its reports went unheeded. The Criminal Code Amendment Act 1968 inserted provisions into the state's principal crimes act, in this case to assist people who had suffered a personal injury while assisting members of the police force. This legislation also allowed courts to provide compensation to victims of crime. These two pieces of legislation were two of the earliest acts introduced under Bjelke-Petersen's Premiership. They were followed by the Vagrants, Gaming and Other Offences Act Amendment Act 1971, which increased penalties for any person caught publishing, selling or distributing child pornography. During the late 1970s, 25 new and amending pieces of legislation were introduced by the Justice Minister, in this case mainly by Bill Lickiss, 
including a review of the civil jurisdictions of the District and Magistrate's Courts, amendments to the Invasion of Privacy Act and amendments to the Jury Act.

\section{Economic and state development}

\section{Primary industries and rural legislation}

Given the National Party's traditional stakeholders worked on the land and resided in country electorates, it was no surprise that a significant (if largely uncontroversial at the time) component of the government's legislative agenda dealt with primary industries. This legislation established statutory marketing and regulatory boards, imposed quota restrictions or entitlements on producers, attempted to stabilise or fix prices and expressed a range of other regulatory provisions. The main agricultural industries relating to cattle, sheep, wheat, sugar, sorghum and other crops not only made a significant contribution to the state's economy, they were important economic activities in regional communities; they were often the lifeblood of regions. Smaller industries also attracted their own legislation, such as those governing the dairy and poultry producers (the notorious Hen Quota Act), and even deer farmers got their own act in 1985. Queensland's Country/National-led governments continually sought to assist and regulate these industries to protect the interests of farmers and producers. Primary industries were particularly vulnerable to drought, floods, price fluctuations and declining world commodity prices. The plight of Australia's farmers was not helped by Britain's decision to join the European Economic Community in the early 1970s, cutting off a once lucrative market for produce.

The government introduced numerous pieces of legislation to protect or subsidise these primary industries. They would now be regarded as anticompetitive measures or regulatory regimes designed to restrict trade. The wheat industry was assisted by the Wheat Stabilization Act 1968. It provided for the continuation of the stabilisation arrangements for wheat that had operated since 1948, involving quotas on production, consolidated marketing and guaranteed prices. This complementary legislation brought Queensland in line with the Commonwealth and other states. The Wheat Quotas Act 1970 was also part of a national uniform legislative package operating during the 1970s and 1980s. The Parliament was told that because of a steady increase in wheat supplies globally, Australian wheat production would generate surpluses that would be difficult to sell. This act, accordingly, imposed lower production levels on farmers as a means of income maintenance. Such signs of consensus between 
the state and successive federal governments would become rarer as the BjelkePetersen Premiership wore on, with parochial interests keenly promoted over national policy interests.

The Minister for Lands, Vic Sullivan, introduced a range of legislation relating to primary industries in 1970, among the most notable being the various Farmers' Assistance Acts and the Farmers' Assistance (Debts Adjustment) Acts, which provided for financial grants to the industry administered though the State Rural Reconstruction Board. The new board was given the task of inquiring into the problems affecting Queensland's rural industries and then recommending remedial measures. Drought assistance measures were another dimension of such legislative support. Generally these types of legislation did not raise much contention or arouse the ire of the opposition (even if at times the amounts of assistance or the various regulations imposed were contentious with the farmers who would be affected). Even if these bills attracted relatively little contention, they represented, however, a significant component of the legislature's agenda. Occasionally amendment bills could be deployed and debated specifically to occupy time in an otherwise languid session, and perhaps even to distract attention from more contentious legislation or if trouble was brewing within government ranks. They were politically innocuous pieces of legislation that would produce 'good news' stories for primary producers back home.

Over time, bills were introduced to help producers quit the industry as production methods improved and pressures to rationalise began to occur. For instance, the Marginal Dairy Farms Reconstruction Scheme Agreement Act 1970 ratified an agreement between the Commonwealth and state governments to assist low-income dairy farmers to exit the industry. While the opposition accepted the bill itself, its spokesman, Hughie O'Donnell (Belyando), could not resist alluding to the political tensions in the government's ranks, noting this non-urgent bill had been pushed up the business sheet. He mused:

[I]f it is part of the Government's psychology, in not wishing a rather tense situation to develop in the political atmosphere, that we have seen introduced this afternoon a couple of placid issues designed to tone down any recriminations that might arise on other legislation that could have been discussed because of its earlier placing on the Business sheet. (QPD 1970:vol. 254, p. 1306)

The bill had more to do with the internal politics of the Coalition than it had to do with marginal dairy farmers. The next day, the Opposition Leader, Jack Houston, moved a want-of-confidence motion in the Premier on the grounds that he 'obviously no longer has the support of the majority of members of the coalition parties' (QPD 1970:vol. 255, p. 1329). Politics was not far from the surface in even the most innocuous legislation. 
In the 1970s and 1980s, significant restructuring and deregulation began to occur across many primary industries as the restraints on competition and the reliance on quotas and other market constraints came under attack. Older forms of barrier protection or subsidy were gradually dismantled (as were tariffs on imported goods in the wider economy). Queensland was not at the forefront of such liberalisation and often sought to resist or maintain other forms of marketing assistance. Product-specific legislation was introduced to assist producers in the restructuring process. So, if one type of barrier protection or market-fixing assistance was discouraged, other forms of newer assistance could be opened up. An amendment to the Meat Industry Act in 1977, for example, sought to assist the state's livestock industry, especially the struggling beef industry, by providing for the creation of a new Queensland Meat Industry Organisation and Marketing Authority to help with management and marketing. That same year, the Milk Supply Act 1977 provided for a number of important changes to the dairy industry after considerable lobbying from producers over sales and prices for milk. After the collapse in the price of sugar on world markets during the mid-1980s, amending legislation to the Regulation of Sugar Prices Act was introduced in 1986 to help Queensland's sugar industry adjust to the changing global economic conditions. Sugar was a much-valued crop and processing industry, especially for northern Queensland, and any legislation dealing with sugar usually invited considerable debate about how the north of the state was ignored by the more populated south-eastern corner.

Pests and so-called 'exotic diseases' were a constant threat to primary industries. The main concern - besides trying to prevent or contain the outbreak of diseases in livestock - was about compensation for farmers affected. Legislation was introduced in the late 1960s to compensate farmers affected by a particularly virulent contagious disease in cattle, as with the Foot and Mouth Disease Expenses and Compensation Act of 1969. After the outbreak of further diseases serious to livestock during the late 1970s, the government passed an amendment to the Stock Act, which provided for enhanced animal disease-prevention measures. Three years later, the government introduced a new act into the Parliament: the Exotic Diseases in Animals Act 1981 to allow for the rapid implementation of a set of measures to control and eradicate outbreaks of exotic diseases in animals, as well as to provide compensation for the owners of animals that had died as a result of disease outbreaks. The Plague Grasshoppers Act in 1971 was another that provided for the development of eradication plans for locusts plaguing the agricultural industries. Rabbit control was also a topic of legislative activity that stipulated which poisons could be used and under what circumstances. 
Much of the government's legislative activity directed at the primary industries now appears to have been reactive and ad hoc, dealing with and designed to assist any crisis as it occurred. The Queensland Parliament was not often regarded as an anticipatory or innovative legislature.

\section{Mining and resources legislation}

Some of the most controversial actions of the Bjelke-Petersen government concerned its attitude towards mineral resources. Indeed, 'development' became almost a pathological mantra of the government and often seemed to take precedence over other policy areas (such as education or social welfare). The minutes of cabinet meetings in the early 1970s indicate economic development (especially in the mining and resource-rich regions) was the main focus of many meetings (see Richards 2005:3). This focus on resource development was a continuation of the policy priorities of the Nicklin government, but conducted at a greater pace. The Bjelke-Petersen government was anxious to demonstrate its responsiveness to the needs of mining firms, petroleum companies and other diverse consortia interested in investing in coal. The government provided and funded the necessary infrastructure and other facilities needed to allow the transportation and export of resources (few resources were in fact consumed or processed in the state); this was part of the deal to encourage companies to conduct exploration and invest. The Premier and his ministers were constantly on the lookout to find new ways to encourage foreign investment in the state with the idea of spurring development, and would frequently make overseas trips to promote investment opportunities. Bjelke-Petersen's ability to attract these investors would become legendary. The alleged favours many in his government received in return, dating from the initial years of his premiership, would prove to be increasingly controversial as the years wore on.

The development of the state's export coal industry (both steaming and coking coal) was a top priority, with the exploration of the coal-rich Bowen Basin and its coal seams amenable to the new techniques of open-cut mining. With the rapid postwar development of Japan's steel industry (and subsequent demand for coking coal), combined with Australia's significant freight-cost advantage over other competitors, due to its proximity, the export coal industry boomed in the late 1960s and throughout the 1970s. These were the days of mega-profits for firms such as Utah, Comalco, CSR, Thiess Peabody Mitsui, Alcan, Mount Isa Mines and later BHP, and many of their mining ventures were established under special enabling legislation. An early example of the government's focus on the export coal sector was seen with the introduction of the Central Queensland Coal Associates Agreement Act 1968 authorising the government to enter into an agreement with a business consortium to develop the Goonyella coalfield owned by Peabody. Such agreements codified commitments from private companies 
and government to ensure the investment proceeded with a degree of certainty, but also included the freight rates for transporting coal by Queensland Rail and sometimes special royalty rates or royalty schedules (over time or by volume). In his speech to the House, Bjelke-Petersen stated the Goonyella agreement was a 'milestone in Queensland's march to progress', suggesting it would add to Queensland's reputation as a 'major earner of funds to relieve Australia's balance of overseas payments position' and would provide Queensland with 'lucrative employment opportunities' (QPD 1968:vol. 250, p. 1976).

In 1970, the Greenvale Agreement Act 1970 further diversified the government's resource development ambitions. This agreement allowed Queensland to begin large-scale nickel mining at Greenvale, west of Townsville. The act was the culmination of months of negotiations and, in addition to the mine itself, entailed the construction of a railway line to transport the ore to Townsville and a treatment plant to extract the nickel from the ore. After the surge in oil prices stemming from the Organisation of Petroleum Exporting Countries (OPEC) crisis in 1973-74, the government also began to promote actively the development of a petroleum or oil industry in the state. In particular, the government believed that Queensland's massive deposits of oil shale represented a yet to be tapped economic windfall. In 1980, the government passed the Rundle Shale Oil Agreement Act, facilitating the joint development of the Rundle oil shale deposits near Gladstone with a number of major domestic and international oil companies. In retrospect, the oil shale venture represented one example of when the government's attempts at state 'boosterism' failed. Despite the substantial outlays in capital by both the government and the companies, the drop in international oil prices during the 1980s, coupled with the extremely high cost of refining shale oil, made the innovative project entirely non-viable. The opposition repeatedly seized on the failure of this project to highlight what it regarded as the foolhardy nature of the government's 'development at any cost' mind-set.

The Mining Act (1898-1967) was one of those acts that had been amended many times as circumstances dictated and new techniques for mining and mine safety were adopted. It was a prime candidate for consolidation and in 1968 the government announced it intended to consolidate the existing legislation into one new act (QPD 1982:vol. 289, p. 1644). The consolidated Mining Act 1968 aimed to control and regulate mining operations in Queensland by updating and bringing the state's existing mining legislation into a single act to help provide for more efficient administration and enforcement procedures. As the government admitted, many of the older provisions of the Mining Acts dating back to the late nineteenth century were based on a single-producer 'goldmining philosophy' and were no longer relevant to the present-day circumstances of Queensland's mineral economy - now heavily dependent on 
base metals and open-cut coalmining. Despite the intention to consolidate, a complementary act was still required: the Mines Regulation Act Amendment Act 1968, which brought together various pieces of previous legislation pertaining to the regulation and inspection of metalliferous mining sites. Moreover, a range of further amendments was made to the principal act during subsequent years to clear up a number of anomalies that later became apparent. It was a continual process of updating and revision.

The Mining Royalties Act 1974 gave the Governor in Council the power to vary, by way of regulation, all royalty payments levied on the mining industry. While the specific rates of royalty were not detailed in the act (appearing instead in regulations and schedules under the Mining Act that could easily be changed), the scope for variation allowed for distinctions to be made between small and larger-scale operators, and for the differing commercial values of the resources mined. For non-base minerals, such as mineral sands, clay and sandstone, the rate of royalty was at least doubled in the 1974 act. These changes to the royalty payment system had an enormous impact on the state's coalmining industry as the price of coal escalated on the international market. The government's annual royalty revenue from coal production rose from less than \$1 million in 1973 to $\$ 25$ million in 1976 - a more than tenfold increase in just three years.

\section{Regional development, tourism and recreation}

With regional development, Premier Bjelke-Petersen expressed the view in the debate on the State and Regional Planning and Development, Public Works Organisation and Environmental Control Bill 1971 that 'it was better to underlegislate than over-legislate in regional planning' (QPD 1971:vol. 258, p. 1577). He distanced his government from the proactive approach then being taken by Victoria, which had just introduced a Land Conservation Act. Bjelke-Petersen claimed he wanted to adopt a cooperative approach with local authorities, but left himself the powers to override any local objection of alternative planning priorities. The new act urged local governments to group together for regional planning purposes. As Opposition Leader Houston pointed out at the time, because it was 'the duty of a local government to cooperate' (or risk fines of $\$ 500$ a day if they refused), it appeared to be cooperation by compulsion:

Although the Premier claims this is legislation of co-operation, it gives the Governor in Council the power to veto a decision arrived at by a local authority, to prevent it from doing a certain job that it has planned to do, or even to force it to do a job that it does not want to do. How, then, can the Bill be referred to as legislation of co-operation-unless, of course, it is co-operation of the Nazi type? (QPD 1971:vol. 258, p. 1578) 
Labor was suspicious about such expansive planning powers. Ed Casey suggested that the legislation would effectively establish a 'fourth tier of government' that 'no-one - not even the Parliament...the democratic institution set up to look after the wants and needs of the men, women and children in this State- will have any say in how it operates' (QPD 1971:vol. 258, p. 1593).

Other concerns were raised with this legislation in that it specifically allowed senior officials (including the Coordinator-General) dealing with planning issues to hold private interests in public companies seeking planning approvals. Houston asked the Premier why this clause had been inserted, thereby creating potential conflicts of interest. Opposing such provisions, the Labor leader said that officials

[c]ould buy shares in a company that was run down, knowing full well that eventually it could come good because of some... development that was going to take place in the future. The Coordinator-General should be paid a salary sufficiently large to ensure that he would not need to be a member of such a company...I am suggesting to the Government that it is not good enough for the Opposition. I want the Premier to give us the reason for it...It is not in the old Act because I happen to know it well. It is something that no Labor Government would have stood for. Cabinet Ministers or top public servants would never have been allowed to hold shares in companies that had dealings with the Crown. Here we are writing into the bill the very right to do that. (QPD 1971:vol. 258, p. 1636)

The Premier thought the clause was not a problem as he believed the CoordinatorGeneral ought not be deprived of the right to invest money in companies, especially those that had no bearing or influence on any planning matter; and if a company were to be involved in a planning issue on which the official was involved, they would, of course, exclude themselves from the decision process. This was a clear case of the Premier's wish not to 'over-legislate' with unnecessary provisions!

While 10 regional areas covering the whole state were announced by the Coordinator-General under this act, these were subsequently abolished in 1977. Local councils never warmed to the legislation, constantly fearing that their decision-making powers were being eroded. It seemed a failed experiment. Subsequently, the government's interest in regional planning focused more on local government jurisdictions. Amendments to the State Development Act were introduced in 1979 to allow statutory instrumentalities more scope to borrow finance to enable. The government continued to emphasise regional development but on an ad hoc basis with their interest motivated by large-scale regional projects such as the Aurukun bauxite-alumina mine at Weipa (1975), 
the Wivenhoe Dam (1979), further expansions as the Gladstone alumina smelter and power station, the lure of integrated tourist resorts from the late 1970s and, in the early 1980s, regional casinos at Breakwater Island in Townsville and Broadbeach on the Gold Coast.

The Bjelke-Petersen government was keen to develop Queensland as a tourist destination and began various campaigns to lure domestic and overseas tourists north to the Sunshine State, with such promotions as 'Queensland: beautiful one day, perfect the next'. The government established the Queensland Tourist and Travel Corporation (QTTC) in 1979 under its own act as a statutory body with a mandate to promote tourism and specific venues and resorts. This authority was initially meant to assist private sector operators with marketing in Australia and overseas. In 1984, the government amended this legislation to enable the QTTC to enter into partnership arrangements to encourage the development of tourist resorts along the coast. It also confirmed it would transfer selected sites of crown land for such developments, which would be overseen by the QTTC. By the mid-1980s, the government was claiming tourism was the state's second-largest industry - but again, one of the emerging problems with the fast growth of this industry was that many of those involved in such bodies and in public policy decisions themselves had substantial commercial interests in the industry.

Perhaps the most infamous piece of tourism legislation was the so-called Integrated Tourism Acts, which bypassed regular planning processes and could be tailored to suit particular developer's needs. One such act, the International Tourist Centre Agreement Act 1978, was passed to enable the Japanese entrepreneur Yohachiro Iwasaki to begin the development of an integrated tourism resort at Yeppoon on the central Queensland coast near Rockhampton. The original plan was for a large-scale international resort (despite Rockhampton not being an international airport at the time), with promises of major investment (but no firm commitments). This legislation became a source of continuing controversy amid allegations that Iwasaki had received special treatment from the government. In response, an interdepartmental committee was formed to investigate and in its report it recommended that 'detailed information and a revised plan' be drawn up and tabled in the Parliament. The committee noted, among other things, the government's apparent willingness to assist 'aliens' and 'non-Queenslanders' without requiring much in the way of guarantees in return (see Richards 2005:4). Although four stages were planned, only two had been completed by 1988 (a scaled-down hotel-resort, an administration building and a large golf course), and the government decided that, because satisfactory arrangements with the Iwasaki company could not be concluded, the overall agreement would be terminated. The whole process seemed a fiasco and the Ahern government eventually repealed the act in April 1989. 
Two significant boosts to tourism (and the development of leisure industries more generally) were the hosting of the Commonwealth Games in 1982 and World Expo 88 in Brisbane. Both events were accompanied with special enabling legislation (and both are discussed in Chapters 15 and 16).

\section{Alcohol, gambling and the attention to recreation and leisure}

The government's attitude to alcohol was almost ambivalent. On the one hand, liquor was highly regulated. It was tightly controlled through the hotel licence arrangements (and 'tied houses'), with restrictive opening hours, no Sunday trading, bans on women drinking in pubs, bans on shops or other venues selling liquor and prohibitions on drinking outdoors on footpaths. On the other hand, from economic necessity (urged on by lobbying from the hotels and clubs, restaurants, tourism operators and the leisure industry), there was pressure to liberalise the availability of alcohol, relax serving restrictions and extend the types of licences permitting the sale of alcohol (including to taverns, bistros, vignerons, restaurants and eventually the introduction of 'bring-yourown' licences for eating establishments). The government put pressure on itself when it increased state taxes and charges to the liquor industry, meaning it then had to liberalise further to enable the various licence holders to afford the additional payments.

Women were allowed to drink in public bars first in 1970 as a result of reforms to the licensing laws passed by the Attorney-General, Peter Delamothe, in April that year. Delamothe's amendments also enabled hotels to operate on Sundays. He stated in the Parliament: 'it is a social injustice to deny to Brisbane workers the Sunday drinking rights that their fellow members enjoy in most of the States' (QPD 1970:vol. 253, p. 2601). The Liquor Act Amendment Bill (QPD 1973:vol. 263, p. 2390) was amended again to reduce the legal age for the purchasing of alcohol from twenty-one to eighteen years. Although this was an important bill, it was another that was introduced during a late-night sitting. During the late-night debate, perhaps due to fatigue, Tom Burns was accused of recycling chunks of the minister's introductory speech. He was soon reminded that 'he may not quote from a speech in the same session of Parliament', leading John Murray (Lib., Clayfield) to state: 'If ever there was a case for a daily Hansard, this is it' (QPD 1973:vol. 263, p. 2499). While the Licensing Commission regularly reviewed, and relaxed, liquor laws, far more contentious was the law applying to drink-driving. Many Members of Parliament had consistently 
opposed drink-driving laws and resisted any subsequent tightening. There was outright opposition to random breath testing at the roadside and such laws were eventually introduced only in 1988 by the Ahern government.

Throughout his entire Premiership, Bjelke-Petersen expressed repugnance towards all forms of gambling. Although a few forms of community betting existed (such as Golden Casket and the soccer pools), his opposition had prevented the development of legal casinos throughout the 1970s and into the 1980s (but not the illegal ones), leading to a major loss of potential revenue for the state. Other states were operating strategically placed casinos as a deliberate part of their tourism strategies. Anxious Treasury officials watched the state losing revenue as bus-loads of Queenslanders departed from Brisbane or the Gold Coast and ventured over the border to visit NSW casinos. Eventually, the Treasurer, Llew Edwards, with the relentless support of the gambling industry and other business interests, overcame the Premier's obstinacy and announced in 1981 that two licences for operating casinos would be granted. The Casino Control Act1982 was passed (to cries of hypocrisy from Labor) to enable the government to undertake negotiations with interested operators and to regulate the industry. Two licences were issued in 1982, with Labor alleging that one casino licence went to the 'National Party stalwart, Sir Leslie Thiess' as consolation for 'missing out on the Winchester South Coal deal' (QPD 1982:vol. 289 , p. 2651). Both casinos (located regionally in Townsville and the Gold Coast) were established under legislation in 1983 and 1984.

In the area of consumer protection, the principal bill, the Consumer Affairs Bill 1970, introduced by the Minister for Labour and Tourism, John Herbert, established a Consumer Affairs Council as a statutory advisory body, along with a Consumer Affairs Bureau (QPD 1970:vol. 254, p. 1151). These bodies were given the functions of making policy recommendations to the minister on issues of consumer protection, promoting the interests of consumers, collecting information relevant to consumers and investigating complaints, and were empowered to pursue prosecutions against those engaged in fraudulent or deceptive practices.

The government also introduced a further series of bills in 1973 aimed at protecting consumers. This legislation included: the Pyramid Selling Schemes (Elimination) Act 1973; the Tow-truck Act 1973, which was introduced after a spate of complaints about unscrupulous tow truck operators; and the Small Claims' Tribunal Act 1973, which established Australia's first Small Claims Tribunal. The government argued this tribunal enhanced consumer protection for Queenslanders through the establishment of a cheap, commercial dispute forum. This was followed by the Residential Tenancies Act1975, which was 
designed to recognise equally the legitimate interests of landlords and tenants. It removed the previous dispute arrangements from the Termination of Tenancies Act 1970 .

Consumer protection could also extend to the protection of property after natural disasters. After the disastrous Brisbane floods of 1974 that saw much of the city underwater, and to help Queensland prepare for future disaster-relief operations, the government introduced its State Counter-Disaster Organization Act 1975, which established a State Counter-Disaster Organisation, charged with the coordination of counter-disaster measures within Queensland. As parliament resumed in the aftermath of the 1974 floods, a range of measures was introduced during the next session to provide assistance to victims of the floods.

\section{Industrial relations and work-related legislation}

Industrial relations was an area of perennial government legislative interest. Legislation was introduced during the early 1970s (including the Arbitration Act 1973) to update and modernise the system of conciliation and arbitration. Intent on limiting and controlling union power in state-supervised industries, the government introduced a large number of legislative acts throughout the 1970s and early 1980s. The Industrial Conciliation and Arbitration Act Amendment Act 1974, and further amendments made in 1975 and 1976, allowed civil action to be taken against a union and for damages to be awarded to employers for losses caused by strikes or obstructions from various forms of unlawful union activity. The 1975 amendments went further in enabling the Industrial Commission to hold secret strike ballots, determining whether strikes should be called or continued. The Industrial Court was also given the power to determine the membership of a union, taking away the right of a union to determine its membership. The Industrial Conciliation and Arbitration Act and Another Act Amendment Act of 1983 came about through submissions invited by the Minister for Employment and Labour Relations, Bill Knox. The bulk of the amendments related to the workings of the commission and the Industrial Court and unions and employers were consulted as part of this process.

Workplace safety laws were similarly important. The Construction Safety Act 1971 was an important piece of industrial legislation concerned with workers in the Queensland construction industry. The act prohibited fraudulent building practices, required the notification and investigation of work accidents and attempted to ensure the prevention of accidents. This was followed by the Workers' Compensation Act Amendment Act 1973, which enhanced compensation measures available to injured workers. Another major series of legislative provisions in this area was the Industry and Commerce Training Act 1979. The 
aim of this act was to regulate apprenticeships within the state, encompassing training in diverse trades, manpower planning and determining the allowances and rates available to trainees. In a similar vein, various targeted legislation made provision for specific training purposes, such as the Nursing Studies Act 1976, which was intended to formalise the registration of training organisations. An amendment to the Factories and Shop Act in 1983 removed the last vestige of discrimination against females from Acts administered by the Department of Employment and Labour Relations' (Record of the Legislative Acts 1982-83, p. 67). This amendment also removed the existing regulations prohibiting women, children or younger males from working overnight between the hours of $6 \mathrm{pm}$ and 6 am.

In 1979, after experiencing industrial disruption in essential services, the government passed draconian legislation in the form of the Essential Services Act, which effectively provided statutory backing and special enforcement powers to any officers the government authorised to act in a dispute. It was presented as a bill 'relating to the protection of the community against the interruption or dislocation of essential services' (QPD 1979:vol. 279, p. 213). It prohibited strikes and lock-outs, allowed the government to 'direct' activities and people engaged in a number of defined essential services, restrict access to services, requisition the property used to provide essential services, authorise entry to premises used for these services, allowed for the deregistration of unions if unions took action to interfere with services and provided for a host of penalties, offences, recovery of penalties and other evidential matters. When a subsequent series of electricity strikes affected south-eastern Queensland in 1985, the government did not, however, evoke this act but chose to declare a state of emergency (as it had done in 1971 against the Springboks protests) by proclamation. In this instance, the government sacked 1100 electricity workers who subsequently lost their entitlements (see Chapter 15 for details) and the electricity supply industry was restructured under a series of legislative measures aimed at deunionising the industry, putting employees on an independent contractor basis.

\section{Transport, infrastructure and the environment}

\section{Transport and infrastructure}

Transport was not an area of excessive legislative activity during this period, although certain acts were exceedingly significant. Brisbane suburban passenger trains were progressively electrified from 1979. The main north-south rail route from Brisbane to Rockhampton was progressively electrified from 1986 to 1990. On the other hand, the Toowong Railway Station Development Project 
Act 1985 unleashed a nightmare for planners and traffic engineers in attempting to combine rail and road systems with a retail and office tower in a highdensity retail and residential area. The government was constantly attracted to integrating the various types of metropolitan transportation and coordinating planning for routes and services. Its ambitious Metropolitan Transit Authority Act 1976 was designed to coordinate urban public transport systems but failed to deliver its intended promise and was replaced by the Urban Public Transport Act 1984, which applied to urban centres throughout Queensland. Under these acts, the Commissioner for Transport was empowered to make decisions in relation to transportation infrastructure, interchange facilities and terminals and, in extreme circumstances, operate any urban passenger service.

The principal act (the Main Roads Act) was revised in 1976 and repeated amendments were made to the Traffic Act, specifying revised definitions of terms, such as 'parking', 'loading' and 'commercial vehicle'. Due to implementation problems with interstate road users and 'shell companies', the government abolished the road maintenance charge levied on Queensland commercial road users in 1979; thereafter the Federal Government extracted contributions for road maintenance through fuel excises.

Port authorities administered many ports under specific acts. There were predictions that ports would experience an exponential expansion in the volumes of cargoes they were handling. New authorities governing these ports were charged with major expansions, levying fees and operating (or overseeing) the business of stevedoring. Brisbane was one such model, with the Port of Brisbane Authority Act 1976 establishing a successful management structure that, over the years, totally transformed the port facilities and the handling of cargoes. Establishing ports as statutory authorities with a commercial focus proved to be an efficient means of administering ports, lessening the need to increase port fees. Other legislation covered more generically ports under the Harbours Act 1978 and regulated canal estates.

Other infrastructural concerns focused on access to water rights and access to water. Here the government's main concerns were with irrigation and irrigation ditches, the management of water and waterways in rural and coastal areas (for example, the Gold Coast Waterways Authority Act 1979), amendments in 1976 to licensing arrangements and the regulation of clean water and various regional waterway acts, which were passed - as were laws to control dam safety and surveillance (in 1975). Land and land development acts were constant targets for minor amendments, as were survey and valuation acts especially during the 1970s. Changing land use and landownership frequently evoked legislative responses, especially as the powers and decisions of the Land Court often had implications for subsequent government policy or in relation to its specific preferences. Scope for ministerial discretion regarding land use and 
land management was generally preserved in legislation (which kept this a highly politicised policy area). Land also attracted ad hoc statutes, where the government declared its intentions of buying, selling, leasing or converting land use (from Labrador to Townsville), and even the Toowoomba showgrounds required its own act.

\section{Environmental policy}

The pro-development ethos shown by Bjelke-Petersen's various ministries meant that environmental considerations rarely featured on the government's radar. Environmental concerns were piecemeal and tended to arise only when conservation issues had the potential to impact on tourism, which was increasingly considered important as a revenue earner. The various legislative attempts to provide for beach protection - first passed in 1968 and amended in 1970 - and applying mainly to the Gold Coast beaches and coastal islands, were motivated more by the enjoyment of tourist visitors than by genuine concerns about erosion.

While other states had established departments of the environment in the early 1970s, the Queensland government did not establish a Department of the Environment until December 1980, when Bill Hewitt (Lib.) was made the first Minister for the Environment (although ministerial responsibility for conservation dated back to 1969). Before the formation of the department, environmental policy was left to the Coordinator-General's Department, which was under the control of the Premier. Although the government had established the Environmental Control Council (ECC) in the early 1970s, in reality this was only an advisory body, which often did not meet and was eventually abolished in 1978. Effectively an interdepartmental committee, the ECC established a process whereby the environmental impacts of a development proposal had to be 'noted'. This initiative was not, however, enforced by legislation so there was no obligation on departments to prepare such impact statements. The ECC was a tepid instrument at best, which could be ignored as the government saw fit (see Hundloe 1985:87).

Although over successive parliamentary terms selected aspects of environmental protection were enacted, the government's environmental credentials were difficult to overstate. It introduced laws to prevent the dumping of rubbish or refuse in harbours in tidal waters. The Litter Act 1973 outlawed the dumping of litter on roads and public places and provided for fines to be issued to people caught littering. One of the more significant pieces of environmental legislation brought before the Parliament was the Pollution of Waters by Oil Act 1973. This also reflected the growing recognition that the Great Barrier Reef was a valuable tourist destination and followed a number of serious oil spills in the 
early 1970s. There was an increasing awareness that existing penalties were no longer adequate, even though the act would be difficult to enforce. This act was part of nationwide legislation and extended the powers of relevant ministers to deal with various types of coastal pollution.

The government also amended the Land Act to protect smaller parcels of land that might not otherwise meet national park criteria. Under these provisions, small areas of land, such as patches of rainforest, lakes or wetlands, could be protected from development or damage. In 1975, the National Parks and Wildlife Act provided for the creation of a body responsible for the state-wide management and administration of Queensland's national parks. Previously, different areas had been administered by different organisations, each covered by different acts of parliament. The government, however, reserved for itself the right to de-list land that had been declared State Forest land and offer it to developers. In the early 1970s, the Lands and Forestry Minister, Wally Rae, was accused of exchanging four parcels of State Forest land on the northern outskirts of Brisbane ${ }^{3}$ for land of much lower value that was already cleared (QPD 1973:vol. 263, p. 1624).

Throughout the 1970s and 1980s, some historic battles were waged between mining companies-invariably supported by the government-and environmentally conscious individuals or groups. Perhaps the most famous was the government's fight with John Sinclair (a local schoolteacher in Wide Bay) over the right to mine and log Fraser Island. The government used parliamentary privilege to condemn Sinclair, used public money to sue him for defamation and then used its position as his employer to intimidate him into silence. Despite fleeing Queensland and losing his superannuation entitlements, Sinclair's campaign was finally successful when the federal Fraser government used its constitutional powers over trade and commerce to end sandmining. Fraser Island also achieved World Heritage listing in 1992. The government's attitude did not, however, soften. After the Fraser government decided to prevent sandmining on Fraser Island by refusing an export licence, the Premier argued 'the decision to ban sand-mining on Fraser Island is a perfect example of undue emphasis being placed on environmental considerations to the detriment of the area in which people are involved for their livelihood' (Record of Legislative Acts 1978-79, p. 12). It was not until 1994 that a comprehensive environmental act was proclaimed.

3 About 1200 hectares in total and described as 'good cypress-pine country', but which Rae claimed was 'no good' land (QPD 1973:vol. 263, p. 1624). 


\section{Education, health, social policy and legislation relating to Indigenous peoples}

\section{Education}

Queensland governments throughout the twentieth century had earned a poor reputation regarding the provision of education, being especially tardy with spending on higher secondary and tertiary education. With the state government's social priorities elsewhere (in the provision of a free hospital system), by the end of the 1960s Queensland's education system still lagged behind other states. This poor record was not aided by the decentralised nature of the state, low densities of population in rural and remote areas and an unplanned pattern of urban development and residential expansion (drift) in the south-east. It was always difficult to plan where best to locate schools to meet growing needs and then to staff them adequately. Jack Pizzey, as Education Minister in the 1960s, had placed considerable emphasis on secondary educational outcomes, which was continued under the Bjelke-Petersen governments. For many years, education spending received the largest increase in the annual budget, yet many still argued that Queensland was falling behind the progress in other states.

In the early years of the Bjelke-Petersen government, the Coalition continued the policy of school expansion and modernisation. After some years of legislative inactivity in the field of education, the government introduced two pieces of legislation in 1970 called the Education Act Amendment Act 1970 (Nos 1 and 2 ), directed at reforms to technical and further education and upper secondary education. With both these acts, the government showed it was prepared to embrace reform. The first, introduced in March 1970, provided a degree of autonomy for colleges of technical education (management by their own councils) and for the expansion of this sector. This act provided the state's major technical education institutes and teacher colleges with the same degree of autonomy as universities. The government promoted this act as being progressive and forward-looking legislation that would allow the state's growing technical and further education (TAFE) sector to meet industry and community needs.

The second act, introduced in December the same year, implemented the recommendations of the 1970 Radford Committee report. This report into school examination procedures for final-year students had been presented to the Education Minister, Alan Fletcher, earlier in 1970. The report advocated the greater use of internal assessment in the examination and grading of students and with some state-wide moderation of grades taking place between schools. After the acceptance of the committee's report, the second amendment act was initiated and passed before Christmas. Among its provisions was the 
discontinuance of the previous external examinations system and its replacement with a Board of Secondary School Studies, which would be responsible for awarding certificates and graduating students in grades 10 to 12 . This meant that all final-year examinations were to be carried out on the basis of internal school assessment procedures. At the time, about only 11000 students were graduating from school at the higher levels. While this change was regarded as an important reform at the time, it was also contentious, with some sections wishing to see the retention of state-wide external exams. Some have since argued that this change could have led to educational standards declining as individual schools and teachers were now principally responsible for judging the standards of their own students. And towards the end of this period of conservative government, the system of cross-school moderation (subjective adjustments) became controversial as many questioned its objectivity as a means of calculating a tertiary entrance score.

Then, in 1973, further amendments to the Education Act were made - this time changing the financing of the further education colleges on a calendar year (rather than as previously the financial year) to enable better planning, requiring the compulsory registration of all teachers and covering the disposal of land reserved for school sites but no longer needed. The opposition supported these measures without contention. Further tinkering amendments were also made in 1973 when it was discovered that the legislation passed earlier in the year was faulty:

Despite careful checking prior to the Bill's introduction and detailed perusal that accompanied its passage through the House, it was found that one paragraph, applying to financial provision in the field of advanced education, was wrongly placed. The effect was that the purpose of the amendment was not achieved. (Record of the Legislative Acts 1973-74, p. 79)

So much for the government's careful checking! The further amendment clarified that colleges did not have to resubmit minor capital expenditures to the Board of Advanced Education once they had been approved in the college's annual budget plan.

Some initial enthusiasm for reform was, however, followed by increased concerns over the school curricula and battles over what children were taught in the classroom. In the 1970s, controversies flared over the teaching of creationism versus evolution and over relatively tame forms of sex education in social studies curricula. Two educational resource kits were banned by cabinet decision after right-wing pressure groups managed to influence the Premier. These petty curriculum battles became much celebrated controversies (especially by the 
combatants) and were used to maintain and create further divisions between the moderate and the conservative sections of society well into the future (Patience 1985:133; Reynolds 2002:35-42; Hughes 1980:289).

Tertiary education was a different story. It is a strange paradox that a National Party-led government that was often deeply suspicious of those with university education and of student radicalism nonetheless instigated a range of legislative measures that greatly expanded the state's tertiary education sector during this period. Two new universities were established in a short time. In 1969, the James Cook University of North Queensland Act 1969 was passed, coming almost 60 years after the establishment of the state's first university: the University of Queensland. This act not only established the state's second university, it provided its first regional university, boosting education facilities in north Queensland - an increasingly important area politically. Soon after James Cook was established, the government enacted the Griffith University Act 1971 for a university on the southern side of Brisbane, named after Sir Samuel Griffith, a former Queensland Attorney-General who had introduced the state's system of free and compulsory primary education. Griffith University became Queensland's third university. Then, much more controversially, in 1987, the Bjelke-Petersen government introduced the Bond University Act 1987, which established Queensland's first private university, located on the Gold Coast. Finally, as part of the general Dawkins' restructure of tertiary education nationwide, the state government created the state's fifth university: the Queensland University of Technology, which was created from the former Institute of Technology and parts of the Brisbane College of Advanced Education. Even at the end of the period of National Party government, however, about only 5 per cent of the adult population of Queensland had a university qualification.

\section{Health}

The Bjelke-Petersen governments preserved the free public health system Queenslanders had long enjoyed through the public hospitals. The government maintained the status quo, and the majority of its policy involvement was budgetary related. The government refused to sign the federal Medicare agreements in the 1980s, but eventually capitulated in Ahern's period and received back funding.

The government had to wrestle with the rapid advances occurring in the fields of science and medicine, shifts in community attitudes and commercial opportunities. Much of the legislation passed was aimed at regulating aspects of public health, usually from a reactive rather than a proactive vantage point. The Sale of Human Blood Act 1974 prohibited the sale and purchase of human blood except in exceptional circumstances and prohibited commercial firms from 
entering the blood market. The Cremation Act Amendment Act 1978 required a medical practitioner to be satisfied that the body to be cremated was not fitted with a cardiac pacemaker or a radioactive implant. The HIV/AIDS epidemic saw a number of amendments to existing legislation introduced to deal with this new illness. The Health Act Amendment Act 1984 allowed the Health Department to track AIDS cases and their known contacts by adding the HIV virus to the list of venereal diseases; it also increased the penalties for knowingly infecting someone with a venereal disease.

The government was also concerned with the establishment, regulation and professionalism of health and para-health workers. The Psychologists Act 1976 established a register of psychologists and regulated the practices of psychology and hypnosis in Queensland. Similar acts were introduced dealing with pharmacists and chiropractors. Other legislation governed the training or education required for categories of health professionals. The Nursing Studies Act 1976 revised the registration and enrolment of nurses and shifted the responsibility for nursing education to a dedicated board: the Board of Nursing Studies. This board could recommend accreditation of schools of nursing and establish the minimum requirements of educating authorities. In 1975, the government also amended the Queensland Institute of Medical Research Act (1945) to allow financial donations made to the institute to be held in trust for specific types of medical research.

\section{Social policy}

Social policy and community welfare were generally neglected policy fields throughout this period. Ministerial responsibility for welfare services had been identified in 1972 but this did not evoke much legislative action. A previous Children's Services Act 1965 was on the statute books to enable neglected children to be removed from their parents or carers to safeguard and protect their wellbeing. This act was revised in 1970 and again in 1980. The age of majority was lowered from twenty-one to eighteen in 1974. And in 1979, the government passed the Adoption of Children Act Amendment Act to bring Queensland into alignment with federal laws to enable overseas adoptions.

Changing community attitudes and expectations towards intellectually disabled people informed the Intellectually Handicapped Citizens Act 1985. Although the act was initially tabled in 1983, it was allowed to lie on the table of parliament to allow discussion and input from concerned parties and organisations. The eventual act provided intellectually disabled people with special assistance and allowed sufferers to obtain legal advice before giving informed consent for medical procedures. 
The government's concern over social problems facing the community could be expressed in many inventive ways. For instance, when Australia moved from imperial to metric measurements, the Queensland Parliament introduced the Metric Conversion Act to authorise the transition in Queensland. Not to be accused of precipitous action, the government introduced this bill two years after the Commonwealth and other states had passed similar legislation. The comments of Bob Moore (Lib., Windsor) when this legislation was introduced reflected something of the anxieties of the government at the time, when he said: 'If anyone says that this metric system has not turned the aged of this nation into a bunch of morons, then that person is not right in the head. There is no grandpa or grandma in this State who knows where he or she is going any more' (QPD 1978:vol. 275, p. 1031).

Such statements indicate politicians were prepared to complain on the people's behalf, but there is little to suggest that government thinking on social policy ever matured.

\section{Legislation related to Aboriginal and Indigenous peoples}

Aboriginal and Indigenous peoples had been granted limited recognition under special legislation introduced in 1965. The Aborigines and Torres Strait Islanders Affairs Act 1965 allowed for the creation of Aboriginal councils on reserves, for special Aboriginal courts to hear minor misdemeanours and recognised children born from a 'tribal union' as legitimate and therefore entitled to succeed to the estate of a parent. While the act at the time was considered progressive legislation, the conferral of the status of 'Assisted Aboriginal or Islander' was paternalistic and open to abuse. Assisted Aborigines and Torres Strait Islanders were effectively under the guardianship of white officers who could 'take possession of, retain, sell or otherwise dispose of any such property' if they were satisfied that 'the best interests of such assisted Aborigines require it' and 'decide whether to allow people to withdraw their earnings and how much they should be allowed to have'. The act effectively allowed Indigenous people to be managed as children. It was not until the Aborigines and Torres Strait Islander Act 1971 that the status of 'Assisted Aborigine or Islander' was removed. The 1971 act also established the position of Director of Aboriginal and Islander Affairs and for the first time in Queensland history allowed for the sale and consumption of alcohol within Aboriginal reserves. Further amendments to the Electoral Act in 1971 made it compulsory for all Indigenous peoples to vote in state elections.

Other legislation sought to protect Indigenous relics, artefacts and historic sites, but was not much resourced in its implementation. In 1978, the government 
introduced the Local Government (Aboriginal Lands) Act to provide a statutory framework for the establishment of 'model' Aboriginal and Islander communities in Aurukun and on Mornington Island. Special leases were granted to the shires and councils allowing occupants their traditional rights to hunt and gather within the leased area but preserving all mineral rights for the Crown. In 1982, the government introduced the Land Act (Aboriginal and Islander Land Grants) Amendment Act to establish deed of grant in trust for Aboriginal lands. The Aboriginal and Torres Strait (Land Holding) Act 1985 enabled perpetual leases to be granted to individuals for residential or small business purposes - framed as a move towards self-sufficiency and responsibility.

Although it is now commonplace to accuse the government of paternalism towards Indigenous peoples during the period covered in this chapter, the more damning accusation seems to be the almost complete neglect of concern for Indigenous issues of any description. Indigenous people were largely invisible to the legislators.

\section{Ahern and Cooper's priorities towards the end of the conservative era}

Coming to office in difficult circumstances in December 1987, Mike Ahern's government (and belatedly that of Russell Cooper) introduced myriad legislation through the Legislative Assembly, almost as if it were a slot machine. The number of bills passed through this Parliament was the largest up to that time, with 169 bills passed before the government went to the polls in December 1989. A constant complaint at this time from the opposition was that legislation was pushed through the Assembly at an alarming rate. Pat Comben claimed that the government remained locked in an authoritarian mode, insisting on its own preferences and doing things its way. They complained that the government "prefers to govern on the basis of, "We are right. Operate the sausage machine. Bring in the legislation through one door, send it out of another, send it up to the Guv. She'll be right, mate; we can bring in another piece of legislation in three weeks' time"' (QPD 1989:vol. 311, p. 3905).

Yet, Ahern as Premier adopted a much more moderate approach to policy and legislation and was prepared to contemplate and act on issues Bjelke-Petersen had ruled out of court. For example, as a means of helping prevent further cases of HIV/AIDS, amendments to the Drugs Misuse Act Bill 1988 finally allowed the free distribution of needles (as deemed necessary by the Minister for Health) and also stipulated that the possession of syringes would no longer be 
considered a criminal offence (QPD 1988:vol. 311, p. 1691). This was a sign that the government was prepared to examine social problems more dispassionately and was less driven by knee-jerk ideology.

A 'historic' reform was the introduction of the Public Accounts Committee Bill to enable parliamentarians to investigate public finances more thoroughly ( $Q P D$ 1988:vol. 309, p. 1159). Such a committee - common in all other Westminster parliaments - had long been deemed unnecessary by the previous government. The new act established a standing committee of parliament consisting of seven members (four of whom would come from the government), with the power to obtain information and documents, summon and call witnesses, deal with any matters of contempt and report its findings back to the Assembly. Ahern, however, placed two restrictions on the committee: it was not able to liaise or cooperate with the Auditor-General; and it could investigate only matters dating from the start date of his Premiership - namely, 1 December 1987.

Responding largely to populist concerns emanating from the Gold Coast, the Ahern government introduced a Foreign Land Ownership Register Bill (QPD 1988:vol. 310, p. 1593). The bill required 'foreigners' who purchased land in Queensland to register their interests with the government. Its introduction was welcomed by the opposition, whose Treasury spokesman, Keith De Lacy, mused that he never thought that I would ever see the day when a foreign land-ownership bill was introduced...I will never cease to be amazed at how the leopard changed its spots' (QPD 1988:vol. 310, p. 2120). Although the bill was passed in 1988, it was not then proclaimed due to objections from business and finance firms but came back for further amendment in March 1989. The act was largely a symbolic exercise and appeared to have no particular effect, except perhaps to discourage potential investors.

Much of Ahern's legislation was a continuation of the prosaic agendas of the previous government - concerned with regulations for the primary industries, tourism, enterprise zones, consumer affairs, the redevelopment of the postExpo Southbank site, daylight saving, new infrastructure, public utilities and some public sector reform. The government also passed many machinery bills, adding clauses to conventional standing statutes such as the Births, Deaths and Marriages Act, the Jury Act and the Trustee Companies Act.

The major difference his administration displayed to that of his predecessors was that by mid-1988 Premier Ahern was constantly forced to respond to the unfolding juggernaut of the Fitzgerald Inquiry. Much of his legislative program was driven by the needs and outcomes of the inquiry. A Commissions of Inquiry Act Amendment Act was passed in 1988. The Criminal Code was amended. Various acts to prevent officials from profiting from crime were introduced, as were laws to seek to prevent superannuation being paid to corrupt officials (or 
in cases where it already had been paid to recover these amounts). In 1989, the Parliamentary (Judges) Commission of Inquiry Act was passed to enable the House to remove Justice Angelo Vasta, a Supreme Court judge, from the bench. In April 1989, a specific act to terminate the employment of the Police Commissioner was passed without opposition. In July 1989, a Commission of Inquiry Continuation Act was required to enable the investigators attached to the commission of inquiry to continue investigating organised crime and misconduct that occurred before the establishment of the Criminal Justice Commission in late 1989.

Other tangential legislation that was associated with Fitzgerald reforms in some way was that to extend the duration of parliament to enable a fairer electoral redistribution to take place before the next election. A Constitution (Referendum) Act was also required to enable the variation to the constitution to proceed (the so-called 'life-raft package'; QPD 1989:vol. 313, p. 278). These bills outraged the opposition, which called them measures of desperation introduced by ministers 'who know that they are facing unemployment in a few months' time'; it claimed these bills were not reforms but a quest for 'naked power and extension of life for this National Party Government' (QPD 1989:vol. 313, p. 257). These acts were never operational and the Constitution (Cancellation of Referendum) Act had to be repealed in late 1989 (QPD 1989:vol. 313, p. 733).

In the final months of 1989, Ahern was replaced as Premier by Russell Cooper, who chose almost immediately to fall back on law and order issues that had served the National Party so well previously. Cooper's legislative window lasted for only a couple of weeks, but in that time he completed the passing of the Electoral and Administrative Review Commission Act and the Criminal Justice Commission Act, together with the two parliamentary committees meant to provide accountable oversight. He called these substantive bills, laconically, a 'major event in the history of the state', and concluded his introductory remarks by suggesting a new era in parliamentary reform would now begin. He said his government was committed

to providing total support to the reforms which have been recommended and is committed to depoliticising the reform process to ensure that it does not fail for party-political reasons or by reason of any lack of political will. It will at all times be willing to co-operate and consult with the opposition parties in the Parliament to ensure that they are duly consulted and properly involved in the reform process. (QPD 1989:vol. 313, p.1383)

It was a climactic end to a very controversial period of Queensland's history. 


\section{Conclusion}

Looking back over the legislative record of the Bjelke-Petersen, Ahern and Cooper governments, we find a reliance on state power across the full gamut of state responsibilities (and even occasional attempts to encroach into areas of federal responsibilities, such as over treaties and international relations). Serving for the longest period as state premier, Bjelke-Petersen developed an authoritarian streak that tended to become magnified as his term evolved. As time went on, his so-called 'business cronies' often had more influence on him than did many of his ministerial or parliamentary colleagues. And this was reflected in his various stances on public policy and in his willingness to use the instrument of legislation to drive home his message.

The imposition of state authority was, thus, the government's preferred policy response to almost any emerging issue or crisis. State authority was deployed in any area that mattered to the government, even if its authority was likely to be of limited efficacy or could serve to impede its objectives. The Parliament was seen as a convenient law-making institution, available to and at the disposal of the government, and able to manufacture all manner of laws at the government's discretion. In most cases, these laws were not subject to any review and were unable to be challenged. They could be overturned or altered only if the government chose to do so subsequently. With a majoritarian, unicameral parliament, there was no check or qualification to this power.

The government was prolific in both its legislative appetite and the regulatory detail it attached to pieces of legislation. Many items of specific policy interest were framed in legislation, from partnership agreements and legal contracts to expressions of intent and statements of symbolism. These were all written into statutes - presumably to give them sanctity and certainty. Legislation was used to codify business deals with miners and tourist operators, recording specific commitments with firms over development projects. It was used to impose the most minuscule of regulations on producers, consumers, developers, operators, employers and employees, passengers, patients, licensees, rate-payers and even interstate operators using Queensland's roads. Towards its own rural supporters, the government adopted a helping-hand approach relying on regulatory provisions, stabilisation and in dire cases supported by various assistance packages for those in need. Conversely, it adopted a heavy-handed approach when dealing with those it regarded as its opponents or who might be hostile to its intent. This was a divisive period in Queensland's history, made perhaps more so by the very legislative actions of the government.

It is possible today to highlight many faults and shortcomings in its legislative approach, just as it was when the legislation was introduced. The government 
can be accused of excess, of unnecessary provocation and of indifference or neglect. It should also be recalled, however, that its policies were relatively popular at the time and accepted by the mainstream. Labor only twice (in 1969, just, and comfortably in 1972) out-polled the combined Coalition vote, and thereafter its vote fell well behind the conservatives (and was still behind the combined National and Liberal vote for the six years they were out of coalition). The government's tough stance on law and order won it popular support - not lost it - and this was a calculated strategy undertaken by Bjelke-Petersen, who had to ensure mainly that the government held its nerve.

The opposition was frequently suspicious of the motives behind the government's legislative decisions and used debates on the legislation to express its concerns. This 'noise' was, however, also influenced by Labor's own predilections and interest base. In the end, unlike in many other parliaments, in Queensland, the legislation was solely the responsibility of the government of the day; it could not claim it had to compromise its intentions and ultimately it was held accountable for that legislation. 



\section{The doldrums in opposition, 1968-1989}

By 1968, after 10 years in opposition, Labor was finally getting its act together, presenting itself as a viable alternative to the government. While Labor had regrouped and seen off the rival QLP-DLP challenge, the Coalition government had entered a period of instability. In 1968, Frank Nicklin, the 'Gentleman Premier', had finally retired and his successor, Jack Pizzey, died suddenly after only six months in office. The new Premier, Joh Bjelke-Petersen, had difficulties convincing his colleagues that he had the wherewithal to lead the government and be electorally competitive. Labor had replaced the veteran Jack Duggan with Jack Houston, who was finally making some impression with voters. Labor's vote had been increasing but was no threat to the conservative Coalition's hegemony.

Yet Labor was afflicted with bouts of internecine conflict and found it difficult to present a unified image to the electorate. It appeared that the parliamentary party (and its union wing) was perpetually feuding and driven largely by enmity, unfit to govern and incapable of denting the Coalition's popularity. Over successive elections, Labor looked divided, presented dull and predictable campaigns and had bland leaders who spent their time looking over their shoulders. As one contemporary commentator noted: 'The Labor Party, with wondrous inventiveness, manage[d] to find new ways to stab itself in the back' (The Age, 29 November 1980). Labor's three decades in opposition were not due entirely to the government's constraints or the gerrymander; Labor would have to share some of the blame for its internal disarray and factional brawling.

Life in opposition was a difficult, morale-sapping time for Labor members and supporters. There were few high points to celebrate. As the years in opposition went by, Labor became disheartened and many veterans believed they would never gain government, so there was little point in putting in the hard yards to address the state of the party. Labor politicians appeared to have internalised a 'work to rule' policy (putting in the minimum public service hours) and there was little incentive to be innovative or entrepreneurial. ${ }^{1}$ When the Parliament was not in session, Labor parliamentarians were likely to be spotted on their local bowling green or fishing, rather than actively working their electorates.

\footnotetext{
1 This view is supported by Wayne Goss's admission that in the 1970s many in the Labor Party thought 'simply being in Parliament in Opposition was a pretty good job. You have a press conference now and again, or more likely just issue a press release, and then you go to lunch' (see S. Rodgers, 'Time exposure puts Goss in the fourth dimension', City News [Quest], 21 August 2003, p. 31).
} 
Tom Burns even called his boat The Electorate so he could say he was out in the electorate. As a former state AWU secretary said in 1987, 'too often it would seem some people in the party have been satisfied with the spoils of defeat' ( $Q P D$ 1987:vol. 307, p. 4298). During the early 1970s, Labor had attempted to recruit well-known or noteworthy candidates (often with strong track records in local government) to contest marginal seats. For the most part these 'star' candidates failed to make it into the Assembly and the culture remained unchanged. By the 1980s, some refused to accept electronic 'pagers' because they felt their time was their own. The problem for the ALP was how to jettison time-servers and dullards and recruit new talent that had voter credibility. It was not until the mid-1980s that an entirely new generation of Labor politicians took the fight to the government.

\section{Labor's leadership: repeated defeats lead to instability}

The parliamentary Labor Party went through two distinct periods while in opposition. The first phase was one of stability. From 1958 to 1966, the party was led by Jack Duggan, who was well regarded by the parliamentary rank and file. During this period, there were few alternative leadership contenders in the ALP Caucus. Then, for almost seven years (1966-74), the opposition was led by Jack Houston. After Houston was successfully challenged in mid-1974, Labor plunged into a period of instability, with six leaders during the next 16 years. Like opening batsmen scoring ducks, each Labor leader would face one election and lose, retire to the backbench and let another shadow minister have a go. The revolving leadership came to resemble a round-robin affair, with Caucus asking whose turn would be next. Although Labor gradually clawed some ground back after the devastating loss it suffered in 1974, it looked unlikely to threaten the government's majority hold on power until the Nationals tried to govern alone and the Fitzgerald Inquiry delivered a powerful issue on which to campaign.

Table 13.1 Labor's opposition leaders, 1969-89

\begin{tabular}{|l|l|l|l|l|}
\hline $\begin{array}{l}\text { ALP leader years } \\
\text { served }\end{array}$ & $\begin{array}{l}\text { Election defeat/ } \\
\text { win }\end{array}$ & $\begin{array}{l}\text { Seats won } \\
\text { (Coalition) }\end{array}$ & Seats won (ALP) & $\begin{array}{l}\text { Government } \\
\text { majority }\end{array}$ \\
\hline $\begin{array}{l}\text { Jack Houston, } \\
\text { 1966-74 }\end{array}$ & 17 May 1969 & 45 & $31(+2$ inds) & 12 \\
\hline $\begin{array}{l}\text { Jack Houston, } \\
\text { 1966-74 }\end{array}$ & 27 May 1972 & 47 & $33(+2$ inds) & 12 \\
\hline $\begin{array}{l}\text { Percy Tucker, July- } \\
\text { Dec. 1974 }\end{array}$ & $\begin{array}{l}\text { 7 December } \\
1974\end{array}$ & 69 & $11(+2$ inds) & 56 \\
\hline Tom Burns, 1974-78 & $\begin{array}{l}12 \text { November } \\
1977\end{array}$ & 59 & 23 & 36 \\
\hline
\end{tabular}




\begin{tabular}{|l|l|l|l|l|}
\hline Ed Casey, 1978-82 & $\begin{array}{l}29 \text { November } \\
1980\end{array}$ & 57 & 25 & 32 \\
\hline $\begin{array}{l}\text { Keith Wright, } \\
\mathbf{1 9 8 2 - 8 4}\end{array}$ & $\begin{array}{l}22 \text { October } \\
1983\end{array}$ & $\begin{array}{l}41 \text { (no } \\
\text { Coalition) }\end{array}$ & 32 (+8 Libs) & $\begin{array}{l}1 \text { (then } 5 \text { after } \\
\text { two Liberal } \\
\text { defections) }\end{array}$ \\
\hline $\begin{array}{l}\text { Nev Warburton, } \\
\mathbf{1 9 8 4 - 8 8}\end{array}$ & $\begin{array}{l}1 \text { November } \\
1986\end{array}$ & $\begin{array}{l}49 \text { (no } \\
\text { Coalition) }\end{array}$ & 30 (+10 Libs) & 9 \\
\hline $\begin{array}{l}\text { Wayne Goss, } \\
\mathbf{1 9 8 8 - 8 9}\end{array}$ & $\begin{array}{l}2 \text { December } \\
1989 \text { (election } \\
\text { win) }\end{array}$ & $\begin{array}{l}27(+8 \\
\text { Libs) }\end{array}$ & 54 & 19 \\
\hline
\end{tabular}

Source: Queensland Parliamentary Record 2004.

The first 17 years in opposition under the leaderships of Duggan and Houston coincided with growing dominance of the Trades Hall group in the parliamentary Labor Party (PLP). ${ }^{2}$ Nomination for a parliamentary seat by union or party officials was often viewed as a cushy reward for long-serving apparatchiks rather than as a means of getting the best talent into the Parliament. The Coalition constantly seized on the protracted rivalry and rupture between the parliamentary and organisational wings of the party as evidence of disunity and a Caucus dominated by extra-parliamentary unions. Over time, the ALP lost the support of many regional and provincial voters who had traditionally been loyal supporters. It was not until the 1960 state election that the Labor Party first managed to win more city electorates than country ones (Hughes 1980). The gradual loss of these country seats - which had been a source of electoral strength since the party's inception - was a demographic shift that was hard to overcome in the short term. It was increasingly apparent that habit voting, old methods of campaigning and tired messages no longer resonated with the changing demographics. Instead of devising ways to attract new constituencies (more educated voters, women, tourism-based regions), however, the party remained loyal to its ideological roots and to its male-dominated, blue-collar constituency.

2 Labor politics in the 1960s and 1970s was far from harmonious. Before federal intervention in 1978, real tensions existed between the previously dominant ALP right faction (which included the AWU in the 1960s) and the leftish Trades Hall group. The AWU was affiliated in the 1960s, but disaffiliated in the 1970s and rejoined in the 1980s. After federal intervention, a new factional realignment occurred with the formation of the Socialist Left group. The ALP was then divided into two broad groups: the former right-wing Trades Hall 'Old Guard' plus the AWU versus the Socialist Left and the branch-based Reform Group. The AWU then aligned with the Shop Assistants' Union and established its own 'Centre Majority' faction. Some non-aligned ALP members also established a 'Centre Left' faction around Bill Hayden and David Hamill. The 'unholy alliance', when the right (AWU-led faction) and the Socialist Left combined against the Old Guard unions, saw the emergence of the rightish Labor Unity faction. The parliamentary Labor Party was considered extraneous to the main action as these various groups battled it out for ideological control of the agenda, which only added to the difficulties for successive Labor leaders (see Fitzgerald and Thornton 1989:173-208). In the Parliament, Old Guard members included Tom Burns, Kev Hooper, Jim Fouras, (initially) Bob Gibbs and Terry Mackenroth. Gibbs then joined the Socialist Left, which was augmented by Anne Warner, Ken Smyth and Ken Hayward. Townsville's Geoff Smith was for a while the sole AWU-aligned MP. Wayne Goss initially had some AWU backing but remained largely independent; when he won the leadership in 1988, he was supported by all non-Labor Unity members in Caucus (that is, Socialist Left, Centre Majority [AWU], the Centre Left and independents). 
Houston's tenure as leader began a period of dominance by the Trades Hall faction in the parliamentary party. His deputy was another Trades Hall sympathiser, Percy Tucker. When Houston stood for the leadership position, he was unsuccessfully challenged by Pat Hanlon, the son of former premier Ned Hanlon, who, according to Harold Dean (ALP, Sandgate, 1966-77), was the 'pick of caucus but lacked the fighting spirit of his father'. Despite Houston's denials that his victory was a Trades Hall takeover (Courier-Mail, 3 October 1966), many saw his win as evidence that the darling of the left wing of the Labor Party' had come good. His opponents, such as Bill Hewitt, certainly saw the rise of Houston as a sign of the 'strengthening of the Trades Hall grip on the PLP' (QPD 1966:vol. 243, p. 867; Courier-Mail, 13 October 1966, 14 October 1966). It was not until Wayne Goss was elected leader in 1988 that the Trades Hall unions' dominance over the party would slowly weaken.

Houston created the first full shadow cabinet in Queensland in 1968 (shadowing every ministry), but the government refused to acknowledge his shadow ministry or accept that an alternative government existed. In the official record of Hansard, all Houston could do was report his own reappointment as leader, announce Percy Tucker as his deputy and mention that Horace Davies and Doug Sherrington were now the party whip and secretary respectively ( $Q P D$ 1969:vol. 251, p. 22). Later, Evan Marginson replaced Sherrington as secretary (QPD 1972-73:vol. 259, p. 19). Any official recognition of the shadow ministry was slow in coming. The first listing of a full shadow ministry, published in the 1978 Parliamentary Handbook, caused such government furore that it was not listed again for many years. According to one contemporary parliamentary librarian, the publication of such a list was not well received by the government. Earlier acknowledgments tended to be more ad hoc or involved occasional slips. In 1968, the Treasurer, Gordon Chalk, referred during the Government Loan Bill debate to his opposite number, Pat Hanlon, as 'the hon. member for Baroona, who no doubt is the shadow Treasurer of the Opposition' (QPD 1968:vol. 249, p. 549).

Houston's initial shadow cabinet was elected by Caucus and comprised the leader, the deputy, the party whip and six shadow ministers (a seventh was added in 1969, and four more in 1970). From 1970, all 14 members of the opposition executive were shadowing ministers (Hughes 1980:69). The composition of the first 'shadow cabinet' is shown in Table 13.2.

The existence of a shadow cabinet remained controversial until Mike Ahern became Premier in 1987. 
Table 13.2 Jack Houston's shadow cabinet, 1970

\begin{tabular}{|l|l|}
\hline Shadow portfolio & Shadow minister \\
\hline Premier and State Development & Jack Houston \\
\hline Industrial Development & Percy Tucker \\
\hline Treasury & Pat Hanlon \\
\hline Education and Cultural Affairs & Horace Davis \\
\hline Labour and Tourism & Fred Bromley \\
\hline Works, Housing and Police & Fred Newton \\
\hline Health & Jack Melloy \\
\hline Primary Industries & Edwin Wallis-Smith \\
\hline Lands & Hughie O'Donnell \\
\hline Conservation, Marine and Aboriginal Affairs & Doug Sherrington \\
\hline Justice & Col Bennett \\
\hline Mines and Main Roads & Martin Hanson \\
\hline Transport & Ray Jones \\
\hline Local Government and Electricity & Harold Dean \\
\hline
\end{tabular}

\section{Prospects for victory? Labor's more competitive campaigns, 1969-72}

The early years of Bjelke-Petersen's Premiership were decidedly shaky. He was the default candidate chosen when others had gone and had been long overlooked as a leadership contender by the Country Party's long-serving and respected leader, Frank Nicklin. With Bjelke-Petersen initially seen as weak and idiosyncratic, the Labor Party sensed it had a chance. When the Speaker, David Nicholson, publicly reprimanded the Premier for misleading the House in 1968, the opposition, sensing blood, repeatedly attacked the Premier on the floor of the Parliament. The Springboks rugby tour of 1971 showed, however, the Queensland electorate another side of this 'strongman' leader. Queenslanders susceptible to the lure of a strong, tough leader rewarded their new Premier, who soon learnt that decisiveness and a 'can-do' approach were electorally popular.

Perhaps because of Bjelke-Petersen's woodenness and unpopularity at the start of his term of office, the 1969 and 1972 elections appeared to present realistic opportunities for Labor. Its primary vote was high in both elections (45 per cent in 1969 and 46.75 per cent in 1972). While Labor out-polled the combined Coalition vote in both elections, its level of popular support did not translate into seats. Labor won 26 seats in 1966, then increased its representation to 31 seats in 1969 to the Coalition's 45; and again in 1972, Labor managed to capture 33 seats in an expanded parliament to the Coalition's 47. In 1969, Labor won just five additional seats. Two of these (Bundaberg and Cook) were won 
from independents who had previously held the seats as QLP candidates. The Country Party lost Logan (which they had held since its creation in 1960) to Ted Baldwin and the Liberals lost two seats: Rex Pilbeam's seat of Rockhampton South to Keith Wright, and Merv Anderson's seat of Toowoomba East to Peter Wood.

The ALP was philosophical about losing the 1969 election and seemed to have recovered from its devastating split. The party's hopes were dashed, however, in the next two years when the ALP suffered two successive by-election defeats (Albert and Maryborough). Labor's defeat in the July 1971 Maryborough byelection was particularly significant. It had been a safe ALP seat since 1915 and its sudden loss consolidated Bjelke-Petersen's grip on the Premiership.

In spite of these reversals, Labor was attempting to sound positive under Houston's leadership and, according to one-time deputy leader, Jack Melloy, the 1972 election was one Labor felt certain it could win. Houston was becoming a 'steady parliamentary performer' and momentum seemed to be building in the ALP's favour. This optimism was aided by a fall in the government's majorityfrom 20 seats in 1966 down to just 12 seats in 1969 - a decline attributed largely to Bjelke-Petersen's initial weak performance as leader (see Chapter 8 for details).

Just as Labor was becoming competitive, it descended into another bout of internal party brawling over factional influence. Three right-wing sitting members, Ed Casey, Col Bennett and Merv Thackeray, failed to hold onto preselection for their safe seats early in 1972 (Sunday Sun, 30 January 1972). It was rumoured that up to 10 members were threatened with dis-endorsement and that three sitting members had approached the DLP seeking its support in the event ALP endorsement was withdrawn (Hughes 1980:69-70). This blatant factional move was described as a 'Trades Hall purge'; the axing of three parliamentarians prompted a former speaker and life member of the ALP, Johnno Mann, to resign from the party in protest. It signalled the strengthening of the left-aligned Trades Hall group over the parliamentary Labor Party. One of the dis-endorsed parliamentarians (and a future Labor leader), Ed Casey, was returned as an independent for Mackay. Casey was very bitter, claiming that parliamentary democracy had been eroded by the factional stoush. He accused Houston of taking instructions from the 'inner executive' of the ALP and reported that over the past six months Houston had 'dispensed with shadow cabinet meetings' and had not called Caucus together (Courier-Mail, 12 October 1972).

Surprisingly, given the internal difficulties, Labor did even better in the 1972 election, achieving a high-water mark not surpassed until it finally won office in 1989. Labor's gains were limited, however, because of a new electoral redistribution. In August 1971, the Electoral District Act 1971 had increased the 
number of electorates from 78 to 82 and the number of differently weighted zones from three to four. The south-eastern zone now held 47 seats; the provincial cities zone had 13 seats; the western and far northern zone had seven; while the country zone contained 15. The most disadvantaged party as a result of these electoral changes was the Liberal Party. Despite Labor's increase in primary votes (rising to 46.75 per cent), the opposition won only two additional seats while the Country Party retained all its seats despite a drop of more than 1 per cent of its vote. Labor had out-polled the combined Coalition vote by 4.5 per cent across the state, so felt cheated by the outcome and complained publicly for years about the effects of the government's malapportionment. Labor appeared to be on an upward trajectory, especially as federal Labor was to win office under Gough Whitlam only six months later, in December 1972.

After suffering defeat at the 1972 election, the Labor Party started to 'fall apart again', according to former members. The Trades Hall group continued to throw its weight around and had consolidated its position at the election. Labor dissidents, such as Ed Casey, argued that the party needed 'someone who can pull the ALP in Queensland back on the rails and make it the great party that it was' (Courier-Mail, 12 October 1972). With morale dented, speculation began to emerge about a change of leadership. The Sun, for example, in a prescient editorial, damned Houston with faint praise, saying:

Under the looming shadow of Jack Duggan, we say Jack Houston has performed well. His debating skill has improved enormously; he has a presence and an integrity recognised by all parties. But some of the new Labor members in Parliament, backed by some of the outside Labor bosses, think he has not been forceful enough. And despite Labor's proud boast that once it has chosen a leader the party sticks by him, the odds against Mr Houston being allowed to hang on much longer are shortening fast. (Sun, 8 May 1973)

One of Houston's perennial image problems was that he had long been considered a 'personable, non-aggressive leader' (Courier-Mail, 16 June 1966), perhaps unable to go for the political jugular. The press by now depicted his performances as weak and lacklustre. Houston was finally removed after a sudden party-room vote in July 1974, which was initiated by Percy Tucker after he gave indications to Houston that he would not challenge.

Tucker was supposedly Houston's loyal deputy, but agreed to stand against him in 1974 with a commitment to be more aggressive against the government. Regarded as a robust and forceful character, Tucker surprised many when he won the internal ballot over the more high-profile Tom Burns. Tucker held the marginal seat of Townsville West and was the first ALP leader to have held a seat outside the south-east of the state since Forgan Smith (who had held 
Mackay, but who as Premier resided in Brisbane). Encouraged by a small group of parliamentary supporters, Tucker toppled Houston by two votes (17-15). The momentum for the change had, however, come entirely from within the parliamentary Caucus - not from the extra-parliamentary unions. Casey's assertion that the party's 'inner executive' at Trades Hall was running the show did not appear to be true in this case. The State President, Jack Egerton, was overseas, and following the new leader's appointment, there was some criticism that the unions had not been consulted (Hughes 1980:71).

\section{Facing annihilation, years in the wilderness: 1974-80}

The election of the Whitlam government had a devastating impact on the statebased Labor Party. Whitlam polarised Queensland, attracting ardent supporters but increasingly mobilising vehement opponents. By 1974, Queenslanders, especially in country and regional areas, despised the new Prime Minister and Bjelke-Petersen took every opportunity to drive the wedge deeper. In the Parliament, the opposition failed to lessen the effect of the government's continued assault on federal Labor. As a new leader, Tucker was keen to assert his leadership credentials and foolishly challenged the Premier to call an early election on the issue of unemployment (something Chalk had been talking about for a while before Bjelke-Petersen finally acted). Tucker's much-quoted challenge to Bjelke-Petersen was at the time - and in retrospect - a stupendous error of judgment. When Bjelke-Petersen obliged the Opposition Leader and announced the election, the result was entirely predictable. Labor lost 22 seats, reducing it from 33 seats to 11. Labor lost many of its recent electoral gains (Albert, Isis, Redlands, Toowoomba East and Pine Rivers), but also many traditional seats. Tucker lost his own seat in the onslaught, as did his deputy, Fred Newton, and was replaced as leader by Burns, who was the only conceivable candidate.

Burns was a relative newcomer to the Parliament, yet as a former state secretary he had much party experience outside the Assembly. Despite his easygoing and calm demeanour, Burns soon found he could not run the gauntlet of the internal disunity ailing the ALP. The internal disarray was so dire in the 1970s, the federal ALP threatened direct intervention in a bid to end the warfare (Fitzgerald and Thornton 1989:262; Courier-Mail, 1 August 1978). Burns was an affable, 'straight-talking, no nonsense' ideas man, but was replaced as leader after just three years (see Murphy 1980:156). He gave the ALP some muchneeded professionalism and a fillip after the 1974 electoral loss but from such a low base electoral victory was inconceivable. 
From 1974 to 1977, the government ran the Parliament with a 'business-asusual' approach, showing minimal regard for the opposition. Leading the parliamentary Labor Party, with its 11 members and party confidence at an alltime low, was a tough assignment. The opposition appeared aimless and, in stark comparison with the session before, only two Labor members were suspended as the government relaxed its control and allowed the ALP to vent its spleen. Labor's efforts to shed light into the dark recesses of the government amounted to little. Queensland voters seemed immune to the opposition's complaints over the growing police state, serial 'states of emergency' and constant police interference in civic life. Still, Labor slowly regrouped and received a slight return in voter support at the 1977 election.

Although Labor doubled its numbers at the 1977 poll (to 23 seats), it appealed only to its bedrock of loyalist supporters for a further six years, capturing only two more seats in 1980. The 1977 electoral loss ended Burns' short stint as leader, although he waited until after the 1978 Sherwood by-election to resign. He stayed on the backbench for six years before being appointed deputy leader under Nev Warburton in 1984. Burns would finally be rewarded for his service and loyalty when Wayne Goss appointed him as Deputy Premier after the ALP's victory in 1989. In 1978, the Caucus turned to the renegade Ed Casey, who found he had just two years to establish his leadership credentials before the electoral term expired. He too would face just one election and bow out of the role in 1982 .

\section{Satisfied with the spoils of defeat}

In the early 1980s, the ALP was in the midst of a bitter internal reform process forced on it by federal intervention. Reformers argued the reform process was long overdue, yet it caused considerable political and financial distress within the party and was deeply resented by the 'Old Guard' unions. From the torment of the reform came the creation of competing factions - dominated by different wings of the union movement: the 'Old Guard' (Labor Unity faction), the Socialist Left and the AWU faction.

The government used these internecine conflicts to portray the ALP as a party riddled with internal squabbles and unable to govern. It proved an effective message. In the Parliament, the Premier constantly reminded Queenslanders of the parlous state of the alternative government. He was wont to taunt the Labor factions by referring to them as 'the old guard, the new guard, the mud guard'. Scathing of Casey's leadership, Bjelke-Petersen claimed in a dissent motion:

The history and performance of the Leader of the Opposition - publicly, privately and politically - have not been very creditable. He has been 
in and out of business and has left a trail of wreckage. He has been in and out of the Labor Party and has caused much havoc. He is even now in conflict with his own Executive and his own party, as well as with others, both in his party and outside it, with whom he cannot live in harmony...The ALP style of politics in Queensland has reached an alltime low. Its smears, innuendoes, character assassination, rumours, half truths, disruption of Parliamentary proceedings and community life, support for rule from the street, lack of respect for you, Mr Speaker and Parliament itself, have been the trade mark of Labor under the Leader of the Opposition... That will be the story that the historians will tell if they take the trouble to write anything seriously about the Leader of the Opposition. (QPD 1979:vol. 279, p. 804)

Casey hit back during the valedictory addresses the next year with his version of how the Parliament was failing the people of Queensland:

Mr Casey: Parliament has creaked its way through the rituals of suppressing the very information that it should be providing for the people of Queensland. For three years it has virtually roared and snored its objections to the freedoms of expression and debate that should be the basis of its existence. Question-time is a joke and ministerial statements have become a time-abusing farce.

Mr Bjelke-Petersen: You make them a farce.

Mr Casey: The Premier and his Ministers should allow ministerial statements to be debated, as they are in other Parliaments. We would then see how often Ministers made use of that practice, which often cuts down on question-time. (QPD 1980:vol. 282, p. 819)

In response, the Premier rose, calling a point of order - a rarity during a valedictory speech. Yet in reality he had little to be worried about. Casey could not turn Labor's fortunes around.

Polls conducted in the lead-up to the 1980 election indicated that the ALP had little chance of wresting government away from the Coalition. Defiant to the end, Casey rejected this analysis, remaining 'convinced that his party could win' (Melbourne Argus, 22 October 1980). His optimism could have come from the outbreak of increased tension between the conservative parties, which both ran separate campaigns and were quite openly hostile to each other. Still, Labor found it hard to gain traction. TheAustralian (28 November 1980) summed up its plight in the lead-up to the 1980 election, saying:

One feels sorry for the Labor Party. Its limited advertising shows they are out of funds; they have two separate organisations [the old and new 
guard] campaigning and authorising advertisements; and in contrast with the flamboyant campaign of former federal president $\mathrm{Mr}$ Tom Burns three years ago, Mr Casey is very dull.

Even the most loyal Labor supporter could not help but be dismayed by the ineptitude and mistakes that continually emerged from the two disaffected party organisations. The Premier, who was constantly able to depict Labor as unready to form a viable government, mercilessly exploited this factional discontent. Journalist Peter Morley noted that 'in 1980, it was personalities not ideologies which split the...party' (Courier-Mail, 27 June 1984). Some 'small-l' Liberal backbenchers (who were increasingly compromised by the actions of the executive) even began to feel sorry for the opposition, and some began to 'coach' the ALP members, reminding them that the role and performance of the opposition were 'extremely important' to the Parliament (see Rosemary Kyburz, in $Q P D$ 1979:vol. 279, p. 755).

Union control over the parliamentary Labor Party was a constant theme of criticism from the government. A typical exchange, regarding the power of the extra-parliamentary executive of the ALP, occurred in the 1982 estimates debate for the Department of Transport. Terry Gygar (Lib., Stafford) challenged Brian Davis (ALP, Brisbane Central) about the ALP's stance on an inquiry into the railways:

Perhaps he would like to take a point of order and tell the Committee when was the last time that he voted against the directions of the Trades Hall. I think Vince Gair was the boy who last did that. And look what happened to him in 1957. The puppet masters... are pulling the strings, and their puppets in this Chamber are dancing to the tune. Why, I do not know. One can only speculate that they are doing it for some motive, because they are not totally mindless, no matter how they might display themselves in this Chamber. (QPD 1982:vol. 289, p. 2308)

Rival ALP factions were each challenging the legitimacy of the others, while seeking control of the party as a whole. Litigation was inevitable. In July 1981, the Queensland Supreme Court determined that the new administration was legally entitled to regard itself as the Queensland Branch of the ALP. Such determinations, however, served only to reinforce popular perceptions of disunity, and did nothing to eradicate the internal feuds in the short term.

\section{Attacks on corruption by the opposition}

From the early 1980s, the opposition began to attack the government over corruption and misconduct issues. Kev Hooper (Archerfield), as spokesman for 
Police and Prisons (a position he had held since 1974), was relentless in the House on these issues, constantly raising allegations about drug trafficking, prostitution, illegal gambling and SP bookmaking. He argued these types of activities could not flourish without the institutional protection of the Police Force, the Police Department and various ministers in government. Hooper talked about illegal casinos operating in Fortitude Valley. Hooper named two of the known operators: Geraldo Bellino and Vittorio Conte. He adversely named the Police Commissioner, Terry Lewis, and Assistant Commissioner, Tony Murphy. Years later, during the Fitzgerald Inquiry, his statements in the House-and reported in newspapers such as the Telegraph-became exhibits because the allegations were found to be virtually true regarding SP bookmaking. The Fitzgerald Report (1989:54) discussed information in Terry Lewis's diaries that suggested that Hooper was receiving information from senior police officers as early as 1978 about police misconduct. Hooper also advocated for justice for Lorrelle Saunders, a police officer who was jailed due to false evidence, but later exonerated. Ed Casey was also active in making allegations about undue influence or favouritism in the awarding of government contracts.

Within two years of the 1980 election loss, however, Labor was again undermining the standing of its leader. It was again looking for an alternative candidate who could match it with the government. Casey's personal opposition to abortion law reform and his dislike of federal intervention did not help garnish him any support. He claimed that he had been 'subjected to a stream of criticism from sources within the party designed to destroy public confidence in [his] capacity to govern' (Sunday Mail, 10 February 1980, cited in Fitzgerald and Thornton 1989:323).

The Coalition could hardly believe its luck and pounced on these new cracks in Labor's facade. They sensed an opportunity to prosper from the ALP embarking on yet another leadership change. Ian Prentice, a Liberal Party moderate, provided sarcastic commentary during a debate on a matter of public interest:

I have stood in this Parliament previously and criticised the Labor Party for being subject to outside direction. Although I do not necessarily change that view I must say that I have come to realise over the past few days how understandable it is. Its capacity for decision-making is wanting. If it is a matter of giving examples, one example is that the major task of any party in any Parliament is to select a leader, one man who can lead an Opposition into government. What has the Opposition done in this regard? Following the last election it selected one, Ed Casey. $\mathrm{He}$ is a kindly man who has done the party well. No sooner did he get into power than Opposition members started wheeling and dealing behind the back door, in the bar, in the garage and round the traps to get rid of him. He had been there for five minutes and they tried to knock 
him off. It is accepted in every Parliament that party members have a right to elect their leader [but] not every week. If Opposition members could wind up their energy, get people to talk to one another and decide on a person who should be elected as leader - even if they did it every week - I would say that they had the ability to make a decision. But no, they have not even got that far... We are on the eve of the Battle of the ALP. It will be interesting to learn who disappears into the mire, never to raise his hopes again. (QPD 1982:vol. 289, pp. 1593-4)

The ambitious Keith Wright emerged from the fray and was elected leader in October 1982. Neville Warburton was appointed as his deputy, replacing the articulate but ineffectual Bill D'Arcy. They were supported in their bid by both the union and the administrative wings of the ALP (Fitzgerald and Thornton 1989:325). Despite being a generation younger than the Premier, Wright, a Baptist lay preacher, shared a similar belief system to his political adversary in the House. Wright claimed, for example, that 'once you enter the political arena, there's no protection other than the on-going promise Christ has given us'. Divine protection allowed the devout Wright to 'embark on a course that may not be popular, because I believe I am within God's Will in that area' (National Times, 3-9 August 1984). Despite Wright's confidence that divine intervention would reverse the ALP's fortunes, he made little impact in the election of 1983.

One major change made by Wright was to replace the shadow ministry with a system of eight committees chaired by members of his new executive. The experimental committee system comprised the portfolio areas headed by shadow ministry members (Table 13.3).

Table 13.3 Keith Wright's eight shadow committee arrangements

\begin{tabular}{|l|l|}
\hline Portfolio responsibility & Opposition shadow minister \\
\hline Economic Strategy & Keith Wright \\
\hline Development and Employment & Nev Warburton \\
\hline Justice and Law Reform & Bob Gibbs \\
\hline Local Government & Eric Shaw \\
\hline Rural & Ed Casey \\
\hline Family Welfare & Terry Mackenroth \\
\hline Transport and Public Facilities & Les Yewdale \\
\hline Environment, Tourism and Leisure & Tom Burns \\
\hline
\end{tabular}

The experiment was, however, short-lived and within a year the eight committees were abandoned. ${ }^{3}$

3 By 4 November 1983, the Caucus had decided to return to the former arrangement of a shadow ministry. Wright supported this move although it was not his initiative. 
Federal Labor's victory in 1983 buoyed the spirits of the state ALP. In the months leading up to the 1983 state election, Wright unveiled the party's 'new direction', emphasising reform to the Parliament, the public service, the electoral system and to the economy. 'Keith Wright - the New Direction' was the unimaginative slogan for the election campaign. The Courier-Mail's editorial (16 June 1983) considered this new direction 'sensible and realistic' and believed that it struck at the heart of the government's weaknesses: 'the unreasonable attitude to the electoral system; the apparent disdain for the institution of Parliament; the increase in power of Cabinet. In a word, the Government's style.' This so-called 'style' implied arrogance, complacency and disdain. The Parliament was not recalled for seven months during the height of the Coalition crisis, so fearful was the government of a no-confidence motion. Criticism of the government's attitude towards the Parliament grew louder as the ALP and the Liberal backbench became frustrated by the chaotic nature of the government's legislative program. A typical example was Wright's criticism that over four months

[w]e have sat for 11 days. Last week there was a sitting to $2.15 \mathrm{am}$ and another one to $2 \mathrm{am}$. This morning we sat until $4 \mathrm{am}$, and we are still sitting at 1.15 am today. Why? It is because of the way in which the Government is running the Parliament. The Government runs the Parliament as if it is running a Saturday afternoon flea market. It has no idea what is important. It is not prepared to give proper consideration to the legislation that comes before the Assembly. (QPD 1982:vol. 290, p. 4157)

The domineering Bjelke-Petersen suddenly appeared more vulnerable in 1983 and Wright hit the campaign trail with a vengeance and with confidence he might win. Labor's unequivocal message was that in contrast with the feuding conservative parties, it was disciplined and united. Although some in the party thought realistically that they were gearing up to fight the 'one after' election (that is, 1986).

The 1983 election was a pivotal one for Queensland, with the Nationals and Liberals contesting as separate entities. The former coalition arrangement was in tatters and the old adage about 'keeping your enemies close' seemed not to be heeded on the conservative side. Llew Edwards had been toppled from the Liberal leadership and replaced with Terry White, who Bjelke-Petersen refused to accept back into the cabinet or as leader. Seven Liberal ministers then resigned as a protest against the Premier's stance. At the grassroots level, two long-serving Liberals, Bob Moore (Windsor) and Bill Kaus (Mansfield), defected to the Nationals after losing Liberal endorsement. Suddenly, the government was in disarray and Wright could portray himself as the Premier in waiting. He released details of his intended cabinet and gave notice that the Treasury 
portfolio would be replaced with two departments: finance and economic development (Daily Sun, 15 October 1983). While Wright was presented with a golden opportunity, he had not calculated on the power of incumbency, the superior campaign the Nationals would manage or the money the Nationals would be able to muster to fight the campaign on television. Local media reports predicting the dawn of a new era were premature (Sunday Sun, 16 October 1983).

The 22 October 1983 election result proved Bjelke-Petersen's gamble paid off: his party alone was now able to form the Government of Queensland. As the ALP ruefully returned to the opposition benches, Tom Burns rose on the first sitting day after the election bemoaning that after a two and a half month adjournment, the Parliament had spent

half a day on an abortive motion moved by the Premier. The debate was gagged by the Government. The Premier stopped his own Deputy Leader from speaking in the debate. Question-time has been taken up by long statements and Dorothy Dixers. I ask you, Mr Speaker, to table the cost of calling this Parliament together for a three-day session, to be misused for political purposes by the Liberal and the National Parties. Where were the Premier and Deputy Premier and Treasurer for the whole of question-time on the first day that this Parliament sat after a long recess? It is a scandal, and we are entitled to better treatment. (QPD 1983:vol. 290, p. 3094)

It appeared that business was back to normal for the Queensland Parliament.

The 1983 poll impacted on the Liberal Party so severely that it has never fully recovered from the debacle. It lost a total of 14 seats and was reduced to only six parliamentarians after the post-election defections of Don Lane and Brian Austin to the National ministry. The election was also a turning point for the ALP, which had won seven new seats, but had returned 10 new members. Many of these would be integral to the party's ultimate victory in 1989, including: Wayne Goss, Pat Comben, Keith De Lacy, David Hamill, Ken McElligott and Anne Warner. Labor's gains in 1983 were its best result since the Labor split of 1956. After the election, one columnist, Malcolm Farr, writing the 'George Street Beat', remarked that

[t]he party [now] has the makings of one [of] the most effective groups of spokesmen for the past 20 years. Some of them are so bright and young they make the power merchants on the Government benches look grey and tired in comparison. There is a plan to improve the shadow front bench by making way for bright-young things Pat Comben, Bill Price, David Hamill and Keith De Lacy. (Sunday Sun, 12 August 1984) 
Other commentators were less positive and viewed the 1983 result as disappointing for Labor when considered alongside the disarray of the conservatives. Labor won 32 seats - 19 in Brisbane and the south-east and 13 from the country and provincial towns. It lost the seat of Maryborough again (this time with the former Liberal member Gil Alison taking the seat as a National, from Brendan Hansen), and while party reformer Denis Murphy claimed the seat of Stafford from the Liberals, he died the next year after a battle with cancer that precluded him from making any sort of impact in the Parliament. Murphy appeared on the floor of the Chamber three times - first to be sworn in, the second time for the condolence motion of another Labor warrior, Kevin Hooper (Telegraph, 27 March 1984), and finally to attend the last sitting day of the session. He did not survive long enough to make his maiden address. Murphy had been earmarked as a potential leader, but his legacy lay in his work outside the parliamentary arena. His eulogy in the House paid tribute to his commitment to the labour cause while his blueprint for reform contributed to the eventual revival of the party.

Despite the optimism Labor had shown before the 1983 poll, the subsequent Labor convention was 'like observing tribal warfare... where the atmosphere [was] poisonous and volatile' (AustralianFinancial Review, 27 June 1984). Wright warned the convention that the ALP must stop its internal factional bickering if it wanted to 'smash the National Party's stranglehold' (Daily Sun, 27 June 1984). Later, he agreed that 'anyone seeing the Labor Party on display there would have been disgusted. If the ALP is going to be the government it has to clean up its faction[al] fighting.' As Wright said, 'it's no wonder traditional ALP voters won't support us' (Telegraph, 8 August 1984).

Foreshadowing changes to his shadow ministry line-up, Wright criticised some on his frontbench, claiming they tended to be 'lazy and undisciplined' (Daily Sun, 9 August 1984). While he had indicated that should he fail to win the next election he would stand down as leader, he would not be given that opportunity. By August 1984, the media was arguing that he did not have a 'firm hand on the tiller' (Sunday Sun, 12 August 1984). His position was further eroded when the Liberals reclaimed Denis Murphy's seat of Stafford in the by-election caused by his death. Wright then made some headway in uniting the administrative and parliamentary wings. He reported that the two bodies had 'agreed to get together and fight the true opponent'. His plan included a direct parliamentary assault on ministers the ALP regarded as weak or ineffective, including: Martin Tenni, Vince Lester, Bob Katter, Peter McKechnie and Bill Gunn (Daily Sun, 21 August 1984). Despite Wright's plans, he did not survive long enough to give effect to any strategy. The truce between the organisational and political factions was short-lived and, within a week of this announcement, Wright quit state politics, opting to contest the federal seat of Capricornia (which he subsequently won). 
Press reports blamed the Stafford by-election loss and the failure of the party to revamp its frontbench as contributing causes leading to Wright's resignation. In reality it was more likely that if he had not gone voluntarily, he would have been pushed.

The steady, if colourless Nev Warburton was selected as the sixth Labor leader to front up to Bjelke-Petersen (and the ninth since the Coalition won office in 1957). The Premier was reportedly unperturbed by these events, saying Warburton was 'just like the others' (Daily Sun, 29 August 1984). Labor's Lazarus, Tom Burns, was returned as deputy leader. In the Parliament-now governed by the Nationals alone-little had changed and there was no relaxation of the procedures to allow more probing opposition scrutiny. A few newer members gained attention attacking the government's fiscal and social policies, but this was deflected by a confident ministry, which seemed unconcerned by Labor's efforts. Helpful rulings by the incoming National Party Speaker, John Warner, bolstered its confidence.

Warburton responded to suggestions Labor were poor economic managers by releasing an economic strategy, but this was mocked by the Premier and the local press. The Premier dismissed the plan by saying ' $[\mathrm{w}]$ hat a strategy it was! What a disaster! Mr Invisible and his policies were roundly ignored almost everywhere he went. His strategy was branded a failure. Honourable members do not have to take my word for that' (QPD 1985:vol. 299, p. 137).

He then taunted the opposition by repeating media reports calling for the ALP to 'take the strategy back to the drawing-board'. He quoted the paper as saying 'apart from other faults the plan is dull. It lacks imagination and flair qualities' (QPD 1985:vol. 299, p. 137).

\section{The 1986 election: further attempts to make corruption allegations stick}

If Labor was disheartened by its successive defeats, it often comforted itself with the aspiration that it might do better at the 'one after'. This was never truer than after 1983. Yet, according to the Labor State Secretary, Peter Beattie, the party had, at every electoral campaign since 1957, "pinned their hopes on the "next" election'. While Labor had faced 10 defeats in a row, somehow the 1983 result seemed to change the landscape for Labor. Gradually, the parliamentary party became more disciplined and displayed signs it was ready to govern. Beattie again asserted that the ALP now had the 'confidence and determination to win' (Daily Sun, 27 June 1984). This time, the party's finances were in a healthy state, helping the party gain momentum. New polling also gave reason for optimism. 
A Morgan Gallup poll published in July 1984 indicated that the ALP had 47 per cent acceptance among Queensland voters while the National Party had only 35 per cent and the Liberals recorded just 14.5 per cent (Courier-Mail, 18 July 1984). Reports suggested an ALP victory was possible for the first time in decades. Bjelke-Petersen dismissed these reports out of hand, quipping that there 'should be a poll on whether or not there should be opinion polls' (Daily Sun, 18 July 1984).

The revolving door of Labor's leadership incumbents continued, however, to harm the party's chances. The Australian Financial Review (30 August 1984) characterised the selection of Warburton as a continuation of the conservatism of the Queensland ALP as well as a sign of compromise between the right and left factions. In reality it was a sign that the Old Guard (Labor Unity faction) was still exercising its muscle within the Caucus. An editorial in the CourierMail (30 August 1984) suggested, using rugby metaphors, that while Wright was 'a stylish, erratic wing three-quarter' what Labor needed was 'a bullocking, hard-working, tight-head prop'. Warburton's 1986 campaign slogans, 'Nev Warburton - your honest choice for Queensland' and the equally unimaginative 'Nev for Premier', indicated Labor had not gauged the electorate well. It signalled that any flamboyancy among the leadership of the past had well and truly evaporated.

Warburton's frontbench continued toiling away trying to expose corruption and a general lack of accountability. Wayne Goss - one of the Parliament's best performers - Tom Burns and Bob Gibbs sought to make concerted attacks on the government over the issue of corruption and alleged conflicts of interest. They highlighted ministerial land grabs for so-called 'friends' of the National Party, conflicts of interest over ministerial business interests (so-called 'extraparliamentary activities') and secret defamation settlements involving cash payments to the Premier. For instance, during 1985, the opposition became fixated on Russ Hinze's acquisition of a TAB licence for his Oxenford pub. Goss claimed that due to this repeated questioning in the House, Hinze was forced to hand back the licence (see Chapter 15; QPD 1985:vol. 299, p. 1227). Allegations were also made about Alan Bond's $\$ 400000$ cash payment to the Premier to settle a defamation matter (QPD 1986:vol. 303, p. 37). The government appeared unconcerned by the opposition's attack until suddenly in 1987 its accusations were given some credence when Deputy Premier, Bill Gunn, announced the Fitzgerald Inquiry into police corruption. As early as 1985, Goss claimed in the Parliament that the evidence mounting against the government was convincing:

The evidence that the Opposition has presented is overwhelming, and in any other State...it would be enough to bring down the relevant Minister and, possibly, the Government of the day. However, it is a sad commentary on the quality of this Government and politics in 
Queensland that it is often said that proving an overwhelming case...is not enough in Queensland-you have to catch them red-handed. That makes the job of the Opposition so much harder; but so be it. ( $Q P D$ 1985:vol. 299, p. 324)

The allegations of cronyism and corruption gained additional leverage when the Premier's former media adviser, Allen Callaghan, was jailed for misappropriation. Despite an unfavourable electoral redistribution in 1985, the ALP remained optimistic in the lead-up to the 1986 poll. The government's woes did not, however, translate into automatic approval for the ALP. With polls showing Warburton's approval rating had slumped to 29 per cent, he was the 'least popular ALP leader in Queensland's recent political history' (QPD 1985:vol. 301, pp. 2333-4). Moreover, because of the ALP's continuing organisational conflicts, the conservative parties still had cause to press the theme that the 'ALP was a party of warring factions' (Bill Knox in the Courier-Mail, 27 June 1984).

In reality, the government was becoming more than a little concerned about such attacks. The blatant 1985 electoral redistribution was evidence of how much the government was worried and felt it needed to corral the Labor vote. The issues of corruption raised by opposition members in the House over many years did not, however, gain real traction with the voters until early 1987. Despite the electorate's apparent complacency, suddenly the opposition's accusations were given some credence after a series of investigative reports in the Courier-Mail by journalist Phil Dickie and an ABC Four Corners program, 'The Moonlight State', concerning police corruption.

\section{Renewal and finally becoming electable: 1986-89}

Despite a concerted effort in 1986, Labor was again thwarted at the polls. Warburton proved to be no charismatic leader or natural vote winner and Labor's poor showing saw it lose two seats and its vote fall by 2.63 per cent overall. The conservative Old Guard had not offered an attractive option outside Labor's heartland. Warburton was therefore allowed his obligatory 'one go' and, once a major factional realignment took place, he was given his marching orders and replaced by one of Labor's best prospects, the young Wayne Goss. This was the time - in the dying days of the Bjelke-Petersen government-when Peter Beattie made the assessment that 'too often it would seem some people in the party have been satisfied with the spoils of defeat' (QPD 1987:vol. 307, p. 
4295). Senior Nationals such as Russell Cooper were delighted to reiterate these words in the Parliament, implying Labor was still a complacent opposition more interested in its own internal machinations than in public administration.

Throughout these wilderness years, the ALP had been its own worst enemy. It was frequently caught between a rock and a hard place. For example, during the debate on the Drugs Misuse Bill (QPD 1986:vol. 303, p. 459), the ALP allowed bad policy to get in the way of political tactics. Despite having major reservations about the legislation and agreeing with the Bar Association's view that the bill was 'barbaric' legislation (Daily Sun, 2 October 1986), the ALP was too scared of being labelled 'soft on drugs' by its political adversaries to really oppose the bill. While such assessments might seem to be overly harsh with hindsight, the Drugs Misuse case indicates the intense pressure the ALP was under. It sought to defend civil liberties while attempting to appeal to a largely conservative voter bloc that had responded favourably to years of 'tough-oncrime' rhetoric and strong government actions. Finding the middle ground was a tactical nightmare.

Labor was jolted out of its complacency by the sudden removal of BjelkePetersen from the political scene in late 1987. A generational change saw Mike Ahern installed as Premier with a new team and fresh agenda. Bob Gibbs summed up the general feeling in the Labor camp at the removal of BjelkePetersen: 'It is... a day of great relief to the members of the Opposition - the day that...Bjelke-Petersen has departed this Parliament. One can understand their relief and light-heartedness at losing such an abhorrent person from the scene of Queensland politics' (QPD 1987:vol. 307, p. 4741).

Warburton welcomed the passing of Bjelke-Petersen but seemed to disapprove of the manner by which Ahern and his lieutenants conducted the coup in the last days of November 1987. He also spoke of the former Speaker, Kev Lingard, 'swimming ambitiously towards that sunken flagship of the National Party', referring to the friends of Bjelke-Petersen group who had tried to rally around the former Premier in his last days (QPD 1987:vol. 307, p. 4738). Warburton's own days as party leader were, however, also numbered.

Behind the scenes, the tired factions of the Labor Party had ceased warring for the moment. A new spirit of 'consociationalism' now prevailed (see Wanna 2000) and agreements were hammered out to ensure power-sharing arrangements between the factions that guaranteed factional representation. In particular, an 'unholy alliance' between the right and left (the AWU and the Socialist Left) not only introduced a new stability in the organisational wing but increased the focus on the leadership of the parliamentary party. The impetus for a leadership spill in the parliamentary party gathered momentum and both groupings 
became convinced of the need for a new leader. They pooled their numbers and rallied behind one of the more outspoken AWU-aligned shadow ministers, Wayne Goss.

When the Parliament met on 8 March 1988, Goss announced to the House that he was the new Opposition Leader. Tom Burns was reappointed as deputy leader. In the Parliament, the new team faced a new Premier, Mike Ahern, and a new Liberal leader, Angus Innes. Goss was permitted to table his full shadow cabinet in the House and it was included in Hansard for the first time (QPD 1988:vol. 307, p. 4846). This was a small but significant indication that the opposition represented an alternative government in waiting.

Table 13.4 Wayne Goss's shadow cabinet, 1988

\begin{tabular}{|c|c|}
\hline Shadow portfolio & Shadow minister \\
\hline $\begin{array}{l}\text { Opposition Leader, Shadow Treasurer and the } \\
\text { Arts }\end{array}$ & Wayne Goss \\
\hline $\begin{array}{l}\text { Deputy Opposition Leader, Police and Main } \\
\text { Roads }\end{array}$ & Tom Burns \\
\hline $\begin{array}{l}\text { Justice and Attorney-General, Community } \\
\text { Services }\end{array}$ & Paul Braddy \\
\hline Primary Industries & Ed Casey \\
\hline Health, Environment and Conservation & Pat Comben \\
\hline Tourism, Sport and Racing & Bill D'Arcy \\
\hline Finance & Keith De Lacy \\
\hline Land Management and Forestry & Bill Eaton \\
\hline Mines and Energy & Bob Gibbs \\
\hline Education and Youth & David Hamill \\
\hline Works, Welfare, Housing and Family Services & Terry Mackenroth \\
\hline $\begin{array}{l}\text { Regional and Northern Development and Small } \\
\text { Business }\end{array}$ & Ken McElligott \\
\hline Water Resources and Maritime Services & Ron McLean \\
\hline $\begin{array}{l}\text { Industry, Communications, Technology and } \\
\text { Consumer Affairs }\end{array}$ & Glen Milliner \\
\hline Local Government and Expo & Eric Shaw \\
\hline $\begin{array}{l}\text { Corrective Services and Administrative } \\
\text { Services }\end{array}$ & Geoff Smith \\
\hline Transport & David Underwood \\
\hline Employment, Training and Industrial Affairs & Ken Vaughan \\
\hline
\end{tabular}

Warburton was not included in Goss's shadow ministry. From this list all but three would feature in Goss's first cabinet when the ALP was elected on 2 December 1989. Eric Shaw became an independent in 1988, after a preselection battle in Manly that saw the AWU's Jim Elder nominated for the seat. Elder won the seat for the government in 1989 and became a minister in 1992. Bill D'Arcy ('the phantom') never sat in the ministry, but would remain in the Parliament 
until January 2000, becoming Chairman of Committees for one term. He raised the ire of Goss after he missed a crucial vote in the House in July 1989 and was subsequently suspended from Caucus for three months and from official party positions for one year. David Underwood announced his resignation from the Assembly before the poll, becoming the Labor Mayor of Ipswich in 1991 before breaking with the party and holding that office as an independent.

Goss had 20 months before the next election to make an impact. He immediately began to pressure the Premier to accept responsibility for what had occurred during his time as a minister in the Bjelke-Petersen cabinet. Ahern denounced these attempts as imposing 'guilt by association' but some mud inevitably stuck (see QPD 1988:vol. 310, pp. 1630-1). When the by-election in the Merthyr seat of disgraced former National minister Don Lane was held in May 1989, it was the Liberals who were victorious - a change of government at the next election was not a foregone conclusion. Goss tried numerous tactics to weaken the standing of the National Party.

Goss's attack focused on the leader and a few long-term ministers. He used a comparison with Bjelke-Petersen's tough and dogmatic style to depict Ahern as weak and vacillating. De Lacy also pushed the theme by poking fun the Premier and saying he needed lessons on 'how to look tough, to act tough and to develop the appropriate gestures - close the fist, thump the table, raise the voice and narrow the eyes' (QPD 1988:vol. 310, p. 1759). Deriding Ahern's statement that he would 'make an important decision each week', Goss asked the House if 'anyone [could] imagine Joh Bjelke-Petersen having to actually announce that he was going to make a decision?' (QPD 1989:vol. 313, p. 13). The ALP observed opinion polls showing the public perceived the Premier as weak and indecisive. It was Ahern's history as a cabinet minister under BjelkePetersen that was, however, the ALP's main target. A typical contribution was Goss's statement that

there is no such thing as retrospective honesty...[Ahern] is the only person in the National Party ranks in this House who served through the entire Bjelke-Petersen Premiership. He sat as a Government member for 12 years and in Cabinet for eight years. In all that time, is there evidence of Mike Ahern ever raising his voice against corruption in public, in the party room, in Parliament or in Cabinet? No! (QPD 1988:vol. 309, pp. $1044-5)^{4}$

Labor's strategy was now twofold: to push corruption as a major indictment of the government's stewardship and to begin to assemble its own reformist agenda in preparation for government.

4 The Liberal's Bill Lickiss was elected in 1963 but the Liberals were not in government from 1983 to 1988 and Russ Hinze had resigned five months earlier, in May 1988. 
Inside the party, Goss's main task was to make the ALP fit for government. This was not without its problems. Under the surface, many of the old personalities and factional struggles remained. In the party campaign literature, Goss's name was ubiquitous. Despite early concerns that he lacked public appeal, Goss was soon praised for his tough approach. When he spoke in the House about what his government would do when elected, the public gallery erupted in spontaneous applause. He said:

Let us aim for the goal of giving this State a future and good Government. It is time for no confidence to be shown in the Government of this State. It is time for an election. It is time for a real change. It is time to clean up the mess. It is time for the people of this State to say, 'We've had enough. You're out'. A Goss Government will give the people of this State that future. It will work within the Fitzgerald framework. I commit a Goss Government to that future. Today I commit a Goss Government to the implementation of the EARC [Electoral and Administrative Review Commission]. After December - or whenever the Premier has the guts to call an election - the Labor Party will be ready to move and give this State an honest future, not a dishonest one; not a step back into the darkness; not a Government of dishonour and scheming ambition. The Labor Party will provide good government. (QPD 1989:vol. 313, p. 621)

This augured well but there was still a gruelling campaign to be fought - under the old electoral boundaries. Winning the Treasury benches was not a foregone conclusion. The ALP had been fortunate to have an influx of new talent in the 1980s, but finding enough shadow ministers of quality, who also met with the approval of the organisational wings of the party, was challenging. Goss wryly noted as much to a senior official when planning his first ministry: 'Remember to leave me with some small, insignificant Departments because I have some small, insignificant Ministers' (cited in Wanna 2003:370). Russell Cooper replaced Ahern just three months out from the election and suddenly the opposition faced a new adversary. This leadership change and the retention of Bill Gunn as Deputy Premier resulted in moments of humour in the House. Ed Casey could not help but jest: 'Mr Speaker...I want it to be known that the vicious rumour circulating throughout Queensland that, when Wayne Goss becomes Premier, this man will bob up as his deputy, is not true' (QPD 1989:vol. 313, p. 617).

After 32 years in the wilderness and 11 leadership changes, the Labor Party was elected to government in its own right in December 1989. It had been a long crawl back from the abyss. Successive leaders attempted, but failed, to win a majority of the state-wide vote and the various malapportionment schemes had served to deflate the proportion of seats they might otherwise have won. Labor's high-water mark in terms of voter support was in 1972 (with 46.75 per cent), after which it hovered around the low-40 percentages. Not until 1989 did 
Labor achieve a majority of the vote - and then only just (50.32 per cent, but delivering 54 seats). Labor had rebuilt itself and made itself electable to ordinary Queenslanders. About 10 per cent of the electorate voted Labor for the first time in their lives in 1989. It was a huge swing, but it also took the collapse of the Coalition, two terms of the unrestrained National Party governing alone, two decades of Premier Bjelke-Petersen's hubris and vindictiveness and eventually a royal commission of inquiry into police misconduct before Labor was finally able to sell itself as an alternative government and be entrusted again with the governing of the state. Goss and his team of more able shadow spokesmen finally fell over the finishing line as the victors. The new Deputy Premier, Tom Burns, summed up the elation in the Labor camp with the memorable quote: 'I'll have to suck a lemon to get the grin off my face' (Sunday Mail, 10 December 1989).

\section{Withholding recognition and resources from the opposition}

Throughout its period in opposition, the Labor Party was parsimoniously funded and had little administrative support or other resources. Unlike in other Westminster systems, where the Leader of the Opposition holds an important institutional position, the Queensland parliamentary system embraced a 'winner-take-all' style of government. Jack Houston recalled the limited assistance available during his period as Opposition Leader (1966-74):

The Leader had a private secretary and [one] typist, circumstances which helped bring about the development of Shadow Ministers and their committees. These early committees were within the party and not recognised by the Government. The Shadow Minister and his committee had the responsibility of researching all matters that came under their Shadow Ministry and except in matters of major policy they led the opposition debate in the house and framed questions of concern to their minister. (Personal correspondence, 3 March 1997)

The government's reluctance to provide the opposition with additional resources was driven by the Premier and was seen as payback for the time when the Coalition was in opposition and received few resources. It was straight retribution. Joh Bjelke-Petersen was, according to Bill Hewitt, 'an OldTestament Christian' - a fire-and-brimstone proponent who believed in an 'eye for an eye' - who thought what was good enough for the Country Party in its wilderness years in opposition was good enough for Labor. As with many selftaught lay preachers, he maintained a belief in simple faiths: there was only one 'right way' and all others were satanic or sinful. Bjelke-Petersen was, thus, 
angered by any opposition to his government and his antipathy was expressed through denying the opposition recognition or resources to perform credibly. It was as if it was God's duty to deny any opponents sustenance.

Throughout the 1970s and 1980s, the opposition complained that inadequate resourcing prevented it becoming a professional team making an effective contribution in the Parliament and hindered its ability to campaign and travel across the vast state. This lack of resources meant that Labor's capacity to challenge the government rested purely with the leader and a few senior shadow spokespeople. Houston frequently requested additional assistance and he often compared Queensland's poor treatment of its opposition with the more generous resourcing of oppositions in other states. According to Houston, Victoria's Opposition Leader had a political secretary, research officer, personal secretary, two typists and a chauffeur. The NSW opposition was accorded similar treatment. In Queensland, the Opposition Leader had only a secretary, typist and chauffeur, and everyone else had nothing. Houston told the Parliament in October 1969:

I am not looking for additional staff only so that I may say that the Leader of the Opposition has more staff. As you realise, Mr Ramsden [the temporary Chair of Committee], a great deal of work has to be done to make democracy work. There are two essential sections: the Government, on one side, presenting its legislation; the Opposition, on the other, presenting its view of the legislation, whatever it happens to be. The presentation of such cases involves a great deal of time and research, and one cannot do the work today with the same number of staff that one had 10 or 20 years ago. I know it can be said that certain things happened to the then Opposition under Labour Governments. However, I am not interested in what happened then. If it was not in the best interests of the Opposition in those Parliaments, I regret it, but I am interested in what is happening today. (QPD 1969:vol. 251, p. 742) ${ }^{5}$

The Speaker's letter of reply to Houston's representations indicated he would raise the matter of resources with the Premier personally and, in a separate letter to the Speaker, the Premier stated he would be pleased to discuss such proposals with the Speaker at a mutually convenient time. Nothing changed. Houston was fobbed off with the excuse that the government could not provide more staff because of the limited space in the parliament building (QPD 1969:vol. 251, p. 742). An incensed Houston responded, stating 'where to put any extra staff is secondary to what I consider more important - that is, the provision of such extra assistance' (QPD 1969:vol. 251, p. 742).

5 For more on the institutional importance of the shadow cabinet, see Bateman (2009). 
In the 1970s and 1980s, the Premier frequently used his government-funded jet to tour the state at his convenience, while the Opposition Leader, Ed Casey, was forced to use standard-schedule commercial flights. The Liberal leader was also allowed to use the jet for meetings and in the election campaign. As Casey pointed out, his travel arrangements involved 'very early starts, using up time that I should be working on co-ordination of the campaign' (Melbourne Argus, 29 October 1980). The government paid for just one flight in the 1980 s election and Casey's request that cabinet consider a more generous allowance including unlimited air travel for his deputy was summarily dismissed. The Premier's response was unequivocal: Casey was getting far better treatment than any previous opposition leader had enjoyed.

Further controversy arose when the opposition was moved out of Parliament House and away from the media. Cabinet decided to relocate the Opposition Leader's office to Watkins Place in Brisbane's CBD. Burns queried the decision as to why the opposition had been summarily relocated by cabinet and wondered whether it would ever be allowed back. The reason for the move was due to the renovation, so he asked:

What is the nature of such renovations? For what purpose will the room be used when they are completed; I am talking about the staff office that we now have? Does the Cabinet decision also mean that there will be no provision for accommodation...for Opposition staff in the new parliamentary wing, even though lengthy discussions have been held on this subject and designs still exist within the Minister's department for accommodation for Opposition staff in the new building? Is the space allocated to my staff in the new building now being given to the Executive Council or to Cabinet for its use? (QPD 1978:vol. 275, pp. 1458-9)

His question was given short shrift. The Works Minister, Claude Wharton, replied:

Cabinet has decided that it is appropriate to provide suitable offices for the Leader of the Opposition and his staff in Watkins Place...I sympathise with the Leader of the Opposition, who apparently will have difficulty in getting to and from work. I also sympathise with his staff. This government always thinks of the employees.

Mr R. J. Gibbs: Oh, go away!...

Mr Wharton: No special provision is made in any other Parliament for the Leader of the Opposition and his staff. I point out that the Premier 
and the Treasurer have no provision for office staff in this building, nor has any other Minister... The Leader of the Opposition will just have to get used to doing what they do. (QPD 1978:vol. 275, pp. 1458-9)

In 1980, Bill D'Arcy, as deputy leader, asserted that the Queensland opposition remained the 'worst off in Australia' (QPD 1980:vol. 282, p. 90), while his leader, Ed Casey, suggested his staffers were the 'most disadvantaged public servants in Queensland', especially since the office of the Leader of the Opposition was physically moved away from the Parliament. He complained 'this is the only Opposition under the Westminster system to be so treated' (QPD 1980:vol. 282, p. 819). Labor also complained that when Queensland delegations attended constitutional conventions (attended by the Commonwealth and states and territories), whereas other jurisdictions sent equal numbers of government and opposition members, Queensland short-changed the opposition. Of the 12 delegates per jurisdiction, if other states tended to send six government and six opposition representatives, Queensland sent 10 government delegates in 1974 to two from Labor, and in 1978 and 1982 sent nine government delegates to the opposition's three. While the Premier said it was the Queensland Parliament's prerogative to determine the numbers (and he believed they should approximate the party numbers in the Assembly), Labor argued it was a form of 'one-eyed, lop-sided representation' that was due to the 'undemocratic manipulation of a Premier' (QPD 1982:vol. 287, pp. 5149-50).

\section{Parliamentary tactics to blunt opposition attacks}

Speakers in the Queensland Parliament have often not been impartial advocates of parliamentary democracy. This often resulted in the Speaker taking a tough line on what was allowed during debate and, at times, giving greater leniency to government members. Speakers kept the opposition members on a tight leash, vetting their questions, forewarning ministers of impending attacks and seeking to expedite government business. Speaker Selwyn Muller was not alone in his view that it was the Speaker's job to interpret decisions in the manner the government of which he was a member would wish, he was just the one to articulate it in this frank fashion (Courier-Mail, 8 October 1979).

While Speakers such as Bill Lonergan and later Muller tended to rule the Parliament with a government-aligned iron fist, it was Muller's successor, the 'quiet and gentle' John Warner, who bore the brunt of the opposition's later fury. Dissent motions against the Speaker increased in the 1980s as the ALP stressed the links between corruption highlighted daily in the press and the treatment of Parliament by the government. On one such occasion, Gibbs complained: 
In a period of three years, Mr Speaker has made two conflicting statements, and only last week, Mr Speaker acted incorrectly and unfairly and has deliberately gone out of his way to protect the Government. I draw to honourable members' attention the fact that before this 1986 session commenced, the Premier himself went on record as saying that he would tell Mr Speaker how to run this Parliament. That was printed in the media... As every day goes by, it is becoming very obvious that the privilege of this Parliament is being abused by the Government and by the Premier...As of late, because of the incompetence of $\mathrm{Mr}$ Speaker, this House certainly does not resemble an open Parliament, one where full and fruitful discussion can take place... Is it any wonder that members on this side of the House and members on the Government side of the House - even though they will not admit it in this Chamberhave lost confidence in Mr Speaker? For the sake of all parliamentarians, he should stand down and resign. (QPD 1986:vol. 302, pp. 3793-4)

Bjelke-Petersen expected the Speaker of the day to follow his instructions. This placed a heavy burden on the person in the chair and led to a number of public stoushes between the Premier and the Speaker.

The internal procedures of the Parliament did not help the opposition. Parliamentary practice reflected the government's attitude that the Parliament was there to serve its agenda, and the provisions of Standing Orders were used to assist the government to the detriment of the opposition. Moreover, these procedures were often open to interpretation and various Speakers interpreted the Standing Orders in a way that protected the government or deflected attacks.

The suspension of an opposition member was one such tactic. Table 13.5 shows the instances when members were suspended from the House. These suspensions were usually for seven days, but some were for up to 14 days. Examining these suspensions now, there appears to be a strong correlation between the number of members ordered to leave the parliamentary precinct and the magnitude of the electoral challenge posed by the opposition. When the contest was relatively even and the opposition was in fighting form (the lead-up to the 1972 election), or when the government felt challenged, the numbers of suspended members increased (1969-74). Most suspensions were for refusal to withdraw a comment or interjection considered inappropriate, un-parliamentary or offensive. These comments and interjections were usually directed towards another Member of Parliament. Sometimes Labor members would test the waters and deliberately misbehave to make a point, baiting a Speaker to see how they would react. They often made endless points of order, frequent interjections and allegations of personal impropriety. At times, the Chamber resembled an unruly schoolyard in which name-calling and accusations flew in all directions. On just four 
occasions members were asked to leave the Chamber due to inappropriate dress standards - usually no jacket or tie (Hinze, 10 December 1970; D'Arcy, 9 March 1973; Gibbs, 18 March 1982; and Smyth, 19 April 1989).

The government would move a member be suspended and then use its numbers in the vote to ensure the sanction was ratified. Between 1957 and 1989, Russ Hinze was the only member of the government suspended from the House. His suspension was for the remainder of the day after he offended the Speaker (see QPD 1974:vol. 265, p. 486). Throughout this period only two government members were asked to 'withdraw' (leave for a few hours): Don Lane (Lib.) was asked to withdraw in 1972 and again in 1975, and Lindsay Hartwig (NP and later independent) in 1978.

Table 13.5 Members of Parliament suspended, 1957-89

\begin{tabular}{|c|c|c|c|}
\hline Parliament & MP & Party & Date \\
\hline 35th 1957-60 & - & - & - \\
\hline 36th 1960-63 & Bennett, C. J. & ALP & 21 November 1962 \\
\hline 37 th $1963-66$ & $\begin{array}{l}\text { Wallace, G. W. G. } \\
\text { Bennett, C. J. }\end{array}$ & $\begin{array}{l}\text { ALP } \\
\text { ALP }\end{array}$ & $\begin{array}{l}4 \text { March } 1964 \\
11 \text { March } 1965\end{array}$ \\
\hline 38th1966-69 & $\begin{array}{l}\text { Bromley, F. P. } \\
\text { Tucker, P. J. R. } \\
\text { Jones, R. } \\
\text { Graham, F. D. } \\
\text { Bennett, C. J. } \\
\text { Bennett, C. J. }\end{array}$ & $\begin{array}{l}\text { ALP } \\
\text { ALP } \\
\text { ALP } \\
\text { ALP } \\
\text { ALP } \\
\text { ALP }\end{array}$ & $\begin{array}{l}6 \text { September } 1966 \\
17 \text { April } 1968 \\
26 \text { September } 1968 \\
3 \text { December } 1968 \\
3 \text { December } 1968 \\
6 \text { December } 1968\end{array}$ \\
\hline 39th1969-72 & $\begin{array}{l}\text { Tucker, P. J. R. } \\
\text { Hanson, M. } \\
\text { Bennett, C. J. } \\
\text { Sherrington, D. J. } \\
\text { Sherrington, D. J. } \\
\text { Davis, B. J. } \\
\text { Bennett, C. J. } \\
\text { Baldwin, E. A. }\end{array}$ & $\begin{array}{l}\text { ALP } \\
\text { ALP } \\
\text { ALP } \\
\text { ALP } \\
\text { ALP } \\
\text { ALP } \\
\text { ALP } \\
\text { ALP }\end{array}$ & $\begin{array}{l}19 \text { August } 1969 \\
2 \text { December } 1969 \\
2 \text { December } 1969 \\
29 \text { July } 1970 \\
25 \text { August } 1970 \\
22 \text { October } 1970 \\
15 \text { September } 1971 \\
8 \text { December } 1971\end{array}$ \\
\hline 40th1972-74 & $\begin{array}{l}\text { Tucker, P. J. R. } \\
\text { Jones, N. F. } \\
\text { Bromley, F. P. } \\
\text { Moore, F. P. } \\
\text { Aikens, T. } \\
\text { Tucker, P. R. J. } \\
\text { Burns, T. J. } \\
\text { Sherrington, D. J. } \\
\text { Hinze, R. J. } \\
\text { Sherrington, D. J. } \\
\text { Tucker, P. R. J. } \\
\text { Moore, F. P. } \\
\text { Wright, K. W. }\end{array}$ & $\begin{array}{l}\text { ALP } \\
\text { ALP } \\
\text { ALP } \\
\text { ALP } \\
\text { NQLP } \\
\text { ALP } \\
\text { ALP } \\
\text { ALP } \\
\text { NP } \\
\text { ALP } \\
\text { ALP } \\
\text { ALP } \\
\text { ALP }\end{array}$ & $\begin{array}{l}5 \text { September } 1972 \\
26 \text { October } 1972 \\
30 \text { March } 1973 \\
5 \text { April } 1973 \\
5 \text { April } 1973 \\
11 \text { September } 1973 \\
11 \text { September } 1973 \\
7 \text { March } 1974 \\
3 \text { September } 1974 \\
24 \text { September } 1974 \\
23 \text { October } 1974 \\
23 \text { October } 1974 \\
31 \text { October } 1974\end{array}$ \\
\hline 41st1975-77 & Hooper, K. J. & ALP & 11 March 1976 \\
\hline 42nd1978-80 & Hooper, K. J. & ALP & 20 May 1980 \\
\hline 43rd1981-83 & Burns, T. J. & ALP & 2 August 1983 \\
\hline
\end{tabular}




\begin{tabular}{|l|l|l|l|}
\hline 44th1983-86 & Underwood, D. F. & ALP & 27 March 1984 \\
& McLean, R. T. & ALP & 22 November 1984 \\
& Gibbs, R. J. & ALP & 20 March 1985 \\
& Hamill, D. J. & ALP & 20 March 1985 \\
& Casey, E. D. & ALP & 18 February 1986 \\
& Burns, T. J. & ALP & 19 February 1986 \\
& Gibbs, R. J. & ALP & 26 February 1986 \\
\hline 45th1987-89 & Burns, T. J. & ALP & 15 October 1987 \\
\hline
\end{tabular}

Source: Queensland Parliamentary Library, Research Section.

On some occasions, the decision by the Speaker to suspend a member could have been prejudicial to the final vote. ${ }^{6}$ An instance of this was during the bitter debate over the Pregnancy Termination Control Bill, when Kev Hooper was suspended for 14 days. Labor frontbencher Bob Gibbs later stated:

In this House just a few hours ago, because of the frustration and the fear experienced by this Government, we saw one of the most shameful acts we have seen in the last $2 \frac{1}{2}$ years, when the honourable member for Archerfield was sent out of the house for 14 days...The Minister knew, as did all Government members know, that the numbers were as close as 37 to 34 . It only needs a few more Government members to sway - that possibly could still happen - for this Bill to be defeated. The Government was prepared to stoop to any low political trick to suspend a member of the Opposition who would have opposed this legislation. (QPD 1980:vol. 281, p. 3698)

The opposition's ability to adequately scrutinise the government was constrained in other ways. Throughout most of this period, the Standing Orders were out of date and, until the Standing Orders Committee was reconstituted in the 1980s, it had not met for more than 20 years. Many of the formal processes of parliament were antiquated and designed to obfuscate, and transparency and accountability were perfunctory at best. The routine practices found in other parliaments (such as dedicated estimates committees) were resisted or ignored. For instance, before the 1990s, the scrutiny of departmental estimates was a haphazard affair. Some departments did not have their estimates of spending (and therefore their intended activities) debated for many years, while other usually less controversial departments were often debated. The committee (parliament as a whole) could not call on officials and estimates debates were largely indistinguishable from other debates in the House. They certainly were not rigorous inquiries into a department's expenditures. As Ed Casey noted during the 1982 estimates debate of the Lands Department:

6 The use of Standing Orders to benefit the government in a close house is avoided now with the addition of a Standing Order that enables the Speaker to order the withdrawal of a member for the remainder for the day, except for divisions - so while suspended from the House, they are still able to vote. 
An extraordinary aspect of recent events in this Parliament is that it is very difficult to obtain a department's annual report until virtually the day prior to the presentation of the Estimates of that department. Unquestionably, a department's annual report is the only appropriate source of information from which members can ascertain what is being done by the Government. (QPD 1982:vol. 289, p. 2475)

Labor's frontbench tried various strategies to show up the government's shortcomings and sometimes they backfired. Their cries of censorship were sometimes taken up by the press as the following editorial attested:

The Opposition's complaint that a ridiculous form of censorship is making a farce of question time... has merit. This censorship of questions is only one of the defects of the system of questions and answers in the State Parliament, but is nevertheless of importance... There is no reason why an implied criticism of the Government, or of a Minister, should be removed from a question. (Courier-Mail, 11 September 1969)

Even such sympathetic views, however, contained criticisms of how the opposition conducted itself in the House. The same editorial also noted: 'The Opposition has contributed to the poor questioning of Ministers by not making the best use of question time. The time of Parliament should not be wasted in providing answers to repetitive questions, or to questions to which the answers are readily available in parliamentary papers' (Courier-Mail, 11 September 1969).

While inadequate resources hampered the opposition's performance, it nevertheless often seemed the Labor Party was itself too complacent. This left the door open to Labor's political opponents, who suggested that the opposition was lazy and that question time was often a wasted exercise, as the only issues raised were those that had been raised in the media the morning before they were then asked in the Parliament. Indeed, Russ Hinze once said that he wondered whether Labor would be able to dream up any questions if the Courier-Mail failed to appear on a sitting day (QPD 1971:vol. 257, p. 1200).

Outside the Parliament, the ability of the opposition to criticise the government was constrained by the threat of legal action. The Premier and his senior ministers used threats of defamation and stopper writs against critics during Bjelke-Petersen's final terms. Even if no damages were awarded against the defendant, they often had to pay the legal costs of ministers. On the other hand, when the Premier faced civil action for defamation (initiated by the environmentalist John Sinclair), he got cabinet to agree to meet all his costs in defending the case. The opposition considered that the use of defamation lawsuits was evidence that the government had something to hide. The threat of legal action toughened Labor's resolve and some on the frontbench started 
interviewing disenchanted public servants to gather information that would further discredit the government. Tom Burns pointed out to the waiting press after he was suspended from the Parliament that 'I have got a ton of time. Joh's given it to me' (Australian Financial Review, 15 October 1986, p. 7).

Some of these publicly funded law suits resulted in personal payments to individuals, including the Premier. During 1986, when the Parliament was discussing the payment of $\$ 400000$ to Bjelke-Petersen by Alan Bond as an outof-court defamation settlement, the Premier responded to questions about who was paying his legal bills by issuing further threats:

Mr Bjelke-Petersen: It will give me great glee and great joy to pay all my expenses when I get the Leader of the Opposition before the court.

Mr De Lacy: Are you going to pay your own costs?

Mr Bjelke-Petersen: Yes. As a consequence of what happened outside the House last night, further action will be taken today by my legal people. Honourable members opposite cannot continue to do these things. They are trying to destroy a Government. By their actions, they are trying to destroy not only me but also the Government...I say to honourable members opposite that, if they again go outside the House and make statements, they will have further troubles and problems on their plate. I assure them that there will be big problems.

Interjection: Is that a threat or a promise? (QPD 1986:vol. 303, p. 168)

Bjelke-Petersen went to great lengths to try to prevent his opponents from speaking out against him, his government and his ministers, or against individuals with close ties to the government. He came to resent parliamentary privilege and what he regarded as the abuse of privilege by his political opponents. Outside the Parliament, however, he was not afraid of taking tough initiatives to prevent criticism, using the law as a means of intimidation. His stopper writs and defamation cases were funded at the public's expense, although any windfall gains tended to be accepted personally. Bjelke-Petersen obfuscated on whether he benefited this way and in the Parliament often refused to confirm or deny exactly what had happened to the damages payments. He did confirm that in the case of Mark Plunkett (who had accused the Premier of undertaking a criminal conspiracy to pervert the course of justice), when legal costs were recovered from him (some \$4500), the funds were paid into consolidated revenue (QPD 1981:vol. 284, pp. 2025-6). 


\section{Conclusion}

The ability of successive governments to limit scrutiny of their actions by the opposition was evident throughout most of the previous century. In this regard, the Coalition governments were no different than their Labor predecessors. Neither side took kindly to criticism or scrutiny and resented ever providing the opposition with opportunities or resources with which to attack the government. The opposition was tolerated to the extent that its members made bland or banal speeches on legislation before the House, but not tolerated if it proposed real alternatives or began to criticise government policy or actions. It is not clear from this period of the Parliament's history whether the government ever accepted the legitimacy of the opposition or its right to question the administration of the state. More habitually, the opposition was treated as a whipping post by the government, which was anxious to deflect any disquiet back onto its opponents. It was a trying time for the Labor opposition of this period, but one in which the labour movement as a whole must bear some responsibility for Labor's ineffectiveness as a parliamentary opposition. 



\section{The demise of the Coalition and the Nationals governing alone, 1981-1983}

In 1980, backroom plans had been already entertained for a stand-alone National Party government supplemented by a few Liberal 'ministerialists' opportunists who would cross over and side with whatever the next ministry turned out to be in order to remain part of the next government. Historically, 'ministerialists' were typically senior parliamentarians who, forgoing party loyalties, decided to collaborate as individuals in the formulation of a new government. After the 1980 election, however, any such musing was put on hold as the two conservative parties lapsed back into coalition. This time, the Nationals clearly imposed their dominance, taking the prime portfolios and consigning the 'leftovers' to the Liberals. Labor began to refer to the junior partners as 'Dr Edwards and his shattered Liberal team' - the losers who were 'now completely the captive of the National Party' (QPD 1981:vol. 283, p. 7).

Despite his vitriolic attacks against the Premier and the National-led government, Llew Edwards retained his position as Deputy Premier and Treasurer - positions he would keep until he was deposed by Terry White on the eve of the Coalition collapse in August 1983, although there was an unsuccessful attempt by dissident Liberals to remove Edwards in November 1981. When the Premier learned about the dissident Liberal plan to topple Edwards, with Angus Innes taking the lead, he declared Innes an 'anti-coalitionist' and someone with whom he would not work. Instead, Bjelke-Petersen began hatching plans to form a minority government with whomsoever among the Liberals who would give him support; and then to govern alone until mid-1982. Eventually, the Premier would fall back on this contingency plan but not until a year later, in mid-1983.

The new Parliament contained 12 new members, meaning that more than onethird of the members had served for just one term or less. Only 28 members had been in the House for more than six years. One member, Rob Akers (Lib., Pine Rivers), called it a 'relatively inexperienced House', while Labor's Tom Burns noted that politics was 'a high-risk industry' (QPD 1981:vol. 283, pp. 284-5). The incoming members were Rob Borbidge, Tony FitzGerald, Nev Harper, Doug Jennings, Max Menzel, Geoff Muntz and Jim Randell from the Nationals; Bill (A. G.) Eaton, Ron McLean and Geoff Smith from Labor; and Ian Prentice and Beryce Nelson (the fifth woman to be elected to the House) from the Liberals. All made their maiden speeches in the early months of 1981, pledging their loyalties 
to the Queen and raising a few parochial issues of concern to their electorates and local industries. Borbidge talked of tourism, casinos and police shortages; Nelson mentioned aged widows, people with disabilities and the road toll fatalities; and McLean discussed local accommodation problems, crisis centres, local libraries, the need for more ferries and the beauty of the Brisbane River.

At the other end of the spectrum, Bjelke-Petersen turned seventy years of age in January 1981; he had by then sat in the Parliament for almost 34 years - 17 as a Minister of the Crown and more than 12 years as Premier. First elected in 1947, he was the last of his generation. In the 1981-83 Parliament, only Bill Knox remained from the 1950s (1957) and only another four from the early 1960s: Vic Sullivan and Claude Wharton (both 1960), Bill Lickiss (1963) and Norman Lee (1964). By 1981, only two ministers besides Bjelke-Petersen were survivors of his first ministry dating from 1968: Knox and Sullivan. The forty-third Parliament (1981-83) would sit for only 130 days during three years - approximately 43 days a year. There would be no by-elections during this Parliament.

\section{An exercise in subterfuge: the quest to 'sell' Muller as Speaker}

Again, considerable bluster, vitriol and breast-beating were evident in the process of electing a Speaker, when the House was 'uncontrolled' (because it was chaired by the Clerk, who had no authority). Lin Powell (NP, Isis) nominated Sel Muller as the Coalition's preferred choice. There was not much by way of reasoned argument from Powell to support his nomination. He traced a superficial, potted history of the Speaker's position in Westminster (in which the Speaker's independence is sacrosanct, unlike in Queensland), before stating that Muller was 'well suited to fit those demanding terms of reference'. Muller's qualifications were apparently that he was born in Boonah, left school at fifteen, worked in primary industry, fought in the Middle East in World War II and maintained an active interest in primary industry before entering the Parliament in 1969. Thus, Powell concluded, 'his career has been long and distinguished' with his interest in politics supposedly dating back to 1935 when his father, Alf Muller, entered the Parliament. Colin Miller (Lib., Ithaca) immediately sprang to second the nomination, praising the nominee, claiming he ran the House well in the second half of the previous Parliament and had presided over innovations such as the introduction of adjournment debates. He ventured that 'I will be very surprised if we do not see a meeting of the Standing Orders Committee' - a statement that was greeted with laughter and derision from the opposition. Miller continued: 
It is important that the Speaker of this Parliament be independent. Whilst I heard members of the Opposition laugh a few moments ago when I referred to a meeting of the Standing Orders Committee, I hope that they will be serious enough to recognise that we should be endeavouring at all times to ensure the independence of the Speaker of this Parliament.

(QPD 1981:vol. 283, p. 5)

Worthy sentiments, indeed, but the mover and seconder of the motion to elect Muller were not so serious that they were prepared to countenance an independent vote for the Speaker from the floor of the House (that is, one not organised by the parties - in effect a conscience vote). The Leader of the Opposition, Ed Casey, revealed he was 'absolutely shocked and amazed' that the government could propose to reinstate Muller in the job given that he had expressed the view that the Speaker was 'elected to apply the wishes of the Government he represents' and had then, in the preceding Parliament, ruled out many opposition questions (QPD 1981:vol. 283, p. 6). Bill D'Arcy-who seconded Labor's nomination of Ray Jones (the Member for Cairns and Labor's longest-serving member, first elected in 1965) - also pointed out that Muller had said that he believed the Speaker's responsibility was to interpret 'decisions in the manner the Government of which he is a member would wish' (QPD 1981:vol. 283, p. 8).

Both Casey and D'Arcy complained about the poor state of the Queensland Parliament, with Casey asserting that Queensland was the only parliament in Australia in which the opposition was denied equal rights in question time, denied equal rights on matters of public importance and denied the right to initiate matters in the House. He claimed that the only way to reverse this was not to trust Liberal reformers who talked about reforms but never delivered, but to appoint a truly independent Speaker.

Kevin Hooper (Archerfield) reminded the House that Dr Norman Scott-Young (Lib., Townsville) had put himself forward to be Speaker and had sent letters around to fellow members seeking support. The letter apparently contained Scott-Young's observations that

for some years I have been disturbed that the power of Parliament has been slowly eroded...[including by legislation, and in recent years it] lost its independence and became virtually a sub-department of the Premier's department... Another reason why I intend to nominate for Speaker is that I consider the Speaker should be elected by the Members of Parliament from the floor of the House. It should not be an appointment arranged by and subject to Party Executive directions...If appointed I intend to act in a completely impartial manner in all matters brought up for deliberation. (QPD 1981:vol. 283, p. 10) 
The 'young turk', Norm Scott-Young, did not, however, have the courage or backbench support to mount a challenge and stand. Rosemary Kyburz (Lib., Salisbury) then spoke favourably to the motion to appoint Muller to the Speakership by claiming the Coalition agreement stated that the Speaker was to come from the National Party. She continued: 'I must say that whilst there is not a great deal of the coalition agreement that I agree with, I am prepared to abide by that [clause]', but added that the Parliament was a 'shemozzle' and needed a proper 'committee system' and a 'new Act of Parliament to govern the functioning of this Parliament entirely'. According to Kyburz, responsibility for the House was divided and

torn between two departments. I believe that those who have been here for some years know that it is torn between the Works Department and the Premier's Department. The internal politics of this place are somewhat mystifying, I must say. I feel very sorry about the singularly low morale of some of the employees of this House. (QPD 1981:vol. 283, p. 12)

She said she 'had a great deal of pleasure in supporting' Muller's nomination because he had 'maintained a high standard of decorum in his role as Speaker' and he was a 'gentleman' who was 'amenable to change' (QPD 1981:vol. 283, p. 13).

Lindsay Hartwig - who had been elected as a National for the seat of Callide until he was expelled by his party colleagues four months after the election and declared himself an independent on 26 March 1981 - also apparently harboured ambitions to become Speaker and had allowed his name to go forward (meaning that he lobbied hard to get support). The newly independent member told the Assembly, however, that

I rise as one who has had the finger pointed at him today, and as one who has levelled some criticism in past weeks about the compilation of Cabinet and how it affects Central and Northern Queensland. My name has also been associated with the speakership. Reference was made this morning by the Premier to the fact that he considered it a joke...I tell the Premier and this Parliament that it was no joke; that I was approached to stand for the speakership. On being approached to nominate for the speakership I considered the matter. I believe that the people who approached me did not do so lightly. I had a conversation with Mr Muller yesterday and told him my attitude to that position. As I see it, it is no joke to have the guts to stand up and point out what I believe is wrong, and to say that I was approached to stand as Speaker. 
For too long people in other places have considered that members of Parliament who are constructive in what they say are activated by sour grapes. (QPD 1981:vol. 283, pp. 14-15)

Hartwig, however, did not stand and completed his speech with 'we look to $\mathrm{Mr}$ Muller to continue to do a good job as Speaker'. The conservative mavericks were toeing the line.

After more than two hours of assertive banter from many participating members, the vote was taken, with Muller receiving 49 votes to Jones on 21, and with 11 members abstaining or voting informally. The vote indicated that up to eight of the Coalition members abstained rather than voting for their candidate. After the conclusion of the vote, the Speaker was congratulated, the full ministry was declared, the opposition officials were listed (but still no full acknowledgment was made of the shadow ministry) and the death of Vince Gair was acknowledged (five years after he last held public office as Ambassador to Ireland and the Holy See). ${ }^{1}$

Under the new regime, question time could last no longer than one hour, questions without and with notice were allowed but no more than three questions in total were allowed per member. While Casey complained about the restrictions, Angus Innes (Lib., Sherwood) spoke against him but urged that the Speaker's undertaking to call the Standing Orders Committee together should happen soon' (QPD 1981:vol. 282, p. 43). Other members made mention of the Speaker's intention to revise the Standing Orders as a matter of urgency. The Opposition Leader later that day complained about passing 'sessional orders' anew each session that had the effect of limiting debates, rather than fully revising the Standing Orders properly. He claimed:

Although Sessional Orders identical with this one have been placed on the Business Paper for a considerable number of years, they have never been debated by Parliament and have never been discussed in any way...Instead of having a meeting of the Standing Orders Committee, we simply pass, year after year, a Sessional Order that is seemingly to play some part in the operations of this Assembly. However, a close analysis of the proposed Sessional Order shows clearly that it is intended to restrict the activities of the Parliament. It is one of those procedures that has made the Queensland Parliament the laughing-stock of all other Parliaments in Australia. It confines discussion to only those matters that the Government brings forward... What we are seeking to do is to give

1 Labor's five officials were: Ed Casey, Leader of the Opposition; Bill D'Arcy, Deputy Leader; Bill Prest, Opposition Leader of Business; Brendan Hansen, Whip; and Les Yewdale, Secretary. 
back to the back-benchers in this Parliament the rights they enjoyed from 1859 until 1966 when they were denied them by procedure and, since 1971, by Sessional Order. (QPD 1981:vol. 283, pp. 131-3)

By 'rights', the Labor spokesman meant that he wanted backbench members to be allowed to introduce private member's bills and have them debated. To which the Primary Industries Minister, Mike Ahern, responded by interjecting that the Labor leadership group 'did not understand what a private member's Bill was about' (QPD 1981:vol. 283, p. 134). Tom Burns then reminded Ahern that he had spoken 'for years about parliamentary reform', but then added: 'He sold his soul to Joh in order to get into the ministry. He has forgotten about parliamentary reform from the day he left the backbenches' (QPD 1981:vol. 283, p. 134). A Standing Orders Committee was appointed and announced by the Leader of the House, Claude Wharton, with the membership including himself, Joh Bjelke-Petersen, Ed Casey, Colin Miller, Bill D'Arcy, Llew Edwards and Bill Prest.

In desperation, Casey even offered to form an alternative government consisting of Labor and dissident Liberals. He told the House:

It is my intention to publicly reveal for the first time the details of that offer. We indicated that we were prepared to enter into discussions with the Liberal Party with a view to forming a minority Government to be formed by either party. Such agreement would include the introduction of electoral legislation to bring down a redistribution based on a one vote-one value principle. It would also include the election of a Speaker and a Chairman of Committees; the retention by whichever of the two parties supported the Government in office of all existing entitlements, with more just staff arrangements; and agreement on a legislative program and a firm commitment to regular consultation. (QPD 1981:vol. 283, pp. 98-9)

According to Casey, this minority government agreement would be kept in place only long enough to make the arrangements and then hold a fresh election on the new boundaries.

\section{Conflicts of interest: the triumph of the 'brumbies'}

In the first question time, Casey asked the Premier why he had appointed Russ Hinze (fast becoming the 'Minister for Everything') as minister responsible for the racing industry, having removed it from Dr Edwards' portfolio. Casey 
continued: 'how does he justify his choice of the member for South Coast as both Police and Racing Minister when he owns one of the largest racing stables in the State and must inevitably initiate decisions from which he will benefit personally?' In response, Bjelke-Petersen claimed 'members on this side... are involved in various forms of business activity and interest. When any of those activities are under discussion or review, the person concerned makes a statement or declaration in relation to his interest.' He claimed that the same provision applied to cabinet, but that 'no set rule concerning the activities of members of Parliament' existed (QPD 1981:vol. 283, p. 54). At the same time, Llew Edwards attempted to introduce a code of ethics for ministers based on the model introduced in the United Kingdom by Margaret Thatcher, but was unsuccessful, with the Premier claiming that 'no code written or otherwise, can make any man honest if he has not lived that way all his life' (AJPH 1981:vol. 27, no. 3, p. 390).

The Parliament was also informed that the National Party Senator Glen Sheil had resigned his position as of 6 February 1981 to contest a lower house seat. ${ }^{2}$ The State Parliament was asked to approve the nomination of Mrs Flo BjelkePetersen as his replacement. Casey greeted news of this proposal with some notunexpected caustic comments. He made a link to the extra superannuation she would receive if appointed to take up the Senate place before her (elected) term began via the casual vacancy route. Casey said:

On Thursday, the implacable opponent of parliamentary superannuation in 1948 [the Premier] will ask this Parliament to send Mrs BjelkePetersen early to Canberra to allow her to collect at least $\$ 150,100$ superannuation after only six years and one election. The personal deep hatred of superannuation has suddenly disappeared when personal gain is involved. (QPD 1981:vol. 283, p. 99)

While the Opposition Leader reflected on 'how times have changed', the Liberal Dr Scott-Young suggested that Bjelke-Petersen did not understand superannuation or the benefits it would bring back in 1948 .

The notice of a senate vacancy was tabled on 12 March; it was the first such vacancy to occur in Queensland under the new constitutional amendment (the revised Section 15 on casual vacancies) passed to prevent such abuses as had occurred when the conservative governments in both New South Wales (under Premier Tom Lewis) and Queensland (under Bjelke-Petersen) had broken

2 After not being re-elected at the 1980s election, Sheil was encouraged to run for a federal lower house seat by the Premier. He got his chance sooner than he might have expected when the Federal Member for McPherson, Eric Robinson, died in January 1981. Sheil ran as an endorsed National in the by-election, but lost to the Liberal candidate, Peter White. Later he made a successful bid to re-enter the Senate in the double dissolution of 1984 and remained in the upper chamber until 1990. 
convention in 1975 by appointing senators who did not enjoy the approval of the party they supposedly represented. The Speaker called for nominations for the vacancy. The Premier immediately rose to nominate his wife, saying 'I nominate Florence Isabel Bjelke-Petersen, housewife, of "Bethany", Kingaroy, for election to hold the place in the Senate rendered vacant through the resignation of Senator Glen Sheil' (QPD 1981:vol. 283, p. 226). The Premier's justification was that

[s] he has become a senator-elect in a completely orthodox way. She was properly nominated for consideration by the National Party...[and] the central council selected her as one of three for the National Party's Senate ticket, and during the party's annual conference she was elected, again by the central council, to the number one position...Florence was elected last October by the people of Queensland to take a position in the Senate as a National Party Senator from 1 July 1981. (QPD 1981:vol. 283, p. 227)

He neglected to mention that Flo was shoehorned in over sitting Senators Glen Sheil and Ron Maunsell largely at his own behest, and causing some resentment among the party faithful. He also did not disclose, as Lindsay Hartwig did, that when Flo won endorsement at the party's state conference, only two sitting National MPs had seen fit to support her (himself and the Premier perhaps?). The Premier responded to criticism that his family was milking the superannuation system by saying it is not Florence who is to blame in relation to this question of superannuation. It is the system that has been set up by Canberra, rushed through in the House of Representatives by John Howard in 11 minutes' (QPD 1981:vol. 283, p. 227).

Never one to let a free fight pass by without comment, Ed Casey chimed in:

This Parliament has witnessed some amazing scenes but perhaps none more amazing than those associated in recent years with Senate replacements. None had greater ramifications than those which occurred in this Parliament on 27 August 1975 and again a week later on 3 September 1975 in what subsequently became known as the Field Affair. On that occasion the Premier, who is still the incumbent in that office, led his cohorts in the National Party and slaves in the Liberal Party into a situation... of complete defiance of the intent of the Australian Constitution and the accepted practice throughout Australia in relation to Senate replacements. (QPD 1981:vol. 283, pp. 227-8)

Casey accused the Premier of 'impatient husband-and-wife greed' (QPD 1981:vol. 283, pp. 227-8). Although Labor did not oppose the nomination, they objected to Bjelke-Petersen giving three names, as though the Parliament 
was being asked to decide between a panel of three for the job (as the Premier had insisted Labor ought to do in 1975). He insisted that the spirit of the constitutional amendment was that 'a casual Senate vacancy in a State should be filled not only by a nominee of the same political party but by the proper choice of that political party' (QPD 1981:vol. 283, p. 229). His view was that the National Party executive had not formally chosen Flo and the Premier was now trying to bypass that stage and use his numbers in the Parliament to nominate his wife, even though she was a senator-elect and had headed the Nationals' ticket. Despite Casey's consternation, the constitutional amendment to Section 15 did not state that the party had to formally choose the candidate, only that the nominee had to be a member of the same party and be recognised as such (that is, the party could veto or debar any candidate it did not endorse). As government members kept interjecting, Casey then added, swatting back at persistent interjections from the new Transport Minister, Don Lane, 'they can put a ministerial saddle on them, Mr Speaker, but they are still the same old brumbies'.

After one and a half hours of unedifying debate, much of which from Labor's side was spurious, Flo Bjelke-Petersen was elected on the voices (that is, no vote was required).

\section{A farrago of doubts over mining leases}

Foreign ownership of Queensland mines continued to generate political heat for the government. According to the opposition, the government was acquiring a reputation for being merely a rubber-stamp government in relation to mining lease approvals, suggesting close links between business and the government. During the early 1980s, the fiasco of the Winchester South leases emerged not only as a controversial decision, but as suggestive of favouritism and kickbacks.

When the Winchester South deposits (near Moranbah in the Bowen Basin) were discovered, the state government decided to auction off the rights to the mining leases. The government prepared a competitive tender process for a licence to prospect and then mine steaming coal said to be worth at least $\$ 2$ billion. The process was, however, anything but rigorous. In all, 32 tenders were received from interested concerns - a record for an Australian coal lease. The DirectorGeneral of the Mines Department, Jack Woods, supposedly undertook an evaluation of each tender but the evaluation mysteriously went missing and no record of it could be found in the Mines Department or in cabinet records. There was some suggestion that, even after these extensive tenders had been received, the process was short-circuited by the Premier and the Mines Minister, Ivan Gibbs. 
Cabinet was faced with a fait accompli, which, according to one source, led to 'cries of disbelief', particularly because the decision was taken before the tenders had been fully evaluated, especially by Treasury, which was bypassed in the process (Stuart 1985:65). Treasury had been hoping to acquire a good deal for the mining lease but by all accounts the amount the successful tender promised was considerably less than other tenders had offered the state government (AJPH 1981:vol. 27, no. 3, p. 391). The cabinet submission of 9 March 1981, under Gibbs' name, advocated the case for one consortium over all the others and recommended this consortium be given a three-year 'accelerated' exploration licence to assess the site and begin production. The full submission was leaked to the press and the opposition and tabled in the Parliament. There was some speculation that the submission had been leaked by a disgruntled minister, possibly the Treasurer or his department, who did not approve of the decision.

The 'winner' of the coal auction was the consortium of BP Australia (50 per cent), Drayton Mining (25 per cent) and Westfield Holdings (25 per cent). Drayton Mining was owned by Sir Leslie Thiess, a personal friend of the Premier, and a former owner of the mining company Thiess Holdings, which had been acquired by CSR Limited. Frank Lowy, who was already starting to acquire a shopping centre empire in Queensland, owned Westfield. The Australian Financial Review (1 April 1981) suggested that the close personal relationship between the Premier and Sir Leslie Thiess was not unrelated to the outcome of the tender. Thiess was apparently anxious to get back into the coal industry with its then mega-profits after his earlier company had been taken over by CSR in a hostile action, which he had strenuously opposed. According to Gibbs, the BP/Drayton/Westfield deal promised the government additional royalties but over the longer term (for example, an extra \$1 per tonne but only starting in 1985 , rising to $\$ 4$ per tonne by 2005). Later in the Parliament, Labor accused Jack Woods of taking his holidays at Thiess's beach house with members of the Thiess family at the same time as the tenders were closing (QPD 1981:vol. 283, p. 680). More than a decade later, Thiess was considered by a jury to have bribed the Premier 'on many occasions' in order to secure government contracts, including the Winchester South lease, and to build a host of other public facilities (prisons, cultural centres and Expo 88) (see Tiffen 1999:214-15; Stuart 1985:65).

Labor was torn between arguing that the coal companies were engaged in the 'raping of Queensland's assets' and complaining that the additional royalties meant that previous deals with mining companies were too low and, therefore, 'selling Queensland's rich mineral assets too cheaply' (QPD 1981:vol. 283, p. 166). They also lamented that such deals were dominated by foreign interests and excluded ordinary Queensland investors. They also accused Sir Edward 
Lyons of being the mysterious middleman who had secured the deal (an accusation rejected by the minister). Bill D'Arcy was well armed in his attacks on the government because he possessed a complete cabinet proposal (in the name of the minister) and the decision. In a 40-minute address, D' Arcy accused the government of making ad hoc and stopgap decisions to favour mates. He commented that 'it is an insult to the tenderers, some of whom reportedly spent up to $\$ 500,000$ on preparing their tenders, merely to be listed in a table' (in the body of the submission). He added it was 'gross incompetence of the highest order' that the project was 'not economically evaluated by the Treasury and the Co-ordinator-General's department'. He asked the minister if it were true that the bid by the BP/Thiess/Lowy consortium was the best, 'why did Cabinet immediately set about renegotiating the tender', and suggested that if one tenderer could improve their offer why were others not also allowed to improve their offers (QPD 1981:vol. 283, pp. 416-19)? He pointedly said:

How can the Minister claim that he knew best? He was away for quite a considerable time during the evaluation period. The tenders were quite detailed and complex in nature. I doubt that he would have had time to consider the tenders-because Einstein, he ain't...I have tabled the Cabinet documents referring to Winchester South so that future generations of Australians, Queenslanders and parliamentarians will be able to judge for themselves the naïve way in which resources worth $\$ 1,600 \mathrm{~m}$ were handled by the Minister for Mines and Energy. (QPD 1981:vol. 283, pp. 416-19)

Questions continued about the Winchester South deal, especially about why other offers were not considered. In response to such publicity, the government passed the State Development and Public Works Organization Act Amendment Act 1981, which allowed the government to declare any development project a 'prescribed development' or 'declared industry' meaning any development agreements did not need to come before the Parliament and any necessary approvals could be decided in secret by the Executive Council. The act also allowed for state government assistance to the local authorities in the provision of infrastructure when declared industries came into the local authority's area. On the whole, however, the act provided a way of minimising the scrutiny of the Parliament to examine development applications.

\section{Parliament 'not equipped to discharge its obligations'}

The Parliament sat for 61 days in 1981 and passed 130 bills; it was one of its busiest years of the period. Most legislation in the new Parliament was 
amendment legislation, often of a mundane or minor nature. ${ }^{3}$ It seemed hard for some members to maintain an interest in the matters at hand. Even on important pieces of legislation such as the Clean Air Act Amendment Bill 1981, the Minister, Bill Hewitt, could rise to say at the second reading stage that 'in the absence of anyone else wanting to speak' after only nine members had commented on the amendments (QPD 1981:vol. 284, p. 2032).

Occasionally, ministers introduced legislation pretending the changes were minor, when in fact they were more substantial — a form of subterfuge. Ministers labelled their proposed amendments 'machinery measures' hoping to get them through without attracting attention. Labor members, however, were often awake to such ploys. The vigilant Kev Hooper claimed that he was loath to trust ministers when they said changes were 'mechanical' and Terry Mackenroth reflected:

About 18 months or two years ago the Minister brought before us amendments to the State Housing Act and told us that they, too, were machinery measures. Of course, after the Bill was passed and became law, we found that it enabled the Housing Commission to sell land at Redbank Plains. That aspect was not mentioned in the debate, nor were honourable members told that the real purpose of those amendments to the Act was to allow that to occur. (QPD 1981:vol. 284, p. 1699)

Even the Petroleum Act Amendment Act was regarded as a 'machinery measure designed to correct a number of anomalies' (Ken Vaughan, ALP, Nudgee, in QPD 1981:vol. 283, p. 462). This was despite suggestions that seismic testing and drilling in the Gulf of Carpentaria might be a "practice run for drilling on the Great Barrier Reef', even though the government had indicated by this stage that it had ruled out any such drilling on the reef - a point reconfirmed by the Mines Minister, Ivan Gibbs, in the debate.

Members sometimes asked why particular pieces of legislation were not being introduced - usually when some perceived need had been identified and the government was procrastinating. For example, a number of ministers were asked why they would not introduce compulsory seatbelts for cars to improve safety, to which one government minister replied that it was entirely an issue for the Main Roads Minister, Russ Hinze. The laws relating to drink-driving were successively tightened - a feature that did not always please the more populist honourable members in the Chamber. Rosemary Kyburz asked in November 1981 'isn't it funny how some members get "thingy" when random breath-testing is discussed', to which Bob Moore (Lib., Windsor) said, 'I am

3 The Evidence and Oaths Acts Amendments, Exotic Diseases in Animals, Canned Fruits Marketing and Dairy Products Stabilisation Acts; even the Hen Quotas Act Amendment Bill (which was, according to one member, 'well intentioned but furry around the edges') and so on. 
one of them' (QPD 1981:vol. 286, p. 4018). If some ministers attempted to take a responsible attitude, others played to the gallery, such as Alex Wilson (ALP, Townsville South), who thought that decreasing the legal drink-driving limit to 0.05 was a revenue raiser that would have the effect of driving people out of pubs to drink at home (QPD 1982:vol. 288, p. 1283); and Kev Hooper, who noted that 'one bottle of beer will put the average drinker above the limit. Some government members would spill more than that' (QPD 1982:vol. 288, p. 1355). Peter McKechnie (NP, Carnarvon) took a brave stand, arguing that because almost half of all drivers killed on Queensland roads had a blood alcohol reading of greater than 0.08 , the government should become tougher on such abusers of the road rules and the police should make more arrests instead of 'manning radar traps' (QPD 1981:vol. 285, p. 2409).

Occasionally, members could be reflexive about the institution of which they were part. Rob Akers seriously thought that there was a risk of all parliamentarians being 'eliminated in one fell swoop' if the swimming pool on level seven fell through to the temporary chamber on level five during a division bell or if a fire started on level three below (QPD 1981:vol. 283, p. 350). He noted with a dry sense of humour that this 'might please many people in Queensland'. This issue was raised as a matter of public interest! Bob Moore reflected:

Most honourable members come into this Chamber by mistake or accident...They do not go to kindergarten, primary school, secondary school and university with the aim of getting into Parliament. Thank God for that! One would not wish to see a parliament full of academics. What I am endeavouring to point out is that very few of us come into this place with a background knowledge of Parliament and of the traditions that should be maintained. (QPD 1981:vol. 283, p. 384)

This was an observation he could well have been able to make then, when politics was usually someone's second career. They had entered politics usually because of their achievements in other spheres of life. Within a few years, however, the Parliament would be dominated by younger, tertiary-trained professional politicians who had set out from early ages precisely to get into the Parliament - and there was no mistake or accident about these careerists getting into the Parliament. He continued:

My next topic concerning this Parliament is to some extent a criticism of the Westminster system. We have a system of Executive Government wherein back-bench members virtually have no say in legislation, as it has been decided by Cabinet. There is something wrong with that...If the Government is worth its salt, it should adopt any good suggestion made or good amendment moved by any member on either side of the Chamber. If Parliament is to work properly, worthwhile suggestions 
should be adopted. Some Cabinet Ministers are being run by their departmental heads. Cabinet does not really carry out its proper function when even Government members have no say in the initial stages of legislation. (QPD 1981:vol. 283, p. 384)

His views were echoed by Guelfi Scassola (Lib., Mount Gravatt), who ventured:

Parliament in Queensland is not equipped to discharge its obligations to the electorate. It has not the tools to examine Government decisions. It can be likened to a carpenter who is asked to build a house without any tools...if one looks at the presentation of financial information to Parliament, one finds that that information is very meagre, given the size of government and the complexities of modern-day administration. Parliament is asked to make decisions on totally inadequate information when appropriating tens of millions of dollars of expenditure for government. (QPD 1981:vol. 283, p. 540)

He added that estimates debates often degenerated into 'Cook's tours of electorates' because members could not find sufficient information to make serious contributions.

In a rambling Address-in-Reply speech, Rosemary Kyburz (Lib., Salisbury), who also engaged in a bit of flirtatious banter with the inveterate interjector Kev Hooper (ALP, Archerfield), spoke expansively of the political situation in Pakistan and the seizure of power by the junta led by Zia ul-Haq. She said the junta 'is doing nothing other than suppress democracy and gaol its critics' and added that 'the fanaticism with which the critics of government are gaoled is really horrifying', before concluding 'at least in Australia, and at least still, in Queensland, we can publicly criticise'. This comment was greeted by Hooper interjecting 'Joh is working on it', to which Kyburz responded: 'I worry about that at times' (QPD 1981:vol. 283, p. 552). It was a testing time for critics, as she admitted.

\section{More skulduggery and 'scurrilous allegations'}

Lindsay Hartwig, who had recently been expelled from the National Party for repeatedly criticising the president of the party, Sir Robert Sparkes, made allegations of political skulduggery in 1981. He was expelled on 23 March 1981 by the party's executive by a vote of 33-2, but he continued to drop bombshells in the media and in the Parliament. The next time he spoke in the Parliament (a week later, on 31 March), he accused the Premier of plotting with the Labor Party to eliminate Liberals before the 1980 election. His premise for making the 
allegations in the Chamber was that the Premier had denied them when they first appeared in the press, so he claimed he wanted to set the record straight. Hartwig stated:

It was an August evening just prior to my overseas trip to Zambia. I was sitting in the [parliamentary] dining-room - I can show honourable members the table - when the member for Archerfield walked in. I was the only member in the dining-room at that time and the honourable member made to go to the area in which the Labor Party usually sits. I said, 'Kevin, come over here and sit with me. There are two of us here; let's talk, even though we are on opposite sides of the fence'. Within a few minutes we were joined by the Premier. I am prepared to go on any lie-detecting machine that anybody can bring forward and I am prepared to swear an oath on the Bible that in the ensuing minutes the Premier and the member for Archerfield (Mr Kevin Hooper) discussed ways and means of defeating Liberal Party members at the coming election. Independent Labor members were mentioned. I heard the Premier say, 'Kevin, we have to seek ways and means of defeating these Liberals'. I don't tell lies, but I kept that a secret. As a matter of fact, I went outside and had a good vomit. (QPD 1981:vol. 283, p. 587)

After an interjection, Hartwig continued:

It sickens me to find the same man - the leader who had stood up in the Whitlam era and said, 'I am anti-Communist. I am anti-socialist' conniving with the ALP to bring about the demise of his Liberal colleagues...I do not care two hoots whether there was a deal struck. The fact remains that I did not discuss this with the member for Archerfield (Mr Kevin Hooper). I did not even name him in [the] 'Sunday Sun'. I did not know that he was going to say that this took place. However, it was on my conscience that the day I was expelled from the National Party I said, 'You will rue the day'. I was referring to the party leaders. The statement was attributed to me that I would destroy the party. One word was left out: I would destroy the party leaders. There are a hell of a lot of good Queenslanders involved in the National Party. I did not say I would destroy the party. However, I make no secret of the fact-I have gone on record saying it - that now Premier Joh's job is on the line and there is a new Premier on the horizon...I assure the House also that when I am finished with Sir Robert Sparkes he will disappear from the State leadership of the National Party. (QPD 1981:vol. 283, p. 587)

He also repeated that during the Bjelke-Petersen Foundation appeal, he had 'received a telephone call asking me to contribute a five-figure amount and to head the list for Central Queensland'. He explained: 
I want to say that that person did not say it would get me into Cabinet. That is something that I considered only later. I point blank refused. Here again, I will swear on oath that I was requested to put in $\$ 10,000$ to the Bjelke-Petersen Foundation to head the Central Queensland list. (QPD 1981:vol. 283, p. 587)

There was some talk of National Party MPs being required to make contributions or have their preselection threatened. Hartwig also recalled that when the abortion bill was being debated,

Bob Sparkes rang me at least three times about that issue. He asked me to do my utmost to get National Party members, including me, to condemn the Bill, cross the floor and vote against it, and so have it defeated...In fact, that sort of action [intimidating a member] carries a gaol sentence. I might add that I am seeking legal advice on those matters. ( $Q P D$ 1981:vol. 283, p. 589)

Then for good measure, he continued his tirade:

I was one of the few members of the National Party at the time who advocated that Flo Petersen go to Canberra. I assure members that I have since been reliably informed that Joh and Florence knew that if Florence could get to Canberra before the end of June she would be eligible for an extra $\$ 140,000$ or $\$ 150,000$ in superannuation. But they conned Sheil into standing for McPherson. Sparkes came out and said that he did not have a hope in hell of winning the seat, but they put him up, got him beaten and then put Florence in. I leave it to the people of Queensland to judge whether that was right or wrong. (QPD 1981:vol. 283, p. 589)

Amid all the allegations of deceitfulness, both Jim Fouras and Keith Wright quipped that Queensland had 'the best Government that money can buy' (QPD 1981:vol. 283, p. 592).

When the Premier heard Keith Wright assert that some business leaders knew they could buy favours from the government, he took offence and rushed back into the Chamber to require Wright to withdraw the remark. He asked the Deputy Speaker, Rob Akers, to make the Labor member 'withdraw that statement immediately, and I will let him off by not having to apologise on this occasion' (QPD 1981:vol. 283, p. 593). The Deputy Speaker ruled that there was no point of order because Wright did not mention any other member by nameat which point a furious Premier rose to insist that the allegations were untrue and that Akers should make him withdraw the remark. The Deputy Speaker responded by restating that there was no provision in Standing Orders under which he could require the member to withdraw the remark. Not accustomed to being overruled, Bjelke-Petersen replied: 
They are offensive to me, and for that reason they must be withdrawn. He has brought the Bjelke-Petersen Foundation into the debate.

Mr Deputy Speaker: Order! The honourable member has not referred to the Premier by name, and there is no provision in the Standing Orders under which I can ask him to withdraw those comments.

Mr Wright: I can understand that the Premier takes exception to what I am saying, because it is very serious.

Mr Bjelke-Petersen: It is not true...Mr Deputy Speaker, how long are you going to allow a member to make statements, quoting somebody outside Parliament, that are completely untrue? (QPD 1981:vol. 283, p. 593)

Akers continued to stand up to the Premier, saying that while government members could defend the government later in the debate, the Labor member had a perfect right to make such statements providing he did not impugn another member directly. After more allegations were made against Russ Hinze, Akers again refused to allow a point of order from the minister. The dispute continued into Doug Jennings' maiden speech, which (contrary to convention) was peppered with interjections from Labor. Jennings complained about the 'scurrilous allegations' that had been made and attacked the Labor members for making 'unfortunate' and 'insulting' references. He continued: 'Opposition members here make allegations about bribery and corruption. They make allegations without one shred of evidence. That is absolutely shameful. They are showing the public what they really are. What I am saying is that Opposition members will have to bring some evidence forward' (QPD 1981:vol. 283, p. 601).

Labor's campaign of discrediting the government by alleging bribery and corruption and highlighting its close connections with developers was gaining momentum. This was the era when police ministers such as Hinze were publicly denying that illegal casinos and brothels were operating in Fortitude Valley. The next day (April Fool's Day), Bjelke-Petersen was forced to defend his foundation, claiming the allegations were 'nothing more than vicious, baseless innuendo'. He also challenged the interpretation of the Deputy Speaker, claiming he should have called the Labor member to order and warned him 'his imputations of improper motives on the part of my Government were highly disorderly' (QPD 1981:vol. 283, p. 676). Immediately after this rebuke from the Premier, Akers was forced to make a personal explanation, insisting that he stood by his ruling of the previous day and asking the Speaker, Sel Muller, to stand by those rulings he gave as Deputy Speaker or 'dismiss me from that position' ( $Q P D$ 1981:vol. 283, p. 677). Muller did neither but did point out after much argybargy that any member (including the Premier) could 'move a motion of dissent 
from the Chairman's ruling, and it must be debated at the time' (QPD 1981:vol. 283, p. 678). As this had not occurred, Muller declared the continuation of the discussion a pointless debate and closed the subject.

Behind the scenes the government turned up the heat on Akers, who admitted he was 'in enough trouble already' (QPD 1981:vol. 283, p. 695) when goaded by Labor to speak out on issues against the government. His wife, Rosemary Kyburz, came to his defence, protesting about the Premier's intentions to undermine the powers of the Parliament while seeking to 'protect a knight of the realm' from allegations made under privilege. She quoted from a media release from the Premier that stated that the government was 'considering steps to provide redress for members of the public attacked by politicians under Parliamentary privilege' and pointing out that the Premier had sought advice from the Crown Law Office. He was also considering legislating to compel the media, which ran any allegation, to run a person's rebuttal as part of the story. She described the moves, not as providing the public with a right of reply, but merely trying to protect his business mates about whom allegations were continually being made. She continued:

I do not believe that it is a very fair way of running this Assembly to allow people outside who happen to hold high positions in the community to whisper in the Premier's ear and demand protective legislation...As I said, what incensed me particularly was that the Premier made a public statement in order to protect a particular person. The utter hypocrisy of the Premier's statement was made obvious this morning when he chose to attack another member and to question the privilege that he usurped yesterday. (QPD 1981:vol. 283, p. 689)

Bringing some climax to the various allegations of impropriety, the opposition moved a motion of censure against the government (under an adjournment motion). Five speakers prosecuted Labor's case - Ed Casey, Tom Burns, Ray Jones, Ron McLean and Brendan Hansen - while Val Bird and Joh Bjelke-Petersen defended the government. The tactic backfired on Labor. In the original motion Labor had indicated five matters of concern when, as the Speaker pointed out, under Standing Orders it was allowed to debate only one matter in a censure motion, and the Speaker selected the Port of Brisbane Authority's operations. The attack, thus, fell a little flat, and the vote was lost on party lines 23 ayes to 44 noes (QPD 1981:vol. 283, p. 745). 


\section{Light relief: outward-opening or revolving toilet doors}

In one of the more infamous but absurd moments in the Queensland Parliament, Vince Lester presented what he regarded a most 'serious matter': the opening of toilet doors. Admitting that he had forwarded a submission to the Local Government Department advocating outward-opening or sliding doors, he noted the department had issued directives that toilet doors be made more accessible in public buildings. He welcomed the fact that disabled and paraplegic people would soon be able to access toilets more conveniently. He had long advocated that toilet doors should open outwards or even open upwards to facilitate entry and exit or if need be provide access to a carer. He claimed that 150 people died each year locked in toilets (although he did not source his claim) and added 'I'll bet there is no member of this Parliament who does not know someone who has not suffered a problem with a toilet door' (QPD 1981:vol. 283, p. 997).

Some of the other members expressed a little mirth indicating they did not share his passion, yet for a full 10 minutes Lester treated the Parliament to a homily on toilet doors! There was even some discussion about whether toilet doors could, indeed, slide around and revolve or whether outwards opening was more practical. Lester appeared unperturbed by the fact others did not see the gravity of his case. At one stage he advocated outward-opening doors for the Parliament, appearing on television to further his campaign. He would forever be known as the 'Member for Toilet Doors that Open Outwards'. His other nickname was the 'Member for Walking Backwards' because he had walked backwards to raise money for charity.

\section{Where to draw the line on developments and interventions}

In the late 1970s and 1980s, it became increasingly clear that the government did not know where to draw the line when it came to promoting development. The government had tried strenuously to extract oil from the Rundle Shale oil deposits. It had long harboured ambitions to drill the Great Barrier Reef for oil. It had attempted to mine sand from Fraser Island but was prevented by the federal government, which denied an export licence. It then tried to sponsor sandmining on Moreton Island, with the Premier claiming that after sandmining the island would 'be rehabilitated in such a way that we won't recognise it' - to which the Opposition chimed in 'nobody will recognise it' (QPD 1981:vol. 284, p. 1406; vol. 283, p. 384; vol. 283, p. 384). There were other 
schemes involving islands, which the government appeared to condone that were effectively fraudulent, such as the attempts to sell land that flooded at high tide on Russell Island.

This development-led government was not, however, averse to interfering with the market. During the 1980s, many Queensland businesses started to become takeover targets for southern companies eager to expand into the state. When Australian National Industries Limited made a takeover bid for the engineering firm of Walkers Limited at Maryborough, the move encouraged the Brisbanebased Evans Deakins Industries to put a counter-bid. When Evans Deakins itself came under attack by Clyde Industries Limited, the Treasurer, Llew Edwards, informed the Parliament that the government had purchased three million shares in the Brisbane firm for $\$ 3$ a share (which was almost $\$ 1$ higher than the market price). The taxpayer-funded purchase was made to defend the company, even though it represented a paper loss of \$3 million. Treasurer Edwards did not really justify the government meddling in the market, except to say that he had heard praise heaped on the government from the senior management of the firm and that the government expected to earn dividends of about $\$ 250000$ from its new shareholding.

Then, after years of opposing the introduction of casinos, the government eventually caved in to pressure from the industry and regional towns eager to secure a licence. The government invited applications from interested operators in mid-1981 and announced that Treasury would evaluate the proposals (QPD 1981:vol. 284, p. 1798). Once again, however, the government sought to influence the outcome of the tender process by reshaping the draft legislation to eliminate two-thirds of the 28 tenderers from the final selection process (leaving just nine progressing to the next round). Labor's inveterate whistleblower, Kev Hooper, made a prediction in August 1981 that

[w] hen the casino licences are granted, the consortium led by Sir Leslie Thiess will get a guernsey, and I will tell the House why. Sir Leslie Thiess recently flew his multi-million dollar executive jet to Townsville to attend the National Party conference, even though he is not a member of the National Party. Sir Leslie hung around on the outskirts of the conference waiting to transport National Party Ministers who were inconvenienced by the transport strike. Sir Leslie is openly boasting to his cronies that he is odds-on to get the casino licence at Townsville, as he has already been given a down-payment for services rendered to the Bjelke-Petersen Foundation with the lucrative Winchester South coalmine lease earlier this year. The moral of the story is that if one makes a hefty donation to the Bjelke-Petersen Foundation, one can do anything in Queensland. (QPD 1981:vol. 284, p. 1527) 
He was not wrong. Two licences for casinos were granted in 1982: one for Townsville and the other for the Gold Coast (but not one at that stage for Brisbane). Sir Leslie Thiess would secure the Townsville casino licence (the Breakwater Island Resort Proprietary Limited bid controlled by Thiess's Drayton Investments Proprietary Limited). It was reported that the Premier had supported the Thiess bid while Edwards had favoured an alternative bid, even though Edwards stated that the north Queensland licence was based on merit and he would stake his 'reputation and integrity on that' (QPD 1982:vol. 287, p. 4280). In March 1982, the Gold Coast licence was granted to Jupiter's Hotel, owned by the Victorian building firm Jennings Industries.

Some years later, it was revealed that Thiess had given substantial free loans to the Hinze family, had rented a Gold Coast penthouse to Russ Hinze and his wife for $\$ 1$ a month and, as a result of a defamation case, was also considered to have bribed the Premier. Bjelke-Petersen, however, felt so confident at this time that the opposition had no tangible proof of any direct corruption linked back to his government that he offered in March 1982 to allow the opposition the opportunity to table any documents they might possess that supported their 'allegations, innuendoes and smears regarding casinos, police, gaols or any other matter'. To suggestions that he had accepted a multimillion-dollar bribe over the casino licences, the Premier issued a challenge in the Assembly: 'There is the table. Let us see your documentary proof. Let us see your evidence. Talk is cheap' (QPD 1982:vol. 287, p. 4278). Not surprisingly, when asked to show definitive proof, those members of the Assembly most critical of the Premier were not able to table any documents. Some investigatory trails would, however, open up much later (see Fitzgerald 1989:102-3).

The horseracing industry also came in for some direct government assistance when the government announced it would purchase the Albion Park racecourse (through the Racing Corporation) for $\$ 9$ million, to enable a major redevelopment to occur. Nev Warburton could not help but point out the irony of 'a Tory, freeenterprise Government being the owner of a multimillion dollar racecourse. It is no wonder that Government members shake their heads in wonderment at their own inconsistencies' (QPD 1981:vol. 285, pp. 2717-18).

On the other hand, the government made progress with amendments to the highly contentious Margarine Act (a talismanic issue with dairy farmers since the 1950s), streamlining regulations regarding packaging and promotion and bringing them more into line with uniform national legislation across the states. The sale and promotion of margarine had long been controversial in a state highly protective of its dairy industry. Many members believed animal fats were more wholesome than margarine and that butter as a natural dairy product was 'healthy for you'. They complained that margarine manufacturers were creating an artificial product (from sunflower seeds!) and trying to mislead consumers 
with suggestive advertisements. The Primary Industries Minister, Mike Ahern, said that in his 14 years in the Parliament he had sat through many difficult debates about the liberalisation of margarine, but in this instance he thanked members for their general support, adding that 'all members displayed a spirit of goodwill towards the legislation' (QPD 1982:vol. 287, p. 4710). He promised members that the new clauses calling for ministerial approval before margarine could be promoted and sold would be interpreted with discretion and that 'the spirit of the legislation will be kept clearly in mind' in his deliberations.

Ahern was probably the first Primary Industries Minister in Queensland to recognise that some deregulation of the highly restrictive, producer-inspired regulations was a necessary economic adjustment. He received fewer bouquets from the opposition, however, when he introduced the Sugar Acquisition Bill in late 1982, with Labor members claiming they had not been given time to find out the implications of the bill and that a promised public inquiry had not eventuated. Ahern hit back, saying, 'I have not heard so much rhetoric, hyperbole and sheer fiction spoken in this Chamber for a long time' ( $Q P D$ 1982:vol. 289, p. 1859).

\section{Circuses and distractions}

Speculation increased in late 1981 that a ministerial reshuffle was in the wings. The Courier-Mail suggested on 21 October that Vic Sullivan and Ken Tomkins, two National Party ministers, would be dropped from the ministry. Sullivan had been a minister for 14 years by then, having been appointed first in January 1968 by Jack Pizzey. Tomkins had joined Bjelke-Petersen's fourth ministry after the 1974 election. The Minister for Commerce and Industry, Vic Sullivan, made an unorthodox rebuttal to these rumours by making a formal ministerial statement to the Parliament. His statement, which was described by Rosemary Kyburz as nothing more than a 'political speech', denied Tomkins or he would be sacked and pointed out that the Premier had gone 'to the trouble of issuing a complete denial of any reshuffle or any dismissal'. For the record, Sullivan denied the two ministers 'were incompetent' and that 'the party was disillusioned with us'. He demanded the journalist concerned, Peter Morley, be sacked for concocting a harsh 'story based on bar-room gossip - based on animosity - or an attempt at political back-stabbing' (QPD 1981:vol. 285, p. 3115). He then launched into a tirade against Morley and journalists who perpetuated the 'pure fabrication' of reports that often fed into radio and television news.

Given that the Premier had been forced to state publicly that no reshuffle was being considered, his hands were now tied. If the Premier had been considering making changes, the story effectively put an end to that for the time being. 
There were also some suggestions that National Party parliamentarians were seeking about the same time to depose Sullivan as deputy party leader and replace him with Mike Ahern, who had recently joined the ministry (a meeting to discuss this issue was apparently called but was cancelled by the Premier).

Lindsay Hartwig (Ind., Callide) later claimed that 'Morley wrote what he was told to write', implying perhaps the Premier had briefed the journalist ( $Q P D$ 1981:vol. 285, p. 3248). He added a little later that the 'Premier has not denied that they will be sacked' and said:

When I came here there was such a thing as seniority. No matter who he is, a person who is elected as a member of Parliament must have a chance of getting into Cabinet. The latest technique does away with seniority. To get into Cabinet, a member needs to have gone to the right school, to be of the right religion, and to be a few other things. (QPD 1981:vol. 285, p. 3397)

In July 1982, both ministers were again given a verbal dressing down by the Premier - in cabinet and in private - and by the media, for taking a seven-day 'fishing trip' around the islands of the Torres Strait in the government-owned coastal ketch, the Melbidir, along with Ted Lyons, some Coalition backbenchers (such as Bob Moore and Len Stephan), public servants and other friends. The trip seemed to be a jaunt at taxpayers' expense for no particular purpose except to escape the Brisbane winter and enjoy a spot of fishing. ${ }^{4}$ Although the Nationals began to talk of a spill, the Premier told the Courier-Mail (21 July 1982) that it was not the time, place or circumstances to give Mr Sullivan a kick in the pants'. Both Sullivan and Tomkins indicated, however, that they would not recontest their seats at the 1983 election, with Tomkins expressing the sentiment that he had entered the Parliament principally 'to have fun' and, after having some fun, he now felt the fun was gone and it was 'getting a bit hard' (Courier-Mail, 22 July 1982).

That Morley might not have been fabricating his news reports was revealed in December 1982 when both Sullivan and Tomkins were dropped from cabinet. The two new ministers appointed as replacements were Lin Powell, who came in as Minister for Education, and John Goleby, assuming the position of Minister for Water Resources and Maritime Services. Bill Gunn was promoted to the Commerce and Industry portfolio and responsibility for police was shifted from Hinze to Bill Glasson. The ageing Minister for Works and Housing, Claude

4 It was not uncommon for parliamentarians from both sides of the Chamber and their associates to make pleasure trips on the Melbidir. When Sullivan and Tomkins were criticised for their holiday, Bob Moore stated that the ALP was being hypocritical as many of its MPs had taken similar trips (naming R. Jones, P. Tucker, M. Thackeray, R. Bousen, J. Aiken and L. Jensen), adding that many journalists such as Dick Palk, Peter Trundle, Hugh Lunn, Allen Callaghan and a young Michelle Grattan had also enjoyed the hospitality. 
Wharton, also came in for some attack, with Labor members claiming that, at the age of almost seventy years, he was in 'the twilight of his career' and that the 'long knives are out, and his days are numbered' (QPD 1982:vol. 288, pp. 951-2). Kev Hooper mischievously claimed that a relative newcomer, Geoff Muntz (NP, Whitsunday), was after Wharton's job. Hooper said Muntz was the

member whose name the National Party pundits are touting. He has all the attributes. He is not overbright. He has a good, solid, National Party background. His good father was the numbers man for Mr Hinze on the Gold Coast. As is said in National Party circles, it's dollars to doughnuts that Mr Muntz will be the next Minister [for Works and Housing]. (QPD 1982:vol. 288, pp. 951-2)

Muntz would make the ministry but not until August 1983 after the Coalition dissolved. In a subsequent debate on the appointment of Supreme Court judges, Hooper described Des Frawley of making a 'terribly sexist remark' and epitomising 'the male chauvinist pig in this Chamber' after he had said 'some of us are glad that there is not' a woman on the bench (QPD 1982:vol. 288, p. 1046). In response to allegations aired in the media that he had abused his expenses, Frawley later complained of the poor deal politicians got, saying he would be glad to leave the place. Claiming MPs were not overpaid, he fumed:

Members of Parliament cannot even obtain an allowance for clothing. My salary of $\$ 33,600$ a year is not excessive, and I want the rise. When I retire from Parliament after the next election I will make just as much money as I earn now. I would not come back into Parliament if I was paid a salary of $\$ 50,000$ and an allowance of $\$ 20,000$. When my present term is finished, I am out for good. I shall never enter Parliament again. I can earn just as much money outside Parliament in private enterprise. (QPD 1982:vol. 288, p. 1091)

He also spoke of the long hours politicians put in, the many thankless tasks he undertook and the public meetings he attended, which all contributed to a 'mental torture'. He later complained of being made to make a $\$ 250$ donation to the Bjelke-Petersen Foundation, saying 'it did hurt' (QPD 1982:vol. 289, p. 1508).

During 1982, much attention in Queensland was focused on the XII Commonwealth Games, held at the specially built Queen Elizabeth II Stadium in Brisbane, during late September and early October. Bill Knox presented a bill making the opening day of the games (30 September) a public holiday. The games-like Expo 88, the plans for which were already under way - was intended to be a showcase for not only Queensland but the government itself. The government sought to enact special legislation but left it until relatively late in the piece. 
The Commonwealth Games Bill was introduced only in late November 1981 and passed in March 1982. It provided for increased and emergency powers for the police in the case of the threat of terrorism or civil disturbance (and political protests) and for security guards to execute their powers of arrest if people did not follow their directions. Police also began checking ticket sales to ensure known protesters could not gain access to venues while pretending to be spectators. The Labor opposition labelled the bill as overkill (following an editorial in the West Australian), with Tom Burns suggesting, with some sarcasm, 'the legislation is an example of the National Party policy that it will show the world how a free society works even if it has to lock everybody up in the process' (QPD 1982:vol. 287, p. 4476). Three other topics associated with the games attracted attention in the Parliament: a special high-alcohol beer had been produced to commemorate the games; souvenirs were manufactured in Hong Kong and not Queensland; and not enough Queensland athletes had been selected because of discrimination from 'southern selectors'.

Despite a threat of a black African boycott, the games was a huge success, although not everybody was happy with every detail. Bjelke-Petersen moved a motion recording the Parliament's appreciation to all who had contributed to the success of the games. Reminiscent of former Prime Minister Robert Menzies when the Queen made her first official visit, the Premier said the Queen's presence had provided the people of our State with the opportunity to express their loyalty and support'. He continued: 'Nowhere was that support more evident than at the tumultuous closing ceremony. The emotion of those moments as Her Majesty departed the arena will live in everyone's memory. Never have we witnessed a more heartfelt a more spontaneous expression of good will towards our monarch' (QPD 1982:vol. 288, pp. 1203-4).

Dr Edwards made a special point of thanking the magnificent 'hostesses' at the events, who were 'charming, beautifully attired, courteous and enthusiastic' (QPD 1982:vol. 288, p. 1205). Scottish athletes were not as impressed; they complained that they had to camp in office accommodation built nearby at Griffith University's Nathan campus and had to share one shower!

\section{From reserves to limited Aboriginal land tenure}

Indigenous issues began to attract increased attention by the 1980s. Queensland had adopted a paternalistic stance towards the various Indigenous communities and was certainly not at the forefront of progressive reform. Remote communities were administered as 'reserves' with any property managed by appointed directors. When the Parliament had focused on Aboriginal matters, it had more recently been in relation to preserving Aboriginal relics. An Aboriginal 
and Islander Commission had been established in 1979, providing some level of representation to Indigenous peoples and allowing coordination with Indigenous local councils. The Premier was not sympathetic to the concept of Aboriginal self-determination or to the granting of full Indigenous title to lands and had blocked earlier attempts by Indigenous groups to purchase a pastoral lease (leading to the famous Koowarta vs Bjelke-Petersen case in the High Court in May 1982). Bjelke-Petersen had no time for Aboriginal activists or Indigenous leaders who sought greater recognition of their culture and traditional ownership of the land. In particular, he resented Indigenous protests on land rights issues at public events such as the Commonwealth Games. Indeed, he had stated publicly that Aboriginal activists were being trained in Libya to undertake terrorist activities - a claim vehemently denied by the Indigenous community and the Commonwealth Department of Foreign Affairs.

Nevertheless, the government decided in 1982 to grant Aboriginal and Islander communities limited land tenure: a restricted Aboriginal leasehold ownership of lands for 50 years. The new tenure did not include freehold title of land or mineral rights. The legislation - the Land Act (Aboriginal and Islander Land Grants) Amendment Bill — was rushed through the Parliament in just four days, with criticisms that Aboriginal communities had not been adequately consulted (although church leaders apparently had been consulted). Under the act, local councils would be given land tenure under a 'deed of grant in trust' (DOGIT) arrangement whereby the minerals remained the property of the Crown and the leasehold could be revoked under the Land Act. While Aboriginal groups were unsure about the benefits of the land title changes and how secure they were, the issue led to a major argument between the President of the National Party, Sir Robert Sparkes, and the Premier. Sparkes wanted the legislation to itemise the specific transgressions that could result in local councils having their land title revoked (see $A J P H$ 1982:vol. 28, no. 3). After the two had a 'blazing row' in Rockhampton, the Premier was supposed to have walked out of the meeting (QPD 1982:vol. 287, p. 4716).

The Labor Party opposed the legislation outright, with some members claiming it was a 'cruel deception' (Jim Fouras) that would 'confuse the very people whom it was meant to benefit' (Bob Scott). The amendment bill led to a lengthy debate lasting well into the early hours of the next sitting day (see QPD 1982:vol. 287, pp. 5172-4, 5304-49, 5377-418), but was eventually passed in March 1982. In the next Parliament, the Minister for Aboriginal and Island Affairs, Bob Katter, moved a bill that extended the deed of grant in perpetuity (QPD 1985:vol. 298, p. 4894). Subsequent amendments to this act were made in 1984 and 1985. 


\section{Towards the bitter end}

Bjelke-Petersen returned from an overseas trip to New Zealand to find that in his absence cabinet had made a decision on establishing a register of foreign ownership contrary to his expressed wishes. Once returned, he declared the draft legislation void and said that such a register would discourage foreign investment in Queensland and would never become law while he was Premier. Labor accused him of displaying the tantrums of a 'spoilt child' over his behaviour with the cabinet. He did, however, allow the Standing Orders Committee to meet (up to six times) in 1982, after which it produced a report in March 1982 that was finally accepted in February 1983. The report advocated some minor changes to question time (the rotation of questions between the opposition and government, with members being allowed to ask up to three questions). When the committee's report was debated and some opposition members criticised the timidity of the reforms, the government Whip, Don Neal (NP, Balonne), said prosaically 'let us not rush in' to formalising proposed changes (QPD 1983:vol. 290, p. 3407). On the other hand, the Parliament was being summoned to meet far less frequently. When the second session of Parliament adjourned on 30 March 1983, it had met for only 11 days in the past nine months. It would meet for only another three full days in August before being dissolved as an emergency measure on 9 August - well before the 1983 election.

Industrial disputes were again on the rise, with state government blue-collar workers (represented by 21 unions) beginning a 35-hour week campaign in 1982. Cabinet had apparently agreed to a 38-hour week for its own blue-collar workforce - again, when Bjelke-Petersen was overseas - but final approval had stalled on particular trade-offs from the unions. A rail strike was called, which paralysed the state railways and led to accusations of communist infiltration into the unions. Don Lane, Transport Minister, suggested that the strike was political, seeking to bring down the government. He quoted from a number of pamphlets with slogans such as 'Let's hit the streets and Smash Joe' and 'Joh must go' (QPD 1982:vol. 288, p. 508). Even Labor members referred to the strike as 'a dispute that could cripple Queensland' although their attack was reserved for the government for declaring a state of emergency under the Essential Services Act (Ron McLean, in QPD 1982:vol. 288, p. 449).

The Coalition's final budget to secure parliamentary approval (for 1982/83) was brought down by Treasurer Edwards in September 1982. Edwards reported that the previous budget had resulted in a small deficit of \$170 888 - much less than anticipated since an economic recession was under way and there were higher than expected wage increases for government employees. The main features of his budget were: Queensland would receive a net increase in Commonwealth revenues of 8.1 per cent; the government would continue to provide free public 
hospital treatment; there was increased demand for essential services from population growth; rail freight revenues would be impacted by the depressed demand for coal by Japan; and the government would direct any additional resources to education. Total revenues and expenditures were expected to be $\$ 3.668$ billion. His budget contained some tax increases (with rail freight rates increased by 15 per cent and a doubling of stamp duties on motor vehicles and boats) although other concessions were relaxed (such as payroll tax and stamp duties on residential homes). Edwards reminded the Parliament that Queensland had the 'enviable position of being the lowest tax State in Australia' and had given significant concessions in death duties, payroll tax, land tax, stamp duty, road maintenance charges and permit fees (QPD 1982:vol. 288, p. 1147). Education received a 20 per cent increase, rising to $\$ 838$ million (including decreasing class sizes as recommended by the Ahern Select Committee). Culture and arts received a 29 per cent increase, rising to just less than \$5 million; road spending increased by 19.5 per cent to $\$ 405$ million; police numbers were increased by 154, bringing their budget up to $\$ 172$ million or a 22 per cent increase. Public health and hospitals received $\$ 640$ million, up by 20 per cent; railways were allocated $\$ 697$ million; primary industries received $\$ 79$ million compared with welfare services, which received $\$ 69$ million, which had also increased by 22 per cent. An amount of $\$ 1.5$ million could be found for national parks. Edwards claimed the budget was 'a very satisfactory one' with overall spending up by 17 per cent. To many, it was a pre-election budget with substantial increases in public spending. The Australian Bureau of Statistics (ABS) indicated in early 1983 that Queensland had the highest budget deficit of all states ( $\$ 460$ per capita) in both absolute and relative terms and that, contrary to the government's low-tax mantra, it had been increasing taxes at a rate that was the second-fastest in Australia (AJPH 1983:vol. 29, no. 3, p. 491).

\section{The boot is on the other foot-and the resignation of Ed Casey}

Labor continued to accuse the government of bribery and corruption in the Assembly, even if specific allegations could not often be proved. The boot was placed on the other foot when the Premier accused Ed Casey of taking bribes before the 1980 election of up to $\$ 30000$ from a Mr Ted Vibert from the Australian Club Development Association to gain the party's support for introducing poker machines. There were no allegations Casey had taken the money personally, but rather that he had sought to open special campaign accounts with the Commonwealth Bank to assist Labor's 1980 campaign. The Premier claimed that Casey had been bribed and that it was an offence to bribe a Member of Parliament. Casey denied to the media that he had received such 
funds, but was later forced to correct his story, admitting he had received the money. At the next cabinet meeting, Bjelke-Petersen discussed whether he should recall the Parliament to debate the Opposition Leader's behaviour and whether he had acted improperly.

The matter was allowed to drop only after it was revealed that Vibert had made some other donations, to sympathetic Liberal Party candidates, and had also made a donation to the Bjelke-Petersen Foundation. Senior government members were fearful the issue would backfire on them if they continued to pursue it. The Premier, undeterred, set up a Dorothy Dixer from Ted Row (NP, Hinchinbrook) in August 1982 asking him about the police investigations. In answering Row, the Premier alleged Casey had refused to be interviewed by police and that an inconclusive report had been submitted to the Justice Department for consideration. Casey denied he had refused to cooperate with the police and attempted to clear himself of any impropriety. In future years, it would be revealed that prominent politicians on both sides accepted monies from developers and business interests and tried to conceal such illicit payments from any public scrutiny. Large cash donations from lobbyists associated with the poker machine industry, in particular, were a favourite source of such funds.

The scandal was not over, however, for Casey. Immediately after the budget was delivered, Bill Hewitt claimed Casey was 'constantly having to look over his shoulder because his own leadership [was] by no means secure'. He described Casey as a 'Claytons' leader (that is, not the real thing, referring to the nonalcoholic drink) (see QPD 1982:vol. 288, p. 1236). He blamed the deputy Labor leader, Bill D'Arcy, for the destabilisation, saying Casey had but three options: invite D'Arcy to give his support to the next election, challenge his leader or step down from his post. While Kev Hooper claimed in the House in September 1982 that there was no move to depose Casey, he was ousted during the second week back after a parliamentary break.

The Parliament was informed on 21 October that Keith Wright had been elected leader, with Neville Warburton (who was soon called the 'invisible man') as his deputy. Wright was relatively independent of the Labor factions, but, in the words of one journalist, he had 'risen entirely without trace' (Charlton 1983:128). He came in for an immediate baptism of fire with Llew Edwards and Bob Katter both claiming in sequence that the new leader was not interested in economic issues and 'did not appear to consider the Budget of Queensland as of major importance, because at no stage during the debate did he address the committee' (QPD 1982:vol. 289, pp. 1695, 1912). The Premier also cryptically insinuated in a television interview that Wright 'would not be where he is if people knew what I know' (Walter and Dickie 1985:36). Later in the 1983 election campaign, he was even more caustic, continually referring to Wright as 'Mr Wrong' (Coaldrake 1989:11). He also accused Wright of having misused 
his parliamentary entitlements (as reported by Auditor-General Jim Peel's report) and owing some $\$ 3042$ to consolidated revenue (QPD 1982:vol. 289, p. 2680). These instances of MPs abusing travel entitlements (and refusing to make reimbursement) were subsequently dredged up to attack various Labor spokespeople whenever they accused the government side of inappropriate behaviour. Peel reputedly received a roasting from those MPs named in his report.

\section{The futility of taking strong principled stances}

Two seemingly routine appointments in 1981-82 both erupted into controversy and strained the bonds of unity in the Coalition. Both involved the Premier determining to impose his own preferences over the cabinet and, in particular, over senior Liberal ministers who had other views or objected to the Premier's choice. Both caused crises in the Coalition and led to dissident Liberal backbenchers taking a stronger line against their own leadership, who they accused of not standing up to the Premier.

First, the Premier decided to appoint his friend and confidant Sir Edward Lyons to the post of Chairman of the TAB in May 1981, against the wishes of Liberal ministers who saw this as nepotism. Lyons had been actively lobbying over the casino licences and was a powerful voice behind the government. BjelkePetersen had an Executive Council minute prepared indicating Lyons would be appointed to chair the TAB board and circulated this to the full cabinet, but the seven Liberal ministers refused to sign the minute to indicate their agreement. The Premier, nevertheless, managed to convince the Governor, Sir James Ramsay, to endorse the appointment. Perhaps celebrating too profusely, Lyons was apparently picked up for drink-driving but, Labor alleged, after a phone call from the Premier to the Police Commissioner, Terry Lewis, no charges were laid, but later he was summonsed. The Police Minister, Russ Hinze, refused to instigate an open inquiry.

Then, during the summer of 1981-82, the Coalition again split over the appointment of a new chief justice. The Liberal Attorney-General, Sam Doumany, took a shortlist of candidates to cabinet, headed by the most senior judge, Mr Justice Jim Douglas. Bjelke-Petersen did not support this proposal; indeed, he vetoed it, because he had been told (by Don Lane, who had seen the paperwork) that Douglas had once voted Labor in a postal ballot - at the 1972 state election for the seat of Merthyr. ${ }^{5}$ Instead, the Premier favoured $\mathrm{Mr}$

5 Coaldrake (1989:86) also claims that the Premier objected to 'the view that the preferred choice of the judiciary should be automatically endorsed by the government' and that he was miffed that he had been barred from attending the official opening of the new Supreme Court building in 1981 because he was a 
Justice Dormer (Bob) Andrews, as did Lyons, who had been lobbying for the appointment of Andrews. Doumany threatened to resign from the ministry if his nomination was not accepted. After protracted discussions and a two-hour cabinet fight, Doumany proved unable to convince the Premier and his National Party ministers, but managed to have his second choice accepted as a compromise candidate: Sir Walter Campbell, a judge of the Supreme Court. Then, at the Premier's instigation, cabinet proceeded to make a second appointment to the court (Senior Puisne Judge) with the Premier insisting his candidate, Andrews, be appointed. After another two-hour debate, Bjelke-Petersen had another Executive Council minute prepared nominating Andrews, but, when the Liberal ministers were asked to sign, they expressed their dissent. Knox wrote 'with the exception of William E Knox' (that is, he did not agree to the recommendation), and the other six ministers including Lane wrote: 'this minute does not have my support' (see Lane 1993:Appendices 5, 6, 7). Bill Hewitt recalled the Premier looking directly at Knox and saying 'even you Bill?'.

Doumany did not carry out his threat to resign his post. Instead he told the Parliament, when asked in March:

First of all, I did not make any public statement to the effect that I would resign. In fact, I clarified that many times but the media did not want to clarify it. The matters of the appointment of the Chief Justice and the other appointment to the Supreme Court are closed. It is time to allow the court to operate in the interests of the State and its people. Frankly, at this stage I see no use whatsoever in pursuing the matter further. (QPD 1982:vol. 287, p. 4433)

So, behind the scenes (and sometimes publicly) Liberal ministers took these strong, principled stances against the Premier, on occasions banding together as a dissenting bloc. When they lost, however, they appeared to accept the outcome too meekly. In some ways, taking a stance and losing, then not doing anything about it, harmed the political standing of senior Liberals among their own colleagues.

\section{The demise of the Coalition: the security blanket is withdrawn}

After more than 25 years in existence, the formal coalition between the National and Liberal Parties came to a sudden end. Relations had long been acrimonious and both parties had contributed in their own ways to the corrosion of the 
arrangements. There was not one single reason or action that led to the collapse of the coalition but, rather, a multitude of factors had been simmering for almost two decades and they were coming to boiling point.

The Nationals had slowly eroded the initial coalition agreement to keep the number of ministries relatively equal between the parties. More and more they had advantaged themselves at the expense of the Liberals. Under BjelkePetersen, the ratio of Nationals in cabinet to Liberals had gone from seven to six, to 11 to seven. They operated from an ingrained belief that they 'owned' their political territory and seats within it and regularly admonished the Liberals for running three-cornered contests against their sitting members (or in seats they regarded as theirs). They had fiercely rebuffed Liberal attempts to capture any of their seats and, on the few occasions when the Liberals had won a National seat, fought back and retook those seats (leaving only Redcliffe as a former National seat held by the Liberals in 1982-83). The Premier was quite prepared to work with ardent coalitionists who worked for the government and did not oppose his plans, but was increasingly determined he would not work with dissidents who were not above all else loyal to the Coalition. He told the Parliament 'I am fighting for democracy now. I have been fighting for democracy for most of my life' (QPD 1983:vol. 290, p. 3048) - democracy presumably meant entrenching National Party rule!

The Liberals were infuriated at the 'permanency' of their junior status and their own incapacity to rectify the situation. In every other state, the Liberal Party was the superior partner, whereas in Queensland it was regularly humiliated. They were incensed by the erosion of ministerial posts in cabinet, the allocation of Liberal ministers to lesser portfolios and fights over Treasury. They had opposed many of the Premier's idiosyncratic schemes or laws, such as the Tarong power station, street marches, the Bellevue demolition, various government appointments and some of his more crackpot ventures. The outright reluctance of the Nationals to cease their advantageous manipulation of rural and regional electoral weighting was seen as denying the Liberals their rightful heritage (see Miller and Koch 1983). Moreover, while the Liberal backbench and many local branch members had for some time sought to differentiate themselves from the Nationals, especially over issues of accountability, this strategy had risen to new heights under the leadership of Llew Edwards.

Symbolic of the need to differentiate, the Liberals coalesced around the fundamental issue of a public accounts committee (PAC) for the Queensland Parliament. The lack of a PAC had been a constant source of irritation for both the Liberals and the ALP and various proposals had been hotly debated in the Parliament for many years. It was seen as a litmus test of how far the Nationals would accommodate Liberal sensibilities. Labor had been goading the Liberals in public over why they would not unilaterally support the introduction of a 
public accounts committee (to which Labor would contribute its numbers in support). Edwards' pragmatic response was that establishing a public accounts committee was Liberal Party policy, but the Liberals were part of a coalition so could not act until the Nationals also agreed.

Tensions were heightened when two Liberal MPs (Bill Kaus and Bob Moore) jumped ship to join the Nationals in July 1983. Kaus and Moore had been disendorsed in Liberal preselections for their seats of Mansfield and Windsor. Their defections took the number of National seats to 37 in the Assemblystill five short of a majority. Although Moore claimed Kaus had been knifed by the Transport Minister, Don Lane, to bolster his own numbers in his push towards the leadership, Lane blamed the party executive for dispatching two pro-coalition MPs. The party's president, Gary Neat, and Terry Gygar were both blamed in the Parliament for cutting off the heads of these backbenchers.

The rift in the Coalition intensified and then imploded almost by accident when the Speaker lost control of the Parliament on 4 August 1983. Initially, the Speaker, Sel Muller, ruled that permission to move a motion without notice (to suspend Standing Orders - in other words, government business - to enable the Parliament to discuss the establishment of a PAC) from Ian Prentice was agreed to, saying the 'ayes have it'. He then contradicted himself, first by calling for a division, then cancelling his decision. Edwards, fearing a divisive vote on such an issue, tried to pretend that the Speaker's cancellation was for the motion without notice, when it appeared to have been on the need for a division. By then completely confused, Muller ruled that the debate continue, but members now did not know whether this meant normal business or the motion without notice. At a subsequent division, the motion was lost by 45 to 32, meaning the House had not given permission to Prentice to move his motion without notice to suspend government business. Prentice would later pay dearly for his stance, sacrificing his political and legal career, as 'Bjelke-Petersen demanded, and got, a ban on solicitors' firms giving Prentice work as a barrister' (Lamont 2005:2).

Ten Liberals sided with the Nationals to defeat Prentice's motion, including five of their ministers. The Environment Minister, Bill Hewitt, abstained, but was accused by the Premier of being disloyal and hiding in the toilets (as a minister, it could have been more courageous to have abstained-and in fact he was in the gallery watching the proceedings!). One relatively new (and junior) minister, however, Terry White, along with seven Liberal backbenchers (Akers, Greenwood, Gygar, Innes, Kyburz, Prentice and Scassola) all joined Labor in voting in support of the motion (see Miller and Koch 1983). The split was on.

Terry White, as Minister for Welfare Services, crossed the floor over a minor procedural issue (but substantively over a proposal to establish a PAC). The Nationals regarded a cabinet minister voting against the government as a hanging 
offence. It is not clear whether White had crossed the government on a policy issue (as cabinet had not made a decision either way on establishing an accounts committee), but he had shown political dissent against his own government, thus breaching cabinet solidarity. After question time was over, a special cabinet meeting was called (to which Hewitt and White were not invited) after which Edwards sought White's resignation, which was not forthcoming, so Edwards sacked him. Surprisingly, the Parliament spent the rest of the afternoon with a distracting polemical debate about the threat to the federal system posed by the new Hawke Labor government, moved by the Premier with an emotional speech on states' rights.

Events then became frenetic. With the Parliament in disarray and 'uncontrollable', the Premier sought a special adjournment from the Assembly on the morning of 9 August. White announced he would challenge Edwards for the leadership at a special meeting of their parliamentary party on the afternoon of the same day. Edwards had the backing of the Premier and thought he was safe and could just survive, but he had given a number of his colleagues reason to be disaffected with his leadership and had lost the support of the party's organisational wing. Edwards attempted to portray the reason for White's sacking as one of disloyalty in not supporting government business in the House, but he looked disingenuous (especially as it appeared publicly that White had been sacked for his support of an accounts committee). At the party meeting, Edwards did not have the support necessary to carry on as leader. He tried to prevent a spill motion for the leadership post and, when he lost this, he immediately left the meeting and resigned the party leadership on the spot (although he remained Treasurer and Deputy Premier for another week).

White was elected unopposed as the new leader with Sam Doumany as his deputy. They announced the new leadership arrangement and set off walking to the Executive Building to call on the Premier. The Premier left them waiting in the reception area for an hour before speaking to them for 15 minutes. BjelkePetersen refused to accept White back into the ministry, preferring to keep Edwards on as Treasurer. Bjelke-Petersen's so-called 'knock-out' victory was then to call a meeting of six Liberal ministers on 15 August at which he ascertained that they were reluctant to resign and were doing so only because the Liberal Party executive insisted. The Premier conveyed the 'reluctant' resignations of all seven Liberal ministers to the Governor, Sir James Ramsay, that same day. On the Premier's advice, the Governor refused to accept the 'reluctant' resignations. Bjelke-Petersen had managed to pull a rabbit from the hat. As two journalists said at the time, the Liberal ministers, 'with the exception of Hewitt, were pretty happy that an "out" had been found; they had stood up for their party by resigning, but their resignations had been rejected' (Miller and Koch 1983:35). 
Meanwhile, White, who was feeling ambushed, wrote to the Premier (on 11 August) stating he should not have been sacked and should be reappointed. The Premier ignored his pleading letter. The next day, White then had the Liberal State President, Dr John Herron, issue a public ultimatum to the Premier stating that, unless White was reinstated, no coalition between the parties existed. The Premier was given until $7 \mathrm{pm}$ on Sunday (14 August) to respond, but he ignored the demand. The Liberals had called a press conference in anticipation of an answer, when in the words of a former Liberal minister:

The deadline for Joh to accept White as Deputy Premier came at $7 \mathrm{pm}$, and in anticipation the media were assembled in depth. It did not have the dignity of most state funerals but was just as final in its consequences. This was enhanced by the spectacle of White dramatically tearing up a piece of paper - a press statement as it happened - to dramatise the tearing up of the coalition by the National Party! Television editors and other story-tellers have since used that scene frequently to demonstrate Terry White tearing up the coalition agreement, a distortion of what actually took place. It is a piece of drama that I don't think he will ever live down and it has already been enshrined in history. (Lane 1993:112)

Politically, Bjelke-Petersen benefited enormously from the impression that White had 'torn up' the Coalition agreement.

Keen to assert himself as Premier-in-waiting, Labor's Keith Wright first called on the entire Liberal parliamentary party to join with Labor and form a short-term Liberal-Labor administration, which was refused by the Liberals. Wright would later release details of his cabinet, implying Labor was ready to govern, and gave notice that the Treasury portfolio would be replaced with two departments: finance and economic development (Daily Sun, 15 October 1983).

Tired of the fight, the former Attorney-General, Sam Doumany, after less than a week as deputy Liberal leader, indicated he would step down from the position to attend to his electoral duties. He fought the 1983 election as a Liberal (and lost his seat) but then drifted to the Nationals. Meanwhile, Colin Miller (Lib., Ithaca) was appointed to the ministry as Environment Minister in August 1983 replacing White (with Hewitt moving to White's former portfolio). All seven Liberal ministers, however, resigned en masse for a second time on 18 August, and this time their resignations were accepted. Edwards decided to retire from politics and not contest his seat at the forthcoming election.

The Governor, on advice from the Premier, dissolved the Parliament on 13 September 1983. 


\section{The 'rump executive': governing without calling the Parliament}

It was a tough time for the Nationals to contemplate governing alone in circumstances in which they could find themselves as a minority government. Throughout the early 1980s, the Nationals had been rocked by a series of controversies and political scandals, coming in short succession one after another. The media was beginning to highlight conflicts of interest, nepotism, abuses of power and suggestions of outright political corruption. Decisions over new developments and project approvals seemed to be determined in mysterious and reprehensible ways, certainly without much transparency. The eponymous Bjelke-Petersen Foundation was regarded with suspicion and distrust.

By 1983, Bjelke-Petersen's claim of superior economic management was looking increasingly hollow as a state recession loomed and the unemployment rate rose to one of the highest in the country (jumping from 54000 to 75 700). The 'cranes on the skyline' test was slipping. Although the Queensland government had agreed to abide by the nation-wide wages pause called by the Fraser government, and held some charges and fees down, it allowed politicians' salaries to rise by almost 12 per cent in September 1982 and by a further $\$ 500$ per annum in December 1982.

The rump ministry retained the 11 National ministers, augmented with six novice Nationals promoted to the ministry (Angelo Bertoni, Neil Turner, Vince Lester, Martin Tenni, Nev Harper and Geoff Muntz). The Premier assumed the portfolio responsibility for Treasury. The full ministry consisted of

- Premier and Treasurer: Johannes Bjelke-Petersen

- Deputy Premier and Minister for Commerce and Industry: Bill Gunn

- Minister for Local Government, Main Roads and Racing: Russ Hinze

- Minister for Northern Development and Aboriginal and Island Affairs: Val Bird

- Minister for Works and Housing: Claude Wharton

- Minister for Mines and Energy: Ivan Gibbs

- Minister for Primary Industries: Mike Ahern

- Minister for Lands, Forestry and Police: Bill Glasson

- Minister for Tourism, National Parks, Sport and the Arts: Tony Elliott

- Minister for Education: Lin Powell

- Minister for Water Resources and Maritime Services: John Goleby

- Minister for Justice and Attorney-General: Nev Harper

- Minister for Employment and Industrial Affairs: Vince Lester 
- Minister for Transport: Neil Turner

- Minister for Health: Angelo Bertoni

- Minister for Welfare Services and Ethnic Affairs: Geoff Muntz

- Minister for Environment, Valuation and Administrative Services: Martin Tenni

Between August and November, the 'rump' executive led by Bjelke-Petersen governed alone, not wishing to call an election and not wishing to summon the Parliament, where confidence in the government could be tested and possibly lost. The Governor was apparently content (at the Premier's behest) for the minority government to govern and make decisions without testing whether it in fact had the confidence of the House. Politically, the government was in effect a 'caretaker government', which should have administered the state in caretaker mode until the election outcome was known and without making any major decisions. The Governor was, however, content to regard the new executive constitutionally as a successive ministry, with full powers even though the election date had been announced for 22 October (more than two months away). In supporting the Premier so openly, the Governor's decisions led to some criticism from outside observers because they challenged many of the understood constitutional conventions about 'confidence' and 'caretaker' status.

Eventually, the minority Nationals governed alone for 82 days precisely to demonstrate they could do so, giving Bjelke-Petersen time to display that he did not require the Liberals in his ministry to form an effective single-party government. Cabinet continued to meet, decisions were taken and announced. Importantly, therefore, the Nationals' 'rump' served its intended purpose: permitting time for the government to administer the state while simultaneously adopting a perpetual campaigning mode. Local media reports predicting that the dawn of a new political era was fast approaching were premature (Sunday Sun, 16 October 1983).

The Nationals favoured a fear campaign. The Premier, falling back on familiar rhetoric, sought to tarnish Labor as a dangerous party of socialists and high taxes, which would do the bidding of the centralist and corporatist Hawke government. With the other mainland states having voted in Labor governments, the Nationals presented themselves as Queensland's defenders from the 'socialist' menace that had swept much of Australia. With superior campaign tactics, the Nationals aimed their campaign at parochial appeal and the paternalism of strong leadership. One of the party's main campaign advertisements was a map of Australia coloured entirely red, except for Queensland and Tasmania, with the slogan 'Now, more than ever, Queensland needs Joh'. Rather than outline a raft of new policies, however, Bjelke-Petersen focused on his past achievements. He recommitted himself to maintaining the state's low-tax regime and boasted 
of Queensland's reputation as being friendly to business. His campaign stressed the traditional message that only the progressive, free enterprise-orientated National Party could ensure Queensland's continuing economic growth and prosperity. On his next ministry, he ventured that he would consider admitting Liberal ministers to a future conservative government - but not anyone who had voted in the leadership ballot for Terry White, whom he considered a small-l Liberal. The Nationals claimed that the Liberal Party was one of 'socialist-lites' and 'trendies', with the Premier suggesting its leader had shown his willingness to flirt with the ALP and could not be trusted with running the affairs of the state.

The Liberal Party's campaign stressed traditional individual values. It played up the themes of the rights of ordinary citizens to a job, economic prosperity and open and accountable government. It portrayed itself as the real defender of the Westminster system. Emphasising the Liberal Party's commitment to accountability in government, White campaigned strongly on the issue of a parliamentary Public Accounts Committee. White's strong advocacy for the PAC was in part based on his claim that PACs elsewhere had saved millions of dollars. He claimed a PAC would enable the government to slash state taxes. White sought to differentiate the Liberals from the Nationals in social and environmental policy areas and stressed the right to peaceful protest would be restored under a Liberal-led government.

Labor entered the campaign with renewed vigour. Wright campaigned energetically around the state and early polling suggested that Labor would perform well. In the campaign, Labor highlighted the divisions between the conservative parties, claiming it was now the only party that could provide political stability. 'Let them fight and let us govern' was a frequent catchcry. Central to Labor's message was its focus on people and families, rather than on power and greed - the basis of the conservative's legislation. Labor's policy stressed improved health, welfare and housing services and facilities, cheaper electricity prices and job creation initiatives. A large amount of Labor's campaign, like the Liberal Party's, centred on accountability and the need for better transparency in government, highlighting the lack of honesty and integrity of the National Party. Some were concerned, however, that Wright was putting too much emphasis on the instability of the conservatives at the expense of economic management issues. Labor hoped its negative campaign would resonate with voters.

In the last weeks of the campaign, the Liberals appeared hapless and suffered a series of embarrassing reversals. As one source reported:

The Liberals for the first time were in the position of having to mobilize a campaign without any of the considerable advantages of political 
office. The difficulties facing the Liberals only multiplied, however, over the pre-campaign and campaign periods. The Liberals were dogged by an almost unending series of divisive incidents. Malcolm Fraser's open letter criticizing the Queensland branch and Mr White's behaviour; Mr Sam Doumany's resignation as deputy parliamentary leader, $\mathrm{Mr}$ Doumany's subsequent invitation to Tasmanian Liberal Premier, Robin Gray, to campaign on his behalf, though it was also evident that Mr Gray was interested in supporting Mr Bjelke-Petersen and the National Party; the actions of four senior Liberals, all formerly state cabinet ministers, in campaigning as coalition Liberal; the entry into the campaign of former Liberal premiers Sir Henry Bolte and Mr Tom Lewis (in addition to Mr Gray) to support the Nationals; and the undenied report, just six days before polling day, that Mr Brian Austin was planning to challenge Mr White's leadership. Nor was the Liberal campaign assisted by the decision of Dr Edwards to retire from politics, vacating his vulnerable seat of Ipswich. (AJPH 1984:vol. 30, no. 1, p. 261)

The wheels had fallen off the Liberal campaign in a big way. Conservative voters were thus given a stark choice: to vote for a strong Premier who could form a single-party majority government or persist with their traditional voting habits and perhaps see the Coalition continue its squabbling.

\section{A new watershed: the 1983 state election}

After five successive elections that had produced relatively stable outcomes (those from 1960 to 1972), the seismic shift of 1974 led to a pattern of Coalition electoral dominance that was replicated in 1977 and 1980. The 1983 state election was another such seismic shift in popular opinion, which would have a significant impact for the next six years.

Unlike the 1974 election, which saw the Coalition vote jump by 16.7 per cent, Labor's drop by 11 per cent and the DLP disappear, the 1983 election redistributed votes among the former coalition side. In 1983, Labor's vote moved only marginally, finishing slightly ahead of what it had achieved in 1977 as it recovered somewhat after the 1974 rout. On the conservative side, however, the Nationals shanghaied the Liberal vote, capturing an additional 11-12 per cent of the state-wide vote at the expense of the Liberal Party. In short, Queensland Liberal voters transferred their allegiance; they backed the dominant partner in 'their' government.

The 1983 election also had some parallels with the tumultuous events of 1957. Just as the long-term Labor government was falling apart in 1956-57, so the Coalition government had fallen apart in $1982-83$ as the Liberal and 
National Parties bickered ostensibly over the refusal of the Nationals to agree to establishing a parliamentary public accounts committee (hardly a momentous issue in itself but symbolic of their differences). As in 1957, now the cabinet could not abide working together and sections of the government were prepared to publicly turn their backs on former colleagues. And, again like 1957, now hardened belligerents wanted everything their own way and were unprepared to compromise.

Two things, however, were significantly different between 1957 and 1983. First, the Liberals did not use their numbers to bring down the Nationals' rump government in the Parliament. If the Liberals had had the will or the opportunity to side with Labor to deny confidence to the Nationals, they could have defeated Bjelke-Petersen by 47-35. They did not adopt this tactic, however, even if some countenanced it; and then over the months that the Parliament did not sit it was not a possible course of action. Second, the Nationals' firepower in the 1983 election was formidable. The Nationals had the upper hand from the outset, with superior campaigning skills, bountiful campaign funding from wealthy donors prepared to invest in the longevity of the government and the benefit of electoral boundaries favouring its supporters. As a consequence, the Nationals captured a swathe of new territory in 1983, winning Brisbane electorates they had never held before and that they would awkwardly hold onto until 1989.

The 1983 election outcome was historic: for the first time the National Party won half the seats in the Parliament and with two ministerial defections could govern alone. As the election results began to filter in on the evening of 22 October, it became apparent that a massive swing to the Nationals was occurring. The National Party's vote rose to 38.9 per cent, delivering the party a gain of six seats. Crucially, for the first time, the Nationals achieved a strong result in metropolitan areas, winning six seats in Brisbane (all captured from the Liberals). New members included: from the Brisbane metropolitan area-Yvonne Chapman (Pine Rivers), Leisha Harvey (Greenslopes), Earle Bailey (Toowong), Brian Cahill (Aspley) and Ian Henderson (Mount Gravatt); plus a number of new members who retained National seats, including - Russell Cooper (Roma), Kevin Lingard (Fassifern), Brian Littleproud (Condamine), Sandy McPhie (Toowoomba North), Lyell (Bill) Newton (Caboolture) and Mark Stoneman (Burdekin). In addition, the former Liberal Bill Kaus retained Mansfield for the Nationals, having swapped parties when his preselection as a Liberal was denied.

The Liberals lost two-thirds of their seats, dropping from 22 to eight, and then to just six after the former Liberal ministers Brian Austin and Don Lane defected to the Nationals. To remain in government and maintain stability, the two renegades bargained for their old portfolios of Health and Transport, which the Premier accommodated. Their defection increased the government's majority to four and meant the Nationals could provide the Speaker and still command a majority 
of 41-40 on the floor of the Assembly. The six Liberal survivors included: Angus Innes, Bill Knox, Norman Lee, Bill Lickiss, Col Miller and Terry White. Prominent Liberals to lose their seats included: Sam Doumany, Bill Hewitt, Rob Akers, John Greenwood, Terry Gygar, Rosemary Kyburz, John Lockwood, Beryce Nelson, Ian Prentice, Guelfi Scassola and Norman Scott-Young. In Don Lane's (1993:126) terms, 'most of the trendies had been thrown out of their seats by a voting public clearly fed up with the Party that had literally walked out of coalition Government'. Bob Moore, a former senior Liberal who did not secure preselection and jumped to the Nationals in July 1983, also lost his seat. In Callide, Lindsay Hartwig was returned as the sole independent.

Labor's slender increase in its state-wide vote (to 43.98 per cent) resulted in a net gain of seven additional seats, taking Labor's tally to 32-its best result since 1972. Incoming Labor members included: Pat Comben (Windsor), Wayne Goss (Salisbury), David Hamill (Ipswich), Ken McElligott (Townsville), Denis Murphy (Stafford), Bill Price (Mount Isa), Tom Veivers (Ashgrove) and Anne Warner (Kurilpa). All Labor's gains were at the expense of the Liberals except Mount Isa, where Price defeated the Nationals' Angelo Bertoni. New members in seats retained by Labor included: Clem Campbell (Bundaberg) and Keith De Lacy (Cairns). Labor lost one seat, Maryborough, where Brendan Hansen was narrowly defeated by the former Liberal Gil Alison now representing the Nationals.

\section{Conclusion}

The 1983 election confirmed that Joh Bjelke-Petersen was a political phenomenon. The Nationals had crashed through largely thanks to the political astuteness and appeal of Bjelke-Petersen. He had won spectacular victories in the mid-1970s and now repeated the feat in 1983. He had pulled off a most remarkable coup. Along with Sparkes and Evans, he had transformed the rustic old Country Party organisation with narrow sectional interest and a declining electoral base into a modern state-wide party dominated by a broader array of commercial, mining and tourism interests. He had blended the ideologies of parochial 'country-mindedness' and religious puritanism with rampant developmentalism, 'boosterism' and states' rights chauvinism. Certainly, the government and most of the media interpreted the 1983 election as a vindication of his policies to that point: the promotion of opportunistic development while taking a tough stance on opponents and critics.

Yet, despite the elation, not everyone in the National camp was ecstatic. Some senior Nationals in the parliamentary and organisational wings were, for a time, anxious to be rid of Bjelke-Petersen. He had already been Premier for more 
than 15 years and had grown dictatorial and belligerent. He was perceived as frustrating the ministerial ambitions of members in the parliamentary party. There were then many senior ministers among the Nationals who held ambitions to become Premier, including Russ Hinze, Bill Gunn and Mike Ahern. Moreover, while Sir Robert Sparkes and Bjelke-Petersen had prospered as a duumvirate in the 1970s, by the early 1980s, their relationship was gradually deteriorating into outright warfare.

To many 'neutral' observers, the fact that the Nationals managed to win government in their own right had its shortcomings. There were now even fewer checks and balances on the Nationals' ministry, fewer differences of opinion that could provide healthy debate inside government and fewer proprieties that had to be seen to be observed. Some in government began to think they were above the law or could legislate to fix anything they chose. With the Premier and his handpicked National ministry freed from the counselling and safeguards provided by the Liberals, the idiosyncratic nature of the government became more pronounced. The question of where to draw the line in decisions or projects the government became involved in would become increasingly problematic. 'Group-think' took over. And as time went on, the 1983 election outcome would prove a curse as well as a blessing for the government. 


\section{The implosion of Joh Bjelke- Petersen, 1983-1987}

The 1983 election ended the 'constitutional crisis' by providing the Nationals with exactly half the seats in the Parliament (41) and the opportunity to supplement their ministry with Liberal ministerialists who would agree to join the new government. The Premier had a number of options to secure his majority. Many of the surviving former Liberal ministers were not generally regarded as 'anti-coalitionists' in the previous government. The six potential ministerialists who might have been persuaded to change allegiances were: Norm Lee, Bill Lickiss, Brian Austin, Don Lane, Colin Miller and even Bill Knox. According to the Courier-Mail (15 July 1983), when two Coalition backbenchers, Bill Kaus and Bob Moore, had quit the Liberals and joined the Nationals in July, two Liberal ministers, Norm Lee and Bill Lickiss, already had indicated they would consider jumping ship. It was almost as if a race to defect was on. The two other Liberals to survive the 1983 poll, Terry White and Angus Innes, would not have been acceptable to the Premier and his senior ministers. In total, six of the eight Liberals had been ministers (although Miller had served for just 13 days after White was sacked and before the resignations of all the Liberals were accepted). Knox had been a minister since 1965 and Lee and Lickiss had been ministers since early 1975. They had some pedigree. Austin and Lane (and White) each had one parliamentary term as minister.

Two Liberals, however, took the issue into their own hands. The day after the election, Austin and Lane had discussed the prospects of defecting and swapping parties, with Austin saying 'I'm sick of this...I reckon we ought to give 'em the arse. What about joining the National Party' (Lane 1993:126). They communicated with the National Party's headquarters, indicating they would change allegiances and provide the government with a workable majority in the Parliament. Both these former ministers had earned a reputation as effective ministers who fought for the government as a whole in the previous term. Bjelke-Petersen also got on personally very well with Austin, who was an effective minister, and he respected Lane's political skills. The Premier immediately invited these Liberal ministerialists to meetings at his offices in the Executive Building. Interestingly, at this juncture, the Premier did not approach his former Deputy Premier, Bill Knox, or for that matter Norm Lee or Bill Lickiss, about joining the new government. Perhaps sensing that the new stand-alone National government needed some astute political heads, BjelkePetersen accepted the offer from Austin and Lane, who together by then had about 18 years' parliamentary experience. 
So it was that shortly after the election result was clear the new ministry was announced. Bjelke-Petersen's eighth ministry consisted of 18 ministers (again), with both renegade Liberal ministerialists in senior posts and the Premier hanging onto the Treasury portfolio. His deputy, Bill Gunn, was effectively appointed as minister without a portfolio (but assisting with Treasury matters), and for most of the term he had no other departmental responsibilities until he was acting minister for Water Resources in late 1985 and then given Police in February 1986. Of those ministers who had been in the previous ministries (the 1980-83 Coalition ministry or the rump National ministry of late 1983), Val Bird had retired from politics at the election, Angelo Bertoni had narrowly lost his seat of Mount Isa and Tony Elliott (the former Tourism Minister) was dropped entirely. Two new faces were included: Peter McKechnie (the son of the former Country Party minister Henry McKechnie) and the maverick Bob Katter, from the northern electorate of Flinders (the son of Bob Katter senior, federal Country Party member, 1966-90). There were a fair number of dynastic National Party families represented in the new ministry.

\section{The eighth Bjelke-Petersen ministry}

The full ministry consisted of

- Premier and Treasurer: Johannes Bjelke-Petersen

- Deputy Premier and Minister Assisting the Treasurer: Bill Gunn

- Minister for Local Government, Main Roads and Racing: Russ Hinze

- Minister for Works and Housing (and Leader of the House): Claude Wharton

- Minister for Mines and Energy: Ivan Gibbs

- Minister for Industry, Small Business and Technology: Mike Ahern

- Minister for Transport: Don Lane

- Minister for Lands: Bill Glasson

- Minister for Health: Brian Austin

- Minister for Education: Lin Powell

- Minister for Water Resources and Maritime Services: John Goleby

- Minister for Primary Industries: Neil Turner

- Minister for Employment and Industrial Affairs: Vince Lester

- Minister for Environment, Valuation and Administrative Services: Martin Tenni

- Minister for Justice and Attorney-General: Nev Harper

- Minister for Welfare Services and Ethnic Affairs: Geoff Muntz

- Minister for Tourism, National Parks, Sport and the Arts: Peter McKechnie 
- Minister for Northern Development and Aboriginal and Island Affairs: Bob Katter

Ken Vaughan (ALP, Nudgee), a future minister himself, said of the new line-up that the first thought that ran through my mind when I saw the line-up for Cabinet was that Cabinet would be nothing more than a wood-heap of logs' (QPD 1983:vol. 292, p. 351). Other opposition members were equally dismissive of Bjelke-Petersen's eighth ministry and the Nationals' second alone. Ron McLean (ALP, Bulimba) described the cabinet as full of 'yes men' who would not stand up to the Premier (QPD 1985:vol. 298, p. 3995). Brian Davis (ALP, Brisbane Central) complained that after almost a year Vince Lester had made no speeches in the Parliament in his new portfolio (QPD 1984:vol. 296, p. 1940).

The Parliament had to be summoned quickly as the government was in danger of running out of finance as the appropriation bill to grant supply for 1983/84 had been moved before the election but not passed. Hence, the Clerk issued the summons to members informing them the Parliament would sit on 22 November just one month after the election. On the first day, the Premier nominated John Warner (NP, Toowoomba South) for the Speakership - a motion seconded by his deputy, Bill Gunn. A relatively quiet member, Warner had been nine years in the Parliament and was one of the longest serving MPs on the Nationals' side with uninterrupted service. Don Neal and Ted Row (the latter of whom would become Chairman of Committees) both had slightly longer service and Gil Alison and Bill Kaus had begun their parliamentary careers before Warner, but Alison had lost his seat in 1977 and regained it in 1983 while Kaus had swapped parties before the 1983 election. Tony Elliott had service equal to Warner but was overlooked for the post, even though he had been a minister for three years.

Bjelke-Petersen gave a very curt, five-sentence speech that was intended to support Warner, noting merely that he had represented his electorate since 1974 and served on a procedural committee of the Parliament - the Privileges Committee - and had 'demonstrated his high regard for the institution of Parliament and all it stands for' (QPD 1983:vol. 292, p. 4). Gunn supported the nomination with an almost identical set of words, adding that Warner had also served as a pilot in the Royal Australian Air Force (RAAF). Efficiency of effort was apparently the watchword of the new Parliament.

The new Liberal leader, the recycled Sir William Knox (inheriting the post after Terry White had resigned following the massive defeat inflicted on the Liberals), chose to nominate Colin Miller for Speaker because of his previous experience as Chairman of Committees, a move seconded by Bill Lickiss. Labor decided to forgo its right to nominate a candidate from its own ranks, preferring instead to back Miller for the role. Wright made a lengthy speech complaining about the political situation, about the Premier's treatment of the Parliament gagging 
debate and avoiding scrutiny and lamenting that the Parliament had met for only 14 days and 10 minutes in almost a year. He labelled the Parliament a farce. Casey followed him, accusing Claude Wharton of reneging on agreements to improve Standing Orders and claiming the Nationals had deliberately misled the Liberal reformers into thinking reforms were under way when in fact they had no intention of going ahead with them. Casey said, with some feeling, 'those Liberal members were like mushrooms; they were deliberately kept in the dark' (QPD 1983:vol. 292, p. 14). A number of contributors to the debate complimented the former Speaker, Sel Muller, on doing a good job as Speaker despite the difficult sessions over which he presided.

After a relatively short debate, the House confirmed Warner's appointment as Speaker by a vote of 42 to 39 with one abstention (probably Lindsay Hartwig). When Ted Row was nominated as Chairman of Committees, the Liberal leader complained that convention dictated Colin Miller from the Liberals should be preferred, but was reminded by Ivan Gibbs that technically the Liberals were not now a recognised party in the Assembly (that is, they had too few members, with just six sitting MLAs). Knox was reminded that these were new times with new conventions applying or, as journalist Quentin Dempster put it a couple of days later in the Telegraph, the 'Hayseeds' were able to 'stack the odds' ( $Q P D$ 1983:vol. 292, p. 40).

Within weeks of the Parliament sitting, however, Warner was having trouble imposing his authority on the House and maintaining order. His immediate deputy, Row, also had difficulty at times keeping order when he was chairing. Minor points of order would blow up out of all proportion and lead to almighty stoushes. Both their rulings were frequently challenged. One such incident occurred in December 1983 when Keith Wright moved a motion of dissent against the Speaker's ruling given on 15 December. Wright was complaining that Wayne Goss had asked for 'untrue' and 'offensive' statements made by the Justice Minister, Nev Harper, to be withdrawn, but the Speaker had refused to accept the point of order. After many accusations and points of order had been thrown across the Chamber, and threats made by the Speaker to 'name' the Labor member, Goss was permitted to make a short personal statement clarifying his position, but Harper was not asked to withdraw. Two sitting days later, the rancorous dissent motion against the Speaker's ruling ranged far and wide over the interpretation and enforcement of Standing Orders. The dispute lasted for more than an hour before the motion was ultimately lost; but the incident indicated that the lawyers were beginning to exert their influence on the proceedings of the Chamber. Goss, once referred to as the 'self-proclaimed new turk' (by Sandy McPhie), was fast earning a reputation for his tenacity and his ability to get under the skins of the Nationals' frontbench, but also for his nitpicking focus. 
Almost as a footnote to the proceedings, Labor announced its own officials: Keith Wright remained Leader of the Opposition, with Nev Warburton his deputy, Tom Burns the whip, Les Yewdale as secretary and Brian Davis as the Leader of Opposition Business. Within a year, there would be a change in Labor's leadership team with the departure of Wright from state politics. Rather than risk a spill, the Caucus promoted all the existing incumbents up one position, making Warburton leader from 29 August 1984 and bringing in Bill Prest as Leader of Opposition Business in the House. At the outset of the new Parliament, the Liberals confirmed Knox was their new leader, with Lickiss as his deputy and Angus Innes as whip.

\section{Surviving financially in the 'show that goes on here'}

For the first time in his parliamentary career, Bjelke-Petersen presented the combined budget documents to the Parliament for approval. On 24 November, he introduced an appropriation bill seeking an authorisation of $\$ 2.345$ billion supply to last into January 1984 so that the government did not run out of money before the main budget authorisation was secured. He vehemently denied that the state was running out of money (despite coming very close to doing so because money would have run out by mid-December according to the former Treasurer, Llew Edwards, and even earlier, according to Treasury). Moreover, he lambasted the Leader of the Opposition for having the temerity to suggest during the election campaign that the state was running out of money! He claimed such statements were a form of 'outright deceit' even though he was moving the emergency supply appropriation as he spoke (QPD 1983:vol. 292, p. 78). The Opposition Leader, Keith Wright, denied Labor had used scare tactics in the campaign, stating that the government was spending $\$ 340$ million a month and fast running out of funds. He claimed that there was 'talk around the Chamber that this Appropriation Bill had to go through today' (QPD 1983:vol. 292, p. 115). The bill was passed on the voices about $10.30 \mathrm{pm}$ that same day. After the passage of this temporary measure, the full state budget was brought down on 1 December 1983. The main budget introduced no tax increases, but provided for a range of tax concessions especially in relation to stamp duties on business transactions and stock exchange transfers. Expenditure rose by 15.5 per cent (to $\$ 4.237$ billion) even though the Premier projected a balanced outcome. Despite the government claiming it had sufficient funds, it kept the Parliament sitting until 22 December (very late in the year) to pass the budget bills. 
During these debates, the Liberal Party confirmed through one of its senior members, Norm Lee, that it would support the Nationals' government at all times on money matters 'unless it did something completely silly' (QPD 1983:vol. 292, p. 107). As an experienced minister, Lee also commented that he personally thought it was inadvisable for the Premier to attempt to do both jobs adequately:

I do not envy the Premier, who is now both Premier and Treasurer. What that amounts to is this: he, as Premier, has to look in a mirror and say, 'How do you do, Mr Treasurer?' and that he has to walk over to the other side of the room and, as Treasurer, say, 'How do you do, Mr Premier?' He has a very difficult task ahead of him. No longer can he blame the Treasurer. (QPD 1983:vol. 292, p. 734)

After the success of the Commonwealth Games, the executive was planning a further public spectacle. The government heard that hosting the biennial World Expo event (awarded by the International Exposition Committee) was a possibility and that 1988 was available for a bid. The state government began planning to host Expo 88, seeking the Federal Government's support (which was achieved under duplicitous circumstances). Prime Minister, Malcolm Fraser, was opposed to providing federal assistance, but while he was absent, the Premier convinced the acting Prime Minister, Doug Anthony (a fellow National), to give Commonwealth approval. Even at this stage, however, there was some misunderstanding in Brisbane about what the Expo event involved, with some senior Nationals and their business associates believing it was a commercial trade fair at which they could sell goods and promote local produce. It was only later after approvals had been given that the government realised Expo was a promotional and cultural event that prohibited sales of goods and for which only an admission charge was acceptable (with a theme of 'Leisure in the Age of Technology'). Labor questioned the Premier and Treasurer's 'often repeated assurances that the 1988 Expo will not cost Queenslanders one cent and that the Expo will be financed from admission fees, rentals and the sales of assets at an enhanced value' (Jim Fouras, in QPD 1983:vol. 292, p. 139). The initial planning envisaged that a private company would stage Expo 88 and cover its costs or even make a profit. The Premier gave public assurances that the event would be fully self-funded and claimed that the opposition had been briefed in August 1983 and had raised no objections. He did not disclose, or might not have fully known then, that Expo 88 would break even only by a substantial transfer of valuable land (about $\$ 200$ million) from the Crown to the statutory authority responsible for the event (see Chapter 16). Enabling legislation, the Expo '88 Bill, was introduced on 21 December 1983, establishing the Brisbane Exposition and South Bank Redevelopment Authority and declaring the chosen site of Southbank, which was described as a 'rundown, unattractive area'. The Premier also confirmed in the Parliament that Llew Edwards was engaged 
to assist in making the official application to the Paris-based International Exposition Committee and to help with initial preparations, undertaking 'to do the work for nothing' (QPD 1983:vol. 292, p. 499).

By early 1984, the opposition, sensing that Bjelke-Petersen was not entirely comfortable with Treasury matters, began to refer to him as the 'Premier-cumTreasurer' who avoided giving explanations and instead used his time speaking to money bills to wage political attacks. It was clear that on financial and economic matters, Bjelke-Petersen would stick to a tight script-most likely written by the head of Treasury, Leo Hielscher-and would often table more detailed budgetary documentation.

Many members gave their maiden speeches in the short sitting towards the end of 1983. For the first time, two women members moved and seconded the Address-in-Reply debate to the Governor's speech. Yvonne Chapman (NP, Pine Rivers) lavishly praised the National Party's record of achievements, stressed the abolition of many taxes and avoidance of others, but presented a wish list of new initiatives her electorate needed. Leisha Harvey (NP, Greenslopes) cited Thomas Jefferson as saying that the 'only legitimate object of good government' was 'the care of human life and happiness', which she took narrowly to mean freedom of choice and the security of private property. They both spoke of family, freedom and individual enterprise, but also of balancing community needs and social opportunities. Anne Warner (ALP, Kurilpa), one of three female new members (the first time three had been elected in one election), could not resist a few cheap shots under her own heading of 'more general matters'. She argued that, with Bob Hawke having championed the idea of consensus through the Economic Summit, in the present 'national mood of consensus, I felt it was necessary to recognise that there should be some common ground between myself and others, including my political opponents and even the Premier'. She reflected 'after much soul-searching' that 'we are both members of minority groups. I am one of three female members of this House, and the Premier - assuming that he voted for his party - is one of a 38 percent minority who did so' (QPD 1983:vol. 292 , p. 377). Warner also thanked her campaign directors, one of whom was Di Fingleton, later to head the Magistrate's Court and subsequently feature as the defendant in a prominent trial.

Keith De Lacy (ALP, Cairns) said he was honoured to be elected to the illustrious Chamber and that he felt 'a little intimidated, to be participating in the show that goes on here' (QPD 1983:vol. 292, p. 154). He sounded a little overwhelmed by the occasion but quickly adjusted to the cut and thrust of parliamentary politics. Brian Cahill (NP, Aspley), also giving his maiden speech, spoke of having an 'overwhelming faith and belief in Almighty God and all His powers', claiming 'it was our Lord who said "Without Me you can do nothing"'. He also warned that the ALP 'will not impose their agnosticism on Queensland-certainly not 
as long as this Government guides our destinies' (QPD 1983:vol. 292, p. 161). David Hamill stated that the Queensland Assembly met infrequently and was 'not one of the most hard-working Chambers in Australia', before turning to the issues of unemployment, electricity and mining. He finished with an attack on Austin and Lane, calling them body-snatchers who were 'selling their own bodies for a reasonable sum to the National party...[in] one of the most cynical political exercises in the history of our State' (QPD 1983:vol. 292, pp. 165, 169). Russell Cooper (NP, Roma) revelled in the historic circumstance of the Nationals governing in their own right and committed himself to working in the footsteps of his predecessor, Ken Tomkins, who had campaigned strenuously for the abolition of death duties (apparently many members were keen to associate themselves with this reform, especially in the bush). Pat Comben's (ALP, Windsor) maiden speech celebrated Queensland's long list of democratic reforms dating from the 1890s (Labor governments, adult franchise, one vote, one value in 1910, compulsory voting [!] and the abolition of the 'useless Upper House') before he went on to lament the depletion of animal and plant species. The fundamentalist Christian Ian Henderson, who had captured Mount Gravatt for the Nationals, mentioned all the Ian Hendersons he knew or had been mistaken for, including a snooker champion and a pastor of religion, before confessing his admiration for Vince Lester on his campaign to get toilet doors to open outwards. He also would later complain that 'in this Assembly, we hear from Marxists, feminists, socialists, pragmatists, capitalists, and so on; rarely do we hear the Christian voice in this political forum' (QPD 1984:vol. 295, p. 436).

Wayne Goss (ALP, Salisbury) spoke of prison reform, hospitals, high schools, economic planning and 'a more just, fair society'. He thought that the words of US actor James Cagney best described the present government's mentality towards its citizens: 'steal a buck and they put you in jail, steal a million and they call you sir!' (QPD 1983:vol. 292, p. 219). Kev Lingard (NP, Fassifern) spoke of growth, inspiration, the family, education, the importance of discipline, welfare dependency, tranquillity and development strains, and the responsibilities of government to govern. The maverick Earle Bailey, the former television Lotto presenter and grandson of Australian Prime Minister Earle Page, who served only one term (1983-86), fumed about local landlords who had become 'avaricious vultures' preying on small businesses. He too favoured 'freedom of the individual' (QPD 1983:vol. 292, p. 356), advocated a flat tax scheme, an end to excessive taxation and government borrowing and voluntary voting, complained about the impact of high electricity charges on pensioners and the threatened closure of the Toowong Library.

Many other members (such as Bill Price, Mark Stoneman, Ken McElligott, Clem Campbell, Tom Veivers and Brian Littleproud) used their opening addresses to extol the virtues of their local electorates while seeking accelerated development. 
Generally the initial addresses from the new members were of a higher quality and were more substantial than those of their immediate predecessors (and also a little more politically acrimonious). Most were not particularly memorable, with the possible exception of Goss's carefully crafted broadside. Interestingly, most maiden speeches were interrupted by interjections from across the Chambercontrary to convention - and the Speaker constantly had to remind members of the accepted practice that maiden speeches were heard in silence and without interruption. Such was the atmosphere.

\section{The sudden deaths of two sitting Labor members}

The most significant aspect of the Address-in-Reply debate conducted in November 1983 was that Dr Denis Murphy (ALP, Stafford) was unable to make his maiden speech due to severe ill health. Murphy had been diagnosed with cancer and was hospitalised during the last weeks of the campaign, although his illness had been kept secret until it was no longer possible to do so. He attended the Assembly on 22 November to be sworn in after he won his Brisbane seat. He made another appearance on 27 March 1984 specially to attend the condolence motion for his mate, Kev Hooper, who had died suddenly on 9 March 1984, shortly after being re-elected. Murphy had attended with the intention of speaking to the motion of condolence but did not take part in the speeches. He attended for the third and last time on 12 April, for part of the proceedings, the last day of the first session of the forty-fourth Parliament. He did not speak formally in the Parliament and took part in only three votes: one for the Speaker at the opening of the new Parliament; a second time opposing the suspension of a Labor member moved by the Premier; and a third with the opposition over the Racing and Betting Act. Despite Murphy's obvious illness, the government refused to 'pair' him for the period of his absences. He died on 21 June 1984, aged just forty-seven. The condolence speeches given by 10 members were effusive in their appreciation of his scholarship and political activism. Peter Beattie (1990:61, 65) later described Murphy as the 'noblest of us all', adding that it was 'ironic indeed that someone who had probably read more parliamentary speeches than any other member would be denied the chance to contribute his own thoughts for permanent enshrinement in Hansard'.

Murphy's death followed by just three months the sudden and quite unexpected death of Labor's forthright advocate Kev Hooper. He died after surgery on 9 March 1984. Many members were clearly distressed at the unexpected news. Keith Wright read from a letter he had received from the family, which spoke of their shock but also mentioned his prodigious work habits as a local member. 
The Premier described Hooper as a 'man whose outspoken ways placed him in the public spotlight on very many occasions', who had a 'colourful turn of phrase', noting: 'he had a strong constitution and a sense of humour, qualities that serve politicians well in the cut and thrust of debate and the life we share in this House' (QPD 1984:vol. 294, p. 2006). Tom Burns recalled 'comrade' Hooper's last day in the Parliament (6 March, when he asked two questions - one on the $\mathrm{TAB}$ and Sir Edward Lyons and the other on the police - and took part in an early division). He said:

On the last day he was here I said to him, 'Nick off, Hoop, and make certain you look after yourself. Don't come back until you are OK'. He said to me, 'Put me down for the hawkers, pawnbrokers and matters of public interest debates next week'. I bet that someone on the government side was going to get it today when the Hawkers Bill and the Pawnbrokers Act Amendment Bill were being debated. (QPD 1984:vol. 294, p. 2013)

David Hamill spoke of Hooper's 'well directed barbs' (or his 'loud, whispered interjections'), saying 'although one could say that Kevin sometimes used a howitzer when a pea-shooter may have been the only weapon necessary, his sorties against injustice and corruption endeared him to the hearts of the ordinary people of Queensland' (QPD 1984:vol. 294, p. 2011). Beattie recalled Hooper's funeral was well attended with politicians from all parties present. He even mentioned that Russ Hinze attended having said he would 'miss the old bugger'. Beattie (1990:64) described Hooper as 'one of the most under-rated men ever to sit in the Queensland parliament'. Many of Hooper's frequent allegations of official police corruption and official misconduct would later turn out to be proved correct.

The Governor's second opening speech to the Parliament (in August 1984) attracted some controversy because the Governor engaged in some decidedly partisan comments, such as regretting the downgrading of the monarchy, the change in the national anthem without reference to the people, proposals to change the national flag, complaints about the Commonwealth Government attempting to change state responsibilities without recourse to Section 128 of the Constitution and changes to the Citizen Act removing reference to the monarchy. Parts of the address read like a promotional campaign speech. Keith Wright, in his penultimate speech in the Assembly, criticised the politicisation of the Governor's address, labelling it a 'political document' full of 'platitudes' and 'undiluted Government propaganda which bears little resemblance to the truth' (QPD 1984:vol. 295, pp. 156-8). The Deputy Speaker, Ted Row, continually reminded him that he was not permitted to make imputations against the 
Crown or a representative of the Crown such as the Governor', to which Wright continually responded that if the Governor's speech contained propaganda he was entitled to challenge it without attacking the Governor personally.

Amid much controversy and some public demonstrations by staff, students and members of the public, the University of Queensland awarded the Premier an honorary doctorate in 1986. University staff placed a full-page open letter of protest in the Courier-Mail objecting to the University Senate's decision. One of Queensland's most celebrated poets, Judith Wright, returned her own honorary doctorate as a personal protest. In the Parliament, Hamill (a former university staff member) claimed the nomination was railroaded through the University Senate and that the honorary degrees committee did not recommend the award. He claimed:

[T] he Premier of Queensland does not exemplify any of the lofty ideals associated with the University. The only reason for the recommendation being made by the Senate was...that the Premiers of Queensland, at the time of the [university's] 25th anniversary and the 50th anniversary, received an honorary Doctorate of Laws. The Senate could think of no reason other than tradition to give the Premier a Doctorate of Laws. (QPD 1985:vol. 298, p. 4820)

\section{Four by-elections in quick succession}

Four by-elections were required in 1984-85- three due to the deaths of sitting members and one to a resignation.

Hooper's seat of Archerfield on the southern side of Brisbane was one of Labor's safest seats. Despite the state secretary, Peter Beattie, considering running for the seat, the ALP preselected the secretary of the local Inala branch, Henry Palaszczuk, after an internal tussle. Palaszczuk was comfortably elected at the 19 May 1984 poll, although a swing away from Labor of more than 10 per cent was recorded. Stafford was a more difficult contest. Terry Gygar had finished third to Denis Murphy in the 1983 poll, with Murphy beating the Nationals' Pat Blake by 39 votes. Labor nominated a relatively high-profile candidate, Janine Walker, who was a prominent ABC Radio current affairs presenter in Brisbane. The Nationals ran with Pat Blake again and the Liberals renominated their defeated member, Terry Gygar. At the by-election held on 4 August 1984, Gygar recaptured his old seat in a 'very tight finish'. He outpolled the Nationals' candidate by just 39 votes to finish second (with the Liberals on 27.5 per cent to the Nationals on 27.3 per cent) but then took the seat by 8061 votes to 6907 on a two-party preferred basis (indeed, the Nationals' preferences to the Liberals were very disciplined, with only 3.6 per cent drifting away to Labor). As one 
commentator stated at the time, the 'failure by Labor to hold one of its own city seats in a by-election situation [was] particularly damaging to the party's stocks in terms of maintaining political momentum in the lead-up to the 1986 poll' (see AJPH 1985:vol. 31, no. 1, p. 305). One consequence of this by-election was that Colin Miller resigned from the Liberal Party, declaring himself an 'independent Liberal', because the party had renominated Gygar for the seat - a person he regarded as one of the chief culprits behind the Coalition collapse in 1983.

The Leader of the Opposition, Keith Wright, announced in late August 1984 that he was standing down from the position and would leave the Parliament later in the year to contest the federal seat of Capricornia at the next federal election (called early by Prime Minister Hawke for 1 December 1984). Poor polling and the loss of Stafford in the earlier by-election had finally convinced Wright to go. Nev Warburton (ALP, Sandgate) replaced him as Leader of the Opposition on 29 August 1984, becoming the sixth leader to face Bjelke-Petersen and the ninth since Labor was consigned to the opposition benches in 1957. In Wright's valedictory speech, he acknowledged the positive influence of Jack Egerton and Tom Burns on his political career and claimed his major achievements were in the areas of consumer and citizen rights. Wright's resignation from the State Parliament (eventually occurring on 5 November) necessitated a further byelection, for the seat of Rockhampton, which was duly held on 16 February 1985 against the backdrop of a state-wide electricity crisis. Although the Nationals ran a creditable campaign (which the Liberals did not contest), Labor's Paul Braddy, a local solicitor, retained the seat comfortably in the two-horse race, with 58.98 per cent of the total vote to 41.02. Braddy's election helped settle Warburton's leadership at a volatile time, while adding to the talent pool Labor was gradually building in the Parliament.

Finally, a fourth by-election proved necessary due to a tragic fatal tractor accident involving the Minister for Water Resources, John Goleby, in September 1985. The by-election for the seat of Redlands presented the government with a challenge to replace the well-known and popular local member and presented Labor with the opportunity of capturing a seat without an incumbent. Seven candidates stood for election on 2 November 1985. The Nationals did not really have an obvious local candidate, so instead chose a local solicitor, Paul Clauson, who joined the party only four days before the preselection was held. He was not a political activist and was apparently chosen because of his television potentiality and his legal background. The Liberals went for a big name, selecting Max Bolte, a local garden centre businessman who was related to the former Victorian Premier Sir Henry Bolte. Labor's preselection was more problematic, with a fiercely fought three-way struggle between Con Sciacca (who had already lost twice before), the state secretary, Peter Beattie, and Ron Pokarier. Sciacca had strong local-branch support and some support 
among the party's central executive (the electoral college). Beattie had a high profile in the media but lukewarm support in the local branches and electoral college. He managed to attract only one-third of the local plebiscite votes and did not attract a significant vote from the central college to beat Sciacca. The Nationals' campaign in the by-election was one of pork-barrelling-promising the electorate a new hospital, nursing home, more police and a rail link, but threatening that these would not be forthcoming if the electorate did not vote National. The Labor and Liberal campaigns again focused on accountability and attacks on the government (although Labor's very unpleasant and public, messy preselection battle overshadowed the poll). In the final vote, the novice Paul Clauson won by the narrow margin of 213 votes on a two-party preferred basis, with Sciacca capturing 43.28 per cent of the primary vote to Clauson's 37.21 per cent and Bolte's poor 14.26 per cent. The final result was close only because more than 25 per cent of Bolte's preferences drifted to the Labor candidate. After Labor's loss in the by-election, Terry Gygar said 'poor old Warbie; he is a great guy but he has not got it' (QPD 1985:vol. 300, p. 2306). Warburton's standing in the opinion polls fell further after the by-election result, causing much comment in the Assembly.

\section{The Parliament as the 'laughing stock of Australia' - or those in glass houses who always throw stones}

Parliament is essentially an adversarial institution, but at times it could work smoothly with some camaraderie shown by political opponents. Such was not the case during the 1983-86 Parliament. Relations between the three party blocks and the 89 members of the Assembly were vitriolic and spiteful. Labor members were particularly angry and vocal, picking on Lane and to some extent Austin, calling them 'scabs', 'defectors' and 'grubs' for siding with the Nationals and calling other Liberals 'invertebrates'. Labor's more forceful attackers included Keith Wright, Bob Gibbs, Tom Burns, Terry Mackenroth, Nev Warburton and increasingly Wayne Goss, Pat Comben, Brian Davis and occasionally David Hamill. Indeed, Hamill was suspended for a week for screaming 'Sieg heil! Sieg heil!' at the Premier (QPD 1985:vol. 298, p. 4130), while Warburton claimed the government's behaviour during the forty-fourth Parliament was 'atrocious', stumbling 'from one crisis to another' (QPD 1985:vol. 299, p. 19). Government ministers would hit back with their own brand of invective or abuse, or with claims that the Opposition Leader's job was being eyed by any number of rivals. Labor members were accused of being soft on drugs, sympathetic to petty criminals and constantly running political vendettas against the police. Some Labor members were accused of being 'drunks', 'louts' and 'rubbish'. The 
government's main protagonists were often Don Lane, Russ Hinze, Bill Gunn and Brian Austin with various backbenchers making occasional contributions, such as Rob Borbidge, Tony Elliott, Kev Lingard or Sandy McPhie, who frequently taunted Labor and called Warburton 'the quiet and ineffectual union troublemaker' (QPD 1984:vol. 295, p. 398). Lane in particular liked goading Goss, whom he described as a 'trick lawyer' who was always 'attempting to make a cute legalistic point' (QPD 1984:vol. 294, p. 2030). Government ministers would also continually make interjections and call points of order when opposition spokespeople were speaking so that they ran out of their allotted time for speaking. The Liberals were generally a little more civil, but some of the more calming influence they brought to the Chamber had dissipated as their numbers had declined.

Arguably by the 1980s, the so-called 'gentlemanly' breed of parliamentarians who had sat through the 1960s had all but disappeared and given way to a rougher, more street-smart breed of professional politicians. The Parliament was rapidly developing into a continuing gladiatorial brawl, with members looking for any excuse to bring on a fight. The Speaker warned members constantly about their behaviour and complained that there was often too much commotion and noise made in the Chamber to hear the speeches being made. Members were repeatedly asked to withdraw remarks the other side found offensive or unparliamentary. Allegations that other members were 'lying' were frequently made, requiring a withdrawal because 'lie' was considered unparliamentary, whereas 'untruth', 'mendacious' and 'deceitful' were accepted.

A typical incident occurred in April 1984. Labor's Ed Casey was complaining of the 'great racket' of converting leasehold land into freehold land and had accused the Premier of manipulating land deals and of using public funds to service his own family property. He said the Premier was 'the recipient of one of the first condominiums built on [Hamilton] Island' (QPD 1984:vol. 294, p. 2318). The next day, the Premier issued a 'personal explanation' denying as 'blatantly untrue' that he owned any condominiums, then used his 'explanation' to accuse Casey of having taken bribes from the poker machine industry and having 'robbed the public purse' (QPD 1984:vol. 294, p. 2398). Keeping the saga going, Casey, the next day, then reported:

Yesterday in this Parliament the Premier used the guise of a personal explanation to make scurrilous accusations against me, the content of which (mainly because of the uproar which existed in the Chamber at the time) I only became aware of through this morning's media. Let me assure this House that his allegations are completely untrue and are clouded by the deep personal hatred that he has displayed towards me since I first entered this Chamber. If I had ever, as alleged by him, 'thieved Government moneys', he failed in his duty as leader of the 
Government to prosecute me; hence he is equally guilty of his own charges. People who live in glass houses should never throw stones. (QPD 1984:vol. 294, p. 2490)

Members began to make far more 'personal explanations', jumping up to seek a correction to slurs or something another member had said of them (Goss frequently availed himself of such statements). For a while, these 'personal explanations' were something of a bandwagon. Supposedly these explanations were about correcting the record, but they were used to fling back the mud or make counter-allegations. On a matter of privilege, Mike Ahern complained that both Wright and Goss had made 'personal explanations' that had gone beyond the 'normal', with the intention of seeking to prosecute quarrels with other members in such explanations. He pointed out, while asking for the Speaker's clarification, that personal explanations should not seek to become 'speeches to political matters' (QPD 1984:vol. 294, p. 2513). It was not uncommon for personal explanations to lead to 10 minutes of bickering across the floor, with the various protagonists taking these opportunities to niggle each other while ostensibly defending their good names. On one occasion, Warburton even went so far as to move a want-of-confidence motion in the government purely because the government had used its numbers to refuse to allow Casey to make a personal explanation!

The government began winding back the number of sitting days as a political tactic. The overall number of sitting days dropped in the 1983-86 Parliament to just 143 days (or 46 a year), down from the previous level of between 160 and 200 days over the three sessions. In the 1987-89 Parliament, sitting days were reduced even further, falling to a mere 131 days (or just 43 days a year). Fewer sitting days provided fewer opportunities for the opposition to enjoy parliamentary privilege and receive media coverage under the protection of the Parliament. They also meant, however, that in order to pass legislation, long sitting days were typical especially at the end of sessions when the government wanted to process legislation before a break. For instance, in two sitting weeks in April 1984, the Parliament went well past midnight three times in short succession. The 3 April sitting ended at 12.58 am on 4 April; the 10 April sitting ran until 3.59 am on 11 April; and then the 12 April sitting day finished at 8.43 am the next day, having sat all night. Labor complained bitterly about the lengthy recesses of parliament, within which it argued the executive ran the state without any parliamentary scrutiny. Labor members also complained that ministers were filling question time with lengthy pre-prepared answers to questions on notice, which was a tactic of filibustering designed to 'totally eat up Question Time' (QPD 1984:vol. 295, p. 258). They resented, too, that supplementary questions had been abolished under sessional orders. 
Moreover, after a few relatively quieter parliaments, a large number of members were forced to withdraw (a day suspension) or were suspended in 1983-86. During the three-year period, Labor members on 22 separate occasions were ordered to withdraw from the Chamber - some, such as Bob Gibbs and Bill Prest, on many occasions. This level of expulsions had not been seen since the early 1970s. Further, another six Labor members were suspended for up to 14 days in this Parliament, with Gibbs suspended twice. When the Premier moved to suspend Tom Burns for five days, Burns responded with, 'why don't you give me five months you old dill'. The Premier responded with, 'You'll get more if you keep going', to which Burns replied, 'You haven't got the guts to do it.' As the House moved to a division on the expulsion, Burns said: 'President Marcos ought to come over here to find out how to run his Parliament. You would be able to teach Marcos a few things. This is what they call the Marcos of Queensland rules' (QPD 1986:vol. 302, p. 3600). After calling the Speaker a 'government stooge', Burns was duly suspended.

The well-known public administration academic Dr Ken Wiltshire claimed that the Queensland Parliament had become 'the laughing stock of Australia'. His comment was echoed in the Chamber by Keith De Lacy (QPD 1984:vol. 295, p. 209). Perhaps Bjelke-Petersen took heed as, in one of the lighter moments of this Parliament, the Premier was asked whether he had seen the Gillies Report (a satirical political comedy show on ABC Television that regularly ran impersonations of the Premier). He replied with a straight face: 'Yes I do have a copy, but I have not had time to read it yet.'

The opposition began to respond to the government's tight control of the Assembly by walking out of the Chamber en masse on different occasions (for example, after midnight on 20 March 1985 and again on 17 October 1985), usually in protest over the government's industrial relations policies or inflammatory comments by the Premier. Labor was particularly incensed over the government's tough stance in the SEQEB electricity strike (see below). Other sources of concern to the opposition were procedural; it argued that the government was not adhering to its procedural policy of now allowing two full days to study proposed bills before they were debated. A number of bills in 1984 were introduced at the second reading stage and debated the next day with the government suspending Standing Orders to enable it to do that. The government's defence was that the Parliament was 'extremely busy', citing that during 34 sitting days 60 pieces of legislation had been enacted (QPD 1984:vol. 294, p. 2767).

The government also complained on occasions that the behaviour of the opposition was deteriorating. The Premier complained about the opposition's conduct, saying that Labor members asked questions 'but they will not allow Ministers to answer. They subject Ministers to a continual barrage of 
interjections' (QPD 1984:vol. 296, p. 2487). Labor's anger was motivated by its contention that ministers were refusing to answer questions; although the Speaker, John Warner, ruled that 'the Chair has no control over the contents of an answer given by a Minister, provided it conforms to the rules...an answer to a question cannot be insisted upon if a Minister refuses to answer' (QPD 1984:vol. 296, p. 2487).

\section{Budgets and arguments over taxation}

The 1984/85 state budget committed total outlays of $\$ 4.645$ billion and was described by the Premier as a 'capital works and employment budget' (especially as unemployment in Queensland was about 11 per cent). As was common in this era, the budget proposed no increase in state taxation, but committed an additional $\$ 600$ million to capital works (much of which was borrowed under relaxed Loans Council requirements). Crucially, the budget provided for an additional 1155 school teachers, 100 police, 461 hospital staff and '12,000 man years of additional employment directly and 40,000 man years in employment totally' (QPD 1984:vol. 295, p. 768). Education spending rose by 15.7 per cent to $\$ 1.072$ billion (or about one-quarter of the overall budget); health rose to $\$ 691$ million or 16.2 per cent, while the rest of the budget contained many smaller assistance programs and capital spending across departments. The Premier publicly thanked Leo Hielscher, as Under Treasurer, for his sterling efforts in producing the most recent budget. Unlike Sir Gordon Chalk (and earlier Treasurers), however, who would sit through most of the budget debates, Bjelke-Petersen departed from tradition and absented himself from the Chamber for most of the debate.

Labor was not impressed with the budget, labelling it 'a document of deception', 'a political stunt' and the 'greatest con trick that has ever been perpetrated'terms its members had used to categorise previous ones too! Warburton accused the Premier of attempting to roll three years of capital spending into one year to give the impression that much infrastructural investment was occurring, when he claimed that, of the supposed $\$ 600$ million committed, only $\$ 55$ million was in fact committed in the present budget year ( $Q P D$ 1984:vol. 295, pp. 804-5). Warburton argued that the budget was not balanced because a 'large proportion of government activity has to be funded through borrowings' (QPD 1984:vol. 295 , pp. 812-13). For whatever reason, whether it was that the Premier was involved, the 'spin' was excessive or members were better educated and prepared, this budget attracted much more focused debate on the real financial information than previous ones. The budget debates set a new standard of financial scrutiny that was to be continued in the years ahead. 
If the government was ever happy to spruik its low-tax credentials, not all its supporters were equally so moved. Sir Roderick Procter, a National Party trustee, publicly attacked the government over its excessive coal freight charges and proposed 20 per cent casino tax, claiming these were the highest rates in the world. He added, 'so much for our so-called low-tax State' (QPD 1985:vol. 299, p. 20).

The 1985/86 budget was again framed in difficult circumstances, with the Premier accusing the federal Hawke government of reining in its own deficits by clawing funds back from the states. He thought Queensland had been denied 'many millions of dollars to which it is clearly entitled' (QPD 1985:vol. 299, p. 793). In total, the budget committed more than $\$ 5.048$ billion in spending - an increase of 10 per cent from the previous budget. The balanced budget continued the capital works injections, spread across education, water infrastructure, hospitals, roads and public buildings. Spending on education amounted to $\$ 1.175$ billion and health to almost $\$ 1$ billion. Together these two policy areas amounted to 40 per cent of outlays. Transport received $\$ 973$ million, and lands, forestry and police another $\$ 271$ million. Despite the tough economic times, the Queensland government was expanding spending at a rapid pace, despite the opposition criticising almost every area of spending as inadequate.

\section{The vexatious SEQEB dispute: 'do not test this government's patience and resilience too far...'}

The electricity industry came into prominence in 1984-85, triggering a major political dispute between the government and the trade union movement. Electricity in south-east Queensland had been consolidated under a single authority or public enterprise: the South-East Queensland Electricity Board (SEQEB) (previously Brisbane City Council had powered Brisbane). By the mid1980s, however, the industry was facing commercial pressures, growth strains and industrial unrest.

The government had talked tough on industrial relations for years and was waiting for a chance to 'take on' some of the Labor-aligned unions. Its chance came to confront the powerful Electricity Trades Union (ETU) when the government refused to agree to an increased wage claim from the union and the SEQEB electricians chose to strike and walk off the job, leading to two weeks of power blackouts. Bjelke-Petersen was anxious to 'keep the lights on' and had some opinion-poll support for his stance. He sought to remove the job security of the workers if they continued to strike. The government proclaimed a state of emergency on 7 February 1985 to address the threat to the supply of electricity 
and then sacked 1100 union electricians and linesmen. The government then replaced the unionised electricians with non-union private contractors, on new contracts that outlawed strikes.

A marathon parliamentary debate occurred over the SEQEB dispute, going from 11.36 am on 26 February 1985 to 11.30 pm the same day. It was a ferocious debate, as the government's credibility as a tough negotiator was on the line, while on Labor's side one of its staunchest unions was under a concerted attack from the government. Bjelke-Petersen accused the unions of mounting a campaign of 'industrial thuggery, threats and intimidation', claiming that the 'Parliamentary Annexe and the Executive Building were repeatedly evacuated after the receipt of phone calls alleging that bombs had been placed in them' (QPD 1984:vol. 297, p. 3720).

The government prosecuted its case with a vengeance, producing saturation advertising, although interestingly it did not invoke the Essential Services Act. Rather, the government chose to introduce three related sets of legislative changes: the Industrial (Commercial Practices) Bill, the Electricity (Continuity of Supply) Bill and amendments to the Industrial Conciliation and Arbitration Act - all in early 1985. The government followed these amendments with a new bill: the Electricity Authorities Industrial Causes Bill, which had four main purposes. These were to: 'Make it clear that strikes are illegal, to abolish compulsory unionism for electricity workers, to set up a separate tribunal to hear disputes in this essential industry, and to provide for summary dismissal or suspension where employees disobey the no-strike provision' (QPD 1985:vol. 298, p. 4213).

Labor accused the government of guillotining all four bills through the Assembly. The Continuity of Supply Act was also amended two weeks after it was rushed through the House, to expressly prohibit industrial harassment and give the police wider powers of arrest.

During March 1985, thousands of blackouts and power cuts occurred, exacerbated by big storms and falling trees. The Opposition Leader claimed that the system was at risk of collapse and that much of the infrastructure was either faulty or in need of replacement. The Minister for Energy, Ivan Gibbs, issued a ministerial statement denying the industry was in crisis, but admitting that 2800 blackouts had been registered the previous day. He claimed that most of the homes had power restored within two hours, which he maintained proved 'that the newly appointed SEQEB teams were not inexperienced' (QPD 1985:vol. 298, p. 3826). Disturbances and protests inside Parliament House led the Speaker to order evictions and restrict entry to the public gallery; and on 20 March the Assembly was in lock-down mode, as the doors and gates were locked to prevent protesting unionists from entering the House. Two Labor 
MPs, Terry Mackenroth and Anne Warner, were arrested at demonstrations for breaking assembly laws. When a farmers' demonstration took place outside Parliament House in Canberra about the same time, Ed Casey was most pointed when he said Federal Police did not go 'rushing in, grabbing, bashing, kicking and shoving the people and throwing them into paddy-wagons because they were outside Parliament House' - but in Queensland they did (QPD 1985:vol. 299, p. 63).

Gibbs accused the ALP, the TLC, the Australian Council of Trade Unions (ACTU) and the ETU of using 'guerrilla warfare tactics' and famously threatened:

Let me make it very clear to all members of this House that this Government will not tolerate such behaviour from members of Parliament, members of the Senate [such as George Georges] or any union members, their wives, their families and friends, who try to prevent people going about their lawful business...Let me give fair warning to the members of the Opposition, the Labor Party and unions generally: Do not test this Government's patience and resilience too far or you may well rue the day that you continue to defy the laws of this State. (QPD 1985:vol. 298, pp. 4286-7)

Warner defended her right to protest leading to her arrest and responded to taunts she was associating with 'thugs and criminals' by saying 'yesterday morning I was not associating with thugs and criminals. In fact, the only place in which I do that is, perhaps, here, rather than when I am outside with comrades' (QPD 1985:vol. 298, p. 4829). Voters had their own say, however, and in March Labor suffered a massive defeat - 'one of the biggest landslides ever seen in local government' - on the Gold Coast, leading the Premier to boast that Labor would be devastated in an early poll.

The SEQEB dispute again raised the issue of who was running the state. The government was concerned to end the strike and be seen to be tough on protesters. Labor compared the government actions with the Nazi regime, calling the laws 'Police-State legislation'. When the word 'Nazi' was used, it was sometimes ruled to be offensive and unparliamentary by the Speaker, although the word 'fascist' was acceptable (QPD 1985:vol. 298, p. 3995). For Labor, too, the dispute again raised the issue of the 'unfair assembly laws', civil rights and the legitimacy of political protest.

And, as if the confrontation with unions was not enough in itself, the government conducted a series of raids on so-called abortion clinics in May 1985. The raids were intended to close down the emergent abortion clinics, which the government felt were performing abortions too liberally. Police broke into suspected clinics in Brisbane and Townsville 'looking for foetuses' followed 
by television crews that had been tipped off by the authorities in order to secure maximum media coverage (The Age, 22 May 1985). The Attorney-General, Nev Harper, confirmed that cabinet had decided to close down these 'factories' after receiving a petition from the Right to Life organisation in 1984. Two doctors were charged under the criminal code, while Goss protested that the raids had breached doctor-patient confidentiality. The raids were widely perceived as an attack on the rights of women by conservative men.

\section{A litany of allegations}

During the entire period of 1984-86, the Parliament was treated to a litany of allegations of corruption, kickbacks and suggestions of misconduct. In the months before his death, John Goleby was accused by Terry Mackenroth and Tom Burns of using his ministerial position to remove a Fraud Squad detective investigating a particularly sensitive case (involving the former businessman and now-bankrupt Frank Luton). Goleby had given a press conference in which he stated he had met Luton on only a few occasions, after which he was peppered with opposition questions. Mackenroth claimed that Goleby had met Luton on many occasions and he invited the businessman to his home for discussions. Mackenroth demanded the minister's resignation for misleading the Parliament, which was not forthcoming. Goleby made a ministerial statement on 9 October 1984 objecting to the smear campaign, denying the allegations and claiming that the detective had been transferred more than a month before Goleby had become a cabinet minister, but he admitted that he had spoken to police about the matter. The Labor frontbencher, whom Goleby nicknamed 'Motormouth Muckenroth', continued to pursue the matter, tabling further documents and calling for a complete investigation. It also transpired that Russ Hinze had met Luton, but he claimed in another ministerial statement that he was not aware the fraudster was under investigation.

Further questions of impropriety were raised about Sir Ted Lyons, who was both a National Party trustee and Chairman of the TAB. He was an inveterate gambler, who bet more than $\$ 700000$ in one year, much of it with the TAB. He had also developed a habit of wagering phone bets with the TAB on credit (that is, they were not backed by cheques received by the agency at the time of the bet), which was contrary to the rules. Burns raised allegations in the House about Lyons' inappropriate betting. As Racing Minister, Hinze was asked to investigate, which he did, taking the issue to cabinet. There were many other complex business deals and investments that involved Lyons directly or indirectly during this period (see Fitzgerald 1989:96-103; Whitton 1989:100-3), including with Rothwells Bank and Lindeman Island, and all the while the Premier still retained the services of Lyons as a financial adviser throughout 1984. Concerned 
by Lyons' credit betting and conflicts of interest, the TAB board, meeting in April 1985, voted by seven to three to recommend the minister remove Lyons as chairman. Lyons initially refused to resign and a cabinet decision on his future was deferred. He resigned from the TAB one week after the board's vote.

In August 1985, Goss raised other issues concerning Hinze's political interference and conflict of interest in granting a TAB betting licence to his own pub, the Oxenford Tavern, through his private company Junefair. Goss claimed that the opposition's case was 'overwhelming' and that 'in any other State, in any other Western democracy, it would be enough to bring down the relevant minister and, possibly, the government of the day' (QPD 1985:vol. 299, p. 324). As Hinze tried to ride out the storm, Goss tried to subpoena witness statements on oath from board members. Later, after he had left state politics, Goss recalled that during this episode

I remember one day I was pursuing Russ over an alleged conflict of interest which had arisen. I think I was probably a bit 'suspicious and unfair', but he was the Minister for Racing; he had responsibility for the TAB; he had a tavern at Oxenford the driveway of which the Pacific Highway runs through, and there was a TAB licence to be allocated to Oxenford. It was to go to a newsagent couple, but it was recommended instead to go to the Oxenford Tavern, or adjacent to it. Anyway I was able to produce a document and table it. Russ and I had our respective press conferences and battered each other around the head. I left and walked onto the [parliamentary] veranda out here and I heard a voice call out, 'Hey Gossie'. I turned around and there is Russ lumbering along the veranda. He said, 'Come and have a beer'. This was around 11 o' clock in the morning, which is a little bit early for me, but it seemed like an offer that was too good to refuse. So we wandered into the Strangers' Bar... Anyway, Hinze bought me a beer and he said, 'Listen, why don't you go after some of those other bastards. They are much more corrupt than I $\mathrm{am}^{\prime}$. I did not know at first what to make of this offer but, usually being fairly quick to spot an opportunity, I said, 'Look I will be in that, Russ, but on one condition'. He said, 'What's that?' I said, 'You have got to provide me with the documents'. He just laughed, had another drink of his beer, and on we went. (Goss 1998)

Again, Hinze tried to brazen it out, claiming he did not seek to influence the decision, but refusing to say whether he had attended the meeting at which the decision was made. Eventually, he would have to return the TAB licence due to such pressure, which he did, after the media ran hot on the issue, in late September 1985. 
Occasionally, Liberal members and sometimes even government backbenchers were also motivated to ask questions about alleged corruption, sometimes with a Dorothy-Dixer quality about them. Yvonne Chapman asked Hinze whether taped allegations published in TheAge newspaper by journalist Bob Bottom, which concerned efforts to influence a Queensland Turf Club inquiry into race fixing and involving three Queensland knights, was evidence that Queensland was complacent about organised crime. Hinze named the three knights (Sir Jack Egerton, by then the Deputy Mayor of the Gold Coast, Sir James Killen, a former federal minister, and Sir Edward Williams) but said there was no evidence they were involved in organised crime and praised the police for doing a good job (QPD 1984:vol. 295, pp. 1017-18).

The Police Commissioner, Terry Lewis, was knighted in 1986, at the Premier's behest, becoming the only serving police officer to be so awarded in Australia. At the time he was knighted, however, he was already falling under suspicion by the new Police Minister, Bill Gunn, who had been informed of allegations of Lewis's corruption and who resented the direct line of communication (and influence) Lewis seemed to have with the Premier.

\section{Ensuring the next win: the Electoral Redistribution Bill 1985}

The Nationals were unfettered in the electoral redistribution of 1985 . Previously, the Nationals might have paid only token reference to the Liberal Party's concerns in redistribution exercises, but now the governing party was unencumbered by such concerns. This was an opportunity when the Nationals could design a system precisely to suit their interests and enhance their chances of expanding their urban base by capturing Brisbane electorates.

In 1985, Queensland still did not have an independent electoral commission; rather, cabinet selected specially appointed electoral commissioners for each redistribution. Cabinet could dictate many of the framing parameters of the redistribution, such as the number of seats in the Parliament, and stipulating the number of zones. These parameter settings were not arbitrary, but were carefully calculated to maximise the conservative vote and in the 1985 case the number of National Party seats winnable. Cabinet approved the boundaries of the four zones, leaving the boundaries of individual seats to the commissioners. Regional National members advised on their own country seats, which were then coordinated by Sir Robert Sparkes and David Russell QC while Don Lane was entrusted with maximising the National representation in the south-eastern corner of the state. Lane had worked on earlier redistribution exercises (for the Liberal Party) and, by 1985, boasted that Sparkes regarded him as 'something 
of an expert on such matters for the south-east zone'. Lane recalled that he worked with a small team on the redistribution for about nine months before the Electoral Districts Bill was introduced to the Parliament, meeting in the National Party's 'bunker' - its headquarters in Spring Hill. He also briefed cabinet on the merits of increasing the number of seats from 82 to 89 - four extra for the city and three for the bush (Lane 1993:160; Coaldrake 1989:33).

To constitute the three commissioners, the Premier chose John Andrews, a public servant and Main Roads engineer, Col Pearson, the head of the Justice Department, and Sir Thomas Covacevich, a lawyer from Cairns and a fundraiser for the National Party. Andrews was reportedly 'surprised by the thoroughness of the National Party submission' (Lane 1993:162) and famously told reporters that while the Premier had not sought to influence the outcome, the commissioners were unable to change the distribution of seats between the zones. He claimed that he was just doing his duty under the act, which stipulated the zones and the number of seats that were required in each zone.

The quota for the number of electors per seat in each of the four zones indicated the degree of malapportionment the government insisted on. The metropolitan or south-eastern zone, with 51 seats, had an average enrolment for each seat of 19 357. The provincial cities zone, a series of coastal strips dotted all the way through to Cairns, had 13 seats with a quota of 18149 electors. The country zone was a long hinterland strip of territory, nestled along the coast but extending some 200-400 kilometres inland, and running almost the length of Queensland from Goondiwindi to Mareeba. It was allocated 17 seats each with a quota of 13 131 voters. The final zone, the western and far northern zone, occupied most of the interior landmass of the state and had a quota of just 9186 for each of its eight seats. City seats, therefore, had twice the number of voters as those in the interior. It was a case, in Coaldrake's (1989:39) words, of 'leaving nothing to chance'.

In the Parliament, Nev Warburton acknowledged that 'no matter how legitimate and constructive the Opposition's objections to this legislation may be, we accept the inevitable. It will be forced through' (QPD 1985:vol. 298, p. 5100). Although Labor was not in a position to alter the legislation, Warburton promised his party would establish an independent electoral commission, one quota for the entire state (that is, no weighted zones) and a variance between electorates of only plus or minus 10 per cent. Bill Knox agreed with Warburton, saying that it was 'probably correct for the Leader of the Opposition to say that there is no more important legislation before the House, because it concerns the survival of members of Parliament' (QPD 1985:vol. 298, p. 5111). Both sides of the House attempted to cite the electoral authority Professor Colin Hughes to support their case, with Bjelke-Petersen claiming Hughes had stated the electoral system was not biased, while David Hamill quoted Hughes as giving 
the opinion that Queensland had the second-worst electoral system in Australia (with Western Australia the worst). The Electoral Districts Bill was passed by the Nationals' numerical superiority after midnight with the Liberals voting with Labor to unsuccessfully oppose the legislation. It was also a telling sign of the low importance attached to Indigenous matters that after the electoral bill was passed, in the early hours of the morning, the House was then required to debate the amendments to the Aboriginal and Torres Straits leaseholding legislation (DOGIT provisions).

Later that year, when a series of further corrections and amendments was made to the Electoral Districts Act, due to errors in the initial bill (which were not noticed by government members, including the Deputy Premier, Bill Gunn), Warburton made further claims. He stated:

This electoral legislation was conceived, developed, and honed into its final form by the faceless men at Bjelke-Petersen House under the direction of the National Party's hatchet man, Sir Robert Sparkes. That is where it occurred. This intervention by the National Party organisation is not a case in isolation. In other policy areas the National Party organisation is developing proposed legislation and offering it to Ministers to present to their department, to the Cabinet, and to the Parliament as a fait accompli. To the forefront in this regard-apart from Sir Robert Sparkes - is a person named David Russell. With due respect to the Governor in this State, I point out that that gentleman happens to be the son-in-law of Sir Walter Campbell. Clearly, the National Party likes to keep things in the family. (QPD 1985:vol. 299, p. 330)

The blatant stacking of the 1985 redistribution came in for some direct criticism in the subsequent Fitzgerald Inquiry and was referred to explicitly in the inquiry's report. Fitzgerald argued:

The fairness of the electoral process in Queensland is widely questioned. The concerns which are most often stated focus broadly upon the electoral boundaries, which are seen as distorted in favour of the present Government, so as to allow it to retain power with minority support. Irrespective of the correctness or otherwise of this view, the dissatisfaction which is expressed is magnified by the system under which electoral boundaries are determined. It has not always been obvious that the Electoral Commissioners were independent of the Government. Submissions and other material upon which the Commissioners have proceeded have been secret. The Commissioners did not report to Parliament, but to the Premier. (Fitzgerald 1989:127) 
Mysteriously, the National Party submission to the Electoral Redistribution Commission subsequently went missing and has never reappeared. There were many rumours circulating in Brisbane that the last copy was shredded in the Premier's Department some time in the late 1980s, before Wayne Goss was sworn in as Premier on 7 December 1989.

\section{New governor and changes to the ministry: more than a tinker at the edges}

In August 1984, the Premier informed the Parliament that the Governor had approved the addition of 'Youth' to Geoff Muntz's portfolio responsibilities, but no other restructuring of the ministry occurred at this time. After the death of John Goleby in September 1985, however, more changes were needed. Bill Gunn was appointed as the Acting Minister for Water Resources and Marine, serving between September and early February 1986. Meanwhile, in July 1985, a new Governor was appointed. Having been overruled in his first choice for the Chief Justice, the Premier decided to promote the compromise candidate for the Chief Justice position, Sir Walter Campbell, to the post of Governor, thereby creating a further vacancy on the Supreme Court. Wally Campbell was selected as Governor from the bench, which was not an unusual pedigree given many chief justices had served as the Administrator in the absence of a Governor, but he was an unusual choice in the sense that he had an understanding of politics and, although he had some family connections with the Nationals, he had an independence of mind. Campbell performed his first public duty by opening the third session of the forty-fourth Parliament on 20 August 1985. After his forced departure from politics in late 1987, Bjelke-Petersen would say the 'only thing' he regretted doing was appointing Campbell to the Governorship (Wear 2002:125).

Shortly after Campbell's elevation to Governor, Bjelke-Petersen surprised many when he embraced the Australia Acts in State Parliament. These acts, negotiated between the Commonwealth and state governments and the British government, removed the final constitutional links between Britain and Australia. Australia had repatriated its own constitution. The acts removed legal appeals to the UK Privy Council. Despite the seemingly republican motivation of these acts, the Premier said 'taken as a whole...I commend the package' to the House ( $Q P D$ 1985:vol. 300, p. 1500). Bill Knox, a former Attorney-General, said he never thought he would see the day when the National Party would present such legislation favourably.

A more significant reshuffle was unveiled to the ministry in February 1986. Responsibility for police matters was moved from Bill Glasson to Gunn, and 
Mapping and Surveying were formally added to Glasson's portfolio of Lands and Forestry. Martin Tenni was moved from Environment to Water Resources and Maritime Services, and his former portfolio of Environment, Valuation and Administrative Services was broken up, with Environment given to Brian Austin, who became Minister for Health and Environment. Geoff Muntz swapped Welfare Services, Youth and Ethnic Affairs for Corrective Services, Administrative Services and Valuation. Bob Katter was given additional responsibility for Community Services, along with his Northern Development and Aboriginal and Island Affairs portfolio. And, Yvonne Chapman, an experienced local councillor who had been in the Parliament for just more than two years, was elevated to the cabinet - the first woman cabinet member appointed in Queensland. She became Minister for Welfare Services, Youth and Ethnic Affairs from 6 February 1986. An avid supporter of the Premier, she would serve as a minister for the remainder of the life of the Bjelke-Petersen-led government, but not under Mike Ahern in either of his two ministries. She would return to the ministry in September 1989 in the dying days of the National Party administration in the short-lived ministry of Russell Cooper.

\section{Mr Speaker Warner's last stand}

Before the 1986 election, the Speaker, John Warner, indicated he would not be recontesting his seat and as a consequence would serve just the one term as Speaker. He had had a fairly torrid time as Speaker and had been humiliated when he was publicly criticised by the Premier for not being up to the job. Many Speakers of the Queensland Parliament had hides thicker than rhinoceroses; Warner did not. He had made many peculiar or incorrect rulings on divisions and over which motions were being debated (see, for example, QPD 1984:vol. 296, p. 1678, and vol. 297, p. 2989). As Speaker, he appeared uncertain and too ready to change his mind on different rulings, and kept getting members mixed up, sometimes appointing the wrong members to act as tellers in divisional votes (that is, when they were voting the other way). He had also struggled to bring opposition members to order and was accused of not being even-handed to their main spokespeople. On one occasion in question time, the federal National Party leader's comments that Labor policies were responsible for the AIDS epidemic led to pandemonium breaking out, with the Speaker unable to control the heated emotions (see, for example, QPD 1984:vol. 297, pp. 2888-902). It was claimed that National members were publicly suggesting that Warner was not up to the job and that at least two ministers were lobbying to have him replaced. Labor's Bob Gibbs also called on Warner to resign for acting incorrectly and unfairly. In one mind-boggling incident in November 1985, the Labor opposition asked for leave to move a motion suggesting the Speaker enjoyed the confidence of the 
House (!) and supported this with their 'ayes' only for the government to defeat the bid with their 'noes'. In the resulting division, the government prevented the opposition from debating its confidence in the Speaker by a vote of 42 to 38 - hypocrisy in the extreme!

A few years later, after Warner's death in 1991, Tom Burns recalled the difficult times Warner had experienced in chairing the Assembly compared with his predecessors. Burns stated that by the time Warner came to occupy the chair, Bjelke-Petersen had come to expect that the Speaker of the day would follow closely his instructions. Burns continued:

John Warner was a quiet and gentle man. The way in which he attempted to handle this Parliament provided a bit of respite following the Speakers who had preceded him in this place. I entered this Parliament at the end of the Nicholson era. Dave Nicholson attempted to get rid of Joh. Three or four others, including Jim Houghton, were involved. That was a fairly prickly mob...However, in the chair, Dave was a fairly tough master. Bill Lonergan followed Dave as Speaker. Of course, Bill got up against the numbers in this place. He was also a prickly character. The next Speaker was Jim Houghton, who had been defeated by Bill Lonergan. Jim had been an Independent member, a Liberal Party member, a Country Party member and a National Party member - a real rebel in his own way. He turned out to be a good Speaker. The next Speaker was Sel Muller, who began on the wrong foot by stating that his loyalty was to the Government, not to the House. He also was a bit of a rebel. Then came John Warner, who was gentle and kind. As the Premier rightly said, he was the type of person who would find it very difficult to be a tough Speaker. The position of Speaker aged John considerably. At times, he found it very hard to be the Speaker in this place. Sometimes, I was disappointed with what happened in this place. I admit that I was never the best behaved person in Opposition, and I am sure that John would accept that admission today. In 1985 or 1986, a Premier's announcement appeared on the front page of the newspapers that John was not up to doing the job. I did not believe that it was necessary for that announcement to be made. It was not fair, and I said so to John and also to Joh. This place can be very hard. (QPD 1991:vol. 319, p. 897)

This somewhat sympathetic pen-portrait of Warner from one of his political opponents is one of the few comparative assessments of Speakers made by a long-serving member of the Assembly, able to not only reflect back over time but understand the context. 


\section{The 1986 election: Don's party or a chance to conquer Australia?}

The 1986 election was another fiercely fought contest. The National Party was sitting on a slender majority and occupying electoral territory it never thought it would control. With a replenished team, Labor thought it was becoming competitive and could win; it was hoping a 'correction' to the aberrant result of 1983 would see it take ground from the Nationals. Meanwhile, the Liberals, with effectively five sitting members (after Col Miller had declared himself an independent Liberal), were anxious to regain their lost territory.

The 1986 result showed, however, that 1983 was no one-off aberration. In the enlarged Parliament, the Nationals increased their seats from 43 to 49, providing them with a comfortable majority of nine on the floor of the Assembly. The government increased its primary vote to 39.64 per cent (up by nearly 1 per cent). New National members included: Clive Berghofer (Toowoomba South), Tony Burreket (Townsville), Huan Fraser (Springwood), Leo Gately (Currumbin), Tom Gilmore (Tablelands), Denis Hinton (Broadsound), Di McCauley (Callide), Tom Hynd (Nerang), Craig Sherrin (Mansfield), Doug Slack (Burnett) and Howard Hobbs (Warrego), who replaced the Primary Industries Minister, Neil Turner, who had chosen at that stage to retire from politics. Labor went backwards, losing two seats net (from the 1983 result) but because they had previously lost Stafford to the Liberals the real loss was one seat in 1986. Their primary vote fell by 2.5 per cent, dropping down to 41.35 per cent. Two sitting Labor members were defeated, in Ashgrove and Mount Isa. Labor's new members included: Len Ardill (Salisbury), Ken Hayward (Caboolture), Ken Smyth (Bowen) and Dean Wells (Murrumba). The Liberals won two seats net over their 1983 result (but four if the defections of 1983 were counted as Nationals). Four fresh faces joined the Liberal Party room, taking its total to 10. Denver Beanland won Toowong, defeating Earle Bailey. Peter Beard defeated Labor's Bill Price in Mount Isa. Alan Sherlock defeated Labor's Tom Veivers in Ashgrove. And, the little-known Lyle Schuntner held Mount Coot-tha (Bill Lickiss's old seat) for the Liberals. Interestingly, Beard, Sherlock and Schuntner would each serve for only one term, as would five Nationals: Burreket, Fraser, Gately, Hinton and Sherrin.

The result in terms of seats proved a vindication of the careful planning undertaken by the Nationals led by Sparkes and Lane in the redistribution process. Of the 51 seats in the south-eastern zone, the Nationals won 23 to Labor's 19, with nine going to the Liberals. In the 17-seat country zone, the Nationals won 15 to Labor's two. In the western and far northern zone, the Nationals captured six of the eight seats (with one each falling to the Labor and Liberal Parties). And in the provincial cities zone, with 13 seats in total, the 
Nationals won five to Labor's eight. The fact that the Nationals could extract 23 seats from the south-eastern corner of the state largely enabled them to form government in their own right again.

Of the new seats created at the 1985 redistribution, the Nationals won Springwood (Huan Fraser), Broadsound (Denis Hinton), Glasshouse (Bill Newton), Currumbin (Leo Gately), Nerang (Tom Hynd) and Nicklin (Brian Austin). Austin moved to the Sunshine Coast seat after his Brisbane seat of Wavell was abolished. Labor captured Thuringowa (Ken McElligott), Bowen (Ken Smyth), Logan (Wayne Goss), Manly (Eric Shaw) and Townsville East (Geoff Smith); all except Smyth were sitting members. The new seat of Moggill was won by the long-serving Bill Lickiss, who had followed most of his former electorate into the new seat. The one bright note for Labor was that it captured Caboolture (Ken Hayward), vacated by Bill Newton, who moved to the new seat of Glasshouse. Don Lane, contesting Merthyr as a National, narrowly held onto the seat with the result not being confirmed for three weeks after the election. Di McCauley won Callide, returning it to Nationals' hands (it had been held by the independent Lindsay Hartwig). The former Liberal Beryce Nelson returned to the Assembly, this time representing the Nationals in Aspley. For the first time in six years, there were no independents in the House.

Again, as with the previous election, a large influx of new blood entered the Parliament. Twenty new members were elected (although Nelson had previously served for one term). This brought the number of members who were either new or had served for only one term to 44 of the 89-member Assembly.

Most of the election had been fought on predictable themes. The Nationals had championed economic growth and development, saving Queensland from the Hawke socialists in Canberra and internally from anti-Queensland critics and anti-growth advocates. They used a slogan very similar to the one coined for the 1983 election, but this time it was crisper: 'Queensland-there's never been a greater need.' The campaign posters with Bjelke-Petersen and the map of Queensland were recycled for this election. Television ads also showed a fatherly Premier with two of his grandchildren running into his outstretched arms through paddocks of daisies. The background voice-over told viewers that Bjelke-Petersen was a father to Queensland and 'had an undying love for the State and its people' (Australian Financial Review, 14 October 1986). When asked about the quasi-religious nature of the Nationals' campaign, and some religious eulogising about the Premier in song, Bjelke-Petersen simply stated: 'I'm just an ordinary sinner like everyone else' (Courier-Mail, 15 October 1986). At the grassroots level, hundreds of local and provincial projects were announced: road and rail improvements, local dams, tourism projects and hotel complexes, more schools and hospitals. Pork-barrelling was alive and well. 
Labor emphasised the issues of corruption and maladministration and there is some evidence the issue was beginning to resonate with voters (see Whip et al. 1991:70-1). Warburton spoke of the 'little mates' network of corruption in government and the economy (Australian Financial Review, 6 October 1986). He pushed the notion of himself as 'Honest Nev', who would make Queensland respected and accountable; he was the 'Honest Choice for Queensland'. He promised to install a range of watchdog machinery that was 'standard in other States', including 'a functional review inquiry, cabinet subcommittees on economics and priorities, planning and strategy, program and capital budgeting, and parliamentary public accounts, public works and public body committees' (Australian Financial Review, 6 October 1986). One television advertisement depicted a number of cheques passing through a bank teller's window while a narrator's voice said 'there's an awful lot of money changing hands in Queensland these days that really shouldn't be'. This advertisement was, however, stopped by legal action from Allen Callaghan, who at the time was facing trial for embezzling government funds (from the Queensland Film Corporation) and who argued that such ads would prejudice his forthcoming trial. In another election stunt, Peter Beattie and the ALP's state president, Ian McLean, signed a public document in front of a large media contingent calling for urgent electoral redistribution, with obvious spaces left for Liberal endorsement. The Liberals' leader, Bill Knox, claimed this was just another bit of Labor's 'gimmicky garbage' (Australian Financial Review, 8 October 1986).

The Liberals in their own way also stressed accountability, using as their slogan the single word 'Trust' to emphasise their commitment to good government. Knox stated that he would not be making 'pie in the sky election promises'. He tried to differentiate himself from the Nationals and their cronyism, playing down the fact that the Liberals had shared the cabinet table with their former colleagues. He committed the Liberals to abolishing payroll tax altogether. Commenting on the circumstances the Liberals were in, he said the 'blowtorch of reality has hardened the party' after the devastating loss suffered in 1983 (Courier-Mail, 13 October 1986).

The final weeks of the campaign became a little bizarre when Sir Roderick Procter (a long-term National Party trustee) appeared on a current affairs program (the Carlton Walsh Report) and argued that 'the party's return to power would have adverse effects on business and the State economy', suggesting the 'government's tendering procedures, when employed, were often a charade' (Australian Financial Review, 23 October 1986). In response, the Premier stated that he 'would seek another election after November 1st if a National Party government was not elected'. His craving for executive power and disregard for democratic expression led Knox to describe the Premier's statement as 'absolutely crazy...no matter what happens on November 1st, there is no need 
for another election'. Knox added that 'despite all the talk we have been hearing recently, no political party owns the government of the State' (Courier-Mail, 21 October 1986).

The Nationals' campaign theme of continuity and state paternalism was an effective message with the electorate. Even if corny, the Nationals' message resonated with voters. The attempts by Labor and the Liberals to discredit the Nationals' record in government fell flat and the electoral gains by the Liberals were minimal whereas Labor's stocks were reversed. After 26 years in opposition, Labor must have wondered how it could ever make headway. To Labor's supporters, the election night was a rerun of David Williamson's play Don's Party, in which a group of drunken Labor supporters initially believes Labor is going to win when early results come in, but is devastated when the conservatives are returned as the final figures are counted. In claiming victory and thanking Queensland, Bjelke-Petersen declared he would take on Canberra and rid Australia of the Hawke 'socialist' government.

\section{Bjelke-Petersen's ninth and final ministry}

In December 1986, the new ministry was announced. There were relatively few changes. Claude Wharton had retired from politics, as had Neil Turner after serving for one term as Primary Industries Minister (and a short term as Transport Minister when the Coalition collapsed). The two vacancies were occupied by Don Neal (NP, Balonne), who was appointed Minister for Corrective Services, Administrative Services and Valuation, and the Redlands solicitor Paul Clauson, who became Minister for Justice and Attorney-General (the only Attorney-General under either the Nicklin or Bjelke-Petersen governments to hold a law degree). Clauson was later nicknamed 'Silent Paul' because he asked but two questions and made about one and a half speeches in his two years as a backbencher (QPD 1987:vol. 307, p. 4813). Responsibility for the relatively small Arts portfolio was moved from the Tourism Minister to the Minister for Mines, Energy and the Arts, Brian Austin.

The ninth ministry consisted of

- Premier and Treasurer: Johannes Bjelke-Petersen

- Deputy Premier and Minister Assisting the Treasurer and Minister for Police: Bill Gunn

- Minister for Local Government, Main Roads and Racing: Russ Hinze

- Minister for Works and Housing: Ivan Gibbs

- Minister for Mines, Energy and the Arts: Brian Austin 
- Minister for Industry and Technology: Peter McKechnie

- Minister for Transport: Don Lane

- Minister for Lands, Forestry, Mapping and Surveying: Bill Glasson

- Minister for Health and the Environment: Mike Ahern

- Minister for Education: Lin Powell

- Minister for Primary Industries: Nev Harper

- Minister for Small Business, Employment and Industrial Affairs: Vince Lester

- Minister for Water Resources and Maritime Services: Martin Tenni

- Minister for Justice and Attorney-General: Paul Clauson

- Minister for Corrective Services, Administrative Services and Valuation: Don Neal

- Minister for Tourism, National Parks and Sport: Geoff Muntz

- Minister for Northern Development and Community Services: Bob Katter

- Minister for Family Services, Youth and Ethnic Affairs: Yvonne Chapman

There would be no changes to this ministry until the political crisis that erupted in late November 1987.

When the Parliament resumed, Bjelke-Petersen nominated 'his man', Kev Lingard, as the new Speaker, seconded by Bill Gunn. Both the Labor and Liberal Parties again nominated their own candidates to contest the election, with Labor opting to support their Leader of Opposition Business in the House, Bill Prest (to spontaneous laughter across the House), while the Liberals nominated the former minister Bill Lickiss. Nev Warburton claimed, somewhat facetiously, that the Parliament should be voting for Bjelke-Petersen to become Speaker, because he was moving on - after he had indicated he was going to resign to fight for a federal seat in the 'Joh for $\mathrm{PM}^{\prime}$ ' campaign (see below). Labor also spoke of the responsibilities of the office of Speaker and the real challenges facing the new Speaker to enable the Assembly to operate more effectively. After the normal tirade of abuse and personal attacks across the floor, Lingard was elected as Speaker with 46 votes, to 30 for Prest and 10 for Lickiss, with three members voting informally. Lingard said that when 'I took my position in this House as a back-bench member, I did not dare to think that three year's later I would be given the great honour of being elected as your Speaker' (QPD 1987:vol. 304, p. 34). 


\section{The Bjelke-Petersen edifice begins to crumble: Joh for PM, friends fall out, mates in jail}

During 1987, the Bjelke-Petersen government began to implode, due largely to circumstances of its own making. At the height of his power, the Premier's iron grip on power began to falter and his usual political acumen was overtaken by hubris. As one study of his leadership has noted, after seven consecutive election wins 'the septuagenarian Bjelke-Petersen succumbed to a kind of manic grandiosity that climaxed in the delusory and self-destructive "Joh for PM" campaign' (Strangio 2008:242). This was to be the Premier's last 'bushfire' in Australian politics.

The Premier helped initiate and was then courted by the 'Joh for PM' campaign that went barnstorming around Australia in the early months of 1987, capturing enormous media attention in the lead-up to the federal election. The campaign originated from the ambitions of maverick business leaders disillusioned with the Hawke government and with the lack of outright opposition to it. BjelkePetersen's role in the campaign and leadership of the anti-Hawke forces were planned well before the 1986 state poll. The Premier's boast in his electionnight victory speech that he would rid Queensland and Australia of the Hawke 'socialist' government further fed into the intrigue.

'I love Queensland, I love it immensely, the people immensely. I have dedicated over half my life to it. But in this last period, I want to do something for the whole of Australia. I want to get Australia going the right way,' he said (February 1987, cited in ABC News Online, 23 April 2005).

The adventurous campaign was fanned and funded largely by Gold Coast developers, such as Mike Gore, who was part of the so-called 'white-shoe brigade'. These developers saw in the ageing Premier a right-wing ideologue who was particularly pro-private enterprise (certainly very much pro-their enterprises). Gore was assisted by a string of other business entrepreneurs such as Ted Lyons, Lang Hancock, Kerry Packer, John Leard, Charles Copeman, Andrew Hay and Ian McLachlan, as well as diverse other fringe New Right characters such as the former Commonwealth Treasury head John Stone and academics Katherine West and Geoffrey Blainey.

If 'Canberra Joh' had chosen to run for federal office, he would, of course, have had to resign from State Parliament (and the Premiership). It is not clear from the unfolding events when he realised that this would be the certain consequence. The national media was obsessed by the campaign, speculating whether he would go through with it and manage to form his own government federally. John Howard and Ian Sinclair were both opposed to Bjelke-Petersen's 
destabilising tilt at national leadership. In Queensland, however, some political supporters such as Russ Hinze were pushing the Premier to opt for federal politics, principally so that he could succeed him as Premier. Consequently, until late May 1987, it appeared certain that Bjelke-Petersen would choose to fight his now renamed (and less ambitious) 'Joh for Canberra' campaign. Indeed, he confirmed from Los Angeles on 28 May that he intended to nominate for a seat after Hawke sprang an early federal election.

Sir Robert Sparkes was not, however, a convert to the 'Joh for Canberra' push. He had reluctantly agreed to head the campaign but had reservations about the wisdom of the populist push. There were too many uncertainties: how could Bjelke-Petersen become prime minister, would the federal Nationals accept him as leader, would the Liberals stand aside, and could the divided conservatives win the 1987 election? According to Barlow and Corkery (2007:11):

The Joh push floundered on a lack of money, grassroots organisation, and time. Sir Robert Sparkes, the National Party's Queensland president, realised the state branch's drive into Labor and Liberal suburban territory would require massive financial and human resources. The Federal, New South Wales and Victorian National Party organisations were not on side. They had always been junior coalition partners. Despite changing their name from Country Party to National, they were the party of the bush. The federal party already had a leader in Ian Sinclair, who was not prepared to vanish into the ether. The Joh push disintegrated.

Bob Hawke comfortably won the 1987 federal election with a 24-seat majority and with 45.8 per cent of the primary vote. The Liberal vote went backwards by 0.1 per cent, while the Nationals' vote increased by just 0.9 per cent. John Howard forever blamed Bjelke-Petersen for robbing him of a potential Coalition victory.

On the local front, a by-election was required for the Gold Coast seat of Southport after Doug Jennings died of a heart attack in the sauna of the Parliament and was found on the morning of 9 April 1987. His death was reported that morning to the Assembly by the Speaker, Kev Lingard. Jennings had served for six and a half years in the Queensland Parliament as a National (after serving one term in the Victorian Assembly as a Liberal), but had not risen to the ministry or occupied any senior parliamentary position. Five candidates contested the by-election held on 20 June 1987, with the three main parties each standing candidates along with two independents. The seat had been a Country/National seat for most of its history since its inception in 1950, but the Liberals (Peter White) had held it for one term between 1977 and 1980, so felt that they could recapture the coastal seat with a decent candidate. The Liberals considered they would benefit from the disarray caused by the distracting 'Joh for PM' 
campaign that had captivated Australian politics for a while but had by then disintegrated. The Liberals nominated a Gold Coast alderman, Keith Thompson, while Labor ran with Robert Lee without much hope of success. To hold their seat, the Nationals chose a local celebrity and former international rugby league player, Mick Veivers, an acknowledged strong supporter of Bjelke-Petersen. Although the Liberal and Labor Parties attempted to fight the campaign on state-wide issues, it focused mainly on local concerns. In the end, despite the mounting controversies facing the Nationals, Veivers managed to win the seat with a small swing of less than 5 per cent against the government.

Mike Gore had been accused of improperly receiving government loan funds under the Statutory Bodies Financial Arrangements Act, which was established to consolidate loans and borrowings to statutory authorities (electricity bodies, local governments), not Gold Coast entrepreneurs. The Opposition Leader, Nev Warburton, ran a public campaign to discredit this arrangement, at one stage calling for the Governor to sack the Bjelke-Petersen government for behaving unlawfully; whether or not he contacted the Governor with this request, nothing eventuated.

Criminal proceedings were also beginning to catch up with close supporters of the Premier. In April 1987, Allen Callaghan — widely seen as the svengali behind the Premier - was jailed for four years for misappropriating public funds. He had ceased his job as the Premier's media adviser in 1979 and been appointed as deputy director of Culture, National Parks and Recreation, as well as chairman of the Queensland Film Corporation (from 1979), and then as the Under Secretary of the Department of Arts, National Parks and Sport from 1984. He was also appointed as a member of the Queensland Day Committee, on which his wife had served as the executive officer since 1981. While Callaghan was chairman of the Queensland Film Corporation, he had spent some \$43000 on his daughter's wedding from his government credit card. The predicament of Callaghan, as a prominent adviser to Bjelke-Petersen, attracted much continuing commentary in the Parliament with the Premier resolutely defending his former media minder and confidant. The Callaghans were accused of many things in the Assembly, including taking overseas holidays at the taxpayers' expense. Judith Callaghan was jailed, in 1986, for two and a half years for misappropriating public monies 'deceitfully acquired' belonging to the Queensland Day Committee. She was released on health grounds after three months. 


\section{The Fitzgerald Inquiry: a window of opportunity}

The Fitzgerald Inquiry was a pivotal investigation for Queensland, which changed forever the political culture and institutional landscape. Yet its origins and initial developments were almost accidental or totally fortuitous - and these factors would shape the evolution and impact of the royal commission. The context of the Fitzgerald Inquiry is well known and retold in the Fitzgerald Report (1989:Chs 1, 2). Allegations of police corruption had circulated for decades and had been a staple diet of the Parliament over particular sessions. Allegations again surfaced, but this time generated by the investigative reporting of Phil Dickie (at the Courier-Mail) and later Chris Masters (ABC TV's Four Corners). When Four Corners broadcast 'The Moonlight State' documentary that exposed open police tolerance of brothels, illegal betting and carried serious allegations of police corruption, the government chose to act. Fortuitously, with Bjelke-Petersen out of the state stoking up his 'Joh for $\mathrm{PM}^{\prime}$ campaign, Deputy Premier, Bill Gunn (who was also Police Minister), took the decision to establish an inquiry. He did it partly to get to the bottom of the allegations once and for all, but also to show he had the mental toughness and decision-making acumen of a potential leader as part of his plan to succeed Bjelke-Petersen as Premier (Davis and Wanna 1988:80-1). After he made the decision to establish a royal commission, he initially considered appointing the head of the Police Complaints Tribunal, Judge Eric Pratt, to head up the inquiry, thinking it would be over in six or seven weeks. Legal advisers close to the government scoffed at this proposal and when Gunn asked who should head the inquiry, the name of Tony Fitzgerald QC was suggested as an independent and 'fearless' prosecutor then practising in New South Wales. Gunn accepted this advice and appointed Fitzgerald, but restricted the terms of reference to the allegations (and individuals named in the Four Corners program).

The original terms of reference were issued on 26 May by special Gazette, empowering Fitzgerald to 'make a full and careful inquiry' into the activities of the alleged crime bosses: the Bellino family (Gerald, Antonio and Vincenzo), Vittorio Conte and Hector Hapeta; to investigate whether these people were involved in operating prostitution, unlawful gambling or illegal drugs; to investigate whether police had been guilty of misconduct or violation of duty in policing such activities; and to investigate whether any person on behalf of any of the alleged crime bosses directly or indirectly provided benefit (financial or otherwise) to any member of the police force. Fitzgerald was asked particularly to investigate whether any of the crime bosses had made a payment of $\$ 50000$ to 
a political party and whether a party had received such funds from this source. He was also empowered to review previous conduct of former serving members of the force.

The original inquiry was intended as a quick six-week investigation into claims of police misconduct and criminal activity, to clear the air and get embarrassing stories of corruption and prostitution off the front pages. It did the very opposite. The royal commission, supported by a team of dedicated investigators, morphed into a full-blown inquiry that brought down a corrupt police commissioner, exposed the dishonest networks of graft run by the so-called 'rat pack' senior officers and eventually led to the adoption of a raft of administrative laws and a substantial change in the electoral laws of the state. It also spawned both an independent standing Crime and Misconduct Commission and a dedicated parliamentary committee charged with overseeing criminal justice matters (details of the fallout from the Fitzgerald Inquiry and their repercussions are discussed in Chapter 16).

\section{Ultimately deposed: the burlesque finale to Joh's Premiership}

The last year of Bjelke-Petersen's tenure as Premier was truly burlesquegrotesque to the point of parody and disbelief. The Premier's customary political astuteness seemed to have evaporated, yet he continued to act as though he was infallible. He had stopped listening to advice of which he did not wish to take heed or even receive. He had lost some of his key party supporters in cabinet and some ministers, such as Mike Ahern and Paul Clauson, were beginning to question his judgment and sanity. He had lost the support of his organisational champions in the party and had been publicly defeated in his moves to extend his own personal influence. He had publicly fallen out with former lieutenants such as Sir Robert Sparkes, who he said 'would have to go' as state president. Sparkes was now openly hostile and encouraging revolt against Bjelke-Petersen's leadership, even among ministers. The Premier had lost some key advisers such as Allen Callaghan or had come to disagree with others on political strategy, as with Ken Crooke. He had fallen closer under the influence of other 'advisers' such as Ted Lyons, himself no man of the people, who simply urged the Premier to impose his authority, not to resign and to tough it out.

Bizarre announcements and even stranger events occurred seriatim during 198687. The Premier had given his personal backing to the sale and development of the Lindeman Island resort (involving Ted Lyons' East-West Airlines) but lost the political battle. He created a huge fight over whether condom vending machines could be installed in establishments as an anti-AIDS initiative. There 
had been controversial incidents as police were ordered to remove condom vending machines from toilets at the University of Queensland campus. He had announced that the world's tallest skyscraper would be built in a car park in Brisbane's CBD - a proposal that was greeted with much scepticism.

He announced that he wanted to remain as Premier until after the opening of Expo 88 in April 1988 (until August, after which he would have served for 20 years as Premier and for more than 41 years and three months in the Parliament, making him the longest-serving member). This announcement worried his ministerial colleagues, who thought he was merely buying time and would not resign when the time came.

In late November 1987, Bjelke-Petersen refused to meet with his ministers and discuss his leadership. Instead he opted to sack those ministers he accused of going behind his back and being disloyal. He visited the Governor on 23 and 24 November to try to obtain the Governor's support for his sacking of five ministers, followed possibly by the calling of an early election to resolve the crisis. He also proposed to offer his own resignation and that of the entire ministry, with a new ministry to be sworn in immediately without any of the troublesome ministers. The Governor, Sir Walter Campbell, refused to act immediately on this advice, saying that he 'as Governor would need to be satisfied, before re-commissioning the Premier, that he could form a new administration and that he and his new Ministry had the confidence of Parliament' (Barlow and Corkery 2007:15). He recommended the Parliament be recalled to resolve the political crisis. It was constitutionally the correct and wisest course of action for the Governor to suggest, but it was also a courageous stance by the Governor to rebuff his Premier. At subsequent meetings, Campbell asked for a letter establishing the facts of the crisis and the proposed restructuring, including discussions with the full ministry. He subsequently received further advice from Deputy Premier Gunn and from Ahern and Austin that the Premier no longer had the support of his parliamentary party.

In retaliation, the Premier called in all five ministers he intended to dismiss individually, demanding their resignations, which they all steadfastly refused to give. The five named included even a loyal Bjelke-Petersen supporter, Peter McKechnie, who was told by the Premier that he was being sacked not because he was disloyal, 'just not loyal enough' (Four Corners, ABC TV, 2008). As Coaldrake commented, when asked to resign,

all five refused. Mr McKenzie was reportedly told he was being sacked for showing insufficient loyalty, Mr Muntz was apparently given no reason, Mr Austin because he had been seen speaking with Sir Robert Sparkes at the party's state conference, Mr Ahern for allegedly leaking and 
moral irresponsibility, and Mr Gunn (Sir Joh's deputy) for nominating Sir Robert Sparkes for another term as party president. (AJPH 1988:vol. 34, no. 2, p. 240)

In the end, Bjelke-Petersen sacked three senior ministers: Ahern, Austin and McKechnie. Gunn and Muntz were given a reprieve. To replace these outgoing ministers, he affected a minor reshuffle and appointed two new 'loyalist' ministers - Gordon Simpson (Mines and Energy and the Arts) and Kev Lingard (Health and Environment) - both of whom would occupy the posts for just seven days, equalling the shortest term as a minister. When Allen Callaghan said to the Premier 'the National Party won't be happy with this process', Bjelke-Petersen said back to his former adviser, 'I am the National Party' (Four Corners, ABC TV, 2008). Shades of 'L'État, c'est Moi'.

A stand-off now ensued, with Bjelke-Petersen locking himself in his executive suite in the Executive Building on George Street, not wanting to come out and not wanting to allow his former colleagues in. He remained bunkered in his office for days. ${ }^{1}$ Take-away food was delivered and lamb chops were served for lunch. Only a few selected supporters were allowed access to him.

The tempestuous events surrounding the removal of Bjelke-Petersen did not greatly involve the Parliament itself. The Parliament was told one day (10 November 1987) that the government members had full confidence in BjelkePetersen's leadership (with all 48 on the floor of the Assembly voting in support), then eight sitting days later (on 2 December 1987), the Parliament was informed of the new leadership. The party-room meeting of the Nationals (held without Bjelke-Petersen, who remained in the Executive Building) occurred on 26 November in Parliament House, at which Bjelke-Petersen was deposed and Ahern was elected leader with 30 votes from the 48 available. So unsure were the Nationals that the Governor would accept their advice that they made all members sign a letter agreeing unanimously to the leadership change; it was signed by all 48 members, with Mick Veivers and Don Lane playing enforcers (for an account of the event, see Lane 1993:221). Gunn was elected deputy and Lin Powell nominated as the next Speaker. The Nationals still did not trust BjelkePetersen, who some felt might attempt a vote of confidence in his government on the floor of the Parliament (hoping to secure cross-party support). So, as of 26 November, Ahern was new leader of the Nationals - but not yet the Premier as he was entitled to be. Bjelke-Petersen refused to resign his commissions as Premier and member of the Executive Council.

1 But not six, as Reynolds (2003:344) claims - presumably 26 November to 1 December — as he visited his farm at Kingaroy on a secret mission on 29 November, met with the Governor many times, visited the airport to meet an overseas delegation and visited a goat farm at Toogoolawah (see Sun Herald, 15 November 1992, pp. 21-30). 
According to Russell Grenning (Russ Hinze's press secretary), on the evening of 27 November:

The omnipresent, all-powerful Premier of Queensland had barricaded himself in his office. It was bizarre and Russ [Hinze] went to the door and banged on the door. Joh wouldn't open the door and Russ was bending down, talking to him through the keyhole with tears running down his face, saying 'Joh, come out mate, it's all over'. (Four Corners, $\mathrm{ABC}$ TV, 2008)

His wife, Flo, visited him, to plead with him to come out, as did other former colleagues. And, eventually, he did go home at the weekend, but for an entirely different matter.

Even more bizarrely, Bjelke-Petersen had been conducting a secret 'dialogue with the enemy', contacting the Labor Party through Ted Lyons to seek its support in voting to defeat an Ahern-led attempt to form a Nationals' government with the support of the Liberals and some dissident Nationals. These negotiations led to a meeting with the ALP secretary, Peter Beattie, at the Premier's farm at Kingaroy on Sunday 29 November (see Wear 2002:124; Lane 1993:222-3; Beattie 2005; Bjelke-Petersen 1990). Bjelke-Petersen also entertained the view that he might be able to remain in power by sharing power with his opponents at the head of a loose coalition of dissident Nationals, Liberals and Labor members. His plan was almost beyond belief! The so-called 'deal with the devil' fell flat when the Premier refused to entertain electoral reform and Beattie (and his closest colleagues) refused to facilitate the ploy (there were echoes of the same sort of conspiratorial plotting that had occurred in reverse at the demise of the Gair government with Nicklin).

Nevertheless, with Bjelke-Petersen still hanging onto the Premiership, he called a final cabinet meeting for Monday 30 November, which he chaired and at which his legal fees for defamation cases were discussed (but it was not agreed at this stage that the Crown would pay). Two rival dates to recall the Parliament were also proposed, with cabinet deciding on the earlier date of 2 Decembermoved by Gunn against the Premier's wishes. Ahern, Austin and McKechnie, no longer ministers, were not invited to the meeting but waited downstairs to hear the outcome. When the other ministers appeared from the cabinet meeting, it was agreed that two of Bjelke-Petersen's 'most unabashed supporters', Gibbs and Gunn, would make one last attempt to convince the Premier to surrender (Lane 1993:224). As agreed, these two were to inform the Premier that unless he resigned, the cabinet would not agree to pay his legal bills of about $\$ 200000$ (but possibly up to $\$ 300000$ ). That same afternoon, Bjelke-Petersen signed his letter of resignation from all his official duties and posts dated from 1 December 1987. 
Bjelke-Petersen, then seventy-six years of age, did not reappear in the Parliament after he was deposed. Speaking later of the events, Bjelke-Petersen said: 'Parliament was not sitting, so for the time being there was not a power on earth which could have forced me out of office if I did not want to go' (Wear 2002:124). At the time, he memorably told reporters that

the policies of the National Party are no longer those in which I went to the people. Therefore I do not wish to lead this government any longer. It was my intention to take this matter to the floor of state Parliament, however I now have no interest in leading the National Party any further. I have decided to resign as premier and retire from parliament effective immediately. (ABC News Online, 23 April 2005)

To his mind, it was not he who had been spurned by his own party; he had turned his back on the party he had formerly led.

The measure of a politician is sometimes not how they attain office, but how they leave it. With Sir Joh Bjelke-Petersen, there is no single, definitive assessment of him as a political leader as he departed public office. Five quotes provide some insights from people who were contemporary witnesses at close hand. They include friends and foes, rivals and commentators.

John Howard, federal Opposition Leader in 1987, said:

He will go down in history as the great wrecker of the conservative side of politics; not a man of vision and achievement but a man who for his own selfish power desires, with no basis of any policy or principle, is prepared to embark upon a wrecking course... [but he added in 2005 when the former Premier died] He made an enormous contribution during his premiership. ( $A B C$ News Online)

Bjelke-Petersen's former media and political adviser, Allen Callaghan, reflected: 'He was starting not to listen. Hubris seizes all politicians and we know the old Chinese maxim: absolute power lasts 10 years...I think at the end he had stopped listening to contrary advice' (ABC News Online).

His political opponent at the time, Nev Warburton, said when the Parliament resumed:

[This] is the first sitting in 40 years without the previous Premier and National Party member for Barambah, who, as everyone knows, was politically decapitated yesterday evening. It is the first sitting day in 40 years without this old conservative hero whom the National Party wanted only months ago to make its Prime Minister of Australia but whom it has now dumped and savaged like a pack of hungry dogs...Sir Joh Bjelke-Petersen was a leader who wrecked without sympathy, the 
lives of too many decent Queenslanders for short-term political ends, and he relied for this power on a rigged electoral system that is grossly offensive to fundamental democratic rights...Few tears will be shed for the end of a career that strayed on far too long; but it must be said in fairness that Sir Joh alone is not to blame for all of those sins over the past 19 years that the National Party embraced but now pretends to disown and forget. (QPD 1987:vol. 307, pp. 4737-8)

In the same debate, Bjelke-Petersen's former ministerial colleague and now the Minister for Mines and Energy, Martin Tenni, said:

I believe in my heart that history will judge Sir Joh very generously indeed. His record of achievements for Queensland will never be erased. The people of the far north join with me in placing on record sincere appreciation for the contribution that Sir Joh has made to the development of the far north and the State as a whole. (QPD 1987:vol. 307, p. 4754)

Finally, the Sydney Morning Herald (25 April 2005) depicted the 'life and times of Joh Bjelke-Petersen' in the following terms:

The English historian Lord Acton noted the corruptive tendencies of power and the truism that 'absolute power corrupts absolutely' ... By the late 1980s, however, when Sir Joh was trying to stave off predators within his National Party government, the events in Queensland were giving the clearest illustration in modern Australian history of the essential truth of Lord Acton's observation. Sir Joh, who ruled as premier of Queensland for 19 years with almost total disregard of Parliament, the bureaucracy and convention, had succumbed to pressure and allowed the Fitzgerald royal commission into police corruption, convinced that no probe could dent him. After all, in the run-up to his disastrous 1987 Joh-for-PM bid, he had declared, without hint of jest: 'I'm a bushfire raging out of control'. That campaign - backed by spivs and the disaffected-ruined John Howard's first shot at the prime ministership and ripped apart the National Party. The dissent evident then in conservative politics, with Sir Joh wearing the badge of chief wrecker, would re-emerge a decade later with Pauline Hanson's One Nation. 



\section{The end of an era, 1987-1989}

For God's sake let us sit on the ground And tell sad stories of the death of kings: How some have been depos'd, some slain in war, Some haunted by the ghosts they have depos'd, Some poison'd by their wives, some sleeping kill'd All murder'd - for within the hollow crown That rounds the moral temples of a king Keeps Death his court; and there the antics sits, Scoffing his state and grinning at his pomp.

— William Shakespeare, King Richard II (Act 3[2]:155)

The revelations of the Fitzgerald Inquiry hung over the 'besieged' Ahern government from its initial day in office: 1 December 1987 (Reynolds 2003:348). The revelations and fallout from the inquiry would plague Ahern's Premiership until he was replaced by Russell Cooper at the demise of the Nationals' government in December 1989. These two years were some of the most dramatic in the state's history. Day by day, sensational allegations and admissions were exposed as senior police and informers turned state's evidence and, for full confessions and cooperation, received immunity from subsequent prosecution. Whistleblowers emerged from the woodwork; once one informant talked others followed. The networks of corruption and misconduct were quickly unravelling only to be pursued to the next level by eager and diligent investigators. There were mounting suggestions that the connections stretched to the very top of government. There was a surreal quality to Queensland politics.

Mike Ahern inherited a poisoned chalice. Senior National ministers had long been anxious to displace Bjelke-Petersen from the premiership - by urging him either to retire or move over to the federal level. Once they had seized the prized trophy, however, they found they were holding a 'hollow crown' - assuming the mantle of office that seemed to be nothing more than a facade. Ahern and his ministers would preside over the gradual disintegration of the regime, beset by scandals, revelations of corruption, resignations and retirements. As months went by, the government was wracked by internecine political divisions and there was a good deal of internal dysfunctionality at the centre of government (Reynolds 2002:Chs 5, 8). Despite that, the Ahern government began the long and arduous process of reform, which would run for more than a decade (see Reynolds 2002; Prasser et al. 1992; Stevens and Wanna 1993; Lewis et al. 2010). Ahern's announced intention was to embrace a 'vision of excellence', which variously meant everything and nothing. 
Amid the hurly-burly, Premier Ahern recalled the Parliament for a special sitting on 2 December 1987, lasting for just one full day. The Parliament had been adjourned on 20 November at which point the usual valedictory speeches were made, thanks was given to colleagues, family, staff and the media, and everyone was wished a 'very happy and very blessed Christmas'. Sounding a little weary, the former Premier had stated that the 'House rises for the Christmas recess' in moving that the House be adjourned until 10 am on ate to be fixed by the Speaker. The other party leaders offered their felicitations and the Speaker, Kev Lingard, said that the end-of-session drinks were on him in the Function Room of the Parliament.

At the special resumption, there was much evidence of confusion and apprehension behind the scenes. The Clerk read out Lingard's resignation as Speaker dated from midnight 24 November - owing to the fact he had accepted a ministry (Health and Environment) for seven days in the last attempt by Bjelke-Petersen to shore up his leadership. Ahern had originally intended to call the Parliament back at $2.30 \mathrm{pm}$ on 2 December but had to be informed by the Acting Speaker, Ted Row, that the House had to meet at $10 \mathrm{am}$ as required by the final adjournment vote on 20 November. Ahern had not had time to finalise a new ministry, so had himself and his deputy, Bill Gunn, sworn in as Premier and Deputy Premier, respectively, on 1 December. These two ministers were commissioned as a two-man interim ministry, dividing the entire 18 portfolios between themselves for a period of nine days. This was the only time in Queensland's political history that the resort to such an interim two-person ministry was necessitated. Lane (1993:223) recalled in his memoirs:

A discussion took place regarding the makeup of a future Ahern Ministry and it was agreed by all of us that rather than risk losing the votes in Parliament of any dumped Ministers, Ahern and Gunn should make up a two-man Cabinet until a full Cabinet could be chosen in a less volatile environment. This latter proved to be a major tactical error on my part in agreeing so readily.

When the Parliament resumed on Tuesday 2 December, its first task was to elect a new Speaker. Lin Powell had been nominated by the Nationals' party-room meeting held on 26 November. Ahern had been considering appointing Des Booth (NP, Warwick), a loyal supporter of his, but accepted the nomination of Powell-a known ardent supporter of Bjelke-Petersen-perhaps in an endeavour to hold the fractious party together. Powell had been publicly critical of Ahern and the new Premier might have preferred not to have him in cabinet. So, through tactical necessity, Ahern nominated Powell for the Speakership and Gunn seconded the move. Ahern said that Powell had been an MP for 13 years, 
a minister for five years, Leader of the House for a year, but most importantly 'as a former schoolteacher, he will bring the necessary discipline to this place' (QPD 1987:vol. 307, p. 4736).

Opposition Leader Warburton's response to the nomination of Powell for Speaker was most peculiar. His phraseology gave the impression he had not been expecting the leadership change or the sudden resumption of the Parliament, and was caught out in his response. Suddenly, the arch opponent of the former Premier appeared to be his concerned advocate. The Labor leader claimed that the Nationals had behaved duplicitously, had sabotaged the former Premier, were now denigrating Bjelke-Petersen and had 'dumped and savaged [Joh] like a pack of hungry dogs' (see full quote at the end of Chapter 15). Warburton claimed Ahern 'and his crew were prepared to stoop to the lowest possible depths in order to buy Sir Joh out', presumably referring to the promise the Ahern group had made to the Premier about covering his legal costs. ${ }^{1}$ From Labor's perspective, Warburton was more prescient when he stated that 'a long, often unhappy chapter closes in Queensland and a new uncertain one begins' (QPD 1987:vol. 307, p. 4740). Labor proposed Clem Campbell as its nominee, while Bill Knox nominated Bill Lickiss. The wily old Russ Hinze told the opposition they could expect better government, that some reforms to the Parliament would be introduced now that Bjelke-Petersen was gone and promised 'we are in for better days'. He concluded his short speech, alluding to a project recently embraced by his former leader, by saying 'I have grave doubts that the Opposition will see in Brisbane the tallest building in Queensland' (QPD 1987:vol. 307, p. 4765) - something one wit referred to as 'Joh's last failed erection'. After various speeches from both sides of the Chamber, speculating how far the new administration would in fact reform government and parliamentary practice, and attempting somewhat to reconstruct the historical record, the 'historic' debate descended into name-calling, finger-pointing over who was the biggest drunk in the House, reading out spoof telegrams, speculating on who would become a minister and rehashing the shenanigans of the 'Joh for PM campaign'. Len Ardill asserted with some degree of passion that he would prefer Powell in any position other than as Education Minister (because of his ideological and religious views), a comment that received an interjection of 'you will regret those words' from a government member. Beryce Nelson was so appalled by the debate she stated, 'I am saddened to have to comment on the shabby and

\footnotetext{
1 Wayne Goss claimed in April 1988 that the former Premier had to be prised from office by 'showing him the accounts for legal fees associated with publicly funded defamation actions against members of this Parliament'. He cited a current affairs program that had suggested that the bill for the legal fees was more than $\$ 300000$. He asked Premier Ahern whether these bills had been 'used as a political bargaining chip' in telling the Premier 'he would have to pay them himself if he did not leave office'. Ahern replied that he had 'no knowledge' of the matter of the legal fees, that it was a 'complete fairy story' and claimed he was 'completely unaware of any threats made against the former Premier in respect of the payment of legal fees' (QPD 1988:vol. 308, p. 5778).
} 
pitiful performances today of the members of the two opposition parties' (QPD 1987:vol. 307, p. 4791). After a six-hour debate that rapidly lost all semblance of purpose, Powell received 48 votes to Campbell's 30 and 10 for Lickiss. The vote was decided entirely on party lines. Becoming Speaker did not inhibit Powell from vehemently criticising the Ahern ministry from the sanctity of the Speaker's position.

After the election of the Speaker, the House took a short break to enable the new Speaker to be presented to the Governor, but resumed almost immediately at $5.06 \mathrm{pm}$ to debate a vote of confidence in the new Ahern government moved by the new Premier himself. After announcing the interim duumvirate ministry, Ahern moved 'that this House expresses its confidence in the Government' (QPD 1987:vol. 307, p. 4804). He then spoke to his own motion promising 'stable progressive government', promoting a 'vision of excellence' and predicting 'it is the beginning of a renaissance...the best is yet to come' (QPD 1987:vol. 307, p. 4804). To him, 'what this Parliament is witnessing today-and what the people of Queensland will be relieved to know - is that there is a change of Government without this Government changing' (QPD 1987:vol. 307, p. 4804). Gunn spoke of 'Bjelke-Petersen's great achievements during the prime of his Premiership'. He said the Ahern/Gunn government would build on the 'best of those foundations' and that 'the dawning of a new age in Queensland politics' would be 'like a breath of fresh air through the corridors that has already sent a chill into those on the Opposition benches' (QPD 1987:vol. 307, p. 4807). Ahern tried to contrast his style of 'placing principle before personality' with what he regarded as Labor's unprincipled opportunism. On two occasions, Ahern interjected to ask whether the Opposition Leader, Nev Warburton, had sent the outgoing State secretary, Peter Beattie, to Bethany to meet secretly with BjelkePetersen. Other government members also attempted to paint the Labor and Liberal Parties as 'a coalition in opposition', because they had spent considerable time in the media agreeing with each other on criticisms of the Nationals.

Reynolds (2002:101) has claimed the opposition 'did not seriously contest the debate', yet the two speakers nominated to reply to the motion made no worse a fist of it than Labor usually did when addressing such motions. The opposition complained it was premature to bring on a vote-of-confidence motion before a full ministry was announced. Labor was less impressed with the new language of government, describing the Premier as 'Marshmallow Mike' who hid behind Bjelke-Petersen's skirts. Warburton, in his last day in Parliament as parliamentary Labor leader, moved an amendment asking for the abolition of the gerrymander, a public accounts committee, a review of education, plans to reduce unemployment and a pecuniary interests register for all parliamentarians! He said, 'how can anyone here honestly give support now for a "vision of excellence" which the Fitzgerald inquiry shows day after day has allowed the 
growth of uncontrolled police corruption and organised crime?' (QPD 1987:vol. 307, p. 4811). In seconding Warburton's motion, Tom Burns made a wideranging, damning speech describing Ahern as 'a new Venus rising cleansed from the foam-beautiful, pristine and pure, untainted by the entrenched corruption and cronyism the Fitzgerald commission is now laying bare'. He called for the former Premier to appear before the Fitzgerald Inquiry, while accusing Ahern of making hollow promises about delivering open and honest government. Burns then went through Ahern's record in various ministries, listing what he considered his shortcomings and embarrassments. He also, however, became easily sidetracked, raising issues such as the superannuation payout to the former Premier's pilot, Beryl Young (who had resigned without giving the required notice). Burns finished up by saying that in all his years in state politics, Ahern 'has played the role of the three wise monkeys - hear no evil, see no evil and speak no evil' (QPD 1987:vol. 307, p. 4819). This was a theme against Ahern that Labor would adopt through to the election.

The Liberals, in contrast, had resolved to support the confidence motion, welcoming the new change of government. Bill Knox, in his last day as parliamentary leader, moved his own set of amendments covering police manpower, the need for legislation to prevent the exploitation of young people through prostitution and pornography, public sector reform, a foreign ownership register, the repeal of the Education Act amendments and an end to ministerial land rezoning! No small wish list, but erring perhaps on the side of eclecticism.

Other contributions to the confidence debate were less than laudable, bordered on the ridiculous or were outright inane. Ian Henderson spoke of AIDS and leprosy epidemics, of impending moral collapse, of Caligula and his horse and of Warburton being displaced not by the Member for Logan, Wayne Goss, but by the Liberals' leader, Bill Knox. To interjections that he was 'sick', he compared the Liberal Party with brands of ladies' pantihose and men's underwear, claiming he knew nothing about types of pantihose but citing as his source of information the new Member for Toowong, Denver Beanland. Angus Innes replied to Henderson's rave. He said that it came as something of a surprise to hear Henderson 'did not know anything about pantihose. We thought he wore pantihose; but of course he is a bachelor' and then added he should 'not get quite as excited about the topic' (QPD 1987:vol. 307, p. 4828). Reynolds (2002:100) suggests that Henderson made his 'usual spiteful diatribe' against the Liberals, while Lane (1993:144) remembered that Henderson 'was not on the same wavelength as his country colleagues'. Tony FitzGerald first accused the Liberals of hypocrisy for criticising National ministers of the last government for clinging on to the trappings of office when they themselves had done so in 1983. Then, giving the impression he had brought along the wrong speech, he went into a long detailed argument about electoral representation. He defended 
the proportion of seats the Nationals occupied and quoted from a National Party submission that argued Labor would 'need to win only 51.4 percent of the twoparty preferred vote to become the Government', which evoked a predictable interjection from David Hamill, who said, 'Only 51.4!' (QPD 1987:vol. 307, p. 4837). Sometimes it was as if the Mad Hatter's Tea Party had descended on Queensland from on high. Accompanying this debate were at least three protests or disturbances from people in the public gallery and police and attendants were eventually instructed to empty the entire gallery.

After eight speakers had conducted a pro-forma debate lasting four and one-quarter hours, Brian Austin applied the gag and moved that the motion be put. Wayne Goss was particularly incensed that the new government had gagged its first debate. As the final divisions were being called, Goss said: 'You gagged your first debate. What a Record! You gagged your first debate. What a fraud!' (QPD 1987:vol. 307, p. 4840) (the resort to the 'gag' was something the Ahern-Austin team used frequently to expedite parliamentary business). The confidence motion was won by 57 votes to 27 , with the Liberals voting with the Nationals. When Austin rose to move the adjournment for the Christmas recess, Knox moved that the Parliament return the next week because there was much business to be attended to, but his motion failed and the Parliament adjourned. Again the Speaker provided Christmas drinks and savouries in the members' dining room.

\section{The first Ahern ministry}

The main interest in the new-18 member Ahern ministry was who was to be included and who would miss out. Ahern was apparently in a quandary over whether to make wholesale changes and 'have a clean sweep' or merely settle for a few minor changes. In the end, he chose to compromise. He already had two vacancies (Bjelke-Petersen and Powell), but in a show of resolution he decided to jettison another three former ministers. Paradoxically two of these dropped ministers were key Ahern supporters who had helped engineer his bid to become Premier. In framing his frontbench, the new Premier considered it inadvisable to reappoint two former stalwarts of the government, Don Lane and Russ Hinze, both of whom had come under intense scrutiny by the investigators attached to the Fitzgerald Inquiry. Lane (1993), who had become close friends with Ahern, provided a personal account of his (and Hinze's) sacking (or effectively nonreappointment on 7 December). The Premier had met with Tony Fitzgerald and his senior counsel, Ian Callinan QC, over the weekend and they informed him that some damaging evidence about Lane and Hinze was likely to emerge as they pursued their investigations (initially regarding Lane's involvement in a judicial appointment but later other improprieties and allegations Hinze was 
engaged 'in SP betting'). The diaries of the Police Commissioner, Terry Lewis, were to be produced and admitted as evidence before the commission and there was mention in them of some interference over the appointment of a judge (Eric Pratt to the Police Complaints Tribunal). Ahern suggested to Lane that two junior ministers (perhaps Harvey and Littleproud) would occupy their posts, but would stand down if Lane and Hinze were cleared (requiring undated resignation letters from the new appointees). ${ }^{2}$ Ahern had far less qualms about dropping Yvonne Chapman - a vocal Bjelke-Petersen supporter-from the frontbench. Ahern also chose not to reinstate two former ministers: Tony Elliott, who was Tourism Minister for one term in 1980-83; and Kev Lingard, who had been a minister for a week during the leadership transition.

With a total of five vacancies to fill, Ahern appointed a number of new, younger ministers to his first ministry, including: Rob Borbidge, Jim Randell, Russell Cooper, Leisha Harvey and Brian Littleproud; it was a cautious mix of experience with a balance of country and urban candidates. The relatively new ministers Paul Clauson and Don Neal were retained but Neal was moved from Corrective Services to the portfolio of Water Resources and Maritime Services. The newly elected Denver Beanland (Lib., Toowong) made a telling point later in the Parliament when he said that the Nationals 'have gone to exceptional lengths to try to create the perception that it is a new so-called conservative Government and that it is setting a new trend', when in fact 13 of the ministry were former members of Bjelke-Petersen's cabinets (QPD 1988:vol. 309, p. 850).

The final line up of the first Ahern ministry was

- Premier, Treasurer and Minister for the Arts: Mike Ahern

- Deputy Premier and Minister for Public Works, Main Roads and Expo and Minister for Police: Bill Gunn

- Minister for Transport: Ivan Gibbs

- Minister for Land Management: Bill Glasson

- Minister for Finance and Minister Assisting the Premier and Treasurer (and Leader of the House): Brian Austin

- Minister for Employment, Training and Industrial Affairs: Vince Lester

- Minister for Mines and Energy: Martin Tenni

- Minister for Primary Industries: Nev Harper

- Minister for Environment, Conservation and Tourism: Geoff Muntz

- Minister for Family Services and Welfare Housing: Peter McKechnie

2 Goss accused Ahern in November 1988 of dropping these two ministers - Lane and Hinze - from the frontbench for cosmetic reasons, saying to him 'you knocked off Lane and Hinze to suit your PR advice' ( $Q P D$ 1988:vol. 310, p. 2685). 
- Minister for Northern Development, Community Services and Ethnic Affairs: Bob Katter

- Minister for Water Resources and Maritime Services: Don Neal

- Minister for Justice and Attorney-General: Paul Clauson

- Minister for Industry, Small Business, Communications and Technology: Rob Borbidge

- Minister for Local Government and Racing: Jim Randell

- Minister for Corrective Services and Administrative Services: Russell Cooper

- Minister for Health: Leisha Harvey

- Minister for Education, Youth and Sport: Brian Littleproud

The ministry was sworn in on 9 December 1987 and reported to the Parliament when it next met, in March 1988. Interestingly, one of the immediate policy changes Ahern considered introducing was a 'Code of Conduct for Ministers' (based on one drawn up by Dr Llew Edwards years before for Liberal ministers), but the Premier refused to issue the code when he realised that it contained a provision for the registering of the pecuniary interests of MPs' spouses and immediate family (Lane 1993:223). He thought that a step too far, but in 1989 would introduce such a code to provide guidance to his ministers and help protect his government (Accountability of Cabinet Ministers, Register of Interests).

When the Parliament resumed in March 1988, for the first time each of the three main parties had appointed a new leader. After the Premier had formally confirmed his new ministry, Labor announced that it had replaced the old warhorse Nev Warburton with Wayne Goss as Opposition Leader, with Tom Burns remaining his deputy. Labor was also allowed to table a full listing of its 'Shadow Ministry' of 18, which included some of their newer and tertiarytrained members such as Paul Braddy, Pat Comben, Keith De Lacy and David Hamill, as well as those with a background in trade union matters, such as Burns, Terry Mackenroth, Bob Gibbs, Ron McLean, Glen Milliner and Ken Vaughan (see Chapter 13 for the full list). Warburton was not included in Goss's initial frontbench and two others (Anne Warner and Dean Wells) who would also make it into Goss's first ministry were not then included. As Opposition Leader, Goss would take the fight up to the government doing about as much as he possibly could do in very constrained circumstances. The Liberals also informed the House that Bill Knox was no longer the Liberal leader and that Angus Innes would now lead the party with Peter Beard (Lib., Mount Isa) as his deputy. The race was on to 'cut through' to the electorate with a new generation of political leaders, all of whom were inexperienced in leadership. 
Labor's parliamentary tactics consisted of constantly presenting Ahern as weak, indecisive and vacillating, in contrast with the strong image of the former Premier. Labor kept reminding the Parliament that Ahern had been present through the whole of Bjelke-Petersen's Premiership and had seen what had gone on. He was accused of supporting the Springboks emergency, the ban on street marches, the politicisation of the police, the sacking of SEQEB workers and of turning a blind eye to the corruption and conflicts of interest. He had not raised a voice publicly about dodgy contracts going to National Party knights and others close to the government. The three ministers who had served as Police Minister (the current incumbent, Bill Gunn, as well as former ministers Russ Hinze and Bill Glasson), were also accused of covering up the illegal brothel industry and the prostitution rackets, drug running and illegal gambling. Goss marked the first 100 days of the Ahern administration claiming the government had nothing to show for all the changes and was a 'wavering and limp government'. He quoted the former Premier, by now deeply embittered, as saying '[n]either Flo nor I am prepared to prop up a tired old party that does not know where it's going. It's so tragic it would be laughable if it wasn't so sad. The poor chaps are hopeless' (QPD 1988:vol. 307, p. 4859). Dean Wells accused Ahern's minsters of sitting by in cabinet knowing corruption was flourishing, initially calling them a 'gaggle of fawning Tories' but, after Minister Brian Littleproud complained the words were offensive, he swapped them for a 'group of sycophantic crawlers' (QPD 1988:vol. 310, p. 2154).

Ahern's counter-tactic was to try to appear as if he was offering an entirely new agenda, while allowing the Fitzgerald Inquiry to run its full course. He continually stressed the need for greater economic coordination, for public sector reform and some reform to parliamentary procedures (such as the establishment of parliamentary committees scrutinising public accounts and public works). After the October 1987 stock market crash, a new economic agenda was urgent, especially as some 130000 people across Queensland were now unemployed. Ahern accused Goss of trying to 'talk down' the state's economy (a tactic commonly used by governments against their opponents) and would continually allude to Labor's inability to manage the economy of the state, pointing to the disastrous record of other state Labor governments as evidence of chronic mismanagement (Brian Burke and WA Inc., the Cain government in Victoria and the Bannon government in South Australia). A number of senior ministers began to refer to Goss as 'whinging Wayne', who knocked everything. Ahern became increasingly testy with Goss, accusing him of spinning yarns about the government, saying to repeated criticisms that 'I have heard it all before. I have heard it every day....Every day you're at it. It's the same old gramophone record' (QPD 1988:vol. 310, p. 2309). 
Various ministers in the Ahern government also took to presenting numerous and sometimes lengthy ministerial statements at the beginning of a parliamentary sitting day, partly in order to absorb the time allotted to question time so that tough questions could not be asked by the opposition. The Health Minister, Leisha Harvey, was a particularly regular offender. For instance, in 1988, it was not unusual to have up to six separate ministerial statements each read out by the relevant minister (including routine announcements of the pending retirement of senior public servants - such as Sir Leo Hielscher-or detailed financial statements on the federal Medicare agreements; even one ministerial statement on the supposed evil effects of socialist policies on family life!). This tactic, which infuriated the opposition, often reduced question time to a few questions (as on 15 March 1988 when only two questions were permitted before the Speaker called an end to time). It was a strange way to show commitment to parliamentary reform.

\section{Ahern's initial priorities}

The initial bills introduced and passed by the Ahern government were evidence largely of tidying up in the aftermath of the Bjelke-Petersen era. The government pushed through a backlog of legislation including: the Marine Parks Act amendments, an Industry and Commerce Training Bill, a bill to restrict the Carriage of Dangerous Goods by Road, the Auctioneers and Agents Act amendments, a film censorship amendment bill, amendments to the Meat Industry Act, a Libraries and Archives Bill, changes to the Jury Act, amendments to the Performing Arts Trust Act and the Poultry Act, amendments to the Land Act and Gas Act, to industrial relations in the electricity sector and legislation to prevent unconscionable land dealings. It was a most prosaic beginning and early on it was difficult to detect anything that distinguished the new government from its predecessor.

On coming to office, the Ahern government was blitzed with problems and distractions from many quarters: World Heritage listings of rainforests, proposals to list Fraser Island as a World Heritage site, Medicare agreements with the Commonwealth, the escalation in unemployment numbers, ministerial expenses, payouts and entitlements to Bjelke-Petersen, the mooted visit of the Italian porn star Cicciolina (Ilona Staller), allegations of cronyism on government boards, the infamous 'Route $20^{\prime}$ road upgrade and flyover in Brisbane's western suburbs, Ariadne's canal estates, foreign takeovers, prison break-outs and other disturbances in detention centres, prison inmate security, Power beer and the brewing company's use of voluntary employment contracts, whether to introduce random breath testing for motorists, the integrity of the tertiary entrance scheme, daylight saving, in-vitro fertilisation and surrogate 
parenthood, and the redevelopment of the Expo site after the exposition. Some of the material tabled supposedly over the Cicciolina tour was so explicit it had to be expunged from Hansard, but the record of the rest remains.

Interestingly, one of the initial pieces of legislation introduced by the Ahern government (on only its tenth day back in 1988) was the Parliamentary Members' Salaries Bill, which was designed to provide politicians with increased salaries (pegged to the Commonwealth Remuneration Tribunal rather than the Queensland Public Service) and increased superannuation benefits - to both them and their families. Brian Austin, for the government, argued that setting salaries close to the Commonwealth recommendations for remuneration (at $\$ 500$ less) was more 'cost-effective' and independent. It also made parliamentary salaries in Queensland the second-highest in Australia. Notably, the opposition did not oppose the bill when it came back for debate on 19 April. Keith De Lacy said he had 'drawn the short straw, as it were, to put the Opposition's point of view' to the salary increases. He did comment on the irony of politicians voting themselves substantial pay increases outside the general wage-fixing system, when the rest of Australia (under the Accord arrangements) was being asked to exercise wage restraint (QPD 1988:vol. 308, pp. 6012-13).

Brian Austin introduced the Public Service Management and Employment Bill, claiming it provided the most significant reforms to the public service in the past century. The legislation enabled senior staff to be employed on fixed-term contracts, which the government considered flexible but Labor said left the door open to appointments of staff who had the 'right political affiliation' or had personal connections. ${ }^{3}$ This was evidence in Austin's words of 'a new and enlightened government' (QPD 1988:vol. 310, p. 2802).

Russell Cooper had a particularly torrid baptism as the Corrective Services Minister, with prison riots prevalent and escapes by inmates increasing. To provide him with advice on how to proceed, Cooper invited businessman Jim Kennedy to undertake an investigation of the management of the troubled prison system. Kennedy completed a thorough review and presented his interim report in May 1988, with a final report delivered in September 1988 (Commission of Review into Corrective Services in Queensland). The report advocated that a dedicated statutory authority be established to monitor corrective services. The government introduced three integrated pieces of legislation (the Corrective Services [Administration] Bill, a consolidation bill to bring together the Prisons

3 During these debates, the Employment Minister, Vince Lester, was accused of employing 'hopeless people who have connections to him'. Citing a whole list of nepotistic appointments, De Lacy alleged that Lester had employed his shire clerk's daughter as a departmental liaison officer, a pretty model as another, his Capella teacher became a departmental research officer, while 'his girlfriend' became another liaison officer and received an 'unmarked government car'. At this point, Lester raised a point of order claiming he had no girlfriend and asked that that mention be withdrawn (QPD 1988:vol. 308, p. 6240). He did not ask for other claims to be withdrawn but said they were not all accurate. 
Act and the Offenders Probation and Parole Act, and another to deal with other consequential matters) to establish such an authority - the Queensland Corrective Services Commission - a body at arm's length from the government and with its own board and chief executive officer. While initially sceptical of the efficacy of privately operated prisons (in his interim report), by the time he produced the final report, Kennedy was convinced that there should be greater involvement of specialist private sector operators in prison services. Cooper predicted that the Corrective Services Bill would 'allow much-needed reform to Queensland's corrective services system' (QPD 1989:vol. 310, p. 2096). One consequence of these important reforms was the contract to establish Australia's first privately managed prison, which was signed in September 1989 before the change of government. The Borallon Corrective Centre then came into operation in January 1990.

\section{The 'Expo 88' interlude and the transformation of Brisbane}

Despite some initial protests over dislocation, Expo 88 provided the one welcomed interlude of relief for the Ahern government. Staged on Southbank with fully demountable facilities, Expo 88 was opened by the Queen in April 1988. It was a huge celebration of leisure, technology, history, cuisine and different cultures. In a short time, Expo 88 transformed Brisbane from a sleepy country town that almost closed down at weekends to a vibrant metropolis with entirely new social attitudes to leisure and lifestyles, outdoor eating, restaurants and cafes and shopping. Expo changed the ways that Brisbane people thought of and used the city. It transformed the Southbank area, turning the site from a rundown dump of old wharves and rough pubs into an open parkland, with amphitheatres, restaurants, outdoor barbecues, cafes, modern hotels, cultural venues, fairs, water features, a sandy beach and decorative canals. Southbank was redefined as a place dedicated to eating and drinking and hedonistic pursuits. Brisbanites and out-of-town visitors shared an obvious enjoyment of the cultural event, which ran for six months. And for the first time in living memory, the queues of patients presenting to casualty wards in public hospitals evaporated overnight.

Behind the scenes, however, the enthusiasm for Expo did not prevent the Ahern government from offering a series of contracts to construction firms, suppliers and caterers without going to tender. The former Premier's friend Sir Leslie Thiess won a construction contract despite being ranked seventeenth on merit by the Expo authority - a perplexing decision that was 'leaked' by a cabinet minister. Contracts to provide catering were also offered to local business 
identities with close associations to the National Party, such as Ann Garms, who came in for some criticism in the Parliament for alleged 'cronyism'. Opposition members kept claiming that old habits die hard.

The fate of the Southbank site after Expo 88 was not, however, determined and aroused much politicking. The resulting parklands, public infrastructure and community-based land use came about more by accident than design. Continued public access to Southbank as a leisure precinct was mostly a product of popular pressure and outrage at mega-scale commercial proposals from private interests, with pressure also being applied through the Parliament. Business associates close to the government (such as River City 2000) talked about claiming the site for private development, locating canal estates for executives and building rows of high-rise apartments overlooking the river and CBD. They wanted to clear away the heritage buildings such as the Plough Inn, Greyscourt (Collins Place) or the Allgas Energy building, some of which were then looking a little derelict. The government had announced with some pride that a casino and a 'world trade centre' would be built on the site. The political problem for the government, however, was that Brisbane people now felt the site was 'theirs' and in future should be reserved for public uses (including a parkland setting) to allow a social and cultural precinct to emerge. Denver Beanland, with a background in Brisbane local government, pushed for better planning and for less intensity in the types of commercial development that were being proposed. Finally, on 13 April 1989, after 'six untidy months of political dawdling, political indecision and political cronyism', the Southbank Corporation Bill was introduced to redevelop the site in a sensitive manner ( $Q P D$ 1989:vol. 312, p. 5019).

\section{The man with the plan - but incapable of delivering}

Ahern was keen to distinguish his government from his immediate predecessor's and used economic planning as a way to indicate to the business community and the electorate that he was making a new start and was addressing some of the shortcomings of the former regime. He had introduced some modernising legislation while he was the Minister for Primary Industries, relying on a process of seeking good advice and then providing political backing. This was to be his approach to economic planning and to public sector reform (see Wanna 1995; Reynolds 2002).

Ahern had committed himself to making orchestrated economic planning the leitmotiv of his government, insisting from the outset that 'economic development will remain a keynote of this Government. The centre-piece will be a State economic development strategy' (QPD 1987:vol. 307, p. 4805). The 
political difficulty for him was how to craft a document that provided a coherent strategy without being too critical of the previous administration. He began to criticise, sometimes obliquely, the Bjelke-Petersen government's fascination with ad hoc developmentalism, its obsession with the agricultural industries and absence of any effective planning strategies for growth or to respond to economic challenges. The Queensland economy was still heavily dependent on mining, the processing of agricultural products, tourism and a diverse services sector, but it was not sufficiently diversifying or embracing new economic opportunities.

Ahern tried to mobilise commitment to his own agenda, calling it a 'vision of excellence' - an overarching vision meant to provide a guide to cabinet decision making and offer direction to the local business community. He was personally committed to the notion of embracing a vision but appeared less concerned with the substantive content of the strategy. It was important the government had a vision to show; what it should contain was left to the experts. The driving force behind the strategy was Doug Rowell, Ahern's senior economic adviser and head of the government's Economic Planning Committee (consisting of seven top businessmen), who convinced the Premier of the need for a comprehensive strategy document. Rather than produce an in-house document, the government chose to use external consultants to assess the strengths and weakness of the economy and recommend future planning priorities. Two consulting firms (Stanford Research and Strategies Proprietary Limited) were asked to produce a report from which the strategy would be devised. They were paid $\$ 400000$ and delivered a secret report, Building on Strength, in late 1988, relying heavily on statistical analysis. The report contained some ideas for future growth but also contained some politically sensitive comments - such as that unemployment remained a problem, real incomes were declining and job growth occurred in the low-wage sector. It reflected poorly on the previous administration and accordingly was never released publicly (Wanna 1995:128).

Instead, a more cosmetically appealing, glossy strategy, Quality QueenslandBuilding on Strength: A vision and strategy for achievement, was released in December 1988. It appeared as if the committee could not quite agree on the main message - or opted to include as many buzzwords in the document as possible. It committed the government to adopting a 'market facilitation' approach, based on liberalisation, infrastructural provision, public sector enhancement and a new commitment to 'quality' to provide a powerful focus for future innovation (indeed, a professorship in 'quality' was sponsored at one of the universities, although no-one really knew what that meant). Ten areas were identified as part of an implementation program under headings of: the provision of economic infrastructure, the development of human resources, finance availability, commercialisation of technologies, entrepreneurship, low-tax attractiveness, 
regional development, natural resource management, developing international business links and the adoption of a strategic approach by government itself. Two new advisory committees were formalised - the Economic Planning Committee and a new private sector body designed to have strategic input, the Private Sector Economic Advisory Committee (PRISEAC) - and weekly announcements were promised. A bill to create 'free enterprise zones' in the state (initially around Cairns but later extended to most of the state!) was introduced as a way of luring cheaper manufacturing producers and technology-based firms (but was labelled as 'grossly fraudulent' by Casey). For a while, the government packaged good economic news items, such as when the Industries Minister, Rob Borbidge, announced that under Ahern more than 50 new companies had been attracted to the state (QPD 1988:vol. 309, p. 93). These were, however, not to last.

To push the strategic approach within government, Ahern established an integrated system of cabinet committees, intended to provide better coordination and consider policy in detail before bringing proposals forward for final cabinet consideration. He established committees overseeing economic planning, social planning, technology and infrastructural planning. The cabinet committees soon struck problems, however, as they were not essentially decision-making bodies, so ministers lost interest, and Ahern's ministers were not used to such collegial forms of policy development. His ministers did not share Ahern's obvious enthusiasm for his strategic architecture. After a few months, ministers began to waver in their attendance, with some actively boycotting them, and the weekly announcements faded away. Public reaction to the strategy was lukewarm, if not negative in some quarters of the National Party. Doug Rowell was dismissed in early 1989, attempting to resuscitate the Quality Queensland strategy by employing a PR consultant on $\$ 2500$ a day to sell the strategy to government departments and the local business community. After 15 months of effort, the 'strategy' could not be delivered; it all seemed an expensive public relations exercise.

Ahern attempted to link the strategy with his first budget, in September 1988, claiming the budget was a 'document of confidence that charts a course to take the fastest growing State in Australia into the nineties and through to the new century', but the spending measures taken were largely the traditional ones of more police, more hospital staff, more prison officers and spending on TAFE to assist youth training ( $Q P D$ 1988:vol. 309, p. 727). To criticisms that the presentation of information in the new budget documents was 'unfathomable' and 'confuse[s] and obfuscate[s] much more than they make clear', Goss argued the annual economic statement was 'a replay of [Ahern's] predecessor's' budgets; 
and, accusing the government of being 'lethargic', said: 'if Ahern was a doctor he would have no patient left. He dithers for so long in his diagnosis that he fails to notice that in the meantime his patient has died' (QPD 1988:vol. 309, p. 771).

One politically significant aspect to emerge from the economic deliberations was, however, the contentious issue of daylight saving. Brisbane and Gold Coast businesses had long been lobbying for the state or the south-eastern quarter to go over to summer time in step with New South Wales, and used the opportunity of the strategic planning process to insist the government comply with their wishes. Ahern had some sympathy for their regional concerns (especially those businesses with interstate connections or engaged in tourism) but wavered in his support, knowing the idea of daylight saving was anathema to the bush constituency. His on-again, off-again commitment to daylight saving would run through to late 1989, when he announced a further trial of the idea; but by then his Premiership was under siege and the issue merely inflamed opposition to his leadership from among his party colleagues.

\section{The Barambah by-election: the prized seat falls to the Citizen's Electoral Council}

The resignation of Sir Joh Bjelke-Petersen in the super-safe seat of Barambah was an early test for the new administration. The by-election was arranged for 16 April 1988. It was not expected that the government would lose the seat, but in a display of outright defiance the voters elected Trevor Perrett, a breakaway candidate from the far-right Citizen's Electoral Council (CEC), a conservative populist movement influenced by the US conspiracy theorist Lyndon La Rouche. The result highlighted the enormous volatility of the times within the conservative side of politics and was a slap in the face to the Nationals, who regarded Barambah as part of their heartland.

Only four candidates contested the election: the dour and earnest Shire President of Kingaroy, Warren Truss, stood for the Nationals; John Lang for the ALP; Kevin Polzin as a 'New Country Party' candidate; and Trevor Perrett, a former National and councillor with the Cattlemen's Union of Australia, but standing as a CEC representative. In effect, three conservative candidates vied to take the seat, with much of the local politics being about the need to recreate a new conservative movement closer to the people to replace the older, more compromised party. While Truss received 41.27 per cent of the primary vote, Perrett, coming from nowhere, won a massive 31.59 per cent on the first ballot; Labor's Lang captured just 17.65 per cent, while Polzin trailed with just 9.48 per cent. When the preferences of the two lowest candidates were distributed, there was a strong anti-National drift apparent. Perrett won the seat comfortably on 
a two-party preferred basis, receiving 54.11 per cent support to the Nationals' 45.89 per cent. Interestingly, a massive 89 per cent of Labor's preferences went to the CEC candidate rather than to their traditional enemy, the Nationals. In Perrett's maiden speech, he paid tribute to Bjelke-Petersen, saying he and Flo were 'institutions in my area' (QPD 1988:vol. 309, p. 191). After eight months in the Parliament, Perrett ceased being a CEC member and rejoined the Nationals in December 1988, restoring Ahern's numbers in the Chamber for a few months before the Speaker, Lin Powell, resigned and left the Parliament.

\section{The beginning of the Fitzgerald fallout in 1988: a 'tiger by the tail'}

As the Fitzgerald investigators began to probe and public hearings began from late July 1987, it was clear that the police had three significant sets of problems: endemic corruption in certain sections of the organisation; politicisation at the senior levels and among some specialist units such as the Special Branch; and growing doubts as to the capacity of the police to operate as an effective modern force. The Fitzgerald team of 'untouchables' would investigate all three dimensions of these problems. More importantly, the royal commission was provided with the mandate, the resources and the wherewithal to expose the full extent of corruption. The original terms of reference were extended on two further occasions to broaden its powers (24 June 1987 and 25 August 1988).

It at first appeared as though senior police would remain tight-lipped and wait for the initial enthusiasm of the inquiry to dissipate. As Fitzgerald (1989:3) himself noted, the 'general expectation was that the inquiry would be brief and ineffectual, and was primarily a device to ease the political pressure on the Government'. The Commissioner of Police, Terry Lewis, the first witness to give evidence at the public hearings, spoke of the difficulties police faced in enforcing the law against illegal brothel operators, although he evaded the issues of kickbacks, bribery and graft. Police hopes of a cover-up were, however, soon dashed. Under the intense spotlight of forensic investigators and media scrutiny, the police conspiracy of silence broke down. Assistant Commissioner, Graeme Parker, when confronted with evidence of his own corruption in a car park, turned crown witness and provided a detailed confession of the full extent of the web of corruption. He named Lewis as an officer who regularly accepted bribes. It was not just a case of a few 'rotten apples' that had fallen to temptation; rather what was discovered was an organised crime ring, established and nurtured within the police force, intent on profiteering from percentage kickbacks from illegal activities, extending to the very top levels of the force and enjoying political protection. 
As the nefarious web began to unravel, a number of senior police chose to resign, while others were stood down pending further investigations into their conduct. Those officers resigning were doing so in order to be entitled to claim their superannuation payments, rather than risk being charged with official misconduct (and forfeiting their pensions). Wayne Goss indicated in March 1988 that in the first seven months of the inquiry, one deputy commissioner and one assistant commissioner, nine superintendents and 12 inspectors had all taken early retirement or resigned from the force. He asked why the government was not closing the door on corrupt police who were availing themselves of this loophole. He called for immediate legislation to be introduced to the Parliament to prevent such payouts to corrupt police. The government did finally respond by introducing two pieces of legislation: the first in April 1988 preventing police who faced criminal proceedings from benefiting from their superannuation, but only after many police had resigned under the old arrangements; and the other in August 1988 seeking to recover superannuation benefits paid out to any public official who was later convicted of corruption or misconduct. Ahern confirmed in September 1988 that 78 police had voluntarily retired, 97 had resigned, four had been dismissed and one had been discharged since July 1987 (QPD 1988:vol. 309, p. 1037).

When Lewis was named adversely, he was at first stood down, in September 1987, pending further inquiries. Again, Goss wanted to know why the government had agreed to make a superannuation lump-sum payment despite knowing of the allegations. Lewis denied any involvement but mounting evidence of his wrongdoing was forthcoming. The problems for Lewis intensified in a most dramatic way, when his former 'bagman', Jack Herbert (the collector and distributor of the ill-gotten bribes), was arrested and extradited to Queensland (from the United Kingdom, to where he had fled). Herbert was an ex-policeman who had spent much of his career in the Licensing Branch and 'collecting' for Lewis, who had himself been a former 'bagman' for Commissioner Frank Bischof in the 1950-60s. Once Herbert was given conditional indemnity, he cooperated and provided chapter and verse on the entire operation. His evidence 'set beyond doubt the existence of a well-organized network of corruption which had existed and flourished for decades' (Fitzgerald 1989:12). The full extent of the so-called 'Joke' was revealed: detailed records of corrupt payments and bribes from diverse illegal activities - all duly recorded in ledgers - and with corrupt payments according to a pre-agreed formula going to senior police (generally appointed to the Licensing Branch but also crucially including the Commissioner and some of his deputies). How far these payments went was the subject of much speculation, with many believing they went as far as the former Premier. 
Police Commissioner Lewis remained suspended during 1987 and early 1988. Herbert's recorded and hearsay evidence against him was damning. His own diaries also indicated the breadth of his misconduct. As Tom Burns recounted in the House in August 1988: 'hon. members know the commissioner fixed ministerial appointments, transferred crooked cops and interfered in [electoral] redistributions. Today we heard that he took bribes. Police Ministers did nothing when told about corrupt cops by their top legal advisers' (QPD 1988:vol. 309, p. 352). Bill Gunn told the House in September 1988 that as Police Minister, and after taking legal advice, he had written a letter to Lewis asking him to show cause within seven days why he should not be dismissed for his alleged corrupt activities, and that the letter was hand delivered and received by Lewis in the presence of his daughter. Months of indecision or contention then transpired before the Parliament was presented with a bill to dismiss the Police Commissioner, on 18 April 1989, which was passed through all three stages in one sitting day with only the Liberals objecting to the haste of the deliberation. Lewis was then dismissed. Later, in 1989, he was charged with 23 counts of corruption, perjury and forgery, found guilty and given a 14-year sentence of which he served 10 and a half years, and had his knighthood rescinded in 1993. He continued to maintain his innocence.

As sensational revelations cascaded out of the inquiry about police involvement in organised crime, it appeared that the National Party was in a quandary about how to react or reposition itself. After all, the government had presided over the system and at best had turned a blind eye to the activities now being exposed. Equally sensationally, first Ahern and then Gunn accused Bjelke-Petersen of trying to close down the commission before he was deposed. Although BjelkePetersen would later deny in the Parliament and at the Fitzgerald hearings that he had tried to close down the inquiry, Ahern insisted in the Parliament that 'senior counsel was summoned into the presence of the former Premier and was instructed to prepare papers for the termination of the commission of inquiry. That is not an unsubstantiated allegation at all. It is true. It happened. In due course, those matters will surface' (QPD 1988:vol. 308, p. 5901). Gunn also made a ministerial statement claiming Bjelke-Petersen had twice attempted to interfere with the inquiry. Gunn said that although the former Premier had been initially 'supportive of an inquiry', the former Premier had said shortly after (on 17 May 1987): 'I'm greatly concerned about this inquiry. I don't think it's a good idea at all'. He continued: 'Well you've got a tiger by the tail and it'll end up biting you.' Gunn apparently said in reply 'it would bite us if we did not do anything about it', and warned that if Bjelke-Petersen tried to cancel the inquiry he would resign. ${ }^{4}$ The second attempt to curtail the commission,

4 Goss questioned Gunn in April about whether the former Premier had tried to take over the Police portfolio in order to end the inquiry (following newspaper reports to this effect), but Gunn merely referred the Opposition Leader back to his earlier ministerial statement. 
according to Gunn, took place in August when he was absent from Brisbane and the former Premier had 'summonsed a Queen's Counsel to inquire of ways in which the Fitzgerald inquiry may be shortened or expedited in some way'. When Gunn returned to Brisbane, he saw the QC, who confirmed 'what had transpired', saying that Bjelke-Petersen had requested an Executive Council minute be prepared, but that the QC had advised against 'taking any action which shortened or in any way interfered with the inquiry'. Gunn's account corroborated Ahern's version of events, with Gunn indicating he had 'made this statement to ensure that hon. members as well as the public are informed of the true position' (QPD 1988:vol. 308, pp. 5955-6). ${ }^{5}$

On virtually every sitting day of parliament, Labor asked questions about the progress of the Fitzgerald investigations and what the government was doing in response and what it planned to do. Three senior ministers (Ahern, Gunn and Clauson) all gave assurances that the inquiry had the government's full support, that additional resources would be provided, that a deputy commissioner was warranted, that the inquiry's terms of reference could be widened at the commissioner's request and that cabinet confidentiality would be waived to allow ministers and former ministers to provide evidence (releasing them from the oaths of secrecy to the extent necessary to answer questions put by the commission). Some other Nationals, however, seemed concerned primarily with the cost of the Fitzgerald Inquiry. After six months of inquiry, Max Menzel (NP, Mulgrave, and a supporter of Lane) asked a hostile multipart question to the Premier. He asked what was the total cost of the inquiry to date, how much had Commissioner Fitzgerald been paid, how much had been spent on legal counsel, how many people had been charged and how did the release of Lewis's diaries contribute to investigating brothels and illegal casinos? He stated that the legal community was 'receiving a great financial boost to its coffers' and was trying to 'keep the inquiry going at taxpayers' expense with no results'. The Premier confirmed that \$2 976217.93 had been spent on the inquiry to 22 March, that $\$ 433500$ had been paid to Fitzgerald, more than \$1 million had been spent on legal counsel, no criminal charges had yet been made because the commission had yet to report, the diaries were accepted as evidence and he denied the inquiry was being unnecessarily extended. Ahern confirmed, however, that

[t]he inquiry being conducted by Mr Fitzgerald, QC, has the full support of the Queensland Government. All necessary expenses to enable the

\footnotetext{
5 The Speaker, Lin Powell, on 21 April 1988, said he had received a communication from 'somebody so aggrieved that I must bring it to the attention of the Parliament'. The letter was from Bjelke-Petersen's solicitors and claimed 'our client denies that during his period of office... he took any action or made any attempt to terminate the Fitzgerald Inquiry... Our client has further instructed us that the statement that he is under investigation by the Fitzgerald Inquiry is, to the best of his knowledge, untrue...Finally, the changes in the Cabinet which he initiated shortly before his retirement were wholly unrelated to the Fitzgerald Inquiry' (QPD 1988:vol. 308, p. 6244).
} 
inquiry to successfully complete its investigations will be met by the Government. This is a small price to pay to ensure honesty in all levels of government and the police force. It is quite incorrect to state that the inquiry has produced no results. (QPD 1988:vol. 308, p. 5638)

Ahern was between a rock and a hard place. He knew that the inquiry's findings were severely damaging his government, perhaps terminally, but he continued to defend the need for a comprehensive exposé of police corruption and of the imperative of rooting out the culture of corruption in the force. He was also trying, meanwhile, to maintain the support of his ministers and backbench for the inquiry. It was like holding a blowtorch to their heads. Maintaining the support of his party to embrace the proposed remedies would prove to be a much more daunting task and would ultimately cost him his office.

In order to counter the impression that he would not follow through with the spirit of the Fitzgerald reforms and implement the systemic recommendations that were made, Ahern promised in early 1989 to implement all the Fitzgerald recommendations 'lock, stock and barrel'. He also managed to extract the same commitment from the other political leaders: Labor's Wayne Goss and the Liberals' Angus Innes, who were, if truth be known, a little lukewarm to this suggestion. Both tried to quibble rather than embrace a cross-party consensus over the future politics of how to reform the criminal justice system. It was a courageous commitment promoted by the Premier and supported by all sidesespecially when the full extent of Fitzgerald's recommendations was not then known. Ahern's promise was given as a genuine commitment to reform the system and root out corruption once and for all. The sometimes hapless Mike Ahern deserves the abiding admiration of Queenslanders for not listening to the backsliders and opportunists around him, politically protecting the inquiry and seeing the process through to its final conclusion. It was the mark of a true political statesman. It showed he was not like earlier premiers whose instinct was to cover up any suggestion of corruption in the ranks.

After making allegations for decades about police corruption in the Parliament (dating back to the era of Commissioner Frank Bischof) and being brushed aside, Labor now had concrete evidence of systemic misconduct. The many allegations made by Kev Hooper between the late 1970s and early 1980s (leaked to him by police disturbed by the stench of corruption and in one case by a former Police Minister, Max Hodges, appalled by mounting evidence but feeling unable to act himself) were subsequently tendered in evidence to the commission. For the first time in many years, the Labor opposition looked as though it had a real issue with which to inflict damage on the government - a government increasingly reeling as the revelations mounted. As Goss and his team (including advisers 
Kevin Rudd and Glyn Davis) imposed an intellectual discipline on its alternative policy responses, Labor also sounded like it had real solutions to the enormous complexity of the problems at hand.

\section{Exit Russ Hinze and Don Lane: more than a whiff of corruption}

Expelled from the ministry but now causing mischief on the backbench and with the media, Russ Hinze was feeling the heat of the Fitzgerald investigations, for taking inducements and bribes in exchange for favourable government decisions. Earlier allegations of his involvement in SP bookmaking were unable to be proven. Hinze had by this stage fallen out badly with Ahern, whom he accused of dumping him unnecessarily. When Hinze began sulking and refusing to attend the House, Goss was quick to ask a question without notice of the Premier:

In view of the unacceptable behaviour of Mr Hinze, a member of this House in (1) undermining, by public criticism, the work of the Fitzgerald inquiry and (2) failing to fulfil his obligations as a member of this House, I ask: is the Premier prepared to exercise his authority as Leader of the National Party Government and advise Mr Hinze that his conduct is unacceptable in terms of somebody who seeks to be a Minister and that, unless he ceases his criticism of the Fitzgerald inquiry forthwith and immediately attends the sittings of this Parliament, the Premier is not prepared to reappoint Mr Hinze to the Ministry, irrespective of whether he is cleared by the Fitzgerald inquiry? (QPD 1988:vol. 307, p. 5047)

While the Premier accused Goss of 'posturing on this issue', he did acknowledge that 'a former senior Minister in this Government has been named before the Fitzgerald inquiry and this has created a substantial problem for this Government' (QPD 1988:vol. 307, p. 5047). He added that he did not need the assistance of the Opposition Leader to deal with this matter.

Hinze made many public attacks on Commissioner Fitzgerald and the inquiry staff, seemingly believing that attack was the best form of defence. In 1988, he was forced to make a formal apology to the commission, after being threatened with contempt unless he complied. The former 'Minister for Everything' did not survive much longer and resigned from the Parliament on 25 May 1988 (and the Parliament was officially informed in August 1988). Hinze appeared before the inquiry in November 1988 to give evidence and subsequently faced charges for receiving money corruptly. He faced a total of eight counts for receiving bribes including from the property developer George Herscu. Hinze died in 
June 1991 before he could be brought to trial, while his business partner and associate, Herscu, was charged in 1990 and found guilty of bribing Hinze, and was given a five-year jail sentence.

Don Lane was also mentioned in the Fitzgerald hearings and was later questioned by the commission about his financial affairs and allegations he had been involved in graft and paid bribes from illegal brothel owners. Lane seemed to adopt a strategy of 'scuttling the entire ship', implying that if he was going down then so too was everyone else. He told investigators that large amounts of unexplained additional income had come from misusing his ministerial expenses, but claimed such practices were widespread in the ministry. Newspaper headlines proclaimed 'Lane exposes cabinet rorts'. When Goss asked whether the Premier would establish a second commission of inquiry to investigate ministerial expenses because of the 'theft from the public purse', Ahern confidently replied that his actions in leaving Lane out of the cabinet in December 1987 had been vindicated and that Lane's admission merely confirmed his suspicions. Ahern also stated that Lane was making up 'untruths' as a 'defence', to which Goss replied: 'what purpose does that serve? It is still an admission of criminal conduct, is it not?' (QPD 1988:vol. 310, p. 2406). Lane also named Geoff Muntz and Martin Tenni; and Norm Lee, Bill Knox and Neil Turner were also implicated (although they all defended themselves against any allegations). After providing incriminating evidence against himself and others in the government, Lane resigned from the Parliament on 30 January 1989. He would later stand trial and be convicted of falsifying his expense claims and sentenced to 12 months' jail. Lane managed to have a final personal statement tabled in the Parliament (by Max Menzel), in which he claimed he was largely innocent and that 'there were a few withdrawals to correspond with my claimed expenditure for tax purposes of my parliamentary electorate and other allowances'. He claimed the 'humiliation and public scorn that my family and I have suffered... has been devastating. In addition it has been both abhorrent and distressing for me to have had to name former colleagues.' After listing his achievements as an MP and minister, he concluded: 'I submit than any fair or balanced assessment of my performance from 1971 to 1988 should take into consideration this abbreviated account of achievements which have created real benefits for Queensland and for Queenslanders' (QPD 1989:vol. 311, pp. 3753-4).

Questions about the inappropriate use of ministerial expenses and departmental funds continued to be raised in the House against some of Ahern's ministers, such as Leisha Harvey, who was accused of using departmental funds for personal purposes. It was also claimed that Harvey (whose inner-city seat of Greenslopes 
was five minutes from the Parliament) had moved to 'live permanently in the Parliamentary Annexe'. In denying she lived there permanently, she responded that

every Minister is entitled to accommodation in the Parliamentary Annexe, and on occasions I, too, stay at the Annexe, usually when Parliament sits late at night, when I have deputations late at night, attend late-night functions in the city, or have an early in the start in the city the following day. (QPD 1988:vol. 309, p. 1390)

Harvey would not be the first minister, or the last, to be accused of moving into the annexe to reduce their living costs. In November 1988, however, Goss challenged Ahern in a dispute over ministerial accountability about Harvey's dubious record to date, claiming 'I challenge the Premier to deny that the use of departmental funds by the Minister for Health is standard practice for the Ministry, including himself. The silence is golden. It is the corks in the ears, the blindfold over the eyes and the plaster over the mouth again' (QPD 1988:vol. 310, p. 2310). By late 1988, Harvey was being accused constantly of using departmental funds for personal requirements and was quickly becoming a liability. Day after day in the Parliament, a barrage of questions was asked about ministerial expenses and the claiming of inflated (or fictitious) cash advances by ministers (and sometimes just poor record keeping). In the end, Bill Gunn asked the head of the Premier's Department, Eric Finger, to review the procedures, while Ahern belatedly introduced his pecuniary interest and code of conduct for ministers in April 1989, which publicly disclosed the interests of ministers but kept the interests of family members on a confidential register. While the initial code applied to ministers, a second one accompanying it applied to all parliamentarians, as Ahern argued that there was 'no justifiable or substantive reason for limiting such declarations solely to the Ministry' (QPD 1989:vol. 312, pp. 4700, 4939). Goss noted that it had taken the Premier a year to deliver and that it was further evidence of dithering. Suddenly, however, many ordinary members were now worried their names would be tarnished.

\section{The South Coast and Merthyr by-elections: both body blows to Labor}

With the resignations of the former ministers - first, Russ Hinze, and then Don Lane-from the Parliament, two by-elections were required in 1988-89. Both occasions should have provided a big boost to Labor, in the context of the Fitzgerald revelations and a sense of general disarray within government, but both by-elections produced conservative victories, with the Nationals holding their Gold Coast seat against a serious challenge from the Liberals, and the 
Liberals beating off the Nationals to retake their Brisbane seat lost when Lane defected. Both by-elections were devastating for Labor, which suffered a major reversal on the South Coast and could only manage to hold its vote steady at the Merthyr poll.

The by-election for South Coast was held on 28 August 1988. Ten candidates contested the seat. Judy Gamin, a local businesswoman and regional vicepresident for the Nationals, stood against the Liberals' Bob Quinn, a local teacher and director of the Gold Coast Educational Centre. Labor ran with Dallas Watson. The maverick conservative and former Nationals MP (for Callide) Lindsay Hartwig stood as a CEC representative, and Bruce Whiteside, an anti-Japanese foreign investment campaigner, ran as a so-called 'Australian independent'. One Democrat candidate stood and four other independents also ran, one of whom, Philip Black, was an expelled former National who campaigned with the endorsement of Joh Bjelke-Petersen.

The primary vote produced a three-way split, with the Nationals' Gamin narrowly leading Quinn by 30.43 per cent to 28.89 per cent. Labor trailed in third place with just 22.85 per cent; it had weathered a 7.42 swing against it on the primary vote. The other seven candidates received only handfuls of votes, with the exception of Black, who captured 7.92 per cent. Although Quinn managed to close the gap on his National challenger, Gamin hung on and won the seat by just 144 votes. With most of the independents being conservative, and Labor and Democrat preferences going towards the Nationals' candidate (55 per cent of ALP preferences went to Gamin), the National candidate took the seat with 50.38 per cent to the Liberals' 49.62 per cent. Gamin became only the eleventh woman ever to be elected to the Assembly. When she presented her first speech, she avoided any mention of Hinze, but reported how horrified the people of the South Coast were at the sordid evidence mounting up from the Fitzgerald Inquiry, saying she was 'totally behind the Ahern administration in its resolve to fully implement whatever recommendations are made by Commissioner Fitzgerald' (QPD 1988:vol. 309, p. 613).

The Merthyr by-election was called for 13 May 1989. The election took place not just in the aftermath of the Fitzgerald hearings; this electorate, based on the trendy inner-city areas of New Farm and Fortitude Valley, was the epicentre of much of the organised crime and illegal brothels. Eight candidates chose to contest the seat, representing a broad mix of society and a range of talents. Four stood as independents. Crime boss Gerry Bellino, who had been named in the terms of reference establishing the Fitzgerald Inquiry, nominated as a mark of defiance. He was accompanied by Nigel Powell, a former undercover policeman who had contributed to the 'Moonlight State' program and had been a witness to the inquiry. Also standing for notoriety was Tanya Wilde, the first transsexual political candidate to run for office. Another local independent, 
I. Ciadamidaro, completed the set. All the main parties (the Liberals, Labor, the Nationals and Democrats) contested the seat. Santo Santoro was a wellknown local Liberal identity and branch activist, who had narrowly lost to Lane in 1986. He was challenged by Barbara Dawson from the Labor Party and by Betty Byrne-Henderson, a local businesswoman, who attempted to retain the Nationals' short-term hold on the seat. The Democrat candidate was John Brown.

The campaign naturally highlighted the issues of corruption and misconduct, but other issues crept in - such as local facilities and violence against homosexuals. In the final vote, Wilde received 3.14 per cent of the vote and out-polled Brown, Bellino and the last independent. Powell received a respectable 7.46 per cent of the vote. The Nationals lost half their vote, dropping to 16.02 per cent. Labor scored 32.73 (a gain of only 0.23 per cent). The Liberals were the biggest winners, polling 35.91 per cent in their old seat. On a two-party preferred vote, Santoro took the seat for the Liberals by 56.95 per cent to Labor's 43.05 per cent. To disguise the ignominy for Labor, the assistant state secretary, Wayne Swan, attempted to distract media criticism by trying to talk of a 'three-party preferred' outcome - a nonsense concept. When Bellino lost his deposit, he announced 'it's been a long, hard campaign, and I have come to the conclusion that I'd rather be called a crime boss than a hypocritical politician' (CourierMail, 15 May 1989).

\section{Ahern refreshes his ministry}

In early 1989, after merely a year in office, Ahern chose to refresh his cabinet. Keeping the ministry at 18, he appointed himself (in addition to his previous responsibilities) as Minister for State Development. He dropped the beleaguered Leisha Harvey (increasingly the target of opposition attacks) from the cabinet and promoted the newcomer Craig Sherrin. If changes of personnel were minimal, up to nine ministers were, however, reshuffled into other portfolios or had their responsibilities extensively restructured by Ahern. Ivan Gibbs went from Transport to Health; Peter McKechnie went from Family Services to Transport, and Sherrin was appointed to the Family Services portfolio. Responsibility for Police was moved from Bill Gunn to Russell Cooper, who was also given Emergency Services and Administrative Services. The job of overseeing Corrective Services went to the Attorney-General, Paul Clauson, while Tourism was added to Rob Borbidge's duties. Ahern's second ministry consisted of

- Premier, Treasurer and Minister for State Development and the Arts: Mike Ahern 
- Deputy Premier and Minister for Public Works, Housing and Main Roads: Bill Gunn

- Minister for Health: Ivan Gibbs

- Minister for Finance and Minister Assisting the Premier and Treasurer (and Leader of the House): Brian Austin

- Minister for Land Management: Bill Glasson

- Minister for Employment, Training and Industrial Affairs: Vince Lester

- Minister for Mines and Energy: Martin Tenni

- Minister for Primary Industries: Nev Harper

- Minister for Environment, Conservation and Tourism: Geoff Muntz

- Minister for Transport: Peter McKechnie

- Minister for Community Services and Ethnic Affairs: Bob Katter

- Minister for Water Resources and Maritime Services: Don Neal

- Minister for Justice and Attorney-General: Paul Clauson

- Minister for Industry, Small Business, Technology and Tourism: Rob Borbidge

- Minister for Local Government and Racing: Jim Randell

- Minister for Police, and Minister for Emergency Services, and Administrative Services: Russell Cooper

- Minister for Education, Youth and Sport: Brian Littleproud

- Minister for Family Services: Craig Sherrin

The second Ahern ministry survived unchanged for just seven months before being restructured again in the context of a deepening political crisis.

\section{The tiger that roared: the quest for political accountability}

In early 1989, Tony Fitzgerald was by now ensconced amid realms of transcripts, interviews, evidence, exhibits and submissions the commission had gathered or received, writing up his final report for presentation to the government and the Parliament. The commission's continuing inquiries were being overseen by Fitzgerald's deputies, Judge Patsy Wolfe and the newly appointed Gary Crooke QC, to enable Fitzgerald to pay full attention to the crafting of the final report. The need for continuing and further investigations was soon recognised and an 'implementation team' was considered essential and would be recommended by the commissioner when he delivered his report. The implementation team 
was established on 6 July 1989 and headed by Peter Forster, who was charged with assisting the reform process and continuing the investigations begun by Fitzgerald but not yet concluded (QPD 1989:vol. 321, p. 5555).

Fitzgerald presented the final report to Premier Ahern and the Police Minister, Russell Cooper, on 3 July 1989. It truly was a bombshell. The report noted the commission had held public sittings over 238 days, it had questioned 339 witnesses and had amassed transcripts totalling 21504 pages and exhibits totalling 2304. The commission had existed for more than 13 months and resulted in a final report of 388 pages. Its major recommendations were for the Parliament to establish two continuing commissions. The first commission was to focus on criminal justice matters (to monitor, review, coordinate and initiate reform in the administration of criminal justice and to continue the investigations emanating from the Fitzgerald Inquiry and discharge those functions not appropriate to be carried out by the police department: civilian oversight, dealing with issues of misconduct and even responsibility for areas of organised crime). The other continuing commission was to specialise in electoral and administrative law and its main ambit would be to 'provide an independent and comprehensive review of administrative and electoral laws and processes' (see Prasser et al. 1990).

The emphasis Fitzgerald placed on electoral reform was something of a surprise, given the terms of reference of the inquiry, but he located administrative accountability within a broader context of political accountability to the Parliament and the electorate. The submission made to the inquiry by the pressure group Citizens For Democracy was particularly persuasive and sections of the final report attested to their influence on the commission. Significantly, these two standing commissions would both report directly to multi-party parliamentary select committees with relevant mandates and expertise.

Although Fitzgerald (1989:127) did not specifically recommend electoral reform or advocate for any proposed changes to the electoral system, he stated in his report:

A fundamental tenet of the established system of parliamentary democracy is that public opinion is given effect by regular, free, fair elections following open debate. A Government in our political system which achieves office by means other than free and fair elections lacks legitimate political authority over that system. This must affect the ability of Parliament to play its proper role in the way referred to in this report. The point has already been made that the institutional culture of public administration risks degeneration if, for any reason, a Government's activities ceased to be moderated by concern at the possibility of losing power. 
The fairness of the electoral process in Queensland is widely questioned. The concerns which are most often stated focus broadly upon the electoral boundaries, which are seen as distorted in favour of the present Government, so as to allow it to retain power with minority support. Irrespective of the correctness or otherwise of this view, the dissatisfaction which is expressed is magnified by the system under which electoral boundaries are determined. It has not always been obvious that the Electoral Commissioners were independent of the Government. Submissions and other material upon which the Commissioners have proceeded have been secret. The Commissioners did not report to Parliament, but to the Premier.

There is a vital need for the existing electoral boundaries to be examined by an open, independent inquiry as a first step in the rehabilitation of social cohesion, public accountability and respect for authority. Such an inquiry should be conducted by a person or group of people of undoubted integrity whose judgement will be acceptable to all political parties and the general community. It should be allowed to do its task unfettered by predetermined restrictions.

The inquiry must be permitted to reconsider basic assumptions which shape the present electoral boundaries, such as whether there is a genuine justification for a zonal system. If it finds that there is a justification for the present system, it should assess the appropriate zones and what, if any, special considerations ought to apply in different zones. The inquiry must be totally open with public access to the evidence and submissions received by it. It should be given appropriate staff and adequate resources to fulfil its task and it should report directly to Parliament.

In short, Fitzgerald's report delivered the most trenchant critique of the executive's interference in electoral matters, in cold, dispassionate terms and in words that could not easily be discounted. The clarion call to re-evaluate the electoral system was a bolt from the blue. People had expected recommendations about police procedural reform, but the emphasis on political accountability and public legitimacy was totally unexpected. The tiger had roared, and bitten the body politic.

The recommendations for reform of the administration of the police seemed to almost take second place, despite occupying a good half of the final report. Systemic problems with the secretive and repressive police culture and the lack of adequate professional training came in for particular criticism from the investigators. The former Commissioner Ray Whitrod (who had been forced out by Bjelke-Petersen, especially when he insisted Lewis be promoted) had already criticised the intellectual capacities of sections of the police (with his 
infamous 'ning-nongs' statement about his officers). Bill Gunn echoed this in early 1988 when he expressed the view that 'Queensland police officers are fat, lazy, pampered and poorly-trained', leading Goss to question whether he should remain in the portfolio. The Fitzgerald investigators considered the militaristic nature of the 'force' was problematic and organisationally dysfunctional, encouraging obsequious behaviour to superiors, blind obedience to orders and a culture of silence. In the final report, Fitzgerald (1989:200) argued: 'the Queensland Police Force is debilitated by misconduct, inefficiency, incompetence, and deficient leadership.' A police 'code' existed under which it was considered impermissible for police to criticise each other, especially to outsiders, and any breach of the code was punishable internally. Commissioner Fitzgerald detailed exactly how networks of corruption could thrive for decades in such a culture, listing those involved, the amounts of bribes received, from which activities and operators the bribes or payments were collected and to whom they were paid among officialdom. Herbert's books went back at least 20 years. Under such a police culture, if any whistleblowers had the courage to speak out they risked their careers (and perhaps lives). Hence, police culture had to change and be modernised, while whistleblowers had to be accepted and protected. There was a need for a standing misconduct commission along the model of the NSW Independent Commission Against Corruption (ICAC); there was a need for independent oversight (including parliamentary oversight); and there was a need for a more professional regional structure, and for more educated recruits and university-level training.

Fitzgerald's report contained many more specific recommendations, such as the abolition of the existing complaints' tribunal and the various special units (such as the Special Branch and the Licensing Branch) and he also recommended preventative policing, community policing and a list of efficiency measures to streamline operations (such as increased 'civilianisation' of administrative work, stopping the use of police vehicles as 'taxis' for senior police officers and police patrol cars operating using single officers in the vehicles). He also insisted that to be consistent with a 'separation of powers' doctrine, the portfolios of the Attorney-General (with responsibility for crown law and the provision of legal advice to the government) and Justice (courts, prison administration) should be functionally separated.

\section{Other allegations of official misconduct in the judiciary}

By the late 1980s, there was considerable speculation that the judiciary had developed unhealthily close links with the government and that certain lawyers 
with close connections to the Nationals (or to the police) were favoured in judicial appointments. Police Commissioner Lewis had recorded numerous incidents involving discussions with members of the judiciary and about their suitability to be appointed to particular positions. These issues came before the Fitzgerald Inquiry, which, as part of its investigations into corruption among senior police officers and former ministers, also began to investigate certain matters relating to the appointment of judges and their known associations. There was suspicion that some judges had participated in the cover-up of official misconduct or other corrupt activities. Two serving judges received considerable attention. Among the judiciary, Supreme Court Judge Angelo Vasta and Judge Eric Pratt, from the Police Complaints Tribunal, were both on friendly terms with the government, both were referred to by witnesses and in the case of the former also appeared in Lewis's diaries. Pratt had very close connections with the government and had been appointed earlier to head up the special industrial tribunal set up to oversee the electricity industry after the SEQEB dispute. As Coaldrake (1989) pointed out at the time, the Police Complaints Tribunal was meant to be at 'arm's length' from the police, but its head was a personal friend of the Police Minister, Bill Gunn, and had a special relationship with the Police Commissioner.

With Labor attempting to maintain the heat, Tom Burns took the opportunity to ask the Premier in March 1988, whether

[i]n order to be consistent with the so-called principles which demanded that Messrs Hinze, Lane and Lewis be stood down from their public positions... will the Premier now furnish Parliament with an explanation why the following people have not been stood down following strong allegations of serious impropriety against them: Angelo Vasta of the Supreme Court, Eric Pratt of the District Court and the Police Complaints Tribunal, 'Top level Ted' Lyons of the Mortgage Secondary Market Board and Ron Redmond, the Acting Police Commissioner. (QPD 1988:vol. 307, p. 4981)

Ahern answered that such matters were for consideration, adding that he had discussed issues raised with his ministers and that 'in respect of the allegations in relation to the judiciary, that is a matter for the Attorney-General and the Chief Justice of Queensland' (QPD 1988:vol. 307, p. 4981).

Two weeks later, commenting on a Sydney Morning Herald story that the head of the Police Complaints Tribunal, Judge Eric Pratt, was considering accepting an offer of reappointment when his term expired on 11 April, Goss asked the Premier whether such an offer had indeed been made. Ahern was definitive that 'no offer has been made, nor will one be made' (QPD 1988:vol. 308, p. 5377). In the same question time, Nev Warburton also asked Gunn whether he had written in February to Judge Pratt (and the head of the Police Union) offering 
them both reappointment to the tribunal. Gunn was then forced to admit he had written to the judge, pleading that such processes were 'perfectly normal' but had been made 'before certain events took place' at the commission of inquiry (QPD 1988:vol. 308, p. 5382). Labor continued to keep turning up the heat on Pratt, attacking him in the Parliament, with Bob Gibbs unkindly suggesting that he was known among his colleagues as 'Eric P. Ratt'. Labor believed that as head of the complaints tribunal he had been soft on complaints against police, tending to hose them down to avoid conflict or embarrassment.

Judge Vasta was named adversely in the inquiry hearings largely in relation to allegations of improper influence and a 'special' friendship with the former Police Commissioner, Terry Lewis. After he was named in the inquiry hearings, Judge Vasta was initially stood aside (removed from the Supreme Court's calendar of cases) by order of the Executive Council on 24 October 1988. Vasta wrote to Ahern stating that the allegations against him be referred to a panel of judges. When Ahern prevaricated for a few days, Vasta accused Ahern of having a plan to get rid of him, a claim denied by Ahern as 'grossly offensive'. Believing that the judge had close connections with the Nationals and especially the former Premier, Labor, however, kept up the pressure on Ahern and Vasta through carefully worded questions and repeated goading about the apparent lack of action over the impasse.

The judiciary had not been the primary object of Fitzgerald's inquiry but aspects of concern had arisen almost as collateral damage. The questions raised over both these members of the judiciary posed a dilemma for the Premier. Ahern agreed to accept Vasta's suggestion as a solution to the judicial impasse and, after consultation with the Law Society and Bar Association (but not the opposition), appointed a review tribunal of three retired judges from interstate to consider the appropriateness of Vasta and Pratt to remain members of the judiciary. The tribunal (of Harry Gibbs, George Lush and Michael Helsham) exonerated Pratt of any suspicion of misconduct (as did the final report of the Fitzgerald Inquiry) but found inconsistencies in Judge Vasta's affairs, especially in his taxation records. He was summonsed to appear before the bar of the Parliament on 7 June 1989, and duly appeared. ${ }^{6}$ He made a lengthy speech in his own defence lasting for almost three hours, tabling many supporting documents and waging attacks against Fitzgerald, implying there was almost a conspiracy against him, perhaps even because of his Sicilian background. When he first appeared at his 'ceremonial beheading', he said: 'I come here with a great deal

6 The Parliament was recalled for a special sitting day (30 May 1989) to consider a motion to require Judge Vasta to appear before the Assembly to show cause why he should not be removed from office. Ahern read out a list of the judge's largely commercial 'deceptions' and 'false evidence' as well as his allegations that the Chief Justice, the Attorney-General and Commissioner Fitzgerald QC had conspired to injure him. Ahern estimated that the cost of bringing the Parliament back for the special sitting inviting Vasta to appear cost \$39000 ( $Q P D$ 1989:vol. 312, pp. 5146-57). 
of trepidation. This is a fear not generated by my having to speak to you but because I have a distinct apprehension that most of you consider that my fate has been sealed' (QPD 1989:vol. 312, p. 5216). He complained of the 'lynchmob mentality' in which an alleged law-breaker would be rounded up and told 'we will give him a fair trial but hang him afterwards'. There was some truth in his views, as some of the members admitted that while they listened to Vasta's case nothing could change their minds. The government was also interested in making an example of Vasta. The Assembly then debated his removal from the Supreme Court on a motion moved by the Premier and, after a division on a tactical matter (whether to proceed with the dismissal of the judge or delay the vote for another week), the Parliament agreed without any dissent to remove Judge Vasta from his position. Goss mentioned that some in the opposition had misgivings or doubts and wanted more time to consider the judge's speech, but made clear that he did 'not think that after some reflection I will change my mind' (QPD 1989:vol. 312, p. 5271). Angus Innes added that he too was not persuaded by the judge's submission. The Vasta trial was an event rare in the annals of parliamentary history, when the Parliament sits effectively as a higher court deciding on the fate of judicial officers.

\section{Despite the disarray, the election is no 'foregone conclusion'}

Despite the intense media coverage of the Fitzgerald revelations involving police, the judiciary, crime bosses and politicians, it was not clear whether the Labor opposition was benefiting from the fallout. Ahern was winning kudos in many quarters for his tough preparedness to fix the previous problems of endemic corruption and for his openness to reforms and different policy ideas. Meanwhile under his watch, Labor had lost three by-elections in a row and performed particularly badly in the most recent Merthyr by-election. Commentators were pessimistic about whether Labor could ever form government. The ABC's Quentin Dempster argued in May 1989 that it was not a 'foregone conclusion' that Labor would benefit from the disarray and the entrenched corruption. He pointed to a list of appreciated reforms that Ahern had introduced, saying:

Queensland has been blessed with a pecuniary interests register, a parliamentary public accounts committee, a public works committee; Sir Terence Lewis has been summarily dismissed by a special Enabling Act of Parliament; the Premier has announced he will personally wield the sword for the ceremonial beheading of Mr Justice Vasta before the parliamentary mob on June 7...A change of government is possible, which is more than objectively could be said six months ago. Now the 
ALP has embarked on a television campaign to discredit the only other option - a return to a National-Liberal coalition. This is smart politics and recognises the dilemma still facing Queensland voters. (Sunday Mail, 21 May 1989)

Dempster went on to claim that if the Merthyr result were any guide, Labor would remain locked firmly in opposition. He wrote that the political analyst Dr Peter Coaldrake had estimated that according to recent polling and taking into account the South Coast and Merthyr by-elections, the result of the next state election would be the Nationals finishing with 31-36 seats, the Liberals increasing to 15-18 and the ALP falling short of government with 38-40. The historian Ross Fitzgerald had also predicted that Labor would remain on the opposition benches for another two elections (that is, not form government until 1995 at the earliest) (see QPD 1989:vol. 312, p. 5556). Dempster finally reasoned that 'with the soft cushion of a coalition to fall back on to ensure he holds the premiership, Mike Ahern has a good chance of surviving '89'. In retrospect, these prognoses appear flawed, but when the predictions were made they were probably realistic. Labor was still polling only 42 per cent in opinion polls in early October. When Coaldrake's critical book Working the System was published in July 1989, Ahern dismissed it as the work of a 'card-carrying member of the Labor Party', who along with Goss and 'his mate on the 7.30 Report [Quentin Dempster, was] a co-conspirator' aiming to bring down the government ( $Q P D$ 1989:vol. 313, pp. 138-9).

\section{Parliamentary reform arrives at last}

Legislation to establish a Public Accounts Committee (PAC) was introduced in the Parliament in October 1988, with the delay perhaps indicating it was not the burning priority some in the new government had asserted. Nevertheless, reform was finally under way. Ahern stated that it was 'with a great deal of pride and pleasure that I introduce this historic piece of legislation which I have called for on the floor of this Parliament' (QPD 1988:vol. 309, p. 1159). He claimed the Parliament would now be able to review government with more independence and be able to play a more significant role in the government of the state. The government's proposal for a local PAC had, however, significantly weaker powers than those of comparable jurisdictions. For instance, under Ahern's proposal, ministers retained a veto over releasing information or documents, departments were not compelled to cooperate with the committee and the Auditor-General was unable to brief or cooperate more generally with the committee. Although the new PAC was finally welcomed by the Labor and Liberal Parties, the opposition's main concern at the time was whether the committee would be able to investigate ministerial expenses. Goss labelled the 
PAC, overall, 'token legislation', which was a 'cheap charade', rather than the openness and accountability that the people were promised (QPD 1988:vol. 310, p. 2403). He suggested a minor amendment to a clause that he circulated and which the Premier indicated he was prepared to accept. Goss was allowed to move the minor amendment, which was accepted. Ahern also volunteered that the government was prepared to review the PAC in the future and if it was not working then he would 'ensure it operates in the traditional mode' (QPD 1988:vol. 310, p. 2473). Less courtesy was extended to the Liberal leader, who suggested that the chair of the PAC should not be from a party or parties 'from which the Executive is formed' (that is, it should be a non-governmental chair as practised in the United Kingdom and New Zealand). His amendment was defeated with both the government and opposition voting against and only the Liberals voting for this proposal (losing eight votes to 68). Terry Mackenroth said in the debate that 'Mr Hewitt should have been invited back today to make a speech from the pedestal. That would have been a great thing' ( $Q P D$ 1988:vol. 310, p. 2442). Hewitt had, of course, been a tireless proponent of a PAC from the 1960s. The first PAC was established in November 1988 by the Parliament with the inaugural members being Gil Alison (chair), Des Booth, Clem Campbell, Huan Fraser, Ken Hayward, Len Stephan and Terry White. It had been an arduous journey and a long time coming!

The PAC bill was followed by the Parliamentary Services Bill, which sought to give the management of the Parliament a greater degree of independence from the executive and to allow for a tripartite Parliamentary Services Commission to determine its internal management. Interestingly, the legislation to introduce a companion public works committee was not introduced until April 1989 and was far less contentious even though its range of investigatory powers would be equivalent to the PAC's.

\section{Mired amid further controversies}

Much of the Ahern government's legislative agenda in 1988-89 was driven by reactions to the Fitzgerald Inquiry and by specific requirements advised by lawyers associated with the commission in the Attorney-General's Department. Many of these acts were technical clarifications making special provision or clarifying points of law. The government was almost arm-twisted to deliver the statutes, and many second reading speeches from the relevant minister began with phrases such as 'we have been informed or advised that...[this matter or that matter] needs to be clarified or amended'. The opposition felt the bills were being railroaded through the Chamber. The Criminal Code was amended; the Parliament passed the Parliamentary Judges Commission of Inquiry Act, the Commission of Inquiry Act Amendment Act, the Crimes (Confiscation of Profits) 
Act, the Commissioner of Police (Vacation of Office) Act, even the Hon. Angelo Vasta (Validation of Office) Act and the Commission of Inquiry Continuation Bill to establish the continuing 'implementation unit'. Together, they formed a heady brew of legislative issues attempting to steer the way from intrigue to integrity. At the presentation of these bills, the issue of corruption constantly surfaced in the political arena as well as what the government was proposing to do about the various matters. On occasion, bills would be announced before they were printed and circulated to members, leading to bewilderment from the Labor or Liberal Parties as to what they were meant to discuss (having had only the minister's second reading speech to go on) (for example, QPD 1989:vol. 312, p. 4680).

While the Ahern government generally sought to encourage economic growth, there were limits to its enthusiasm. Sections of the National Party (especially the Gold Coast developers) were increasingly anxious over an upsurge in the foreign takeover of Queensland assets, especially Japanese interests purchasing land, hotels, office buildings and commercial sites. The local-developer brigade was worried it would never get the assets back and that profits would go offshore. The anti-Japanese investment campaign was none too subtle with local lobby groups forming (such as the nationalistic 'Heart of a Nation' group) and photographs appeared in popular newspapers showing the Gold Coast strip covered with arrows falling from the sky, each one indicating a Japanese-owned high-rise. An anti-Japanese candidate had stood in the South Coast by-election and attracted publicity for his cause. In October 1988, a Foreign Land Ownership Register Bill had been introduced, with some support from the opposition (both Bill Eaton and Keith De Lacy welcomed the bill), and was passed at that time, intending the register to begin in December 1988. This was cancelled, however, due to negotiations (after the bill was passed) with the Law Society and various financial industry bodies. Amendments were apparently required. In March 1989, a row in cabinet was reported over whether to proceed with the register, which was perceived by Japanese investors as an impediment to invest. The government's indecisiveness was commented on in the Parliament even though it appeared that only the Liberals opposed the intent of the proposed register. After amendment legislation was passed in March 1989, the Foreign Land Ownership Register finally came into effect in April 1989. The government also moved to repeal the Queensland International Tourist Centre Agreement Act (the infamous special legislation allowing Iwasaki to develop 8000 ha of prime coastline at Yeppoon; see Chapter 11).

The government was also still toying with the idea of adopting daylight saving, at least for parts of the state, but had made no firm announcement. Ahern was attracted to a trial as a way of gauging popular support and Nationals from the Gold Coast, Sunshine Coast and metropolitan area were constantly pushing the 
issue. Even the idea of a trial, however, was contentious outside the south-east. Unable to decide, the Premier wavered between going ahead and cancelling the idea. Meanwhile, in the Parliament, Goss moved a motion without notice urging the adoption of a daylight saving trial and was defeated in a vote by the government 38 votes to 45 . In an attempt to create a short-circuit, Ahern announced unilaterally that a trial of daylight saving would occur during the summer months of 1989-90 and introduced the Daylight Saving Bill on 6 September 1989. To some of Ahern's wavering supporters, this was the last straw.

\section{Another accident waiting to happen? Speaker Powell resigns and Speaker Lingard returns}

Speaker Lin Powell resigned from the National Party on 3 May 1989 (declaring himself an independent), then spectacularly, he resigned from the Speakership on 5 July and from the Parliament altogether on 31 July 1989. He had never supported the Ahern administration, but the catalyst for his resignation appeared trivial, although both sides saw some deeper skulduggery behind the scenes. The lead-up to the incident began innocuously. Tom Burns had been stirring Ahern over the government's response to the AIDS issue and asked the Premier whether he had anything to do with the 'homosexual lobby' trying to embarrass him. Ahern answered that he had had nothing to do with the homosexual lobby. Burns believed from media reports that Ahern had had some discussions with the homosexual lobby and in particular the AIDS Council of Queensland. He then wrote to the Speaker raising as a matter of privilege the suggestion that Ahern had misled the Parliament. As the Assembly was preparing to debate the Fitzgerald Report on 5 July 1989, the Speaker told the House that the matter of privilege was not a matter for him to determine, 'but rather one that should be referred to the privileges committee', whereupon Goss rose and moved that the complaint be so referred. The government was placed in an awkward position, not wanting the Premier referred to the committee but with the opposition backing the Speaker's preferred course of action. The government used its numbers to defeat Goss's motion 36-44, thus in effect voting against its own nominee as Speaker, who had now turned independent. Powell then informed the House that as a result of the vote he had no option but to resign. Two hours later, after the Clerk read out Powell's resignation, Goss immediately renominated Powell for the Speaker's job, but Ahern moved that Kevin Lingard (who was Speaker for nine months in Bjelke-Petersen's last year in office) take the chair (QPD 1989:vol. 312, p. 5430).

The debate was on; the gloves were off. For the next two hours, the Parliament indulged in a senseless series of allegations and counter-allegations before 
putting the motion to confirm Lingard in the post. Even Powell joined the debate - now as an ordinary member - denying he had conspired to resign and saying he would have preferred to go to the next election as Speaker rather than as an 'independent backbencher' (although shortly after this he decided to quit politics altogether). After a debate lasting almost 12 hours and finishing at 3.35 am the next day, the vote for Lingard was 42 to 40 with one informal. Lingard became only the second Speaker to hold the position for two non-consecutive terms.

The events leading up to Speaker Powell's resignation were somewhat perplexing. That sitting day, the Parliament was due to debate the Fitzgerald Report for the first time. Powell had come into the House and in effect ruled that the privileges matter against the Premier be referred to the privileges committee for investigation. The opposition seemed primed to support his chosen course. Ahern seemed to be ready to nominate Lingard to replace him. And the media had been tipped off beforehand that something was going to happen. It also transpired that the former Premier, Bjelke-Petersen, had attended Parliament House and had lunch with Powell and Ted Lyons (leading to certain suggestions they could have put Powell up to it - but he had already told Burns and some colleagues before the lunch). A furious Ahern claimed that the stunt was another 'Kingaroy cow yard conspiracy' cooked up by the vengeance-seeking former Premier and Powell and with Goss and Innes as co-conspirators. Bill Gunn called it 'one of the most shonky, shabby stunts ever brought before this House' by the non-government parties wasting time rather than debating Fitzgerald. Goss, however, accused the government of not standing by their Speaker (who was increasingly acting as an independent because of his animosity towards the government) and of trying to engineer his replacement with a more amenable chair. When Powell announced his resignation, Goss asserted, 'we all saw the National Party Whip, Mr FitzGerald come into the House, go up to Austin and say "what are we going to do?" Austin gave the orders and Ahern fell into line.' He claimed government members were now going red in the face realising what they had done. He claimed the object was 'to get rid of an independent Speaker so that the Government can control the debate on the Fitzgerald report' ( $Q P D$ 1989:vol. 312, pp. 5431-5).

Then, the next day, almost as an afterthought, the Assembly conducted a further 10-hour debate on the Fitzgerald Report. Ahern described it as a black day for Queensland when the Labor and Liberal Parties conspired to get rid of the Speaker, but welcomed the Fitzgerald Report with 'pride and pleasure', claiming it was 'the most far-reaching report ever to have been resourced and obtained by any Government in the whole of the British Commonwealth' (QPD 1989:vol. 312, p. 5565). For the Parliament, however, it was an anticlimax.

Ah! Politics, politics! 


\section{The final discord on electoral reform}

The pronounced emphasis Fitzgerald placed on political legitimacy and electoral accountability placed the Ahern government in a quandary. Ahern had personally given an assurance to implement the Fitzgerald recommendations 'lock, stock and barrel'. Now, some five months away from the next state election, Fitzgerald had called for 'free and fair elections' and specifically recommended an independent inquiry be undertaken, unfettered by any predetermined restrictions (that is, no statutorily imposed zonal system or other forms of malapportioning votes). Fitzgerald had not said the zonal system was unjustified or that one vote, one value should prevail; merely that the present system was widely questioned and was in need of fundamental review. It is highly unlikely any serious review involving public submissions and public hearings could be completed before the election was due, let alone any redistribution occur before the poll.

Ahern attempted to catch his Labor and Liberal opponents unawares. His audacious solution (provided to him, unintentionally, by the Citizens For Democracy) was to extend the present Parliament by up to six months through a special referendum, ostensibly to allow an electoral redistribution to take place before the next election. The Constitutional (Extension of Duration of Parliament) Bill was introduced in July 1989 (along with an accompanying bill to hold a constitutional referendum) with the intended date for holding the referendum being 14 October. The Premier hoped the proposal would gain tripartisan support. In effect, he was prepared to gamble and offer a political deal; would his opponents accept the challenge? For the Labor and Liberal Parties, the proposal offered the prospect of fairer electoral boundaries (perhaps, but certainly not guaranteed); for Ahern, he stood to gain more time to both implement those aspects of Fitzgerald he chose and put Fitzgerald behind him and focus on other issues. The referendum required the endorsement of each major party otherwise it would not succeed. Both Labor and the Liberals were wary. They did not necessarily fully trust Ahern to stand by his words; after all, the government would remain in control of the rules of the game and could decide which aspects of any future recommendations it would adopt. If, for instance, a review came back with the recommendation to have electoral equity, there were concerns Ahern could ignore such recommendations and some time in 1990 go to the polls on the old boundaries. Again there was no love lost and deep distrust from all sides.

Goss was the first to come out and proclaim the proposal was a 'sham' and that the government was calculating that the referendum would fail (as most do) and that this would then be used to claim that the electorate was against electoral reform so an election on the existing boundaries could take place at the normal time. A Machiavellian sceptic might surmise that such tactics could take 
electoral reform out of the equation and deflate Labor's case. Goss responded by stating that 'the Labor Party wants electoral reform but it doesn't trust this government or its package' of proposals (QPD 1989:vol. 313, p. 89). He also claimed that the government could undertake a five-month redistribution if it so chose, as it had done in a hurry in 1977 (but presumably that is without a prior independent review of the system as a whole). Ahern responded with equal gusto, saying 'members opposite are hypocritical in the extreme in voting against a real, guaranteed, ironclad possibility of independent electoral assessment and reform in this State'. He accused Goss of merely seeking to smear his reputation and confuse the electorate so they would vote 'no' in the referendum. Tellingly, he insisted that while Goss was opposing the opportunity for electoral reform in the House, his state secretary, Wayne Swan, was running around with a petition asking for an electoral redistribution before the next election. When Goss claimed that was not true, Ahern produced the petition and began reading from its contents.

Ahern had also introduced as part of these electoral proposals a separate draft bill to establish the Electoral and Administrative Review Commission (EARC) as recommended by Fitzgerald. The bill, based on draft legislation included in the Fitzgerald Report, proposed a continuing independent commission, headed by a commissioner. When introducing the bill, Ahern announced he was guillotining the legislation, allowing only three days (rather than seven sitting days) for the Parliament's deliberations before gagging debate, and presumably passing the bill. Labor was predictably disappointed with the intended legislation, not because it opposed such a body or the need for review, but because the bill mentioned only analysis of the zonal system and did not include any mention of examining the principle of one vote, one value.

The maelstrom of conservative party-room politics intervened, however, before all these electorally related bills could finally be passed and, while the extension of the parliamentary legislation and the referendum proposal passed their three readings, the EARC bill did not. Dissidents in the ministry and on the Nationals' backbench were nervous about the direction in which Ahern was taking them. His Premiership was in terminal decline and over the coming days he had many other pressing things to occupy his mind.

\section{Premier Russell Cooper: a last, desperate hurl of the dice}

After the release of the Fitzgerald Report in July 1989, it appeared to many Nationals in both the parliamentary and organisational wings that Mike Ahern could no longer 'contain the damage' and a new leader ought to be found. There 
was not much choice. Arguably, the sole shining light emerging from the first two Ahern ministries was Russell Cooper-an increasingly forceful cabinet minister who had developed a strongman image in government and in public perceptions. In the Corrective Services portfolio, he had embraced a major reform program, overcame intractable problems in the sector and established a new business-like statutory framework for managing prisons (including competitive bidding to operate them). As Police Minister, he had shown an appreciation of the need for thorough reform to root out poor practice. If anyone could claim some glory for real achievements it was him. He was more conservative than Ahern (who was increasingly seen by his colleagues as 'too moderate') and embraced a homophobic, Bible-based morality. His more traditional 'Country Party' image seemed to appeal to voters in the bush - and, as a consequence, resonated with the party's president, Sir Robert Sparkes (and to some extent with Bjelke-Petersen, who was still undermining Ahern from the hustings). Cooper was a little uncertain when faced with complex agendas, famously flunked a journalist's curly question about the separation of powers and was uncharitably referred to as a 'Joh clone' by the Labor Party and sections of the Brisbane media and as a 'closet Bjelke-Petersen' by Goss. Cooper himself partly fanned this image when he kept talking about 'this accountability thing' that had to be attended to as though it were some foreign being, and used the odd Joh-like expression, repetitively, such as 'there's no question about it'. He would later say that when he became Premier he was on a 'hiding to nothing' (Four Corners, ABC TV, March 2008).

The machinations to remove Ahern in mid-late 1989 were not straightforward and the Cooper forces took two goes to unseat the Premier. Initially one of Ahern's backers, Cooper began to have doubts about whether under Ahern's leadership they would be able to retain government at the forthcoming election. He successfully combined two diametrically opposed groups of dissidents: those former Ahern supporters who now shared Cooper's reservations about Ahern's ability to win; and those 'Joh loyalists' who had never fully welcomed Ahern's takeover. The first attempt to depose Ahern failed. On 27 August, three conspiring ministers (Cooper, Paul Clauson and Bob Katter) resigned from cabinet, initiating a spill the next day. Attempting to tough it out, Ahern narrowly won the party-room vote by 26-21 - in effect, by three votes (although Cooper's side had been claiming they had 28 votes locked in; Sydney Morning Herald, 29 August 1989). In the lead-up to this ballot, Sparkes remained loyal to the Premier. The resignation of the three ministers necessitated a minor reshuffle in Ahern's third but short-lived ministry. Three relative lightweights were promoted: Tony FitzGerald, who had been taking on a far more active role in parliamentary debates, was made Justice Minister, replacing Clauson; 
Huan Fraser was appointed to the Industry portfolio; and Tom Gilmore received Community Services, Ethnic Affairs and Northern Development (replacing Katter).

Not to be dismayed, the plotters orchestrated a second tilt. With the daylight saving trial, announced in September 1989, becoming the catalyst for much internal dissatisfaction, Cooper called another party-room spill for 25 September and won the leadership ballot this time with the full support of Sparkes. The political calculation among the party stalwarts appeared to have changed to one of minimising losses at the forthcoming poll. Ahern was expendable so was beheaded. Ironically, opinion polls subsequently suggested that popular support was gradually returning to the embattled Ahern in the months out from the election - and that Cooper could have dashed this return of conservative support in the clumsy takeover. Cooper's desperate actions merely underscored the impression that the Nationals were not fit to govern.

Ahern quit the Premiership with a philosophical, if stoic, acquiescence and returned to the backbench, where he was gently taunted by the Labor members. Once Ahern was removed, Goss claimed in the Assembly that Ahern was deposed because he had been intending to introduce reforms - something he had not said when Ahern was in office. Ahern did not resign from the Parliament and, indeed, recontested his seat at the 1989 election, which he duly won, before resigning and causing a further by-election for Landsborough in 1990.

On 25 September, Russell Cooper was appointed as the new Premier of Queensland. Cooper's term of just two and a half months was to be among the shortest in the history of Queensland. To provide a degree of stability, Bill Gunn, the man largely credited with starting the reform process by initiating the Fitzgerald Inquiry more than two years earlier, remained as the Deputy Premier. He had occupied this role under three premiers in as many years. Cooper's ministry was a strange amalgam of old hands, surviving Ahern ministers and incorporated dissidents. Ahern and Brian Austin refused to serve in the new ministry. Cooper dropped Bill Glasson, Peter McKechnie, Martin Tenni, Geoff Muntz and Craig Sherrin and did not reappoint the short-termed Tom Gilmore. Paul Clauson and Yvonne Chapman were reinstated. Ahern's last-minute appointments, Tony FitzGerald and Huan Fraser, were retained. Finally, Mark Stoneman, Gil Alison, Ian Henderson and Beryce Nelson all became ministers for the first time. Under Cooper, the portfolios were entirely rejigged, with Vince Lester and Bob Katter receiving the biggest promotions. Lester's new responsibilities seemed to go to his head straight away as he thought the police were there as a personalised taxi service to take him on errands - something the media was quick to pounce on. Cooper's full ministry was sworn in on 25 September 1989. 
- Premier, Treasurer and Minister for State Development: Russell Cooper

- Deputy Premier and Minister for Finance and Minister for Local Government: Bill Gunn

- Minister for Health: Ivan Gibbs

- Minister for Police, Employment, Training and Industrial Affairs: Vince Lester

- Minister for Land Management: Nev Harper

- Minister for Mines and Energy, Northern and Regional Development: Bob Katter

- Minister for Water Resources and Maritime Services: Don Neal

- Minister for Attorney-General, Heritage and Arts: Paul Clauson

- Minister for Tourism, Environment, Conservation and Forestry: Rob Borbidge

- Minister for Works and Housing: Jim Randell

- Minister for Education, Youth, Sport and Recreation: Brian Littleproud

- Minister for Community Services, Emergency and Administrative Services: Tony FitzGerald

- Minister for Industry, Small Business and Technology: Huan Fraser

- Minister for Transport and Ethnic Affairs: Yvonne Chapman

- Minister for Primary Industries: Mark Stoneman

- Minister for Main Roads and Racing: Gil Alison

- Minister for Justice and Corrective Services: Ian Henderson

- Minister for Family Services: Beryce Nelson

The Parliament met the next day, on 26 September, to allow some revised Fitzgerald legislation to be passed in the session and to ensure 'clear, full and proper debate' (QPD 1989:vol. 313, p. 1161). It sat for a total of just nine days throughout the months of September and October, before being dissolved by proclamation on 19 October 1989. On the first morning back, Premier Cooper flagged that his leadership heralded a renewed emphasis to 'ensure a State in which law and order prevails'. He declared: 'these are extraordinary times that require clear thinking and a fresh approach' to governing, although there was not much time to change anything substantial. He informed the House that the reforms begun under Ahern would continue, but announced a new initiative called the 'Premier's Independent Commission for Change and Reform' (PICCAR, often parodied as 'piker' by his opponents). This commission, which was chaired by Jim Kennedy, was envisaged to last for one year initially, until the Fitzgerald arrangements were up and running. PICCAR's chief role was to 'supervise and be responsible for the implementation of the Fitzgerald recommendations, including the establishment of the Electoral and Administrative Review Commission (EARC) and the Criminal Justice Commission (CJC)'. Cooper 
assured the Parliament that the commission would guarantee the complete independence of these bodies'. PICCAR was also empowered to report and recommend to the Premier any area of Queensland administration that Kennedy believed needed further review or reform (QPD 1989:vol. 313, p. 611). Many saw the PICCAR initiative - although too short to have much effect - as an attempt to ride shotgun over the whole process.

After these announcements, and to derail any possible opposition attack before it had begun, Cooper immediately moved a motion of confidence in his government. In his defence, Cooper referred to the problems Labor governments were experiencing in other states, while Gunn spoke of his pleasure in supporting the new Premier (to taunts from Labor that he was 'now known as King Rat'). Goss suggested that, unlike the earlier motion of confidence moved by Ahern in his government, this later move was a 'pathetic precedent'. He claimed that the 'disappointing spectacle' of a Premier having to move 'confidence in himself when everybody knows that his party is racked by division' did not inspire much confidence (QPD 1989:vol. 313, p. 618). Significantly, Goss gave one of his best speeches in the Parliament in this debate, receiving a standing ovation from the public gallery, causing the Speaker to warn he would clear the gallery if it did not stop applauding. Arguing the state needed a strong future with good government, he said:

It is time for no confidence to be shown in the Government of this State. It is time for an election. It is time for a real change. It is time to clean up the mess. It is time for the people of this State to say, 'We've had enough. You're out'. A Goss Government will give the people of this State that future. It will work within the Fitzgerald framework. I commit a Goss Government to that future. Today I commit a Goss Government to the implementation of the EARC...the Labor Party will be ready to move and give this State an honest future, not a dishonest one; not a step back into the darkness; not a Government of dishonour and scheming ambition. The Labor Party will provide good government. (QPD 1989:vol. 313, p. 621)

Now that Cooper was the main 'enemy', Labor members could afford to display some belated sympathy for the former Premier-reminiscent perhaps of the opposition's comments made after the ousting of Bjelke-Petersen. Burns, however, gave a few characteristic twists of the knife in his assessment of Ahern:

Since yesterday Queensland has had its second unelected Premier in as many years. Mr Cooper, like Mr Ahern, has never received a mandate from the voters of Queensland. The only mandate that he has been given has come from National Party headquarters and Sir Robert Sparkes. $\mathrm{Mr}$ Ahern was no leader. He could not make decisions. The only time he 
rallied his party behind him was last Friday, and they stabbed him in the back. I understand why he has moved up to the back of the Chamber. I would not let them get behind me again either. However, Mr Ahern was working towards ending corruption. That is why the National Party could not let him survive. (QPD 1989:vol. 313, pp. 628-9)

With the Liberals choosing to support the motion of confidence in the Cooper administration, the motion was carried by a margin of 57 to 29, with only Labor members voting against.

Goss was scathing about the new Cooper ministry. He reminded the Parliament that since the Nationals had formed government alone in 1983 there had been seven different ministries (and other tinkering changes) and 36 different National Party members had been made ministers during that period; it seemed, he said, as if 'every player gets a prize'. Such turnover caused Goss to joke that 'the remaining six [National backbenchers] should not despair...because at the rate the National Party is going, all its parliamentary members will get a turn by the time this year is out' (QPD 1989:vol. 313, p. 650). In contrast, he reasoned, his shadow ministry was 'stable, united and confident', although the Liberal leader, Angus Innes, said the opposition was full of 'retreads' because 'behind Mr Goss and behind the veneer, there is the same tired, recycled, old failed performers who have to be disguised' (QPD 1989:vol. 313, p. 637). And so it went, with the predictable argy-bargy that often occurred in the House as election time drew closer.

Under Cooper's interregnum, the House debated 25 pieces of legislation in nine sitting days. Fourteen of these bills were initiated during Cooper's term in office (although several bills had previously been withdrawn and were being reintroduced). Most importantly, the government introduced and passed the Fitzgerald-inspired Electoral and Administrative Review Bill to bring about an Electoral and Administrative Review Commission and a Parliamentary Electoral and Administrative Review Committee; and the Criminal Justice Bill to provide for the establishment of the Criminal Justice Commission (CJC) and its corresponding parliamentary committee (QPD 1989:vol. 313, pp. 1377-81). Other important pieces of legislation were constitutional in nature. Labor's Dean Wells sarcastically referred to the Constitution (Cancellation of Referendum) Bill as 'historic' because it was the only time in history he could remember that a government 'has ever been so incompetent as to call a referendum and then subsequently cancel it' (QPD 1989:vol. 313, p. 733). In contrast, Labor's Ken McElligott welcomed the Constitution Act Amendment Bill because it proposed formal recognition of local government.

Other bills introduced during this final session of the Parliament concerned items of interest to the government's core constituencies such as mining or 
primary industries, including: the Wheat Marketing Facilitations Bill, the Sugar Milling Rationalisations (Far Northern Region Act) Amendment Bill and the Cotton Industry Deregulation Bill. Some of these bills were contentious, as with the Central Queensland Coal Associates Agreement Amendment Bill, which led the Liberal leader Innes to make the political point that Labor's 'grandstanding' over its opposition to this bill was futile and that 'if the Government had been defeated in the House, the election date would not have been advanced one single day' (QPD 1989:vol. 313, p. 726).

There was inevitably some final tidying up to do-over minor electoral amendments, two new universities (Central Queensland and Southern Queensland), university amalgamations around Brisbane (the University of Queensland and the Agricultural College at Gatton, and Griffith University with the Brisbane College of Advanced Education) and amendments to statute laws. Dean Wells mockingly congratulated the new Justice Minister, Ian Henderson, for introducing the Elections Act Amendment Bill, saying because of the time of night ' $[\mathrm{t}]$ is now the very witching time of night, when churchyards yawn and hell itself breathes out Contagion to this world'. He predicted that it would be only the first and last bill Henderson introduced (even though Tony FitzGerald and not Henderson introduced the bill and Henderson merely opened the second reading debate). Wells noted that it seemed like only yesterday that he was making 'congratulatory remarks to the honourable member for Lockyer [FitzGerald] on his first Bill as Minister for Justice [the Elections Act amendments, adding] It was his last Bill as Minister for Justice' (QPD 1989:vol. 313, p. 998).

When Mark Stoneman presented his Stock Act and Local Government Act Amendment Bill on 28 September, he began by making a speech to the wrong act. After he had cited the supposed purpose of the bill, Ed Casey jumped to his feet to correct him! Casey said, 'I believe the Minister is reading the wrong speech. He should be reading a speech on the amendment of the Stock Act and the Local Government Act', whereupon Stoneman said plaintively, 'My apologies, Mr Speaker. I thank you Mr Casey' (QPD 1989:vol. 313, p. 967). Attention to detail and to matters at hand seemed to be honoured only in the breech.

In the final days of the forty-fifth Parliament, Russell Cooper announced a timetable for the implementation of some of the Fitzgerald reforms and stated that Noel Newnham had been appointed as the new Interim Police Commissioner (to which Wayne Goss complained that he had not been consulted on the appointment). Goss also asked the Premier whether it was true that four current or former cabinet ministers were about to be charged over the misuse of their ministerial expenses and cash advances, and fished around to find names, asking whether Vince Lester was one of those 'potentially being investigated' (QPD 1989:vol. 313, pp. 1160, 1273, 1280). Lester could have been investigated (as 
were other ministers) but was not charged. ${ }^{7}$ At the time, Terry Mackenroth asked whether notices of intention to prosecute had been issued to these ministers and whether Ian Callinan QC had briefed cabinet on how to respond to Doug Drummond's queries about ministers' use of their expense accounts. In various replies, Cooper insisted that he was aware of rumours about ministers being charged, that the ministers were presumed innocent until proven otherwise and that Callinan had not briefed cabinet, but added 'if the people who have been sent letters requiring some form of explanation have sought legal advice, I say good luck to them' (QPD 1989:vol. 313, p. 1437).

The Opposition Leader managed one last salvo against the government in a matter-of-public-interest debate on 17 October 1989. Goss zeroed in on the recent performance of the government, stating:

The future of this State hangs in the balance. Today I propose to sum up the past and also point to the future under the next Labor Government. Mr Speaker, in what is to be the last week of this Parliament I am reminded that you and I and many others were first elected to this place six years ago this month. I am reminded of - and I want to quote frommy first speech in this place, which I think summed up the legacy at that time of 26 years of National-Liberal Government and still today accurately sums up the legacy of 32 years of conservative Government. I said-'Queensland is a State of great wealth, rich in both natural resources and talent, yet impoverished in its system of government and the way in which it provides for its people. With each passing year, powerful interests accrue more power, and patronage and favouritism increase - at the expense of the living standards and freedoms of average Queenslanders...We have not seen "government of the people, for the people, by the people"; we have seen government for the benefit of Sir Robert Sparkes, Sir Edward Lyons, Sir William Allen, Sir Charles Holm and "Sir" Fred Maybury, who is six weeks too late [because imperial honours had just been removed]. They are the persons who have derived the benefits from the administration of this State'...

In six weeks' time, the wheel of history will turn a full circle as Queenslanders see and realise, as the polls are reflecting, that they have the capacity to change this State for the better... The people of this State can see the wide and dark shadow full of guilty secrets that has been hidden behind the closed doors of Executive Government and behind

7 Later, five ministers did face charges and trial: Don Lane, Brian Austin, Leisha Harvey, Geoff Muntz and Ivan Gibbs. The first four were each found guilty and jailed while Gibbs was found not guilty at his trial and released. 
the doors of the bunker in which the deals are done and the strings are pulled...The National Party-Liberal Party legacy is a betrayal of trust.

(QPD 1989:vol. 313, p. 1441)

The speech was not rebuffed by any great oratory. Later, Lyle Schuntner (Lib., Mount Coot-tha) said Goss's speech had displayed considerable 'bitterness, vindictiveness and hatred' and added 'those are not the bases on which the future of Queensland will improve' (QPD 1989:vol. 313, p. 1494).

On the final day, a revised Criminal Justice Bill was introduced incorporating further suggestions from public submissions and was read three times and passed in the day's sitting. In the last hours, Cooper's valedictory address noted that Ted Row, Bill Glasson, Peter McKechnie, Martin Tenni and Gordon Simpson from the Nationals' side were retiring from the Parliament; that Brian Davis, Les Yewdale, Bob Scott and Eric Shaw were not standing again for Labor; and that Bill Lickiss and Norm Lee from the Liberals were retiring as well at the election. He concluded that 'this has been a most productive Parliament. I look forward to the next Parliament with anticipation and relish' (QPD 1989:vol. 313, p. 1802).

\section{The 1989 election campaign: floods of gays, clean out the rats...}

After the failed bid to delay the state election, via a proposed referendum, Premier Russell Cooper nominated 2 December as the date of the election; it was with some apparent reluctance that he called the election after such a short time at the helm (Gold Coast Bulletin, 24 October 1989, p. 1). The eventual date he chose was no accident. Seventeen years earlier to the day, Gough Whitlam's Labor Party had come to power in Canberra. Whitlam's unpopularity in Queensland helped boost Bjelke-Petersen's image as a tough and decisive premier in the mid1970s and Cooper hoped the symbolism of 2 December would portend success for the Nationals and remind Queenslanders that voting for a Labor government would jeopardise the state's economy. The difficulty for Cooper, however, was that this was the first election since 1969 to be held without Bjelke-Petersen leading the campaign. Cooper was far less savvy and knew from the start it was going to be a tough fight (Courier-Mail, 25 November 1989; Sydney Morning Herald, 24 October 1989).

From the beginning of the campaign, his approach seemed to be to press ahead and ignore the almost daily media circus that continued to unearth new allegations as those connected with the Bjelke-Petersen regime fell in the wake of Fitzgerald's report. Criminal charges, continuing trials and a string of guilty verdicts kept the sensational coverage going. His key message was to say 
repeatedly that 'corruption was not a poll issue'. Travelling the state, Cooper asserted that the corruption issues that had dominated the media for the past couple of years were overstated distractions. He told supporters in Hughenden, for example, that 'we have been plagued by the Fitzgerald Inquiry...but we started it and we will finish it' (Northern Miner, 17 October 1989). He preferred to direct attention towards moral issues such as abortion and homosexuality, to galvanise the religious right. Indeed, some right-wing religious groups also lent support to the Nationals' campaign, with the Toowoomba-based Logos Foundation leading the charge by urging voters to remember that corruption was one of the 'secondary issues' and 'that the primary factor in a society is its moral values' (Sydney Morning Herald, 24 October 1989). To get this message across, the Nationals ran advertisements suggesting that should Labor be elected to government, its stated policy of decriminalising homosexuality would see a 'flood of gays crossing the border from the Southern States'. Cooper also tried to copy Bjelke-Petersen's tough stance on crime, suggesting at one point that Queensland should 'bring back the noose' and reintroduce capital punishment, much to the disgust of the moderates in his own cabinet, although this idea was supported by the Attorney-General, Ian Henderson, who wanted to hold a referendum on the issue (Sun, 30 October 1989). In return, Labor reiterated its criticism of Cooper that he was nothing more than a 'clone of Joh' seeking to wind the clock back.

Playing to what it considered one of its strengths, the government directed attention towards its economic record. The Nationals' campaign theme of 'Queensland, Be Proud' reminded voters of Queensland's unprecedented economic growth under the Nationals. Its media advertisements sought to magnify a nagging fear in the heart of some swinging voters that Labor would not have the discipline to effectively manage the economy. One National advertisement asked: 'Can Queensland afford three years of hard Labor?' (Australian Financial Review, 30 October 1989). The government itself, however, had few new announcements to make on the economic front. As a measure of some desperation, Deputy Premier Gunn was moved to promise that poker machines would be allowed into Queensland clubs if the government were returned as a stimulus to tourism - an opportunistic U-turn in policy (The Canberra Times, 26 October 1989).

The Liberal Party had virtually conceded it could not get back into government unless it was part of a coalition arrangement (QPD 1989:vol. 313, p. 1442). Making it difficult for the Liberals, however, its leader, Angus Innes, made it clear that his party would not join with the Nationals in a coalition unless it was the senior partner (Gold Coast Bulletin, 12 October 1989). This implied that the party that won just 10 seats in 1986 would need to see a massive surge in its voter support to get it above the Nationals (perhaps securing as many as 30 
seats - an enormously daunting task and a rash statement indeed!). In the final week of the campaign, Innes's rash statement was blamed for a crash in Liberal support - down from 26 per cent to 18 per cent just before the poll (Australian Financial Review, 27 November 1989).

Needing an overall swing of 5.5 per cent to oust the conservatives, Goss stressed that 1989 was a choice between a Goss Labor government and stability or 'a divided coalition, a constitutional crisis and another election in three months' (Gold Coast Bulletin, 24 October 1989:2). Labor's campaign slogan was 'Wayne Goss and Labor - the only change for the better'. He pleaded with the electorate to give him a one-term chance and if Labor did not perform to kick it out at the next election. He attacked the record of the Nationals' government, saying the 1989 poll was about a 'fresh start', adding Queenslanders had to 'clean out the rats, clean out the cupboards and start again' (Sydney Morning Herald, 24 October 1989). Against the scare tactics used by Premier Cooper, Goss promised to not increase taxes, to deliver honest government and to restore integrity to public life. Goss committed Labor to introduce the raft of accountability arrangements advocated by Fitzgerald, including electoral reform and widespread public sector reform. He gave commitments to regional economic development, to establish a state bank and promised educational reform, housing assistance and to stop the proposed Wolffdene Dam. Later, he would famously tell his supporters to 'take a cold shower' at the victory celebrations held in the tally room and that he would manage his government so as not to 'frighten the horses', which became a virtual mantra.

In the context of the Fitzgerald fallout, however, and with the recent leadership instability, Cooper had difficulty convincing voters the Nationals deserved to be returned. Opinion polls showed the Nationals were unpopular with the electorate while the ALP's support rose from an initial 42 per cent to a final 48 per cent in a poll conducted by Newspoll a day or so before the election (The Australian, 2 December 1989). The government's standing was not helped by the release of Queen's Council Doug Drummond's report on misuse of ministerial expenses during the campaign. While Cooper was again insistent that the 'presumption of innocence' should apply to his ministerial team and to former ministers, the incident seemed to remind the community of the 'snouts in the trough' mentality that prevailed in the government.

In total, 334 candidates stood for election in 1989 - the most candidates ever to stand. Labor again contested every seat, standing a number of 'hopeful' candidates in seats it did not believe it could win; the Nationals managed to contest 85 seats, while the Liberals ran 77 candidates in 76 seats - the most it had ever attempted. Interestingly, the Australian Democrats managed to field just seven candidates (less than half the number they had stood in 1986), while the Greens, who were rumoured to be considering standing candidates, did not 
field any candidates in 1989 (and, indeed, did not do so until 1995). Heralding in a generational change, the conservatives selected two of the youngest candidates ever to stand at a state election. Lawrence Springborg, described in the media as a '21 year old farm labourer', ran in the prized seat of Carnarvon (vacated by Peter McKechnie) for the National Party, while the Liberals' preselected eighteen-year-old Peter Dutton to run against ALP stalwart Tom Burns in Lytton (see Sun, 30 October 1989). Although Springborg, who would come to lead the Nationals in 2003, was successful in his election to the Parliament, Dutton not surprisingly failed in his first bid for a seat, but was to win the federal seat of Dickson for the Liberal Party in 2001.

The 1989 poll was the third election in a row that was most fiercely contested and in which a high degree of volatility was predicted. Although the result might have appeared inevitable in retrospect, in the lead-up to the election, the result was very much in doubt and Goss warned Labor supporters not to take victory for granted. Labor still had to contend with the zonal malapportionment that inflated the seats of the Nationals. The conservatives had retained the three by-elections in the lead-up to the state-wide poll and Labor's vote had remained frozen and had sometimes fallen backwards. National Party strategists indicated that the seats they considered winnable were the Liberal-held seats of Mount Isa, Ashgrove and Yeronga (where Norm Lee was retiring), while the ALP-held seats of Thuringowa, Mourilyan and Cook were under serious challenge. The Liberal Party, stressing it was the sole 'private enterprise' party, believed it would do well given the cronyism and odium of corruption hanging over the Nationals. The party hinted that more than 40 of the 89 seats could change hands - and it was hopeful of capturing seats on the Darling Downs as well as the Sunshine and Gold Coasts. It indicated it was targeting five National-held seats - those of: Isis, Maryborough, Barambah (now National, as Trevor Perrett had rejoined the Nationals in December 1988), Townsville and even Whitsunday.

Labor's campaign director, Wayne Swan, made a direct appeal to peel off conservative voters. He argued that there were a lot of 'die-hard National Party voters who were saying "we'll vote for Labor just this once-we'll give them a chance"'. He told the media that the party would not lose any seats and had targeted 20 seats to win-namely: Barron River, Mulgrave, Tablelands, Mount Isa, Flinders, Whitsunday, Broadsound, Maryborough, Isis, Glasshouse, Pine Rivers, Stafford, Ashgrove, Nundah, Yeronga, Redlands, Springwood, Toowoomba North, Currumbin and Warrego (Sun, 30 October 1989). Significantly, Labor captured 16 of the 20 seats Swan had targeted (failing to capture only Currumbin, Flinders, Tablelands and Warrego).

Shortly after the polls closed on 2 December 1989, there was no doubt who had won. Even as early as 8 pm it was clear Labor had achieved a substantial swing, increasing its vote by about 9 per cent. It had been elected as the new 
government of Queensland. For the first time since 1957, Labor received more than 50 per cent of the primary vote, eventually winning 54 seats in the new Parliament (an increase of 24 seats over the number it had won at the 1986 election). The Liberal Party also gained a swing towards it of 4.5 per cent, taking its vote to 21.05 per cent. This level of support, however, translated into just eight seats in the House - two less than it won in 1986. The main losers were the Nationals, who lost 22 seats in total, returning to the Parliament with 27 seats won on 24.09 per cent of the vote.

A total of 50 sitting members were returned and two former members were re-elected to the House (Labor's Jim Fouras representing Ashgrove, and eventually in 1990 after a case of disputed returns, the Nationals' Neil Turner in Nicklin). No fewer than 28 new Labor members entered the Assembly in what was its largest injection of Labor talent in decades. These new members included (alphabetically): Ray Barber (Cooroora), Peter Beattie (Brisbane Central), Lorraine Bird (Whitsunday), Steve Bredhauer (Cook), Darryl Briskey (Redlands), Dr Lesley Clark (Barron River), Ken Davies (Townsville), Bob Dollin (Maryborough), Wendy Edmond (Mount Coot-tha), Jim Elder (Manly), Gary Fenlon (Greenslopes), Dr John Flynn (Toowoomba North), Matt Foley (Yeronga), Phil Heath (Nundah), Ray Hollis (Redcliffe), Don Livingstone (Ipswich West), Tony McGrady (Mount Isa), Bill Nunn (Isis), Jim Pearce (Broadsound), Warren Pitt (Mulgrave), Laurel Power (Mansfield), Molly Robson (Springwood), Robert Schwarten (Rockhampton North), Judy Spence (Mount Gravatt), Jon Sullivan (Glasshouse), John Szczerbanik (Albert), Rod Welford (Stafford) and Margaret Woodgate (Pine Rivers). Thirteen of this group would become ministers in future Labor governments; a further two parliamentary secretaries; two would become Speakers of the Assembly; and one, Peter Beattie, a subsequent Premier.

The Liberals picked up five (then four) additional seats: Ray Connor (Nerang), Trevor Coomber (Currumbin), John Goss (Apsley), Bob King (Nicklin, but which was overturned in court in November 1990 in favour of the Nationals' Neil Turner) and Bob Quinn (South Coast). Dr David Watson retained the seat of Moggill for the Liberals (replacing the retiring Bill Lickiss). Quinn and Watson would become ministers in a future Coalition government and at different times party leaders and Connor would also make the ministry. Three new National Party members were elected to safe seats - Vaughan Johnson (Gregory), Marc Rowell (Hinchinbrook) and Lawrence Springborg (Carnarvon) - and all would become ministers in the Borbidge government.

Claiming victory, Wayne Goss became the State's thirty-fourth Premier, on 7 December 1989, shepherding Labor back into government after 32 years in the wilderness. Although he toyed with creating a smaller ministry (for better central coordination), he decided to retain the 18 positions but reconfigure the portfolios. 
His initial ministry was, like Frank Nicklin's in 1957, totally inexperienced in government but with many years' experience in the toils of opposition. It included

- Premier, Minister for Economic and Trade Development and for the Arts: Wayne Goss

- Deputy Premier and Minister for Housing and Local Government: Tom Burns

- Minister for Police and Emergency Services: Terry Mackenroth

- Treasurer and Minister for Regional Development: Keith De Lacy

- Minister for Tourism, Sport and Racing: Bob Gibbs

- Minister for Transport and Minister Assisting the Premier on Economic and Trade Development: David Hamill

- Minister for Employment, Training and Industrial Relations: Nev Warburton

- Minister for Resource Industries: Ken Vaughan

- Minister for Primary Industries: Ed Casey

- Minister for Health: Ken McElligott

- Minister for Education: Paul Braddy

- Minister for Environment and Heritage: Pat Comben

- Attorney-General: Dean Wells

- Minister for Family Services and Aboriginal and Islander Affairs: Anne Warner

- Minister for Justice and Corrective Services: Glen Milliner

- Minister for Administrative Services: Ron McLean

- Minister for Manufacturing and Commerce: Geoff Smith

- Minister for Land Management: Bill Eaton

The Labor government had its own agenda and policy priorities, but it also had to wrestle immediately with the Fitzgerald reform agenda. Queensland was about to embark on a whole new chapter in its political history. 



\section{Conclusion: do the 'ayes' have it?}

The Queensland Parliament is an inherently political and adversarial institutionvibrant in some areas, moribund in others. Under the Constitution, it is principally its own 'boss' and has all the strengths and weaknesses that concept implies. If perhaps not Australia's most reformist parliamentary institution, it nevertheless is not a static institution in any way. It changes over time as circumstances change; it is refreshed with new personnel and procedures; it can be analytical or banal; it can display prudence or excess; it can be characterised by goodwill or enmity; it can be a workhorse or it can be symbolic. In many ways, parliament is a mirror of society, reflecting its values, visions and apprehensions. It consists of elected members who represent specific constituencies at the local level and who share the concerns and biases of those communities. Parliament can also react to itself and become self-referential, and it will take heed of coverage of itself and its activities by the media and react to changing attitudes and the expectations of the wider community.

Parliament is an important part of the political system, but it is only one part of that system. Although it considers itself supreme, it has rivals and combatants and other institutions vying for attention. The other components of the political system include the executive, which sits in and dominates the Parliament but is separate from it. So too are the media, the courts, other levels of government, the array of interest groups and social movements, other forums and tribunals and the citizenry. In short, the Parliament is not an island sitting alone in deliberation; it is a player in the system and not necessarily centre-stage at all times.

Perhaps the best way to consider the workings and outcomes of the Queensland Parliament is to think of it as the coming together of four sets of influences. These are

- the place where the legitimate expression of politics occurs, which meets at relatively regular intervals, where events and activities take place and where power is exercised

- the people who make up the institution, the interests and constituencies they represent, their personalities, their qualities and foibles

- the political agendas, ideas and discourses that flow through and inform parliament, its debates, grievances and controversies

- the practices and procedures that provide order, the rules of the game and the terms of political engagement. 
These influences are discussed below in relation to the Queensland Parliament during the period 1957-89.

\section{Parliament as 'place': a political institution}

The Queensland Parliament is an adversarial place where events, decisions and outcomes take shape. It is a highly formalised institution, with a physical presence, a building and facilities. Some of its traditions date back centuries through the influence of English parliaments, but also new and reconfigured conventions are constantly being applied. The Chamber is a special place of debate with its own special 'privilege' and other important protections, and with public records of its business.

A history of the Parliament has to be sensitive to these institutional structures, events and developments. Politically significant events also occur, however, outside the Parliament. A history of the Parliament is not a history of the whole society or of all dimensions of politics. It is not a history of the entire state and everything that occurs within it. Indeed, parliament is in many ways only a subset of these broader concerns and is often selective about the issues on which it chooses to focus.

It is, therefore, incorrect to think that parliament deals only or mostly with the important matters of state. Some momentous issues are not much evident in its records and developments occurred in Queensland during these decades that did not attract a great deal of attention from the floor of the Parliament. The police raid on Cedar Bay in 1976 was one case that for various reasons attracted little serious debate at the time. Indigenous issues were not at the forefront of the Parliament's agendas during the time covered in this history. One additional reason for this is that the Parliament was often not sitting when tumultuous events were taking place. It was not uncommon in the period for parliament not to be sitting for months at a time-sometimes up to six months and even up to eight. The Assembly generally sits for about 60 days a year (that is, there are 300 days when it does not sit). A particular event could be over when the Parliament finally came back into session, meaning the event received no serious attention or debate. Subsequently, mention could be made through a comment tacked onto a speech on some other matter, or the occasional throwaway line here and there. Conversely, some less significant issues or trivial things could consume or waste an enormous amount of time.

The Queensland Parliament is a winner-takes-all institution and, so, to the victor go the spoils. The party or parties able to form a majority and govern are also able to control the legislature. There were many dimensions to this control. The government always selected the people to fill the senior positions including 
the Speaker, Chairman of Committees and the deputy chairs (which for most of the time contained only one or maybe two non-government members; see Chapter 1 for a list of these offices). The government steadfastly refused during this period to contemplate having an open (non-whipped) vote for the Speaker or for senior positions (including chairs of committees). Significantly, for most of the time, the Parliament had no parliamentary committee system in existence, although belatedly a scrutiny of legislation committee was established followed by an accounts and works committee in 1988-89. Again, the government also claimed the chairs of these committees. There has not yet developed a tradition whereby non-government parliamentarians are expected to take responsibility for chairing these potentially important committees. Although the opposition may provide the deputy chair, it is rare that they get to chair the committee themselves.

During the period of this history, the government's domination over the House ensured that only government business was ever attended to. With the exception of grievance motions (matters of public importance, want-of-confidence motions), there was almost no non-government-led business to mention and certainly no private member's bills to debate. It was a closed shop.

\section{Parliament and its people}

Parliament is an institution of people with interests in politics and public policy. They have ambitions, egos, reputations, jealousies, rivalries, likes and dislikes and even hatreds. In some ways, these qualities are what make parliament work as a deliberative forum where the interests of electors are represented, given voice and grievances aired. During this period, many members made carefully structured contributions to the debates and raised searching questions, taking their contributions very seriously. Others were less careful and put little thought into their occasional contributions or spoke off the cuff.

Politicians enter parliament with a range of skills and from different walks of life, with different backgrounds and motivations for being there. In the period of this history, some were dedicated, honest and conscientious, but few were angels. Many were eccentrics and had their own foibles or idiosyncrasies and some had dark secrets that sometimes emerged much later in their careers. Some, like Tom Hiley, were known for their dandy style of dress and walking with a cane. Others were known for what they consumed-whether it was food or alcohol. Others became notorious for their meanness and parsimony of purse. Paradoxically, two of Labor's more effective opposition spokesmen during the period (Bill D'Arcy and Keith Wright) would later both be charged with serious crimes and jailed. A good many politicians, including one premier, died in 
office, as sitting members (a list is included in Appendix 3) or very shortly after leaving parliament. The high rate of fatalities was predominantly because politics was a second career and perhaps personal lifestyle concerns were not then such a priority.

Because parliament was composed of political opponents who often had long histories of personal conflict, members would often express their adversarialism in personal terms. To leave these personal dimensions out or censor them would not be to present parliament as it really was. Members would often resort to name-calling or invective and descend into personal abuse. 'Dishing it out', as it was called, was a routine weapon in the political arsenal of members. So, too, was making allegations about one's opponents to await a predictable reaction. Even frontbenchers who were responsible for leading their own side of politics were not averse to handing out the occasional personal invective - such as Tom Burns, Ron Camm, Ed Casey, Llew Edwards, Bill D'Arcy, Keith Wright, and later, both Mike Ahern and Wayne Goss could go feisty rounds together. Burns was once ejected from the House for refusing to withdraw a remark after he had alleged the Treasurer, Llew Edwards, had come to him 'snivelling looking for preferences'. When Edwards objected, Burns said to the Speaker, 'I am sorry, but you will have to throw me out because I won't withdraw or apologise to the worm ever' (QPD 1982:vol. 288, p. 81). They were meant to be debating an appropriation bill. On another occasion, Burns claimed that half the people in the National party in the North cannot read' and, when Martin Tenni complained, Burns called him a 'mongrel dog' who liked to hand it out but who 'does not like to cop it'. Again, when asked to withdraw the remark, he said, 'I withdraw the words "mongrel dog". I will call him an average dog, or just an ordinary dog' (QPD 1981:vol. 285, p. 3072). There were few moments of real affection or empathy, with the main exceptions being immediately after the deaths of respected members such as Jack Pizzey, Kev Hooper and Denis Murphy. The Parliament was rarely amicable after 1969.

Some members liked to behave as buffoons, with perhaps the main culprit being Tom Aikens, who for decades was prone to talking absolute nonsense and making speeches consisting mainly of vituperation. Like Ted Walsh, Aikens in his day could be a forceful opponent. Independents in particular often felt more able to criticise both sides simultaneously and occasionally raised issues that neither side wanted aired because there was a 'code of silence' between the major parties on some issues. Their influence waned, however, as the decades wore on and there were no genuine independents after Aikens retired (although Hartwig was elected as a sole independent in 1983). Beside Aikens and Walsh, these spirited individuals included 'Bunny' Adair, Arthur Coburn and, after they fell out with their parties, Alex Dewar, Ed Casey and later Lindsay Hartwig. Some members liked to develop a reputation as opinionated loudmouths, inveterate 
muck-rakers or chose to contribute mainly by baiting the other side - and often these members were somewhat renegades on their own benches, such as Des Frawley, Lindsay Hartwig, Lou Jensen, Brian Davis, Ray Joe Kruger and Lew Yewdale. Most of these members remained perpetual backbenchers with little chance of being considered for the ministry or shadow ministry. A few who became ministers or opposition frontbenchers were similarly inclined, including: the Nationals' Wally Rae, Russ Hinze, Don Lane and occasionally Ken Tomkins and Ivan Gibbs (as well as Brian Austin in the Ahern years) and Labor's Col Bennett, Tom Burns, Pat Hanlon, Fred Bromley, Ed Casey, Kev Hooper, Bill D'Arcy, Doug Sherrington, Percy Tucker and later Bob Gibbs. None of them was shy about 'dishing'.

Other members were more conciliatory and could display professional courtesies. Terry Mackenroth, one of Labor's emerging 'hard-men', worked cooperatively with Bill Hewitt and Sam Doumany. Llew Edwards thanked Bill D'Arcy for his cooperation on the Statutory Bodies Financial Arrangements Bill, claiming 'although at times we tend to throw insults across the Chamber, I want to acknowledge the co-operation that I have received on this occasion, particularly from the honourable member for Woodridge' (QPD 1982:vol. 288, p. 626). On a few occasions members would work cooperatively on informal bipartite or tripartite committees, but generally only on non-contentious matters (such as consumer affairs protection in 1970).

\section{Political agendas and discourses}

Political ideas and policy agendas are the lifeblood of a parliament. The Queensland Legislative Assembly could go from great visions of substance and import to squalid diatribes on censorship issues or recollections of what dresses Mae West once wore. Those members standing up to speak from their 'own seats' in the Assembly (not at a dispatch box) could wax eloquently over issues of high politics and great moments of state and then meander on to the mundane and totally trivial. Because the House had a fair diversity of business matters to cover, on most sitting days its proceedings were often bitty and disjointed. Questions, ministerial statements and formal debates were piecemeal, often tangential and sometimes quite unrelated to each other. The exceptions to this were the set-to debates when both sides would 'debate' each other for 10 to 12 hours on a topic of passionate interest (votes-of-confidence motions, industrial laws, the Essential Services legislation, SEQEB or, at the end of the period, the responses to the Fitzgerald Report). Generally, there was no right, say, to respond to a ministerial statement or question the minister directly on its contents. In speaking to a bill, after the mover and seconders had introduced the debate and had attracted two opposing speakers, the debate would proceed usually with 
alternating contributions. Although speakers were successively alternated in this way, nothing required each debater to respond necessarily to any previous points made (or sometimes even the main point of the debate). Sometimes debates could appear almost as exercises in random thoughts.

Parliamentarians were themselves largely responsible for choosing the topics on which they elected to speak and for selecting the content of their contributions. Together, the whips usually agreed the time allocated for debates, how many speakers would participate and in which order they would appear. Each speaker would, however, have some latitude in deciding what they spoke on and how they chose to address the topic-perhaps factually, polemically, generally, with detailed criticisms or resort to bluster. Some speakers were given short notice by their own whips or party leaders and occasionally members would admit to having drawn the short straw in having to make a contribution. It was frequently the case that government legislation was presented to the Parliament without much, if any, prior warning, not only to the opposition members but to the government's own backbench too. Certainly, the debates in parliament may be initiated (and overall controlled) by the executive, but the content, the ideas and the agendas are fashioned by the members themselves. Members who had a burning issue to get off their chest invariably did so - even if not necessarily at the time of their own choosing. The question remains, however, did these contributions have much impact or effect? The answer, for most legislation, was not much, which is one reason why allegations of impropriety were often made by the opposition as a means of gaining some attention and perhaps action.

The Address-in-Reply debates to the Governor's opening address or budget debates could roam aimlessly into meandering monologues, touching on any topic of particular concern to the member nominated to speak. They were notoriously laced with tangential padding, with members returning to favourite topics or personal obsessions - over time banging on again and again on the same issue. At various stages this was the availability of racy stories or the Premier's use of his aircraft, what Labor's factions were up to this week, aspersions about the judiciary, rumours of Coalition disharmony, women taxi-drivers, tips for the greyhound or trotting races and even where police were placing speeding traps. It seemed a continual battle to hold the attention of members for any length of time. Some members attempted to curtail the number of days allotted to these 'debates' because after one or two of the leaders had spoken they rapidly degenerated into little of any consequence.

The main exception to this characterisation was in the period from the end of 1987 to 1989, with a new Premier and, more importantly to this particular matter, a new opposition leader with a far more disciplined and targeted strategy of opposition. Although it was an acrimonious parliament with everything to play for at the 1989 election, the quality of ideas, questioning, investigative 
scrutiny, the research and thematic coherence improved markedly. A number of Liberal members were also beginning to raise issues against the government during this time from the cross-benches.

Question time also allowed agendas to be pursued. Questions ranged far and wide, sometimes becoming mini-speeches rather than questions, and some members became quite accomplished at delivering a pointed political attack while asking a loaded question. There were some general questions about overall accountability or the government's policy approaches, but most were about electoral matters, usually about some local complaint or timing issue. Although questions always received a response (even if it was a one-word response such as 'No'), they did not always necessarily receive an answer. For about half of the period covered by this history, questions were allowed only on notice (and had to be given to the Speaker ahead of question time before 1970), but thereafter questions were allowed without notice, but in most cases some form of written notice was still required. Only towards the end of the period were questions truly 'without notice' allowed. And follow-up questions by the same questionercommon in some other jurisdictions - were not usually permitted. It is also clear that many members did not put much effort into investigating issues on which to ask questions, relying on the media to provide them with convenient topics. The Courier-Mail was a constant source of available ammunition and sometimes the limit of their research. Criticisms of the lack of adequate resources available to the opposition throughout this period should also be borne in mind.

Probably about three-quarters of the questions asked during the period were serious attempts at eliciting important information and scrutinising ministerial responsibilities (even if the question was based on scuttlebutt). Others, however, were in the category of 'ridiculous questions'. For instance, Norman Lee (Lib., Yeronga) asked a new Primary Industries Minister, Mike Ahern, about the quality of rump steak in Queensland, inquiring whether the minister knew that the manager of the Parkroyal Motor Inn had complained about the local quality and taken rump steak off his menu. Ahern said he read the report in the paper that morning 'with disbelief' and that he was sure it was a 'silly assertion' - yet perhaps no more silly than the question itself (QPD 1981:vol. 282, p. 341). Later, another question was asked about whether kangaroo meat was being substituted for beef in butchers' shops (QPD 1981:vol. 284, p. 1838).

If the executive could control outcomes by relying on its numbers, it could not keep contentious issues permanently off the agenda or prevent issues from recurring, sometimes with repetitive frequency. Lobbying from business, the unions, developers, the gaming industry, local councils, churches and moral crusaders could keep up the pressure over certain issues, keeping them 
regularly at the forefront of debate. During this period, examples included: the introduction of poker machines, casinos, mining leases, leisure resorts, exemptions from planning, film censorship and promiscuity.

\section{Practices and procedures, and the limits of political engagement}

The Queensland Parliament, like every other, runs according to certain practices and procedures. These constitute the rules of engagement and while they might appear to be neutral are weighted in the government's favour because of its ability to enforce its chosen tactical option. The executive dominates parliament through a combination of Governor-in-Council decisions (the ability to summon and dissolve the Assembly) and its control of the House under the Standing Rules and Orders. The executive determines when parliament sits and rises, for how long it sits in a session, when it adjourns for the day or for how long it will be asked to continue debating late into the evening or night. The executive also sets the budget for the operation of the Parliament and usually it did not have much interest in adequate resourcing or in assisting members with research or facilities. Resources provided for the Assembly were tightly rationed (for support to members, for staff, travel, library resources and administrative support); and this would later be given, by both the Fitzgerald Report and the subsequent research of the Electoral and Administrative Review Commission, as one of the weaknesses in the accountability parliament was able to exert on executive government.

Most importantly, the government always imposed tight control over the daily agenda of the House, determining what went on the business paper each day and what would be discussed (and could, and sometimes did, change this during the day itself). The Standing Orders are the crucial ingredient in this control and those in operation during the period covered by this volume were the product of more than a century of rule augmentation covering the internal procedures governing the House. These Standing Orders restrict what kinds of questions are allowed, how long question time lasts, what forms of discipline governments can impose over opponents, the ability to 'gag' the opposition, how documents are tabled and what opportunities oppositions have to state their case, raise grievances or take up points of order. They limit the scope for political engagement to a formulaic but manageable exercise. The Speaker is the enforcer of these rules and would often constrain how far an opposition could go in pursuing some matter and favour the government in specific rulings. Equally importantly, the government could always use its numbers to refuse any opposition request and even expel members for various periods. 
Critics often made accusations that the Standing Orders were archaic and inflexible. There was ample criticism that the rules had not kept pace with modern parliamentary practice elsewhere and indeed until the early 1980s the government had steadfastly refused to allow the committee overseeing these rules ever to meet. Although each parliament would appoint members of a Standing Orders Committee, it would never meet because the government refused to call it together. Even when the Standing Orders Committee (of senior ministers and opposition frontbenchers) did meet in 1980 the prevailing orders were hardly relaxed.

One of the most extreme controls is the expulsion of a member (usually an opposition member) for a variety of reasons (showing dissent, contempt, misbehaviour or unparliamentary language that is not withdrawn). Speakers can order members to 'withdraw' if they (or what they said) were considered to be out of order, meaning that they were prohibited from further attendance but for that day only. For more serious breaches, however, on a motion from the Leader of the House or a senior minister, the Assembly can vote to suspend an offending member for a given number of days. A full list of suspended members is included in Chapter 13, while a longer list of members asked to withdraw for the day is attached as Appendix 4.

Under Westminster conventions, ministers exercise ministerial responsibility usually by attending the House when in session and appearing at a minimum at question time and in key debates over legislation they have introduced or for which they will be responsible. Such conventions were adhered to relatively closely in the Nicklin and early Bjelke-Petersen years, but gradually discarded in later years. As the Bjelke-Petersen Premiership wore on, it was not uncommon for ministers to skip question time entirely or absent themselves when their legislation was before the House. The Opposition Leader, Ed Casey, asked in November 1981 why nine ministers were missing from question time and who was going to accept questions on these portfolios. In 1982, Casey again complained that only four ministers from a ministry of 18 were present, claiming question time was becoming a 'farce' and that Standing Orders should require ministers to be in attendance ( $Q P D$ 1982:vol. 287, p. 5125). Some ministers came in for particular criticism for repeated absences during question time (such as Llew Edwards when he was Treasurer). Bjelke-Petersen when he was both Premier and Treasurer from 1983 to 1987 almost never sat through budgetary debates, as Gordon Chalk and Bill Knox often did.

In an almost senseless show of petulance, the Bjelke-Petersen government would not publicly accept the concept that the opposition was an 'alternative government' waiting in the wings. The government rejected any notion of a 'shadow ministry' - not only Bjelke-Petersen, who was belligerent on this point, but other senior ministers were hostile to the idea. Some senior Liberal 
ministers would acknowledge that the opposition had appointed a spokesperson who would take the lead on matters in their portfolio, but it was far from formal recognition. In the late 1970s, the Parliamentary Library once got into enormous trouble when it asked the Labor opposition for its list of shadow spokespeople and published it as the shadow ministry (thinking they were doing a public service, for the convenient reference of the media and other interest groups, and so on), but the Premier chastised them for doing so. One of the many reforms allowed by the Ahern government was to recognise the shadow ministry and allow Labor to table its spokespeople. It was a small, but important, recognition of the legitimacy of the opposition within parliamentary democracies.

\section{The 'ayes' control proceedings, but still need consent}

Finally, the title of this volume is 'The Ayes Have It', and there can be little dispute about the certainty of this outcome throughout the bygone era covered in this study. The history of the Queensland Parliament during these decades clearly showed that almost invariably the 'ayes' controlled the proceedings, decided things their way and determined what results they wanted (even election results). As Bjelke-Petersen once said, 'the numbers are the only things that matter in politics' (cited in Chapter 7). There was little the opposition could do to prevent abuse, excess or unaccountable behaviour. The 'ayes' might have ruled the day, almost to the point of despotism, but over time they could not prevent the accumulation of demands for systemic reform. All parliamentary systems - even harsh 'winner-takes-all' systems - operate in a social, political and legal context; a context that implies consent, which can resist if necessary and urge reform. In Queensland, that 'context' eventually did fight back, especially in the aftermath of the Fitzgerald Inquiry. A quiet social revolution started in Queensland politics about the time of the passing of the Bjelke-Petersen era. This social revolution imposed new reform agendas on Queensland's system of parliamentary democracy, placed constraints on unbridled executive power and targeted misconduct and corruption that had been allowed to flourish. As a final reflection, the 'ayes' could make history most of the time, but not always under the conditions of their own choosing. 


\title{
Appendix 1
}

\section{The Speakers of the Queensland Parliament, 1957-1989}

\author{
John Henry Mann ('Johnno')'
}

(Speaker, 10.10.1950 to 3.8.1957)

John Henry Mann was born in Rockhampton in 1896. At the age of fourteen, he left his school in Mount Morgan and worked in a variety of manual jobs (as a cane cutter, meatworker, stockman and wharfie) before moving to Brisbane during the Depression, where he was active in several unions. He attended the Workers' Education Association and equipped himself with skills and a profile that helped in his election to the Queensland Parliament for the Australian Labor Party in the 1936 by-election for the seat of Brisbane.

Mann was an enigma - regarded by some as a generous benefactor (in his early years in the Parliament, during the late 1930s Depression, he bequeathed a significant portion of his parliamentary salary to the poorer residents of Spring Hill), and by others as a tough and fierce opponent. He belonged to a diverse range of extra-parliamentary organisations, including the Caledonian Society and the Royal and Ancient Order of Buffaloes. 'Johnno' Mann was a passionate advocate for the disadvantaged but also a great hater, with Jack Egerton, then ALP President and President of the Trades and Labor Council, one of his prime adversaries. Adversarial politics suited Mann, who was never afraid of a fight. In 1950, it looked as though Mann might be dumped from the Parliament, when he almost failed to win preselection for his own seat - securing renomination only after a six-hour debate at the Labor convention held in Toowoomba. Mann would go on to stay in the Parliament until 1969 when he retired as one of the longest-serving members (33 years, one month and 13 days).

Mann was Chairman of Committees between 1944 and 1950 before being appointed Speaker of the Queensland Parliament, a position he held for seven years (1950-57). He ran the Office of the Speaker with 'forceful dignity'. Reminiscing on his years in the chair, Mann advised: 'you never forget you're the boss, and you never let anyone else forget you're the boss. ${ }^{2}$ Mann realised

1 John McCulloch's earlier research on Speakers of the Parliament was drawn on for these portraits.

2 <http://www.parliament.qld.gov.au/aspg/papers/981105.pdf> (viewed 30 March 2009). 
early on in his political career that to survive in Queensland politics you had to tackle allegations head-on and he was not averse to using the media to state his case.

Mann's reputation as a drinker and gambler was legendary. After Mann's retirement, a minister in Frank Nicklin's government remarked 'there were few crimes [Mann] has not, at some time committed' (Sunday Sun, 14 January 1973). The most serious allegation was that Mann had been involved in a corrupt tendering process in relation to sewerage contracts at Redcliffe. A royal commission subsequently exonerated him.

Don Lane (Lib., Merthyr) remembered in his speech during the motion-ofcondolence debate after Mann's death in 1973 that he was "fair dinkum" to his mates. He was open handed towards his friends and constituents, and if any were "down and out", or destitute for money or help in the home, he would be the first to give assistance from his own pocket.' Opposition Leader, Jack Houston, recalled:

$[\mathrm{H}]$ is name constantly crops up here, if not in personal references then certainly in references to decisions that he made during his many years as Speaker...He would fight strenuously if his point of view differed from that of others, but, once the fight was over, 'Johnno' was happy to say, 'Let's go and have a beer together'...He was a person who passed through this Parliament and whose name, deeds, and even legends, will be remembered when most of us have been forgotten. (QPD 1973:vol. 261, pp. 2643-44)

One extra-parliamentary decision of Mann's - to transport a racing greyhound in the Speaker's limousine (which was subsequently involved in an accident)seems, however, unlikely to be repeated.

While facing numerous controversies during his period in the Parliament, Mann was a survivor who emerged relatively unscathed. Humour was his principal armour and was often on display during tough questioning in and out of the House. During one election campaign an opponent attempted to smear his name by suggesting he had spent Christmas Day at the pub rather than with his family. At his next electoral meeting, an outraged Johnno waved the pamphlet alleging this wrongdoing, exclaiming 'this is a damn lie...I didn't leave my family on Christmas Day. It was New Year's Day'! His vote increased at the next election (Sunday Sun, 14 January 1973).

Loyalty and mateship were important to Mann. This was evident in 1972 when he resigned his life membership of the ALP after what he described as the 'lopping of three heads' when the ALP withdrew the endorsement of 
three sitting members: Ed Casey, Col Bennett and Merv Thackeray. Years later, Russ Hinze reflected 'he was a great bloke and a hell of a good Speaker' (QPD 1987:vol. 306, p. 2886).

Mann lived only four years after his retirement in 1969, dying at the age of seventy-three in Brisbane.

\section{Alan Roy Fletcher ('A true gentleman')}

\section{(Speaker, 27.8.1957 to 15.6.1960)}

Alan Roy Fletcher was born in Pittsworth in southern Queensland in 1907. He was educated at the state school in Pittsworth and Scott's College in Warwick. In 1934, following in his father's footsteps, he began running a dairy farm and graingrowing property at Mount Tyson. Later he bought a 400-hectare property at Mount Russell, which had been owned by the late James Tyson. His interests in grain growing led to his being a director of the Queensland Cooperative Milling Association - a position he held until his election as Speaker of the Legislative Assembly.

His career in politics began in 1945 when he was elected to the Pittsworth Shire Council. He was Council Chairman for nine of the 10 years he served as councillor. He was elected Country Party Member for Cunningham in March 1953, a seat he held continuously for more than 20 years until his retirement in December 1974.

Fletcher became Speaker on 27 August 1957, after the election of the CountryLiberal Government; he was the first non-Labor Speaker since 1932. According to Jack Pizzey, Fletcher was considered a 'man of sound judgment, ready wit, impeccable character' and was held in high esteem by both sides of the House (QPD 1957:vol. 220, p. 3). He took on the role of Speaker with 'a high sense of the dignity, traditions, and responsibilities of the office' (Lack 1962:627). He was regarded as having tremendous respect for the institution of parliament (QPD 1957:vol. 220, p. 4) and, according to Lack (1962:627), 'maintained the scrupulous impartiality implicit in the office of Speaker, and strictly enforced the observance of the rules of debate'.

Under Fletcher, the standard of decorum and dignity of parliamentary proceedings were considered to have attained their highest levels for many years. His keen intellect, sound judgment and even temperament were qualities that stood him in good stead in his role as Speaker. Even though he served only one term as Speaker, Fletcher's firm control of debates in the House encouraged much improvement in members' behaviour. He was consistently firm yet courteous. 
He held the position of Speaker until 15 June 1960, when he was appointed Minister for Lands after the re-election of the Country-Liberal Coalition. Adolf Muller had resigned from the Lands portfolio and Fletcher, having had a great deal of experience in land and agricultural practice, was chosen to take his place. According to Lack (1962:627), he was reluctant to relinquish the Speakership.

He was Minister for Public Lands and Irrigation from 1960 to 1963 and then Minister for Lands from 1963 to 1968 under Nicklin's Premiership. When Jack Pizzey succeeded Nicklin as Premier in 1968, Fletcher stood for the job of Deputy Leader of the Country Party, but was beaten by Joh Bjelke-Petersen. He stood again when the latter became Premier later the same year, but a relative newcomer, Ron Camm, was preferred.

Fletcher served as Minister for Education and Cultural Activities in Pizzey's ministry, from January 1968 to Pizzey's death in July 1968. He held the same position in the Chalk ministry (1-8 August 1968) and then in three successive Bjelke-Petersen ministries until his retirement in December 1974. As Education Minster, he was responsible for introducing preschool education into Queensland (QPD 1991:vol. 320, p. 1732).

\section{David Eric Nicholson ('The Cannonball Kid')}

\section{(Speaker, 23.8.1960 to 22.5.1972)}

David Eric Nicholson was born into a farming family in New Zealand in 1904. He was educated at public schools in the small rural town of Masterton before qualifying as a motor mechanic. He was a keen sportsman and his passion for competitive cycling brought him to Australia in 1925. He graduated from cycle racing to motorcycle speedway racing and was the first rider in Australia to ride the 'Wall of Death' at the Brisbane Exhibition. In a farewell poem entitled 'The Carnival of Thrills', written for his racing friends in 1926, he signed himself 'The Cannonball Kid'. His daredevil lifestyle was often referred to later when he became Speaker of the Legislative Assembly.

Nicholson settled in Queensland in 1934 and ran an electrical business in Caboolture for 22 years. He joined the Country Party in 1937 and in 1950 contested a party plebiscite for the seat of Murrumba, north of Brisbane, which he won against seven other candidates. He held that seat with a sizeable majority for 22 years.

He became Speaker on 23 August 1960, a position he held until his resignation on 25 May 1972, which was a record term. In his speech nominating Nicholson for the Speakership, the Minister for Education, Jack Pizzey, referred to him as 'a man of irreproachable character, quick decision and steady nerve' ( $Q P D$ 
1960:vol. 227, p. 3), the latter description presumably referring back to his days as a motorbike speedster. Pizzey believed that he had a high degree of the sense of fair play and impartiality - attributes eminently suitable for a Speaker of the Legislative Assembly. At the time of nominating Nicholson for the Speakership, Pizzey expressed confidence in his ability to maintain the decorum and dignity of the House (QPD 1960:vol. 227, p. 3). Nicholson was elected but not before some political grandstanding occurred. Two other members of the Coalition were nominated by the outspoken Ted Walsh (QLP, Bundaberg) after a marathon twohour discussion. Harold Taylor (Lib., Clayfield) was the first Coalition member nominated by Walsh (QPD 1960:vol. 227, p. 18), but this was speedily rejected by Taylor himself, who was at pains to point out that he had not approached Walsh with nomination in mind and did not want to be regarded as a 'nasty rodent'. Walsh then nominated his second choice, Eric Gaven (CP, Southport), on the grounds that Gaven had been beaten by only one vote when Fletcher won it in 1957 (QPD 1960:vol. 227, p. 19; Lack 1962:580). This final attempt at point scoring failed when Walsh could not secure a seconder. Nicholson was then elected unopposed.

Before becoming Speaker, Nicholson had considerable parliamentary and committee experience. During the thirty-fifth Parliament (27 August 1957 - 3 March 1960), he was Temporary Chairman of Committees, acting as Chairman of Committees on many occasions. He was also Deputy Chairman of the Housing Committee and a member of the Education, Health and Works Committee. He had been a member of the parliamentary committee investigating youth problems and in 1958-59 was the government's representative for the Australia Day Council.

Once Speaker, Nicholson continued to learn about parliamentary processes and was nominated in 1961 as Queensland's representative to attend a course in parliamentary practice and procedure, conducted by the UK branch of the Commonwealth Parliamentary Association. Under his guidance, Parliament House was restored and the Legislative Assembly chamber completely remodelled.

As Speaker, Nicholson defended the system of asking questions on notice, considering that 'a full and complete answer the morning after [was] better than a half answer off the cuff' (Courier-Mail, 24 April 1965). He later became concerned that the introduction of questions without notice meant that question time had degenerated from a 'fact-seeking and finding session into a slanging match', which brought little credit to the Parliament (QPD 1970:vol. 254, p. 767). He did not consider it appropriate for members to read from prepared notes when answering questions without notice - questions were to be concise 
with only sufficient working to make them clear and the answers were expected to be of a similar quality. He frequently appealed for 'sanity and decorum in the House during question time'.

Nicholson was not a Speaker who stifled debate and he allowed members of both sides of the House to have their say. He had the reputation of being a 'career Speaker' (Courier-Mail, 15 October 1970), preferring to remain as Speaker rather than accept a post in cabinet. He was proud of his success in lifting the status of Speaker and was a stout defender of the British parliamentary system. When questions were raised in the House about his involvement in party politics, he distinguished between his role as Speaker in the House and his right to participate in his party's activities outside the House. He stated that while he occupied the chair he did so in the capacity of Speaker, and while he was controlling the conduct of the business of the House, he also acted in the capacity of Speaker (QPD 1970:vol. 254, p. 1259). At other times, however, he proved he was not afraid to enter the political fray in his capacity as a party member, and was part of a deputation of Country Party MLAs that visited Premier Bjelke-Petersen to invite him to resign as premier in 1970 (Hughes 1980:120).

Nicholson resigned as Speaker and Member for Murrumba on 25 May 1972, having been the longest-serving speaker in Queensland parliamentary history. He was considered to be a strict, yet very fair Speaker but also a 'government

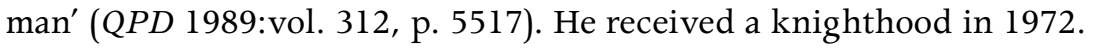

\section{William Horace Lonergan ('Bugger 'em Bill')}

\section{(Speaker, 2.8.1972 to 28.10.1974)}

William (Bill) Horace Lonergan was born at Cloncurry in north Queensland in February 1909. The son of a miner and publican, he was educated at schools in western Queensland before working in various parts of the state as a railwayman, miner, outback worker, construction worker, hotel keeper, car dealer and postmaster. He eventually took up sheep selection and settled at Mundingburra in Townsville.

Lonergan made several attempts to enter parliament. He unsuccessfully contested the seat of Haughton for the Liberal Party in 1950, before joining the Country Party and unsuccessfully contesting Flinders at a by-election on 12 March 1955, and again the next year. He was finally rewarded, winning the seat of Flinders in north-western Queensland in 1957, having defeated a former Labor Prime Minister and Minister for the Army (Frank Forde) by one vote. After Forde lodged an appeal, the Elections Tribunal declared the poll void. In the subsequent by-election, Lonergan finally won Flinders by more than 400 votes. He held the seat until his resignation in October 1974. 
Lonergan became Speaker in August 1972 in quite extraordinary circumstances. The Coalition parties had agreed that James Houghton was to be the new Speaker after the resignation of David Nicholson. Houghton was nominated by the Minister for Primary Industries, Vic Sullivan (CP, Condamine), and his nomination was seconded by Mike Ahern (CP, Landsborough) (QPD 1972:vol. 259, p. 3). In a sensational show of defiance, however, Lonergan, who was at the time the government whip, arranged his own nomination on the floor of the House by two of his Country Party friends, Roy Armstrong (Mulgrave) and Val Bird (Burdekin).

It has been suggested that some members of the Liberal Party did not trust Houghton after his decision to leave the Liberals and join the Country Party in 1962. In the final vote, Lonergan won 47-32 (QPD 1972:vol. 259, p. 14). He was quoted as saying that he was not taking on the Speakership for himself, but to gain some recognition for the northern part of Queensland, which he considered had received a 'raw deal on representation in Cabinet' (The North Queensland Register, 15 July 1972). Lonergan's electorate, based on Charters Towers, covered more than 155000 square kilometres, and he often ran up close to $64000 \mathrm{~km}$ a year driving around it, often camping by the roadside in his travels.

During the two years he served as Speaker, moves were under way to build the Parliamentary Annexe (QPD 1981:vol. 284, p. 1359). Lonergan was keen on the idea of the new building and took a great interest in how members' needs and requirements could be met.

Some years later, during a long debate in the House on a vacancy of the Office of Speaker, Ed Casey (ALP, Mackay) referred to Lonergan as an unpopular Speaker who was not considered very fair. To others in the House, however, he was known affectionately as 'Bugger 'em Bill', which was said to be indicative of his attitude generally, although could have resulted from his early days in the Parliament when he shared a room with Roy Armstrong and reportedly used to scoop all the mail that had piled up on his desk and throw it in the bin with a dismissive 'bugger 'em'. Although he was not the first choice of the government in 1972, he proved himself to be a true government man, leading Casey to conclude that Labor Party members regretted that they had ever helped elect him (QPD 1989:vol. 312, p. 5517).

Lonergan resigned as Speaker of the Legislative Assembly and Member for Flinders on 28 October 1974 due to ill health. He died in Townsville in June 1981. In the motion of condolence on his death, he was referred to as one of the 'true characters' to have passed through the Queensland Parliament. He was a man of the people, a battler and a man who was prepared to fight for what he believed in (QPD 1981:vol. 284, p. 1359). 


\title{
James Edward Hiram Houghton ('Big Jim')
}

\author{
(Speaker, 29.10.1974 to 4.7.1979).
}

Born in 1911 in Sydney, James Edward Hiram Houghton was the son of a stationmaster. He was educated at Humpybong State School at Redcliffe in south-eastern Queensland and at Brisbane Technical College. He worked as a bank officer for 19 years with the Commercial Bank of Australia. After serving in World War II, he became a real estate agent in Proston.

His political career began in local government when he was elected as the first Mayor of Redcliffe in 1955. He entered state politics in 1960 when elected as Member for Redcliffe. Initially, he held the seat as an independent after failing to get Country Party endorsement. Then, after a brief flirtation with the Liberal Party, he joined the Country Party. Later he would explain that he had grown sick of sitting on the cross-benches 'like a mangy dog'! Houghton was appointed secretary of the parliamentary Country Party from 1963 to 1972 and was a member of various parliamentary committees. He was Chairman of Committees from 1969 to 1972 .

Houghton became Speaker on his second attempt on 29 October 1974-a position he held until his retirement from the Parliament in July 1979. His election as Speaker was not without incident. His nomination was moved by Premier Bjelke-Petersen and seconded by the Treasurer, Sir Gordon Chalk. The Labor Party was not prepared to accept Houghton as Speaker and nominated their member for Sandgate, Harold Dean. It was alleged by the Labor Member for Wolston, Evan Marginson, that the Speakership had been held out as a bribe by the National Party to the Liberal Party in return for its agreement to an early election (QPD 1974:vol. 263, p. 1678). In an attack on the suitability of a member of the Labor Party as Speaker, the maverick North Queensland Party's sole member, Tom Aikens, referred to the requirement for the Speaker to have 'honour, probity and courage', suggesting that a member of a party that supported the 'legalisation of abortion, prostitution, homosexuality and homosexual prostitution' could have none of those attributes. It should be noted that Aikens was not referring specifically to Dean, whom he considered to be 'a man of sterling character and of not little courage' (QPD 1974:vol. 265, p. 1679). In the ballot that ensued, Houghton was elected 42 votes to Dean's 29 (QPD 1974:vol. 265, p. 1680).

During his term as Speaker, Houghton was involved in considerable controversy. In May 1978, a serious conflict arose between him and Bjelke-Petersen over the use of members' domestic travel entitlements. When it was disclosed that some members had been converting domestic travel vouchers to obtain overseas tickets for themselves and their wives, Houghton said that he had approved 
these arrangements but subsequently banned the practice while a joint-party committee looked at the provision of overseas travel. The Auditor-General, in the meantime, found that there had been misuse of government funds by past and present members from all parties. The Premier said that he would legislate to prevent misuse of parliamentary funds and threatened to dissolve the Parliament if the legislation did not pass. The Speaker threatened to resign if cabinet attempted to interfere in the domestic affairs of the Parliament. This was averted, but a subsequent amendment to the Financial Administration and Audit Act established the Premier's responsibility for parliamentary appropriations (Hughes 1980:121).

Opposition members tended to regard 'Big Jim' Houghton as a fair Speaker, a fine man but a Speaker who 'fulfilled the Government's wishes' (QPD 1989:vol. 312, p. 5518).

Houghton resigned from the Speakership and the Parliament in July 1979.

\section{Selwyn John Muller ('Here to serve the government')}

\section{(Speaker, 7.8.1979 to 17.10 .1983 )}

Selwyn John Muller was born at Boonah in south-eastern Queensland in October 1918, son of the Country Party Member for Fassifern, Adolf Gustav Muller. After his education at Kalbar State School and Boonah High School, he became a grazier at Kalbar, later chairing the Fassifern branch of the United Graziers' Association. He was also chairman of the Kalbar branch of the Country Party and a member of the Boonah-Kalbar Show Society. During World War II, he served in the Australian Imperial Forces in the Middle East and New Guinea.

He was elected to the seat of Fassifern on his father's retirement in May 1969 and became secretary of the parliamentary Country (later National) Party in 1972, a position he held until 1979. He served on various government committees before becoming Speaker on 7 August 1979, a position he held until his retirement from the Parliament in October 1983. In seconding Muller's nomination for Speaker, Deputy Premier, Dr Llew Edwards, referred to Muller as 'a man of the greatest integrity, honesty, fairness and justice' (QPD 1979:vol. 279, p. 3). His election was opposed by the opposition, who nominated Kev Hooper, Member for Archerfield, but after a lengthy debate, Muller was elected Speaker by secret ballot 54 to 23 (with three informal votes) (QPD 1979:vol. 279, p. 32).

During his Speakership, according to Des Booth (NP, Warwick), Muller was 'noted for his tolerance and common sense' and behaved in an 'unbiased way' (QPD 1983:vol. 292, p. 15). This was not an opinion shared by members of the Labor Party, who considered that his loyalty was to the government, not to 
the House (QPD 1989:vol. 312, p. 5518). During a debate on the Speakership in 1987, Labor's Tom Burns referred to Muller as being 'National Party to the bootstraps', a Speaker who had made it clear that his job was to interpret the rules of the House to suit his party bosses (QPD 1987:vol. 304, p. 14). In 1989, Ed Casey also said of him: 'He was a very honest man. He was so honest that, after he was elected and taken up to the Speaker's chair, he said "Thank you, members, for electing me. I am here to serve the Government".' According to Casey, that is exactly what he did (QPD 1989:vol. 312, p. 5518). In fact, Muller is quoted as saying that it was his 'responsibility as Speaker' to apply the wishes of the government he represented (Courier-Mail, 8 August 1979).

In his role as Speaker, Muller was considered by members of his own party to have contributed to advancing the cause of parliamentary procedure (QPD 1983:vol. 292, p. 15) despite the fact that to others he appeared to 'lack concern about the fate of the parliamentary institution' and did not have an understanding of standing orders (Coaldrake 1989:70). Coaldrake suggests that the sacking of Terry White, a senior Liberal minister, in August 1983 could have been averted if Muller had understood a point of order raised by Deputy Premier Edwards. Muller refused Dr Edwards' call for a division after a motion without notice moved by a Liberal backbencher in favour of bringing forward discussion on the possible establishment of a public accounts committee (QPD 1983:vol. 291, p. 142). White was accused of breaking cabinet solidarity when he supported the motion, which apparently enraged the Premier and Deputy Premier.

A few days later, there was further evidence of Muller's lack of understanding of parliamentary procedure. He disallowed a matter of privilege to take precedence over all other business, a ruling that was considered to be politically expedient for a Coalition government in disarray (Coaldrake 1989:71). The Opposition Leader, Keith Wright, had risen on a matter of privilege but Muller had refused his call, instead allowing Premier Bjelke-Petersen to recommend the indefinite adjournment of the sitting of the Parliament.

Those actions confirmed the concerns about 'executive domination of State Parliament' raised by politicians at the time of Muller's election to the Speakership (Courier-Mail, 8 August 1979).

Muller resigned as Speaker and Member for Fassifern in October 1983.

\section{John Herbert Warner ('A nice bloke')}

\section{(Speaker, 22.11.1983 to 18.9.1986)}

John Herbert Warner was born in Sydney in November 1923. Educated at King's School Parramatta, he served in the Royal Australian Air Force (RAAF) during 
World War II in the Pacific and in the United States. He was made an honorary life member of the Warwick Show and Rodeo Society and was a member of the Royal National Association Brisbane and Toowoomba and a member of the Toowoomba, Downs and United Services Club. Before entering politics he was a farmer.

He was Secretary of the Darling Downs division of the National Party from 1972 to 1974 and in December 1974 became National Party Member for Toowoomba South. Warner's main motivations for entering politics were focused on deathor more precisely the abolition of death duties. This was a personal fight for Warner after his family had been nearly forced to leave their farm after the death of his father. He remained in the Parliament long enough to see death duties finally abolished a decade later (QPD 1991:vol. 319, p. 908). Warner was also an advocate for introducing the death penalty for serious crimes, but despite his efforts, he did not achieve its reintroduction.

Before becoming Speaker, Warner was a member of the Parliamentary Privileges Committee and, from 1979 to 1983, was its chairman. On 23 November 1983, he was elected Speaker by secret ballot, winning 42-39 against the Liberal Party's nominee, Col Miller (QPD 1983:vol. 292, p. 18). He was Speaker until his retirement in September 1986.

From many contemporary accounts, he was considered much too kind and gentle a person to be an authoritative Speaker (QPD 1991:vol. 319, p. 906). In a debate in the House some time after Warner's retirement, Labor's Ed Casey referred to him as 'a nice bloke' but 'a bit of a disaster' (QPD 1989:vol. 312, p. 5518). Even one of his former National Party colleagues, Don Lane (1993:143), referred to him as 'by far the most hopeless Speaker' he had encountered. This comment came after a blistering attack on Lane, when Warner called him a 'turncoat' in cabinet for running a campaign to remove him as Speaker and replace him with Col Miller, a conservative Liberal member.

Warner's time as Speaker has been referred to as 'fairly controversial and torrid' but it was not an easy task to chair the first Parliament to assemble after the breakdown of the Coalition (QPD 1991:vol. 319, p. 908). He had trouble maintaining order in the House and at times appeared to be quite stunned by the antics and behaviour of some of the members. He was, however, noted for his courage in the party room. He was apparently very much a rebel inside the party room and was one of the people who, on numerous occasions, had the courage to stand up to the then Premier, Joh Bjelke-Petersen (QPD 1991:vol. 319, p. 911). According to Bob Katter (NP, Flinders), 'on a number of occasions, he sat down the Premier... and it took a lot of courage to do that' (QPD 1991:vol. 319, 
p. 912). He was reported to have had great difficulties while Speaker because of his fair-mindedness, which was in conflict with the pressures put on him as Speaker in the House with respect to party loyalty.

John Herbert Warner died in Toowoomba in September 1991.

\section{Kevin Rowson Lingard ('Joh's little mate')}

\section{(Speaker, 17.2.1987 to 25.11.1987 and 5.7.1989 to 30.11.1989)}

Kevin Rowson Lingard was born at Miles in south-western Queensland in August 1942, the son of a sales representative. After attending Geham and Harlaxton State Schools and Toowoomba High School, he enrolled at the Brisbane Teachers' College and the University of Queensland, where he gained a BA, a BEdST and an Aed, majoring in history and political studies. Subsequently he taught at schools in Brisbane and Rockhampton. He was a master at a private school in Brisbane, and just before his election became the youngest ever high school principal at the newly established Kingston High School.

Lingard's inaugural address (QPD 1983:vol. 292, pp. 221-5) listed some of his achievements to date. He served on the State Government Boards of Adult Education and Special Programmes, was President of the Queensland Principals' Association, was a trainee teacher interviewer, was president of the Logan City Community Board of the South East Queensland Sports Association, a Queensland representative for rugby league and rugby union, a Brisbane A-grade rugby league coach and an $\mathrm{ABC}$ television and radio commentator. $\mathrm{He}$ was also a member of the Electorate Council and the National Party Education and Sport Policy Committees.

Lingard's parliamentary career began with his election to the seat of Fassifern in October 1983. The recently retired former Speaker, Selwyn Muller, had previously held Fassifern. Lingard took over the seat that had been held by Muller and his father for 48 years. In the Parliament, Lingard served in various capacities, including as a member of the Library Committee (1983-86), a delegate to the Australian Constitutional Convention (1985), delegate to the eighteenth Australasian Conference of Presiding Officers and Clerks (Cook Islands, 1987), a member of the Parliamentary Delegation to Pacific Rim Countries (1988), Commonwealth Parliamentary Association (Qld) Representative (Canberra, 1988; Barbados, 1989), President of the Commonwealth Parliamentary Association (Qld) (1989) and Parliamentary Representative on the University of Queensland Senate (from April 1989).

Lingard served two terms as Speaker (only the second person to do so-A. S. Cowley also having that honour a century before). His first term began on 17 
February 1987 when he was elected after a long debate. His election as Speaker appeared to be a fait accompli, the suggestion being that he had been 'anointed' by the Premier (QPD 1998:vol. 304, p. 28). The National Party was governing in its own right and Premier Bjelke-Petersen had decided that Lingard was to be Speaker. Members of the Liberal and Labor Parties, however, nominated members of their parties against him. Nev Warburton, Leader of the Opposition, attacked Lingard's lack of parliamentary experience and nominated Bill Prest, the Leader of Opposition Business in the House (QPD 1987:vol. 304, p. 10). The Liberals considered that their candidate, Bill Lickiss, was eminently more suitable as Speaker than either of the other nominations as he had considerable parliamentary experience, including two years as Chairman of Committees ( QPD 1987:vol. 304, p. 22). In the secret ballot that ensued, however, Lingard had the numbers; he won 46 votes to Prest's 30 and Lickiss's 10 (QPD 1987:vol. 304, p. 34). Lingard and the Premier explained the three informal votes from National Party members as being due to human error (Courier-Mail, 18 February 1987).

In his acceptance speech, Lingard said that he was 'determined to have strong control, strict discipline and impartiality' (QPD 1987:vol. 304, p. 34). His speech appeared encouraging to both sides of the House. He said:

I warn the government that the Opposition must be allowed to play a constructive role, and it is my duty to ensure that that is continued. Similarly, the Opposition parties must not be allowed to impede the role of the Government in providing good government for the people of this State. (QPD 1987:vol. 304, p. 34)

Even though members of his own party later thought that Lingard had filled the role of Speaker with 'distinction' (QPD 1989:vol. 312, p. 5431), members of the opposition suggested that he had 'knuckled under' to the wishes of Premier Bjelke-Petersen (QPD 1989:vol. 312, p. 5518) protecting the government of the day and the National Party (QPD 1989:vol. 312, p. 5521).

Lingard's first term as Speaker was relatively short; he resigned on 24 November 1987 during a historic dispute within the National Party. A close associate of Premier Bjelke-Petersen, he was appointed Minister for Health and Environment for a week in the dying days of the ninth Bjelke-Petersen ministry (25 November to 1 December 1987). When Mike Ahern replaced Bjelke-Petersen as Premier on 1 December 1987, Lingard returned to the backbench, where he remained until July 1989.

On 5 July 1989, Lingard was nominated again as Speaker after Lin Powell's sudden resignation ( $Q P D$ 1989:vol. 312, p. 5430). Powell was also renominated-by Wayne Goss, Leader of the Opposition, on the basis of his perceived independence as Speaker in the preceding years. The opposition regarded Lingard as far from 
independent (QPD 1989:vol. 312, p. 5518). Premier Ahern's opinion of Lingard had apparently changed though. In nominating him for the Speakership, he referred to his 'proven track record and excellent parliamentary performance as Speaker' (QPD 1989:vol. 312, p. 5434). Other National Party members supported the nomination, referring to him as an 'excellent Speaker' (QPD 1989:vol. 312, p. 5473) and 'a man with great principles and great standards' (QPD 1989:vol. 312 , p. 5448).

After a marathon 11 and a half hour debate, Lingard was elected Speaker at 3.25 am by a small margin: 42 to 40 . It was suggested after his election as Speaker that he could rely on his National Party colleagues only when the party was in crisis (Courier-Mail, 6 July 1989).

He resigned as Speaker when the Labor Party was elected to power in December 1989.

\section{Lionel ('Lin’) William Powell ('I didn't come from a monkey')}

\section{(Speaker 2.12.87 to 5.7.89)}

Lionel ('Lin') William Powell was born in Maryborough in Queensland in May 1939, the son of a schoolteacher. After his primary and secondary school education in Bundaberg and Brisbane, he attended Kelvin Grove Teachers' College and the University of Queensland. He gained a Trained Teacher's Certificate and taught at various schools in Queensland.

Powell entered the Parliament in December 1974, winning the seat of Isis for the National Party. He held that seat until 31 July 1989 when he suddenly resigned from the Parliament. His resignation caused the opposition to protest that a by-election be held as soon as possible to ensure the people of Isis were not without a local member. Powell then formed the New Conservative Party and unsuccessfully contested the seat of Isis as an independent in the 1989 general election.

During his term as National Party Member for Isis, he held two portfolios in Bjelke-Petersen ministries: Minister for Education (6 December 1983 to 25 November 1987) and Minister for Training and Technology (25 November 1987 to 1 December 1987). As Minister for Education, Powell had stood with the conservative right supporting calls for the teaching of creation theory in schools (Courier-Mail, 6 July 1989). In the debate on creation versus evolution, he had very strong views, appearing on television saying 'I know I didn't come 
from a monkey'. He also resisted proposals for sex education in schools and was opposed to the re-employment of teachers with drug convictions (Courier-Mail, 6 July 1989).

Powell was elected Speaker on 2 December 1987 immediately after Mike Ahern had ousted Bjelke-Petersen as Premier. When Ahern became Premier, he was advised by Don Lane to nominate Des Booth (NP, Warwick) for the Speakership, on the grounds that Booth had defended Ahern against Bjelke-Petersen in the party room. It was well known that Powell was not in the Ahern camp (Lane 1993:221-5). Lane's advice was ignored, however, and in nominating Powell, Ahern said: 'I can think of no better candidate to respect this position than Lionel William Powell, and therefore I urge all members to support his nomination' (QPD 1988:vol. 307, p. 4736). Powell won the secret ballot, gaining 48 votes against the 30 for Clem Campbell (ALP, Bundaberg) and 10 for Bill Lickiss (Lib., Moggill). The next day, it was reported that he had been 'elected on the solid bloc vote of the National party members, with the support of the Premier, even though the two had often differed' (Courier-Mail, 3 December 1987). Powell was said later to have accepted the position of Speaker as a consolation prize after his cabinet place was terminated when 'the Ahern push had rolled Sir Joh' (CourierMail, 6 July 1989).

Powell resigned as Speaker on 5 July 1989 after government members of the House voted against him after he had asked the House to refer a letter from the Deputy Leader of the Opposition, Tom Burns, to the Privileges Committee ( QPD 1989:vol. 312, p. 5430). The letter from Burns sought a Privileges Committee investigation into an answer given to the Parliament by Premier Ahern in which he denied that he had ever instructed his staff to encourage the homosexual lobby to make a public issue of AIDS education in 1986. At the time, Ahern was Health Minister and Powell was Education Minister.

Powell's resignation threw the Parliament into chaos. What followed was described in the press the next day as a 'night of uproar'. The House was without a Speaker and the Chamber filled with cries of 'out, out, out', 'shame' and 'you are destroyers of democracy' from the opposition benches (CourierMail, 6 July 1989). Reference was also made to the fact that 5 July 1989 was the day the Fitzgerald Report was to be debated. Burns suggested that it was fitting that the National Party used its numbers to dump the Speaker on that day ( $Q P D$ 1989:vol. 312, p. 5449) and Goss was reported as saying that the National Party had 'got rid of Powell to install a National party "hack" to thwart genuine, productive debate on the Fitzgerald Report' (Courier-Mail, 6 July 1989; see also QPD 1989:vol. 312, p. 5435).

Goss's nomination of Powell as Speaker, seconded by the leader of the Liberal Party, Angus Innes, was referred to in the press the next day as 'an act of 
calculated political mischief-making' (Courier-Mail, 6 July 1989). In support of the nomination, Goss said that Powell had proved his independence as Speaker in the preceding years (QPD 1989:vol. 312, p. 5435). Premier Ahern suggested that the nomination of Powell was a political stunt and had been engineered by the former Premier, who had 'used the Labor party and the Liberal party as agents of his own vindictiveness' (QPD 1989:vol. 312, p. 5431). Ahern nominated Kev Lingard, saying that he would 'grace the office of Speaker very creditably' $(Q P D$ 1989:vol. 312, p. 5432).

After 11 and a half hours of uncontrolled debate, Lingard was elected Speaker by 42 votes to 40 . Powell handed back his commission on 31 July 1989 (QPD 1989:vol. 313, p. 2). 


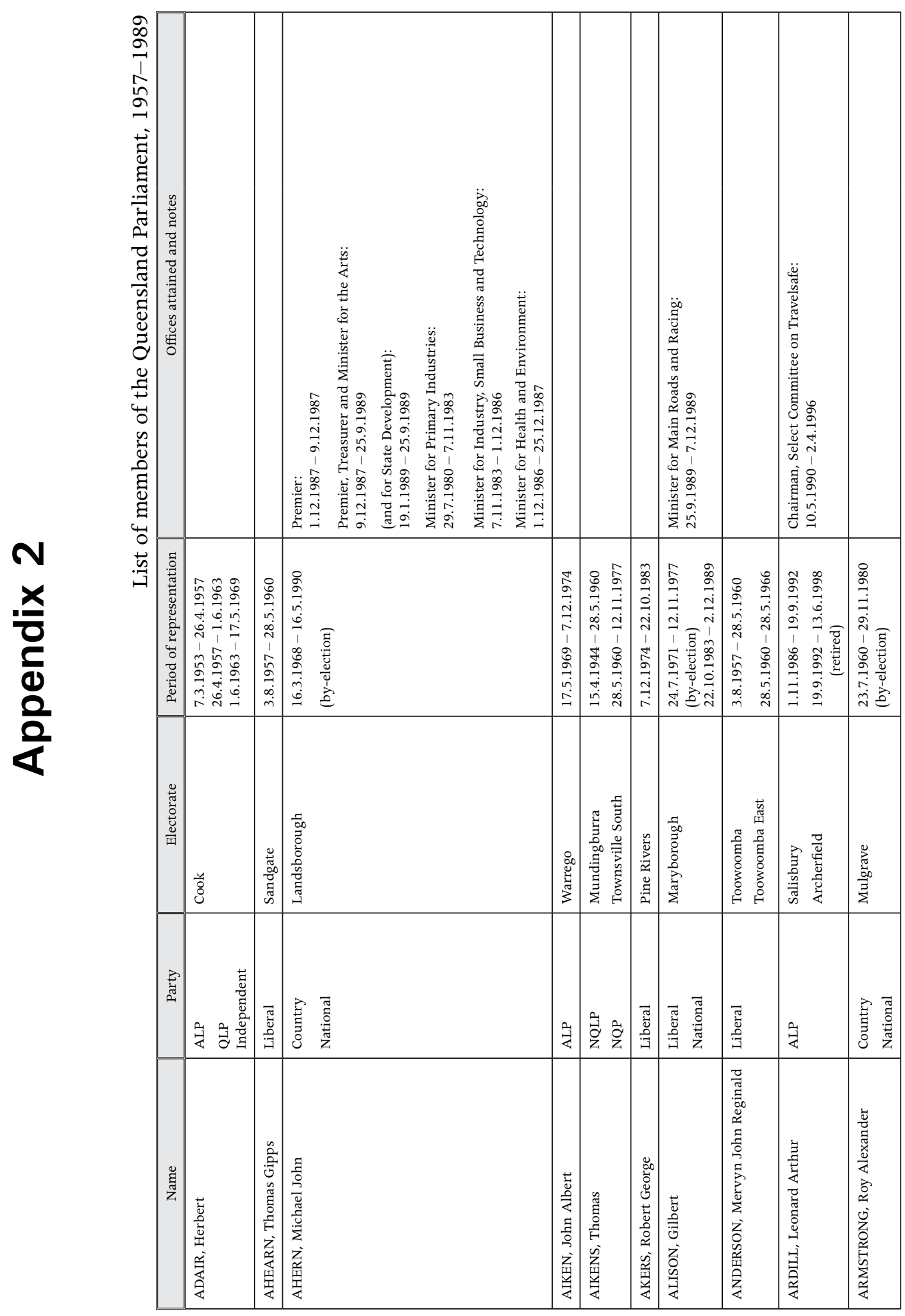




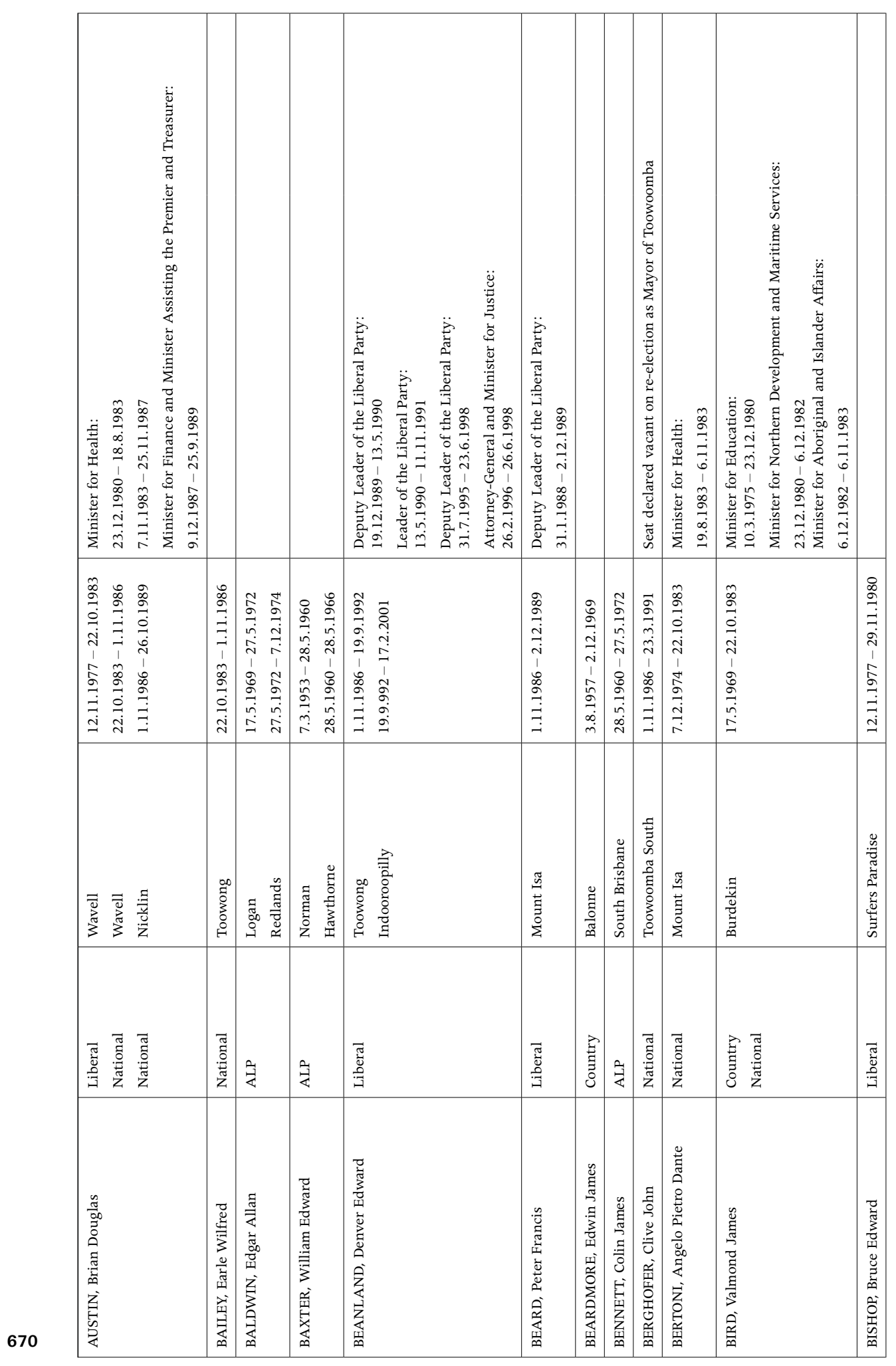




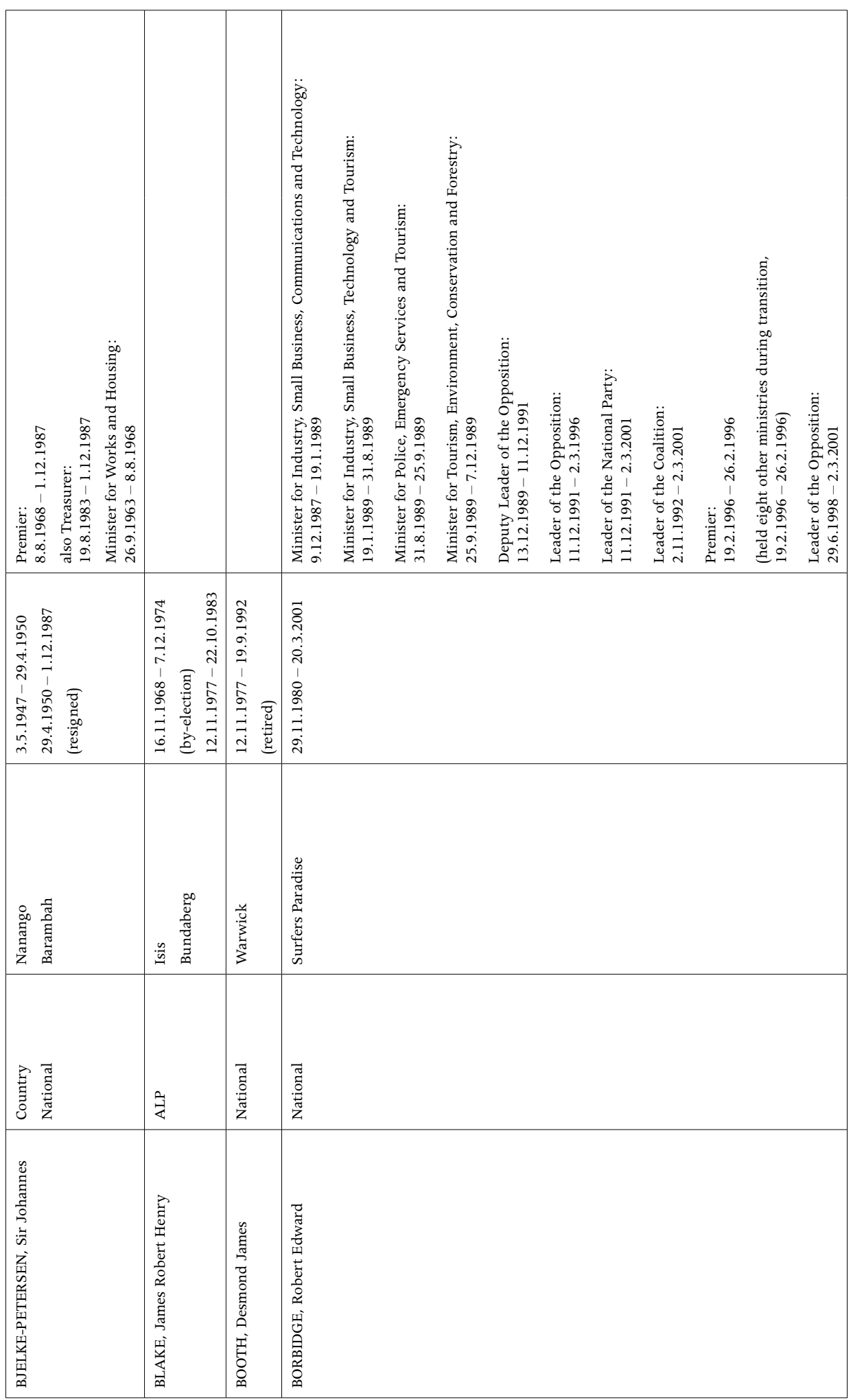


The Ayes Have it - the History of the Queensland Parliament 1957-89

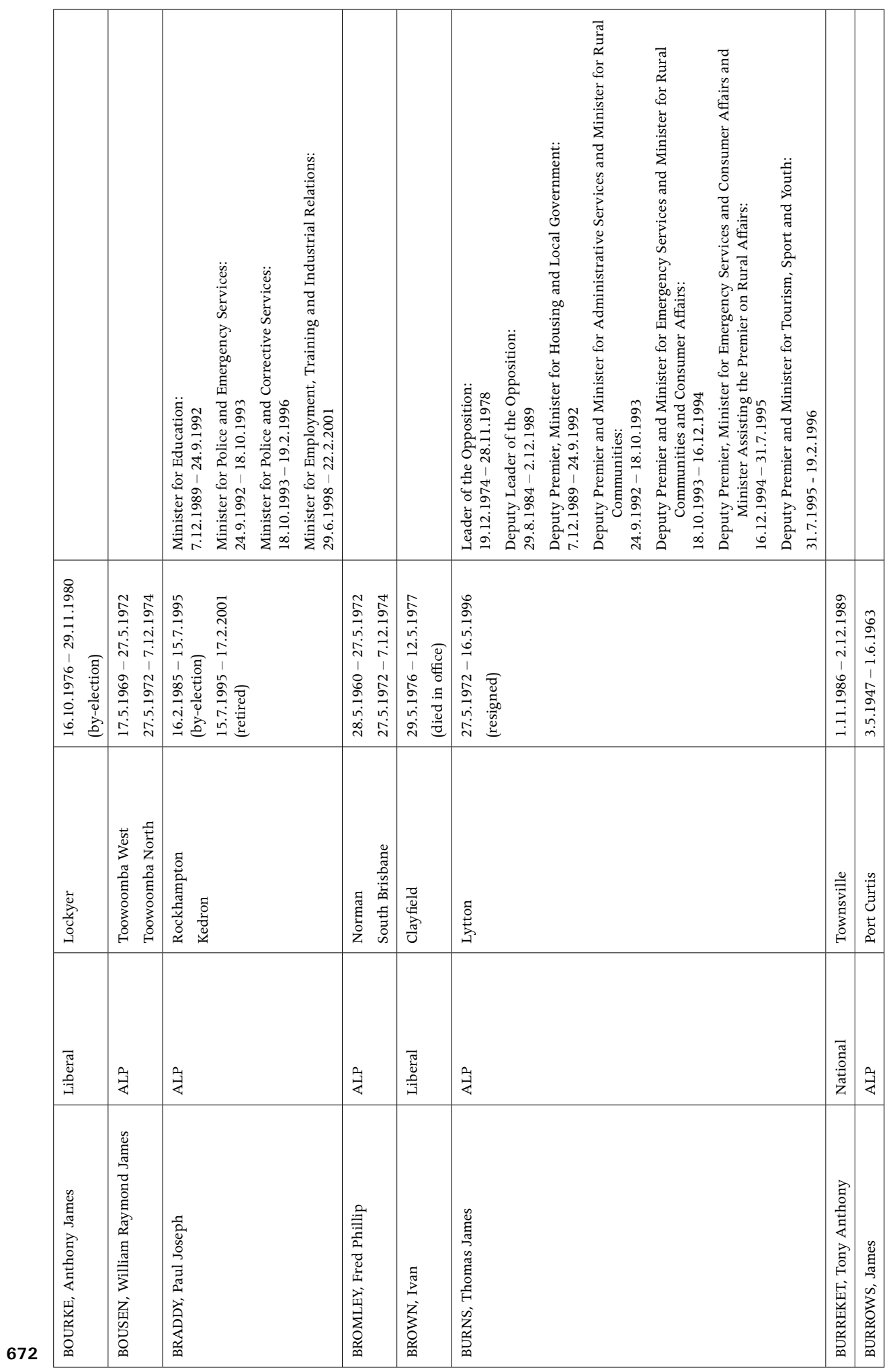




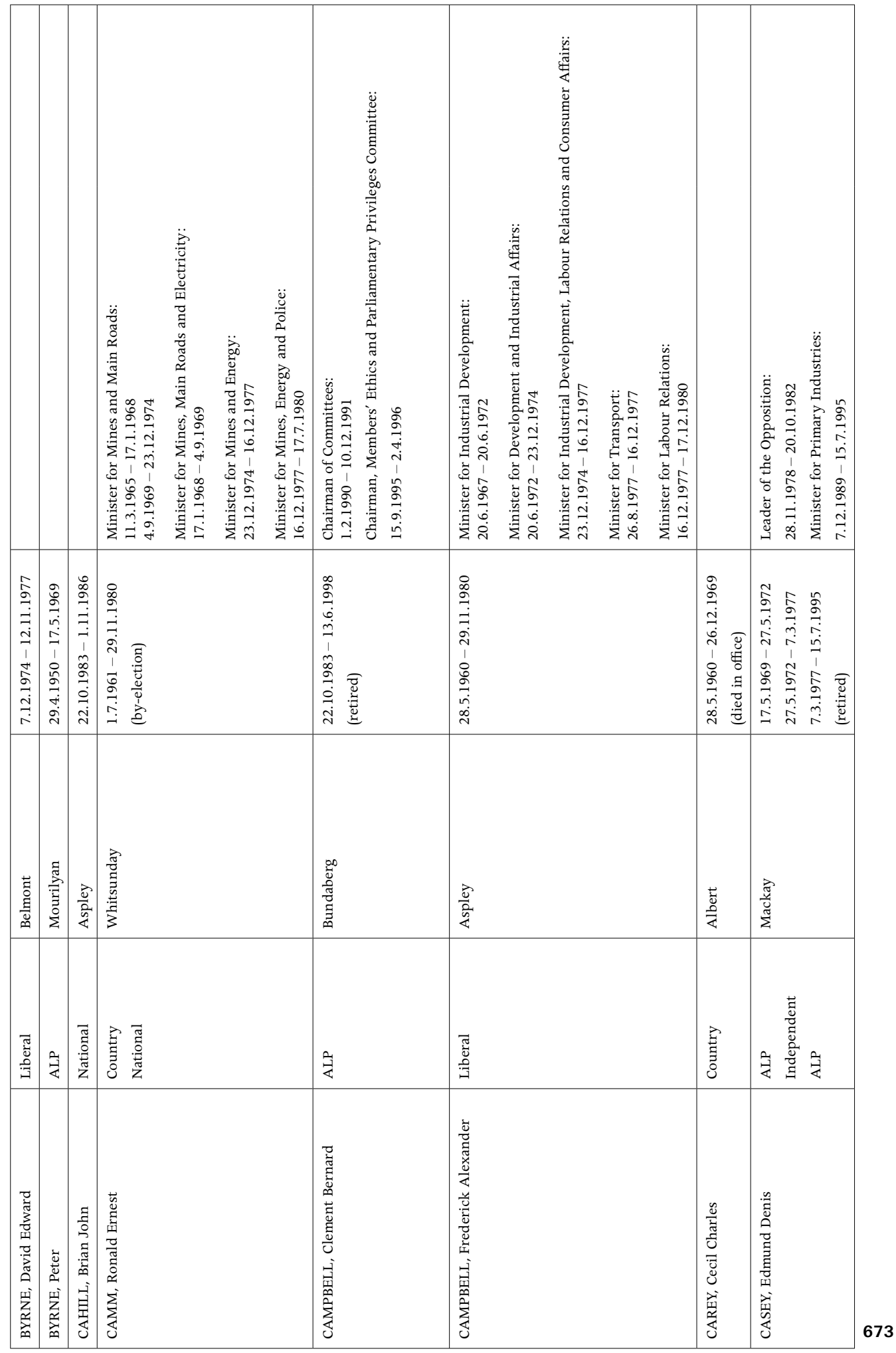


The Ayes Have it - the History of the Queensland Parliament 1957-89

\begin{tabular}{|c|c|c|c|c|c|c|c|c|}
\hline 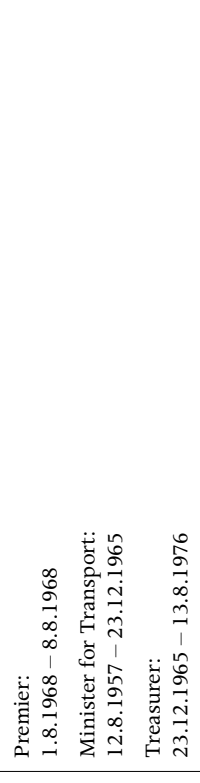 & 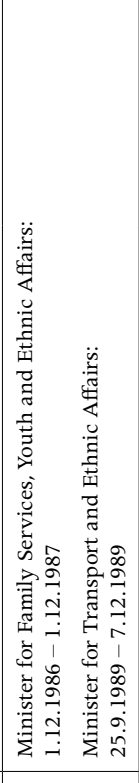 & & 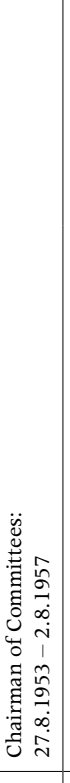 & 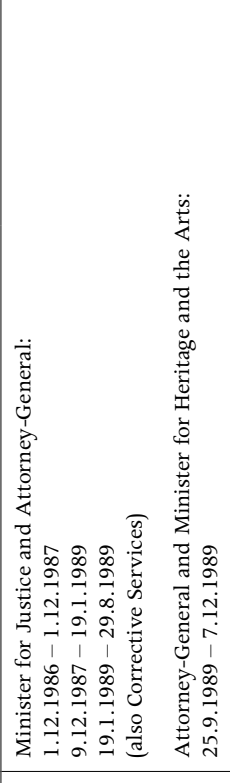 & & 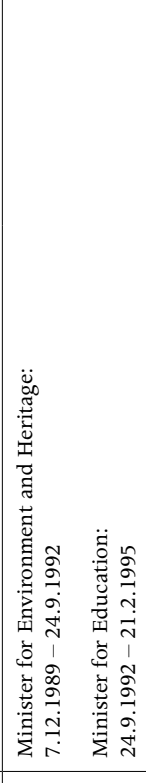 & & 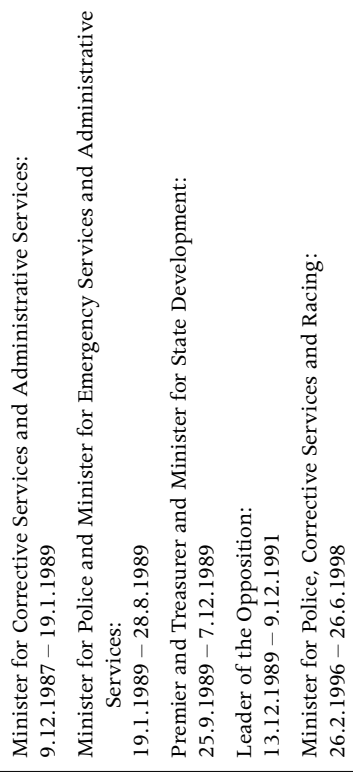 \\
\hline 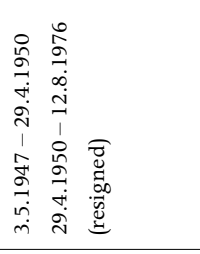 & 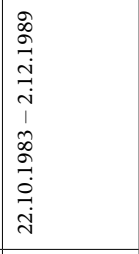 & 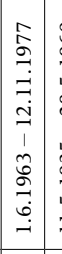 & 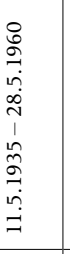 & 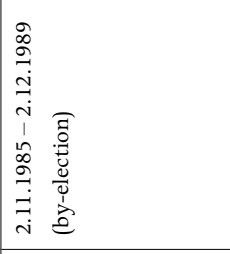 & 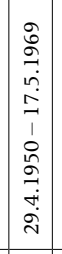 & 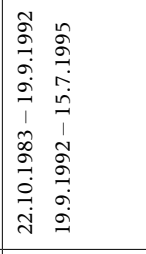 & 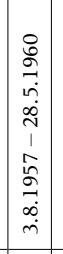 & 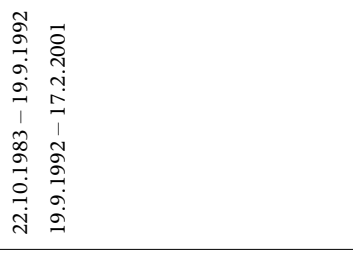 \\
\hline 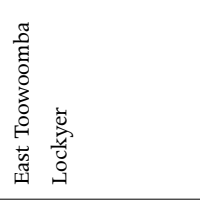 & 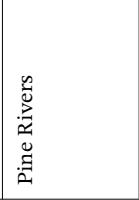 & 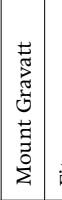 & & 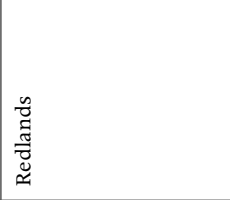 & 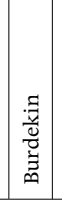 & 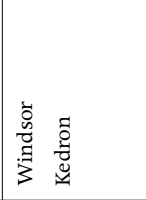 & 辤 & 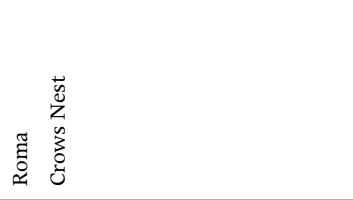 \\
\hline 司 & 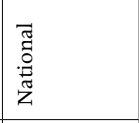 & 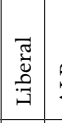 & 会 & 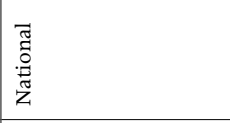 & 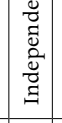 & 定 & 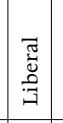 & 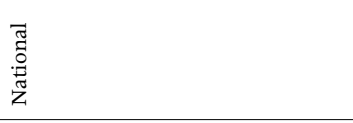 \\
\hline 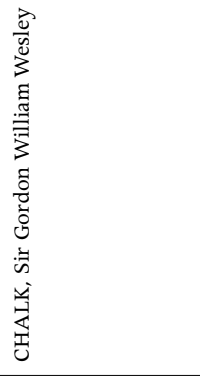 & 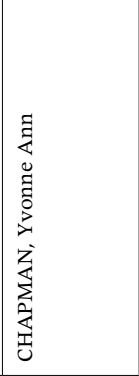 & 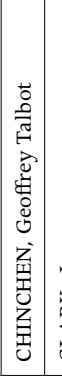 & 递 & 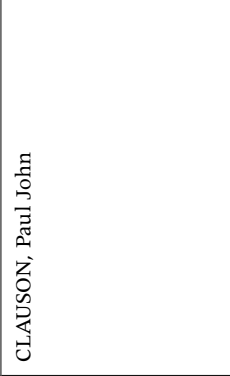 & 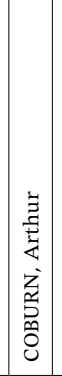 & 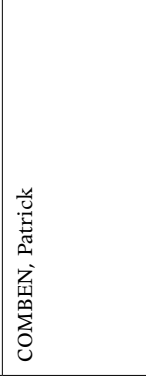 & 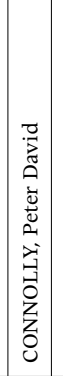 & 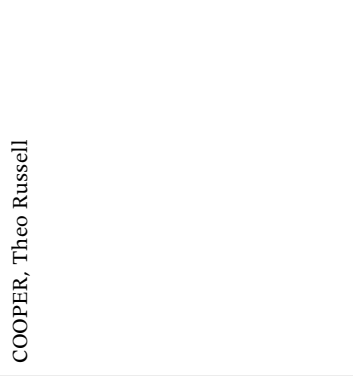 \\
\hline
\end{tabular}




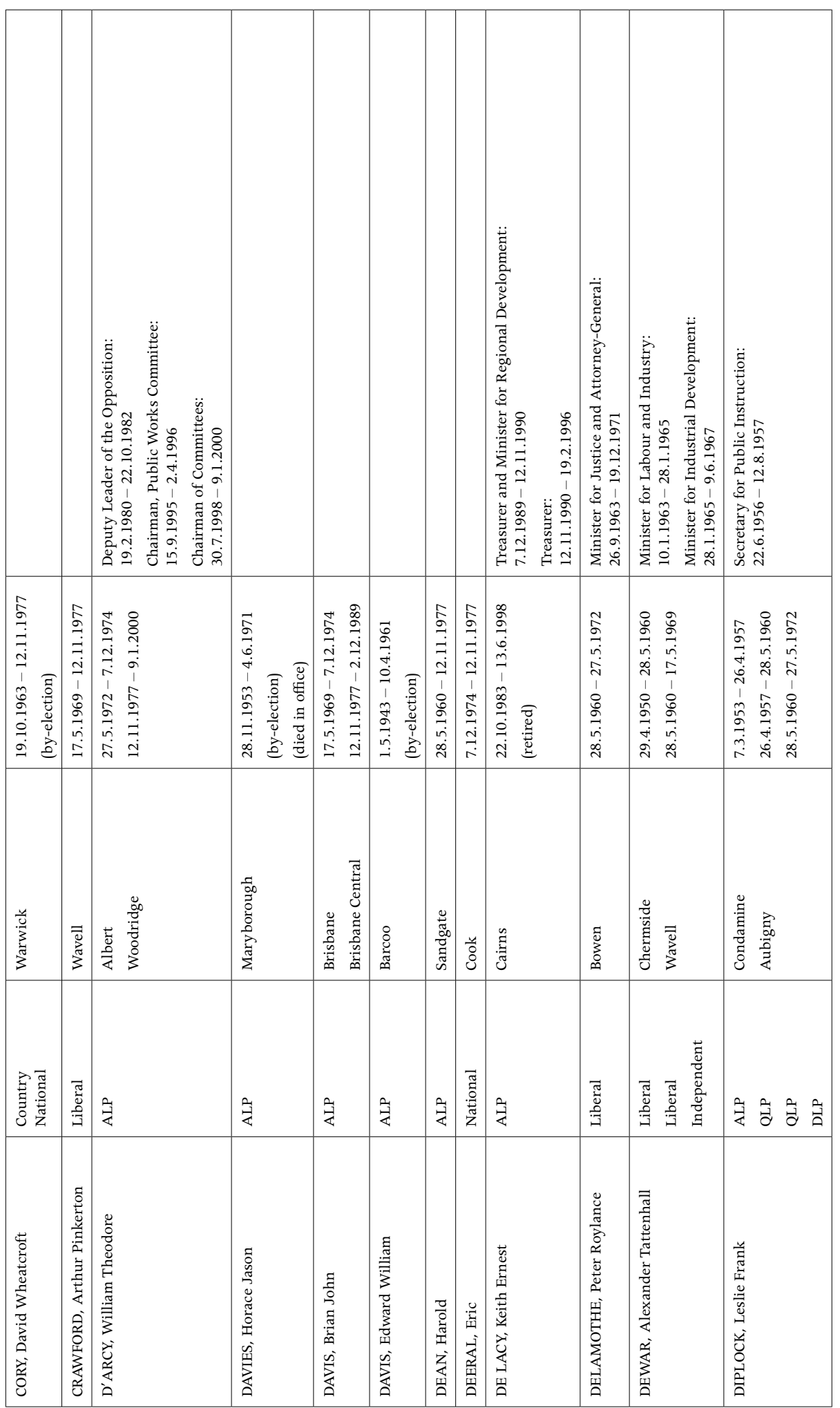




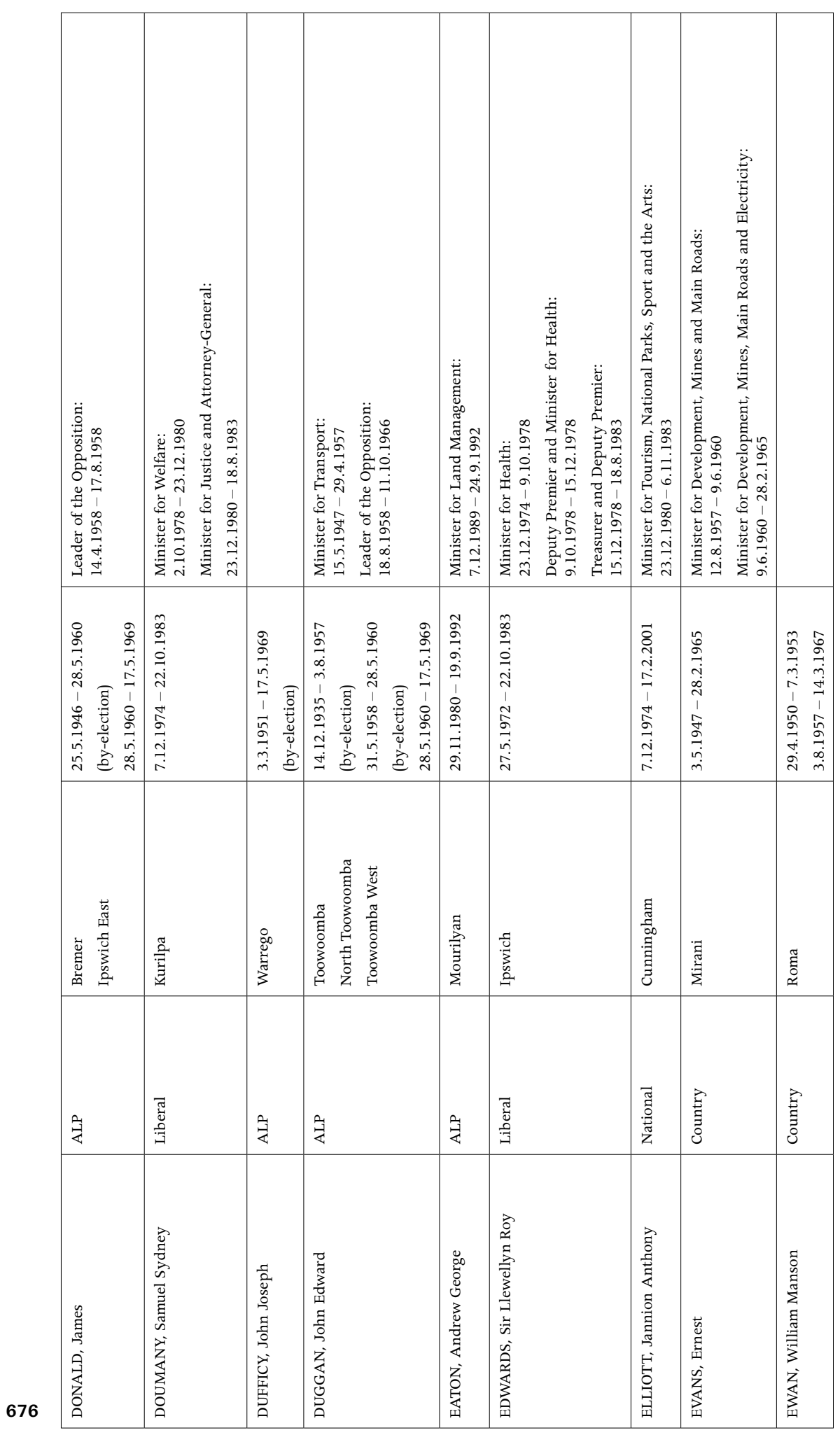




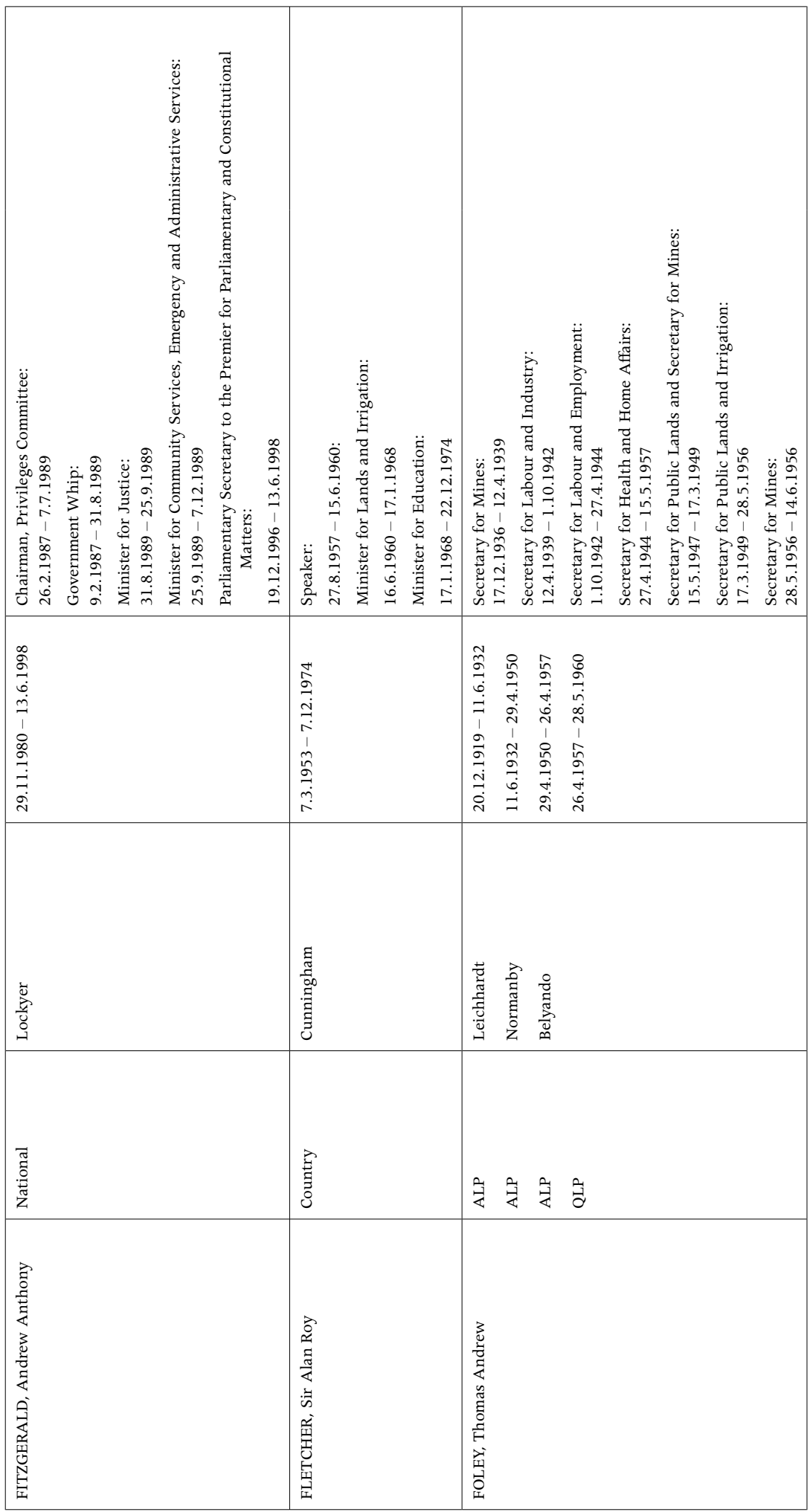


The Ayes Have it - the History of the Queensland Parliament 1957-89

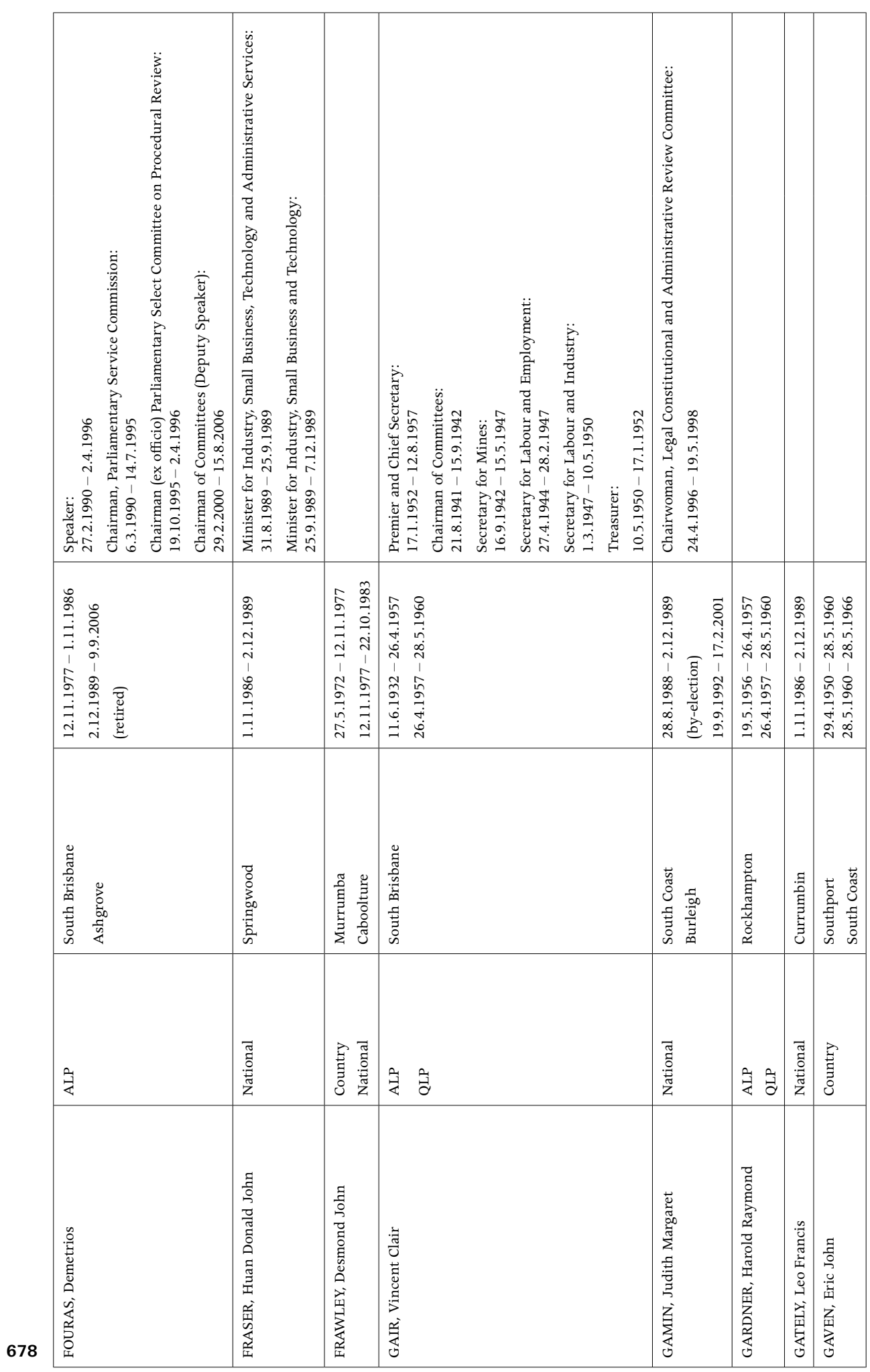




\begin{tabular}{|c|c|c|c|c|c|}
\hline 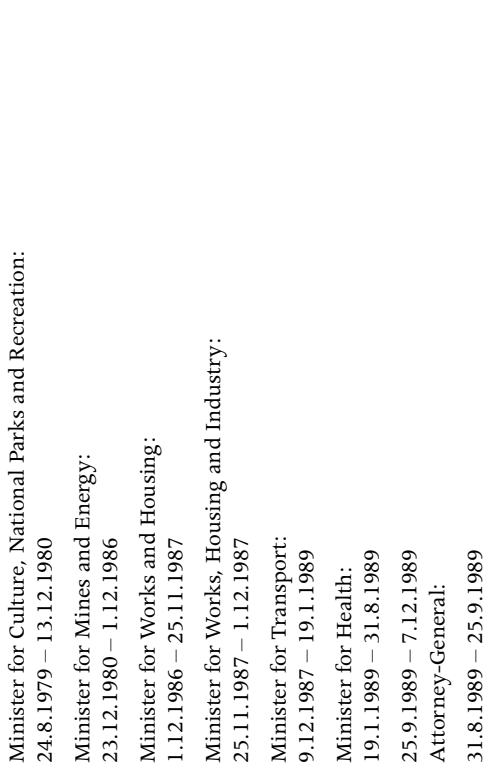 & 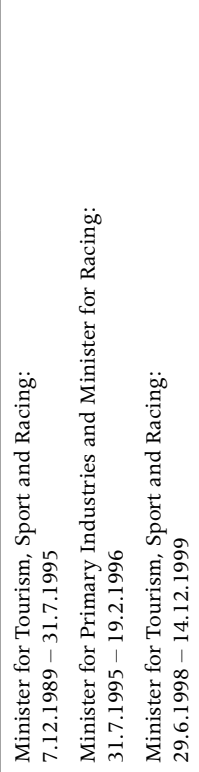 & 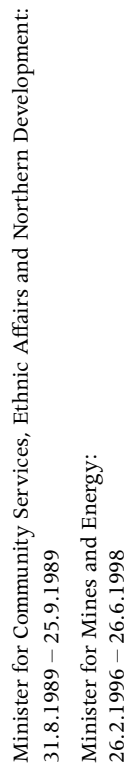 & & 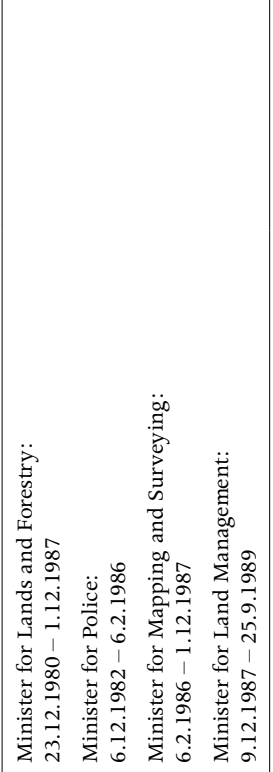 & 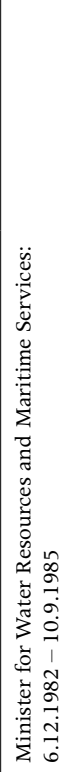 \\
\hline 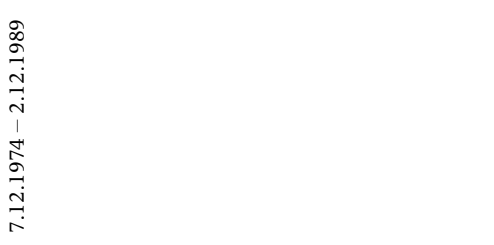 & 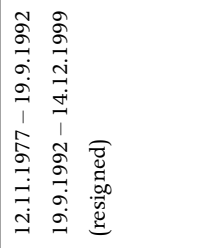 & 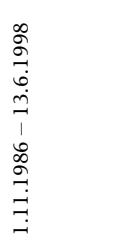 & 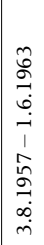 & 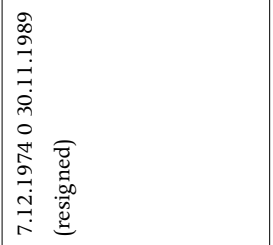 & 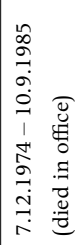 \\
\hline 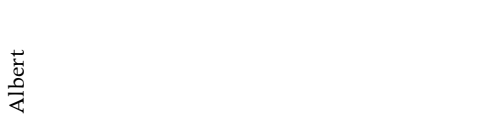 & 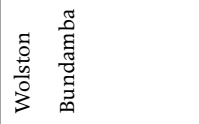 & $\begin{array}{l}\frac{n}{0} \\
\frac{\pi}{0} \\
\frac{0}{0} \\
\frac{\pi}{\pi}\end{array}$ & 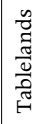 & 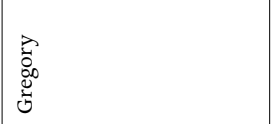 & 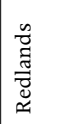 \\
\hline 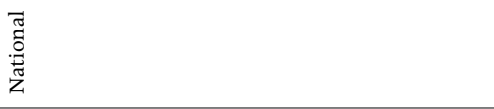 & 妾 & 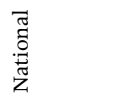 & 害 & $\begin{array}{l}\bar{\Xi} \\
\stackrel{\Xi}{\tilde{J}} \\
\tilde{\widetilde{J}} \\
z\end{array}$ & 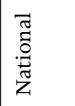 \\
\hline 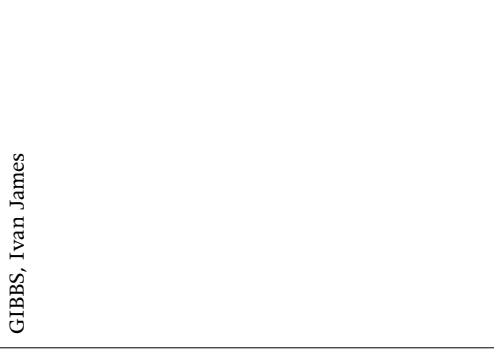 & 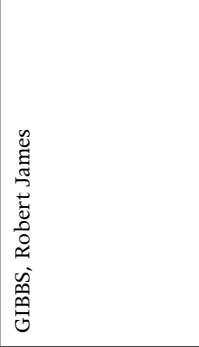 & 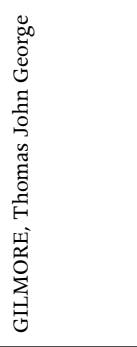 & 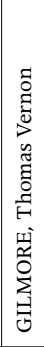 & 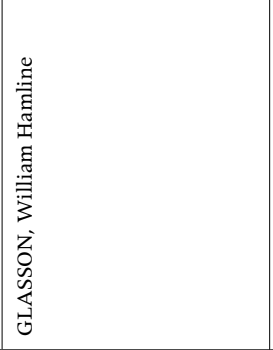 & 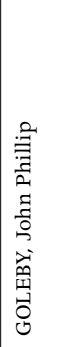 \\
\hline
\end{tabular}


The Ayes Have it - the History of the Queensland Parliament 1957-89

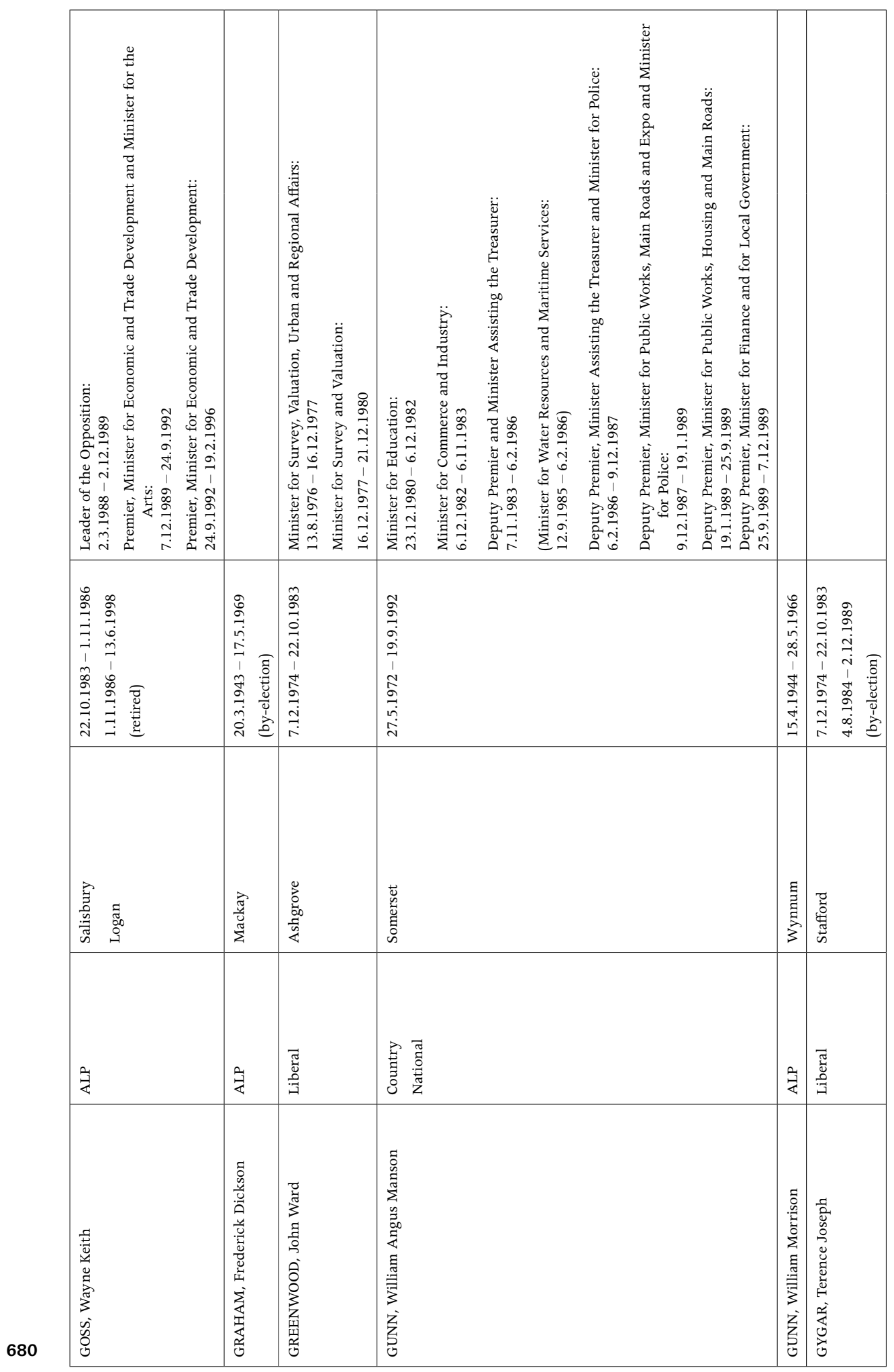




\begin{tabular}{|c|c|c|c|c|c|c|c|c|c|c|c|}
\hline & 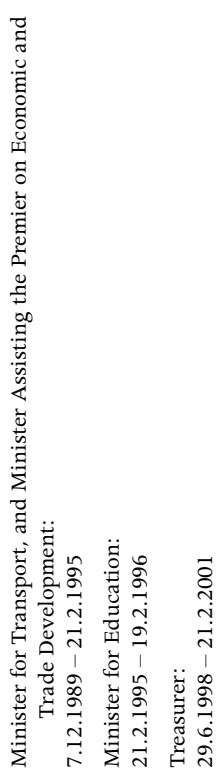 & & & & 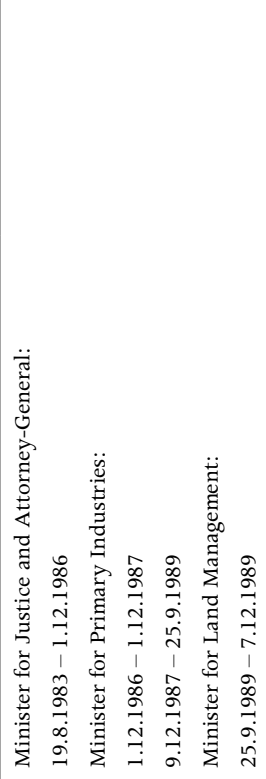 & & & & & 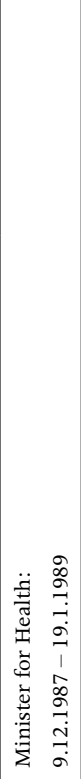 & \\
\hline 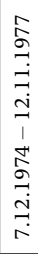 & 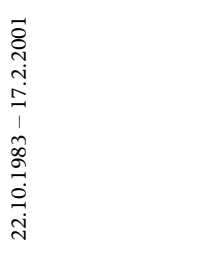 & 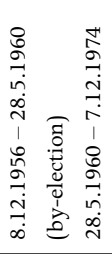 & 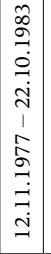 & 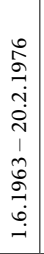 & 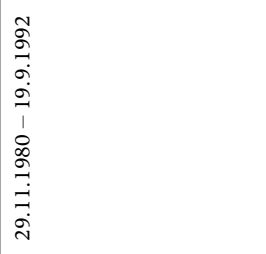 & 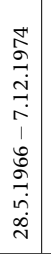 & 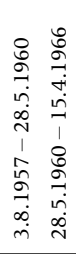 & 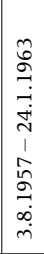 & 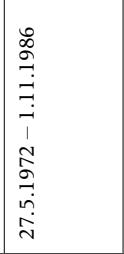 & 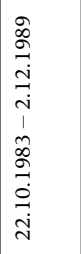 & \\
\hline 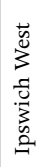 & 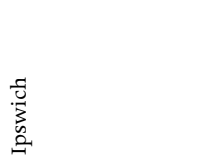 & 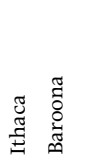 & 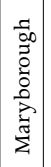 & 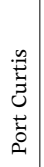 & $\begin{array}{l}\Xi \\
\Xi \\
\\
\end{array}$ & $\begin{array}{l}\text { 音 } \\
\vdots \\
3\end{array}$ & 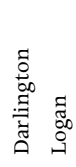 & 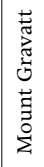 & ฮั & 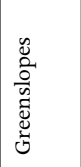 & \\
\hline 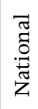 & 家 & $\stackrel{\vec{\theta}}{\vec{\psi}}$ & 安 & 潁 & 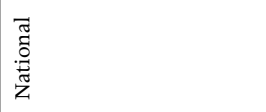 & $\vec{z}$ & $\begin{array}{l}\vec{E} \\
\text { है } \\
\text { ठ }\end{array}$ & 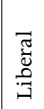 & 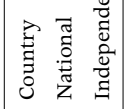 & 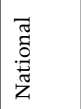 & $\vec{z}$ \\
\hline 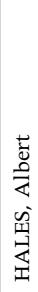 & 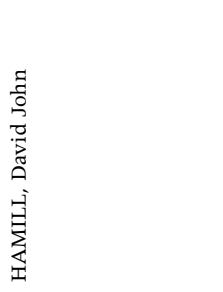 & 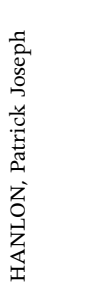 & 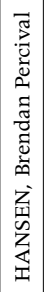 & 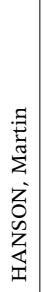 & 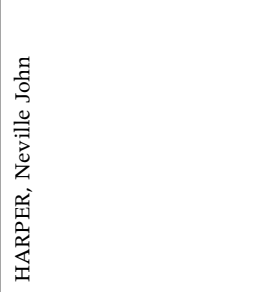 & 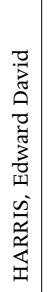 & 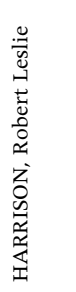 & 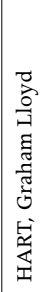 & 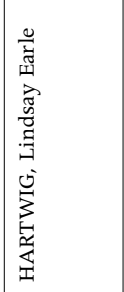 & 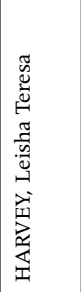 & \\
\hline
\end{tabular}




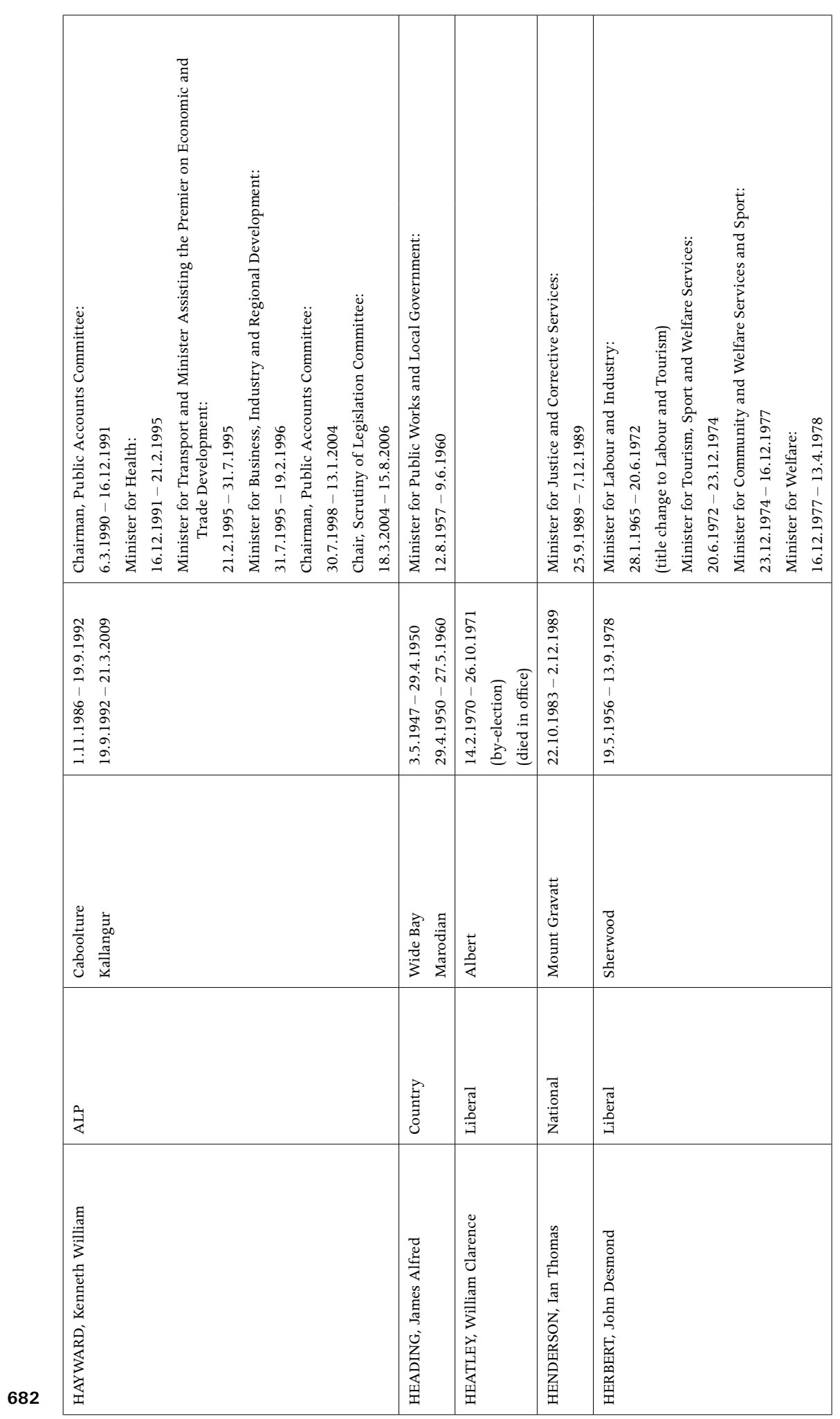


Appendix 2

\begin{tabular}{|c|c|c|c|c|}
\hline 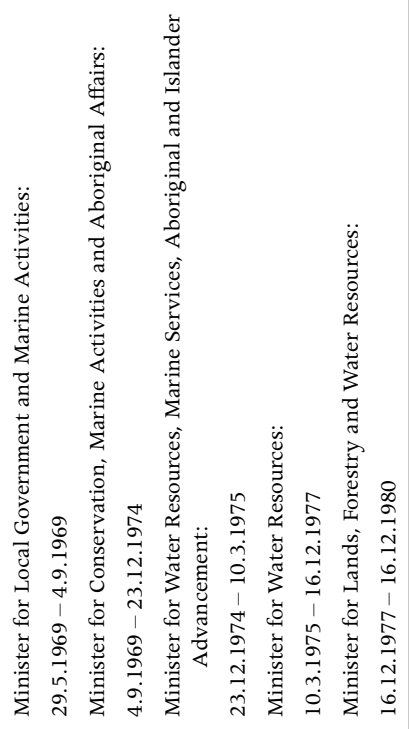 & 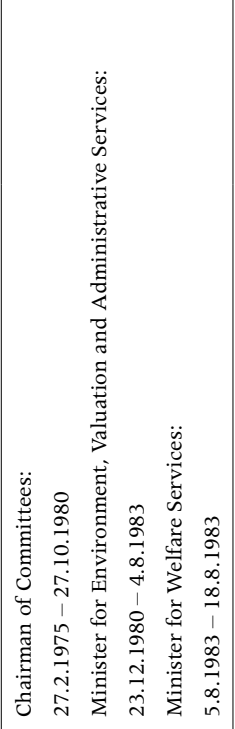 & 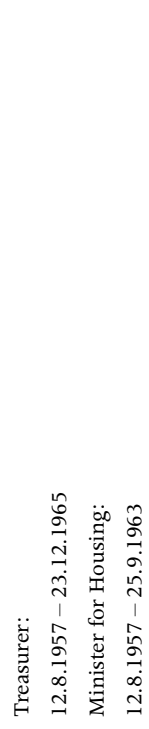 & 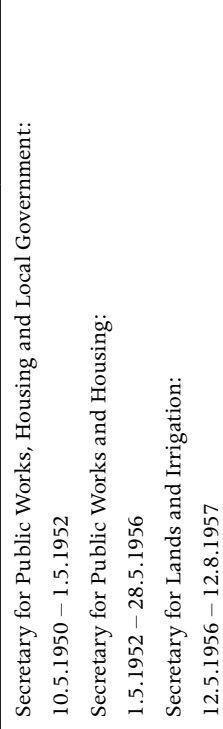 & \\
\hline 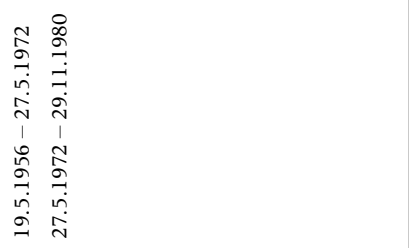 & 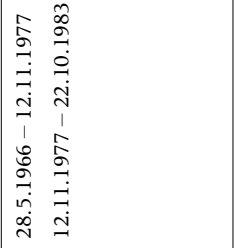 & 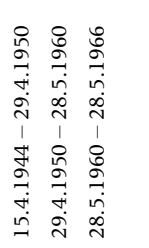 & 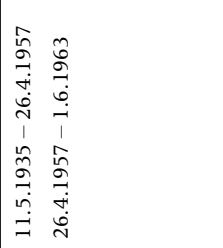 & $\mid \begin{array}{l}a \\
\vdots \\
\vdots \\
j \\
j\end{array}$ \\
\hline 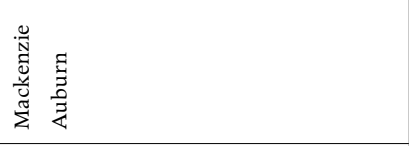 & 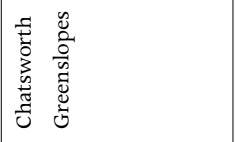 & 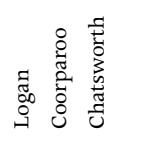 & 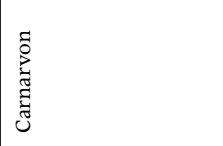 & 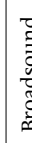 \\
\hline 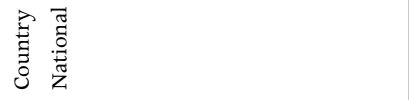 & 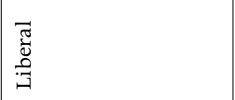 & 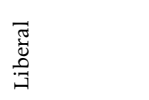 & $\vec{z}$ & 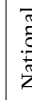 \\
\hline 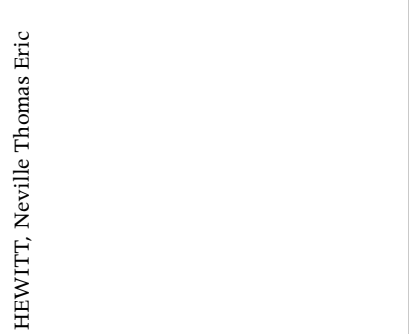 & 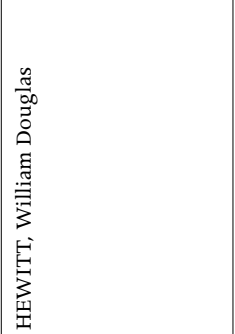 & 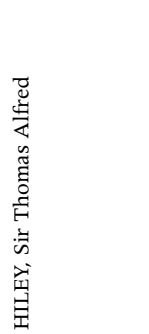 & 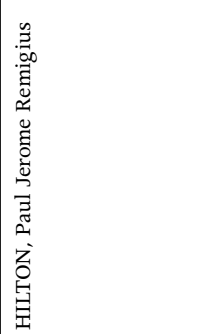 & $\begin{array}{l}0 \\
0 \\
0 \\
0 \\
0 \\
0 \\
0 \\
0 \\
0\end{array}$ \\
\hline
\end{tabular}




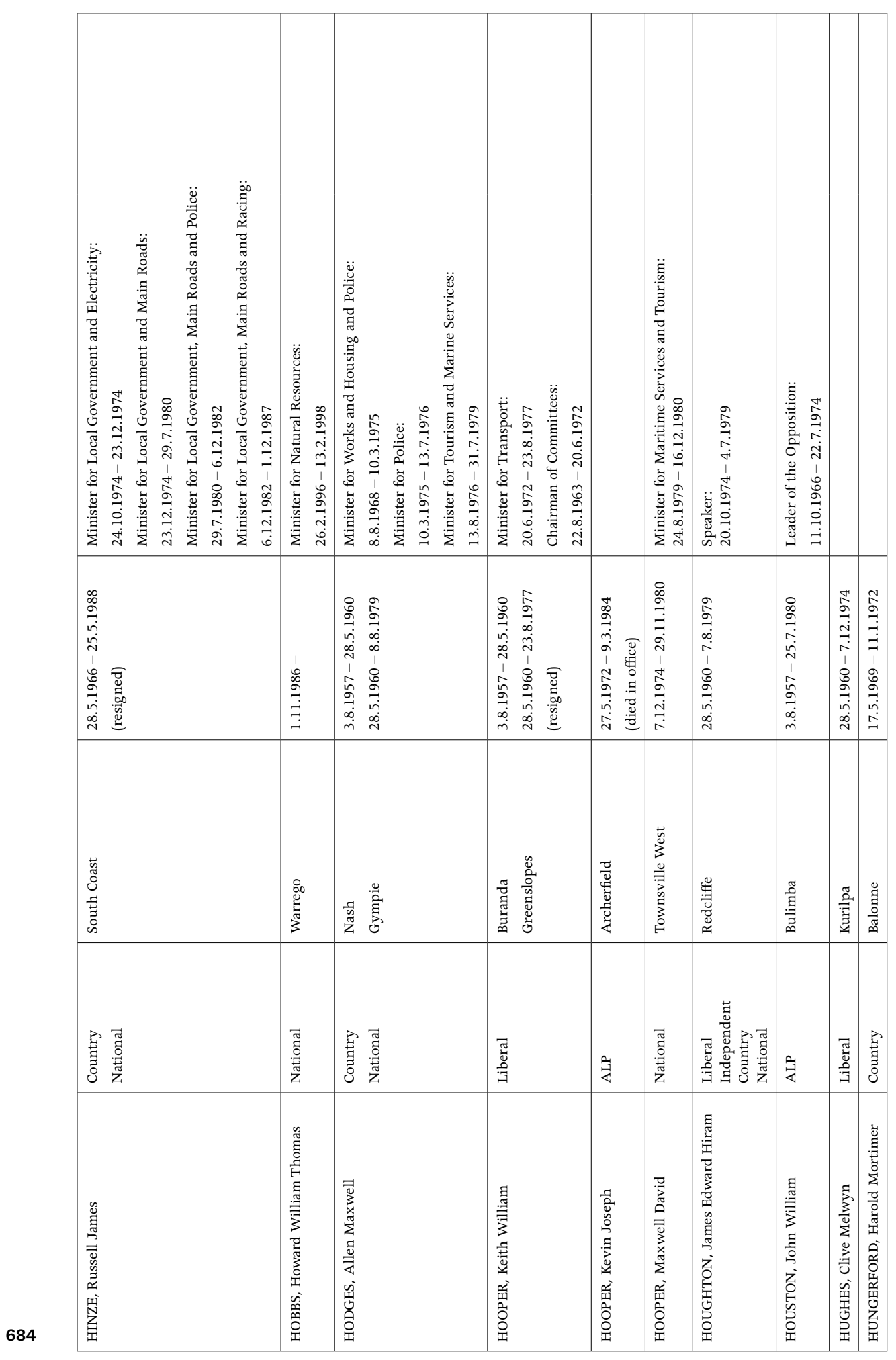




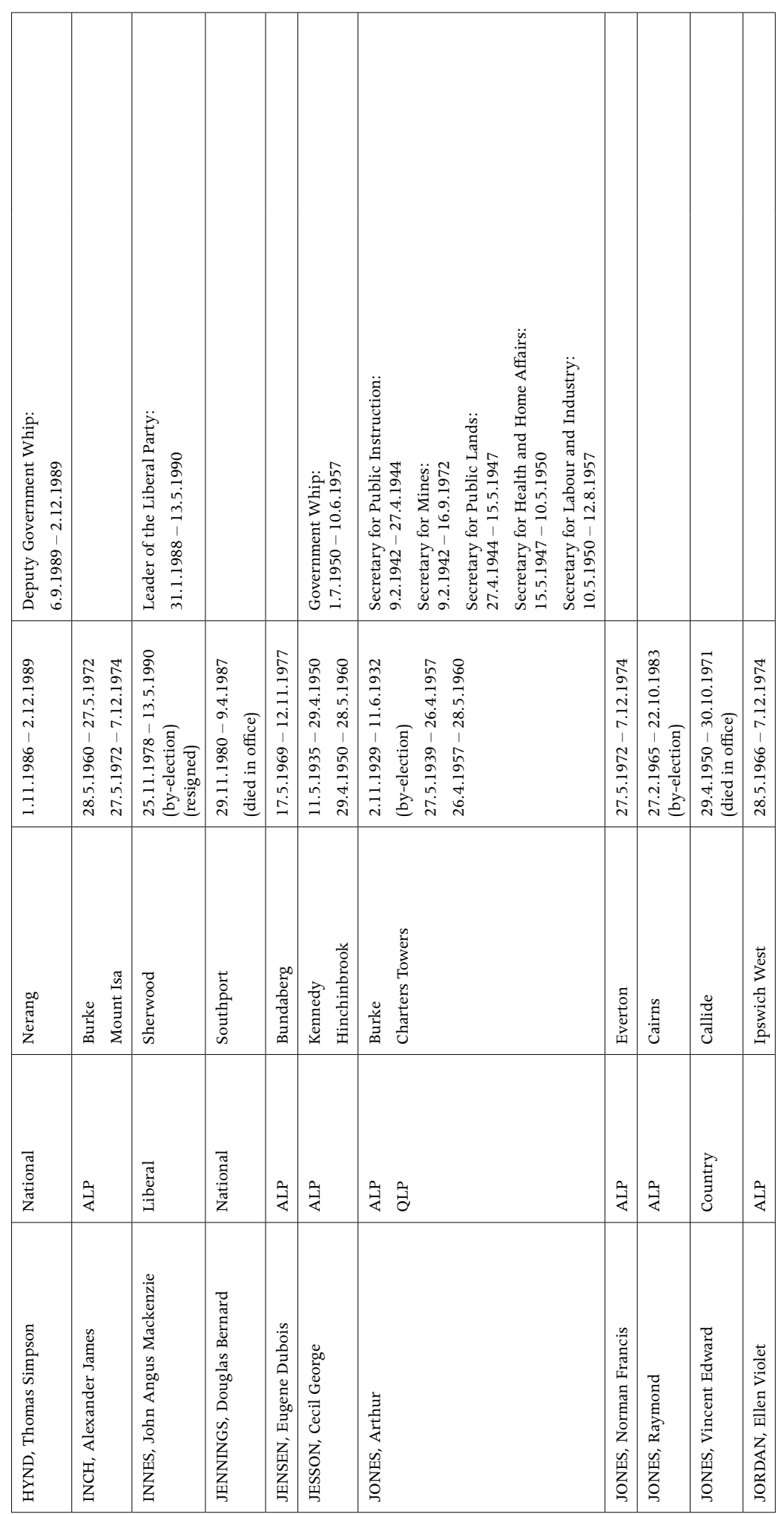




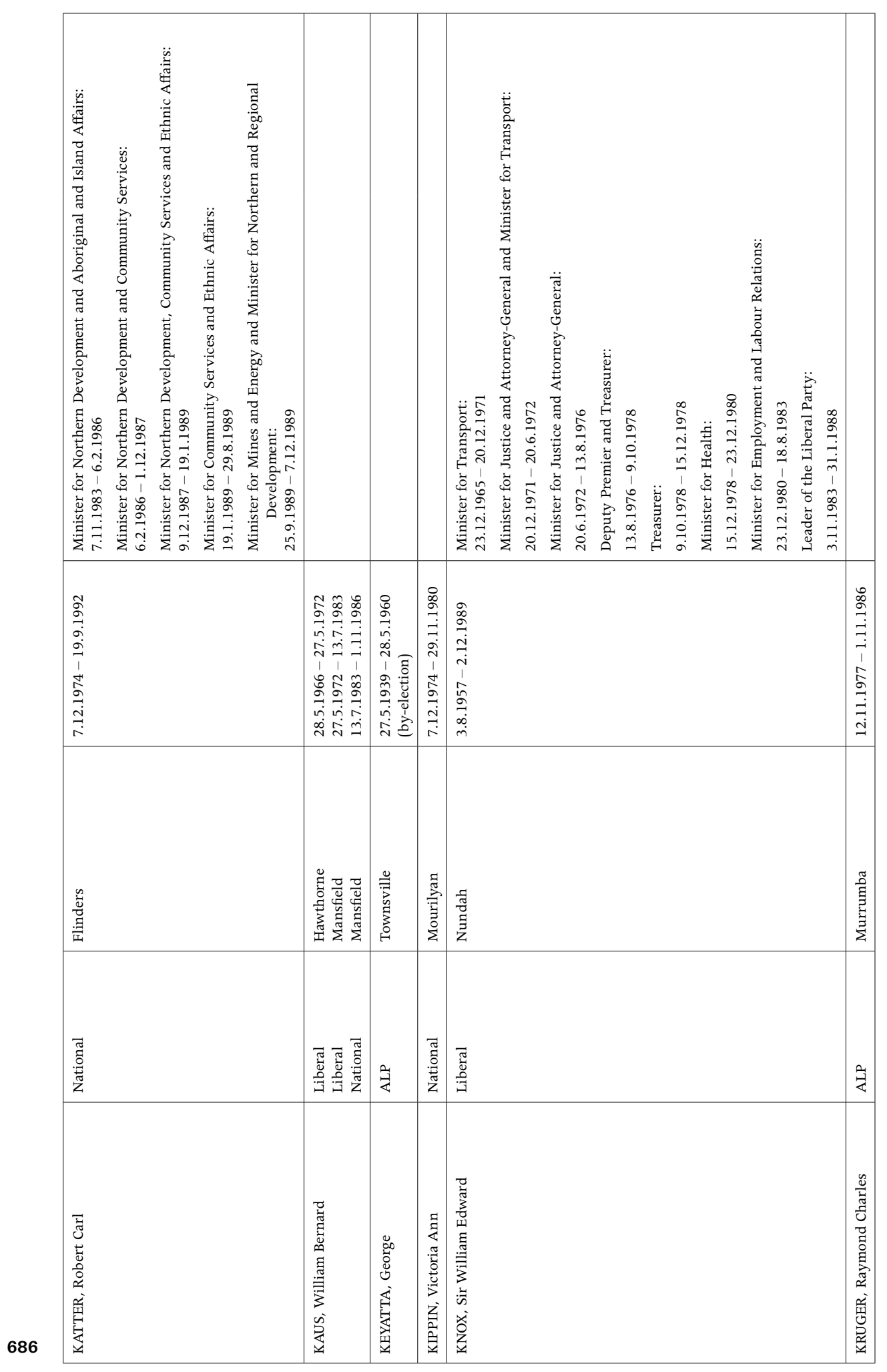




\begin{tabular}{|c|c|c|c|c|c|c|c|}
\hline & & & 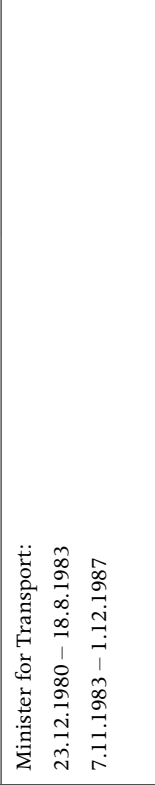 & 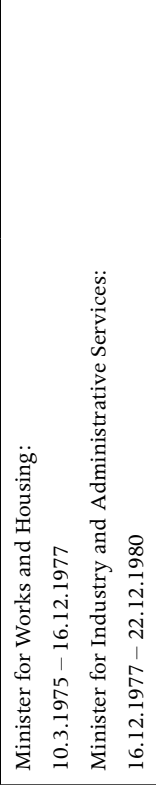 & & 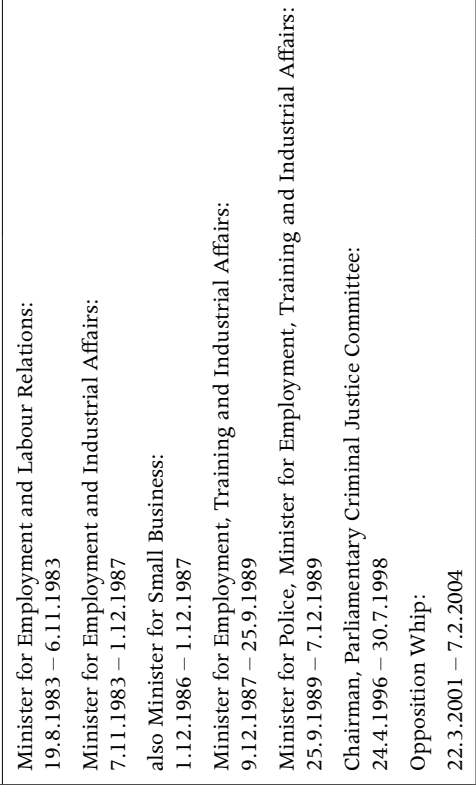 & 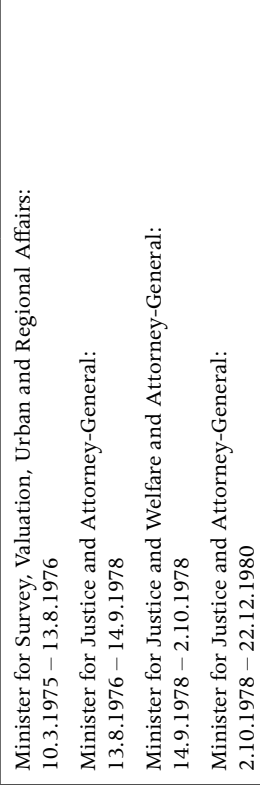 \\
\hline 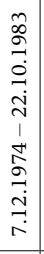 & 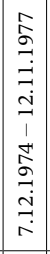 & 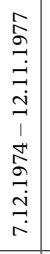 & 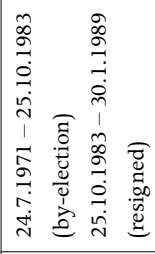 & 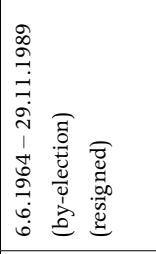 & 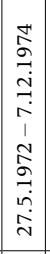 & 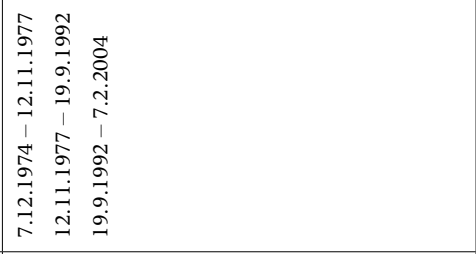 & 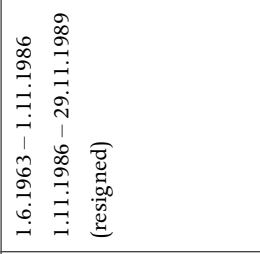 \\
\hline 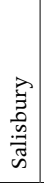 & 离 & 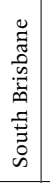 & 訔 & 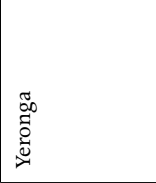 & 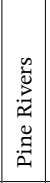 & 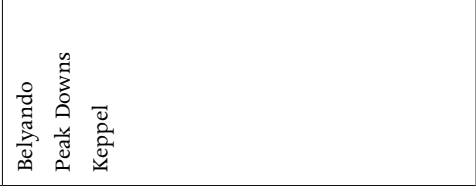 & 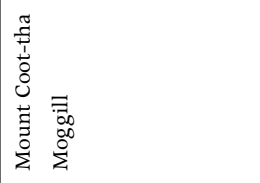 \\
\hline 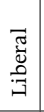 & 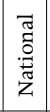 & 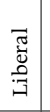 & 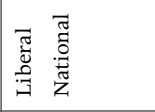 & $\begin{array}{l}\widetilde{\widetilde{J}} \\
\text { 可 }\end{array}$ & $\vec{q}$ & 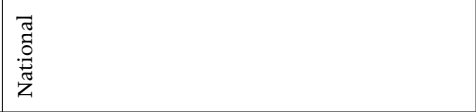 & \begin{tabular}{l}
$\overrightarrow{\widetilde{J}}$ \\
$\stackrel{\Xi}{G}$ \\
\hdashline
\end{tabular} \\
\hline 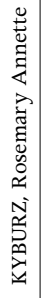 & 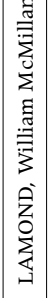 & 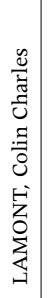 & 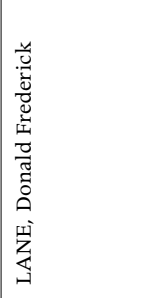 & 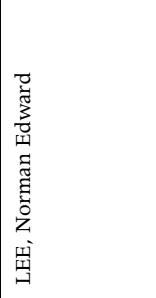 & 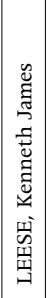 & 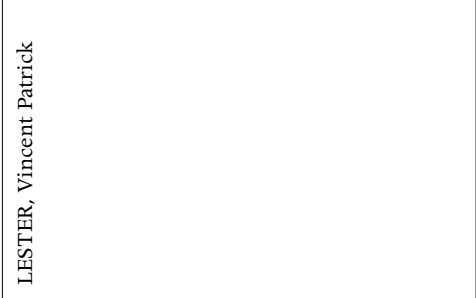 & 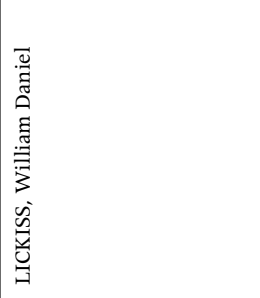 \\
\hline
\end{tabular}




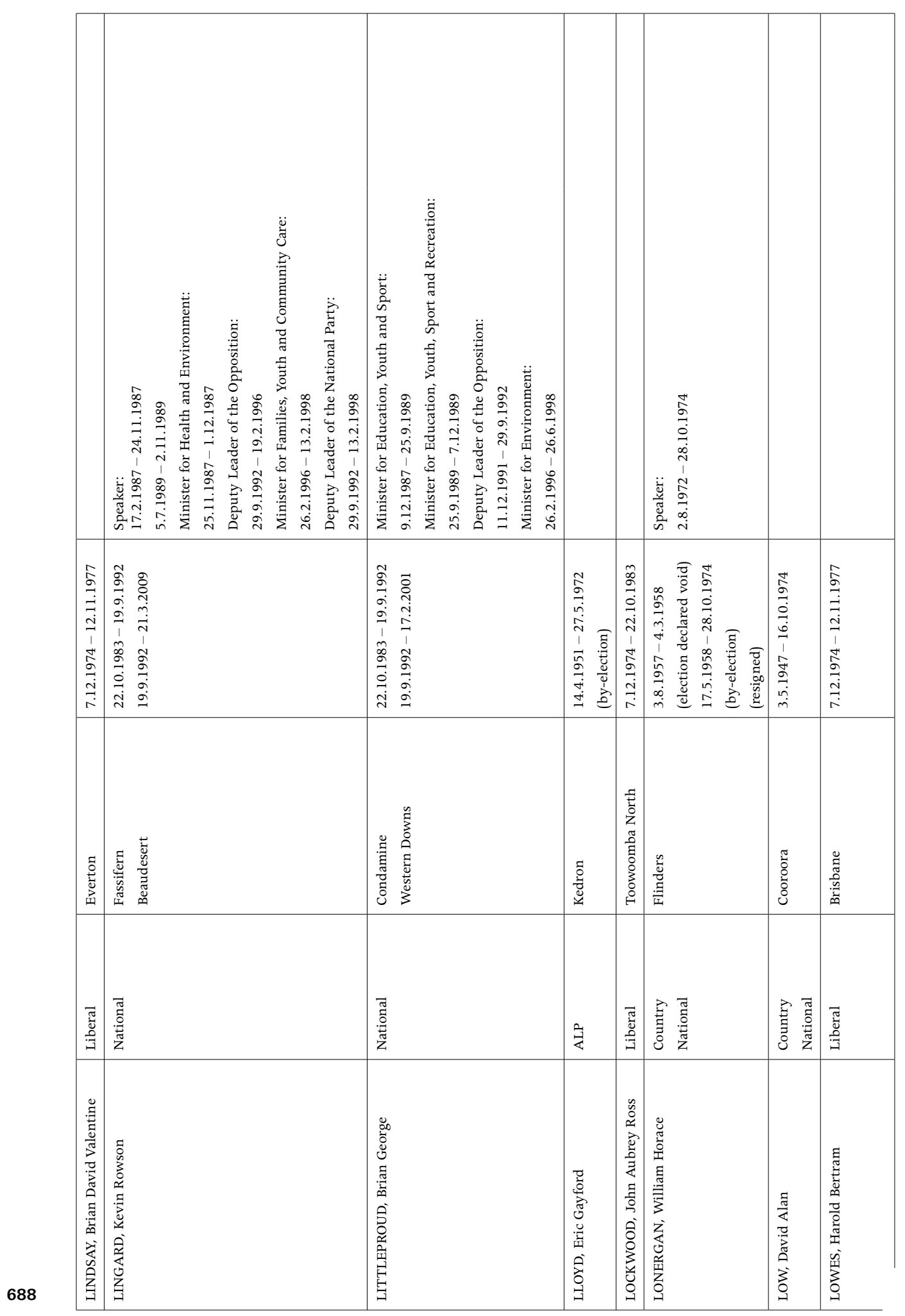


Appendix 2

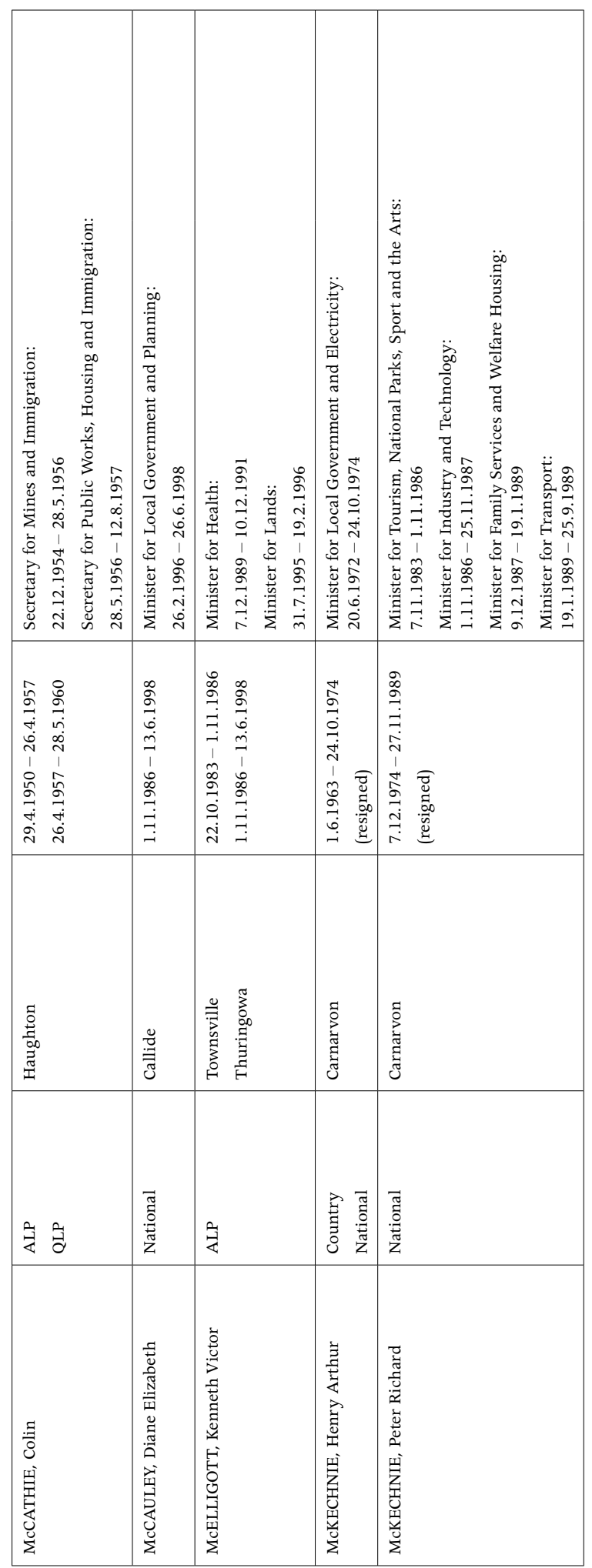


The Ayes Have it - the History of the Queensland Parliament 1957-89

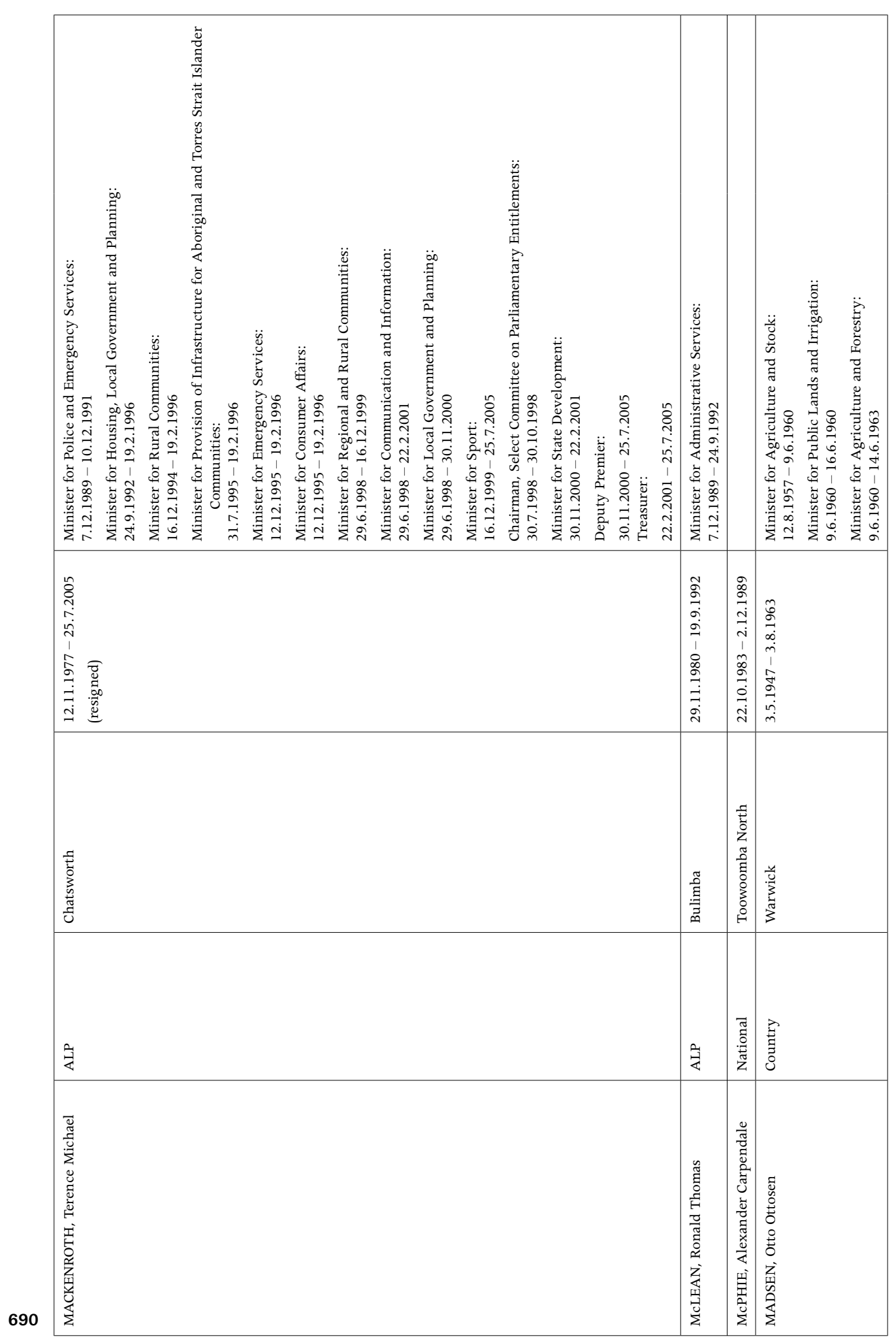


Appendix 2

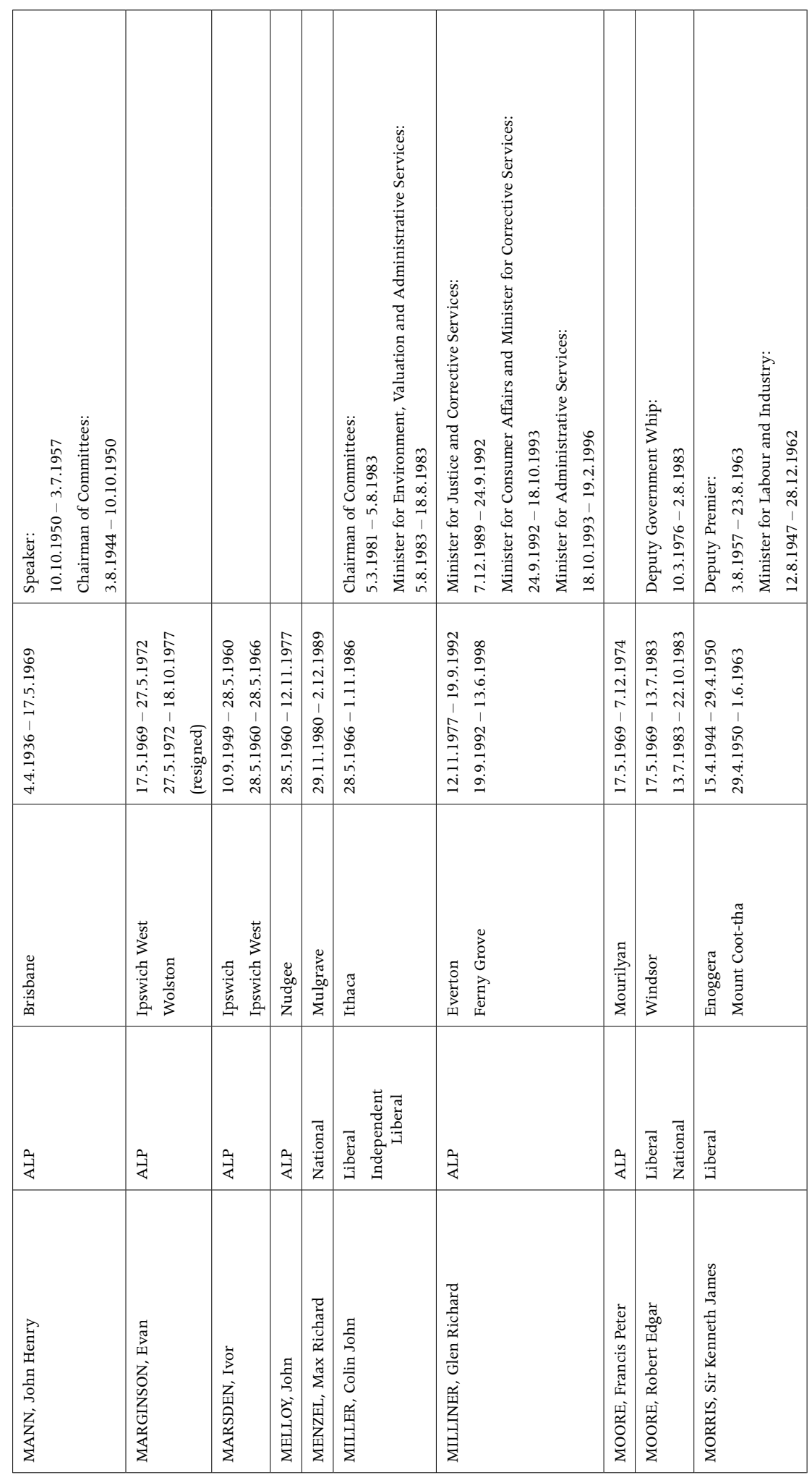


The Ayes Have it - the History of the Queensland Parliament 1957-89

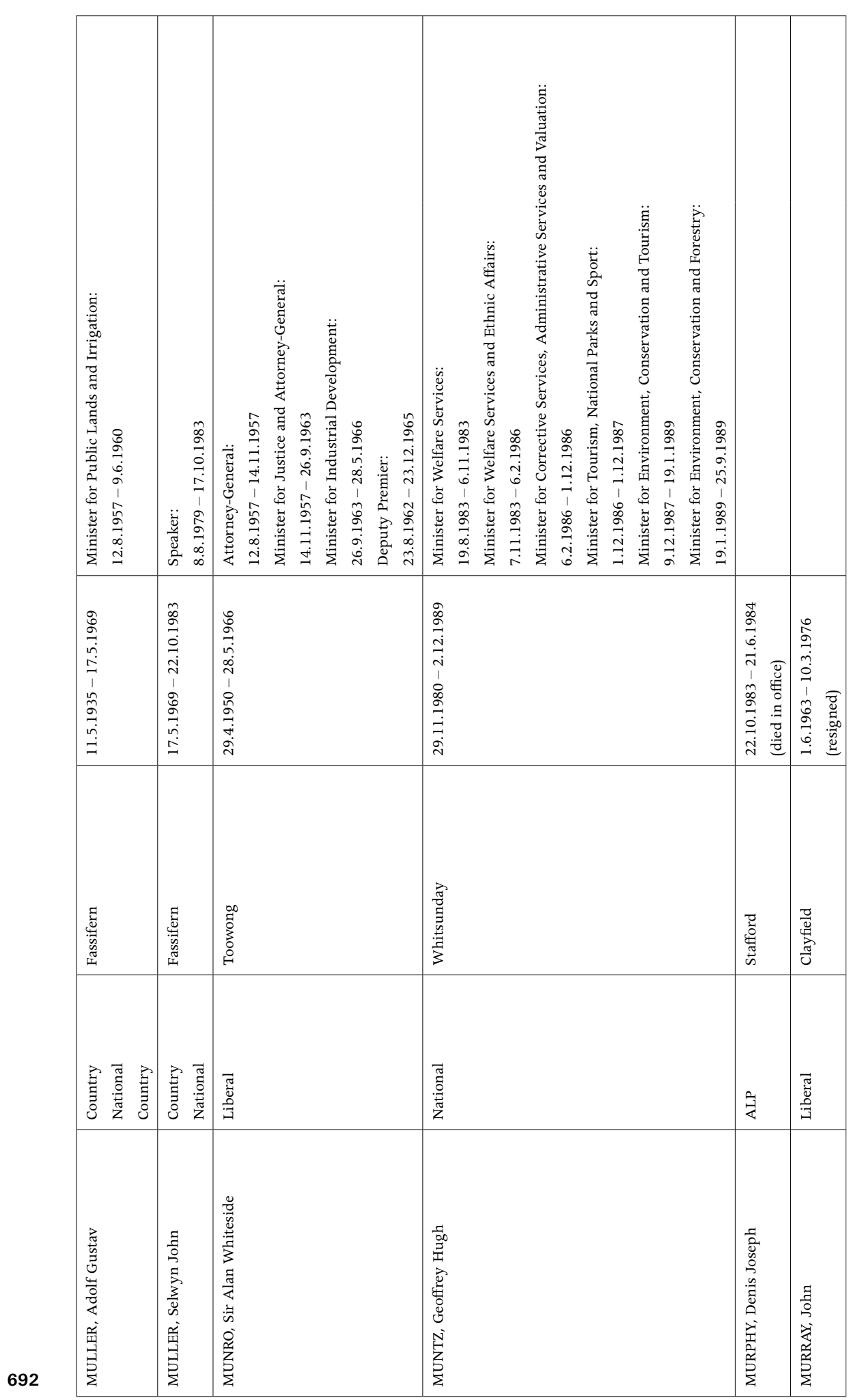




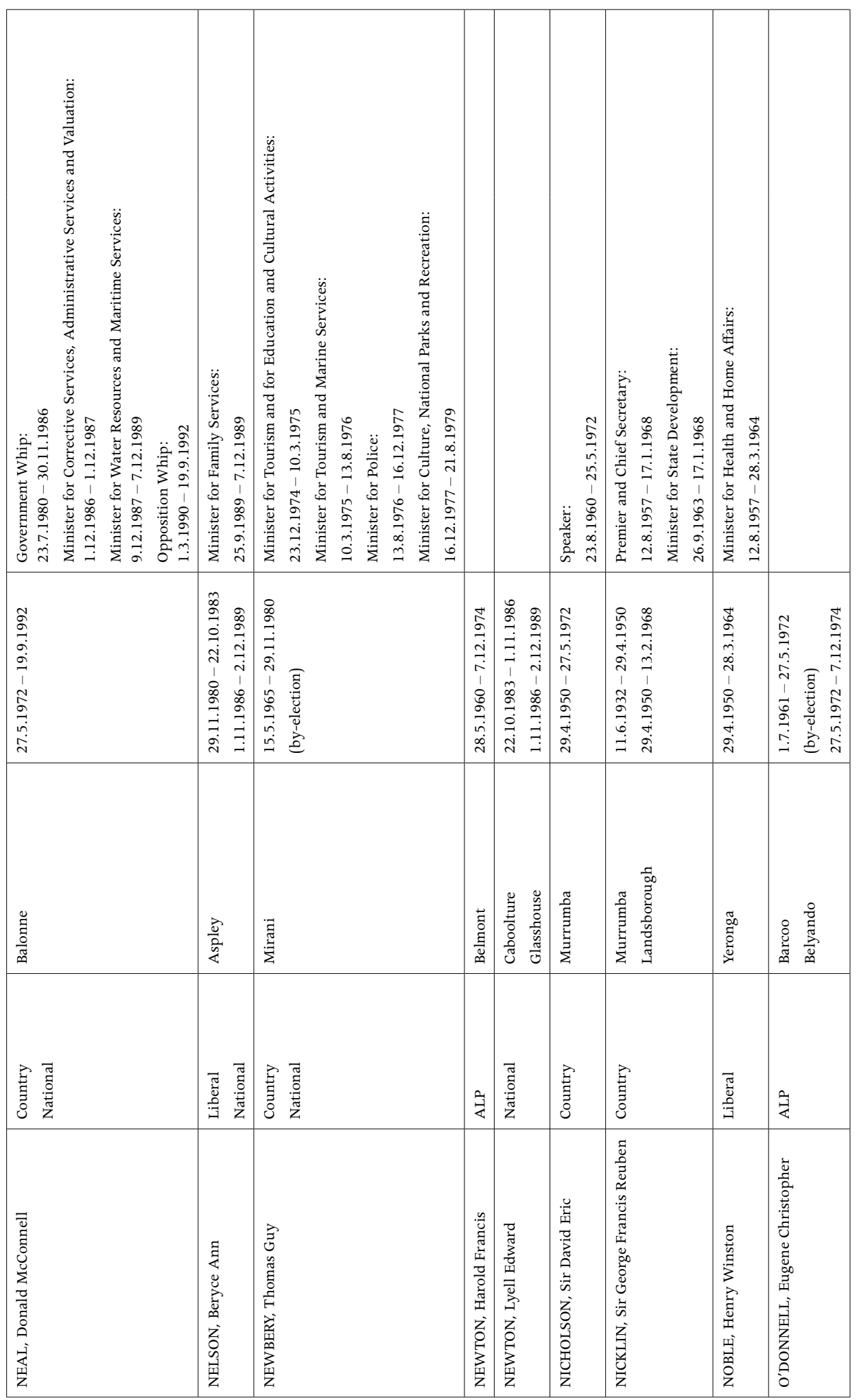


The Ayes Have it - the History of the Queensland Parliament 1957-89

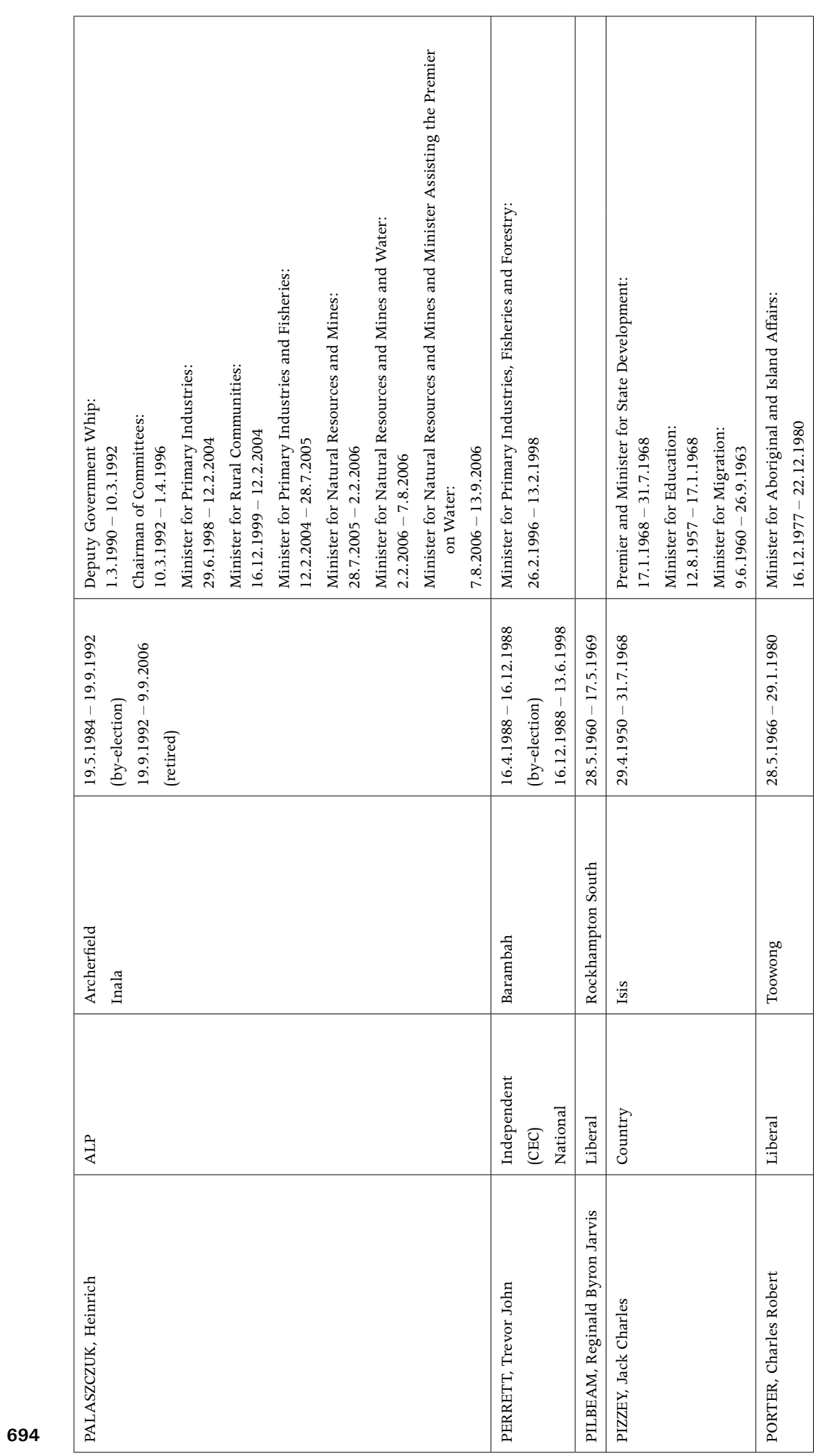




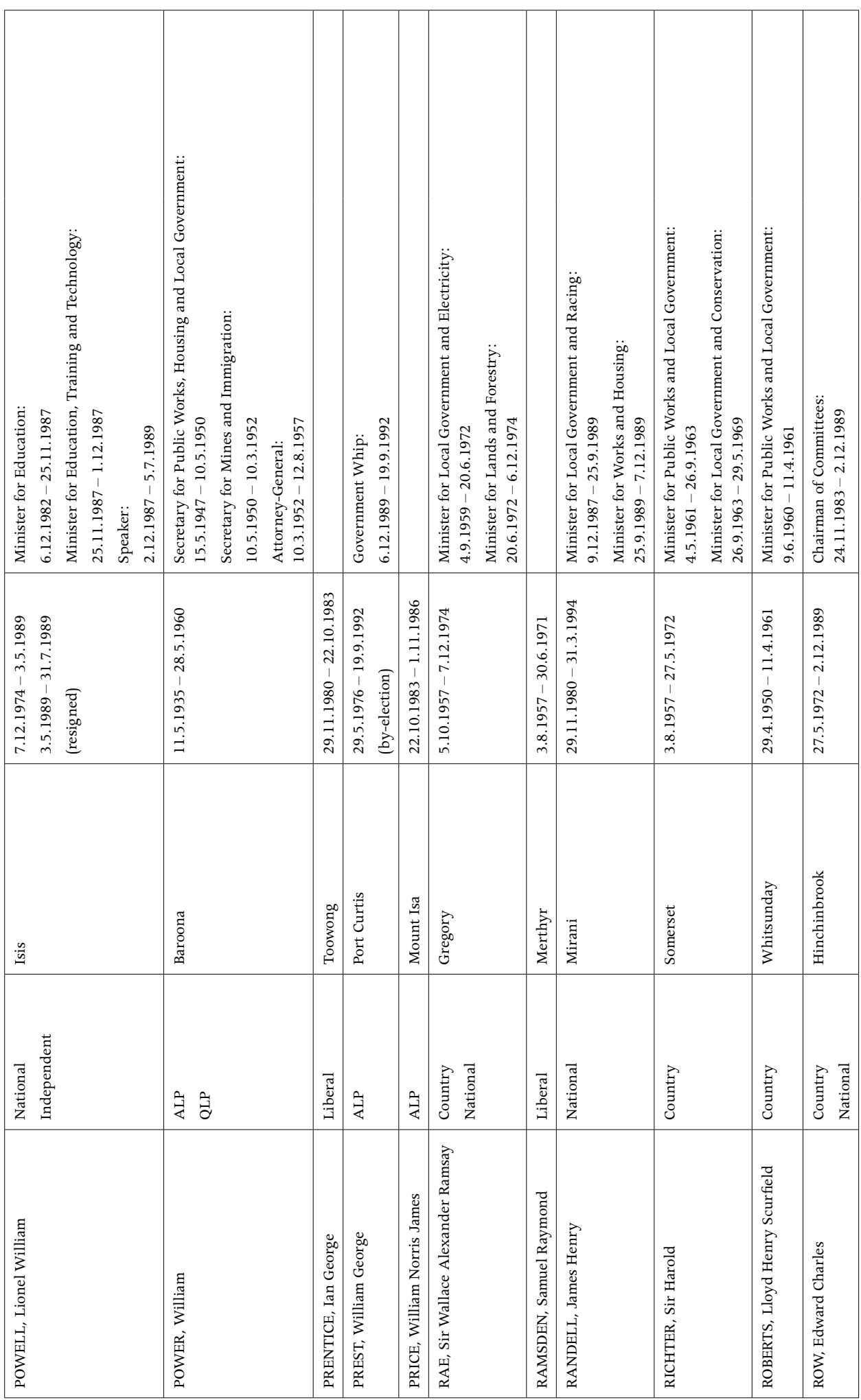




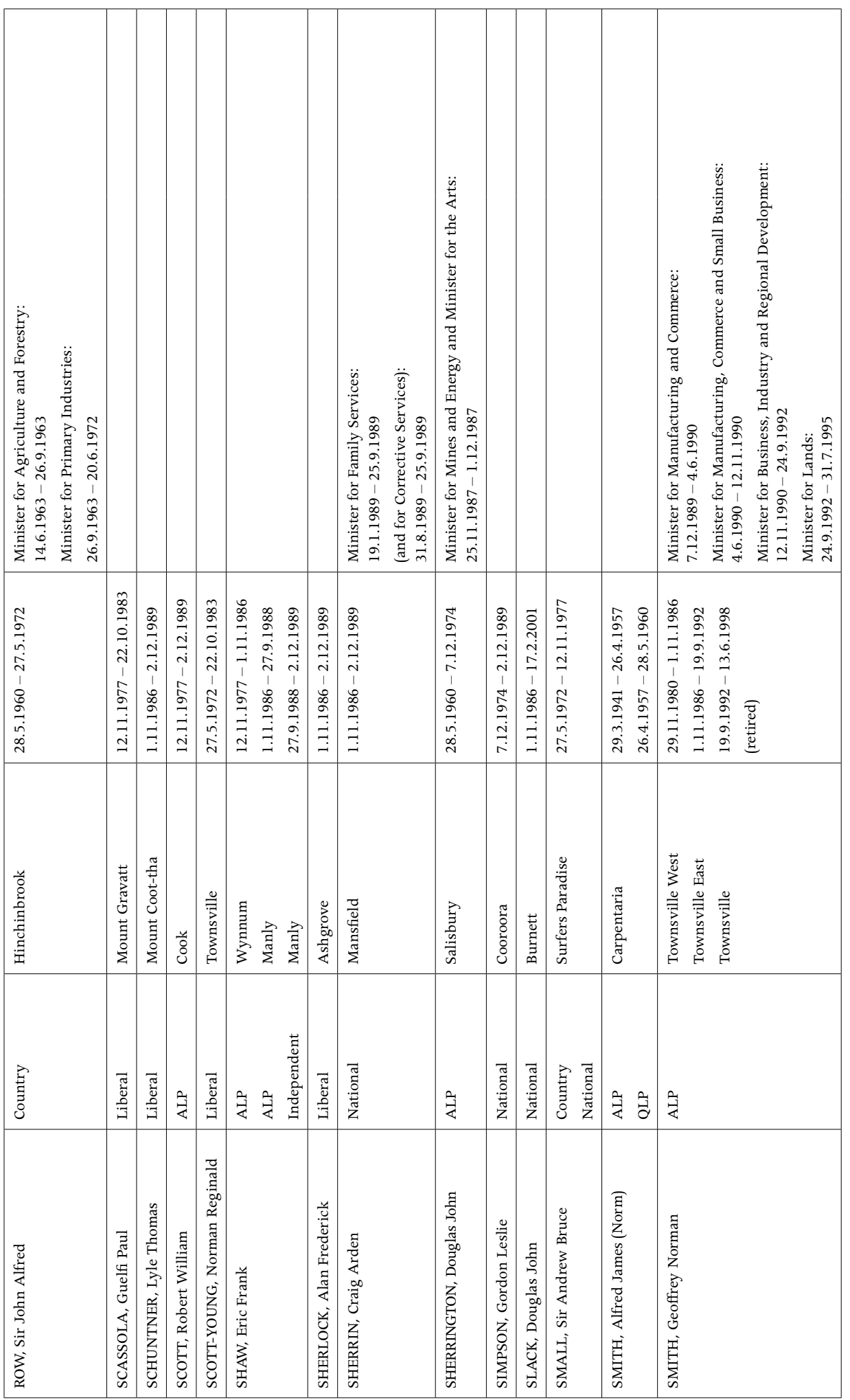




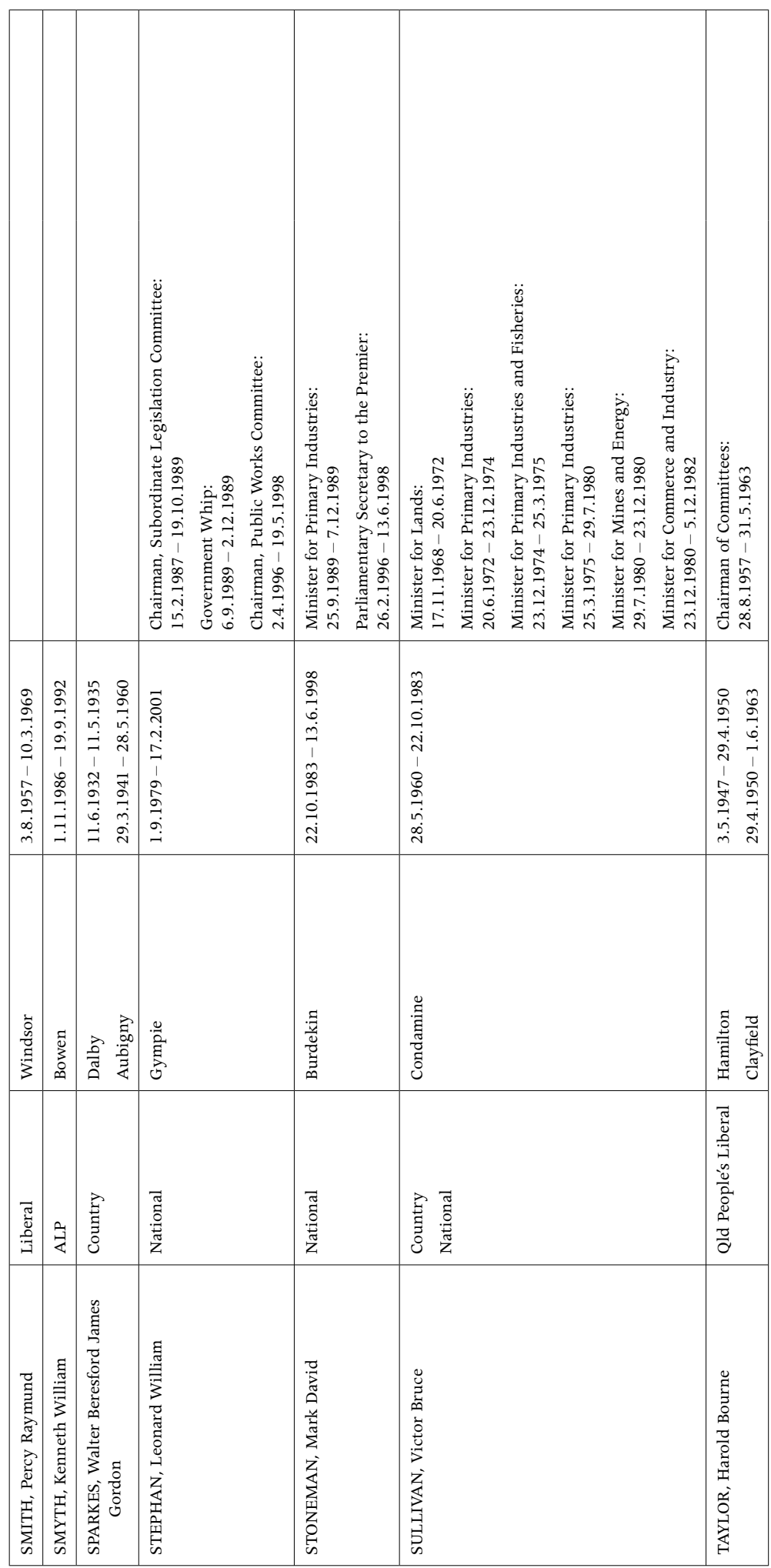


The Ayes Have it - the History of the Queensland Parliament 1957-89

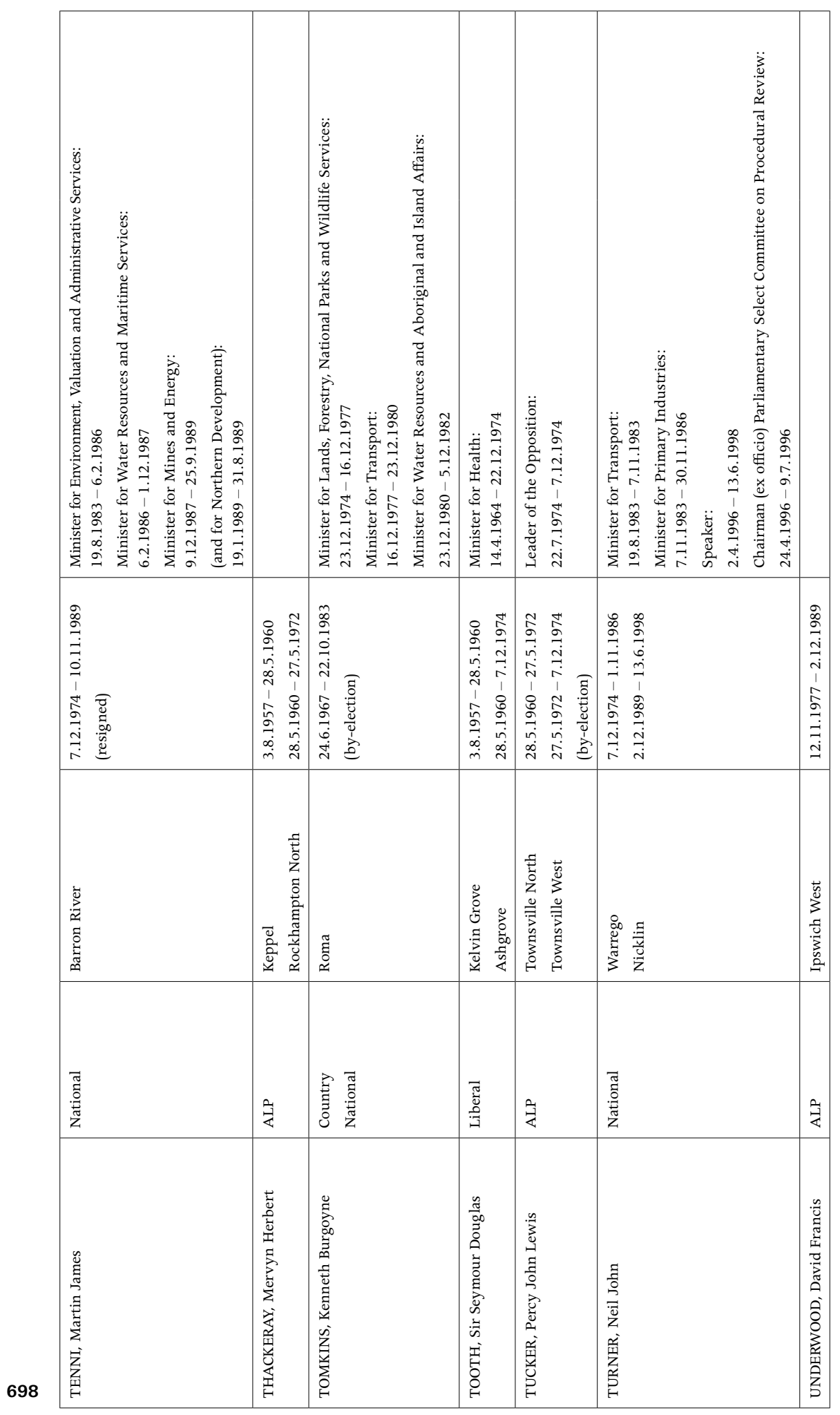




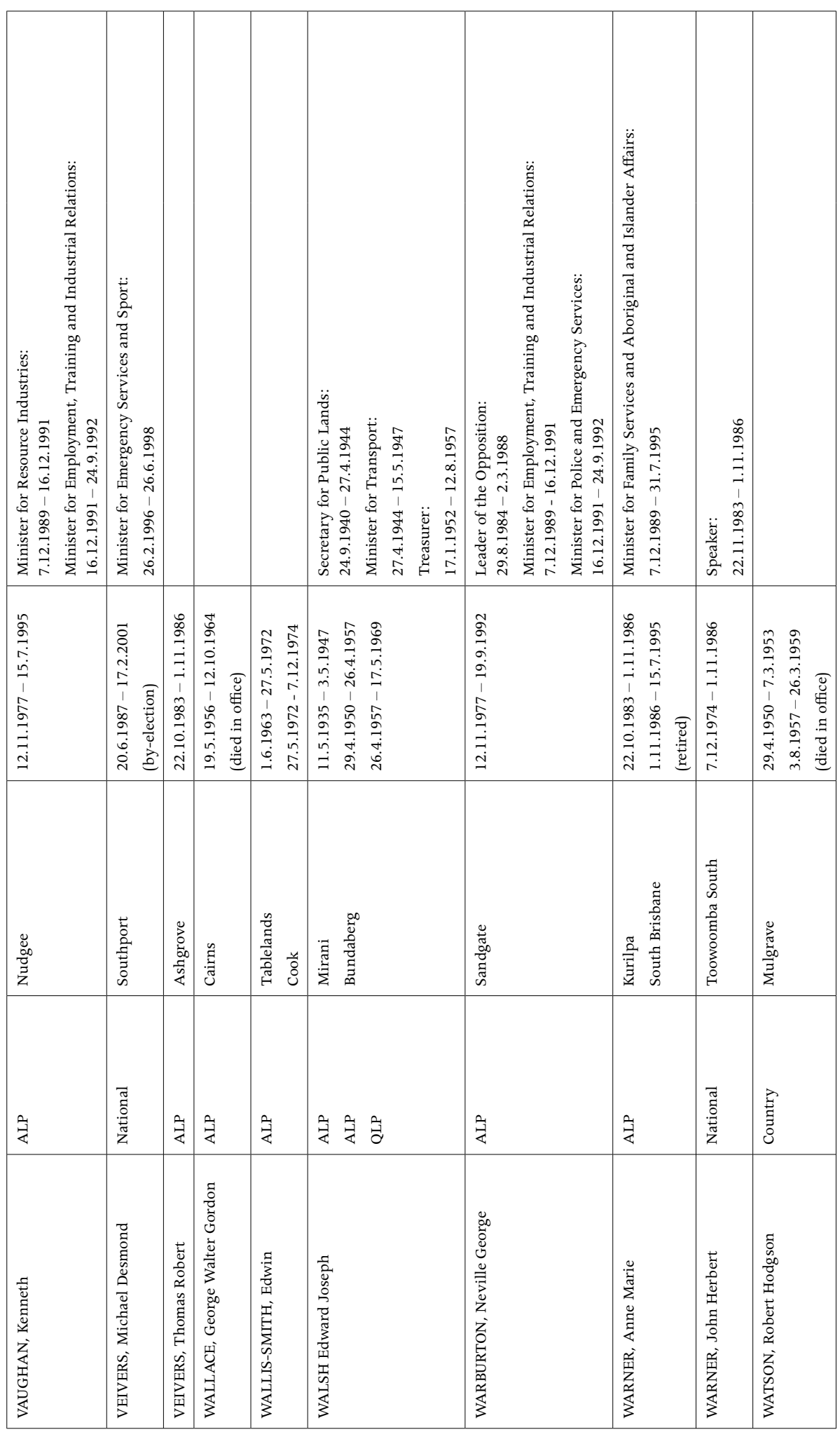




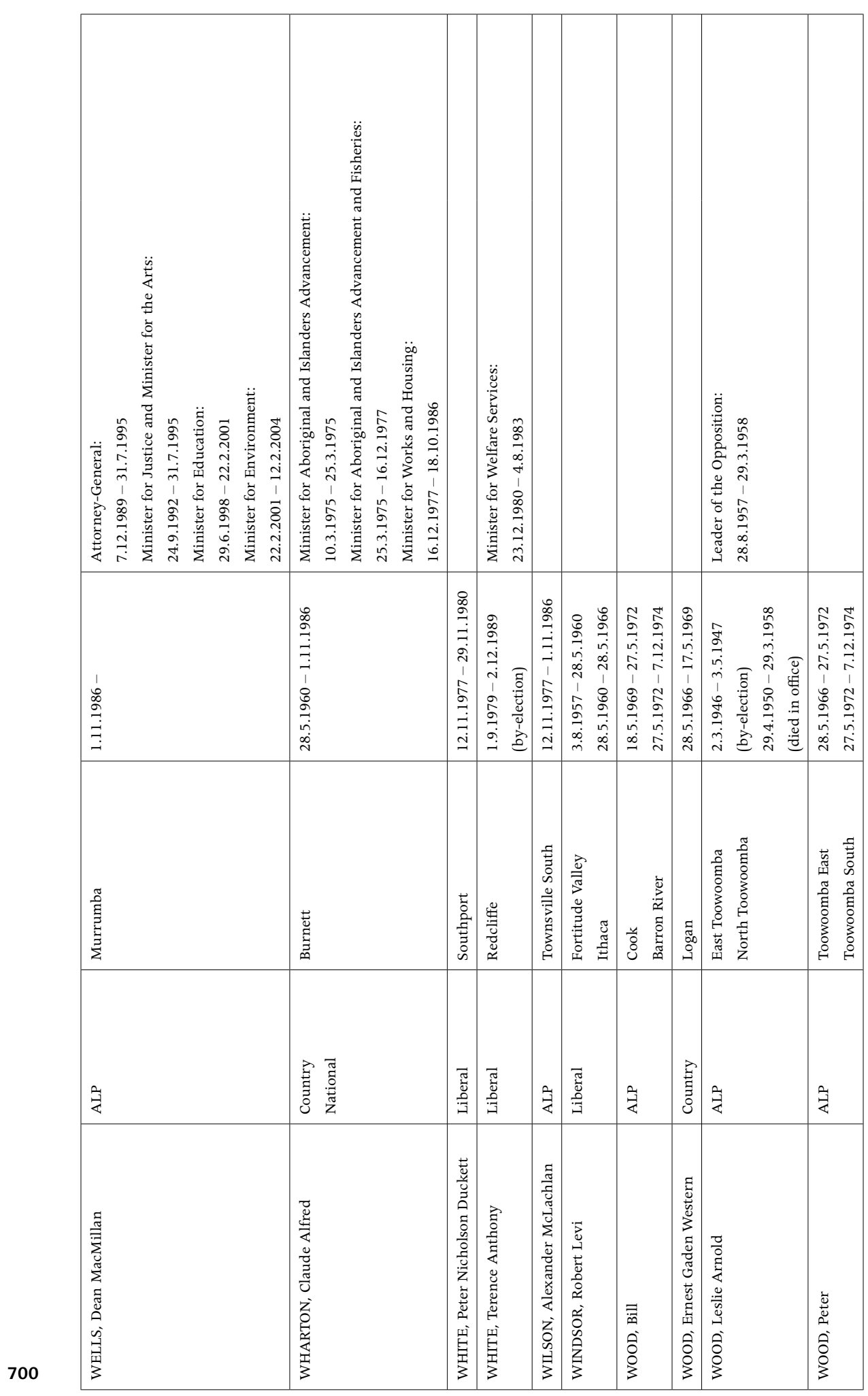


Appendix 2

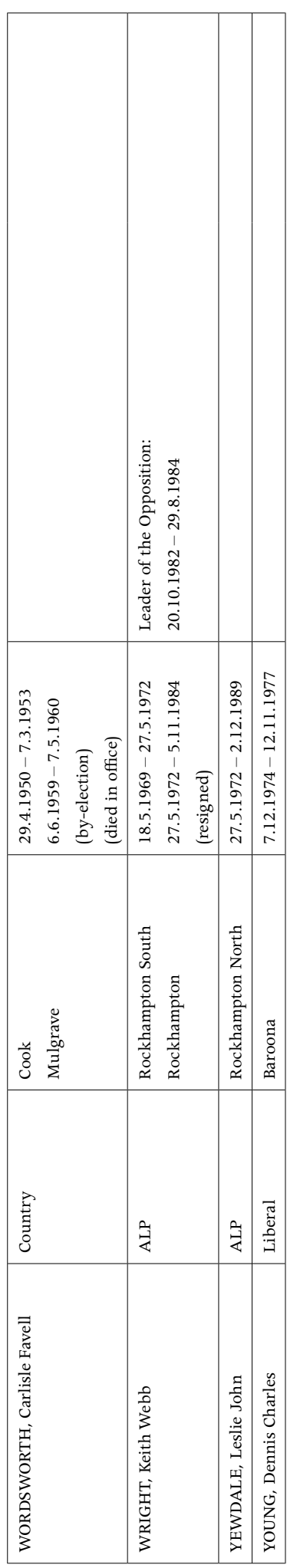





\section{Appendix 3}

Members of the Queensland Parliament who died in office, 1957-89

\begin{tabular}{|c|c|c|c|c|}
\hline Name & Party & Electorate & $\begin{array}{l}\text { Period of } \\
\text { representation }\end{array}$ & Offices attained \\
\hline WOOD, Leslie Arnold & ALP & $\begin{array}{l}\text { East Toowoomba } \\
\text { North Toowoomba }\end{array}$ & $\begin{array}{l}2.3 .1946-3.5 .1947 \\
\text { (by-election) } \\
29.4 .1950-29.3 .1958\end{array}$ & $\begin{array}{l}\text { Opposition Leader } \\
28.8 .1957-9.3 .1958\end{array}$ \\
\hline $\begin{array}{l}\text { WATSON, Robert } \\
\text { Hodgson }\end{array}$ & Country & Mulgrave & $\begin{array}{l}29.4 .1950-7.3 .1953 \\
3.8 .1957-26.3 .1959\end{array}$ & \\
\hline $\begin{array}{l}\text { WORDSWORTH, } \\
\text { Carlisle Favell }\end{array}$ & Country & $\begin{array}{l}\text { Cook } \\
\text { Mulgrave }\end{array}$ & $\begin{array}{l}29.4 .1950-7.3 .1953 \\
6.6 .1959-7.5 .1960 \\
\text { (by-election) }\end{array}$ & \\
\hline DAVIS, Edward William & ALP & Barcoo & $1.5 .1943-10.4 .1961$ & \\
\hline ROBERTS, Lloyd & Country & Whitsunday & $29.4 .1950-11.4 .1961$ & $\begin{array}{l}\text { Minister for Public } \\
\text { Works and Local } \\
\text { Government, } \\
\text { 9.6.1960-11.4.1961 }\end{array}$ \\
\hline MADSEN, Otto & Country & Warwick & $3.5 .1947-3.8 .1963$ & $\begin{array}{l}\text { Minister for Agriculture } \\
\text { and Stock, } \\
\text { 12.8.1957 } \\
\text { Minister for Public Lands } \\
\text { and Irrigation, } \\
\text { 9.5.1960-16.6.1960 } \\
\text { Minister for Agriculture } \\
\text { and Forestry, } \\
\text { 9.6.1960-14.6.1963 }\end{array}$ \\
\hline NOBLE, Henry Winston & Liberal & Yeronga & $29.04 .1950-28.03 .1964$ & $\begin{array}{c}\text { Minister for Health and } \\
\text { Home Affairs, } \\
\text { 12.8.1957-28.3.1964 }\end{array}$ \\
\hline $\begin{array}{l}\text { WALLACE, George } \\
\text { Walter Gordon }\end{array}$ & ALP & Cairns & 19.5.1956-12.10.1964 & \\
\hline PIZZEY, Jack Charles & Country & Isis & 29.4.1950-31.7.1968 & $\begin{array}{c}\text { Premier and Minister for } \\
\text { State Development, } \\
\text { 17.1.1968-31.7.1968 } \\
\text { Minister for Education, } \\
\text { 12.8.1957-17.1.1968 } \\
\text { Minister for Migration, } \\
\text { 9.6.1960-26.9.1963 }\end{array}$ \\
\hline CAREY, Cecil Charles & Country & Albert & 28.5.1960-26.12.1969 & \\
\hline DAVIES, Horace Jason & ALP & Maryborough & $\begin{array}{l}28.11 .1953-4.6 .1971 \\
\text { (by-election) }\end{array}$ & \\
\hline $\begin{array}{l}\text { HEATLEY, William } \\
\text { Clarence }\end{array}$ & Liberal & Albert & $\begin{array}{l}14.2 .1970-26.10 .1971 \\
\text { (by-election) }\end{array}$ & \\
\hline
\end{tabular}


The Ayes Have It: The history of the Queensland Parliament, 1957-1989

\begin{tabular}{|l|l|l|l|l|}
\hline $\begin{array}{c}\text { JONES, Vincent } \\
\text { Edward }\end{array}$ & Country & Callide & $29.4 .1950-30.10 .1971$ & \\
\hline HUNGERFORD, Harold & Country & Balonne & $17.5 .1969-11.1 .1972$ & \\
\hline BROWN, Ivan & Liberal & Clayfield & $29.5 .1976-12.5 .1977$ & \\
\hline HOOPER, Kevin Joseph & ALP & Archerfield & $27.5 .1972-9.3 .1984$ & \\
\hline MURPHY, Denis Joseph & ALP & Stafford & $22.10 .1983-21.6 .1984$ & \\
\hline $\begin{array}{c}\text { GOLEBY, John Phillip } \\
\text { National }\end{array}$ & Redlands & $7.12 .1974-10.9 .1985$ & $\begin{array}{c}\text { Minister for Water } \\
\text { Resources and } \\
\text { Maritime Services, } \\
6.12 .1982-10.9 .1985\end{array}$ \\
\hline $\begin{array}{c}\text { JENNINGS, Douglas } \\
\text { Bernard }\end{array}$ & National & Southport & $29.11 .1980-9.4 .1987$ & \\
\hline
\end{tabular}




\section{Appendix 4}

Members of the Queensland Parliament who were ordered to withdraw (temporary expulsion from the Chamber), 1957-89

\begin{tabular}{|c|c|c|c|c|}
\hline Parliament & MP & Party & Date & Hansard page \\
\hline 35 th $27.8 .57-13.4 .60$ & Aikens, $\mathrm{T}$. & NQLP & 12.8 .59 & 159 \\
\hline 36th $23.8 .60-19.4 .63$ & $\begin{array}{l}\text { Aikens, } \mathrm{T} \text {. } \\
\text { Aikens, } \mathrm{T} \text {. }\end{array}$ & $\begin{array}{l}\text { NQLP } \\
\text { NQLP }\end{array}$ & $\begin{array}{c}10.11 .60 \\
28.9 .61\end{array}$ & $\begin{array}{c}1350 \\
553\end{array}$ \\
\hline 37th 20.8.63-19.4.66 & $\begin{array}{c}\text { Bennett, C. J. } \\
\text { Bennett, C. J. } \\
\text { Bennett, C. J. } \\
\text { Bromley, F. P. } \\
\text { Thackeray, M. H. } \\
\text { Aikens, T. } \\
\text { Aikens, T. } \\
\text { Bennett, C. J. }\end{array}$ & $\begin{array}{c}\text { ALP } \\
\text { ALP } \\
\text { ALP } \\
\text { ALP } \\
\text { Independent } \\
\text { NQP } \\
\text { NQP } \\
\text { ALP }\end{array}$ & $\begin{array}{c}31.10 .63 \\
31.10 .63 \\
10.3 .64 \\
19.3 .64 \\
4.3 .65 \\
16.9 .65 \\
2.11 .65 \\
25.11 .65\end{array}$ & $\begin{array}{l}1120 \\
1135 \\
2359 \\
2715 \\
2348 \\
507 \\
1272 \\
1833\end{array}$ \\
\hline 38th $2.8 .66-8.4 .69$ & $\begin{array}{l}\text { Bennett, C. J. } \\
\text { Newton, H. F. } \\
\text { Newton, H. F. } \\
\text { Graham, F. D. } \\
\text { Newton, H. F. } \\
\text { Newton, H. F. }\end{array}$ & $\begin{array}{l}\text { ALP } \\
\text { ALP } \\
\text { ALP } \\
\text { ALP } \\
\text { ALP } \\
\text { ALP }\end{array}$ & $\begin{array}{c}25.11 .66 \\
28.9 .67 \\
28.9 .67 \\
18.10 .68 \\
19.11 .68 \\
19.11 .68\end{array}$ & $\begin{array}{c}1959 \\
713 \\
718 \\
773 \\
1572 \\
1589\end{array}$ \\
\hline
\end{tabular}


The Ayes Have It: The history of the Queensland Parliament, 1957-1989

\begin{tabular}{|c|c|c|c|c|}
\hline 39th 5.8.69-18.4.72 & $\begin{array}{l}\text { Sherrington, D. J. } \\
\text { Sherrington, D. J. } \\
\text { Bromley, F. P. } \\
\text { Davies, H. J. } \\
\text { Bromley, F. P. } \\
\text { Bromley, F. P. } \\
\text { Bromley, F. P. } \\
\text { Davies, H. J. } \\
\text { Wright, K. W. } \\
\text { Baldwin, E. A. } \\
\text { Hinze, R. J.* } \\
\text { Jones, R. } \\
\text { Aikens, T. } \\
\text { Wood, P. } \\
\text { Moore, F. P. } \\
\text { Moore, F. P. } \\
\text { Jensen, E. D. } \\
\text { Bromley, F. P. } \\
\text { Harris, E. D. } \\
\text { Harris, E. D. } \\
\text { Wood, B. } \\
\text { Jones, R. } \\
\text { Bousen, W. R. J. } \\
\text { Aikens, T. } \\
\text { Bennett, C. J. } \\
\text { Sherrington, D. J. } \\
\text { Moore, F. P. } \\
\text { Davis, B. J. } \\
\text { Bousen, W. R. J. } \\
\text { Sherrington, D. J. } \\
\text { Moorington, D. J. }\end{array}$ & $\begin{array}{l}\text { ALP } \\
\text { ALP } \\
\text { ALP } \\
\text { ALP } \\
\text { ALP } \\
\text { ALP } \\
\text { ALP } \\
\text { ALP } \\
\text { ALP } \\
\text { ALP } \\
\text { CP } \\
\text { ALP } \\
\text { NQLP } \\
\text { ALP } \\
\text { ALP } \\
\text { ALP } \\
\text { ALP } \\
\text { ALP } \\
\text { ALP } \\
\text { ALP } \\
\text { ALP } \\
\text { ALP } \\
\text { ALP } \\
\text { NQLP } \\
\text { ALP } \\
\text { ALP } \\
\text { ALP } \\
\text { ALP } \\
\text { ALP } \\
\text { ALP }\end{array}$ & $\begin{array}{c}21.8 .69 \\
2.9 .69 \\
11.9 .69 \\
12.3 .70 \\
20.10 .70 \\
20.10 .70 \\
20.10 .70 \\
12.11 .70 \\
12.11 .70 \\
12.11 .70 \\
10.12 .70 \\
31.8 .71 \\
1.9 .71 \\
9.9 .71 \\
16.9 .71 \\
16.9 .71 \\
22.9 .71 \\
12.10 .71 \\
12.10 .71 \\
12.10 .71 \\
12.10 .71 \\
14.10 .71 \\
19.10 .71 \\
28.10 .71 \\
9.11 .71 \\
11.11 .71 \\
17.11 .71 \\
17.11 .71 \\
25.11 .71 \\
3.12 .71 \\
3.12 .71 \\
3.12 .71 \\
7.12 .71 \\
8.12 .71\end{array}$ & 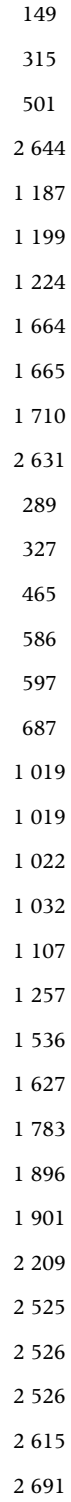 \\
\hline
\end{tabular}




\begin{tabular}{|c|c|c|c|c|}
\hline 40th $1.8 .72-2.11 .74$ & 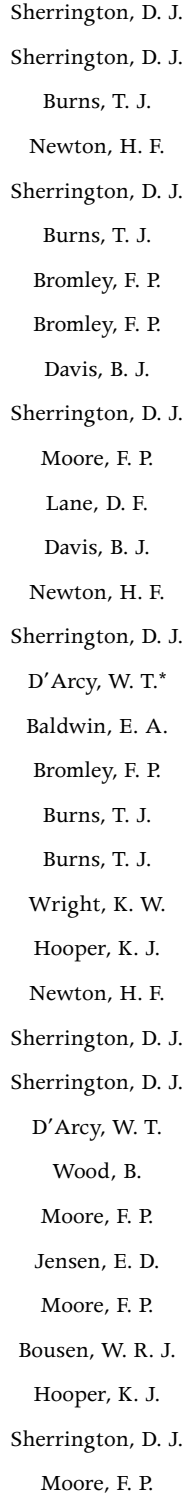 & $\begin{array}{l}\text { ALP } \\
\text { ALP } \\
\text { ALP } \\
\text { ALP } \\
\text { ALP } \\
\text { ALP } \\
\text { ALP } \\
\text { ALP } \\
\text { ALP } \\
\text { ALP } \\
\text { ALP } \\
\text { Liberal } \\
\text { ALP } \\
\text { ALP } \\
\text { ALP } \\
\text { ALP } \\
\text { ALP } \\
\text { ALP } \\
\text { ALP } \\
\text { ALP } \\
\text { ALP } \\
\text { ALP } \\
\text { ALP } \\
\text { ALP } \\
\text { ALP } \\
\text { ALP } \\
\text { ALP } \\
\text { ALP } \\
\text { ALP } \\
\text { ALP } \\
\text { ALP } \\
\text { ALP } \\
\text { ALP } \\
\text { ALP } \\
\text { ALP }\end{array}$ & $\begin{array}{c}30.8 .72 \\
19.9 .72 \\
19.9 .72 \\
17.10 .72 \\
26.10 .72 \\
26.10 .72 \\
26.10 .72 \\
26.10 .72 \\
17.11 .72 \\
1.12 .72 \\
5.12 .72 \\
12.12 .72 \\
7.3 .73 \\
8.3 .73 \\
8.3 .73 \\
9.3 .73 \\
13.3 .73 \\
22.3 .73 \\
9.10 .73 \\
21.11 .73 \\
21.11 .73 \\
28.11 .73 \\
29.11 .73 \\
29.11 .73 \\
11.12 .73 \\
7.3 .74 \\
22.8 .74 \\
22.8 .74 \\
12.9 .74 \\
19.9 .74 \\
15.10 .74 \\
15.10 .74 \\
25.10 .74 \\
29.10 .74\end{array}$ & 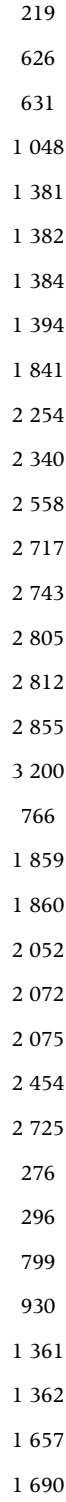 \\
\hline 41st $25.2 .75-10.10 .77$ & $\begin{array}{l}\text { Lane, D. F. } \\
\text { Burns, T. J. }\end{array}$ & $\begin{array}{c}\text { Liberal } \\
\text { ALP }\end{array}$ & $\begin{array}{r}22.4 .75 \\
17.10 .75\end{array}$ & $\begin{array}{r}909 \\
1286\end{array}$ \\
\hline
\end{tabular}


The Ayes Have It: The history of the Queensland Parliament, 1957-1989

\begin{tabular}{|c|c|c|c|c|}
\hline 42nd 28.3.78-27.10.80 & $\begin{array}{c}\text { Hartwig, L. E. } \\
\text { Hooper, K. J. } \\
\text { Hooper, K. J. } \\
\text { Casey, E. D. } \\
\text { Gibbs, R. J. } \\
\text { Jones, R. } \\
\text { Jones, R. } \\
\text { Hooper, K. J. } \\
\text { Gibbs, R. J. } \\
\text { Gibbs, R. J. } \\
\text { Underwood, D. F. } \\
\text { Houston, J. W. }\end{array}$ & $\begin{array}{l}\text { NP } \\
\text { ALP } \\
\text { ALP } \\
\text { ALP } \\
\text { ALP } \\
\text { ALP } \\
\text { ALP } \\
\text { ALP } \\
\text { ALP } \\
\text { ALP } \\
\text { ALP } \\
\text { ALP }\end{array}$ & $\begin{array}{l}17.5 .78 \\
18.5 .78 \\
21.9 .78 \\
12.10 .78 \\
30.11 .78 \\
30.11 .78 \\
15.3 .79 \\
21.3 .79 \\
24.4 .79 \\
24.4 .79 \\
9.8 .79 \\
9.10 .79\end{array}$ & $\begin{array}{c}914 \\
1007 \\
1875 \\
2186 \\
3076 \\
3076 \\
3480 \\
3573 \\
4227 \\
4232 \\
88 \\
810\end{array}$ \\
\hline 43rd 3.3.81-13.9.83 & $\begin{array}{c}\text { Burns, T. J. } \\
\text { Gibbs, R. J. } \\
\text { Hooper, K. J. } \\
\text { Gibbs, R. J.* } \\
\text { Burns, T. J. } \\
\text { Underwood, D. F. } \\
\text { Burns, T. J. } \\
\text { Gibbs, R. J. }\end{array}$ & $\begin{array}{l}\text { ALP } \\
\text { ALP } \\
\text { ALP } \\
\text { ALP } \\
\text { ALP } \\
\text { ALP } \\
\text { ALP } \\
\text { ALP }\end{array}$ & $\begin{array}{c}8.10 .81 \\
18.11 .81 \\
2.3 .82 \\
18.3 .82 \\
4.8 .82 \\
17.8 .82 \\
12.10 .82 \\
17.11 .82\end{array}$ & $\begin{array}{c}2344 \\
3673 \\
4319 \\
4923 \\
82 \\
161 \\
1287 \\
2389\end{array}$ \\
\hline 44th $22.11 .83-30.9 .86$ & $\begin{array}{c}\text { Burns, T. J. } \\
\text { Warburton, N. G. } \\
\text { Prest, W. G. } \\
\text { Underwood, D. F. } \\
\text { Smith, G. N. } \\
\text { Gibbs, R. J. } \\
\text { McLean, R. T. } \\
\text { Prest, W. G. } \\
\text { Gibbs, R. J. } \\
\text { Scott, F. W. } \\
\text { Underwood, D. F. } \\
\text { De Lacy, K. E. } \\
\text { Gibbs, R. J. } \\
\text { Scott, F. W. } \\
\text { Burns, T. J. } \\
\text { Hamill, D. J. } \\
\text { Goss, W. K. } \\
\text { Davis, B. J. } \\
\text { Hamill, D. J. } \\
\text { Prest, W. G. } \\
\text { Prest, W. G. } \\
\text { Davis, B. J. }\end{array}$ & $\begin{array}{l}\text { ALP } \\
\text { ALP } \\
\text { ALP } \\
\text { ALP } \\
\text { ALP } \\
\text { ALP } \\
\text { ALP } \\
\text { ALP } \\
\text { ALP } \\
\text { ALP } \\
\text { ALP } \\
\text { ALP } \\
\text { ALP } \\
\text { ALP } \\
\text { ALP } \\
\text { ALP } \\
\text { ALP } \\
\text { ALP } \\
\text { ALP } \\
\text { ALP } \\
\text { ALP } \\
\text { ALP }\end{array}$ & $\begin{array}{c}2.2 .84 \\
29.2 .84 \\
7.3 .84 \\
8.3 .84 \\
12.4 .84 \\
13.4 .84 \\
13.4 .84 \\
23.8 .84 \\
29.8 .84 \\
24.10 .84 \\
1.11 .84 \\
13.11 .84 \\
20.11 .84 \\
22.11 .84 \\
27.2 .85 \\
9.10 .85 \\
16.10 .85 \\
21.11 .85 \\
18.2 .86 \\
9.9 .86 \\
11.90 .86 \\
18.9 .86\end{array}$ & $\begin{array}{r}1326 \\
1679 \\
1918 \\
2004 \\
2801 \\
2940 \\
2986 \\
85 \\
287 \\
1652 \\
2117 \\
2340 \\
2631 \\
2899 \\
3398 \\
1688 \\
2005 \\
2615 \\
3558 \\
1099 \\
1216 \\
1655\end{array}$ \\
\hline
\end{tabular}


Appendix 4

\begin{tabular}{|c|c|c|c|c|}
\hline 45th $17.2 .87-2.11 .89$ & $\begin{array}{c}\text { Prest, W. G. } \\
\text { McLean, R. T. } \\
\text { Comben, P. } \\
\text { Hamill, D. J. } \\
\text { Gibbs, R. J. } \\
\text { De Lacy, K. E. } \\
\text { Goss, W. K. } \\
\text { Burns, T. J. } \\
\text { Warburton, N. G. } \\
\text { Comben, P. } \\
\text { Smyth, K. W.* } \\
\text { Burns, T. J. }\end{array}$ & $\begin{array}{l}\text { ALP } \\
\text { ALP } \\
\text { ALP } \\
\text { ALP } \\
\text { ALP } \\
\text { ALP } \\
\text { ALP } \\
\text { ALP } \\
\text { ALP } \\
\text { ALP } \\
\text { ALP } \\
\text { ALP }\end{array}$ & $\begin{array}{c}30.8 .88 \\
7.9 .88 \\
19.10 .88 \\
8.11 .88 \\
16.11 .88 \\
16.11 .88 \\
8.3 .89 \\
8.3 .89 \\
14.3 .89 \\
18.4 .89 \\
19.4 .89 \\
7.9 .89\end{array}$ & $\begin{array}{c}245 \\
605 \\
1538 \\
2286 \\
2688 \\
2692 \\
3496 \\
3496 \\
3645 \\
4806 \\
4970 \\
531\end{array}$ \\
\hline
\end{tabular}

* Members asked to leave for being improperly attired (for example, one member was not wearing a tie). 



\section{Bibliography}

Arklay, T. 2000, Reinterpreting electoral relations between the Queensland coalition parties - three-cornered contest 1944-2000, Bachelor of Commerce Thesis, Griffith University, Brisbane.

Barlow, G. and Corkery, J. F. 2007, 'Sir Walter Campbell Queensland Governor and his role in Premier Joh Bjelke-Petersen's resignation, 1987', Owen Dixon Society eJournal, Bond University, Gold Coast, Qld.

Bateman, J. 2009, In the Shadows - The Shadow Cabinet in Australia, Australian Parliament, Canberra.

Beattie, P. 1990, In the Arena: Memories of an ALP state secretary in Queensland, Edited by B. Stevenson, Boolarong Publications, Brisbane.

Beattie, P. 2005, Making a Difference: Reflections on life, leadership and politics, Harper Collins, Australia.

Bjelke-Petersen, J. 1990, Don't You Worry About That!: The Joh Bjelke-Petersen memoirs, Angus \& Robertson, Sydney.

Campbell, M. 1995, Queensland's Electoral History, Electoral Commission Queensland, Brisbane.

Charlton, P. with cartoons by Moir, A. 1983, State of Mind: Why Queensland is different, Methuen-Haynes, North Ryde, NSW.

Coaldrake, P. 1989, Working the System: Government in Queensland, University of Queensland Press, St Lucia.

Cribb, M. B. 1980, 'An out-of-town tryout: the Lockyer by-election', in D. J. Murphy (ed.), The Big Strike: Queensland 1889-1965, University of Queensland Press, St Lucia.

Cribb, M. B. and Boyce, P. J. (eds) 1980, Politics in Queensland: 1977 and beyond, University of Queensland Press, St Lucia.

Davis, G. and Wanna, J. 1988, 'The Fitzgerald Commission: the politics of inquiries', Canberra Bulletin of Public Administration, no. 55 (June).

Delamothe, J. and Stevenson, B. 1989, The Delamothe Story: A lifetime of dedicated service to Bowen, Queensland and Australia, Boolarong Publications, Brisbane. 
Fitzgerald, G. E. [chairman] 1989, Report of a Commission of Inquiry Pursuant to Orders in Council, Brisbane.

Fitzgerald, R. 1984, From 1915 to the Early 1980s: A history of Queensland, University of Queensland Press, St Lucia.

Fitzgerald, R. and Thornton, H. 1989, Labor in Queensland: From the 1880s to 1988, University of Queensland Press, St Lucia.

Ford, D. 1990, 'Devolution of budgetary control in Queensland', in J. Forster and J. Wanna (eds), Budgetary Management and Control, Macmillan Australia, South Melbourne.

Galligan, B. (ed.) 1986, Australian State Politics, Longman Cheshire, Melbourne.

Galton, B., 2008. Ivan Gibbs: Queensland's quiet achiever, Kulgera, Sanctuary Cove, Qld.

Goss, W. 1998, Address to the Australasian Study of Parliament Group (Queensland Chapter), 13 May 1998.

Government of Queensland 1909, Our First Half-Century: A review of Queensland progress based upon official information, Government Printer, Brisbane.

Grimshaw, C. 1960a, 'Queensland-political chronicles', Australian Journal of Politics and History, vol. 6, no. 1 (May), pp. 95-8.

Grimshaw, C. 1960b, 'Queensland-political chronicles', Australian Journal of Politics and History, vol. 6, no. 2 (November), pp. 241-5.

Hamill, D. 1980, 'The Sherwood by-election', in M. B. Cribb and P. J. Boyce (eds), Politics in Queensland: 1977 and beyond, University of Queensland Press, St Lucia.

Harris, S. 1972, Political Football: The Springbok tour of Australia 1971, Goldstar Publishers, Melbourne.

Hazlehurst, C. 1987, Gordon Chalk: A political life, Darling Downs Institute Press, Toowoomba, Qld.

Hielscher, L. 1979, 'A broad outline of Queensland's budgetary system, and the Financial Administration and Audit Act 1977', in R. L. Mathews (ed.), Recent developments in budgeting, Occasional Paper 10, Centre for Research on Federal Financial Relations, The Australian National University, Canberra.

Higgins, J. 1961, 'The Country Party in Queensland, toeing the party line', The Bulletin, 23 September, pp. 15-16. 
Hughes, C. A. 1956 [1957], 'Party and parliament in Queensland', Parliamentary Affairs, vol. X, no. 4, pp. 480-94.

Hughes, C. A. 1969, Images and Issues: The Queensland state elections of 1963 and 1966, [constituency studies by K. W. Knight], Australian National University Press, Canberra.

Hughes, C. A. 1980, The Government of Queensland, University of Queensland Press, St Lucia.

Hughes, C. A. and Graham, B. D. 1974, Voting for the Queensland Legislative Assembly, 1890-1964, Department of Political Science, Research School of Social Sciences, The Australian National University, Canberra.

Hundloe, T. 1985, 'The environment', in A. Patience (ed.), The Bjelke-Petersen Premiership, 1968-1983, Longman Cheshire, Melbourne.

James, P. 1974, In Place of Justice: An analysis of a royal commission, 1963-1964, Shield Press, Deception Bay, Qld.

Johnston, W. R. 1992, The Long Blue Line: A history of the Queensland Police, Boolarong Publications, Brisbane.

Kelly, P. 1976, The Unmaking of Gough, Angus \& Robertson, Sydney.

Koch, T. 2010, Prescription for Change: The Terry White story, University of Queensland Press, St Lucia.

Lack, C. 1962, Three Decades of Queensland Political History, 1929-1960, Government Printer, Brisbane.

Lamont, C. 2005, 'The "Joh years" - lest we forget', Onlineopinion, 30 March 2005, viewed 10 March 2010, <http://www.onlineopinion.com.au/view. asp? article $=3500>$

Lane, D. 1993, Trial and Error, Boolarong Publications, Brisbane.

Lunn, H. 1978, Joh: The life and political adventures of Johannes Bjelke-Petersen, University of Queensland Press, St Lucia.

Lunn, H. 1980, Behind the Banana Curtain, University of Queensland Press, St Lucia.

Lunn, H. 1984, Johannes Bjelke-Petersen: A political biography, University of Queensland Press, St Lucia.

McCulloch, J. 1994, Women Members of the Queensland Parliament 1929-1994, Queensland Parliamentary Library, Brisbane. 
The Ayes Have It: The history of the Queensland Parliament, 1957-1989

MacGregor, B. 1991, The Graduate of Nudgee Orphanage-Fred Newton: The biography of a trade unionist and Labor politician, MacGregor, Rochdale South, Brisbane.

Mackie, P. with Vassilieff, E. 1989, Mount Isa: The story of a dispute, Hudson, Hawthorn, Vic.

Masters, C. 2008, 'Moonlight reflections', Griffith Review, vol. 21, Griffith University, Queensland.

Metcalfe, A. 1984, In Their Own Right: The rise to power of Joh's Nationals, University of Queensland Press, St Lucia.

Miller, I. and Koch, T. 1983, Joh's KO, Boolarong Publications, Brisbane.

Moles, I. 1979, A Majority of One: Tom Aikens and independent politics in Townsville, University of Queensland Press, St Lucia.

Moroney, T. 1983, The Queensland ALP 'Split' of 1957; Information Request Resume, Queensland Parliamentary Library, Brisbane.

Moroney, T. 1998, The rise and fall of the Queensland Parliamentary Service Commission: a study of parliamentary independence vs executive government control, Master of Public Administration Thesis, Department of Government, University of Queensland, St Lucia.

Murphy, D. J. 1971, 'Queensland-political chronicle', Australian Journal of Politics and History, vol. 17, no. 2 (August).

Murphy, D. J. 1980, 'The Labor Party campaign: in search of a purpose', in M. B. Cribb and P. J. Boyce (eds), Politics in Queensland: 1977 and beyond, University of Queensland Press, St Lucia.

Murphy, D. J. (ed.), 1983, The Big Strike: Queensland 1889-1965, University of Queensland Press, St Lucia.

Murphy, D. J., Joyce, R. B. and Hughes, C. A. (eds) 1980, Labor in Power: The Labor Party and governments in Queensland, 1915-57, University of Queensland Press, St Lucia.

Parker, R. 1980, 'Public service neutrality: a moral problem-the Creighton case', in S. Encel, P. Wilenski and B. Schaffer (eds), Decisions in Case Studies in Australian Public Policy, Longman Cheshire, Melbourne.

Patience, A. 1985, The Bjelke-Petersen Premiership, 1968-1983, Longman Cheshire, Melbourne. 
Pike, D. 1967, Paradise of Dissent: South Australia 1829-1857, Melbourne University Press.

Porter, C. 1981, The Gut Feeling, Boolarong Publications, Brisbane.

Prasser, S., Hede, A. and Neylan, M. 1992, Keeping Them Honest: Democratic reform in Queensland, University of Queensland Press, St Lucia.

Prasser, S., Wear, R. and Nethercote, J. (eds) 1990, Corruption and Reform: The Fitzgerald vision, University of Queensland Press, St Lucia.

Pugh, T. P. 1859, Pugh's Moreton Bay Almanac for the Year 1859, Being the Third After Bissextile or Leap Year, Brisbane.

Queensland Treasury 1982, Guide to Public Finance Administration in Queensland, Prepared and issued under the direction of Dr L. R. Edwards, MLA, Deputy Premier, Queensland Treasurer, with text by Leo Hielscher, Under Treasurer and Under Secretary, Government Printer, Brisbane.

Reynolds, P. 1997, Parliamentary procedure, Opening address to the Australasian Study of Parliament Group (Queensland Chapter).

Reynolds, P. 2002, Lock, Stock and Barrel: A political biography of Mike Ahern, University of Queensland Press, St Lucia.

Reynolds, P. 2003, 'Michael John Ahern: the conservative reformer', in D. Murphy, R. Joyce, M. Cribb and R. Wear (eds), The Premiers of Queensland, University of Queensland Press, St Lucia.

Richards, J. 2005, Queensland cabinet minutes (1975): a report for Queensland State Archives, November 2005, School of Arts, Media and Culture, Griffith University, Brisbane.

Smerdon, H. and Bradley, G. 1992, 'The budget process and related issues', in J. R. Nethercote, B. Galligan and C. Walsh (eds), Decision Making in Queensland Government, Federalism Research Centre in association with Queensland Public Sector Management Commission, Canberra.

Stevens, B. and Wanna, J. 1993, The Goss Government: The promise and performance of Labor in Queensland, Macmillan, Melbourne.

Stevenson, B. 1985, George Francis Reuben Nicklin: 'Honest Frank' - the gentleman premier, Masters Thesis, Griffith University, Brisbane.

Stevenson, B. 2003, 'George Francis Reuben Nicklin: "Honest Frank" - the gentleman premier', in D. Murphy, R. Joyce, M. Cribb and R. Wear (eds), The Premiers of Queensland, University of Queensland Press, St Lucia. 
Stevenson, B. 2007, Queensland's Cold War warrior: the turbulent days of Vincent Clair Gair, 1901-1980, PhD Thesis, Griffith University, Queensland.

Strangio, P. 2008, 'The retiring premiers: a new style of leadership transition', in P. t'Hart and J. Uhr (eds), Public Leadership: Perspectives and practices, ANU E Press, Canberra.

Stuart, R. 1985, 'Resources development policy: the case of Queensland's export coal industry', in A. Patience (ed.), The Bjelke-Petersen Premiership, 19681983, Longman Cheshire, Melbourne.

The Commision 1990, Report on Queensland Legislative Assembly Electoral System, Vol 1, The Report, 90/R4, November.

The Commission 1991, Report on Review of Information and Resource Needs of Non-government members of the Queensland Legislative Assembly, 91/R6, December.

Tiffen, R. 1999, Scandals: Media, politics \& corruption in contemporary Australia, UNSW Press, Sydney.

Townsend, I. 1983, Jigsaw: The biography of Johannes Bjelke-Petersen: statesman - not politician, Sneyd \& Morley, Brisbane.

Trollope, A. 1873, Australia and New Zealand, Bernhard Tauchnitz, Leipzig.

Vaughan, G. 1980, 'The 1977 election: maintaining the 1974 realignment', in M. B. Cribb and P. J. Boyce (eds), Politics in Queensland: 1977 and beyond, University of Queensland Press, St Lucia.

Walter, J. 2003, 'Johannes Bjelke-Petersen: "the populist autocrat"', in D. Murphy, R. Joyce, M. Cribb and R. Wear (eds), The Premiers of Queensland, University of Queensland Press, St Lucia.

Walter, J. and Dickie, K. 1985, 'Johannes Bjelke-Petersen: a political profile', in A. Patience (ed.) 1985, The Bjelke-Petersen Premiership, 1968-1983, Longman Cheshire, Melbourne.

Wanna, J. 1995, 'Gateway city? The politics of economic development strategies', in J. Caulfield and J. Wanna (eds), Power and Politics in the City: Brisbane in transition, Macmillan, Melbourne.

Wanna, J. 2000, 'Queensland: consociational factionalism or ignoble cabal?', in J. Warhurst and A. Parkin (eds), The Machine: Labor confronts the future, Allen \& Unwin, Sydney. 
Wanna, J. 2003, 'Wayne Keith Goss: the rise and fall of a meticulous controller', in D. Murphy, R. Joyce, M. Cribb and R. Wear (eds), The Premiers of Queensland, University of Queensland Press, St Lucia.

Wear, R. 2002, Johannes Bjelke-Petersen: The Lord's premier, University of Queensland Press, St Lucia.

Wells, D. 1979, The Deep North, Outback Press, Collingwood, Vic.

Whip, R. and Hughes, C. 1991, Political Crossroads: The 1989 Queensland election, University of Queensland Press, St Lucia.

Whip, R., Western, J. and Gow, D. 1991, 'Election issues', in R. Whip and C. Hughes (eds), Political Crossroads: The 1989 Queensland election, University of Queensland Press, St Lucia.

Whitton, E. 1989, The Hillbilly Dictator: Australia's police state, ABC Enterprises, Crows Nest, NSW.

\section{Primary sources}

Australian Financial Re view

Daily Sun

Inside Canberra

Melbourne Argus

National Times

Northern Miner

Queensland Parliamentary Debates (QPD) 1868-89 [especially 1957-89], Government Printer, Brisbane.

'Queensland political chronicles', Australian Journal of Politics and History $(A J P H)$.

Record of the Legislative Acts 1958-89, Government Printer, Brisbane.

Sunday Mail

Sunday Sun

Sunday Truth

Sydney Morning Herald

Telegraph

The Age 
The Ayes Have It: The history of the Queensland Parliament, 1957-1989

The Australian

The Courier-Mail

The Standard

The Worker

Truth 


\section{Index}

This index covers the text and Appendix 1 . Readers should also consult Appendix 2 for a list of members 1957-89. Names beginning with ' $\mathrm{Mc}^{\prime}$ are interfiled as if spelled 'Mac'. Page locators in italic indicate photographs.

\section{A}

Abel Smith, Sir Henry, 20, 132

Aborigines see Indigenous Australians abortion clinics, 425, 480, 518, 564-5

accommodation, 7, 8, 10-11

Adair, Herbert ('Bunny'), 72, 101, 119, 180, 265

Address-in-Reply debates, 15, 134-6, 198-9, 648-9

Adermann, Neville, 387

Administrator, office of, 41, 42, 48, 128, 291, 570

agricultural industries see primary industries legislation and regulation Ahern, John, 93, 109

Ahern, Michael, 214-15, 294-5, 314, $316,488,582,583-5,630,659$ leadership attained, 584 leadership removed, 629-30 nominates Lingard as Speaker, 625, 666, 668

nominates Powell as Speaker, 590-1, 667

personal style, 398, 592-3

portfolios, 421, 538, 546, 577, 595, 614

as Premier see Ahern government (1987】89)

Ahern government (1987 789 ), 589-628

by-elections, 604-5, 612-14

confidence motion, 592-4

electoral reform proposals, $627-8$

government contracts, $600-1$

Labor attacks on, 597

ministerial expenses misuse, 611-12

ministry, 243-4, 590, 594-8, 614-15, 629-30 priorities and legislative program,

$432,433,463-7,592,598-604$,

$622-5$

response to Fitzgerald Report, 589,

608-10, 621-4

Aikens, Tom, 52, 53-4, 64, 119, 186,

279-80, 331, 394

attack on Chalk, 182, 183

on Brisbane, 338-9

on coalition/opposition, 43

and Egerton allegations, 181-5

on Jordan, 189

on lawyers/judiciary, 80, 148-9

loses seat, 394

opposes supply, 47,48

personal style, 13, 72-3, 80-1, 289, 303, 646-7

on Pizzey, 229

on police inquiry, 102

on Speaker's role, 80,660

Akers, Rob, 367, 405, 515

alcohol-related legislation, 219-21, 451-2

Alcorn, Ivan, 328

Alison, Gil, 322, 484, 543, 547, 623, 631

Allen, Sir William, 403, 635

Amoco (oil company), 153

Ampol (oil company), 153

Anderson, J. R., 169

Anderson, Merv, 93

Andrews, Dormer (Bob) (Justice), 533

Andrews, John, 568

annual leave issue, $32,35-6,49,88,90-1$, 169, 179

Anthony, Doug, 550

appropriation and budget processes, 18

budget and supply debates, 136-9

budget format and presentation, 65

budget growth and expenditure,

$139-42$

budget labels/themes, 142

budgets see under specific governments

departmental estimates, 137-8

standard of scrutiny, 561

Arbitration Court, 90-1

Ardill, Len, 591

Armstrong, Roy, 659

Arnison, Peter, 20 
assembly laws see street marches assent (bills), 18 see also legislative process

Austin, Brian, 542, 545-6, 576, 583-4, $585,599,630$ portfolios, 421, 546, 571, 576, 595, 615

Australian Democrats, 638

Australian Government see

Commonwealth Government

Australian Labor Party 'communist links' accusations, 33, 46, $50-1,67,91,92,106,158,178-9$, $180-1$

continuity in office, 29-30 effect of electoral distributions, 73, 280, 281, 332 see also electoral districts and distribution elections see election campaigns and results

internal conflict, 30, 31-4, 469, 471, 474, 475, 477-9, 484 see also Australian Labor Party split internal discipline, 37, 117, 179, 187-8

in opposition see Australian Labor

Party in opposition

organisational entities, 31-2

police campaigning against, 100

preferences allocation, 415

Queensland Central Executive, 32, 34-40, 50, 169, 187, 188 split see Australian Labor Party split statewide election performance, 280 Trades Hall influence on parliamentary party, 50, 68, 88, $92-3,187-8,326,471,479$

Australian Labor Party (Federal party), expulsion of Groupers, 34-5

Australian Labor Party governments see Gair government (ALP); Goss government (1989); Hawke Labor government (Federal); Whitlam Labor government (Federal)

Australian Labor Party in opposition, 167-202, 238, 373, 469-502 amendments to government legislation, 165

attacks government corruption, 479-87

attitudes and approach, 196-8

becoming electable, 487-92

by-election performance, 386-7, 401, 555-6, 604-5, 612-14, 621

controversies, 181-7

credible opposition, 285, 332

difficulty of adequate scrutiny of government, 426-32, 498, 501

Duggan's performance, 171-3

effectiveness, 194-201

election performance see election campaigns and results

fragmentation and conflict, 167-8, $332,469,471,474,475,477-9,484$

impact of 1983 election, 484-5

leadership, 169-74, 190-3, 362-3, 470-3

opposition-sponsored bills, 165

parliamentary executive/frontbench, 170-1, 193-4, 472-3, 481-4, 489-90, 596

policies and concerns, 195-6, 220-1

resourcing, 63-4, 197-8, 492-5

victory prospects, $473-6$

years in the wilderness, 476-88

Australian Labor Party split, 34-49, 167, 169

ALP $\square$ DLP/QLP relations, 64-70, 277

ALP $\square$ QLP election battles, 50-1, 67, $69,93,116,175,176-9,188$ see also election campaigns and results consequences of, 53, 56, 57

Labor-Country coalition discussions, 41,54

MPs oppose supply, 48 see also Democratic Labor Party; Queensland Labor Party

Australian Workers' Union, 29, 33, 34 conflicts with government, 36-7 Mount Isa Mines dispute, 104-7, 185 relationship with ALP, 70, 471 
B

Bagehot's metaphor, 55

Bailey, Earle, 552, 573

Baldwin, Edgar ('Ted'), 201-2

Barber, Ray, 640

Bauer, Norm, 302

Baxter, Bill, 117, 187-8, 189

Beanland, Denver, 328, 573, 593, 601

Beard, Peter, 573, 596

Beardmore, Eddie, 60, 265-6

Beattie, Peter, 321, 485, 487, 553, 554, 555, 556-7, 575, 585, 640

Beck, Don, 281-2

Bellevue Hotel, 11, 404-5

Bellino family, 480, 581, 613-14

Bennett, Col, 71, 72, 192, 194

on breathalyser legislation, 220-1

dis-endorsement by ALP, 326, 474

on legislation affecting lawyers, 148

NP candidate, 366

personal style, 103-4, 303

on police misconduct, 99-103, 199200

Berghofer, Clive, 573

Berry, David, 73

Bertoni, Angelo, 367, 538, 546

Bethel, J., 119

'Big Jim' see Houghton, James ('Big Jim')

Bill of Rights for Queensland (proposed), 130-1

bills see legislative process

Bingham, Hugh, 250, 319

Bird, Lorraine, 640

Bird, Val, 225, 370, 394, 421, 422, 538, 546, 659

Bischof, Frank, 65, 99, 100-2, 200, 227, 606, 609

Bishop, Bruce, 327, 393, 419

Bjelke-Petersen, Florence, 413, 509-11

Bjelke-Petersen, Joh

attempts to end Fitzgerald Inquiry, 607-8

behaviour in final years, 582-7

business interests, 260-2, 309-12, 352-3

on censorship and pornography, 139 conflicts of interest, 261-2, 307-12,

$352-3,523$

controversies, 258-62

criminal associates, 580

deputy leadership contest, 207-10

dishonesty, 316, 523

dominance over cabinet, 379

eccentric advisers, 397

elections see election campaigns and results

Gair Senate position, 360-2

honorary doctorate, 555

image, 232, 249-51, 266, 267-9, 282,

319-21

insights on, 586-7

'Joh for PM' campaign, 578-9

knighthood, 402

law suits, publicly funded, 499-500

leadership attained, 205, 231, 232, 656

leadership challenged, 312-19, 658

leadership removed, 488, 582-7

legal fees, 499, 585, 591

on the mace and Parliamentary

authority, 21

misleads Parliament, 258-60

on Nicklin, 53, 279

notoriety and success, 373-5

personal style, 249-51, 252, 260-1, $268,282-3,312,401,418,500$,

586-7

on Pizzey, 228, 279

portfolios, 95, 99, 120, 208, 211-12, 229

Premier see Bjelke-Petersen government (1968-87)

relations with Edwards, 413-14

seeks deal with ALP, 585

superannuation, 410, 431-2, 509-10, 519

Treasurer, 549-51, 561

Bjelke-Petersen Foundation, 403, 517-18, 522, 526

Bjelke-Petersen government (1968-87)

attitude to Whitlam government, 349-53, 360-2, 367, 370-3

budgets, 254-5, 301, 347-9, 377, 389-

92, 529-30, 549-51, 561-2 
by-election performance, $257-8$, 279-80, 281-2, 314, 321-2, 385-7, 401-2, 406-8, 555-7 see also election campaigns and results coalition rift, 532-7, 541-2

Commonwealth-State conflict see Commonwealth-State relations conflicts of interest, 307-12, 352-3, 486-7, 508-9, 523, 580 see also corruption and corruption allegations

disintegration, $578-87$

early years, $249-83$

election performance see election campaigns and results emergency measures, 319-21, 562-4 fund-raising, 403-4 see also BjelkePetersen Foundation government advertising, 377 'jobs for the boys', 410 knighthoods awarded, 402-4 lack of openness, 293-300 legislation see Bjelke-Petersen government (1968-87) legislative program

ministries, 237, 240-3, 252-3, 285-6, 335-6, 369-70, 383, 394-5, 420-1, $434,524-6,538-9,546-7,570-1$, $576-7,583-4$

minority government, 503, 538-9

Nationals govern alone, $542-87$

ombudsman appointment, 354-5, 375, 435-6

patronage system, 95, 403-4, 518, 635

plots to eliminate LP, $516-18$

relations between Coalition parties, 313-14

'reluctant government', 363-4

share dealings, 522

unlawful use of funds, 580

Bjelke-Petersen government (1968-87)

legislative program, 253-5, 291, 337-8, 388-92, 398-9, 425-62, 513-16

alcohol and gambling, 451-3

areas addressed, 425-6, 430-1, 432, 466-7

consumer protection, $452-3$ difficulty of adequate scrutiny, 426$32,498,501$ education, $458-60$ electoral laws, 437-40 environment policy, 456-7 financial management in public sector, 436-7

health and social policy, 458-62

Indigenous Australians, 462-3

industrial relations, 453-4

law and order, 440-3

mining and resources, 446-8, 521-2

opposition responses (Address-in-

Reply debates), 292-3, 296

primary industries, 443-6

public administration, 434-7

regional development and tourism, 448-51, 521-4

transport and infrastructure, 454-6 workplace safety, 453-4

Black, Philip, 613

black rod, 22

Blainey, Geoffrey, 578

Blake, J. R. (Jim), 257, 258, 394

Blake, Pat, 555

Boilermakers Case 1956, 155-6

Bolte, Max, 556, 557

Booth, Des, 591, 623, 661, 667

Borbidge, Rob, 419, 503, 504, 558 portfolios, 595, 596, 614, 615, 631

Borbidge government, 59, 327, 640

Bottom, Bob, 567

Bourke, Tony, 111, 387

Bowen, George, 1, 4

Bowls Team, 240

Braddy, Paul, 556, 596, 641

breakaway Liberals see ultra-Liberals breathalyser legislation, 219-21

Bredhauer, Steve, 640

Brisbane

destruction of heritage buildings, 404-5

electoral wards, 144, 338-9

freeway construction/transport planning, 306-7

Southbank redevelopment, 600-1 traffic management, 161-2 
Briskey, Darryl, 640

Bromley, Fred, 193, 194, 263-4, 326,

344-6

Bromley, Herbert, 280

Brosnan, Michael, 48

brothels, 163-4

Brown, Ivan, 386

Brown, John, 614

Brusasco, Ian, 331

Bryce, Quentin, 20

Brych, Milan, 397

budgets see appropriation and budget processes

'Bugger 'em Bill' see Lonergan, William

Bukowski, R. J. 'Joe', 33, 34, 46, 50

Burns, Tom, 281, 326, 331, 471, 494, 549, 556, 596, 625, 639, 641, 667

expulsion from chamber, 344-6, 560

leadership roles, 363, 369, 401-2,

476-7, 485-6, 596

on M. Ahern, 632-3

on parliamentary reform, 341-2

personal invective, 646

on S. Muller, 662

tribute to Warner, 572

Burreket, Tony, 573

Burton, T., 117, 188

business regulation (companies law), 150

Byrne, David, 367, 368

Byrne, Peter, 265

Byrne-Henderson, Betty, 614

Byrnes, T. J., 204

C

Cabinet ministers see ministry

Cahill, Brian, 550-1

Callaghan, Allen, 250, 302, 319, 371, 487, 575, 580, 582, 584, 586

Callaghan, Judith, 580

Callinan, Ian, 594, 635

Calwell, Arthur, 92

Camm, Ronald, 268, 314, 316, 410, 422, 656

deputy leadership contest, 207-10, 231

leadership aspirations, 98-9, 312-13, 314-15 on offshore drilling, 305-6

portfolios, 98, 120, 212, 229, 252, 253,

285, 288, 316, 335, 369, 394

praised by Bjelke-Petersen, 279

and preferential voting system, 83

Campaign Against Resting Politicians/

Campaign Against Rising Prices, 340

campaigns see election campaigns and results

Campbell, Clem, 552, 591, 592, 623, 667

Campbell, Frederick, 120, 212, 230, 253, $286,382,410$

portfolios, 336, 369, 394

Campbell, Sir Walter, 20, 533, 569, 570, 583

candidates see election campaigns and results

'The Cannonball Kid' see Nicholson,

David

Carey, Cecil, 118, 262-3, 281, 302

Casey, Ed, 280, 294, 331, 634

1980 election, 413-14

ALP membership, 326, 394

bribery allegations, 530-1, 558-9

comments on Speakers, 659, 662, 663

dis-endorsement, 326, 474

on 'Grandpa's Parliament', 422-3

leadership roles, 402, 477, 507, 531

on ministers skipping question time, 651

offers to form minority government with LP, 508

on parlous state of parliament, 41112,505

personal style, 402, 417, 480

casinos, 522-3

Catholic influence, 33-4, 51

Catholic $\square$ communist struggle in union movement, 32-3

Cedar Bay raid, 384-5

censorship and pornography, 138

censure motions see want-of-confidence motions

Chairman of Committees, office of, 21, 145 see also Deputy Speaker, office of Chalk, Gordon, 402

1960 election, 71 
The Ayes Have It: The history of the Queensland Parliament, 1957-1989

1966 election, 114,116

1969 election, 267, 274-6, 381-2

1972 election, 327-31

1974 election, 366-7

and appointment of Field to Senate,

372

attacked by Aikens, 182

attitude to Bjelke-Petersen, 251-2, 382

budget labels/themes, 142, 254-5, 301, 323-4, 347-9

Chiropractors' Bill, 164

controversy in his own electorate,

275-6

on Dewar's behaviour, 121-2, 226

and Egerton allegations, 184

on electoral redistribution, 217

Labor-Country coalition discussions, 41

leadership roles, 97-8, 111, 114, 123, 381-2

and Liberal branches in rural areas, 110-11

loyalty to coalition, 76, 110-11, 213-

$16,230,312,318$

ministry, 229-30

in no-confidence motion debates, 64 , 186

personal style, 74, 230, 381

on Pizzey, 227, 228

portfolios, 58, 95, 96, 119, 120, 212, 229, 252, 285, 335, 369

as Premier, 204-5, 229-32

as Premier (speculation), 313, 366-7

private sector job offer, 223

relations with Duggan, 174, 183, 191

retirement, 381-2

on transport/development matters, $82-3,154$

Chapman, Yvonne, 551, 567, 595, 630

portfolios, 571, 577, 631

Chief Justice, office of, 19, 21

appointments, 532-3, 570

salary, 146

Chief Secretary (title), 95

Chinchen, Geoffrey, 94, 113, 164, 307, 342

Chiropractors' Bill, 164
Ciadamidaro, I., 614

Citizen's Electoral Council, 604-5

Clark, Jim, 171

Clark, Lesley, 640

Clauson, Paul, 556, 557, 576, 582, 629, 630

portfolios, 577, 596, 614, 615, 631

Clerk Assistant, 25, 291 see also Deputy

Clerk, office of

Clerk of the Legislative Assembly, 12

Clerk of the Legislative Council, 22

Clerk of the Parliament, 12, 13, 24-5, 266, 291

Cloudland Dancehall, 405

Coalition governments, 331-2, 412-19 agreement on seat entitlements, 83-4, $108-9,110,144,322,392-3$

elections see election campaigns and results

majorities, 285

method of choosing ministry, 78-9, 419-20

party representation in ministry, 288 and preferential voting system, 70, 83-4, 87, 94, 144, 176

relations between Coalition parties, 57, 69-70, 75-84, 107-14, 123, 144, $212-16,274-7,288,313-14,335$, $392-3,412-19,532-7,541-2$

rift in Bjelke-Petersen government, 532-7, 541-2

statewide election performance, 119

see also Country Party; Liberal Party;

National Party; see also specific

governments: Ahern government (1987 [89); Bjelke-Petersen government (1968-87); Cooper government (1989); Fraser Coalition government (Federal); Nicklin government (1957-68); Pizzey government (1968);

'coalition in opposition' concept, 42-4, 48

Coburn, Arthur, 46, 53, 72, 119, 225, 265, 292

Collins, Harry, 30

Colonial Treasurer's Department, 6 
Colston, Mal, 370-1

Comalco share trading, 308-9, 317

Comben, Pat, 483, 552, 596, 641

Comerford, John, 408

commissioners, 12, 13

Committee of Supply, 136, 137

Committee of the Whole, 17, 18, 21, 22, 136

Committee of Ways and Means, 136, 137

committees, Parliamentary see

Parliamentary committees

Commonwealth Games, Brisbane, 526-7

Commonwealth Government, 570

assistance to Queensland, 140, 224,

273, 293, 323-4, 348-9, 550, 562

as scapegoat, 137-8, 301

Commonwealth-State relations

conflict, 273, 301, 349-53, 373, 377, $397-8,521,562$

on constitutional matters, 570

communism, 37

accusations of ALP/union links with, $33,46,50-1,66,67,91,92,106$,

158, 178-9, 180-1

Catholic $\square$ communist struggle, 32-3

community welfare see health and welfare policy and services; social and recreational measures

companies law, 150

confidence, want of see want-ofconfidence motions

conflicts of interest

Bjelke-Petersen government, 261-2, 307-12, 352-3, 486-7, 508-9, 523

Hinze, 523, 565-7

see also corruption and corruption

allegations; probity

Connor, Ray, 640

conservation see environment and conservation

Constitution (Declaration of Rights) Bill 1959, 130-1

Constitution Act Amendment Act 1977, 19

Constitution of Queensland Act 2001, 12

constitutional monarchy, 19, 173-4, 554 see also Elizabeth II (Queen)

consumer protection, 452-3
Conte, Vittorio, 581

continuity in government, 29-30, 53, 54

Coomber, Trevor, 640

Cooper, Frank, 31, 207

Cooper, Russell, 552, 629-31

1989 election, 636-8

attains leadership, 629-30 see also

Cooper government (1989)

personal style, 629

portfolios, 596, 599-600, 614, 615,

629,631

Cooper government (1989), 628-36

confidence motion, 632-3

legislative program, 465-7, 631-5

ministerial expenses misuse, 634-5

ministry, 245, 630-1, 633

Copeman, Charles, 578

corruption and corruption allegations,

29, 199, 479-87

against B-P government members/ associates, 479-80, 486-7, 519-20, 565-7

against Casey, 530

Egerton allegations against Nicklin government, 181-5

against Gair government members, 36

issues faced by Ahern government, 597

issues in 1989 election, 636-7

against Mann, 654

against police see police misconduct/ corruption

road transport industry, 161

SP betting, 163

see also conflicts of interest; Fitzgerald

Inquiry; parliamentary privilege;

pork-barrelling; probity

Cory, David, 94

Country Party

agreement on seat entitlements, 83-4, $108-9,110,213$

deputy leader contest (1968), 207-10, 231

effect of electoral distributions, 71-2, 73

election performance, 119 see also election campaigns and results 
leadership, 232 see also BjelkePetersen, Joh; Nicklin, Frank; Pizzey, Jack

opposes supply, 48

Party influence on Coalition government, 176

preferences allocation, 114, 277

re-branded as National Party, 359-60

see also National Party

statewide vote, 119

and union with Liberal Party

(proposed), 70

and voting system, 70, 83-4, 176,

276-7

see also Coalition governments;

National Party

Country-Labor coalition discussions see

Labor-Country coalition discussions

Country $\square$ Liberal Coalition governments see Coalition governments; and specific governments: Ahern government (1987 89); Bjelke-Petersen government (196887); Cooper government (1989); Pizzey government (1968); Nicklin government (1957-68)

Covacevich, Thomas, 568

Cowley, A. S., 664

Crawford, Arthur, 113, 122, 226, 280

creation theory, teaching of, 666-7

Creighton, Vivian R., 36

criminal justice, 582, 616-17, 633, 636 see also Fitzgerald Inquiry

Crooke, Gary, 615

Crooke, Ken, 582

Culell, F., 277

cultural measures see social and recreational measures

Cunningham, Liz, 394

Curtis, Colin, 151, 152

\section{D}

dams see transport and infrastructure

D'Arcy, Bill, 281-2, 331, 402, 489-90, $497,513,645,647$

Dart, William, 292

Dau, B., 322

Davidson, Ken, 273
Davies, Horace, 61, 170, 171, 193-4, 321, 472

Davies, Ken, 640

Davis, Brian, 344-5, 547, 549, 636, 647

Davis, Glyn, 610

Dawson, Barbara, 614

daylight saving, 324, 604, 624-5, 630

De Lacy, Keith, 483, 550, 596, 599, 624, 641

Dean, Harold, 138-9, 194, 219, 660

death duties, 291, 378-9, 382, 530, 552, 663

death penalty, 663

Deeral, Eric, 367, 380-1

Delamothe, Peter, 93, 97, 323, 325

attacks on, 111

portfolios, 95, 96, 120, 212, 229, 252, 285

Democratic Labor Party, 33, 35, 40,

321-2, 379

affiliation with QLP, 72, 93

election performance, 118-19, 266, 267, 272, 277, 279-80, 327, 368 see also election campaigns and results proposed merger with Country Party, 359

see also Gair, Vince

departmental estimates, $137-8$ see also appropriation and budget processes

Deputy Clerk Assistant, office of, 25

Deputy Clerk, office of, 24-5

Deputy Leader of the Opposition, office of, remuneration, 145

Deputy Premier, office of in Coalition government, 77, 97, 98 combines party leader and Treasurer roles, 97, 98, 382-3

remuneration, 145-6

Deputy Speaker, office of, 21

Devereux, Jack, 34

Devries, George, 31, 53, 169

Dewar, Alexander, 62, 138

leadership aspirations/roles, 97, 111, 122

loses seat, 280

personal scandal, 98, 120-2

on Pizzey, 229 
on police matters, 101

portfolios, 77, 92, 95, 98, 120

preferences (1969 election), 277

resignations from Ministry and LP,

120-2, 225-7, 263-4

Dickie, Phil, 581

Diplock, Les, 31, 59, 61, 107, 116, 118,

180, 188, 229, 279, 325

Dittmer, Felix, 36-7, 43, 48, 52, 235

Dollin, Bob, 640

domestic travel see travel entitlements

Donald, James (Jim), 48, 61, 64, 229, 265

leadership roles, 170, 174

offices held, 170-1

Douglas, Mr Justice Jim, 532-3

Doumany, Sam, 421, 532-3, 647

dress code, 6, 344, 497

drink-driving legislation, 219-21, 451-2

Drummond, Doug, 635, 638

Dufficy, John (Joe), 48, 169, 171, 186, 192, 265

Duggan, Jack, 35, 48, 77-8, 148, 160-1, 162, 186-7, 235

1957 election, 50-1, 52, 53, 56, 169

1960 election campaign, 68, 71, 176,

177,179

1963 election campaign, 89-90, 179

1966 election campaign, 116-17

on A. Muller, 81-2

on communists, 179

on constitutional monarchy, 173-4

contests by-elections, 169, 170

defends Egerton/attacks Walsh and

Aikens, 183-5

Deputy Premier, 30, 33

on electoral system, 144

on industrial legislation, 158, 159, 185-6

leadership roles, 20, 42, 43-5, 50-1, 169-74, 180, 189, 190-2, 476

loses seat (1957), 52, 53, 169

and Mount Isa dispute, 105-6, 185-6

personal style, 33, 171-3, 190

on police misconduct, 101

and preferential voting system, 70

relations with Chalk, 174, 183, 191

relations with Gair, 37-8, 40, 66 relations with Lloyd, 179, 189

relations with Walsh, 167

remains with ALP during Labor split, $34,38,40$

resignation as leader, 191-2

returns to Assembly, 65

supply debates, 44-5, 47

tax irregularities, 170, 191

see also Australian Labor Party in opposition

Dunlop, Roy, 266, 291

Dutton, Peter, 639

E

Eaton, Andrew (Bill), 624, 641

economic development see industrial development; state development

Edmond, Wendy, 640

education and educational institutions

ALP policy, 196

Bjelke-Petersen government position, 253-4

expenditure on, 140, 142

policy and legislation, 116, 126, 134,

$162-3,458-60$

Powell's views when Minister, 666-7

programs banned, 398

question time topics, 59-60

student enrolments, 163

universities, 36, 37, 410, 634

Edwards, J. B., 328

Edwards, Llew, 331, 382, 402, 646, 647, 662

1980 election, 416

budgets, 529-30

and Expo 88, 551-2

leadership roles, 408-9, 482, 503

on Milan Brych's therapy, 396-7

personal style, 417-18

portfolios, 370, 394, 421

relations with Bjelke-Petersen, 41314,416

on S. Muller, 661

Edwards, Percy, 328

Egerton, Jack, 34, 181-5, 303, 415, 556, 567,653

Elder, Jim, 489, 640 


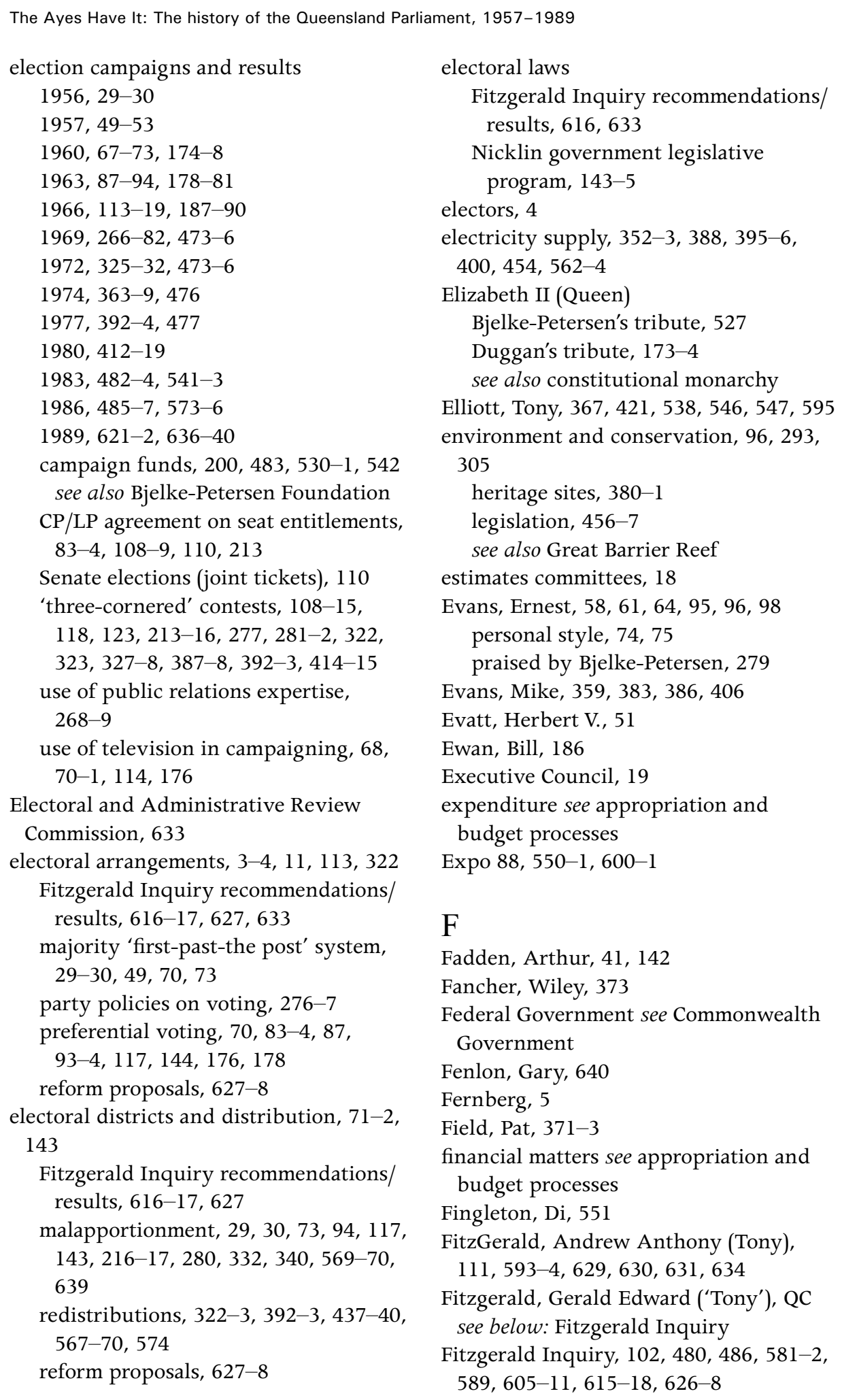

electoral laws

Fitzgerald Inquiry recommendations/ results, 616, 633

Nicklin government legislative program, 143-5

electors, 4

electricity supply, 352-3, 388, 395-6, $400,454,562-4$

Elizabeth II (Queen)

Bjelke-Petersen's tribute, 527

Duggan's tribute, 173-4

see also constitutional monarchy

Elliott, Tony, 367, 421, 538, 546, 547, 595

environment and conservation, 96, 293, 305

heritage sites, $380-1$

legislation, 456-7

see also Great Barrier Reef

estimates committees, 18

Evans, Ernest, 58, 61, 64, 95, 96, 98

personal style, 74, 75

praised by Bjelke-Petersen, 279

Evans, Mike, 359, 383, 386, 406

Evatt, Herbert V., 51

Ewan, Bill, 186

Executive Council, 19

expenditure see appropriation and budget processes

Expo 88, 550-1, 600-1

\section{F}

Fadden, Arthur, 41, 142

Fancher, Wiley, 373

Federal Government see Commonwealth Government

Fenlon, Gary, 640

Fernberg, 5

Field, Pat, 371-3

financial matters see appropriation and budget processes

Fingleton, Di, 551

FitzGerald, Andrew Anthony (Tony), $111,593-4,629,630,631,634$

Fitzgerald, Gerald Edward ('Tony'), QC see below: Fitzgerald Inquiry

Fitzgerald Inquiry, 102, 480, 486, 581-2, $589,605-11,615-18,626-8$ 
charges/legislation resulting from,

464-5, 633, 636-7

cost of, 608-9

election promises following Inquiry, 637-8

on electoral processes, 569

police issues and response, 605-7

report and recommendations, 616-18

report debated in Parliament, 626, 667

team members, 615-16

Flanagan, Peter, 321

Fletcher, Alan, 67, 314, 316, 402, 655-6

CP deputy leadership contest, 207-9

in ministry, $73,95,110,120,211,212$, $229,252,285,336$

as Speaker, 60-1, 79, 655-6

on three-cornered polls, 277

Flynn, John, 640

Foley, Matt, 640

Foley, Tom, 30, 31, 36

Forde, Frank, 48, 658

Forde, Leneen, 20

foreign ownership of resources, 511, 529, 593

Former Members' Association, 3

Forster, Peter, 616

Fouras, Jim, 471, 640

Fraser, Huan, 573, 623, 630, 631

Fraser, Malcolm, 550

Fraser Coalition government (Federal),

377, 383, 457

Fraser Island, 457

Frawley, Des, 526, 647

G

Gair, Vince, 33, 39, 48, 65, 233

1960 election, $71,176-8$

1969 election, 277

background, 207

on communism, 50, 66, 67

expulsion from ALP, 37-9

forms/leads QLP, 39-40, 61

and Labor split see Australian Labor

Party split

loses seat, 71, 72

political appointments, 291

and political autonomy, 35-6 as Premier see Gair government (ALP);

Gair government (QLP)

relations with Duggan, 37-8, 40,

45-6, 66

as Senator, $360-2$

supply debates, $44-8$

union membership, 33

and want-of-confidence motions, 64-5 see also Australian Labor Party split;

Queensland Labor Party

Gair government (ALP, to April 1957),

$32-9,169$

Gair government (QLP, April to

June1957), 39-49

disputes with ALP, 45-9

fall of, 48-9, 234

minority government, $40-1$

supply debates, $44-9$

see also Queensland Labor Party

gambling, 296, 411, 650

casinos, 522-3

legislation, 452

poker machines, 530-1, 637

Gamin, Judy, 613

Gardner, Harry, 48, 61

Garms, Ann, 601

Gately, Leo, 573

Gaven, Eric, 80, 657

George, Cyril, 291

Georges, George, 260

gerrymanders see 'malapportionment'

under electoral districts and

distribution

Gibbs, Bob, 471, 486, 497, 560, 596, 641

Gibbs, Mr Justice Harry, 101, 620 see also Gibbs Inquiry into National Hotel destruction

Gibbs, Ivan, 367, 563-4, 585

portfolios, 421, 538, 546, 576, 595, $614,615,631$

Gibbs Inquiry into National Hotel destruction, 100-2, 149, 199-200

Gilmore, Thomas John (Tom) (NP), 573, 630

Gilmore, Thomas Vernon (Tom) (CP), 60, 180 
'ginger group', 97, 112-13, 123, 214, 215, $222,225,322-3,325,418,419$

Glasson, Bill, 367, 525, 630, 636 portfolios, 421, 538, 546, 570-1, 577, 595,615

Goleby, John, 367, 525, 538, 546, 556, 565

Gore, Mike, 578, 580

Gorton, John, 301, 304

Goss, John, 640

Goss, Wayne, 471, 486, 552, 553, 625, 638,640

1989 election, 638, 639

on Bjelke-Petersen legal fees, 591

on Cooper government, 632, 633, 635-6

on Hinze's conflicts of interest, 566

nominates Powell as Speaker, 625, $665,667-8$

opposition leader, 471, 487, 489-91, 596

personal style, 548

Premier, 491-2, 640-1

shadow ministry, 489-90, 596

Goss government (1989), 491-2, 640-1

government advertising, 377

government funds, misuse of, 660-1

Government House, 5

Government ministers see ministry

Governor, office of, 125-7

appointments, 570

opening speeches, 14, 128-34, 172 see also Address-in-Reply debates points of controversy, 20-1

powers codified, 19

remuneration, 146

role of Governor, 11-12, 18-21

see also Administrator, office of

Gow, D., 180

Graham, Fred, 63, 171, 265

Great Barrier Reef, 293, 297, 304-6, 430, 456, 521

Greater Australia Moderate Party, 328

'Green Mafia', 65

Greens party, 638-9

Greenwood, John, 367, 372, 383, 394

Groupers, 33, 34-5
Gunn, William Angus (Bill) (CP/NP), 331, 484, 583, 585

on Bjelke-Petersen and Fitzgerald Inquiry, 607-8

leadership roles, 584, 590, 630

on police corruption, 567, 581, 607

portfolios, 421, 525, 538, 546, 570,

$576,595,614,615,631$

Gygar, Terry, 367, 404-5, 555

$\mathrm{H}$

Hales, Albert, 367

Hall, Albert, 93

Hamill, David, 471, 483, 552, 554, 555, $568,596,641$

Hancock, Lang, 578

Hanlon (Ned) government, 146, 159, 169

Hanlon, Ned, 29, 31, 134, 204, 207

Hanlon, Pat, 48, 59, 64, 106, 165, 171,

190, 193-4

on changing nature of parliament, 303-4 on communism/ALP links, 180-1 leadership contender, 191, 192

Hannah, Sir Colin, 20, 351, 361

Hansard, 9-10, 25

Hansen, Brendan, 484, 507, 543

Hanson, Martin, 194, 302, 385

Hapeta, Hector, 581

Harley, E., 118

Harper, Neville, 538, 546, 577, 595, 615, 631

Harris, Ted, 371

Hartwig, Arthur, 113, 213-14

Hartwig, Lindsay, 331, 365, 403-4, 5067, 516-18, 525, 543, 613, 647

Harvey, Leisha, 551, 598

misuse of funds and entitlements, 611-12

portfolios, 595, 596

Harvey, Roy, 332

hauliers see road transport industry

Hawke Labor government (Federal), 536, 539, 551, 562, 578, 579

Hay, Andrew, 578

Hayden, Bill, 402, 412, 471

Hayward, Ken, 471, 574, 623 
Heading, James, 58, 73, 291-2

health and welfare policy and services,

133, 196, 355

alcohol and drink-driving legislation, 219-21

Chiropractors' Bill, 164

expenditure on, 142, 273

legislation, 460-1

medical matters, 302, 396-7

see also social and recreational measures

Heath, Phil, 640

Heatley, William (Bill), 77, 281-2, 314, 325

Helsham, Michael, 620

Henderson, Ian, 552, 593, 630, 631, 634, 637

Herbert, Jack (Lewis's bagman), 606, 618

Herbert, John, 6, 186, 401

and allegations against Dewar, 121-2

Chiropractors' Bill, 164

on police matters, 100-1

portfolios, 98, 120, 212, 229, 252, 286, 336, 369, 394

Herbert, Robert, 1

heritage sites and buildings, 380-1, 404-5

Herscu, George, 610-11

Hewitt, Neville, 211, 286, 410, 422 portfolios, 336, 370, 394

Hewitt, W. D. (Bill), 97, 113, 164, 228,

301, 344-5, 405, 422-3, 647

calls for parliamentary reform, 325, 343

Chairman of Committees, 411

portfolios, 288, 421

proxy support for Bjelke-Petersen,

316,317

Hickey, Justin, 403

Hielscher, Leo, 561

Hiley, Tom, 48, 52, 58, 64, 65, 76, 95, 96, 186,402

budget, 142

disagreement with Menzies, 138

leadership roles, 78, 97, 105

and Mount Isa dispute, 107

personal style, $74-5,645$
Hilton, Paul, 30, 48, 72, 89, 157, 158,

160-1, 180

Hinton, Denis, 573

Hinze, Russ, 118, 382, 422

1972 election, 327

1980 election, 415

attitude to Liberals, 118, 210, 277

and challenge to Bjelke-Petersen's

leadership, 314, 315

Chiropractors' Bill, 164

conflicts of interest, 523, 565-7

exchanges preferences with ALP, 277

and Fitzgerald Inquiry, 594-5, 610-11

on Mann, 655

personal style, 118, 297-8, 340-1

portfolios, 366, 370, 394, 421, 508-9, $538,546,565,576$

on reforms, 591

suspended from chamber, 358

Hobbs, Howard, 573

Hodges, Max, 60, 210, 253, 286, 316,

355-6, 383, 406, 422, 609

portfolios, 336, 370, 394, 395

Hoffnung Building, 405

Hollis, Ray, 640

Holm, Sir Charles, 403, 635

Holt, Harold, 111-12, 204

homosexuality, 300, 637

honours and awards see imperial honours

Hooper, Keith, 60, 335, 369, 383, 393

portfolios, 335, 336, 370

Hooper, Kevin, 331, 369, 400, 471, 479-

$80,515,526,553-4,609$

Hooper, Max, 367, 368, 369, 395, 419

Houghton, James ('Big Jim'), 22, 72, 118 , $303,327,660-1$

and challenge to Bjelke-Petersen's

leadership, 314, 315, 316-17

nominated as Speaker, 336-7, 659

party affiliations, 75-6

as Speaker, 72, 395, 406, 572, 660-1

house committees, 23-4

House Leader see Leader of the House,

office of

Houston, Jack, 60, 198-9, 238

1969 election, 271-2, 278, 281 
deputy leader of ALP, 171, 189-90, $191,386,402$

on electoral redistribution, $216-17$

leader of opposition, 192-4, 281, 362$3,470,472,474,475$

on Mann, 654

in no-confidence motion debate, 186

on parliamentary procedure, 166, 198-9

personal style, 192-3

on Pizzey, 227, 229

retirement, 410

shadow ministries, 193-4

Howard, John, 578, 579, 586

Hughes, Clive, 113, 138

Hughes, Colin, 568-9

Hulme, A. S., 83

Hungerford, Harold, 325

Hynd, Thomas, 573, 574

\section{I}

ideology, 37

imperial honours, 65, 73, 353, 402-4

Inch, Alex, 106, 157-8, 186

independent members of parliament, 52-3, 72-3, 93, 108, 118-19, 180, 194, $280,331,394,543,660$

Indigenous Australians

citizenship, 90

heritage sites, $380-1,527-8$

lands and land tenure, 397-8, 527-8

members of parliament, 327, 367, 380-1

policies and legislation for, 133, 162,

$163,189,380-1,462-3,569$

voting rights, 2,189

industrial development, 90-2, 150-4

priority, 58-9, 96, 120, 150-1

state support for private firms, 152-4

see also state development

industrial disputes, 158-9, 529

legislation, 400, 454

Mount Isa Mines, 104-7, 181, 185-7

Moura coalfield, 88

South-East Queensland Electricity Board, 562-5

Springboks' rugby union tour, 320-1
Industrial Groupers, 33, 34-5

industrial relations legislation, 104, 1067, 154-9, 185-6, 453-4, 563 see also trade unions

infrastructure see electricity supply; roads and road construction; transport and infrastructure

Innes, Angus, 401, 405, 503, 545, 593, $596,633,637-8$

international travel see travel entitlements investment projects see industrial development; state development Iwasaki resort project legislation, 395, $428,450,624$

\section{J}

Jennings, Doug, 419, 519, 579

Jensen, Eugene (Lou), 394, 647

Jesson, Cecil, 48, 61, 170, 171

John Petrie (building firm), 7

Johnson, Vaughan, 640

Johnson, William, 291, 299

'Joh's little mate' see Lingard, Kevin

Jones, Arthur, 30

Jones, Clem, 326, 331

Jones, Norman (Gerry), 328, 332, 344-6

Jones, Ray, 194, 255-7

Jones, Vince, 210, 228, 314, 325

Jordan, Violet, 188-9, 263, 302, 337, 369

judiciary, misconduct allegations, 618-21

Jurss, E. R., 322

K

Katter, Bob, 367, 484, 546, 629, 630, 663 portfolios, 547, 571, 577, 596, 615, 631

Kaus, Bill, 117, 164, 188, 545, 547

Kehoe, Greg, 104

Kennedy, Jim, 631

Kev Hooper, 661

Killen, James, 567

King, Bob, 640

Kippin, Victoria, 367, 369

knighthoods see imperial honours

Knox, William (Bill), 60, 83, 186, 402, $504,545,611$ 
and breathalyser legislation, 220-1

budgets, 389-92

on electoral redistribution, 568

on government expenditure, 141

leadership roles, 382-3, 387-8, 408,

547, 549, 593

portfolios, 98, 120, 212, 229, 252, 286,

$335,369,394,421$

Kruger, Raymond (Joe), 394, 647

Kyburz, Rosemary, 367, 369, 404-5, 506, 516

\section{L}

Labor Party see Australian Labor Party;

Queensland Labor Party

Labor-Country coalition discussions, 41, 54

Labour and Industry portfolio, importance of, 58-9, 61

labourism, 32

Lack, Clem, 39

Lamond, Bill, 367

Lamont, Colin, 367

land policy and issues, 89, 152, 464 Indigenous Australians land tenure, 527-8 scandals, 77, 81-2, 558

Lands Administration Commission, 36

Landsborough by-election (1968), 214-16

Lane, Don, 343, 405, 545-6, 574, 584, 654,667

defects to NP, 542-3

enters Parliament, 321

expulsion from chamber, 344, 346

and Fitzgerald Inquiry, 594-5, 611

portfolios, 421, 546, 577

redistribution exercises, $567-8$

on Warner, 663

Lang, John, 604-5

Lavarack, Sir John, 61, 129

law and order legislation, 440-3, 465 see also police

law suits, publicly funded, 499-500

Lawrie, A. G., 83

lawyers

engaged by government, 295- 6 judiciary misconduct allegations,

618-21

legislation affecting, 147-9

Leader of the House, office of, 22-3, 24

Leader of the Opposition, office of, 14,

$15,17,492$

administrative support and resources,

63-4, 492-5

remuneration, 145-6

Leard, John, 578

Lee, Norman, 98, 326, 370, 394, 504, 545, 611,636

Lee, Robert, 580

Leese, Ken, 327

legislation availability for public scrutiny, 429-30

Legislative Assembly, 4, 9-10, 238 see also parliamentary debates

Legislative Council, 4, 10, 22

legislative process, $16-18$

legislative programs see under specific governments

Lester, R. J., 257

Lester, Vince, 367, 484, 630, 634-5 nepotistic appointments, 599 portfolios, 538, 546, 577, 595, 615, 631

Lewis, Terry, 356, 385, 480, 532, 567, $595,605-7,617,619,620$

Liberal Party, 212, 224, 382, 408-9 agreement on seat entitlements, 83-4, 108-9, 110, 213

breaks convention on filling Senate vacancies, 370-3

by-election performance, 281, 314, 322, 386-7, 401, 406 see also election campaigns and results

coalition rift, 532-7, 541-2

contesting seats against $\mathrm{CP} / \mathrm{NP}, 213$ $16,387-8,392,412-15$

defections to NP, 545-6

divisions within party, 97-8, 108-13, $123,213-16,225-7,263-4,541$

effect of ALP preference tactics (1980), 419 
effect of electoral distributions, 73 see also electoral districts and distribution

election performance (summary), 119 see also election campaigns and results

fewer places in Coalition ministry (1980), 419-20

'ginger group', 97, 112-13, 123, 214, $215,222,225,322-3,325,418,419$

impact of 1983 election, 483

influence of 'outside' interests, 76

leader/Deputy Premier/Treasurer roles combined, 97, 98, 382-3

offers merger to Country Party, 359

opposes supply, 48

party status not recognised, 548

political ambitions within Coalition government, 77, 83-4, 97, 107-13, $114,123,216,230-1,274,331,366-$ $7,415,637-8$

preferences allocation, 114

and preferential voting system, 70 , 83-4, 93, 117, 176

proposed union with Country Party, 70

QLP preferences, 93

shadow cabinet see shadow ministry stances against Bjelke-Petersen, 532-3

'three-cornered' contests see under electoral districts and distribution ultra-Liberals, 97, 108, 109, 110, 111, $112,213,214,314,387-8$

Young Liberals, 109-10, 112 see also Coalition governments

Lickiss, William (Bill), 94, 113, 164, 215, $337,383,504,545,549,574,591,592$,

$636,640,665,667$

portfolios, 370, 394

Lindsay, Brian, 367

Lingard, Kevin, 552, 664-6

in ministry, 584, 590, 595

as Speaker, 577, 625-6, 664-6, 668

Littleproud, Brian, 552, 595, 596, 615, 631

Livingstone, Don, 640

Livingstone, Keith, 113
Lloyd, Eric, 48, 61, 64, 100, 106, 152, 158, 186, 191, 192 leadership roles, 170-1, 189-90 and 'party line', 179 relations with Duggan, 179, 189

local government elections, 144-5 issues, 144, 338-9 traffic management role, 161-2 see also Brisbane

Lockwood, John, 367

Logan, Doug, 403

Lonergan, William ('Bugger 'em Bill'), 60, 303, 658-9 and challenge to Bjelke-Petersen's leadership, 314, 315, 316-17 as Speaker, 299, 337, 357-9, 572, 658-9

Longman, Irene, 189

Louat, Frank, 130

Lowes, Harold, 367

Lowy, Frank, 512

Loyal Opposition see parliamentary opposition

Lunn, Hugh, on political culture, 422

Lush, George, 620

Luton, Frank, 403, 565

Lyons, Ted, 403, 512-13, 532, 565-6, 578, $582,585,619,626,635$

$\mathrm{M}$

McCathie, Colin, 31

McCauley, Diane, 573, 574

mace (symbol of authority), 21, 400

McElligott, Ken, 552, 633, 641

McEwen, Jack, 111, 255, 257

McGovern, L. J., 268, 269

McGrady, Tony, 640

McKechnie, Henry, 94, 135, 180, 210, 315, 335, 336

McKechnie, Peter, 484, 515, 583-4, 585, 630, 636 portfolios, 546, 577, 595, 614, 615

Mackenroth, Terry, 471, 514, 564, 565, 596, 635, 641, 647

Mackie, Pat, 105, 106

McLachlan, Ian, 578 
McLean, Ian, 575

McLean, Ron, 547, 596

McMahon, William, 293

McPhie, Alexander (Sandy), 542, 558

Madsen, Otto, 58, 74, 78, 94, 150

Male, Alan, 327

Mann, John, 42, 44, 46, 63-4, 171, 186, $188,235,653-5$

and 'party line', 179

as Speaker, 171, 653-5

tributes on retirement, 265

Mansfield, Sir Alan, 20, 41, 65, 129, 253

margarine, 523-4

Marginson, Evan, 472, 660

Martin, J. P., 71

Masters, Chris, 581

Maunsell, Ron, 361

Maybury, Fred, 635

Melbidir (government-owned ketch), 525

Mellifont, Brian, 321

Melloy, Jack, 151, 190, 193-4, 258-9

on Bjelke-Petersen, 250-1

leadership roles, 369, 386

Members, 645-7, 669-701

accommodation for, 8

defeated see election campaigns and results

died in office, $78,94,98,282,325$, 553-5, 645-6, 703-4

female, 188-9, 245, 369, 551, 571, 613

independents see independent members of parliament

Indigenous Australians, 327, 367

list: electorate, dates, offices attained, 669-701

long-serving, 123, 504, 547, 583, 653

new see election campaigns and results

number of, 4, 7, 9, 285, 326

oath of allegiance/affirmation, 12

probity, 61, 399-400, 508-9, 596, 612

see also conflicts of interest

quorum, 16, 23, 100

remuneration, 145-6, 526, 599

superannuation, 410

support services for, 218-19, 354, 374

suspended, 496-8, 560, 705-9 travel entitlements/claims, 399-400,

$532,660-1$

twins elected as members, 280

Menzel, Max, 608, 611

Menzies, Robert, 36, 138

Metcalf, Les, 112, 276

metric system, 346-7

Miller, Col, 164, 372, 545, 547, 663

Milliner, B. R., 117

Milliner, Bert, 370

Milliner, Glen, 596, 641

mines and mining, 154, 196, 351-2,

521-2

foreign ownership, 272-3, 511

leases, 511-13

legislation, 446-8

strikes see industrial disputes

see also industrial development

ministerial expenses, misuse of, 611-12,

634-5

ministry, 19, 23

female ministers, 571

'minister' (title), replaces 'secretary', 61

ministerial accountability, 307-12

probity rules, 61, 508-9, 596, 612

remuneration, 145-6, 223, 599

size of, 95, 146-7, 223, 286, 369, 434

two-man ministry, 590

see also 'ministry' under specific governments

Minnegal, M., 322

minority governments, 40-1, 503, 538-9

monarchy see constitutional monarchy

money bills see appropriation and budget processes

Moore, Bob, 515-16, 543, 545

Moore, Francis (Peter), 358

Moore, Sir Frank, 403

Moore, W. (Bill), 30, 48

Moores, Tom, 40

Moreton Bay Debt, 1

Morley, Peter, 524-5

Morris, Ken, 31, 43, 48, 58, 64, 67, 402

1957 election promises, 52

1960 election campaign, 68, 71

departure from state politics, $75-8$ 
The Ayes Have It: The history of the Queensland Parliament, 1957-1989

on Duggan, 68

in federal politics, 77

and industrial legislation, 104, 155-7

land scandal, 77

and oil refinery negotiations, $153-4$

personal style, 74, 75

on police administration, 149

relations with Nicklin, 75

Motor Spirits Distribution Bill, 36, 37, 46,48

Mount Isa Mines industrial dispute, 104-7, 181, 185-7

Moura coalfield industrial dispute, 88

the Movement (Catholic political group), 33

Muir, Sir David, 151-2

Muller, Adolf (Alf), 58, 73-4, 210, 304, 656, 661

crosses floor, 211

expelled from Ministry, 81-2

as independent member/candidate, 82,93

rejoins Country Party, 93, 108

tributes on retirement, 265

Muller, Selwyn, 22, 280, 661-2 as Speaker, 407, 504-8, 572, 661-2

Munro, Alan, 43, 58, 60, 95, 402

1963 election campaign, 91-2

on company law, 150

death, 253, 262

elected Liberal Leader, 78

on legislation affecting lawyers, 147-8

and overseas investment, 151

personal style, 74

and preferential voting system, 83

resigns all offices, 96-7

Muntz, Geoff, 526, 538, 546, 571, 577,

$595,611,615,630$

Murphy, Denis, 484, 553, 555

Murphy, Tony, 480

Murray, John, 94, 110, 113, 164, 215,

$222,343,374-5,385-6$

\section{$\mathrm{N}$}

National Hotel Inquiry, 100-2, 149, 199-200

National Party advantage themselves at expense of LP, 534

breaks convention on filling Senate vacancies, 370-3

by-election performance, 386-7, 401, 406 see also election campaigns and results

campaign funds, 483 see also Bjelke-

Petersen Foundation

coalition rift, 532-7, 541-2

Country Party re-branded, 359-60 see also Country Party

governs alone, 538-87

receives ALP preferences, 415

'rump executive', 538-41

see also Ahern government (1987 $\square 89$ );

Bjelke-Petersen government (1968-

87); Coalition governments; Cooper government (1989)

Neal, Don, 331, 547, 576, 577, 596, 615, 631

Nelson, Beryce, 574, 591-2, 630, 631

Nelson-Gracie, Peter, 214

New Conservative Party, 665

'new state' movement, 69, 347, 349

Newbery, Tom, 268, 383, 384, 407-8, 422 portfolios, 370, 394

Newnham, Noel, 634

Newton, Fred, 34, 106, 193-4, 363, 368

Newton, Lyell (Bill), 542, 574

Nicholson, David, 111, 118, 402, 656-8

and challenge to Bjelke-Petersen's leadership, 313-15, 316

as Speaker, 79-81, 181, 259-60, 288-

92, 293-4, 299, 324-5, 572, 656-8

Nicklin, Frank, 31, 41, 46-7, 48, 64, 186, 233, 235, 402

1957 election campaign, 51-2

1960 election campaign, 68, 71

1963 election campaign, 90-3, 179

1966 election campaign, 113-16, 119

biographical details, 54-5

on Country $\square$ Liberal Coalition in opposition, 42-4

defends reputations of ministers, 182-3

exploits ALP policy divisions, 179 
ill-health, 105, 115, 203

and industrial legislation/disputes, 158-9

leadership roles, 87, 119, 123, 203 see also Nicklin government (1957】68) length of service, 123 and oil refinery negotiations, 153-4 personal style, $54-6,68,74,75,84$, 173, 203

relations with Morris, 75

relations with Pizzey, 206, 227

retirement, 203, 205

safe seat, 212

supply debates, 44-5

Nicklin government (1957 668 )

budget and expenditure, 139-42

cabinet procedures, 55-6, 78-9, 115

election performance see under election campaigns and results

influence of 'outside interests', 66-7, 76,176

introduces preferential voting system, 83-4, 144

legislation see Nicklin government (1957 $\square 68)$ legislative program ministry, 58-60, 73-5, 78-9, 95-9, 119-22, 145-7, 236

reasons for re-election (1960), 70-1 relations between Coalition parties, 57, 75-7, 79-84, 144 want-of-confidence motions, 105-6

Nicklin government (1957 $\square 68)$ legislative program, 61, 125-66

appropriation and budget processes, 136-42

areas covered, 125-7, 141-2

Chiropractors' Bill, 164

concerning legal community, 147-9

concerning police rights of appeal, 149

economic and state development, 149-54

education, 126, 134, 162-3

electoral laws, 143-5

government business dominates, 165

health policy and services, 133

industrial relations, 154-9 ministry (size of), 95, 145-7, 434

number of pieces of legislation, 125-7

objectives and achievements

(Governor's opening speeches),

128-34

opposition responses (Addresses-In-

Reply), 134-6

parliamentary salaries, 145-6

social and recreational measures,

163-4

summary, 125-7, 164-6

transport and infrastructure, 82-3,

$89,126,129,132-3,135,160-2$

work-related legislation, 159-60

see also parliamentary procedure

'Night of the Long Prawns', 360-2

Noble, H. Winston, 58, 74, 75, 76, 95, 96, 98

no-confidence motions see want-ofconfidence motions

Nona, Ben, 327

North Queensland Labor Party, 52, 72, 177, 194, 280, 322, 394 see also Aikens, Tom

North Queensland Party, 72

North Queensland (proposed state), 69, 347,349

Nunn, Bill, 640

Nunn, Eric, 281

\section{$\mathrm{O}$}

oath of allegiance/affirmation, 12

O'Connell, Maurice, 5

O'Donnell, Eugene (Hughie), 193, 194, 289, 301-2

offices of profit under the Crown, 147 see also conflicts of interest

Officials in Parliament Act, 95, 146, 147, $286,369,434$

oil industry, 153-4

exploration on Great Barrier Reef, 293, 297, 304-6, 430, 514, 521

share dealings, 260-2

ombudsman, 354-5, 435-6

Opposition see parliamentary opposition

'Orders of the Day', 16 
$\mathrm{P}$

Packer, Kerry, 578

Palaszczuk, Henry, 555

Parliament, 1-4, 643-52

'bulwark of democracy', 201-2

ceremonial opening, 14

characteristics of, 3, 303-4

committees see parliamentary

committees

establishment of Queensland

Parliament, 2, 4

induction program, 11

Legislative Assembly see Legislative

Assembly

Legislative Council see Legislative

Council

members see members

offices and positions, 18-26 see also specific offices

operations of, 11-18, 24-5

role, 25-6

sitting pattern, 10, 134, 136, 285, 398, 559

Speaker see Speaker, office of; Speakers

see also parliamentary debates

Parliament House, 2, 5-10, 236

annexe, 7-8, 290, 405, 659

chambers, 9-10

design and construction, 5-7

facilities (house committees), 23-4

interior, 9-10

location, 5, 8

offices, 7, 10-11, 290

overcrowding, 7

restoration, 8, 405-6, 657

use of, 10-11

parliamentarianism, 32

parliamentarians see members

Parliamentary Annexe see under

Parliament House

Parliamentary Bowls Team, 240

Parliamentary Building Committee, 7

parliamentary buildings, 2, 4-8 see also

Parliament House

Parliamentary Business and Legislative

Committee of cabinet, 23 parliamentary committees, 10, 23-4, 325

accounts and works, 645

Committee of Supply, 136, 137

Committee of the Whole, 17, 18, 21, 22,136

Committee of Ways and Means, 136, 137

on criminal justice, $374,465,582,633$

on education, 398

on electoral and administrative review, 465

'house' committees, 23-4

lack of, 23, 24, 165, 645

Privileges Committee, 343, 377-8, 547, 663, 667

proposed, 139, 325, 342, 343, 597

public accounts committee, 342-3, $464,622-3$

scrutiny of legislation, 645

secretariat accommodation, 8

Standing Orders Committee, 508

on subordinate legislation, 24, 222

on youth problems, 657

see also Privileges Committee

Parliamentary Counsel, 25

parliamentary debates, 427-9, 647-50

budget debates see appropriation and budget processes

opposition-sponsored bills, 165

'personal explanations', 558-9

personal remarks and invective, 302$3,344-5,557-8,560,646-7$

private members' bills, 165, 298, 342

standard of, 57, 301-4, 324-5, 407, 557-61, 646-7, 655, 657-8

without Speaker, 80, 667-8

see also parliamentary procedure; question time; want-of-confidence motions

Parliamentary Draftsman, 221-2

Parliamentary Electoral and

Administrative Review Committee, 633

parliamentary funds, misuse of, 660-1

Parliamentary Librarian, 25

Parliamentary Library, 6, 7, 8, 11, 25,

138, 187, 405, 407, 650, 652

Parliamentary Lodge, 290, 295 
Parliamentary Mace, 21

parliamentary officers, 18-26

remuneration, 145

see also specific offices

parliamentary opposition (institution), 23

amendments to government

legislation, 165

difficulty of adequate scrutiny of government, 196-7, 426-32, 498, 501

opposition-sponsored bills, 165 resourcing, 63-4, 197-8, 492-5

see also Australian Labor Party in opposition; Leader of the

Opposition, office of

parliamentary privilege, 199-201

Privileges Committee, 343, 377-8, 547, 663, 667

parliamentary procedure, $61,84,165-6$,

197-8, 560

Bjelke-Petersen government committee, 296-7

under Bjelke-Peterson government, 373-5, 495-6, 498, 507-8, 650-2

criticism from academia, 298, 560

executive domination of, 165, 166, $283,645,662$

reform, 298-300, 341-4, 622-3

see also parliamentary debates; question time

parliamentary remuneration, 145-6, 223,

526, 599

parliamentary scrutiny, 196-9, 426-32,

498, 501 see also parliamentary

opposition; question time

Parliamentary Services Commission, 24

parliamentary systems, 2-4, 16 see also

Parliament

parties see Australian Labor Party;

Country Party; Democratic Labor

Party; Liberal Party; National Party;

Queensland Labor Party

Pearce, Jim, 640

Pearson, Col, 568

Perrett, Trevor, 604-5, 639

Petrie, John (building firm), 6

Pilbeam, Reginald, 474
Pitt, Warren, 640

Pizzey, Jack

1966 election, 257

background, 205, 206-7

and breathalyser legislation, 219-20

death and tributes, 227-9

on electoral redistribution, 216-17

on Fletcher, 60-1, 655

ill-health, 78, 204, 209

leadership roles, 115, 123, 203-4

on Nicholson, 656-7

personal style, 74, 75, 206-7, 224, 227

portfolios, 58, 59-60, 95, 119, 120,

206

as Premier see Pizzey government

(1968)

relations with Nicklin, 206

seat uncontested, 67

travel, 224-5

Pizzey government (1968), 204, 205-29

achievements and legacy, 222-7

legislative program, 218-22

ministry, 210-12

Pokarier, Ron, 556

police

Cedar Bay raid, 384-5

Commissioner appointments, 65, 302, 355-7, 385, 634

legislation concerning, 440-1

ministerial responsibility for, 212, 356

politicisation, 199-201, 356

powers, 158-9, 185, 319-21, 440, 527, 654

raids on abortion clinics, 564-5

police misconduct/corruption

allegations, 99-104, 186, 199-200, $480,581,609-10$

brutality allegations, 383-4

Fitzgerald Inquiry, 480, 581-2, 605-7, 617-18

political parties see Australian Labor

Party; Country Party; Democratic Labor

Party; Liberal Party; National Party;

Queensland Labor Party

Pollock, George, 169

Polzin, Kevin, 604-5 
The Ayes Have It: The history of the Queensland Parliament, 1957-1989

pork-barrelling, 29, 120, 557, 574 see also corruption and corruption allegations

Porter, Charles, 92, 110, 112, 113, 164, 213, 215, 301, 307, 328, 394

Powell, Lionel ('Lin'), 367, 665, 666-8 in ministry, 525, 538, 546, 577

resignations, $625-6$

as Speaker, 590-2, 625-6, 667-8

Powell, Nigel, 613-14

Power, Laurel, 640

Power, W. (Bill), 30, 48, 64

Pratt, Eric, 581, 619-20

preferential voting see electoral arrangements

Premier, office of, 19 remuneration, 145, 146

Premiers

died in office, 204

long-serving, 123, 203

Premier's Independent Commission for Change and Reform, 631-2

Prentice, Ian, 429, 480-1, 535, 543

President of the Legislative Council, 22

Prest, Bill, 386, 507, 549, 560, 577, 665

Price, Bill, 453, 483, 552, 573

primary industries legislation and regulation, 149-50, 443-6, 523-4

prison system, 599-600

private members' bills, 165, 298, 342

Privileges Committee, 343, 377-8, 547, 663, 667

Privy Council appeals, 353, 434-5, 570 probity, 61, 399-400, 508-9, 596, 612 see also conflicts of interest; corruption and corruption allegations

Procter, Sir Roderick, 403, 562, 575

Public Accounts Committee, 342-3, 464, 622-3

public administration legislation, 434-7

public education see education and educational institutions

public relations consultants, 268-9

public service

legislation, 435

politicisation of, 271-2

reforms, 599 superannuation, 349

public works, 1

Q

Queensland, naming of, 1

Queensland Central Executive see under

Australian Labor Party

Queensland Labor Party, 107, 194

affiliation with DLP, 72, 93, 118

allocation of preferences to Coalition, 178

effect of preferential voting, 84, 87, 93

election attacks on ALP, 50-1, 67, 69, 93, 116, 175, 176-9, 188

election performance see election campaigns and results and industrial legislation, 157, 158

in opposition, 61-5, 168

political significance of, 178

splits from ALP, 39-41 see also

Australian Labor Party split

see also Democratic Labor Party; Gair, Vince

Queensland Labor Party government disputes with ALP, 45-9

members (number of), 168

minority government, 40-1

supply debates, $44-9$

Queensland Parliament see Parliament

Queensland Parliamentary Debates see

Hansard

Queensland People's Party, 31, 97

Queensland Police Force see police

Queensland Trades and Labour Council

see Trades and Labour Council

question time, 15-16, 63, 165, 198-9, 299-300, 499, 649, 651, 657-8

Quinn, Bob, 59, 613, 640

$\mathrm{R}$

Rae, Wallace, 53, 60, 169, 210, 288, 336, 373, 402

railways, 82, 141-2, 154, 195

Ramsay, Sir James, 20

Ramsden, Sam, 60, 110, 139, 163, 321

Randell, Jim, 408, 595, 596, 615, 631 
Record of Proceedings, 25 see also Hansard

recreational measures see social and recreational measures

redistributions of electoral districts see electoral districts and distribution

Redmond, Ron, 619

refusal of supply see supply debates

regional development, 448-51 see also state development

religion, 37 see also Catholic influence remuneration, 145-6, 223, 526, 599

representation see electoral arrangements

Richter, Harold, 60, 83, 143, 285, 314, 325,402

portfolios, 78, 95, 120, 208, 212, 229, 252

road transport industry, 82-3, 89, 160-1

roads and road construction, 132-3,

$161,306-7,388$ see also transport and infrastructure

Roberts, Lloyd, 73, 74, 78, 144

Roberts, William 'Roley', 102

Robinson, Eric, 226, 277

Robson, Molly, 640

Row, Edward (Ted), 331, 547, 548, 554-5, 590, 636

Row, John, 121, 314, 316, 325, 402, 428 portfolios, 78, 95, 120, 208, 212, 229, 252, 286

Rowell, Marc, 640

royal assent, 18

Royal Commission into Land

Administration, 36

Royal Commissions

land administration, 36

police misconduct (Fitzgerald Inquiry) see Fitzgerald Inquiry

police misconduct (Gibbs Inquiry), 100-2, 149, 199-200

Rudd, Kevin, 610

Russell, David, 567, 569

Ryan, T. J., 29

Ryan government, 4
S

salaries see parliamentary remuneration

Santoro, Santo, 614

Sargent, Haydn, 297

Savage, Sir Ernest, 403

Scassola, Guelfi, 516

Schmella, Jack, 34

schools see education and educational institutions

Schuntner, Lyle, 573, 636

Schwarten, Robert, 640

Sciacca, Con, 321, 556-7

Scott, Bob, 528, 636

Scott-Young, Norman, 331, 372, 391, 405, 419-20, 505-6, 509

'secretary' (title), replaced by 'minister', 61

Select Committee on Education in

Queensland, 24

Select Committee on Punishment of

Crimes of Violence in Queensland, 24

select committees, 23-4, 325 see also

parliamentary committees

self-government, 1-2

Senate elections, 110, 412-13

Senate vacancies, 360-2, 370-3, 508-10

Sergeant-at-Arms, 21, 25, 291

sexual harassment allegations, 98, 120-2

Seymour, John (Jack), 221-2

shadow ministry

concept of, 651-2

Edwards, 409

Goss, 489-90, 596

Houston, 193-4, 472-3

Wright, 481-4

Shaw, Eric, 489, 636

shearers' strike, 36

Sherlock, Alan, 573

Sherrin, Craig, 573, 614, 615, 630

Sherrington, Douglas, 106, 156, 159, 191, 193-4, 286-7, 339, 344-6, 430, 472

Sherrington, Robert (Bob), 110, 112, 282

Simpson, Gordon, 367, 584, 636

Sinclair, Ian, 578, 579

Sinclair, John, 457

sitting days, 10, 134, 136, 285, 398, 559

Skinner, Alex, 48 
Small, Bruce, 331, 344-5, 393, 402

Smith, Geoff, 368, 471, 641

Smith, K., 53

Smith, Percy Raymund (Ray), 60, 147, 186

Smith, Sir Henry Abel see Abel Smith, Sir Henry

Smith, William Forgan, 29, 31, 203, 207

Smyth, Ken, 471, 497, 574

social and recreational measures, 650

Bjelke-Petersen government, 451-2, 458-62

expenditure on, 142, 273

Nicklin government, 163-4

see also health and welfare policy and services

Social Credit League, 87

Southbank redevelopment (Brisbane), 600-1

South-East Queensland Electricity Board dispute, 562-5

sovereignty, 19

Sparkes, Sir Robert, 316, 317, 337, 359, $383,398,403,416,516,567,569,579$, $582,629,630,635$

Speaker, office of, 12-13, 21-2, 658

authority, 181

election procedures, 80

remuneration, $145-6$

Speakers

approach, 495-500

biographical details and parliamentary careers, 653-68

Burn's observations on, 572

controversies, 42-4, 79-80, 336-7, $357-9,548,625-6,667-8$

long-serving, 81, 290-1, 658

Speaker's limousine, extra-parliamentary use of, 654

Spence, Judy, 640

Springboks' rugby union tour (1971), 319-21

Springborg, Lawrence, 639, 640

Standard Oil, 153

standing committees, 325,342 see also parliamentary committees

Standing Orders Committee, 508 state development, 90-2

Ahern government, 601-4, 624

ALP policy, 196

Bjelke-Petersen government, 448-51, 521-4

dominates 1969 election campaign, 269-70, 272-3

expenditure on, 142

Nicklin government, 129

priority, 58-9, 61, 96, 120, 150-1

state taxes see taxation

states of emergency, 319-21, 562-4

statutory committees, 23-4

Stephan, Len, 406, 623

Stone, John, 578

Stoneman, Mark, 552, 630, 631, 634

Strangers' Bar, 11

street marches, banned, 391-2, 441-2,

564

suffrage see voting rights

sugar industry, 255-7

Sullivan, Jon, 640

Sullivan, Victor, 210, 211, 212, 230, 253,

286, 314, 315, 316, 422, 504, 524-5

portfolios, 335, 336, 370, 394, 421, 444

superannuation, 349, 410, 431

supply debates, 41, 44-9

refusal of supply (Federal Parliament), 373

refusal of supply (Queensland

Parliament), 48-9

see also appropriation and budget processes

Swan, Wayne, 614, 628, 639

Szczerbanik, John, 640

$\mathrm{T}$

Tarong power station, 352-3, 395-6 see also electricity supply

taxation, 140-1, 415-16

Taylor, Harold, 79-80, 657

television use in election campaigns, 68 , 70-1, 114, 176, 483

Tenni, Martin, 367, 484, 587, 611, 630, 636, 646 
portfolios, 531, 532, 538, 546, 571, $577,595,615$

Thackeray, Merv, 60, 186, 264-5, 266, 326, 474

Theodore, 'Red Ted', 29, 146

Thiess, Sir Leslie, 512, 522-3, 600

Thiess Peabody Mitsui company, 154

Thompson, Keith, 580

Thomson, S. F., 387

three-cornered contests see under election campaigns and results

Tiffin, Charles, 6, 7, 9

Todd, Ron, 327

toilet doors, 521

Tomkins, Ken, 369, 370, 394, 421, 422, 524-5, 552

Tooth, Seymour (Doug), 60, 78, 101, 143, $156,328,402$

portfolios, 98, 120, 164, 212, 219, 229, 252, 286, 336, 355

Torres Strait Islanders see Indigenous

Australians

tourism

Commonwealth Games, Brisbane, 526-7

Expo 88, 550-1, 600-1

Iwasaki resort project legislation, 395 , $428,450,624$

legislation, 450-1

trade unions, $31-4,187$

allegations of communist links, 106, 158 see also communism

Catholic $\square$ communist struggle, 32-3

union leaders, 34

see also industrial disputes; industrial relations legislation

Trades and Labour Council, 32, 37, 104, 106, 158, 181

Trades Hall influence on parliamentary ALP, 50, 68, 88, 92-3, 187-8, 326, 471, 479

transport and infrastructure

ALP policy, 195

Bjelke-Petersen government, 454-6

expenditure on, 135, 141-2

Nicklin government, 82-3, 89, 126, $129,132-3,135,160-2$ travel entitlements, 399-400, 532, 660-1

Treasurer, office of combined with party leader and Deputy Premier roles, 97, 98, 382-3 role in budget debates, 137

Trollope, Anthony, 3

True Labor Party, 326

Truss, Warren, 604-5

Tucker, Percy, 186, 191, 192, 193, 239,

294, 318, 348-9

1974 election, 364-6, 368

leadership roles, 362-3, 401, 472, 475-6

Turner, Neil, 367, 538, 539, 546, 573,

$576,611,640$

twins elected as members, 280

U

ultra-Liberals, 97, 108, 109, 110, 111, $112,213,214,314,387-8$ see also

Liberal Party

Underwood, David, 189, 490

unions see trade unions

universities see education and educational institutions

Usher of the Black Rod, 22

$\mathrm{V}$

Vasta, Angelo, 619-21

Vaughan, Ken, 547, 596, 641

Veivers, Mick, 580, 584

Veivers, Tom, 552, 573

Vibert, Ted, 530-1

Vietnam War, opposition to, 112, 118, 249, 292, 321, 431

Votes and Proceedings of Parliament, 25

voting arrangements see electoral

arrangements

voting rights, 2, 3

W

Walker, Janine, 555

Wallis-Smith, Edwin (Eddie), 94, 180, 194

Walsh, Bryan, 331

Walsh, E. J. 'Ted', 30, 38, 40, 43, 46, 61, 65-6, 186, 657 
and Egerton allegations, 181-5

leaves QLP/becomes independent, 72,

119,180

on legislation affecting lawyers, 148

personal style, 33-4, 73, 80

on police matters, 99, 101

relations with Duggan, 167

want-of-confidence motions, 64-5, 105-

$6,185-7,317-18$

Warburton, Neville, 488, 523

ALP leader, 471, 485-7, 488, 549, 556, 592-3, 596

on Bjelke-Petersen, 586-7

budget debates, 561-2

on electoral redistribution, 568-9

image and standing, 485, 486, 487,

$489,531,557,558$

leadership roles, 471, 481, 485, 531, $549,556,641$

on Lingard as Speaker, 665

personal style, 485,487

on Powell as Speaker, 591

Ward, Vilma, 340-1

Warner, Anne, 471, 551, 564, 596, 641

Warner, John, 367, 662-4

as Speaker, 547-8, 561, 571-2

stands up to Bjelke-Petersen, 663

water supply see transport and infrastructure

Watkins Limited, 7

Watson, A., 53

Watson, Dallas, 613

Watson, David, 640

welfare see health and welfare policy and services; social and recreational measures

Welford, Rod, 640

Wells, Dean, 596, 597, 633, 634, 641

Wensley, Penelope, 20

West, Katherine, 578

Wharton, Claude, 345, 370, 422, 494-5, 504, 508, 525-6, 548, 576, 611

portfolios, 369, 370, 380, 394, 421, 538,546

whip, office of, 23

remuneration, 145

White, Peter, 393, 405, 509, 579
White, Terry, 406, 421, 535-6, 537, 540,

$545,623,662$ leadership roles, 482, 503, 540-1, 547

portfolios, 421

Whiteside, Bruce, 613

Whitlam, Gough, 92, 360-2, 402, 636

Whitlam Labor government (Federal),

349-53, 360-2, 370-3, 476

Whitrod, Ray, 302, 320, 355-6, 383-5,

616-17

Wilde, Tanya, 613-14

Williams, Edward, 567

Wilson, Alex, 515

Wiltshire, Ken, 560

Winchester South mining lease, 511-13

Winders, H., 118

Windsor, Bob, 60

Wolfe, Judge Patsy, 615

women

in cabinet, 571

in parliament, 188-9, 245, 369, 551, 613

policy for, 271

rights of, 565

voting rights, 3

Wood, Bill, 280, 347

Wood, Ernest, 118

Wood, Les, 48, 62, 64

leader of opposition/frontbench, 61, 169-70, 174

Wood, Peter, 94, 188, 280, 474

Woodgate, Margaret, 640

Woods, Jack, 511-12

work-related legislation, 159-60, 453-4

see also industrial relations legislation

Wright, Judith, 555

Wright, Keith, 280, 294, 386, 474, 645,

662

leadership roles, 481, 484, 531-2, 540, 549, 554

resignation, 484, 556

shadow ministry, 481, 484

Y

Yewdale, Les, 326, 507, 549, 636, 647

Young, Dennis, 367

Young Liberals, 109-10, 112 
Z

Zamek, G. A., 322 
